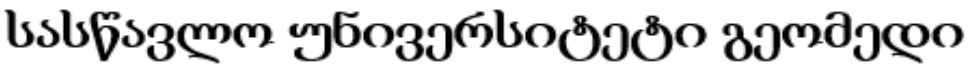 Teaching University Geomedi
}

\author{
ascmbs\% 3 sbstos \\ Malkhaz Vakhania
}

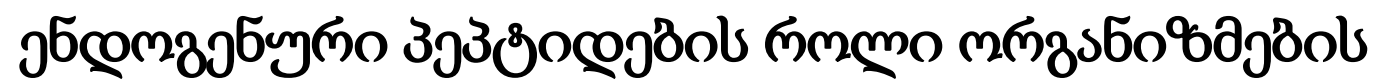

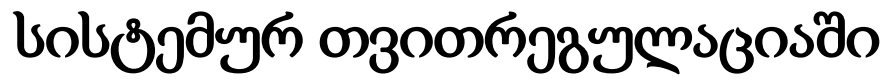
дmbmzณsogos

\section{The Role of Endogenous Peptides in the Systemic Self-Regulation of Organisms}

\author{
Monograph
}

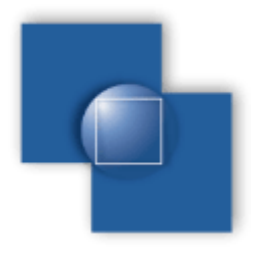

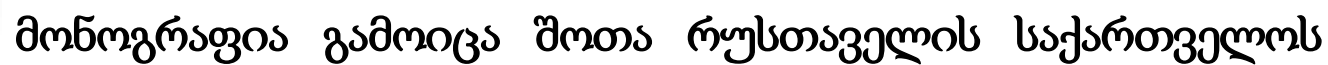

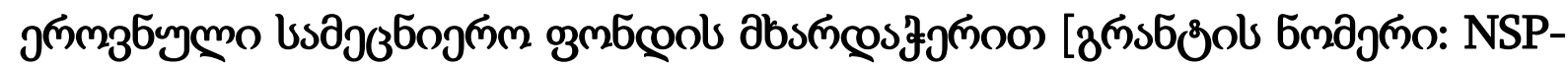
21-402]

This work was supported by Shota Rustaveli National Science Foundation of Georgia (SRNSFG) [grant number: NSP-21-402]

ỏ̇omolvo 2022 


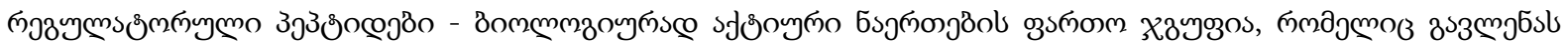

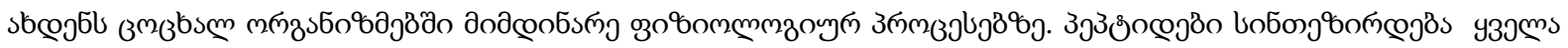

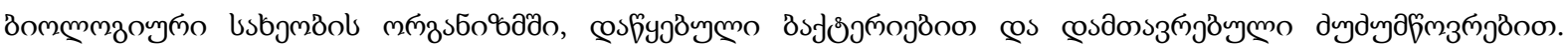

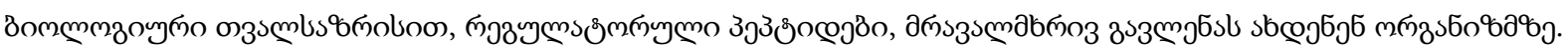

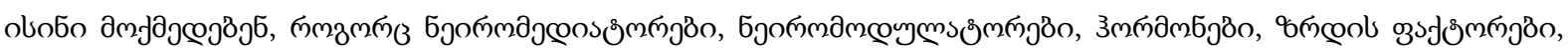

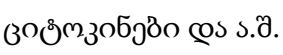

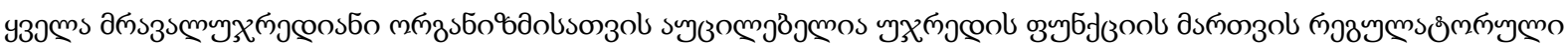

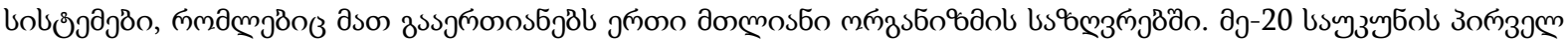

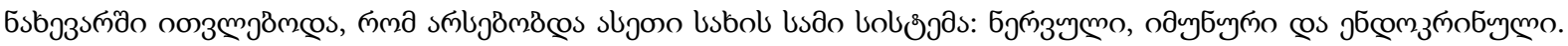

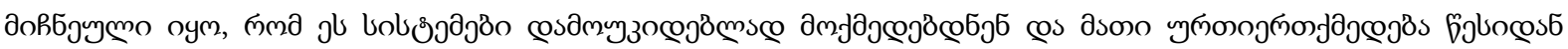

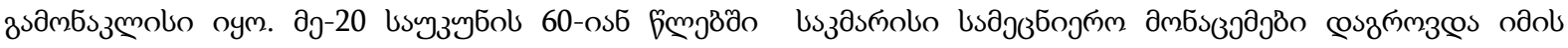

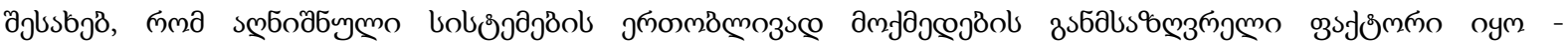

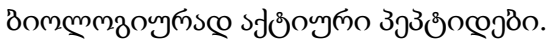

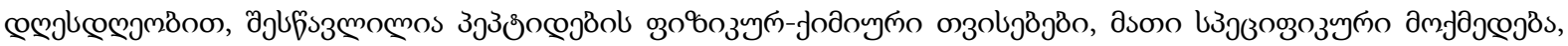

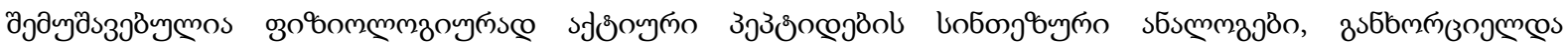

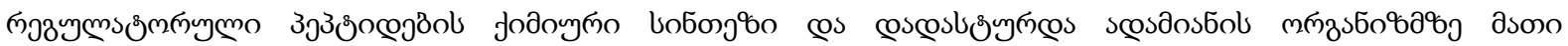

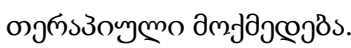

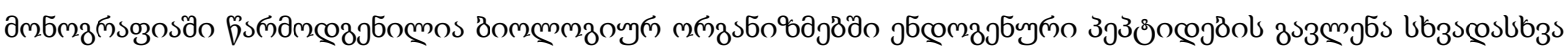

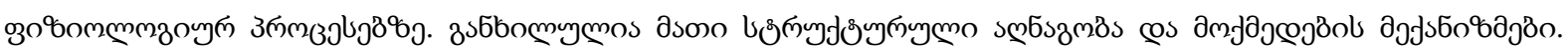

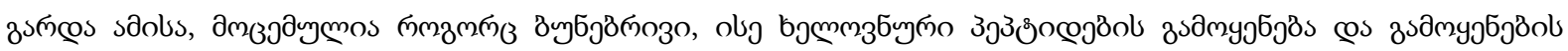

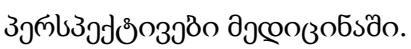

Regulatory peptides are a wide group of biologically active compounds that affect the current physiological processes in living organisms. Peptides are synthesized in the organism of all biological species, from bacteria to mammals. From a biological point of view, the regulatory peptides have a versatile effect on the organism, they can act as neurotransmitters, neuromodulators, hormones, growth factors, cytokines, etc...

The regulatory systems are necessary for all multicellular organisms, to control the function of the cell, to unite it, into one whole organism. In the first half of the 20th century, it was believed that, there were three types of such systems: nervous, immune and endocrine. It was considered that, these systems functioned independently andtheir interaction just was an exceptions. In the 60 s of the 20th century, was accumulated enough scientific data, according to which the biologically active peptides were the determining factors of the joint action of the above systems.

For today, the physicochemical properties, their specific action, synthetic analogues of physiologically active peptides have been explored.The chemical synthesis of regulatory peptides has been implemented and their therapeutic effects on the human body have been proven.

The monograph presents the effect of endogenous peptides on various physiological processes in biological organisms, aslo theirstructural construction and mechanisms of action. In addition, there is discussed, the use and perspectives, of both natural and artificial peptides in medicine.

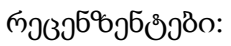

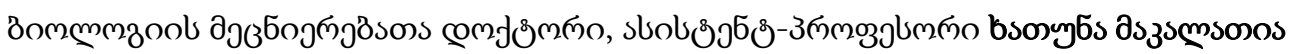

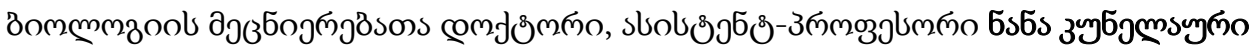

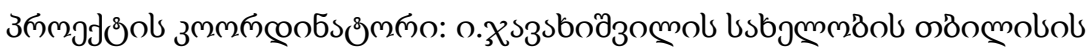

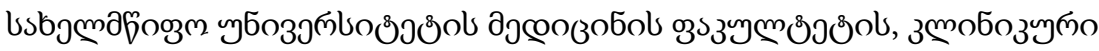

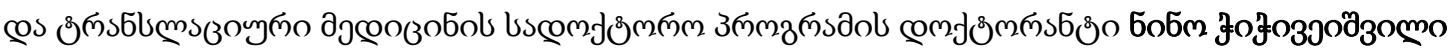

\section{ISBN 978-9941-8-4052-4}

\section{Doi:10.52340/9789941840524}

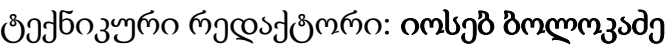

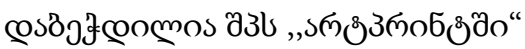

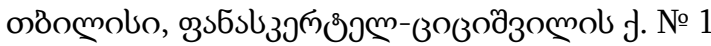




\section{yobssmiso}

gjlsзssmo.

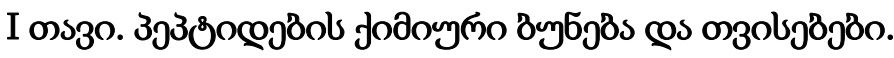

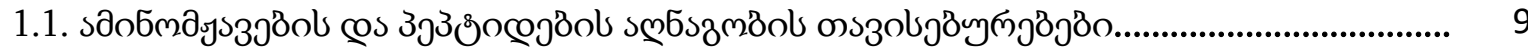

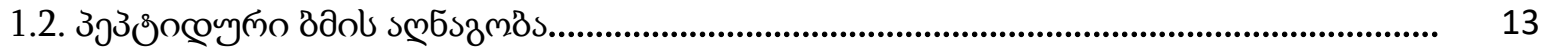

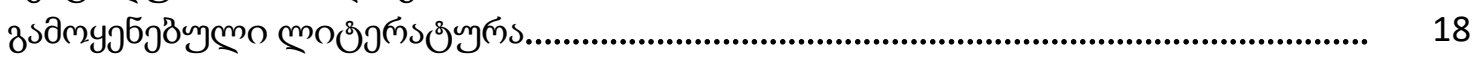

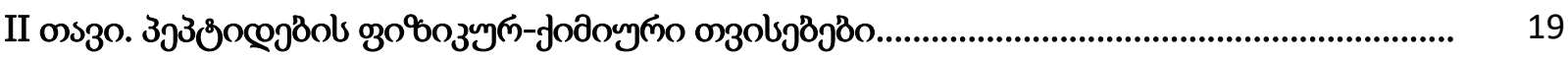

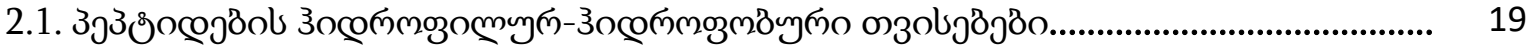

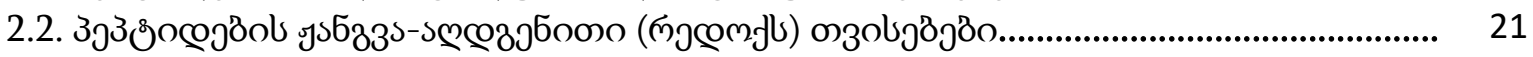

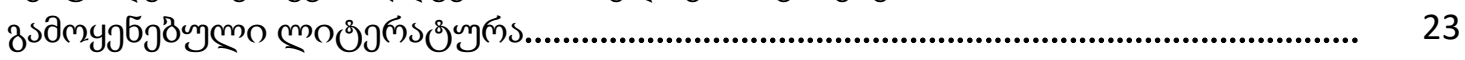

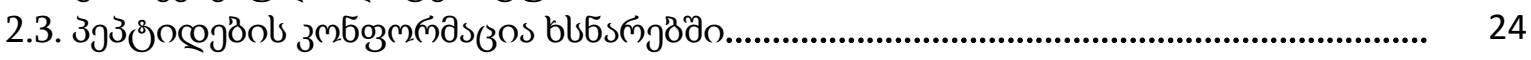

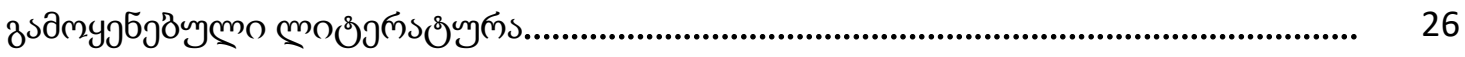

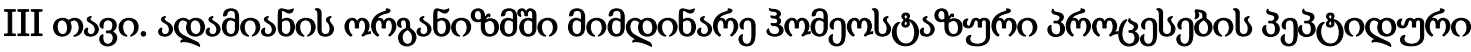

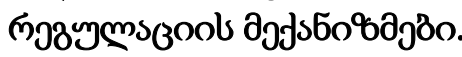

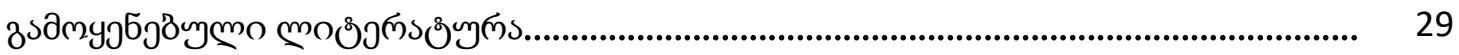

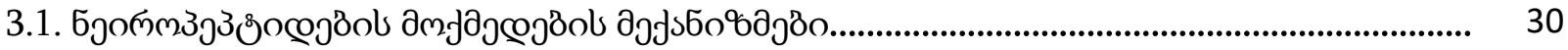

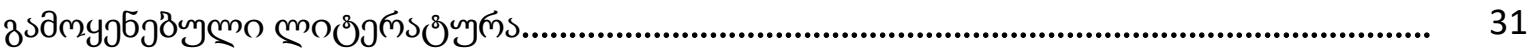

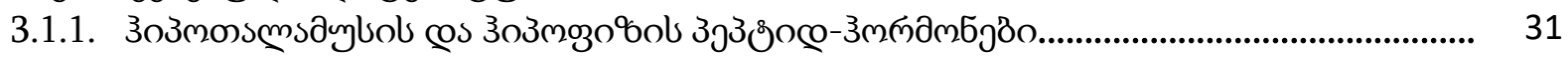

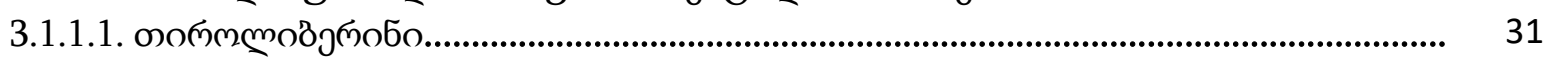

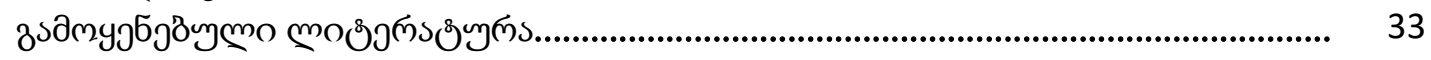

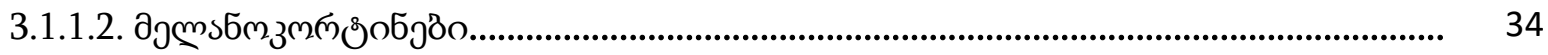

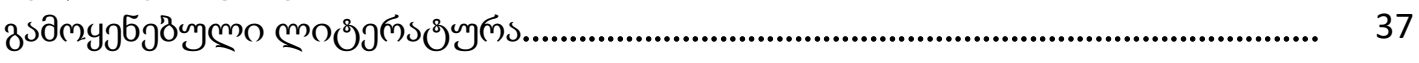

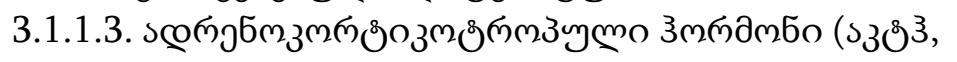

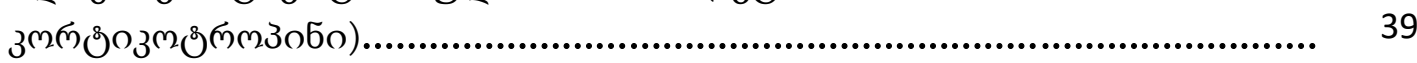

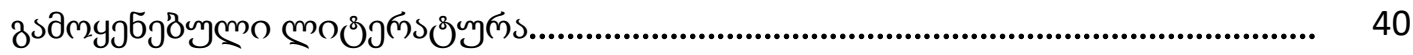

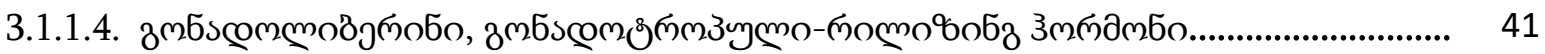

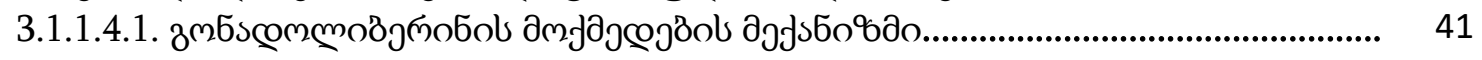

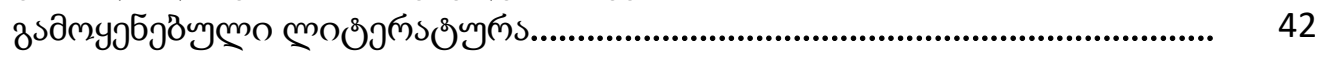

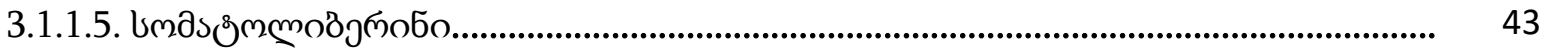

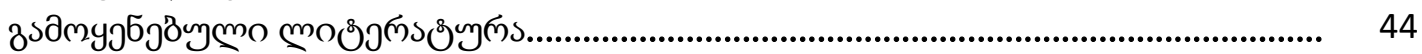

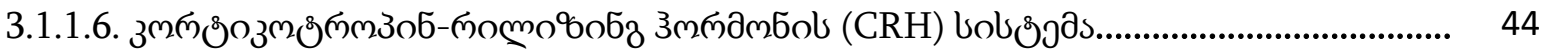

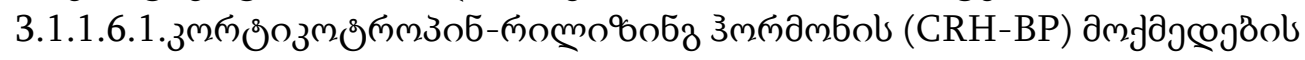

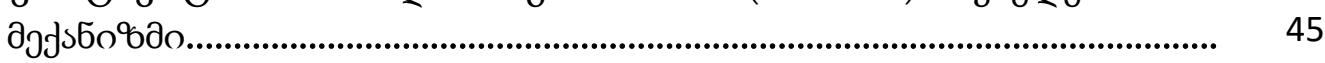

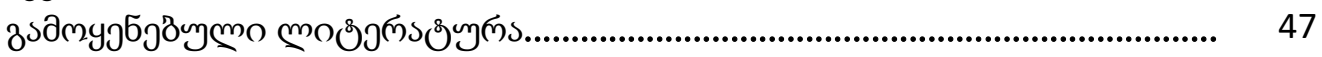

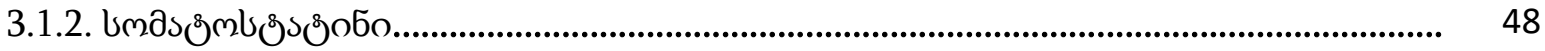

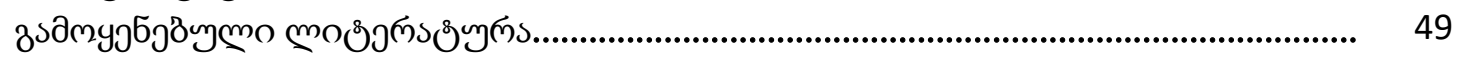

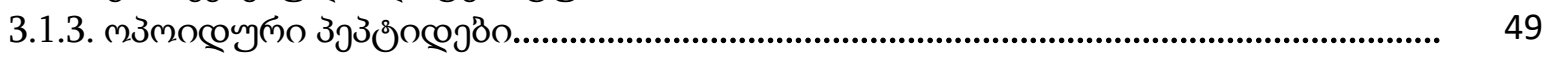

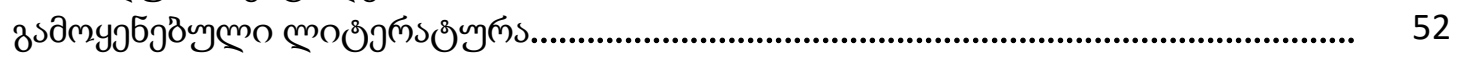

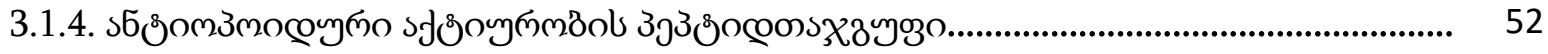

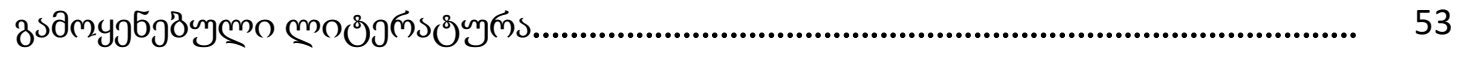

3.1.5. 


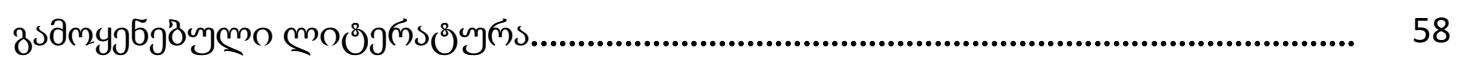

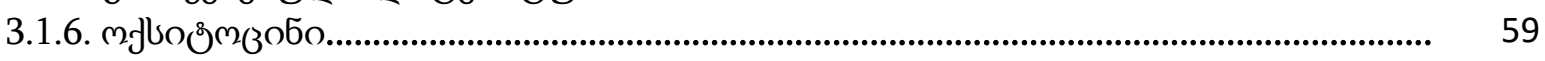

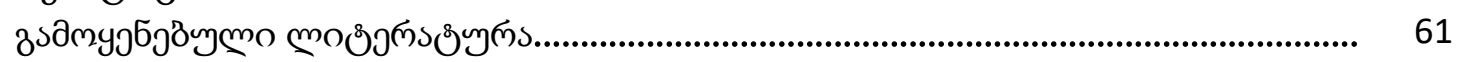

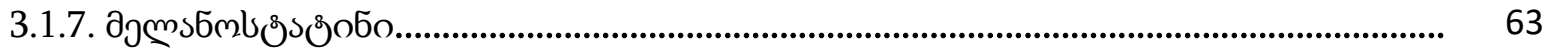

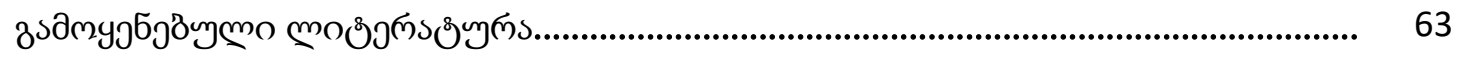

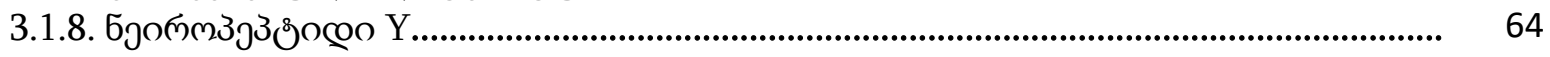

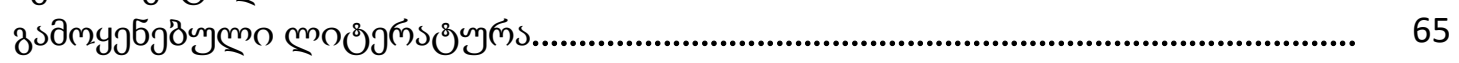

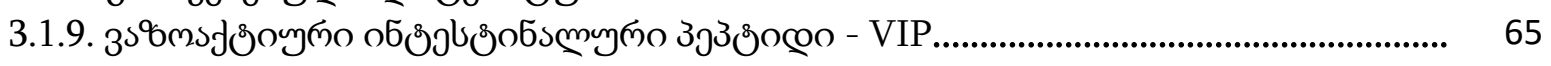

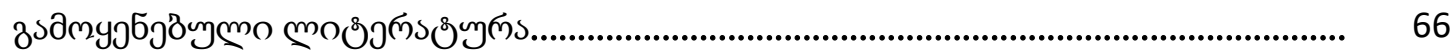

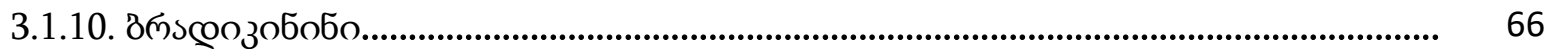

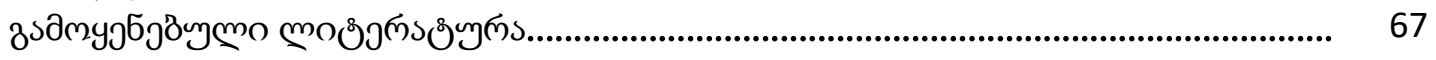

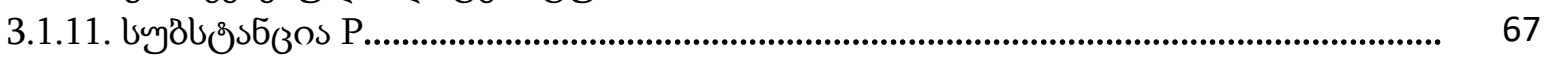

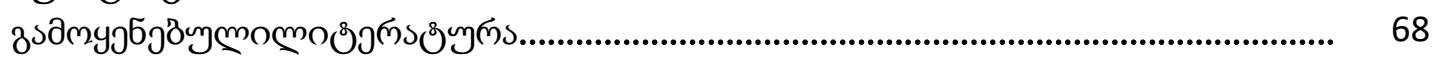

3.1.12. Бэо๓м

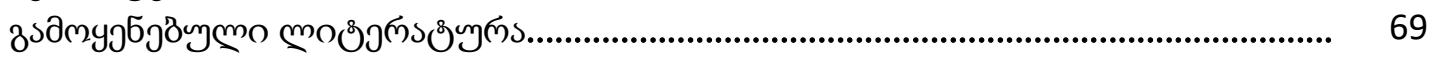

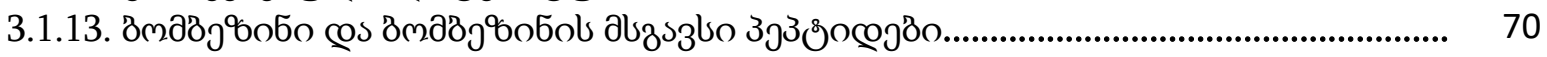

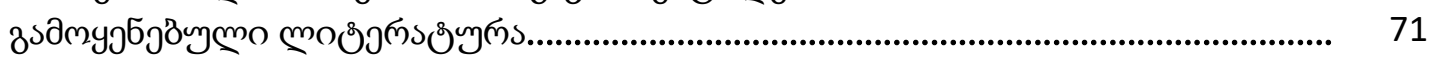

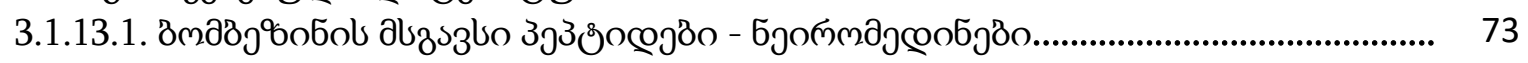

3.1.13.1.1. броґмдрєобо U (NMU)............................................................................. 73

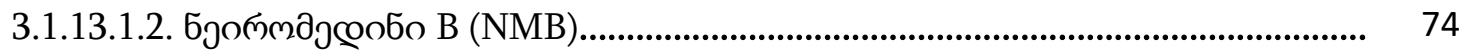

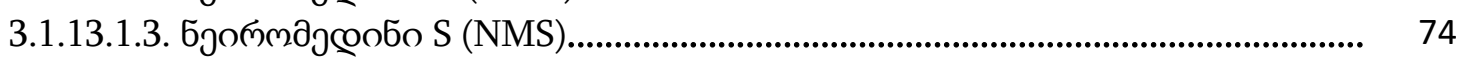

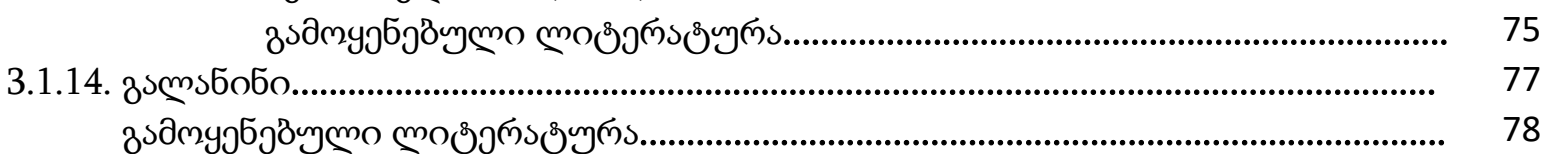

3.1.15. m๓g

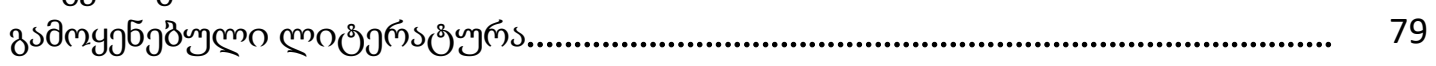

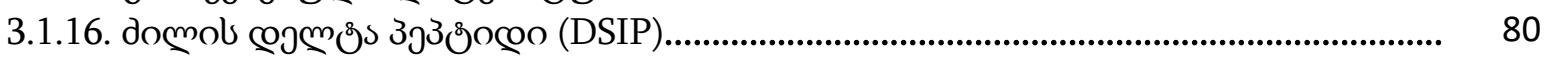

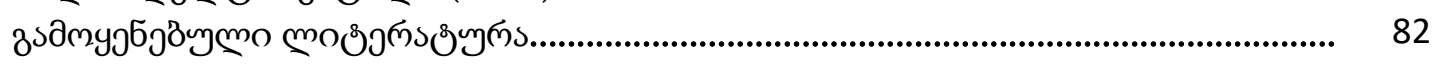

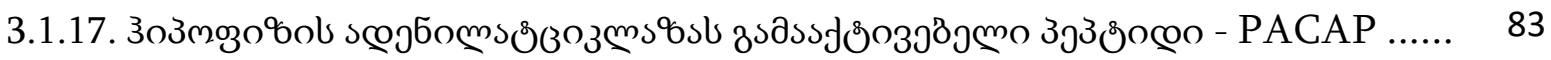

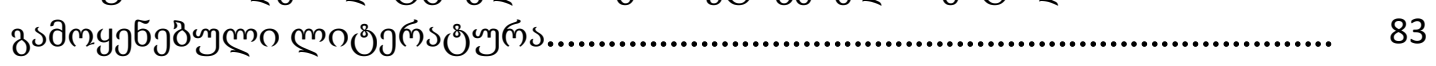

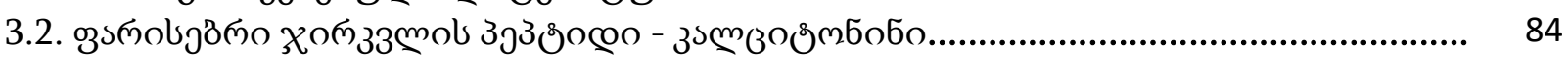

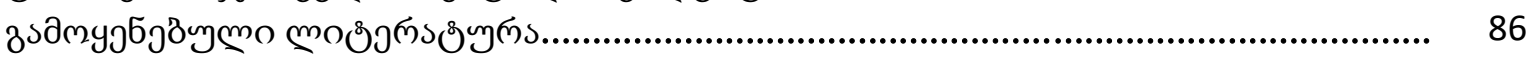

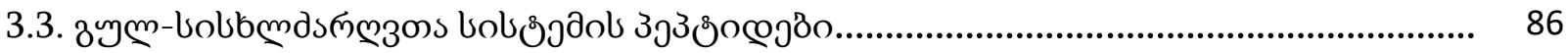

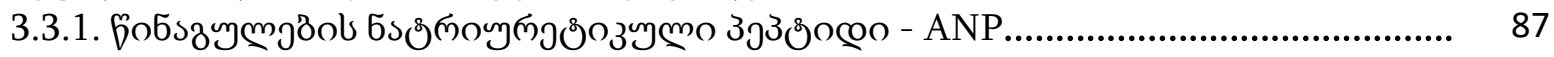

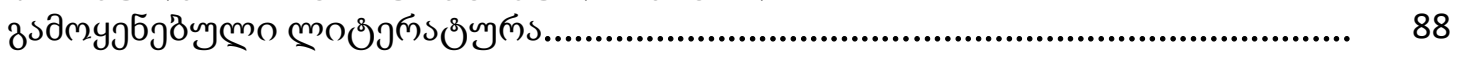

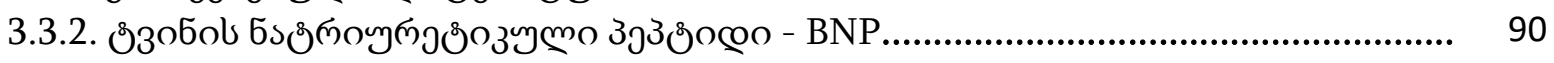

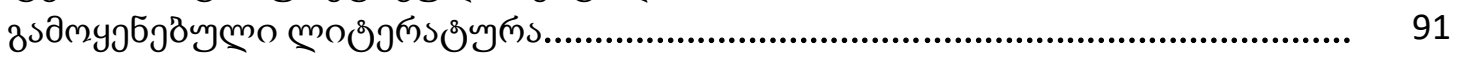

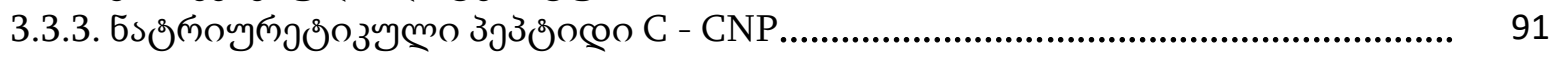

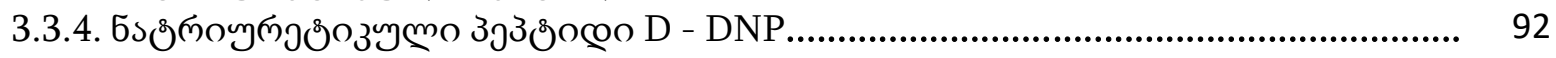

3.3.5. ஏ๓мஹом

3.3.6. 3

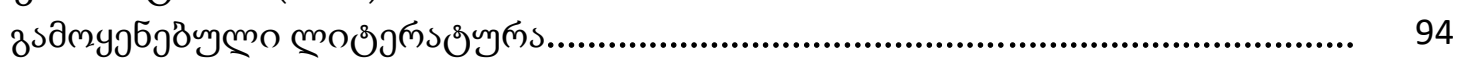

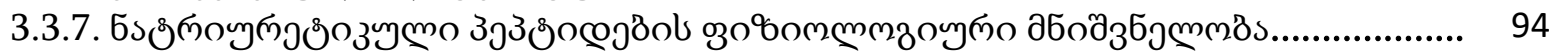

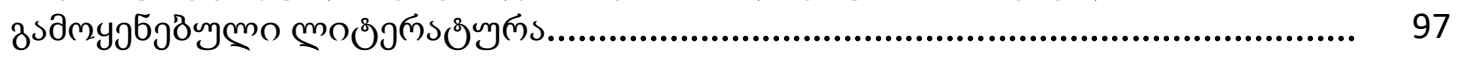

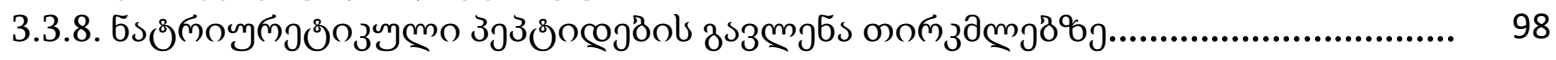

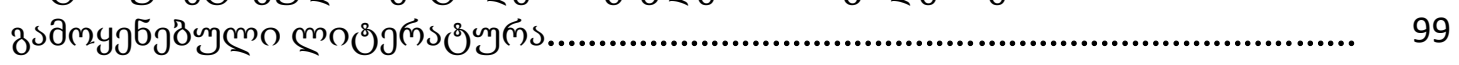

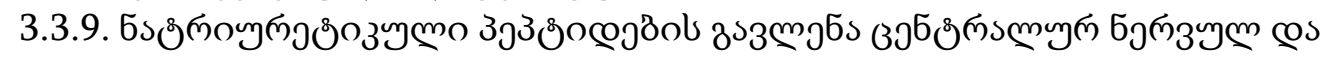

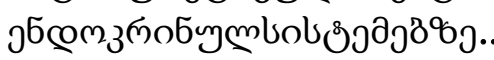




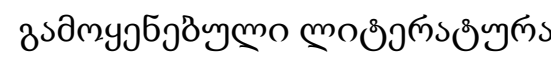

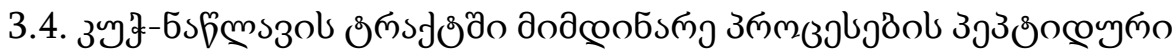

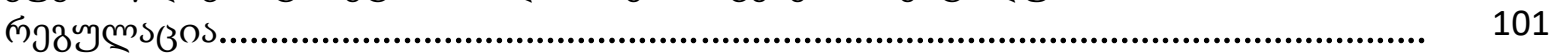

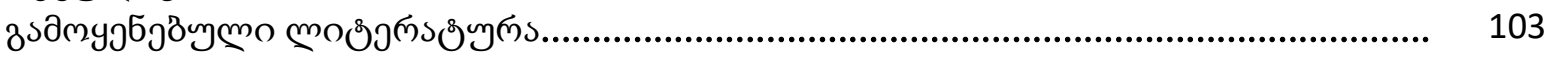

3.4.1. gub 8 nо

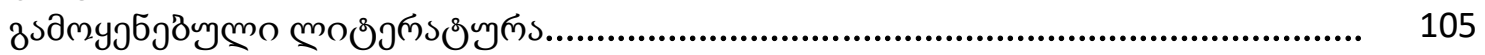

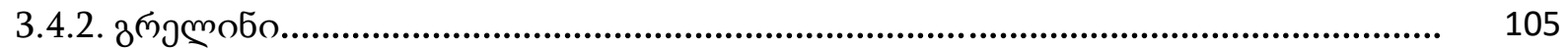

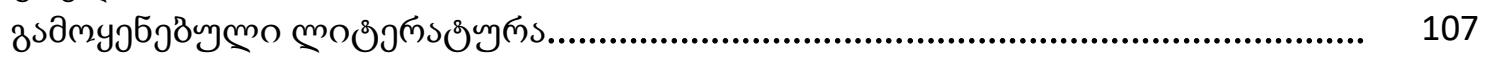

3.4.3. ८ ๒

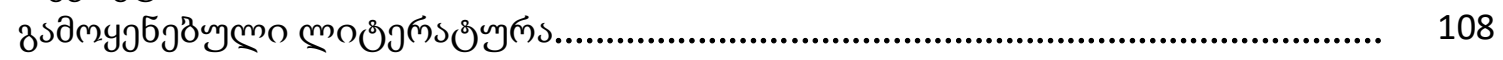

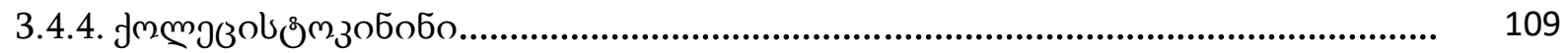

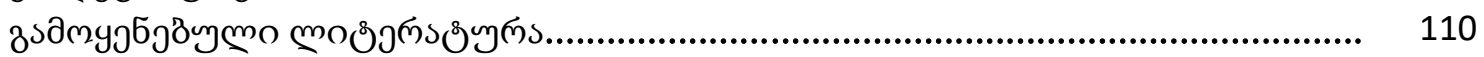

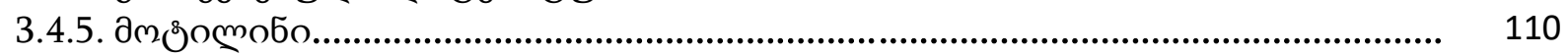

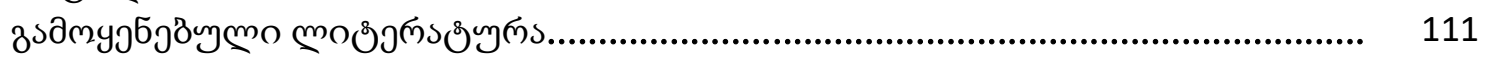

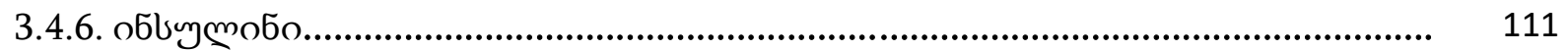

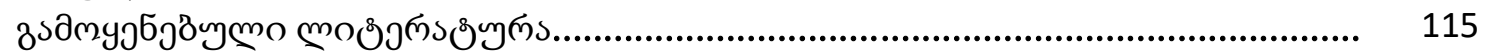

3.4.7.8муздз

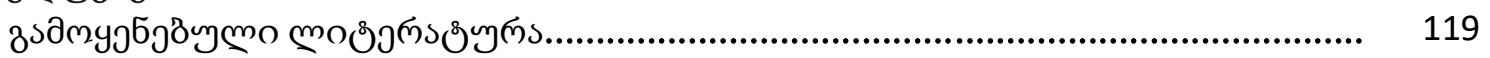

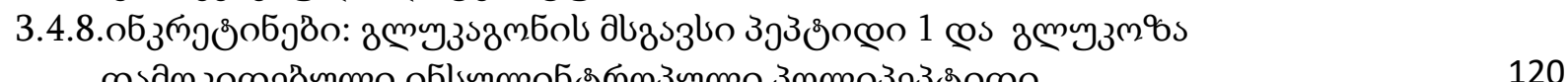

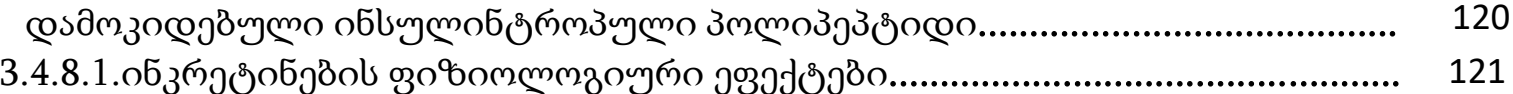

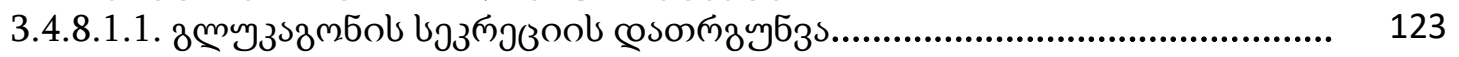

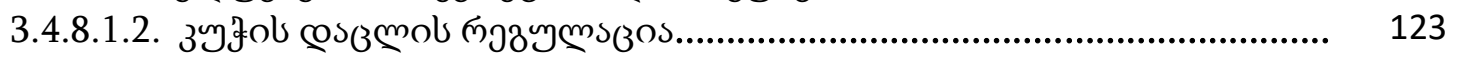

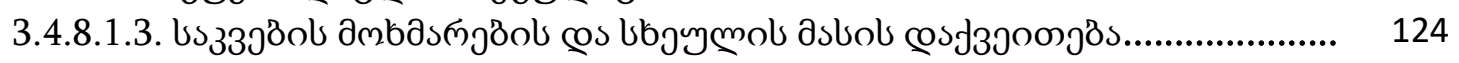

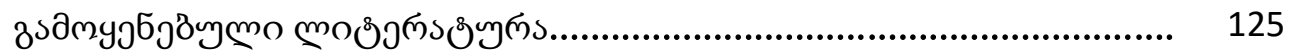

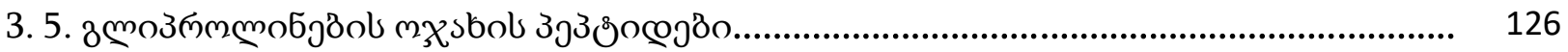

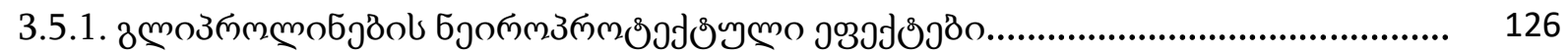

3.5.2. в позпм мпо

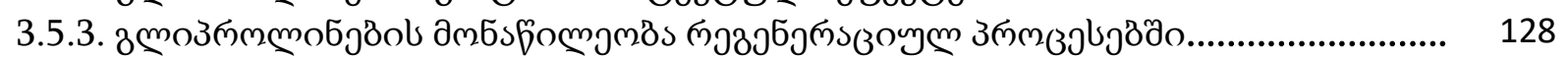

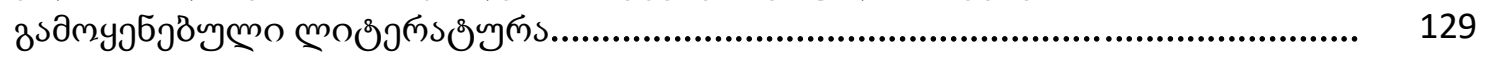

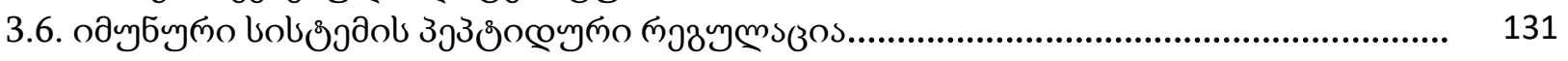

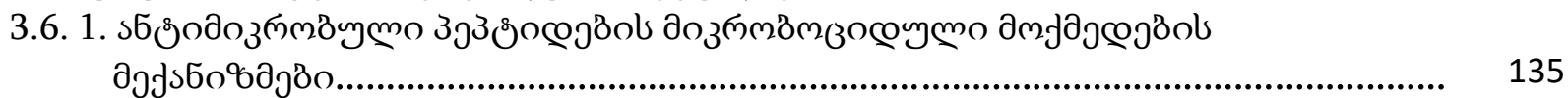

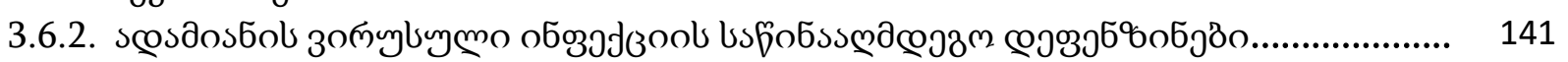

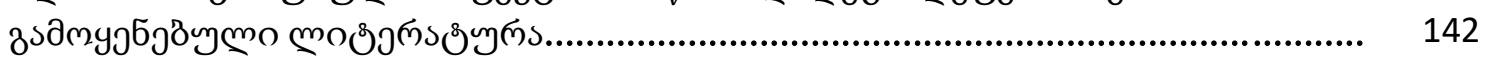

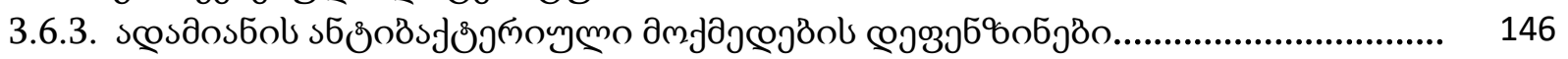

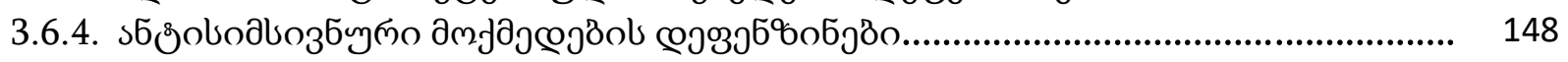

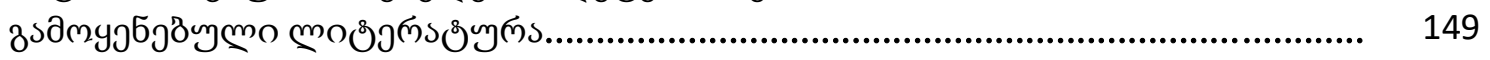

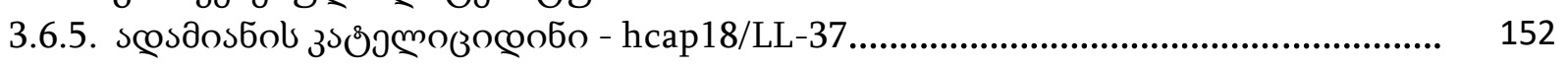

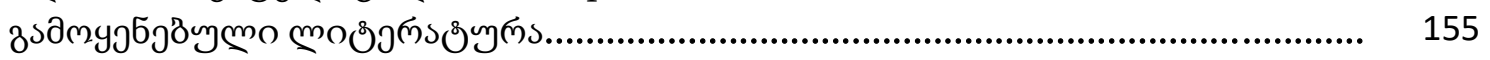

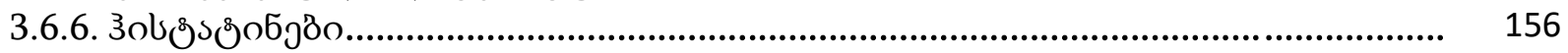

дздмујб

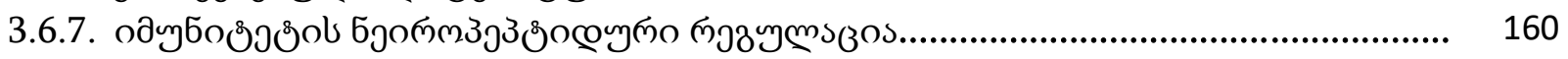

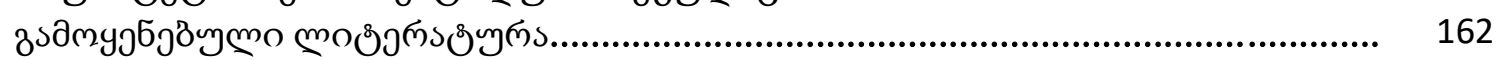

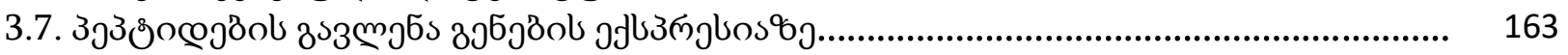

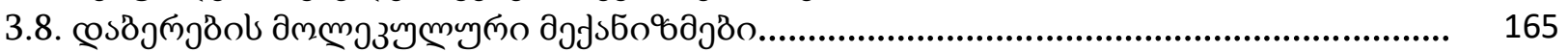

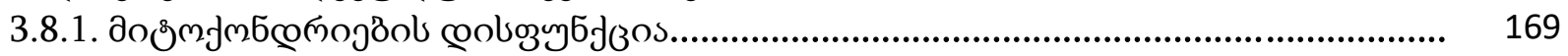




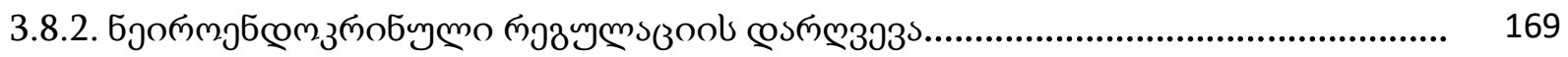

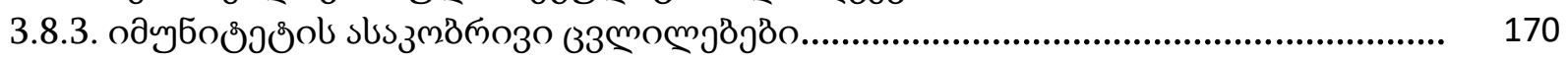

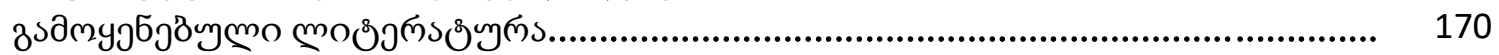

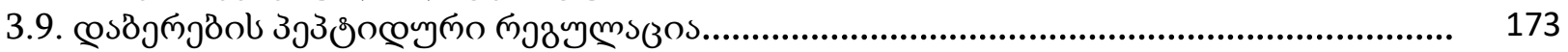

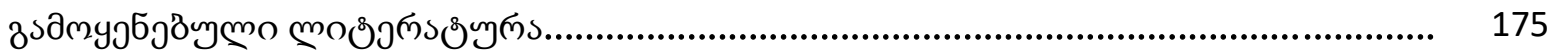

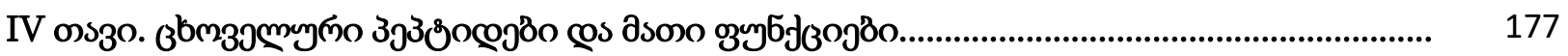

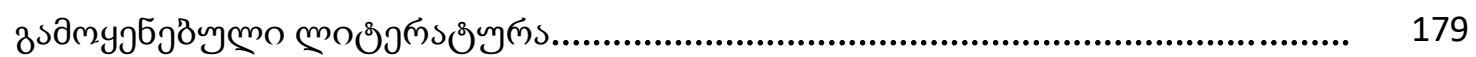

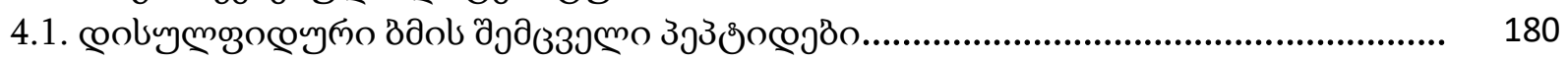

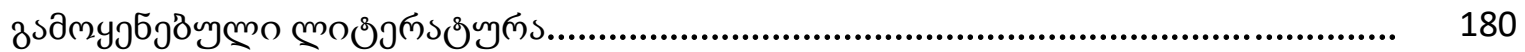

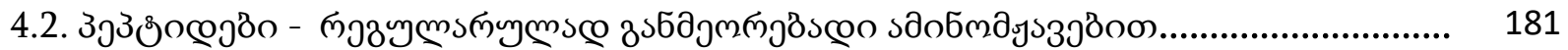

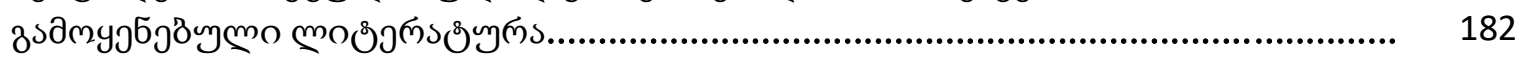

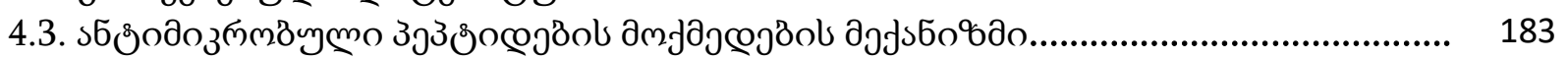

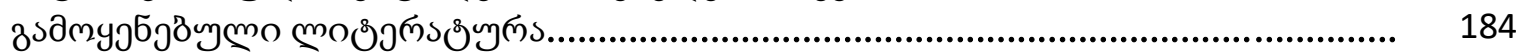

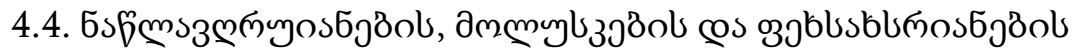

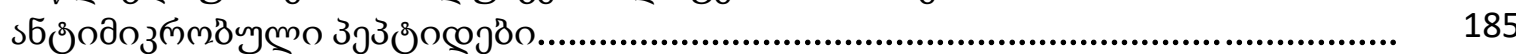

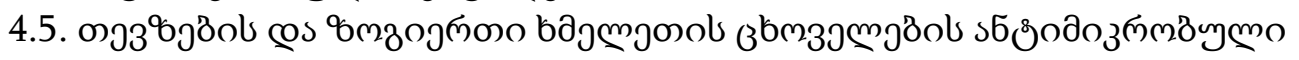

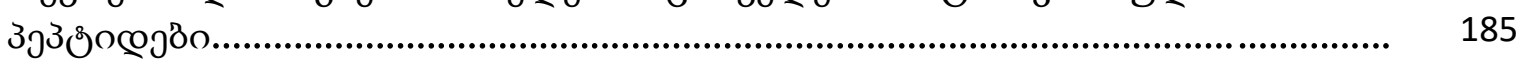

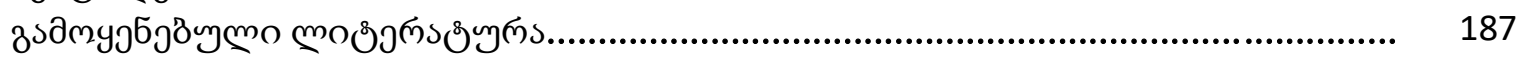

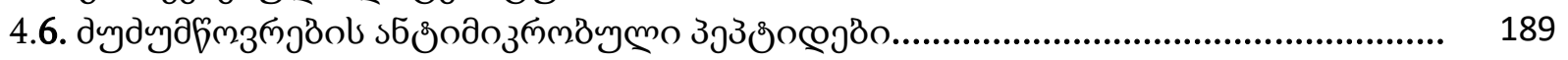

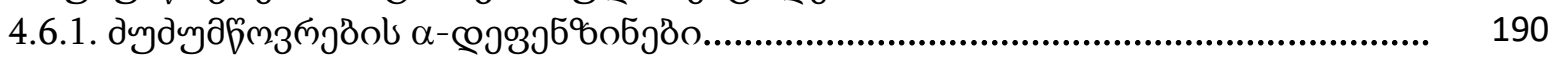

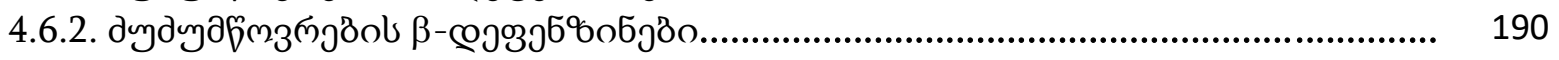

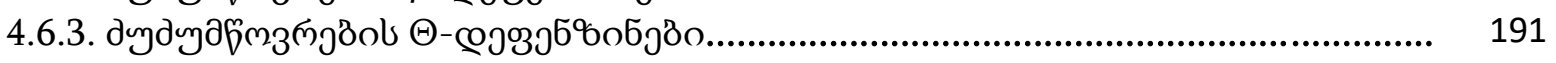

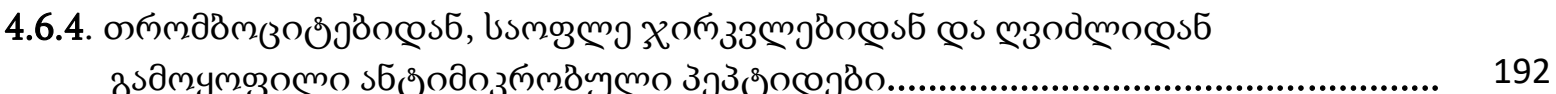

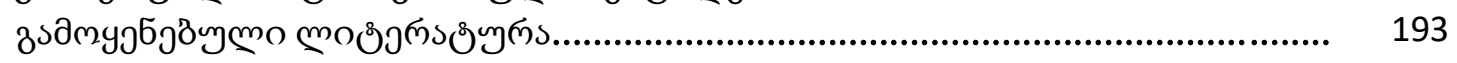

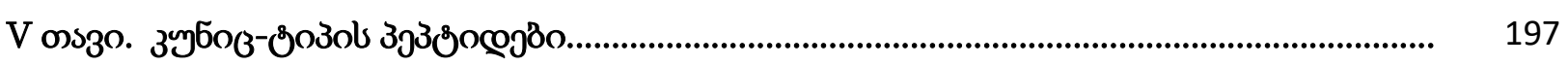

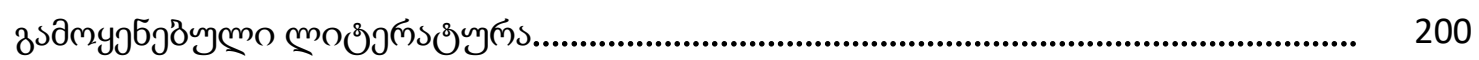

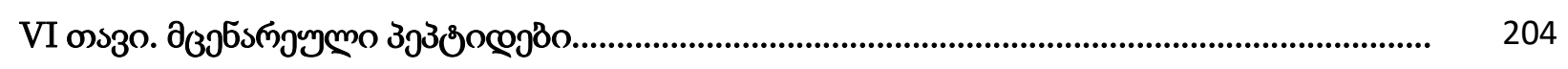

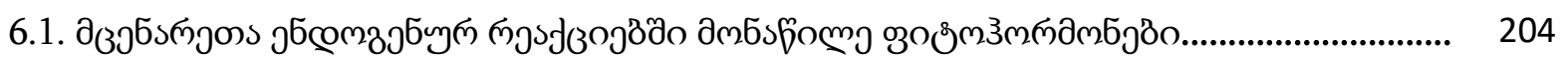

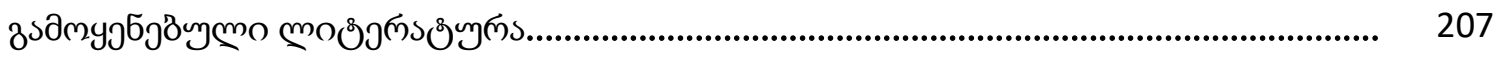

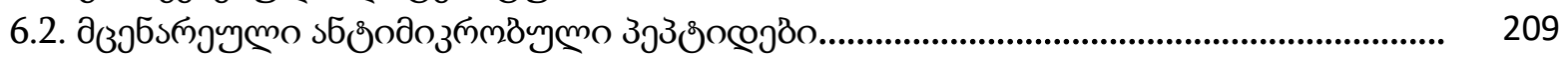

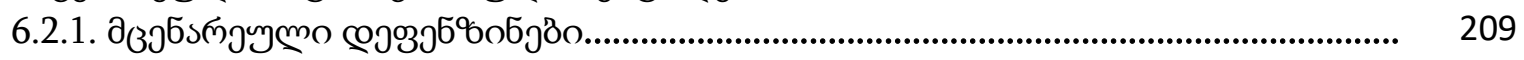

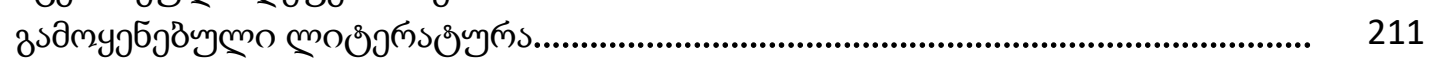

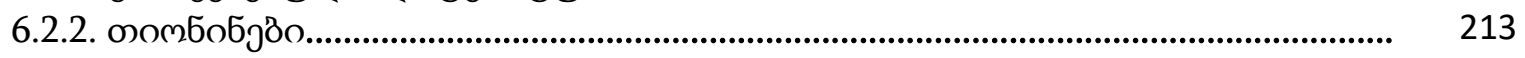

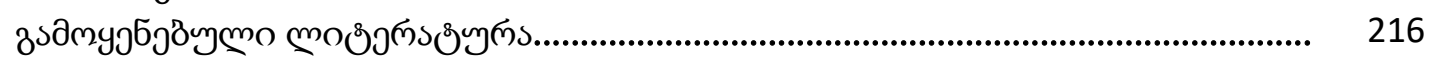

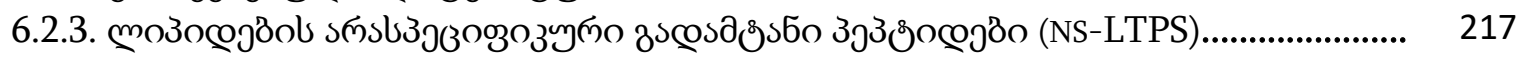

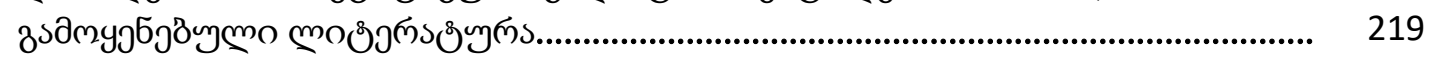

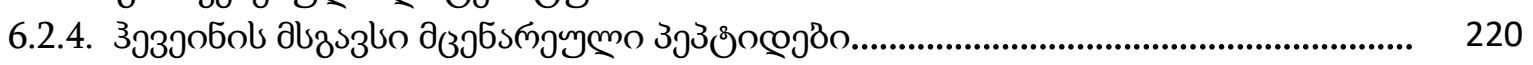

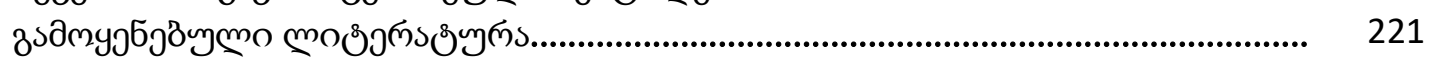

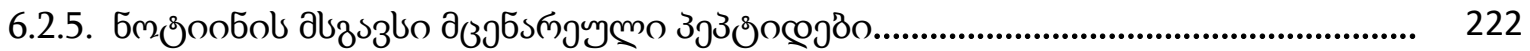

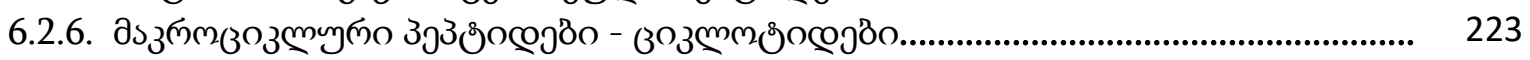

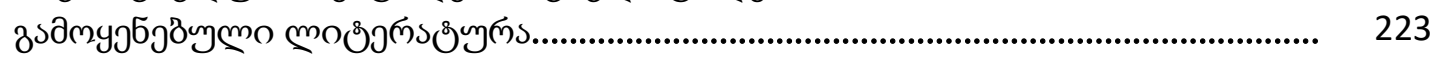




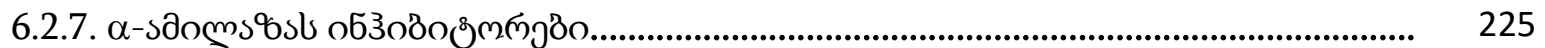

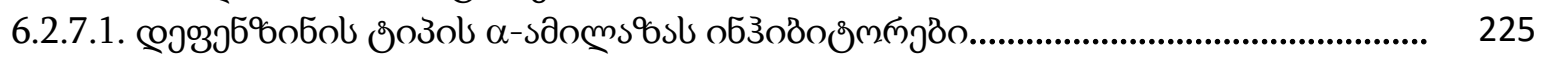

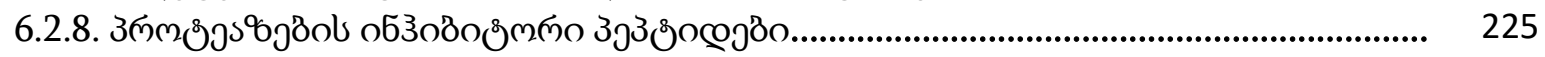

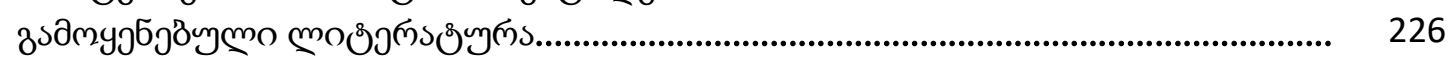

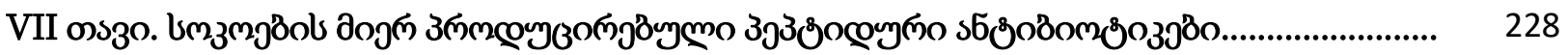

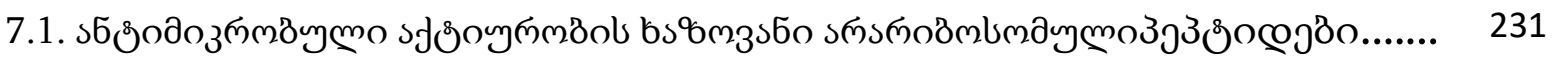

7.1.1. ЗృЗ

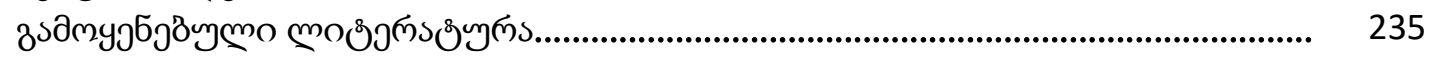

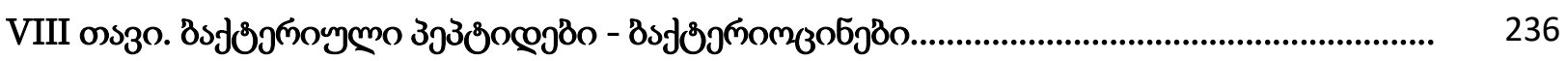

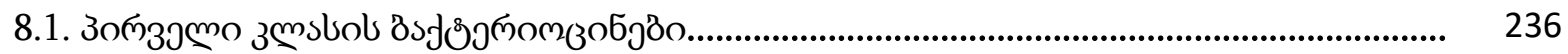

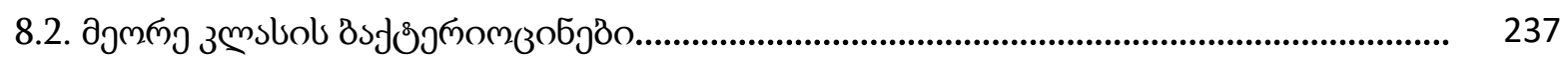

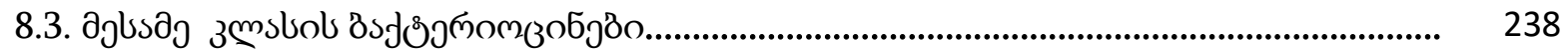

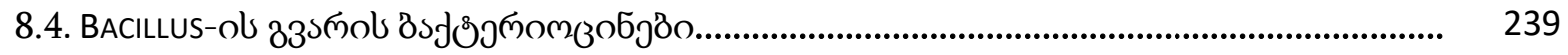

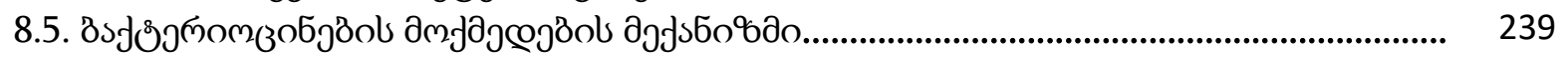

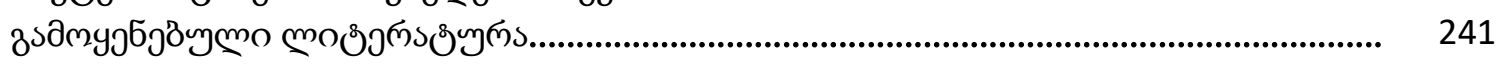

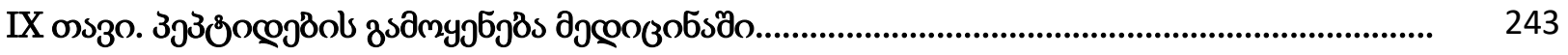

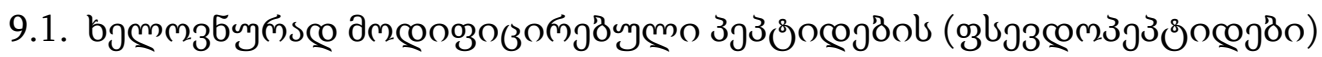

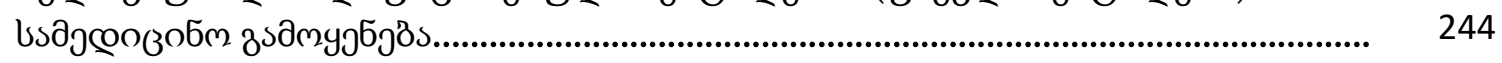

9.1.1. ऽ

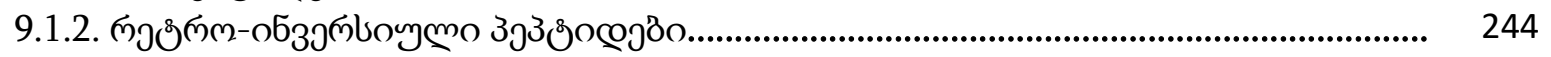

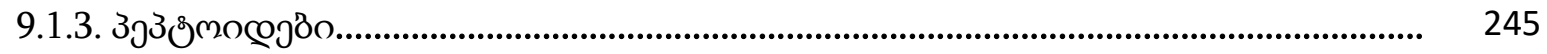

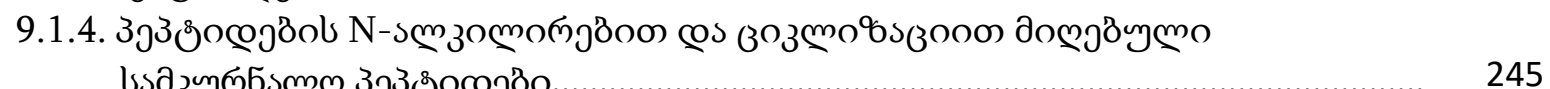

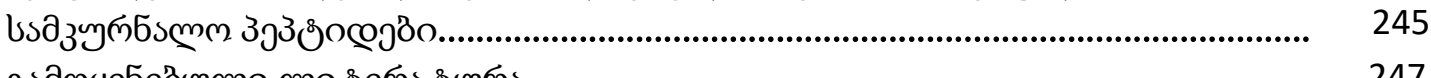

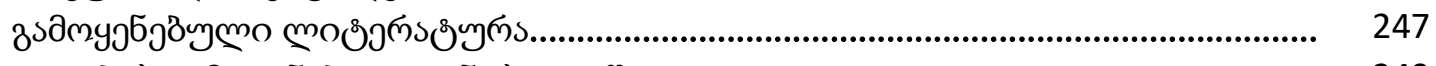

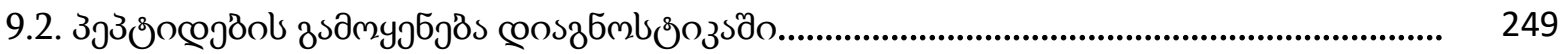

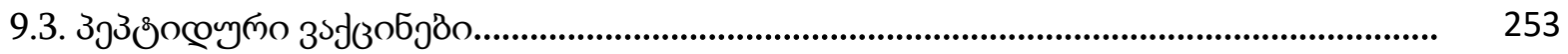

д

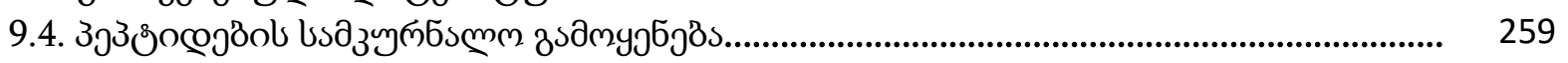

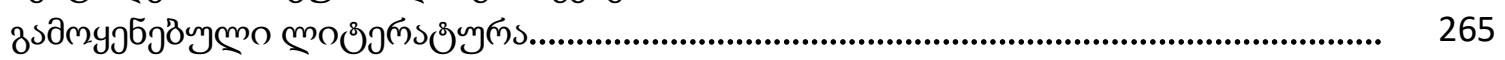

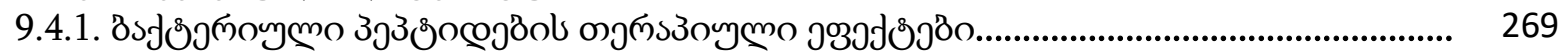

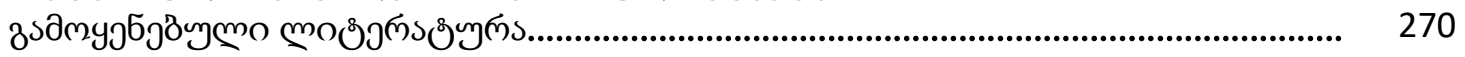

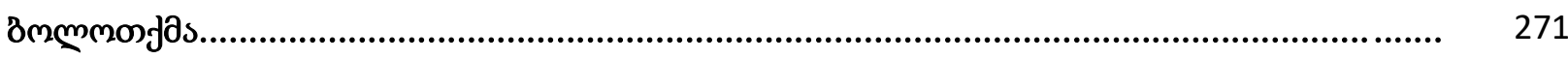




\section{gjusзsmo}

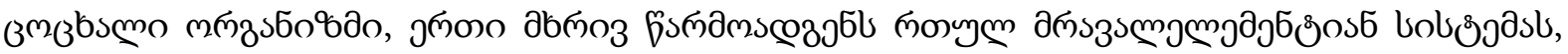

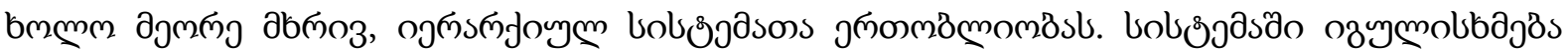

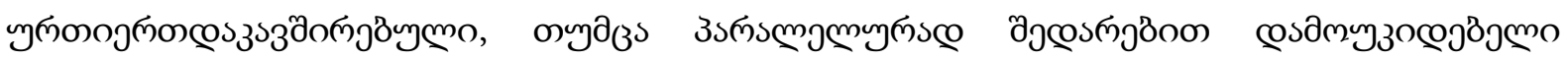

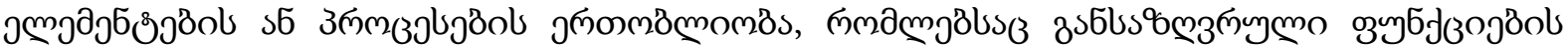

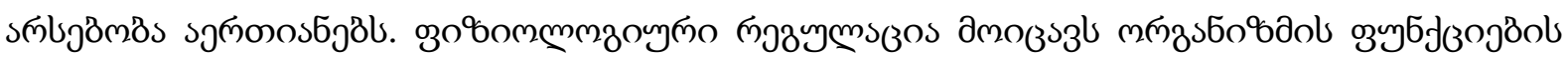

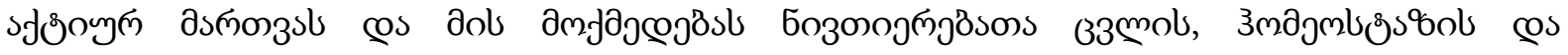

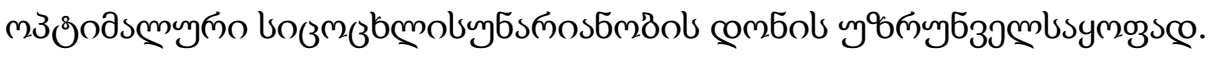

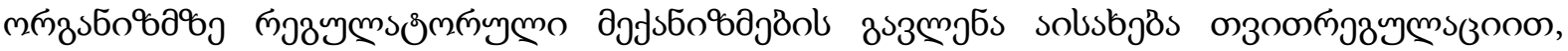

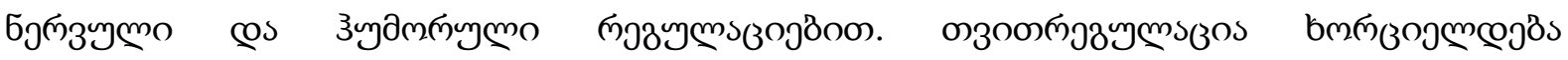

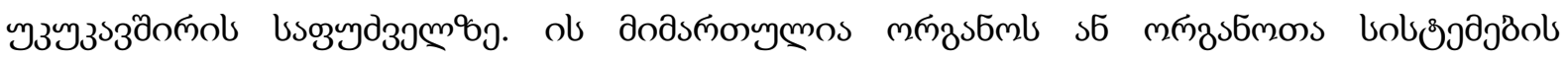

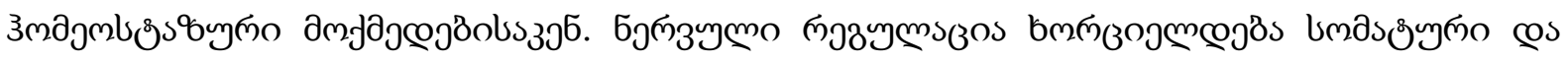

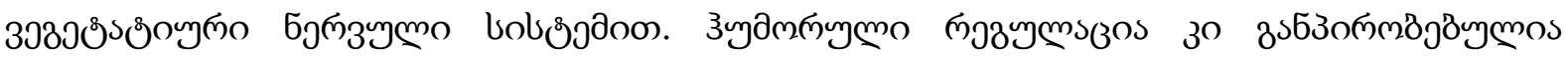

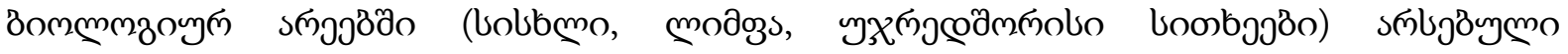

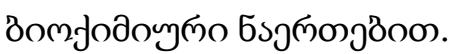

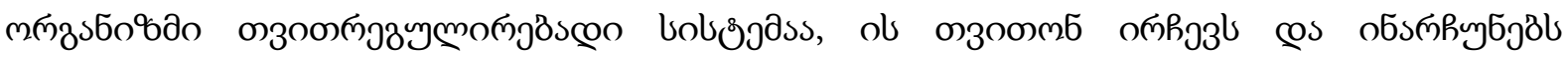

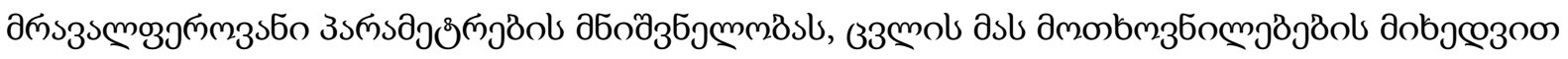

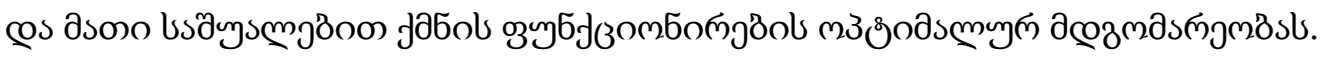

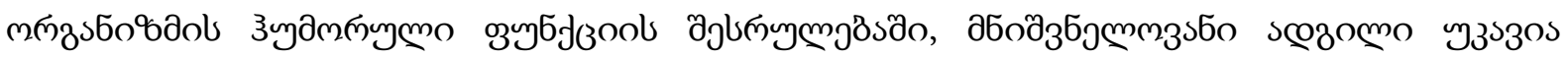

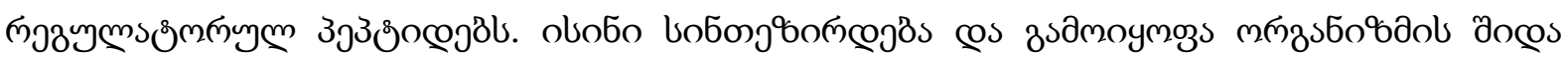

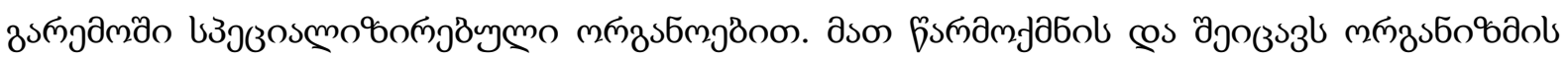

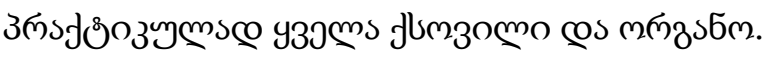

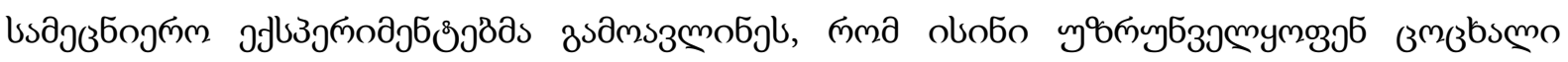

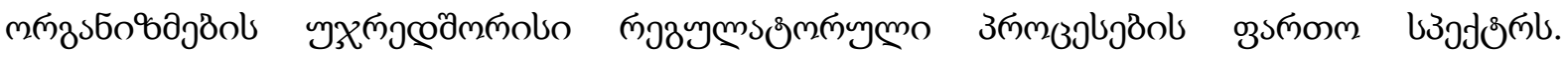

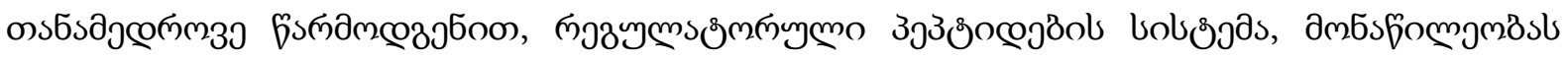

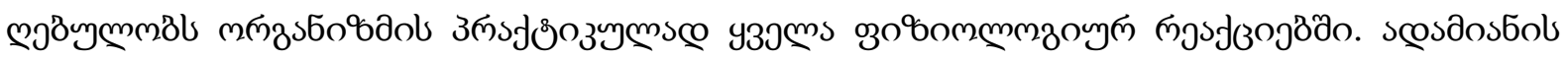

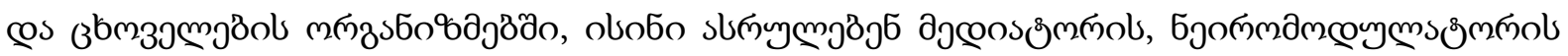

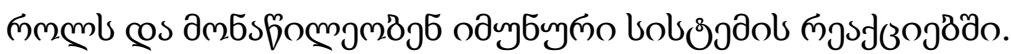

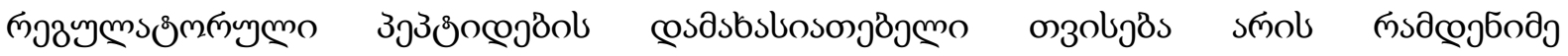

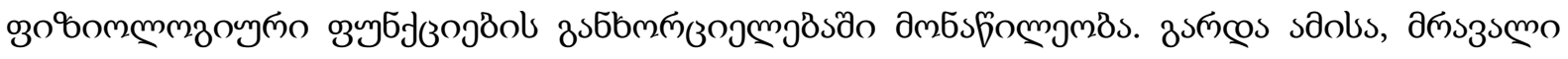

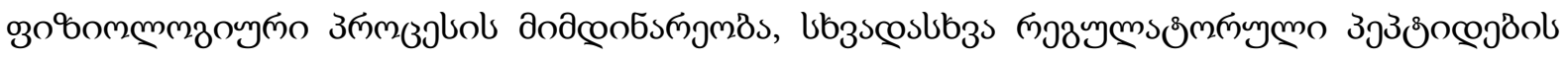

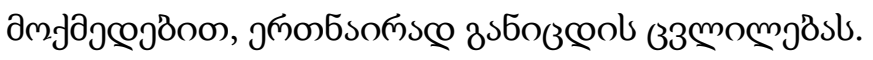

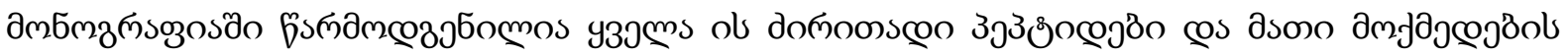

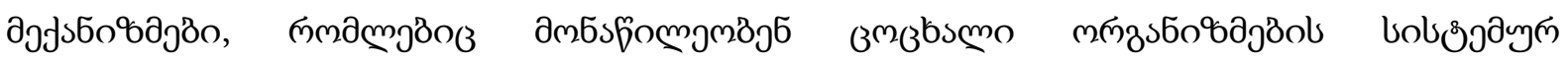

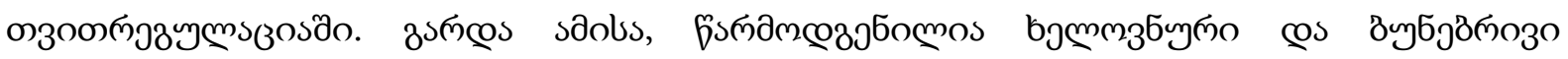

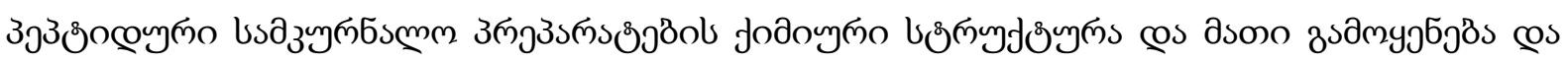

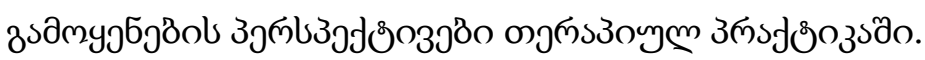




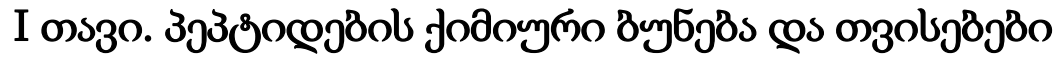

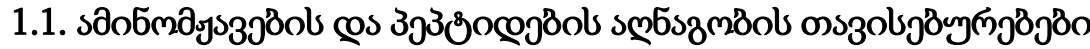

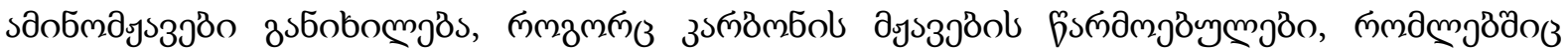

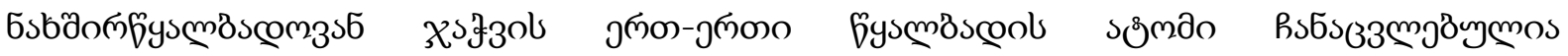

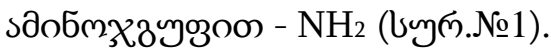

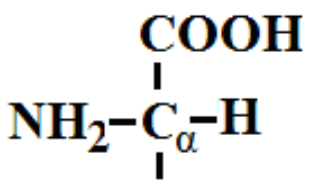

$\mathbf{R}$

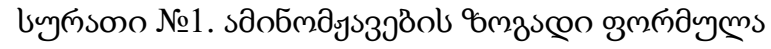

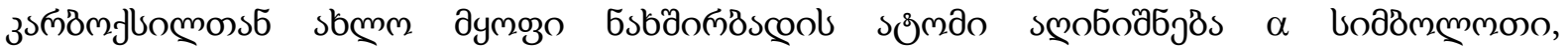

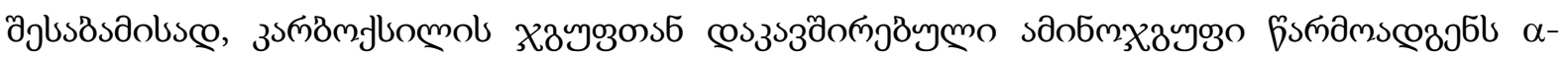

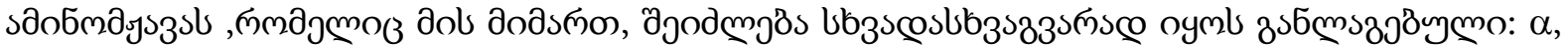

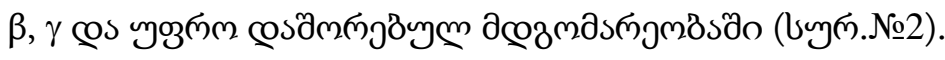

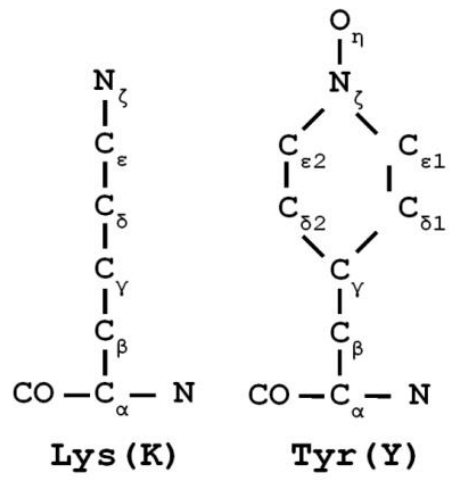

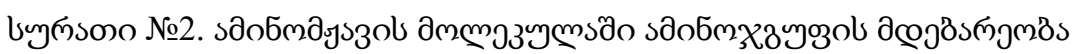

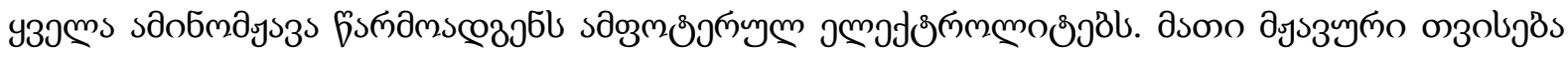

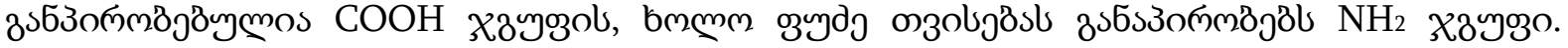

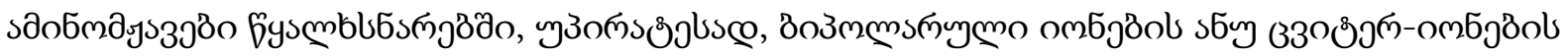
usbon sলrbjömals.

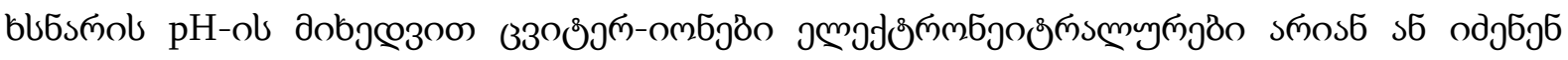

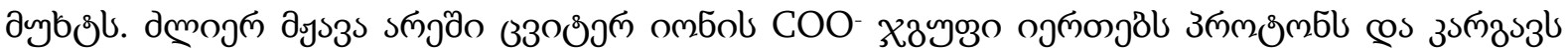

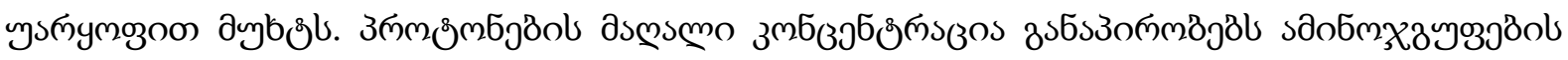

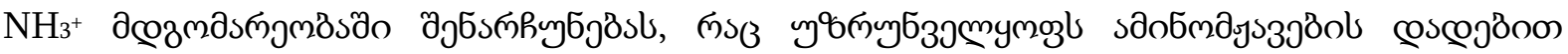

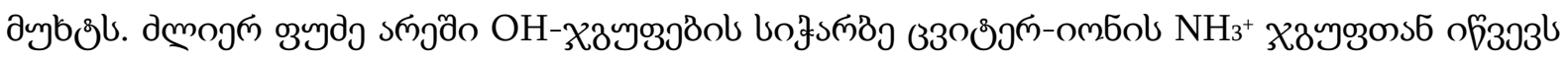

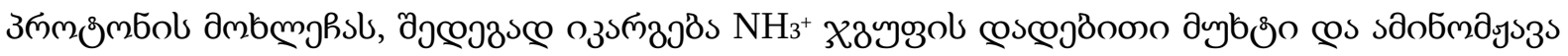

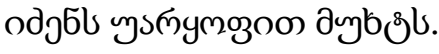

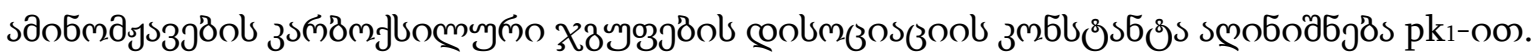




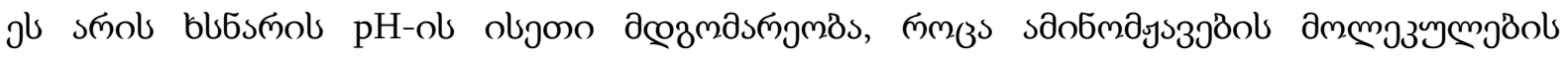

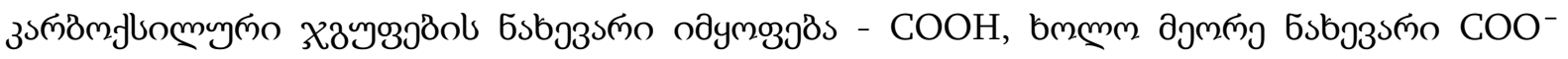

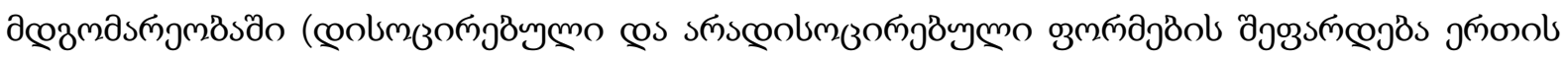
उ̈mmos).

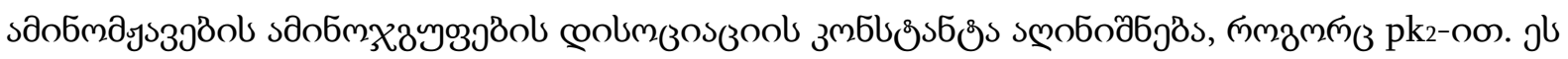

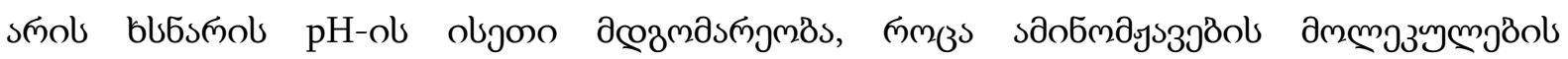

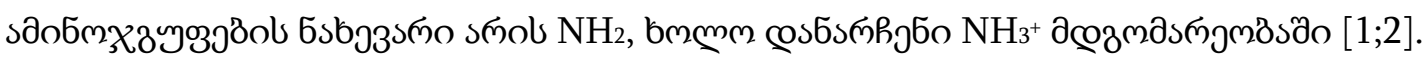

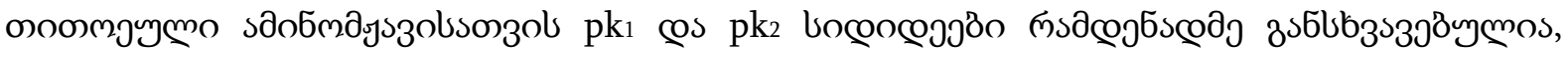

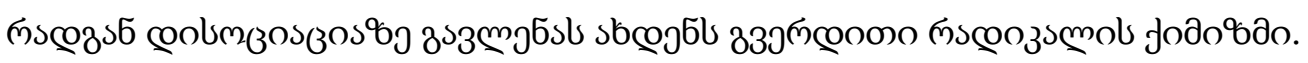

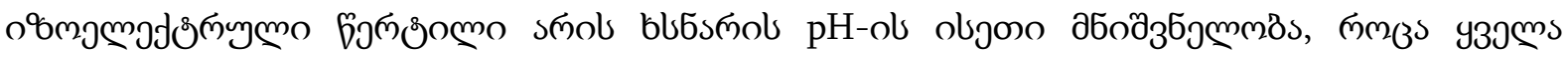

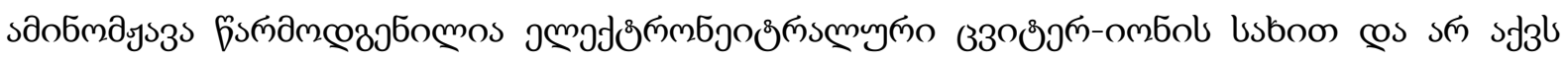

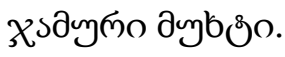

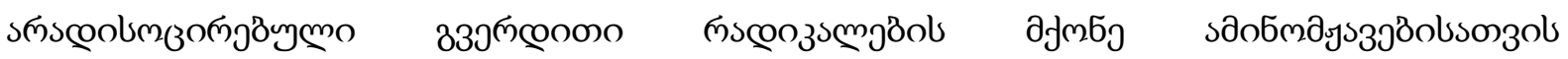

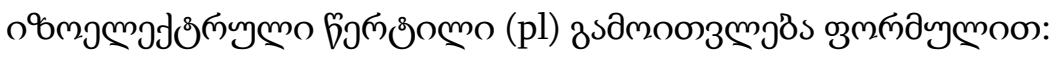

$$
\mathrm{pl}=\frac{\mathrm{pk}_{1}+\mathrm{pk}_{2}}{2}
$$

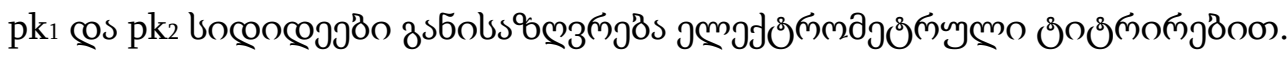

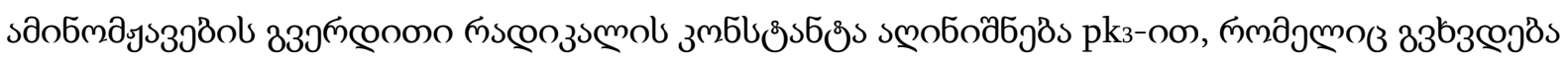

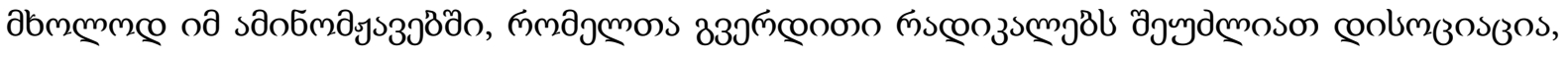

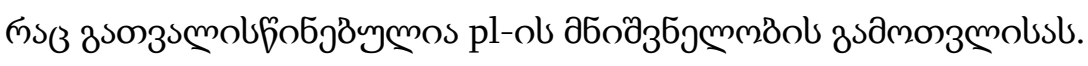

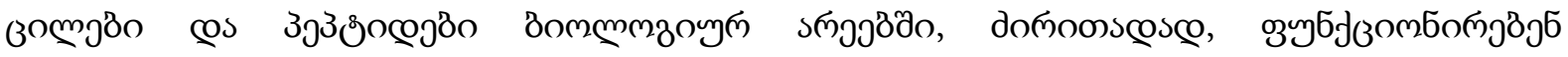

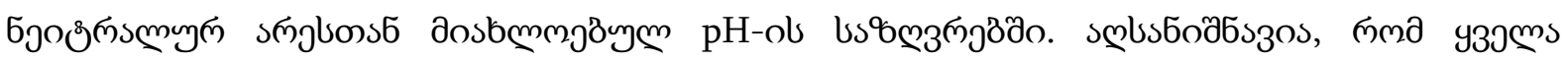

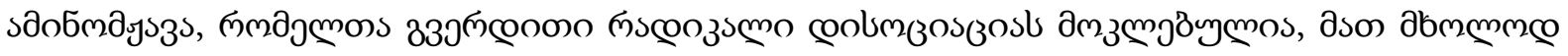

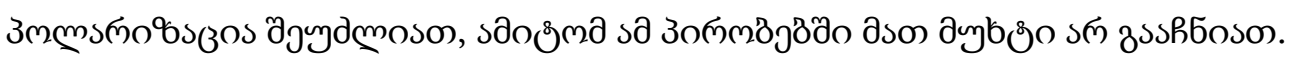

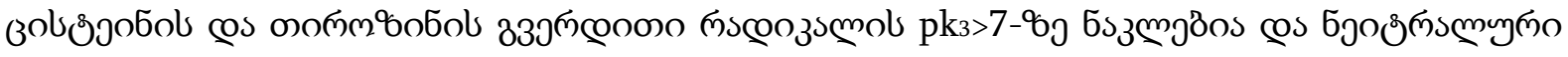

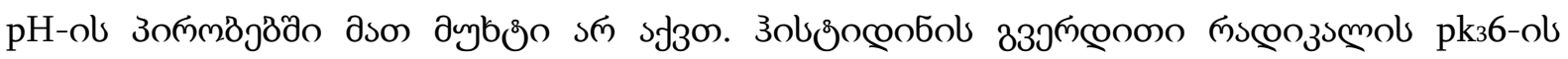

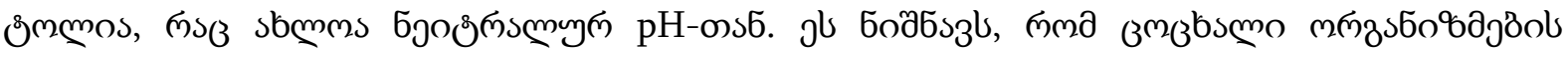

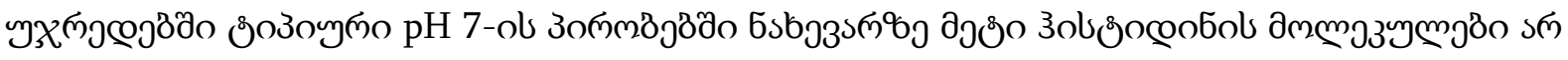

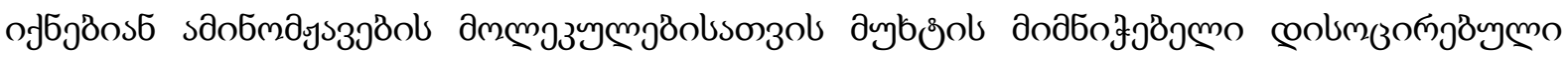

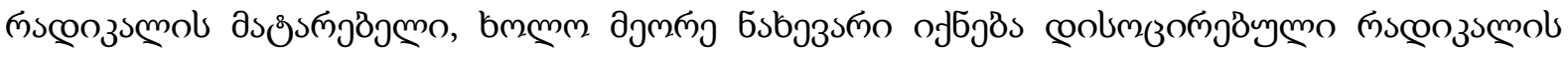

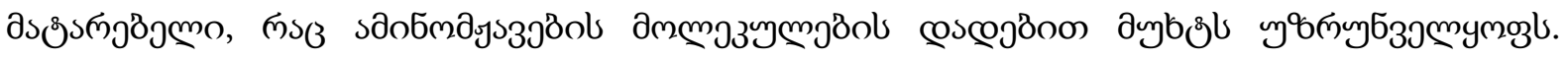

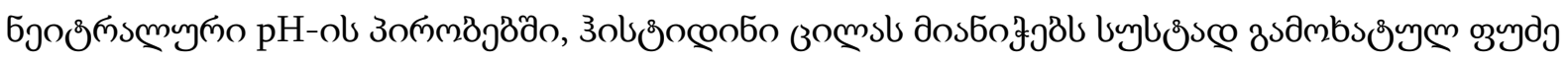

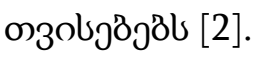

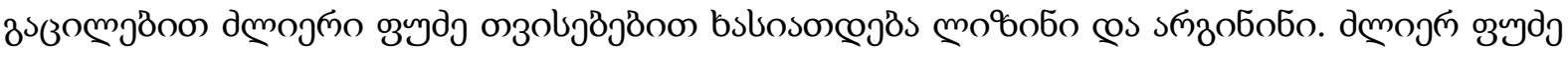

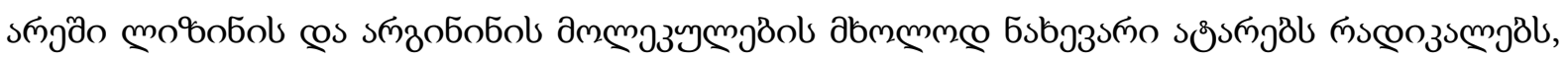

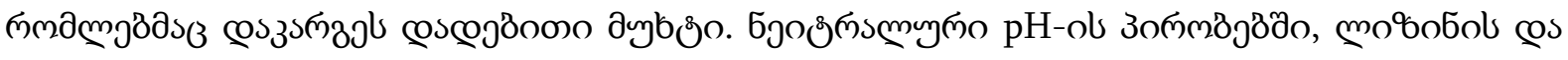

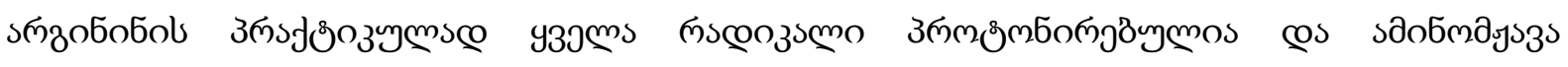

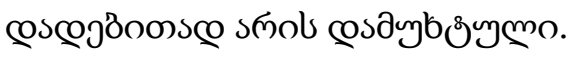

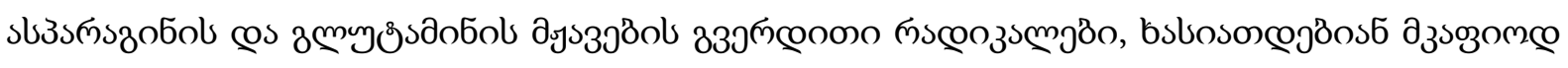

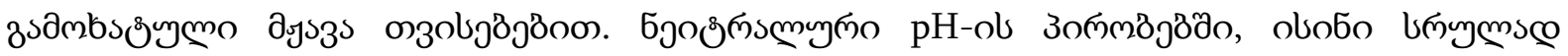




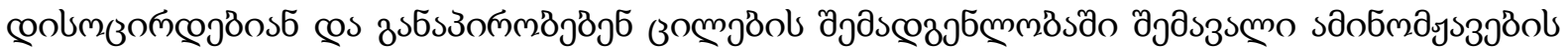
ysmymognon dybşb.

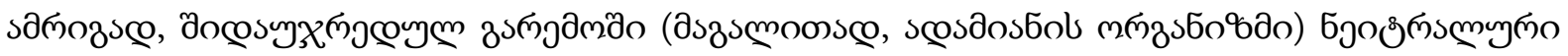

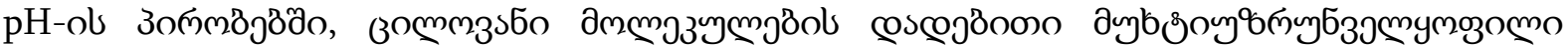

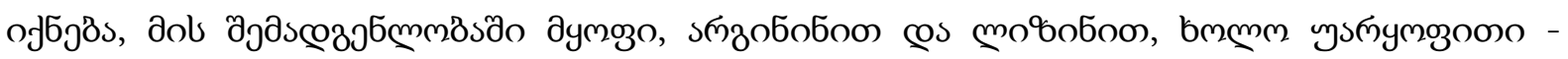

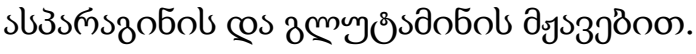

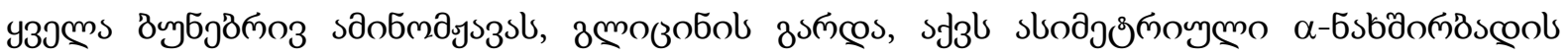

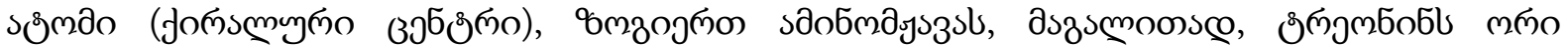

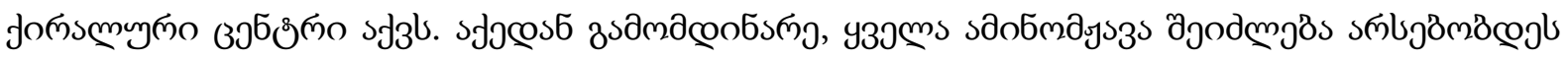

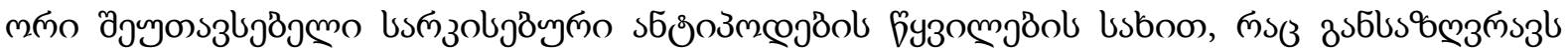

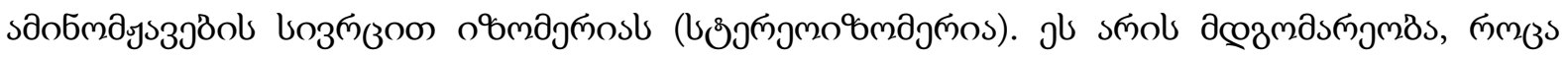

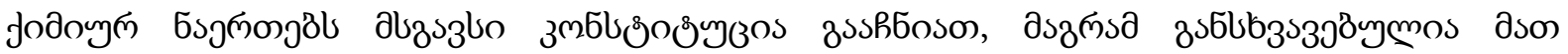

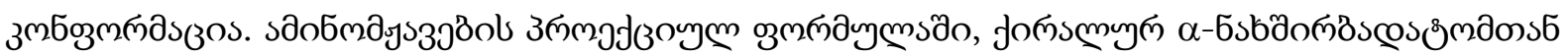

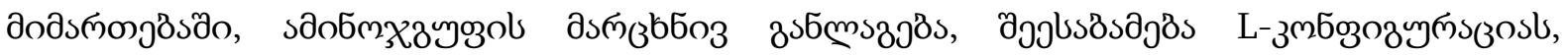

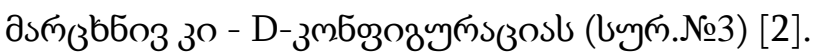

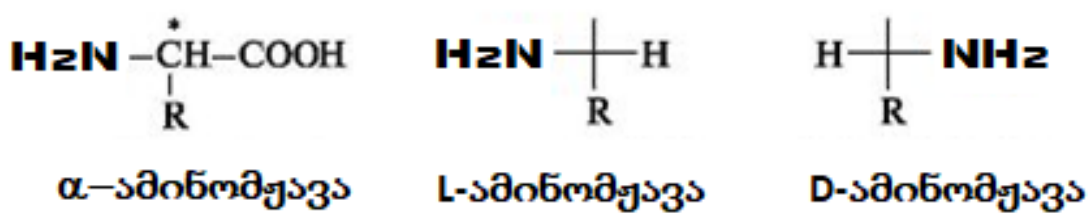

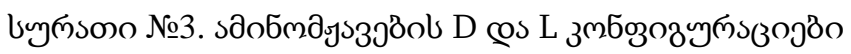

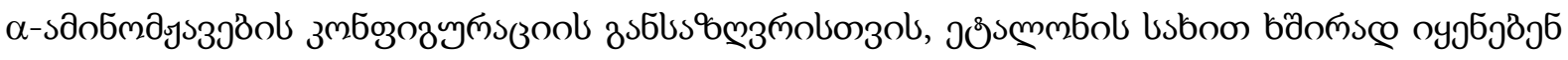

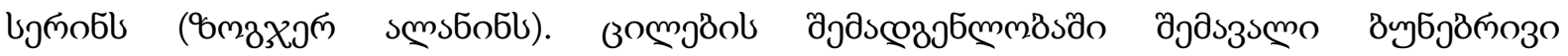

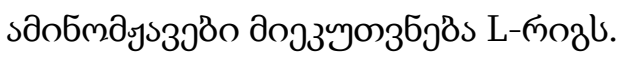

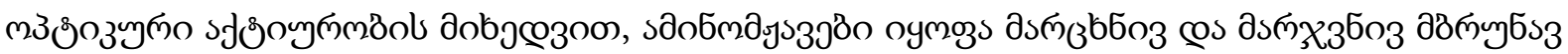

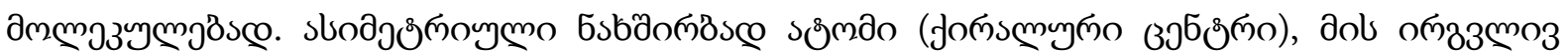

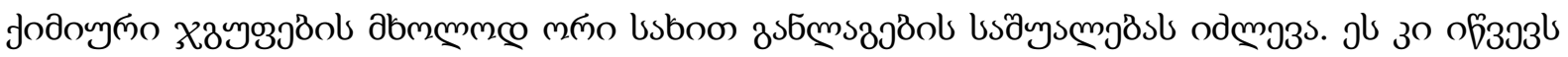

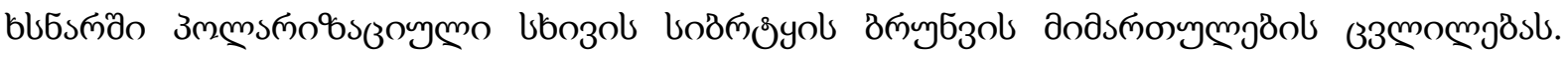

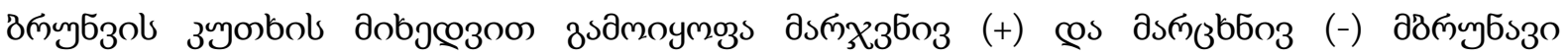

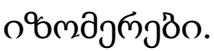

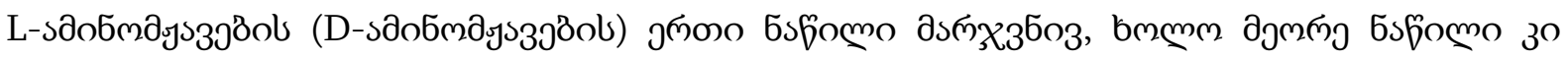

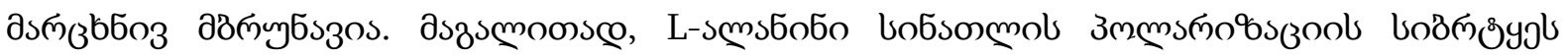

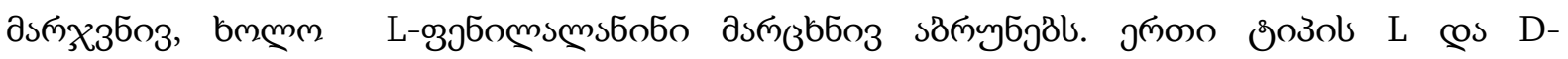

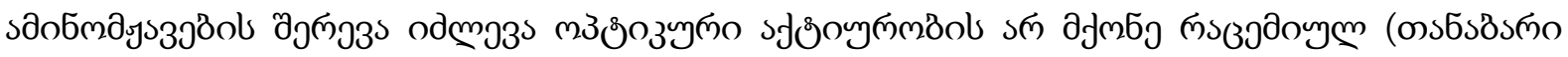

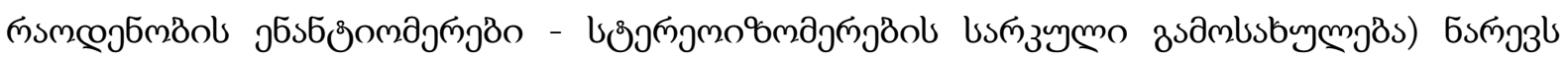
$[1 ; 14]$.

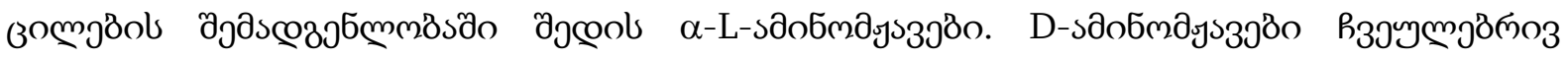

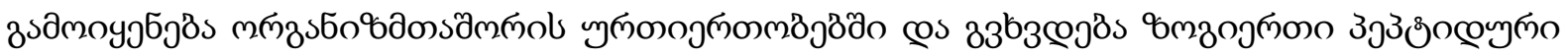

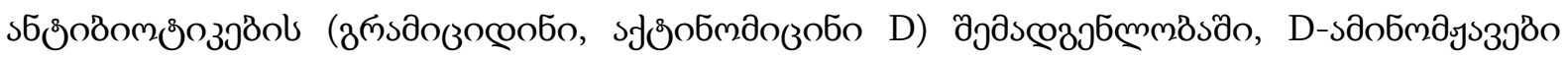

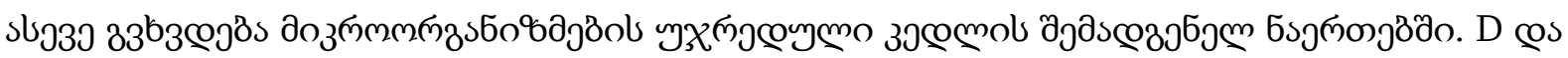




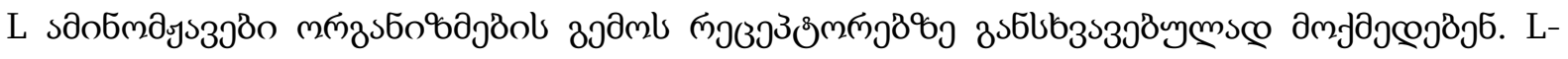

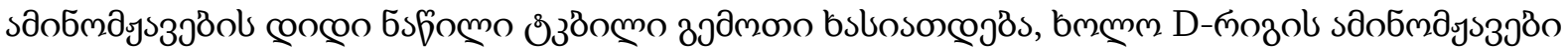

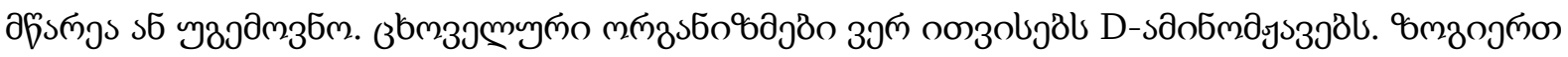

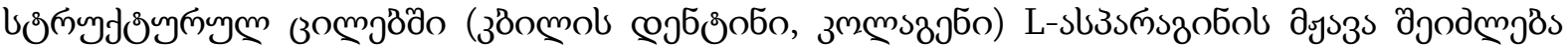

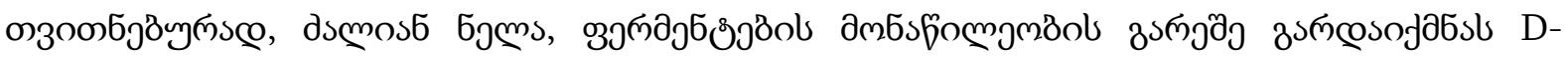

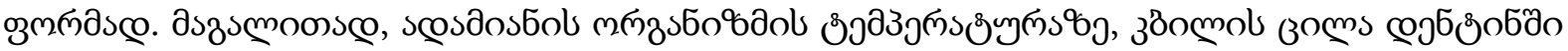

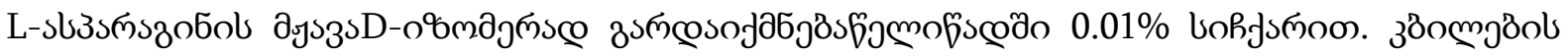

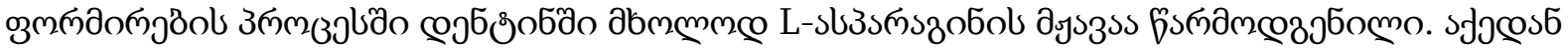

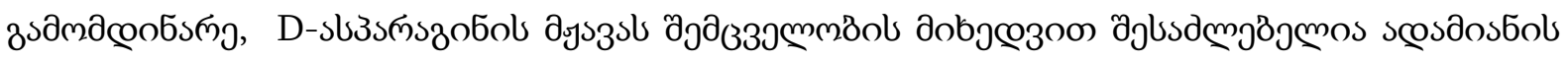
cos zbmzamol sluszol zsamonzms.

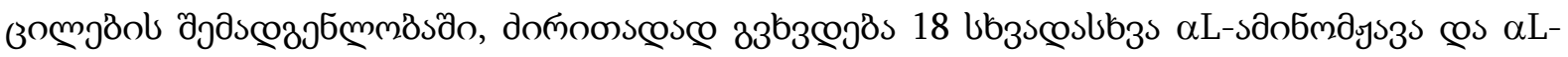

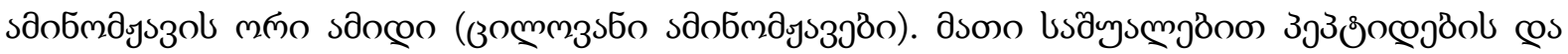

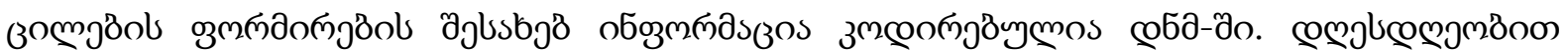

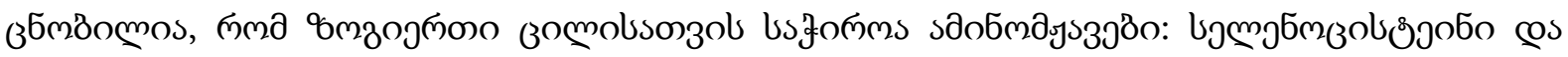

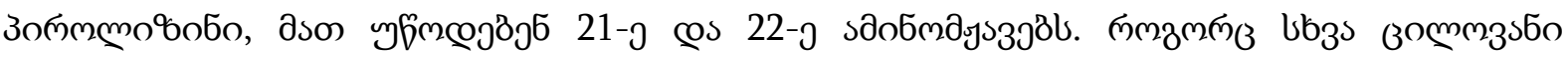

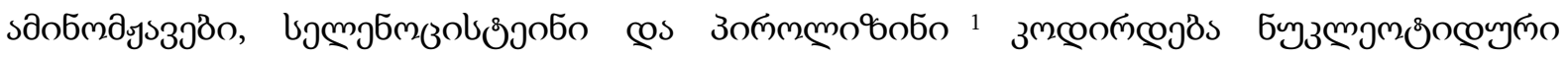

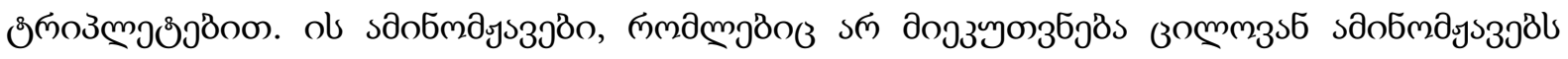

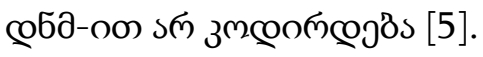

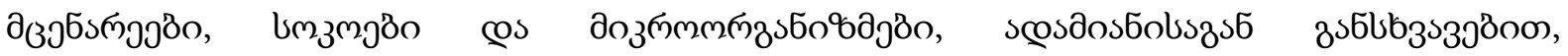

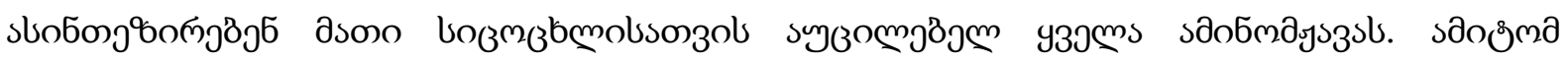

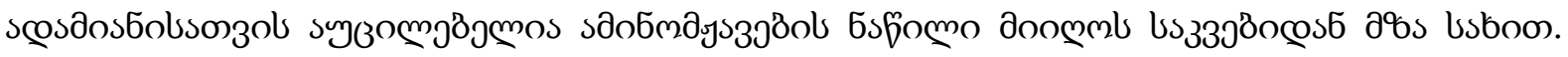

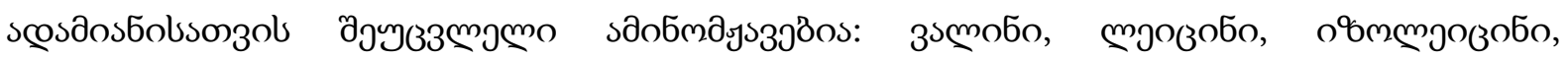

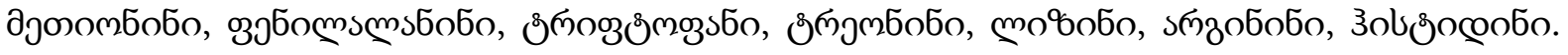

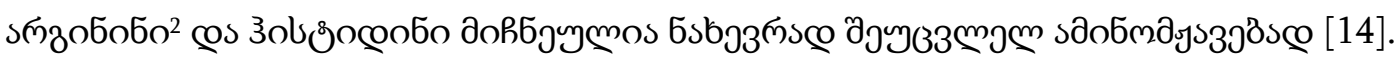

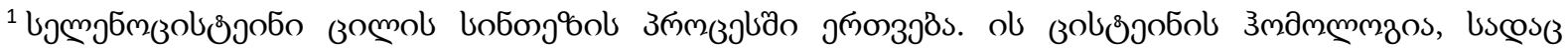

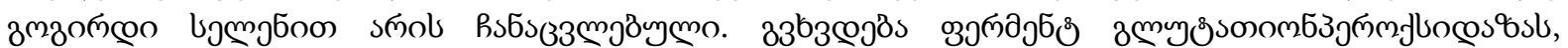

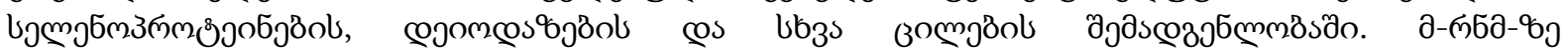

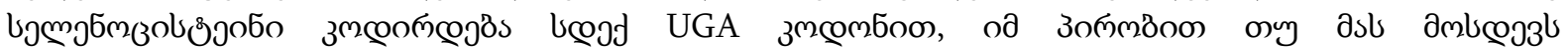

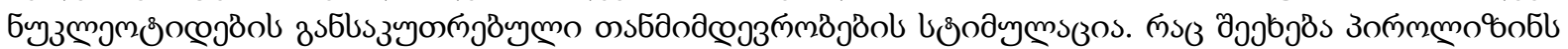

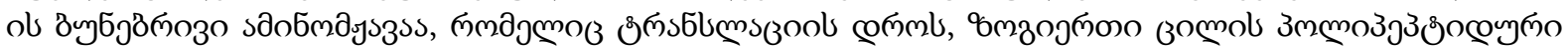

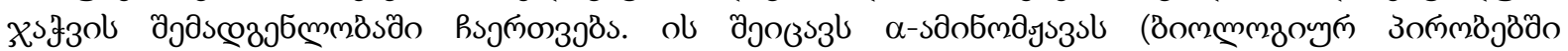

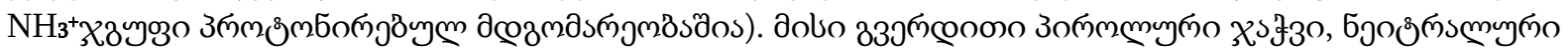

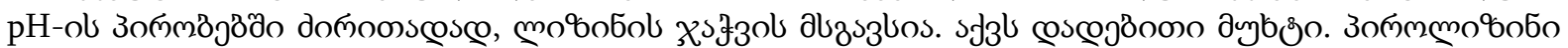

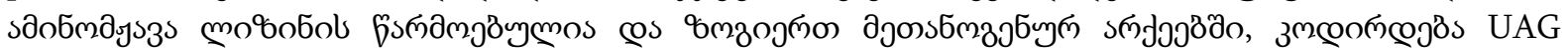

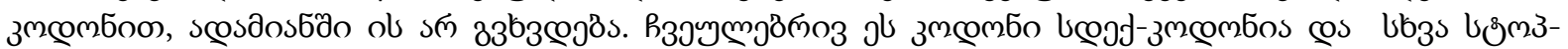

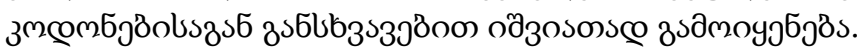

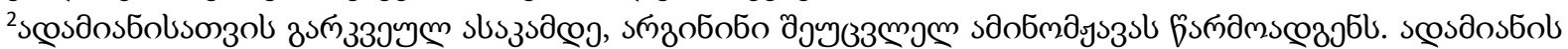

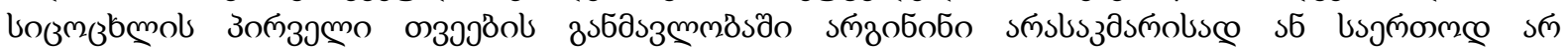

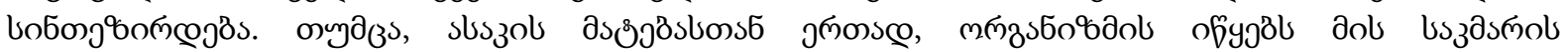

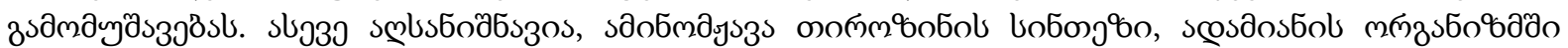

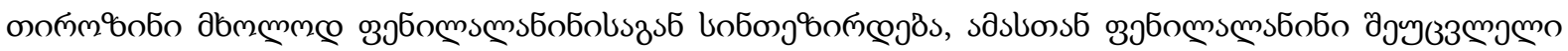

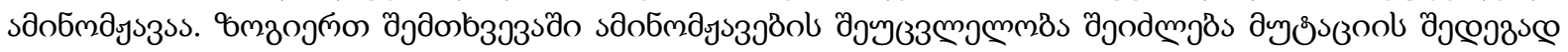
змдмзјбель.
} 


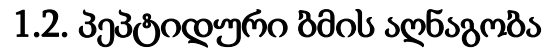

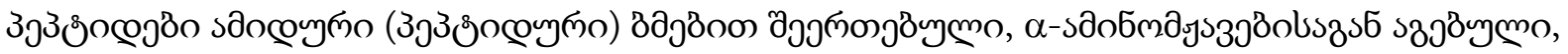

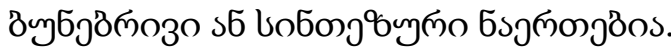

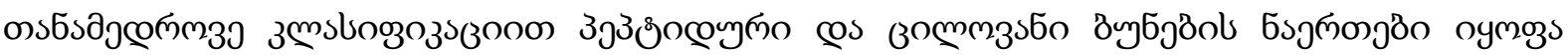

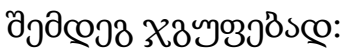

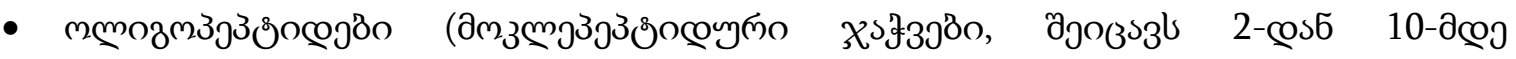

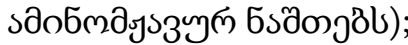

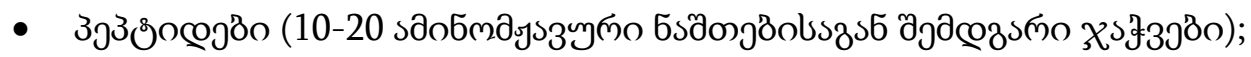

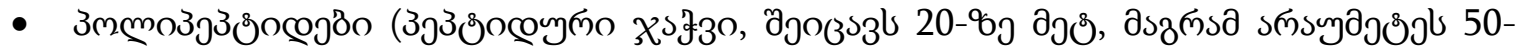

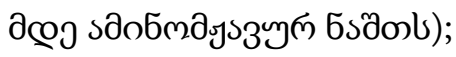

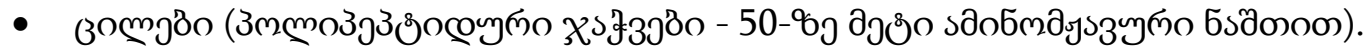

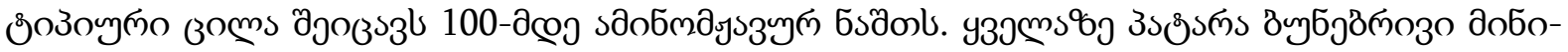

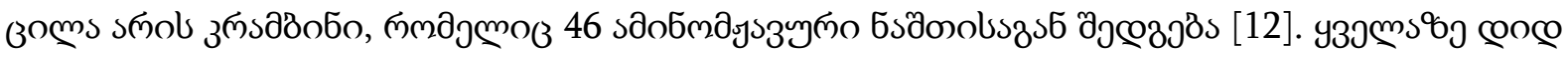

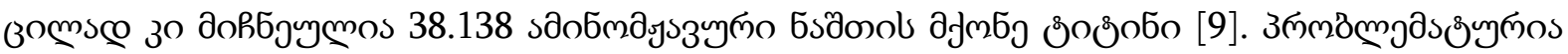

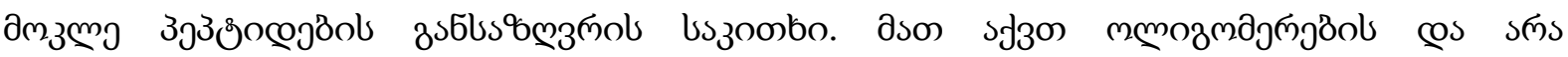

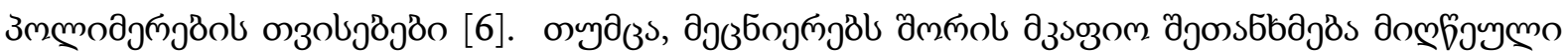

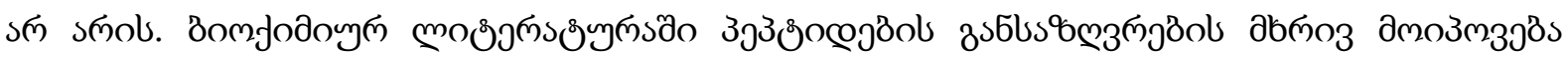

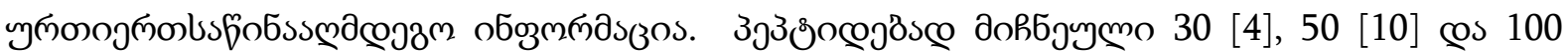

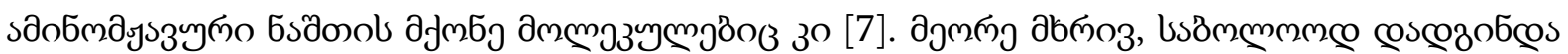

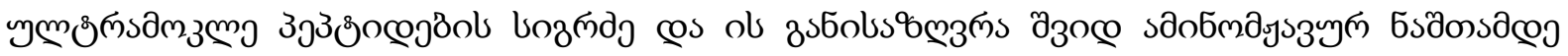

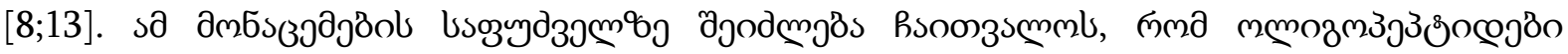

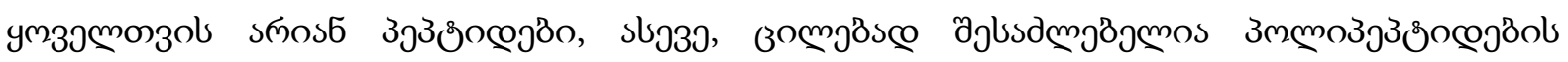

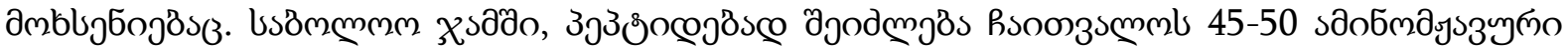

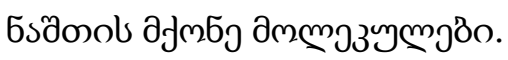

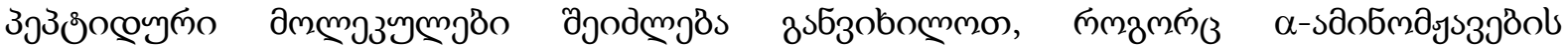

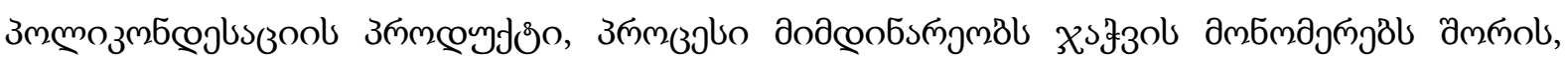

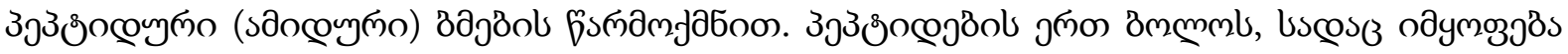

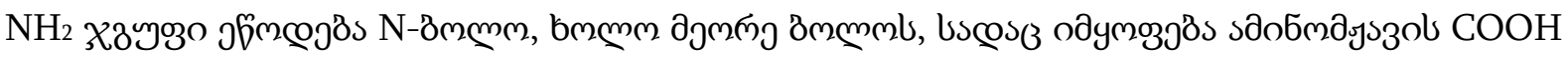

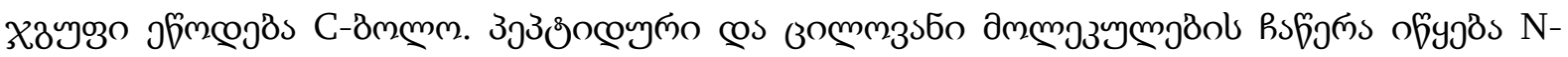
вммммюs6[6].

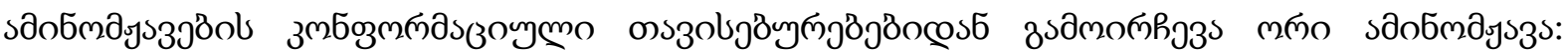

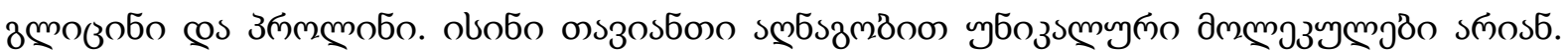

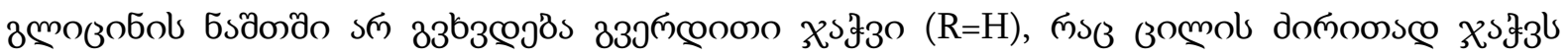

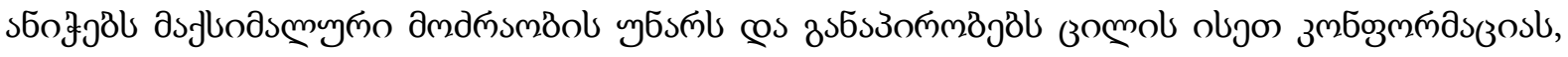

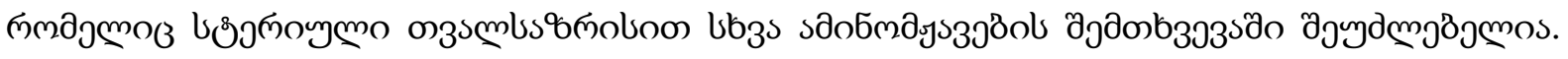

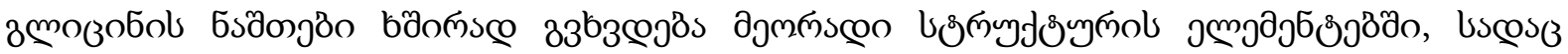

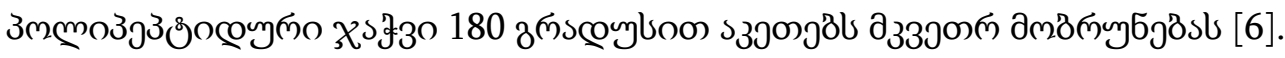

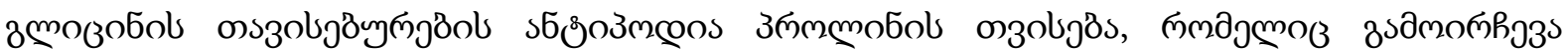

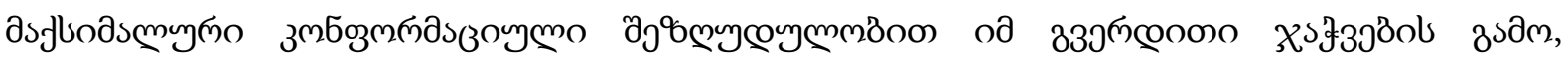

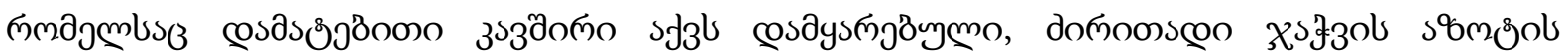




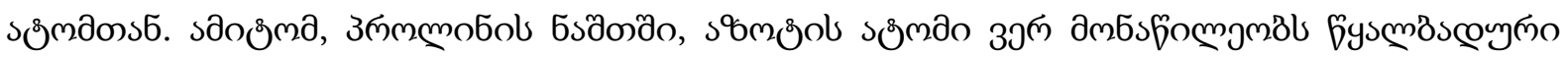

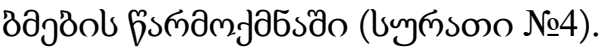

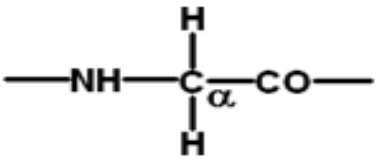

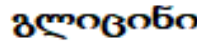

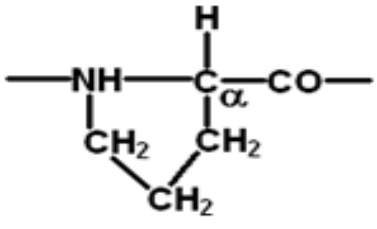

उलмलmo6n

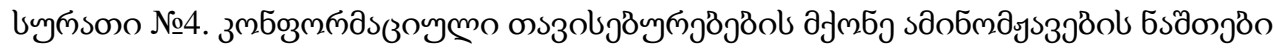

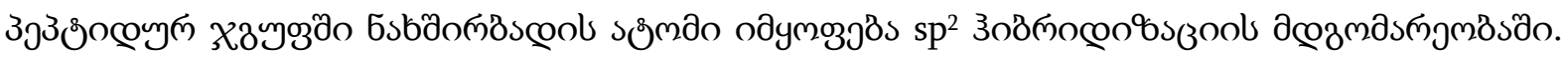

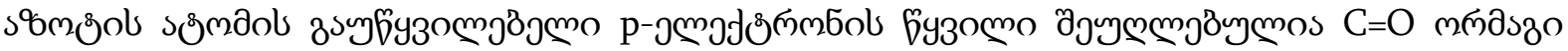

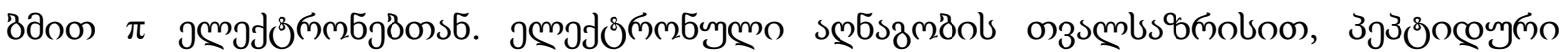

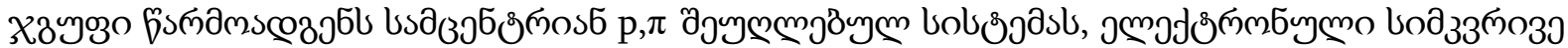

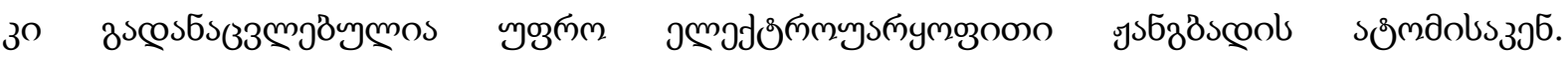

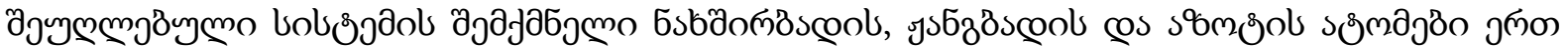

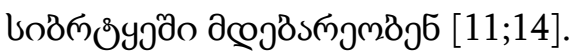

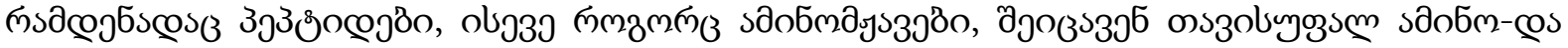

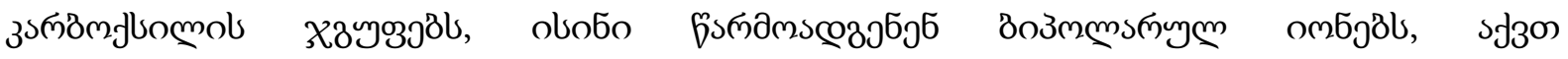

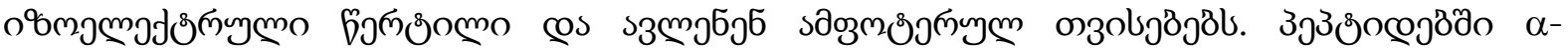

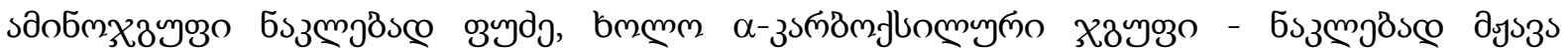

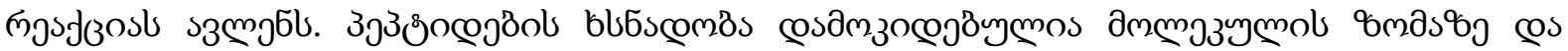

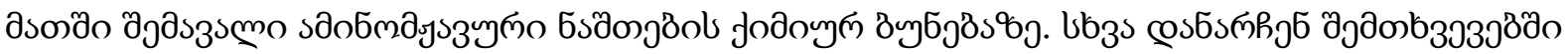

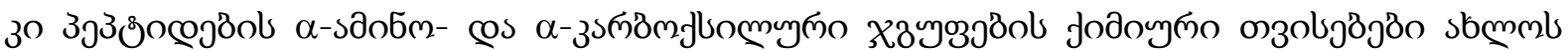

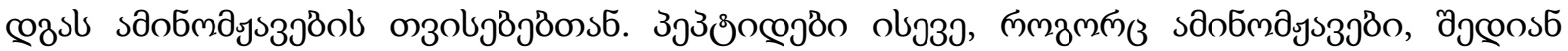

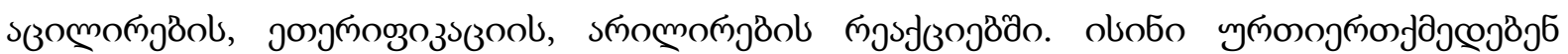

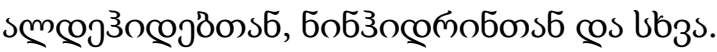

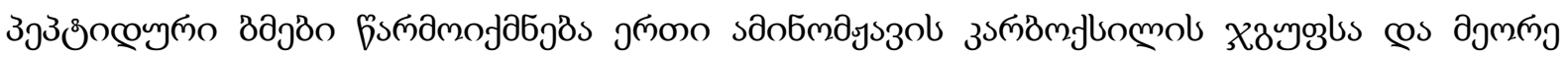

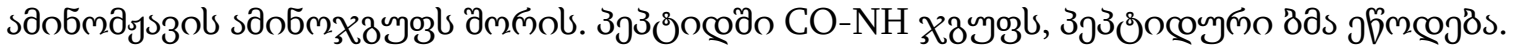

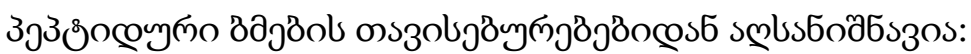

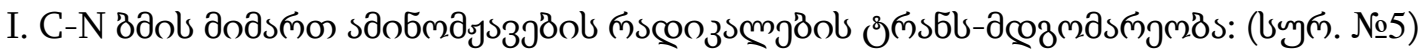

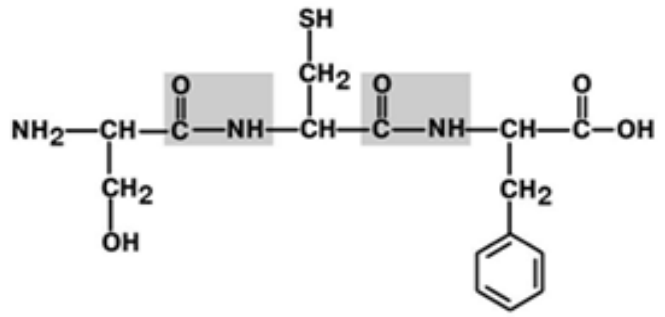

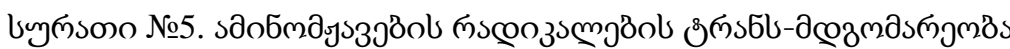




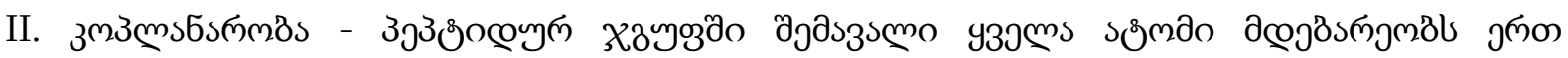

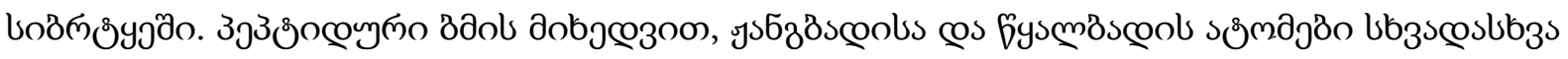

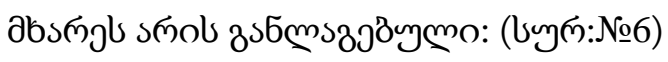

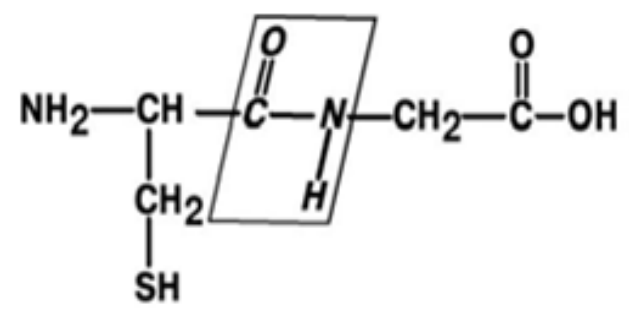

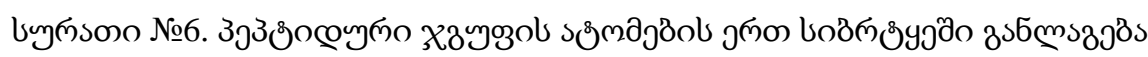

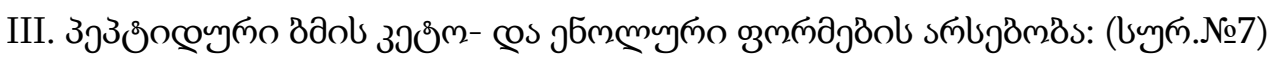

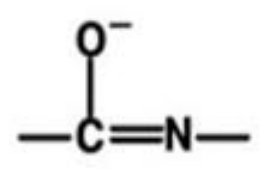

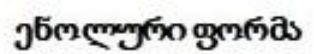

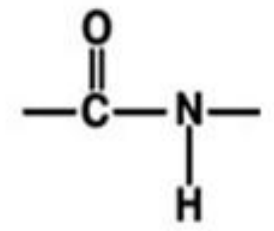

3ग0लmलmas

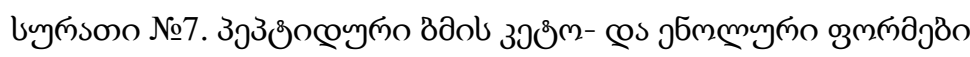

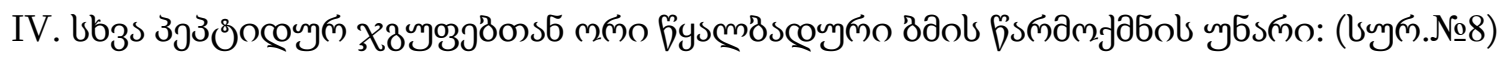

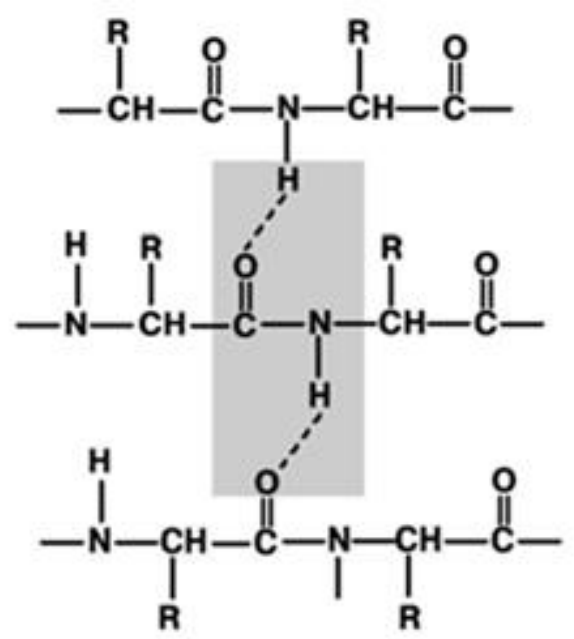

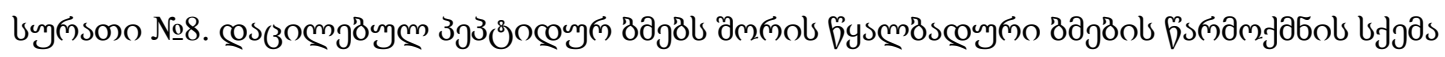

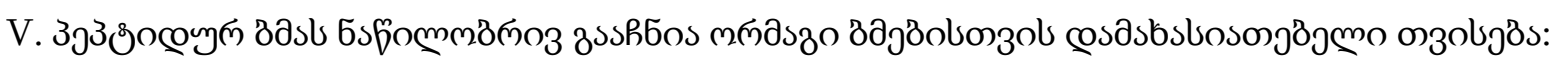




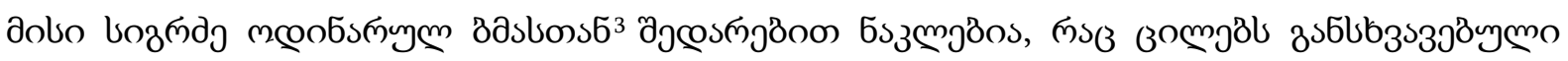

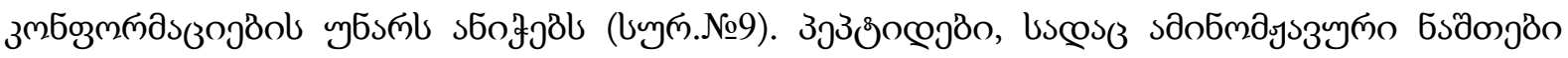

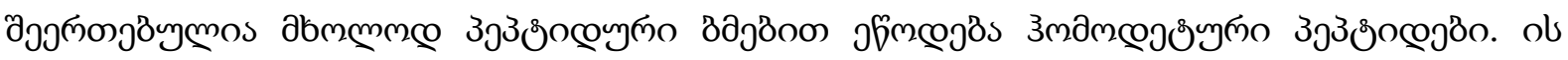

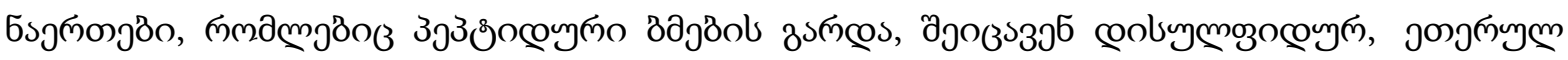

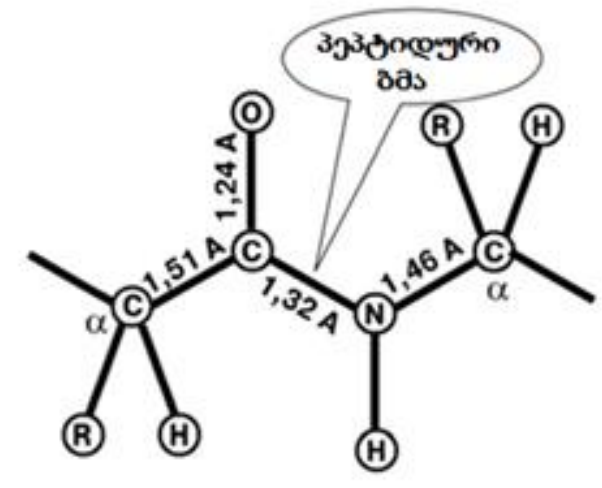

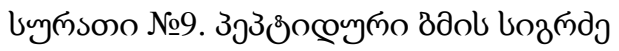

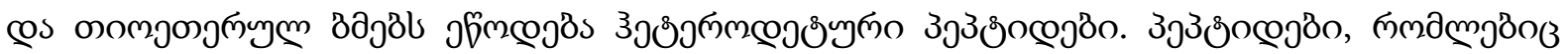

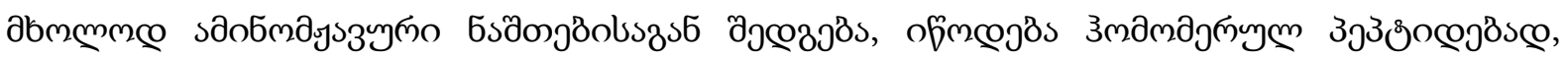

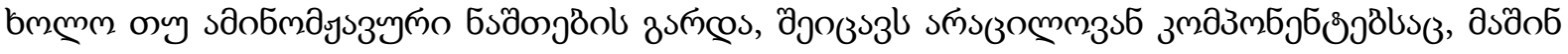

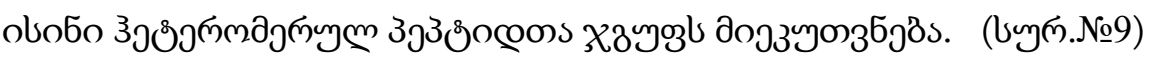

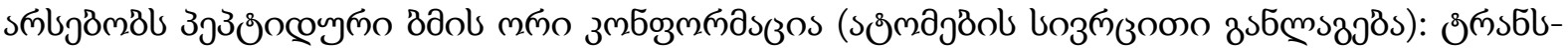

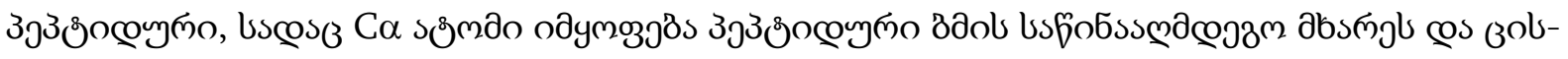

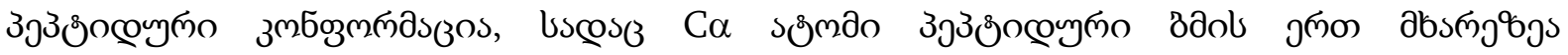

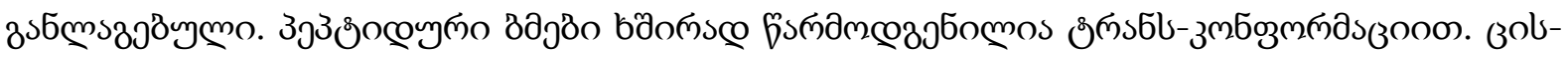

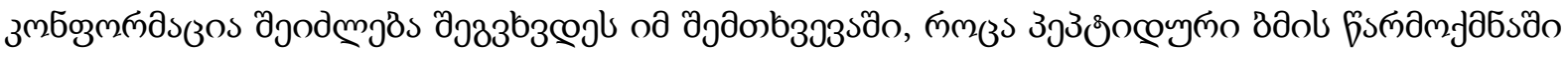

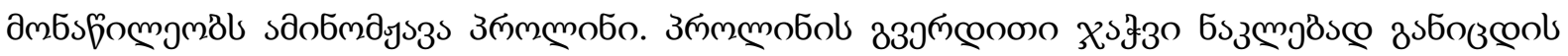

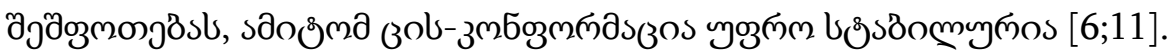

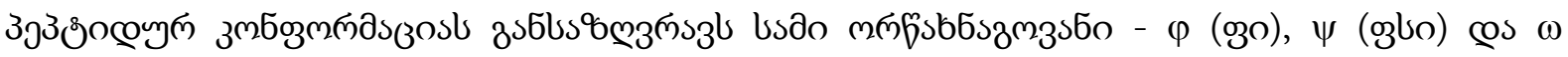

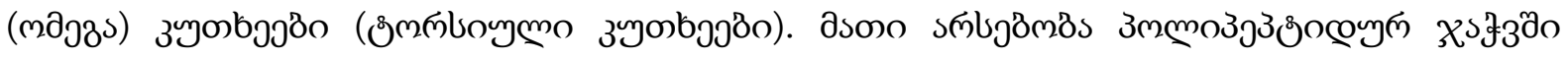

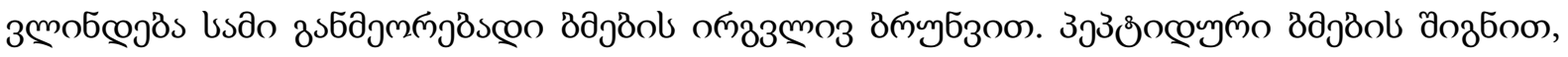

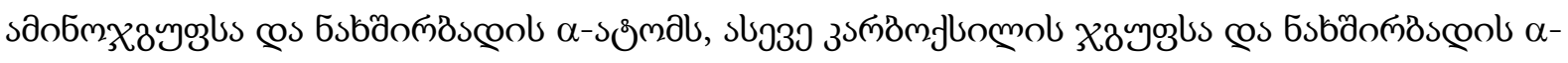

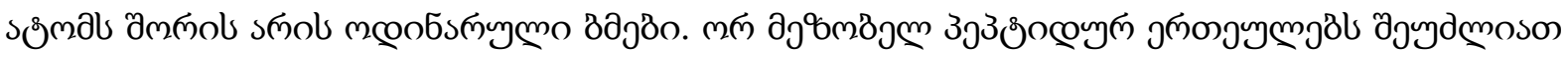

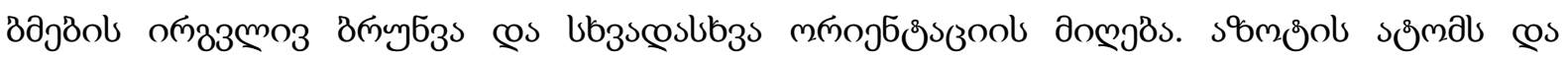

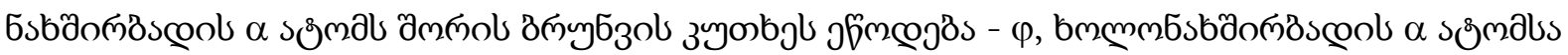

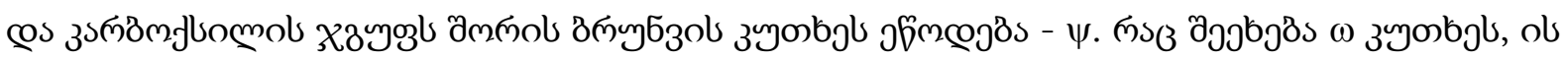

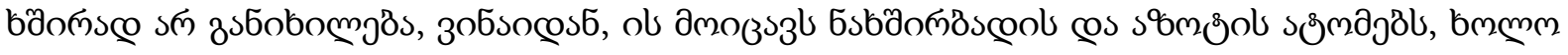

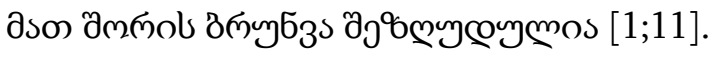

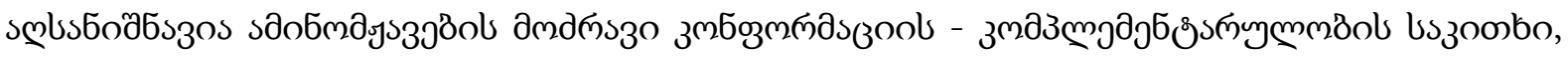

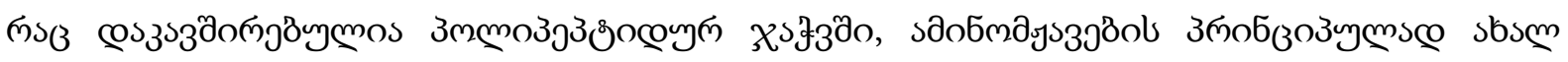

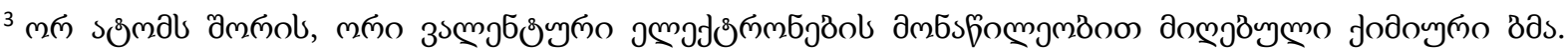

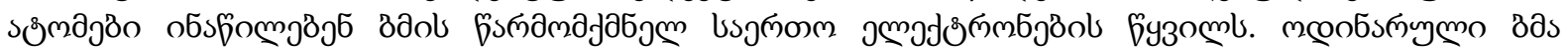

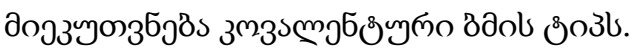




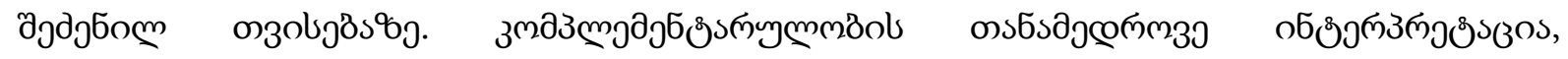

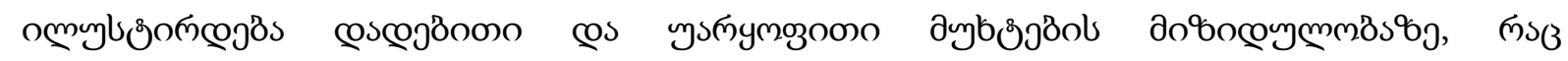

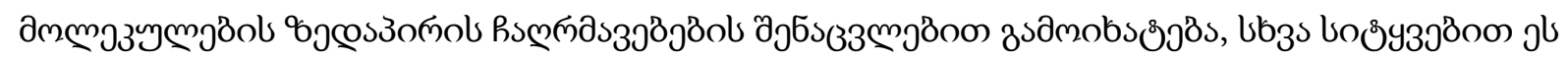

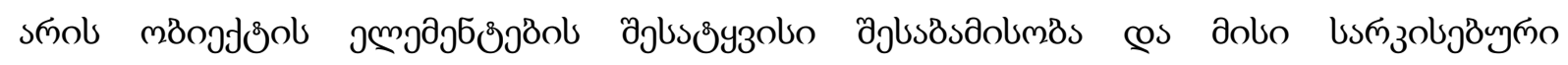
zsambsbymgßs.

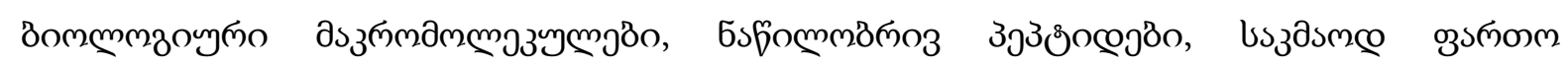

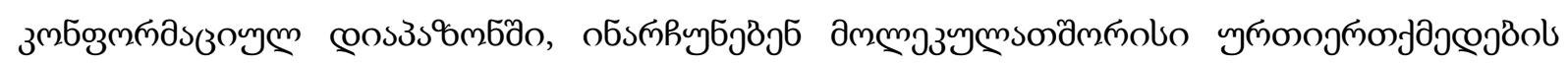

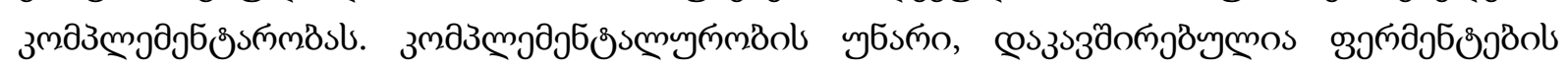

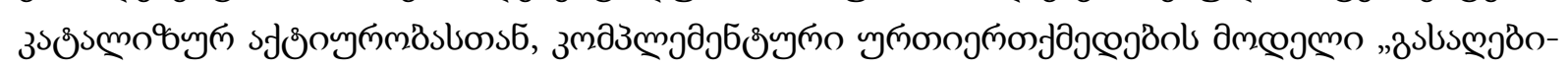

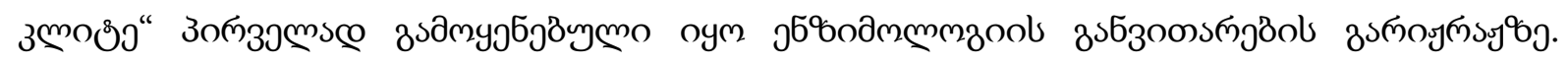

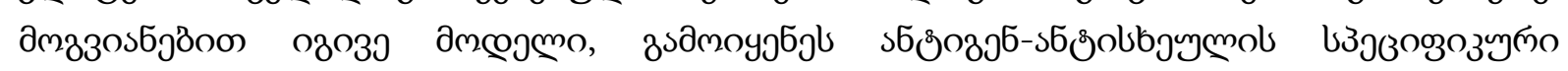

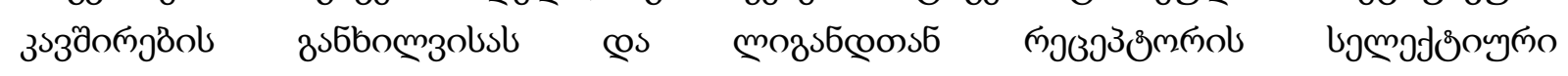

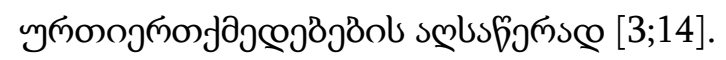

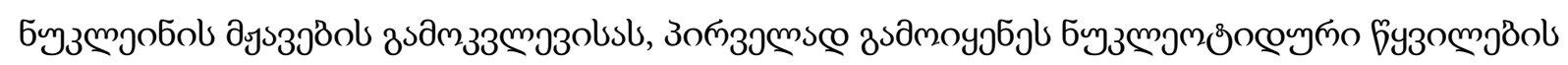

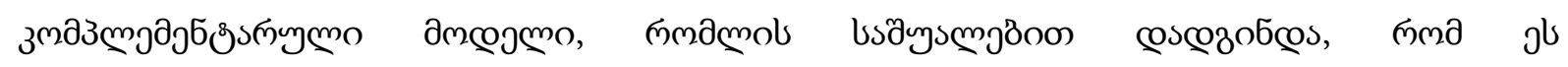

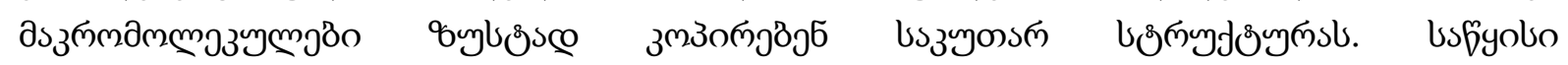

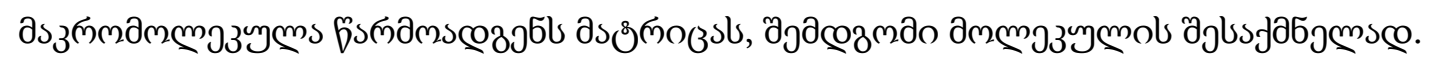

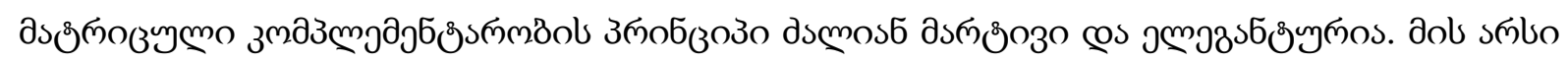

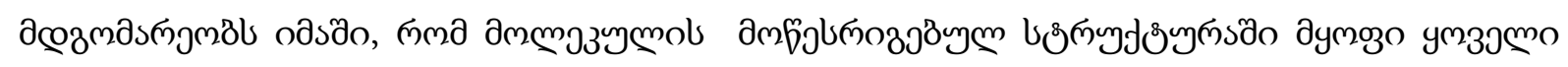

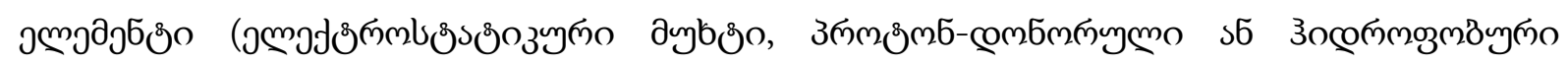

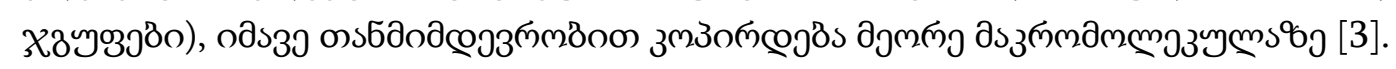

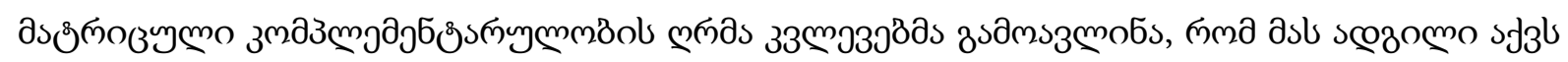

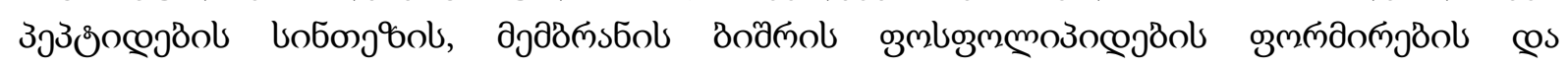

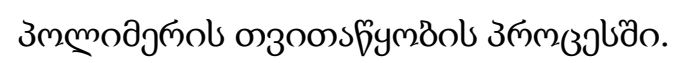

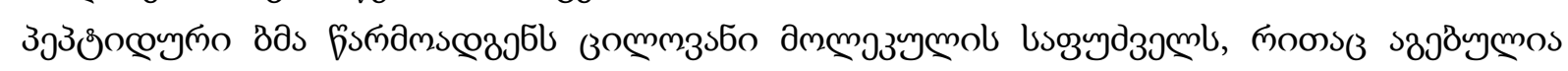

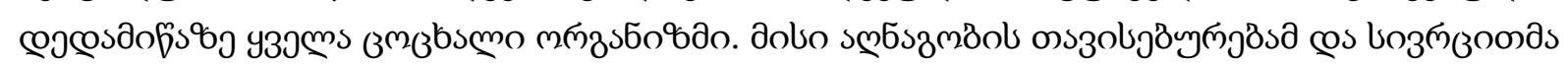

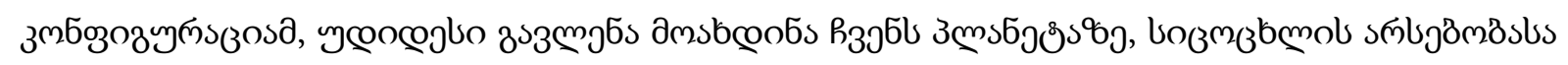

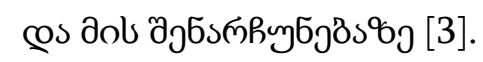




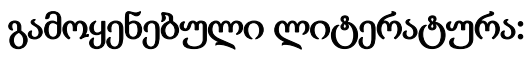

1. BuxbaumE.(2007)FundamentalsofProteinStructureandFunction.Springer, Portsmouth.

2. Byun BJ, Kang YK. Conformational preferences and $\mathrm{pK}$ (a) value of selenocysteine residue. Biopolymers. 2011 May;95(5):345-53. doi: 10.1002/bip.21581. Epub 2011 Jan PMID: 21213257.

3. Conjugated oligomers, polymers and dendrimers: from polyacetilene to DNA: Proc. of the $4^{\text {th }}$ Francqui colloquium, Brusseles, 21-23 oct. 1998/Ed-J.-L. Breda. Paris: De Berg Univ., $1998.662 \mathrm{p}$.

4. Gayathri Srinivasan, Carey M. James, Joseph A. Krzycki. Pyrrolysine Encoded by UAG in Archaea: Charging of a UAG-Decoding Specialized tRNA. Science 24 May 2002:Vol. 296, Issue 5572, pp. 1459-1462DOI: 10.1126/science.1069588.

5. Derakhshankhah, H.; Jafari, S. Cell penetrating peptides: A concise review with emphasis on biomedical applications.Biomed. Pharmacother. 2018, 108, 1090-1096.

6. Hamley, I.W. Introduction to Peptide Science;Wiley: Weinheim, Germany, 2020; ISBN 9781-119-69817-3.

7. Hamley, I.W. Small bioactive peptides for biomaterials design and therapeutics. Chem. Rev. 2017, 117, 14015-14041. [CrossRef][PubMed].

8. Ni, M.; Zhuo, S. Applications of self-assembling ultrashort peptides in bionanotechnology. RSC Adv. 2019, 9, 844-852. [CrossRef] [PubMed].

9. Patel, V.; Asatryan, B.; Siripanthong, B.; Munroe, P.B.; Tiku-Owens, A.; Lopes, L.R.; Khanji, M.Y.; Protonotarios, A.; Santangeli, P.;Muser, D.; et al. State of the art review on genetics and precision medicine in arrhythmogenic cardiomyopathy. Int. J. Mol. Sci.2020, 21, 6615-6662.

10. Pavan, S.; Berti, F. Short peptides as biosensors transducers. Anal. Bioanal. Chem. 2012, 402, 3055-3070. [CrossRef] [PubMed].

11. Petsalaki E, Russell RB (2008) Peptide-mediated interactions in biological systems: newdiscoveries and applications. Curr Opin Biotechnol 19:344-350.

12. Schmidt, A.; Teeter, M.;Weckert, E.; Lamzin, V.S. Crystal structure of small protein crambin at 0.48 A resolution. Acta Cryst. F2011, 67, 424-428.

13. Seow, W.Y.; Hauser, C.A.E. Short to ultrashort peptide hydrogels for biomedical uses. Mater. Today 2014, 17, 381-388.

14. WhitfordD.(2005)Proteins:structureandfunction.JohnWiley\&SonsLtd,WestSussex, England. 


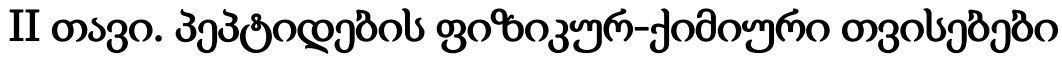

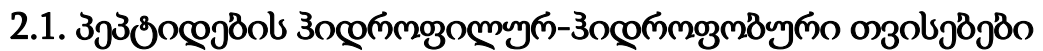

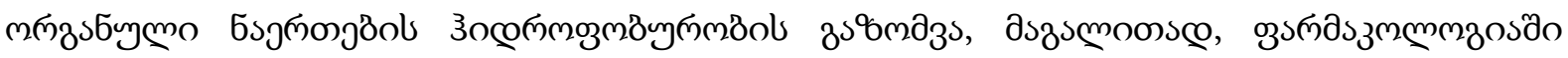

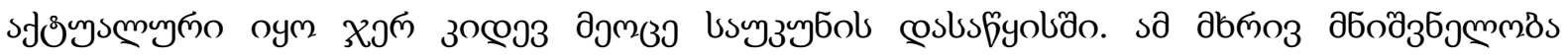

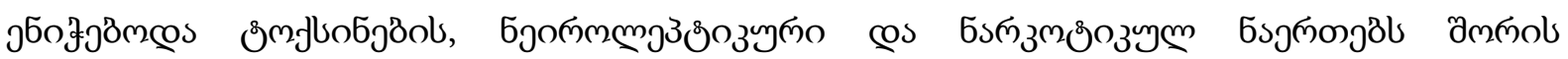

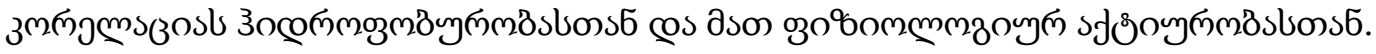

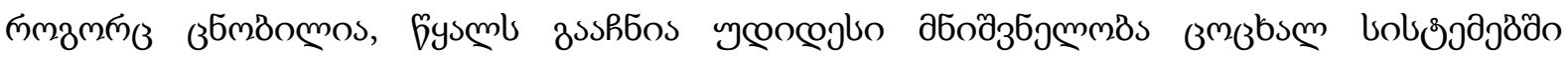

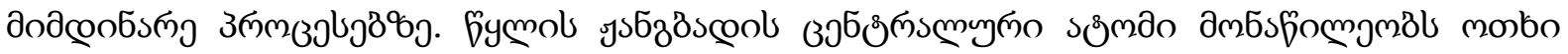

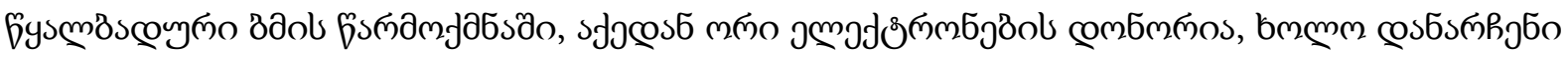

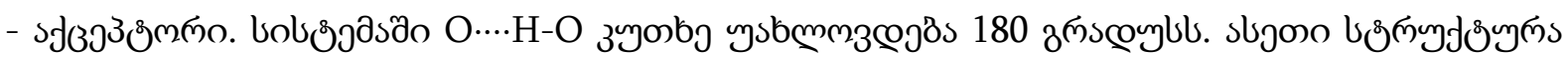

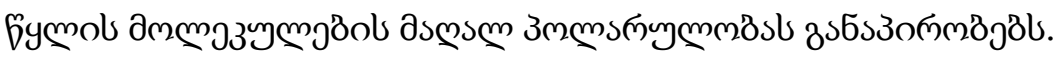

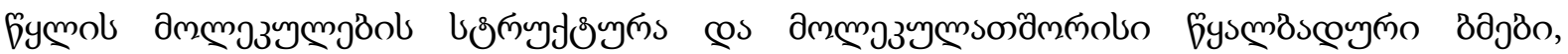

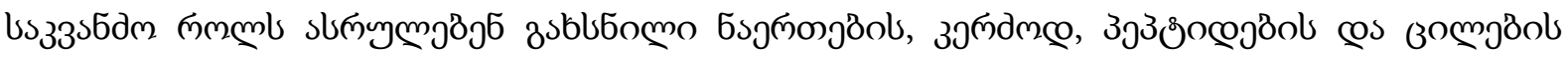

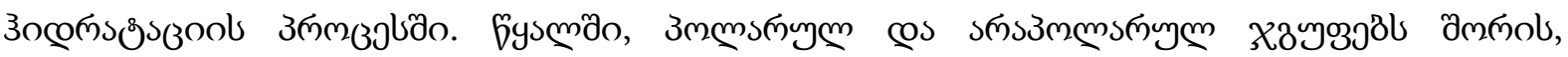

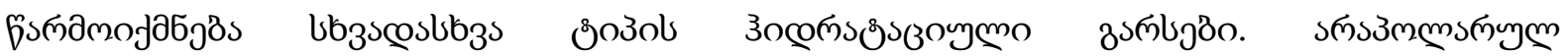

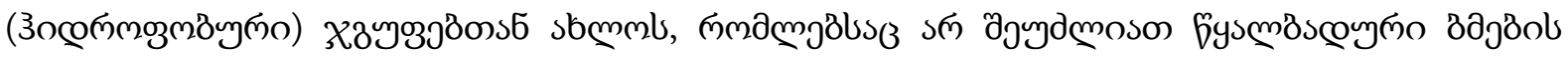

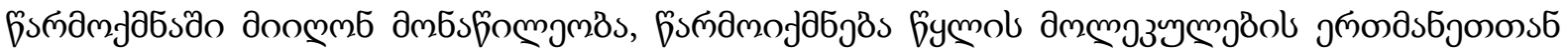

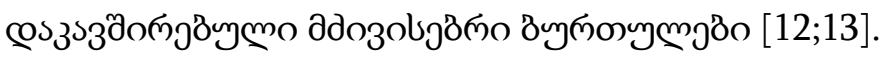

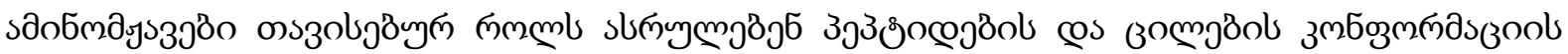

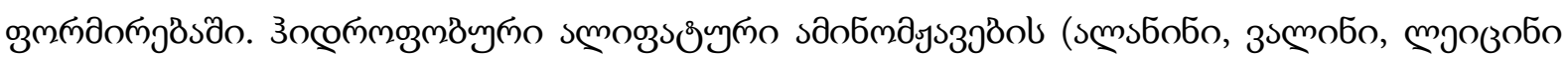

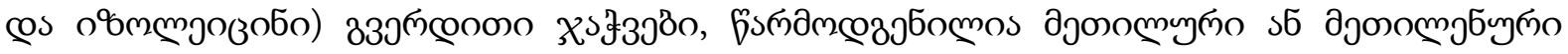

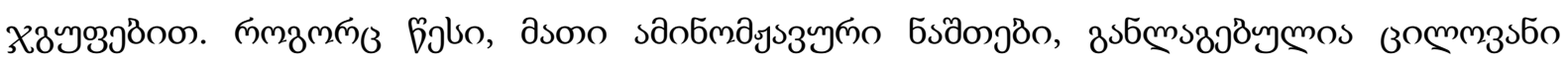

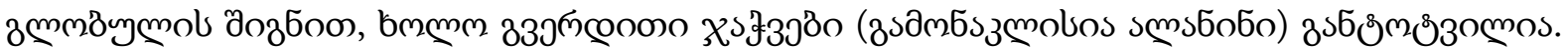

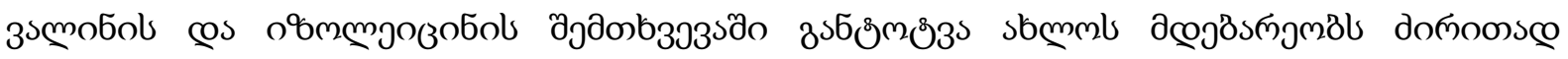

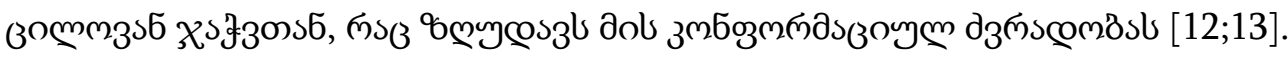

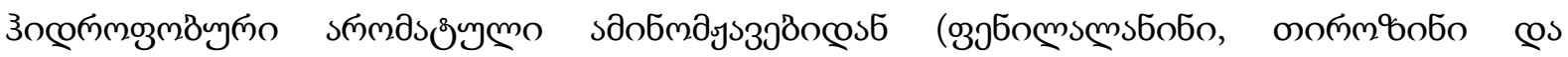

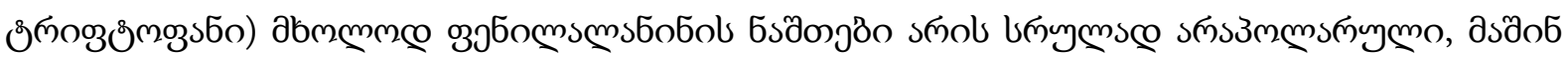

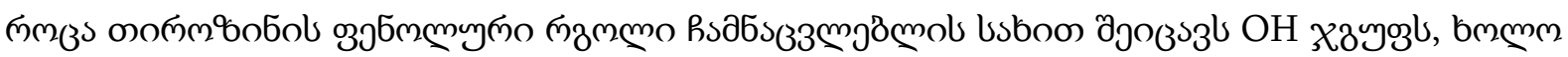

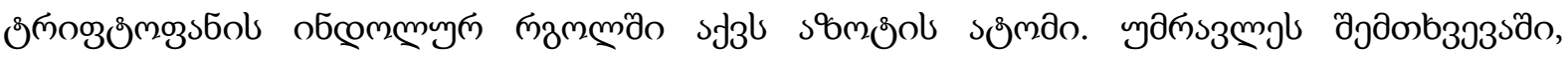

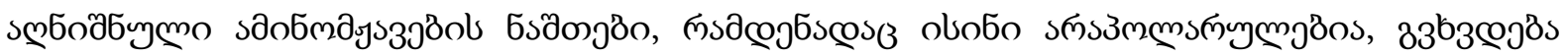

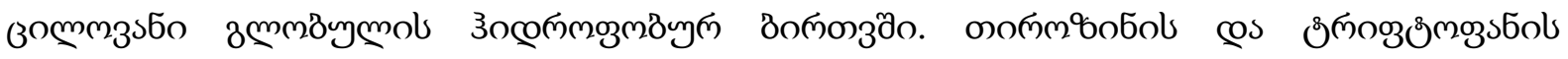

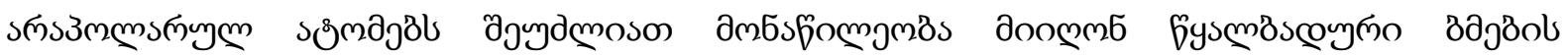

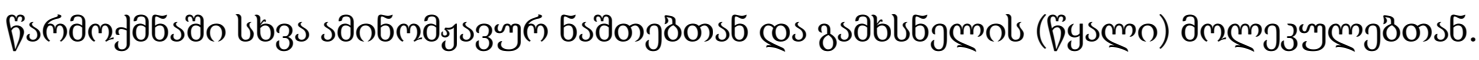

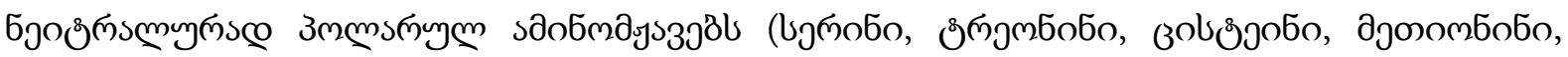

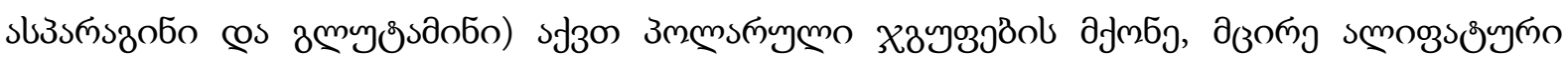

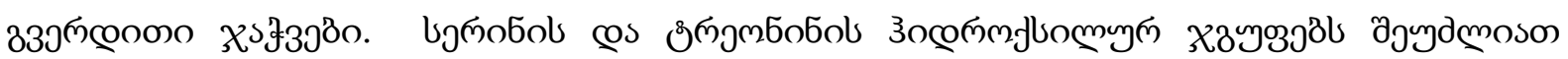

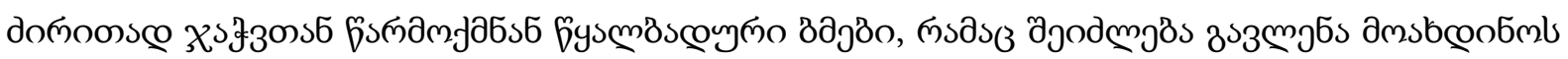

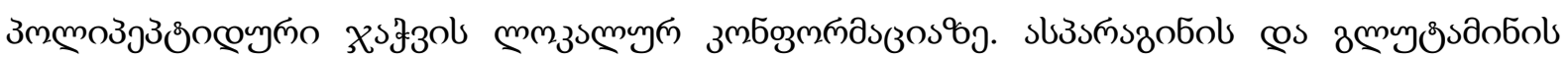




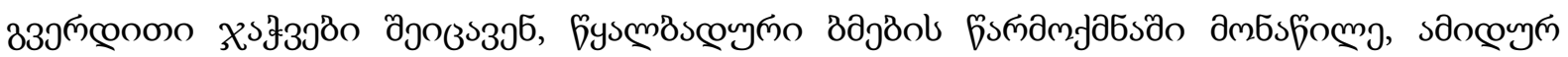

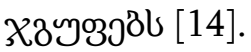

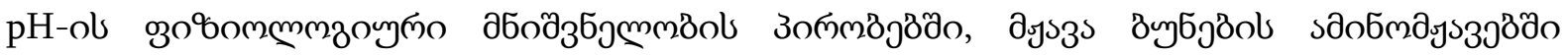

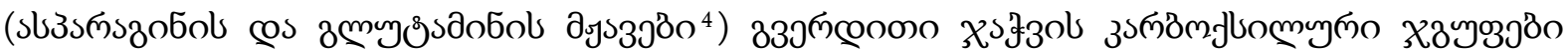

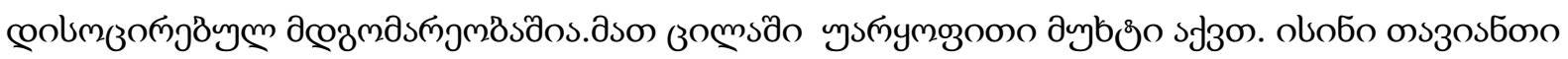

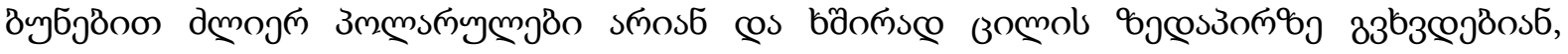

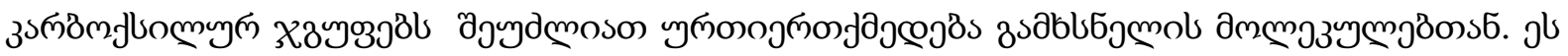

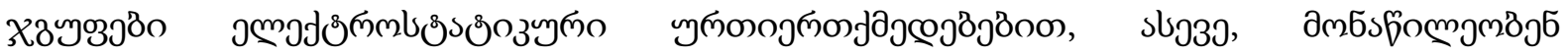

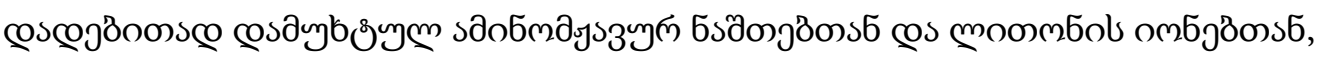

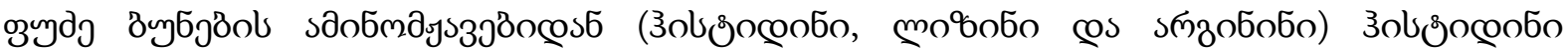

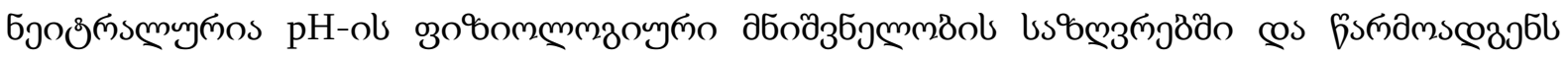

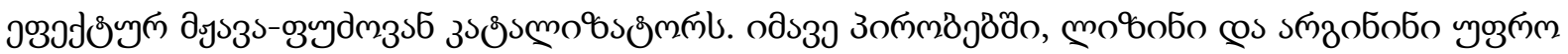

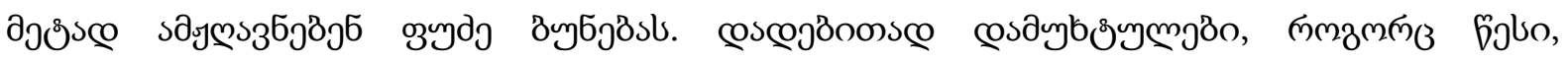

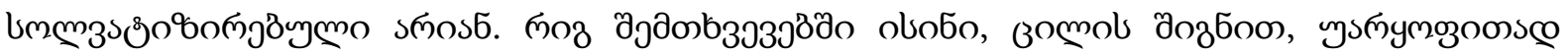

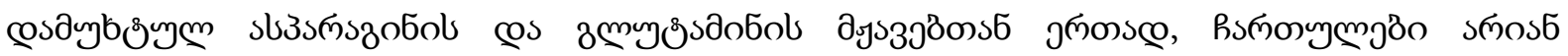

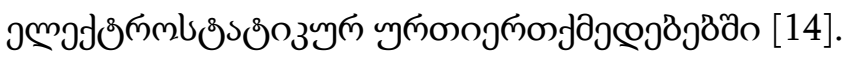

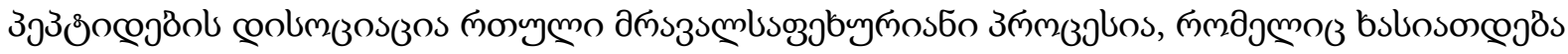

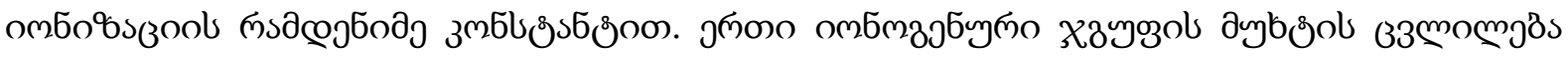

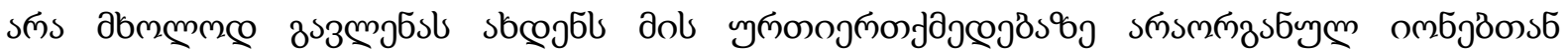

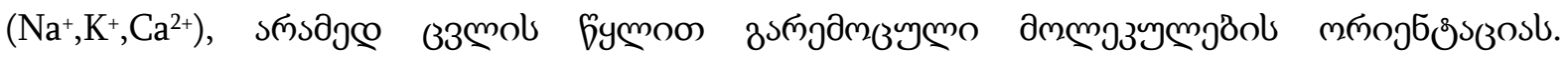

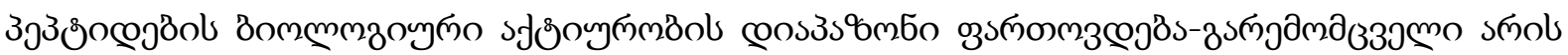

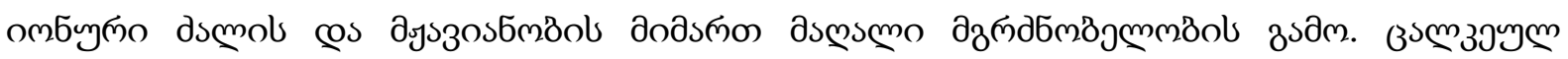

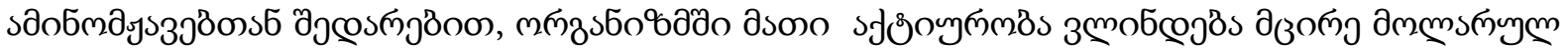

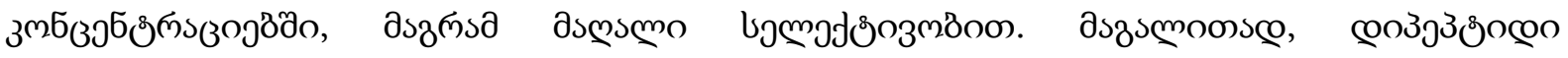

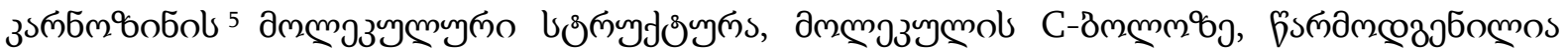

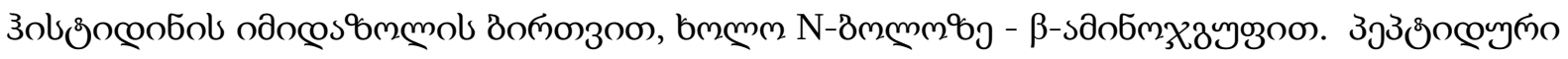

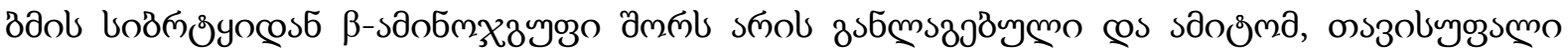

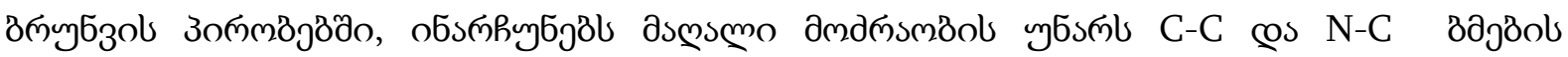

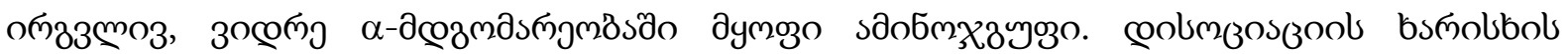

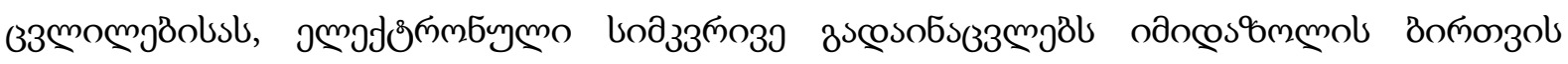

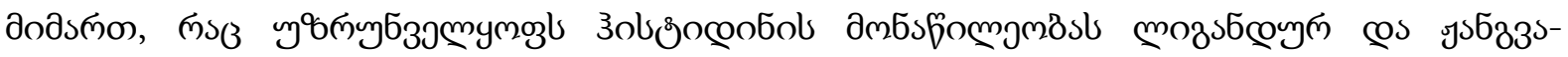

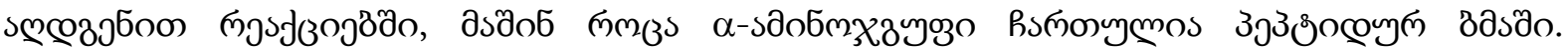

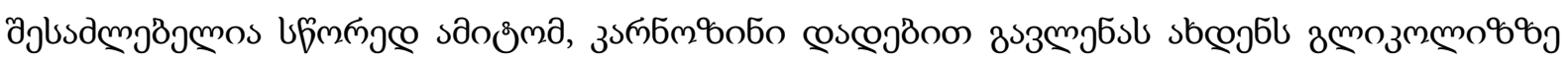

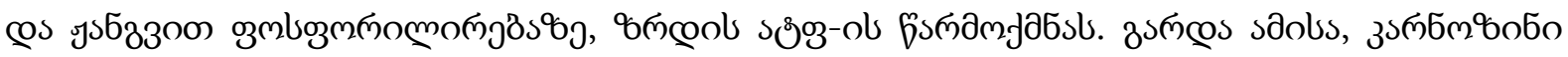

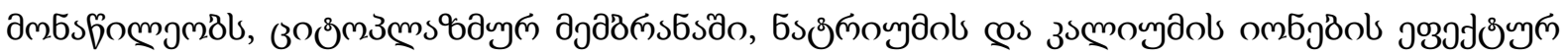

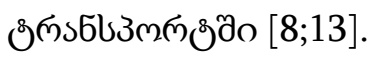

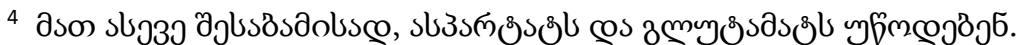

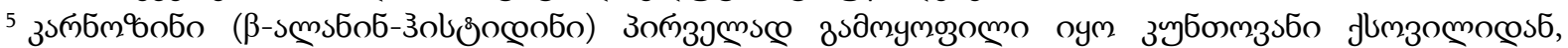

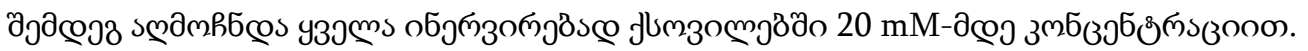




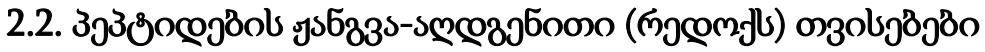

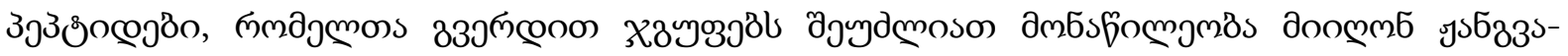

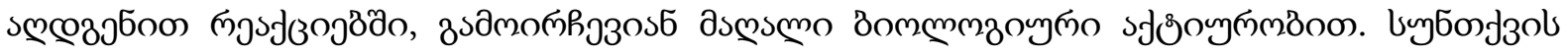

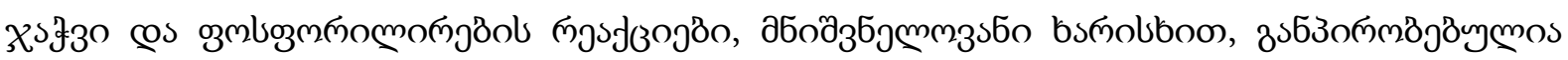

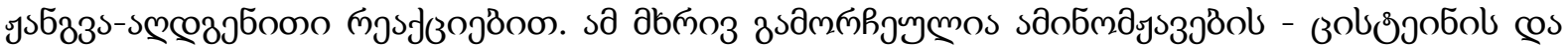

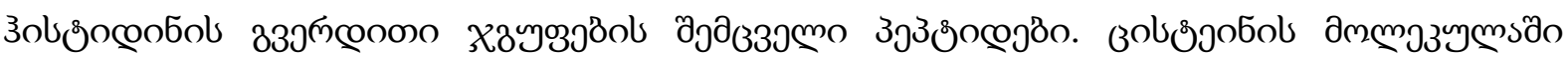

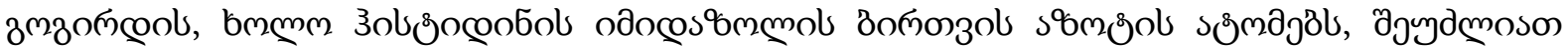

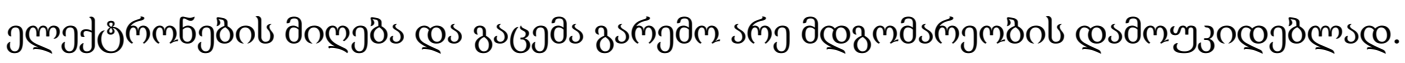

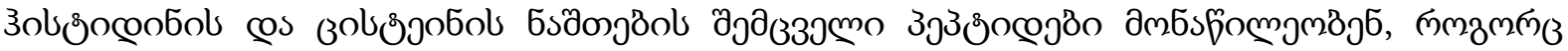

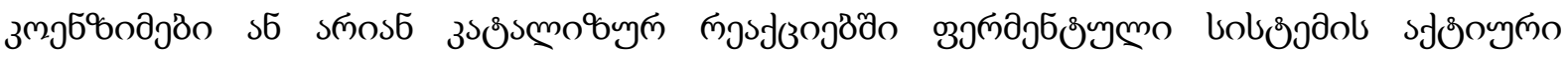

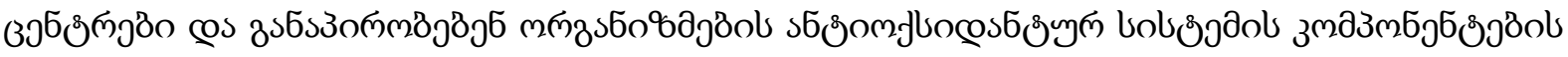

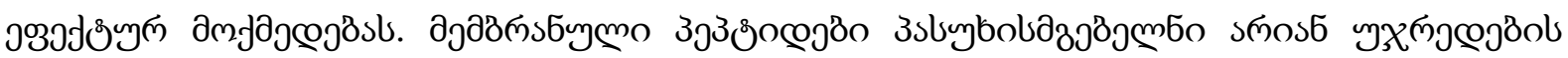

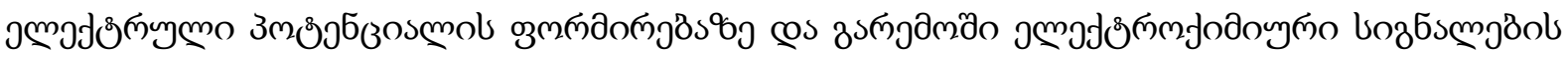
zscos 35 gs $\%$ o.

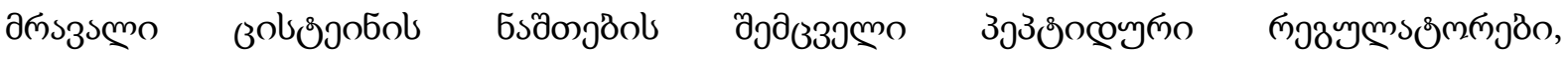

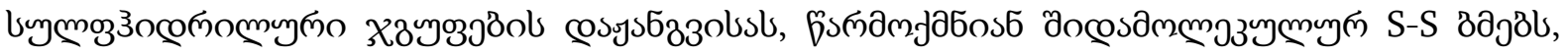

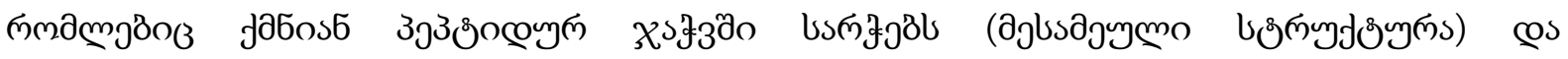

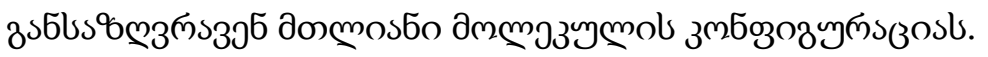

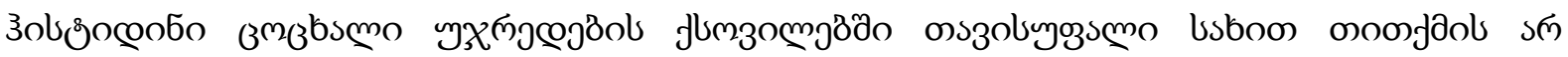

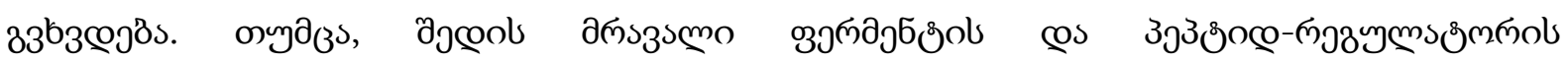

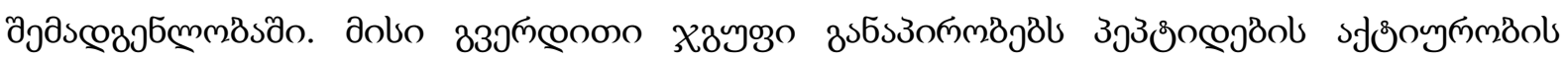

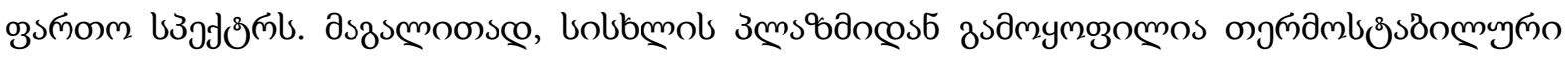

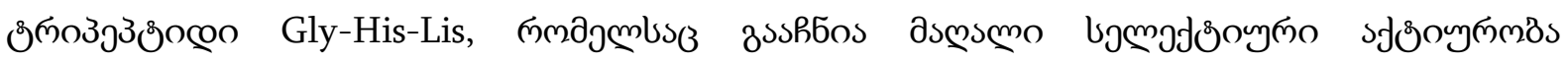

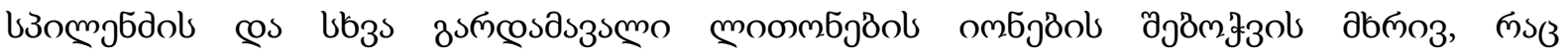

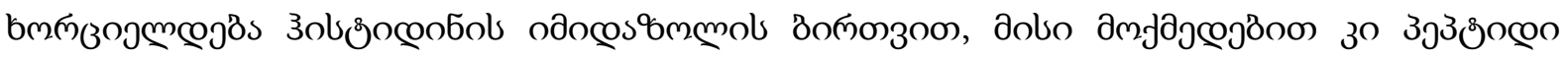

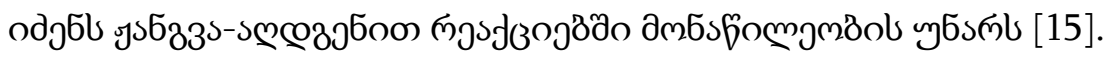

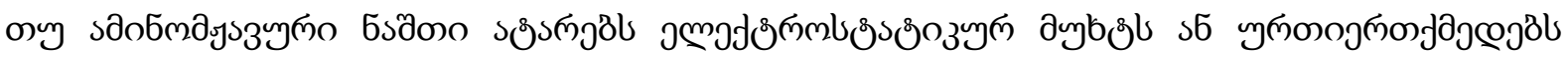

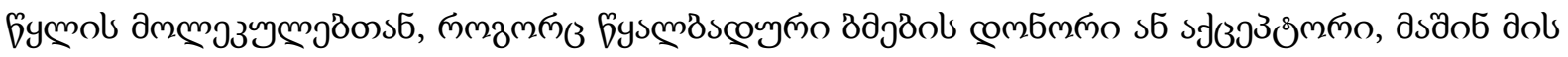

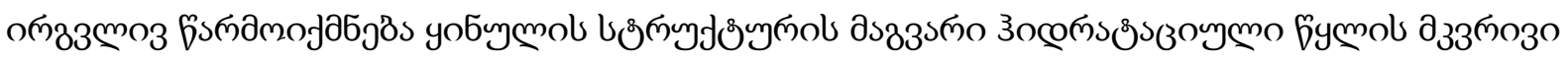

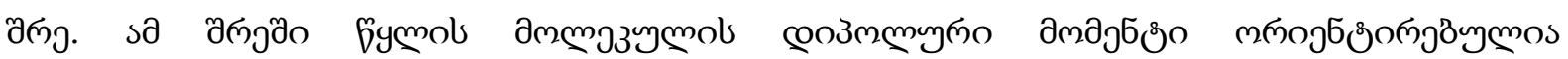

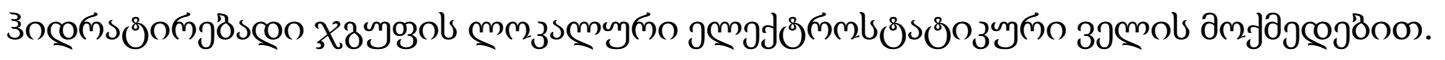

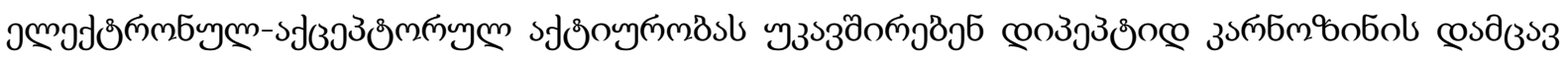

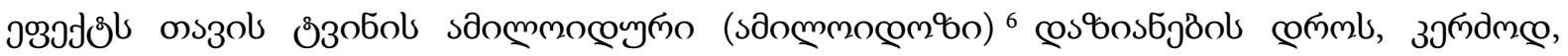

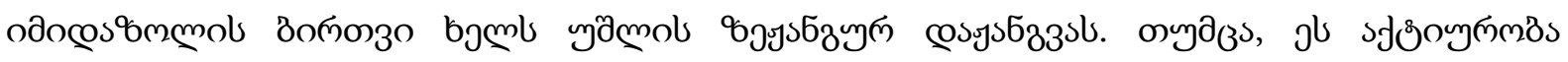

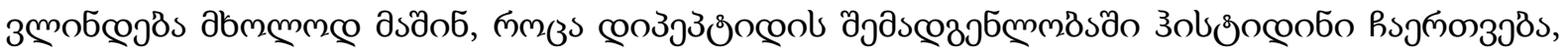

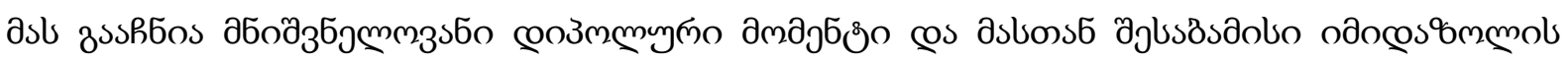

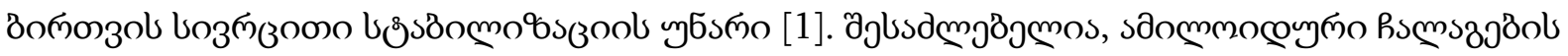

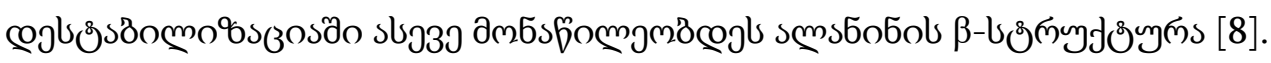

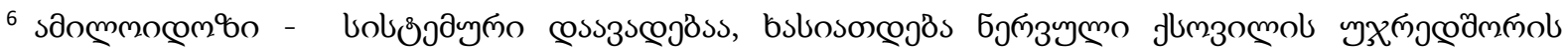

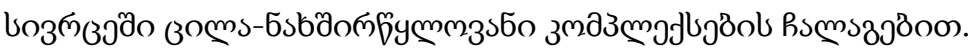




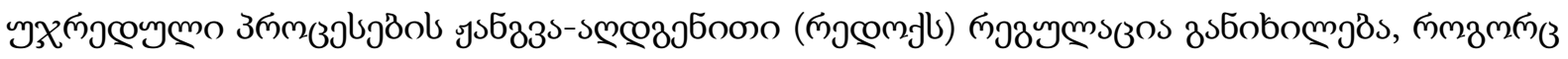

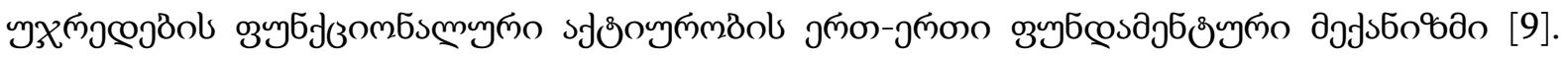

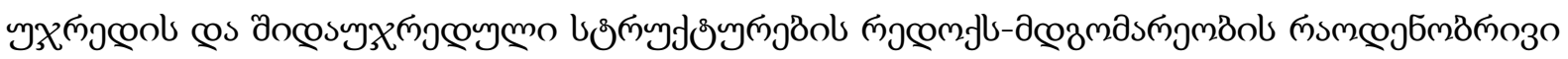

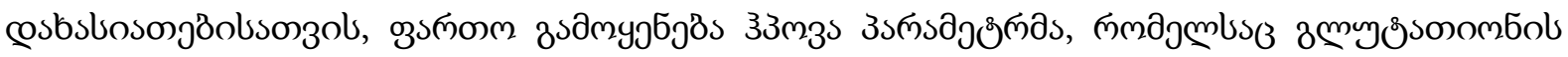

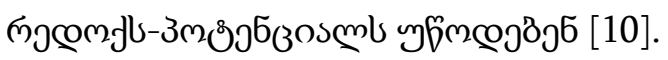

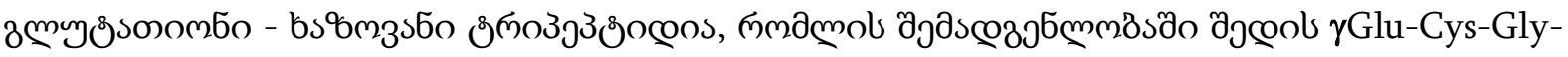

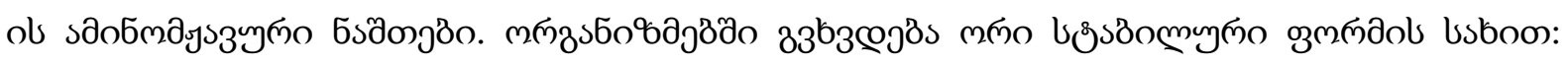

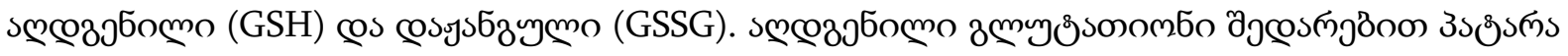

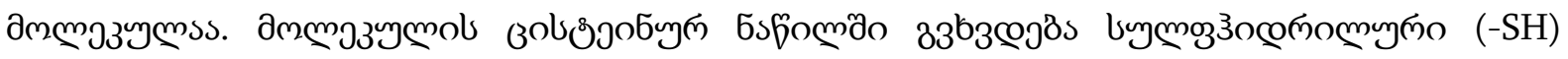

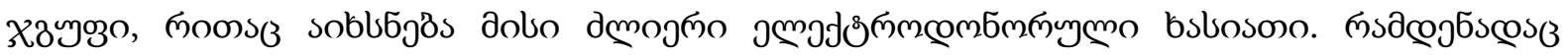

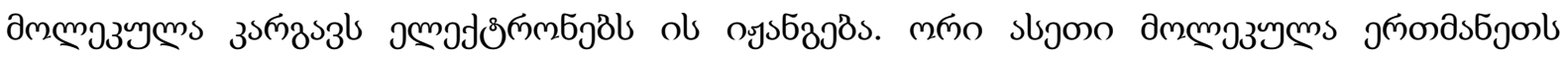

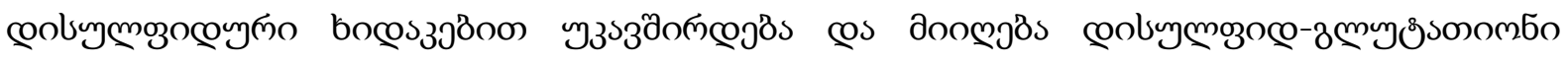

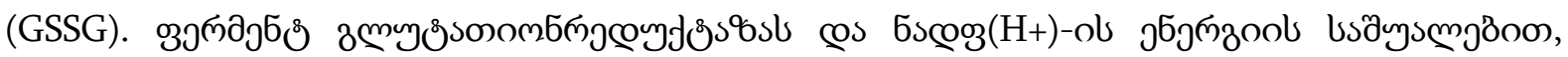

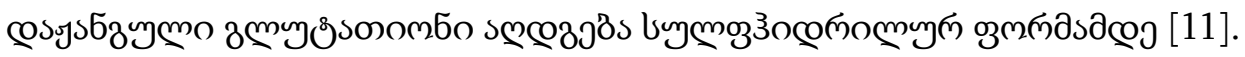

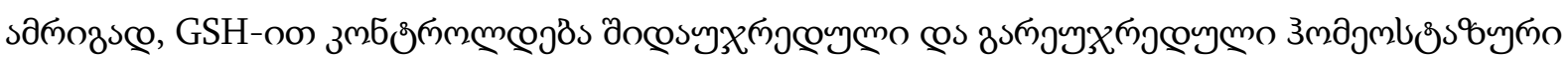

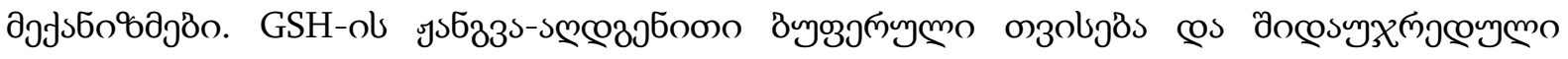

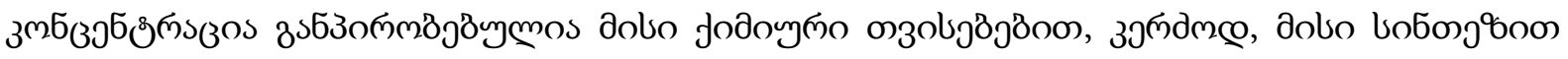

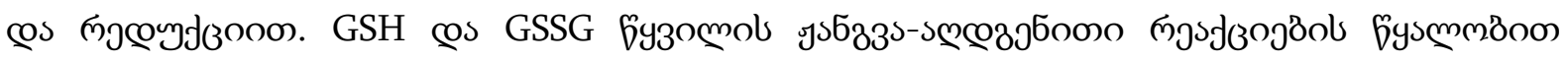

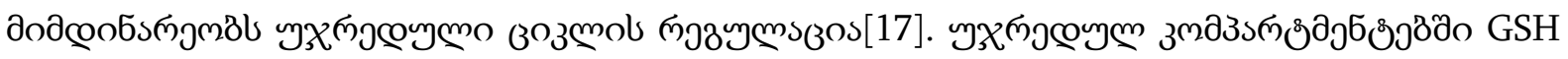

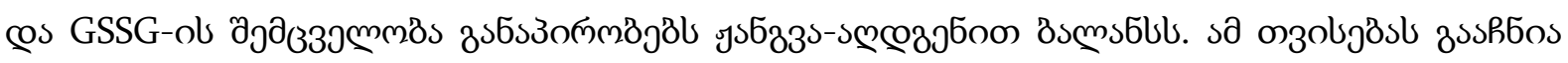

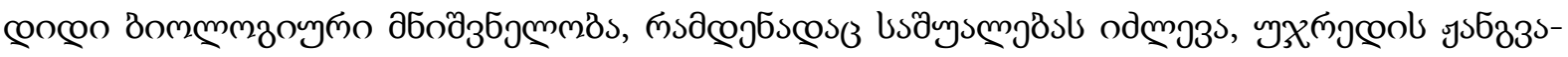
зме

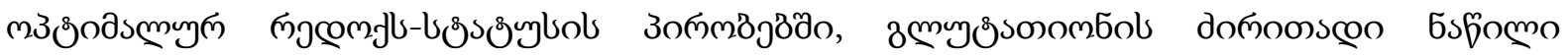

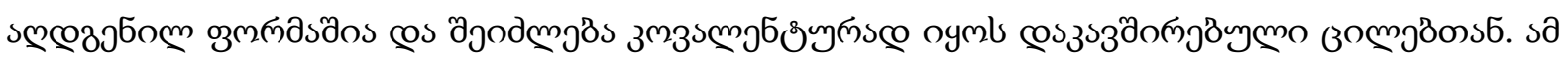

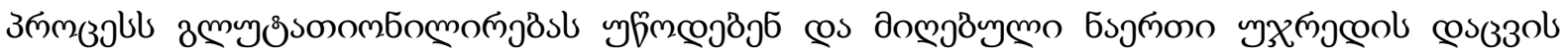

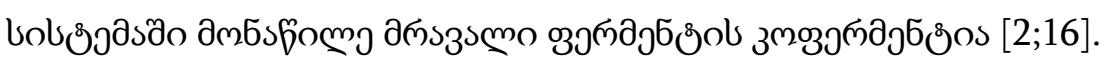

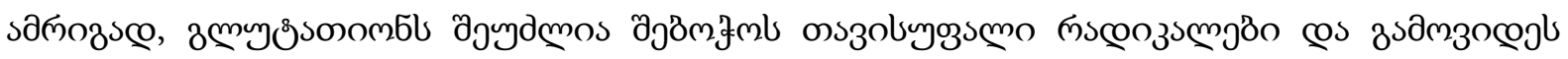

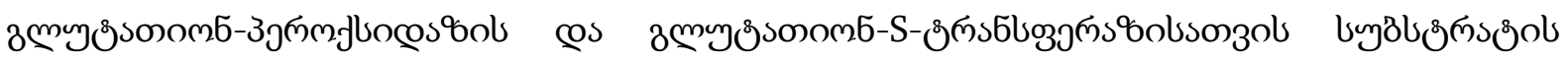

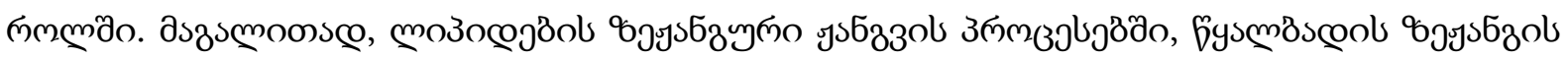

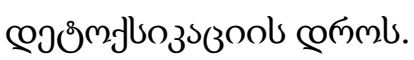

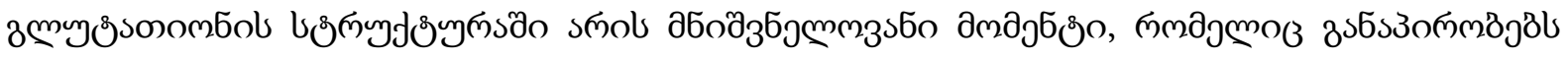

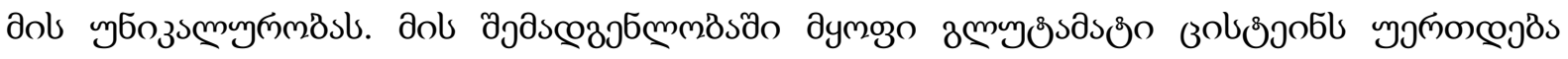

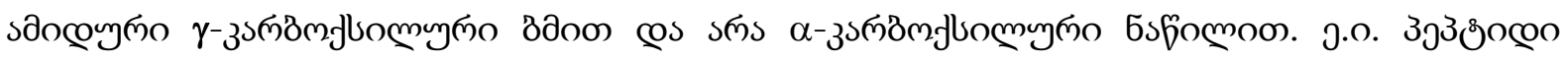

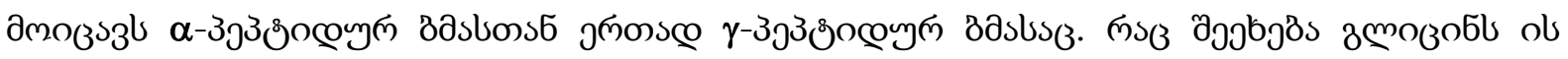

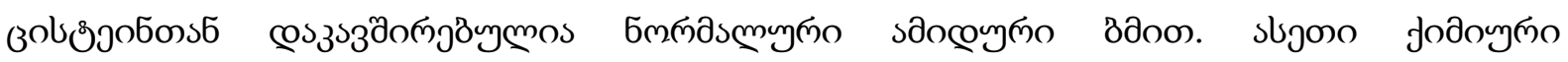

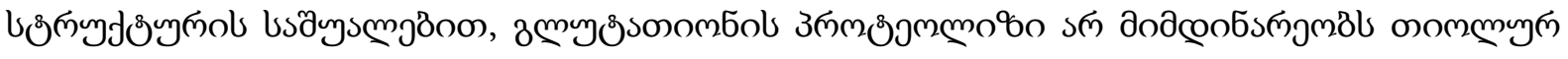

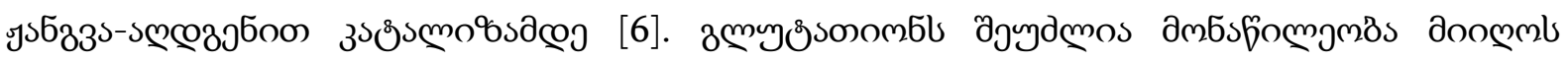

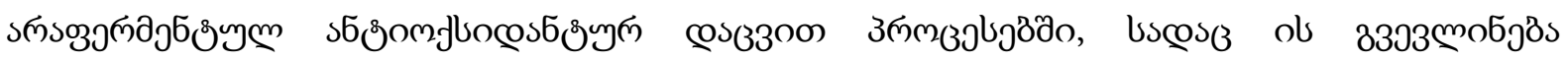

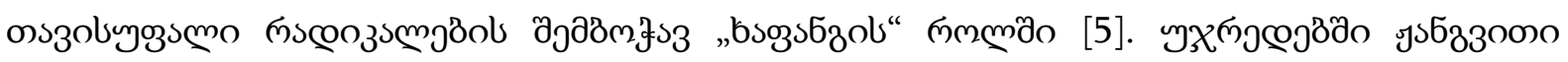

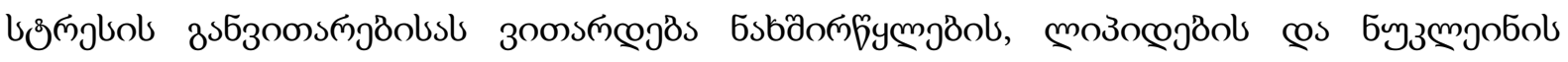

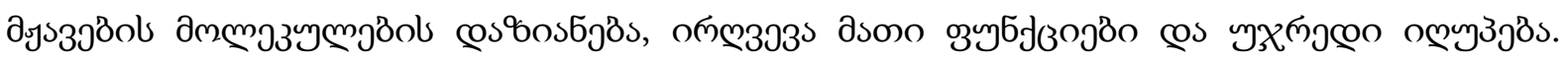

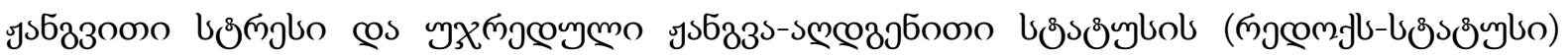




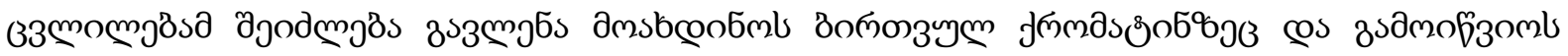

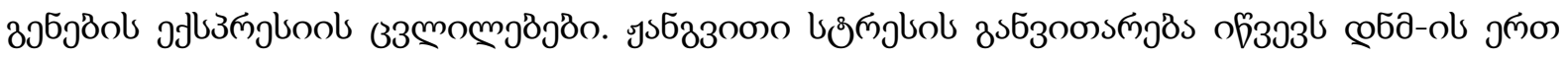

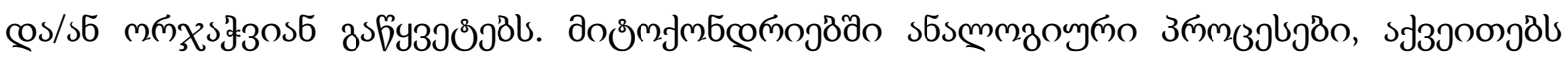

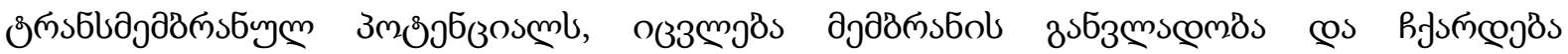

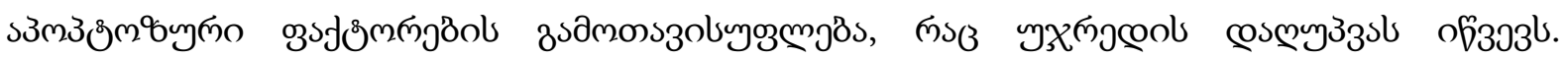

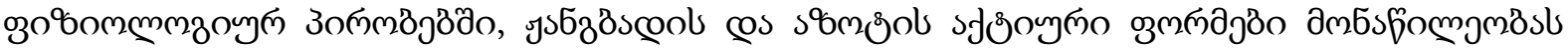

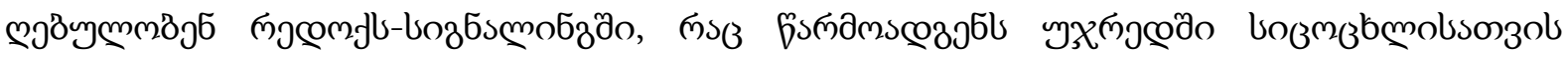

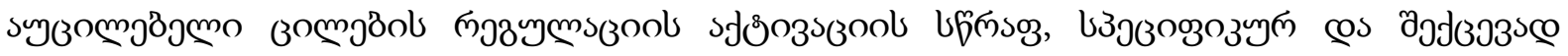

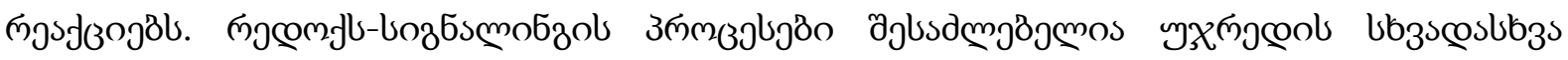

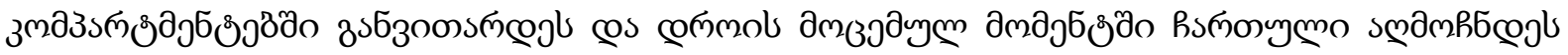

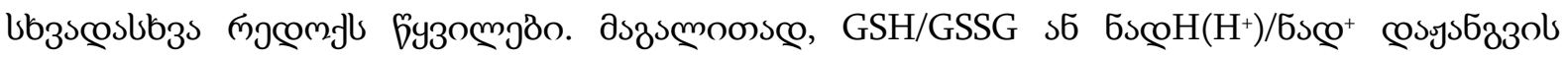

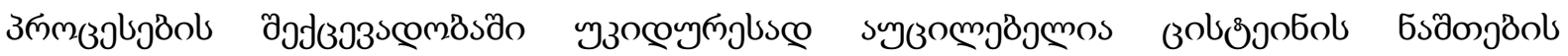

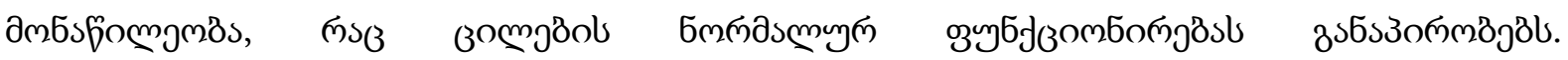

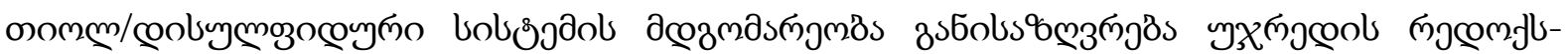

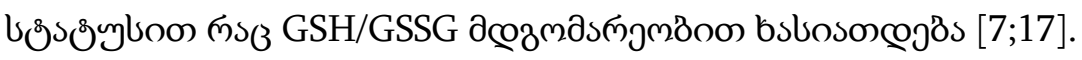

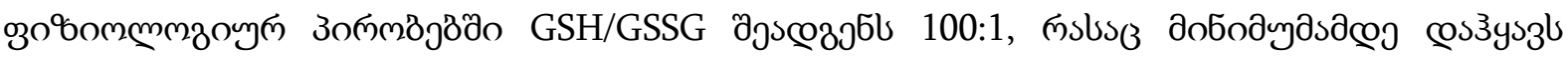

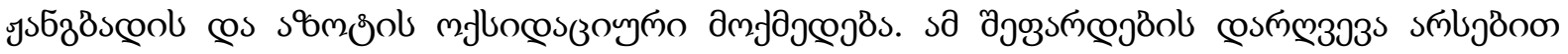

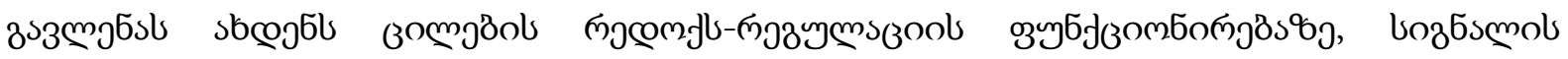

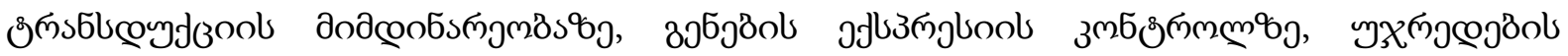

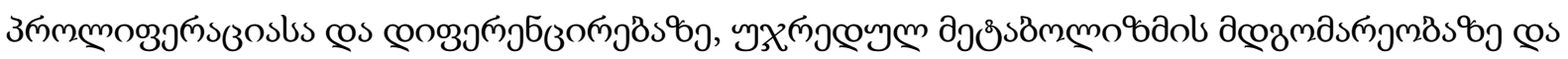

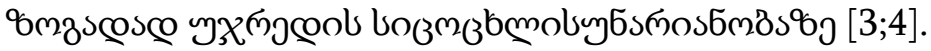

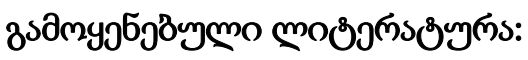

1. Alberts B., Bray D., Lewis J. et al. Molecular biology of the cell. 3rd ed. New York: Garland Publish., 1994. 1294 p.

2. Alscher R.G. Biosynthesis and antioxidant function of glutathione in plants // Physiol Plantarum. 1989. V. 77. P. 457-464.

3. Cai, Z., and Yan, L.J. (2013) Protein Oxidative Modifications: Beneficial Roles in Disease and Health, Journal of Biochemical and Pharmacological Research, 1, 15-26.

4. Fitzpatrick, A.M., Jones, D.P., and Brown, L.A. (2012) Glutathione redox control of asthma: from molecular mechanisms to therapeutic opportunities, Antioxidants \& Redox Signaling, $17,375-408$.

5. Galano, A., and Alvarez-Idaboy, J.R. (2011) Glutathione: mechanism and kinetics of its nonenzymatic defense action against free radicals, RSC Advances, 1, 1763-1771.

6. Glutathione and Sulfur Amino Acids in Human Health and Disease. 2009, Hoboken, New Jersey: John Wiley \& Sons, Inc. p. 626.

7. Go, Y.-M., and Jones, D.P. (2008) Redox compartmentalization in eukaryotic cells, Biochimica et Biophysica Acta, 1780, 1273-1290.

8. Iverson B. L. Betas are brought into the fold // Nature. 1997. Vol. 385, N 6612. P. 113-115.

9. Janssen-Heininger Y.M., Mossman B.T., Heintz N.H., Forman H.J., Kalyanaraman B., Finkel T., Stamler J.S., Rhee S.G., Van der Vliet A. Redox-based regulation of signal 
transduction: Principles, pitfalls, and promises // Free Rad. Biol. Med. - 2008. - Vol. 45, P. $1-17$.

10. Jones D.P. Redox potential of GSH/GSSG couple: assay and biological significance // Methods Enzymol. - 2002. - Vol. 348. - P. 93- 112

11. Lallement P.A., Brouwer B., Keech O., Hecker A., Rouhier N. The still mysterious roles of cysteine-containing glutathione transferases in plants // Frontiers in Pharmacology. 2014. V.5.

12. Lear J. D., Schneider J. P., Kenker P. K. Electrostatic effects on ion selectivity and rectification in designed ion channel peptides // J. Amer. Chem. Soc. 1997. Vol. 119, N 14. P. 3212-3217.

13. Liu Z, Su M, Han L, Liu J, Yang Q, Li Y, Wang R (2017) Forging the basis for developingprotein-ligand interaction scoring functions. Acc Chem Res 50:302-309.

14. London N, Raveh B, Schueler-Furman O (2013) Peptide docking and structure-based characterizationof peptide binding: from knowledge to know-how. Curr Opin Struct Biol 23:894-902.

15. Pickart L. The biological effects and mechanism of action of the plasma tripeptide GlycylHistidyl-Lysin // Lymphokines / Ed. E. Pick. New York; London: Acad. Press, 1983. Vol. 8. P. 425-446.

16. Pompella A., Visvikis A., Paolicchi A., de Tata V., Casini A.F. The changing faces of glutathione, a cellular protagonist // Biochem. Pharmacol. 2003. V. 66. P. 1499-1503.

17. Ortega, A.L., Mena, S., and Estrela, J.M. (2011) Glutathione in Cancer Cell Death, Cancers, 3, 1285-1310.

18. Sanchez-Fernandez R., Fricker M., Corben L., White N., Sheard N., Leaver C., Van Montagu M., Fuze D., May M. Cell proliferation and hair tip growth in the Arabidopsis root are under mechanistically different forms of redox control // Proc Natl Acad Sci U S A. 1997. V. 94. P. 2745-2750.

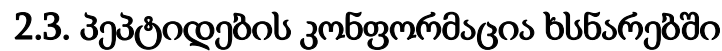

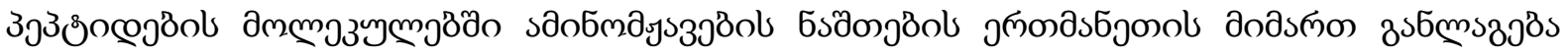

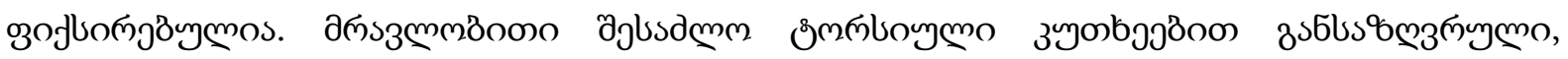

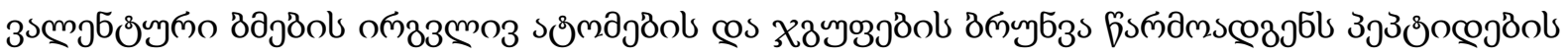

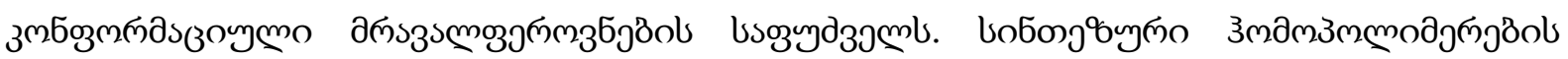

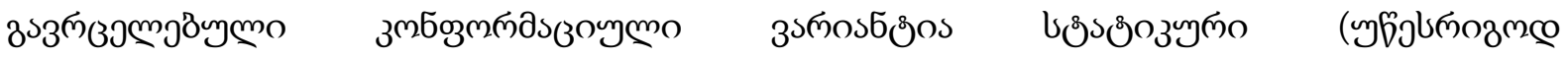

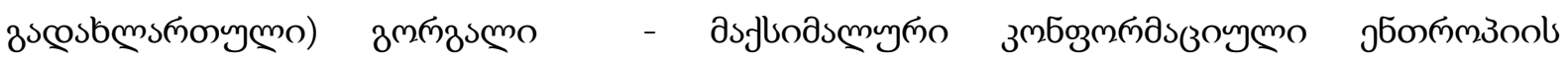

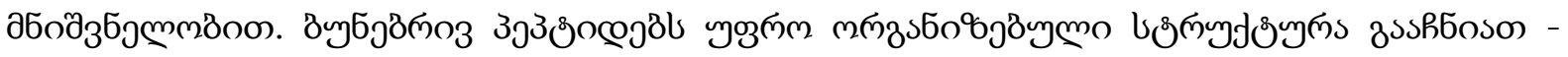

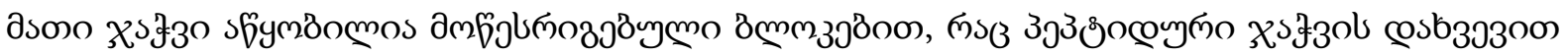

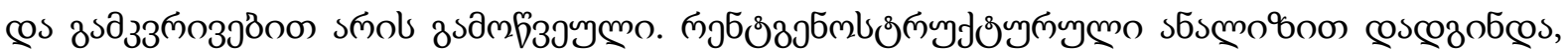

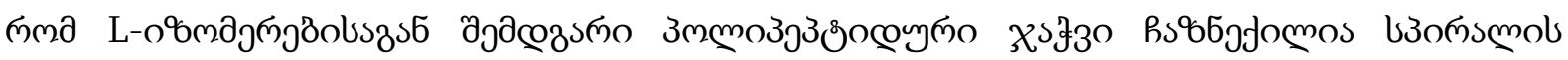
usboon.

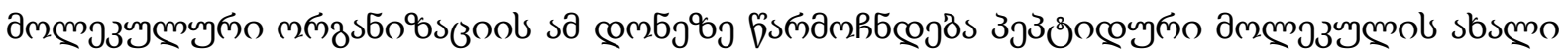

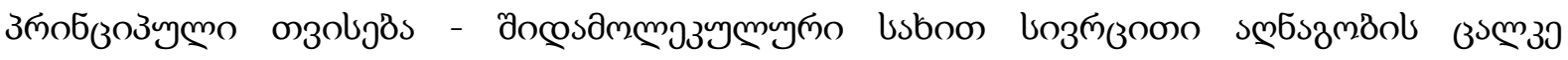

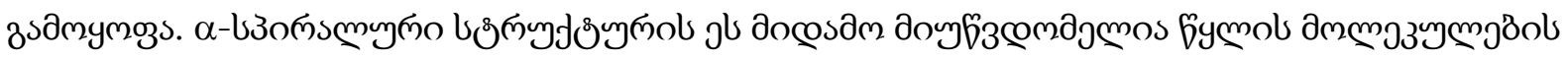




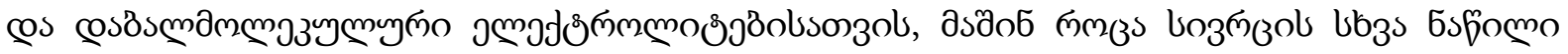

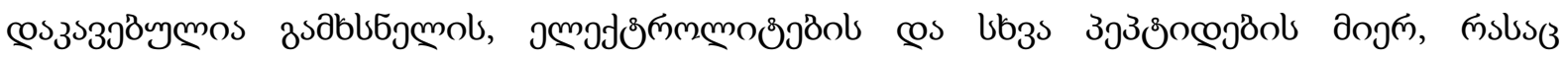

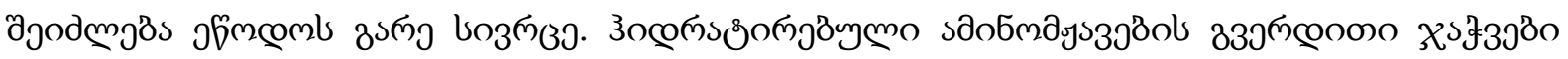

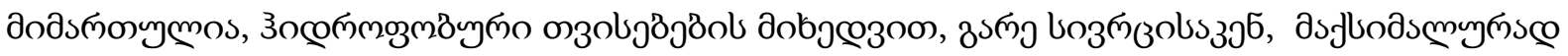

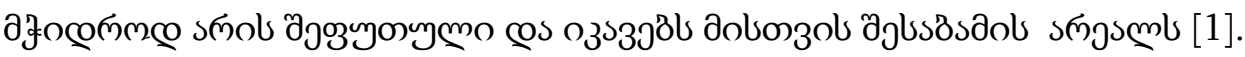

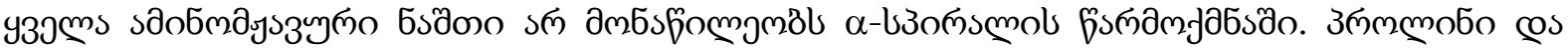

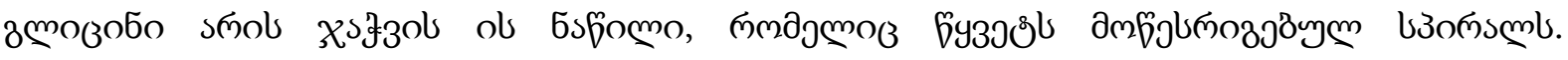

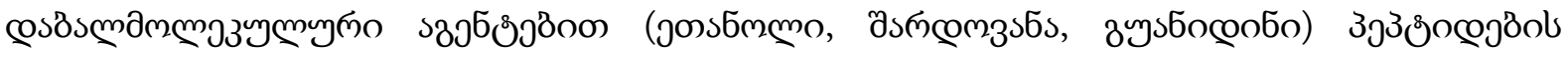

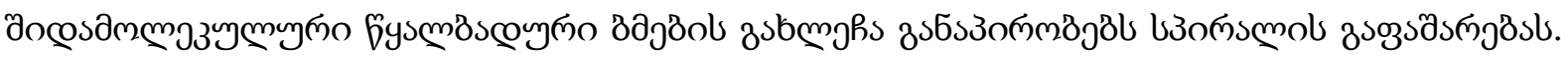

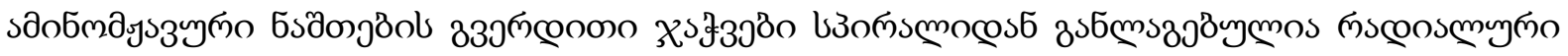

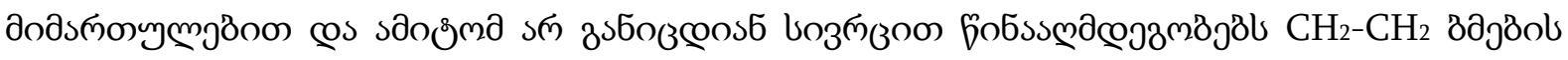

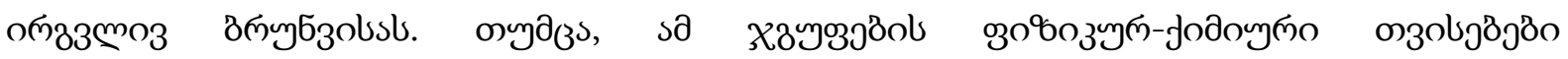

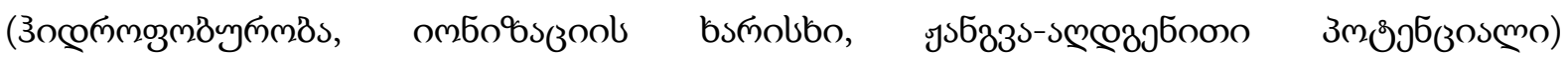

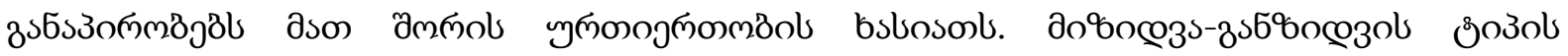

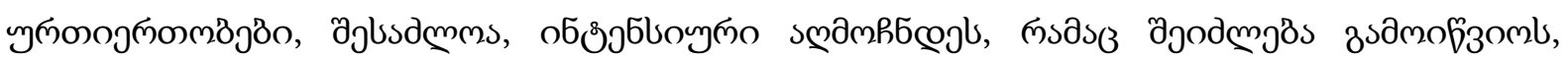

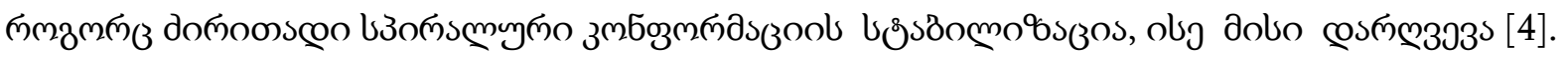

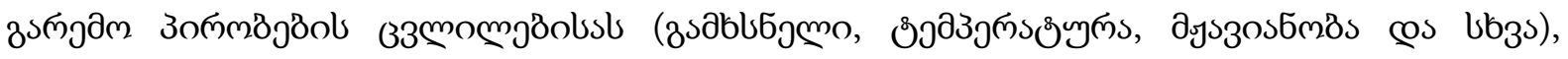

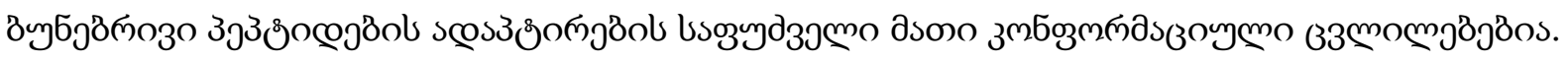

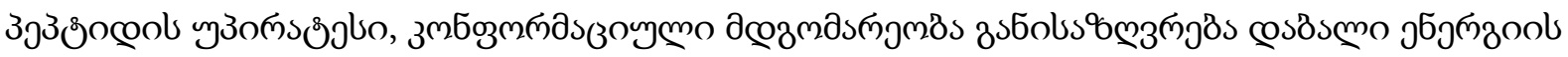

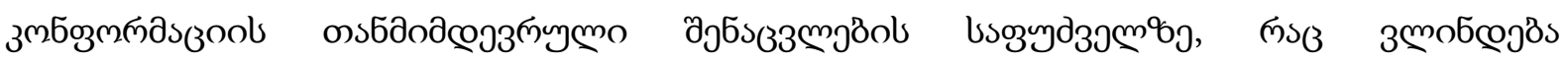

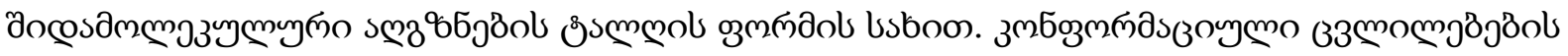

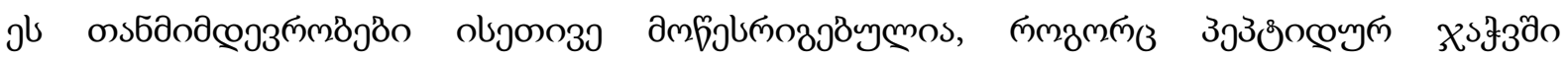

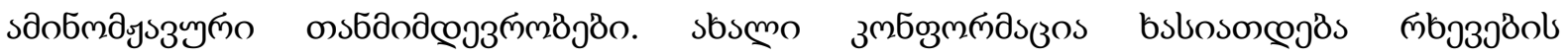

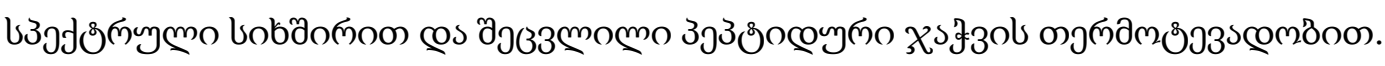

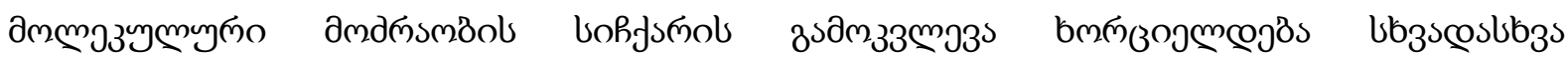

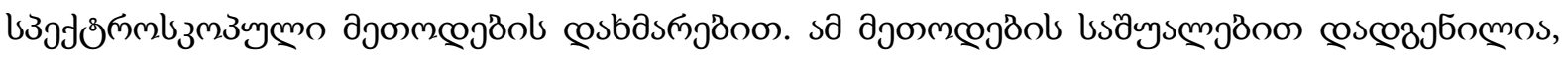

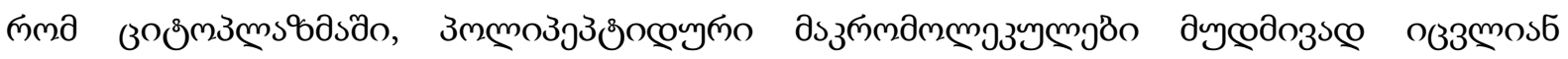

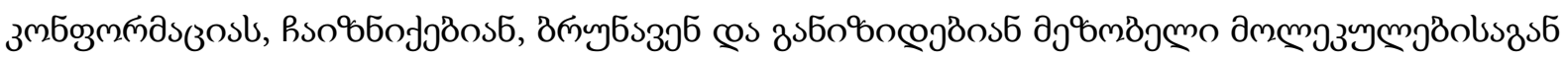
[4].

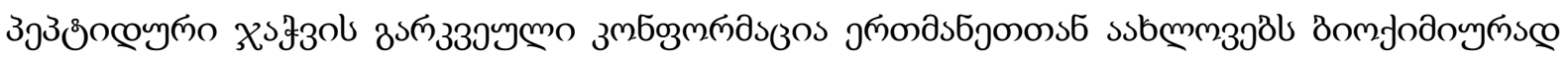

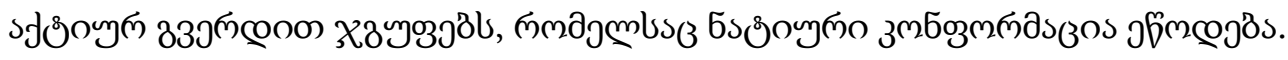

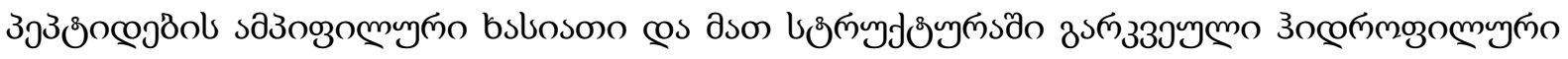

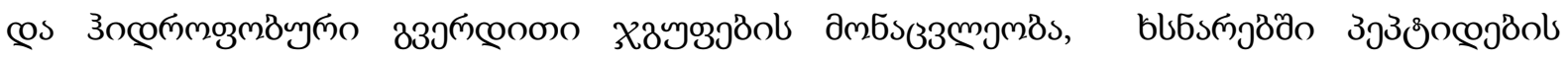

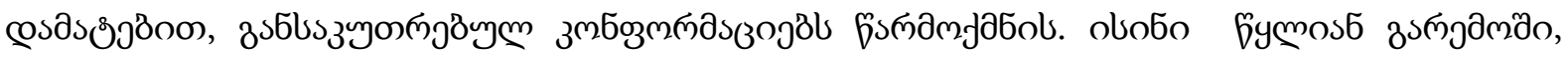

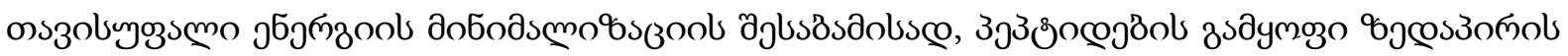

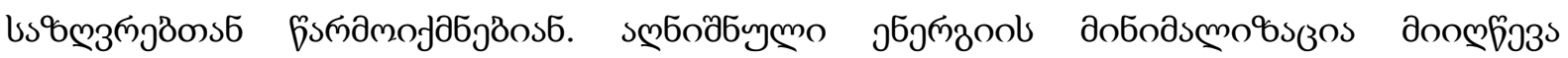

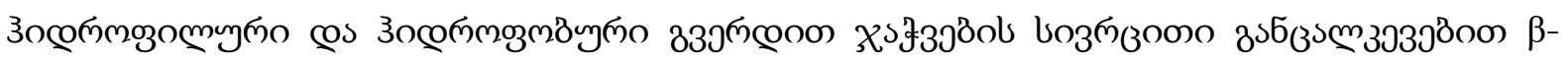

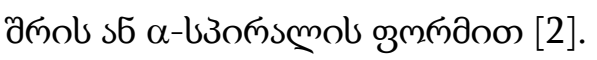

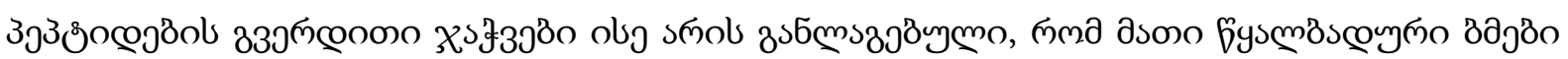

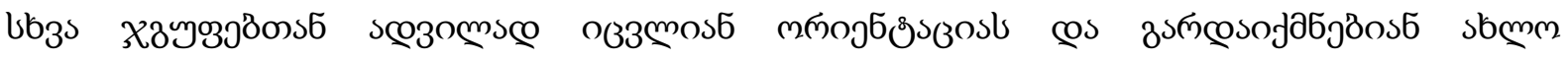

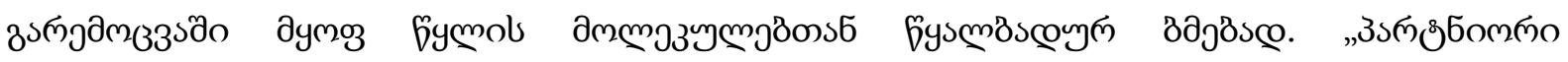

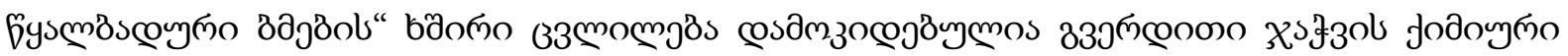




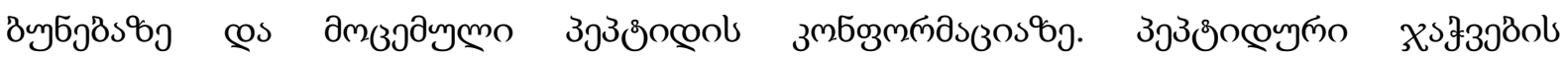

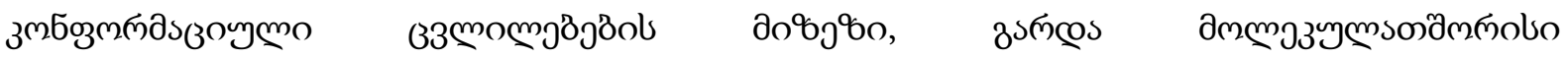

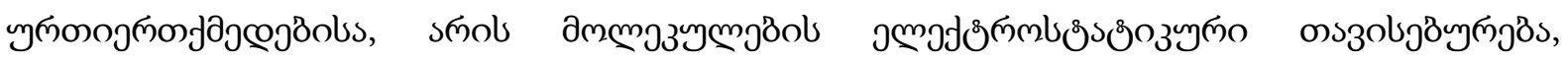

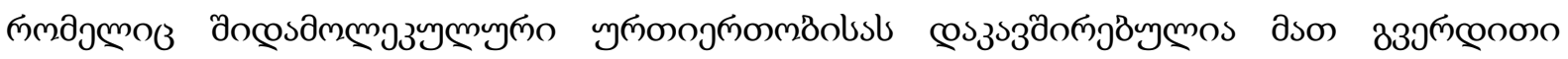

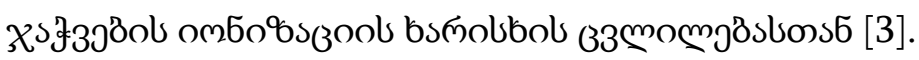

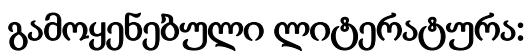

1. Derakhshankhah, H.; Jafari, S. Cell penetrating peptides: A concise review with emphasis on biomedical applications. Biomed. Pharmacother. 2018, 108, 1090-1096.

2. Kaiser E. T., Kezdy F. J. Amphiphilic secondary structure: design of peptide hormones// Science. 1984. Vol. 223, N 4633. P. 249-255.

3. Kolusheva S., Shahal T., Jelinek R. Peptide-membrane interactions studied by a new phospholipid/polydiacetilene colorimetric vesicle assay // Biochemistry. 2000. Vol. 39. P. 15851-15859.

4. Petsalaki E, Russell RB (2008) Peptide-mediated interactions in biological systems: new discoveries and applications. Curr Opin Biotechnol 19:344-350. 


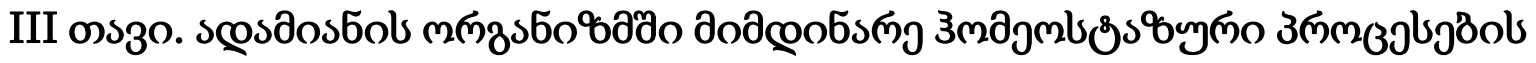

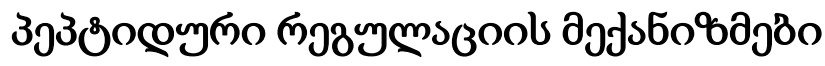

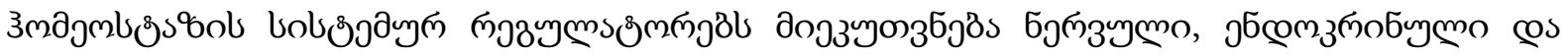

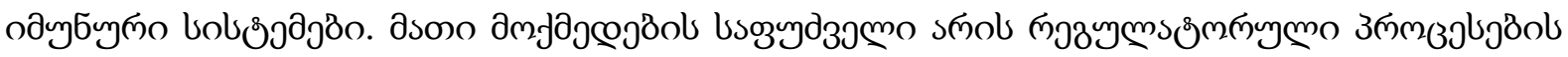

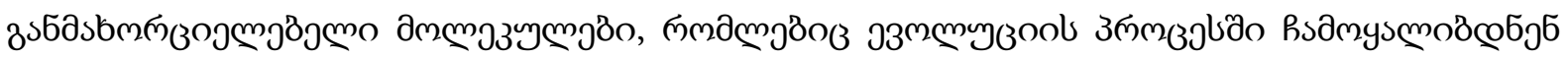

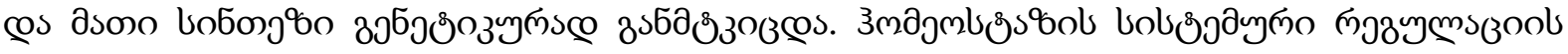

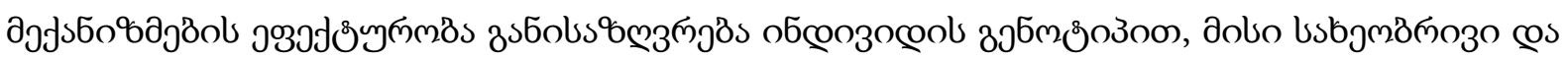

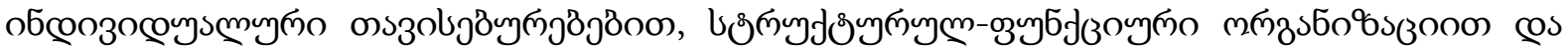

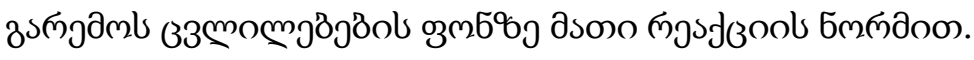

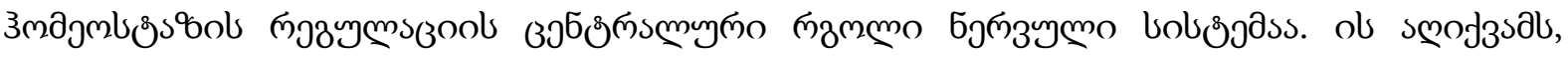

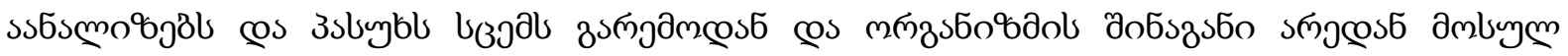

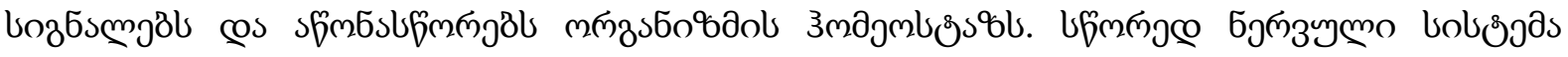

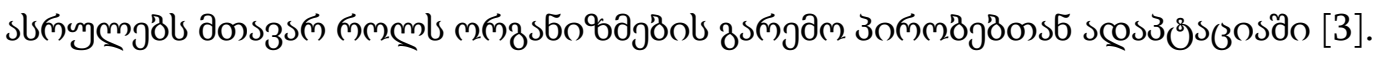

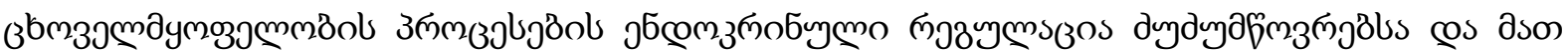

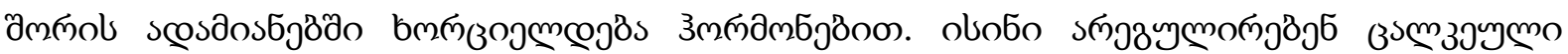

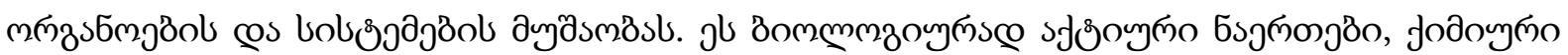

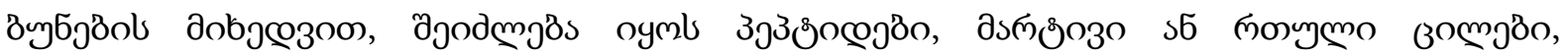

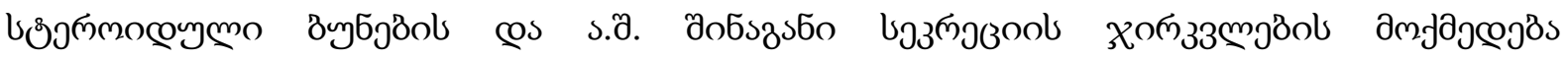

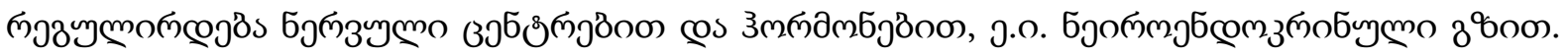

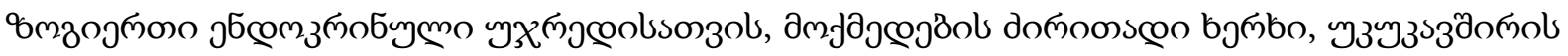

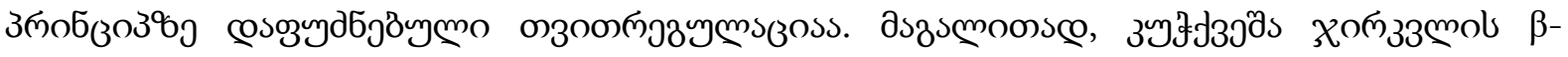

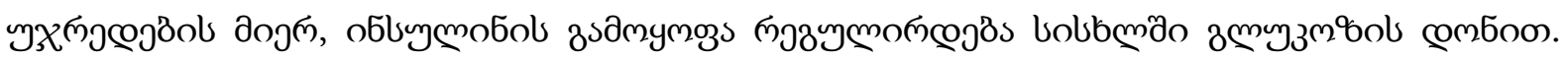

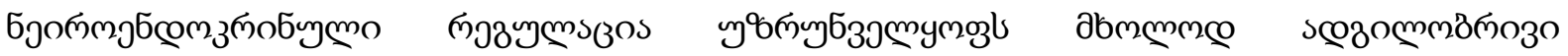

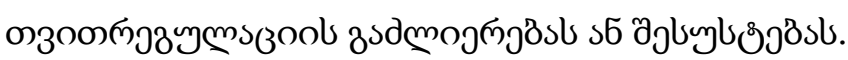

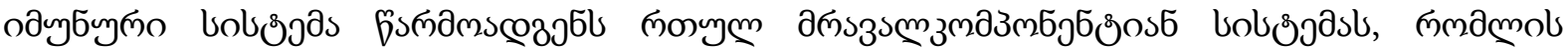

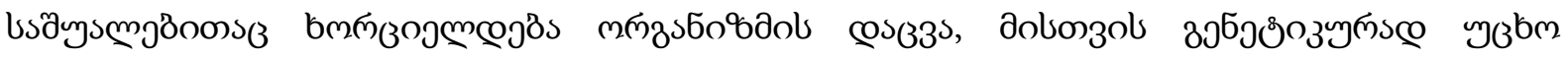

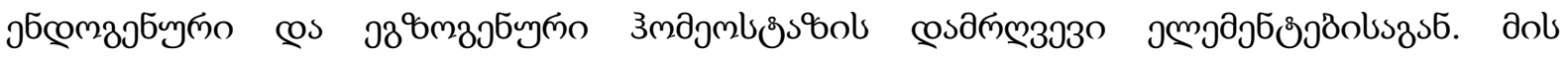

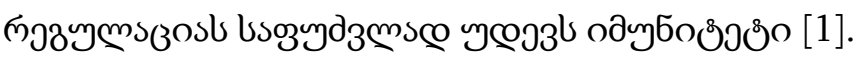

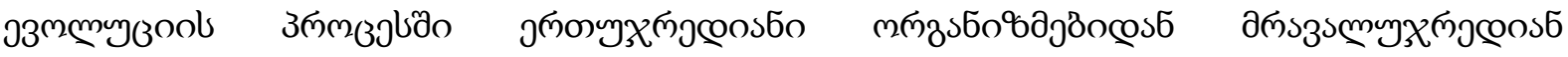

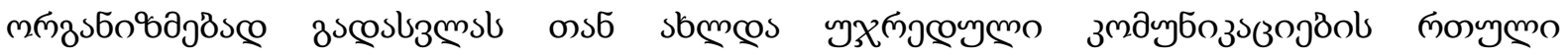

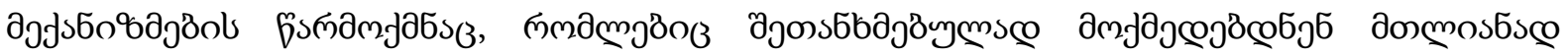

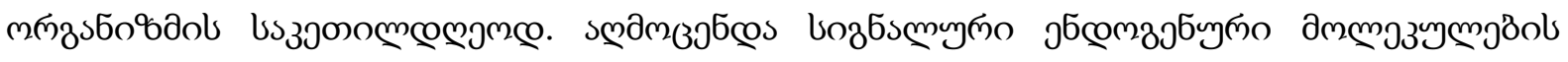

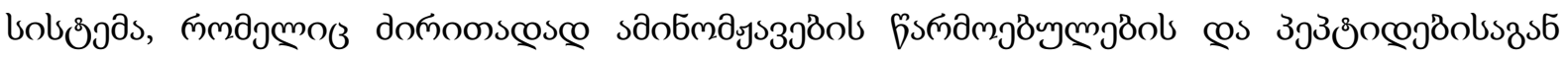

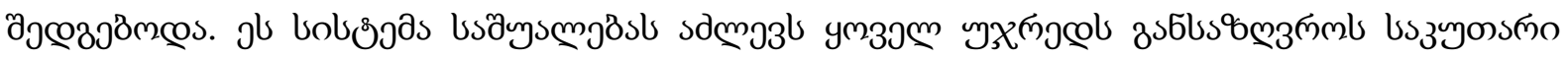

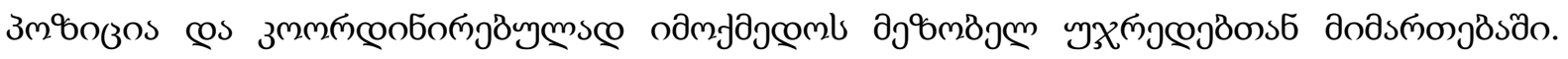

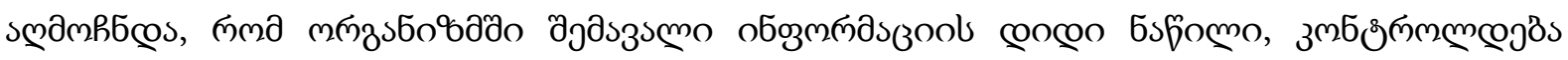

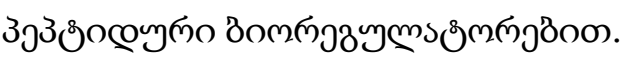

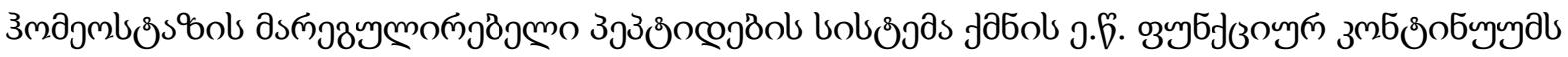

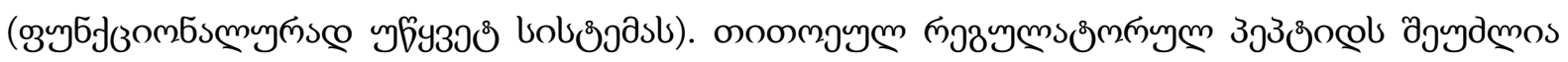

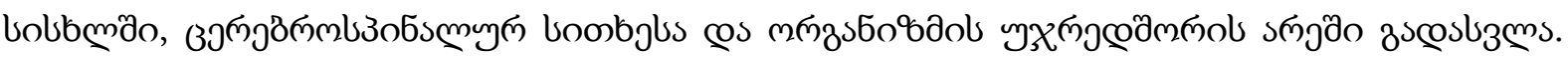




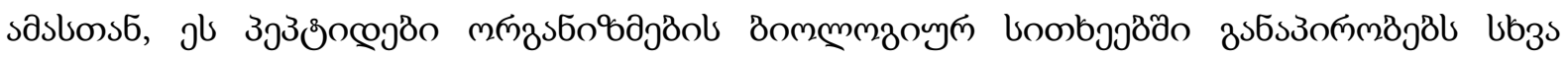

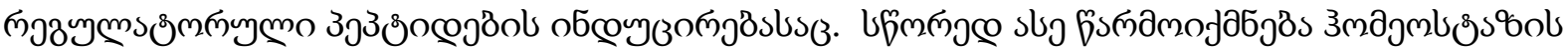

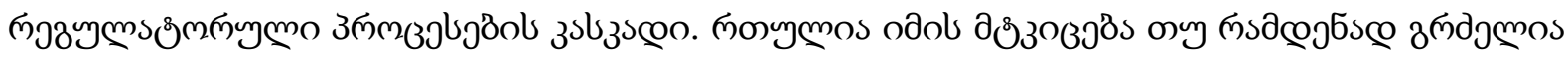

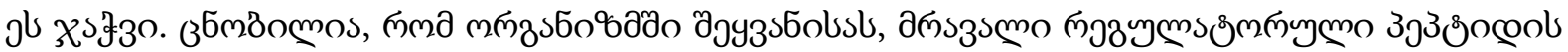

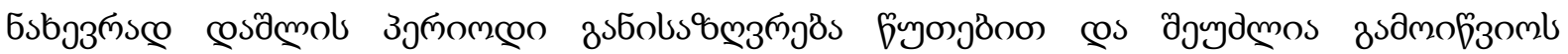

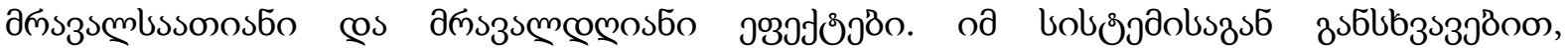

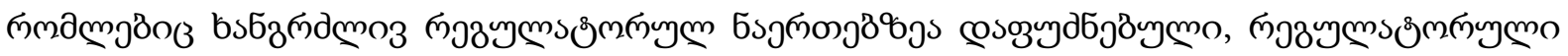

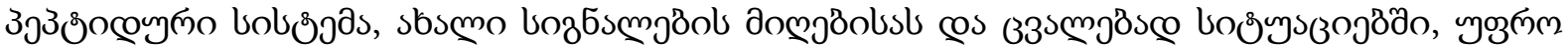

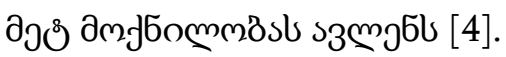

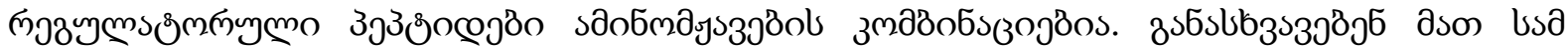

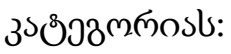

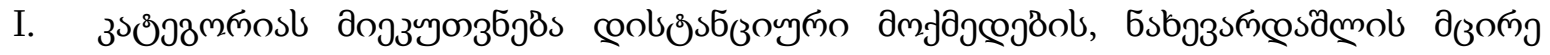

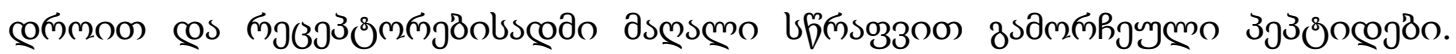

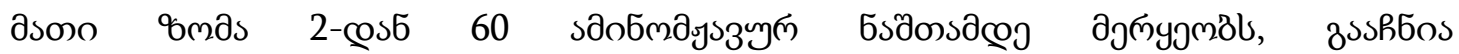

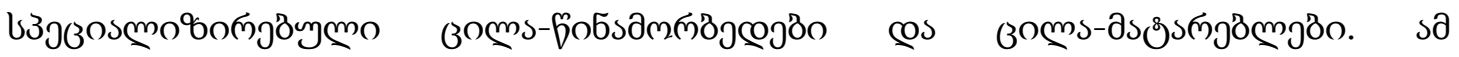

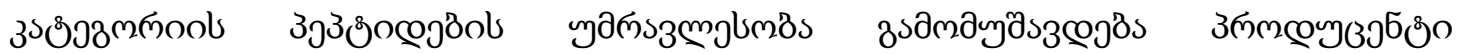

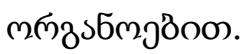

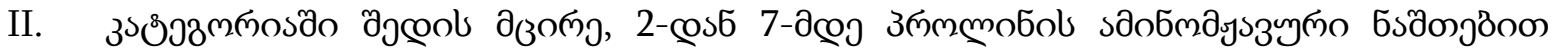

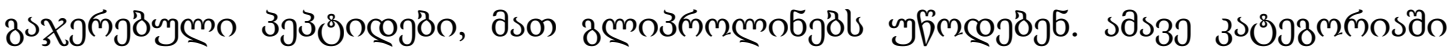

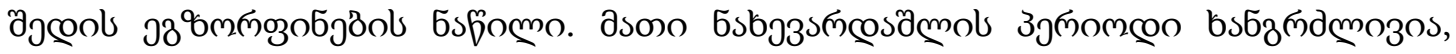

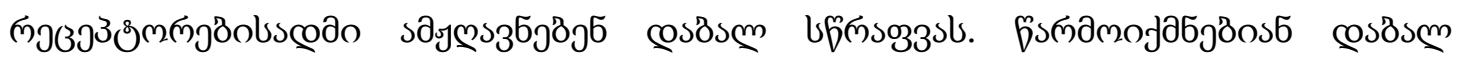

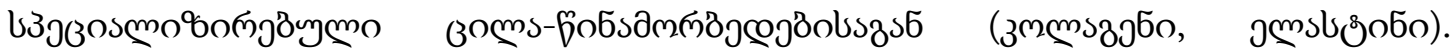

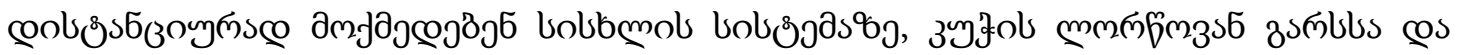
Бs6ुms $33^{8} \%$ o.

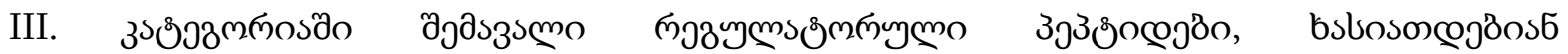

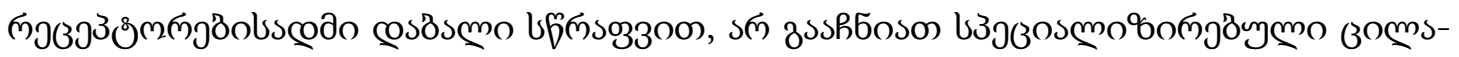

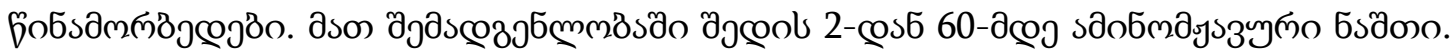

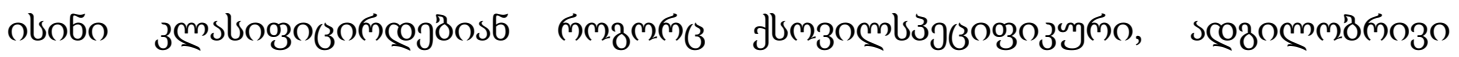

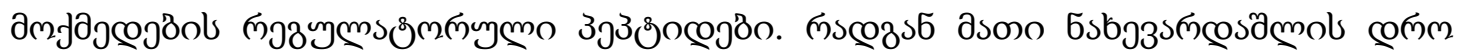

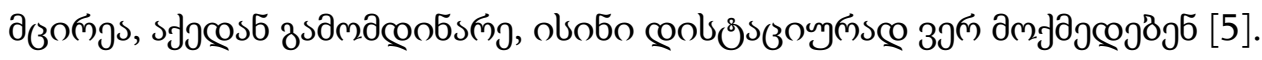

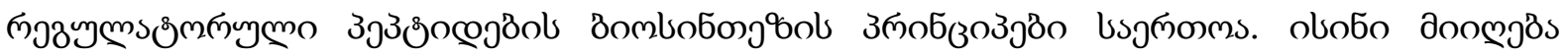

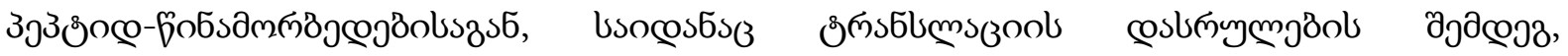

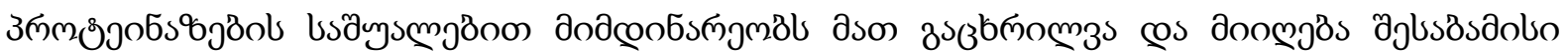

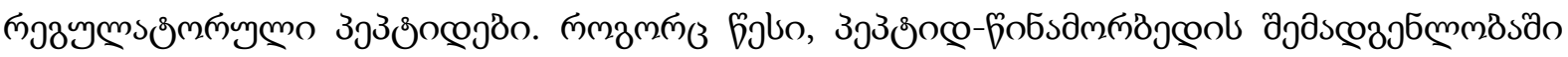

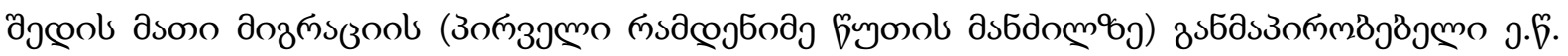

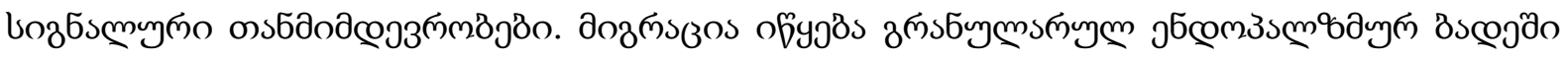

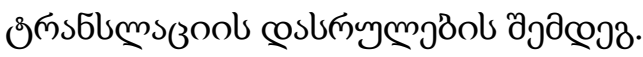

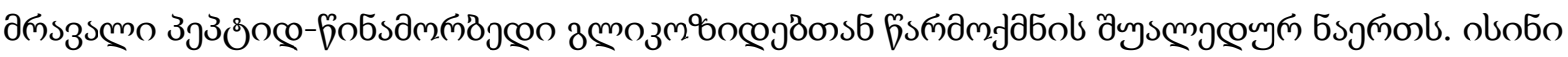

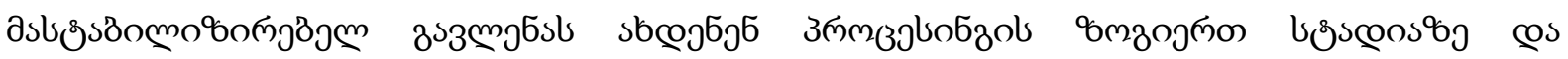

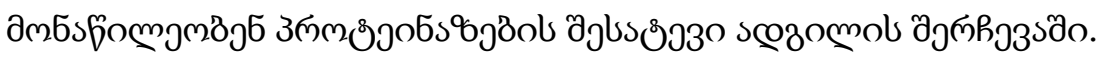




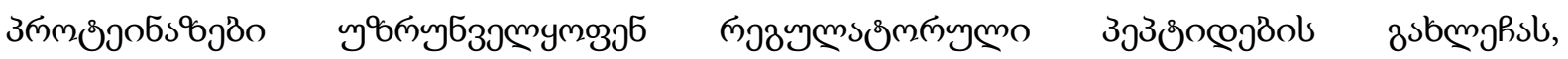

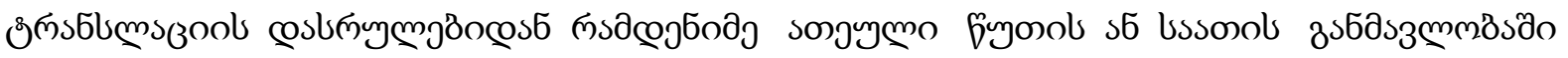

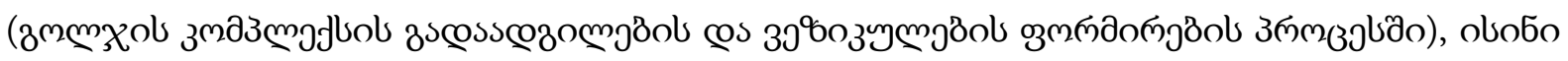

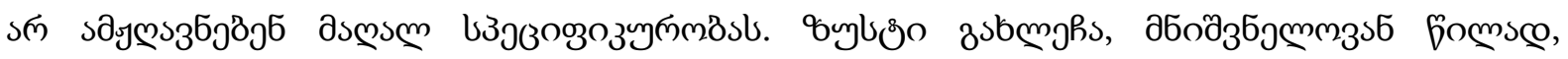

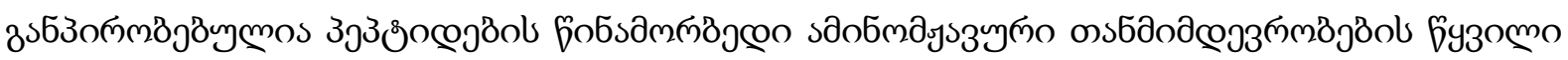

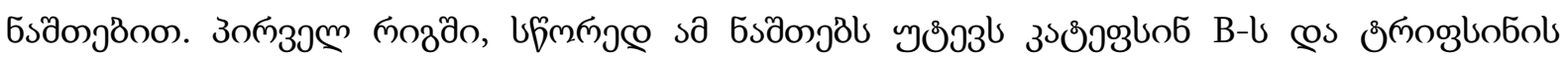

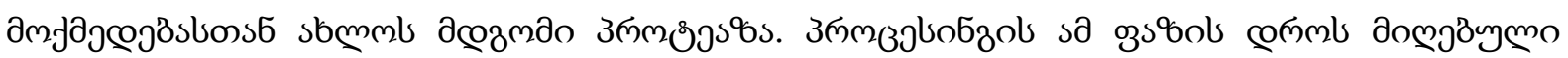

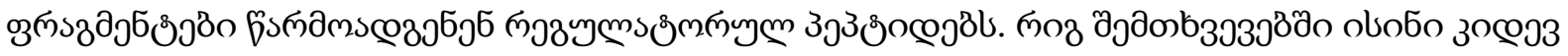

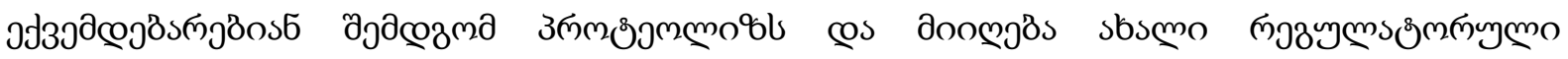

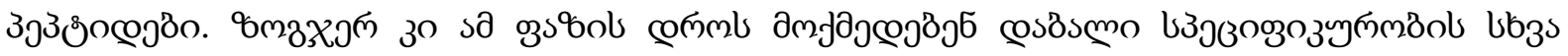

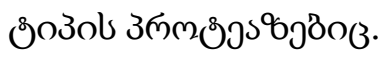

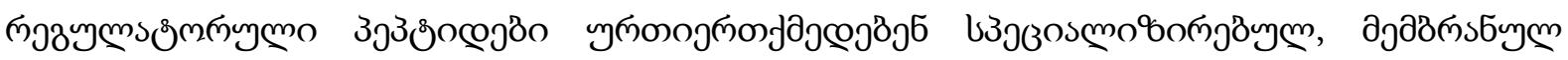

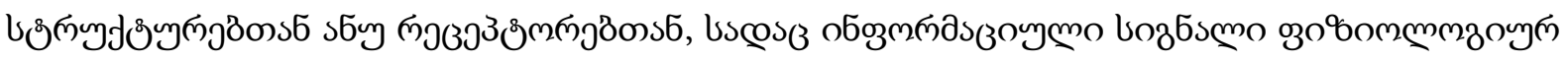

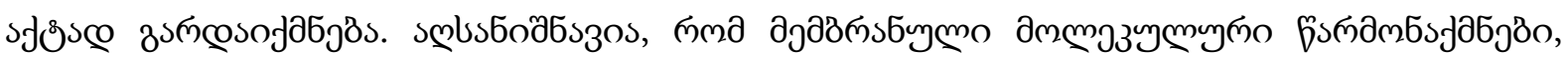

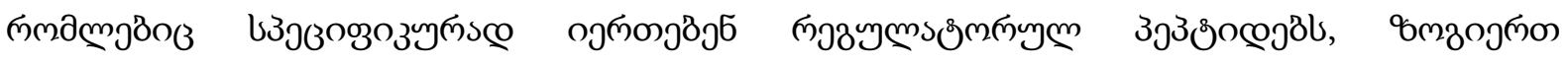

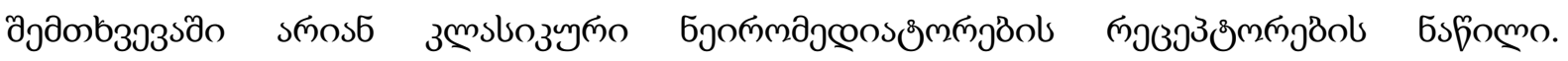

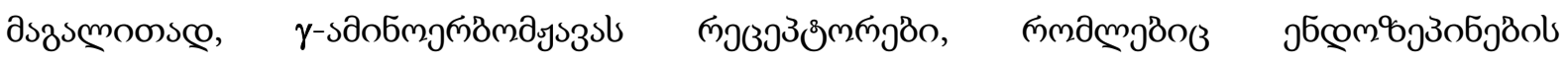

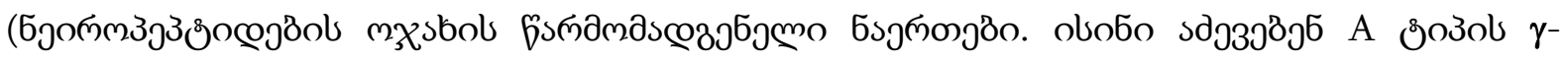

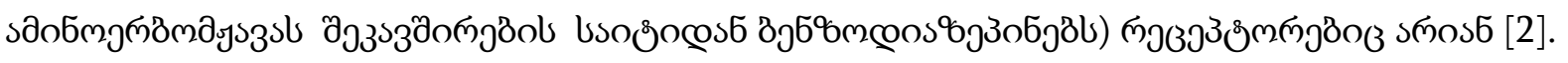

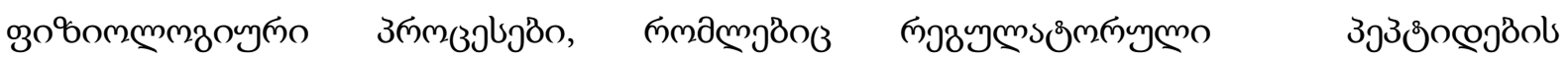

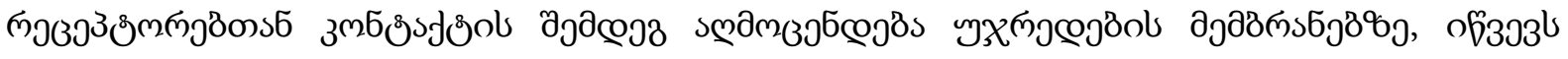

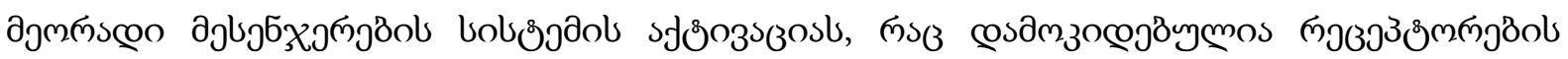
ชิก3\%).

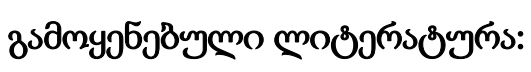

1. Ayala A., Chung C.S., Grutkoski P.S., Song G.Y. Mechanisms of immune resolution // Crit. Care. Med. 2003.Vol. 31, 8 Suppl. S. 558-571.

2. Costa, E. Diazepam binding inhibitor (DBI): a peptide with multiple biological actions [Text] / E. Costa, A. Guidotti // Life Science. - 1991. - Vol. 49. - P. 325-344.

3. Fabry Z., Raine C.S., Hart M.N. Nervous tissue as an immune compartment: The dialect of the immune response in the CNS // Immunol. Today. - 1994. - Vol. 15, № 5. - P. 218-224.

4. Korhonen H., Pihlanto A., Bioactive peptides: production andfunctionality. Int. Dairy J., 2006, 16, 945-960.

5. Ladenheim E.E. Bombesin. In: Kastin AJ, editor. Handbook of Biologically Active Peptides. Amsterdam: Elsevier, 2013. P. 1064-1070. 


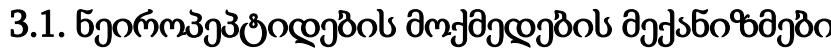

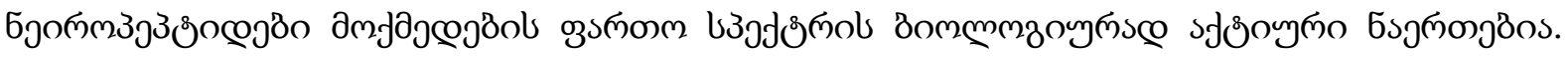

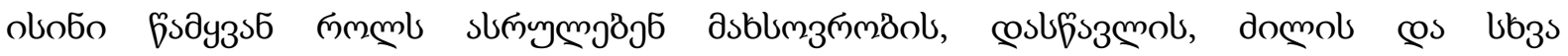

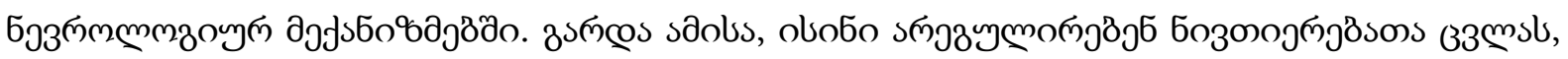

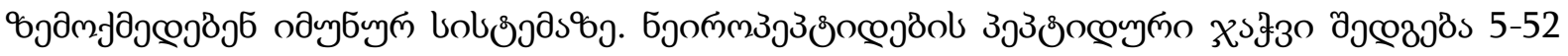

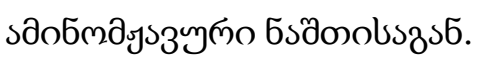

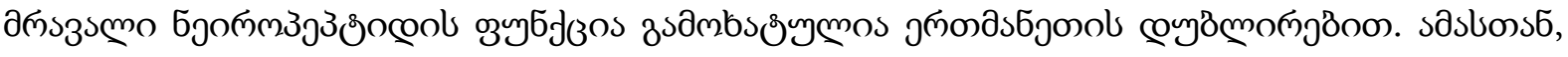

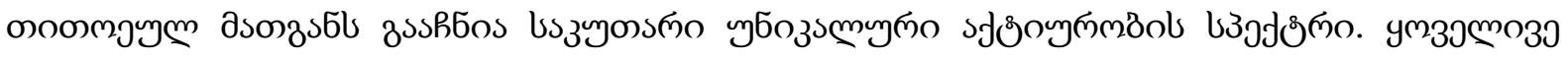

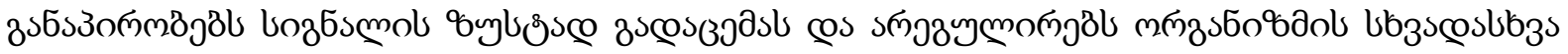

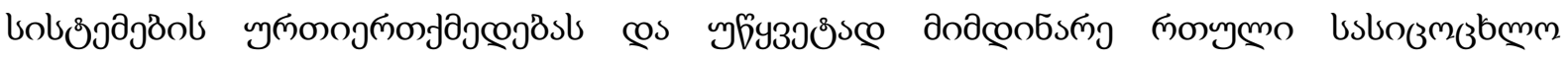

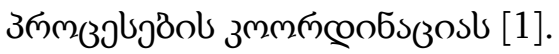

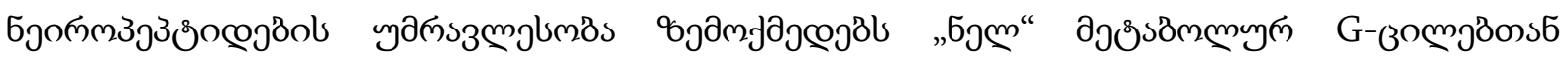

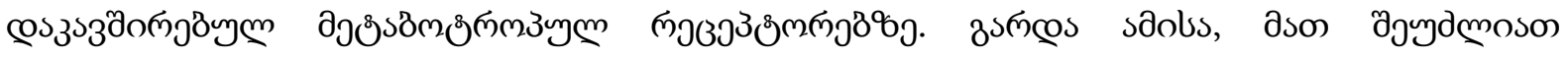

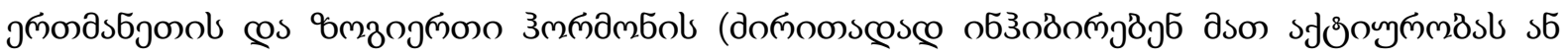

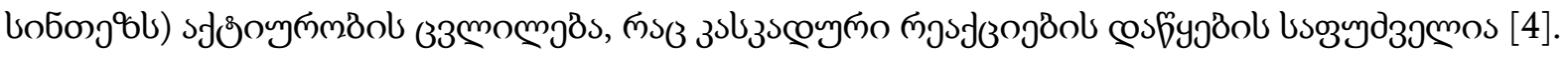

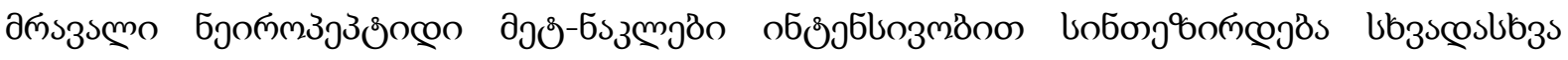

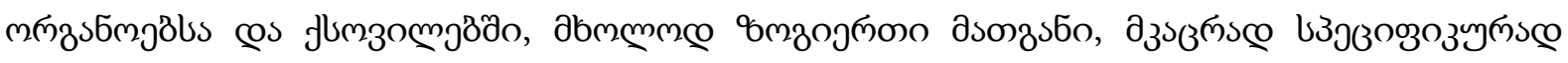

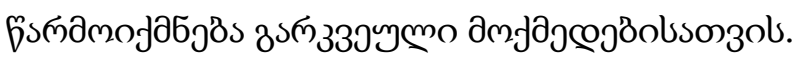

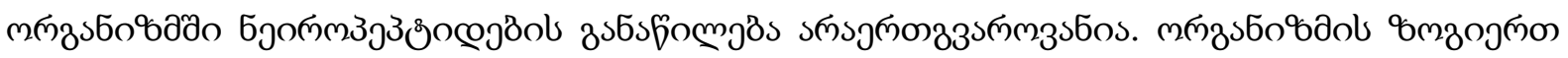

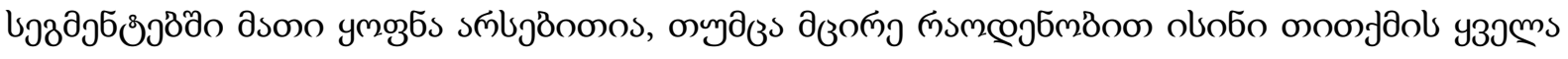

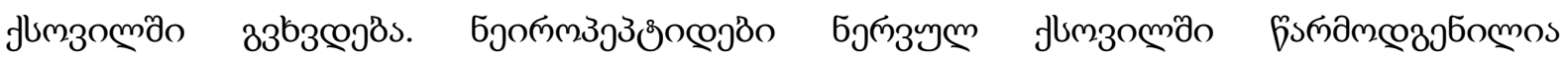

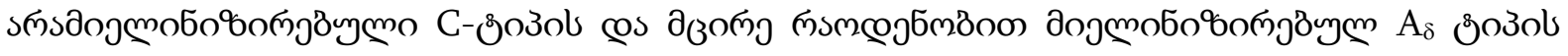

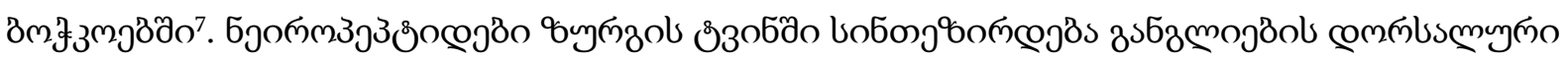

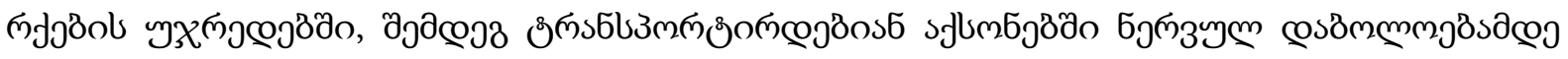

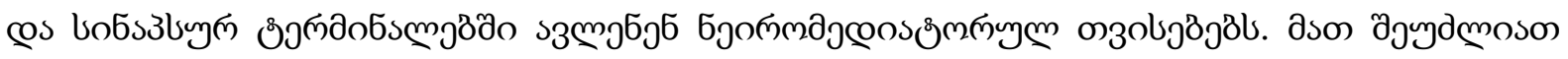

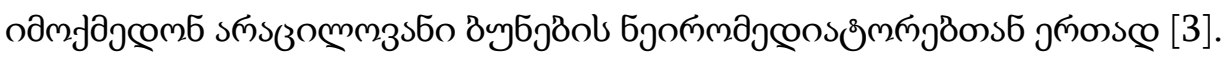

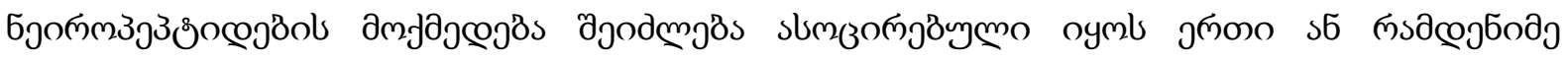

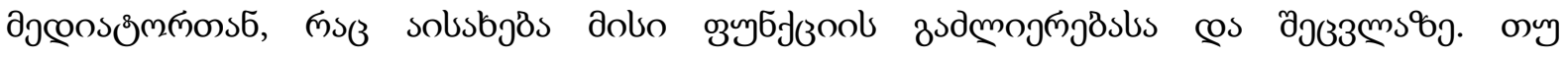

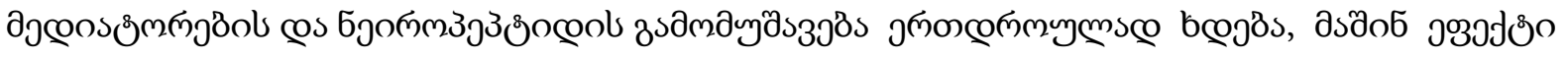

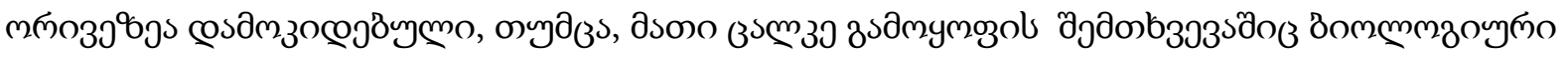

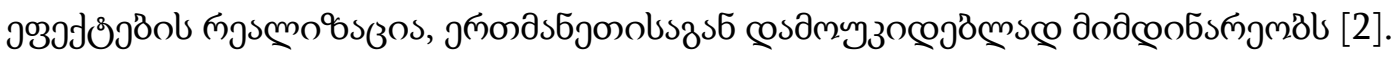

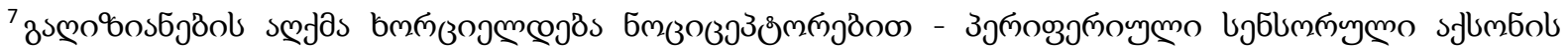

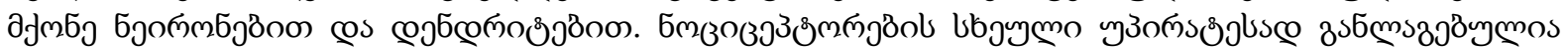

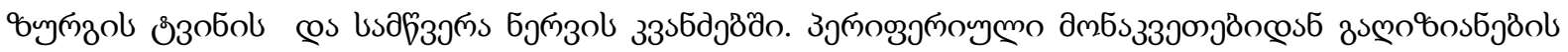

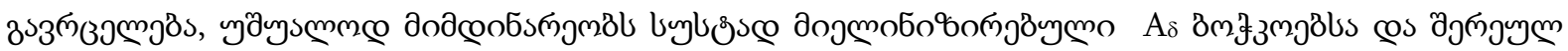

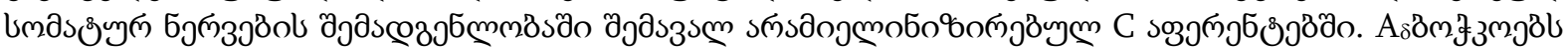

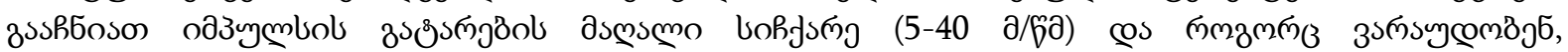

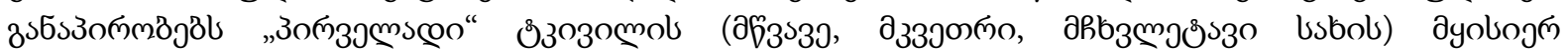

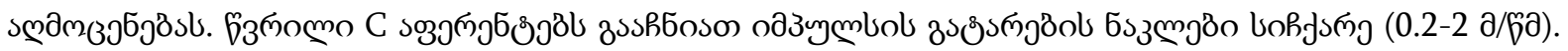

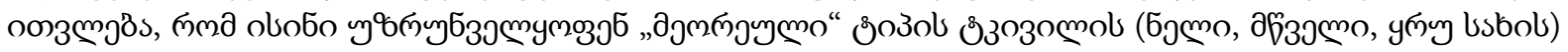

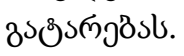




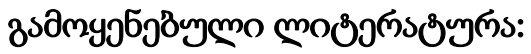

1. Hallberg M, Nyberg F. Neuropeptide conversion to bioactive fragments-an important pathway in neuromodulation. Curr Protein Pept Sci 2003;4(1):31-44.

2. Hokfelt T, Pernow B, Wahren J. Substance P: A pioneer amongst neuropeptides. J Intern Med2001;249(1):27-40.

3. Huang Y, Thathiah A (2015) Regulation of neuronal communication by G protein-coupled receptors. FEBS Letters 589:1607-1619.

4. Nyberg F, Hallberg M. Peptide conversion-a potential pathway modulating G-protein signaling. Current Drug Targets 2007;8(1):147-154.

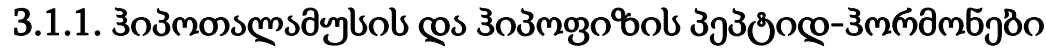

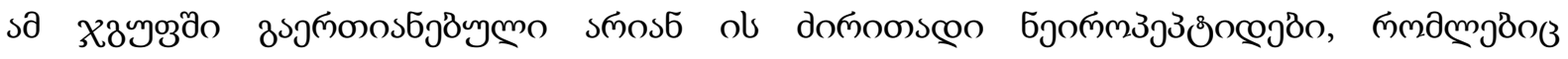

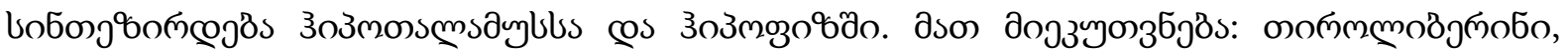

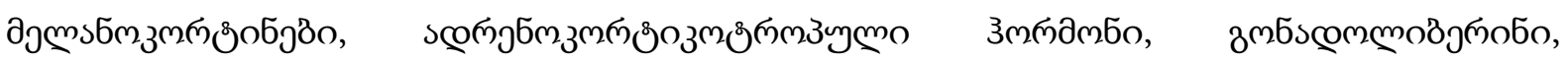

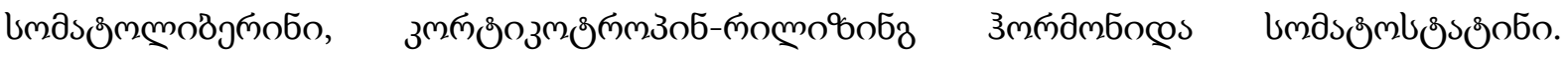

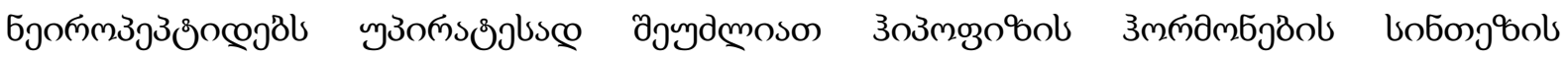

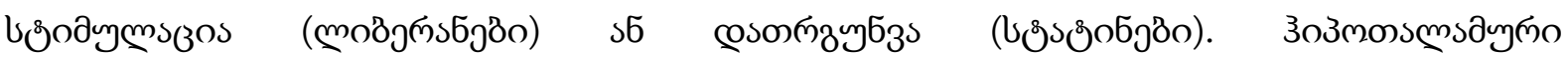

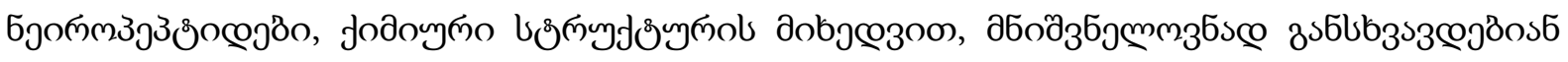

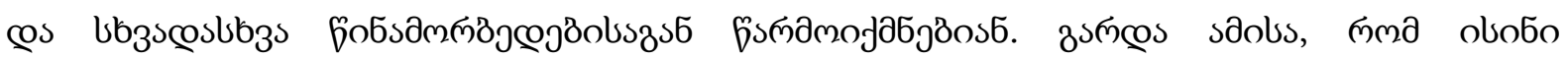

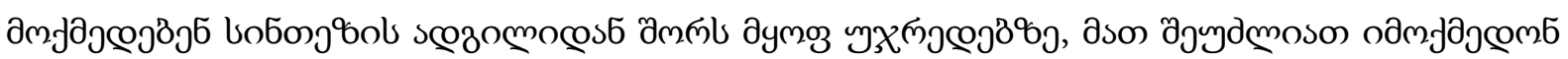

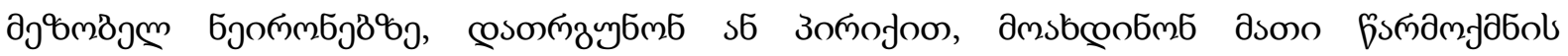

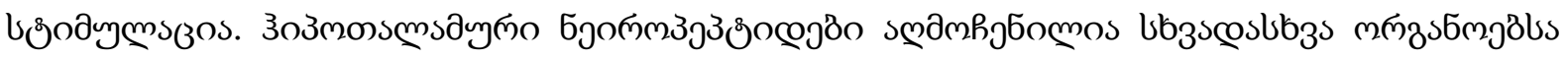

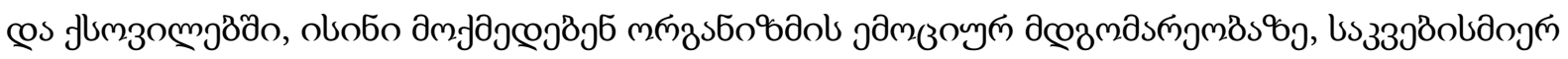

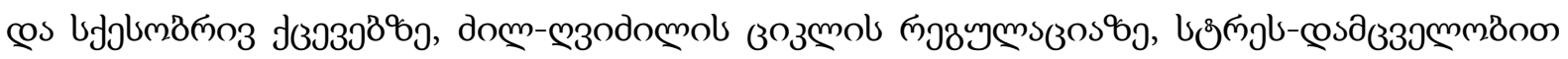

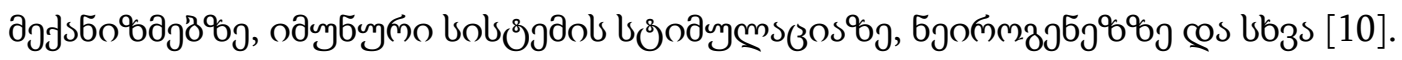

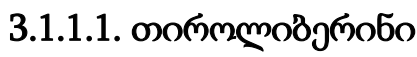

- јазойлумпо озмпдулмs: $\mathrm{C}_{16} \mathrm{H}_{22} \mathrm{~N}_{6} \mathrm{O}_{4}$.

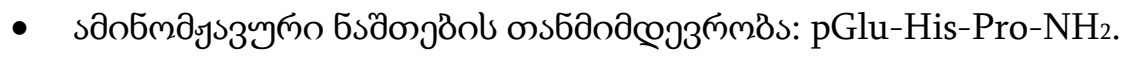

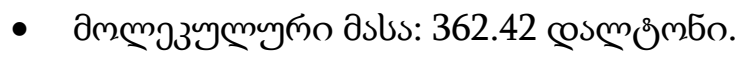

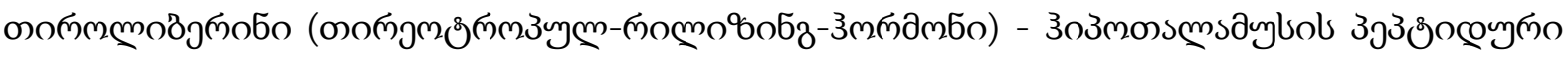

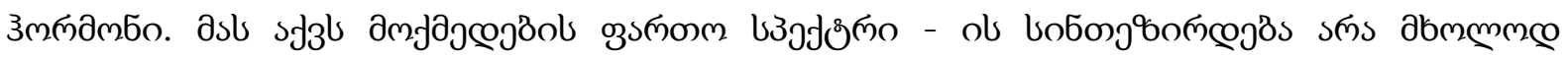

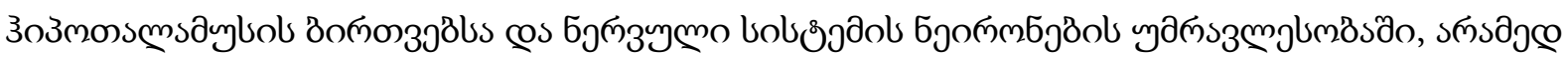

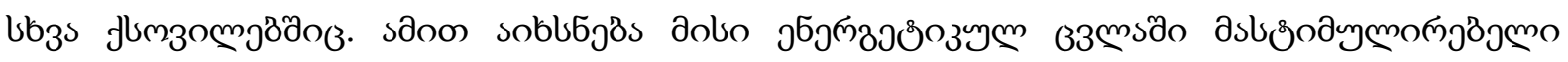

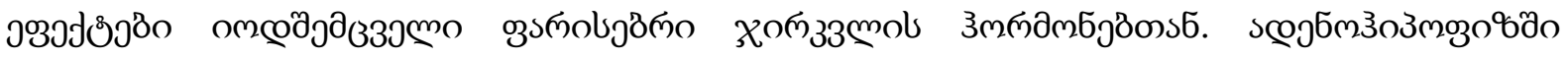

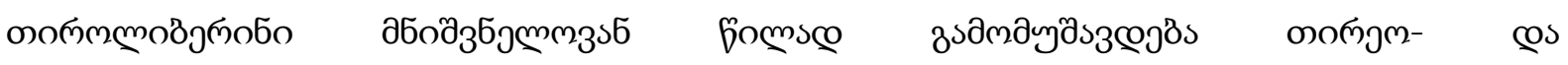

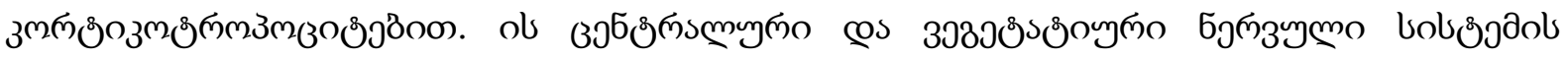

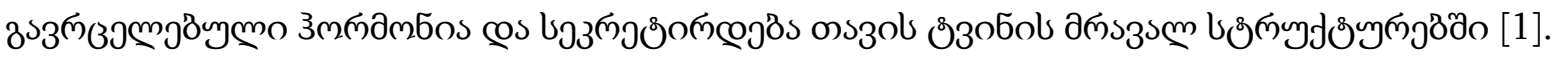

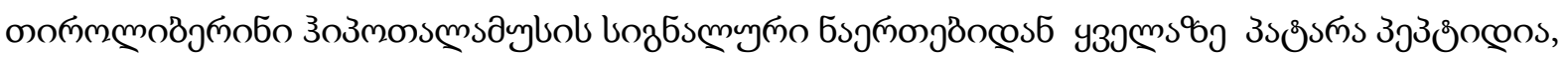




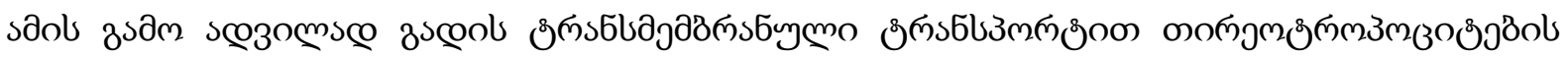

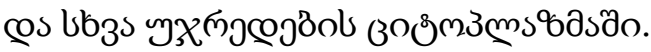

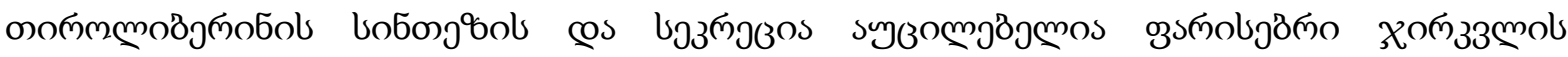

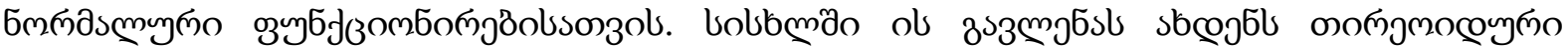

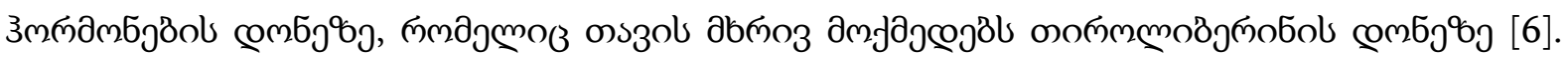

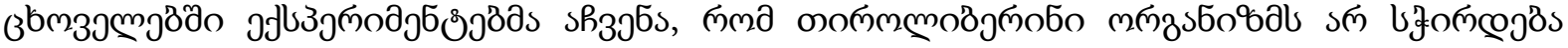

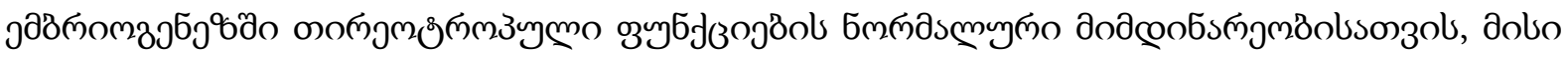

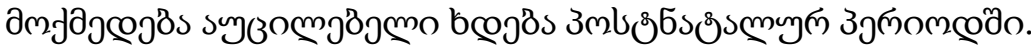

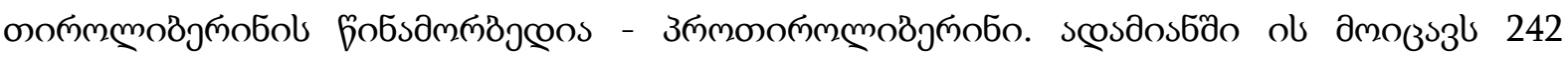

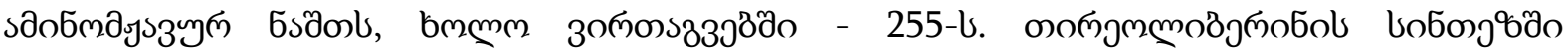

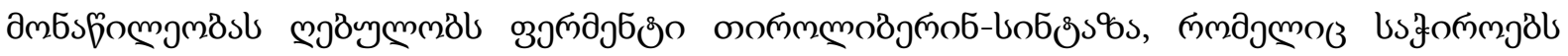

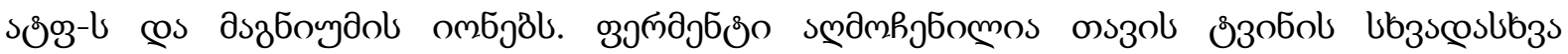

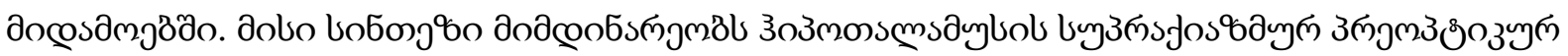

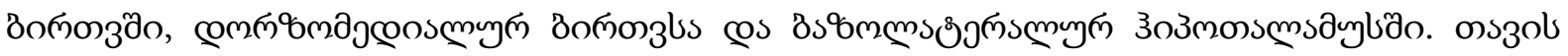

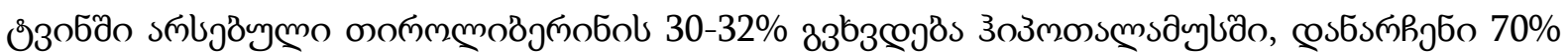

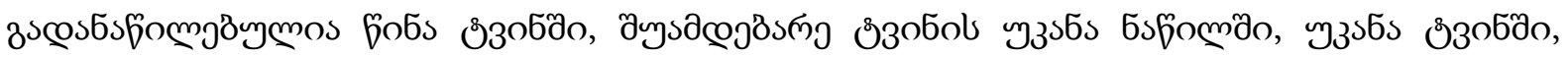

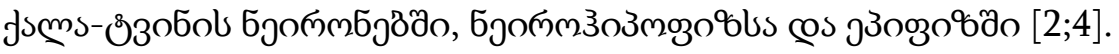

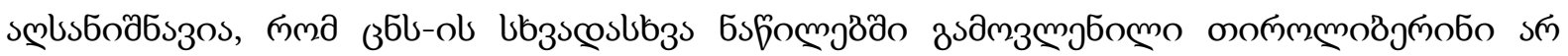

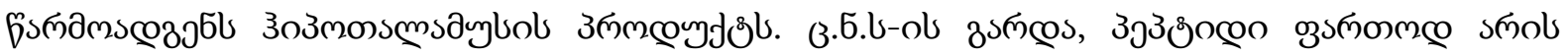

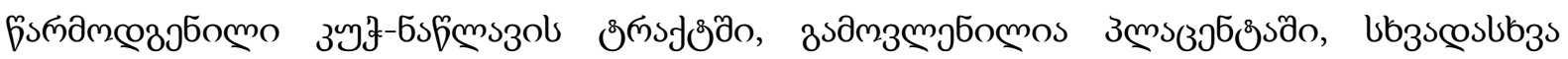

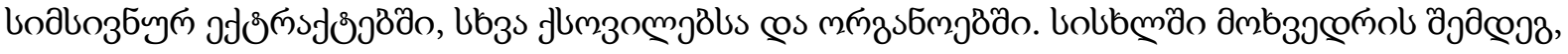

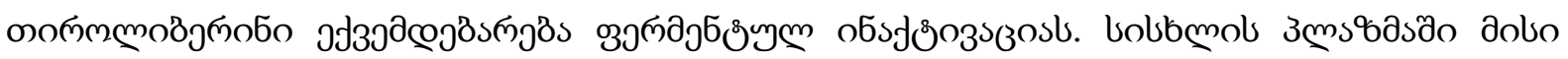

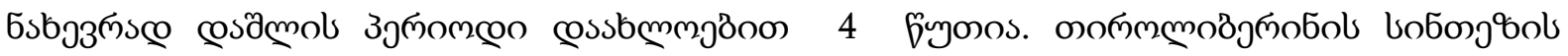

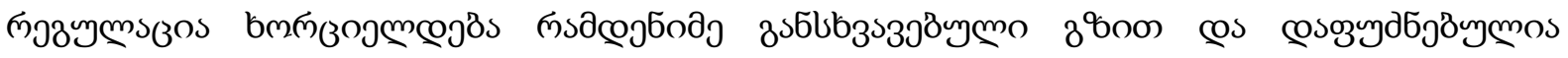

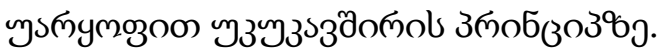

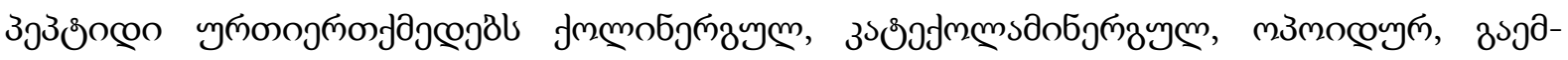

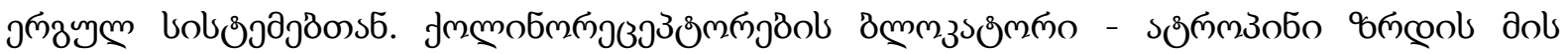

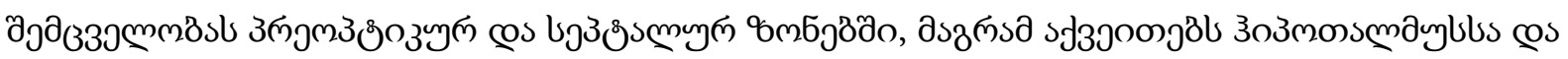
зозмозо\%до [4].

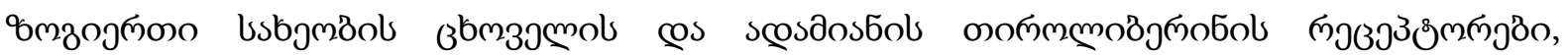

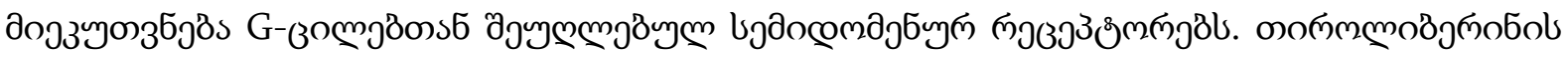

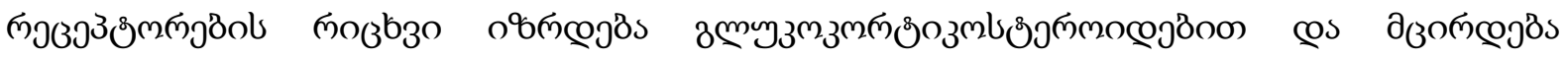

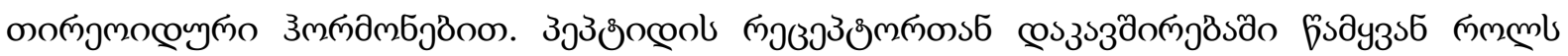

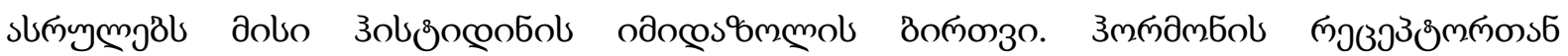

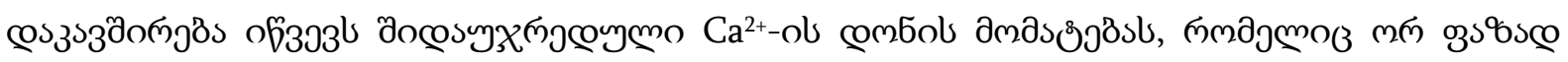

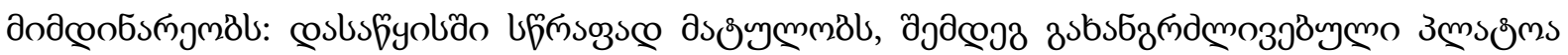

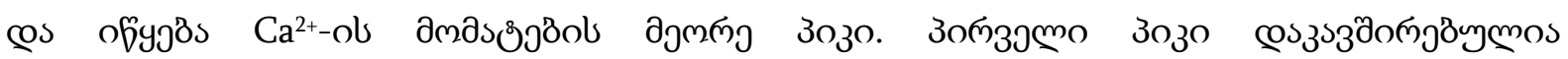

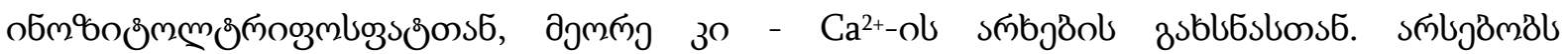

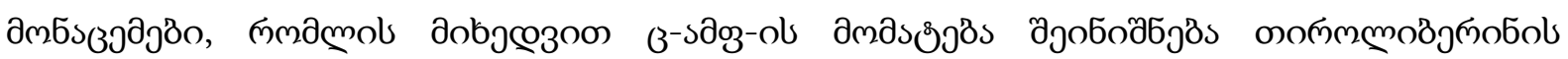

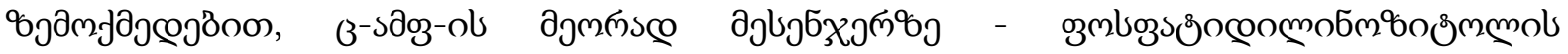

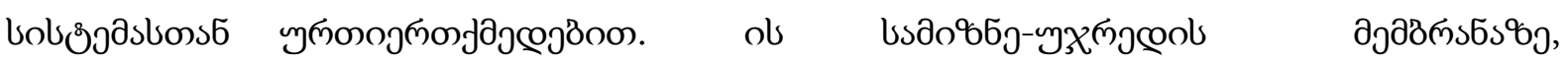

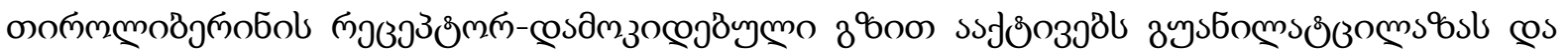




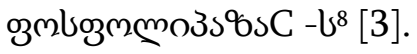

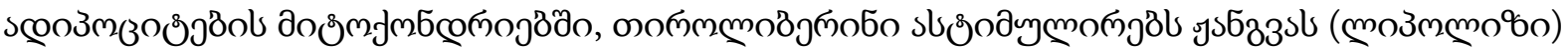

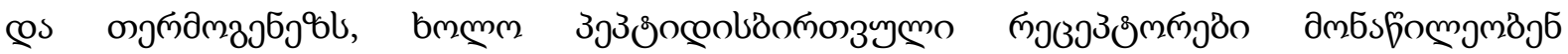

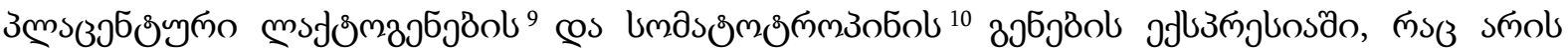

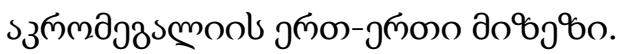

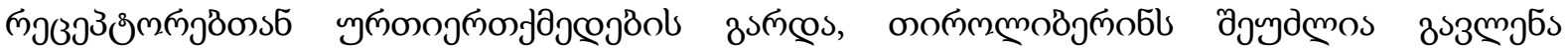

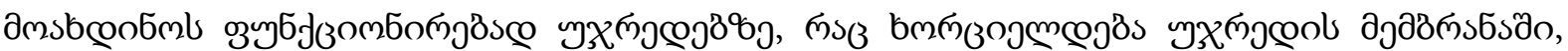

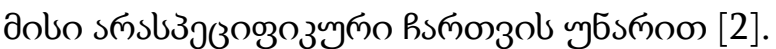

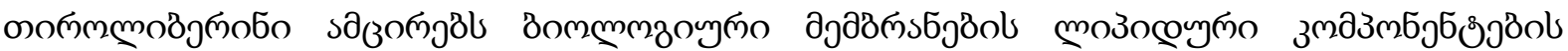

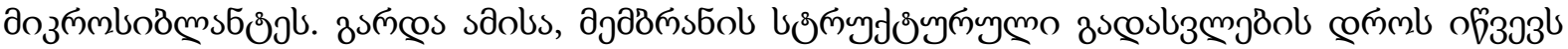

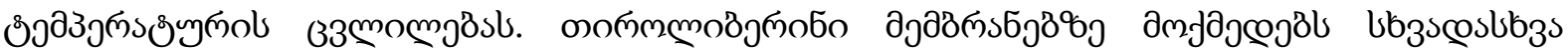

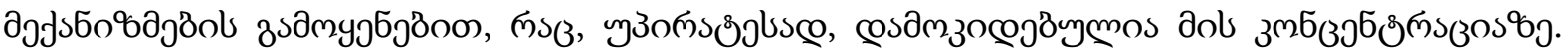

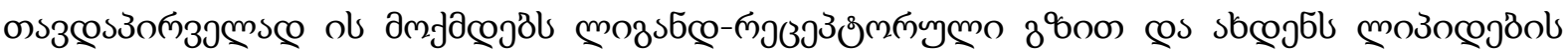

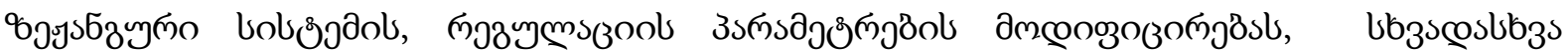

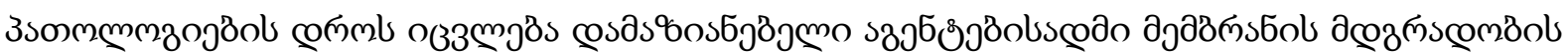

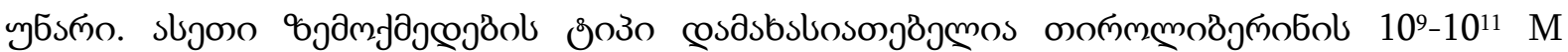

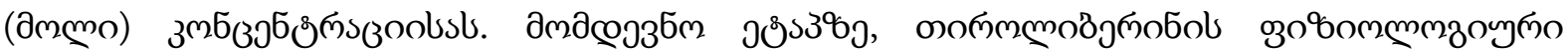

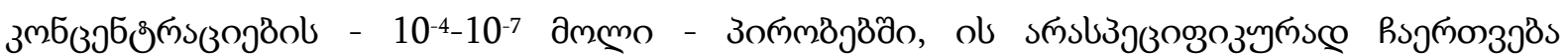

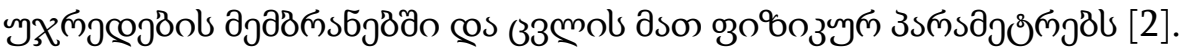

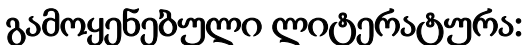

1. E.A. Nillni, K.A. Sevarino. The biology of pro-thyrotropin-releasing hormone-derived peptides //Endocrine Reviews, 1999, V. 20, No 5, P. 599-648.

2. V. Monga, C.L. Meena, N. Kaur, R. Jain. Chemistry and biology of thyrotropinreleasinghormone (TRH) and its analogs. (Review) // Current Medicinal Chemistry, 2008, V. 15, P. 2718-2733.

3. N. Shibusawa, K. Hashimoto, M. Yamada. Thyrotropin-releasing hormone (TRH) in the cerebellum // The Cerebellum, 2008, P. 84-95.

4. R. O'Leary, B. O'Connor. Thyrotropin-releasing hormone. Short review // J. Neurochem., 1995,V. 65, P. 953-963.

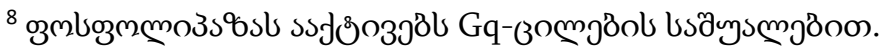

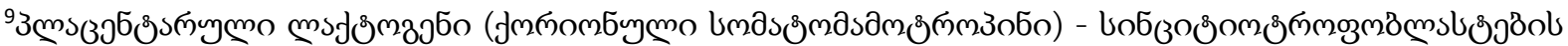

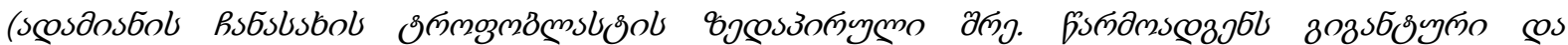

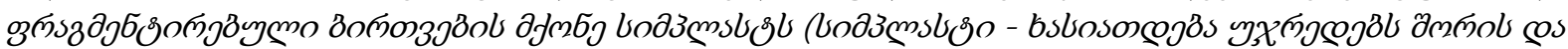

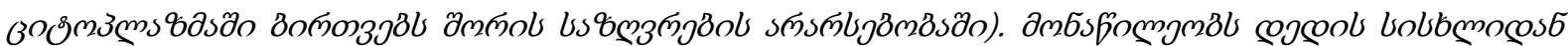

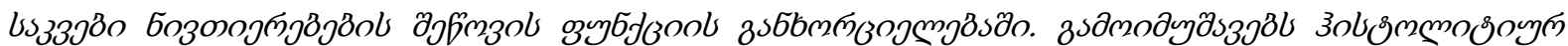

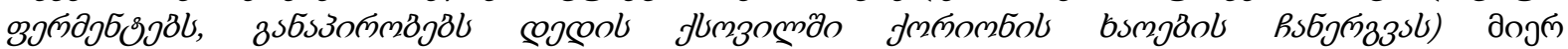

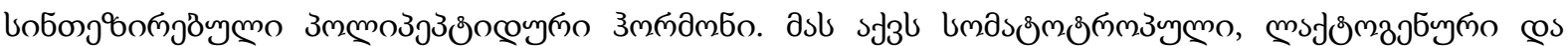

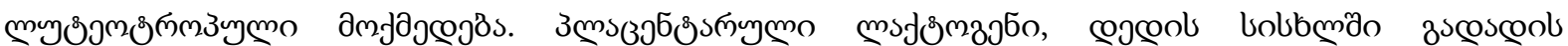

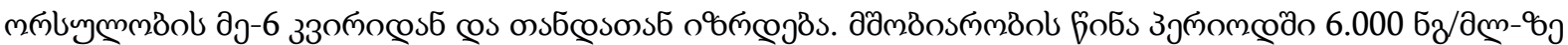

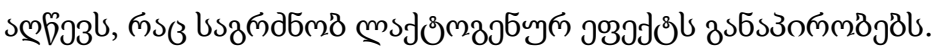

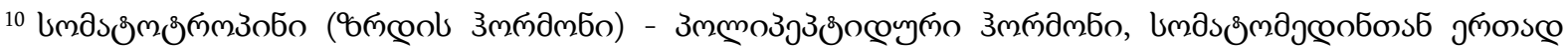

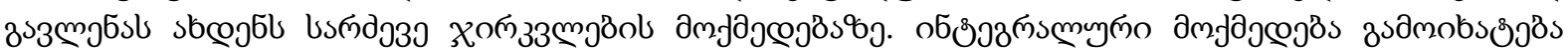

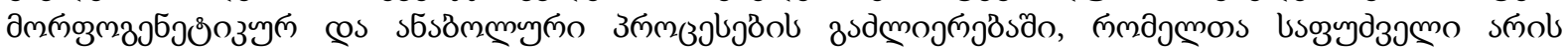

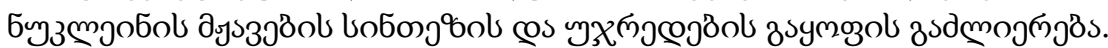




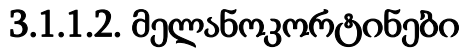

$\alpha-$-дз.

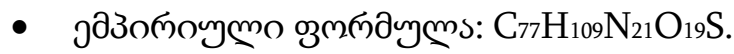

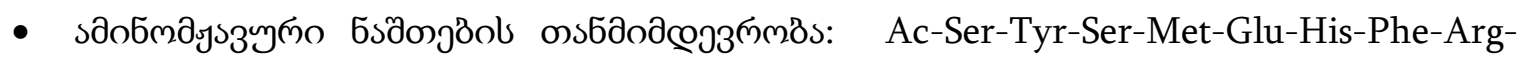
Trp-Gly-Lys-Pro-Val.

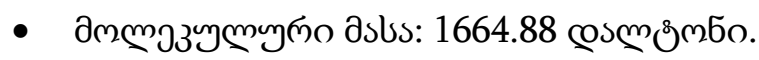

$\beta$-даз.

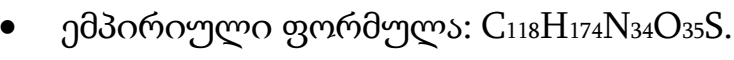

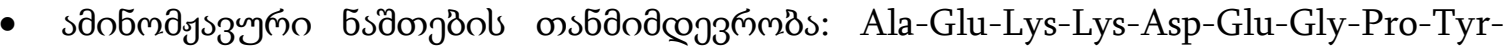
Arg-Met-Glu-His-Phe-Arg-Trp-Gly-Ser-Pro-Pro-Lys-Asp.

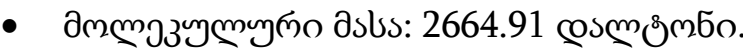

$\gamma$-даз.

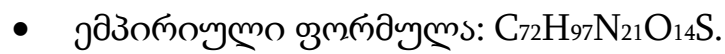

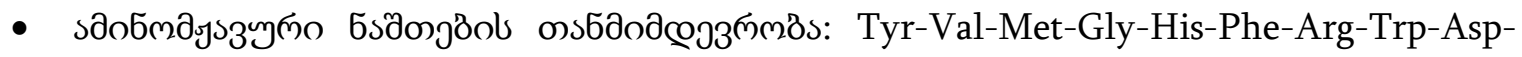
Arg-Phe-Gly.

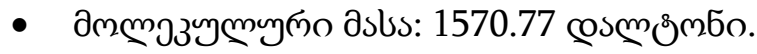

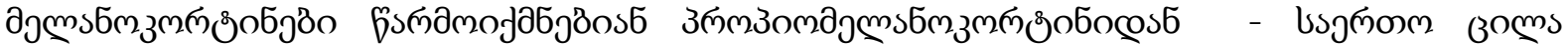

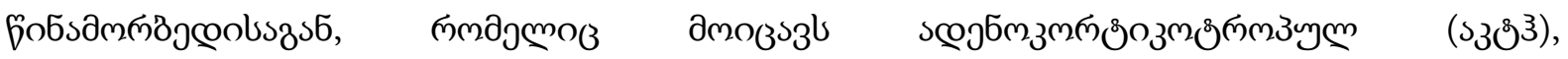

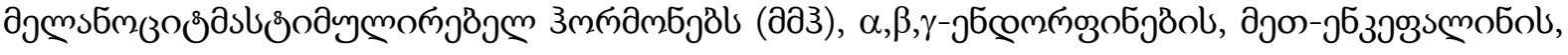

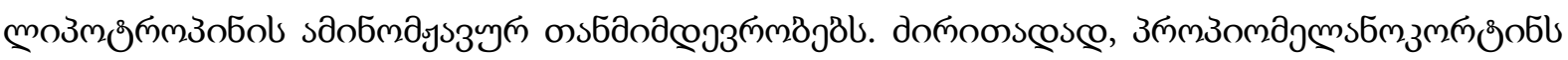

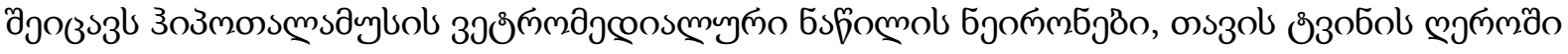

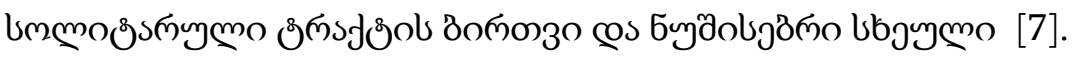

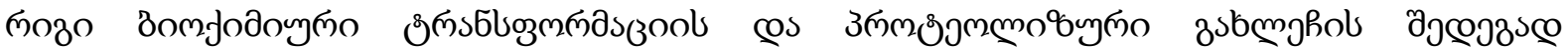

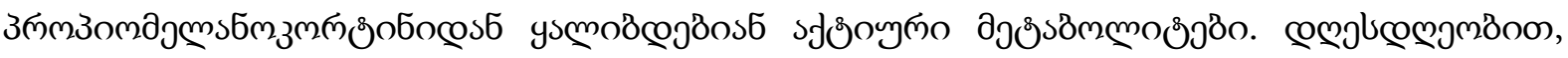

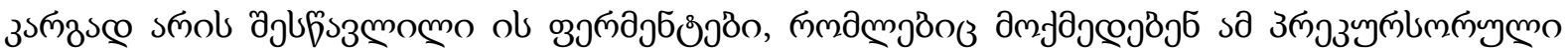

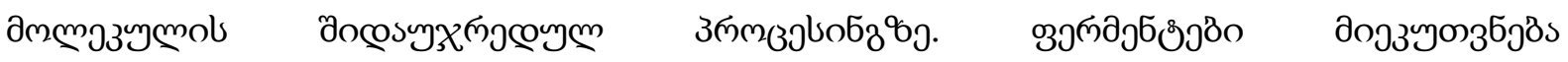

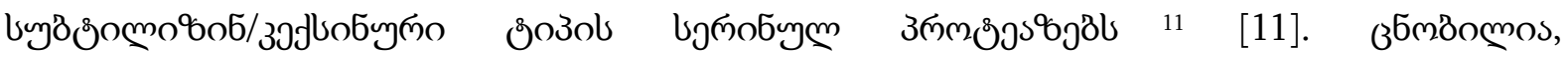

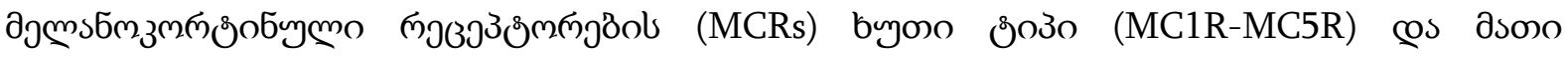

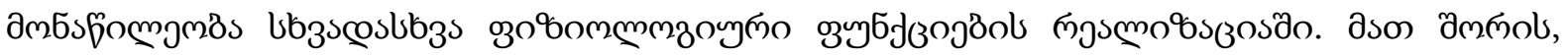

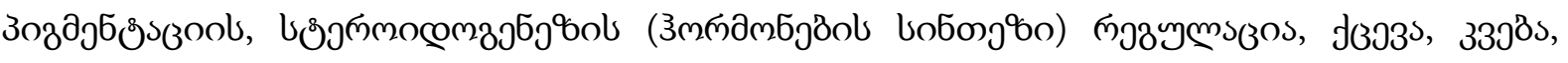

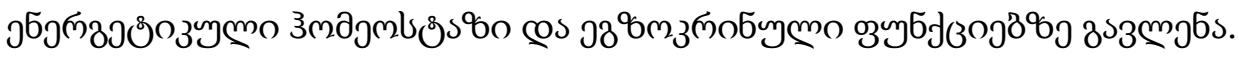

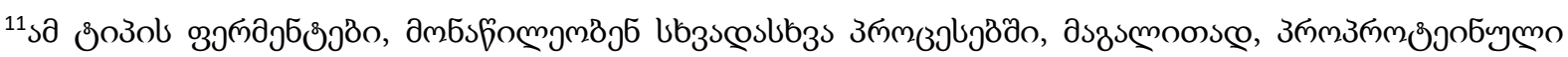

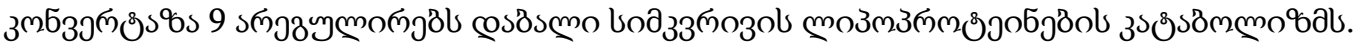




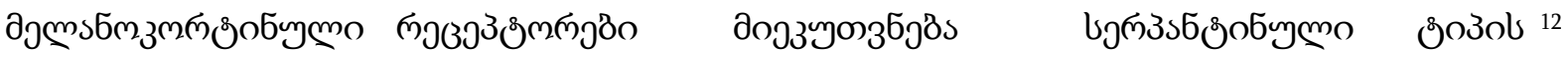

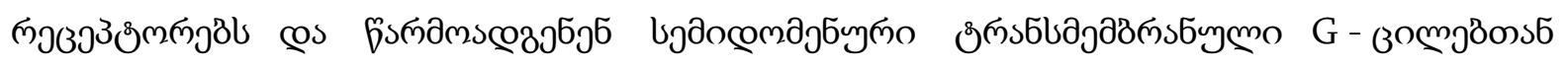

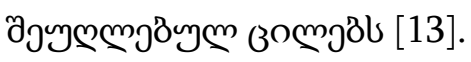

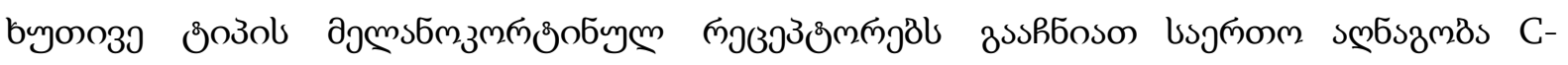

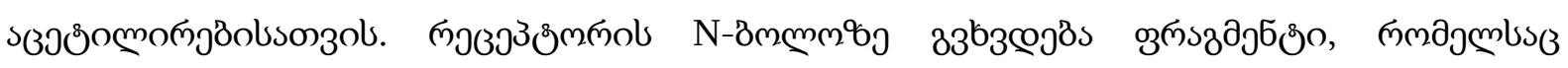

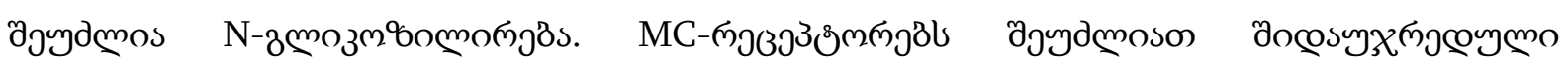

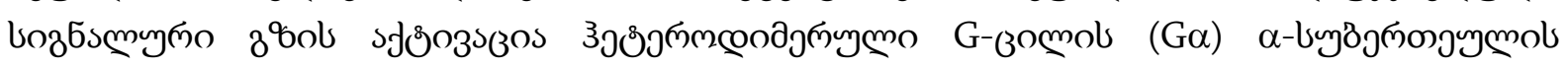

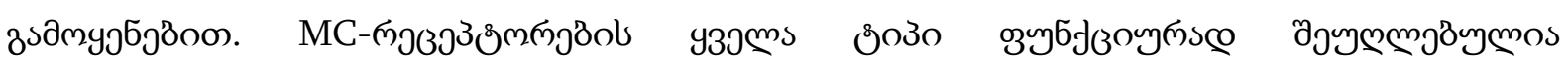

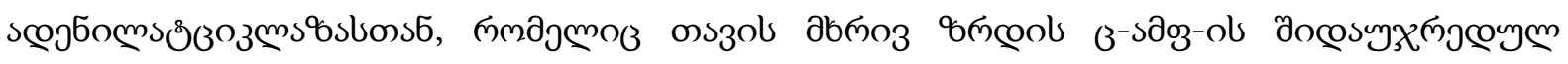
дjа

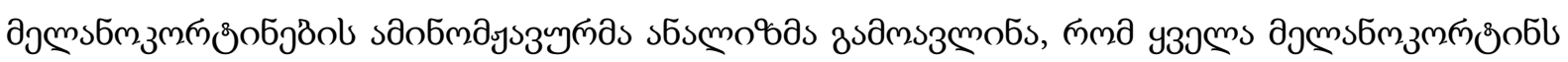

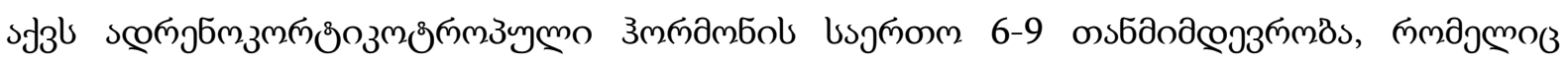

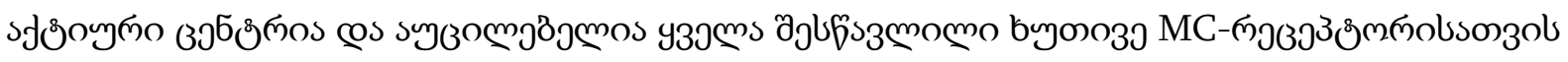

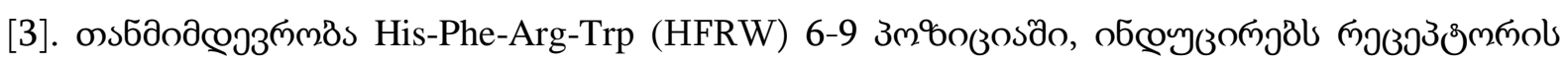

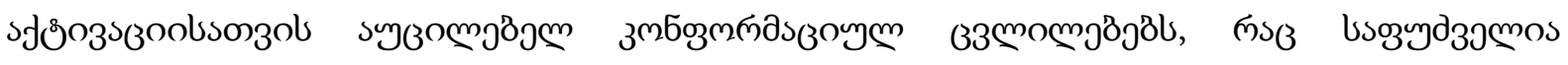

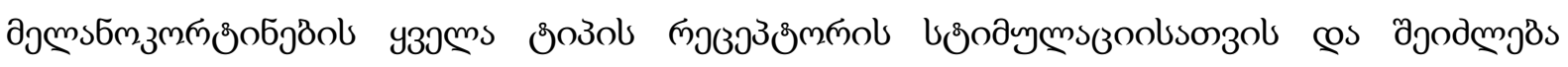

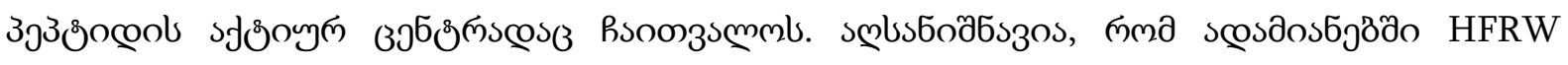

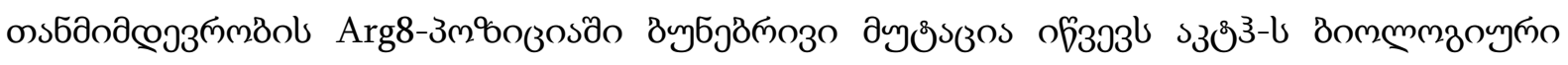

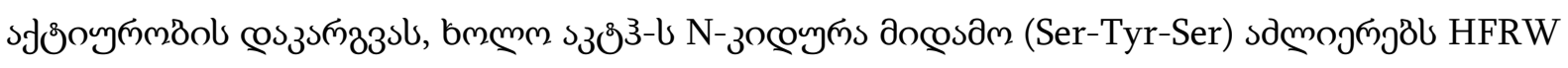

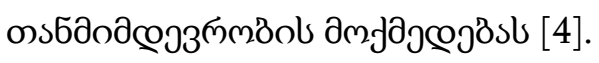

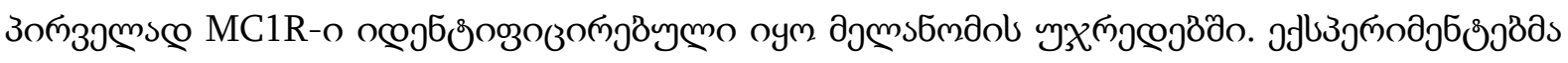

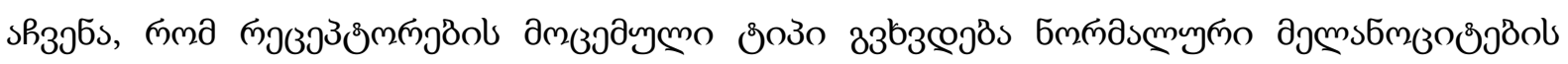

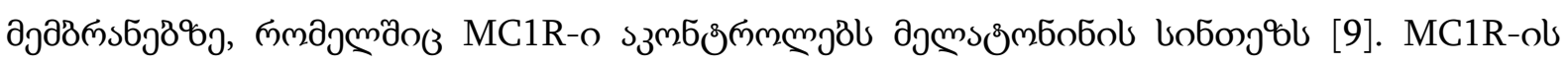

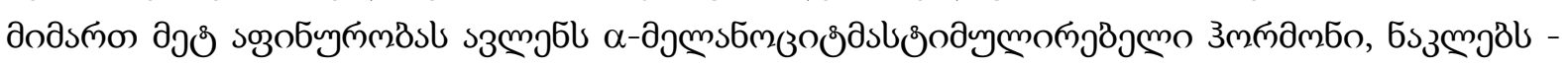

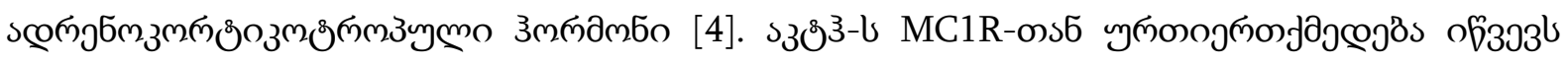

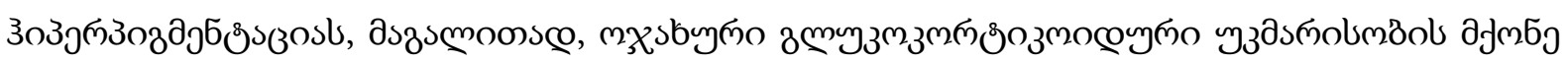

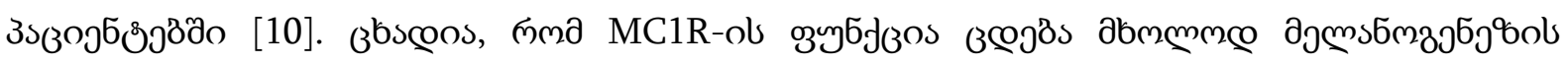

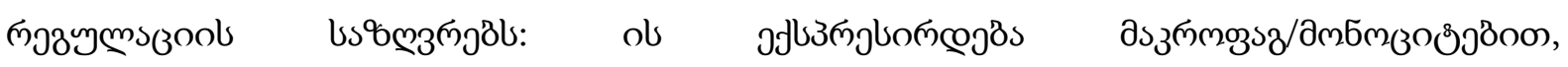

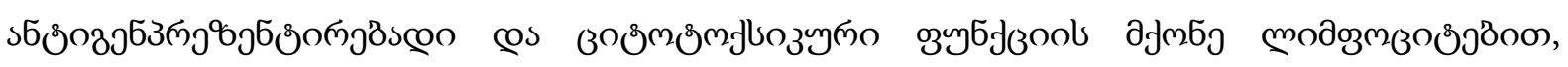

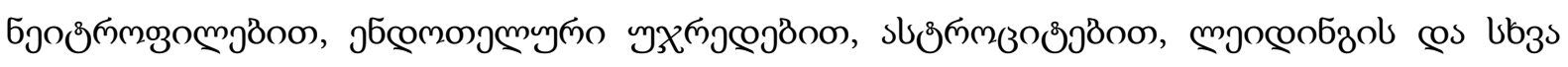

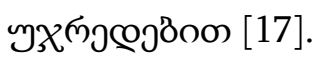

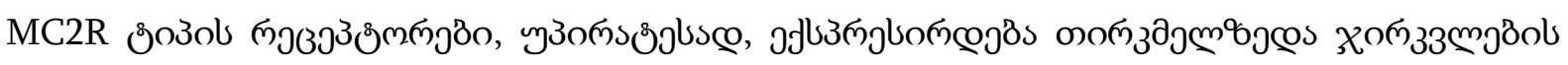

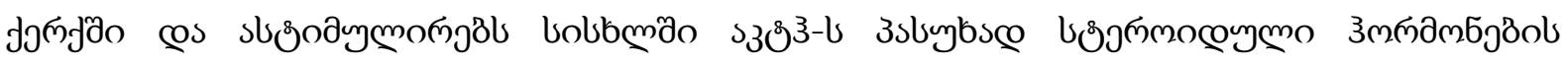

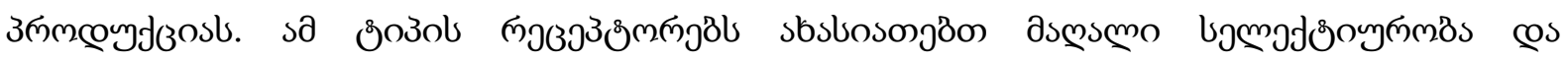

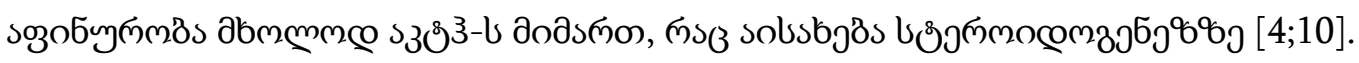

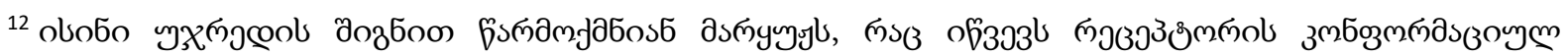

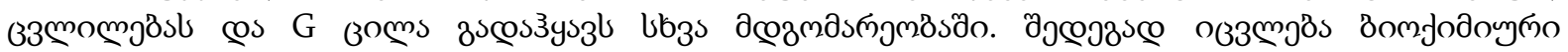

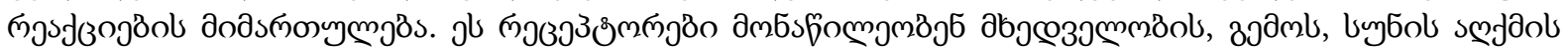

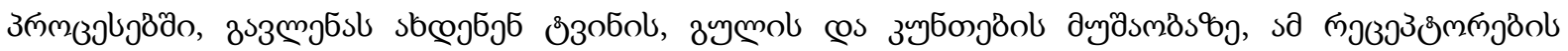

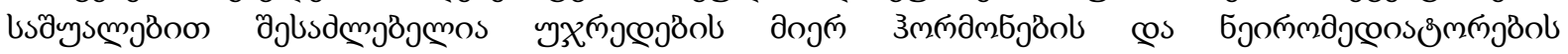

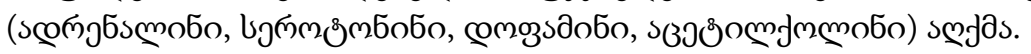




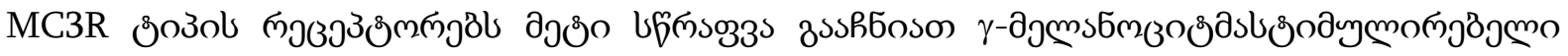

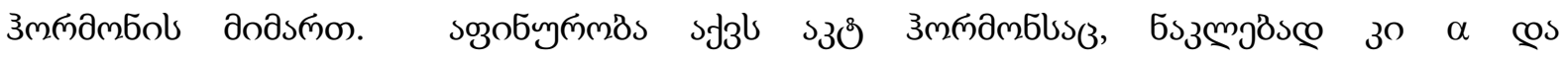

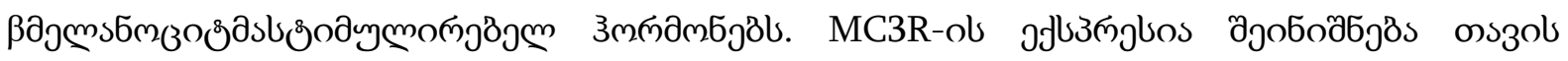

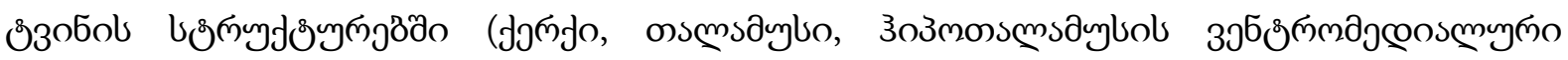

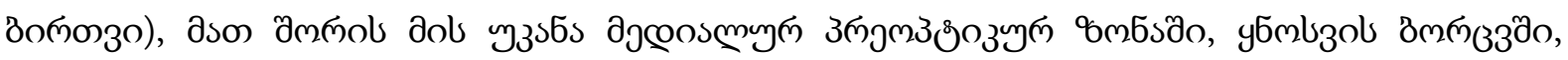

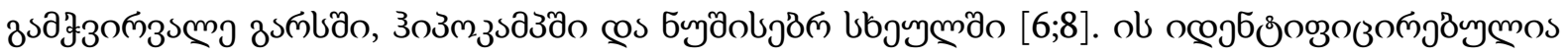

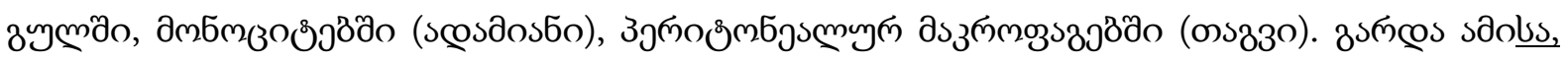

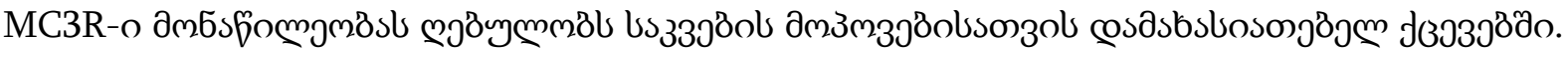

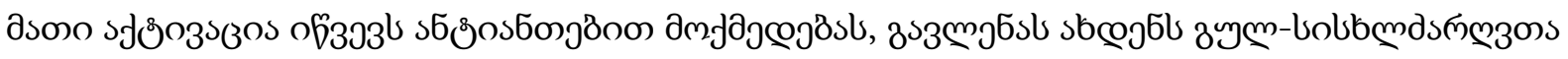

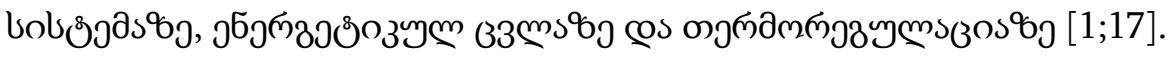

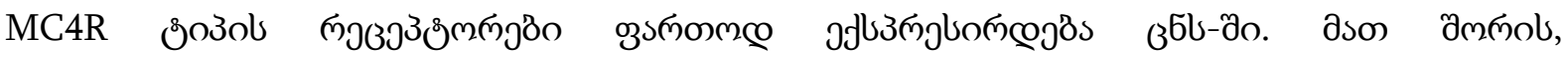

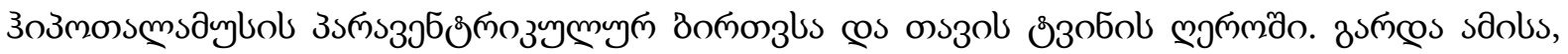

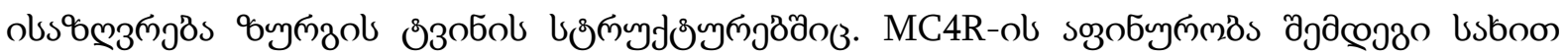

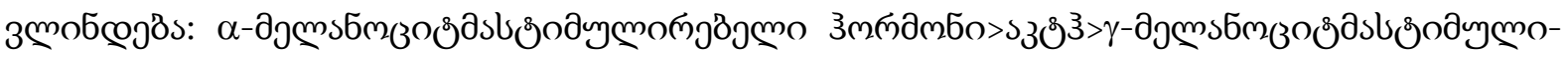

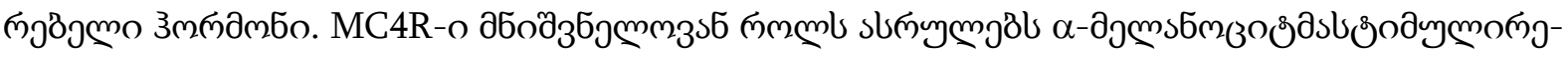

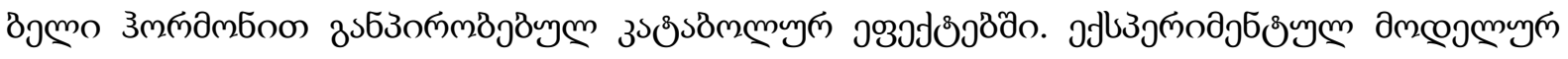

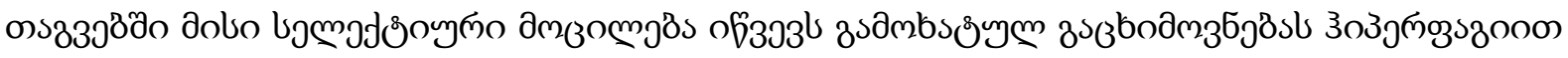

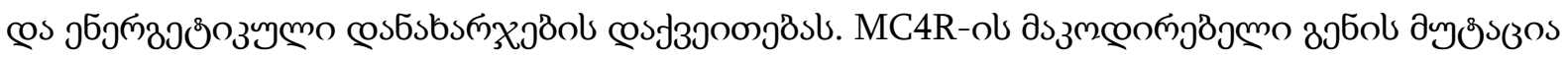

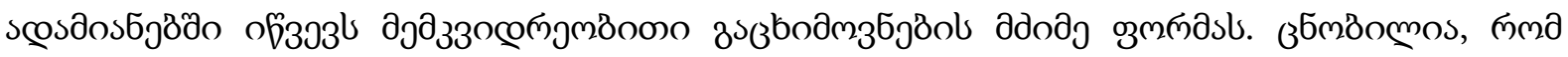

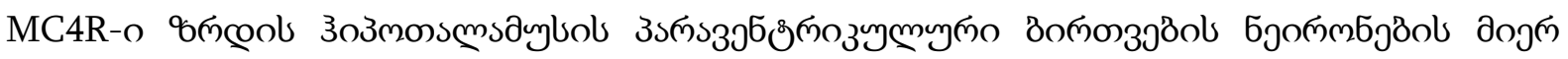

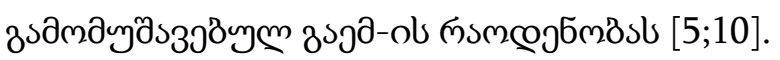

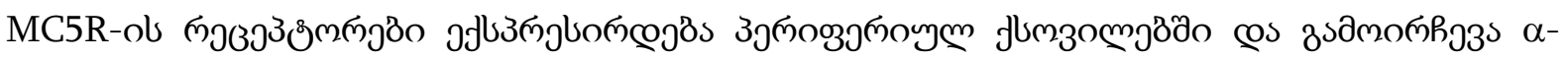

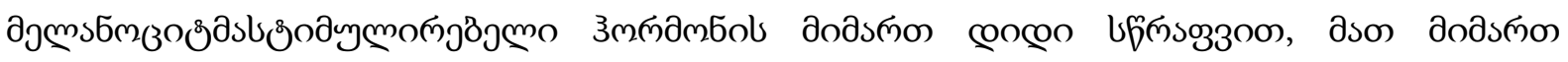

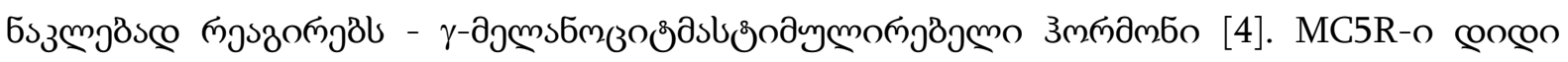

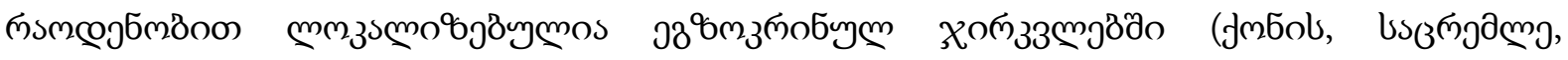

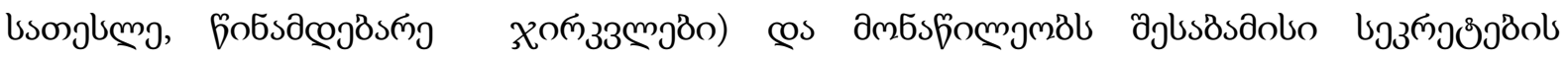

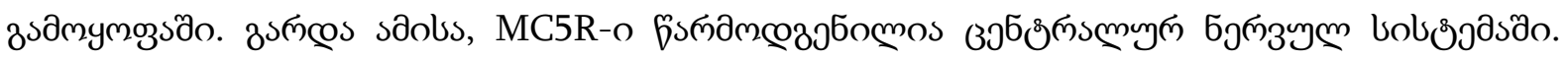

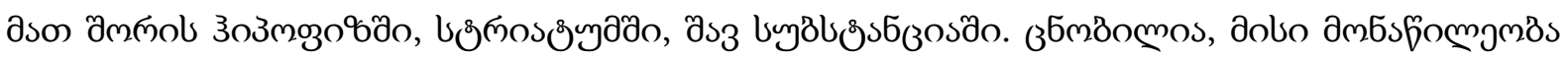

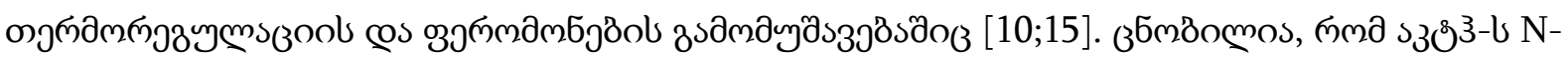

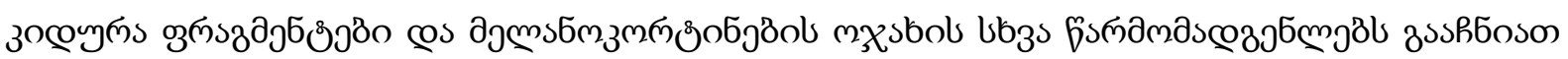

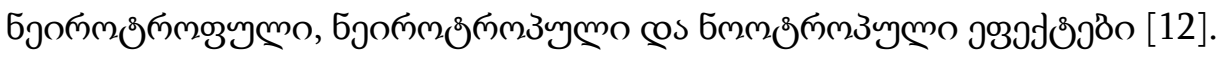

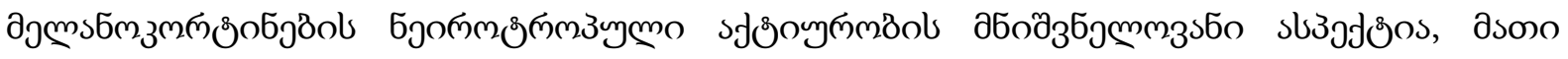

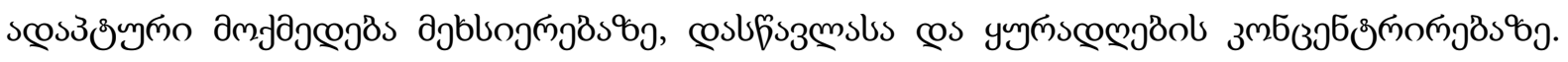

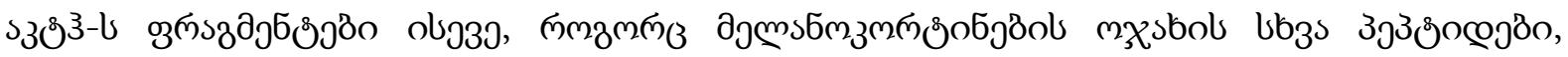

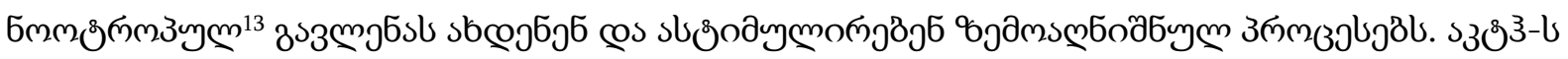

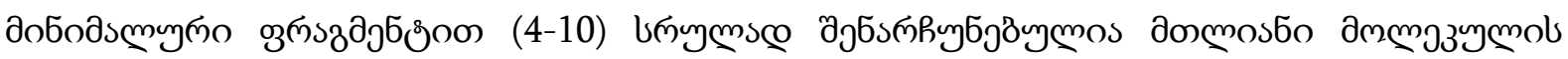

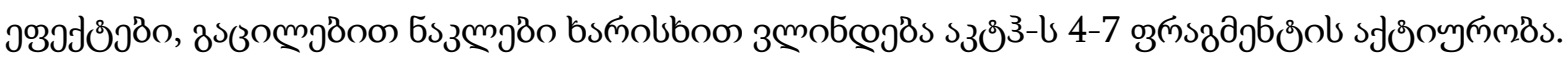

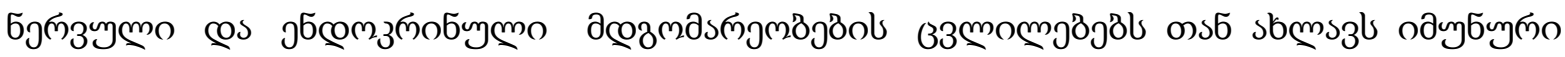

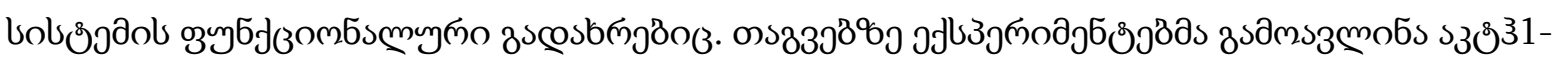

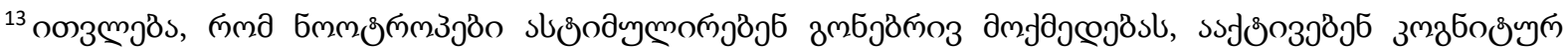

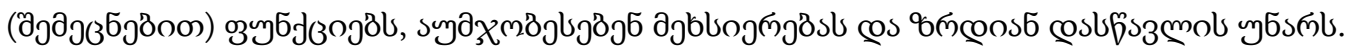




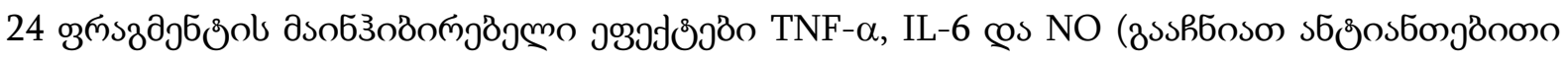

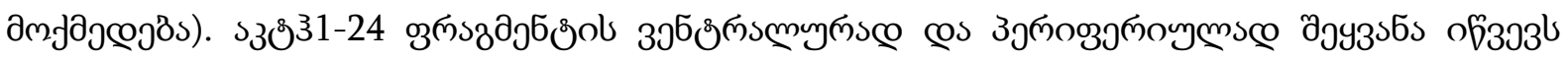

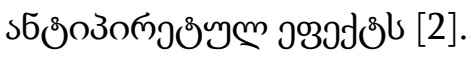

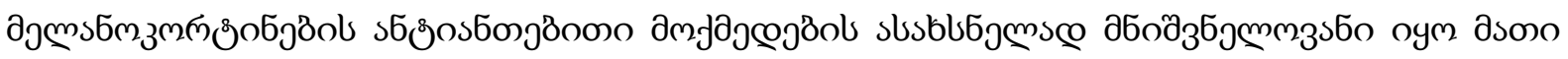

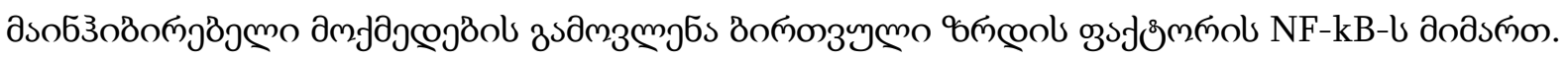

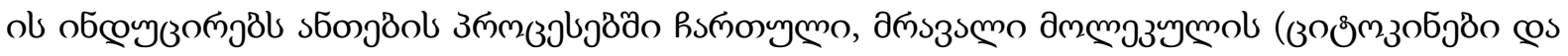

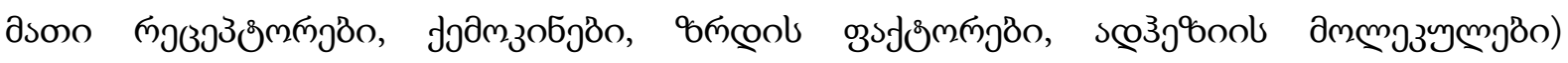

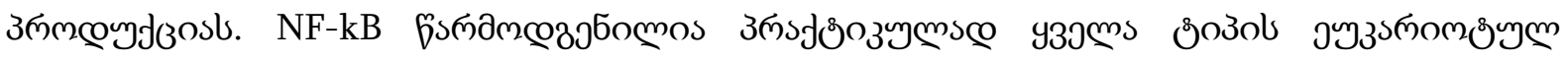

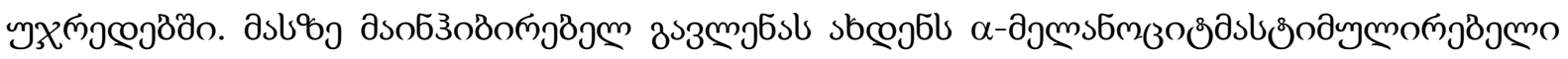

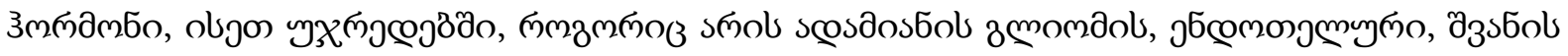

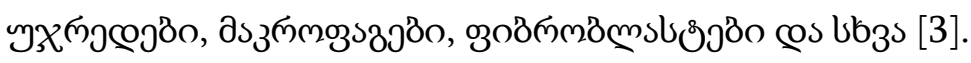

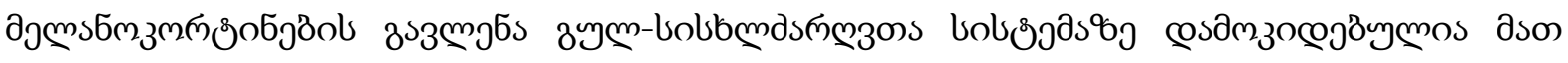

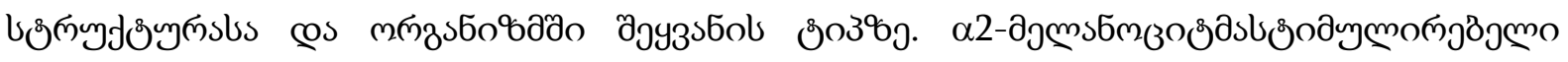

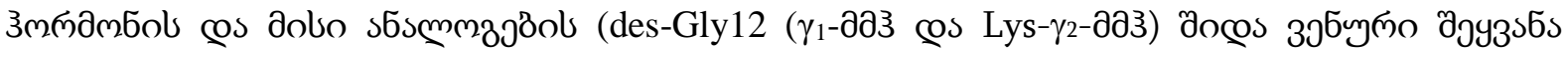

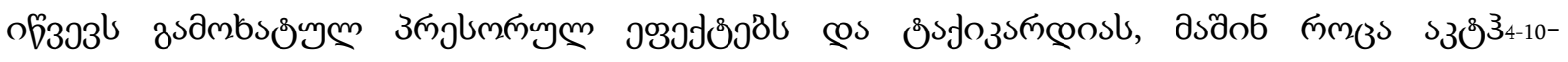

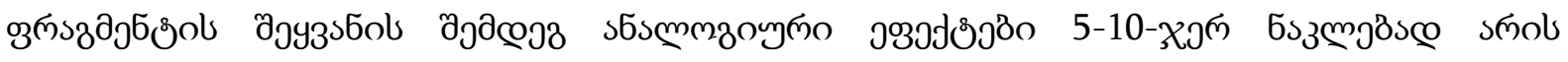

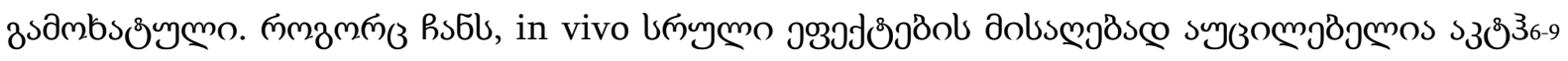

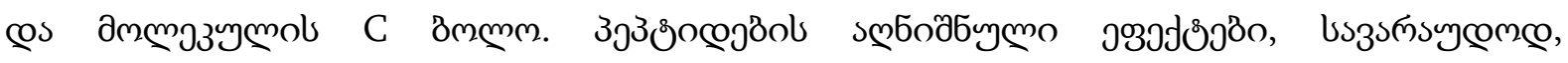

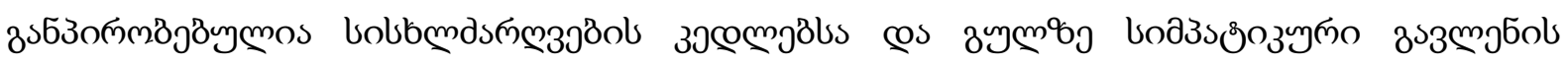

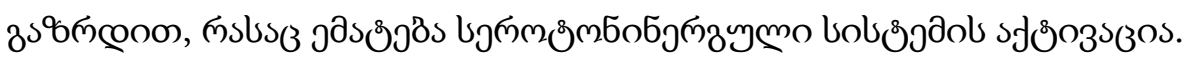

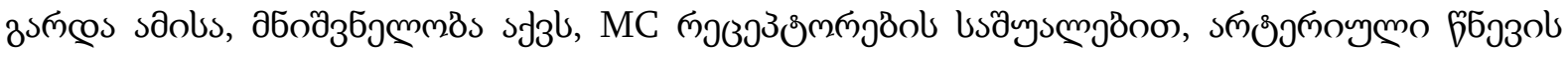

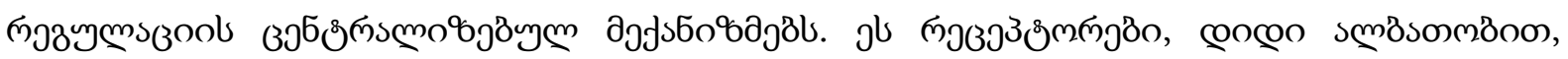

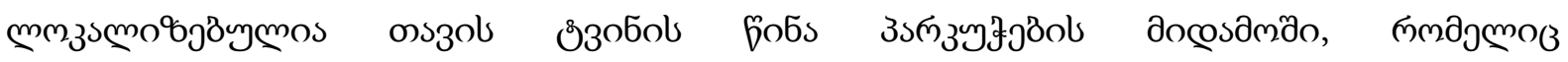

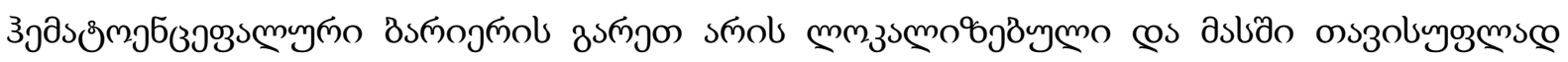

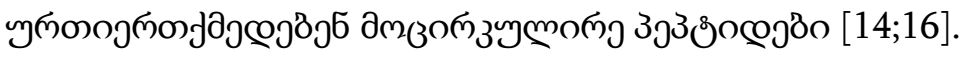

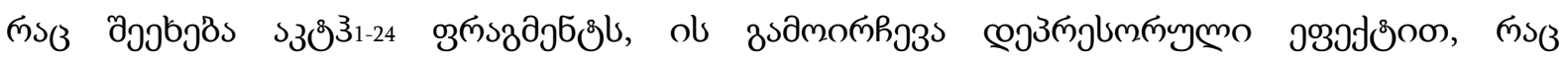

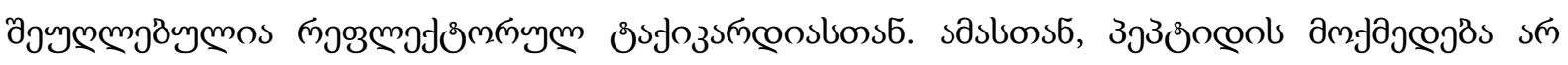

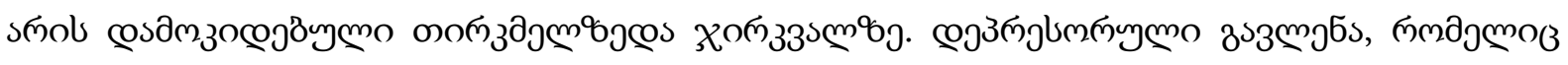

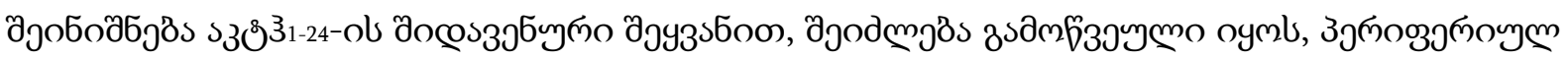

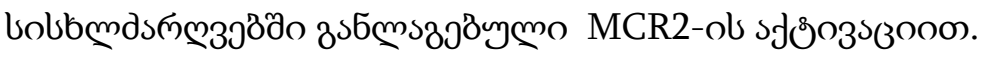

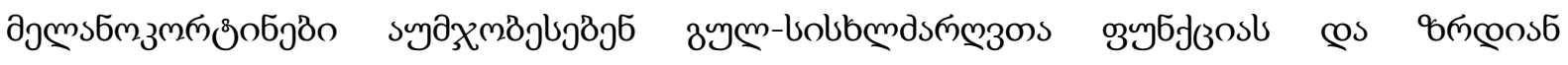

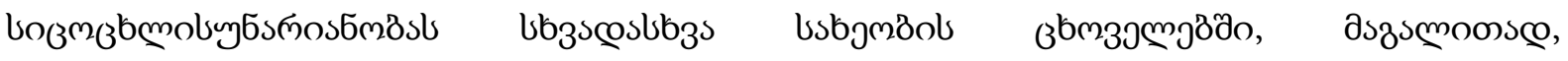

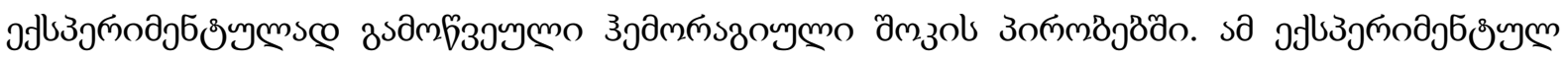

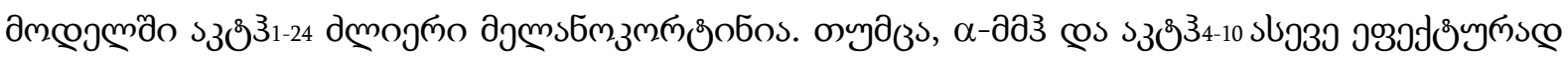

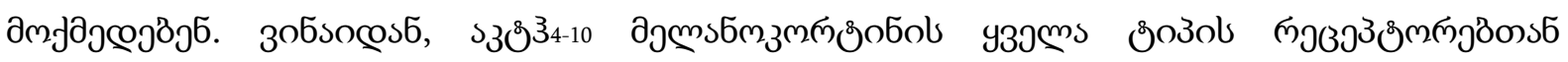

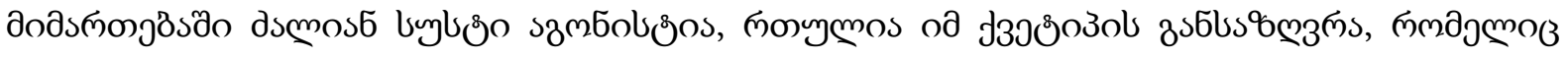

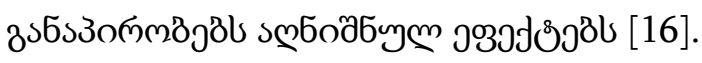

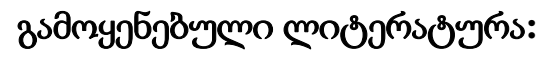

1. Abdel-Malek Z.A. Melanocortin receptors: their func-tions and regulation by physiological agonists and an-tagonists // Cell Mol Life Sci. - 2001. - Vol. 58, N 3. - P. 434-441. - DOI : 10.1007/PL00000868. 
2. Catania A., Gatti S., Colombo G., Lipton J.M. Target-ing melanocortin receptors as a novel strategy to con-trol inflammation // Pharmacol Rev. - 2004. - Vol. 56, N 1. - P. 1-29. - DOI: 10.1124/pr.56.1.1.

3. Catania A., Lonati C., Sordi A, Carlin A., Leonardi P., Gatti S. The melanocortin system in control of in-flammation // ScientificWorldJournal. - 2010. - Vol. 10. - 1840-1853. - DOI: 10.1100/tsw.2010.173.

4. Clark A.J., Forfar R., Hussain M., Jerman J., McIver E., Taylor D., Chan L. ACTH Antagonists

// Front Endocrinol (Lausanne). - 2016. -Vol. 7. - P. 101. - DOI: 10.3389/fendo.2016.00101.

5. Hallschmid M., Benedict C., Born J., Fehm H.L., Kern W. Manipulating central nervous mechanisms of food intake and body weight regulation by intranasal administration of neuropeptides in man // Physiol Be-hav. - 2004. - Vol. 83, N 1. - P. 55-64. - DOI: 10.1016/j.physbeh.2004.07.023

6. Krude H., Biebermann H., Schnabel D., Tansek M.Z., Theunissen P., Mullis P.E., Grüters A. Obesity due to proopiomelanocortin deficiency: three new cases and treatment trials with thyroid hormone and ACTH4-10 // J Clin Endocrinol Metab. - 2003. - Vol. 88, N 10. - P. 4633-4640. - DOI: 10.1210/jc.2003-030502.

7. Lowry P. 60 YEARS OF POMC: Purification and bio-logical characterisation of melanotrophins and cortico-trophins // J Mol Endocrinol. - 2016. - Vol. 56, N 4. -P. T1-T12. - DOI: 10.1530/JME-15-0260.

8. Low M.J., Simerly R., Cone R.D. Receptors for the melanocortin peptides in the central nervous system // Current Opinion in Endocrinol. Diab. - 1994. - Vol. 1. - P. 79-88.

9. Loir B., Pérez Sánchez C., Ghanem G., Lozano J.A., García-Borrón J.C., Jiménez-Cervantes C. Expression of the MC1receptor gene in normal and malignant human melanocytes. A semiquantitative RT-PCR study // Cell Mol Biol (Noisy-le-grand). - 1999. - Vol. 45, N 7. P. 1083-1092.

10. Ramachandrappa S., Gorrigan R.J., Clark A.J., Chan L.F. The melanocortin receptors and their acces-sory proteins // Front Endocrinol (Lausanne). - 2013. - Vol. 4. - P. 9. - DOI: 10.3389/fendo.2013.00009

11. Seidah N.G., Chretien M. Pro-protein convertases of substilisin/kekin family // Methods enzymol. - 1994. - Vol. 244. - P. 175-188.

12. Spruijt B.M. Effects of the ACTH4-9 analog Org2766 on brain plasticity: modulation of excitatory neuro-transmission? // Psychoneuroendocrinology.-1992 -Vol.17,N4.- P. 315-325.

13. Starowicz K., Przewłocka B. The role of melanocortins and their receptors in inflammatory processes, nerve regeneration and nociception // Life Sci-2003.-Vol. 73, N 7.-P. 823-847.

14. Van Bergen P., Van Der Vaart J.G., Kasbergen C.M., Versteeg D.H., De Wildt D.J. Structureactivity analy-sis for the effects of gamma-MSH/ACTH-like peptides on cerebral hemodynamics in rats // Eur J Phar-macol. - 1996. - Vol. 318, N 2-3. - P. 357-368.

15. van der Kraan M., Adan R.A., Entwistle M.L., Gispen W.H., Burbach J.P., Tatro J.B. Expression of melanocortin-5 receptor in secretory epithelia supports a functional role in exocrine and endocrine glands // Endocrinology. - 1998. - Vol. 139, N 5. - P. 2348-2355. DOI: $10.1210 /$ endo.139.5.6008.

16. Versteeg D.H., Van Bergen P., Adan R.A., De Wildt D.J. Melanocortins and cardiovascular regula-tion // Eur J Pharmacol. - 1998. - Vol. 360, N 1. - P. 1-14.

17. Wikberg J.E., Muceniece R., Mandrika I., Prusis P., Lindblom J., Post C., Skottner A. New aspects on the melanocortins and their receptors // Pharmacol. Res. - 2000. - Vol. 42, N 5. P. 393-420. - DOI: 10.1006/phrs.2000.0725 


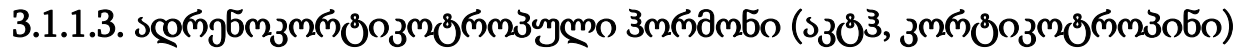

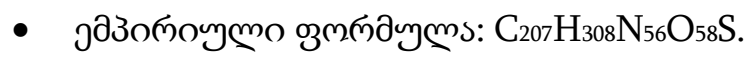

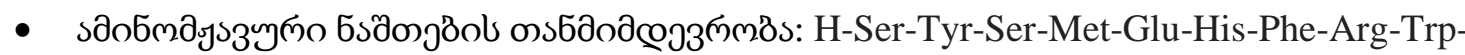
Gly-Lys-Pro-Val-Gly-Lys-Lys-Arg-Arg-Pro-Val-Lys-Val-Tyr-Pro-Asn-Gly-Ala-Glu-AspGlu-Ser-Ala-Glu-Ala-Phe-Pro-Leu-Glu-Phe-OH.

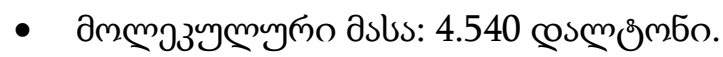

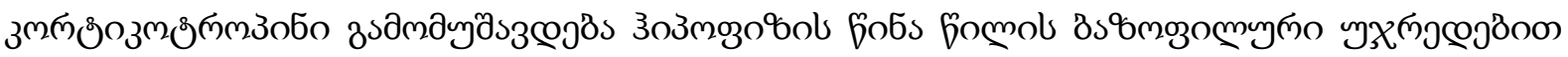

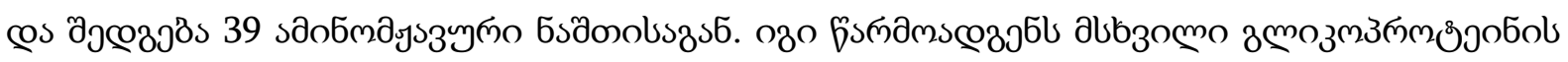

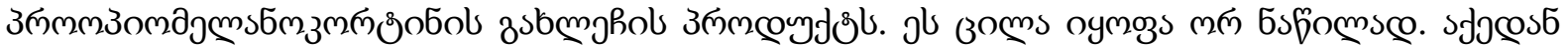

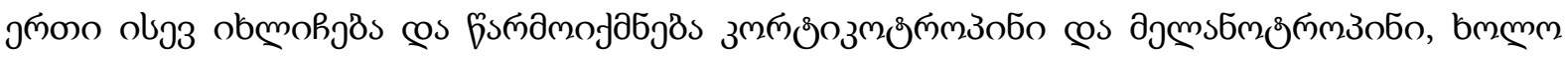

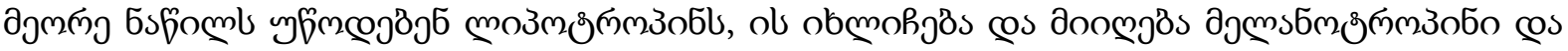

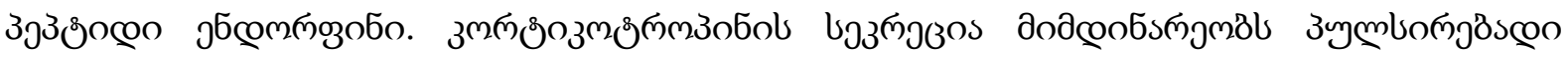

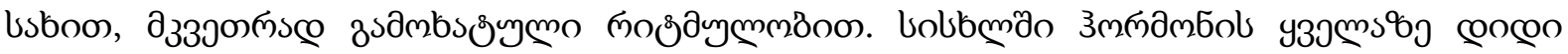

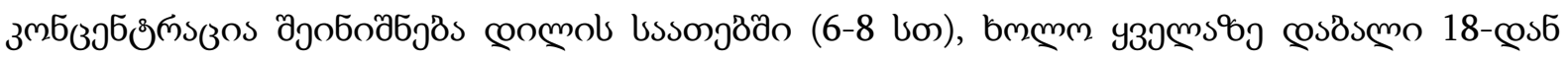

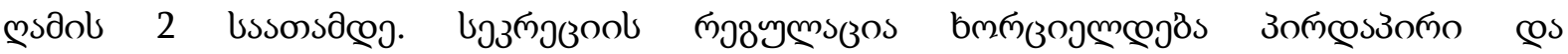

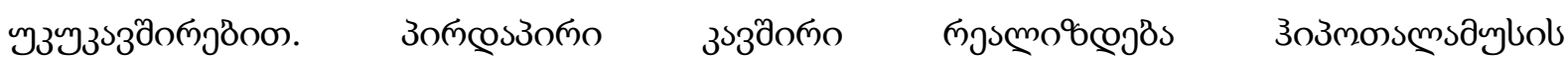

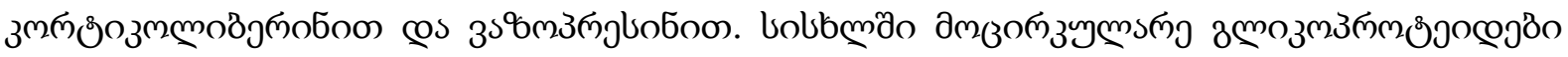

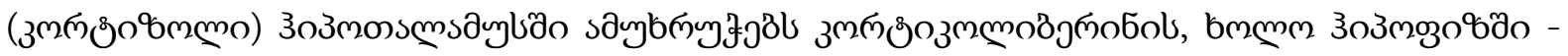

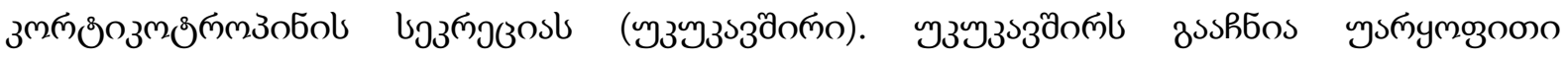

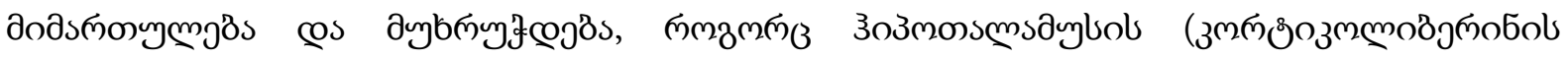

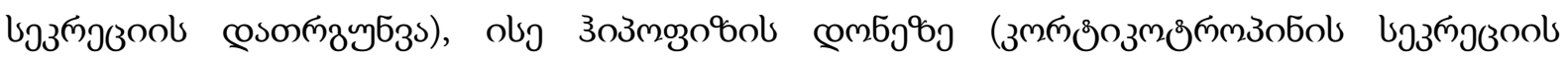

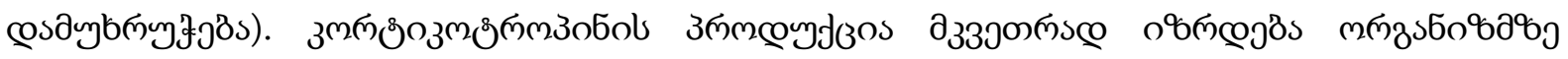

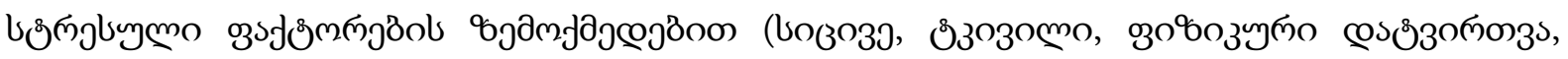

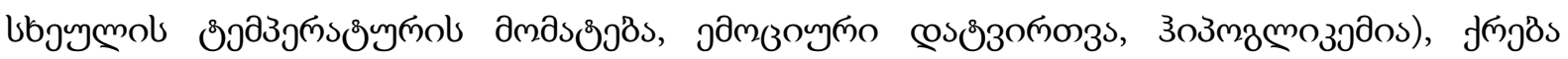

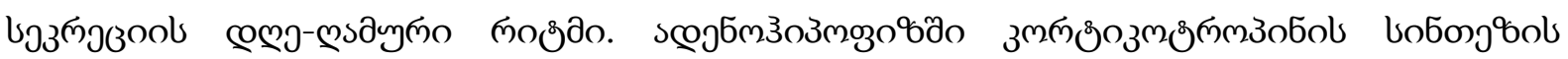

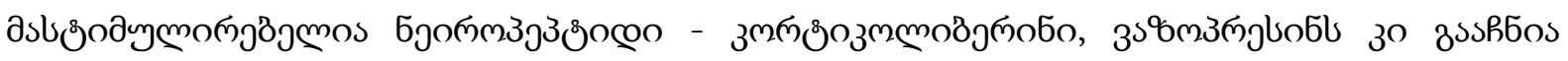

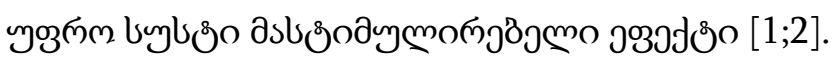

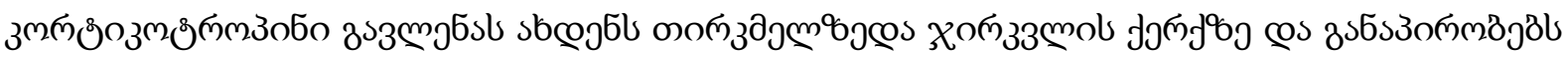

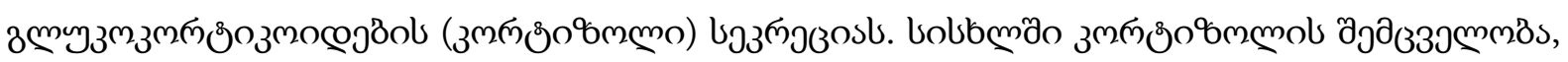

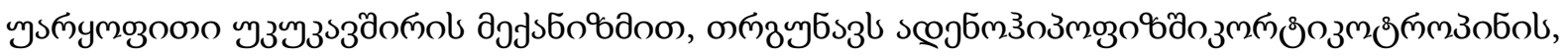

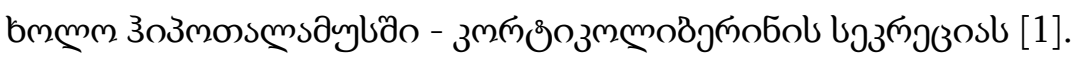

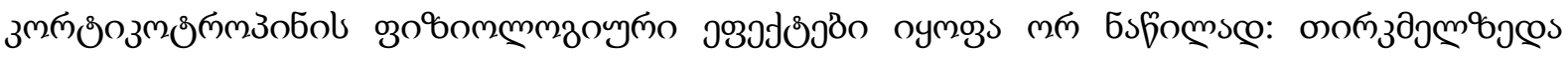

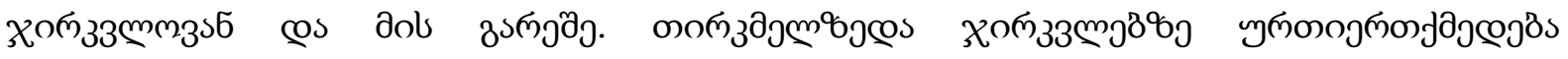

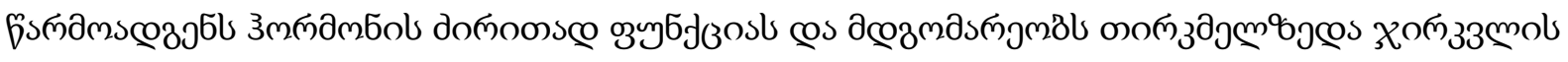

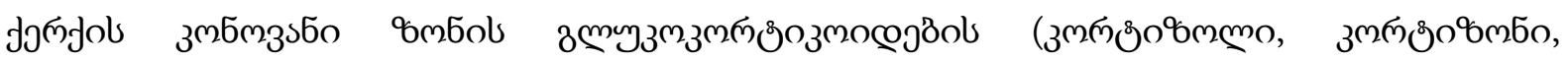

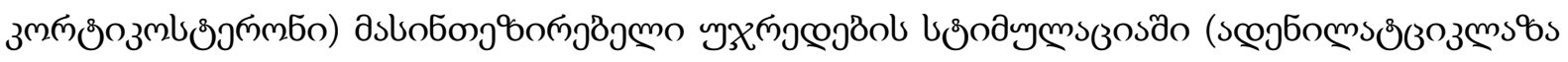

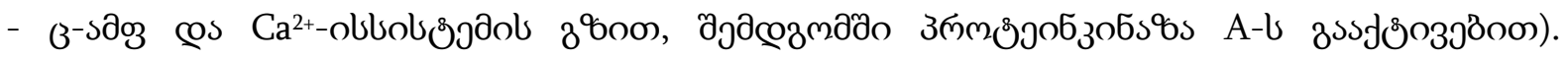

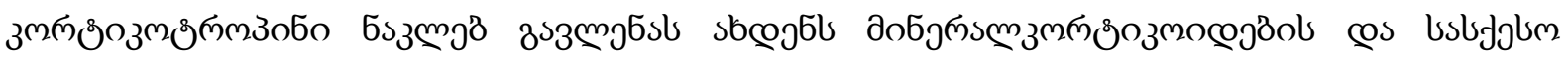

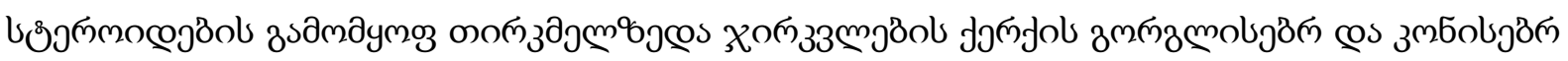




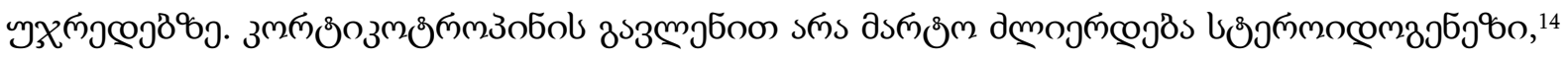

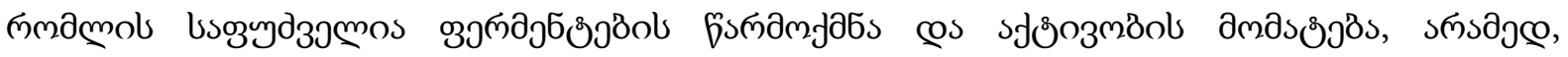

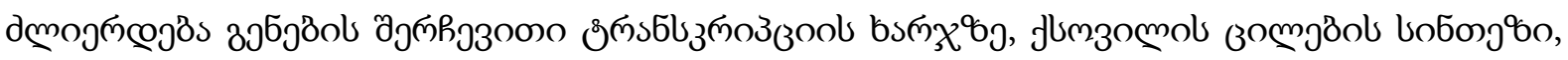

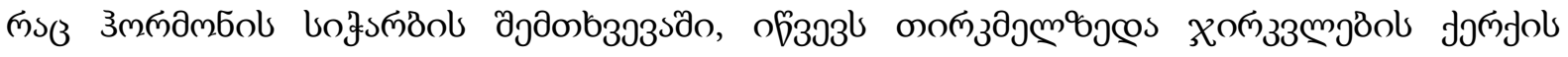

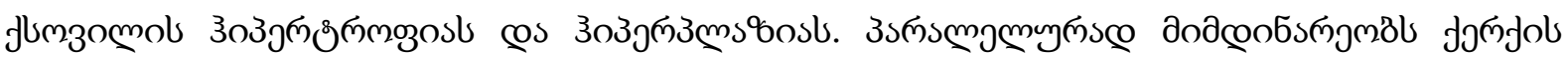

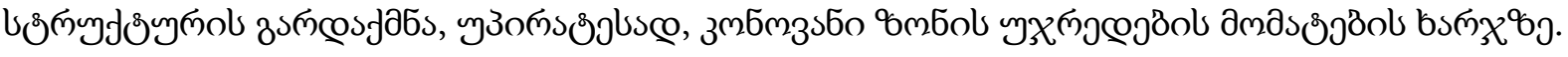

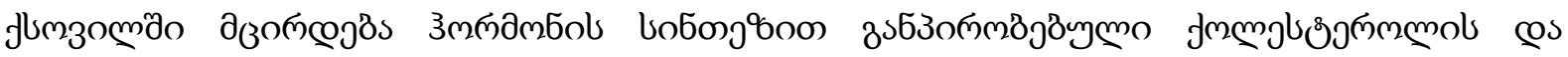

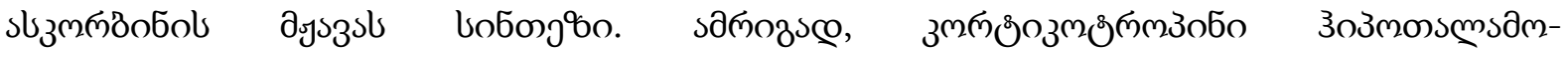

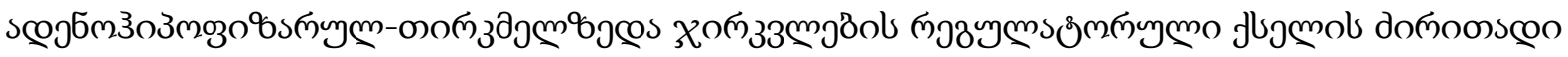

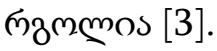

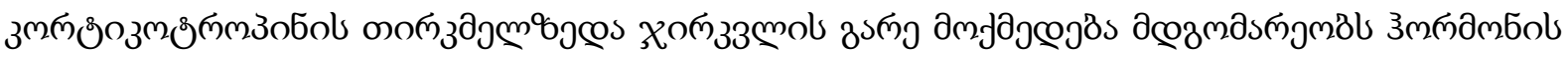

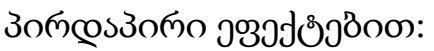

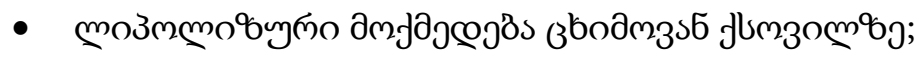

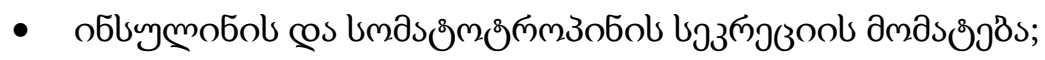

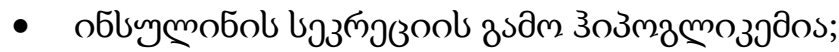

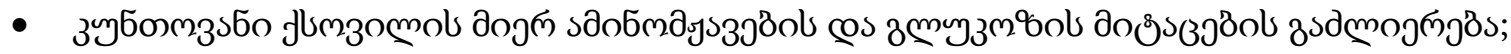

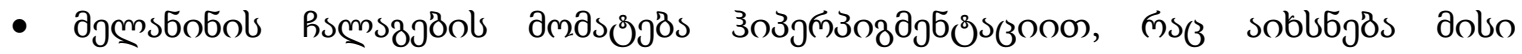

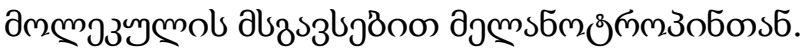

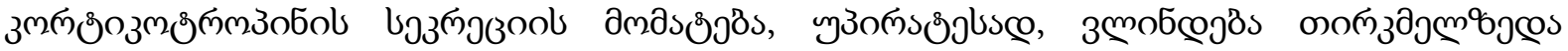

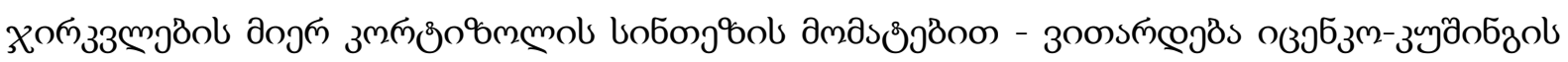

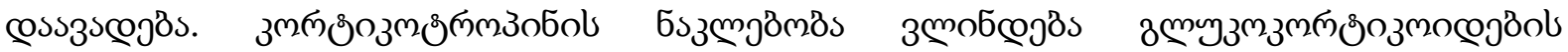

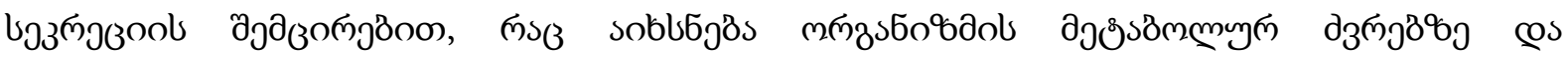

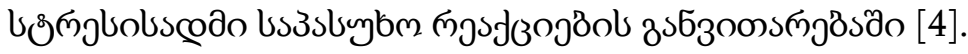

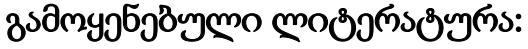

1. Matsumoto H, Maruyama M, Noguchi J, Horikoshi Y, Fujiwara K, Kitada C, Hinuma S, Onda $\mathrm{H}$, Nishimura $\mathrm{O}$, Inoue $\mathrm{K}$, and Fujino M. Stimulation of corticotropin-releasing hormone- mediated adrenocorticotropin secretion by central administration of prolactin-releasing peptide in rats. Neurosci Lett. 2000; 285:234-238.

2. Noguchi T, Makiko S, Maruyama H, and Hashimoto K. Regulation of proopiomelanocortin gene transcription during single and repeated immobilization stress. Neuroendocrinology. 2006; 84:21-30

3. Seasholtz AF, Valverde RA, Denver RJ (October 2002). "Corticotropin-releasing hormonebinding protein: biochemistry and function from fishes to mammals". The Journal of Endocrinology. 175 (1): 89-97. doi:10.1677/joe.0.1750089. PMID 12379493.

4. Textbook of biochemistry with clinical correlations / Thomas M. Devlin: Wiley-Liss., Hoboken, NJ, 2006. - 1208 p.

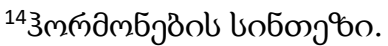




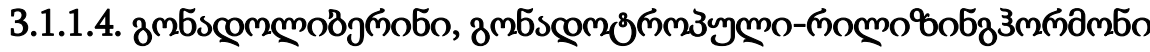

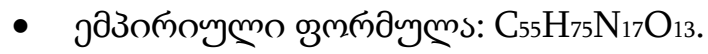

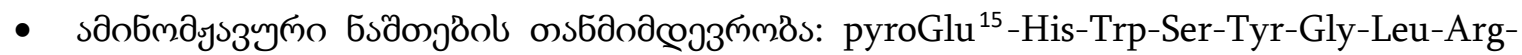
Pro-Gly-NH2.

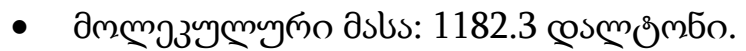

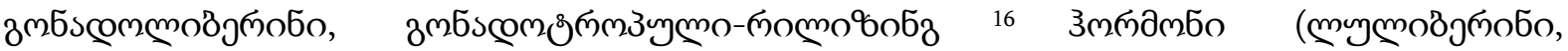

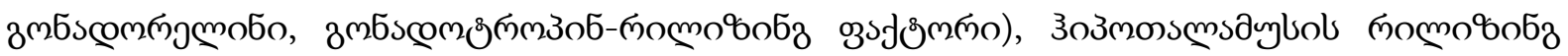

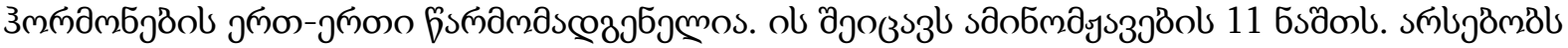

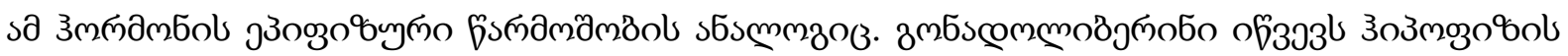

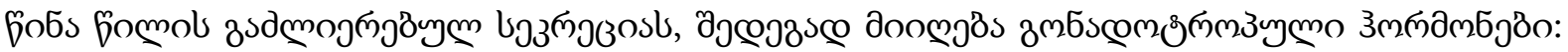

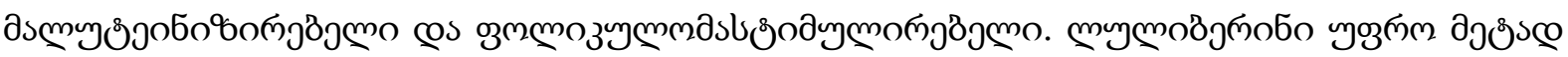

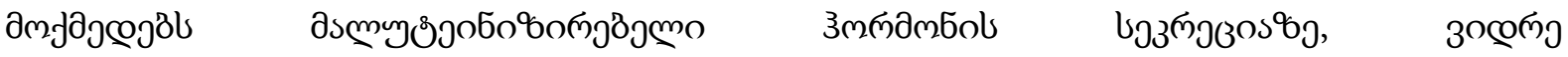

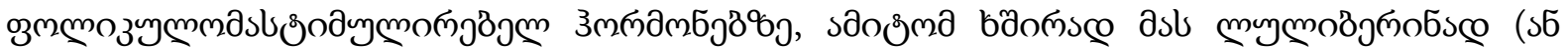

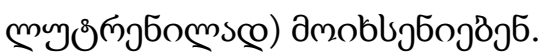

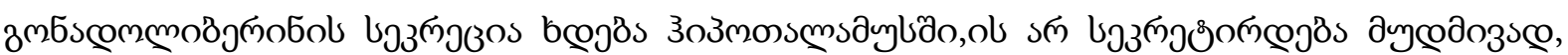

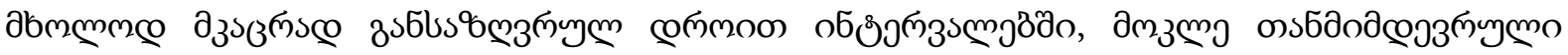

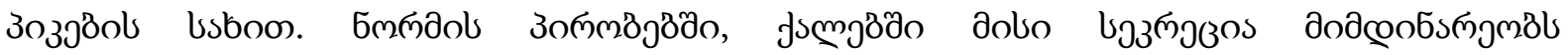

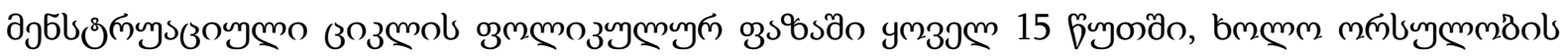

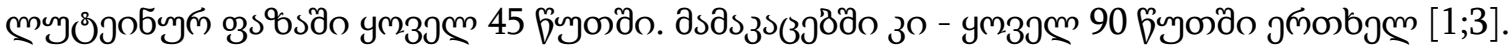

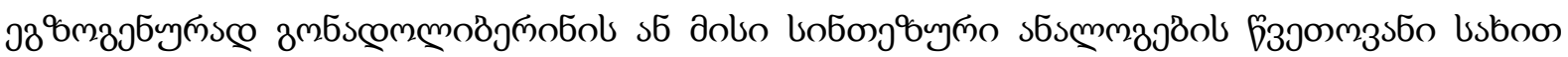

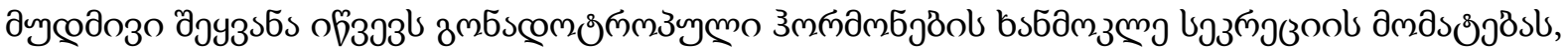

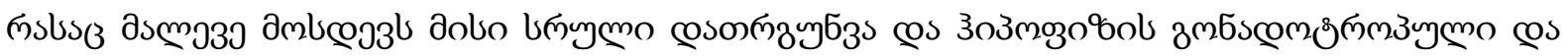

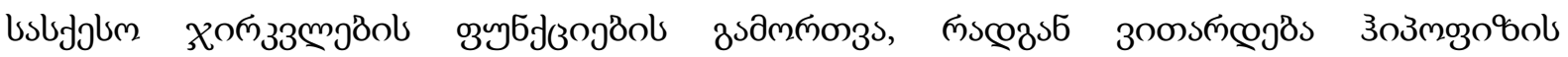

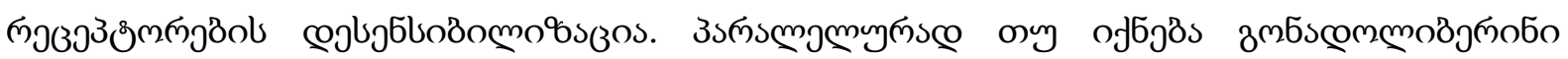

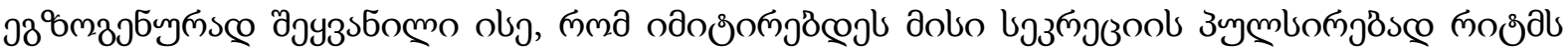

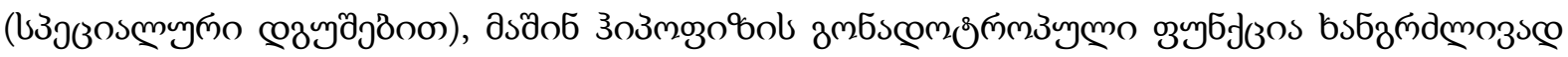

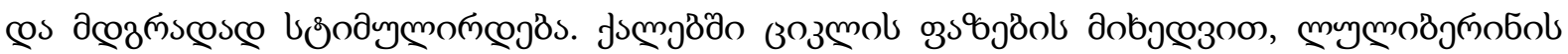

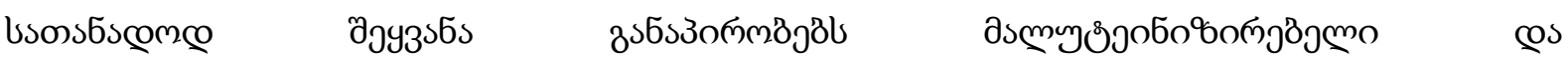

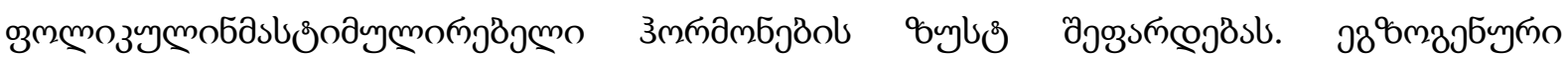

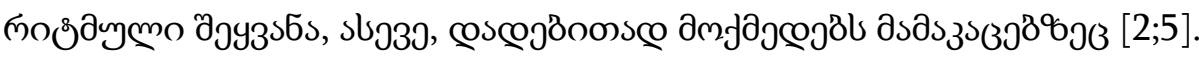

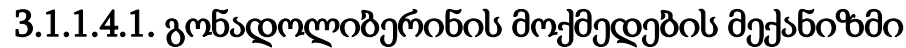

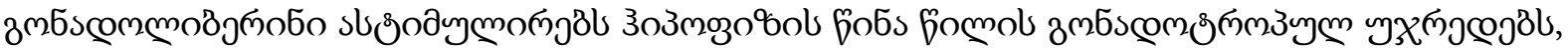

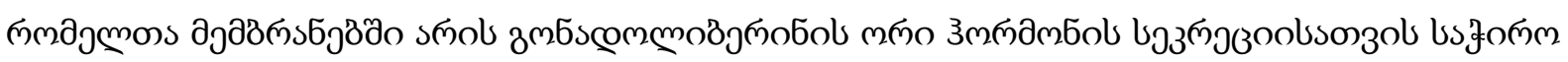

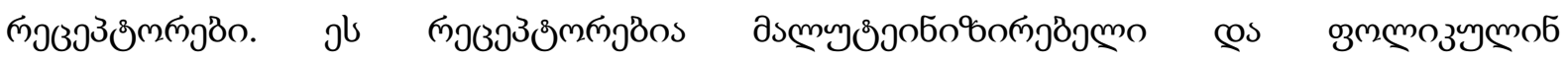

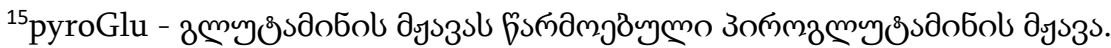

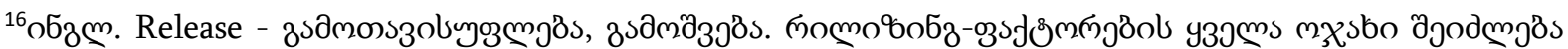

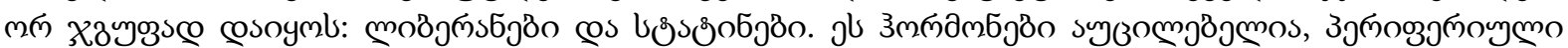

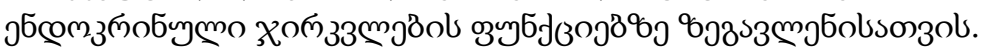




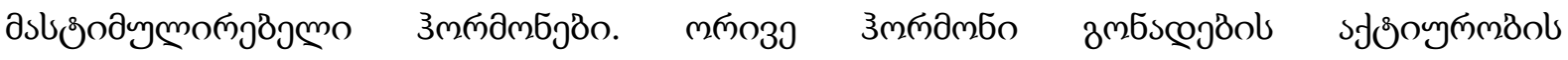

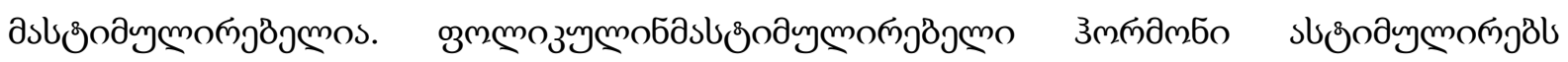

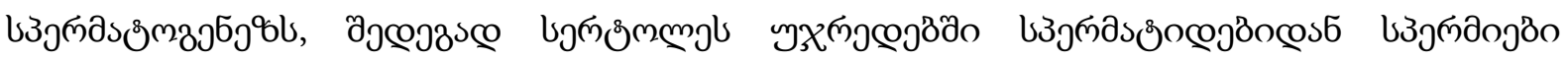

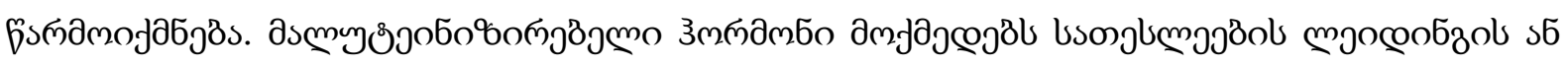

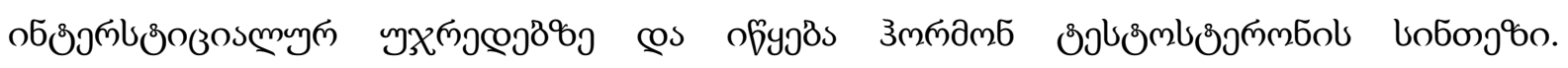

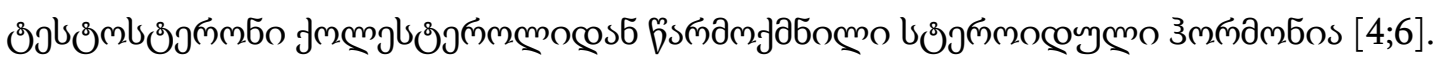

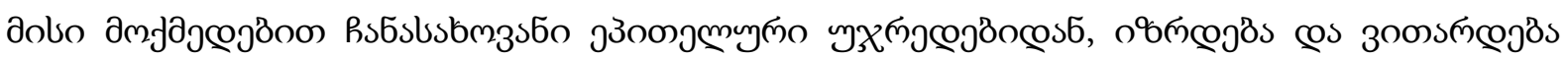

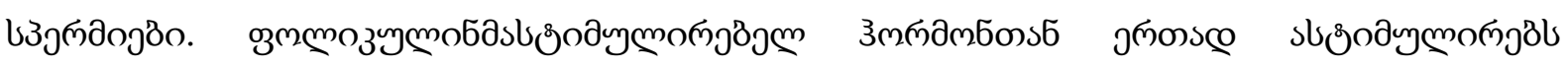

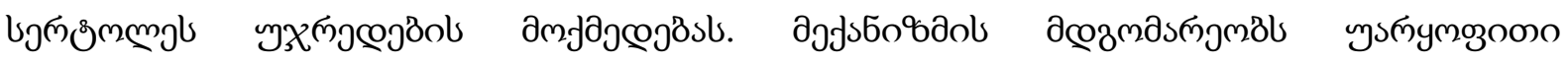

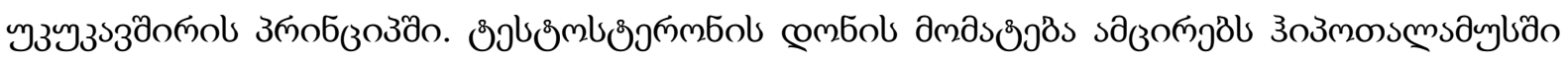

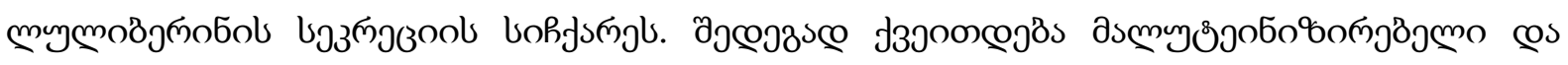

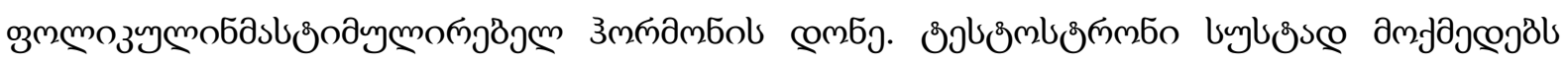

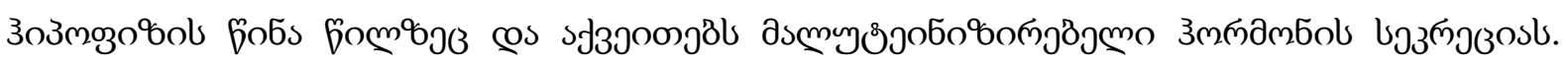

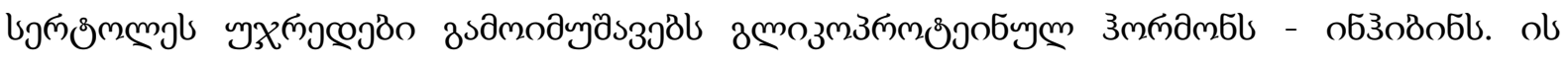

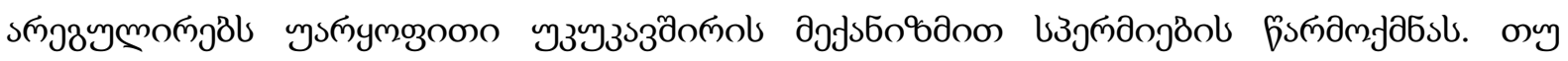

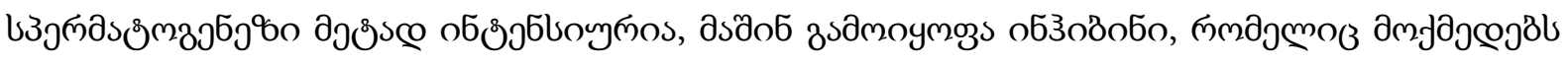

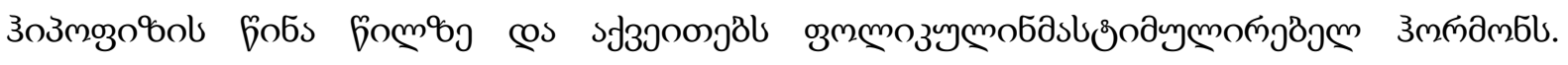

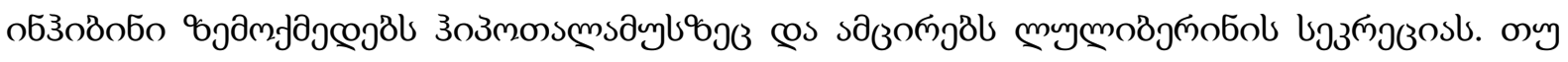

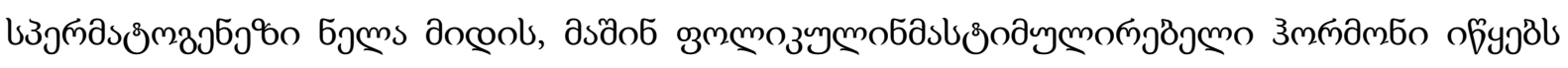
dob bo̊odymonjąsl [2;7].

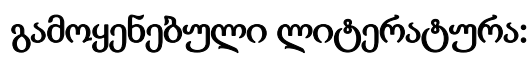

1. Bartsch G., Frick J. Therapeutic effects of luteinizing hormone releasing hormone (LH-RH) in cryptorchidism // Andrologia. 2009. V. 6. N. 3. P. 197-201. doi:10.1111/j.14390272.1974.tb01202.x.

2. Biochemistry /Jeremy M. Berg, John L. Tymoczko, Lubert Stryer: W.H. Freeman and Company, NY, 2007. - 1026 p.

3. Bouman A., Heineman M.J., Marijke M.F. 2005. Sex hormones and the immune response in humans // Hum. Reprod. Update. V. 11. P. 411—423.

4. Brown J.L., Roberson M. Novel insights into gonadotropin-releasing hormone action in the pituitary gonadotrope // Semin. Reprod. Med. 2017. V. 35. N. 2. P. 130 - 138. doi: 10.1055/s0037-1599084.

5. Chanphai P., Vesper A.R., Bekale L., Berube G., Tajmir-Riahi H.A. Transporting testosterone and its dimers by serum proteins // J. Photochem. Photobiol. 2015. V. 153. P. 173-183.

6. Choi J., Smitz J. Luteinizing hormone and human chorionic gonadotropin: origins of difference // Mol. Cell Endocrinol. 2014. V. 383 N. 1-2. P. 203-213. doi:10.1016/j.mce.2013.12.009.

7. Principles of biochemistry /Donald J. Voet, Judith G. Voet, Charlotte W. Pratt: Wiley-Liss., Hoboken, NJ, 2008. - 1100 p. 


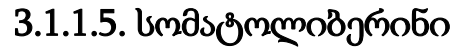

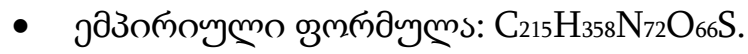

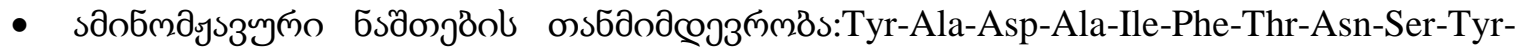
Arg-Lys-Val-Leu-Gly-Gln-Leu-Ser-Ala-Arg-Lys-Leu-Leu-Gln-Asp-Ile-Met-Ser-Arg-GlnGln-Gly-Glu-Ser-Asn-Gln-Glu-Arg-Gly-Ala-Arg-Ala-Arg-Leu-NH ${ }_{2}$.

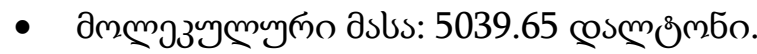

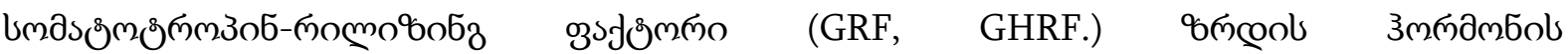

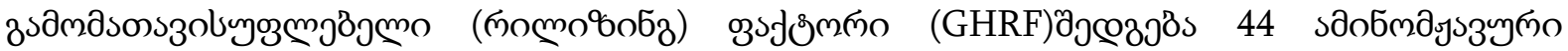

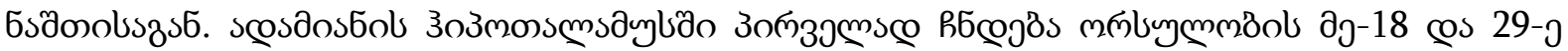

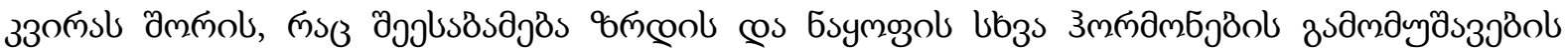

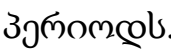

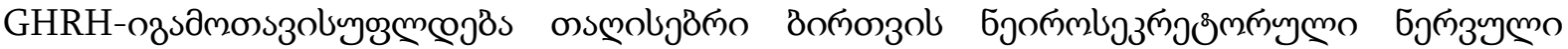

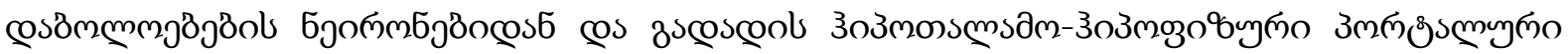

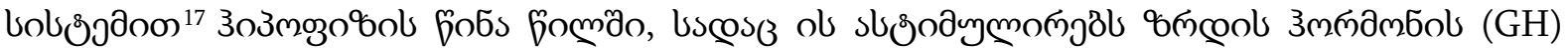

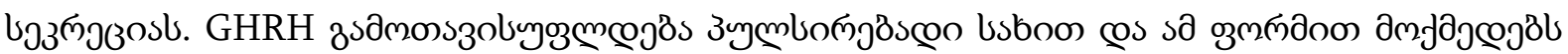

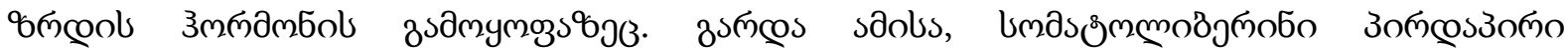

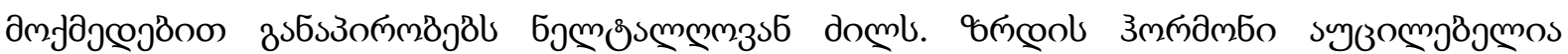

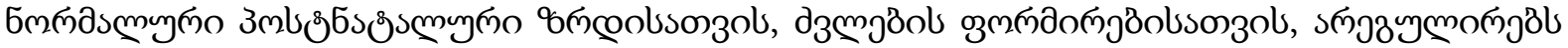

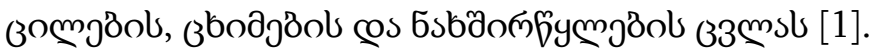

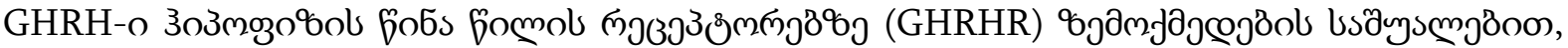

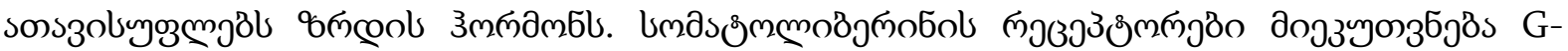

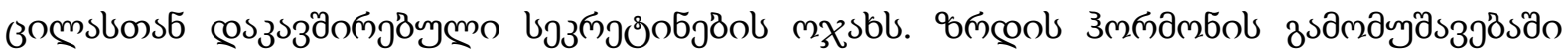

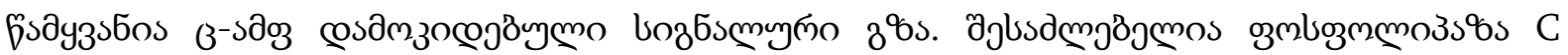

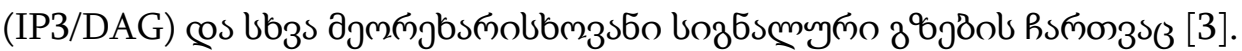

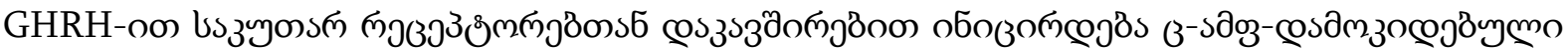

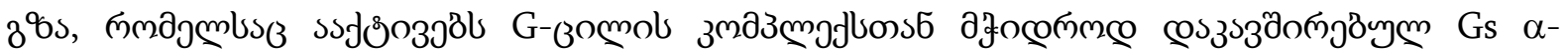

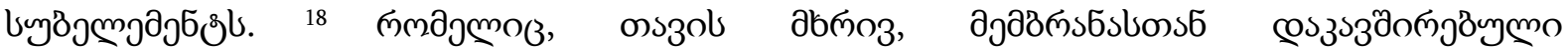

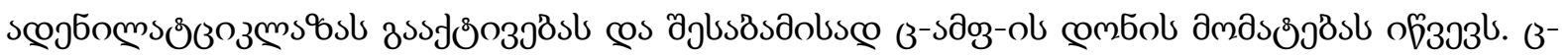

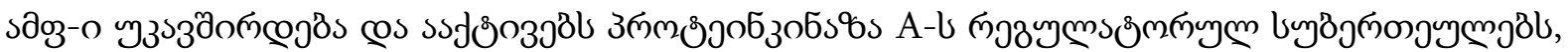

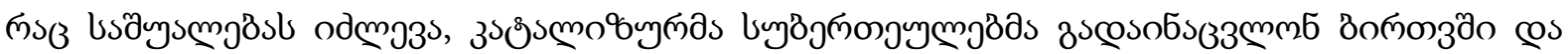

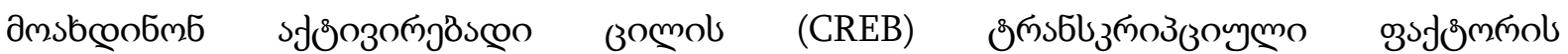

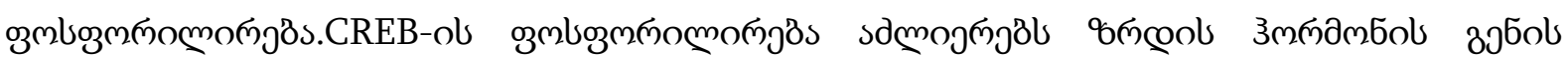

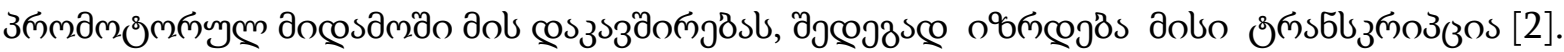

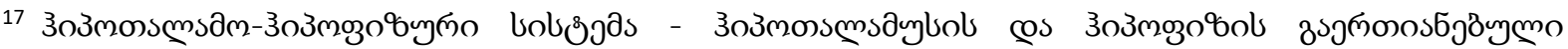

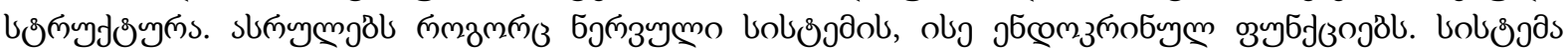

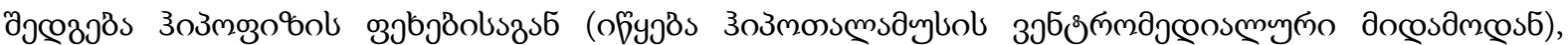

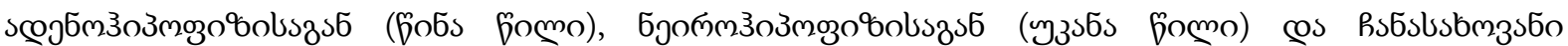

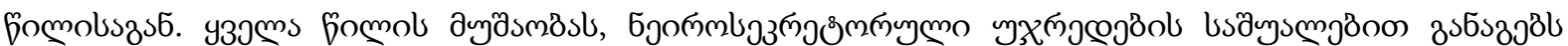

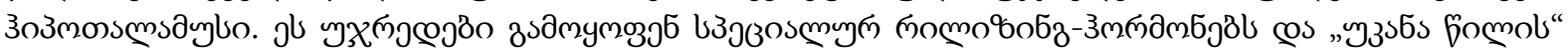

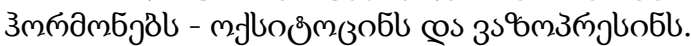

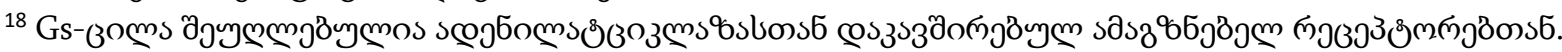




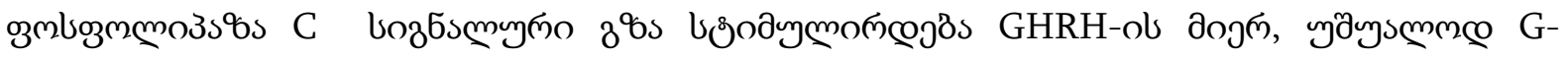

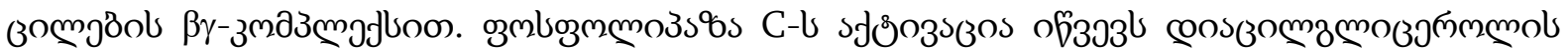

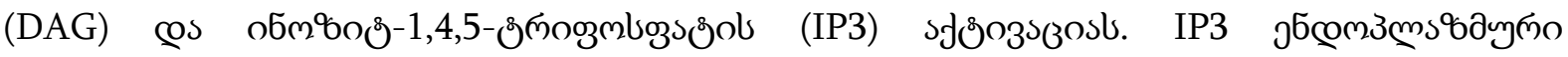

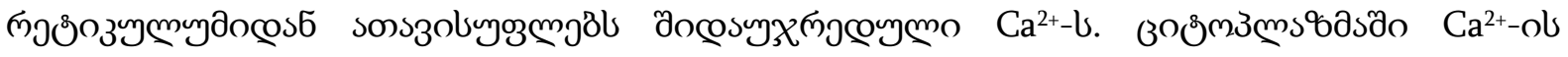

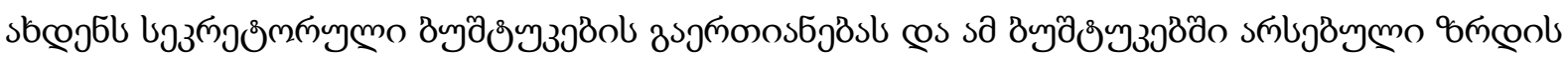

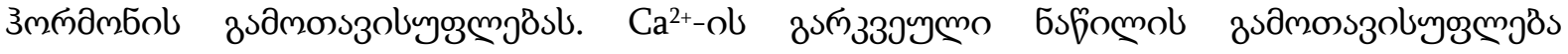

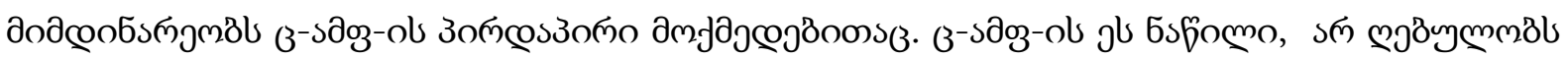

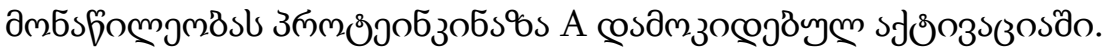

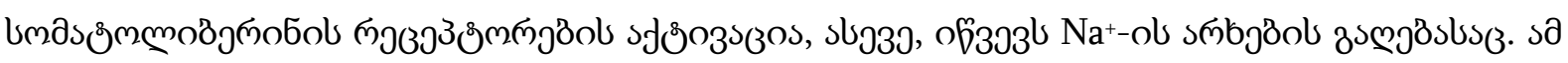

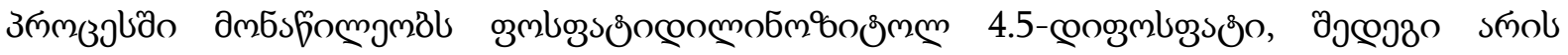

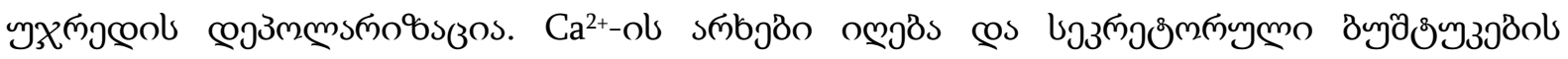

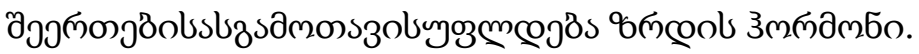

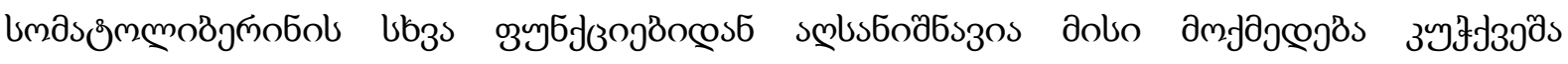

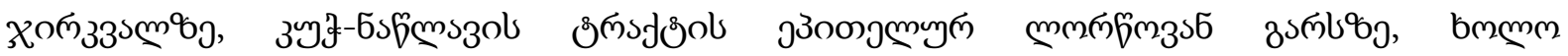

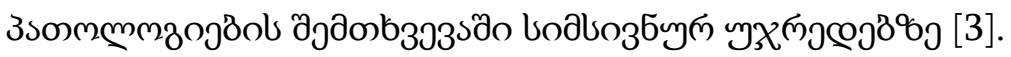

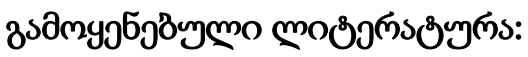

1. Obal F, Krueger J (2001). „The somatotropic axis and sleep.“Rev Neurol (Paris) 157 (11 Pt 2): S12-5. PMID 11924022.

2. Teichman, SL et al. (2006). «Prolonged stimulation of growth hormone (GH) and insulin-like growth factor I secretion by CJC-1295, a long-acting analog of GH-releasing hormone, in healthy adults». J Clin Endocrinol Metab. 91 (3): 799-805. doi:10.1210/jc.2005-1536.

3. Walter F., PhD. Boron (2003). Medical Physiology: A Cellular And Molecular Approaoch. Elsevier/Saunders. p. 1300. ISBN 1-4160-2328-3.

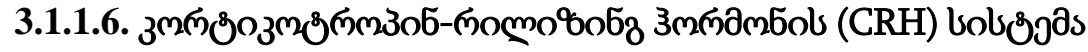

$\mathrm{CRH}$

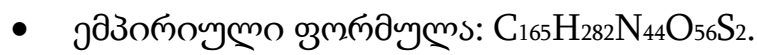

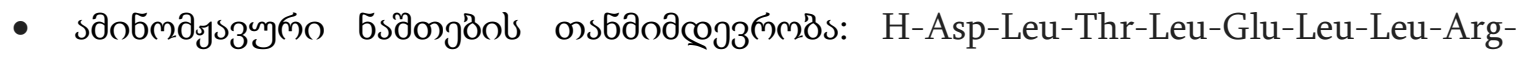
Glu-Met-Leu-Glu-Met-Glu-Lys-Ala-Glu-Lys-Glu-Ala-Glu-Gln-Ala-Ala-Leu-Asn-ArgLeu-Leu-Leu-Glu-Glu-Ala-NH2.

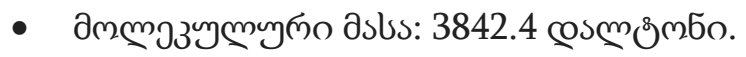

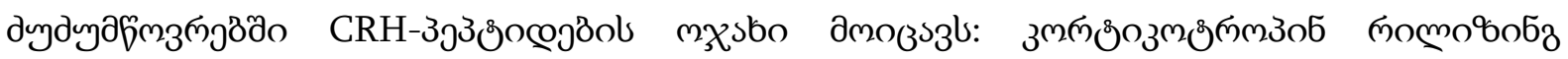

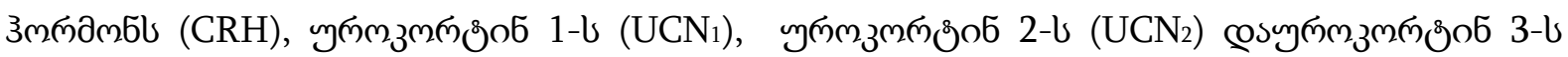

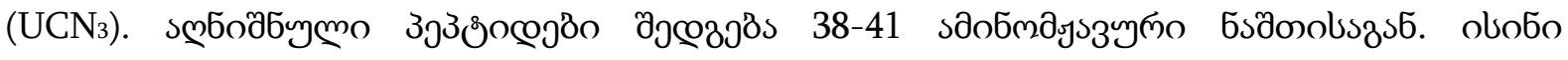

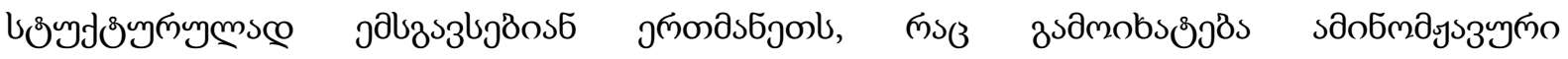

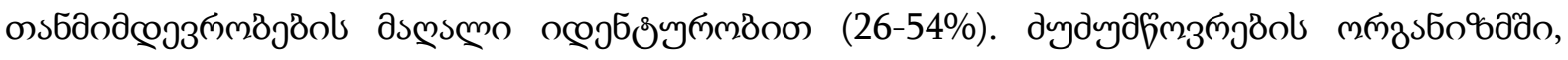




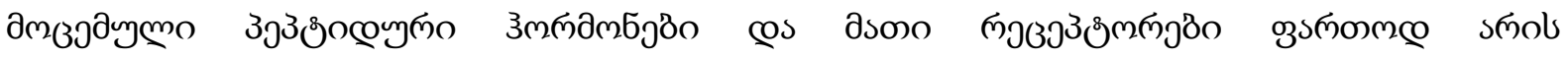

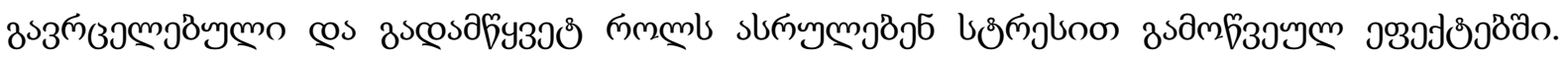

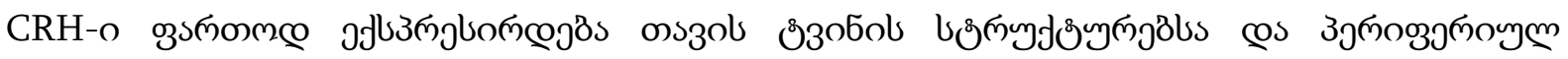

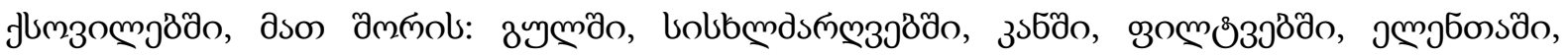

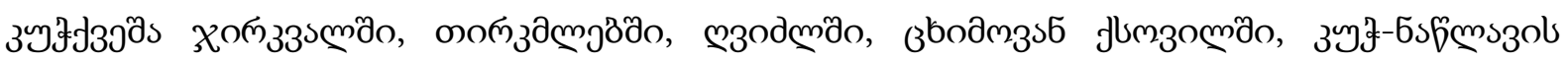

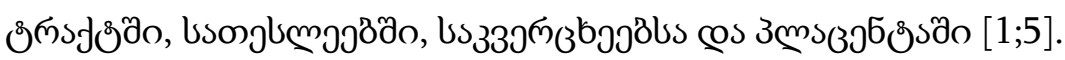

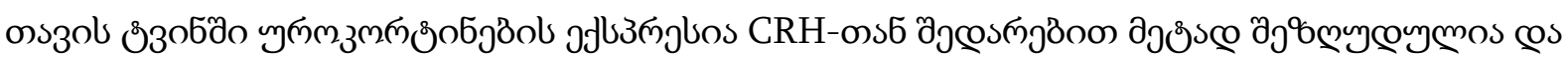

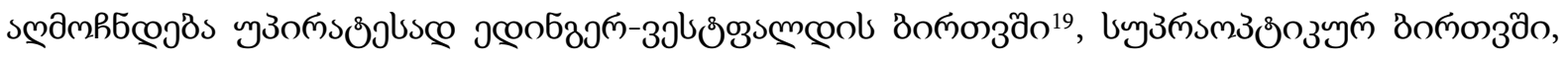

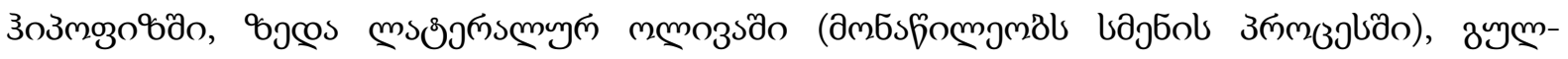

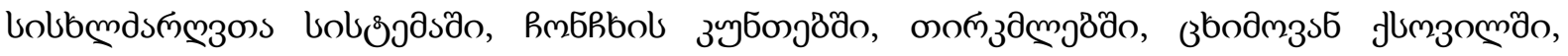

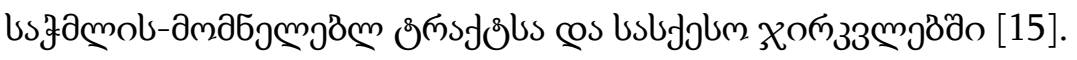

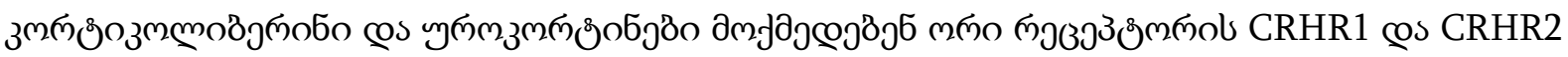

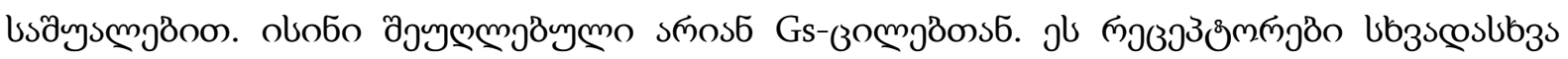

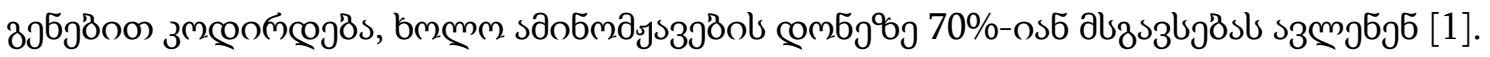

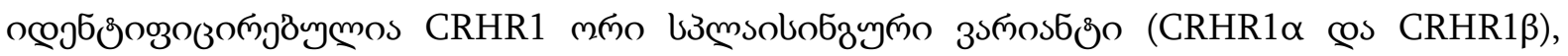

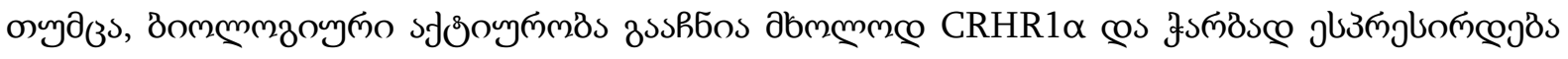

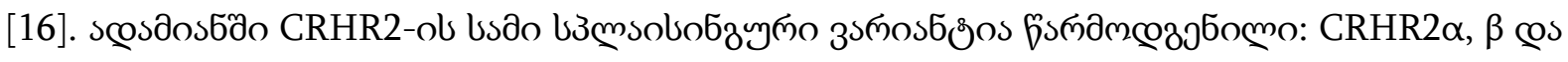

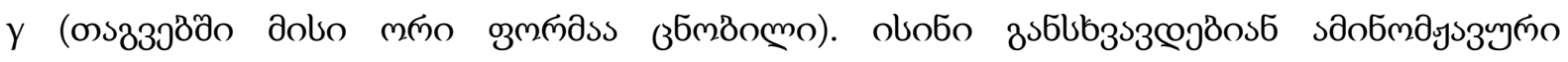

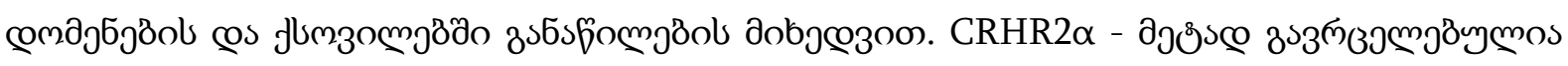

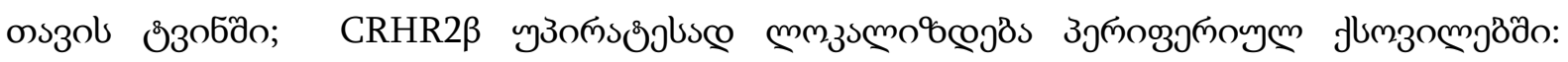

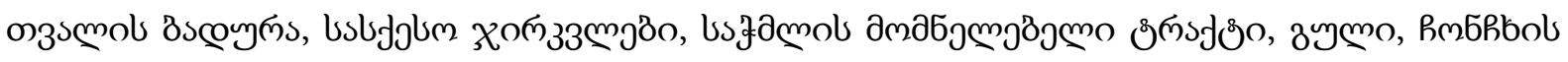

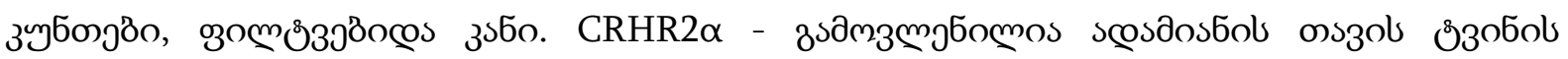

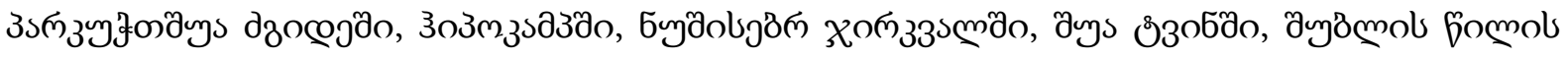

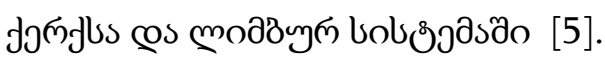

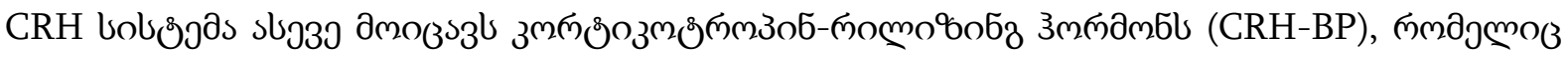

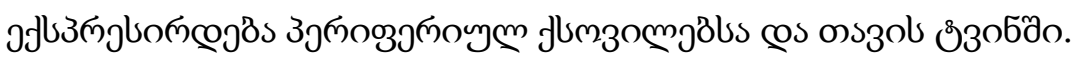

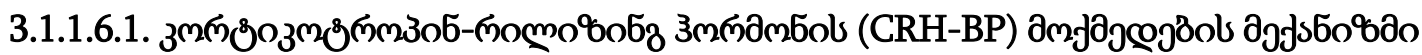

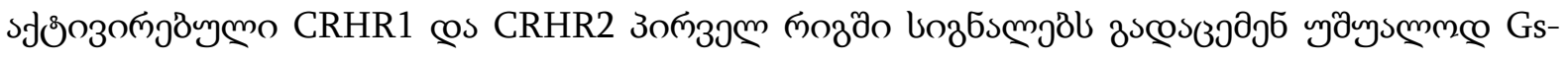

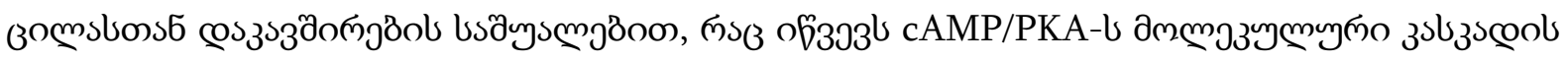

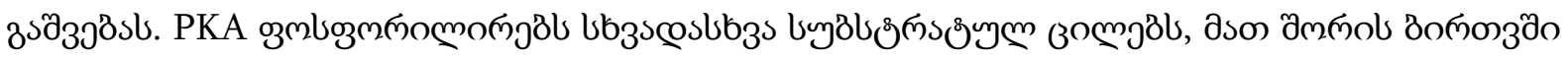

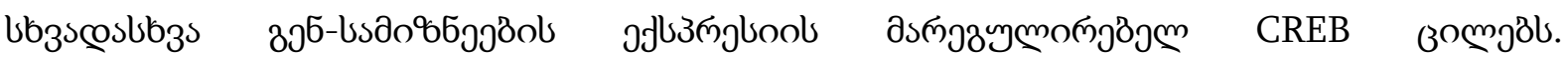

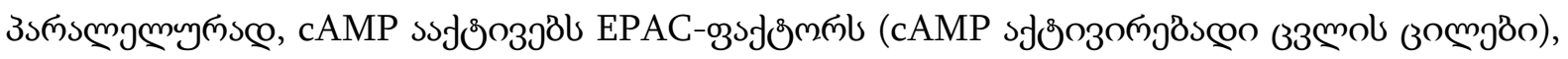

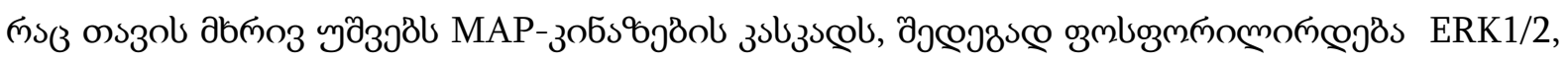

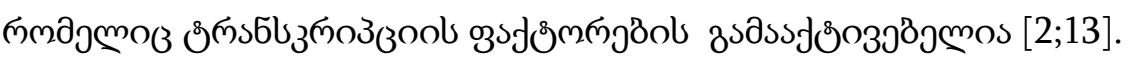

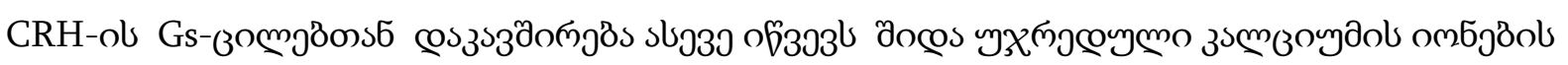

\footnotetext{
${ }^{19}$ эழoб

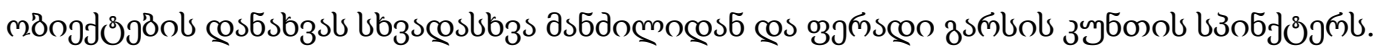




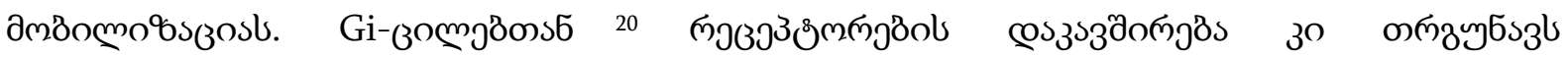

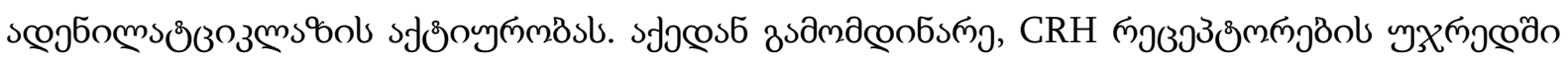

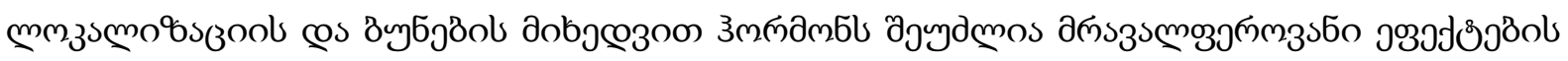
зsдmзmgбs [2;4].

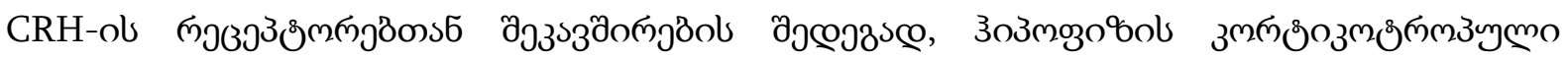

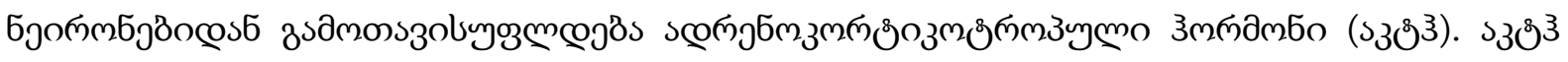

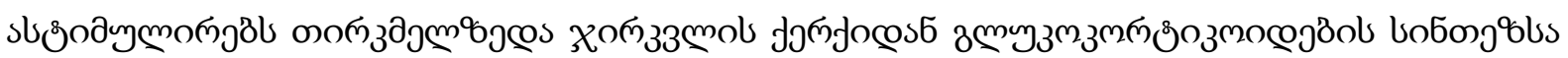

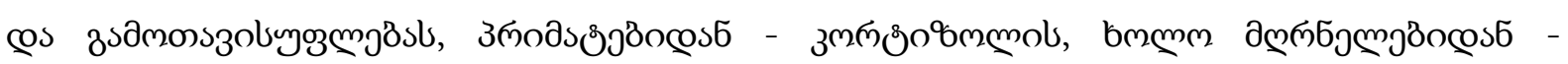

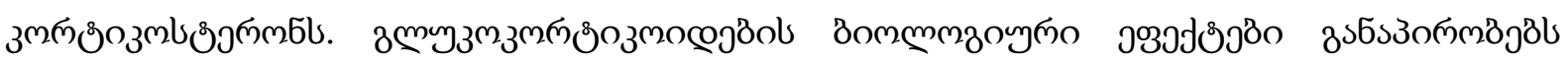

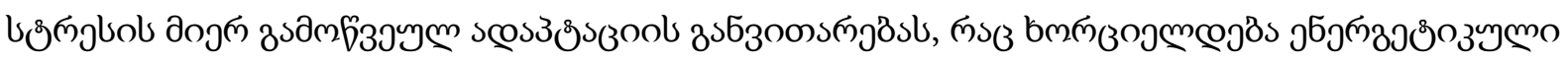

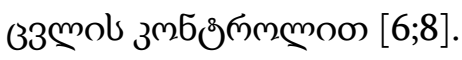

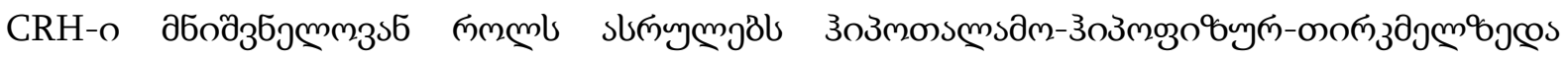

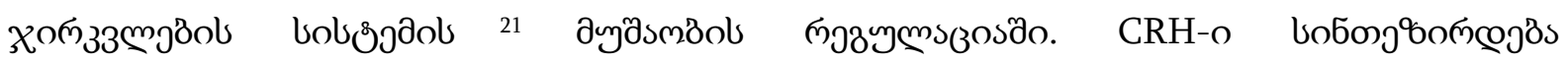

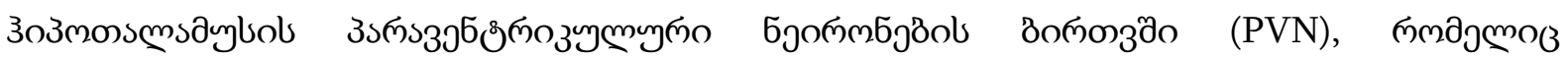

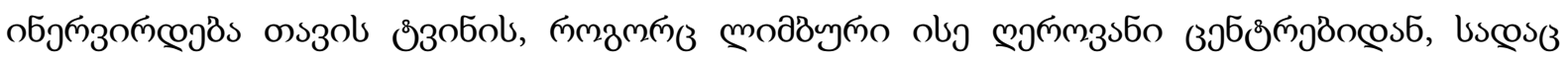

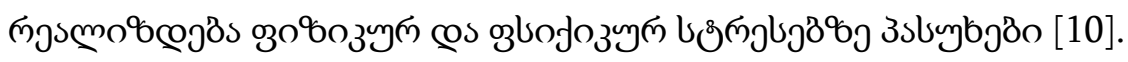

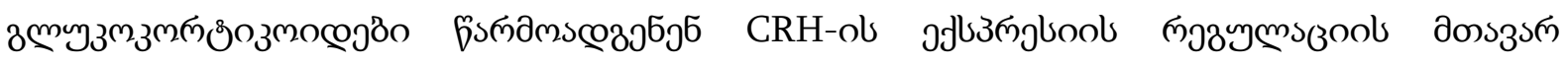

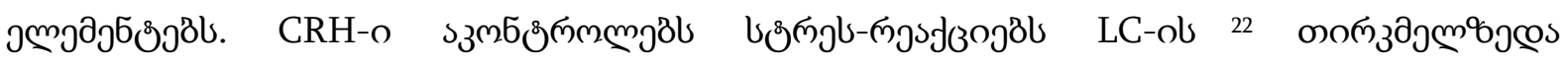

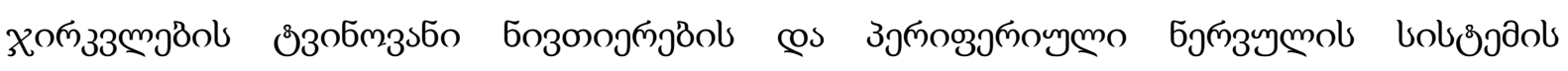

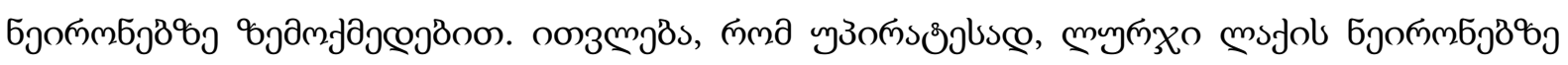

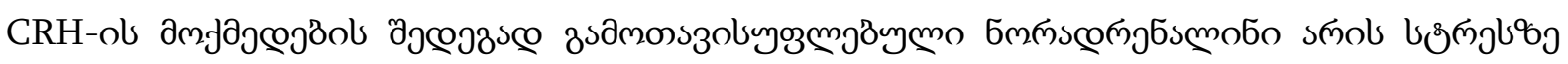

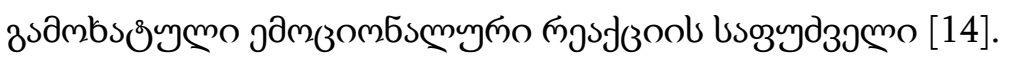

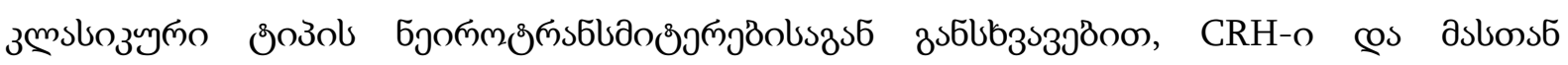

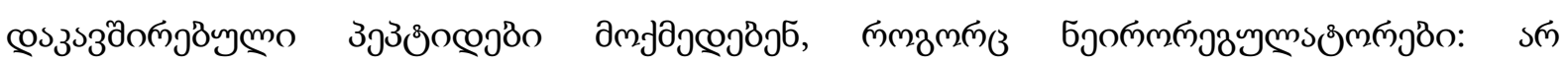
дмдарœ

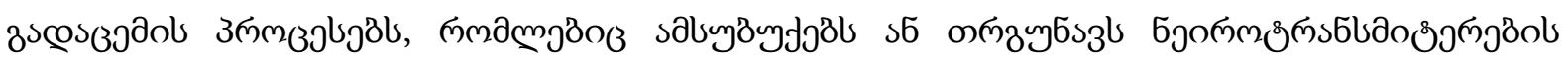

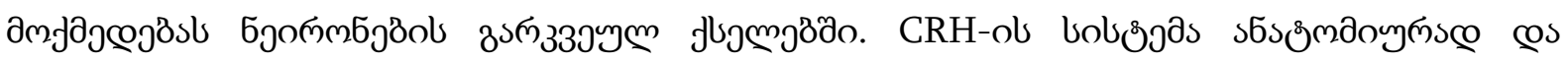

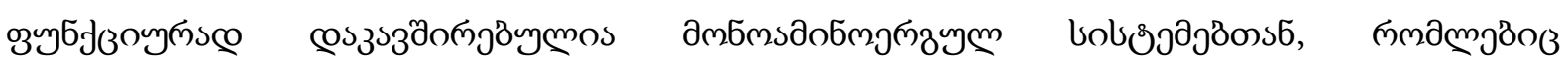

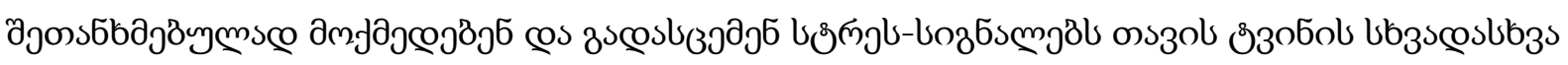

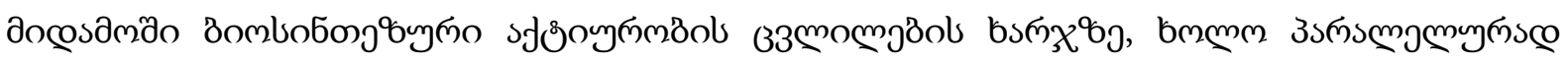

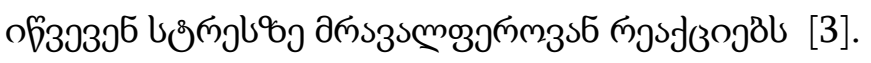

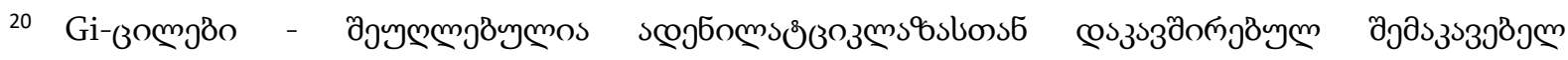

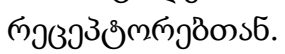

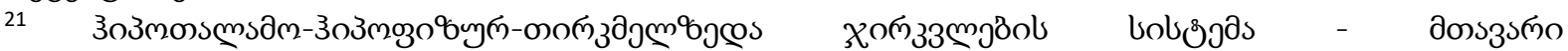

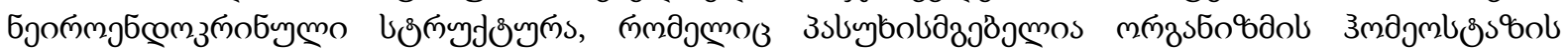

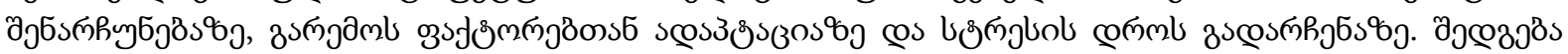

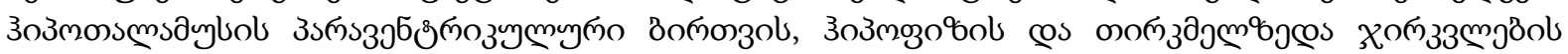

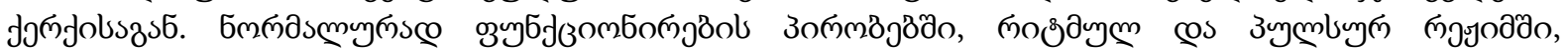

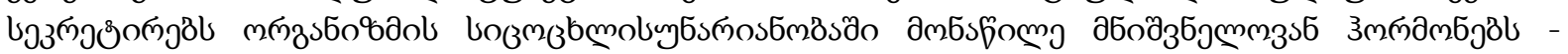

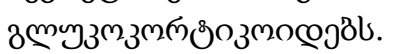

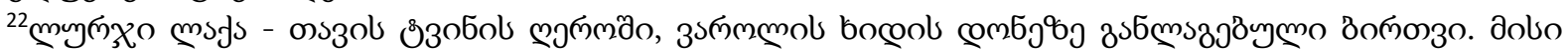

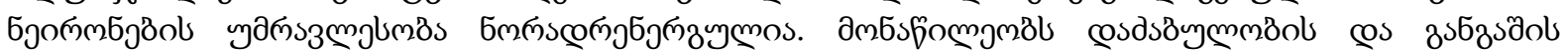

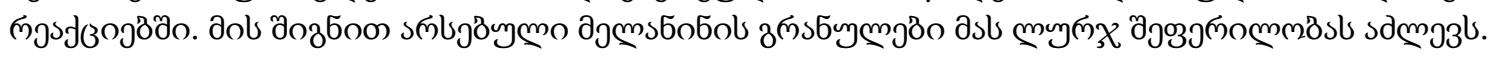




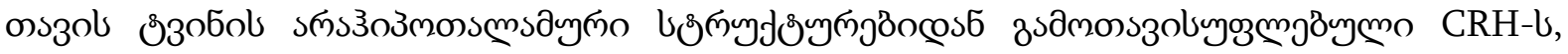

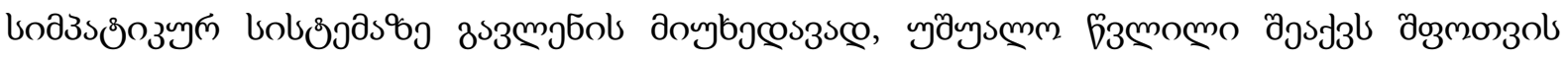

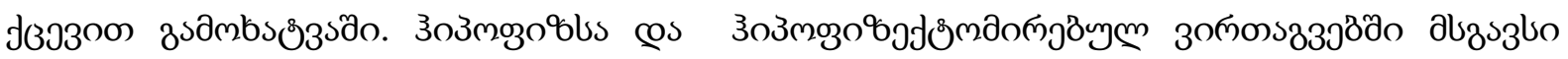

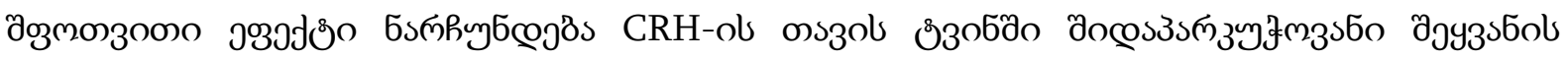

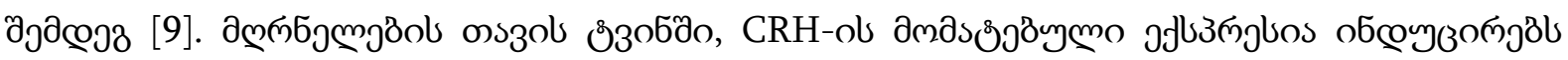

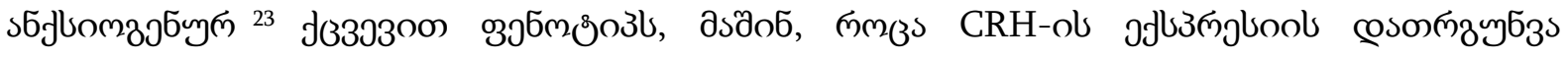

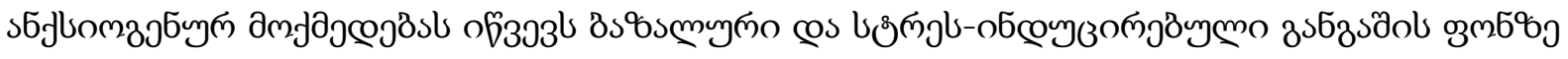
$[7 ; 12]$.

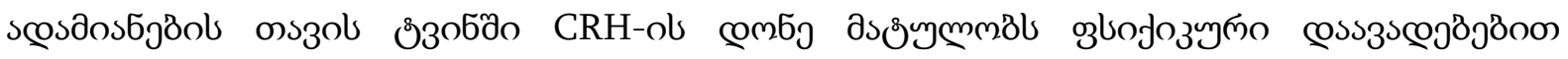

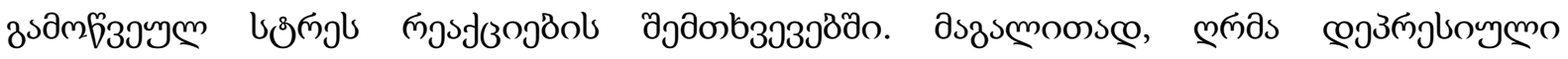

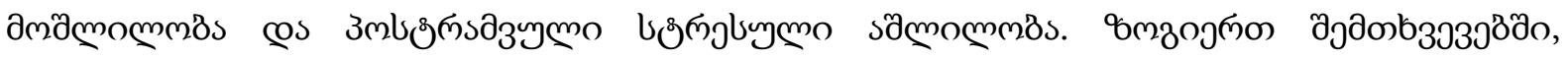

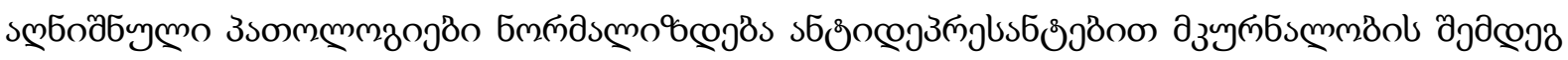
[9;11].

CRH-ob sбjlom

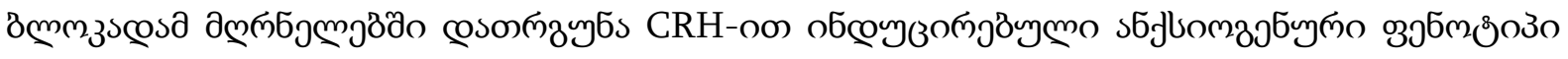
[17].

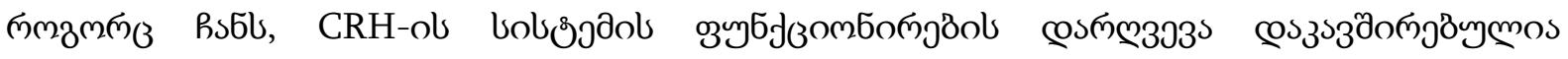

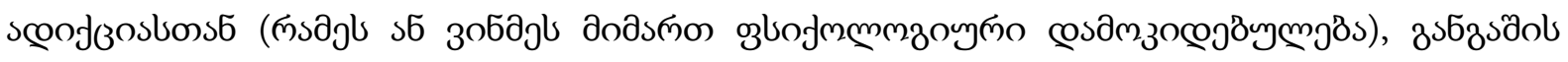

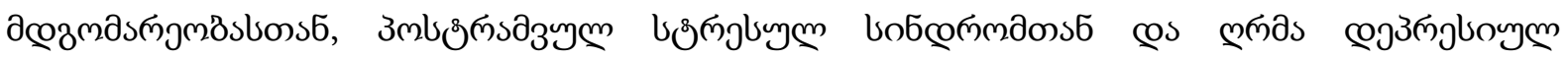
дмдмомомдsboss.

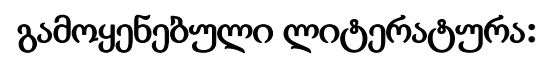

1. Dautzenberg F., Hauger R. The CRF peptide family and their receptors: yet more partners discovered. Trends Pharmacol. Sci. 2002;23: 71-77. DOI 10.1016/s0165-6147(02)01946-6.

2. Deussing J., Chen A. The corticotropin-releasing factor family: physiology of the stress response. Physiol. Rev. 2018;98(4):2225-2286. DOI 10.1152/physrev.00042.2017.

3. Gallagher J., Orozco-Cabal L., Liu J., Shinnick-Gallagher P. Synaptic physiology of central CRH system. Eur. J. Pharmacol. 2008;583: 215-225. DOI 10.1016/j.ejphar.2007.11.075.

4. Gutknecht E., Van der Linden I., Van Kolen K., Verhoeven K., Vauquelin G., Dautzenberg F.M. Molecular mechanisms of corticotropin-releasing factor receptor-induced calcium signaling. Mol. Pharmacol. 2009;75:648-657. DOI 10.1124/mol.108.050427.

5. Hauger R., Risbrough V., Brauns O., Dautzenberg F. Corticotropin releasing factor (CRF) receptor signaling in the central nervous system: new molecular targets. CNS Neurol. Disord. Drug Targets. 2006;5:453-479. DOI 10.2174/187152706777950684.

6. Herman J., Figueiredo H., Mueller N., Ulrich-Lai Y., Ostrander M.M., Choi D., Cullinan W. Central mechanisms of stress integration: hierarchical circuitry controlling hypothalamopituitary-adrenocortical responsiveness. Front. Neuroendocrin. 2003;24:151-180. DOI 10.1016/j.yfrne.2003.07.001.

7. Henckens M., Deussing J., Chen A. Region-specific roles of the corticotropin-releasing

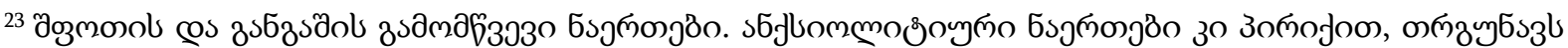

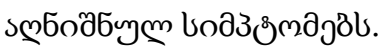


factor-urocortin system in stress. Nat. Rev. Neurosci. 2016;17:636-651. DOI 10.1038/nrn.2016.94.

8. Herman J., Tasker J. Paraventricular hypothalamic mechanisms of chronic stress adaptation. Front. Endocrinol. 2016;7:137. DOI 10.3389/ fendo.2016.00137.

9. Inda C., Armando N., Dos Santos Claro P., Silberstein S. Endocrinology and the brain: corticotropin-releasing hormone signaling. Endocr. Connect. 2017;6(6):R99-R120. DOI 10.1530/EC-17-0111.

10. Lightman S. The neuroendocrinology of stress: a never ending story. J. Neuroendocrinol. 2008;20:880-884. DOI 10.1111/j.1365-2826. 2008.01711.x.

11. Rasmusson A., Pineles S. Neurotransmitter, peptide, and steroid hormone abnormalities in PTSD: biological endophenotypes relevant to treatment. Curr. Psychiatry Rep. 2018;20(7):52. DOI 10.1007/ s1 1920-018-0908-9.

12. Van Gaalen M., Stenzel-Poore M., Holsboer F., Steckler T. Effects of transgenic overproduction of CRH on anxiety-like behaviour. Eur. J. Neurosci. 2002;15:2007-2015. DOI 10.1046/j.1460-9568.2002. 02040.x.

13. Van Kolen K., Dautzenberg F., Verstraeten K., Royaux I., De Hoogt R., Gutknecht E., Peeters P. Corticotropin releasing factor-induced ERK phosphorylation in AtT20 cells occurs via a cAMP-dependent mechanism requiring EPAC2. Neuropharmacology. 2010;58:135144. DOI 10.1016/j.neuropharm.2009.06.022.

14. Valentino R., Van Bockstaele E. Convergent regulation of locus coeruleus activity as an adaptive response to stress. Eur. J. Pharmacol. 2008;583:194-203. DOI 10.1016/j.ejphar.2007.11.062.

15. Waters R., Rivalan M., Bangasser D., Deussing J., Ising M., Wood S., Holsboer F., Summers C. Evidence for the role of corticotropin-releasing factor in major depressive disorder. Neurosci. Biobehav. Rev. 2015;58:63-78. DOI 10.1016/j.neubiorev.2015.07.011.

16. Zmijewski M., Slominski A. Emerging role of alternative splicing of CRF1 receptor in CRF signaling. Acta Biochim. Pol. 2010;57: 1-13.

17. Zorrilla E., Valdez G., Nozulak J., Koob G., Markou A. Effects of antalarmin, a CRF type 1 receptor antagonist, on anxiety-like behavior and motor activation in the rat. Brain Res. 2002;952:188-199. DOI 10.1016/s0006-8993(02)03189-x.

\subsection{2. umasతిmbతిsతిం6ం}

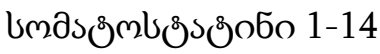

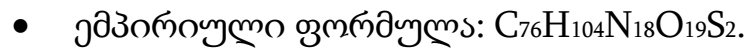

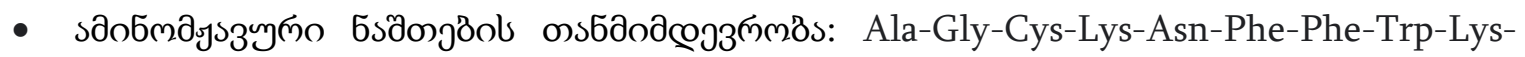
Thr-Phe-Thr-Ser-Cys.

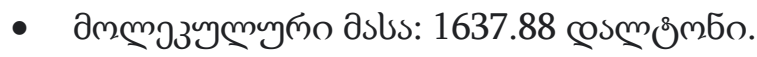

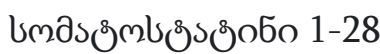

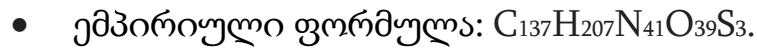

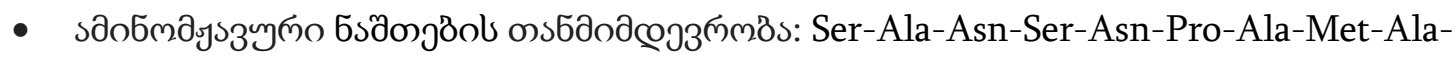
Pro-Arg-Glu-Arg-Lys-Ala-Gly-Cys-Lys-Asn-Phe-Phe-Trp-Lys-Thr-Phe-Thr-Ser-Cys$\mathrm{OH}$.

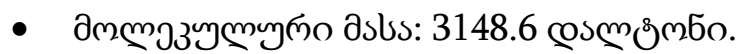




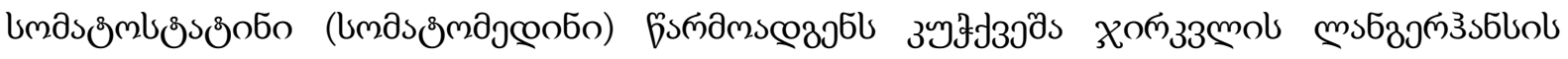

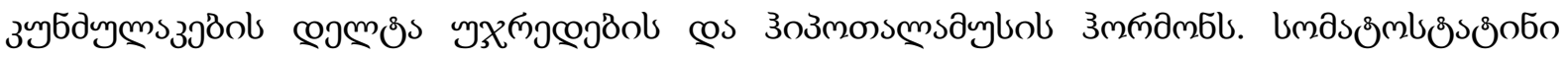

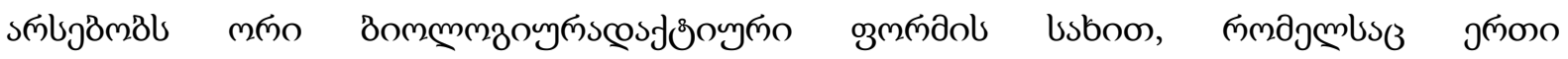

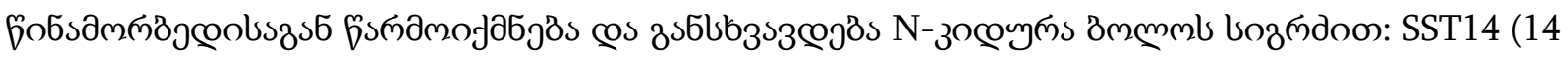

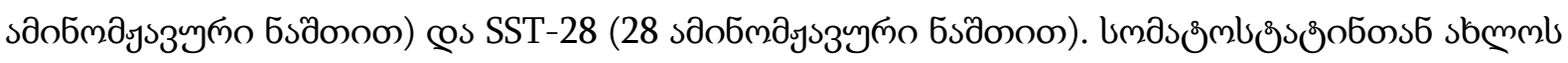

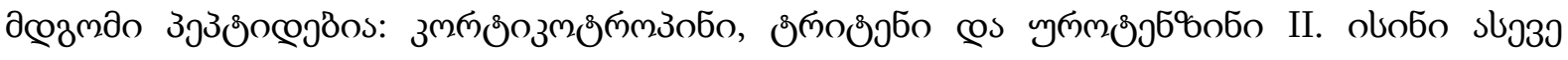

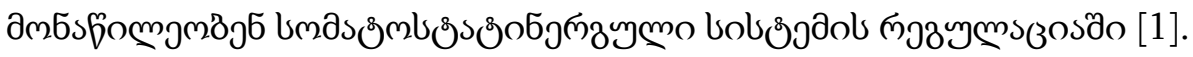

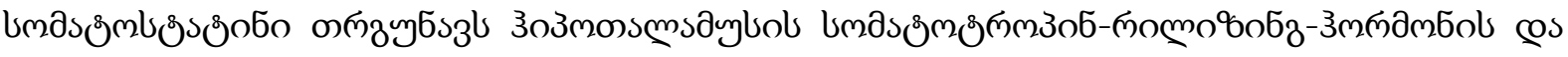

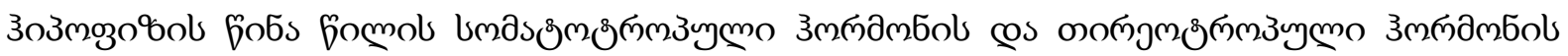

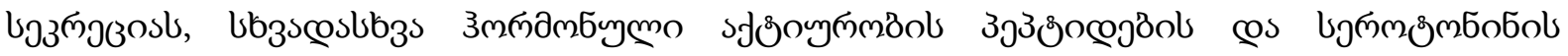

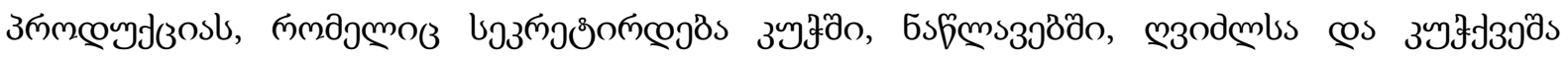

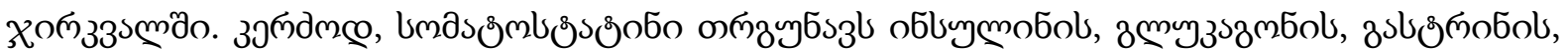

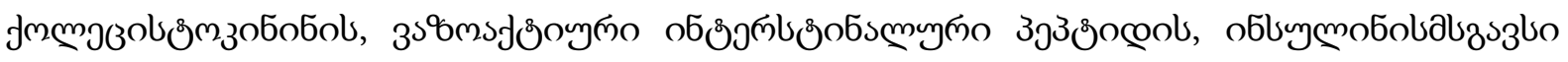

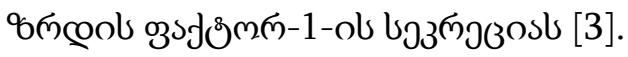

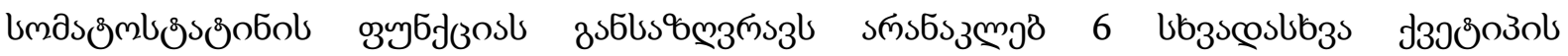

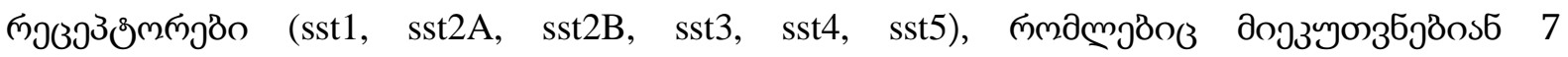

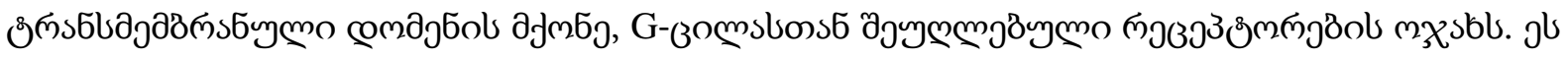

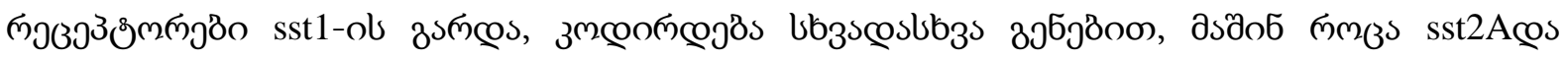

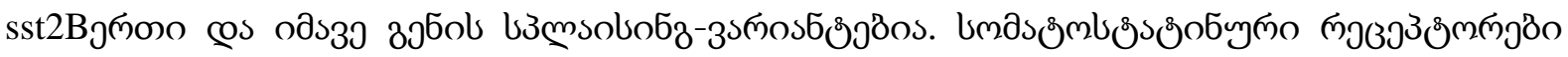

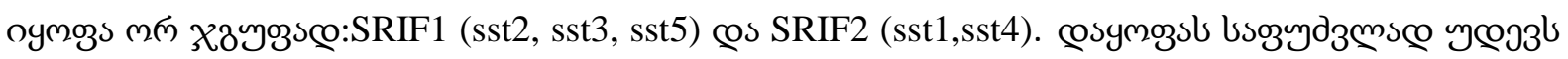

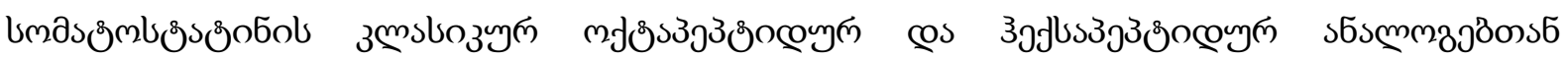

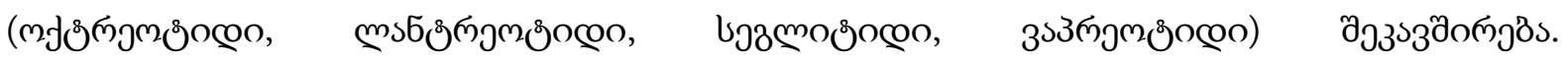

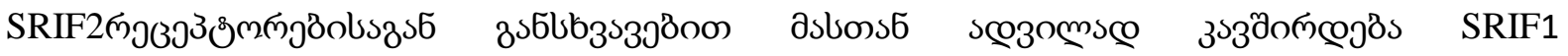

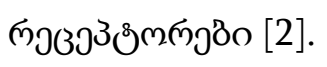

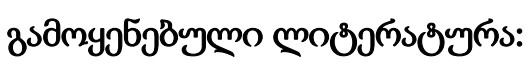

1. Olias G. et al. Regulation and function of somatostatin receptors. // J. Neurochem. 2004. v. 89.pp. 1057-191.

2. Prasad V., Fetscher S., Baum R.P. Changing role of somatostatin receptor targeted drugs inNET: Nuclear Medicine's view. // J. Pharm. Pharmaceut. Sci. 2007. 321s-327s.

3. Tokita K. et al. FK962, a novel enhancer of somatostatin release, exerts cognitiveenhancingactions in rats. // Eur. J. Pharm. 2005. v. 527. pp. 111-120.

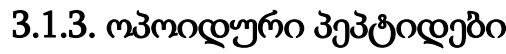

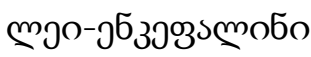

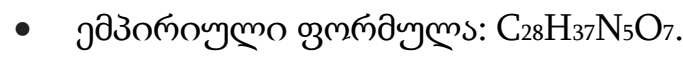

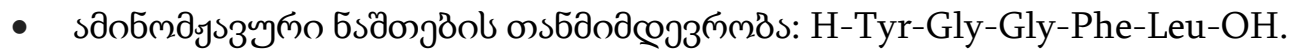




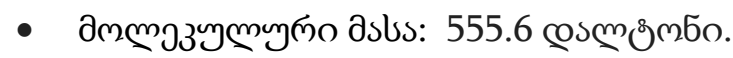

дวо-

- jазополумо озмпаулмs: $\mathrm{C}_{27} \mathrm{H}_{35} \mathrm{~N}_{5} \mathrm{O}_{7} \mathrm{~S}$.

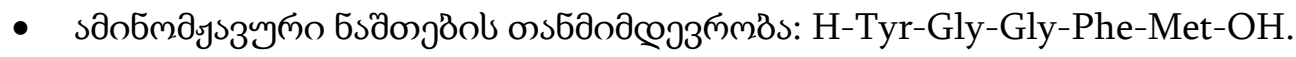

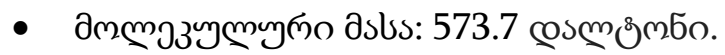

$\alpha-\jmath$ бемпоообо

- jазополумо озмпдулмл: $\mathrm{C}_{77} \mathrm{H}_{120} \mathrm{~N}_{18} \mathrm{O}_{26} \mathrm{~S}$.

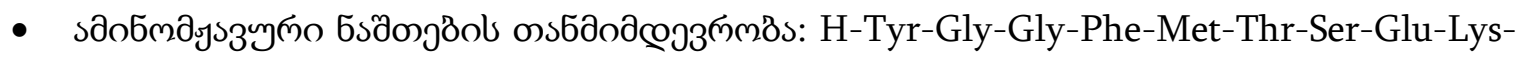
Ser-Gln-Thr-Pro-Leu-Val-Thr-OH.

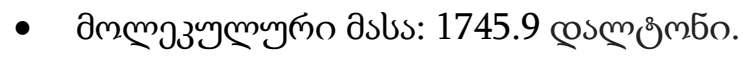

$\beta-$ бемпмозобо

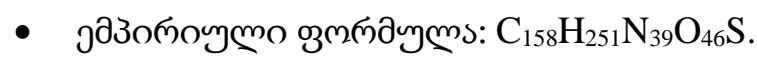

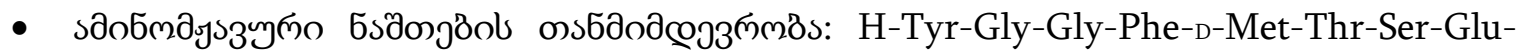
Lys-Ser-Gln-Thr-Pro-Leu-Val-Thr-Leu-Phe-Lys-Asn-Ala-Ile-Ile-Lys-Asn-Ala-Tyr-LysLys-Gly-Glu-OH.

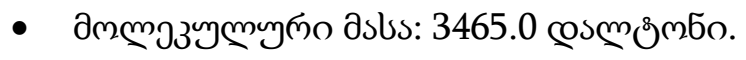

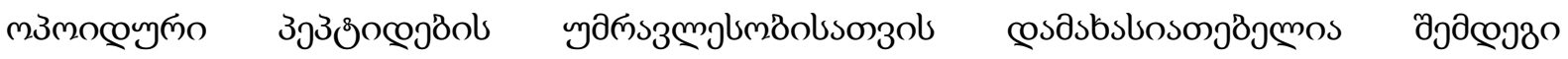

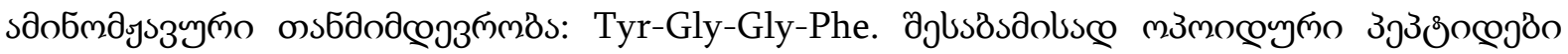

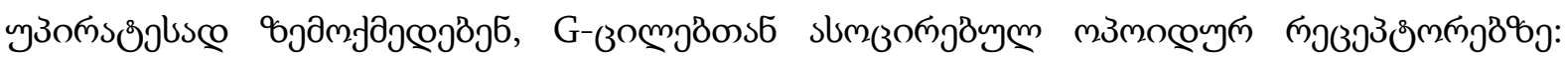

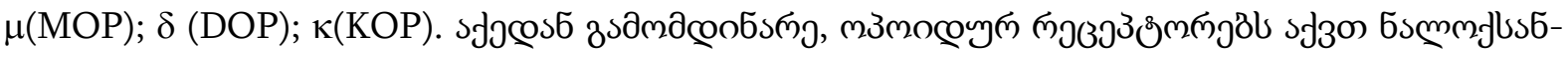

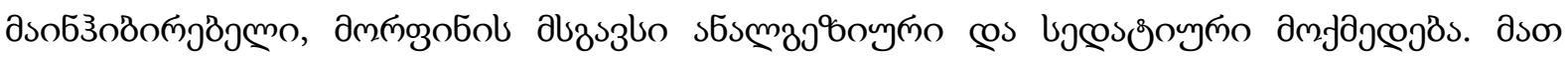

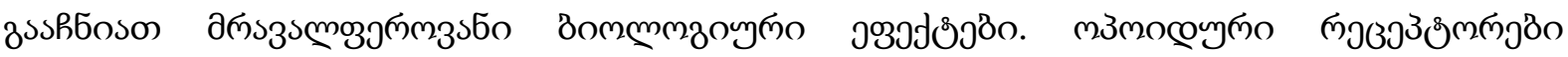

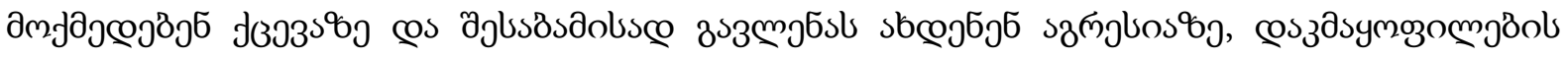

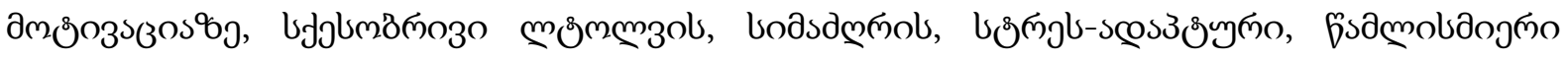

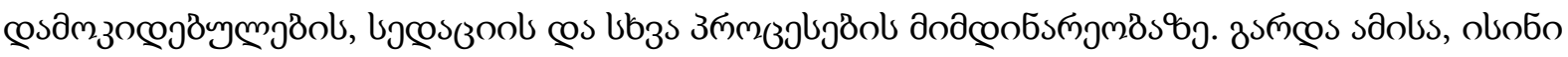

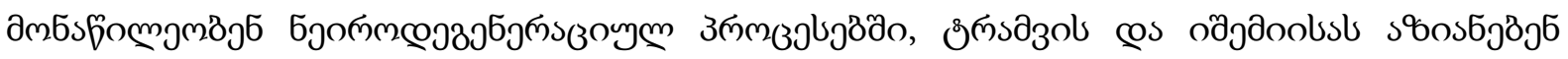
ऽ̊3obol flumomb[4].

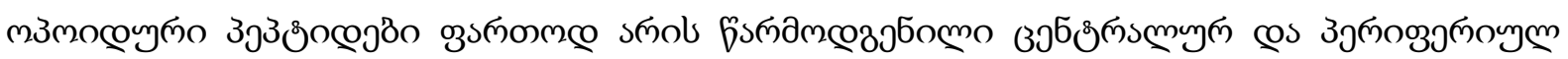

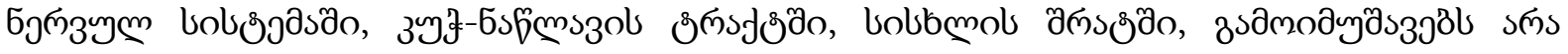

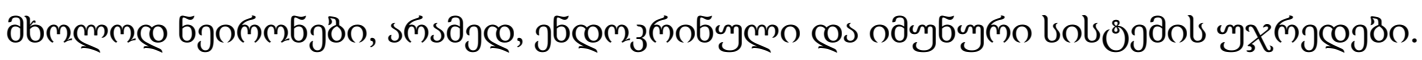

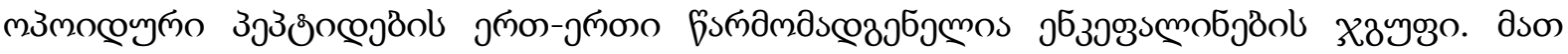

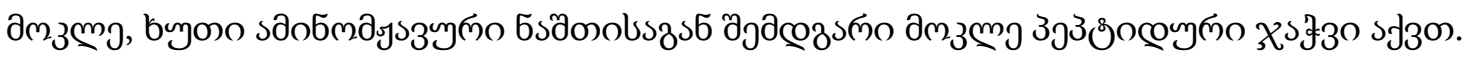

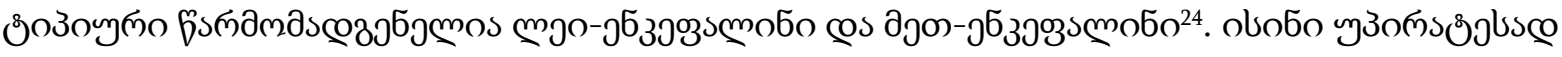

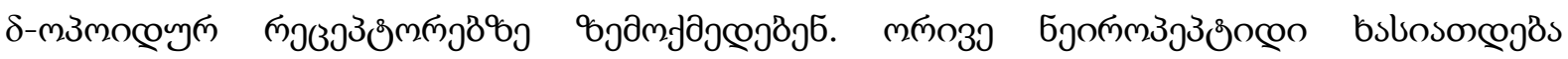

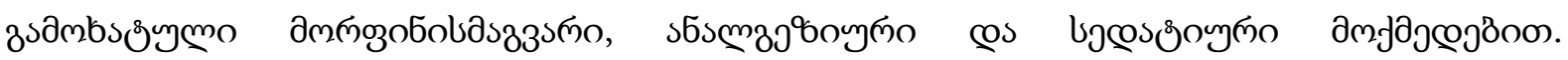

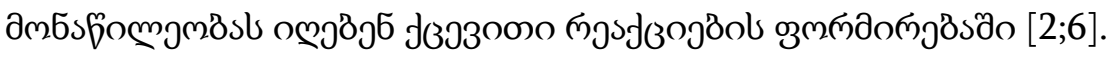

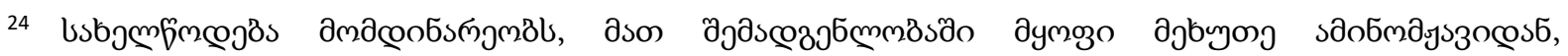

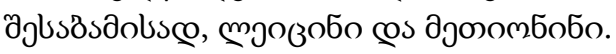




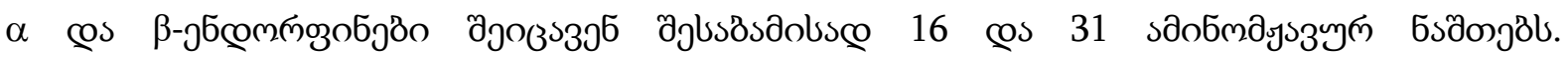

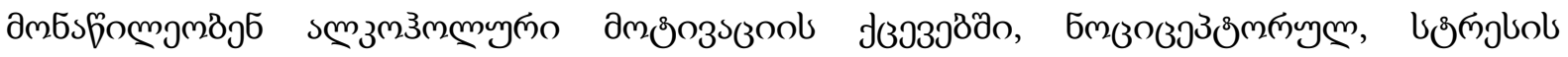

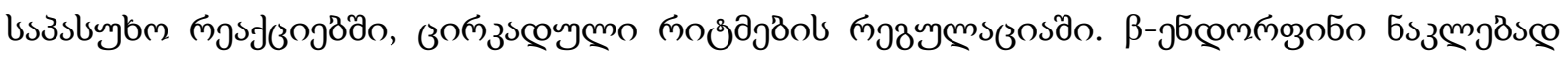

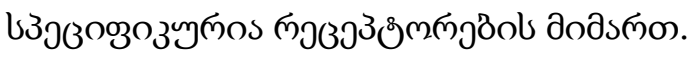

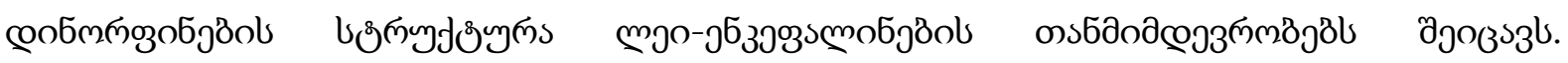

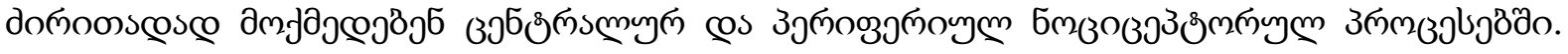

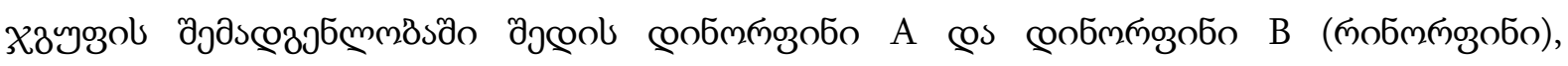

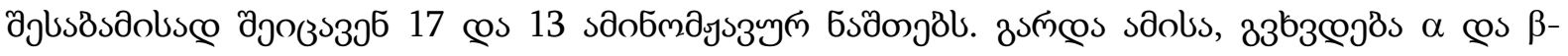

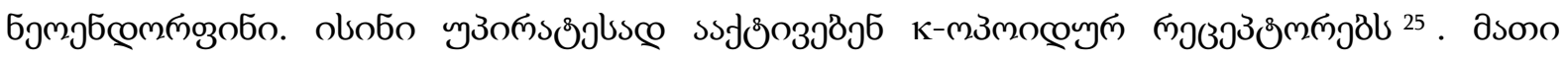

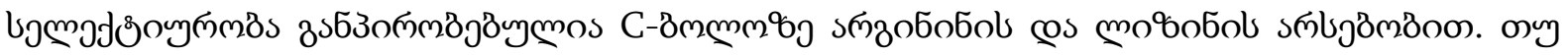

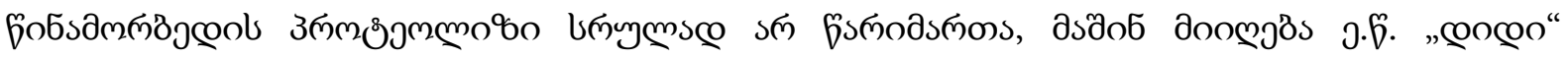

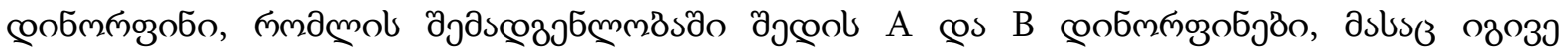

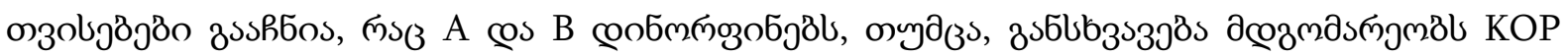

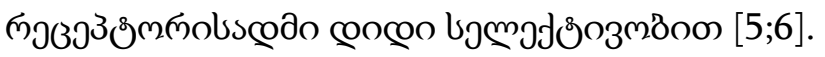

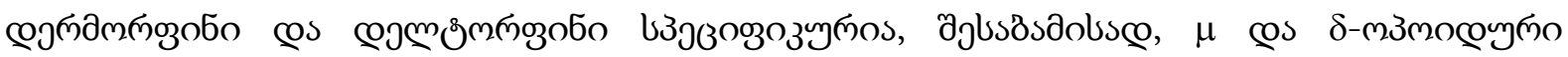

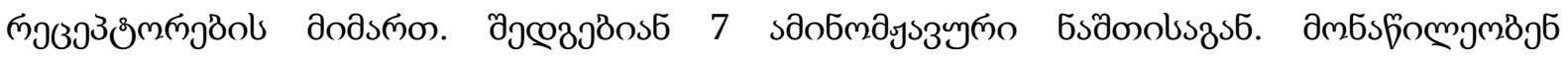

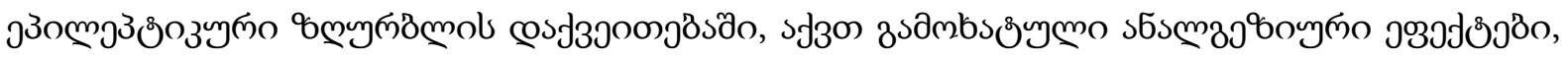

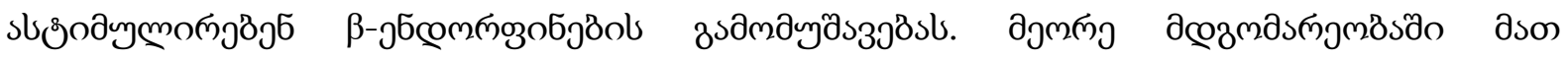

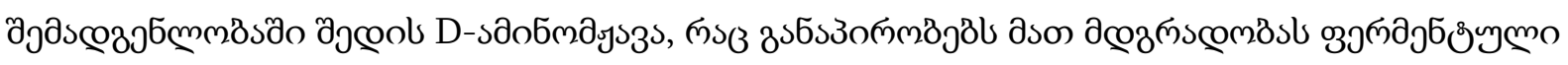

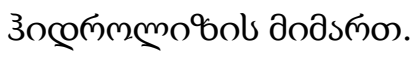

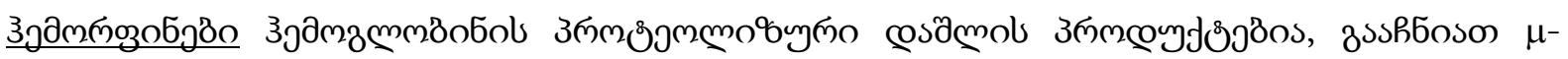

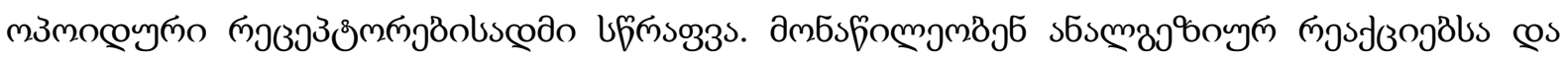

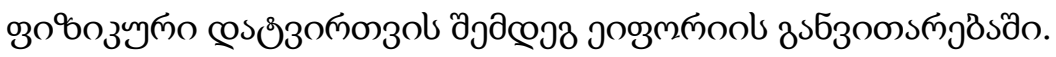

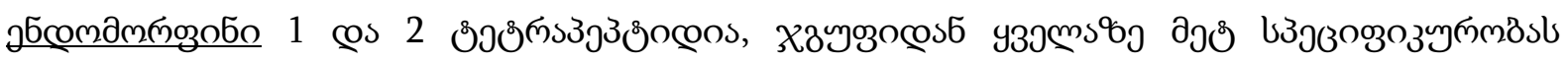

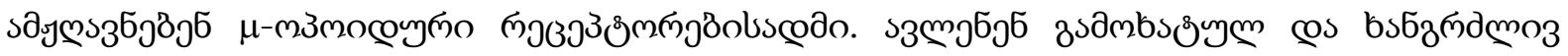

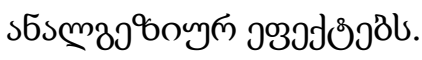

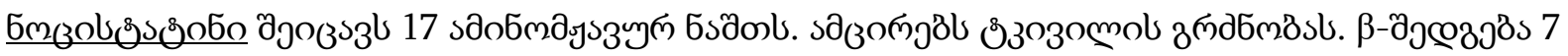

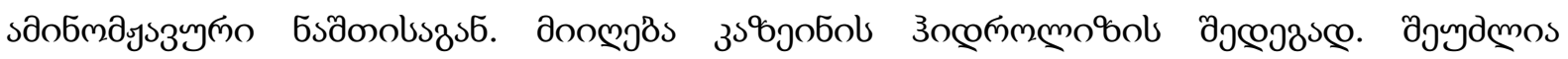

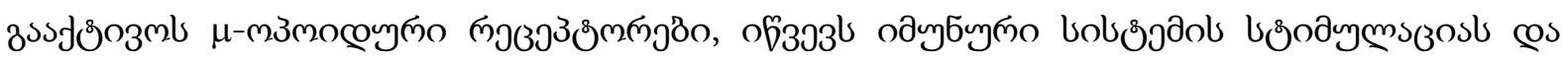

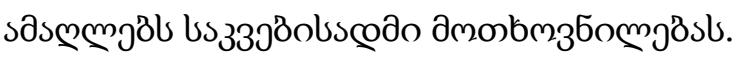

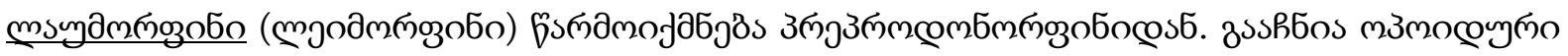

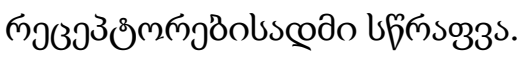

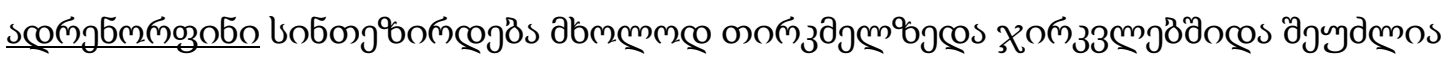

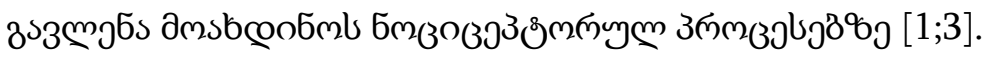

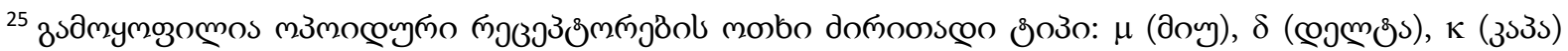

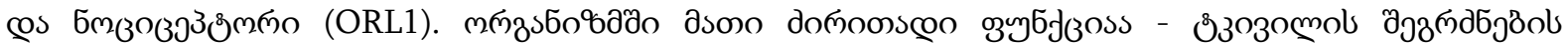

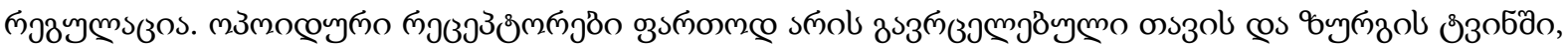

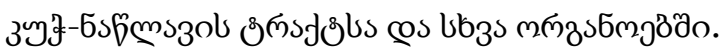




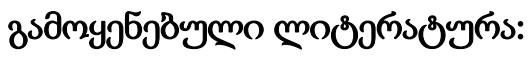

1. Corbett AD, Paterson SJ, McKnight AT, Magnan J, Kosterlitz HW. Dynorphin and dynorphin are ligands for the kappa-subtype of opiate receptor. Nature 1982;299(5878):79-81.

2. Elshourbagy N.A. Receptor for the pain modulatory neuropeptide FF and AF is orphan protein-coupled receptor / J Biol. Chem. Vol. 275. P. 259-265. 2000.

3. Hook V, Funkelstein L, Lu D, Bark S, Wegrzyn J, Hwang SR. Proteases for processing proneuropeptides into peptide neurotransmitters and hormones. Annu Rev Pharmacol Toxicol 2008;48:393-423.

4. Mathias Hallberg. Neuropeptides: Metabolism to Bioactive Fragments and the Pharmacology of Their Receptors / Medicinal Research Reviews, 00, No. 0, P. 1-57, 2014.

5. Nyberg F.,Hallberg M.Neuropeptides in hyperthermia/Progress in Brain Research. Vol. 162. P. 277-293. 2007.

6. Seizinger BR, Hollt V, Herz A. Proenkephalin B (prodynorphin)-derived opioid peptides: Evidence for a differential processing in lobes of the pituitary. Endocrinology 1984;115(2):662-671.

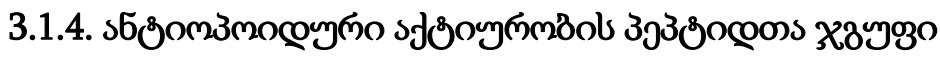

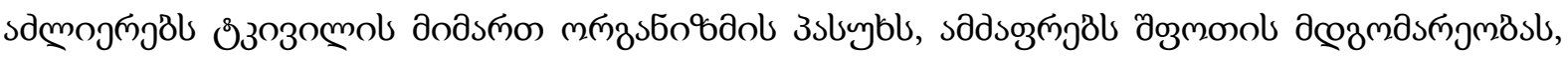

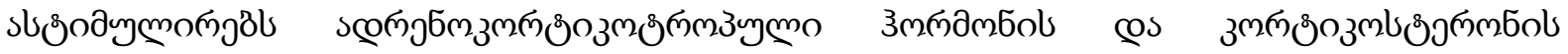

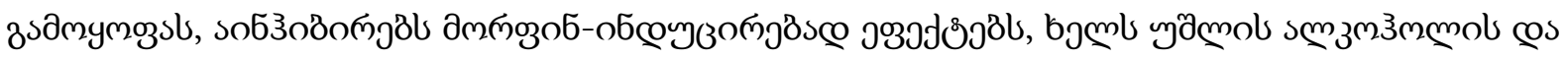

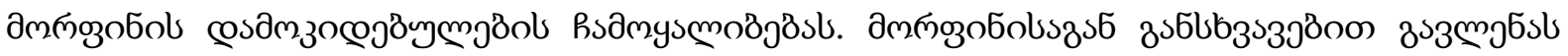

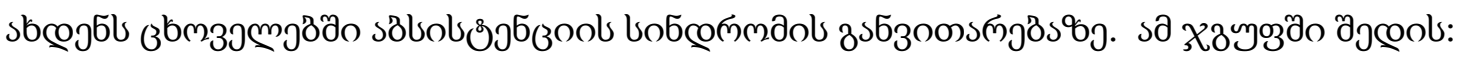

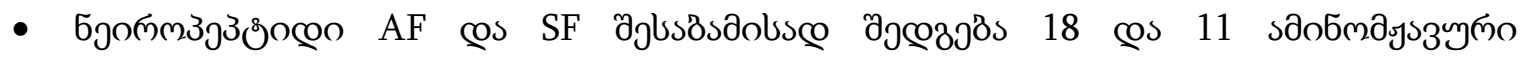

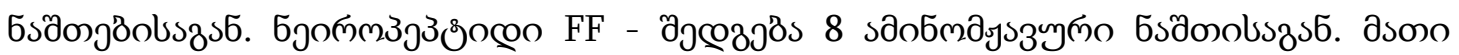

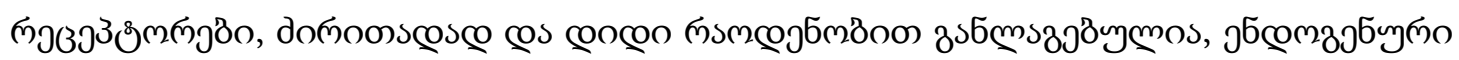

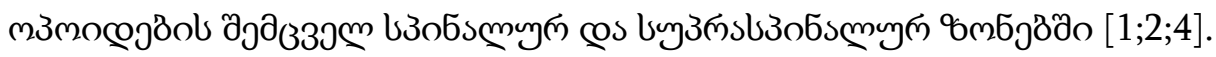

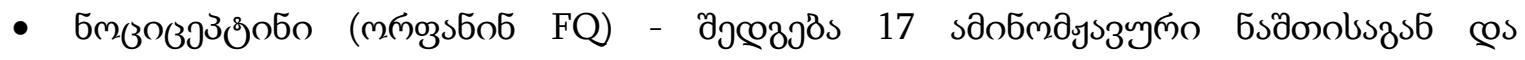

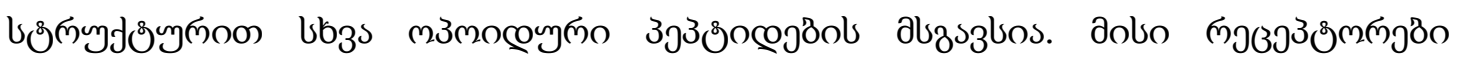

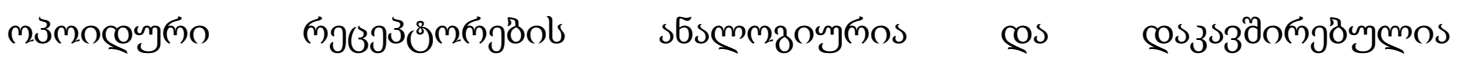

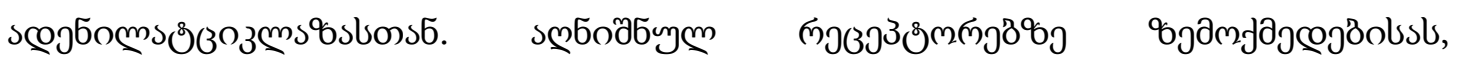

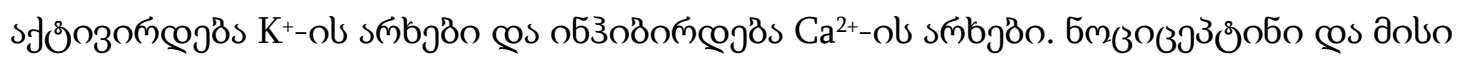

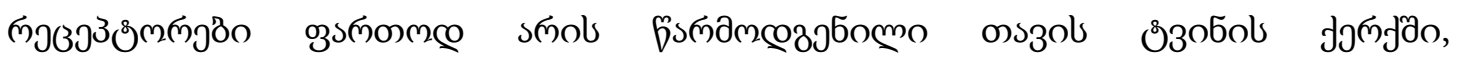

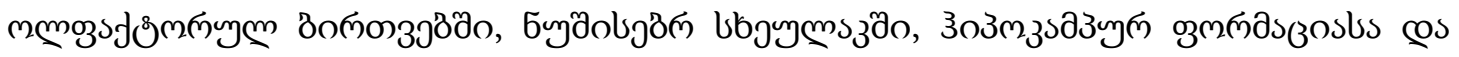

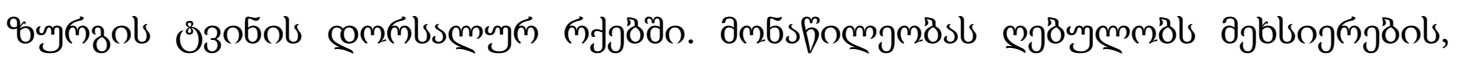

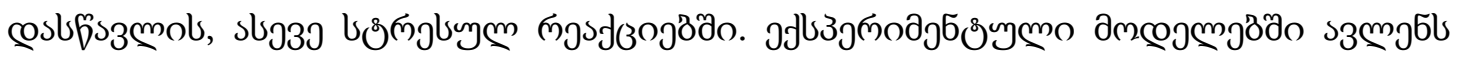

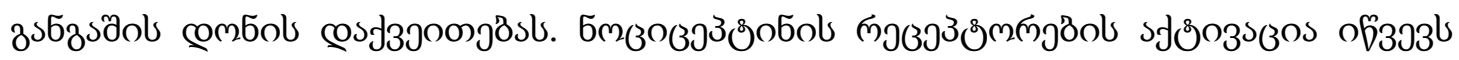

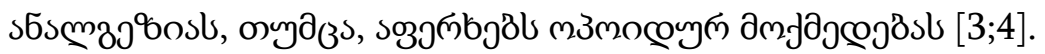




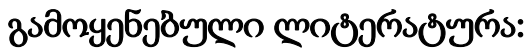

1. Flores CA, Wang XM, Zhang KM, Mokha SS. Orphanin FQ produces gender-specific modulation of trigeminal nociception: Behavioral and electrophysiological observations. Neuroscience 2001;105(2):489-498.

2. Ko MC, Woods JH, Fantegrossi WE, Galuska CM, Wichmann J, Prinssen EP. Behavioral effects of a synthetic agonist selective for nociceptin/orphanin FQ peptide receptors in monkeys. Neuropsychopharmacology 2009;34(9):2088-2096

3. Sandin J, Georgieva J, Schott PA, Ogren SO, Terenius L. Nociceptin/orphanin FQ microinjected into hippocampus impairs spatial learning in rats. Eur $\mathbf{J}$ Neurosci 1997;9(1):194-197.

4. Meunier JC. Nociceptin/orphanin FQ and the opioid receptor-like ORL1 receptor. Eur J Pharmacol 1997;340(1):1-15.

\subsection{5. $358 \mathrm{~m} 3$ mुgrobo}

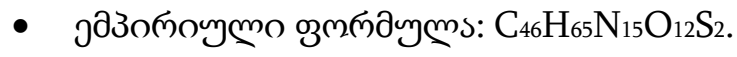

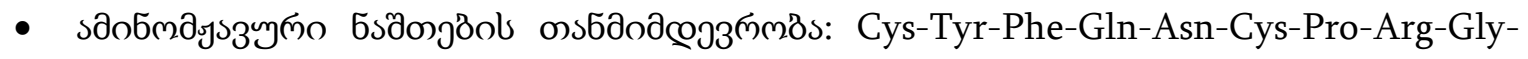
$\mathrm{NH}_{2}$.

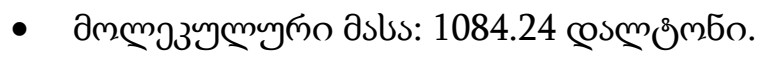

3

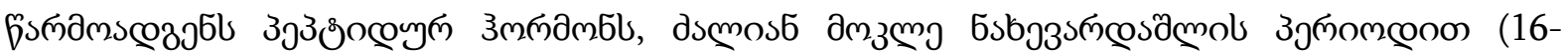

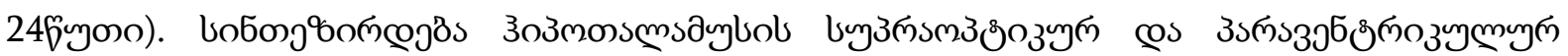

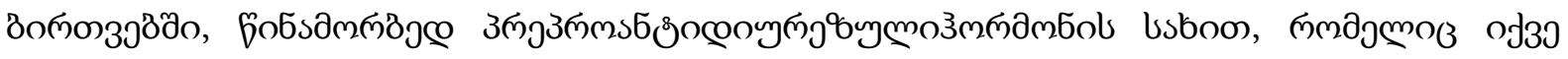

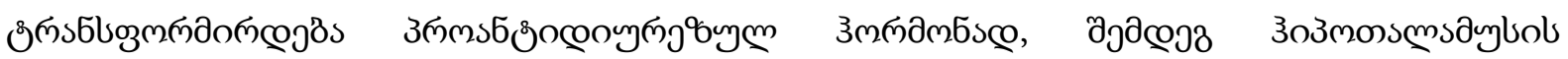

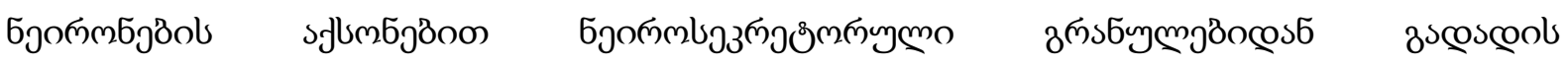

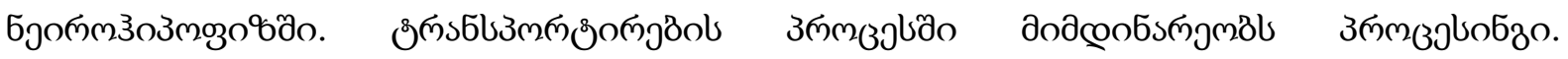

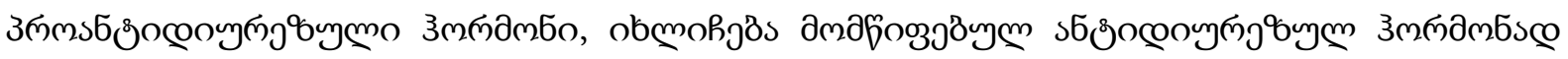
cos зомы бропмозовобsco [3].

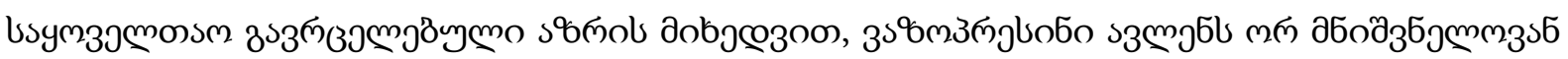

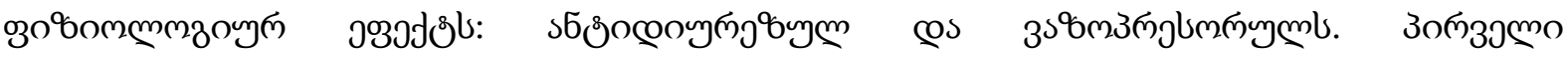

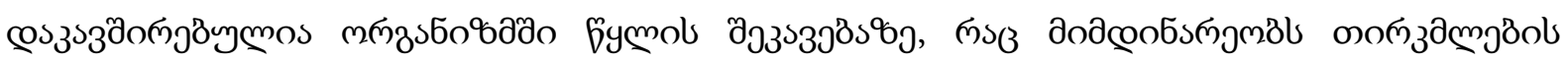

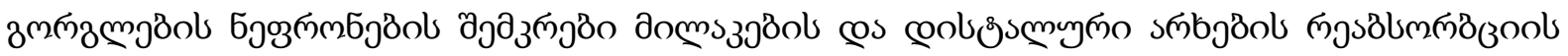

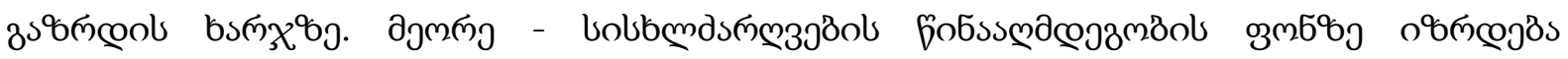

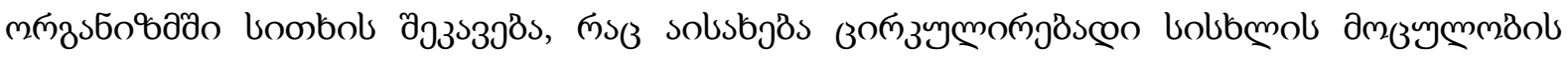

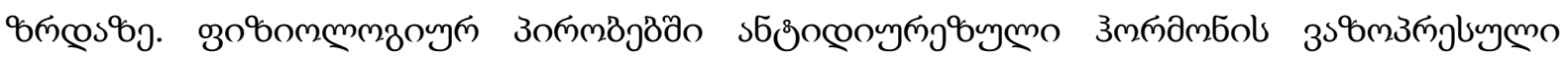

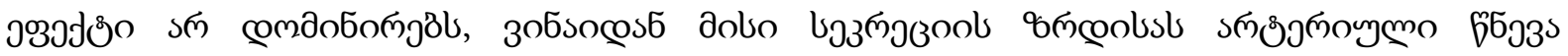

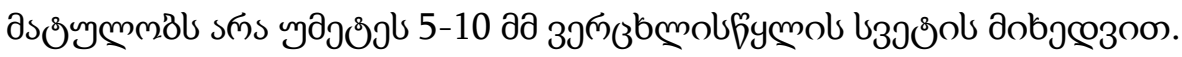

3

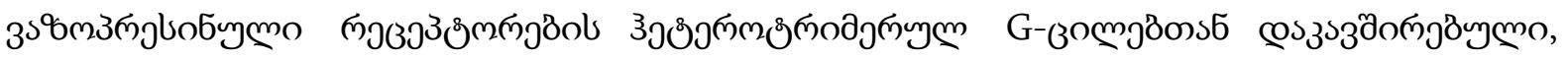




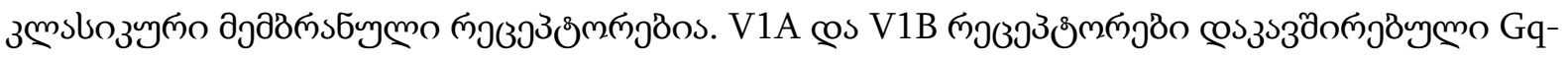

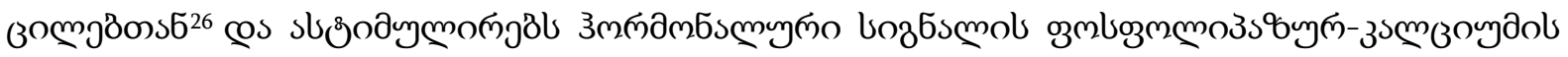

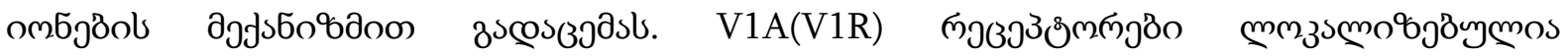

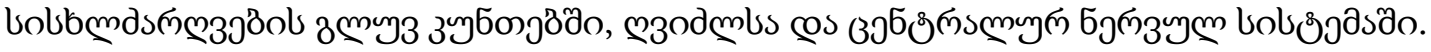

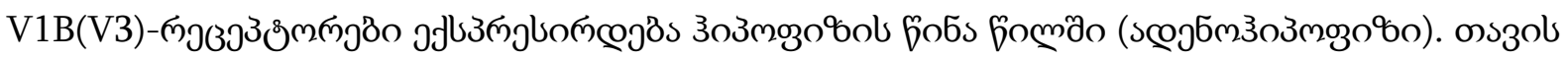

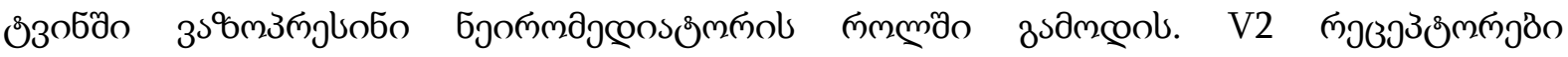

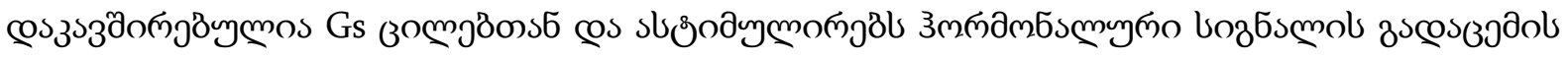

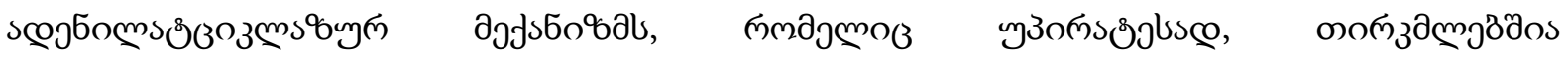

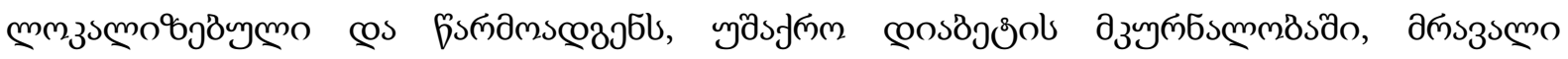

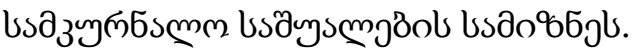

3

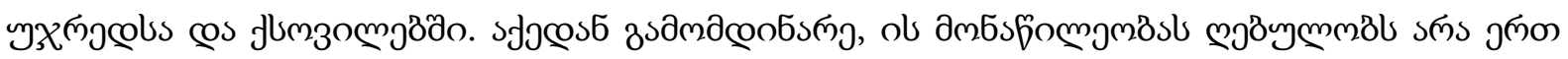

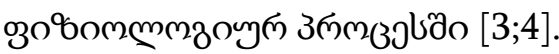

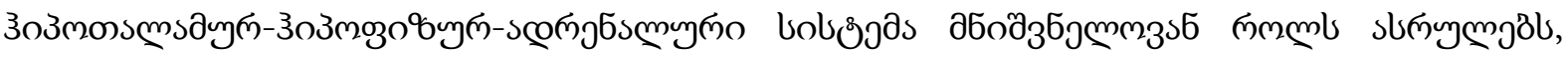

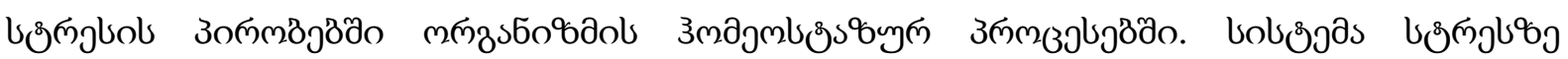

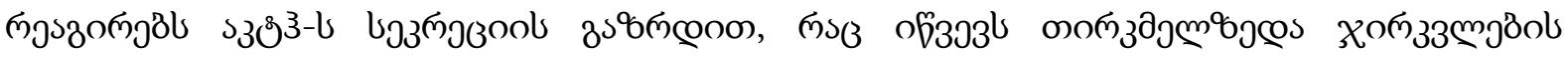

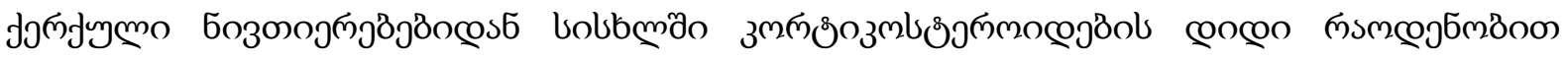

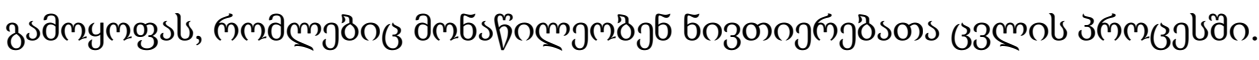

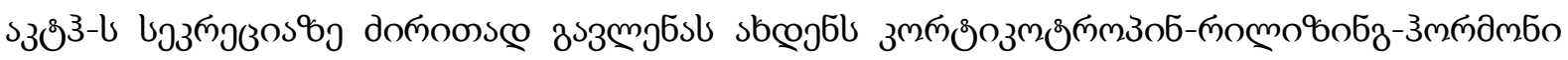

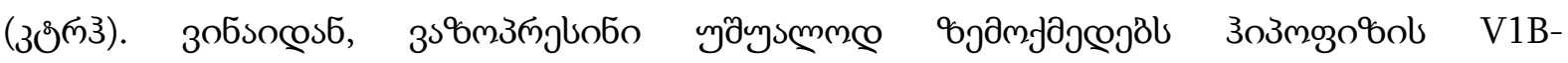

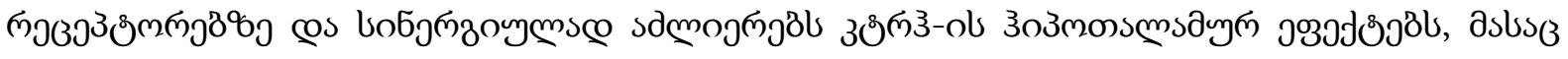

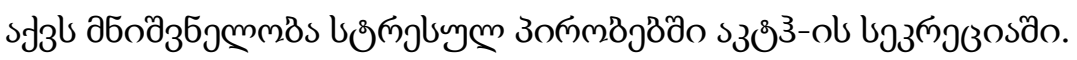

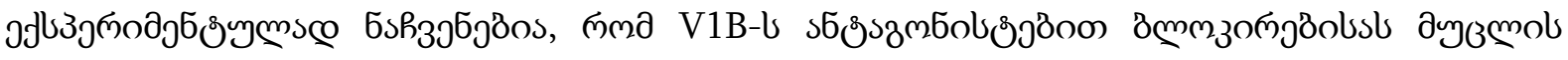

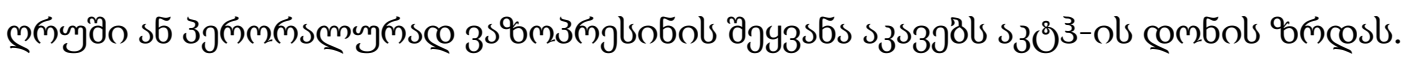

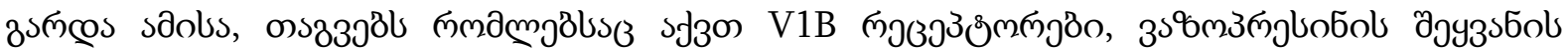

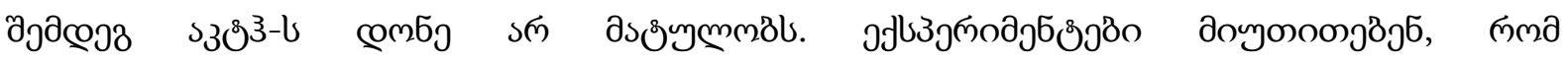

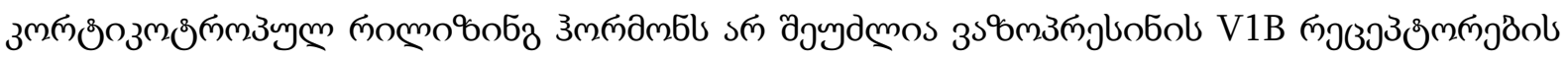

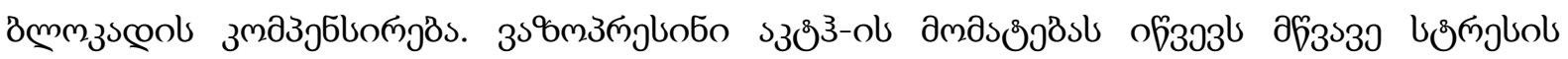

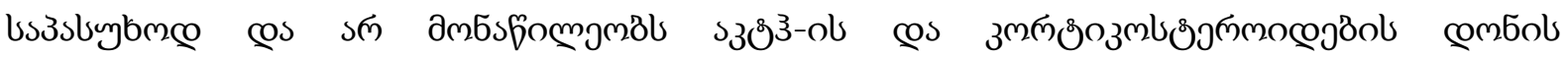

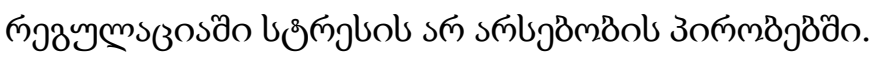

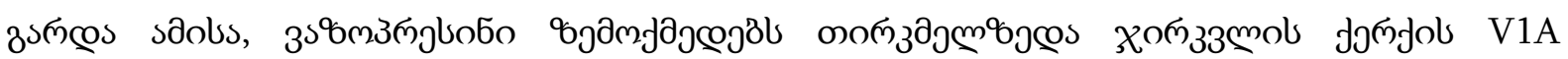

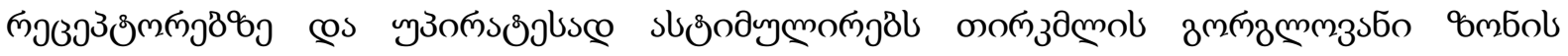

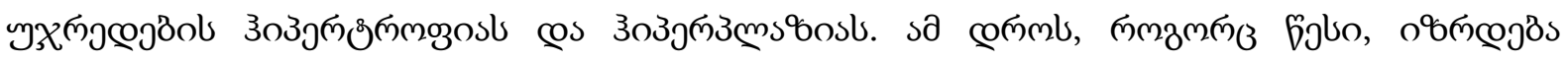

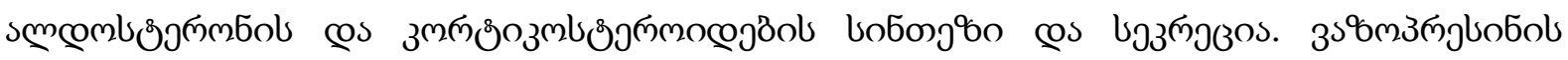

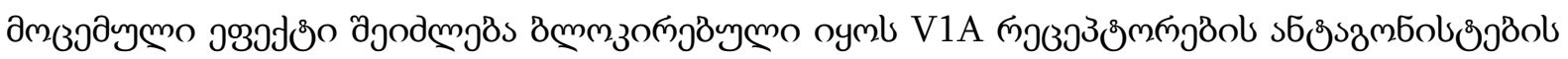
вsдmyјбјठ̊on [7;11].

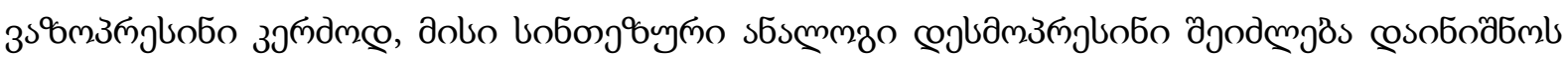

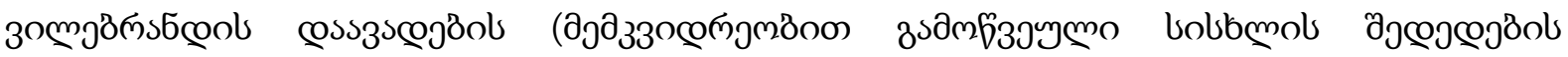

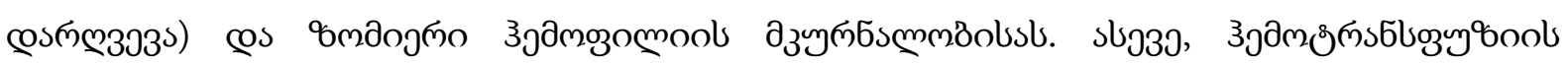

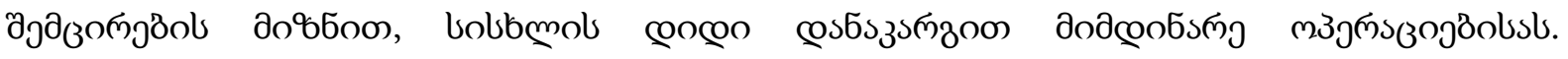

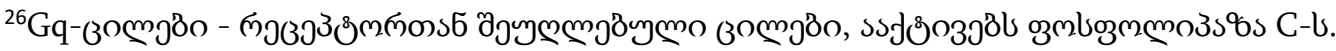




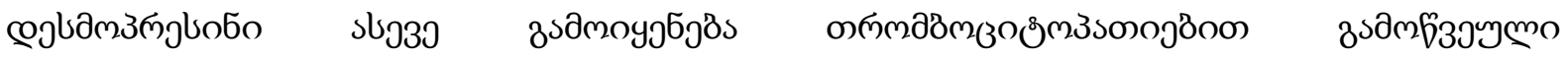

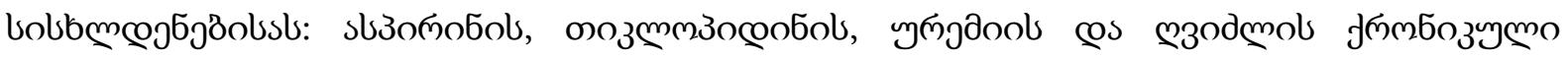

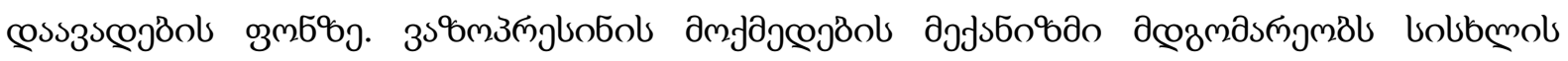

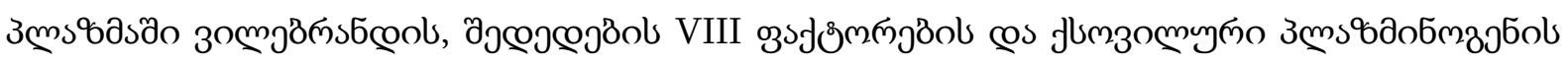

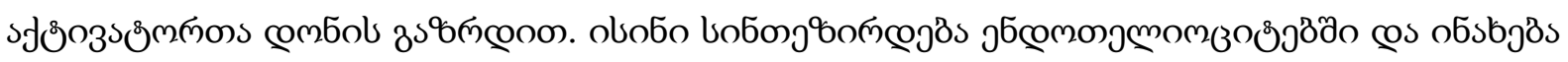

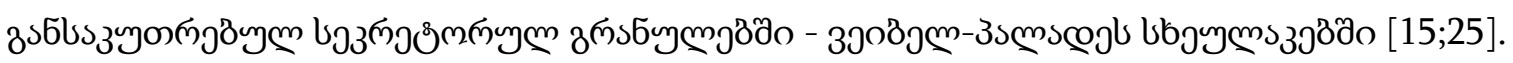

3

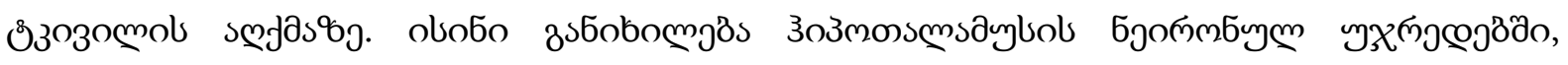

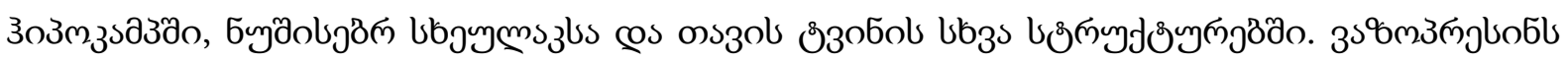

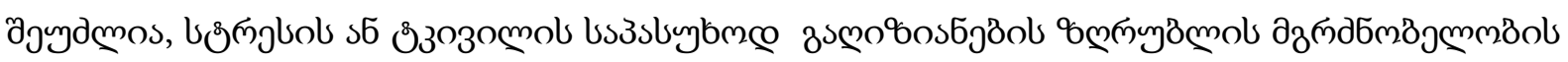

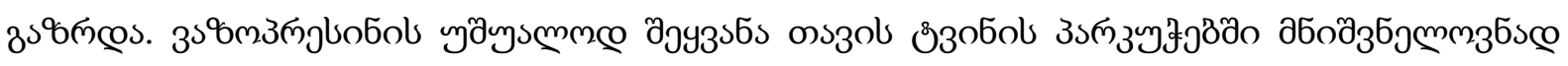

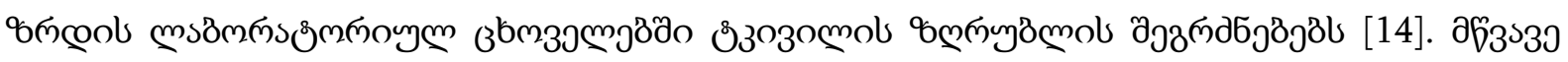

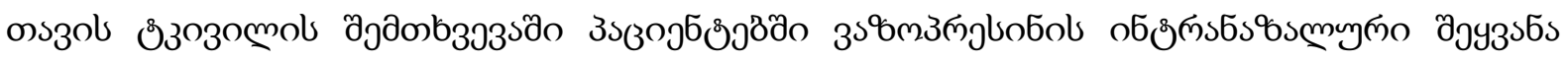

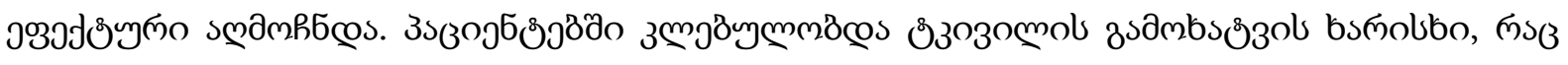

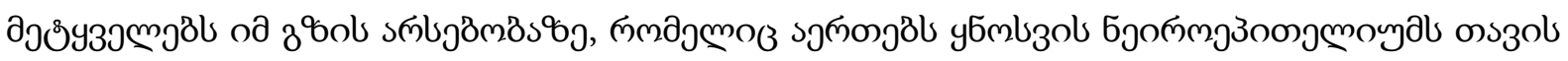

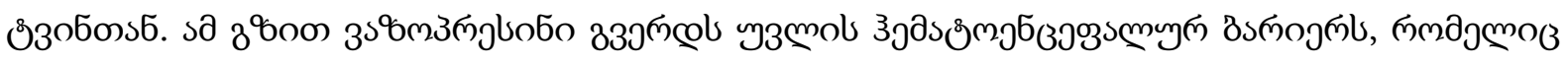

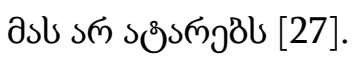

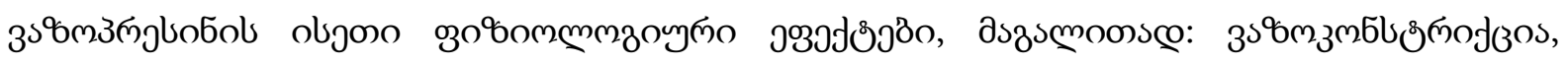

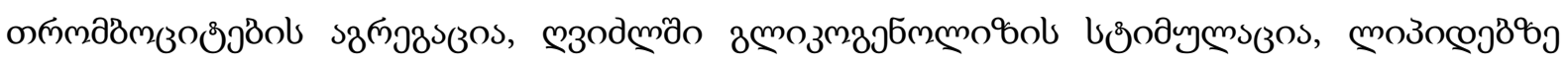

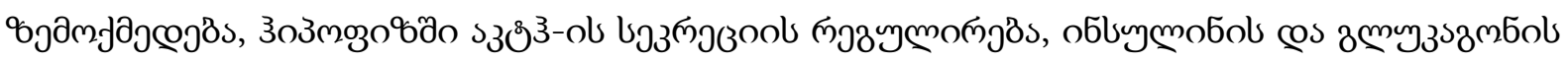

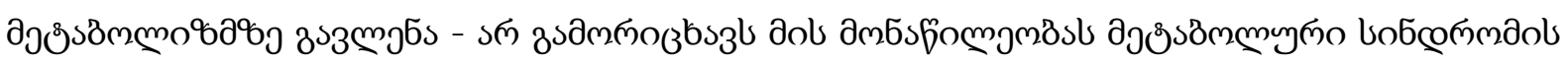

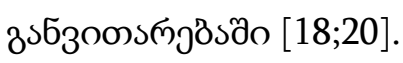

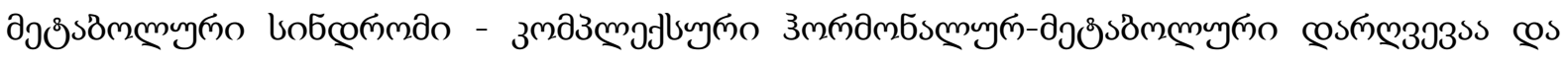

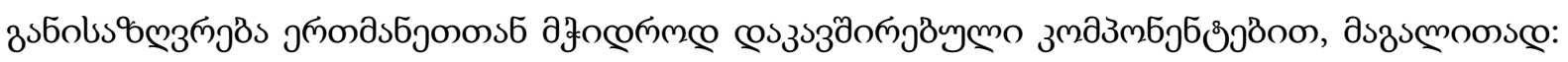

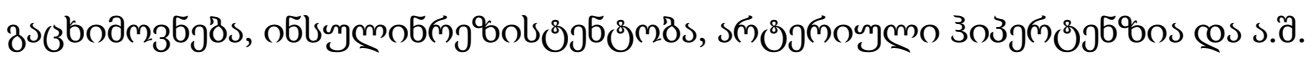

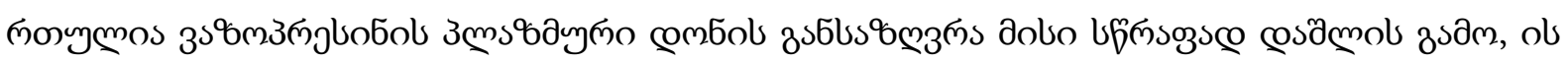

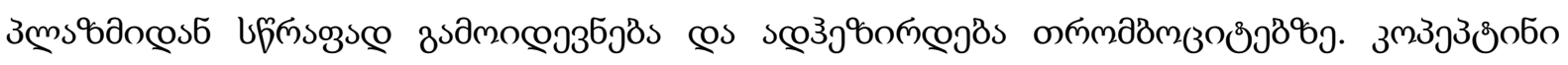

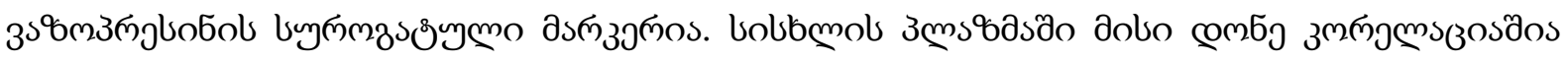
3

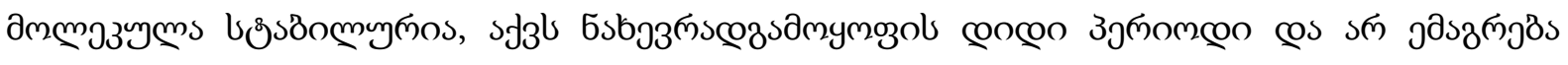

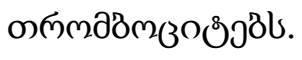

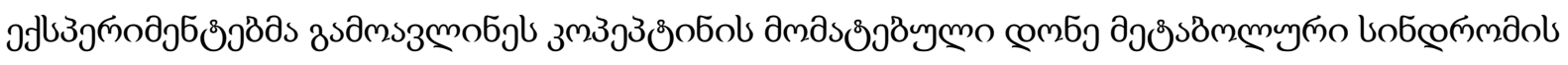

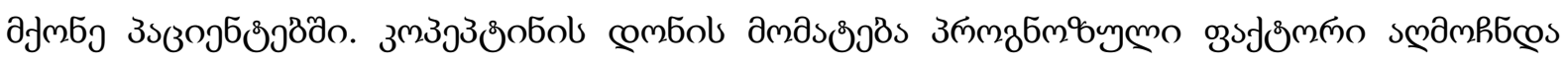

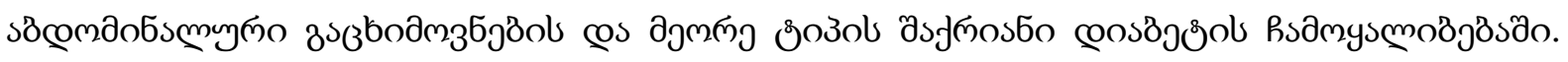

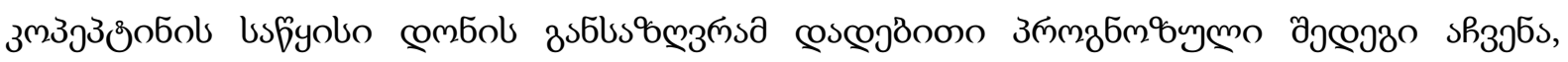

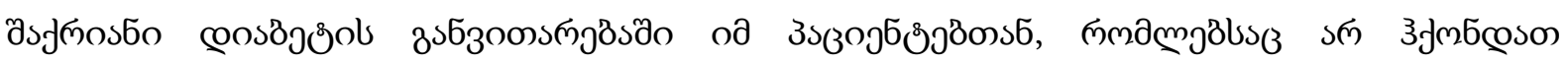

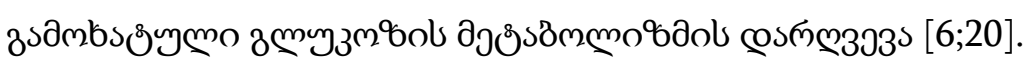

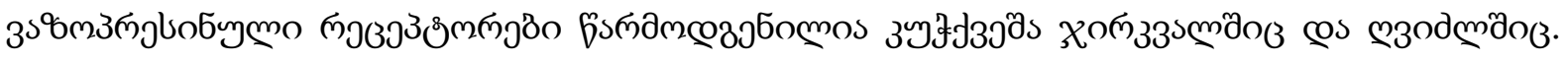

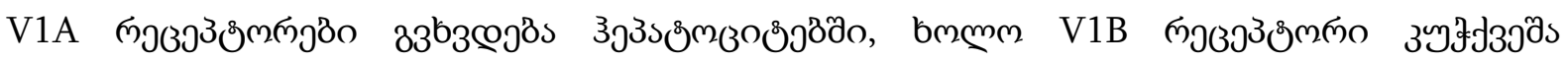

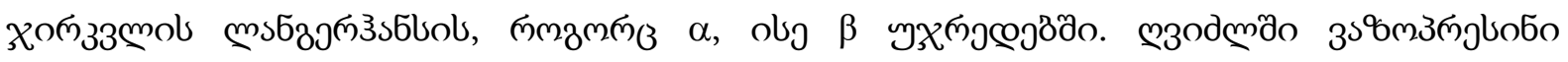

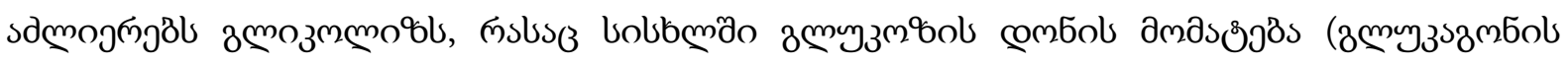

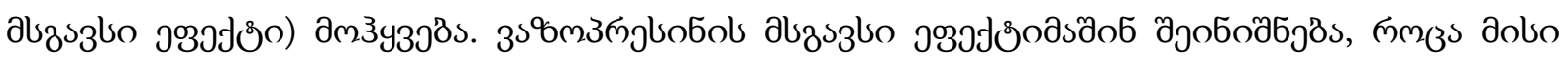




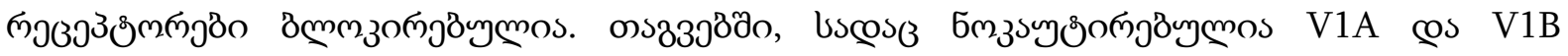

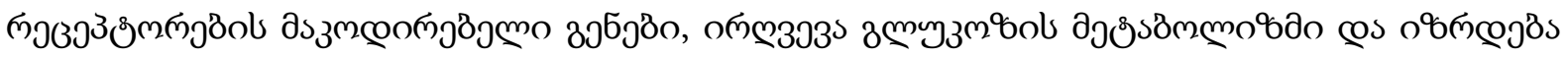

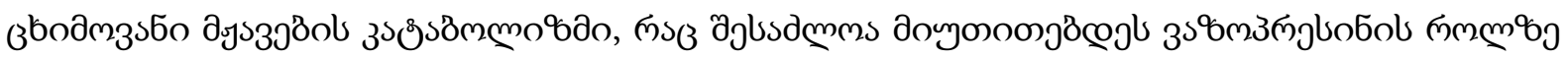

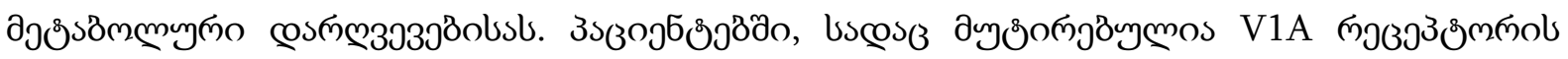

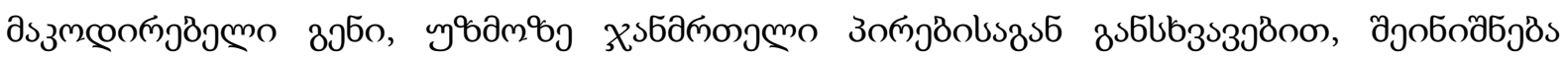
зозупзмоздаоs [11].

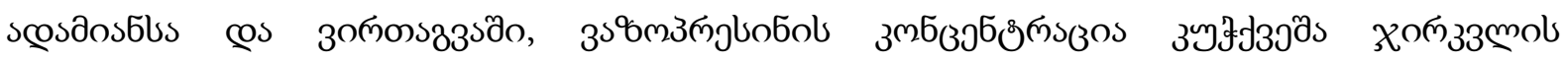

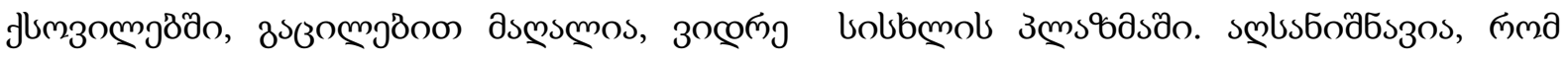
з

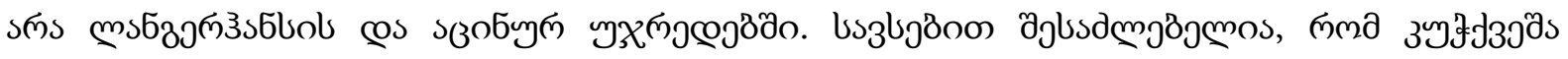

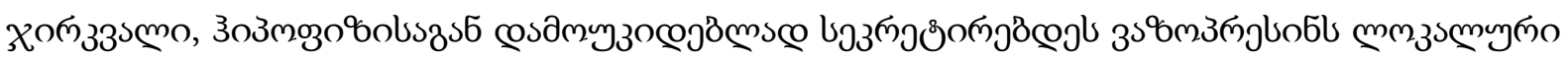

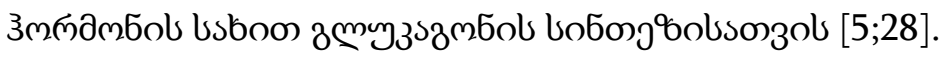

З

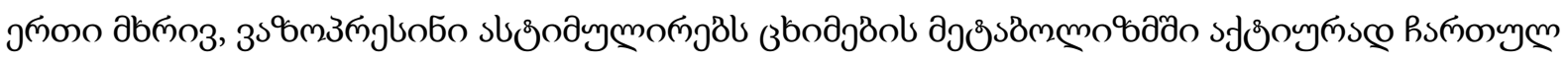

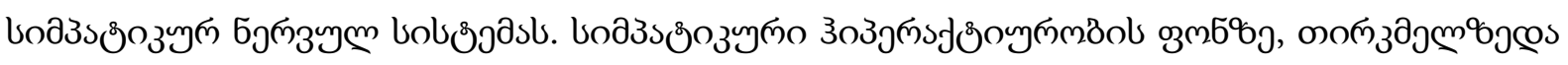

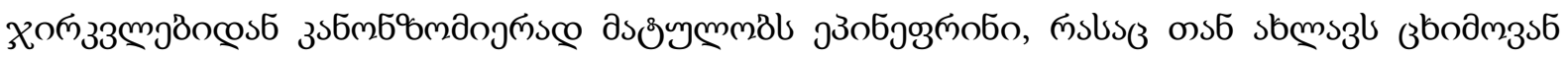

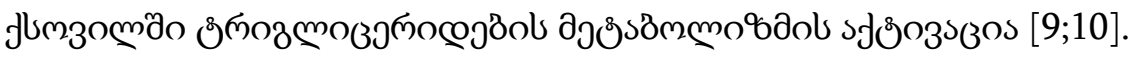

3

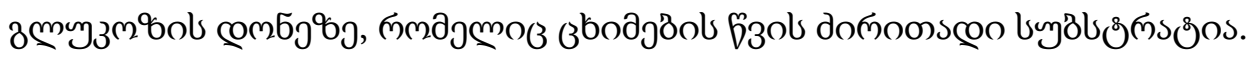

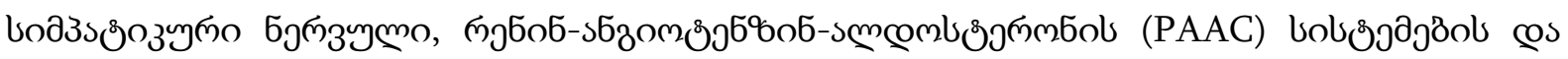

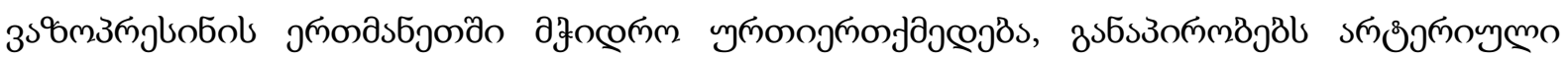

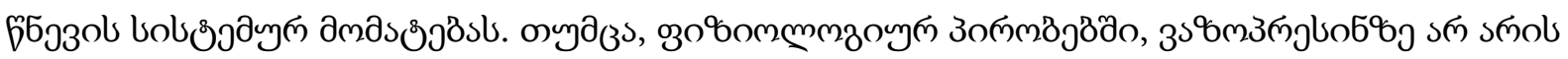

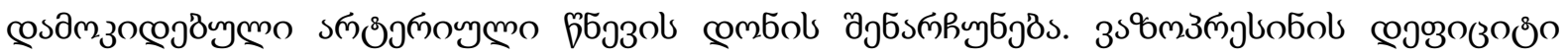

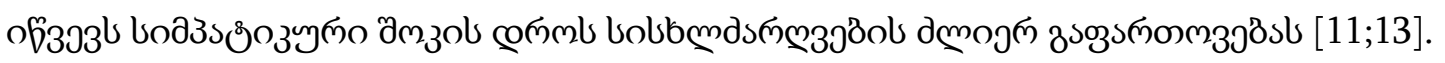

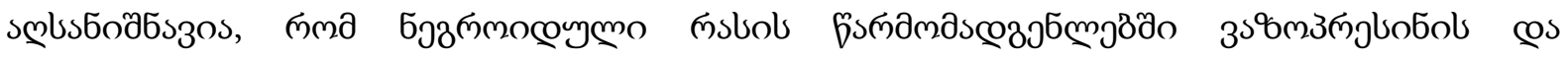

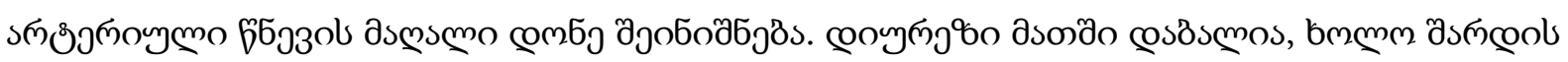

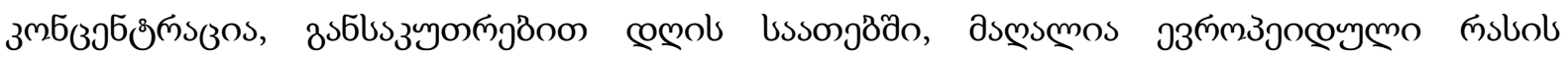

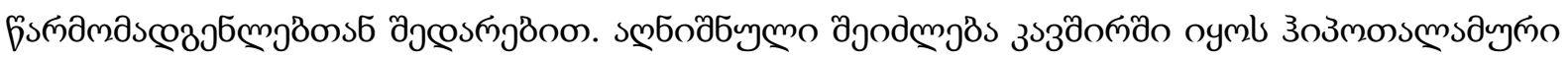

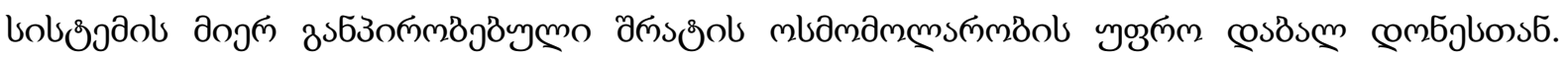
з

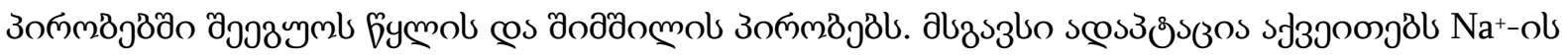

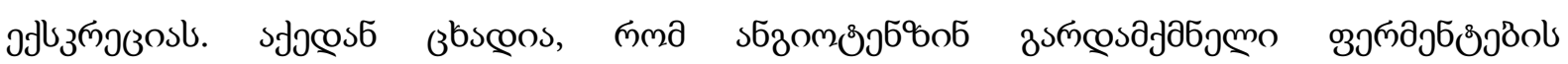

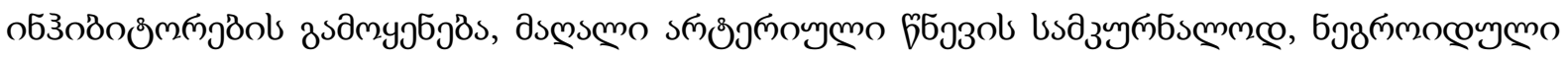

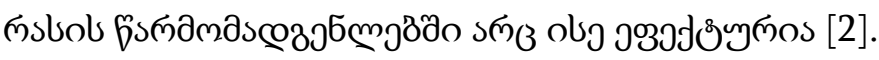

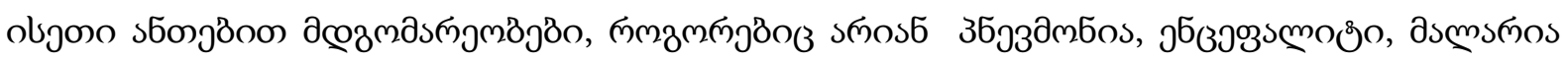

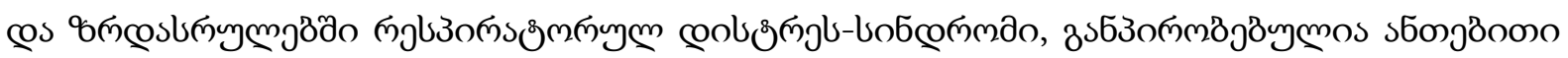

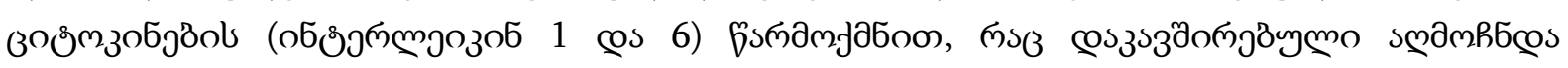

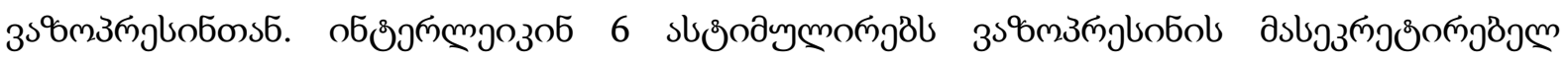

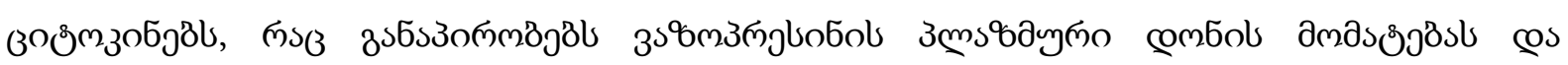

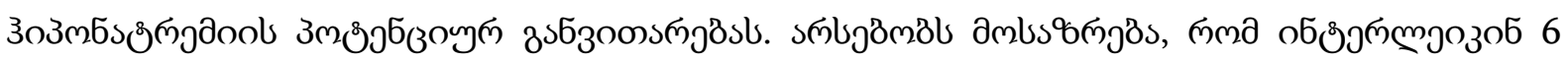

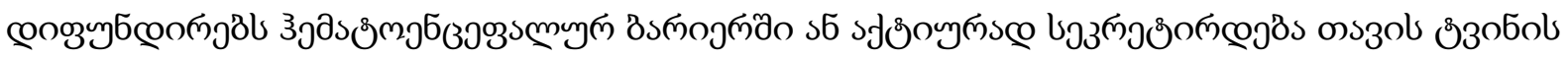

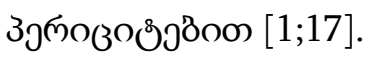




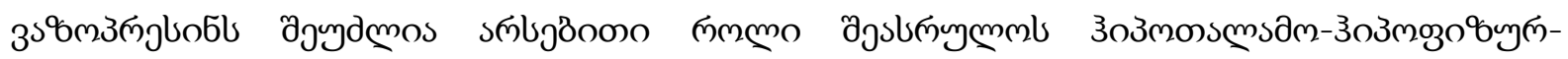

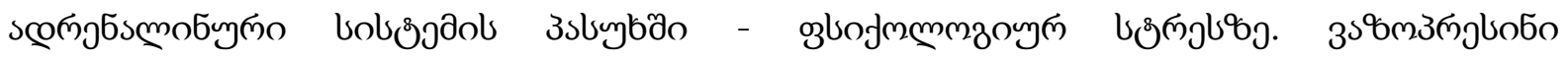

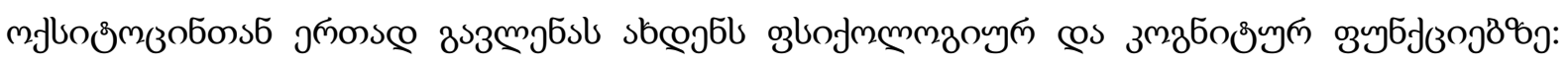

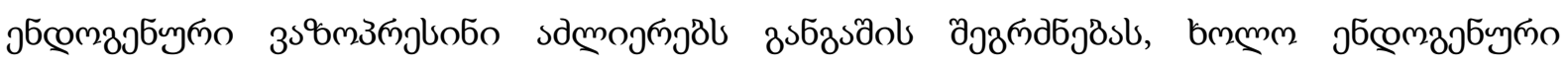

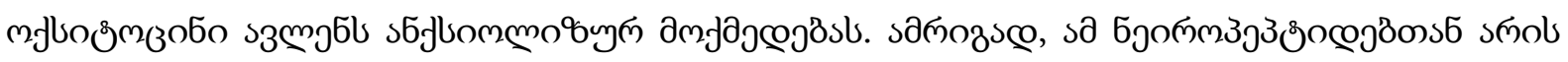

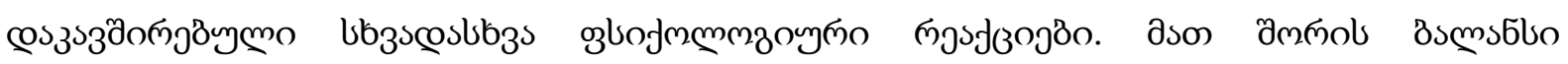

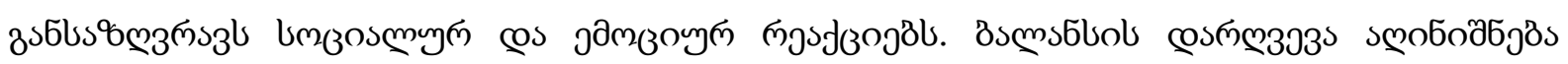

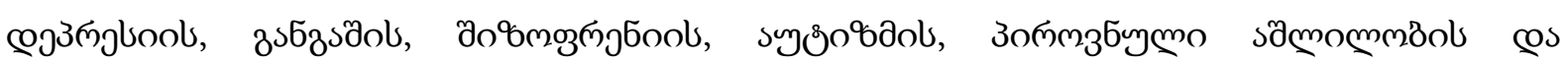

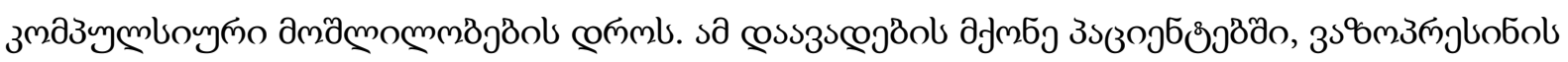

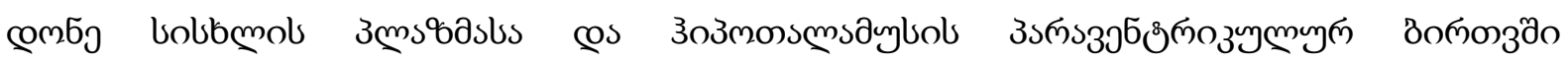

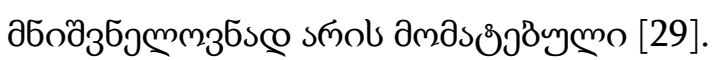

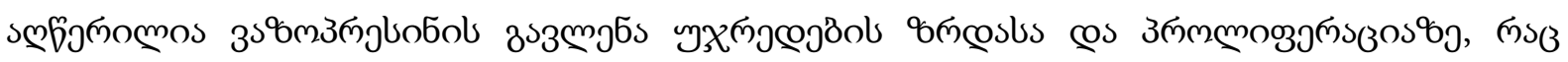

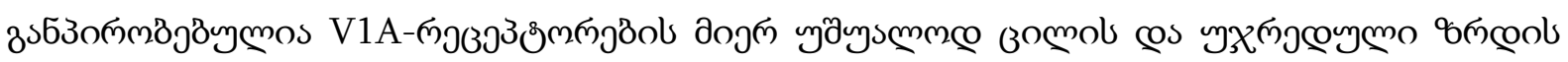

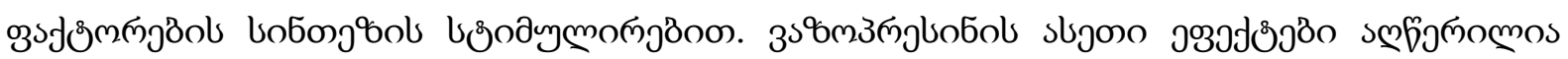

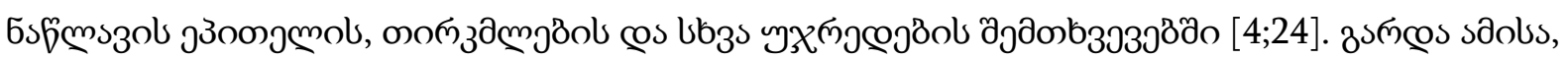

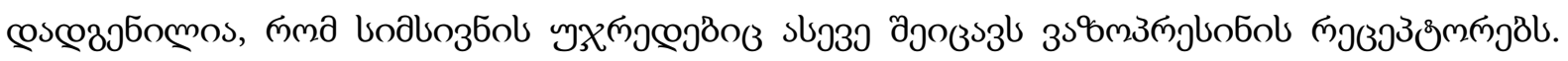

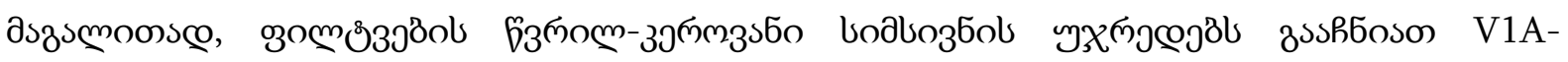

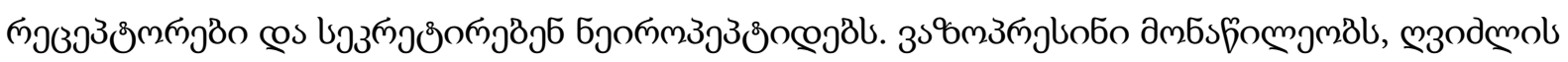

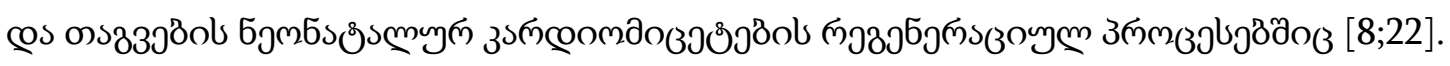

з

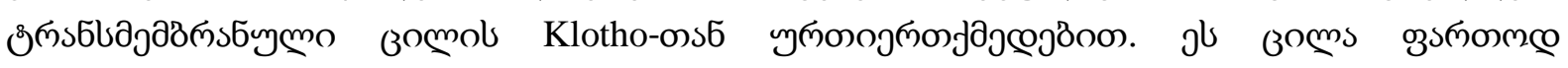

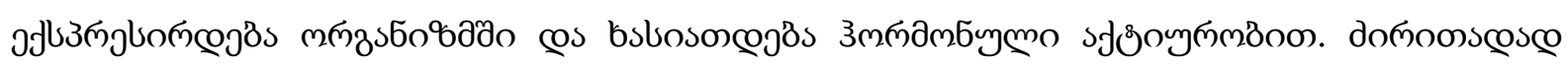
дмдајє

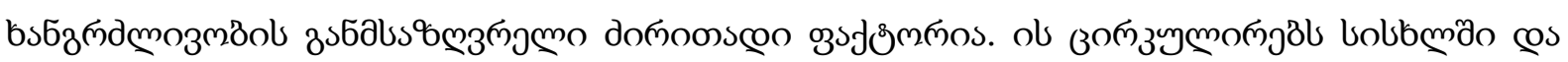

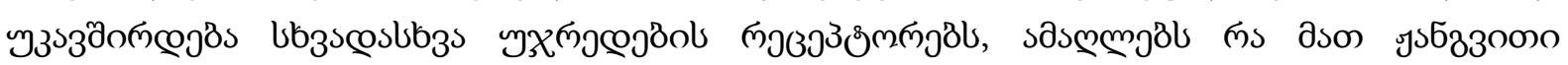

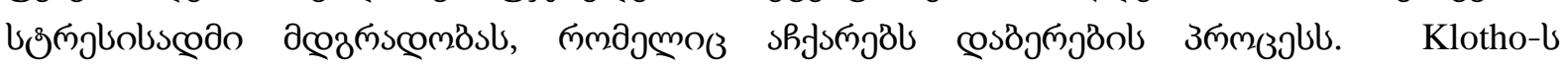

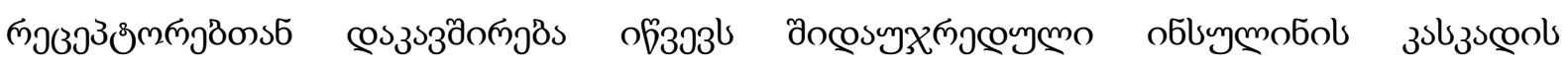

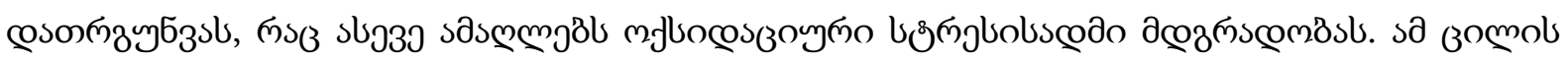

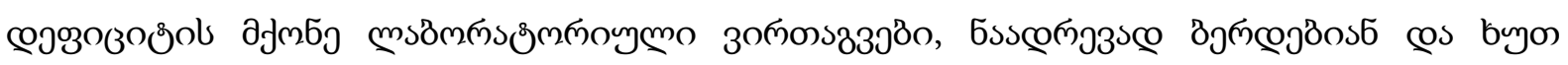

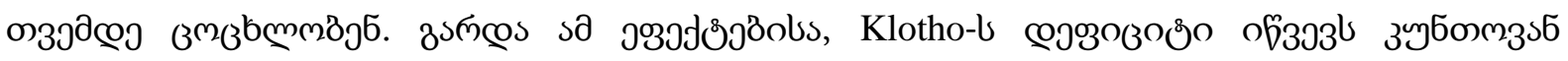

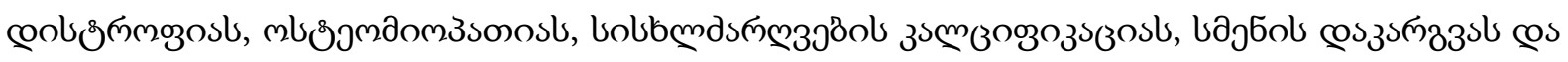

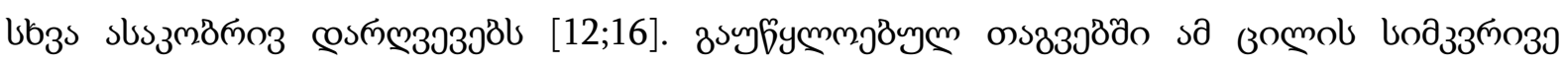

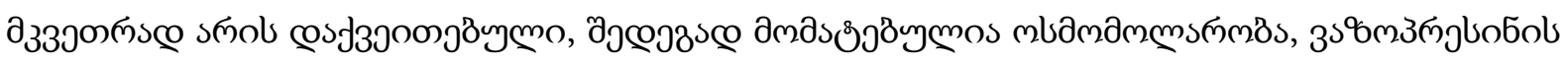

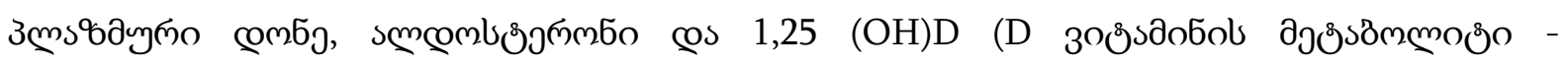

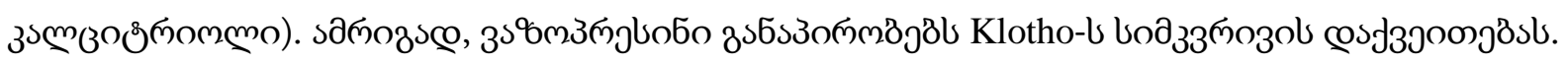

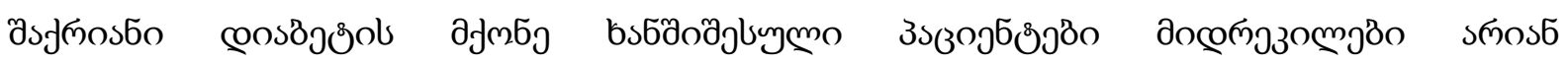

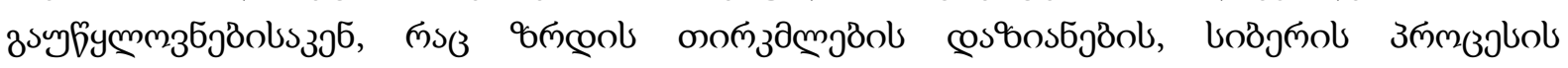

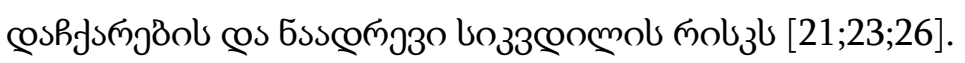




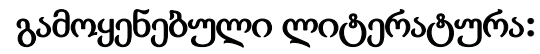

1. Baker C., Richards L.J., Dayan C.M., Jessop D.S.Corticotropin-releasing hormone immunoreactivity in human $\mathrm{T}$ and $\mathrm{B}$ cells and macrophages: colocalization with arginine vasopressin // J. Neuroendocrinol. 2003.Vol. 15. № 11. P. 1070-1074.

2. Bankir L., Perucca J., Weinberger M.H. Ethnic differences inurine concentration: possible relationship to blood pressure //Clin. J. Am. Soc. Nephrol. 2007. Vol. 2. № 2. P. 304-312.

3. Caldwell H.K., Young W.S. III Oxytocin and vasopressin:genetics and behavioral implications // Handbook ofneurochemistry and molecular neurobiology neuroactiveproteins and peptides / A Lajtha, R. Lim. Berlin: Springer,2006. P. 573-607.

4. Chiu T., Wu S.S., Santiskulvong C. et al. Vasopressinmediatedmitogenic signaling in intestinal epithelial cells //Am. J. Physiol. Cell Physiol. 2002. Vol. 282. № 3. P. C434-450.

5. Dheen S.T., Tay S.S., Wong W.C. Arginine vasopressin- andoxytocin-likes immunoreactive neurons in the hypothalamicparaventricular and supraoptic nuclei of streptozotocininduceddiabetic rats // Arch. Histol. Cytol. 1994. Vol. 57.№ 5. P. 461-472.

6. Enhorning S., Wang T.J., Nilsson P.M. et al. Plasma copeptinand the risk of diabetes mellitus // Circulation. 2010. Vol. 121.№ 19. P. 2102-2108.

7. Gallo-Payet N., Guillon G. Regulation of adrenocorticalfunction by vasopressin // Horm. Metab. Res. 1998.Vol. 30. № 6-7. P. 360-367.

8. Ghosh P.M., Mikhailova M., Bedolla R., Kreisberg J.I.Arginine vasopressin stimulates mesangial cell proliferationby activating the epidermal growth factor receptor // Am.J. Physiol. Renal. Physiol. 2001. Vol. 280. № 6. P. 972-979.

9. Havel R.J., Goldfien A. The role of the sympathetic nervoussystem in the metabolism of free fatty acids // J. Lipid. Res.1959. Vol. 1. № 1. P. 102-108.

10. Hiroyama M., Aoyagi T., Fujiwara Y. et al. Hypermetabolismof fat in V1a vasopressin receptor knockout mice // Mol. Endocrinol. 2007. Vol. 21. № 1. P. 247-258.

11. Koshimizu T.A., Nakamura K., Egashira N. et al. Vasopressin V1a and V1b receptors: from molecules tophysiological systems // Physiol. Rev. 2012. Vol. 92. № 4.P. 1813-1864.

12. Kuro-o M. Klotho // Pflugers Arch. 2010. Vol. 459. № 2.P. 333-343.

13. Landry D.W., Levin H.R., Gallant E.M. et al. Vasopressindeficiency contributes to the vasodilation of septic shock //Circulation. 1997. Vol. 95. № 5. P. 1122-1125.

14. Luttinger D., Hernandez D.E., Nemeroff C.B., Prange A.J.Jr. Peptides and nociception // Int. Rev. Neurobiol. 1984.Vol. 25. P. 185-241.

15. Mavani G.P., DeVita M.V., Michelis M.F. A review of thenonpressor and nonantidiuretic actions of the hormonevasopressin // Front. Med. (Lausanne). 2015. Vol. 2.ID 19.

16. Ohnishi M., Razzaque M.S. Dietary and genetic evidencefor phosphate toxicity accelerating mammalian aging //FASEB J. 2010. Vol. 24. № 9. P. 3562-3571.

17. Park S.J., Shin J.I. Inflammation and hyponatremia: an underrecognized condition? // Korean J. Pediatr. 2013. Vol. 56. № 12. P. 519-522.

18. Pasquali R., Gagliardi L., Vicennati V. et al. ACTH and cortisolresponse to combined corticotropin releasing hormoneargininevasopressin stimulation in obese males and its relationshipto body weight, fat distribution and parametersof the metabolic syndrome // Int. J. Obes. Relat. Metab.Disord. 1999. Vol. 23. № 4. P. 419-424.

19. Ring R.H. The central vasopressinergic system: examining the opportunities for psychiatric drug development //Curr. Pharm. Des. 2005. Vol. 11. № 2. P. 205-225.

20. Saleem U., Khaleghi M., Morgenthaler N.G. et al. Plasmacarboxy-terminal provasopressin (copeptin): a novel markerof insulin resistance and metabolic syndrome // J. Clin.Endocrinol. 
Metab. 2009. Vol. 94. № 7. P. 2558-2264.

21. Sopjani M., Rinnerthaler M., Kruja J. et al. Intracellular signalingof the aging suppressor protein Klotho // Curr. Mol.Med. 2015. Vol. 15. № 1. P. 27-37.

22. Tahara A., Tsukada J., Tomura Y. et al. Vasopressin increasestype IV collagen production through the induction of transforminggrowth factor-beta secretion in rat mesangial cells //Pharmacol. Res. 2008. Vol. 57. № 2. P. 142-150.

23. Tang C., Pathare G., Michael D. et al. Downregulation ofKlotho expression by dehydration // Am. J. Physiol. Renal.Physiol. 2011. Vol. 301. № 4. P. 745-750.

24. Wilson M.G., Morley J.E. Impaired cognitive function andmental performance in mild dehydration // Eur. J. Clin.Nutr. 2003. Vol. 57. Suppl. 2. P. S24-29.

25. Weibel E.R., Palade G.E. New cytoplasmic components inarterial endothelia // J. Cell Biol. 1964. Vol. 23. P. 101-112.

26. Xu Y., Sun Z. Molecular basis of Klotho: from gene to functionin aging // Endocr. Rev. 2015. Vol. 36. № 2. P. 174-193.

27. Yang J., Lu L., Wang H.C. et al. Effect of intranasal argininevasopressin on human headache // Peptides. 2012. Vol. 38.№ 1. P. 100-104.

28. Yibchok-anun S., Abu-Basha E.A., Yao C.Y. et al. The role of argininevasopressin in diabetes-associated increase in glucagonsecretion // Regul. Pept. 2004. Vol. 122. № 3. P. $157-162$.

29. Zelena D. Vasopressin in health and disease with a focus on affective disorders // Cent. Nerv. Syst. Agents Med.Chem. 2012. Vol. 12. № 4. P. 286-303.

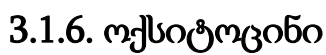

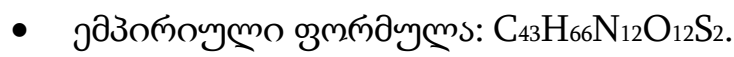

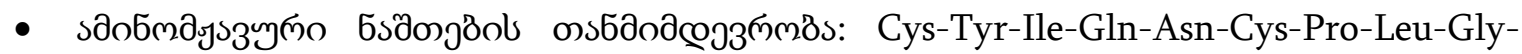
$\mathrm{NH}_{2}$.

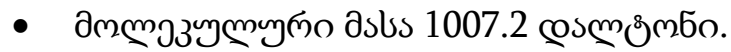

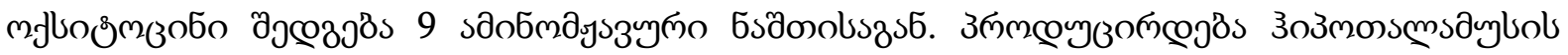

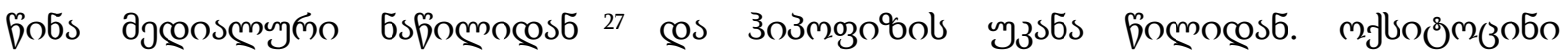

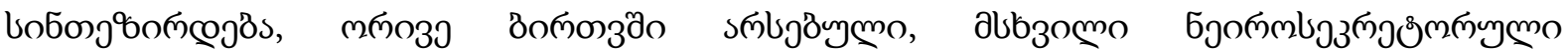
буопмбјв̈осозб [6].

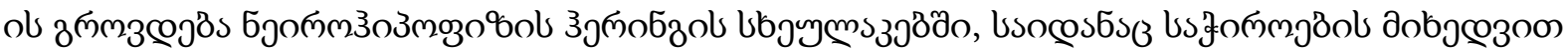

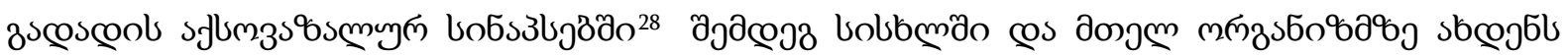
дбобзб

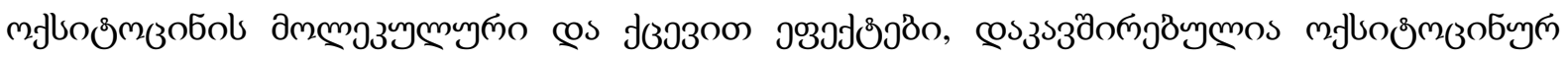

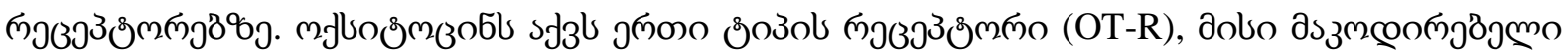

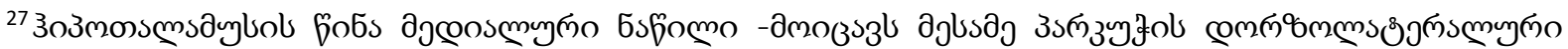

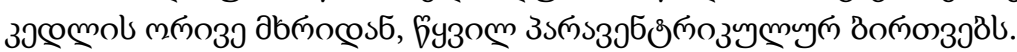

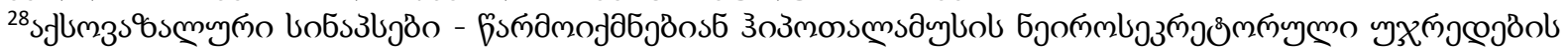

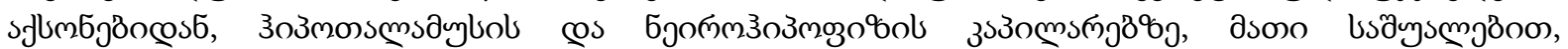

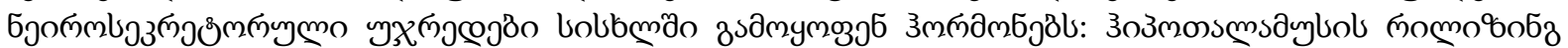

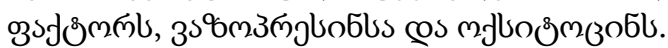




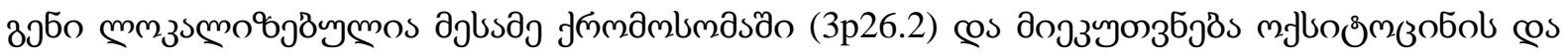

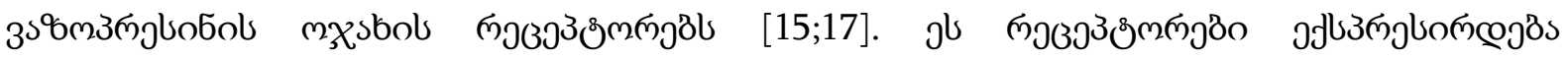

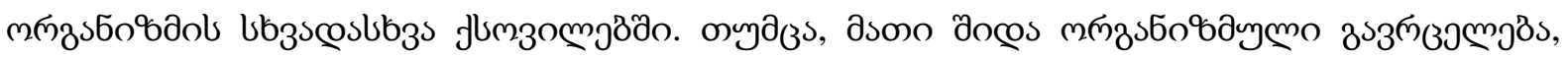

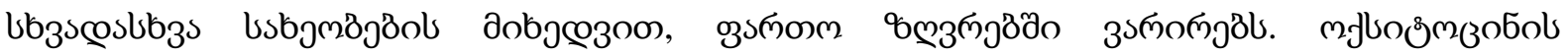

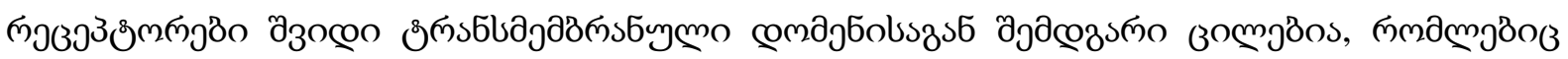

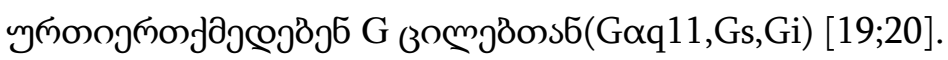

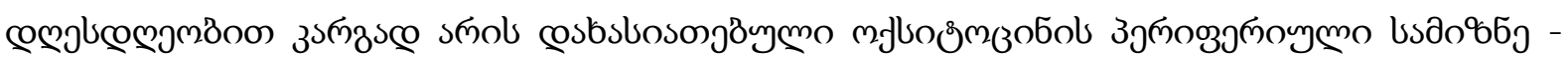

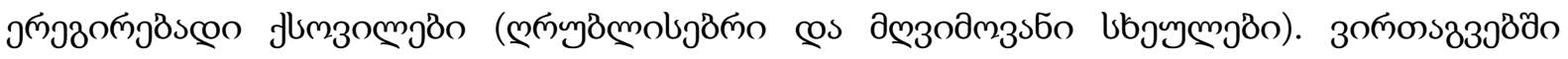

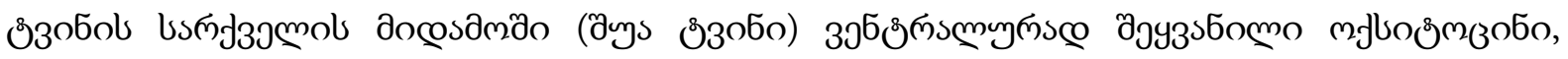

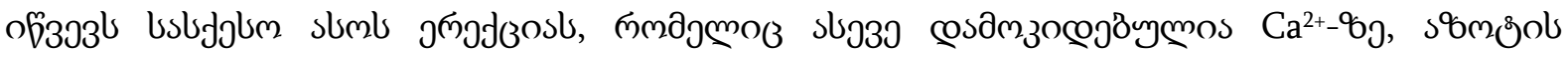

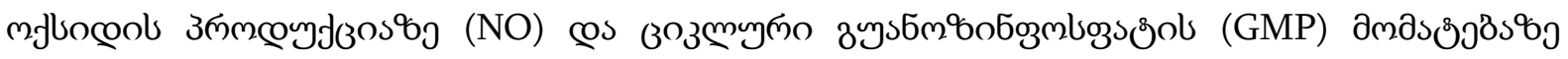

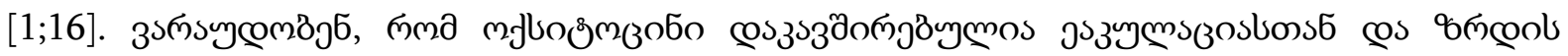

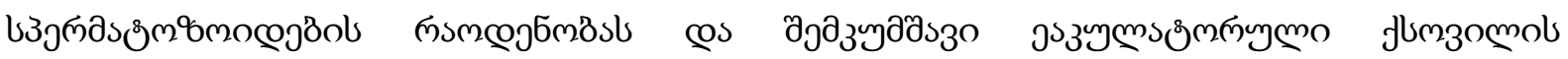

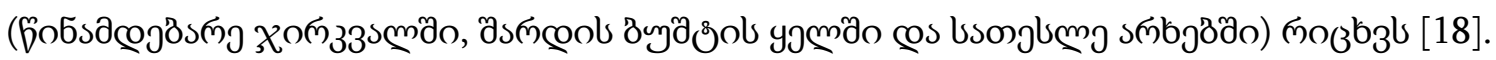

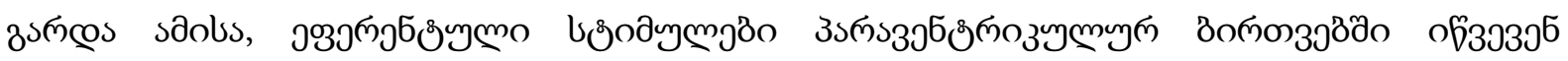

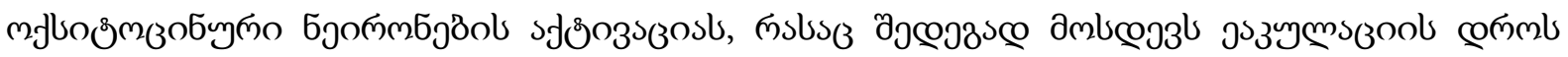

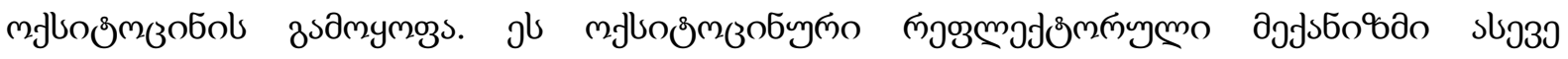

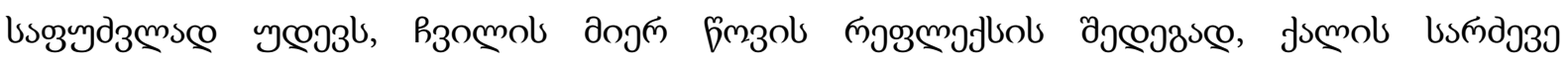

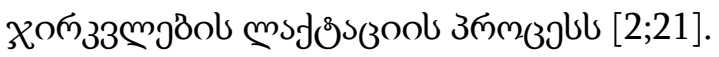

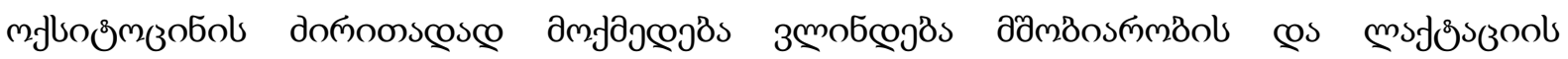

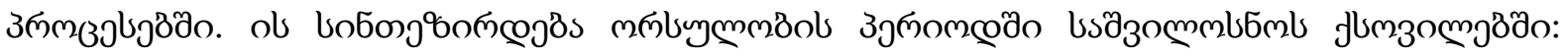

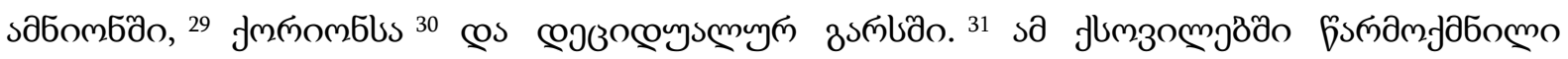

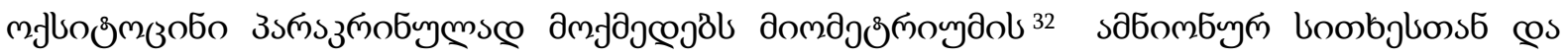

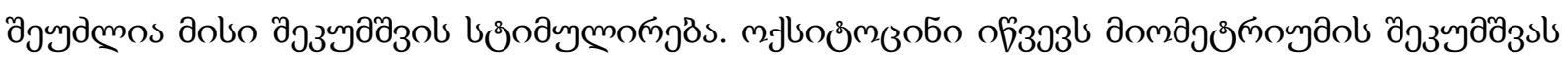

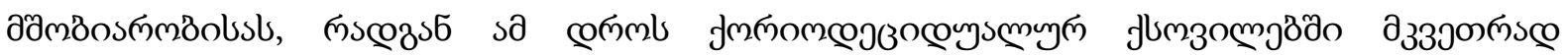

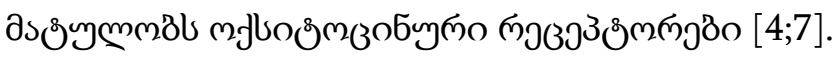

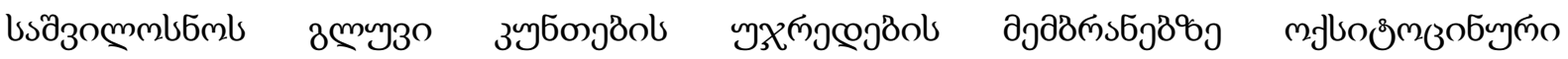

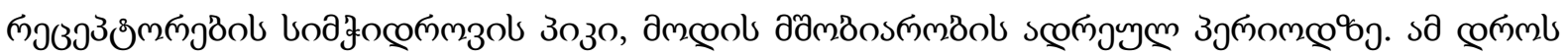

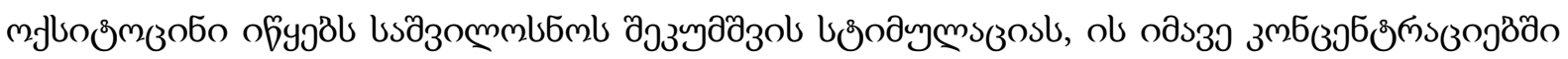

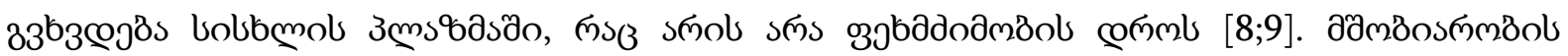

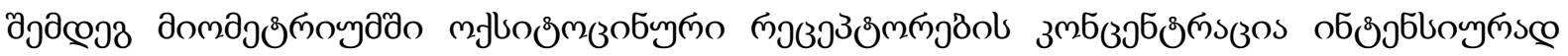

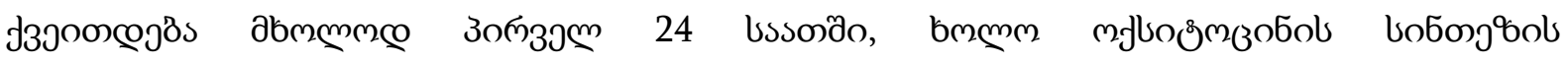

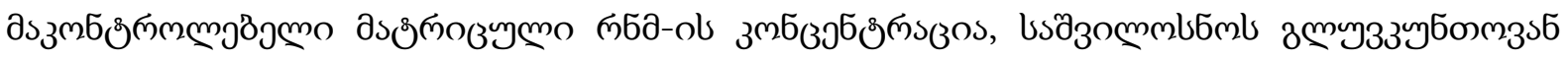

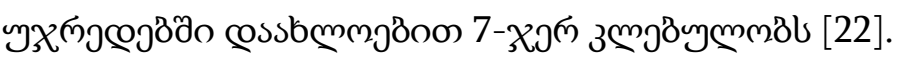

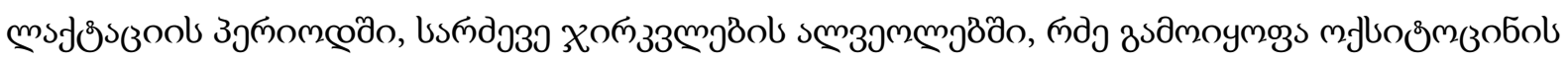

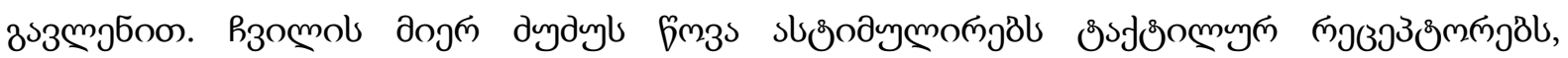

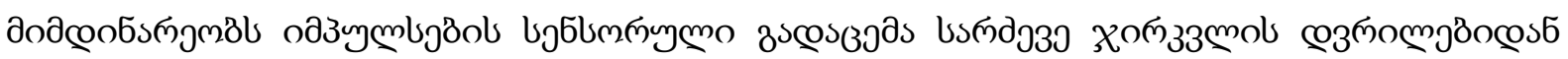

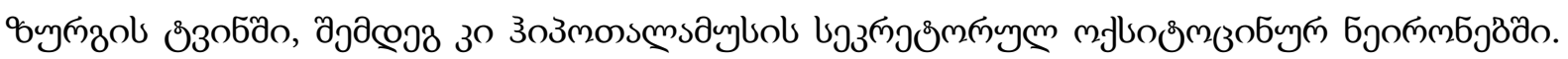

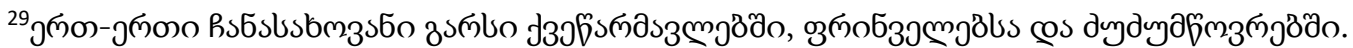

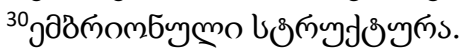

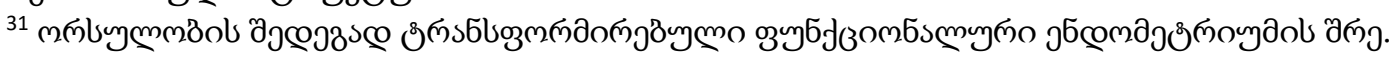

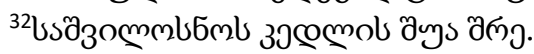




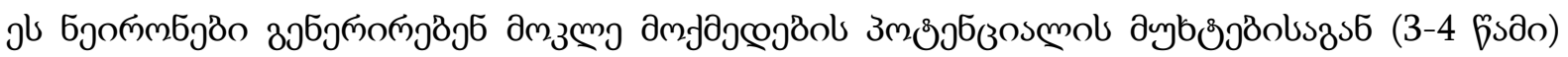

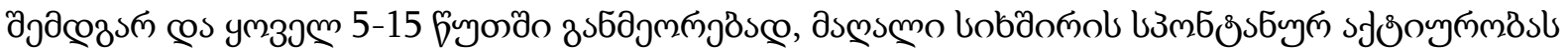
[13].

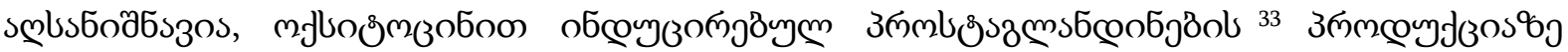

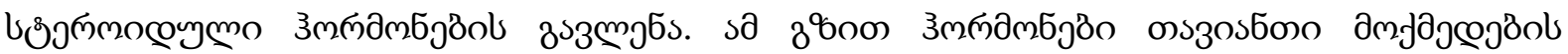

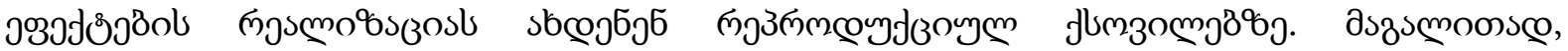

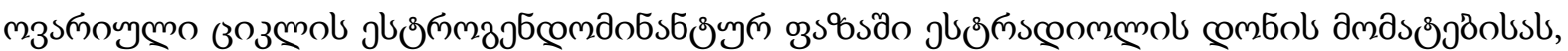

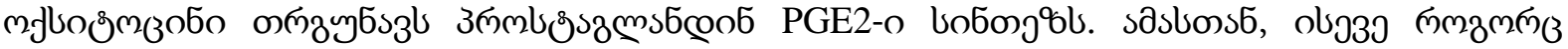

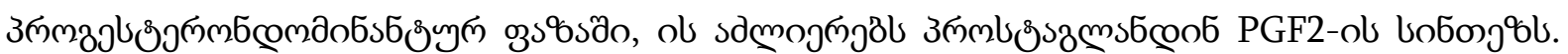

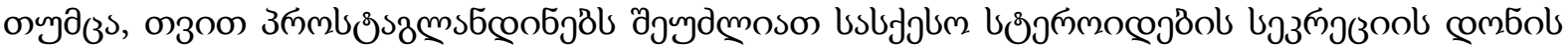

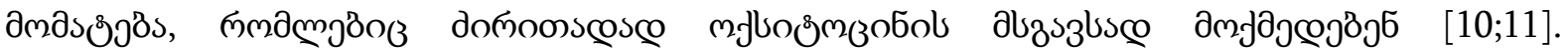

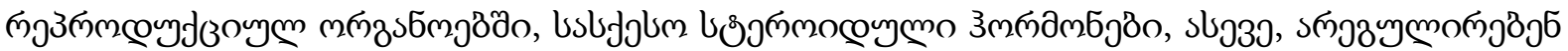

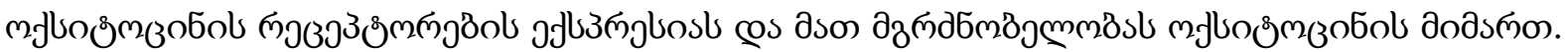

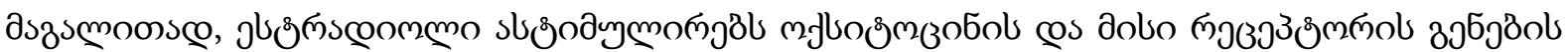

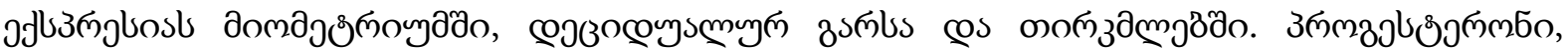

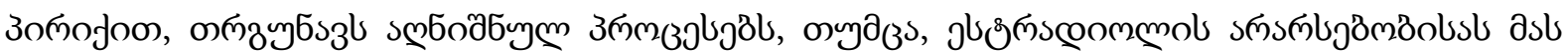

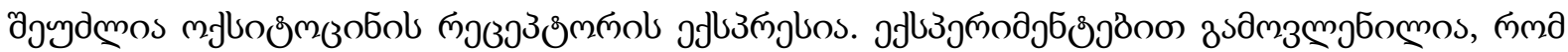

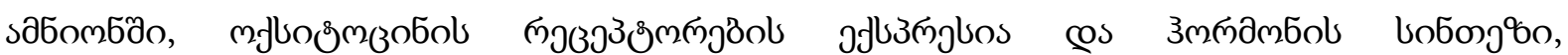

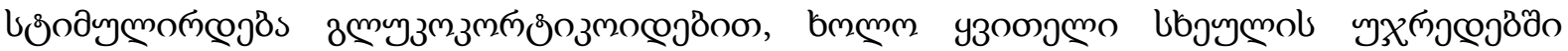

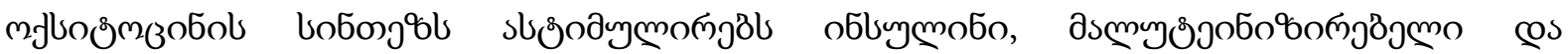

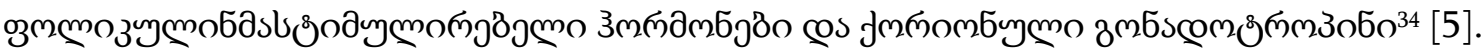

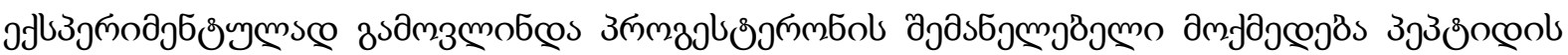

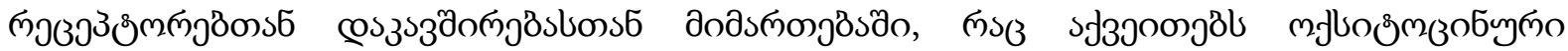

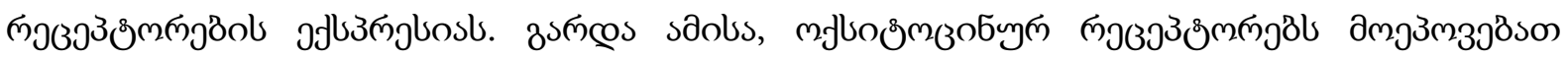

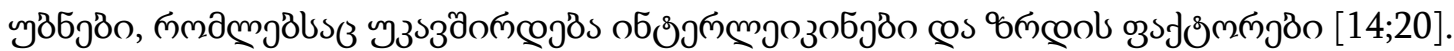

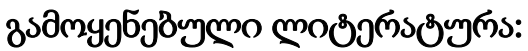

1. Baskerville T.A., Allard J., Wayman C., et al. Dopamineoxytocininteractions in penile erection // Eur. J. Neurosci. - 2009.- Vol. 30. №11. - P.2151-2164.

2. Blechman J., Amir-Zilberstein L., Gutnick A., et al. Themetabolic regulator PGC-1 $\alpha$ directly

3. controls the expression ofthe hypothalamic neuropeptide oxytocin // J. Neurosci. - 2011. Vol. 31(42). - P.14835-14840.

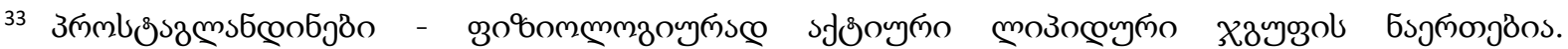

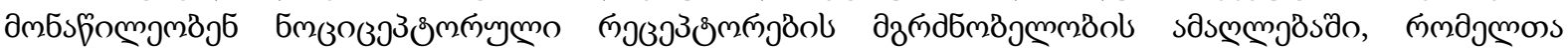

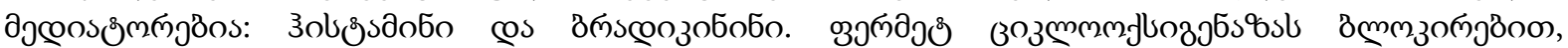

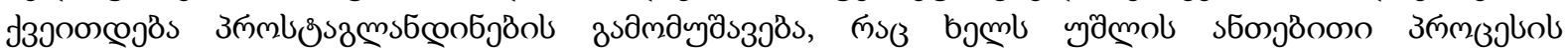
zs

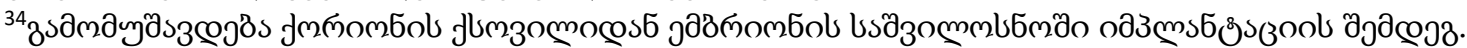


4. Chevaleyre V., Dayanithi G., Moos F., Desarme M.Developmental regulation of a local positive autocontrol ofsupraoptic neurons // J. Neuroscience - 2000. - Vol. 20. №15. P.5813-5819.

5. Chibbar R., Miller F.D., Mitchell B.F. Synthesis of oxytocin inamnion, chorion, and decidua may influence the timing of humanparturition // J. Clin. Invest. - 1993. - Vol. 91. - P.185192.

6. Cho J., Kim H., Kang D.W. Endothelin B receptor is not required but necessary for finite regulation of ovulation // Life Sci.- 2012. - Vol. 91. - P.613-617.

7. du Vigneaud V. Experiences in the Polypeptide Field:Insulin to Oxytocin // Ann. NY Acad. Sci. - 1960. - Vol. 88. №3.- P.537-548.

8. Edwards D., Good D.M., Granger S.E., et al. The spasmogenicaction of oxytocin in the rat uterus-comparison with other agents// Br. J. Pharmac. - 1986. - Vol. 88. - P.899-908.

9. Fuchs A.R., Fields M.J., Freidman S., et al. Oxytocinand the timing of parturition. Influence of oxytocin receptorgene expression, oxytocin secretion, and oxytocin-inducedprostaglandin F2a and E2 release // Adv. Exp. Med. Biol. - 1995.- Vol. 395. - P.405-420.

10. Fuchs A.R., Fuchs F. Endocrinology of human parturition:a review // Br. J. Obstet. Gynecol. - 1984. - Vol. 91. - P.948-967.

11. Hua R., Pease J., Cheng W., et al. Human Labour isAssociated with a Decline in Myometrial Chemokine ReceptorExpression: The Role of Prostaglandins, Oxytocin and Cytokines// American Journal of Reproductive Immunology. - 2013. - Vol.69. №1 . - P.21-32.

12. Jasny B.R., Katrina L. K., Pennisi E. From Genes to SocialBehavior // Science. - 2008. - Vol. 322. - P.891.

13. Ludwig M. Dendritic release of vasopressin and oxytocin// J. Neuroendocrinol. - 1998. - Vol. 10. - P.881-895.

14. McNeilly A.S., Robinson I.C., Houston M.J., Howie P.W.Release of oxytocin and prolactin in response to suckling // Br.Med. J. Clin. Res. Ed. - 1983. - Vol. 286. - P.257-259.

15. Robinson C., Schumann R., Zhang P. Oxytocin-induced desentization of the oxytocin receptor // Am. J. Obstet. Gynec. -2003. - Vol. 188. №2 . - P.497-502.

16. Ross H.E., Cole C.D., Smith Y., et al. Characterization of theoxytocin system regulating affiliative behavior in female prairievoles // Neuroscience. - 2009. - Vol. 162. - P.892-903.

17. Succu S., Sanna F., Cocco C., et al. Oxytocin induces penileerection when injected into the ventral tegmental area of malerats: Role of nitric oxide and cyclic GMP // Eur. J. Neurosci. 2008. - Vol. 28. - P.813-821.

18. Terzidou V., Blanks A M., Kim S.H. Labor and InflammationIncrease the Expression of Oxytocin Receptor in Human Amnion// Biol. Reprod. - 2011. - Vol. 84. - P.546-552.

19. Thackare H., Nicholson H.D., Whittington K. Oxytocin-itsrole in male reproduction and new potential therapeutic uses //Hum. Reprod. Update - 2006. - Vol. 12. №4. - P.437-448.

20. Viero C., Shibuya I., Kitamura N., et al. Oxytocin:Crossing the bridge between basic science and pharmacotherapyCNS // Neuroscience \& Therapeutics. - 2010. - Vol. 16. №5. -P.e138e156.

21. Whittington K., Assinder S.J., Parkinson T., et al. Functionand localization of oxytocin receptors in the reproductive tissue oframs // Reproduction. - 2001. - Vol. 122. - P.317-325.

22. Yanagimoto M., Honda K., Goto Y., Negoro H. Afferentsoriginating from the dorsal penile nerve excite oxytocin cells inthe hypothalamic paraventricular nucleus of the rat // Brain Res.- 1996. - Vol. 733. - P.292-296.

23. Zingg H.H., Rozen F., Breton C., et al. Gonadal steroidregulation of oxytocin and oxytocinreceptor gene expression //Adv. Exp. Med. Biol. - 1995. - Vol. 395. - P.395-404. 


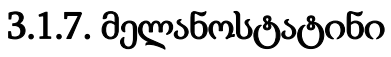

- јазополумо озмпаулмs: $\mathrm{C}_{13} \mathrm{H}_{24} \mathrm{~N}_{4} \mathrm{O}_{3}$.

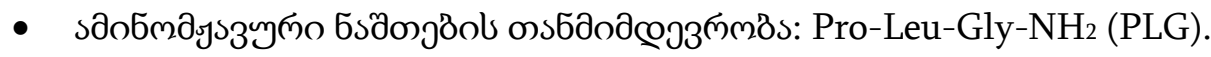

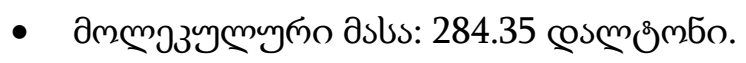

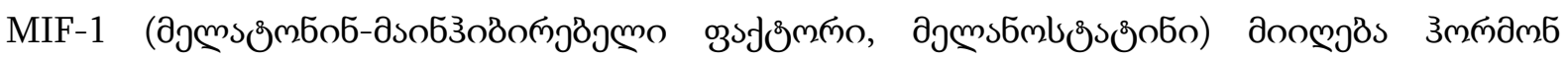

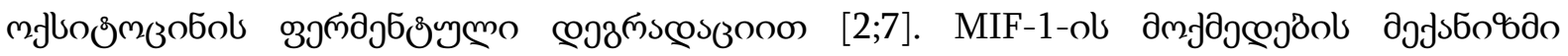

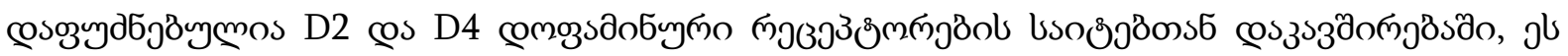

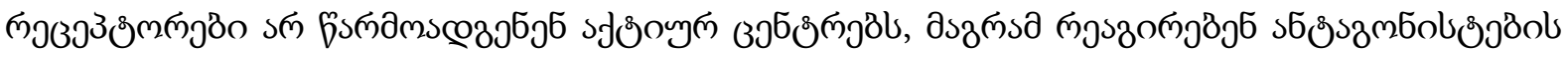

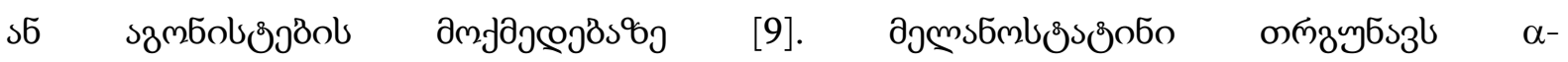

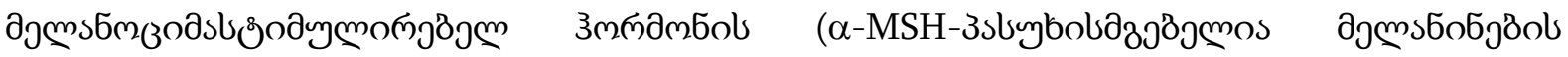

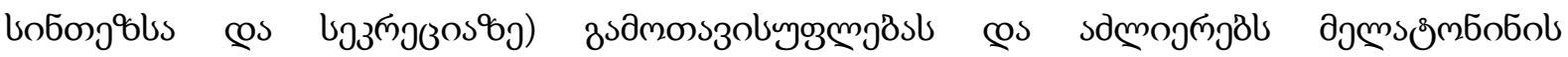

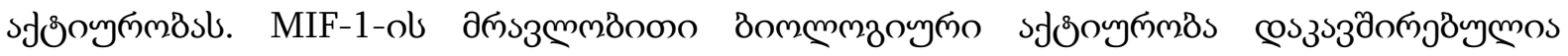

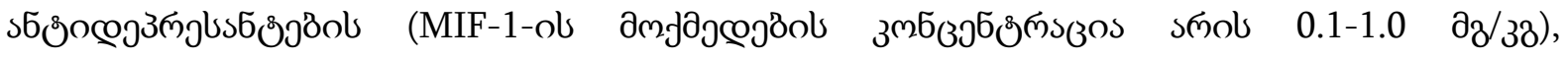

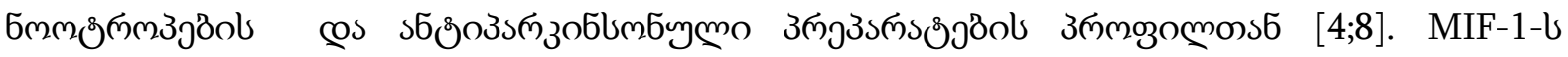

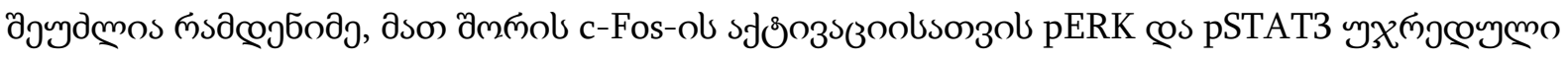

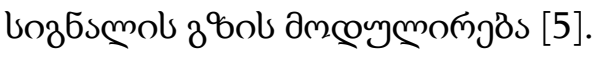

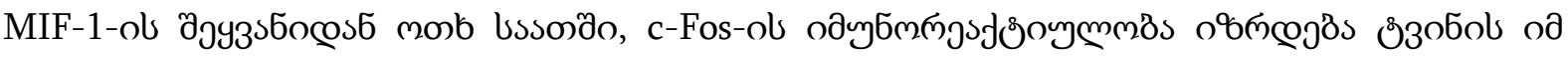

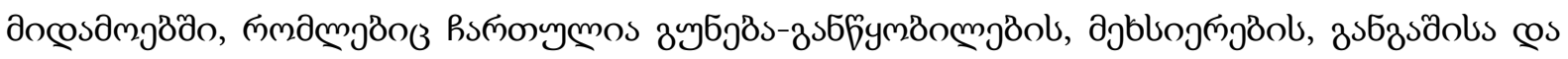

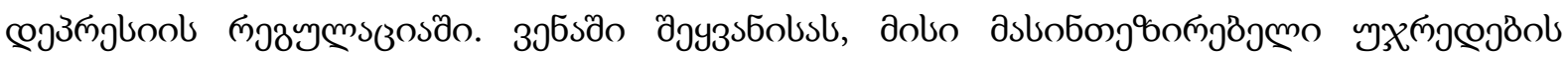

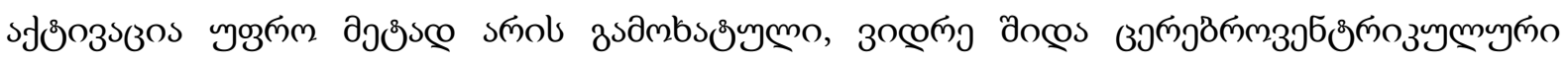

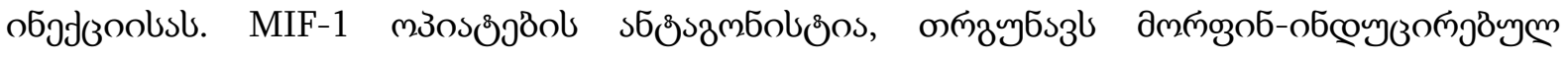

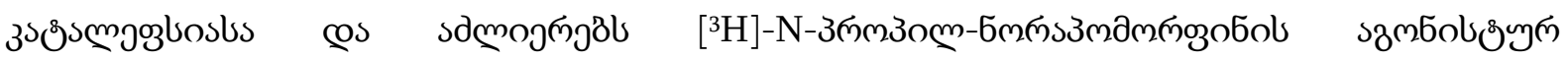

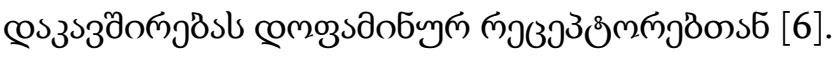

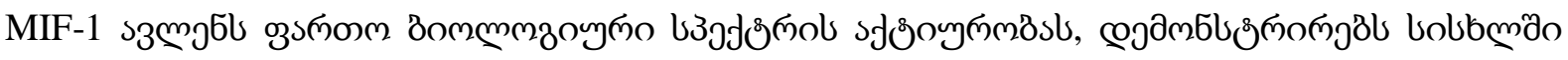

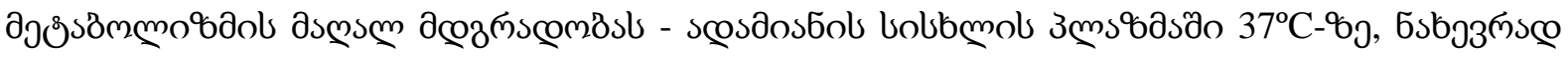

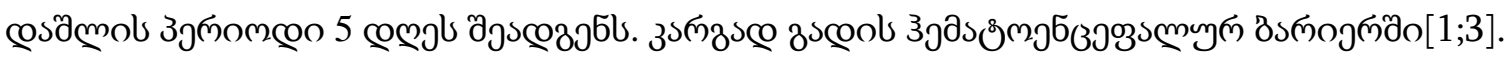

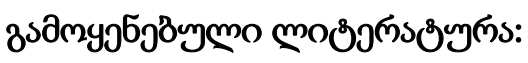

1. Banks, W.A., Kastin, A.J., Opposite direction of transport across the blood-brain barrier for Tyr-MIF-1 and MIF-1: Comparison with morphine. Peptides, 1994. 15(1): p. 23-29. DOI: 10.1016/0196-9781(94)90165-1.

2. Celis, M.E., Taleisnik, S., Walter, R., Regulation of Formation and Proposed Structure of the Factor Inhibiting the Release of Melanocyte-Stimulating Hormone. Proceedings of the National Academy of Sciences, 1971. 68(7): p. 1428. DOI: 10.1073/pnas.68.7.1428.

3. Kastin, A.J., Hahn, K., Erchegyi, J., Zadina, J.E., Hackler, L., Palmgren, M., Banks, W.A., Differential metabolism of Tyr-MIF-1 and MIF-1 in rat and human plasma. Biochemical Pharmacology, 1994. 47(4): p. 699-710. DOI: 10.1016/00062952(94)90133-3.

4. Katzenschlager, R., Jackson, M.J., Rose, S., Stockwell, K., Tayarani-Binazir, K.A., Zubair, M., Smith, L.A., Jenner, P., Lees, A.J., Antiparkinsonian activity of L-propyl-L-leucyl- 
glycinamide or melanocyte-inhibiting factor in MPTP-treated common marmosets. Movement Disorders, 2007. 22(5): p. 715-719. DOI: 10.1002/mds.21256.

5. Khan, R.S., Yu, C., Kastin, A.J., He, Y., Ehrensing, R.H., Hsuchou, H., Stone, K.P., Pan, W., Brain Activation by Peptide Pro-Leu-Gly-NH2 (MIF-1). International Journal of Peptides, 2010. 2010: p. 537639. DOI: 10.1155/2010/537639.

6. Pan, W., Kastin, A.J., From MIF-1 to endomorphin: The Tyr-MIF-1 family of peptides. Peptides, 2007. 28(12): p. 2411-2434. DOI: 10.1016/j.peptides.2007.10.006.

7. Petersson, M., Uvnas-Moberg, K., Prolyl-leucyl-glycinamide shares some effects with oxytocin but decreases oxytocin levels. Physiology \& Behavior, 2004. 83(3): p. 475-481.

8. Sandyk, R., MIF-Induced Augmentation of Melatonin Functions: Possible Relevance to Mechanisms of Action of MIF-1 in Movement Disorders. International Journal of Neuroscience, 1990. 52(1-2): p. 59-65. DOI: 10.3109/00207459008994244.

9. Verma, V., Mann, A.K., Costain, W.J., Pontoriero, G., Castellano, J.M., Skoblenick, K., Gupta, S.K., Pristupa, Z.B., Niznik, H.B., Johnson, R.L., Nair, V.D., Mishra, R.K.J.J.o.P., Therapeutics, E., Modulation of Agonist Binding to Human Dopamine Receptor Subtypes by 1-Prolyl-l-leucyl-glycinamide and a Peptidomimetic Analog. 2005. 315: p. 1228 - 1236.

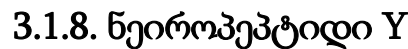

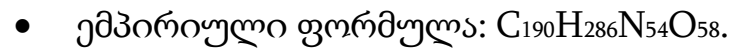

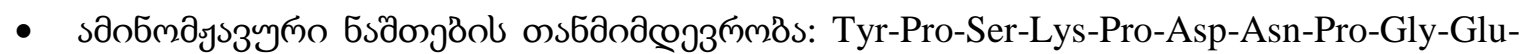
Asp-Ala-Pro-Ala-Glu-Asp-Leu-Ala-Arg-Tyr-Tyr-Ser-Ala-Leu-Arg-His-Tyr-Ile-Asn-Leu-IleThr-Arg-Gln-Arg-Tyr-NH2.

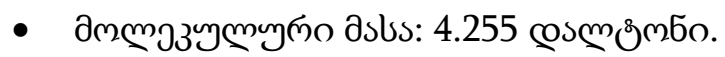

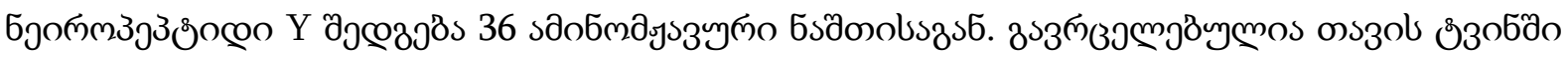

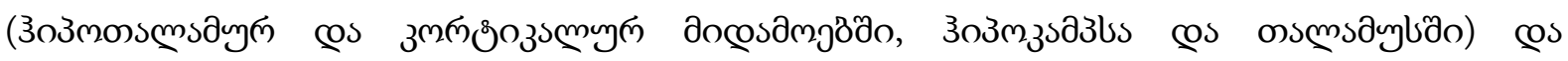

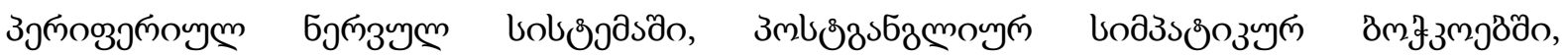

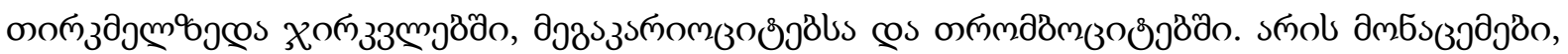

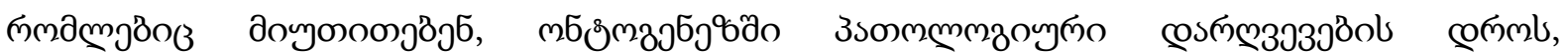

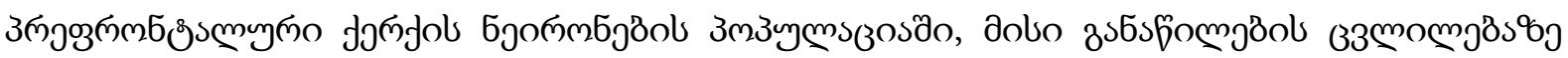

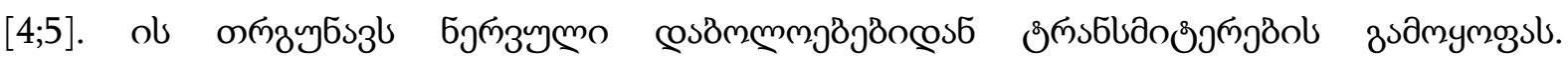

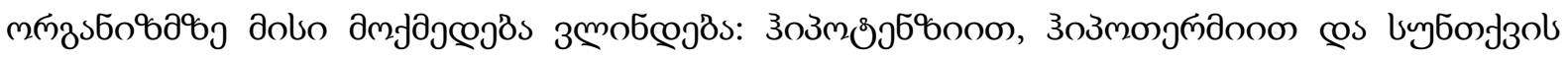

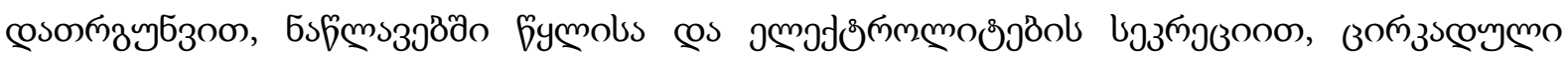

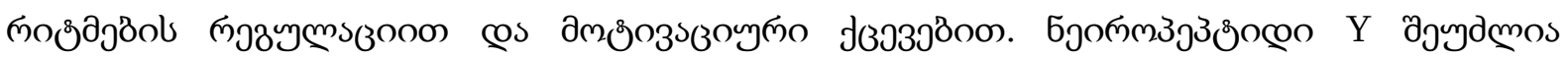

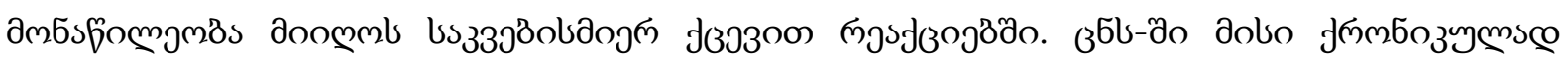

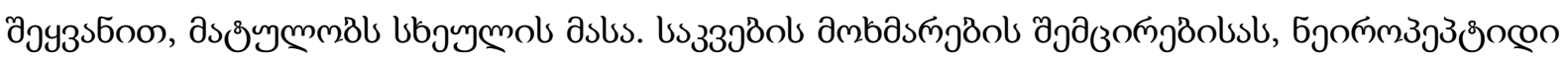

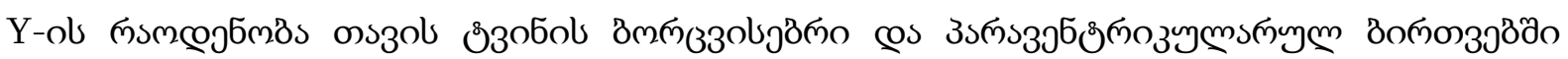

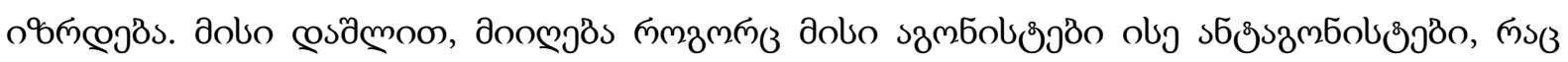

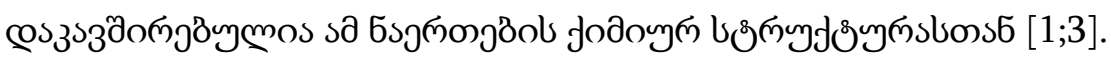

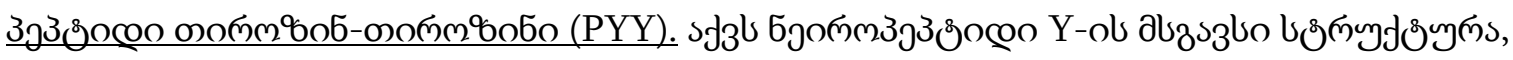

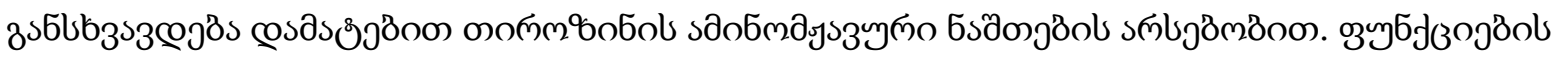

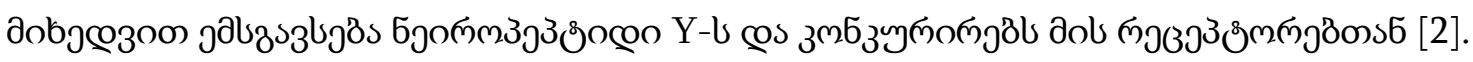




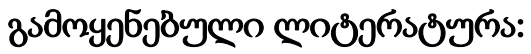

1. Cerda-Reverter JM, Larhammar D. Neuropeptide Y family of peptides: Structure, anatomical expression, function, and molecular evolution. Biochem Cell Biol 2000;78(3):371-392.

2. Labelle M, St-Pierre S, Savard R, Boulanger Y. Solution structure of neuropeptide tyrosine 13-36, a Y2 receptor agonist, as determined by NMR. Eur J Biochem 1997;246(3):780-785

3. Parker E, Van Heek M, Stamford A. Neuropeptide Y receptors as targets for anti-obesity drug development: Perspective and current status. Eur J Pharmacol 2002;440(2-3):173-187.

4. Silva AP, Cavadas C, Grouzmann E. Neuropeptide $Y$ and its receptors as potential therapeutic drug targets. Clin Chim Acta 2002;326(1-2):3-25.

5. Sundstrom G, Larsson TA, Brenner S, Venkatesh B, Larhammar D. Evolution of the neuropeptide $\mathrm{Y}$ family: New genes by chromosome duplications in early vertebrates and in teleost fishes. Gen Comp Endocrinol 2008;155(3):705-716.

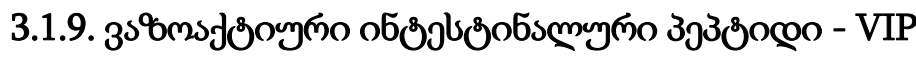

VIP (1-11)

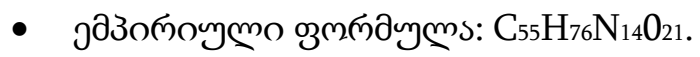

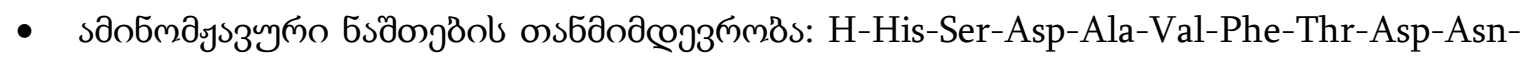
Tyr-Thr-OH.

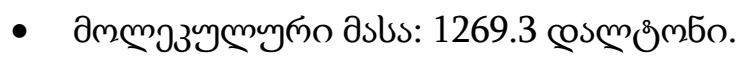

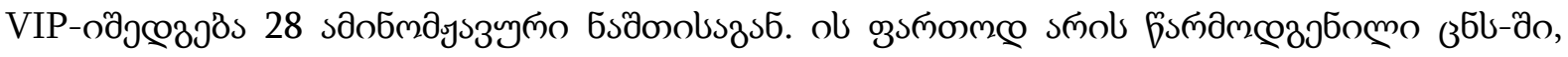

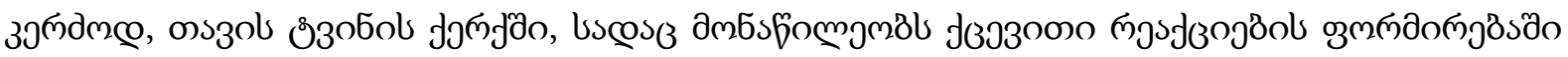

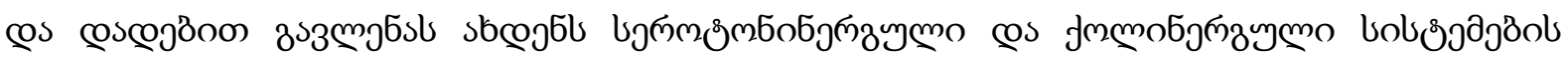

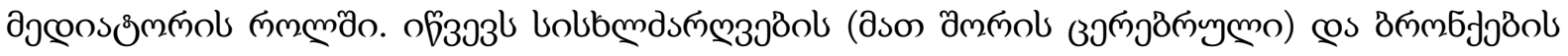

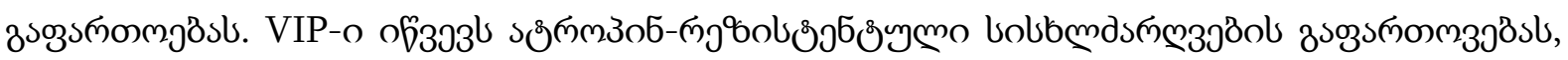

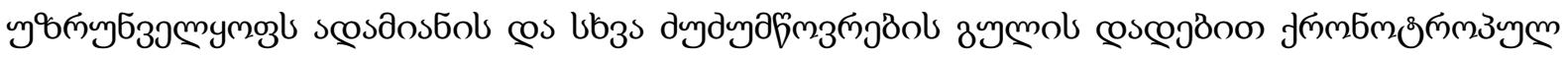

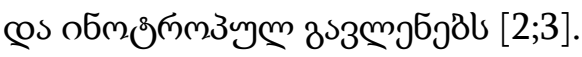

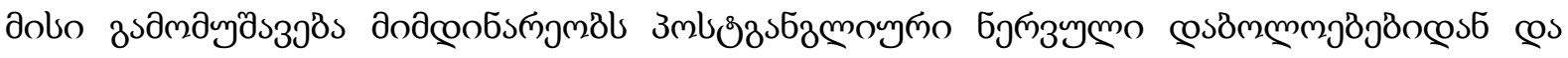

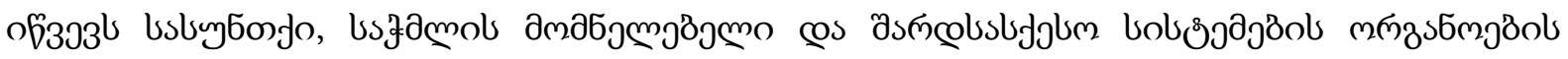

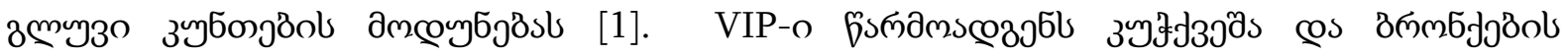

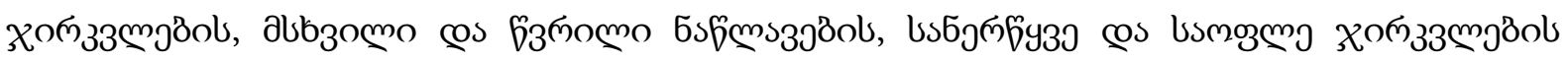

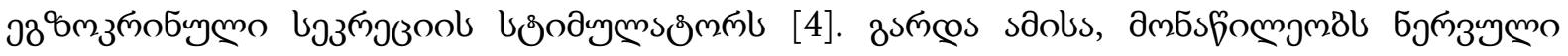

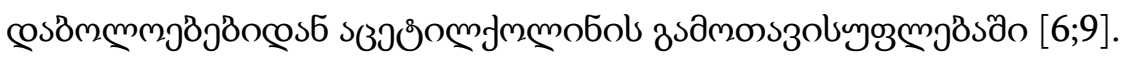

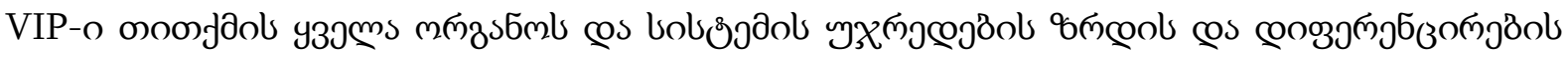

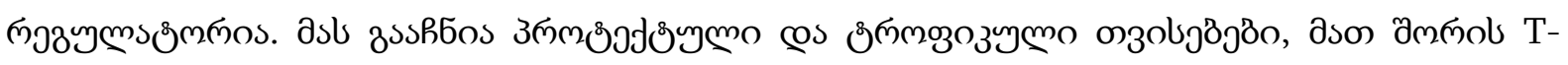

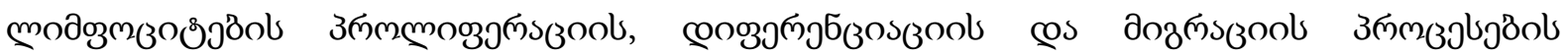

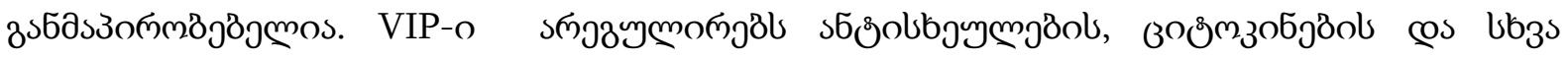

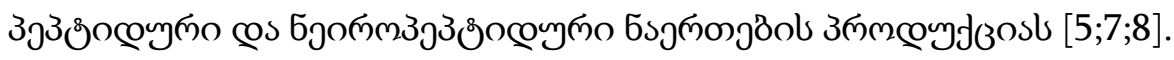




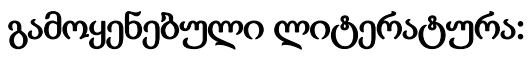

1. Franco-Cereceda A., Lundberg J. Potent effects of neuropeptide $Y$ and calcitonin gene-related on human coronary vascular tone in vitro. // Acta Physiol. Scand. - 1987. - V. 131. - P. 159160

2. Inagaki S., Kito S. Peptides in the peripheral nervous system. // Progress in Brain Research. 1986. - V. 66. - P. 269-316

3. Klimaschewski L., Unsicker K., Heym C. Vasoactive intestinal peptide but not galanin survival of neonatal rat sympathetic neurons and neurite outgrowth of PC12 cells. // Neurosci. Lett. - 1995. - V. 195. - P. 133-136

4. Lundberg J.M. Pharmacology of cotransmission in the autonomic nervous system: integrative aspects on amines, neuropeptides, adenosine triphosphate, amino acids and nitric oxide. // Pharm. Rev. - 1996. - V. 48, N 1. - P. 113-178

5. Madden K. and Felten D. Experimental basis for neural-immune interactions // Phisiol. Rev. 1995. - V. 75, N 1. - P. 77-106

6. Pozo D., Delgado M., Martinez C. et al. Immunobiology of vasoactive intestinal polypeptide (VIP) // Immunology today - 2000. - V. 21 - P. 7- 11

7. Westermann J, Engelhardt B., Hoffmann J. Migration of $T$ cells in vivo: molecular mechanisms and clinical implications // Ann of Int Med - 1995. - V. 135 - P. 279 - 295

8. Voice J., Dorsam G., Chan R. et al Immunoeffector and immunoregulatory activeties of vasoactive intestinal peptide // Regulatory peptides. -2002. - V. 109. - P. 199- 208

9. Zigmond R.E. Fundamental neuroscience.- N.-Y.- L.^ Academic Press, 1999. - P. 2007 p

\subsubsection{8msсозобобо}

- азополумо озмпаулмз: $\mathrm{C}_{50} \mathrm{H}_{73} \mathrm{~N}_{15} \mathrm{O}_{11}$.

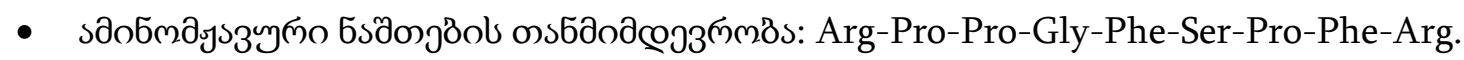

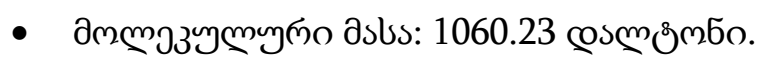

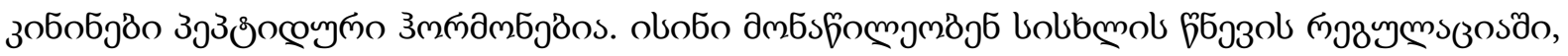

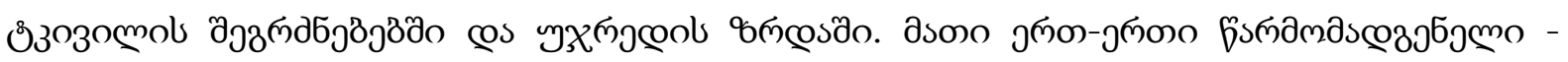

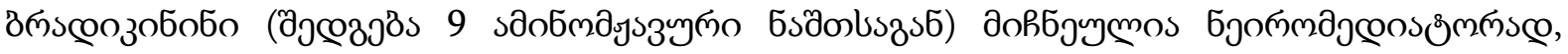

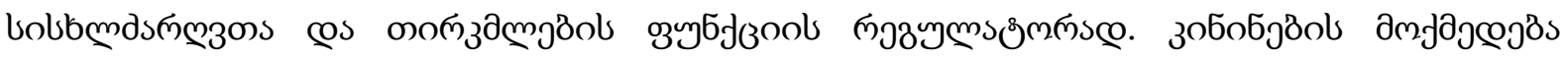

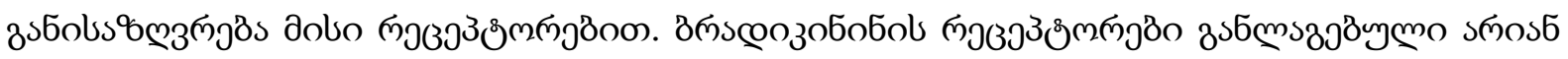

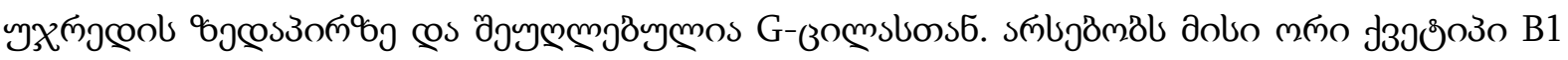

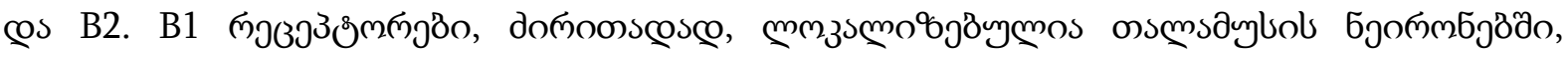

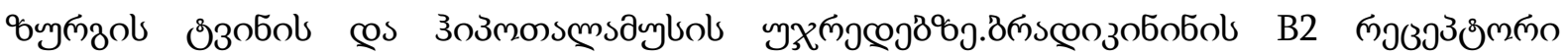

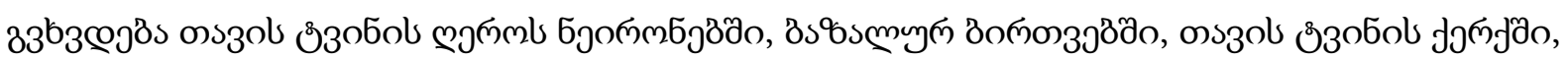

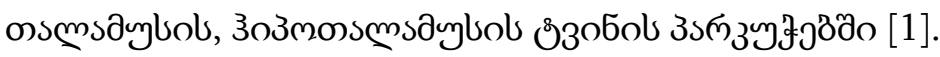

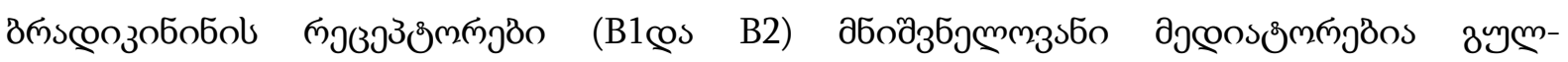

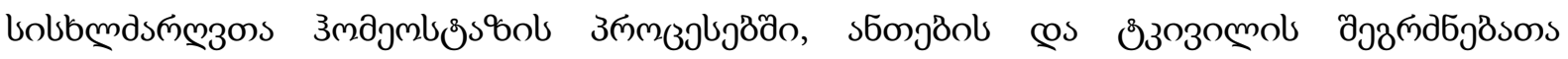

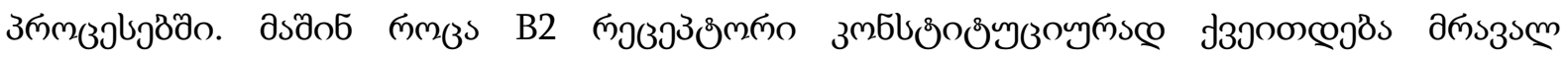

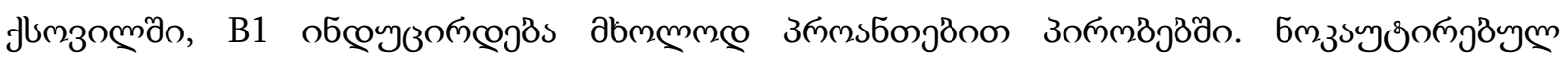

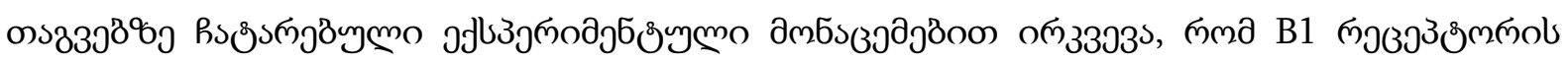




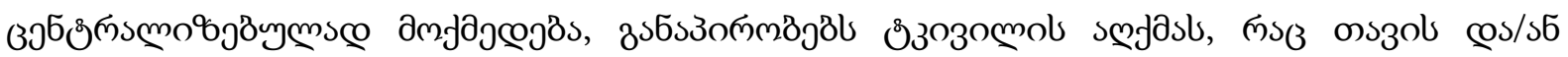

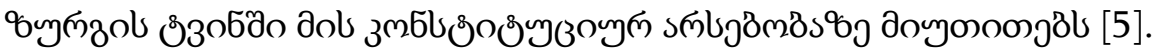

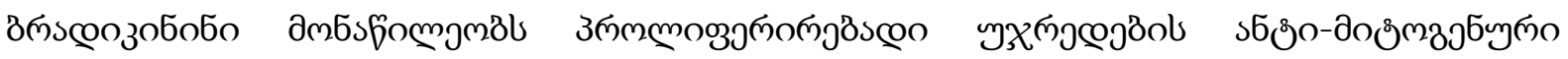

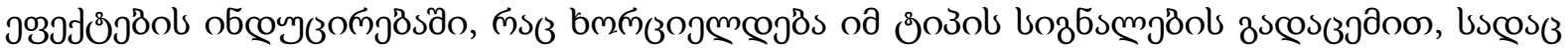

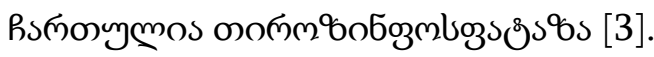

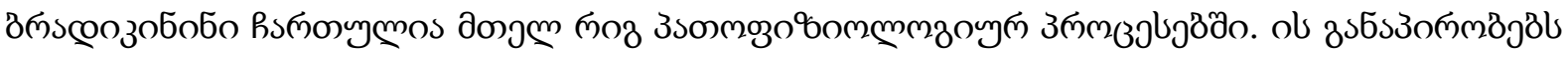

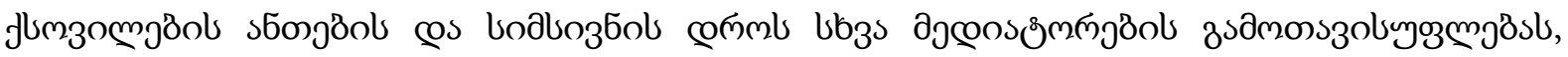

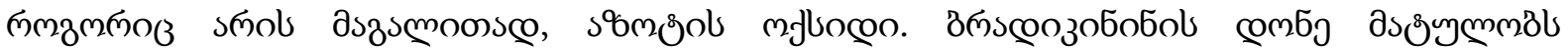

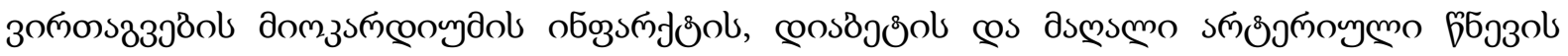

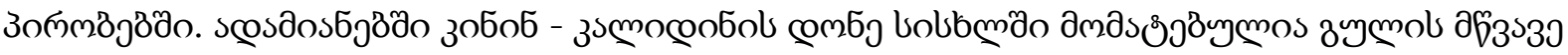

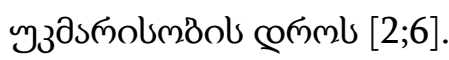

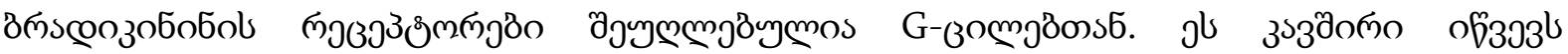

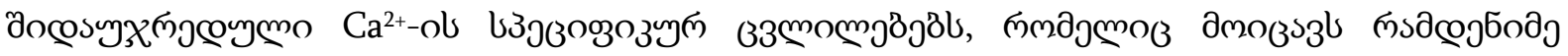

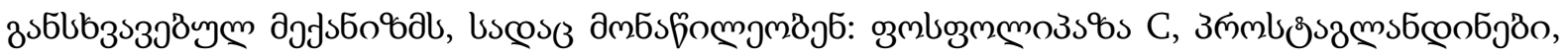
उ๓мऽ์

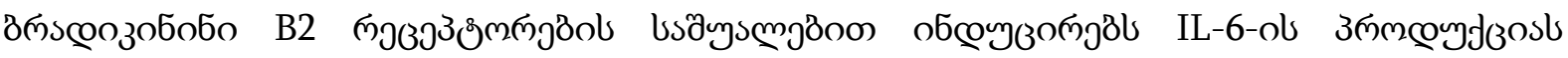

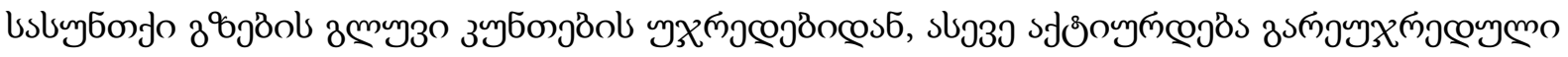

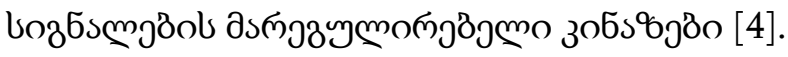

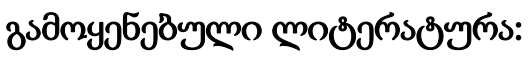

1. Blaukat A. Structure and signalling pathways of kinin receptors. Andrologia 2003; 35:17-23

2. Campbell DJ. Towards understanding the kallikrein-kinin system: insights from measurement of kinin peptides. Braz J Med Biol Res 2000;33:665-677

3. Duchene J, Schanstra J, Cellier E, Bascands JL, Girolami JP.30 years: Happy birthday, GPCR. The bradykinin B2 receptor:an alternative and antiproliferative pathway. Nephrologie 2002;23:39-41

4. Huang CD, Tliba O, Panettieri RA Jr, Amrani Y. Bradykinin induces interleukin-6 production in human airway smooth muscle cells: modulation by Th2 cytokines and dexamethasone. Am J Respir Cell Mol Biol 2003;28:330-338

5. Shughrue PJ, Ky B, Austin CP. Localization of B1 bradykinin receptor mRNA in the primate brain and spinal cord: an in situ hybridization study. J Comp Neurol 2003;465:372-384

6. Wu J, Akaike T, Hayashida $\mathrm{K}$, et al. Identification of bradykinin receptors in clinical cancer specimens and murine tumor tissues. Int J Cancer 2002;98:29-35

\subsubsection{1. by3bsos bros $P$}

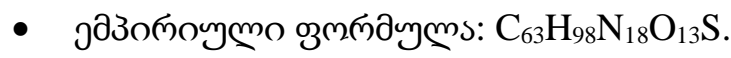

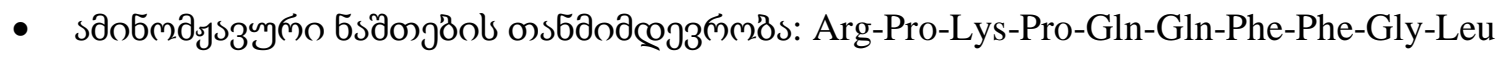
-Met.

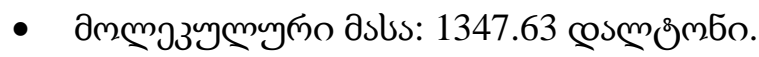




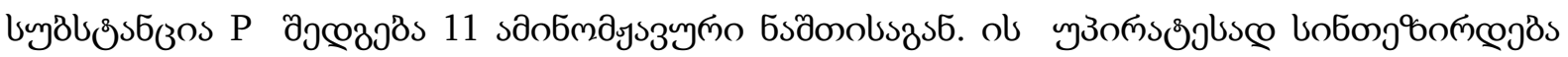

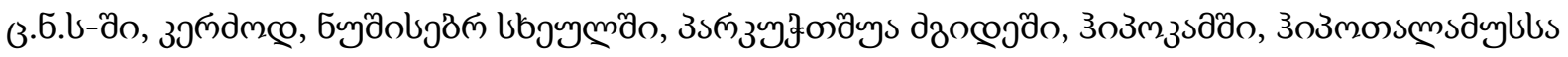

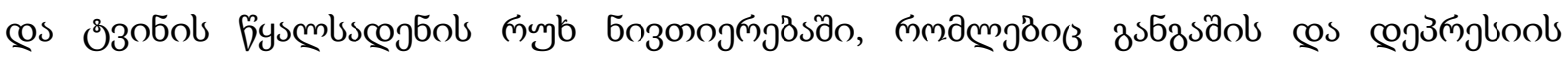

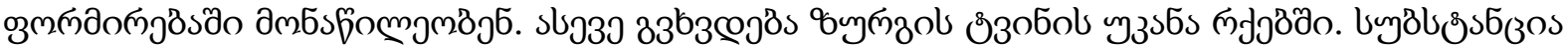

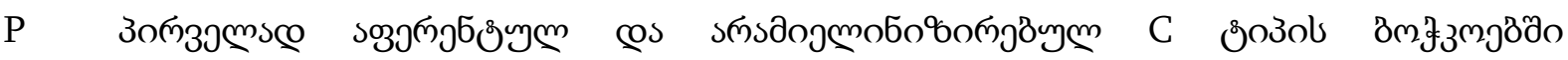

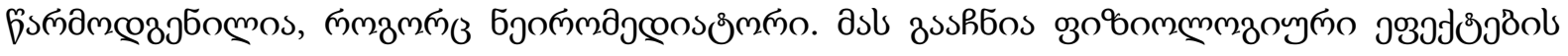

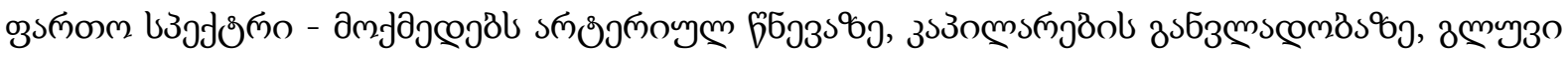

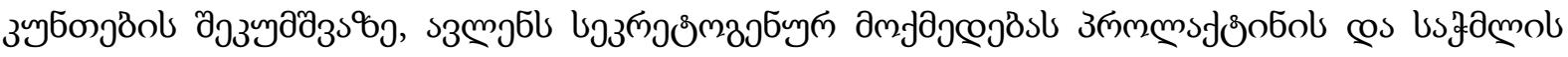

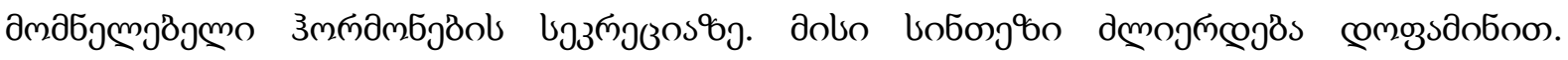

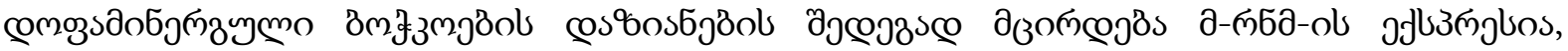

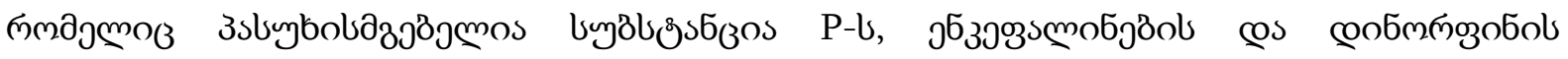
озмдап

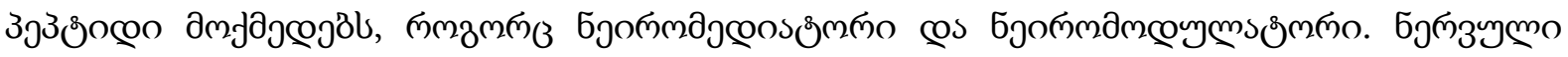

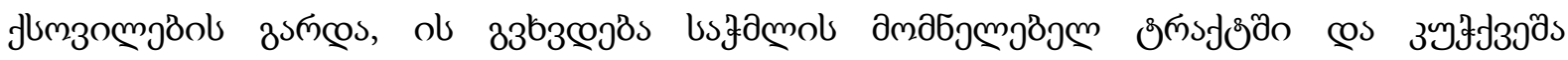

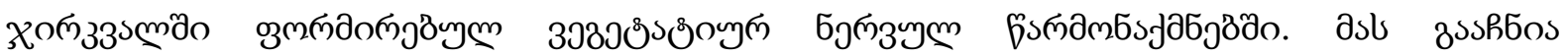

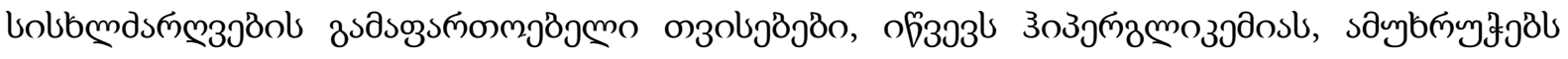

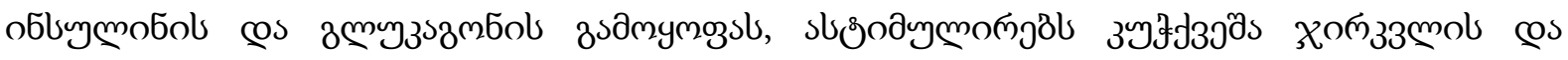

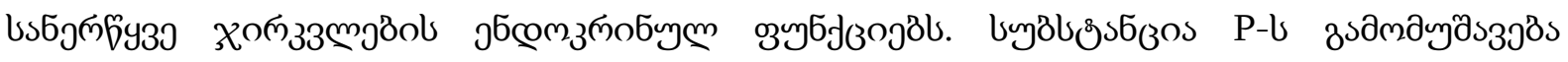

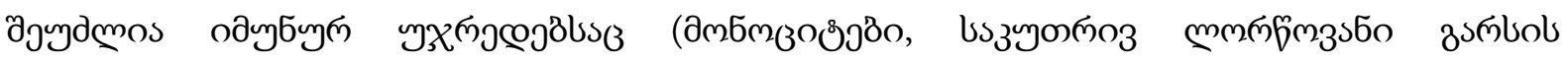

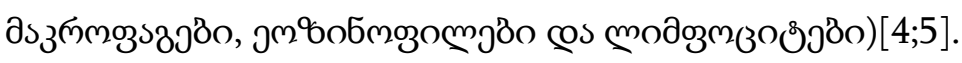

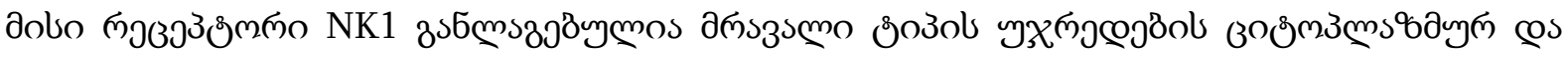

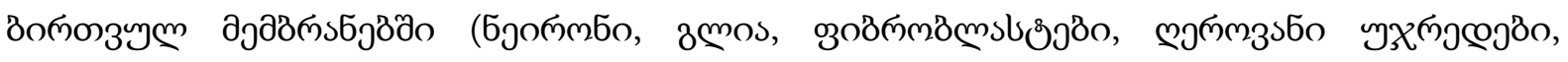

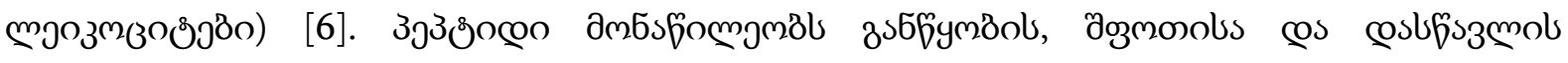

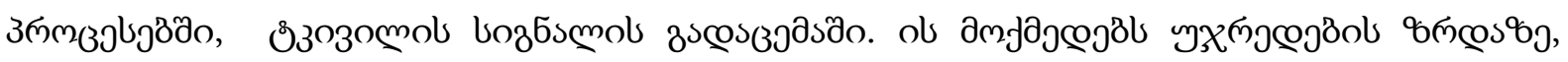

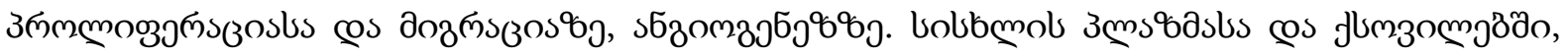

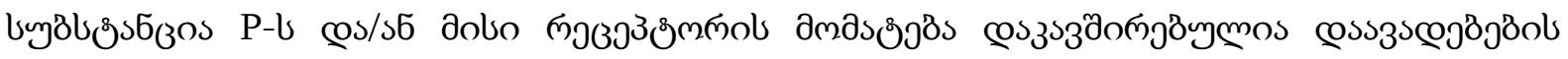

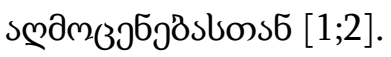

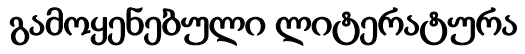

1. Ebner K, Muigg P, Singewald G, Singewald N. Substance P in stress and anxiety: NK-1 receptor antagonism interacts with key brain areas of the stress circuitry. Ann N Y Acad Sci 2008;1144:61-73.

2. Ebner K, Singewald N. The role of substance $P$ in stress and anxiety responses. Amino Acids 2006;31(3):251-272.

3. Feistritzer C. et al. Natural killer cell functions mediatedby the neuropeptide substance P. Regul. Pept. 2003; 116:119-126.

4. Hokfelt T., Pernow B., Wahron J. Substance P: a pioneeramongst neuropeptides. J. Int. Med. 2001; 249: 27-40.

5. Koon H. W., Pothoulakis C. Immunomodulatory Properties of Substance P. The Gastrointestinal Systemas aModel. N. Y. Am. Acad.Sci. 2006; 1088: 23-40.

6. McLean S. Do substance P and the NK1 receptor have a role in depression and anxiety? Curr Pharm Des 2005;11(12):1529-1547. 


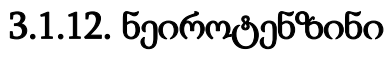

- азополумо озмпаулмз: $\mathrm{C}_{78} \mathrm{H}_{121} \mathrm{~N}_{21} \mathrm{O}_{20}$.

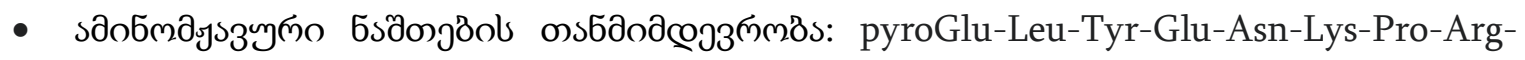
Arg-Pro-Tyr-Ile-Leu-OH.

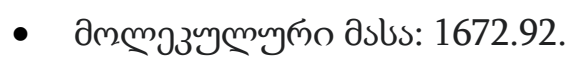

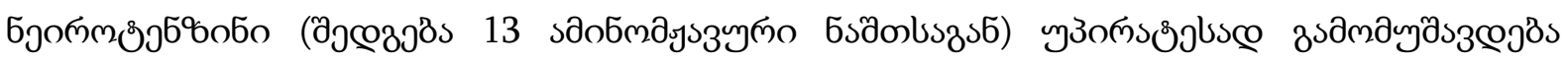

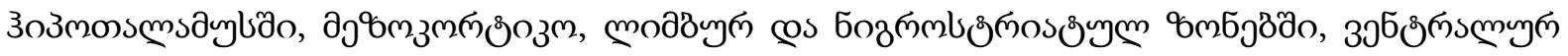

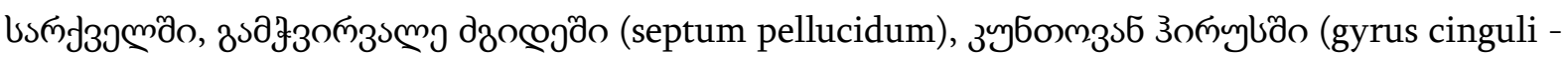

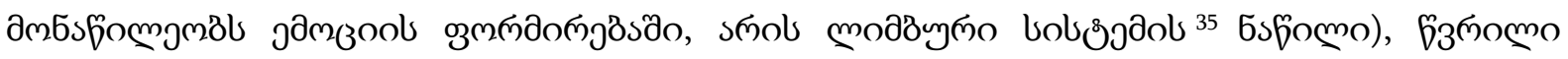

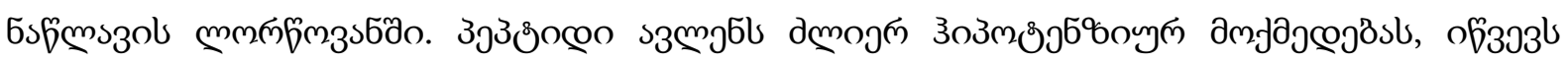

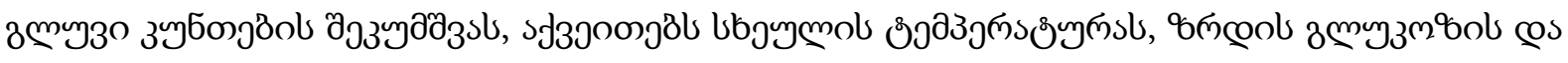

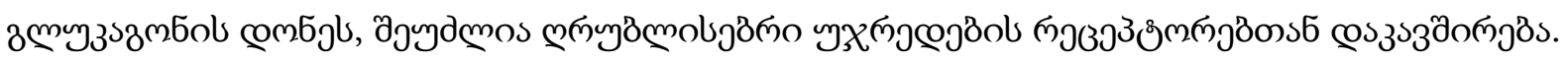

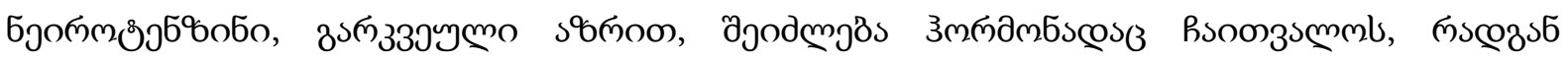

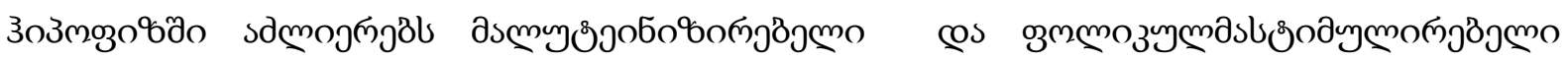

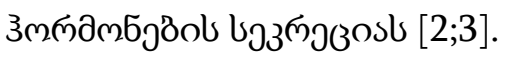

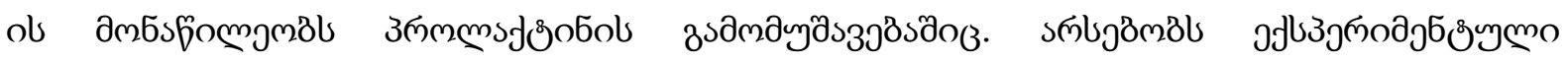

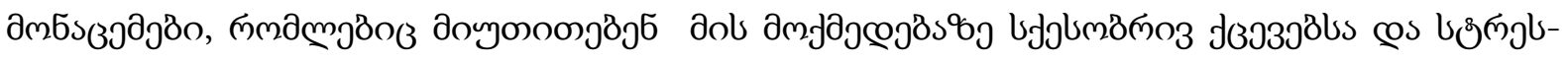

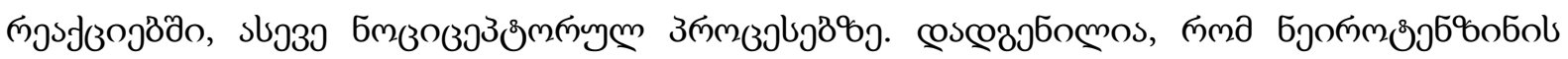

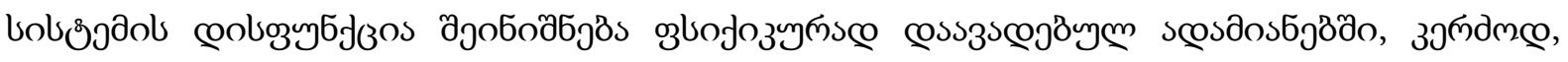

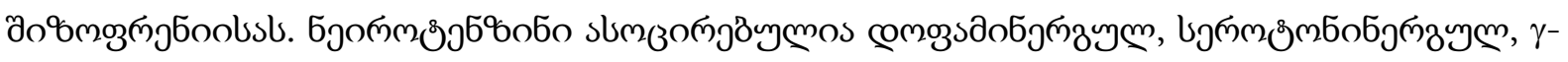

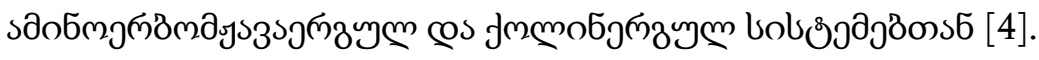

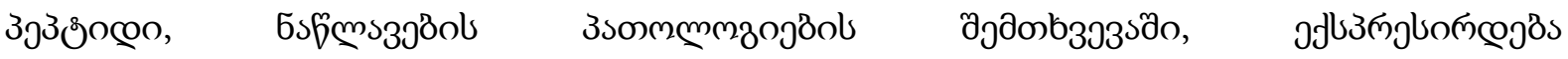

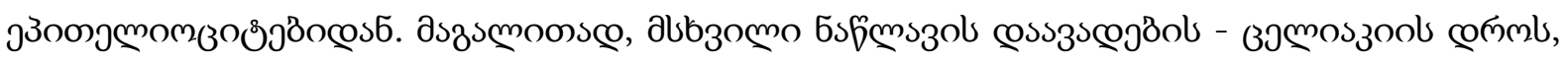

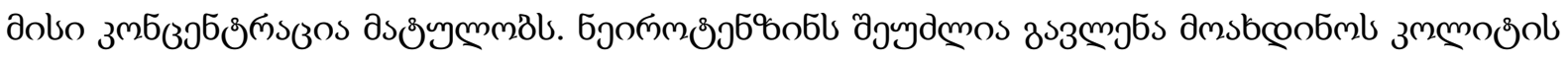

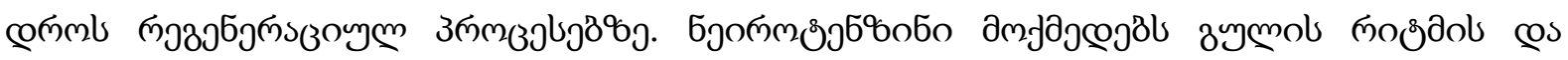

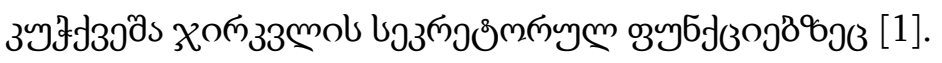

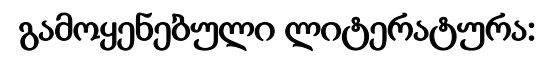

1. Mathias Hallberg. Neiropeptides: Metabolism to Bioactive Fragments and the Pharmacology of Th eir Receptors. Medicinal Research Reviews. 2014; 00(0): 1-57.

2. Riegler M., Castagliuolo I., Wang C. et al. Neurotensin stimulates $\mathrm{Cl}(-)$ secretion in human colonic mucosa in vitro: role of adenosine.- Gastroenterology. - 2000. - Vol. 119, N 2. - P. 348-357

3. Tyler-McMahon B.M., Boules M., Richelson E. Neurotensin: peptide for the next millennium. - Regul. Pept.. - 2000. - Vol. 404, N 1-2. - P. 69- 78.

4. Tyler-McMahon B.M., Stewart J.A., Farinas F. et al. Highly potent neurotensin peptide analog that causes hypothermia and antinociception.- Eur. Journ. Pharmacy. - 2000. - Vol. 390, N 1-2. - P. 107-111.

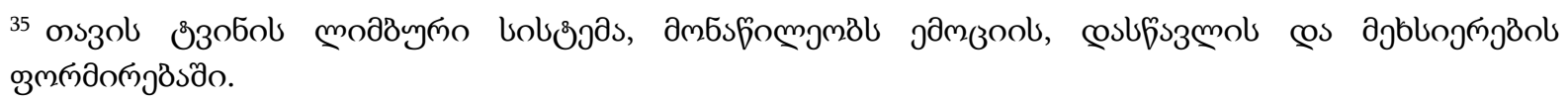




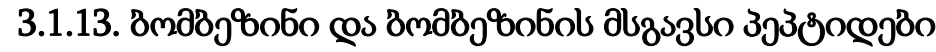

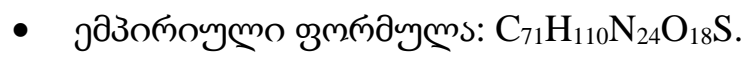

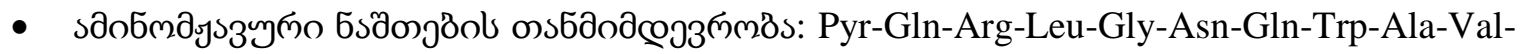
Gly-His-Leu-Met- $\mathrm{NH}_{2}$.

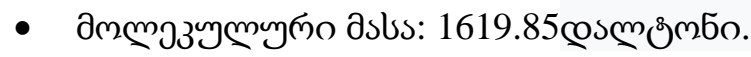

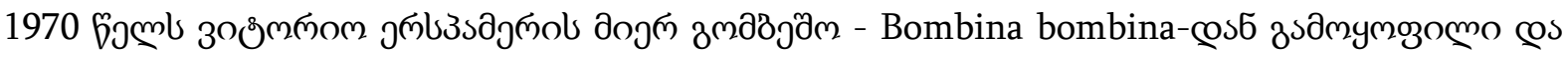

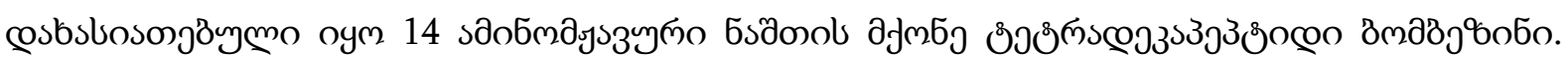

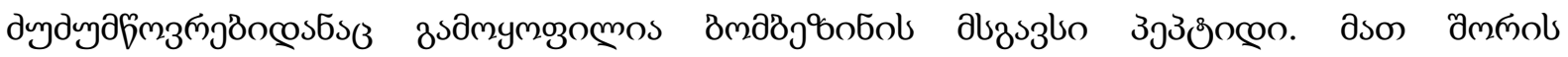

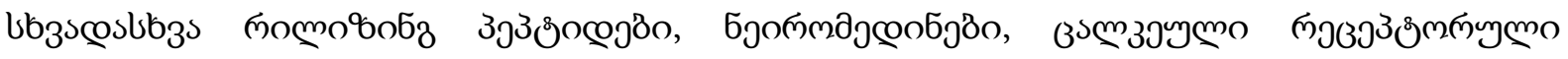

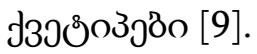

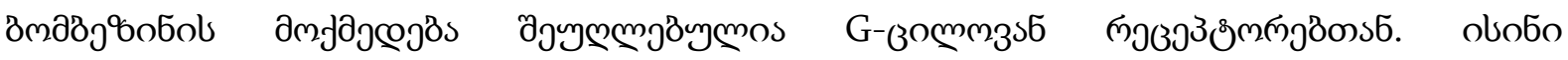

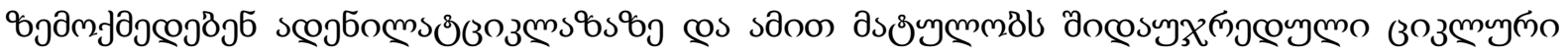

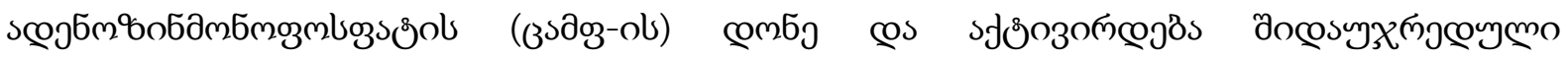

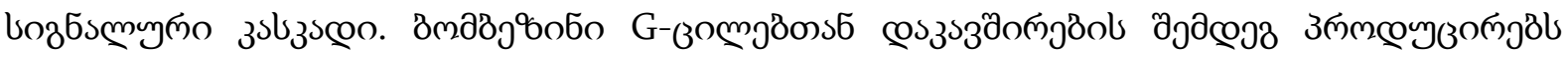

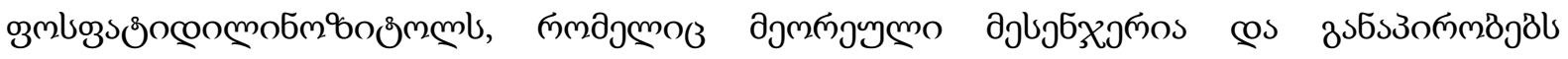

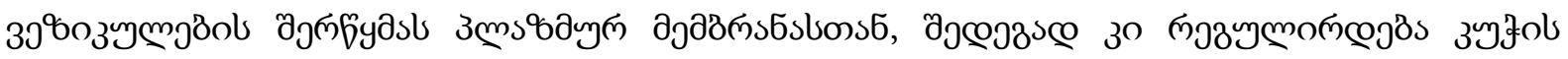

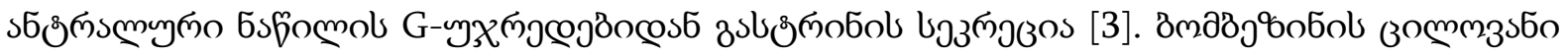

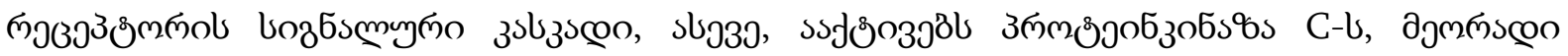

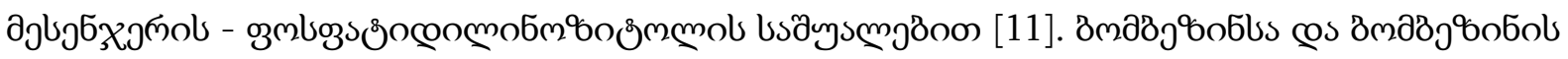

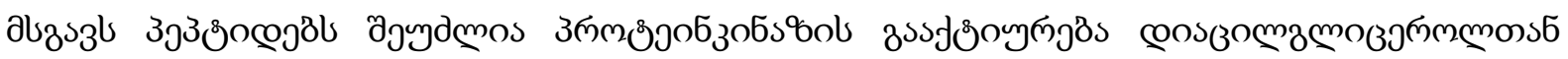

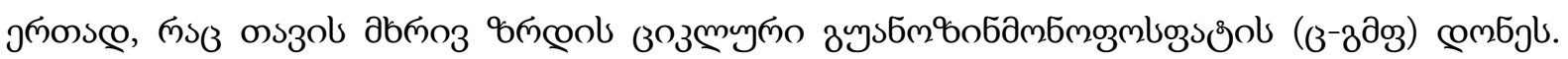

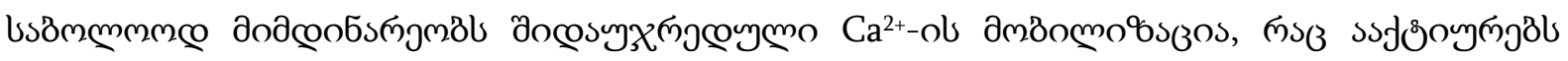

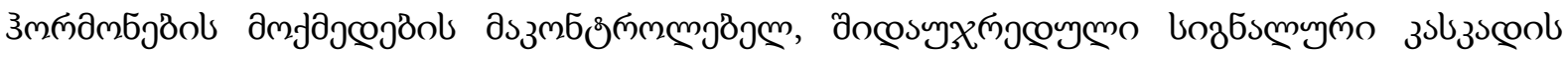

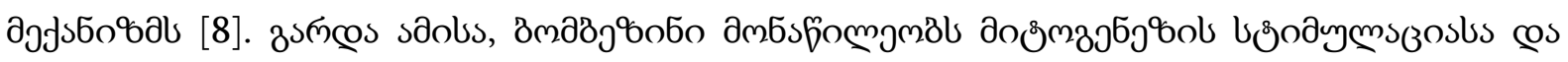

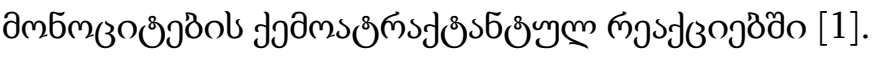

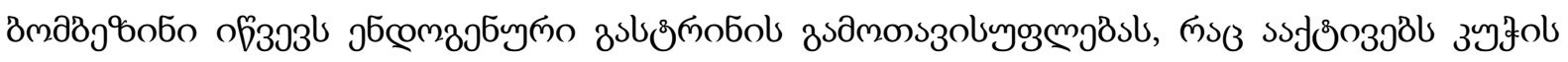

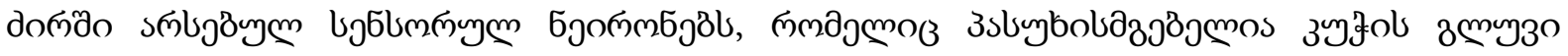

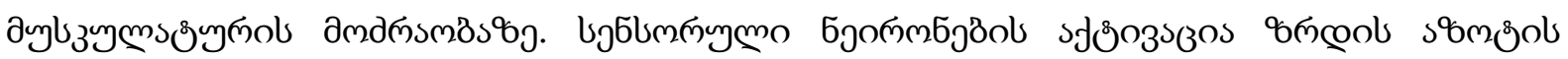

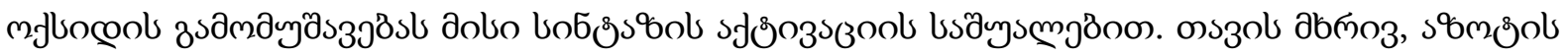
mfluncol bo6

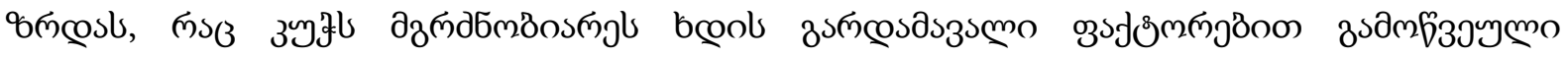

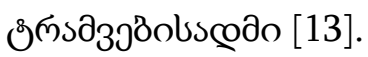

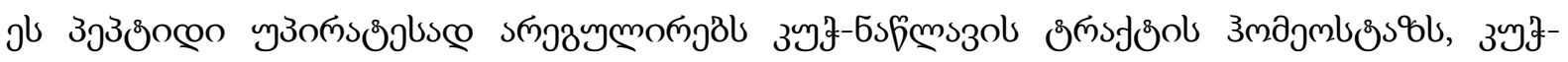

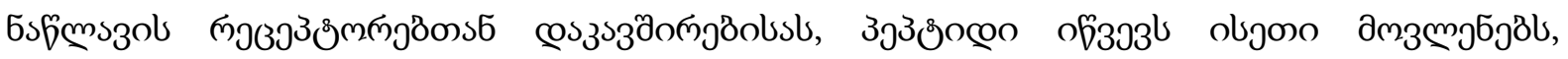

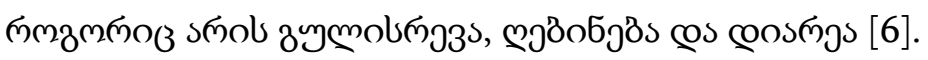

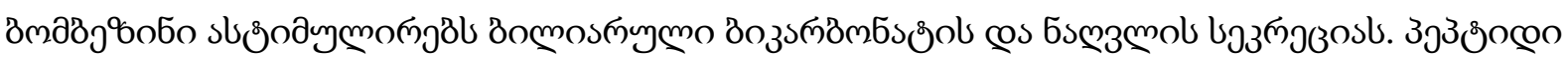

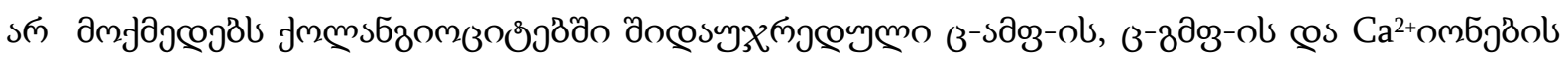

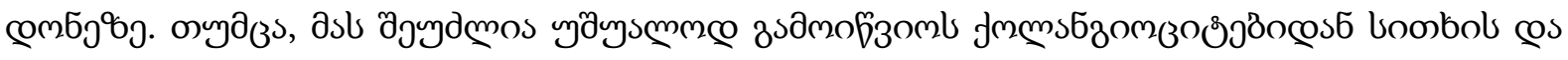

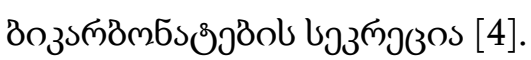

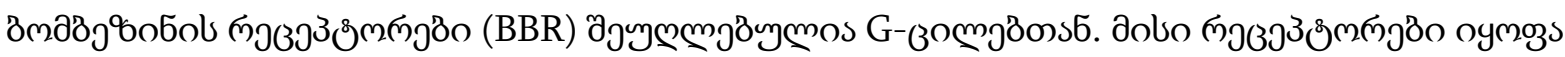




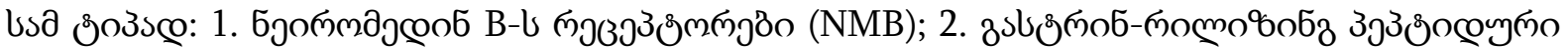

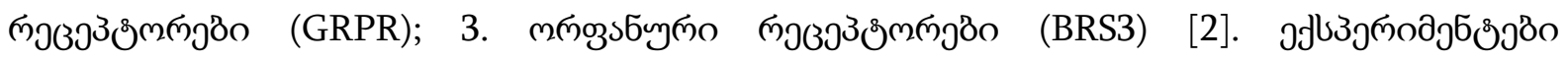

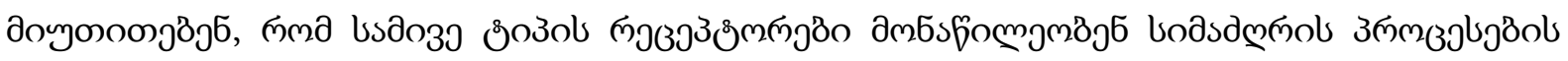

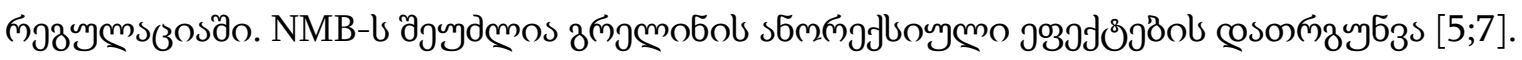

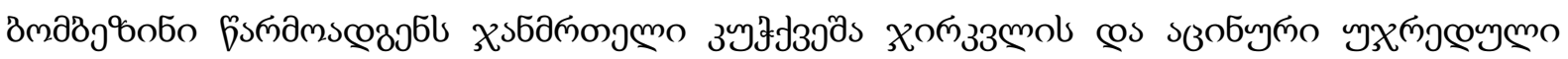

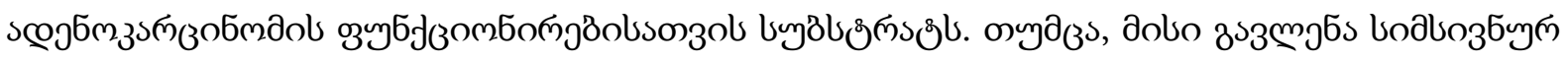

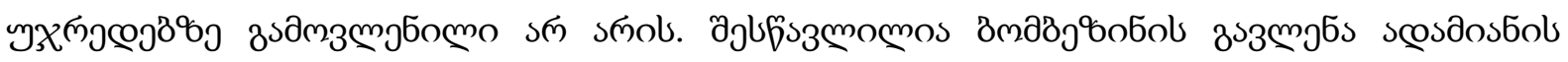

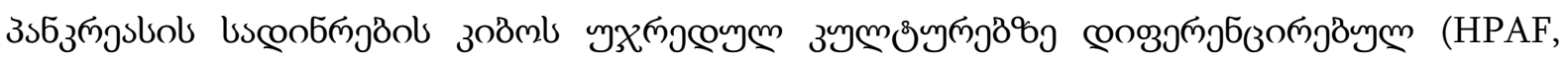

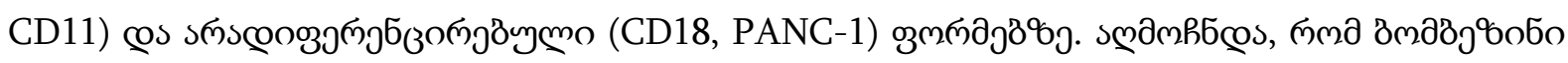

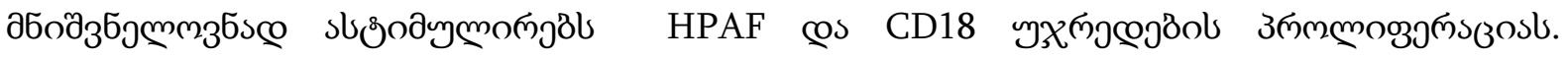

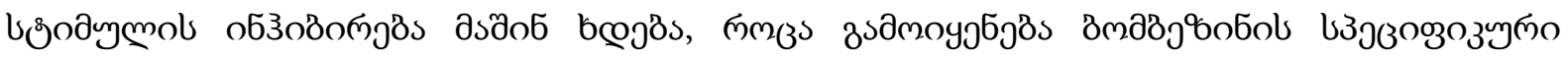

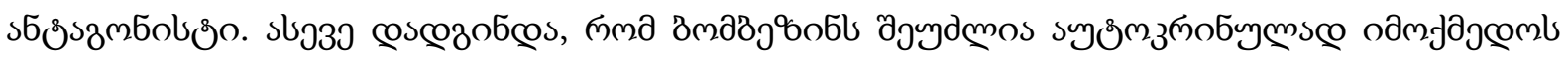

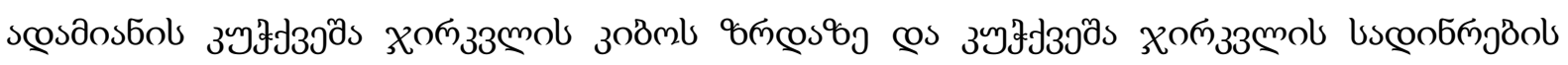

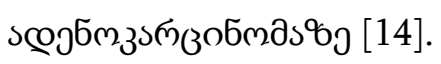

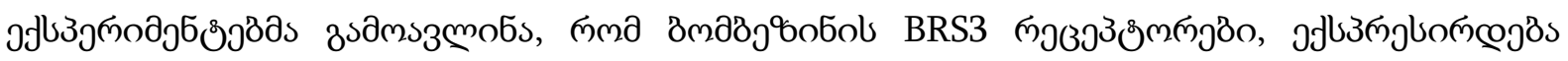

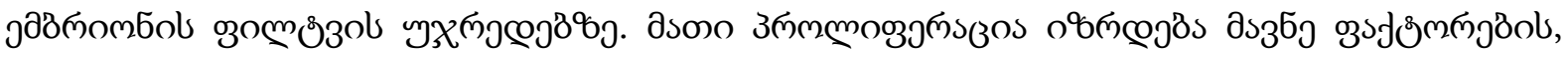

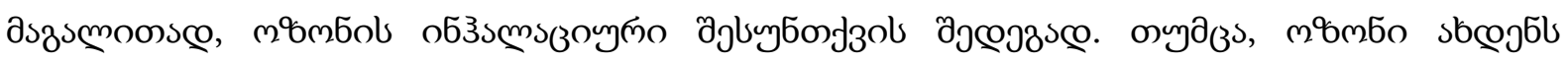

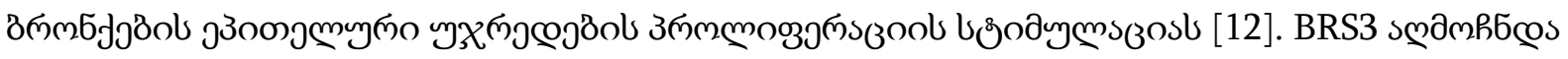

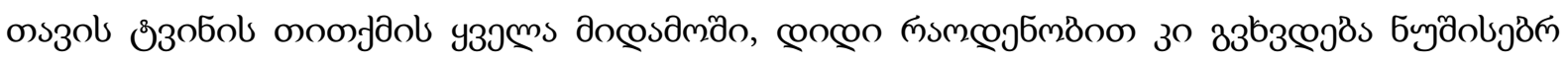

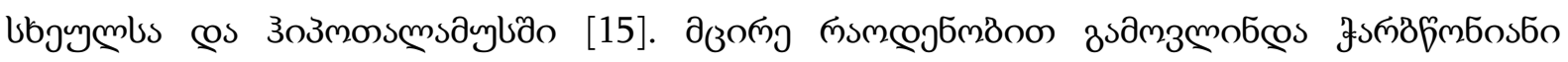

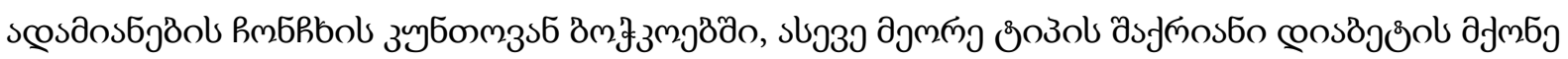

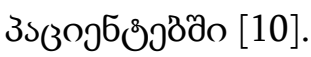

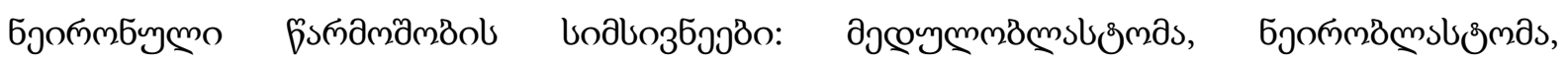

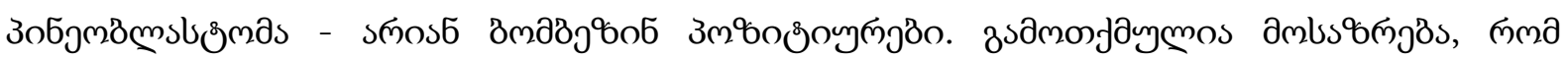

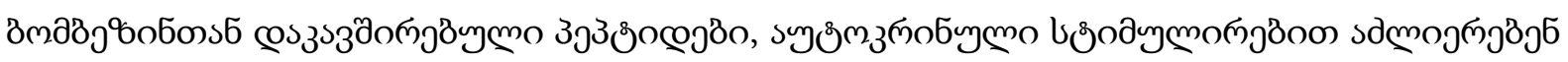

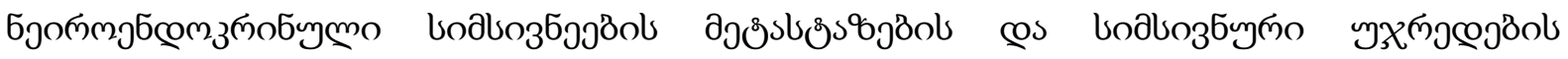

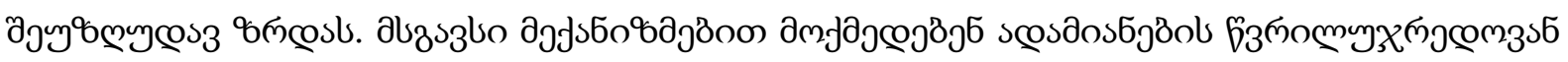

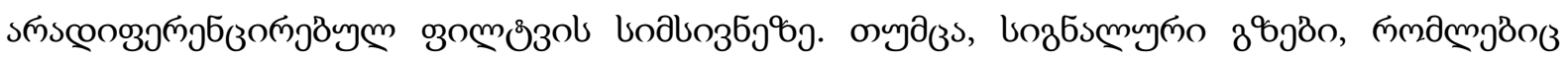

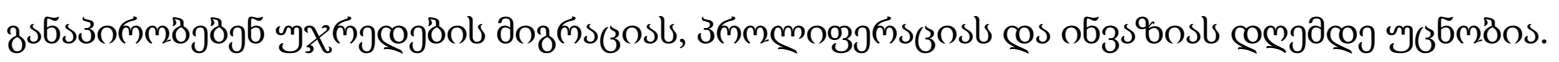

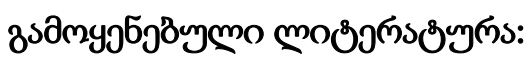

1. Aguayo S.M., King T.E., Waldron J.A., Sherritt K.M., Kane M.A., Miller Y.E. Increased pulmonary neuroendocrine cells with bombesin-like immunoreactivity in adult patients with eosinophilic granuloma. J. Clin Invest. 1990. Vol. 86 (3). P. 838-844.

2. Battey J.F., Way J.M., Corjay M.H., Shapira H., Kusano K., Harkins R., Wu J.M., Slattery T., Mann E., Feldman R.I. Molecular cloning of the bombesin/gastrin-releasing peptide receptor from Swiss 3T3 cells. Proc. Natl. Acad. Sci. U S A. 1991. Vol. 15. no 88 (2). P. 395-399.

3. Campos R.V., Buchan A.M., Meloche R.M., Pederson R.A., Kwok Y.N., Coy D.H. Gastrin secretion from human antral G cells in culture. Gastroenterology. 1990. Vol. 99 (1). P. 36-44.

4. Cho W.K. Role of the neuropeptide, bombesin, in bile secretion. Yale J Biol Med. 1997. Vol. 70 (4). P. 409-16. 
5. Erspamer V., Erpamer G.F., Inselvini M. Some pharmacological actions of alytesin and bombesin. J. Pharm. Pharmacol. 1970. Vol. 22. P. 875-876. DOI: 10.1111/j.20427158.1970.tb08465.x.

6. Erspamer V., Improta G., Melchiorri P., Sopranzi N. Evidence of cholecystokinin release by bombesin in the dog. Br J Pharmacol. 1974. Vol. 52 (2). P. 227-232.

7. Fekete E.M., Bagi E.E., Toth K., Lenard L. Neuromedin C microinjected into the amygdala inhibits feeding. Brain Res Bull. 2007. Vol. 71. P. 386-392. DOI: 10.1016/j.psyneuen.2011.04.005.

8. Gonzalez N., Moody T.W., Igarashi H., Ito T., Jensen R.T. Bombesin-related peptides and their receptors: recent advances in their role in physiology and disease states. Curr. Opin. Endocrinol. Diabetes Obes. 2008. Vol. 15 (1). P. 58-64.

9. Jensen R.T., Battey J.F., Spindel E.R., Benya R.V. International Union of Pharmacology. The bombesin Receptors: Nomenclature, distribution, pharmacology, signaling and functions in normal and disease states. Pharmacol Rev. 2008. Vol. 60 (1). P. 1-42. DOI: 10.1124/pr.107.07108.

10. Ramos-Alvarez I., Martin-Duce A., Moreno-Villegas Z., et al. Bombesin receptor subtype-3 (BRS-3), a novel candidate as therapeutic molecular target in obesity and diabetes. Mol Cell Endocrinol. 2013. Vol. 367. P. 109-115.

11. Rozengurt E. Bombesin stimulation of mitogenesis. Specific receptors, signal transduction, and early events. Am Rev Respir Dis. 1990. Vol. 142. no 6 (2). P. 5-11.

12. Tan Y.R., Qin X.Q., Xiang Y. PPARalpha and AP-2alpha regulate bombesin receptor subtype 3 expression in ozone-stressed bronchial epithelial cells. Biochem J. 2007. Vol. 1. no 405 (1). P. 131-137. DOI: 10.1042/BJ20061754.

13. Tell R., Rivera C.A., Eskra J., Taglia L.N., Blunier A., Wang Q.T., Benya R.V. Gastrinreleasing peptide signaling alters colon cancer invasiveness via heterochromatin protein $1 \mathrm{Hs} \beta$. Am J. Pathol. 2011. Vol. 178 (2). P. 672-678.

14. Wang Q.J., Knezetic J.A., Schally A.V., Pour P.M., Adrian T.E. Bombesin may stimulate proliferation of human pancreatic cancer cells through an autocrine pathway. Int J Cancer. 1996. Vol. 15. no 68 (4). P. 528-534. DOI: 10.1002/(SICI)1097-0215(19961115)68.

15. Zhang L., Parks G.S., Wang Z. Anatomical characterization of bombesin receptor subtype-3 mRNA expression in the rodent central nervous system. J Comp Neurol. 2013. Vol. 521. P. 1020-1039. 


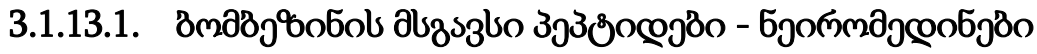

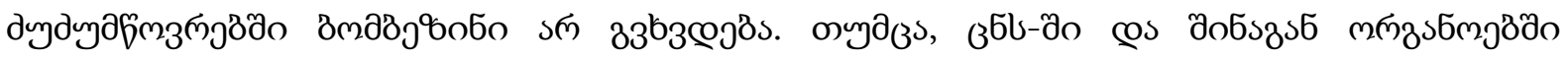

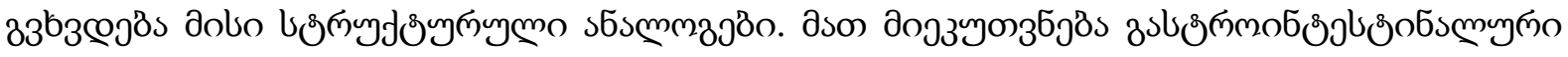

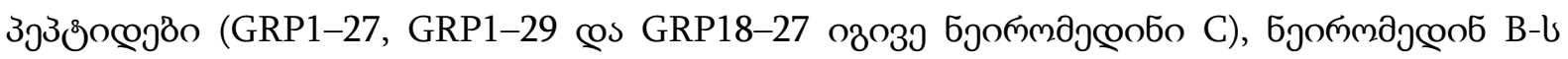

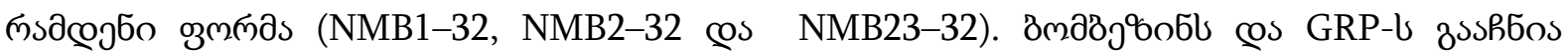

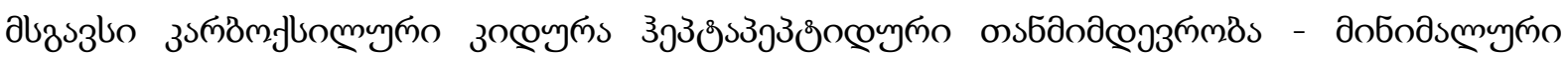

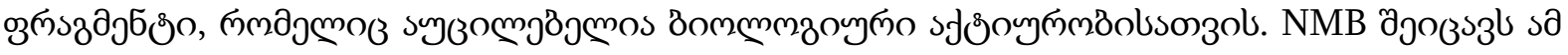

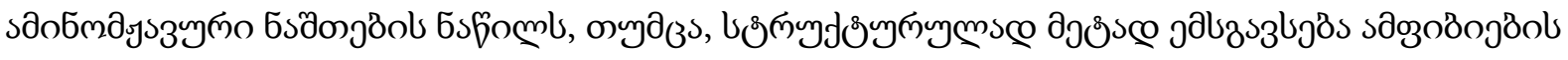

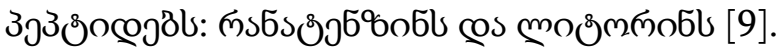

\subsubsection{1. Бропмдащобо U (NMU)}

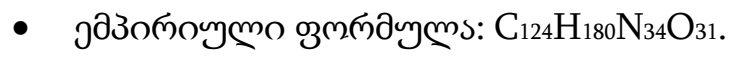

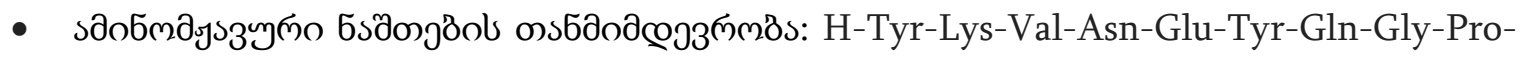
Val-Ala-Pro-Ser-Gly-Gly-Phe-Phe-Leu-Phe-Arg-Pro-Arg-Asn-NH2.

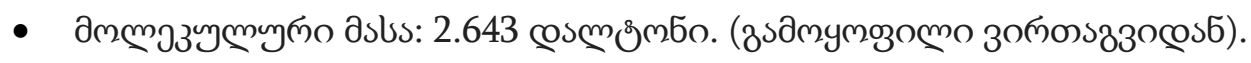

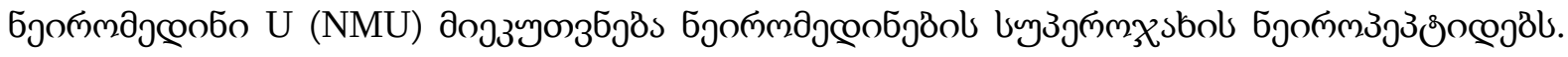

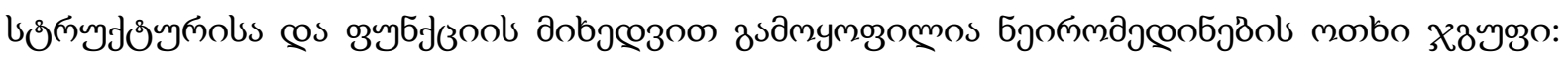

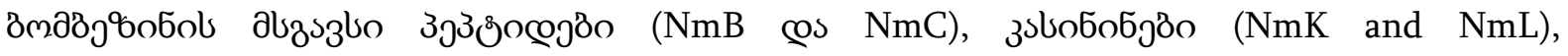
бјопм

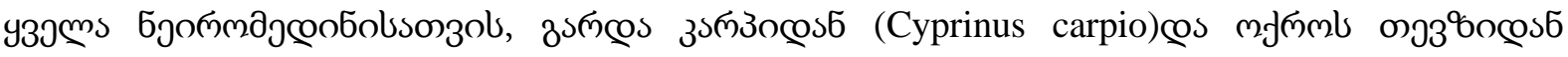

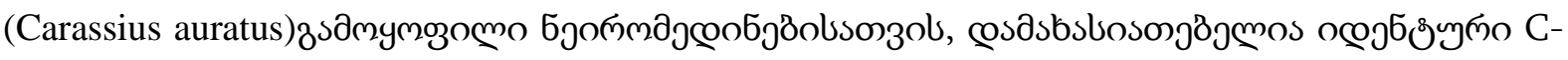

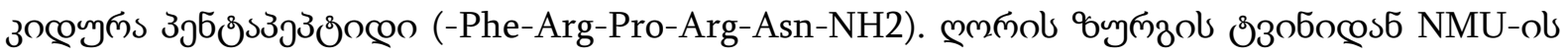

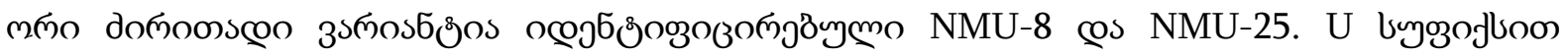

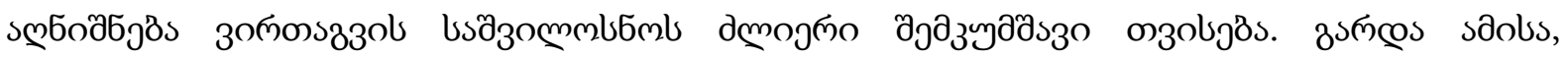

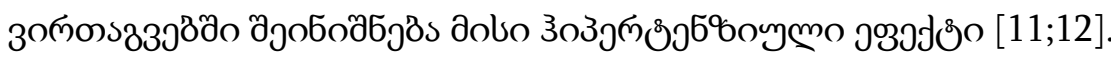

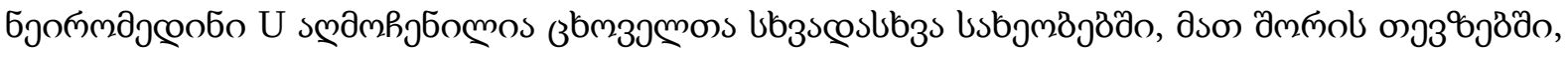

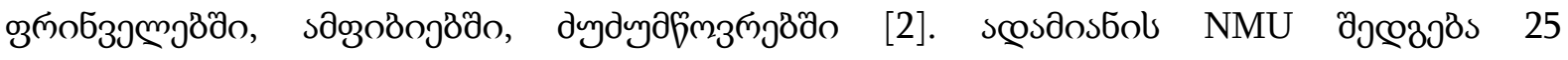

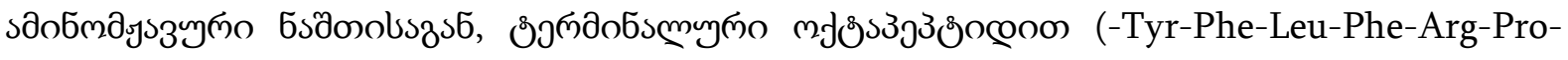

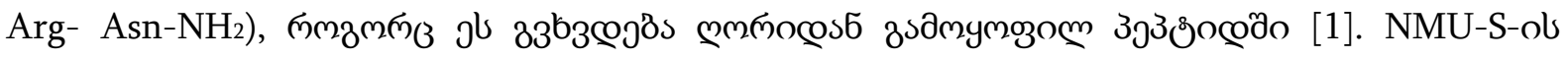

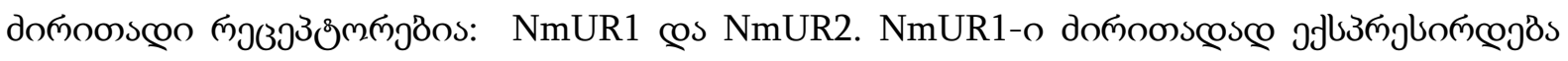

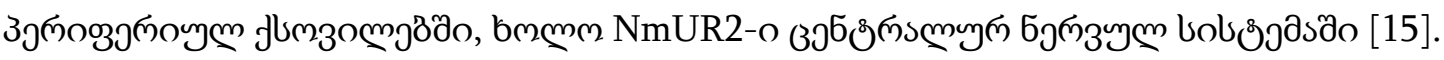

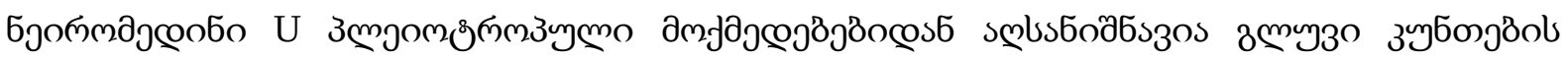

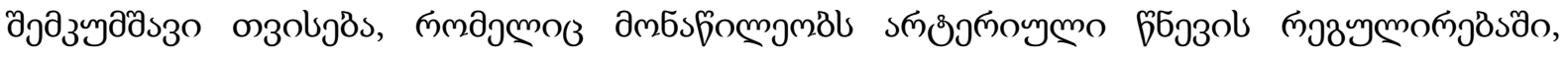

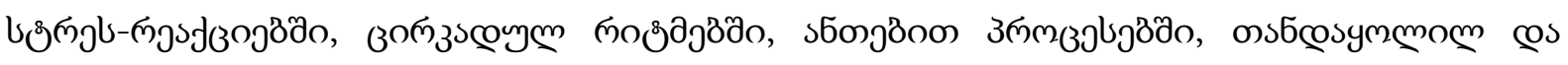

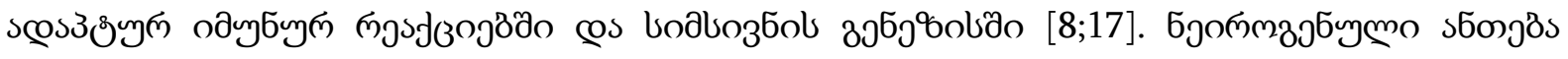

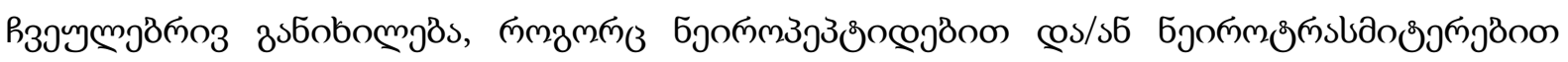

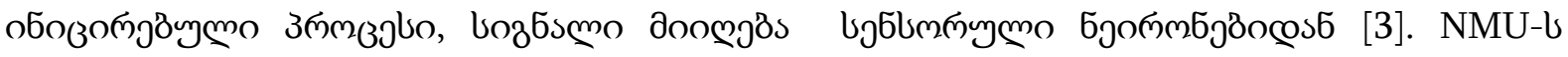

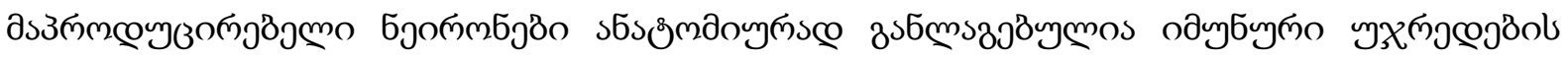




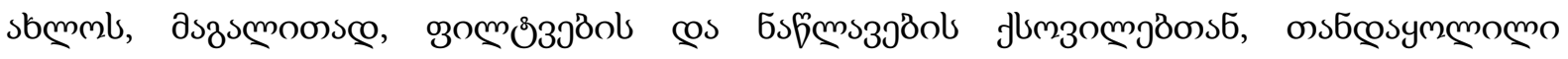

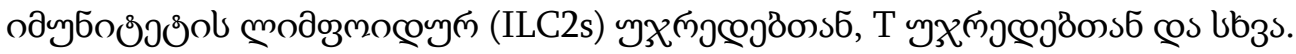

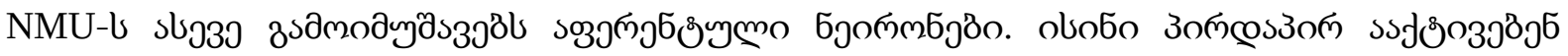

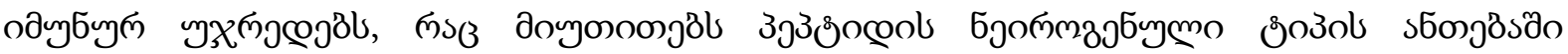

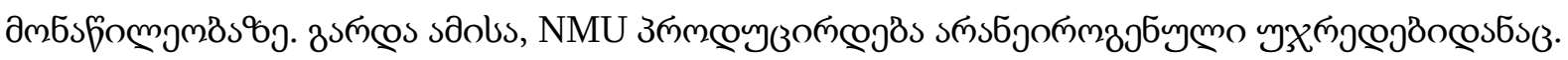

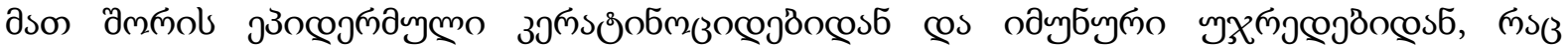

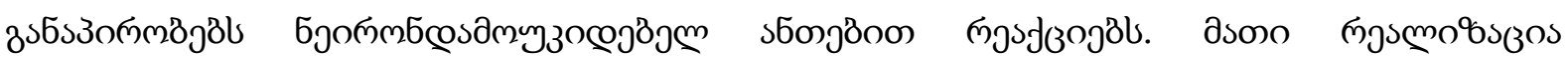

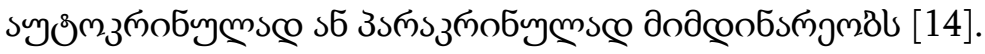

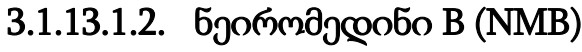

- jазойоумо озмпауумms: $\mathrm{C}_{52} \mathrm{H}_{73} \mathrm{~N}_{15} \mathrm{O}_{12} \mathrm{~S}$.

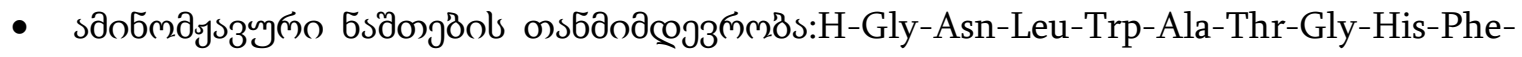
Met- $\mathrm{NH}_{2}$.

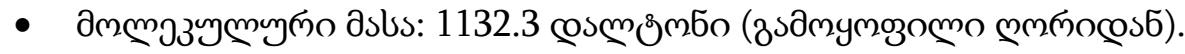

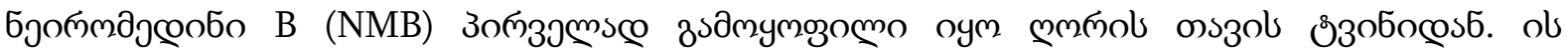

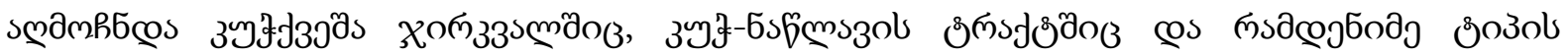

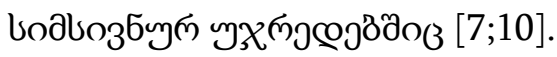

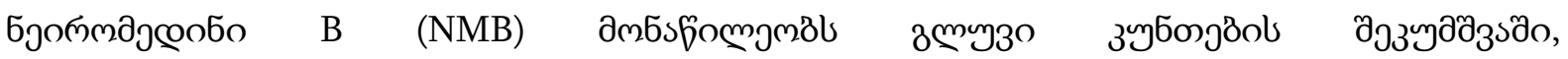

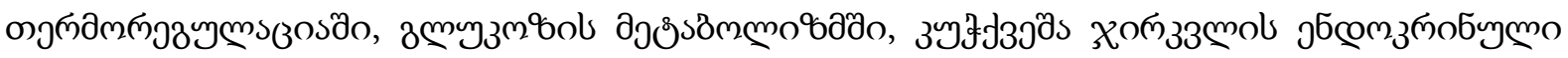
œs

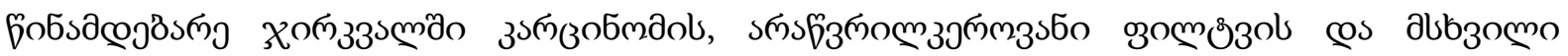

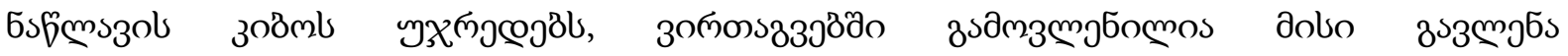
mடலి

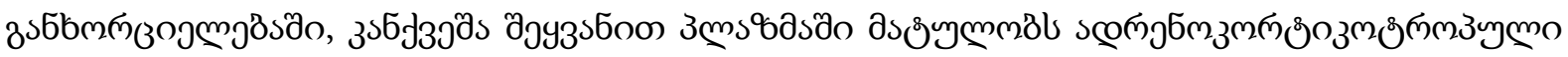

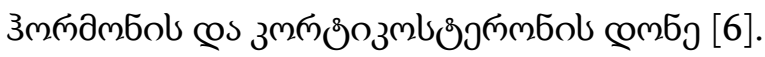

\subsubsection{3. бэокмдэюобо S (NMS)}

- јазоколумо озмпаулмз: $\mathrm{C}_{173} \mathrm{H}_{265} \mathrm{~N}_{53} \mathrm{O}_{44}$

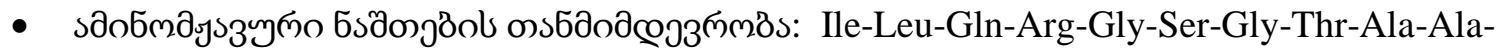
Val-Asp-Phe-Thr-Lys-Lys-Asp-His-Thr-Ala-Thr-Trp-Gly-Arg-Pro-Phe-Phe-Leu-Phe-ArgPro-Arg-Asn- $\mathrm{NH}_{2}$.

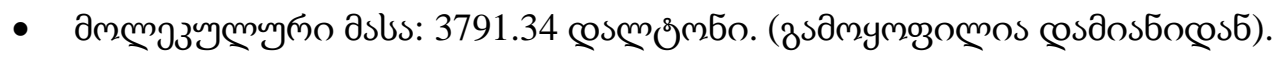

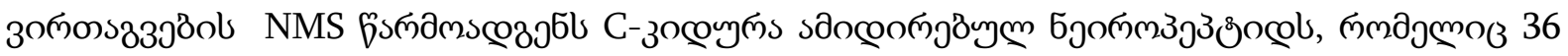

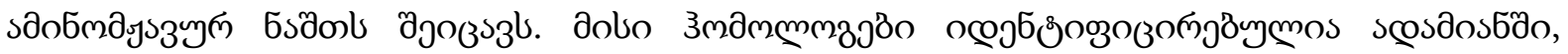
onszzls cos Bsysyão [4;13].

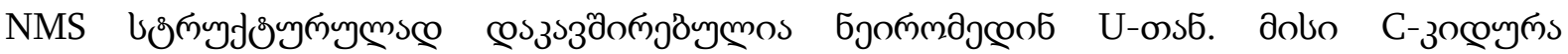

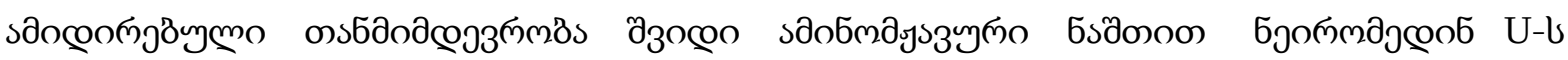




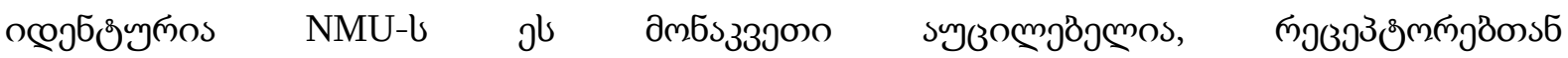

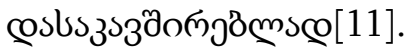

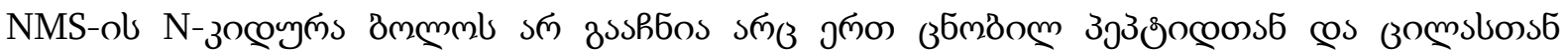

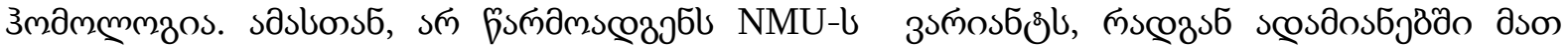

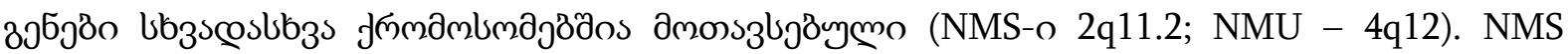

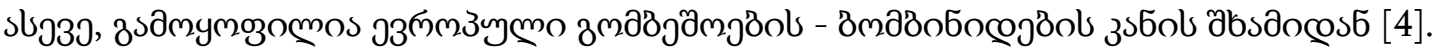

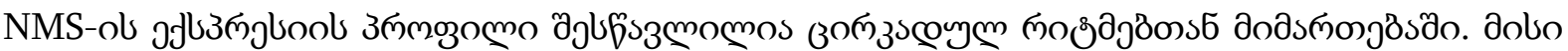

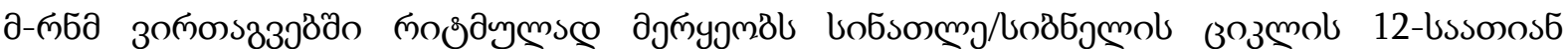

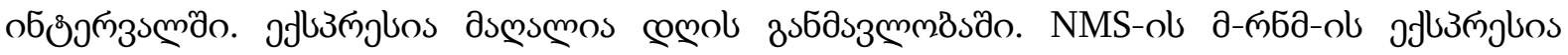

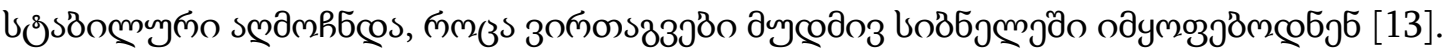

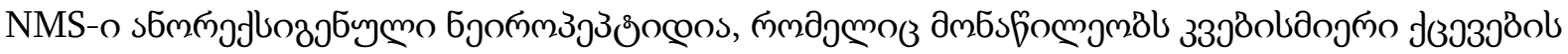

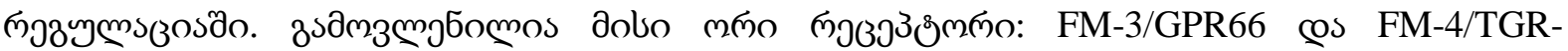

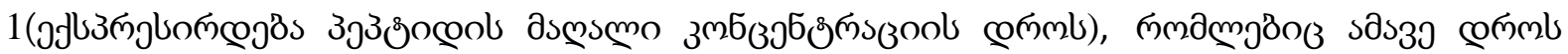

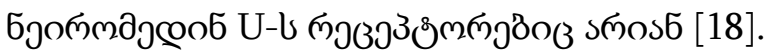

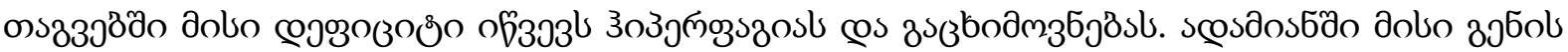

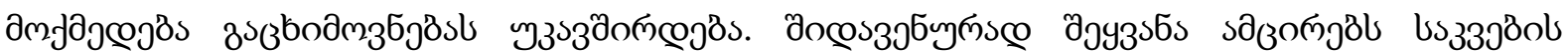

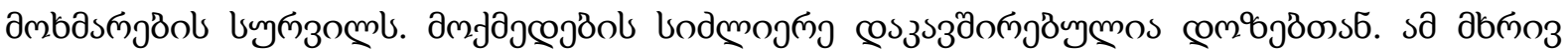

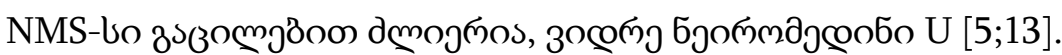

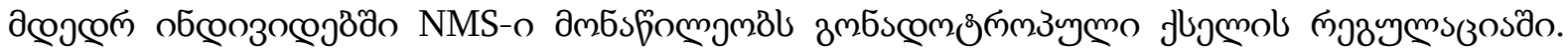

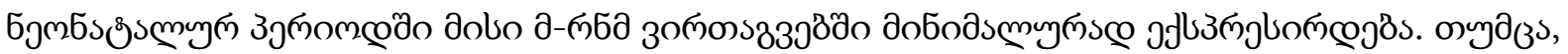

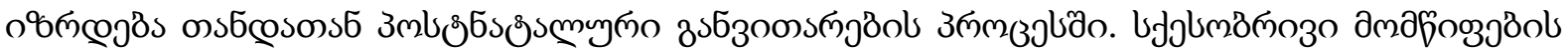

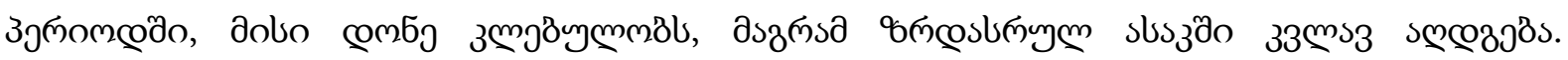

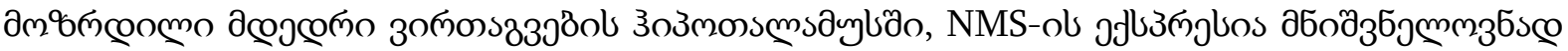

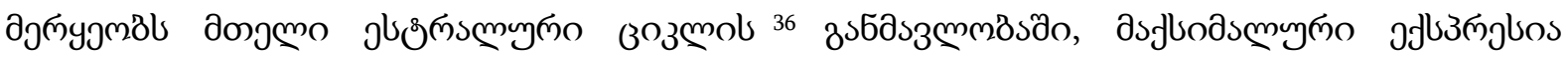

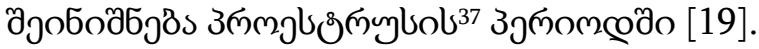

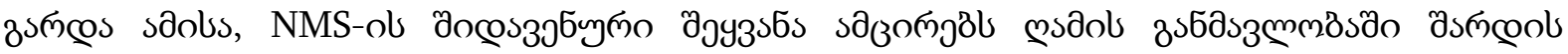

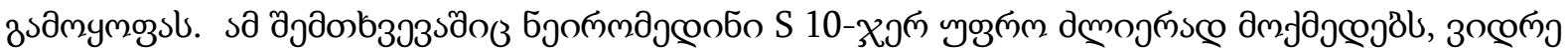
бэопмдјсобо U [16].

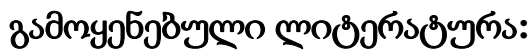

1. Austin C, Lo G, Nandha KA, Meleagros L, Bloom SR. Cloning and characterization of the cDNA encoding the human neuromedin $\mathrm{U}(\mathrm{NmU})$ precursor: $\mathrm{NmU}$ expression in the human gastrointestinal tract. J Mol Endocrinol 1995; 14:157-69.

2. Brighton PJ, Szekeres PG, Willars GB. Neuromedin U and its receptors: structure, function, and physiology roles. Pharmacol Rev 2004; 56:231-48.

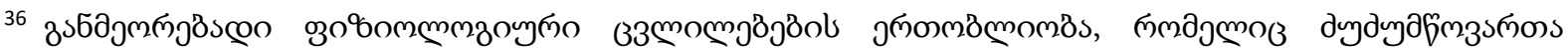

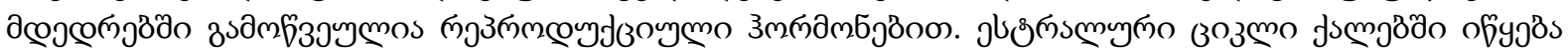

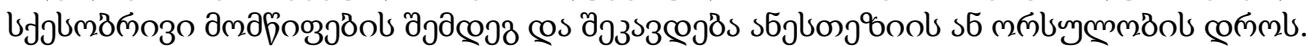

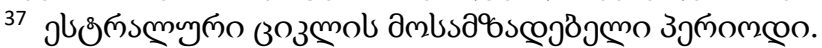


3. Cardoso V, Chesn_e J, Ribeiro H, Garc_1a-Cassani B, Carvalho T, Bouchery T, et al.Neuronal regulation of type 2 innate lymphoid cells via neuromedin U. Nature 2017; 549:277-81.

4. Chen T, Zhou M, Walker B, Harriot P, Mori K, Miyazato M, Kangawa K, Shaw C (2006) Structural and functional analogs of the novel mammalian neuropeptide, neuromedin $\mathrm{S}$ $(\mathrm{NmS})$, in the dermal venoms of Eurasian bombinid toads. Biochem Biophys Res Commun 345:377-384

5. Hanada R, Teranishi H, Pearson JT, Kurokawa M, Hosoda H, Fukushima N, Fukue Y, Serino R, Fujihara H, Ueta Y, Ikawa M, Okabe M, Murakami N, Shirai M, Yoshimatsu H, Kangawa K, Kojima M (2004) Neuromedin U has a novel anorexigenic effect independent of the leptin signaling pathway. Nat Med 10:1067-1073

6. H.Kameda; H.Miyoshi; C.Shimizu; S.Nagai; A.Nakamura; T.Kondo; D.Chida and Tatsuya Atsumi. Expression and Regulation of Neuromedin B inPituitary Corticotrophs of Male Melanocortin 2Receptor-Deficient Miceendo.endojournals.org Endocrinology, July 2014, 155(7):2492-2499 doi: 10.1210/en.2013-2077

7. Itoh S, Takashima A, Itoh T, Morimoto T. Effects of neuromedinsand related peptides on the body temperature of rats. Jpn J Physiol.1995;45:37-45.

8. Martinez VG, O'Driscoll L. Neuromedin U: a multifunctional neuropeptide withpleiotropic roles. Clin Chem 2015; 61:471-82.

9. Minamino N, Kangawa K, Matsuo H. Neuromedin B and neuromedin Ca. Two mammalian bombesin-like peptides identified in porcine spinal cord and brain. Ann N Y Acad Sci 1988;547:373-90

10. Minamino N, Kangawa K, Matsuo H. Neuromedin B is a majorbombesin-like peptide in rat brain: regional distribution of neuromedinB and neuromedin $\mathrm{C}$ in rat brain, pituitary and spinal cord.Biochem Biophys Res Commun. 1984;124:925-932.

11. Minamino N, Kangawa K, Matsuo H. Neuromedin U-8 and U-25: novel uterus stimulating and hypertensive peptides identified in porcine spinal cord. Biochem Biophys Res Commun 1985; 130:1078-85.

12. Minamino N, Sudoh T, Kangawa K. Neuromedins: novel smooth-muscle stimulating peptides identified in porcine spinal cord. Peptides $1985 ; 6: 245-8$.

13. Mori K, Miyazato M, Ida T, Murakami N, Serino R, Ueta Y, Kojima M, Kangawa K (2005) Identification of neuromedin $\mathrm{S}$ and its possible role in the mammalian circadian oscillator system. EMBO J 24:325-335

14. Moriyama M, Matsukawa A, Kudoh S, Takahashi $\mathrm{T}$, Sato $\mathrm{T}$, Kano $\mathrm{T}$, et al. The neuropeptideneuromedin U promotes IL-6 production from macrophages and endotoxin shock. Biochem Biophys Res Commun 2006; 341:1149-54.

15. Raddatz R, Wilson AE, Artymyshyn R, Bonini JA, Borowsky B, Boteju LW, et al. Identification and characterization of two neuromedin $U$ receptors differentially expressed in peripheral tissues and the central nervous system. J Biol Chem 2000; 275:32452-9.

16. Sakamoto T, Mori K, Nakahara K, Miyazato M, Kangawa K, Samejima H, Murakami N (2007) Neuromedin S exerts an antidiuretic action in rats. Biochem Biophys Res Commun 361:457-461

17. Przygodzka P, Soboska K, Sochacka E, Boncela J. Neuromedin U: a small peptide in the big world of cancer. Cancers (Basel) 2019; 11:1312.

18. Tan CP, McKee KK, Liu Q, Palyha OC, Feighner SD, Hreniuk DL, Smith RG, Howard AD (1998) Cloning and characterization of a human and murine T-cell orphan G-proteincoupled receptor similar to the growth hormone secretagogue and neurotensin receptors. Genomics $52: 223-229$ 
19. Vigo E, Roa J, López M, Castellano JM, Fernandez-Fernandez R, Navarro VM, Pineda R,Aguilar E, Diéguez C, Pinilla L, Tena-Sempere M (2007) Neuromedin S as novel putative regulator of luteinizing hormone secretion. Endocrinology 148:813-823

\subsubsection{4. zsems6o6o}

- jазополумо озмпдулмз: $\mathrm{C}_{146} \mathrm{H}_{213} \mathrm{~N}_{43} \mathrm{O}_{40}$.

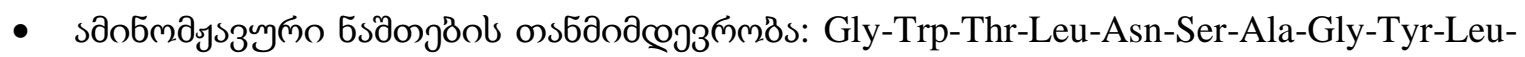
Leu-Gly-Pro-His-Ala-Val-Gly-Asn-His-Arg-Ser-Phe-Ser-Asp-Lys-Asn-Gly-Leu-Tyr-Ser.

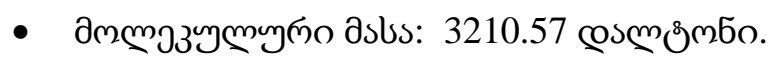

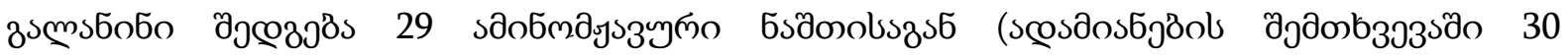

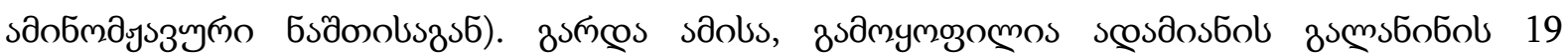

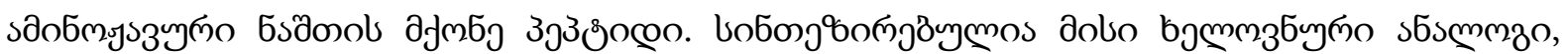

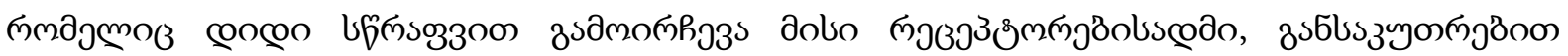

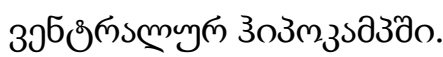

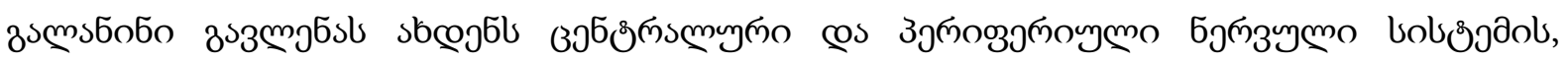

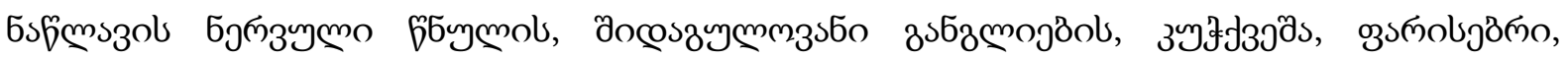

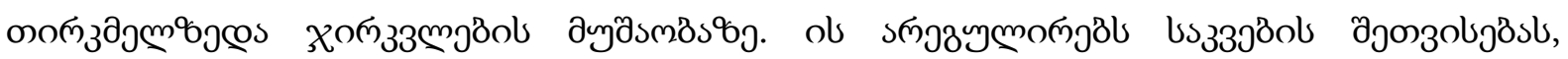

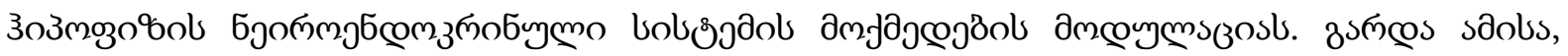

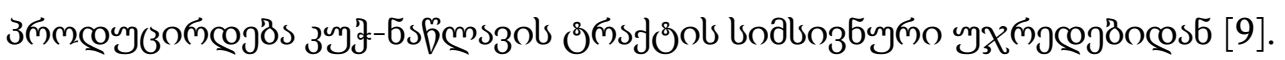

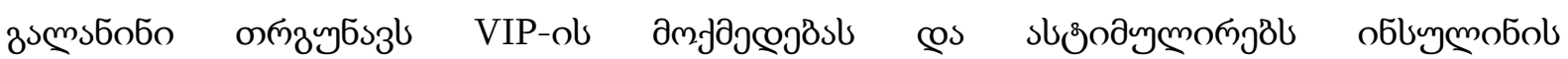

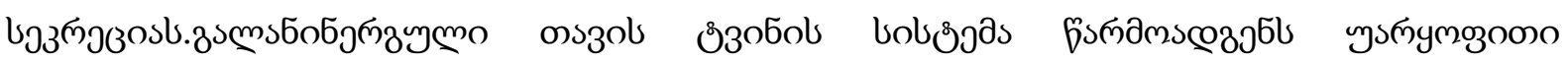

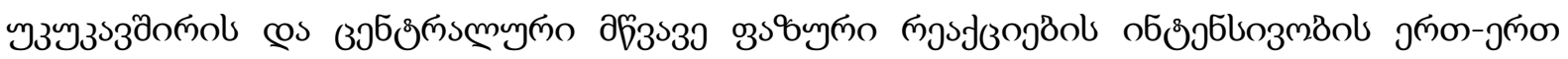

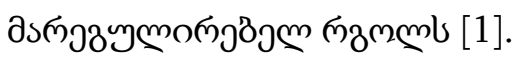

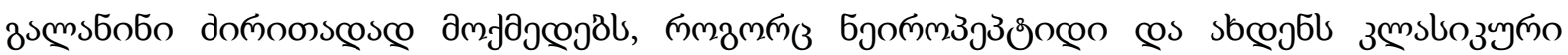

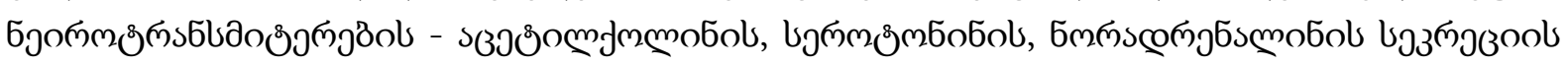

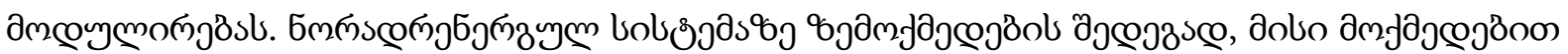

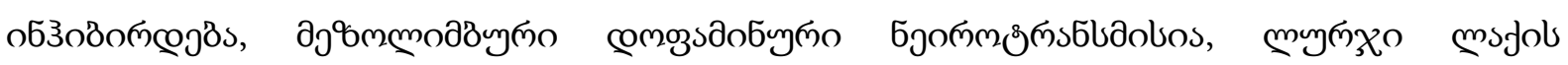

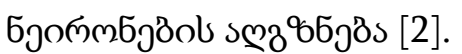

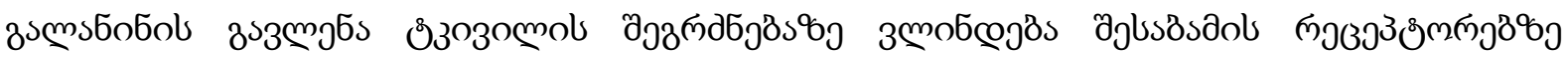

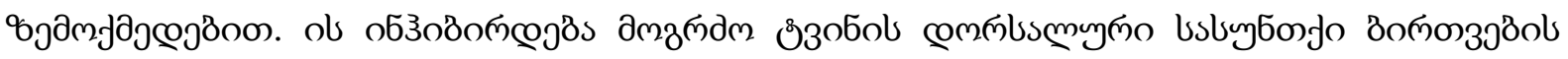

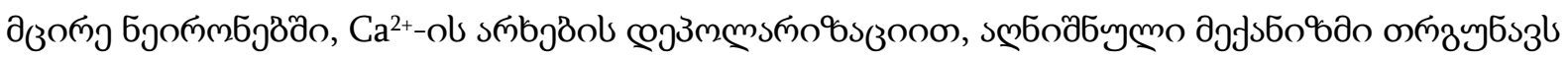

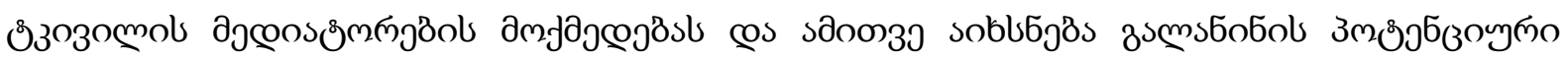

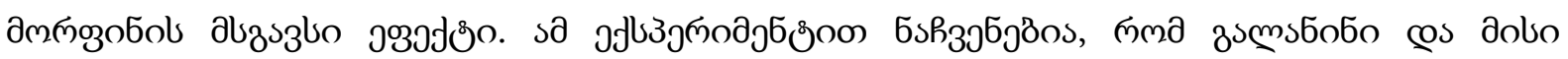

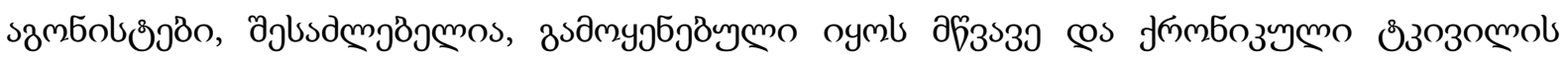

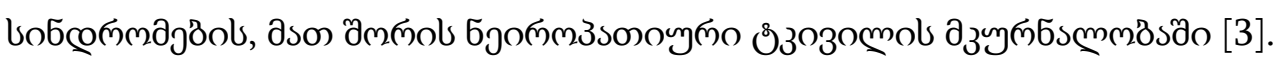

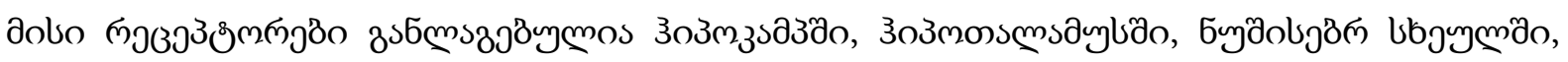

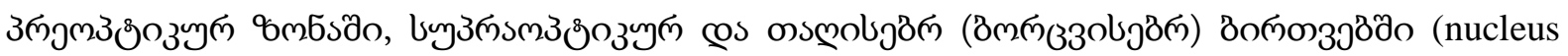

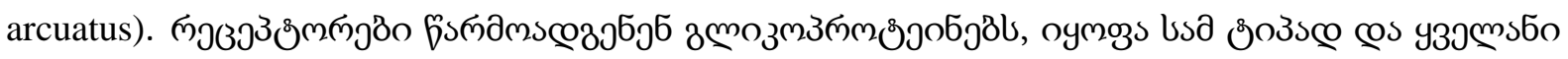

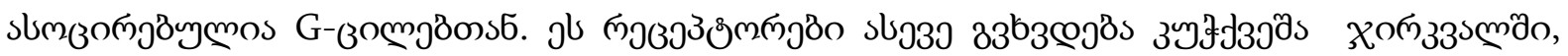

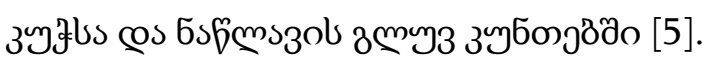




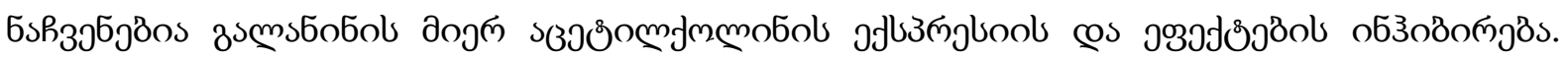

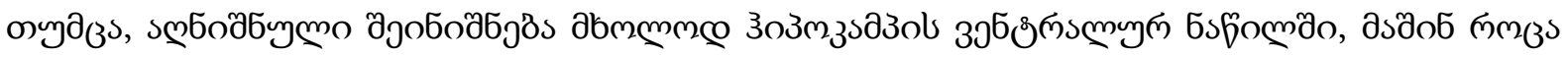

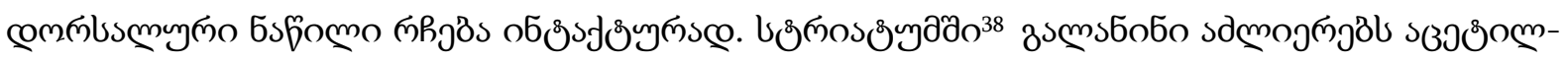

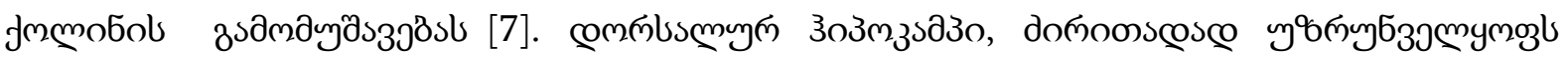

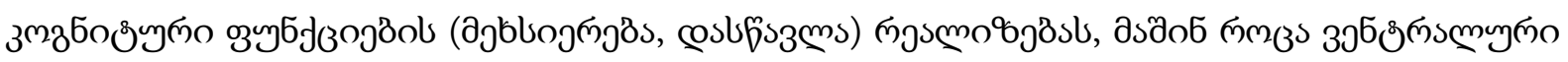

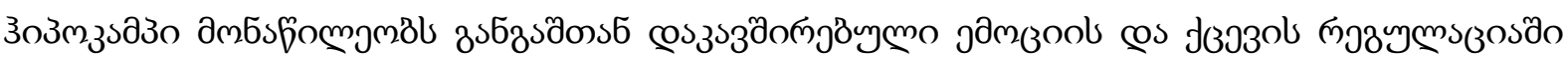

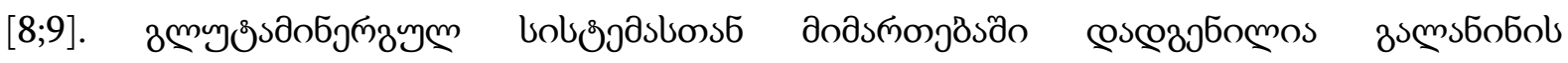

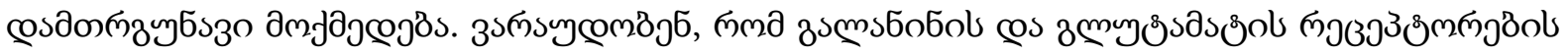

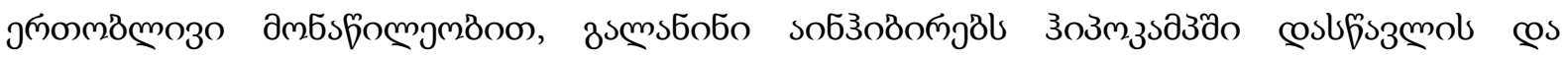

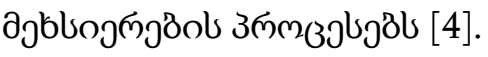

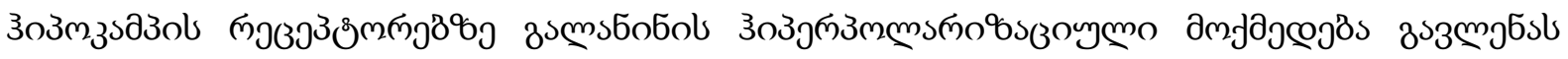

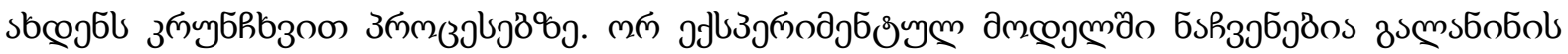

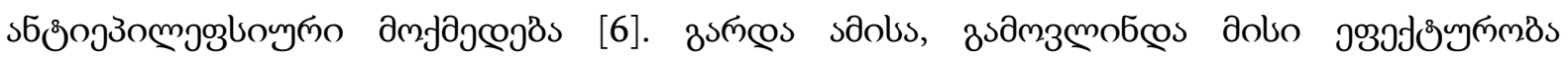

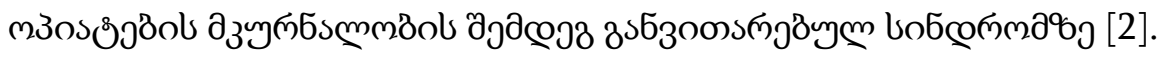

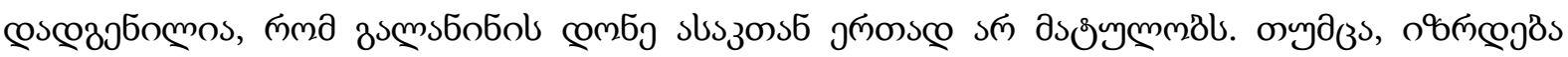

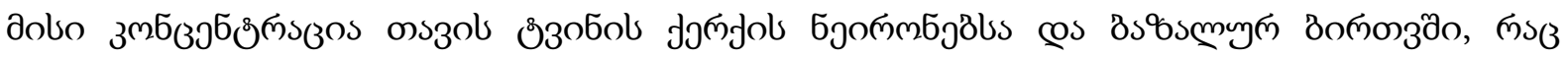

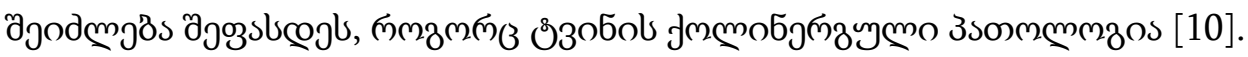

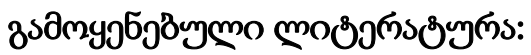

1. Constantin, S. Galanin Activates G Protein Gated Inwardly Rectifying Potassium Channels and Suppresses Kisspeptin-10 Activation of GnRH Neurons / S. Constantin, S. Wray // Endocrinology.-2016 Aug;157(8).-P.3197-3212. doi: 10.1210/en.2016-1064

2. Lang, R. Physiology, signaling, and pharmacology of galanin peptides and receptors: three decades of emerging diversity / R. Lang, A.L. Gundlach, F.E. Holmes [et al] // Pharmacol Rev. 2015.-67(1).-P. 118-175.

3. Lawrence J. M. The Mechanism of Action of the Neuropeptide Galanin, with Special Reference to Nociception // RMIT University, Melbourne: 2014. - P. 45-76.

4. Lyu, C. A preliminary study on DRGs and spinal cord of a galanin receptor 2-EGFP transgenic mouse / C. Lyu, S. Xia, G. Lyu // Neuropeptides. 2020 Feb;79:102000. doi: 10.1016/j.npep.2019.102000.

5. Messanvi, F. Fronto-temporal galanin modulates impulse control / F. Messanvi, A. Perkins, J. Hoffmann [et al] // Psychopharmacology (Berl). 2020 Feb;237(2).-P.291-303. doi: 10.1007/s00213-019-05365-2.

6. Metcalf, C.S. Preclinical evaluation of intravenous NAX 810-2, a novel GalR2-preferring analog, for anticonvulsant efficacy and pharmacokinetics / C.S. Metcalf, B.D. Klein, D.R. McDougle // Epilepsia. 2017.- Feb;58(2).-P. 239-246. doi: 10.1111/epi.13647.

7. Millón, C. The neuropeptides Galanin and Galanin(1-15) in depression-like behaviours / C.Millón, A. Flores-Burgess, M. Narváez // Neuropeptides. 2017.- Aug;64. -P. 39-45. doi: 10.1016/j.npep.2017.01.004.

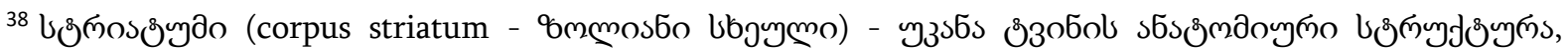

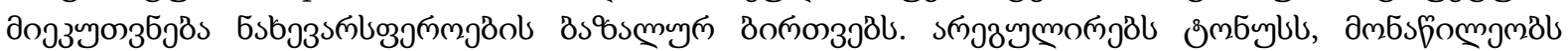

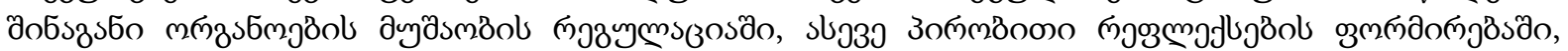

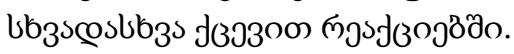


8. Pepeu, G. The fate of the brain cholinergic neurons in neurodegenerative diseases / G. Pepeu, M. Grazia Giovannini // Brain Res. 2017.- Sep 1;1670.-P. 173-184. doi: 10.1016/j.brainres.2017.06.023.

9. sipkova J. The galanin and galanin receptor subtypes, its regulatory role in the biological and pathological functions / J. Sipková, I. Kramarikova, S. Hynie // Physiol Res.- 2017, Nov 24;66(5).-P. 729-740.

10. Tripp, J.A. Mating Behavioral Function of Preoptic Galanin Neurons Is Shared between Fish with Alternative Male Reproductive Tactics and Tetrapods / J.A. Tripp, I. Salas-Allende, A. Makowski // J Neurosci.-2020 Feb 12;40(7).- P.1549-1559. doi: 10.1523/JNEUROSCI.127619.2019.

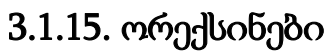

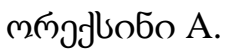

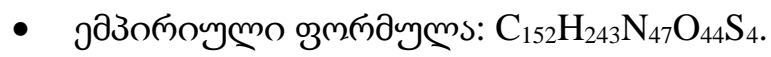

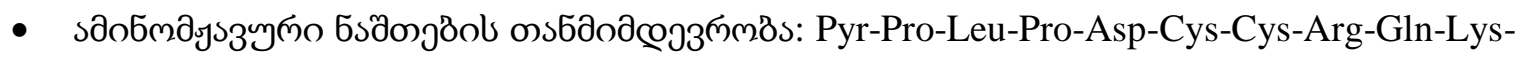
Thr-Cys-Ser-Cys-Arg-Leu-Tyr-Glu-Leu-Leu-His-Gly-Ala-Gly-Asn-His-Ala-Ala-Gly-IleLeu-Thr-Leu-NH 2 .

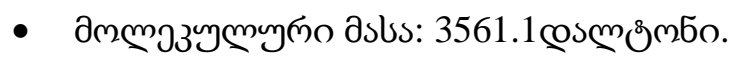

м๓勺วلlo6oB.

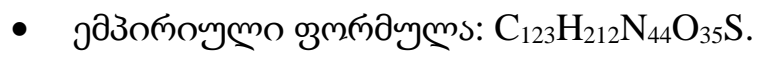

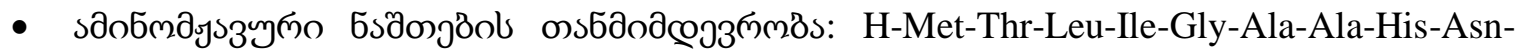
Gly-Ser-Ala-Gln-Leu-Leu-Arg-Gln-Leu-Arg-Gly-Gln-Leu-Gly-Pro-Pro-Gly-Ser-Arg-NH $\mathrm{N}_{2}$.

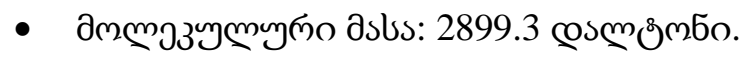

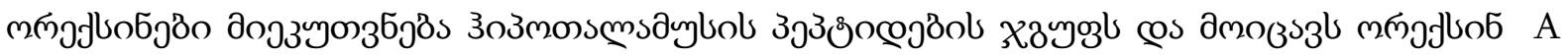

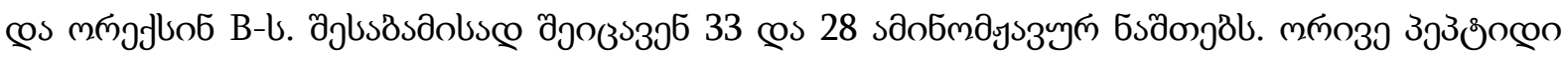

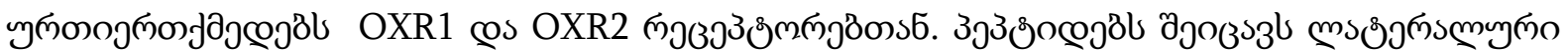

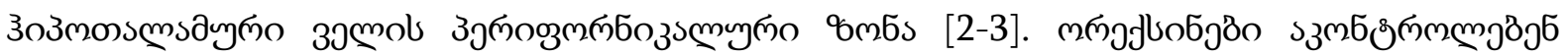

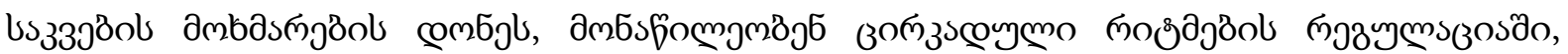

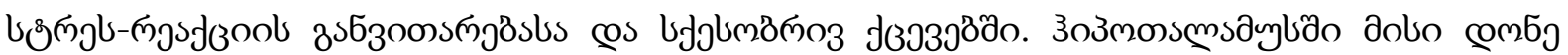

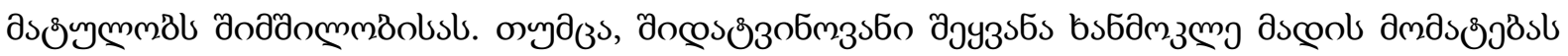

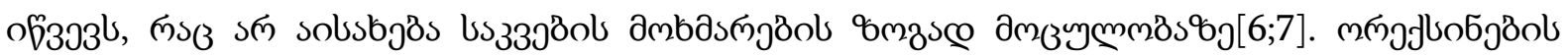

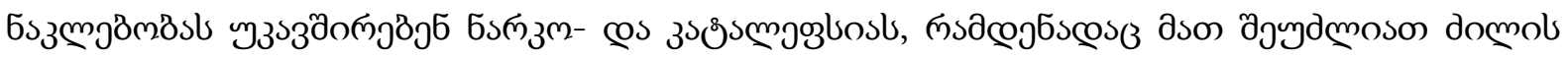

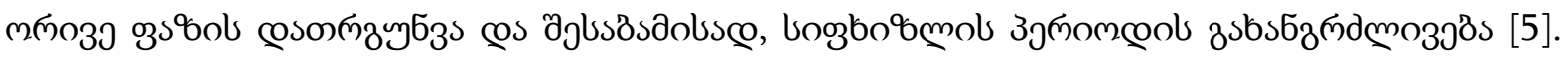

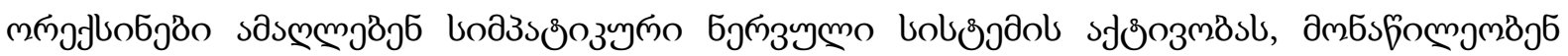

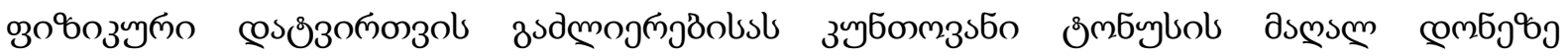

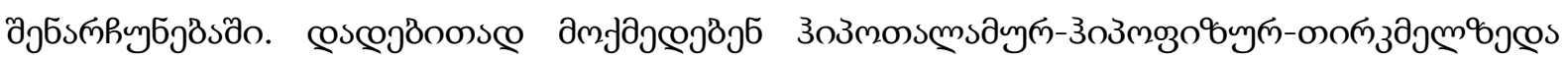

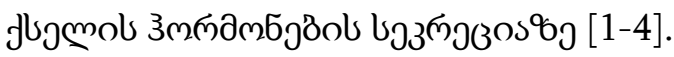

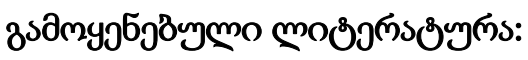

1. Date Y., Mondal M. S., Matsukura S. et al. Distribution of orexin/hypocretin in the rat median eminence and pituitary // Brain Res Mol Brain Res. 2000. Vol. 76. P. 1-6. 
2. Date Y., Ueta Y., Yamashita H., Yamaguchi H. et al. Orexins, orexigenic hypothalamic peptides, interact with autonomic, neuroendocrine and neuroregulatory systems.//Proc Natl Acad Sci USA. 1999. Vol. 96. P. 748-753.

3. Horvath T. L., Peyron C., Diano S., Ivanov A. et al. Hypocretin (orexin) activation and synaptic innervation of the locus coeruleus noradrenergic system // J Comp Neurol. 1999. Vol. 415. P. 145-159.

4. Mondal M. S., Nakazato M., Date Y. et al. Widespread distribution of orexin in rat brain and its regulation upon fasting // Biochem Biophys Res Commun. 1999. Vol. 256. P. 495-499

5. Mignot E., Taheri S., Nishino S. et al. Sleeping with the hypothalamus: emerging therapeutic targets for sleep disorders // Nature Neuroscience. 2002. Vol. 5. P. 1071-1075.

6. Moriguchi T., Sakurai T., Nambu T. et al. Neurons containing orexin in the lateral hypothalamic area of the adult rat brain are activated by insulin-induced acute hypoglycemia // Neurosci Lett. 1999. Vol. 264. P. 101-104.

7. Yamanaka A., Tsujino N., Funahashi H. et al. Orexins activate histaminergic neurons via the orexin 2 receptor // Biochem Biophys Res Commun. 2002. Vol. 290. P. 1237-1245.

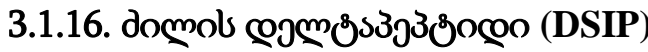

- јазопочумо озмпаулмз: $\mathrm{C}_{35} \mathrm{H}_{48} \mathrm{~N}_{10} \mathrm{O}_{15}$.

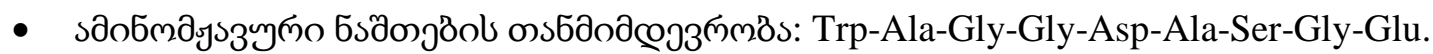

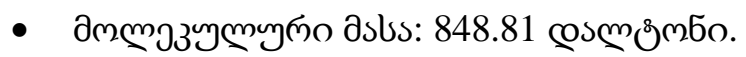

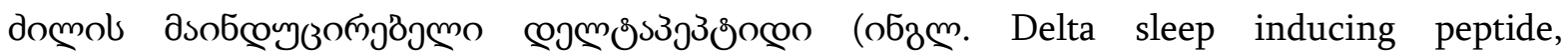

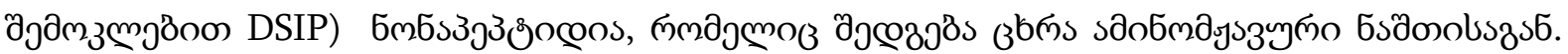

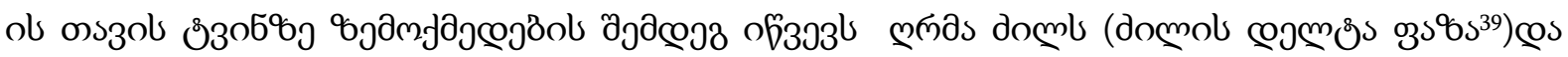

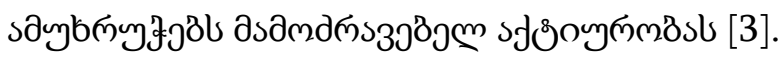

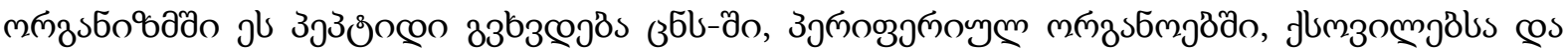

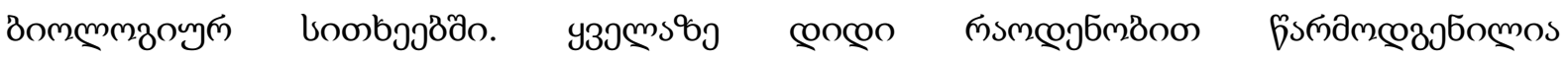

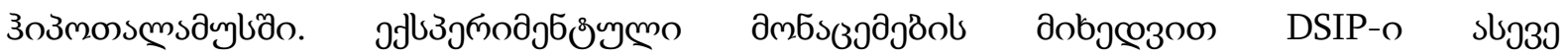

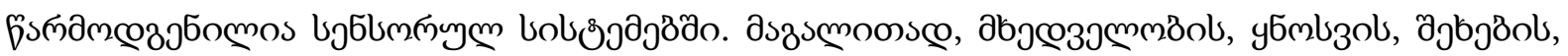

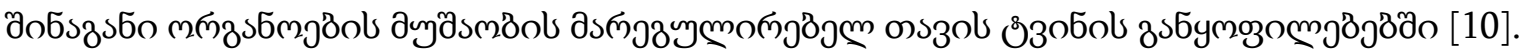

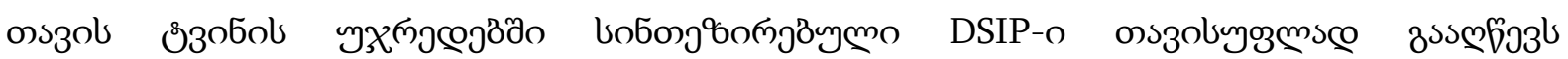

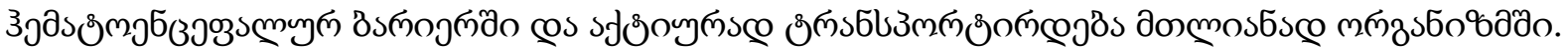

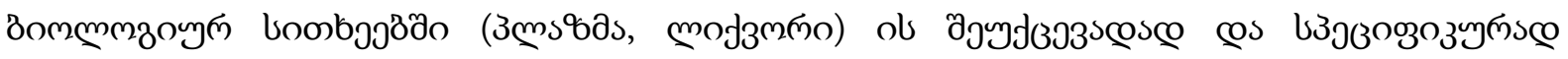

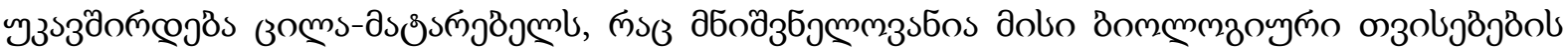

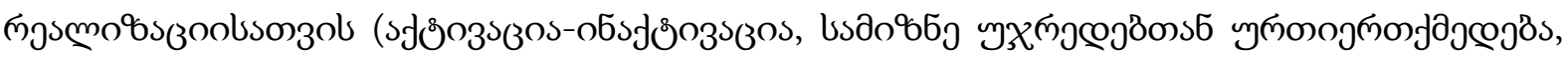

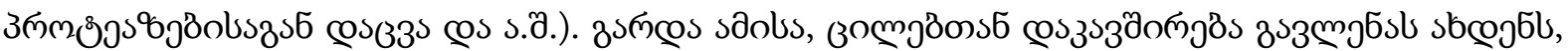

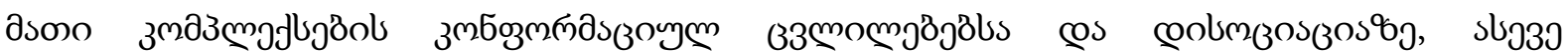

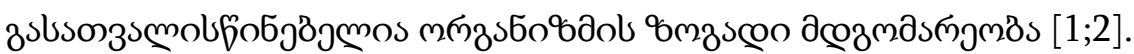

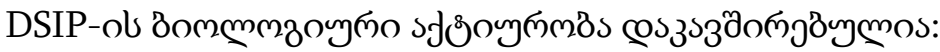

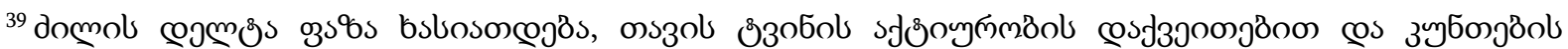

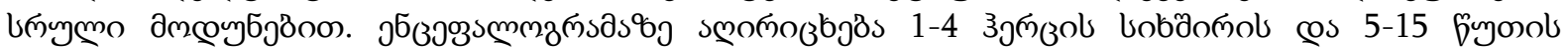

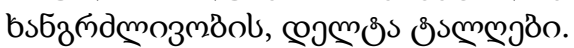




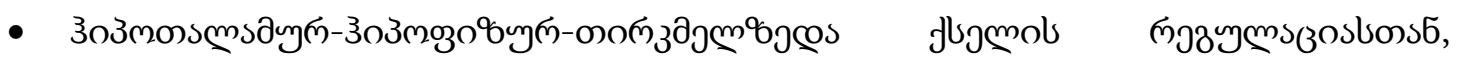

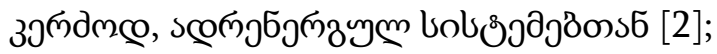

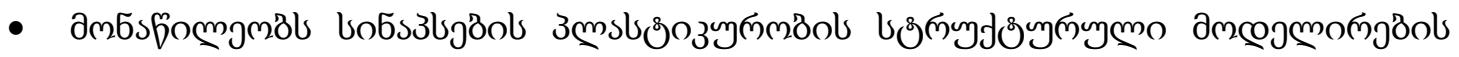

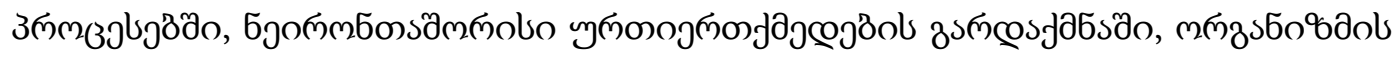

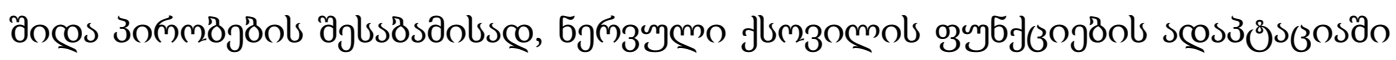
[5-9];

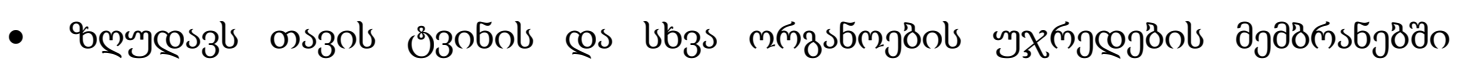
sলু

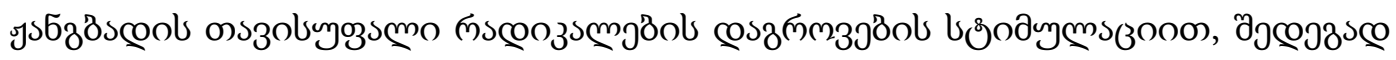

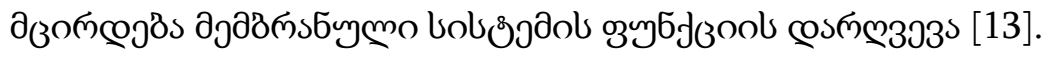

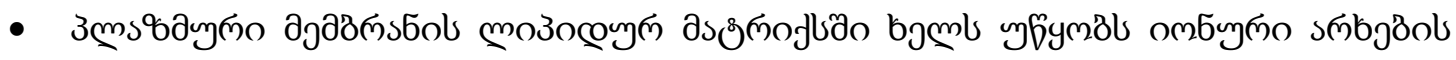

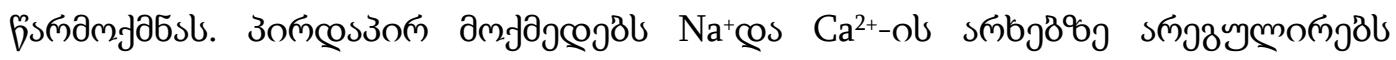

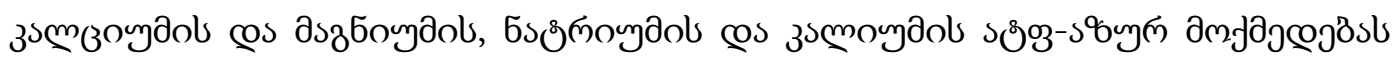
[13].

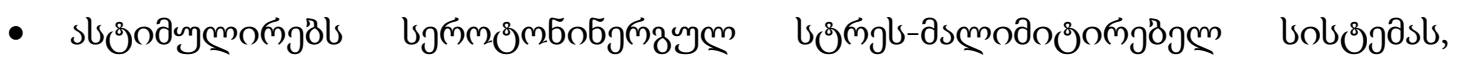

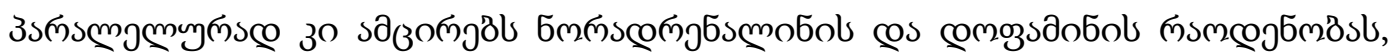

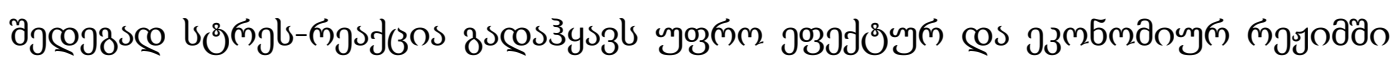
$[4 ; 8 ; 12]$.

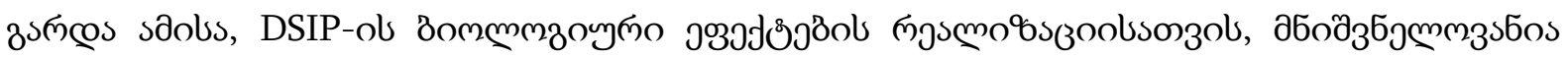

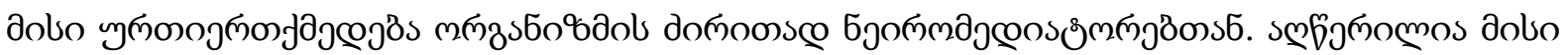

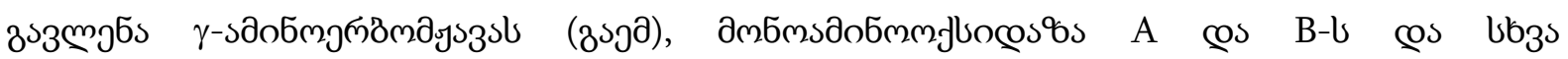

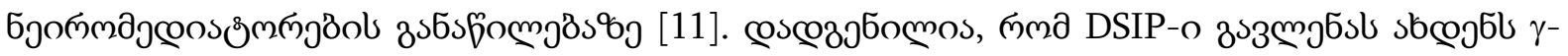

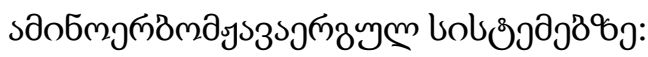

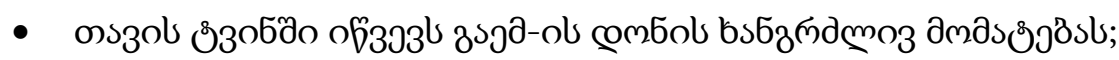

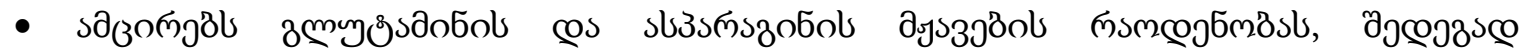

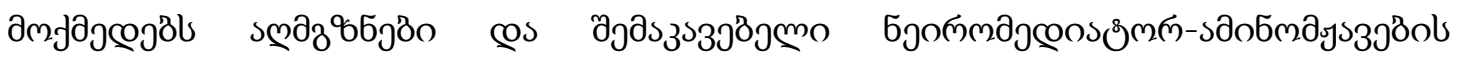
Bsms6b\%g;

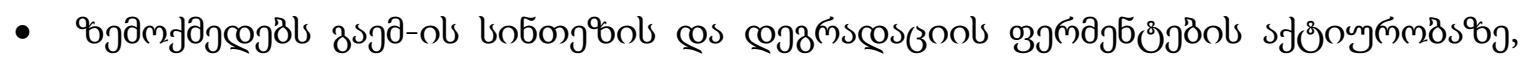

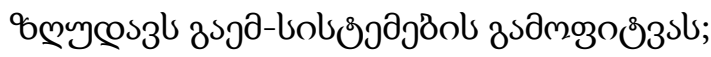

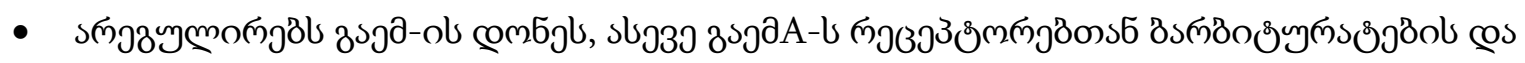

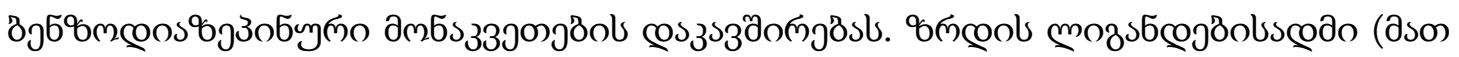

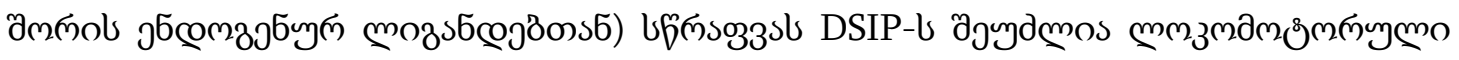

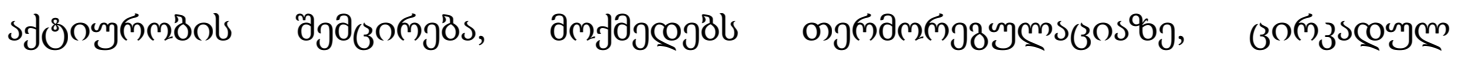

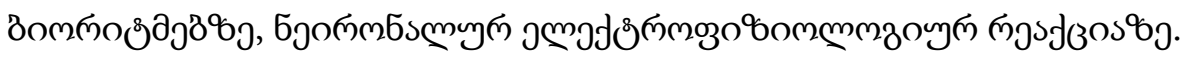

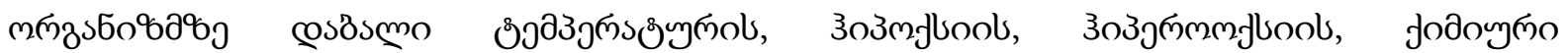

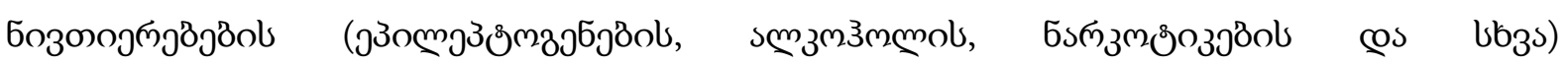

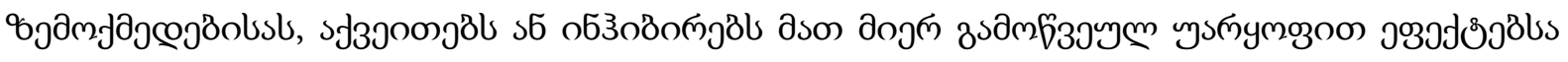

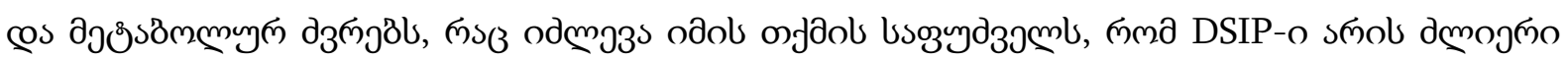

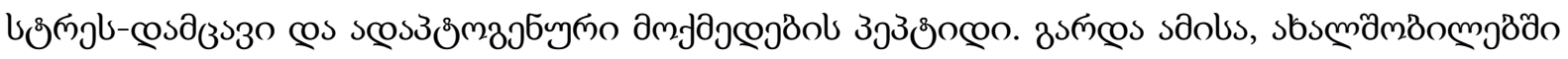

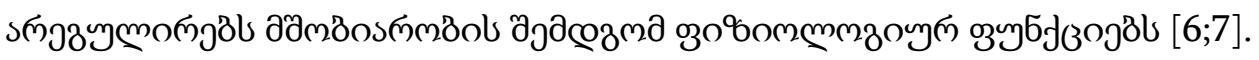




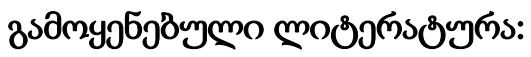

1. Bjartell, A. Delta-sleep inducing peptide: a Mammalian regulatory peptide / A. Bjartell. Lund: Grahns Boktrycker. - 1990. - P.9-42.

2. Bjartell, A. Immunoreactive delta sleep-inducing peptide in the rat hypothalamus, pituitary and adrenal gland: effects of adrenalectomy / A. Bjartell, F. Sundler, R. Ekman // Horm. Res. - 1991. - Vol.36, B1-2. - P.52-62.

3. Graf, M.V. Delta sleep-inducing peptide (DSIP)-like material exists in peripheral organs of rats in large dissociable forms / M.V. Graf, A.J. Kastin // Proc. Soc. Exp. Biol. Med. - 1984. Vol.177, B1. - P.197-204

4. Gershtein, L.M. Regulation by delta-sleep-inducing peptide of the neurochemical changes in the brain associated with dopaminergic system hyperactivity / L.M. Gershtein, E.L. Dovedova // Neurochem. Res. - 1999. - Vol.24, B9. - P.1135-1141.

5. Matsionis, A. Morphometric analysis of synaptic plasticity of sensorimotorcortex under neuropeptidal correction of hypo- and hyperoxic damages /A. Matsionis, I. Pavlov, G. Kuraev [et al] // International Journal of DevelopmentalNeuroscience. - 1996. - Vol.14, B51. - P.84.

6. Najimi, M. Immunohistochemical distribution of DSIPimmunoreactivityin the human hypothalamus during the first postnatal year / M. Najimi, M. Bennis, E.Moyse [et al.] // A preliminary report. Folia Biol. (Praha). - 2001. - Vol.47, B2. -P.66-70.

7. Najimi, M. Distribution of delta sleep-inducing peptide in the newbornand infant human hypothalamus: an immunohistochemical study / M. ajimi,M. Bennis, E. Moyse [et al.] // Biol. Res. - 2001. - Vol.34, B1. - P.31-42.

8. Pollard, B.J. Delta sleep-inducing peptide / B.J. Pollard, C.J. Pomfrett //Eur. J. Anaesthesiol. - 2001. - Vol.18, B7. - P.419-422.139. Yehuda, S. DSIP a tool for investigating the sleep onset mechanism: a review / S. Yehuda, R.L. Carasso // Int. J. Neurosci. - 1988. - Vol.8, B34. - P.345-353.

9. Povilaititc, P. Morphological basis of delta-sleep inducing peptide antistressoryaction: ultrastructural changes of axospinous synapses / P. Povilaititc,A. Matsionis, I. Pavlov [et al.] // International Journal of Developmental Neuroscience.- 1996. - Vol.14, B51. - P.85.

10. Schoenenberger, G.A. Characterization of a delta-electroencephalogram (-sleep)-inducing peptide / G.A. Schoenenberger, M. Monnier // Proc. Natl. Acad. Sci.USA. - 1977. - Vol.74, B3. - P.1282-1286.

11. Sergutina, A.V. Neurochemical characteristics of the effects of deltasleep-inducing peptide in Wistar rats with hyperactivity of the dopaminergic system /A.V. Sergutina, L.M. Gershtein // Bull. Exp. Biol. Med. - 2000. - Vol.130, B11. -P.1074-1076

12. Yanagawa, Y. A novel sodium channel inhibitor from Conus geographus: purification, structure, and pharmacological properties / Y. Yanagawa, T. Abe, M. Satake [et al.] // Biochemistry. - 1988. - Vol.27, B17. - P.6256-6262.

13. Zhang, S. Spontaneous assembly of a self-complementary oligopeptide to form a stable macroscopic membrane / S. Zhang, T. Holmes, C. Lockshin, A. Rich //Proc. Natl. Acad. Sci. USA. - 1993. - Vol.90, B8. - P.3334-3338. 


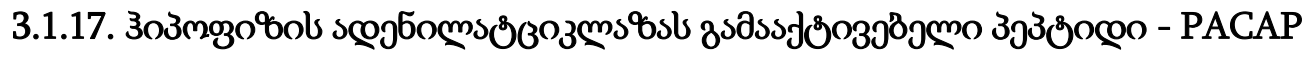

- jазополупо озмпдулмп: $\mathrm{C}_{203} \mathrm{H}_{331} \mathrm{~N}_{63} \mathrm{O}_{53} \mathrm{~S}$.

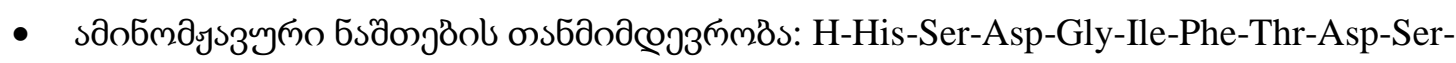
Tyr-Ser-Arg-Tyr-Arg-Lys-Gln-Met-Ala-Val-Lys-Lys-Tyr-Leu-Ala-Ala-Val-Leu-Gly-LysArg-Tyr-Lys-Gln-Arg-Val-Lys-Asn-Lys- $\mathrm{NH}_{2}$

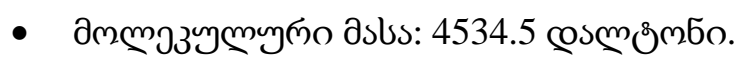

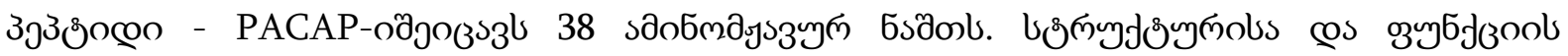

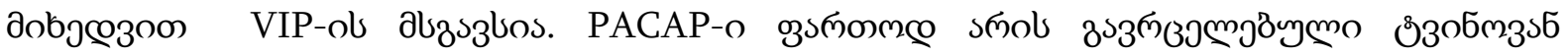

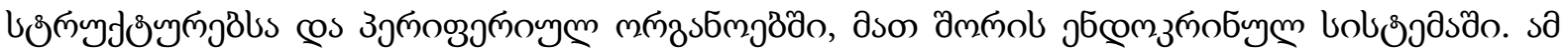

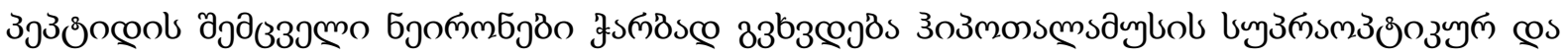

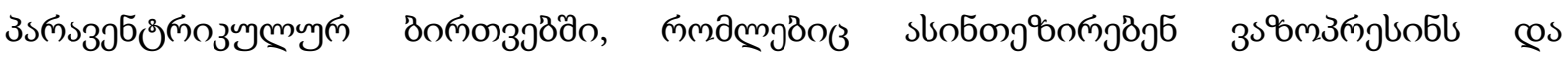

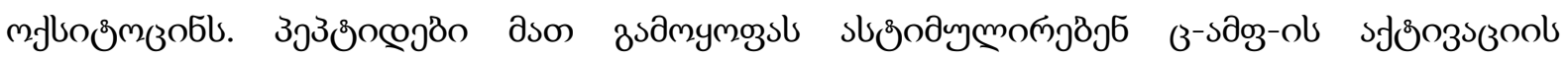

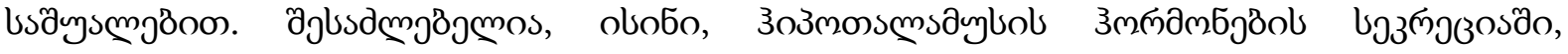

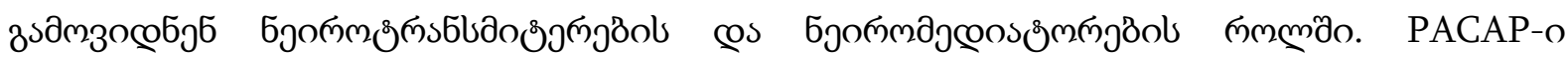

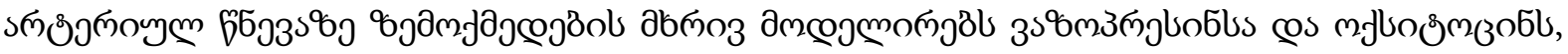

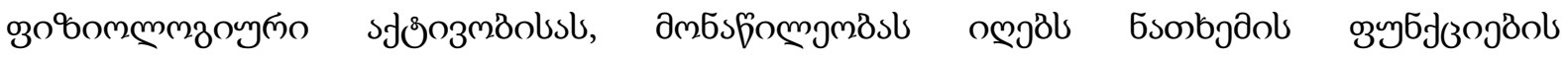

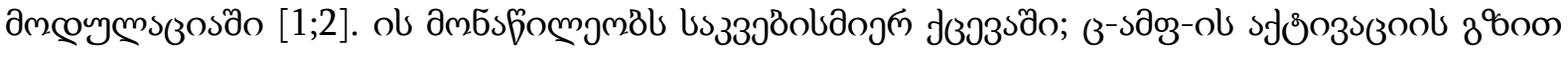

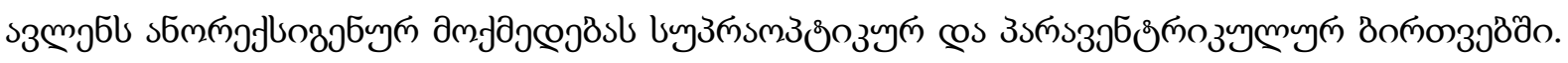

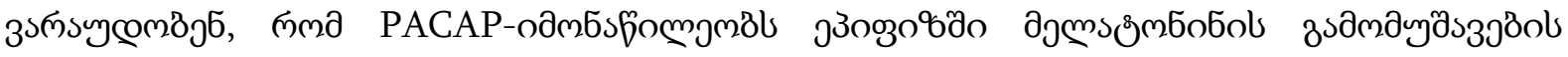

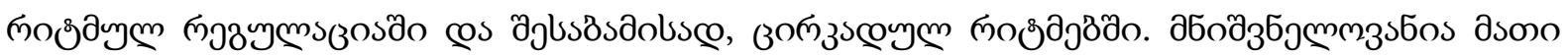
дмбsfom

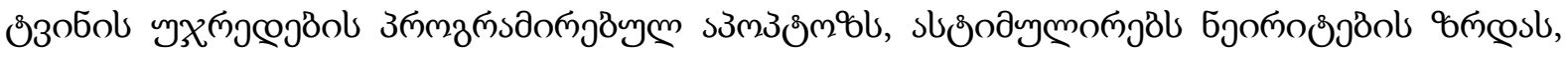

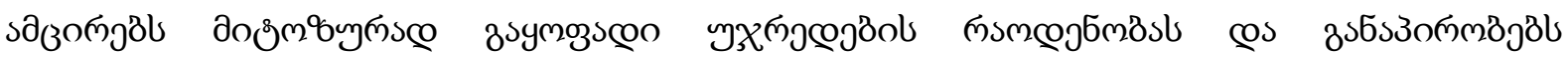

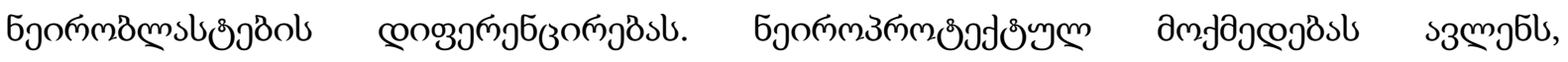

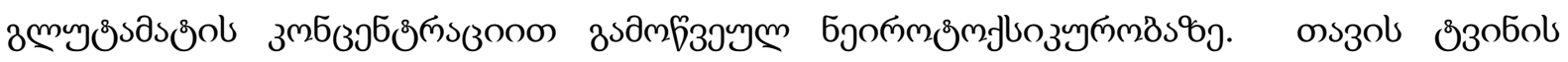

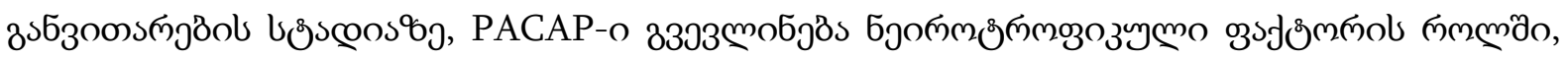

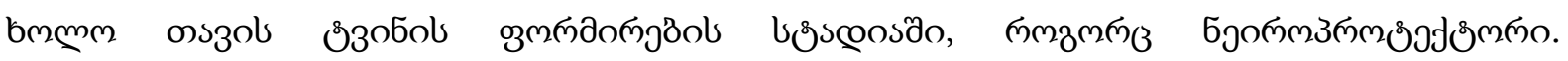

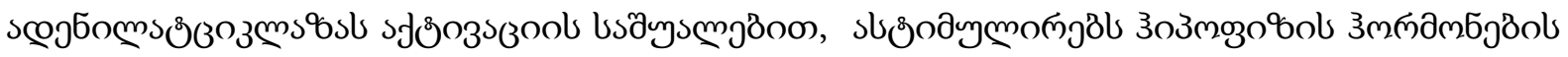
зsдmymogsl [3;4].

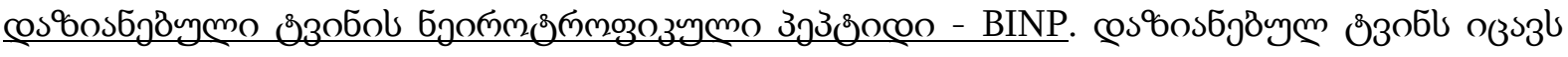

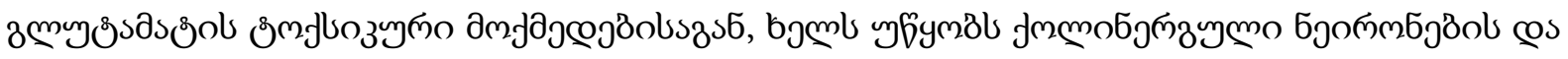

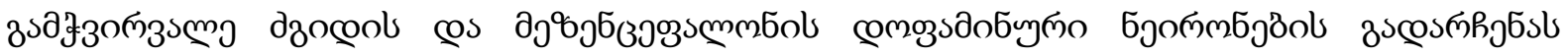

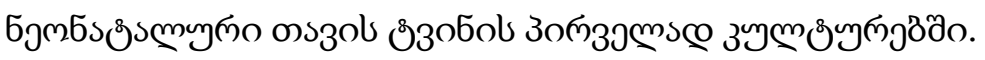

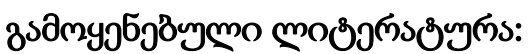

1. Cline DL, Short LI, Forster MAM, Gray SL. Adipose tissue expression of PACAP, VIP, and their receptors in response to cold stress. J Mol Neurosci. (2019) 68:427-38. doi: 10.1007/s12031-018-1099-x.

2. Miles OW, May V, Hammack SE. Pituitary Adenylate Cyclase-Activating Peptide (PACAP) 
3. ignaling and the dark side of addiction. J Mol Neurosci. (2019) 68:453-64. doi: 10.1007/s12031-018-1147-6.

4. Sherwood N.M., Krueckl S.L., McRory J.E.The Origin and Function of the Pituitary Adenylate Cyclase-Activating Polypeptide (PACAP)/Glucagon Superfamily / Endocrine Reviews. 21. Is.6. 2000. P.619-670

5. Vaudry D., Gonzalez B. J., Basille M., Yon L., Fournier A., Vaudry H. Pituitary Adenylate Cyclase-Activating Polypeptide and Its Receptors: From Structure to Functions I Pharmacologucal reviews. Vol. 52, No. 2. P.269-324.

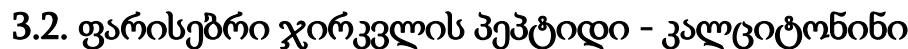

- jазополумп озмпдулмз: $\mathrm{C}_{145} \mathrm{H}_{240} \mathrm{~N}_{44} \mathrm{O}_{48} \mathrm{~S}_{2}$

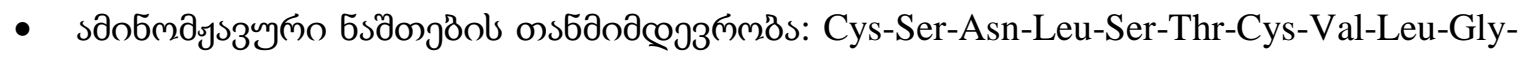
Lys-Leu-Ser-Gln-Glu-Leu-His-Lys-Leu-Gln-Thr-Tyr-Pro-Arg-Thr-Asn-Thr-Gly-Ser-GlyThr-Pro- $\mathrm{NH}_{2}$

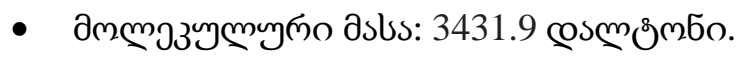

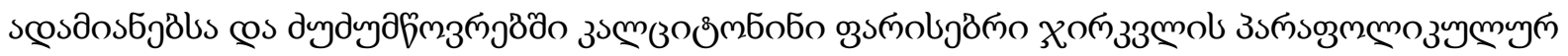

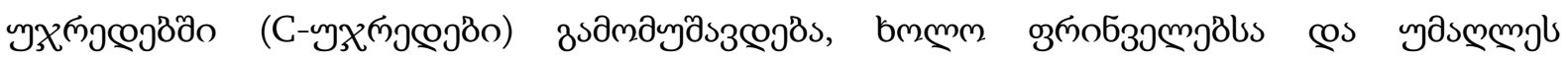

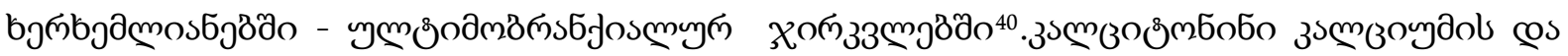

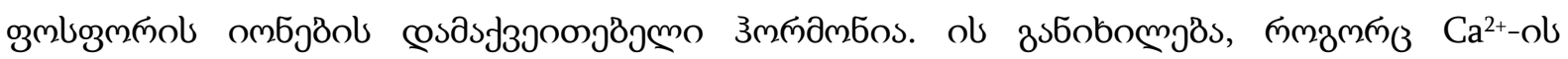

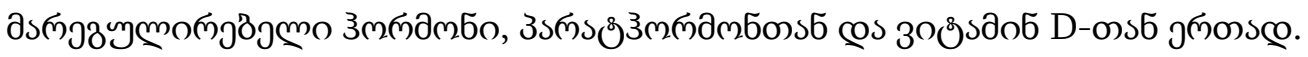

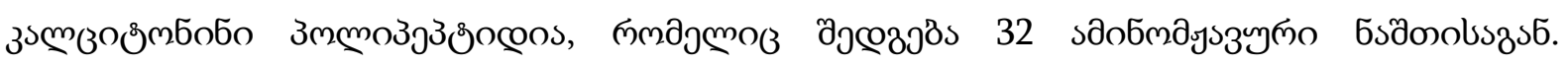

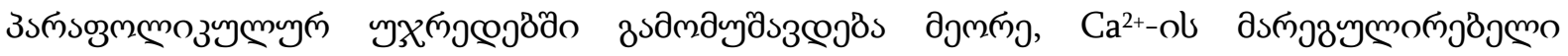

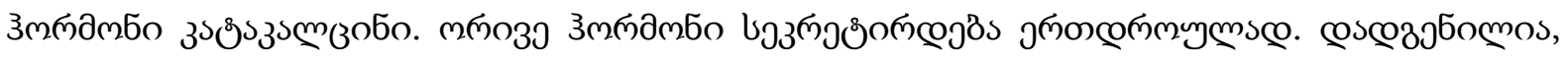

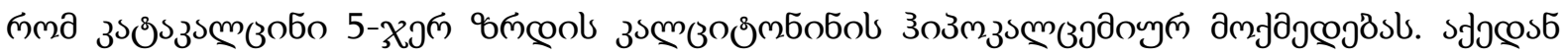

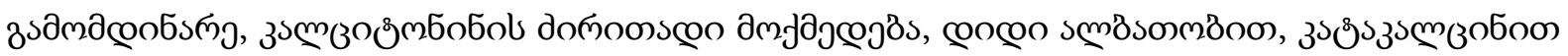

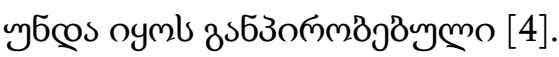

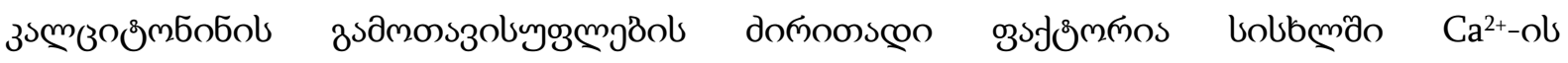

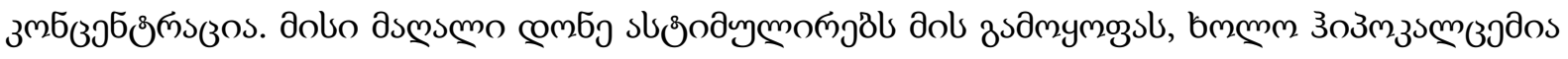

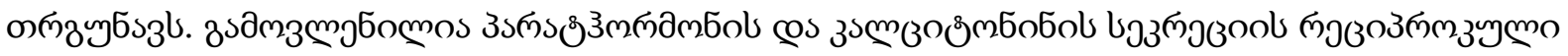

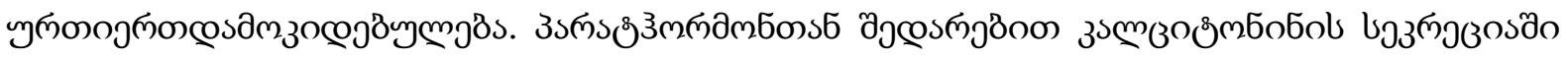

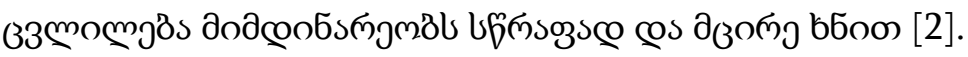

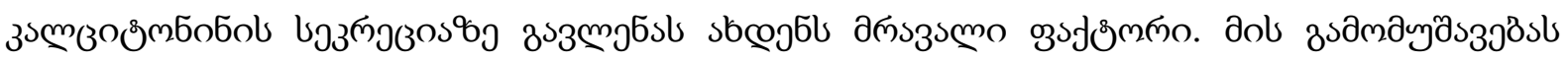

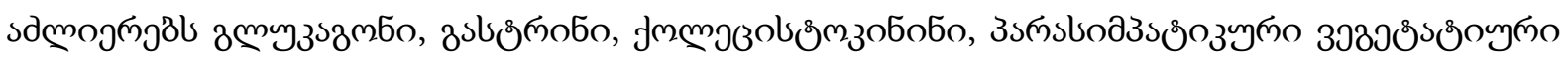

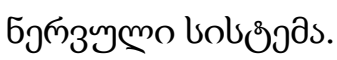

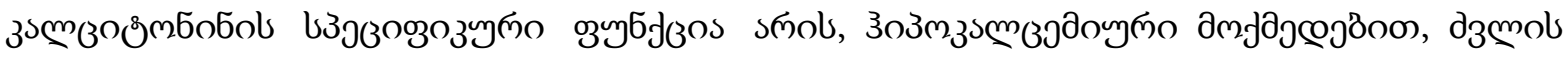

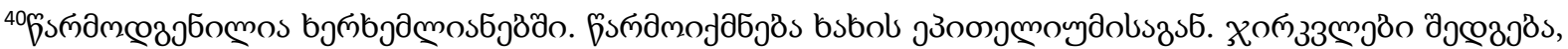

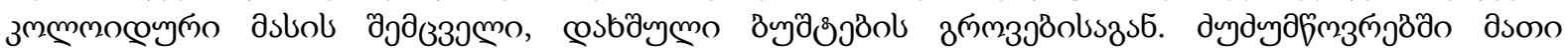

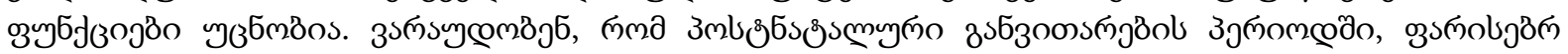

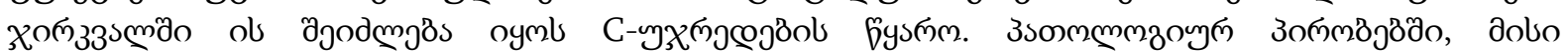

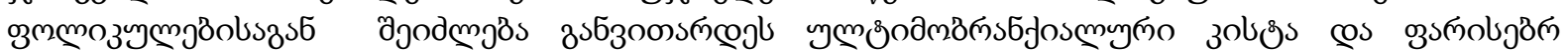

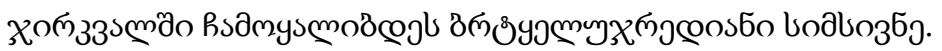




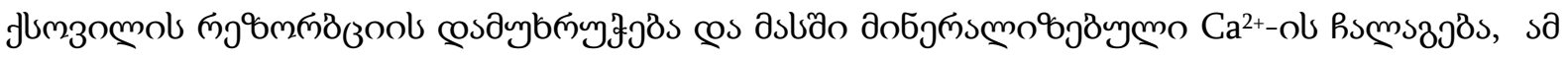

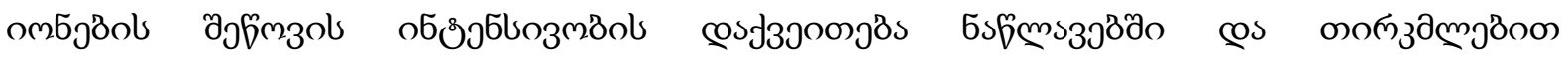

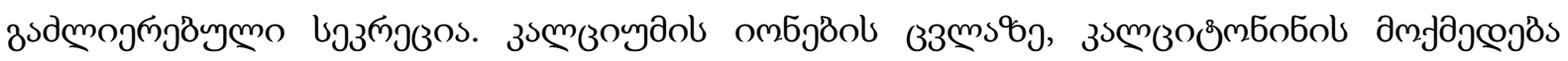

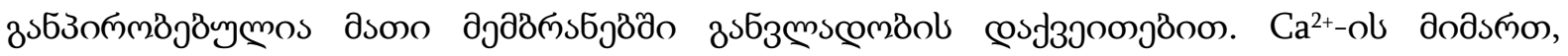

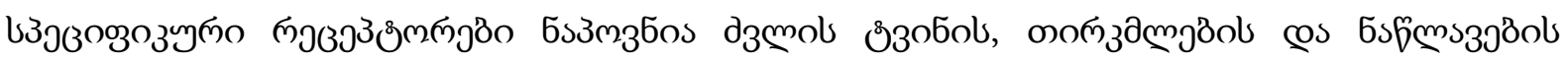

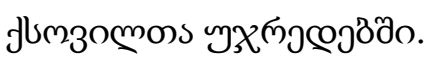

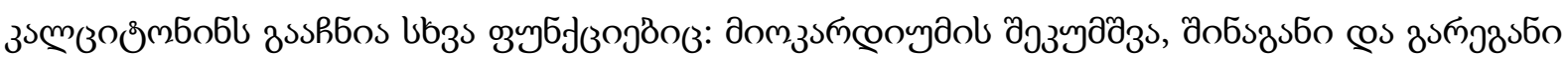

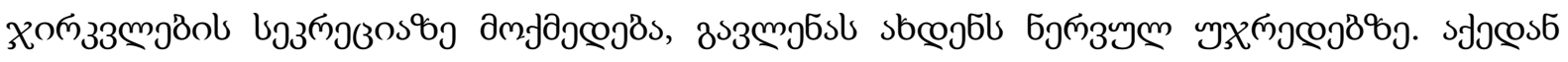

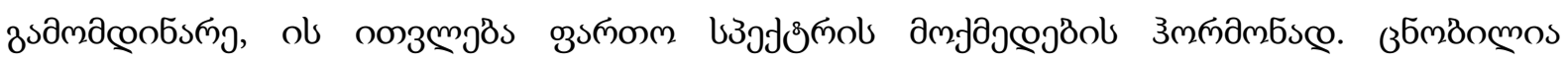

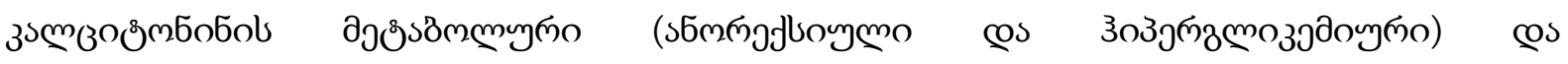

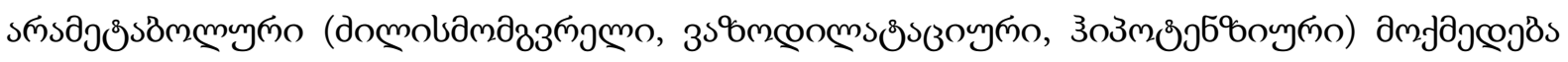
[5].

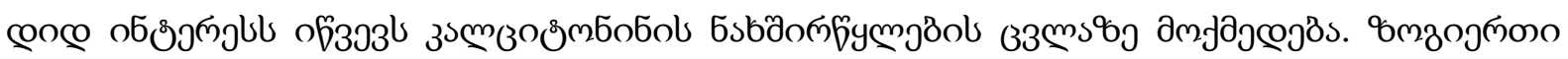

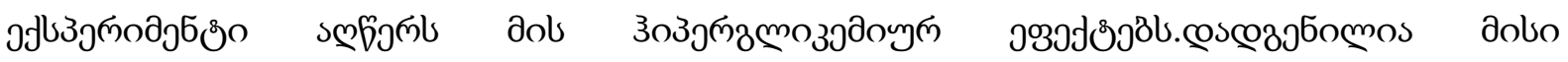

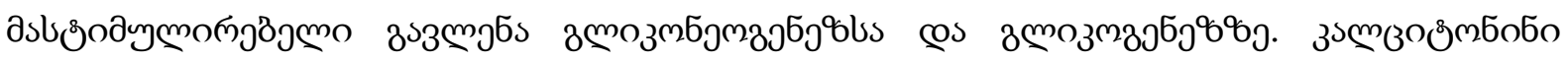

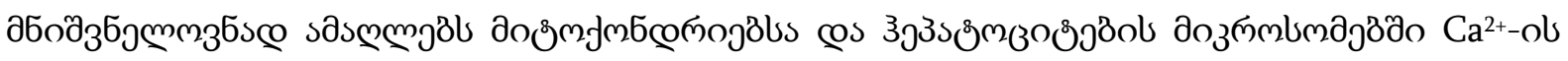

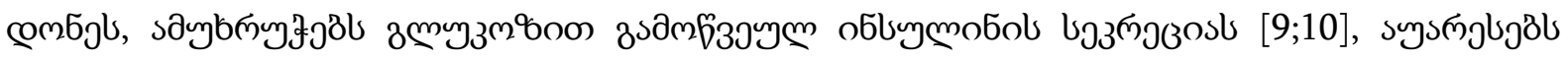

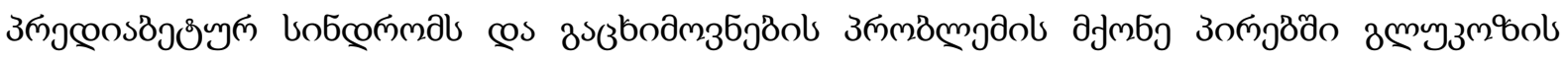

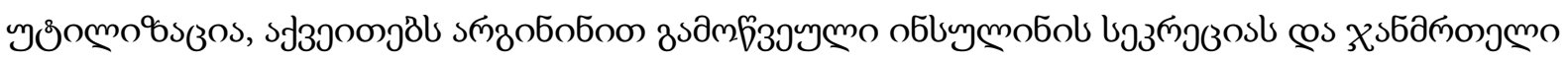

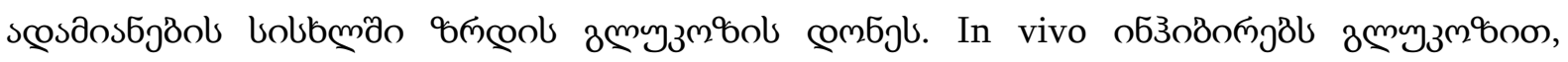

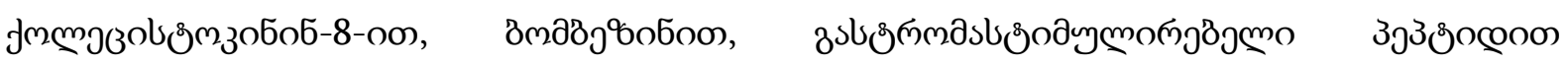

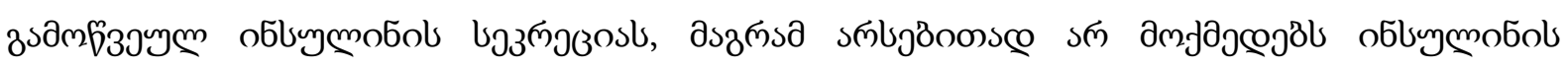

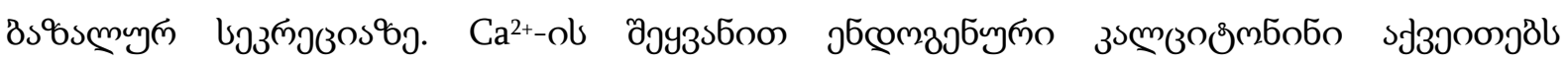

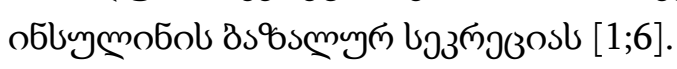

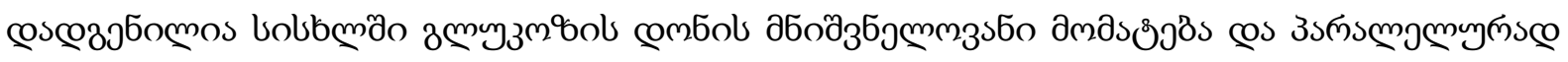

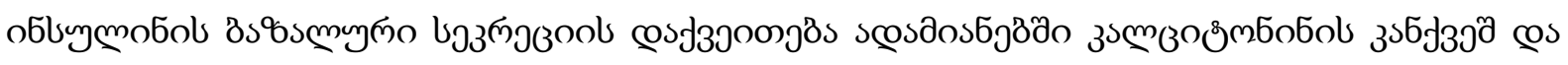

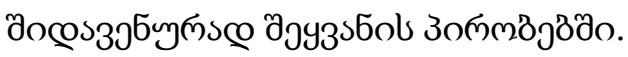

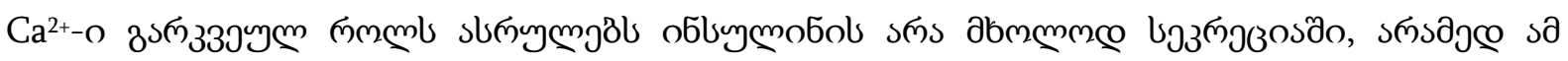

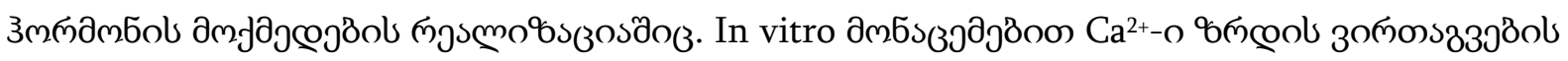

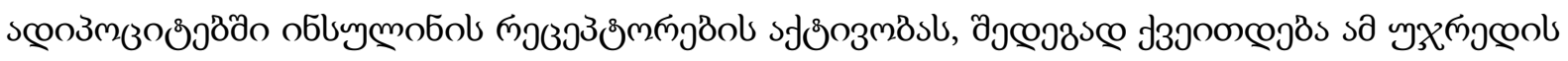

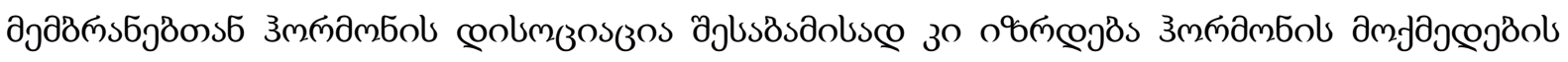

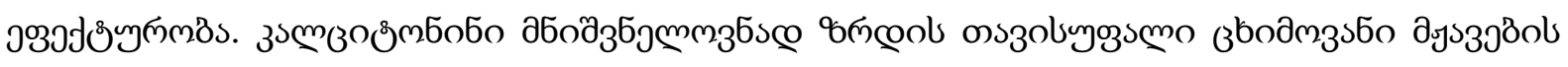

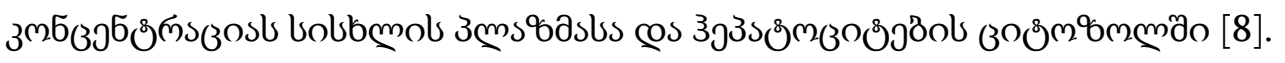

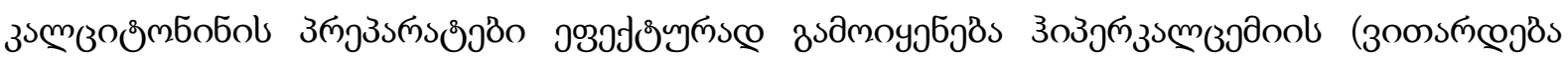

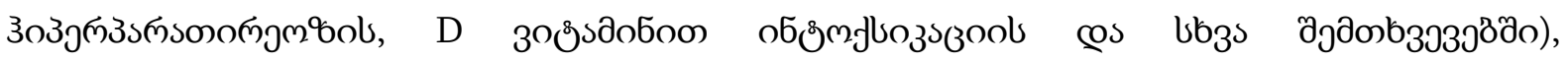

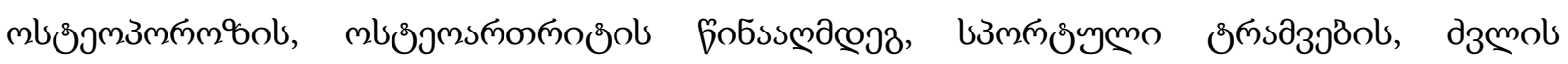

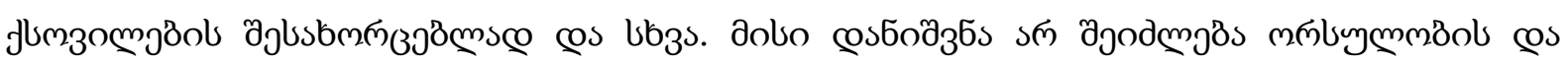

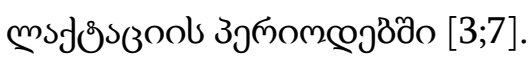




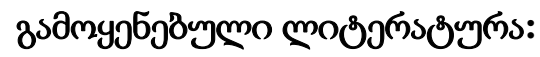

1. Alwmark A., Stavinoha M. W., Cooper C. W. et al. Calcitonin inhibition of insulin release from isolated rat pancreatic islets // Diabetes. 1986. Vol. 35. № 1. P. 58-60.

2. Erdogan M. F., Gursoy A., Kulaksizoglu M. Long-term effects of elevated gastrin levels on calcitonin secretion // J. Endocr. Invest. 2006. Vol. 29. № 5. P. 771-775.

3. Huang H., Ba Y., Cui L. et al. COL1A2 gene polymorphisms (Pvu II and Rsa I), serum calciotropic hormone levels, and dental fluorosis // Community Dent Oral Epidem. 2008. Vol. 36. № 6. P. 517-522.

4. Mac Intyre I. The physiological actions of calcitonin // Triangle. 1983. Vol. 22. № 2-3. P. 6974.

5. Moore M. C., Lin D. W., Colburn C. A. et al. Insulin-and glucagons-independent effects of calcitonin gene-related peptide in the conscious dog // Metab. Clin. Exp. 1999. Vol. 48. № 5.P. 603-610.

6. Starke A., Keck E., Berger M., Zimmermann H. Effects of calcium and calcitonin on circulating levels of glucagon and glucose in diabetes mellitus // Diabetologia. 1981. Vol. 20. № 5. P. 547-552.

7. Villa A., Guerrini M. M., Cassani B. et al. Infantile malignant, autosomal recessive osteoporosis: the rich and the poor // Calcif. Tiss. Int. 2009. Vol. 84. № 1. P. 1-12.

8. Williams P. F., Watson S. K., Turtle J. R. Lanthide interactions with the calcium binding site of the insulin receptor//Proc. Endocr. Soc. Austral. 1981. Vol. 56. № 24. P. 50.

9. Yamaguchi M., Momose K., Takahashi K. Stimulatory effect of calcitonin on fatty acid synthesis in the liver of fed rats // Horm. metab. Res. 1985. Vol. 17. № 7. P. 346-350.

10. Young A. A., Wang M. W., Gedulin B. et al. Diabetogenic effects of salmon calcitonin are attributable to amylin-like activity //Metab. Clin. Exp. 1995. Vol. 44. № 12. P. 1581-1589.

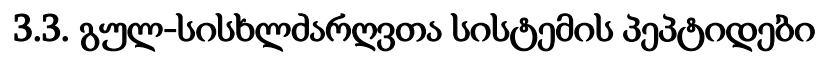

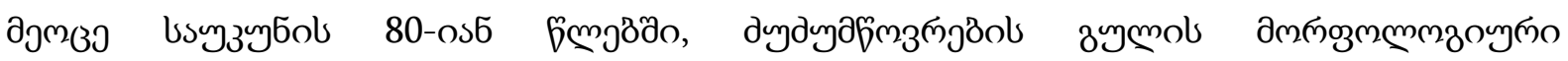

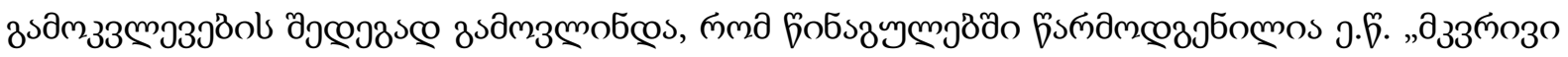

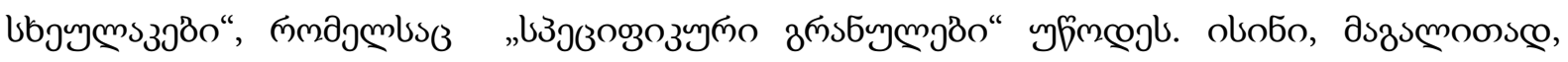

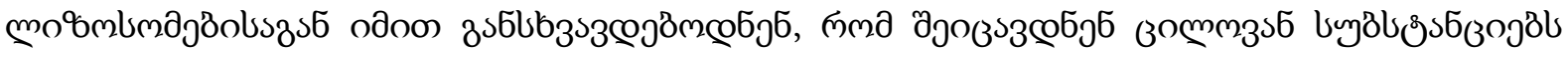

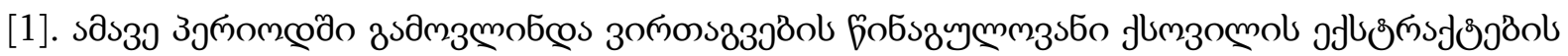

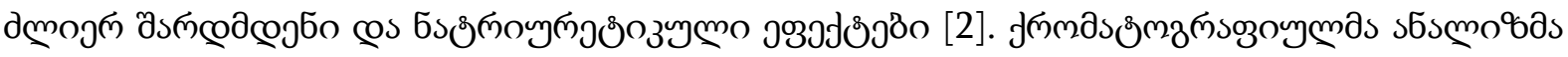

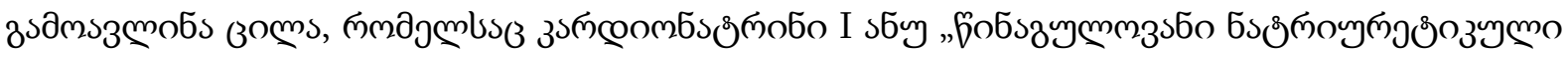

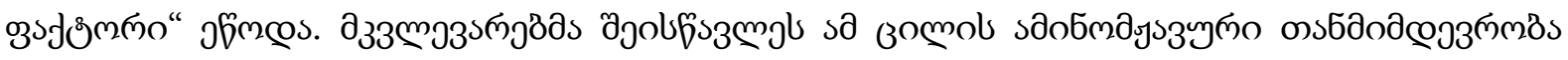

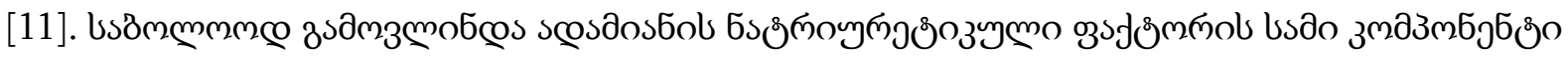

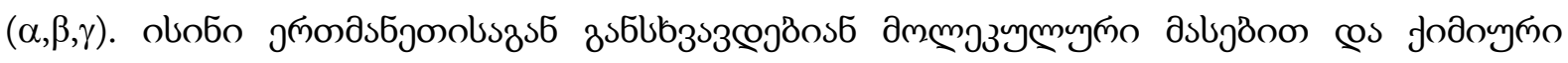

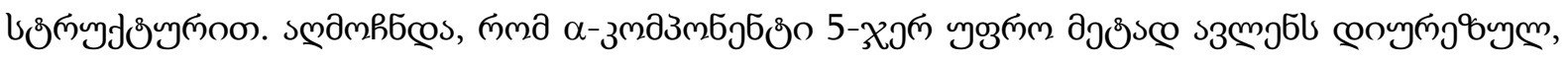

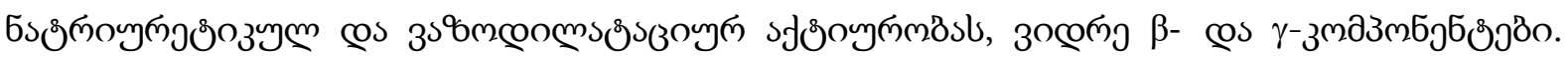

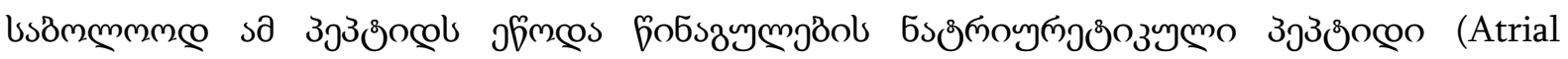
Natriuretic Peptide - ANP).

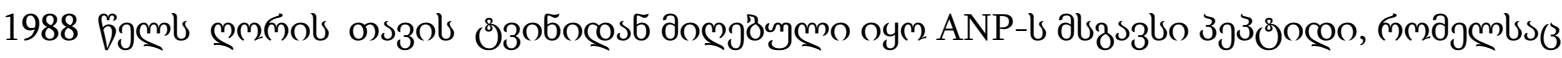




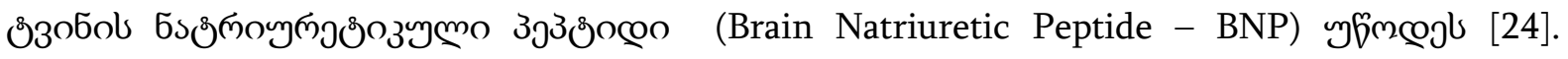

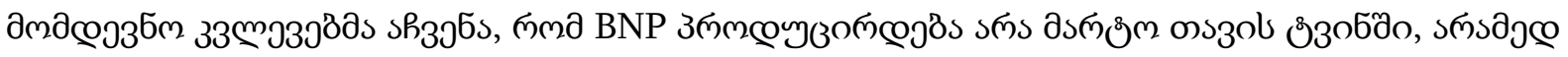

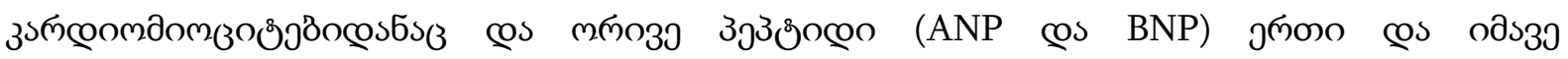

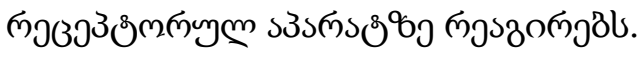

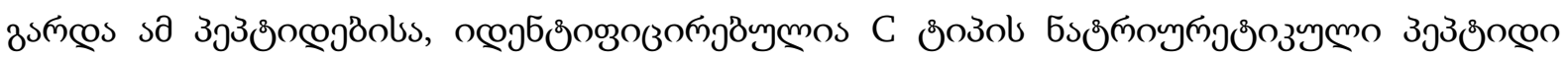

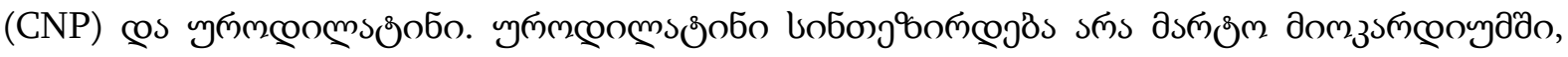

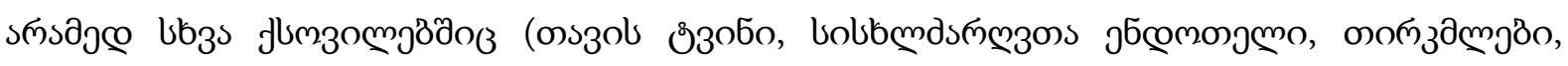

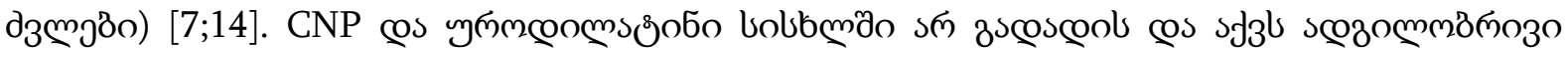

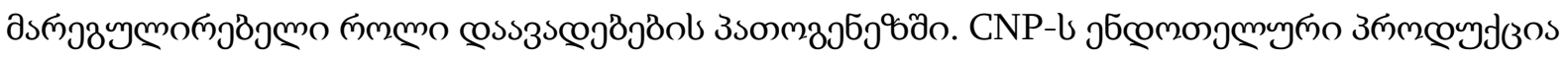

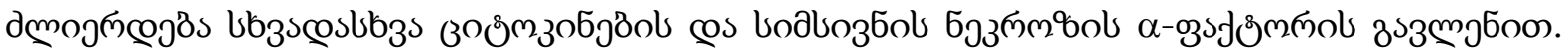

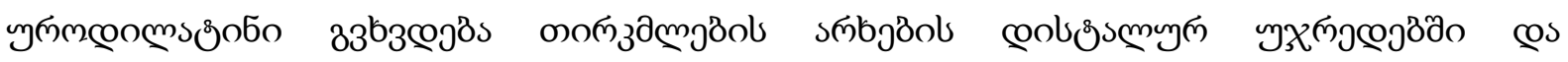

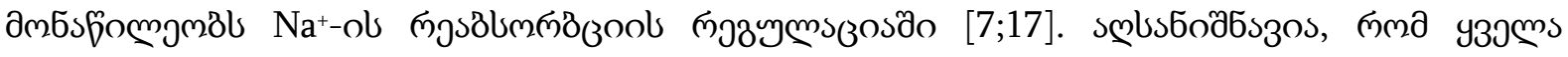

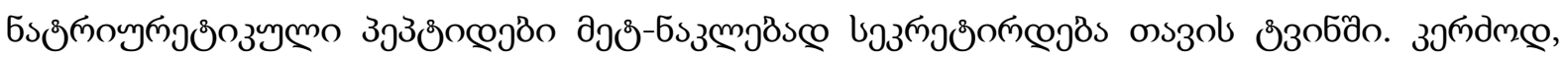

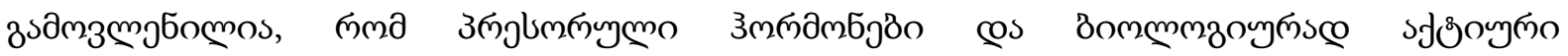

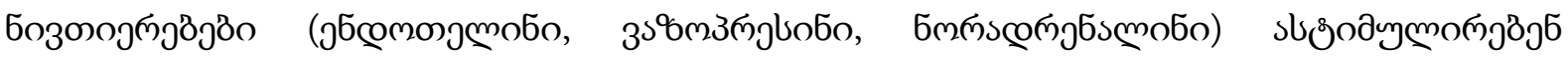

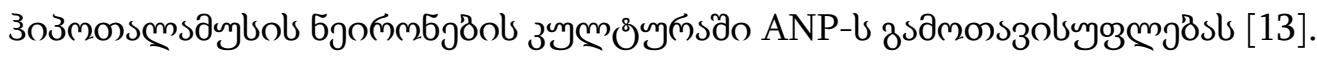

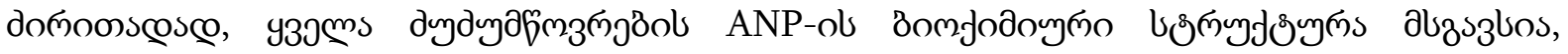

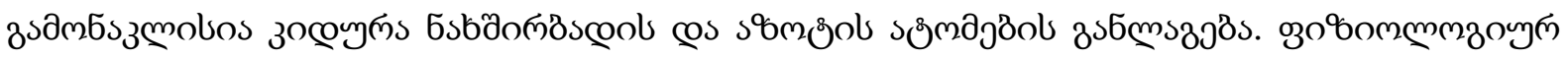

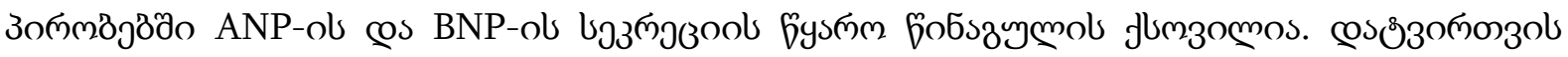

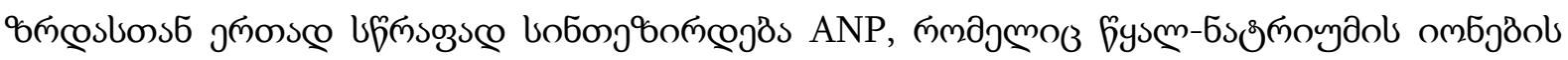

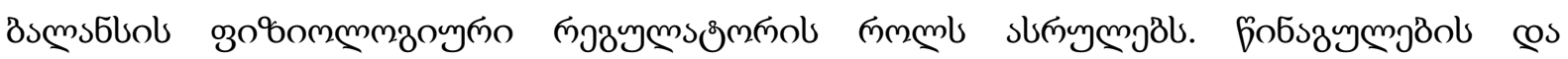

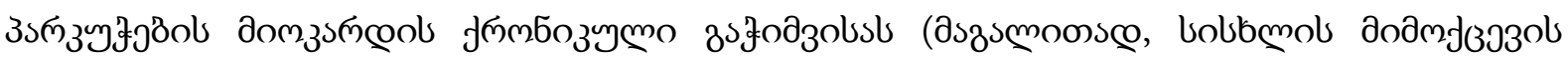

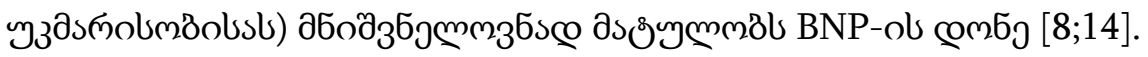

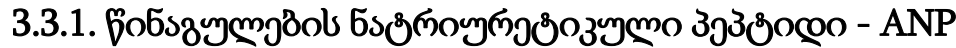

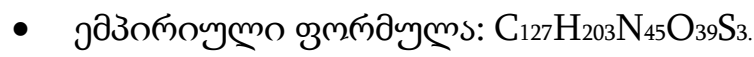

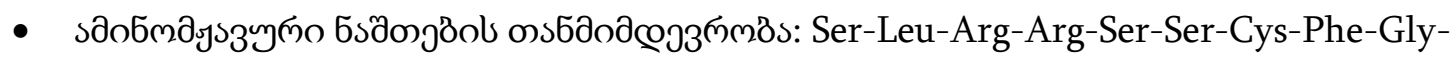
Gly-Arg-Met-Asp-Arg-Ile-Gly-Ala-Gln-Ser-Gly-Leu-Gly-Cys-Asn-Ser-Phe-Arg-Tyr

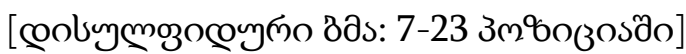

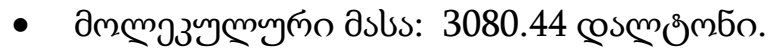

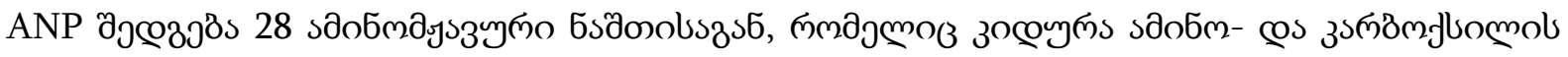

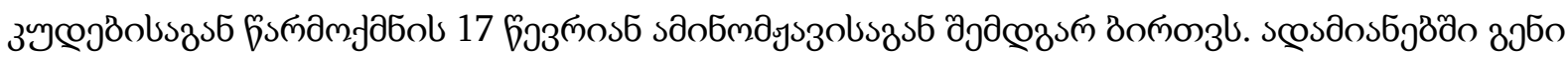

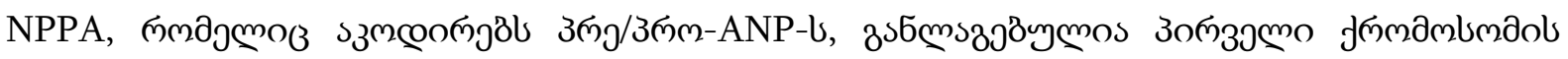

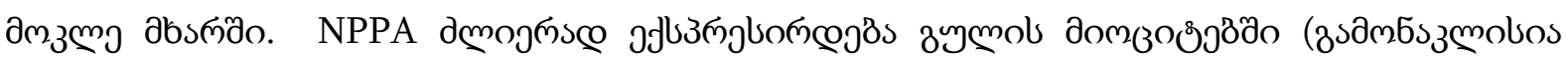

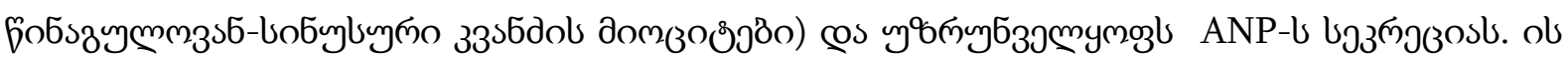

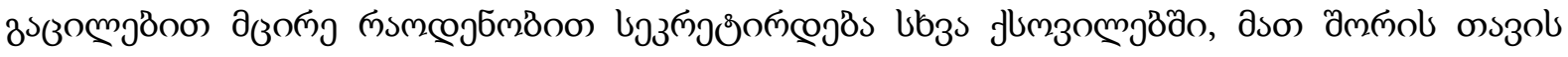

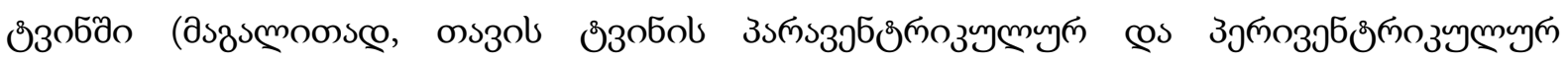

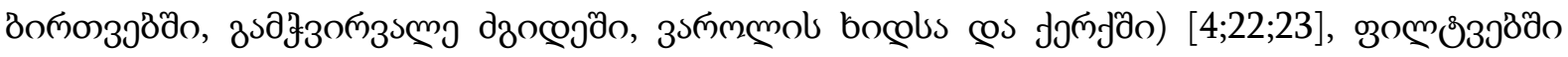

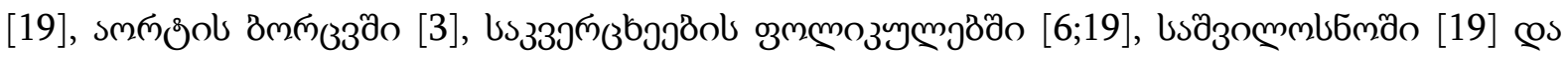




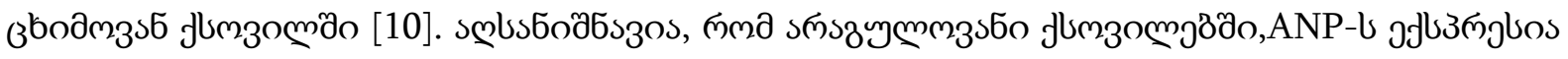

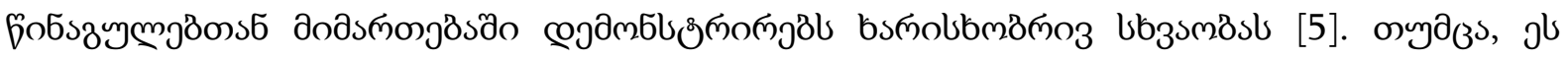

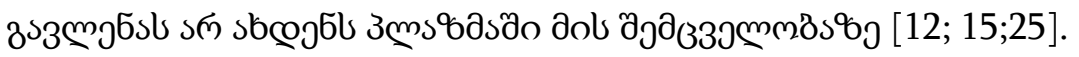

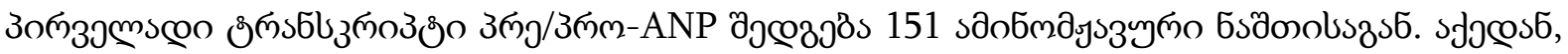

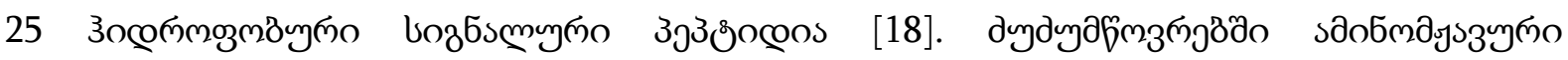

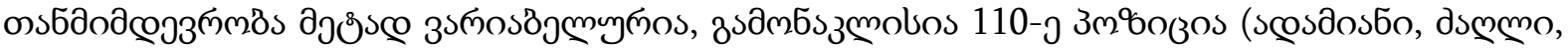

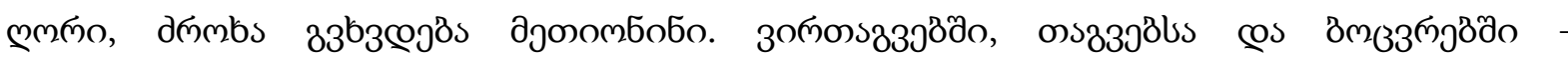

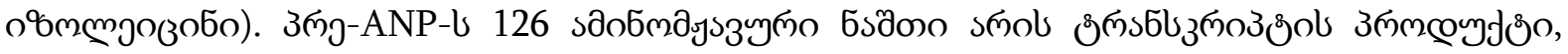

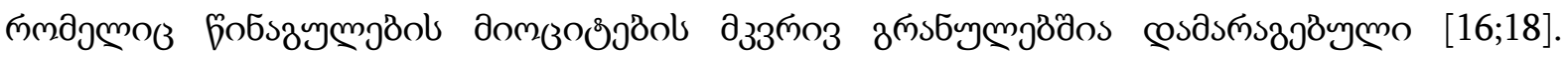

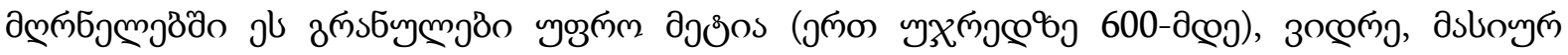

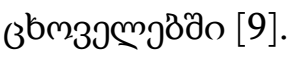

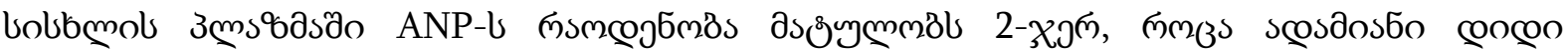

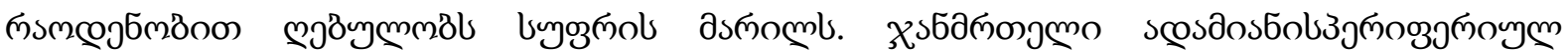

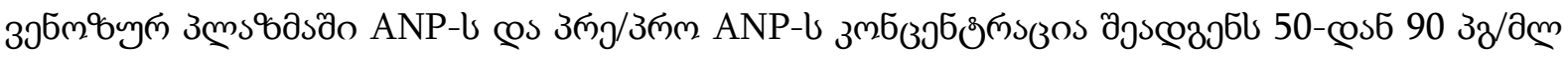

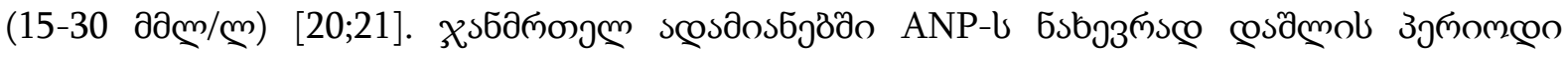

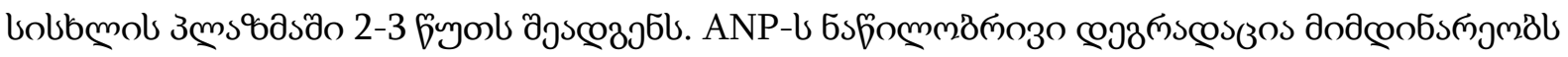

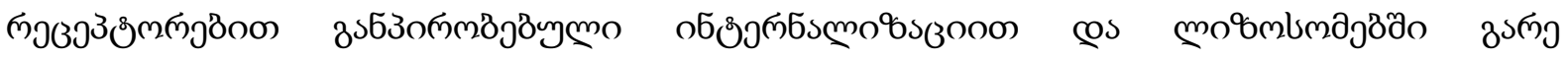

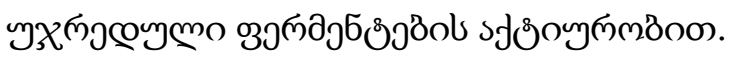

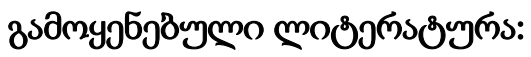

1. Cantin M., Genest J. The heart as an endocrine gland. Clin. Invest. Med.1986; 9 (4): 319— 327.

2. DeBold A. J., Flynn T. G. Cardionatrin I - a novel heart peptide withpotent diuretic and natriuretic properties. Life Sci. 1983; 33 (3): 297-302.

3. Gardner DG, Deschepper CF, Baxter JD. The gene for the atrial natriureticfactor is expressed in the aortic arch. Hypertension 9: 103-106, 1987.

4. Gardner DG, Vlasuk GP, Baxter JD, Fiddes JC, Lewicki JA. Identificationof atrial natriuretic factor gene transcripts in the central nervoussystem of the rat. Proc Natl Acad Sci U S A 84: 2175-2179, 1987.

5. Gerbes AL, Dagnino L, Nguyen T, Nemer M. Transcription of brainnatriuretic peptide and atrial natriuretic peptide genes in human tissues.J Clin Endocrinol Metab 78: 1307-1311, 1994.

6. Gutkowska J, Tremblay J, Antakly T, Meyer R, Mukaddam-DaherS, Nemer M. The atrial natriuretic peptide system in rat ovaries.Endocrinology 132: 693-700, 1993.

7. Hall C. Essential biochemistry and physiology of (NT"pro)BNP. Eur. J.Heart Failure 2004; 6 (3): $257-260$.

8. Hystad M. E., Geiran O. R., Attramadal H. et al. Regional cardiac expres"sion and concentration of natriuretic peptides in patients with severechronic heart failure. Acta Physiol. Scand. 2001; 171 (4): 395-403. 
9. Jamieson JD, Palade GE. Specific granules in atrial muscle cells. J CellBiol 23: 151-172, 1964.Johnson KR, Olson KR. Comparative physiology of the piscine natriureticpeptide system. Gen Comp Endocrinol 157: 21-26, 2008.

10. Johnson KR,Olson KR. Comparative physiology of the piscine natriureticpeptide system. Gen Comp Endocrinol 157: 21-26, 2008.

11. Kangava K., Fukuda A., Kubota I. et al. Human atrial natriureticpolypeptides (HANP): purification, structure synthesis and biologicalactivity. J. Hypertens Suppl. 1984; 2 (3): 321— 323.

12. 12.Kuhn M. Cardiac and intestinal natriuretic peptides: insights fromgenetically modified mice. Peptides 26: 1078-1085, 2005.

13. Levin E., Gardner D., Samson W. Natriuretic peptides. N. Engl. J. Med.1998; 339 (5): 321— 328.

14. Maack T. The Broad homeostatic role of natriuretic peptides. Arq. Bras.Endocrinol. Metab. 2006; 50 (2): 198-207.

15. 15.Mukoyama M, Nakao K, Hosoda K, Suga S, Saito Y, Ogawa Y, ShirakamiG, Jougasaki $\mathrm{M}$, Obata $\mathrm{K}$, Yasue $\mathrm{H}$, et al. Brain natriuretic peptideas a novel cardiac hormone in humans. Evidence for an exquisitedual natriuretic peptide system, atrial natriuretic peptide and brain natriureticpeptide. J Clin Invest 87: 1402-1412, 1991.

16. Nishikimi T, Kuwahara K, Nakao K. Current biochemistry, molecularbiology, and clinical relevance of natriuretic peptides. J Cardiol 57:131-140, 2011.

17. Ogawa Y., Itoh H., Nakao K. Molecular biology and biochemistry of natriuretic peptide family. Clin. Exp. Pharmacol. Physiol. 1995; 22 (1): 49-53.

18. Oikawa S, Imai M, Ueno A, Tanaka S, Noguchi T, Nakazato H, Kangawa K, Fukuda A, Matsuo $\mathrm{H}$. Cloning and sequence analysis of cDNAencoding a precursor for human atrial natriuretic polypeptide. Nature309: 724-726, 1984.

19. Peng JY, Xin HY, Han P, Zhao HB, Bai L, An XP, Cao BY. Identificationand gene expression analyses of natriuretic peptide system in theovary of goat (Capra hircus). Gene 524: 105-113, 2013.

20. Pemberton CJ, Siriwardena M, Kleffmann T, Ruygrok P, Palmer SC,Yandle TG, Richards AM. First identification of circulating pre-proA-type natriuretic peptide (preproANP) signal peptide fragments inhumans: Initial assessment as cardiovascular biomarkers. Clin Chem58: 757-767, 2012.

21. Potter LR, Abbey-Hosch S, Dickey DM. Natriuretic peptides, theirreceptors, and cyclic guanosine monophosphate-dependent signalingfunctions. Endocr Rev 27: 47-72, 2006.

22. Standaert DG, Needleman P, Day ML,Weigand R, Krause JE. Expressionof the gene for preproatriopeptin in the central nervous system ofthe rat. Brain Res 464: 7-13, 1988.

23. Standaert DG, Saper CB. Origin of the atriopeptin-like immunoreactiveinnervation of the paraventricular nucleus of the hypothalamus.J Neurosci 8: 1940-1950, 1988.

24. Sudoh T., Kangava K., Minamino N., Matsuo H. A new natriuretic peptide in porcine brain. Nature 1988; 332 (6159): 78-81.

25. Yasue H, Yoshimura M, Sumida H, Kikuta K, Kugiyama K, JougasakiM, Ogawa H, Okumura K, Mukoyama M, Nakao K. Localization andmechanism of secretion of B-type natriuretic peptide in comparisonwith those of A-type natriuretic peptide in normal subjects and patientswith heart failure. Circulation 90: 195-203, 1994. 


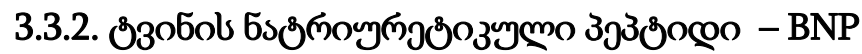

- jазопочумо озмпаулмз: $\mathrm{C}_{143} \mathrm{H}_{244} \mathrm{~N}_{50} \mathrm{O}_{42} \mathrm{~S}_{4}$.

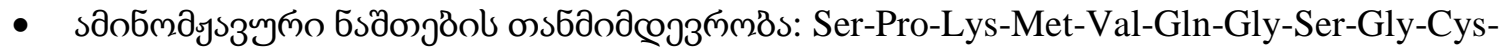
Phe-Gly-Arg-Lys-Met-Asp-Arg-Ile-Ser-Ser-Ser-Ser-Gly-Leu-Gly-Cys-Lys-Val-Leu-ArgArg-His.

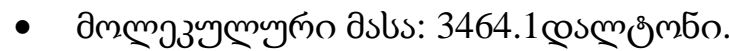

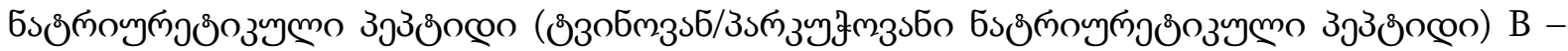

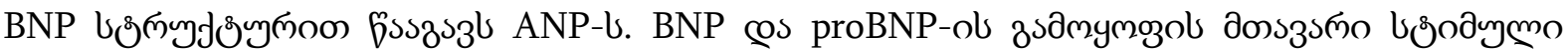

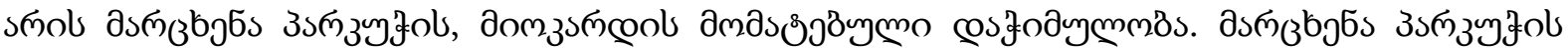

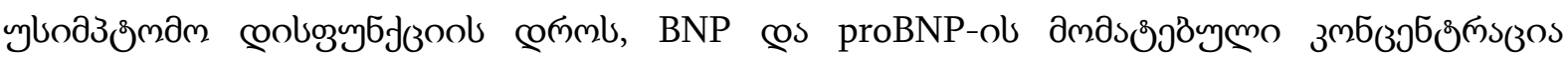

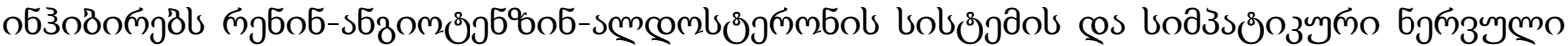

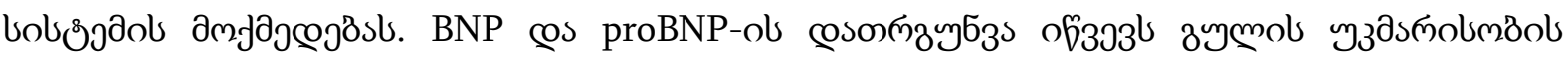

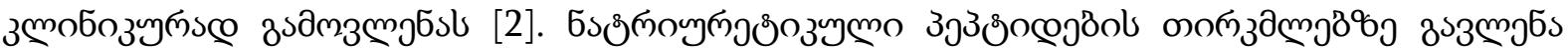

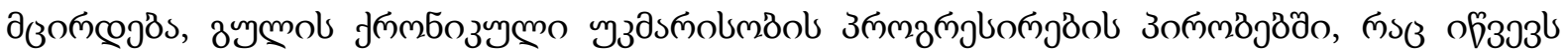

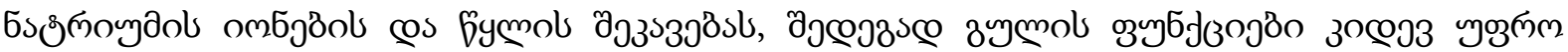

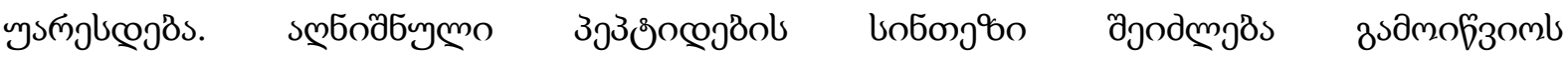

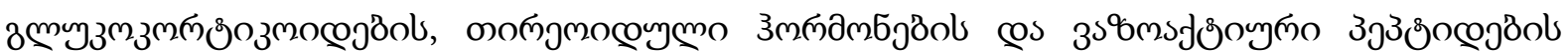

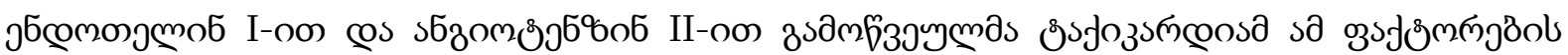

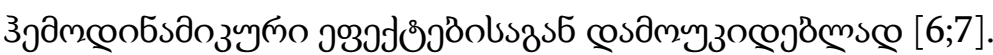

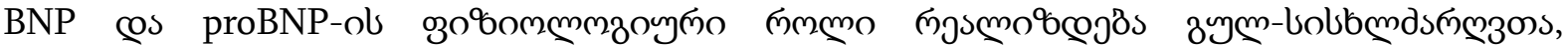

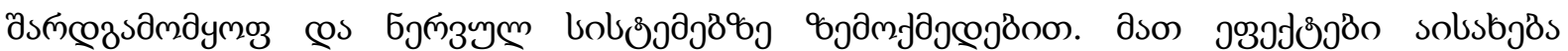

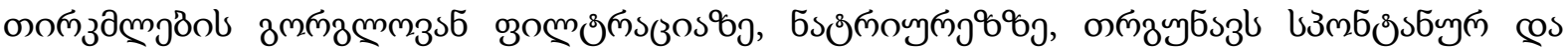
sбзомґ

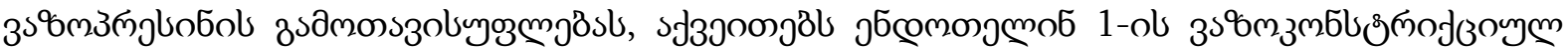

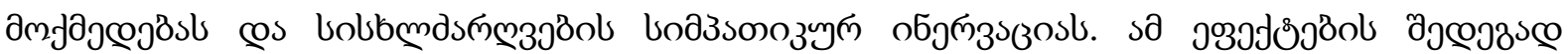

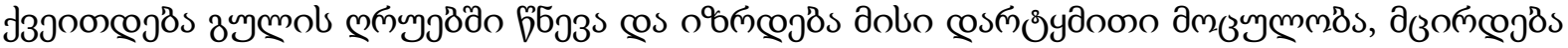

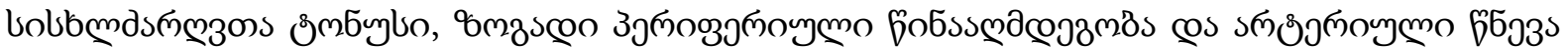
[3;5].

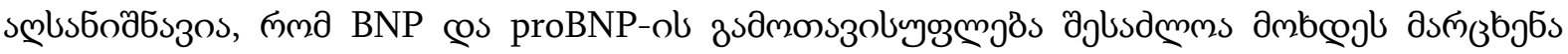

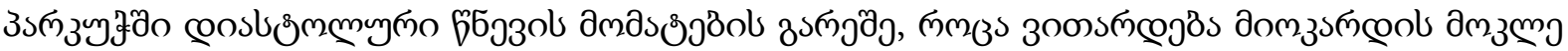

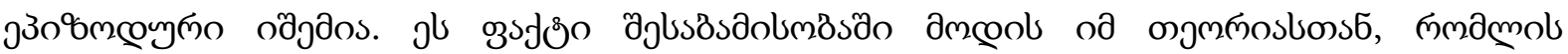

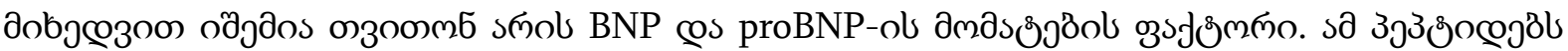

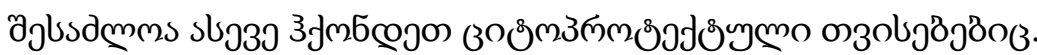

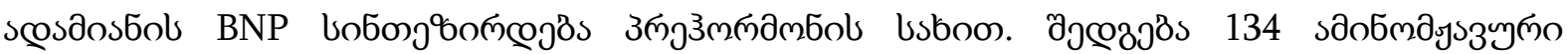

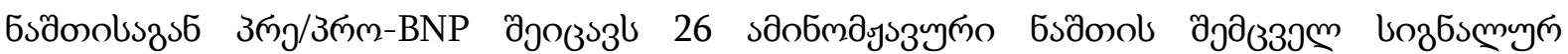

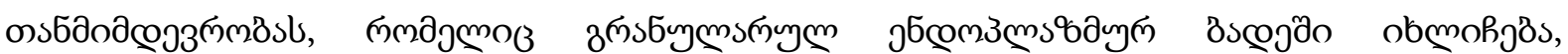

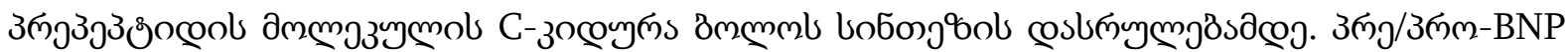

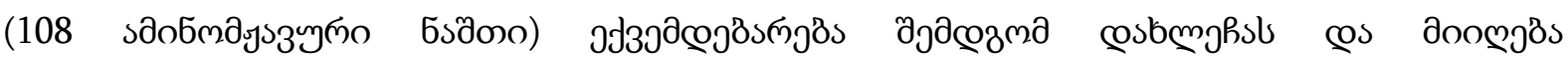

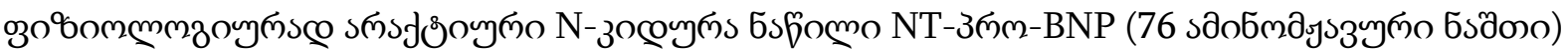

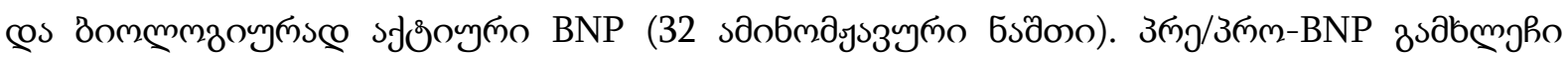

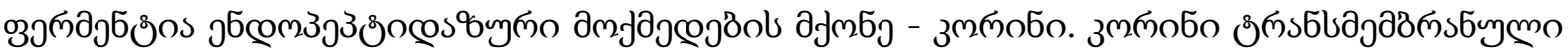




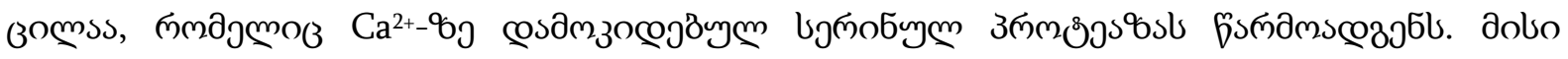

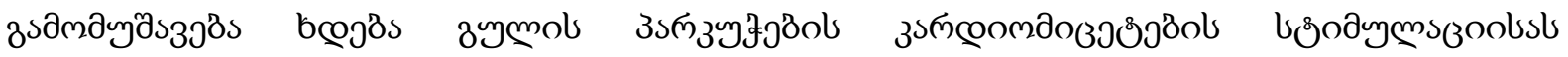

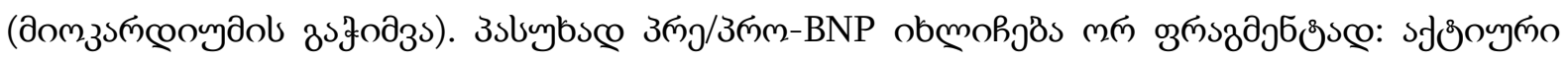

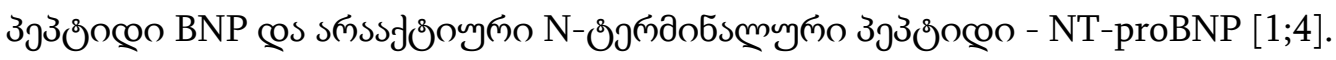

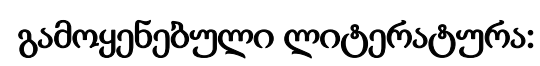

1. Cantin M., Genest J. The heart as an endocrine gland. - Clin Invest Med 1986; 9 (4): 319327.

2. Cleland J.C.F., Goode K. Natriuretic peptides for heart failure. Fashionable? Useful? Necessary? // Eur J Heart Failure. - 2004. - Vol. 6. - P. 253256.

3. Clerico A., Iervasi G. et al. // Circulating levels of cardiac natriuretic peptide (ANP and BNP) measured by highly sensitive and specific immunoradiometric assays in normal subjects and in patients with different degrees of heart failure. J Endocrinol Invest 1998; 21: 1703179.

4. Kungawa K., Matsuo H. Purification and complete amino acid sequence of a human atrial natriuretic peptide (ahANP) // Biochem Biophys Res Commun. - 1984. - Vol. 118. - P. 131139.

5. Maeda K., Takayoshi T. et al. // Plasma brain natriuretic peptide asa biochemical marker of high left ventricular end diastolic pressurein patients with symptomatic left ventricular dysfunction. Am HeartJ 1998; 135: 8253832.

6. Tsutamoto T., Wada A. et al. // Attenuation of compensation ofendogenonous cardiac natriuretic peptide system in chrinic heartfailure: prognostic role of plasma brain natriuretic peptide concentrationin patients with chronic symptomatic left ventricular dysfunction.Circulation 1997; 96: 5093516.

7. Yamamoto K., Burnett J. // Superiority of Brain Natriuretic Peptide as a Hormonal Marker of Ventricular Systolic and Diastolic Dysfunction and Ventricular Hypertrophy. Hypertension, 1996; Vol 28, No 6, 9883994.

\subsection{3. бรకిణంตణ}

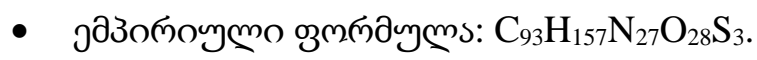

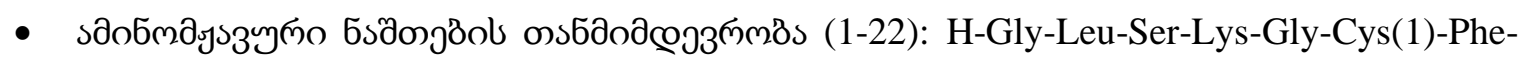
Gly-Leu-Lys-Leu-Asp-Arg-Ile-Gly-Ser-Met-Ser-Gly-Leu-Gly-Cys(1)-OH

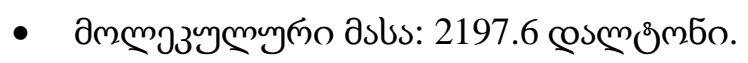

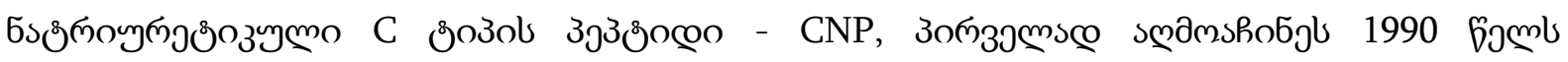

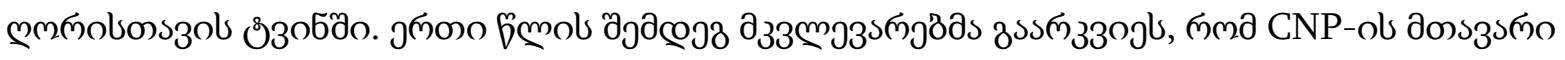

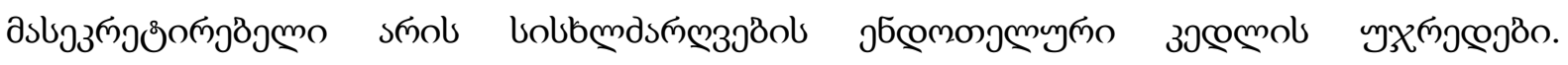

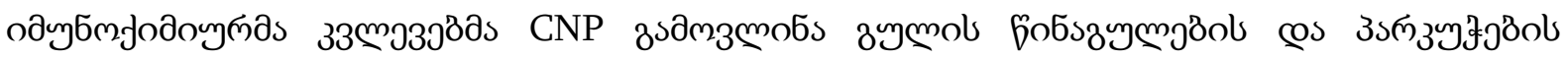

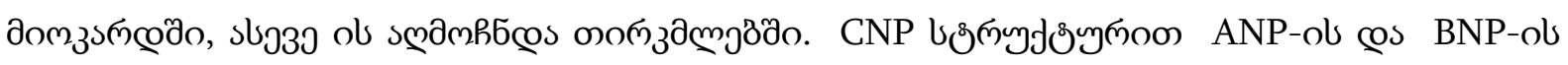

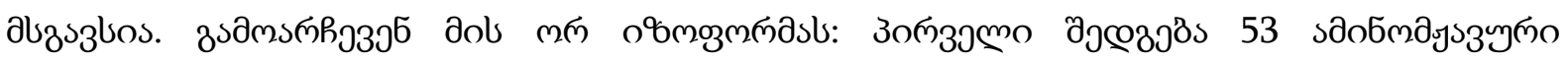
5sð̃onbszs5 (H-Asp-Leu-Arg-Val-Asp-Thr-Lys-Ser-Arg-Ala-Ala-Trp-Ala-Arg-Leu-Leu-Gln-Glu-HisPro-Asn-Ala-Arg-Lys-Tyr-Lys-Gly-Ala-Asn-Lys-Lys-Gly-Leu-Ser-Lys-Gly-Cys-Phe-Gly-Leu-Lys-Leu-

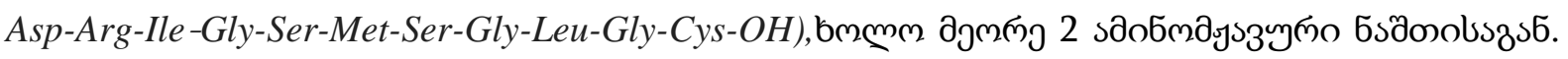




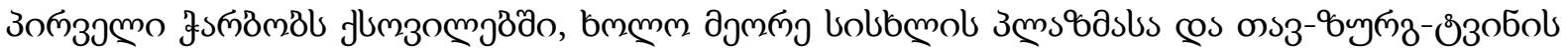
boobjôo.

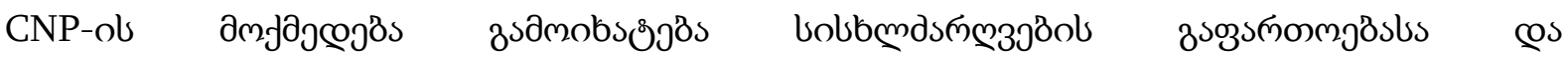

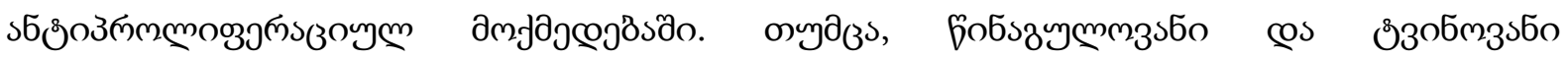

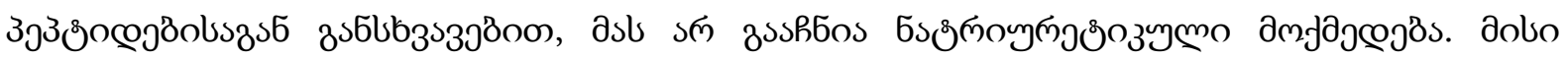

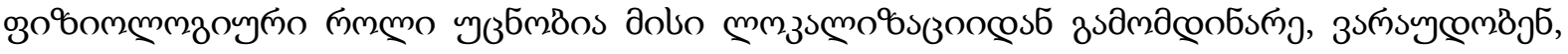

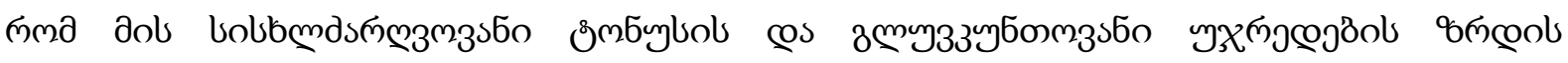

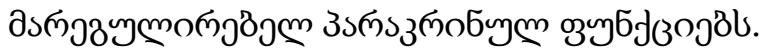

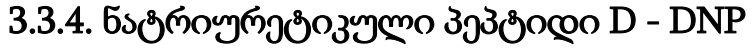

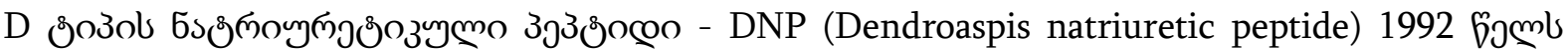

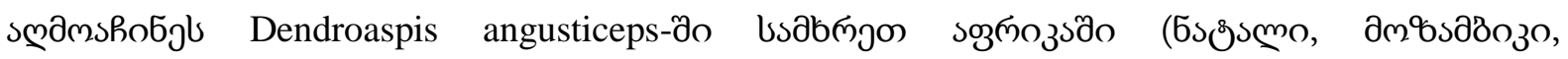

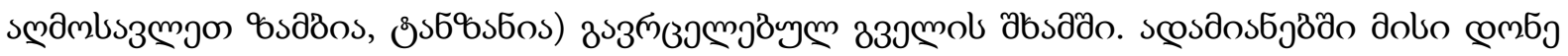

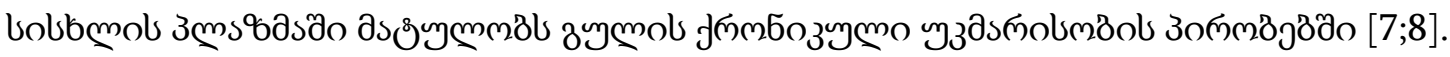

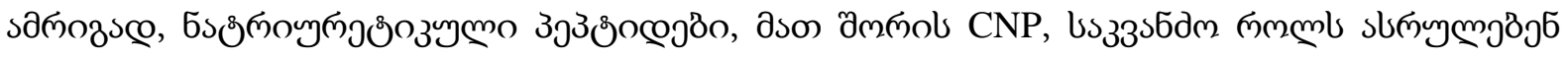

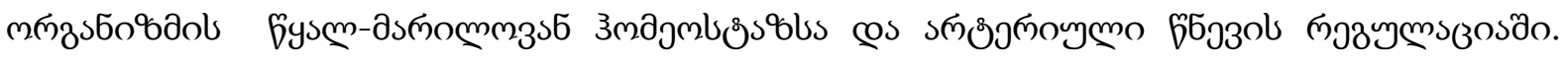

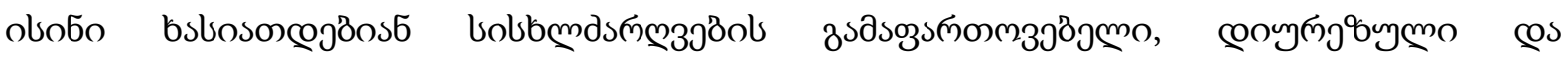

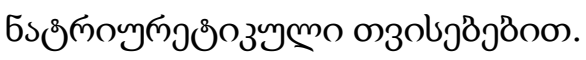

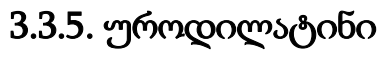

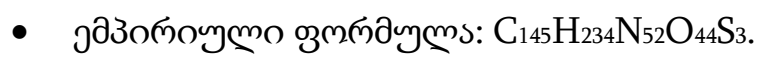

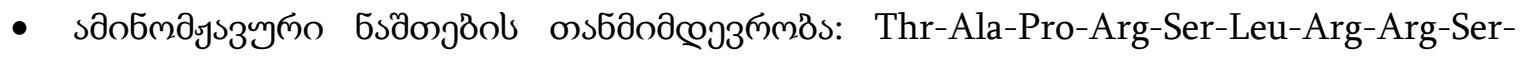
Ser-Cys-Phe-Gly-Gly-Arg-Met-Asp-Arg-Ile-Gly-Ala-Gln-Ser-Gly-Leu-Gly-Cys-Asn-SerPhe-Arg-Tyr [œolymmozocymo ठдs: 11-27].

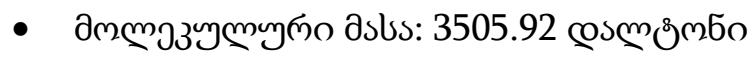

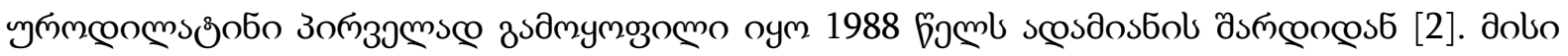

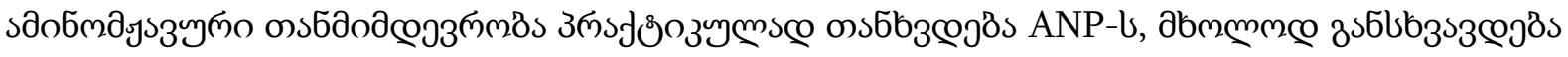

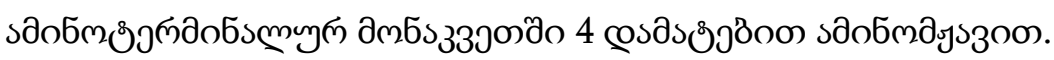

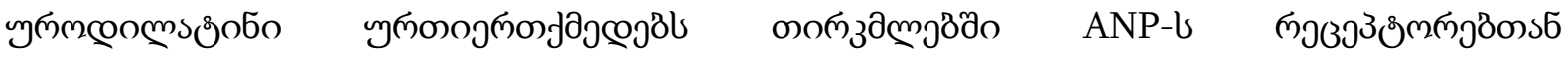

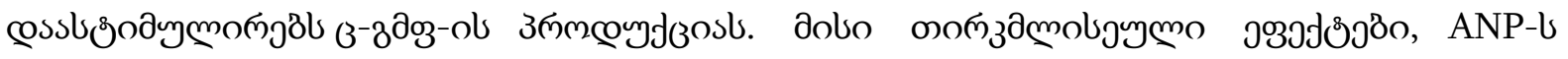

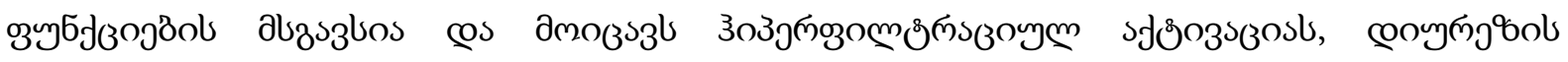

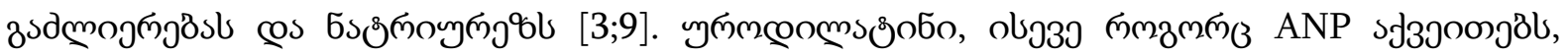

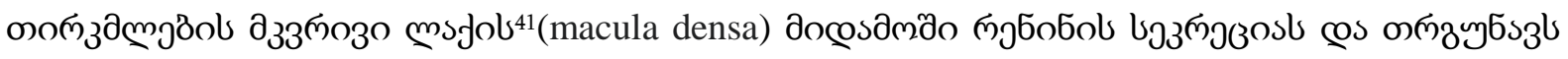

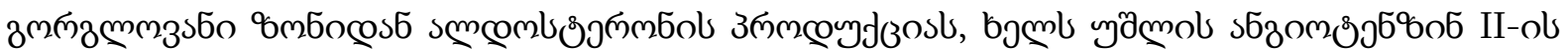

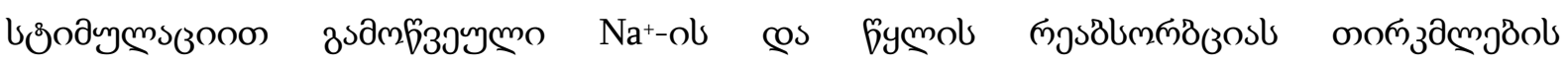

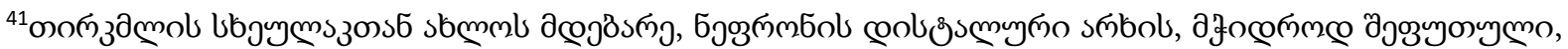

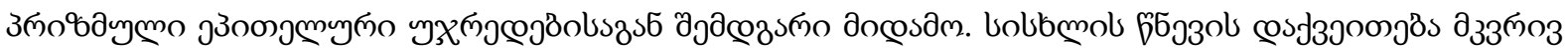

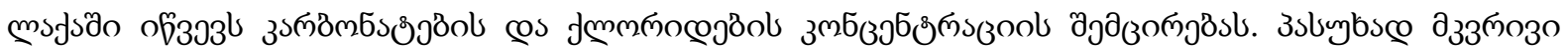

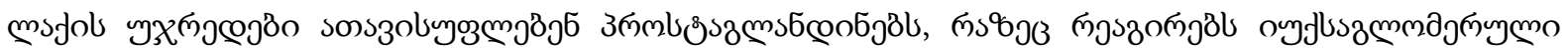

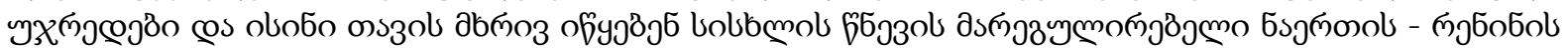
zsдmosszolygogmgast.
} 


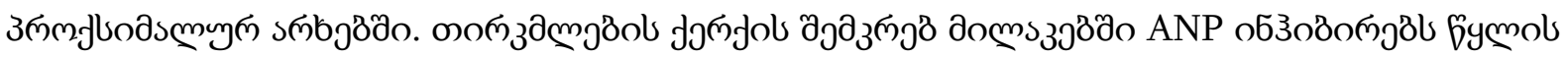

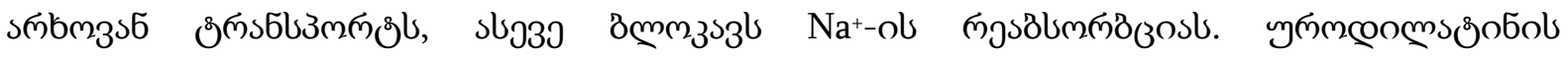

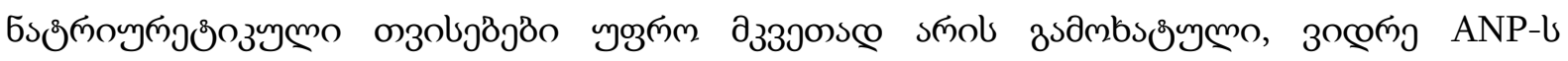

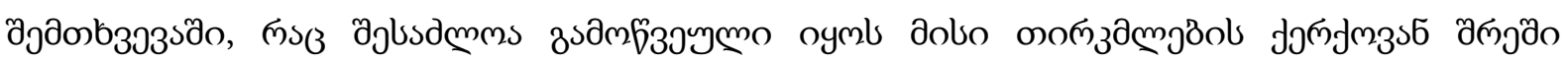

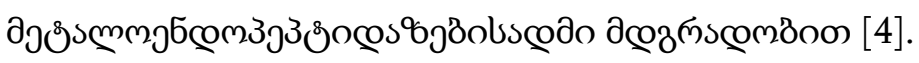

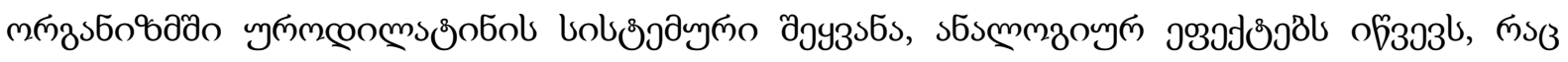

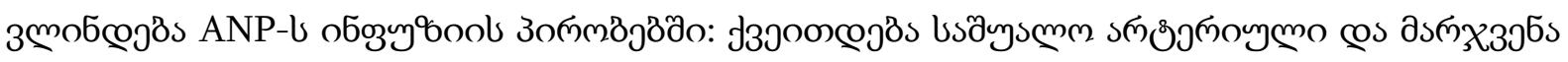

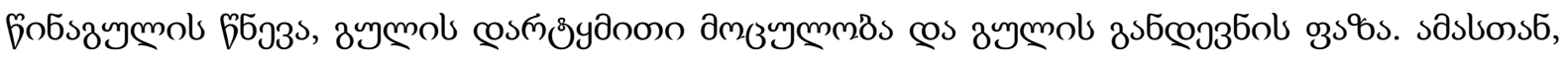

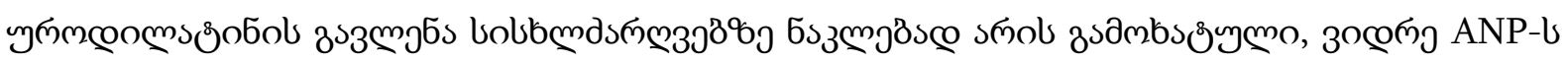

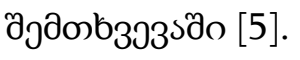

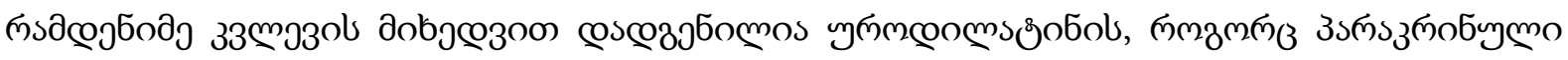

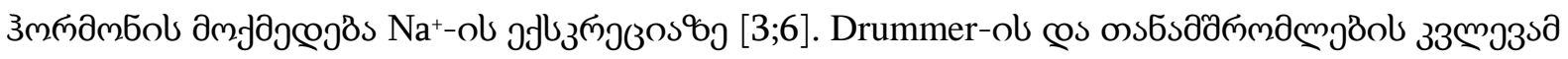

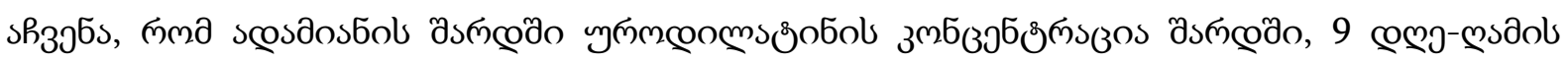

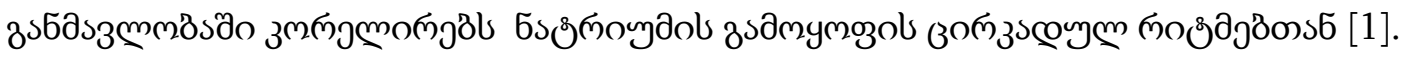

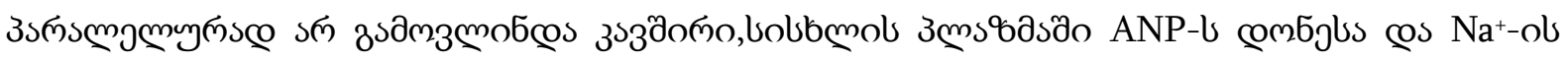

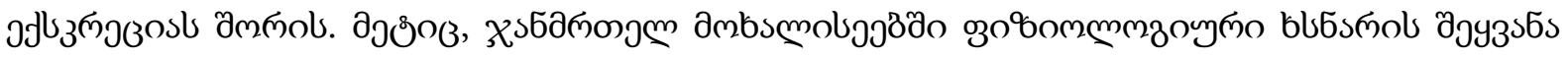

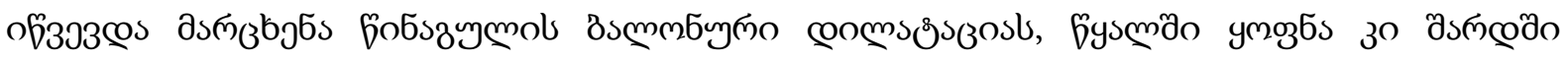

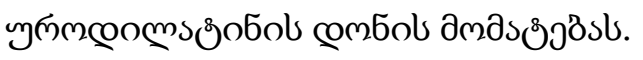

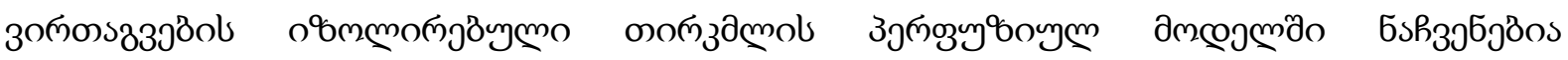

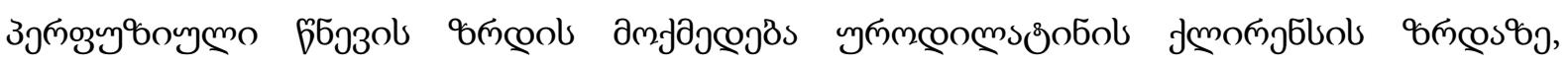

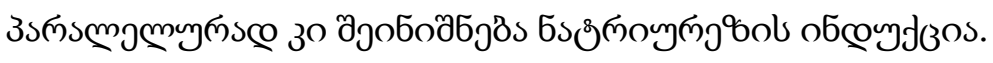

\subsubsection{3งใmbsతిణo6o (VNP)}

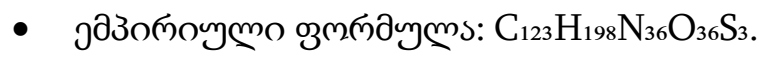

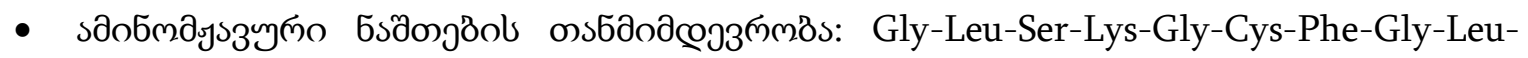
Lys-Leu-Asp-Arg-Ile-Gly-Ser-Met-Ser-Gly-Leu-Gly-Cys-Asn-Ser-Phe-Arg-Tyr

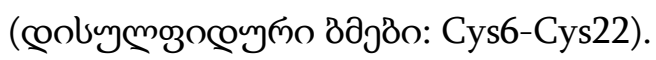

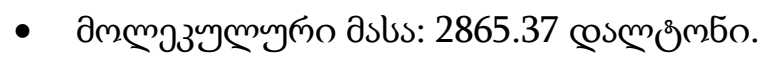

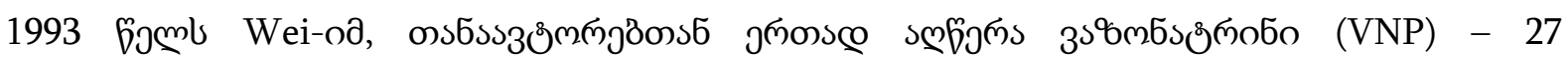

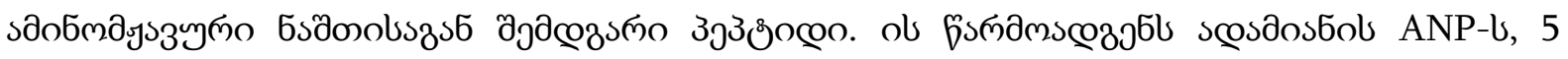

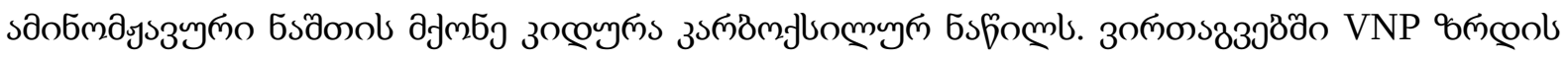

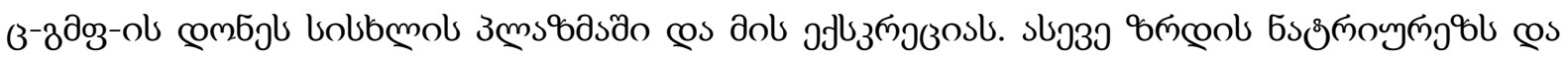

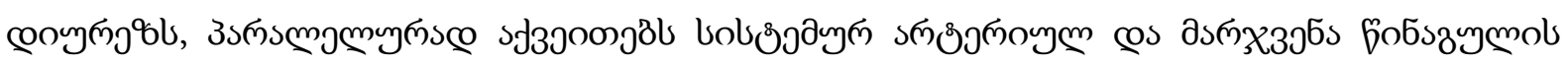

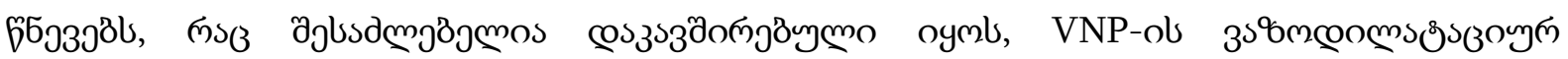

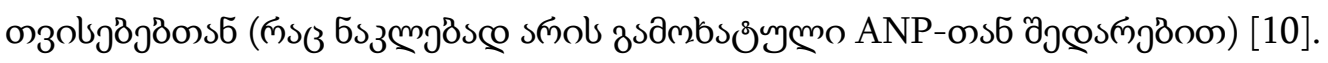




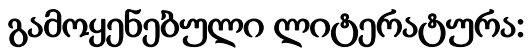

1. Drummer C., Fiedler F., König A., Gerzer R. Urodilatin, a kidney-derived natriuretic factor, is excreted with a circadian rhythm and is stimulated by saline infusion in man. J Am Soc Nephrol 1991; 1(9): 1109-1113.

2. Feller S.M., Gagelmann M., Forssman W.G. Urodilatin: A newly described member of the ANP family. Trends Pharmacol Sci 1989; 10(3): 93-94.

3. Forssmann W., Meyer M., Forssmann K. The renal urodilatin system: clinical implications. Cardiovasc Res 2001; 51(3): 450-462.

4. Heim J.M., Kiefersauer S., Fülle H.J., Gerzer R. Urodilatin and beta-ANF: binding properties and activation of particulate guanylate cyclase. Biochem Biophys Res Commun 1989; 163(1): $37-41$.

5. Hildebrandt D.A., Mizelle H.L., Brands M.W., Hall J.E. Comparison of renal actions of urodilatin and atrial natriuretic peptide. Am J Physiol 1992; 262: R395-R399.

6. Komatsu Y., Nakao K., Suga S. et al. C-Type natriuretic peptide (CNP) in rats and humans. Endocrinology 1991; 129(2): 1104-1106.

7. Nathisuwan S., Pharm. L. et al. // A Review of VasopeptidaseInhibitors: A New Modality in the Treatment of Hypertension andChronic Heart Failure. Pharmacotherapy 2002, 22(1): 27342.

8. Schiger J.A., Heublein D.M. et al. // Presence of Dendroaspis natriureticpeptide3like immunoreactivity in human plasma and its increaseduring human heart failure. Mayo Clin. Proc. 1999; 74: 1263130.

9. Valentin J.P., Humphreys M.H. Urodilatin: a paracrine renal natriuretic peptide. Semin Nephrol 1993; 13(1): 61-70.

10. Wei C.M., Kim C.H., Miller V.M., Burnett J.C.Jr. Vasonatrin peptide: a unique synthetic natriuretic and vasorelaxing peptide. J Clin Invest 1993, 92(4): 2048-2052.

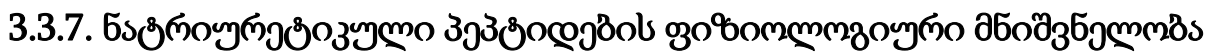

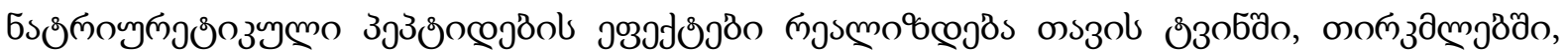

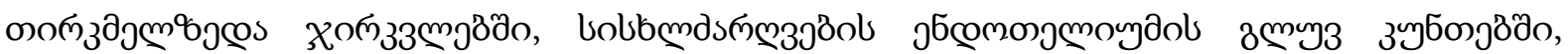

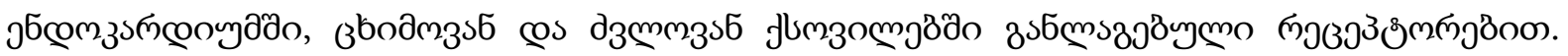

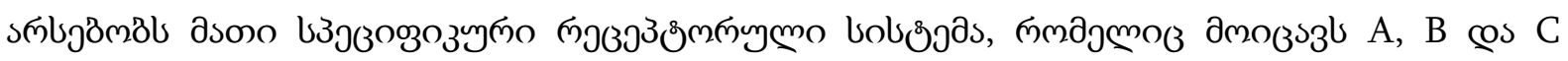

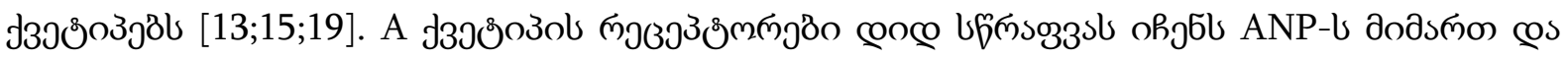

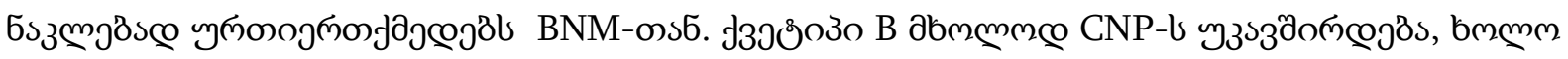

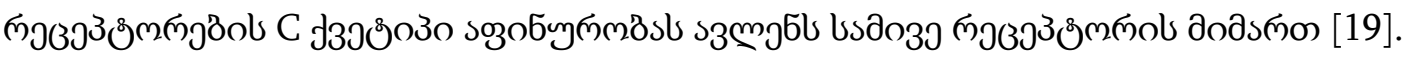

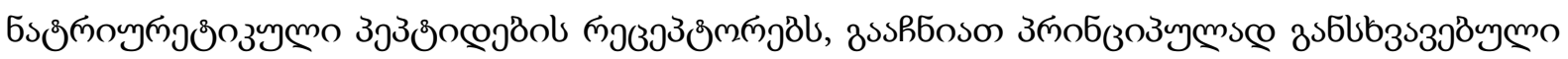

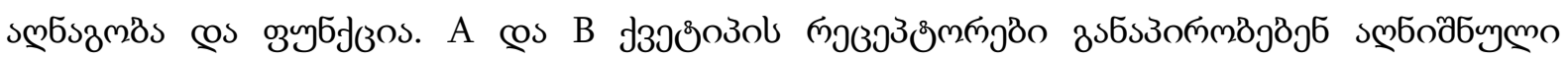

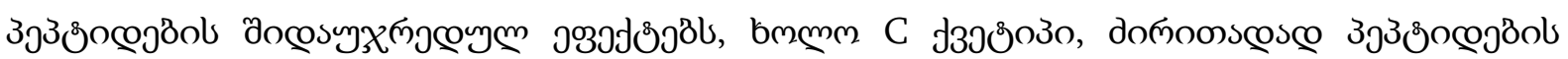

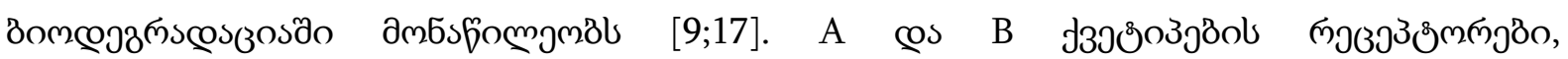

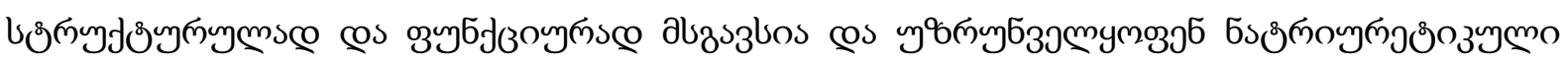

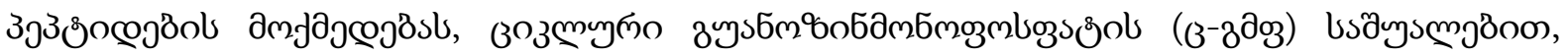

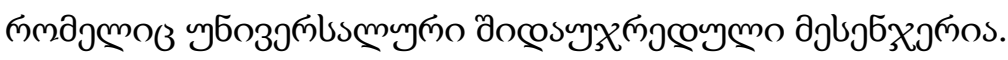




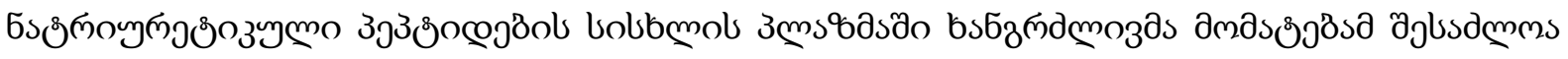

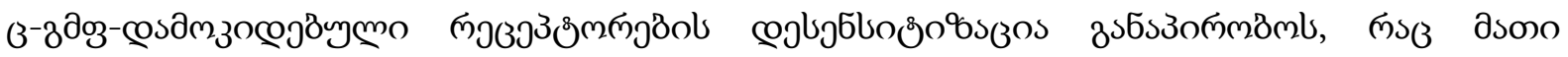

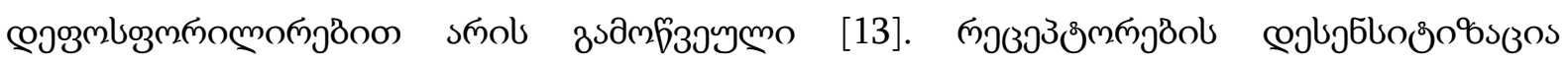

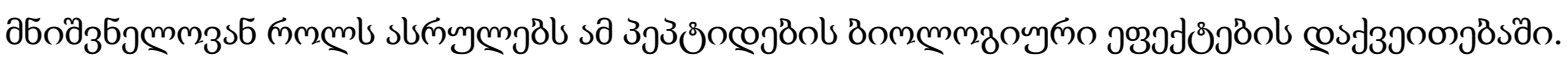

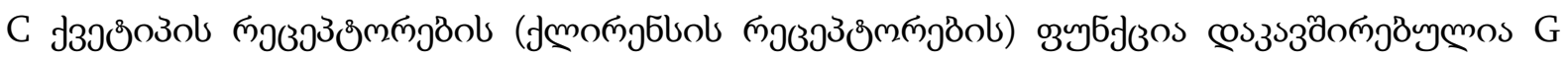

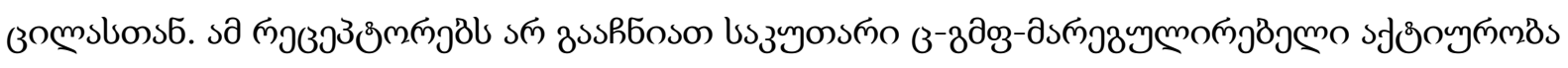

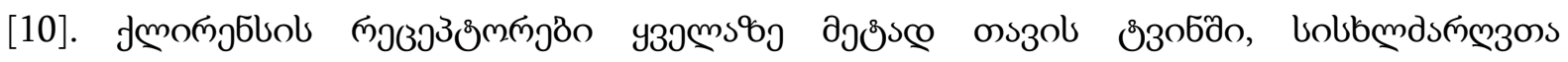

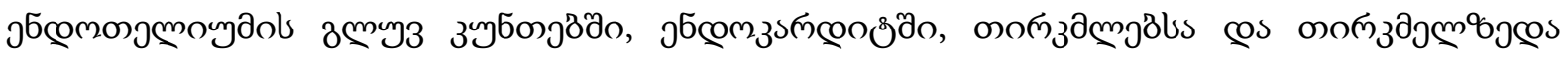

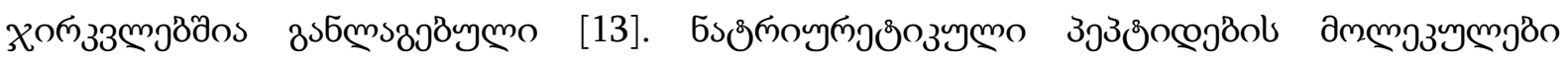

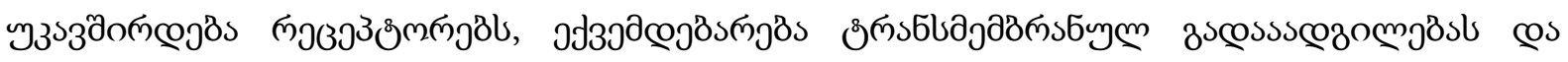

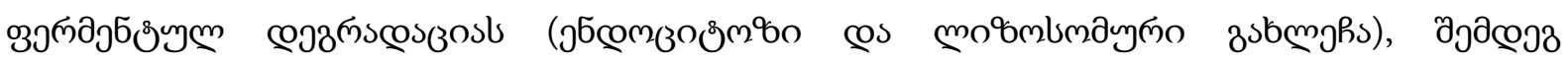

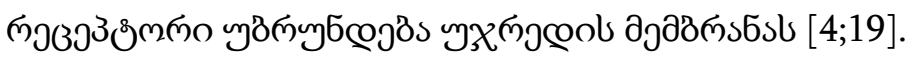

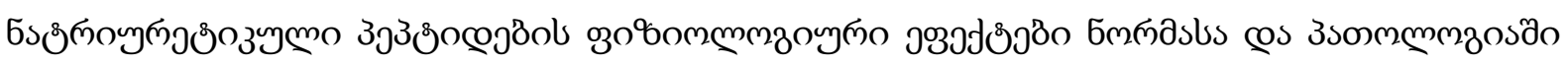

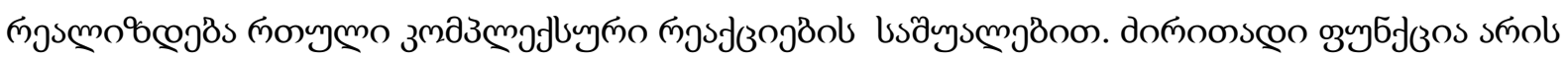

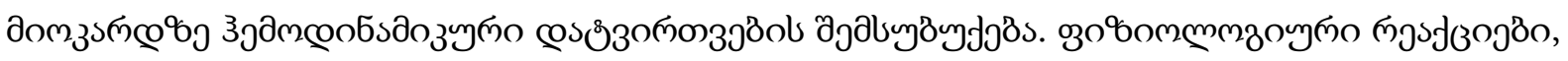

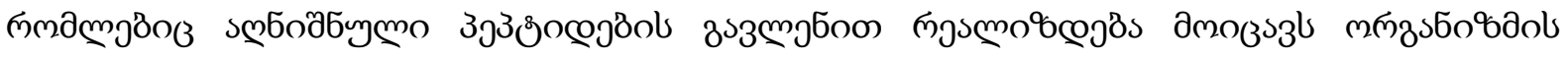

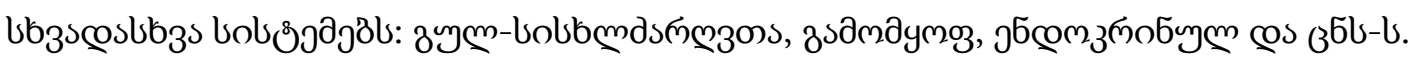

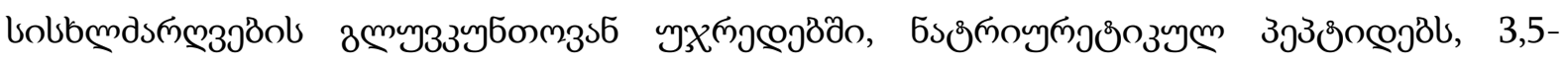

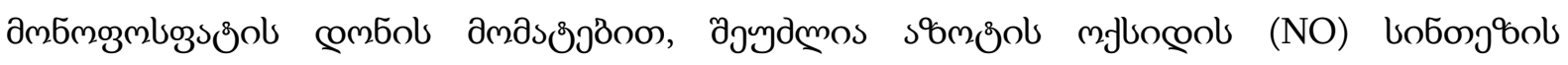

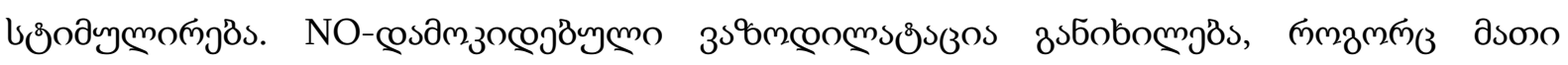

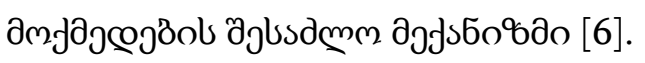

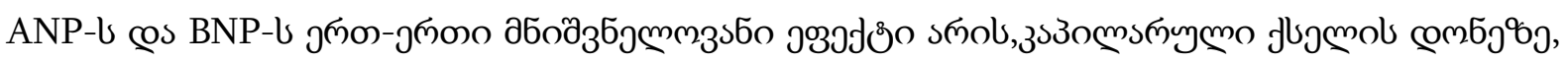

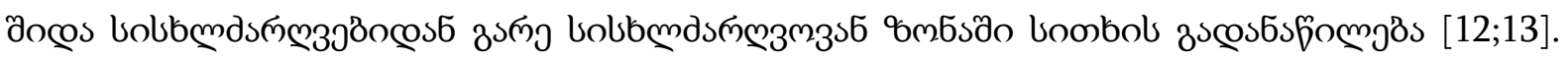

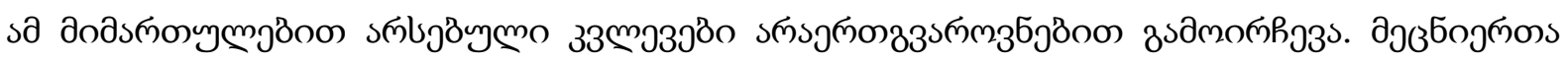

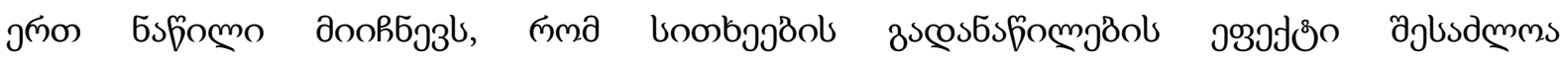

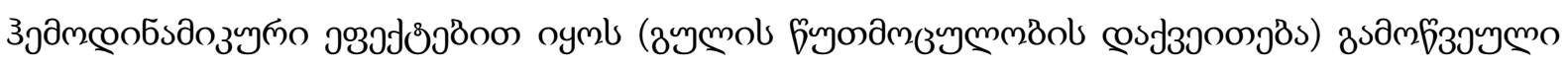

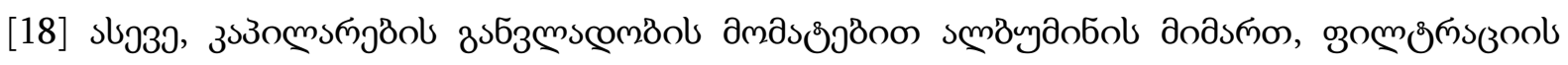

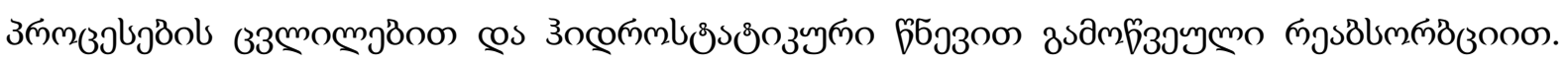

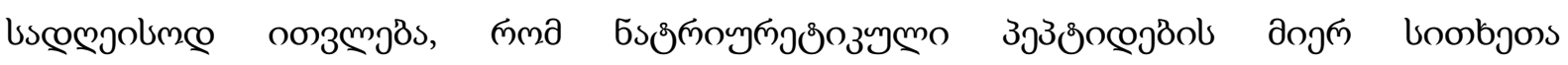

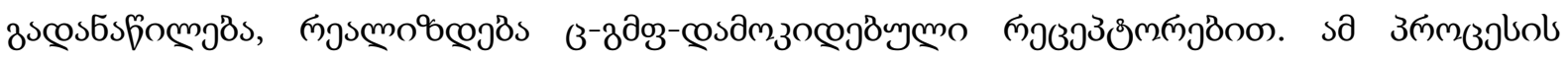

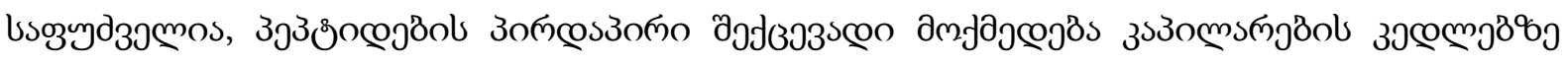

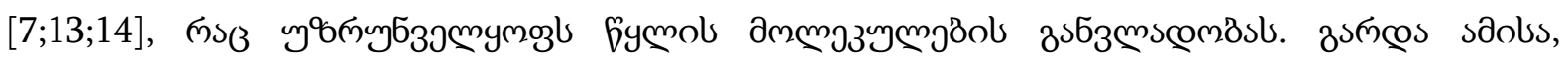

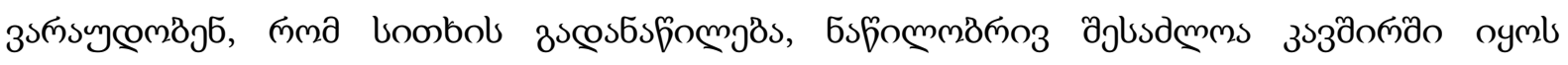

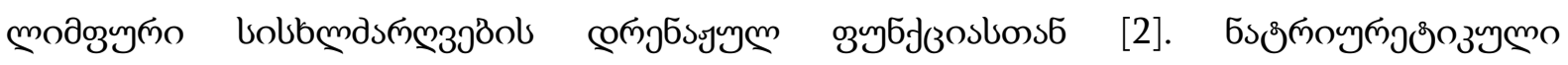

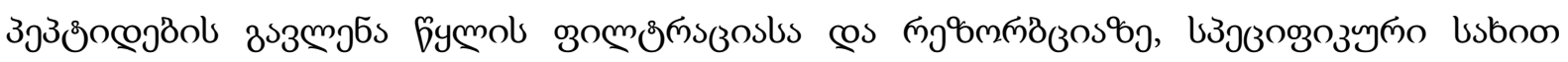

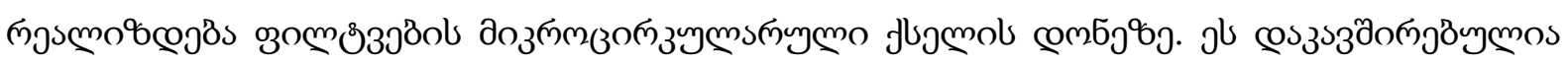

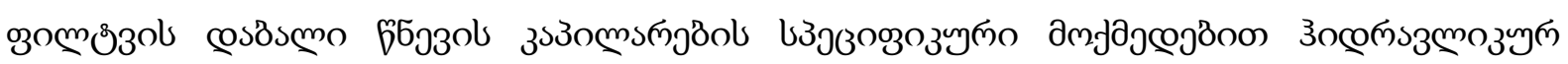

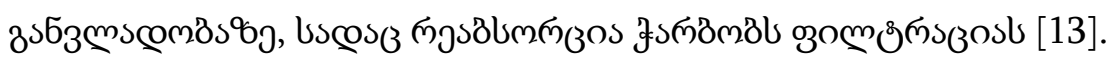

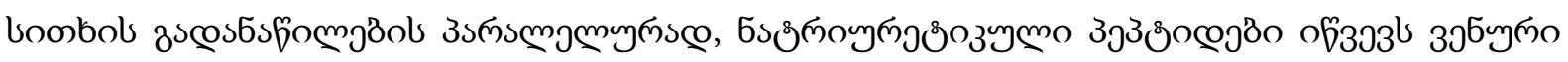

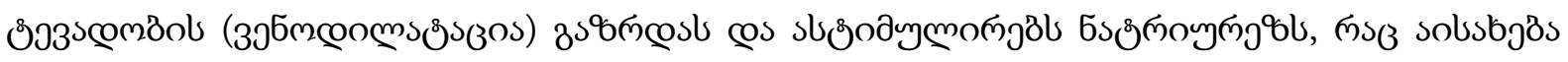

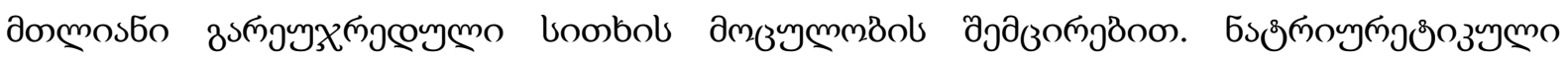

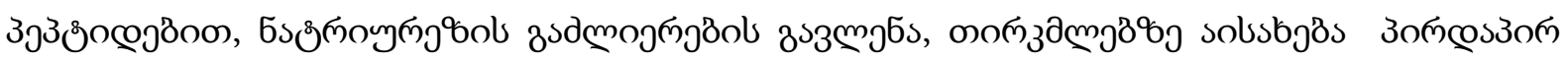




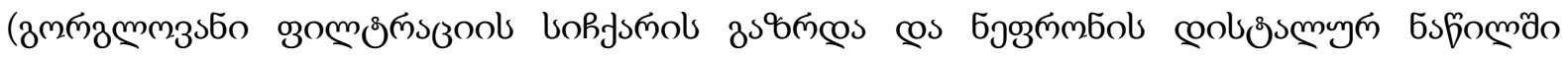

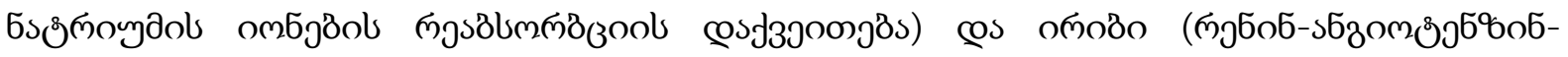

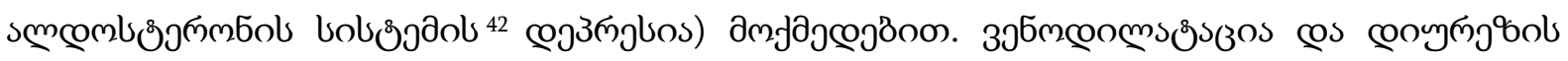

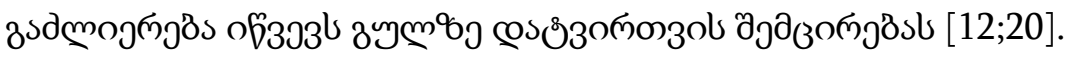

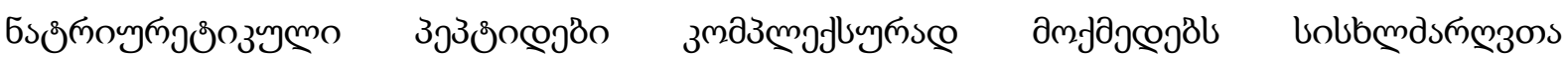

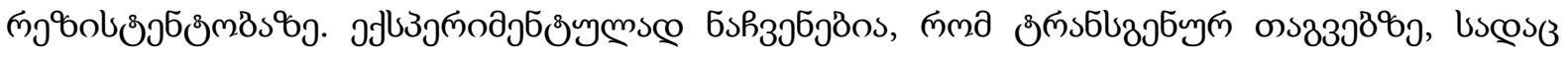

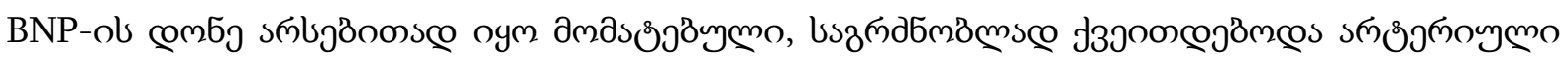

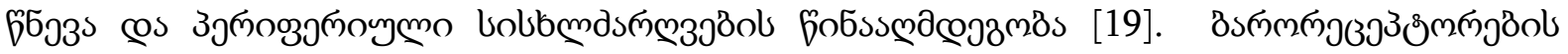

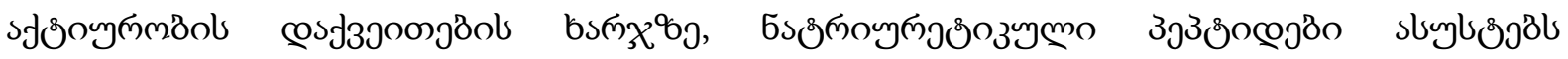

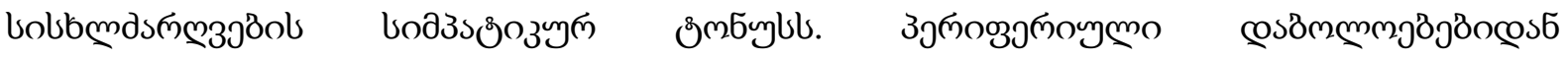

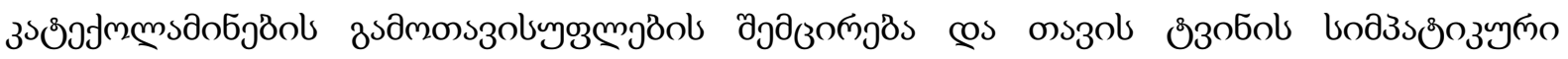

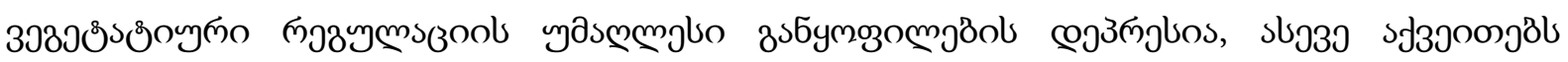

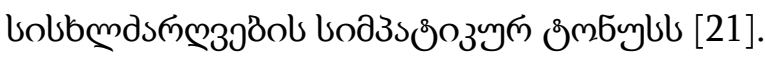

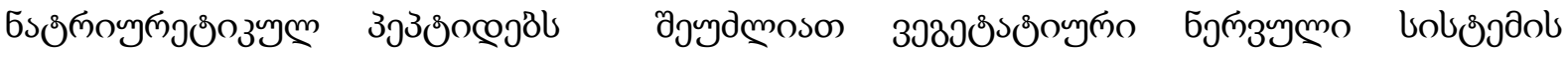

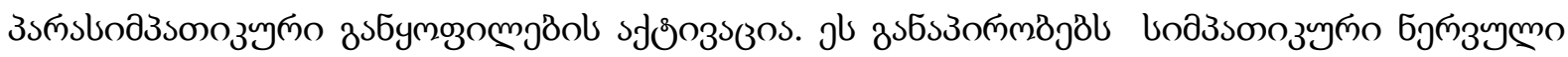

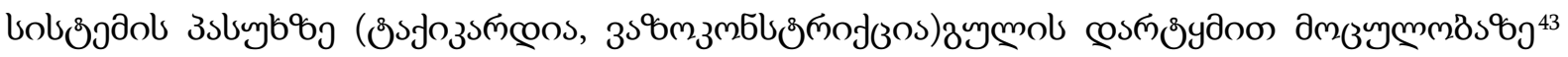

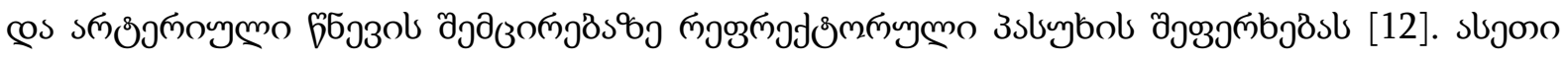

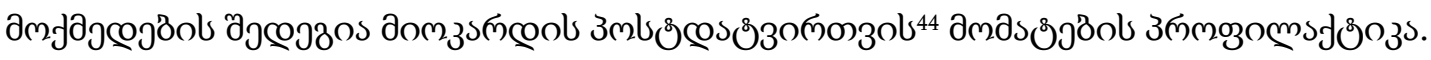

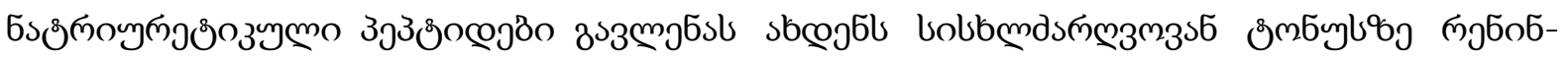

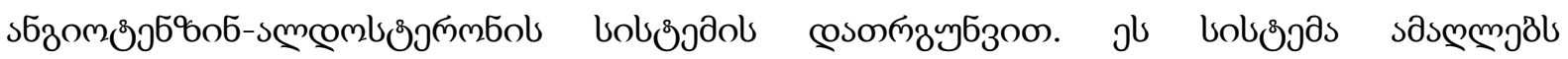

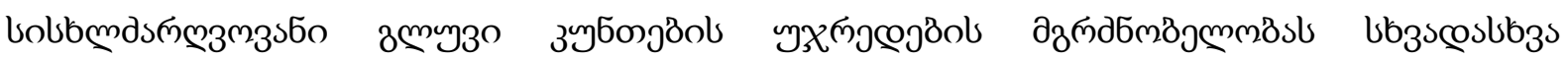

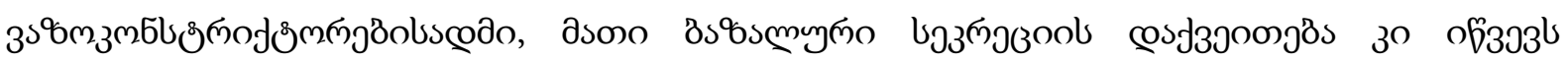

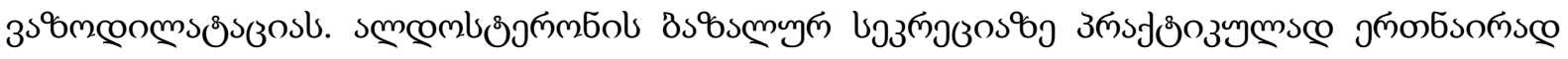

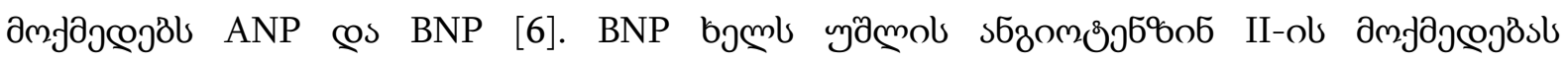

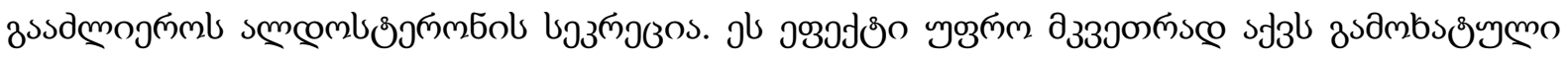

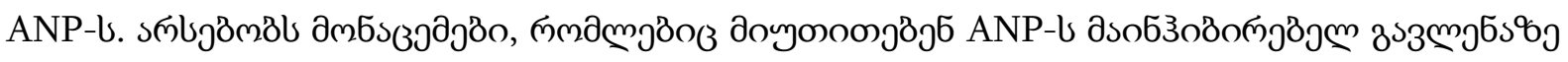

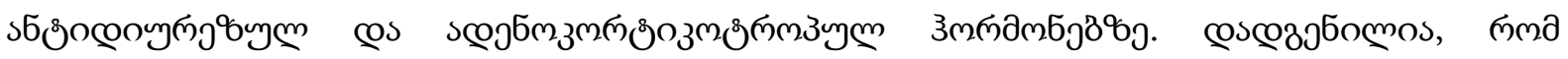

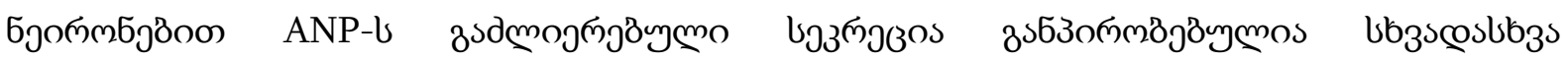

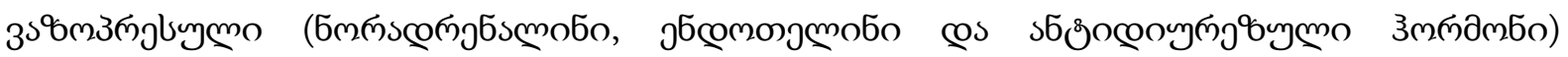

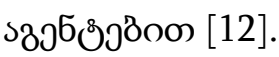

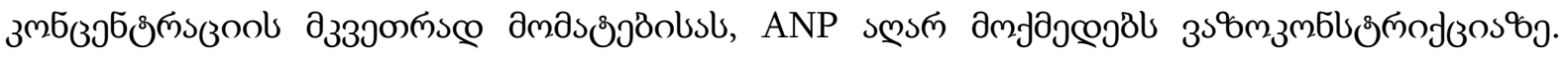

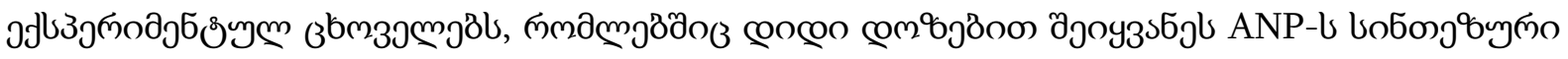

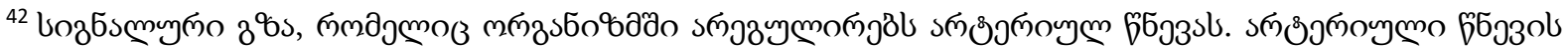

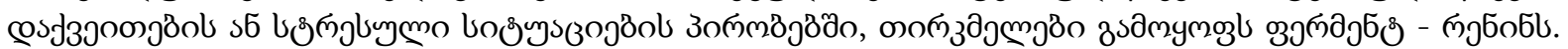

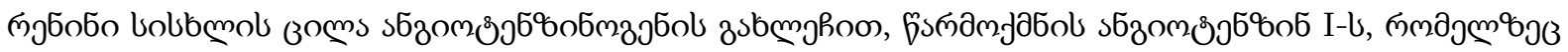

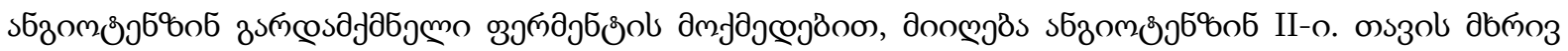

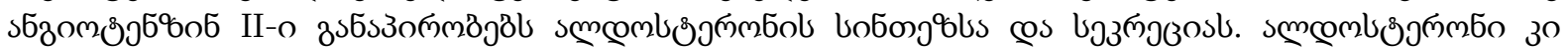

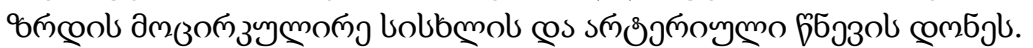

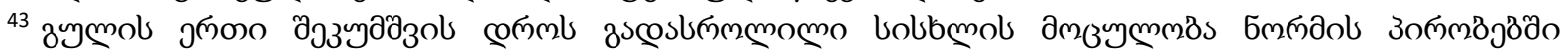

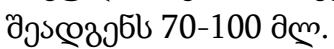

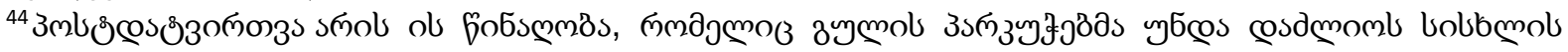

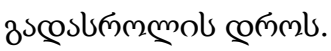




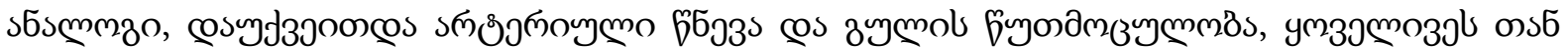

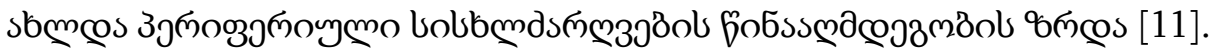

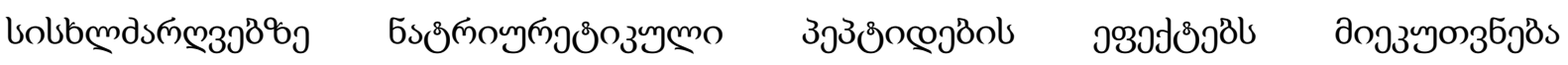

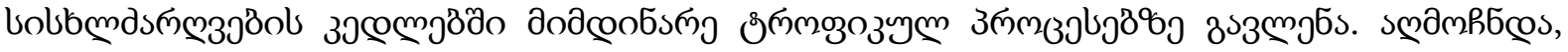

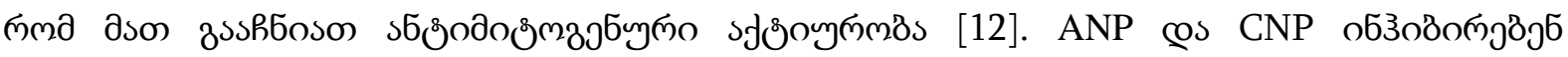

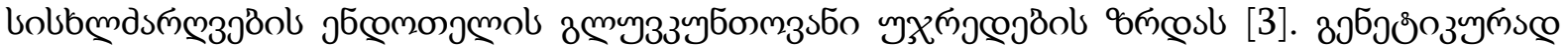

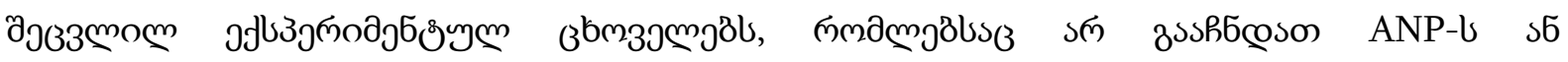

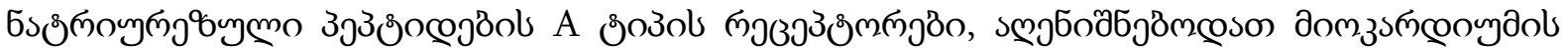

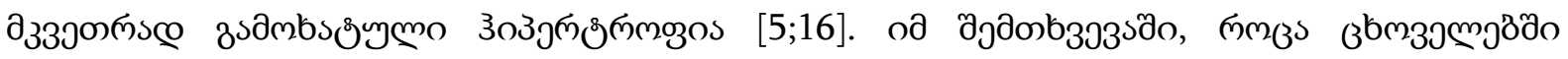

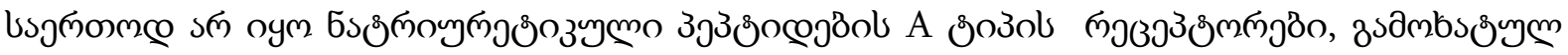

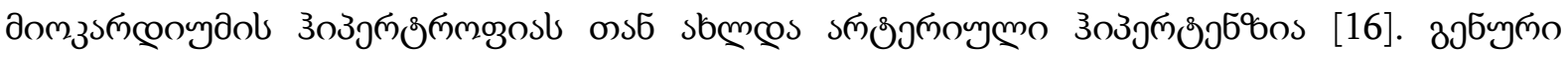

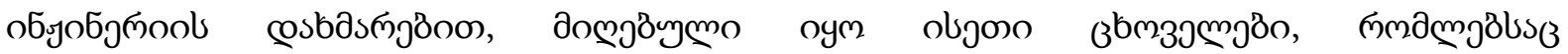

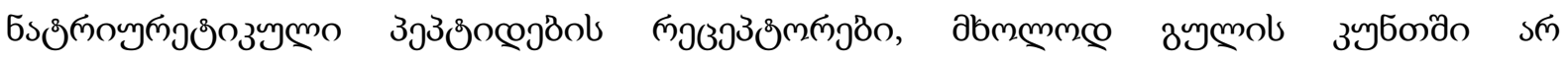

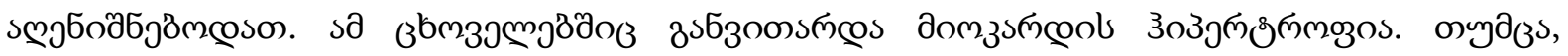

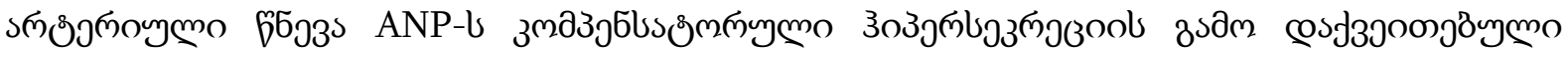
sмдмһб६сs [5].

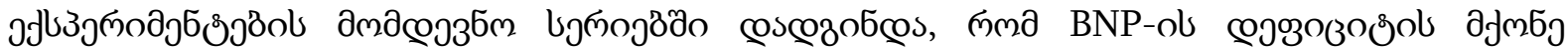

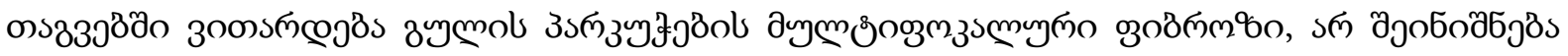

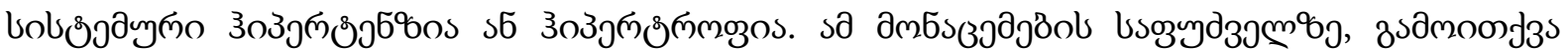

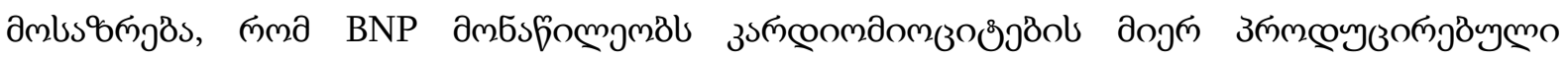

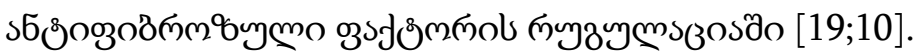

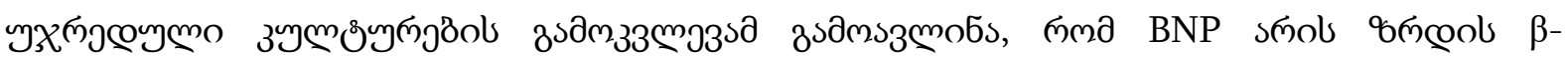

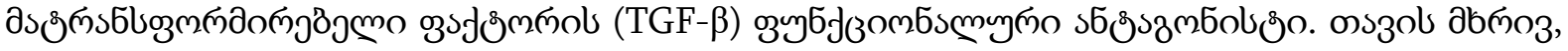

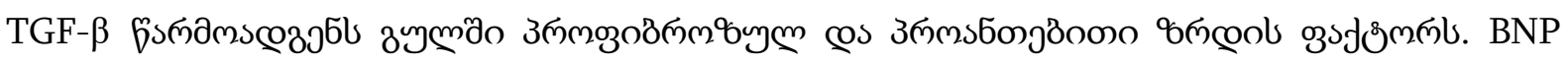

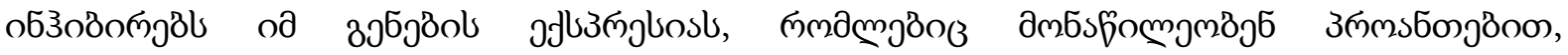

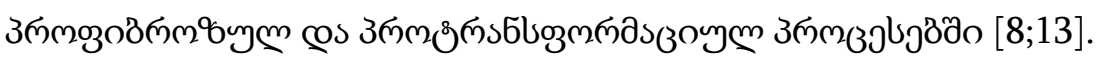

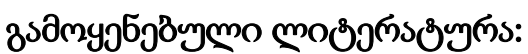

1. Almeida F. A., Suzuki M., Maack T. Atrial natriuretic factor increases hematocrit and decreases plasma volume in nephrectomized rats. LifeSci. 1986; 39 (13): 1193-1199.

2. Atchison D. J., Johnston M. G. Atrial natriuretic peptide attenuates flowin an isolated lymph duct preparation. Pflügers Arch. 1996; 431 (4):618-624.

3. Furuya M., Aisaka K., Miyazaki T. et al. C"type natriuretic peptideinhibits intimal thickening after vascular injury. Biochem. Biophys.Res. Commun. 1993; 193 (1): 248-253.

4. Hall C. Essential biochemistry and physiology of (NT"pro)BNP. Eur. J.Heart Failure 2004; 6 (3): $257-260$.

5. Holtwick R., van Eickels M., Skryabin B. V. et al. Pressure"independentcardiac hypertrophy in mice with cardiomyocyte"restricted inactiva"tion of the atrial natriuretic peptide receptor guanylcyclase"A. J. Clin. Invest. 2003; 111 (9): 1399—1407.

6. Hunt P., Espiner E., Nicholls M. Et al. Differing biological effects ofequimolar atrial and

7. brain natriuretic peptide infusions in normal man. J. Clin. Endocrinol. Metab. 1996; 81 (11): 
$3871-3876$.

8. Huxley V. H., Tucker V. L., Verburg K. M., Freeman R. H. Increased capil"lary hydraulic conductivity induced by atrial natriuretic peptide.Circulat. Res. 1987; 60 (2): 304-307.

9. Kapoun A. M., Liang F., O'Young G. et al. B"type natriuretic peptideexerts broad functional opposition to transforming growth factorbeta in primary human cardiac fibroblasts: Fibrosis, myofibroblastconversion, proliferation, and inflammation. Circ. Res. 2004; 94 (4):453 - 461.

10. Koller K., Goeddel D. Molecular biology of the natriuretic peptides and their receptors. Circulation 1992; 86 (4): 1081-1088.

11. Kone B. C. Molecular biology of natriuretic peptides and nitric oxidesynthases. Cardiovasc. Res. 2001; 51 (3): 429-441.

12. Lappe R. W., Smits J. F., Todt J. A. et al. Failure of atriopeptin II tocause arterial vasodilation in the conscious rat. Circ. Res. 1985; 56(4): 606-612.

13. Levin E., Gardner D., Samson W. Natriuretic peptides. N. Engl. J. Med.1998; 339 (5): 321— 328.

14. Maack T. The Broad homeostatic role of natriuretic peptides. Arq. Bras.Endocrinol. Metab. 2006; 50 (2): 198-207.

15. Melo L., Steinhelper M., Pang S. C. et al. ANP in regulation of arterialpressure and fluid"electrolyte balance: lessons from genetic mouse mod"els. Physiol. Genomics 2000; 3 (1): $45-58$.

16. Nakao K., Ogawa Y., Suga S., Imura H. Molecular biology and biochemistry of the natriuretic peptide system. II: Natriuretic peptide receptors.J. Hypertens. 1992; 10 (10): $1111-1114$.

17. Oliver P. M., Fox J. E., Kim R. et al. Hypertension, cardiac hypertrophy, and sudden death in mice lacking natriuretic peptide receptor A. Proc.Natl. Acad. Sci. USA 1997; 94 (26): $14730-14735$.

18. Porter J. G., Arfsten A., Fuller F. et al. Isolation and functional expressionof the human atrial natriuretic peptide clearance receptor cDNA. Biochem. Biophys. Res. Commun. 1990; 171 (2): $796-803$.

19. Trippodo N. C., Barbee R. W. Atrial natriuretic factor decreases whole"body capillary absorption in rats. Am. J. Physiol. 1987; 252 (5): 915-920.

20. Vanderheyden M., Bartunek J., Goethals M. Brain and other natriureticpeptides: molecular aspects. Eur. J. Heart Failure 2004; 6 (3): 261-268.33.

21. Vesely D. L. Natriuretic peptides and acute renal failure. Am. J. Physiol.Renal Physiol. 2003; 285 (2): F167-F177.

22. Yang R. H., Jin H. K., Wyss J. M. et al. Pressor effect of blocking atrialnatriuretic peptide in nucleus tractus solitarii. Hypertension 1992; 19(2): 198-205.

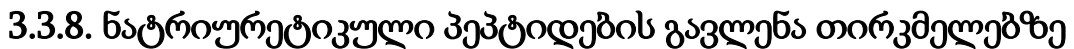

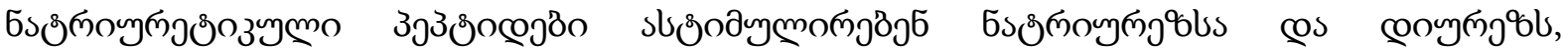

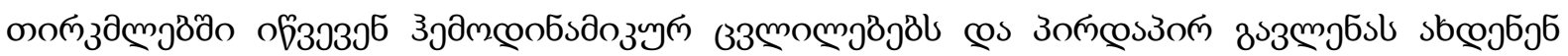

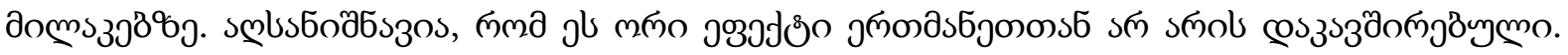

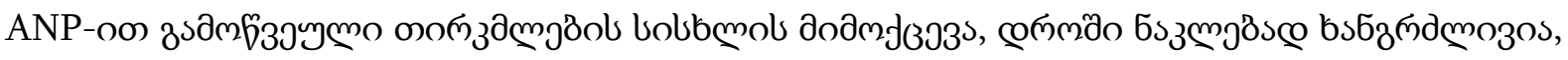

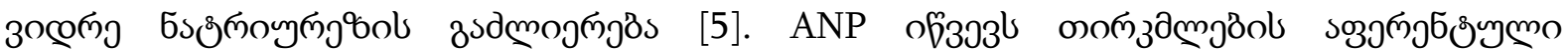

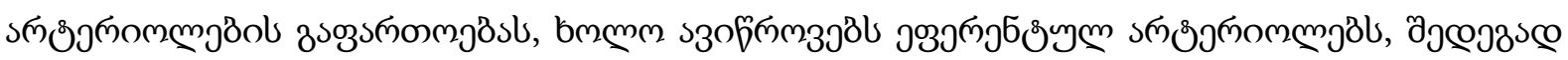




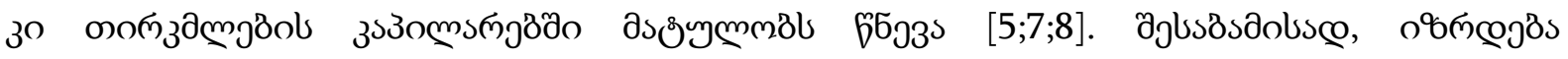

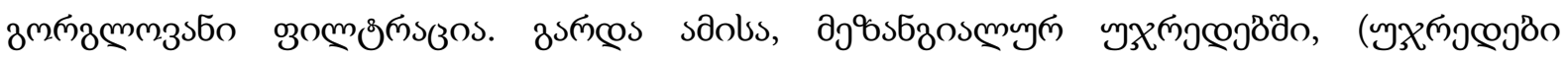

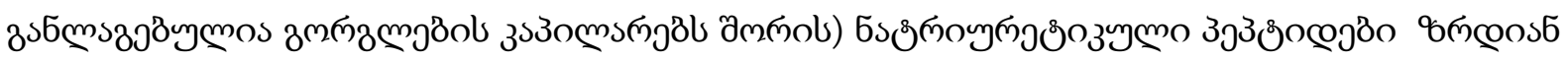

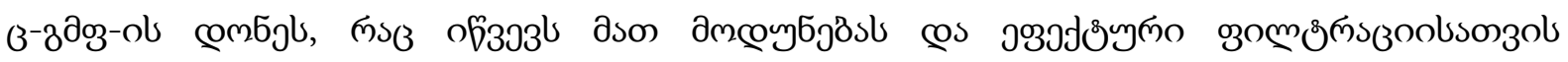

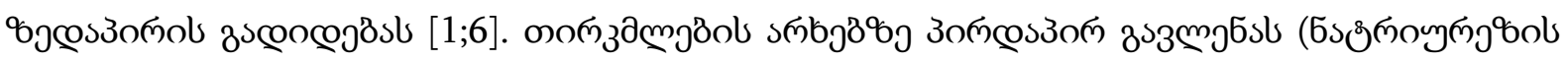

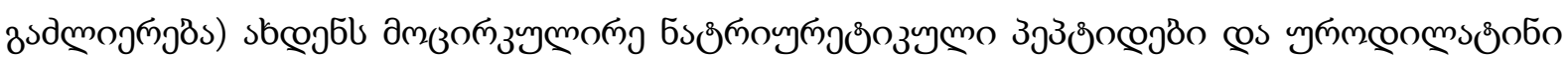

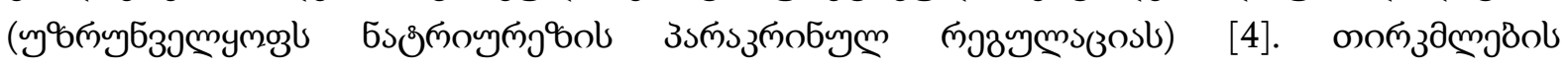

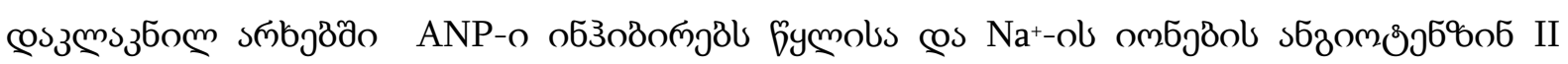

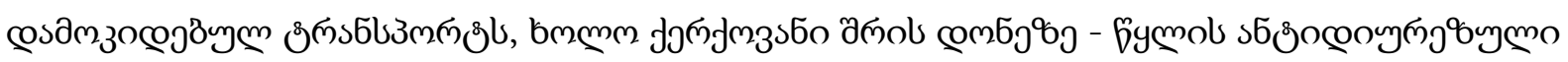

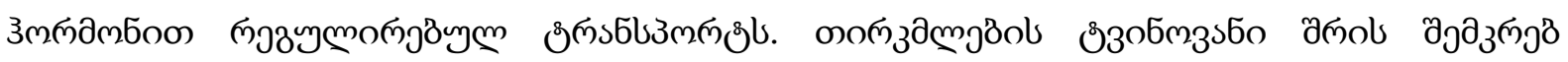

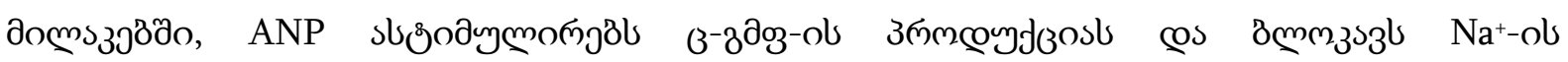

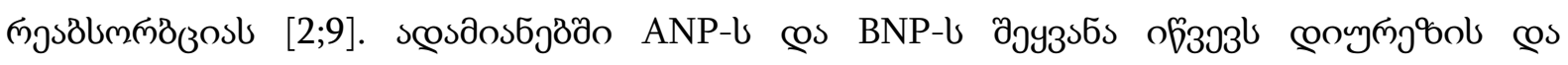

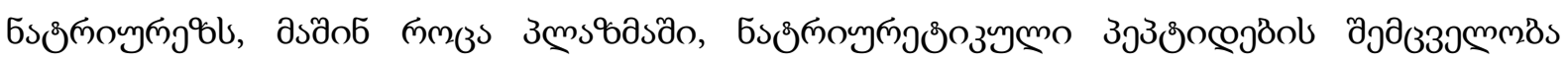

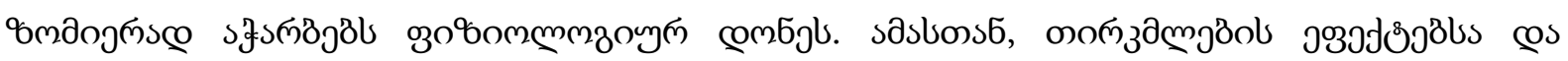

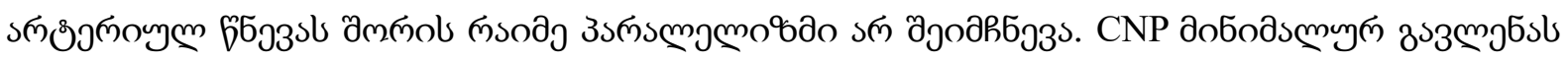

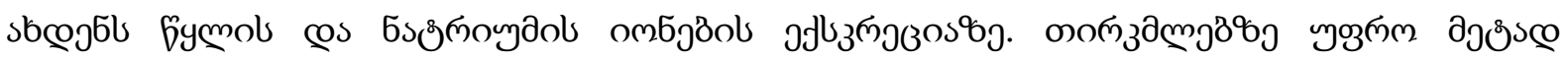

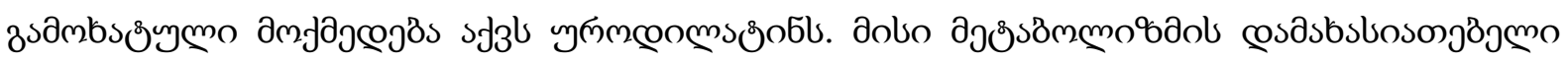

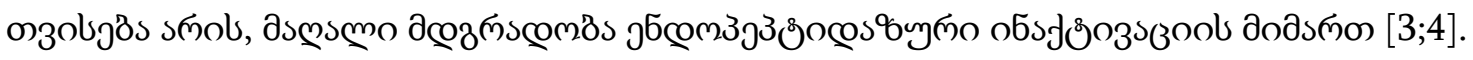

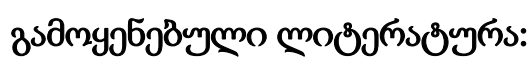

1. Fried T. A., McCoy R. N., Osgood R. W., Stein J. H. Effect of angiopeptin III on determinants of glomerular filtration rate in the in vitro perfused dog glomerulus. Am. J. Physiol. 1986; 250 (6 Pt 2): 1119-1122.

2. Harris P. J., Thomas D., Morgan T. O. Atrial natriuretic peptide inhibitsangiotensin"stimulated proximal tubular sodium and water reabsorption. Nature 1987; 326 (6114): 697-698.

3. Hunt P. J., Richards A. M., Espiner E. A. et al. Bioactivity and metabolismof C"type natriuretic peptide in normal man. J. Clin. Endocrinol.Metab. 1994; 78 (6): 1428 - 1435.

4. Levin E., Gardner D., Samson W. Natriuretic peptides. N. Engl. J. Med. 1998; 339 (5): 321— 328.

5. Marin!Grez M., Fleming J. T., SteinhausenM. Atrial natriuretic peptidecauses pre"glomerular vasodilatation and post"glomerular vasocon"striction in rat kidney. Nature 1986; 324 (6096): 473-476.

6. Stockand J. D., Sansom S. C. Regulation of filtration rate by glomerularmesangial ceels in health and diabetic renal disease. Am. J. Kidney Dis.1997; 29 (6): 971—981.

7. Vanderheyden M., Bartunek J., Goethals M. Brain and other natriureticpeptides: molecular aspects. Eur. J. Heart Failure 2004; 6 (3): 261—268.

8. Weidman P., Hasler L., Gnadinger M. et al. Blood levels and renal effectsof atrial natriuretic peptide in normal man. J. Clin. Invest. 1986; 77 (3):734-742.

9. Zeidel M. L. Regulation of collecting duct Na reabsorption by ANP 31"67.Clin. Exp. Pharmacol. Physiol. 1995; 22 (2): 121-124. 


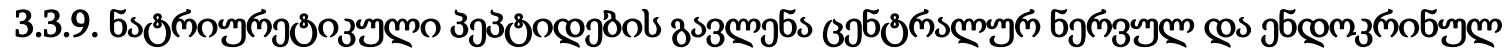

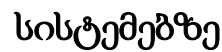

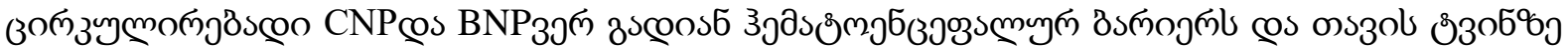

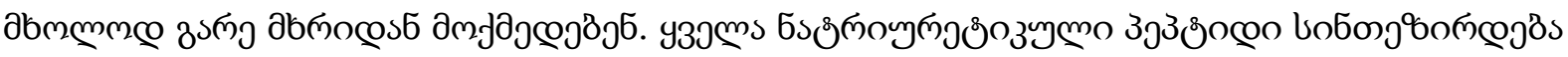

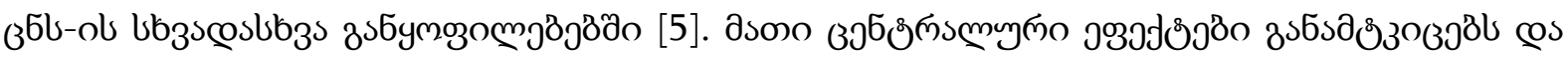

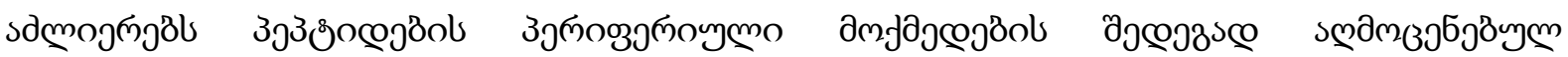

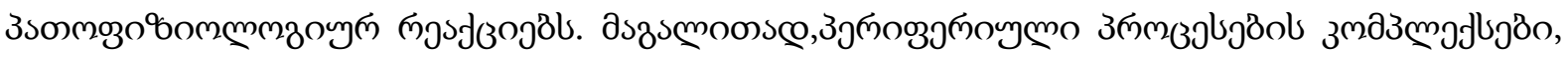

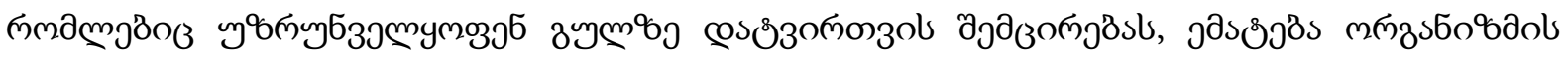

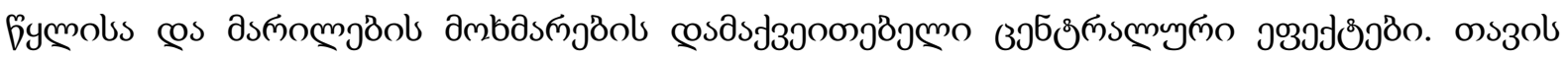

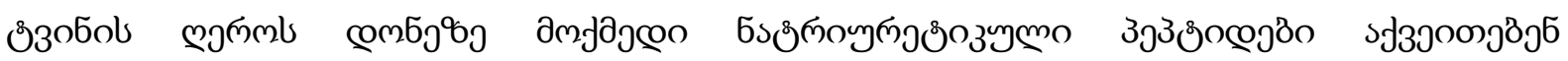

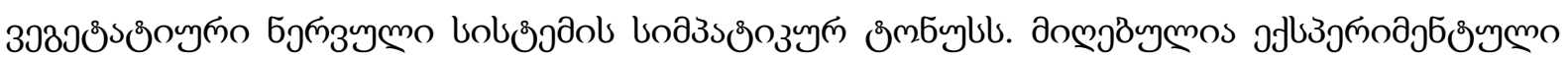

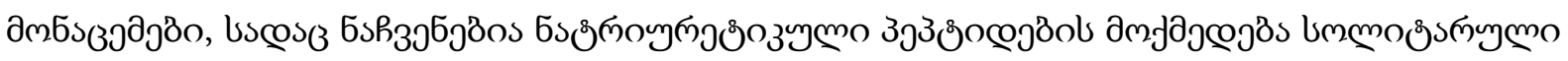

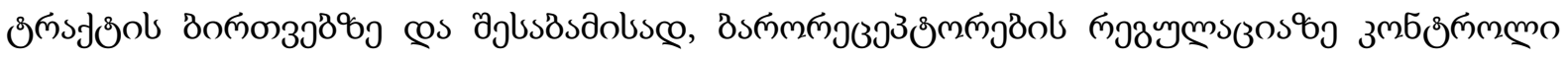
$[1 ; 8]$.

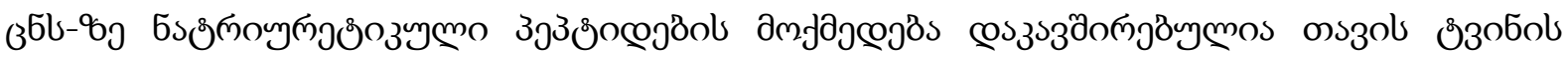

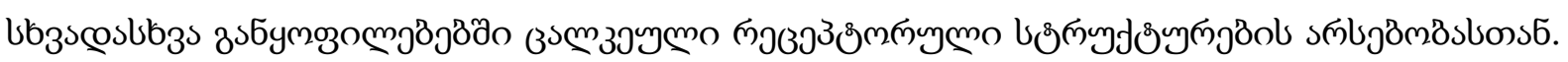

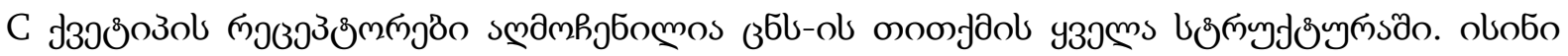

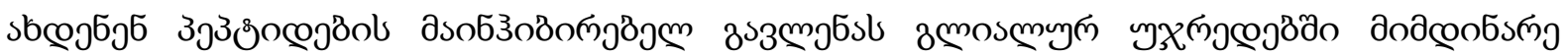

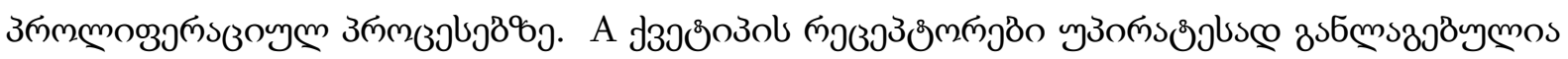

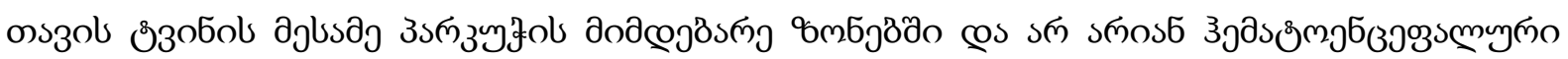

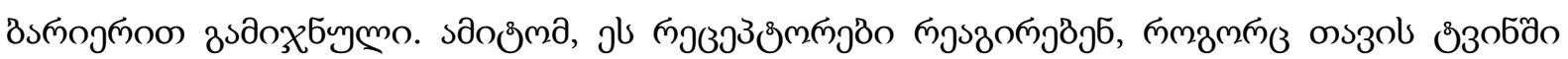

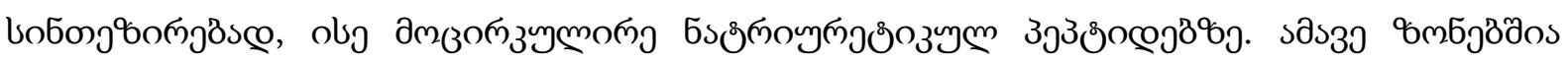

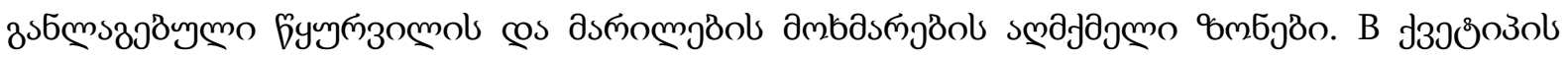

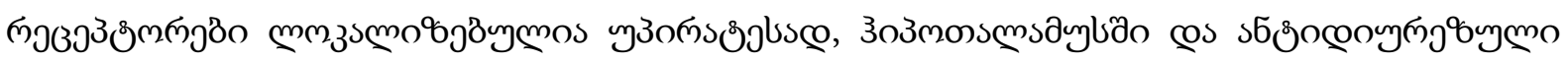

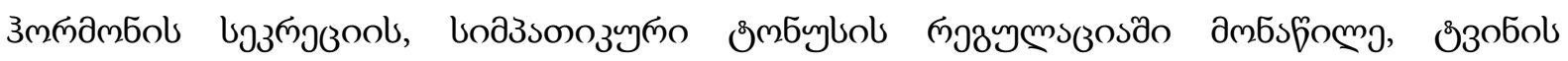

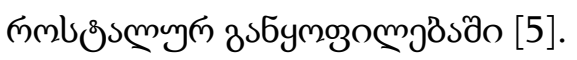

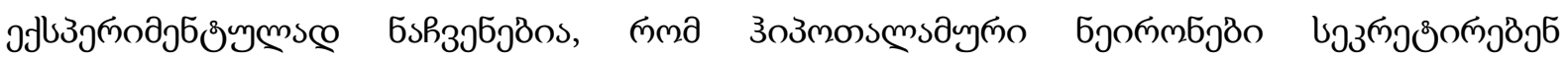

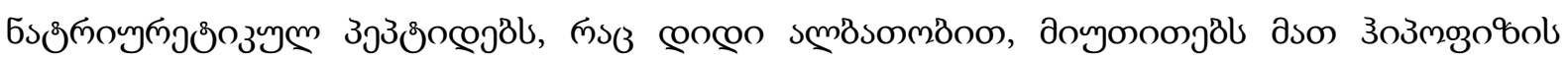

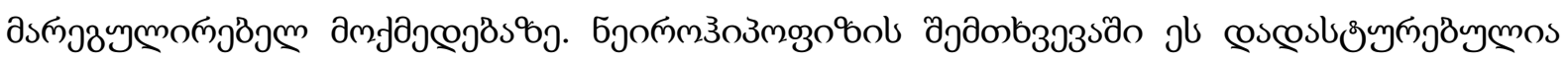

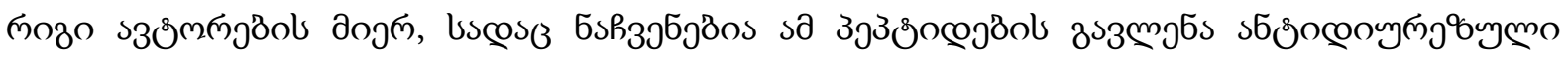

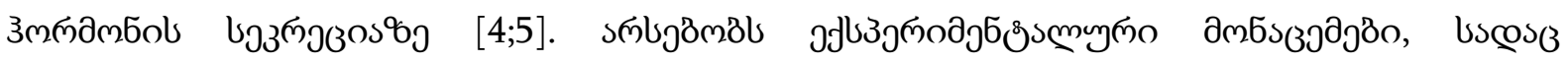

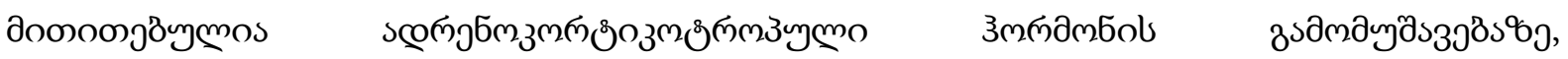

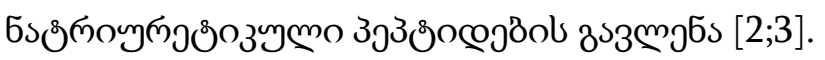

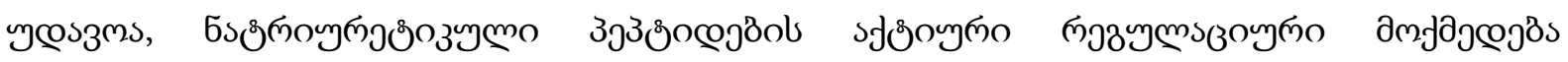

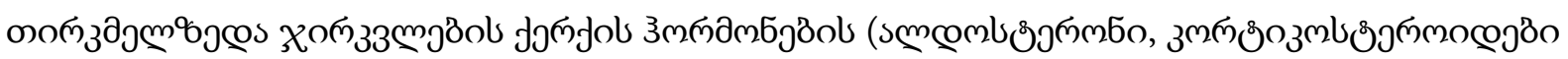

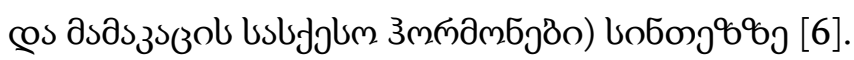

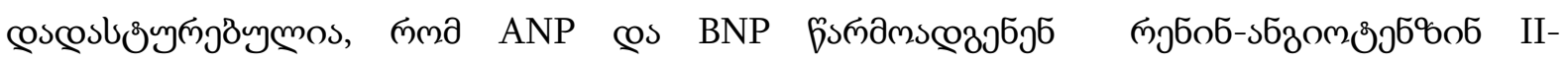

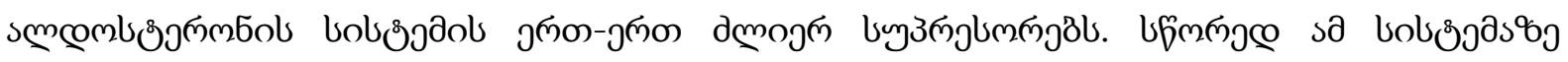

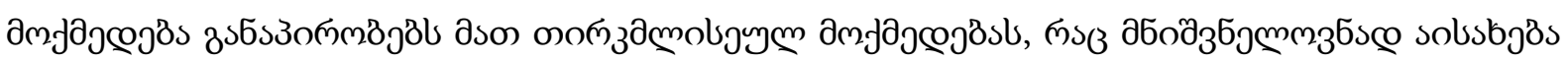

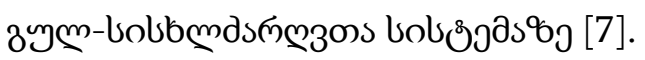




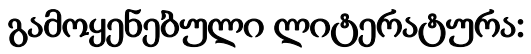

1. Blackburn R. E., Samson W. K., Fulton R. J. et al. Central oxytocin andANP receptors mediate osmotic inhibition of salt appetite in rats. Am.J. Physiol. 1995; 269 (2 Pt 2): R245R251.

2. Gardi J., Biro E., Vecsernyes M. et al. The effects of brain and C"typenatriuretic peptides on corticotrophin"releasing factor in brain of rats.Life Sci. 1997; 60 (23): 2111-2117.

3. Guild S., Gramb G. Characterisation of the effects of natriuretic peptides upon ACTH secretion from the mouse pituitary. Molec. Cell.Endocrinol. 1999; 152 (1-2): 11-19.

4. Hunt P.,Espiner E.,Nicholls M. et al. Differing biological effects ofequimolar atrial and brain natriuretic peptide infusions in normal man.J.Clin. Endocrinol.Metab.1996;8 (11):3871— 3876.

5. Levin E., Gardner D.,Samson W.Natriuretic peptides. N.Engl. J.Med.1998; 339 (5): 321328.

6. Nawata M., Ohashi M., Haji M. et al. Atrial and brain natriuretic peptide in adrenal steroidogenesis. J. Steroid Biochem. Molec. Biology1991; 40 (1-3): 367-379.

7. Vanderheyden M., Bartunek J., Goethals M. Brain and other natriureticpeptides: molecular aspects. Eur. J. Heart Failure 2004; 6 (3): 261-268.

8. Yang R. H., Jin H. K., Wyss J. M. et al. Pressor effect of blocking atrialnatriuretic peptide in nucleus tractus solitarii. Hypertension 1992; 19(2): 198-205.

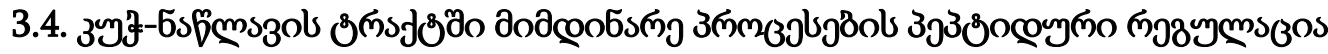

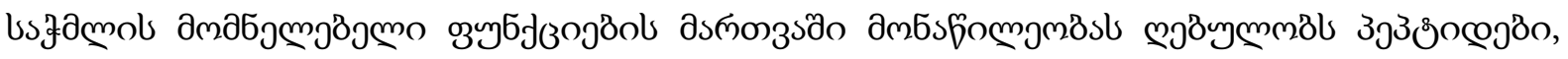

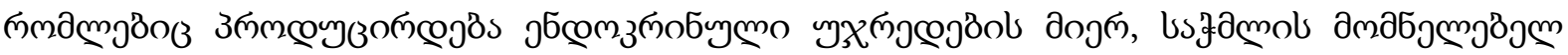

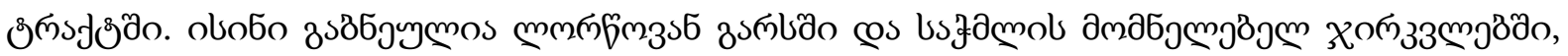

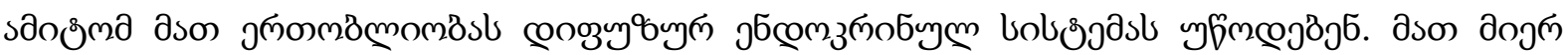

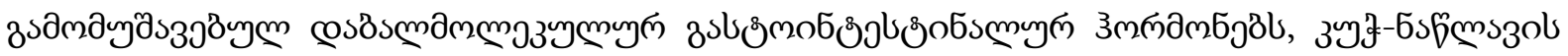

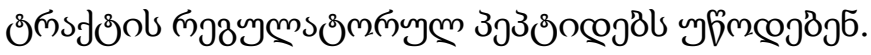

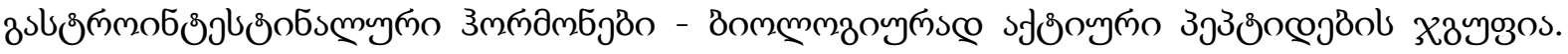

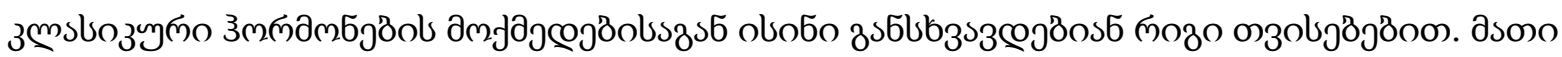

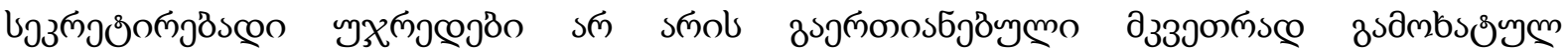

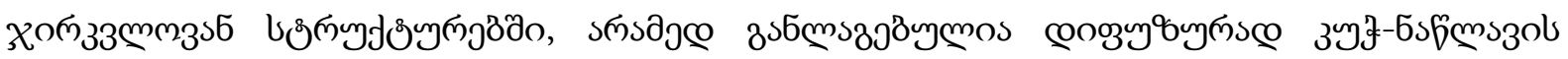

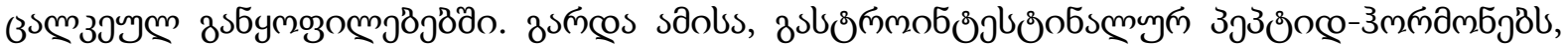

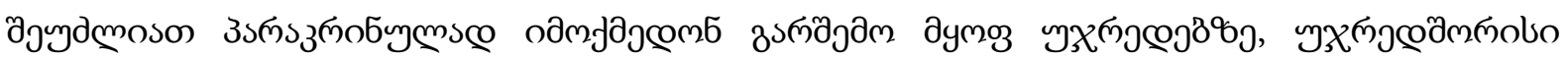

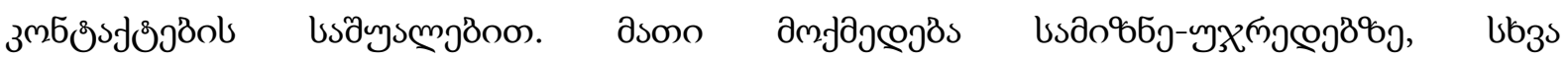

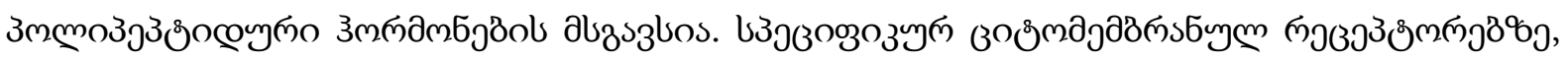

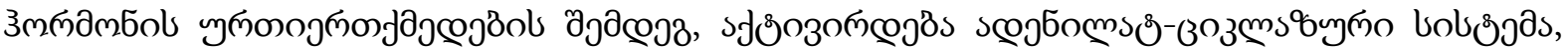

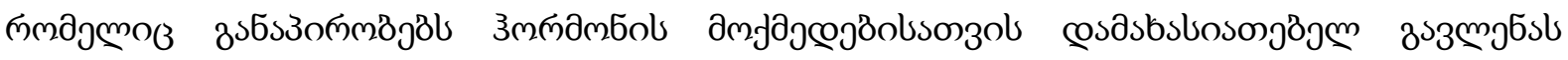

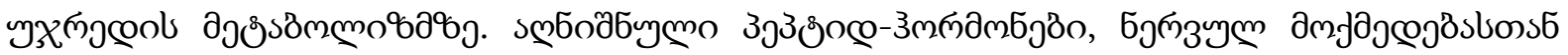

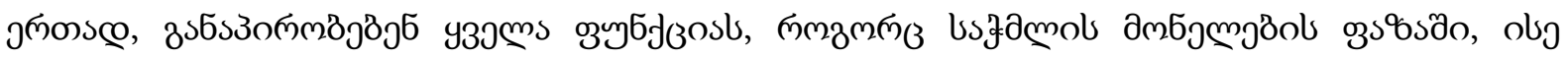

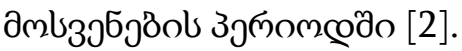




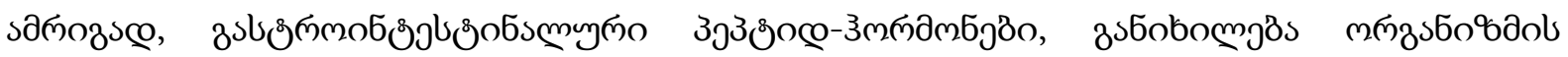

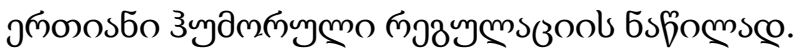

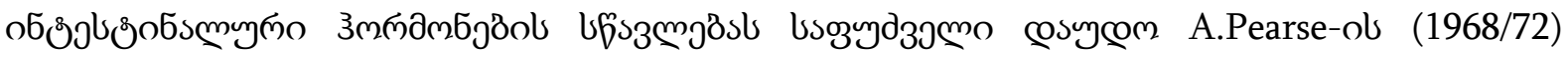

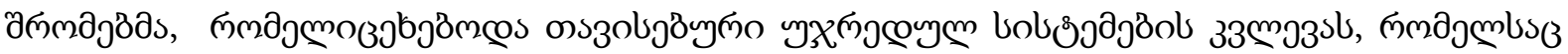

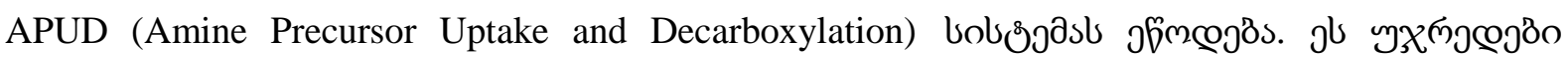

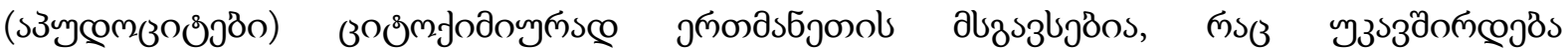

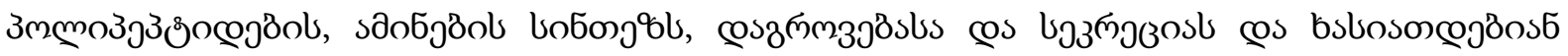

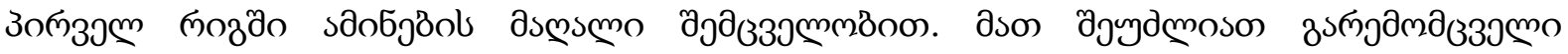

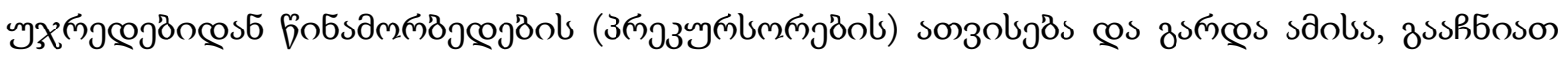

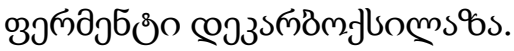

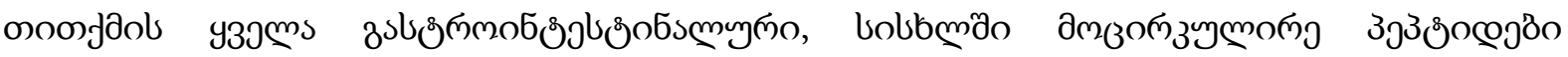

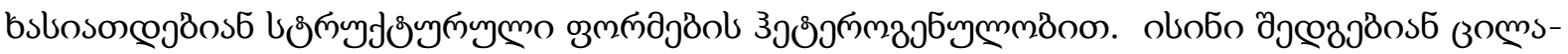

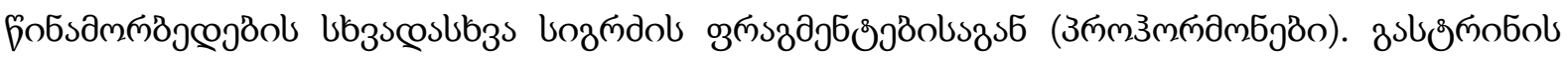

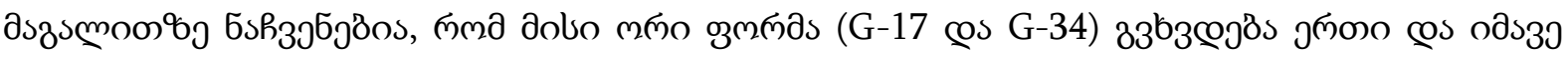

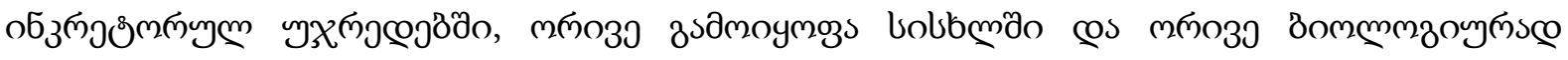

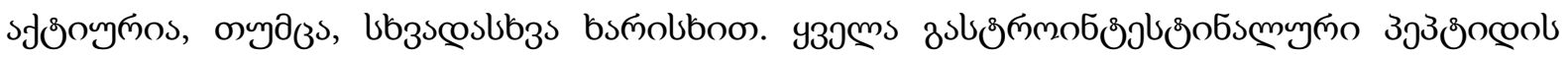

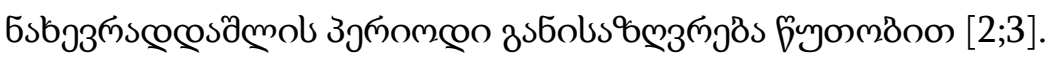

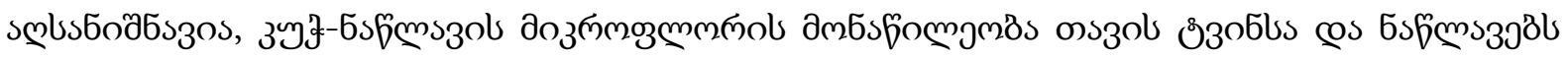

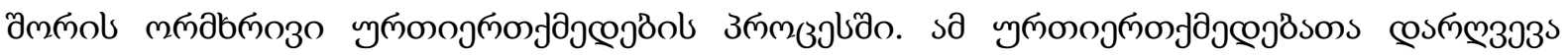

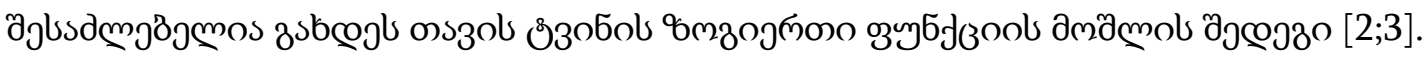

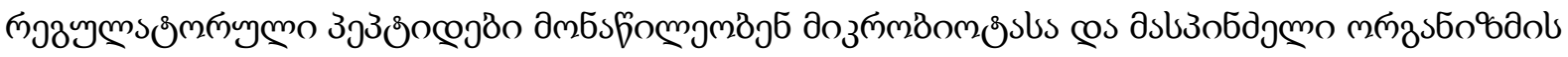

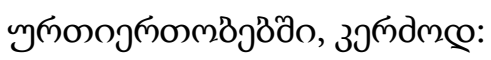

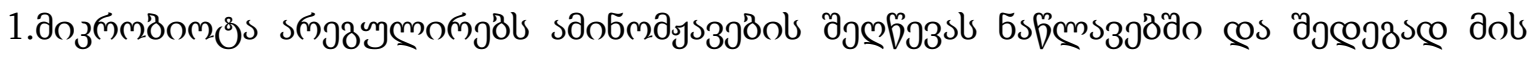

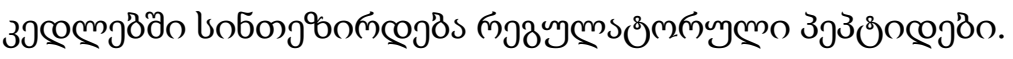

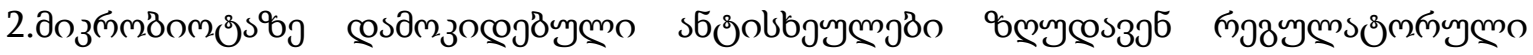

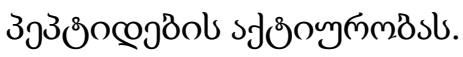

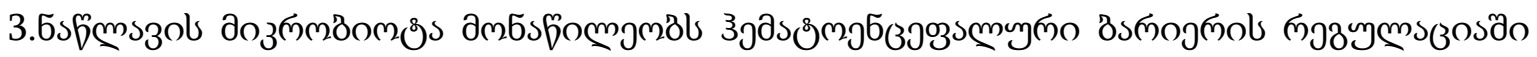

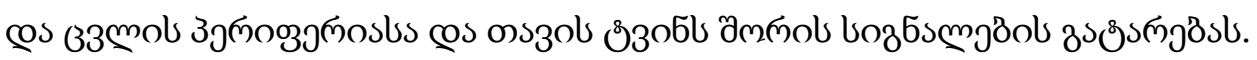

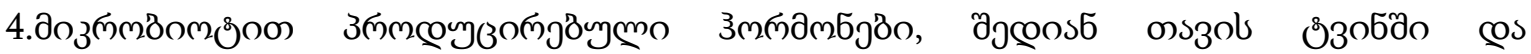

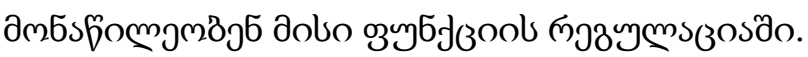

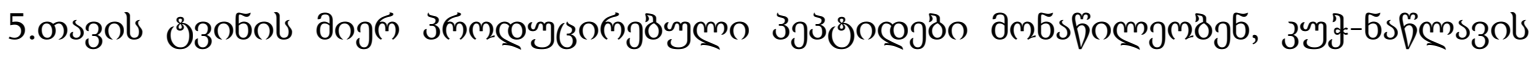

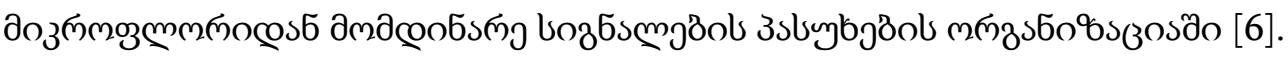

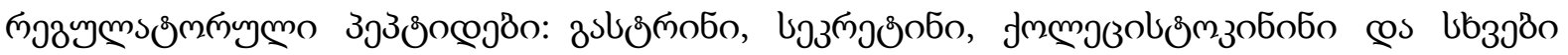

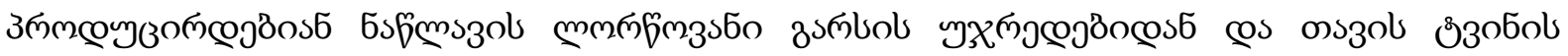

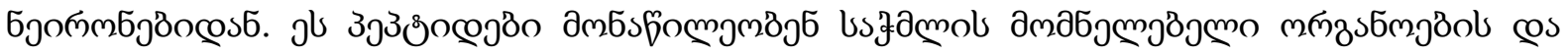

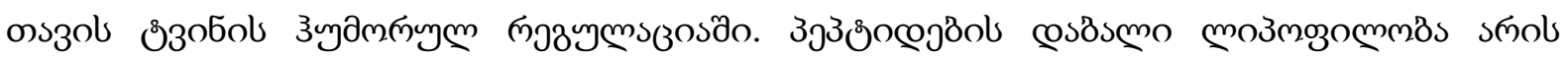

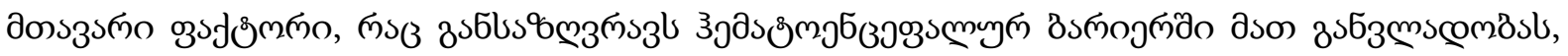

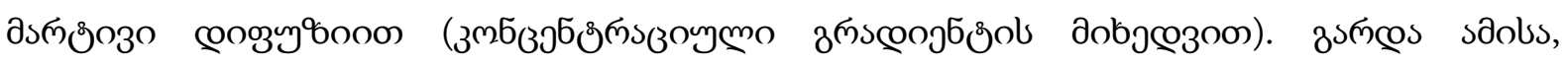

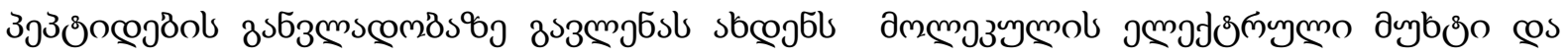

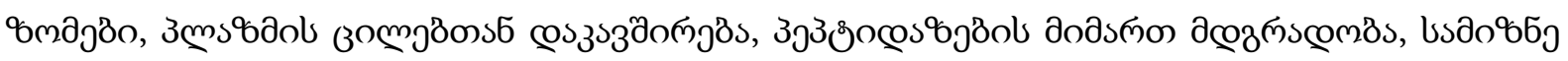

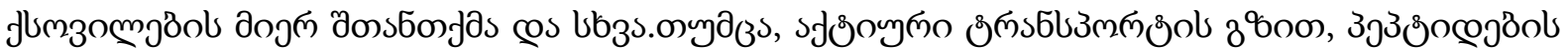




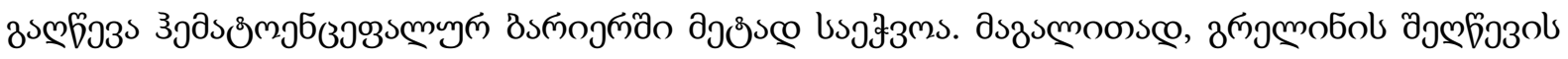

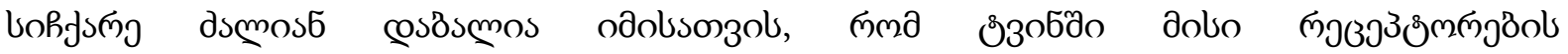

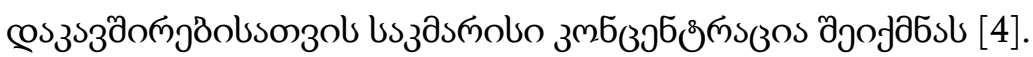

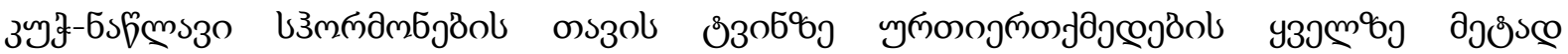

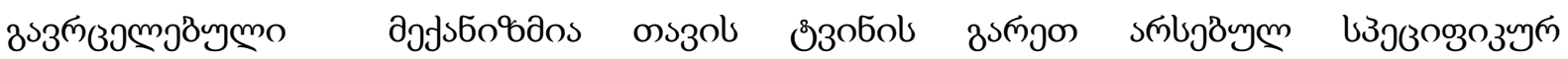

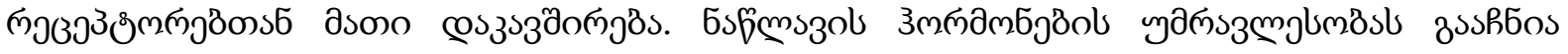

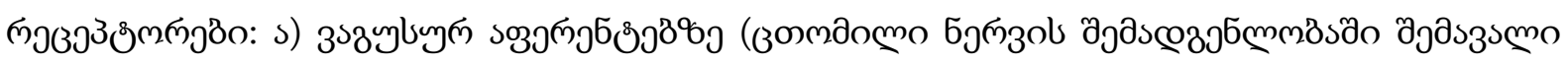

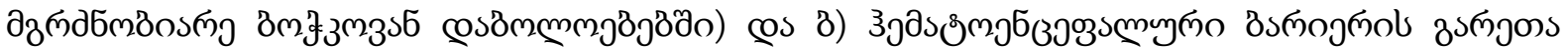

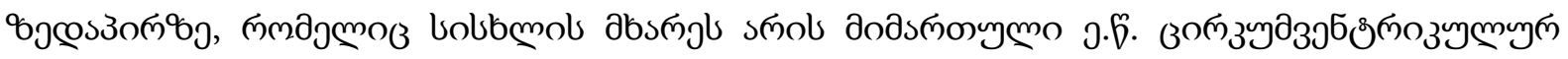

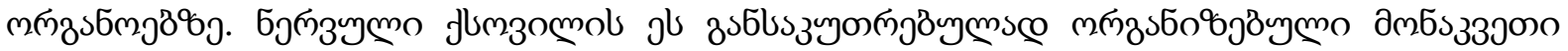

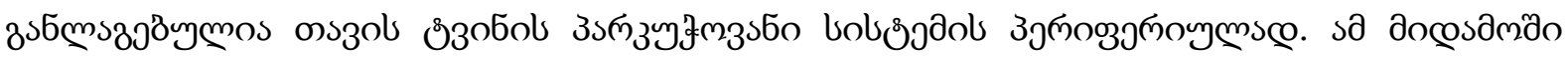

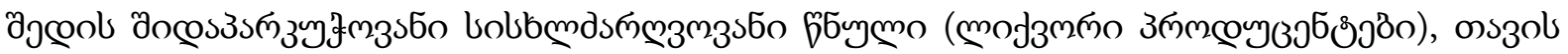

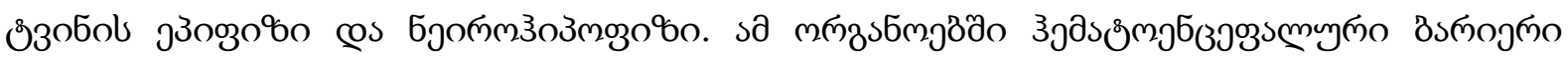

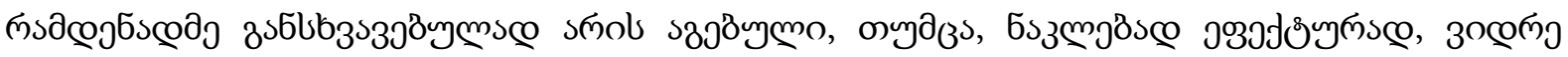

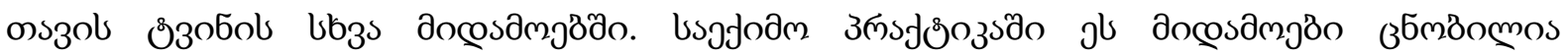

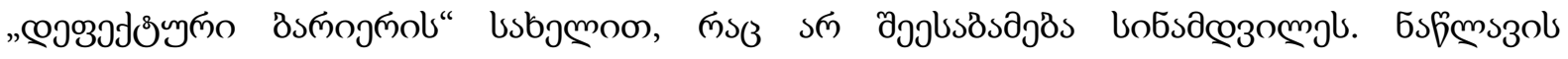

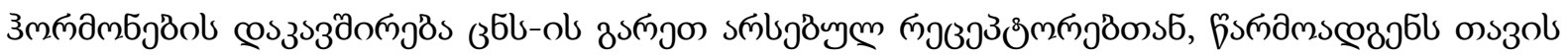

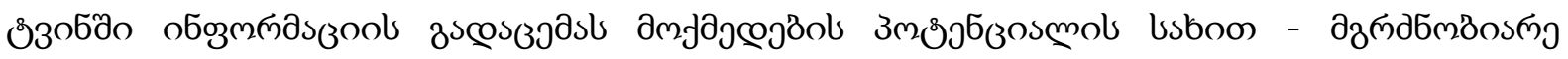

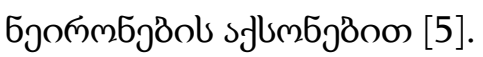

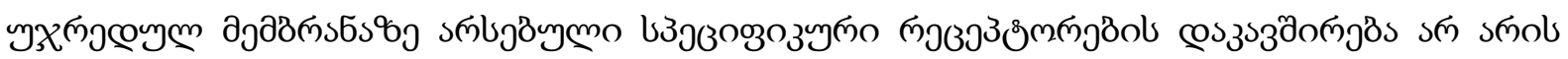

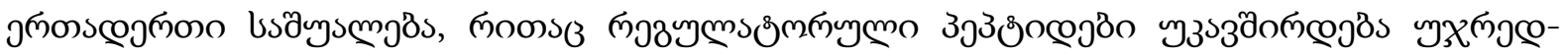

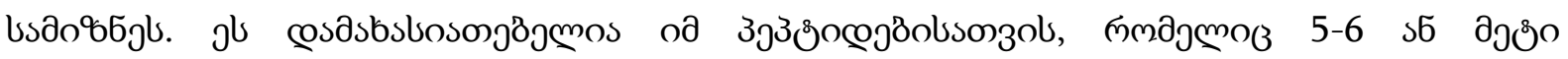

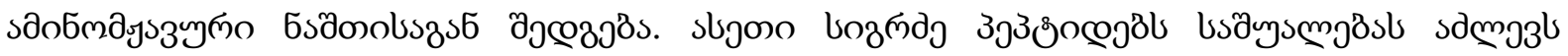

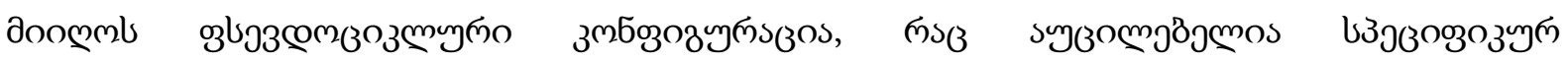

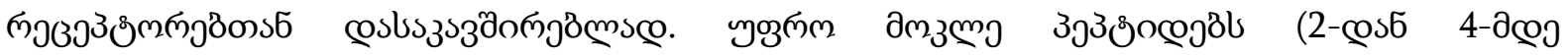

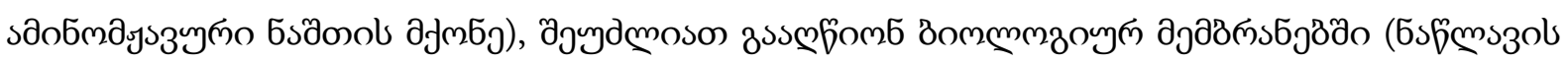

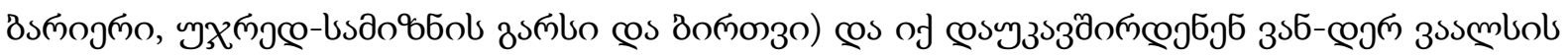

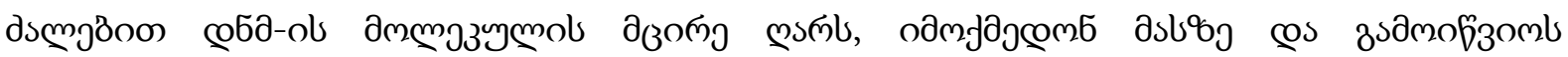

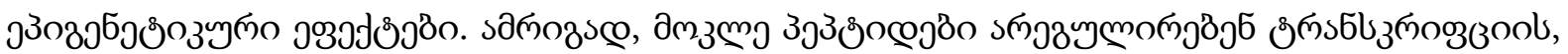

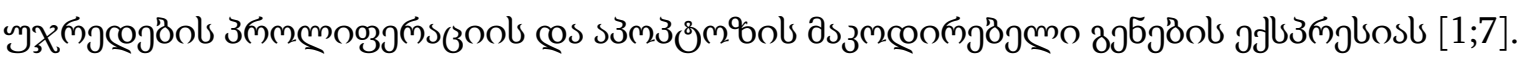

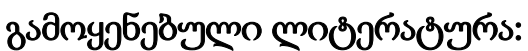

1. Anisimov V.N., Khavinson V.Kh. Peptide bioregulation of aging: results and prospects. Biogerontology. 2010; 11: 139-49.

2. Chaudhri O., Small C., Bloom S. Gastrointestinal hormones regulating appetite. Philos. Trans. R. Soc. Lond. B. Biol. Sci. 2006; 361(1471): 1187-1209.

3. Elisei C., de Castro A.P. Insight into role of microbiota-gut-brain peptides as a target for biotechnology innovations. Front. Biosci. (Elite ed.). 2017; 9: 76-88.

4. Fry M., Ferguson A.V. Ghrelin: central nervous system sites of action in regulation of energy balance. Int. J. Pept. 2010; 2010: 616-757. 
5. de Lartigue G., de La Serre C.B., Raybould H.E. Vagal afferent neurons in high fat dietinduced obesity; intestinal microflora, gut inflammation and cholecystokinin. Physiol. Behav. 2011; 105(1): 100-5.

6. Holzer P. Neuropeptides, microbiota, and behavior. Int. Rev. Neurobiol.2016; 131: 67-89.

7. Khavinson V.Kh., Linkova N.S., Polyakova V.O., Kheifets O.V., Tarnovskaya S.I., Kvetnoy

8. I.M. Peptide tissue-specifically stimulate cell differentiation during their aging. Cell Technol. Biol. Med. 2012; 1(5):148-51.

\subsection{1. zsboిmobo}

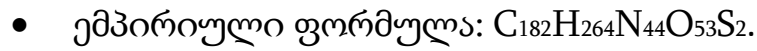

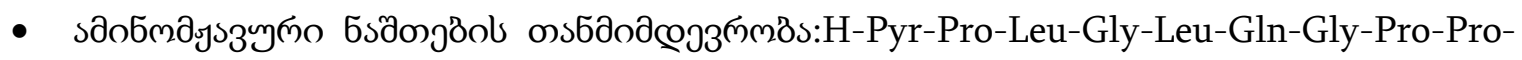
His-Leu-Val-Ala-Asp-Leu-Ala-Lys-Lys-Gln-Gly-Pro-Trp-Met-Glu-Glu-Glu-Glu-Glu-AlaTyr-Gly-Trp-Met-Asp-Phe-NH2.

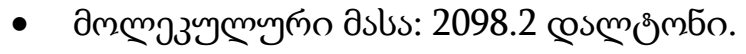

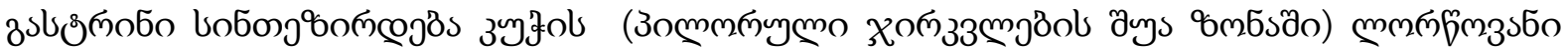

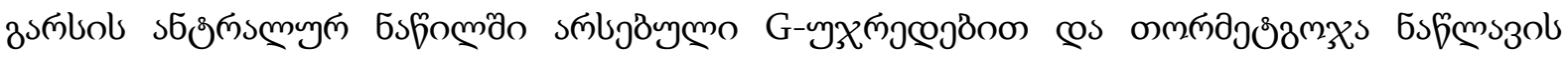

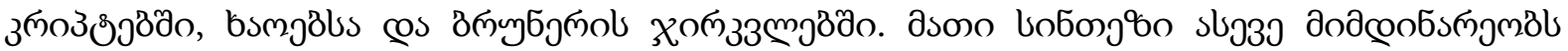

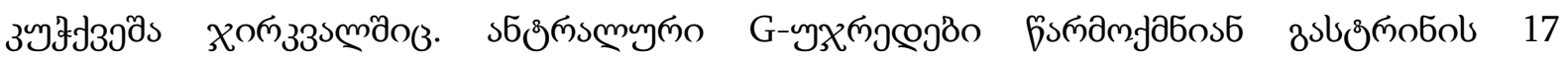

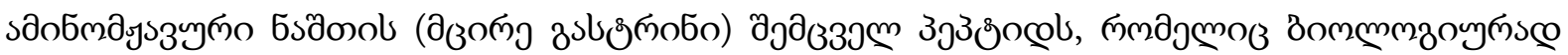

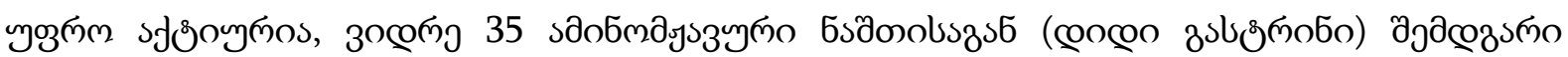

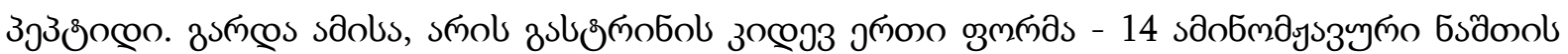

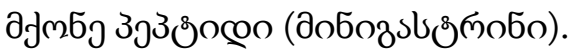

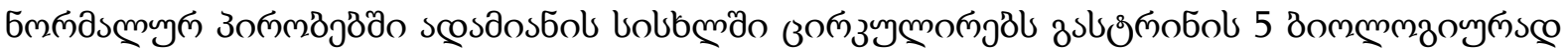

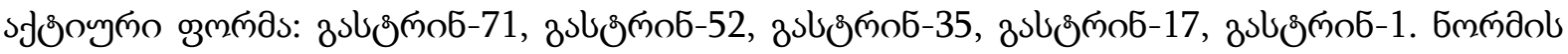

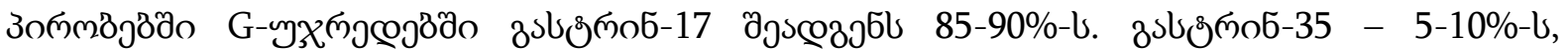

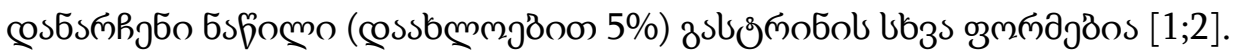

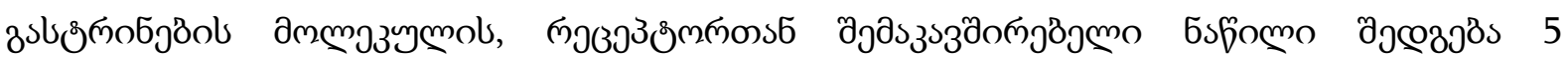

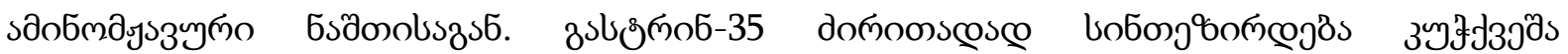

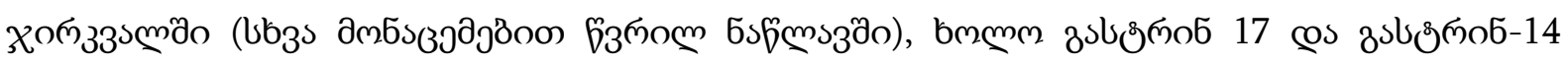

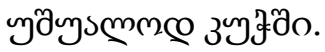

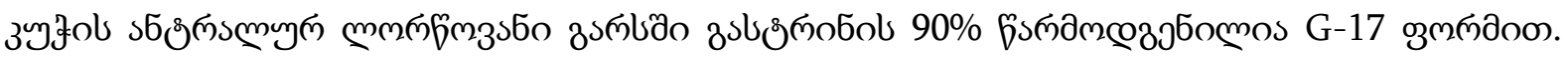

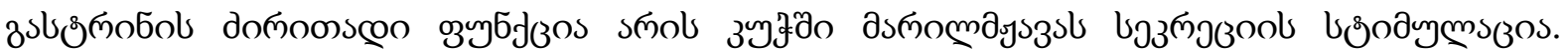

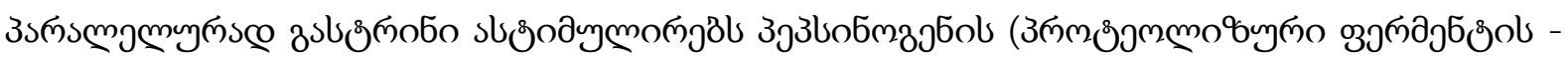

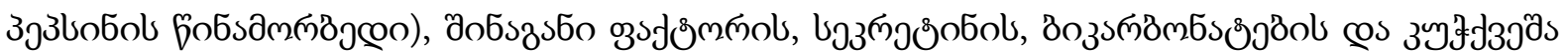

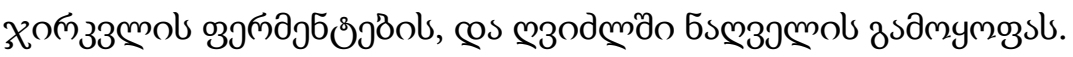

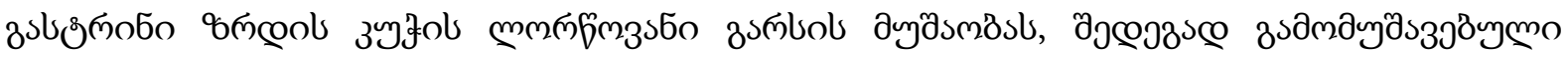

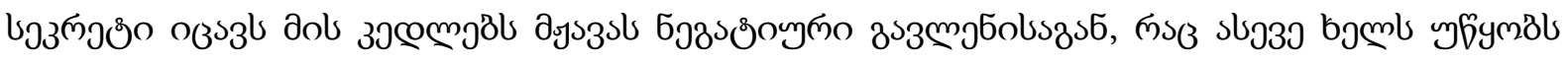

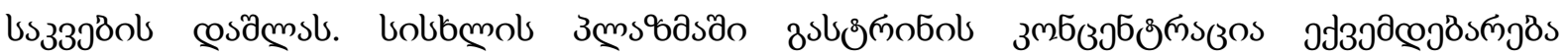

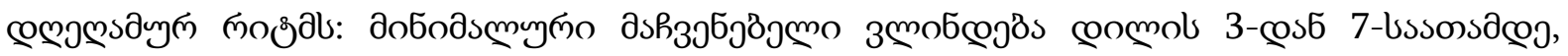




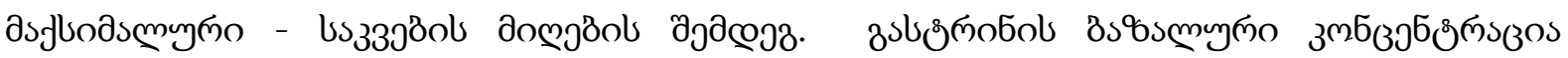

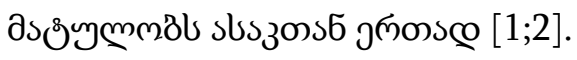

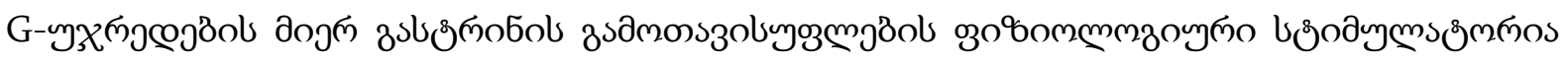

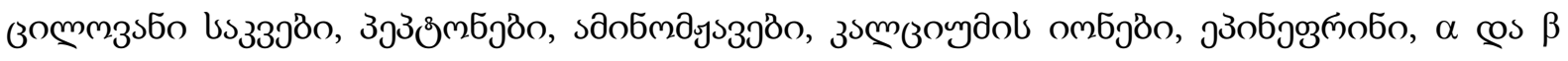

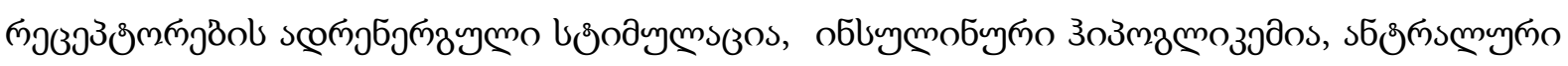

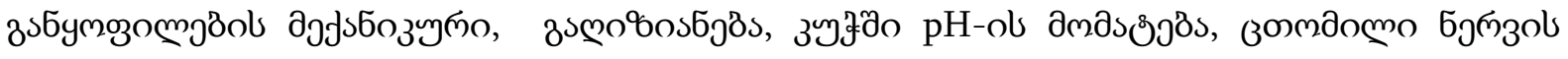
(nervus vagus) తిmbigluob amas

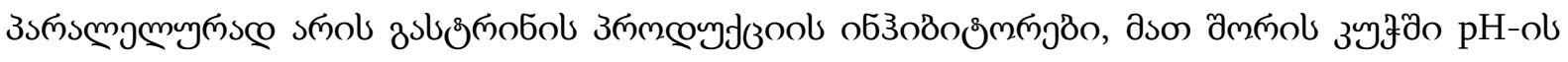

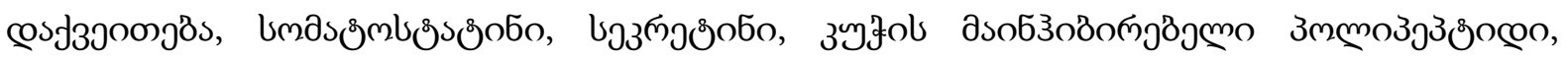

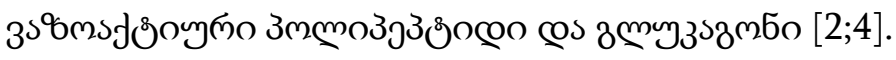

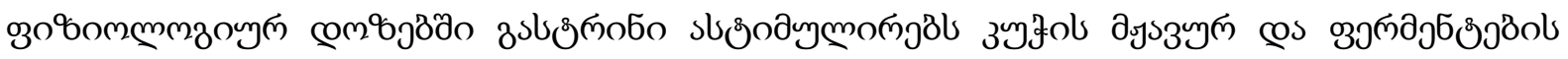

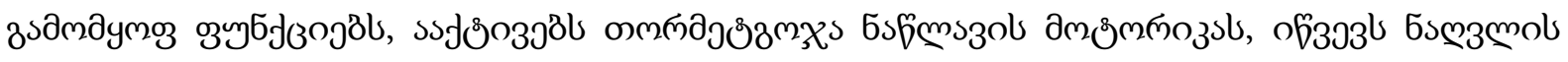

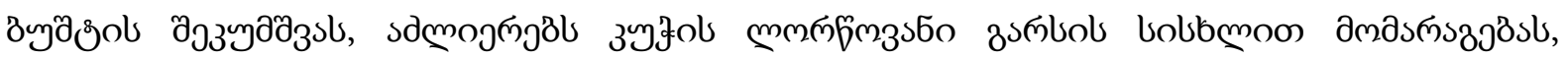

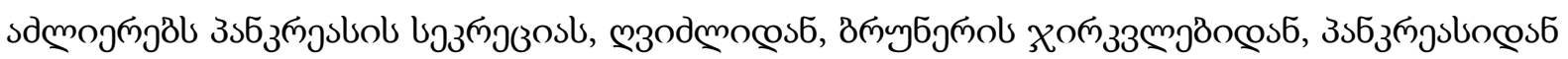

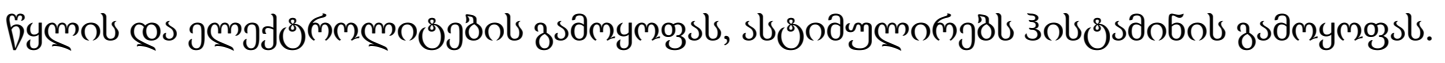

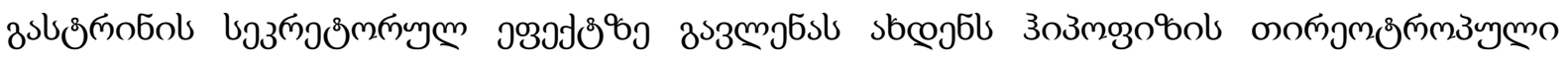

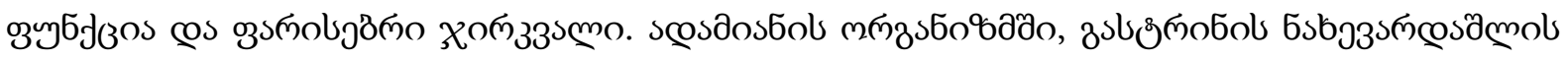

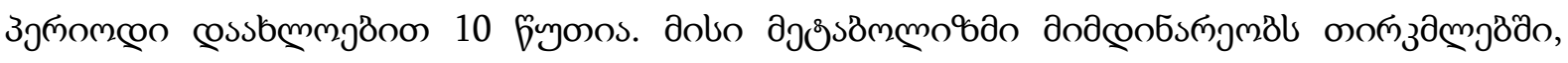

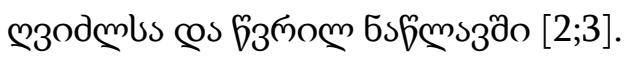

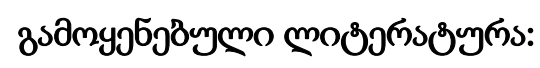

1. Cases J. 2009 Primary liver carcinoid tumour with a Zollinger Ellison syndrome - an unusual diagnosis: a case report. Gabriela Rascarachi, Mónica Sierra, Mercedes Hernando, Rubén Diez, Laura Arias, Francisco Jorquera, Santiago Vivas, and José Luis Olcoz.

2. Chaudhri O., Small C., Bloom S. Gastrointestinal hormones regulating appetite. Philos. Trans. R. Soc. Lond. B. Biol. Sci. 2006; 361(1471):1187-1209.

3. Rehfeld JF, Bardram L, Hilsted L, Poitras P, Goetze JP. Pitfalls in diagnostic gastrin measurements. Clin Chem. 2012;58(5):831-6. doi: 10.1373/clinchem.2011.179929.

4. World J Gastroenterol. 2009 January 7; 15(1): 1-16. Importance of gastrin in the pathogenesis and treatment of gastric tumors. Michael D Burkitt, Andrea Varro, and D Mark Pritchard.

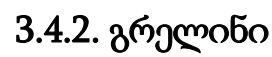

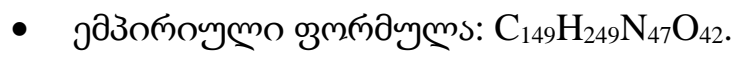

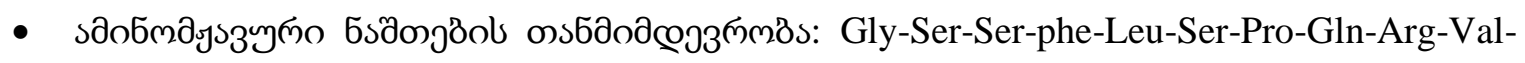
Gln-Gln-Arg-Lys-Glu-Ser-Lys-Lys-Pro-Pro-Ala-Lys-Leu-Gln-Pro-Arg.

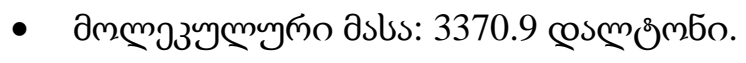

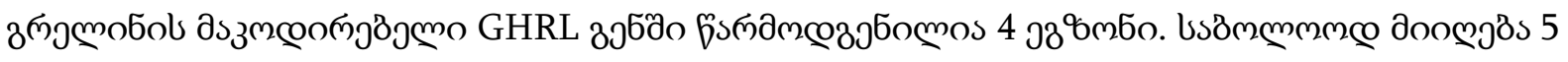

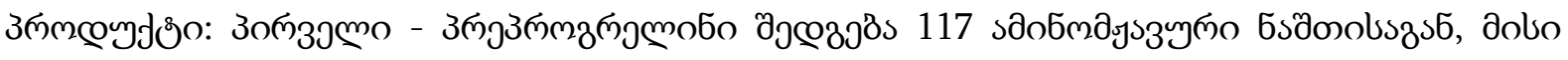




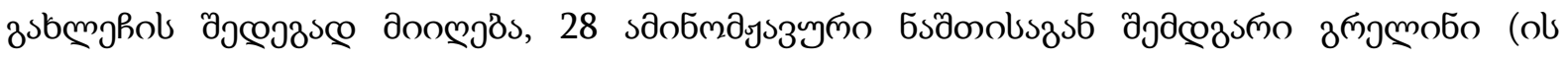

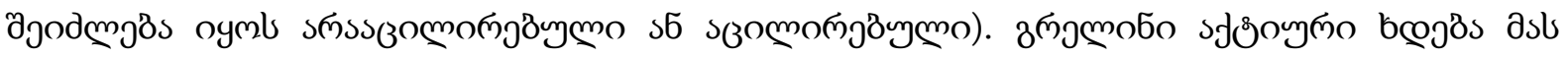

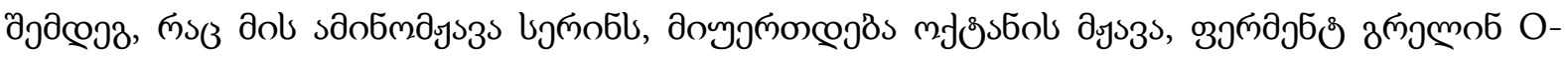

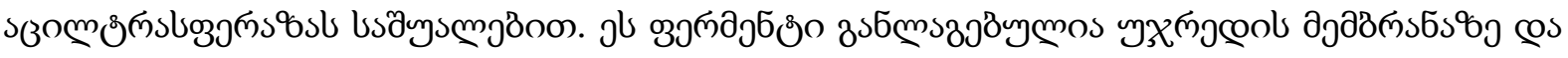

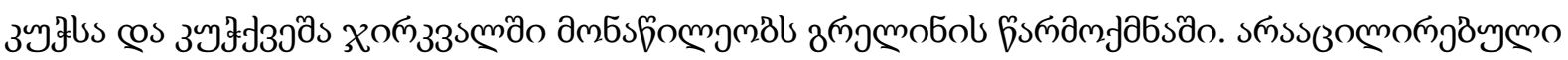

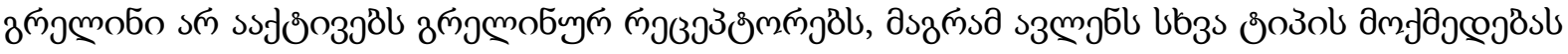

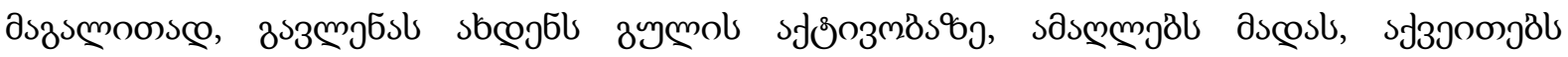

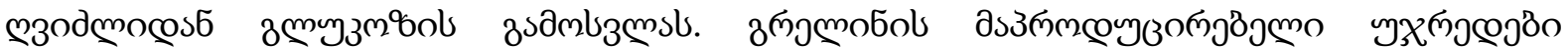

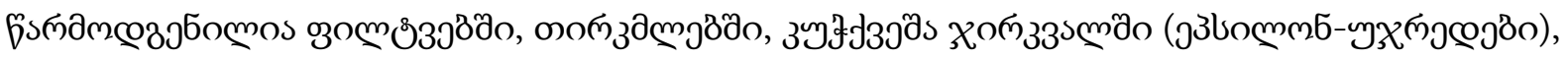

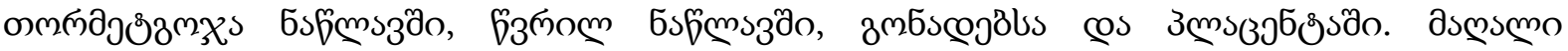

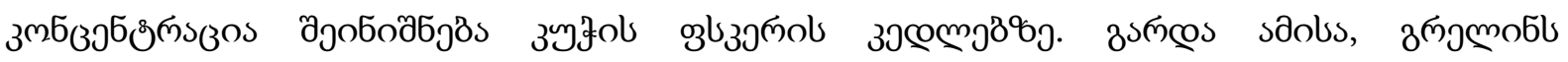

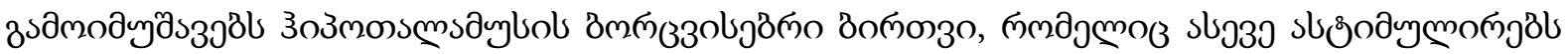

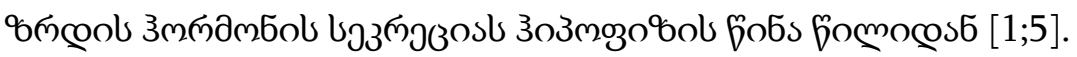

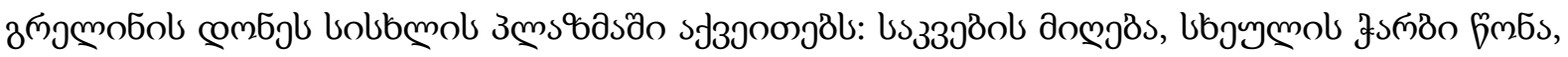

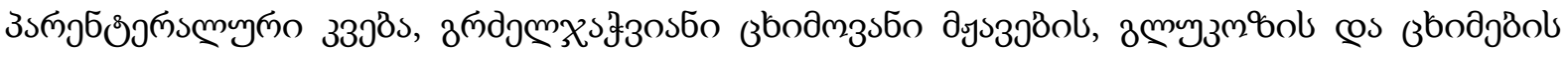

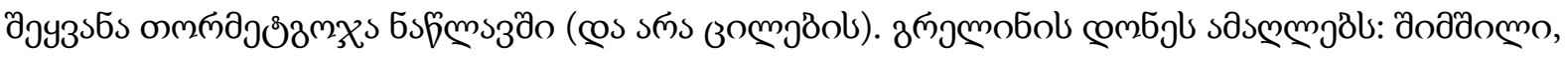

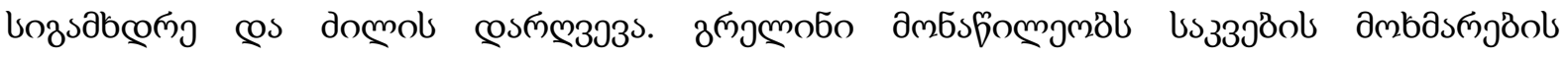

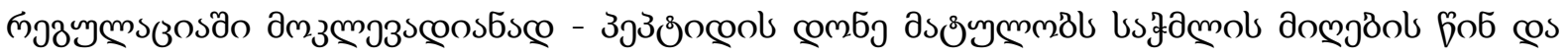

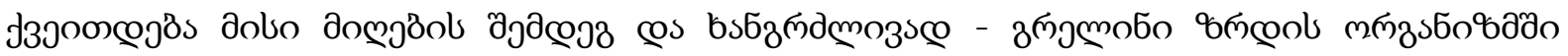

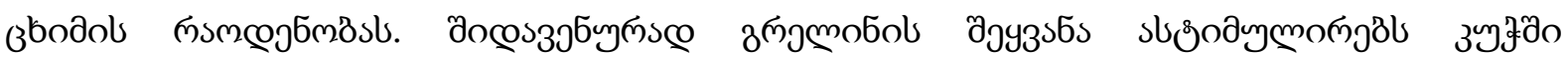

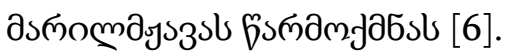

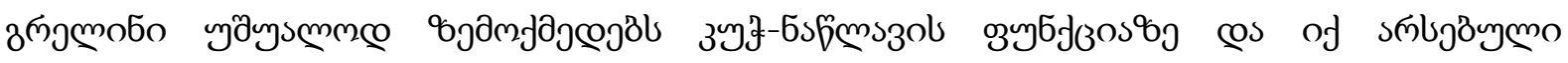

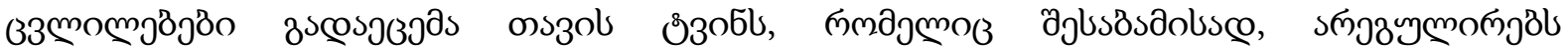

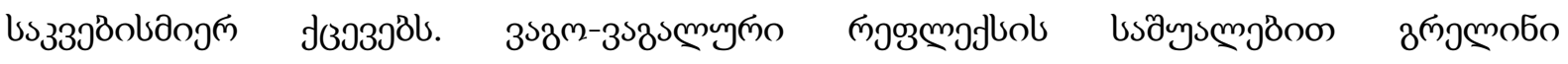

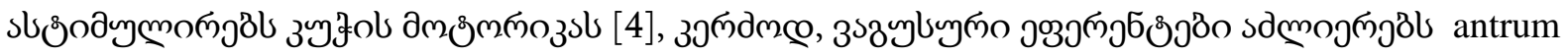

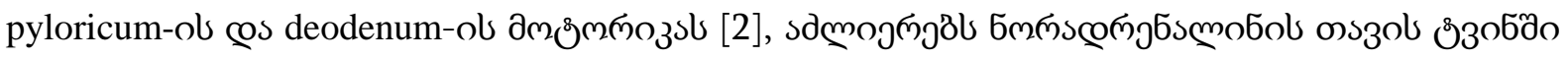

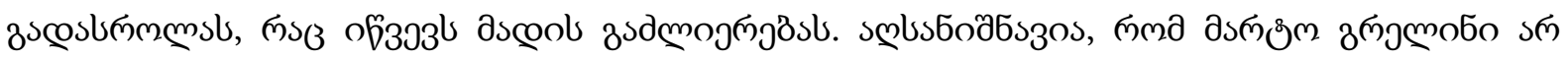

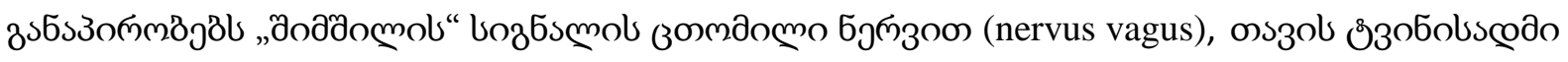

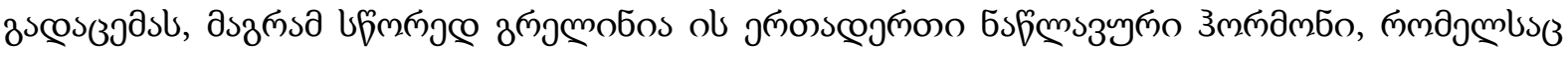

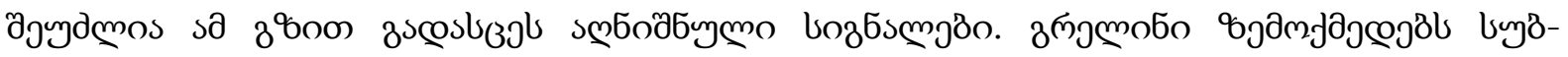

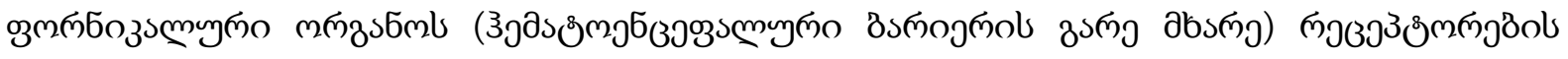

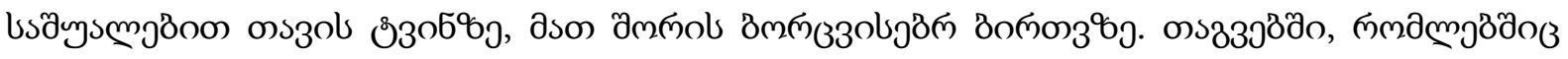

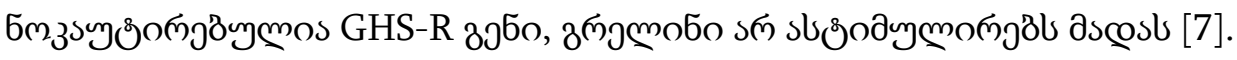

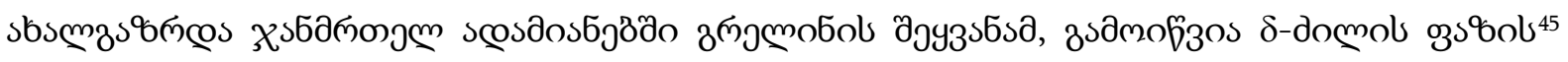

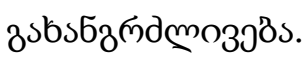

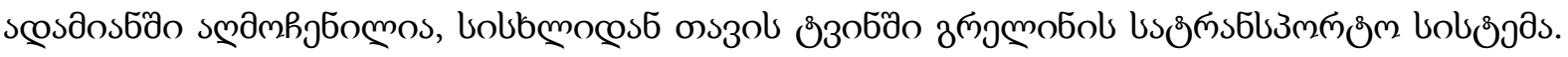

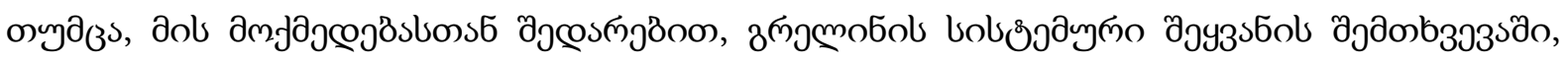

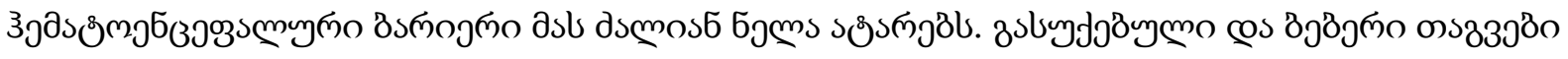

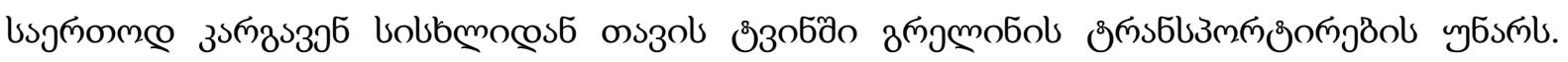

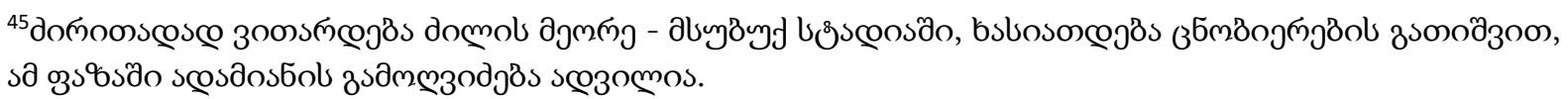




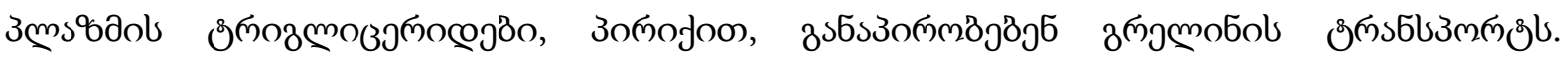

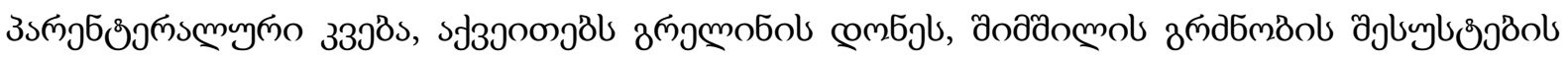

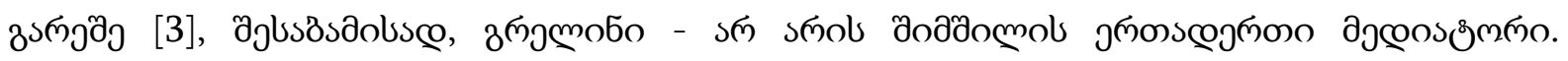

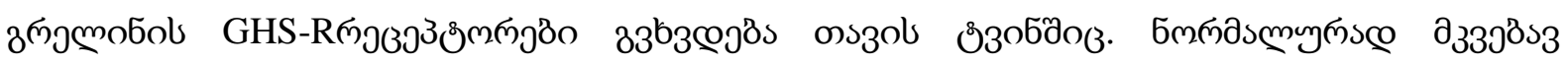

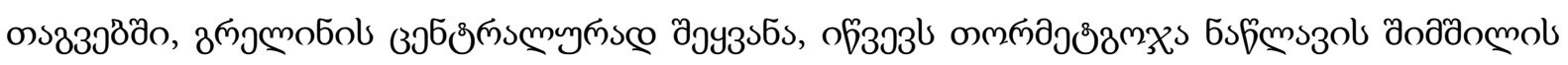

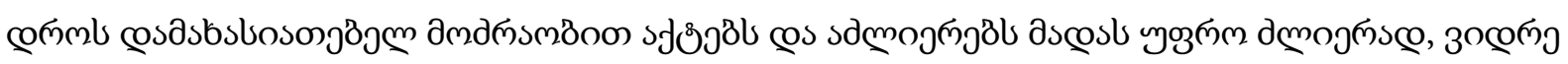

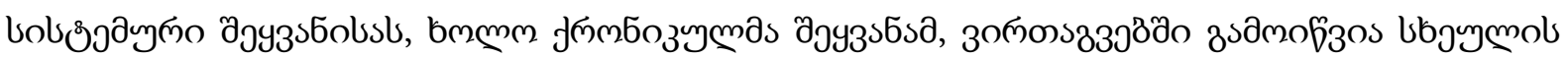

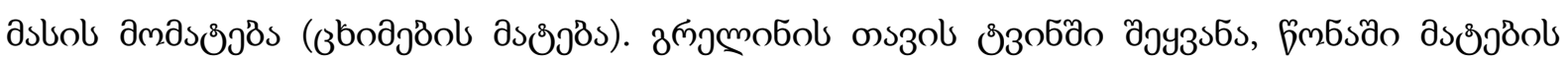
бобззопмдss [3].

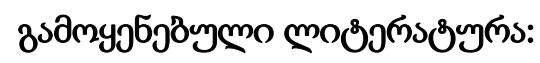

1. Chaudhri O., Small C., Bloom S. Gastrointestinal hormones regulating appetite. Philos. Trans. R. Soc. Lond. B. Biol. Sci. 2006; 361(1471):1187-1209.

2. Fujimiya M., Asakawa A., Ataka K., Kato I., Inui A. Different effects ofghrelin, des-acyl ghrelin and obestatin on gastroduodenal motility inconscious rats. World J. Gastroenterol. 2008; 14(41): 6318-26.

3. Murray C.D., le Roux C.W., Gouveia C., Bassett P., Ghatei M.A.,Bloom S.R. et al. The effect of different macronutrient infusions onappetite, ghrelin and peptide YY in parenterally fed patients. Clin.Nutr. 2006; 25(4): 626-33.

4. Nakamura T., Onaga T., Kitazawa T. Ghrelin stimulates gastric motilityof the guinea pig through activation of a capsaicin-sensitive neuralpathway: in vivo and in vitro functional studies. Neurogastroenterol.Motil. 2010; 22(4): 446-52.

5. St-Pierre D.H., Wang L., Taché Y. Ghrelin: a novel player in the gutbrainregulation of growth hormone and energy balance. News Physiol.Sci. 2003; 18: 242-6.

6. Takayama K., Johno Y., Hayashi K., Yakabi K., Tanaka T., Ro S. Expressionof c-Fos protein in the brain after intravenous injection ofghrelin in rats. Neurosci. Lett. 2007; 417(3): 292-6.

7. Zigman J.M., Nakano Y., Coppari R., Balthasar N., Marcus J.N., LeeC.E. et al. Mice lacking ghrelin receptors resist the development ofdiet-induced obesity. J. Clin. Invest. 2005; 115(12): 3564-72.

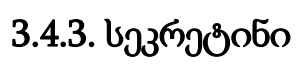

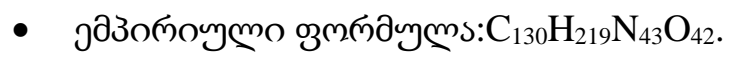

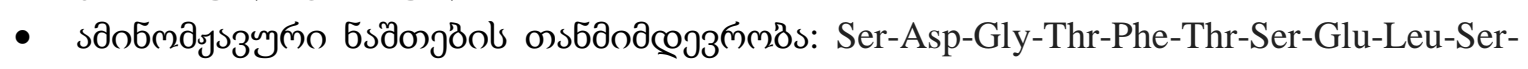
Arg-Leu-Arg-Asp-Ser-Ala-Arg-Leu-Gln-Arg-Leu-Leu-Gln-Gly-Leu-Val

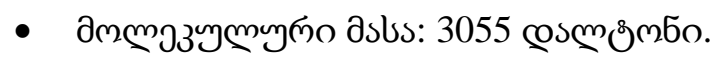

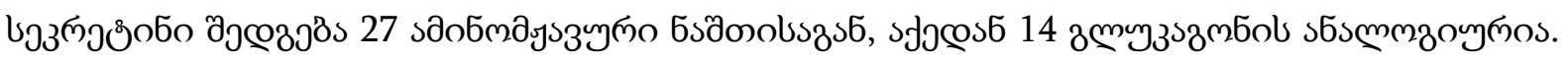

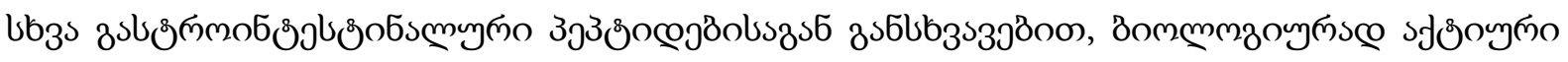

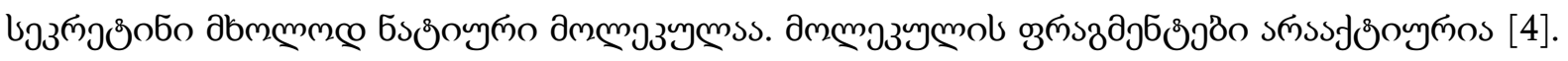

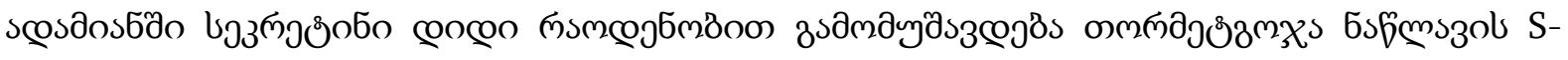

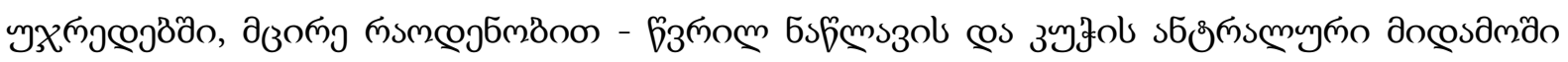

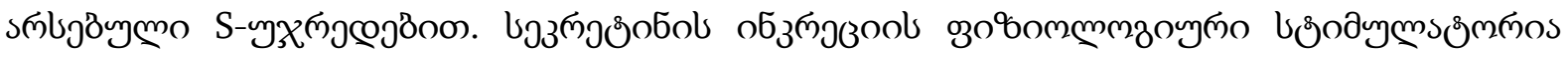




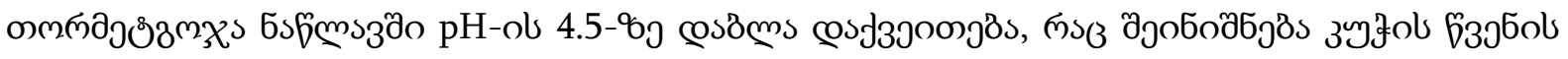

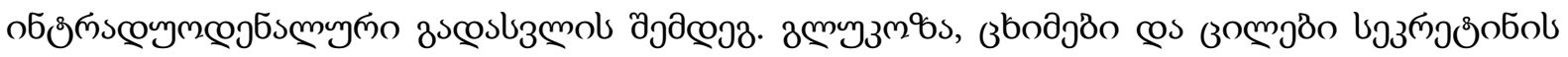

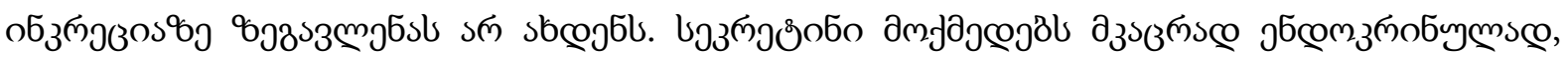

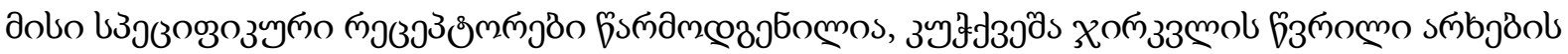

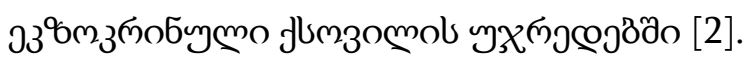

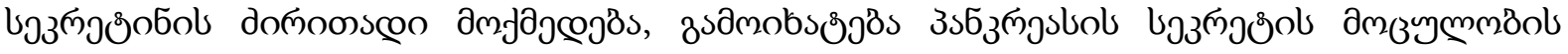

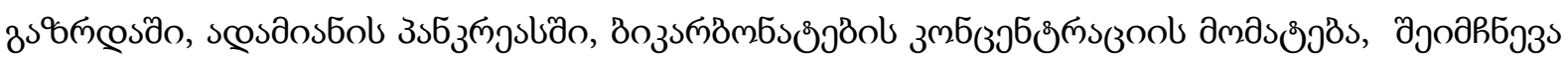

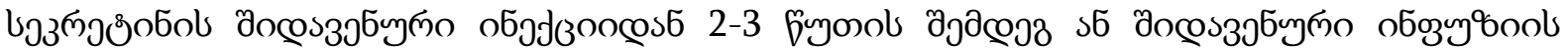

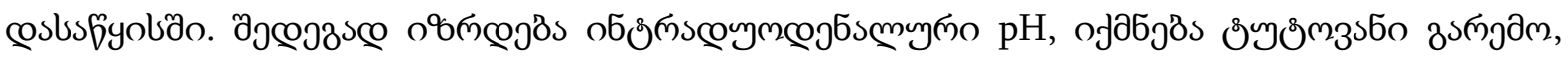

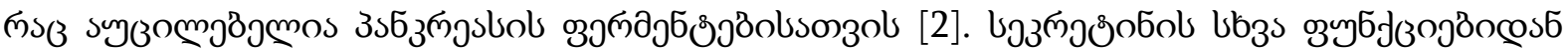

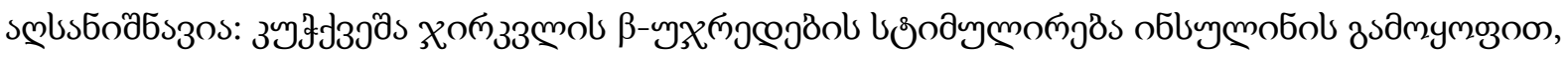

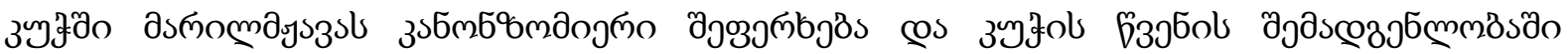

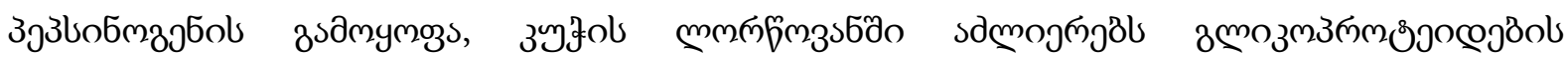

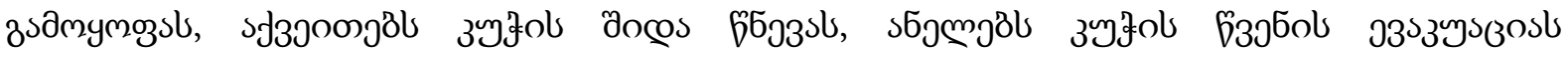

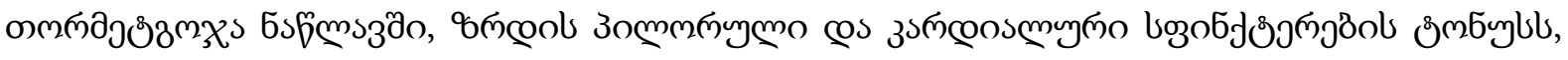

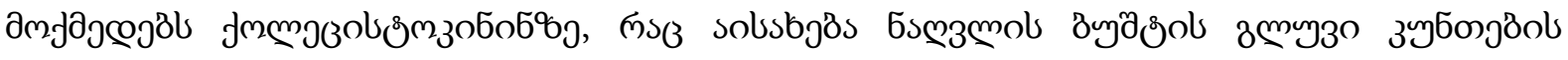

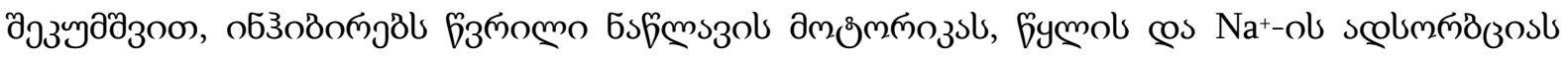

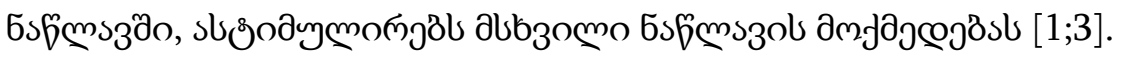

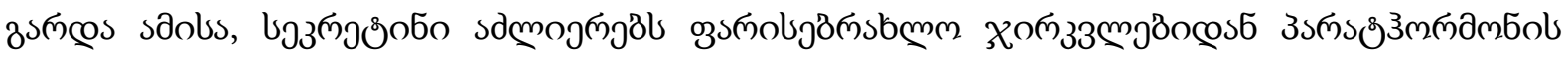

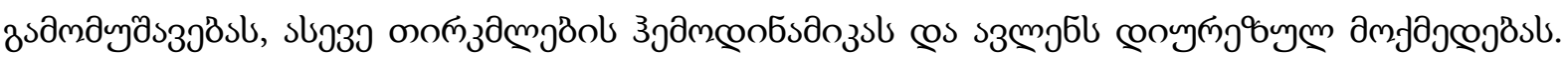

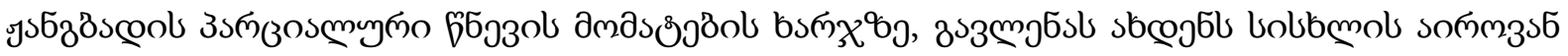

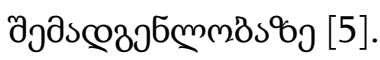

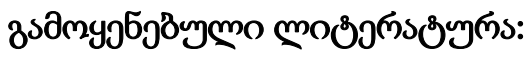

1. Chu JY, Chung SC, Lam AK, Tam S, Chung SK, Chow BK (2007). „Phenotypes developed in secretin receptor-null mice indicated a role for secretin in regulating renal water reabsorption“. Molecular and Cellular Biology. 27 (7): 2499-511. doi:10.1128/MCB.0108806. PMC 1899889. PMID 17283064

2. Gafvelin G, Jörnvall H, Mutt V (Sep 1990). „Processing of prosecretin: isolation of a secretin precursor from porcine intestine" (PDF). Proceedings of the National Academy of Sciences of theUnitedStatesofAmerica. 87 (17):67815. Bibcode:1990PNAS...87.6781G. doi:10.1073/pnas.87.17.6781. PMC 54621. PMID 2395872.

3. Ganong, William F. (2003). „Regulation of Gastrointestinal Function". Review of Medical Physiology (21st ed.). New York: McGraw-Hill, Medical Pub. Div. ISBN 978-0-07-140236-1

4. Kopin AS, Wheeler MB, Leiter AB (1990). „Secretin: structure of the precursor and tissue distribution of the mRNA". Proceedings of the National Academy of Sciences of the United StatesofAmerica. 87 (6):2299303. Bibcode:1990PNAS...87.2299K. doi:10.1073/pnas.87.6.2299.

5. Lee VH, Lee LT, Chu JY, Lam IP, Siu FK, Vaudry H, Chow BK (2010). „An indispensable role of secretin in mediating the osmoregulatory functions of angiotensin II". FASEB Journal. 24 (12): 5024-32. doi:10.1096/fj.10-165399. PMC 2992369. PMID 20739612 


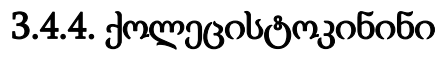

- јазопомумо озмпдум⿻s: $\mathrm{C}_{166} \mathrm{H}_{261} \mathrm{~N}_{51} \mathrm{O}_{52} \mathrm{~S}_{4}$.

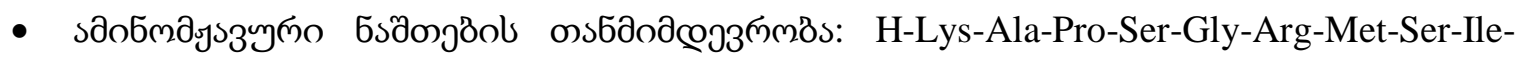
Val-Lys-Asn-Leu-Gln-Asn-Leu-Asp-Pro-Ser-His-Arg-Ile-Ser-Asp-Arg-Asp-Tyr-Met-GlyTrp-Met-Asp-Phe- $\mathrm{NH}_{2}$

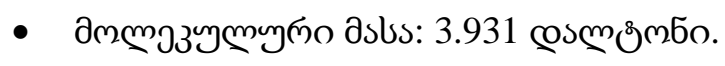

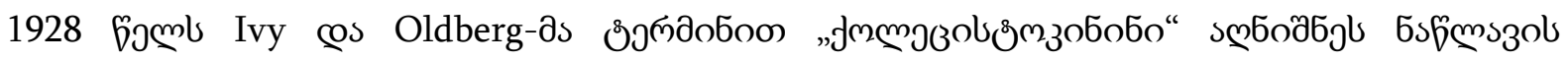

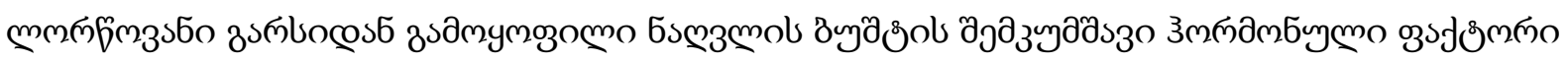

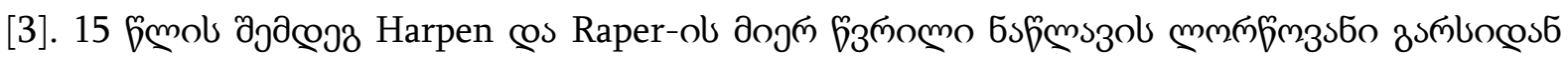

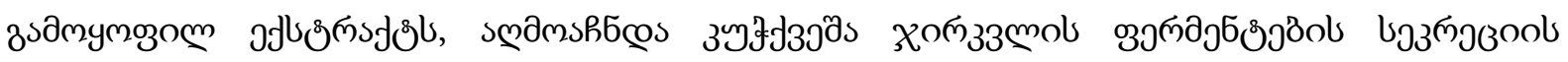

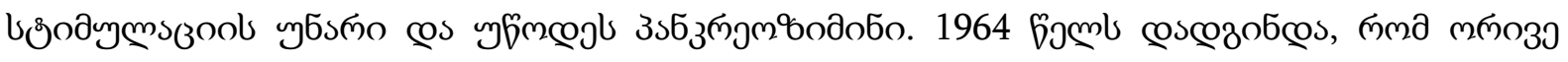

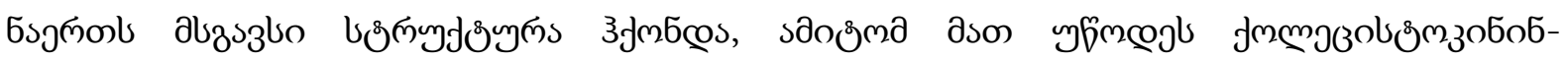

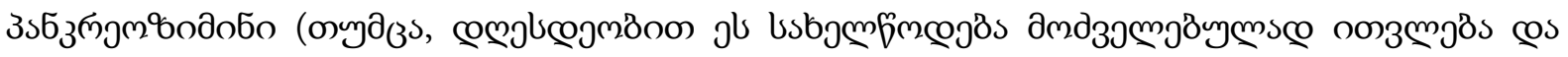

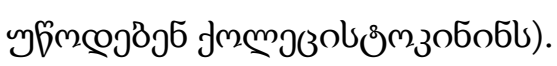

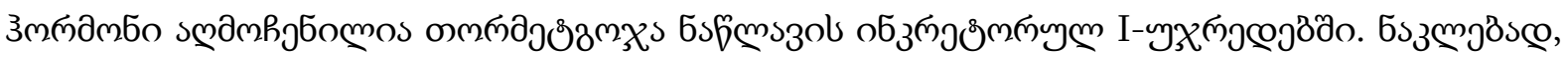

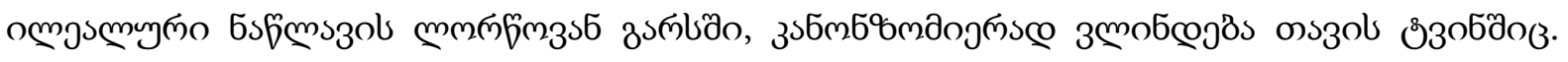

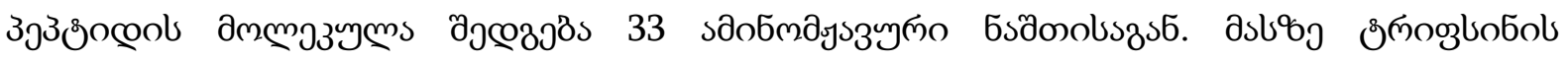

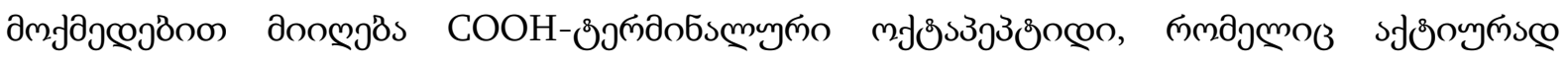

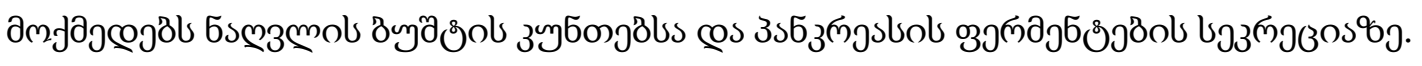

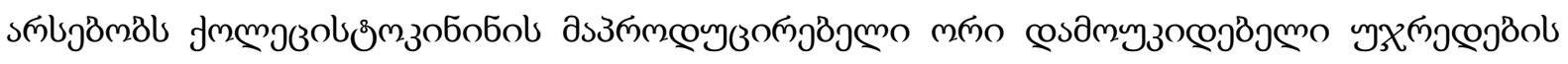

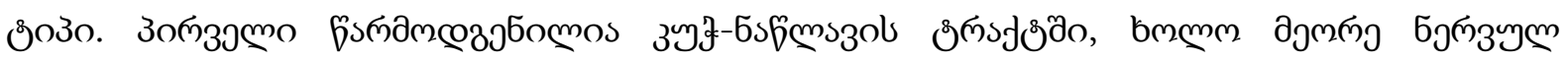

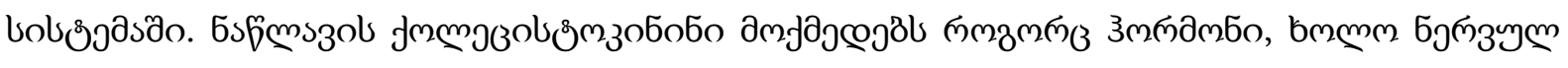

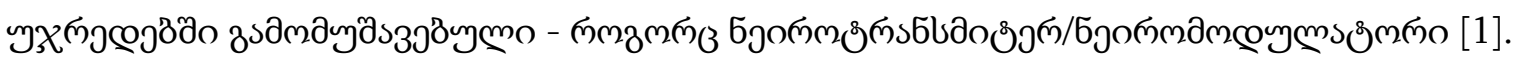

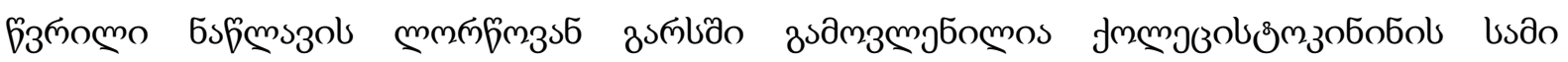

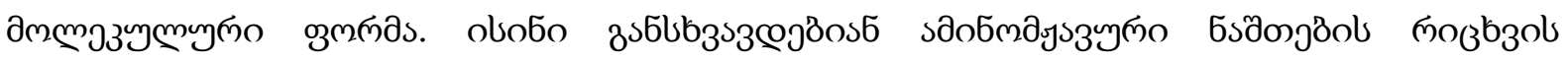

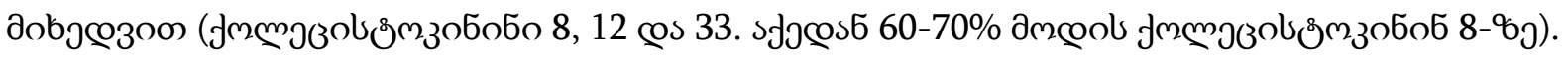

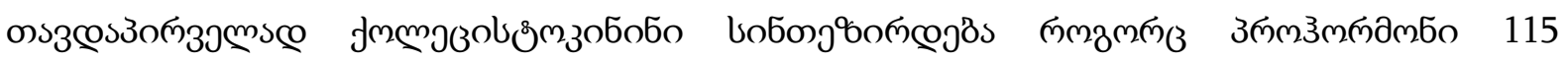

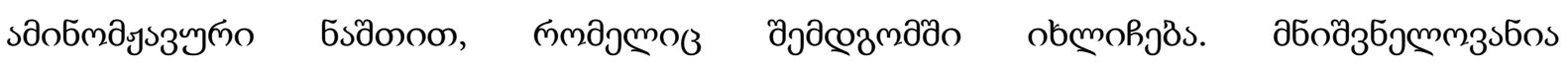

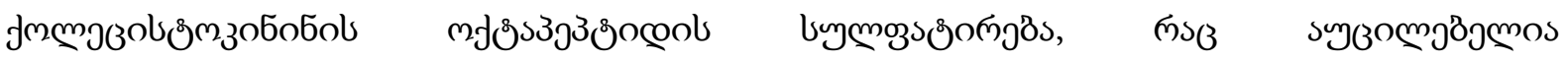

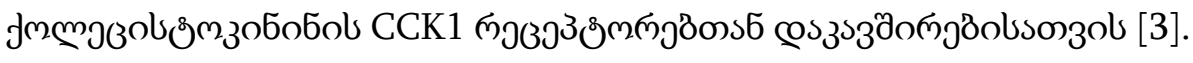

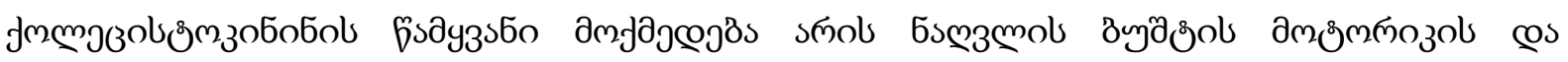

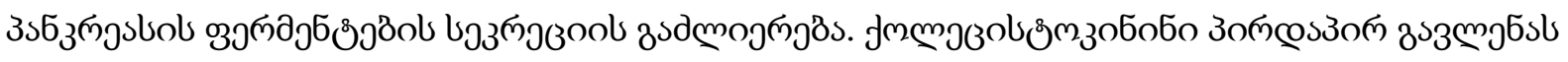

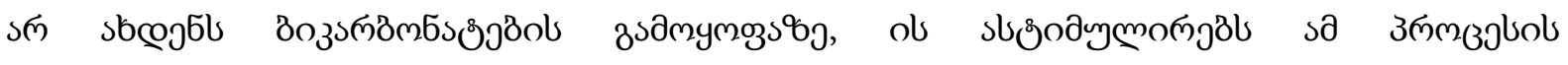

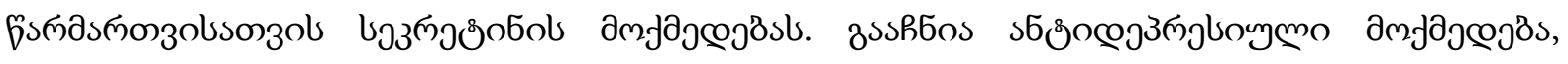

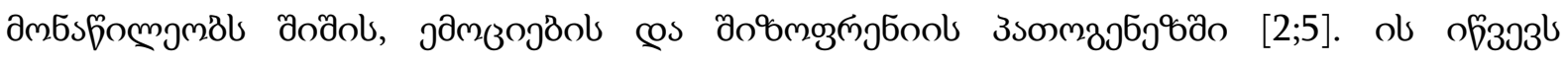

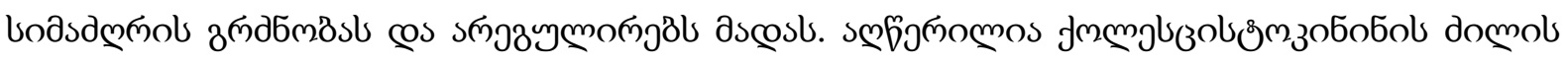

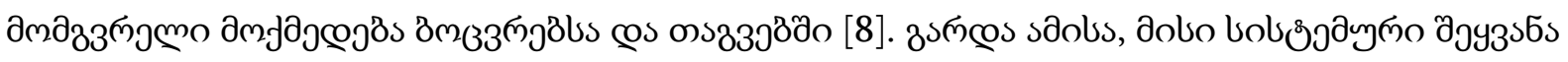

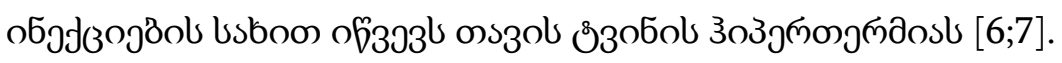




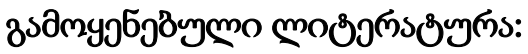

1. Beinfeld, M.C., 2003. Biosynthesis and processing of pro CCK: recent progress and future challenges. Life Sci 72, 747-757.

2. Bradwejn J. The cholecystokinin hypothesis of anxiety and panic disorder. Cholecystokinin. CCK 1993: International Symposium Proceed., Chatman, Massachusetts. // Ann.NY Acad.Sci. 1994, Vol. 713, P.1-467. P.273. Ann.NY Acad.Sci. 1994.

3. Crawley, J.N., 1985. Clarification of the behavioral functions of peripheral and central cholecystokinin: two separate peptide pools. Peptides 6 Suppl 2, 129-136.Crawley, J.N., Corwin, R.L., 1994. Biological actions of cholecystokinin. Peptides15, 731-755.

4. Ivy, A.C., Oldberg, E., 1928. A hormone mechanism for gall-bladder contraction and evacuation. Am J Physiol 86, 599-613.

5. Schiantarelli P. The therapeutic potential of cholecystokinin receptor antagonists in CNS disorders. // Pharmacol.Rev. 1993, Vol. 28, P.1. Pharmacol.Rev. 1993

6. Rezayat, M., Ravandeh, N., Zarrindast, M.R., 1999. Cholecystokinin and morphineinducedhypothermia. Eur Neuropsychopharmacol 9, 219-225.

7. South, E.H., 1992. Cholecystokinin reduces body temperature in vehicle- but not capsaicinpretreatedrats. Am J Physiol 263, R1215-R1221.

8. Szentirmai, É., Kapás, L., Sun, Y., Smith, R.G., Krueger, J.M., 2007b. Sleep response toghrelin, leptin and cholecystokinin in ghrelin knockout mice. Sleep 30, A18.

\subsection{5. పmతింmoбo}

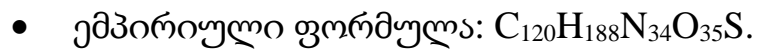

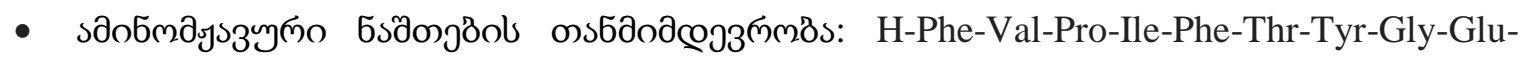
Leu-Gln-Arg-Met-Gln-Glu-Lys-Glu-Arg-Asn-Lys-Gly-Gln-OH.

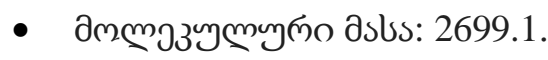

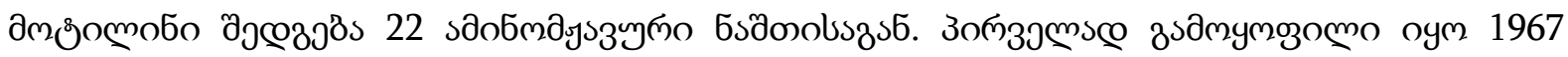

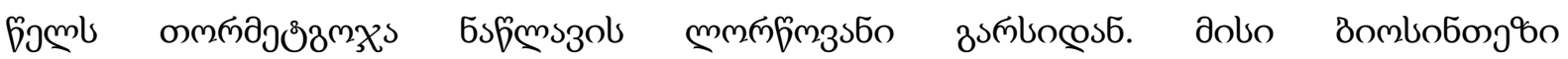

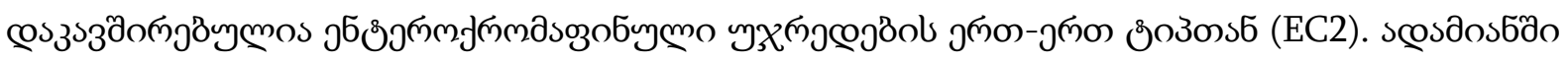

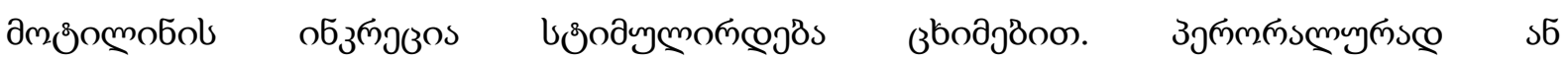

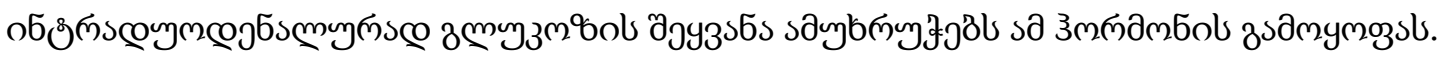

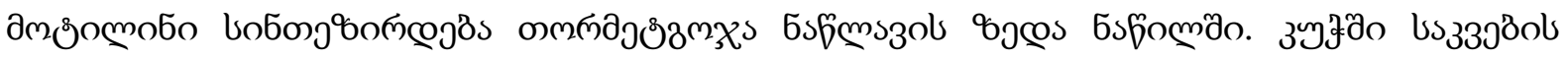

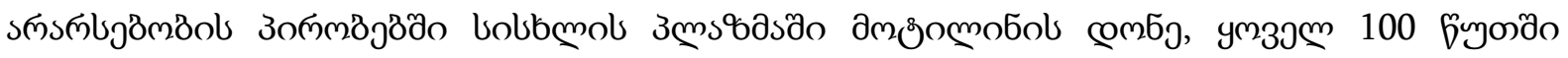

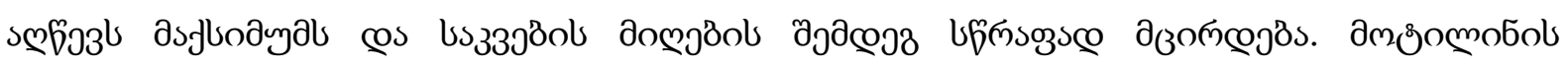

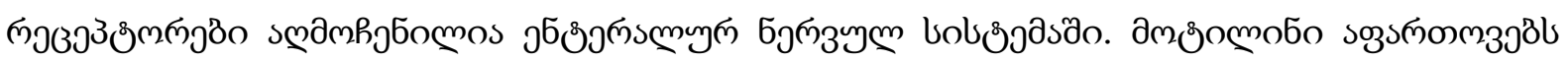

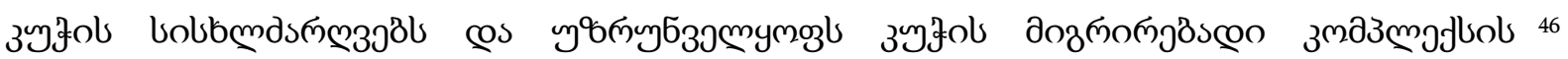

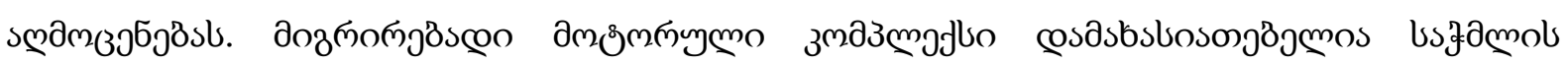

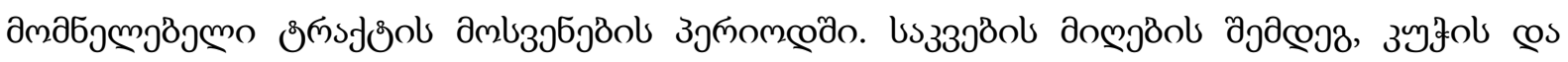

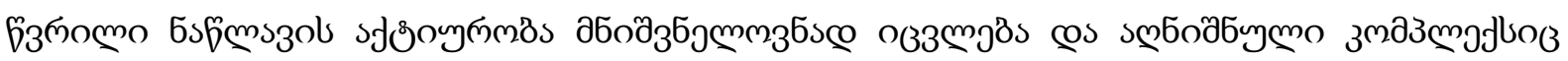

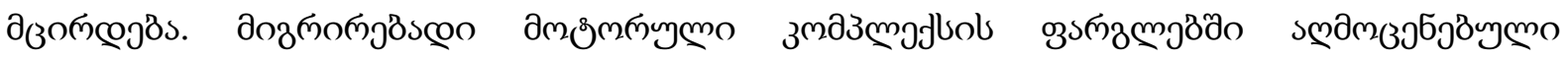

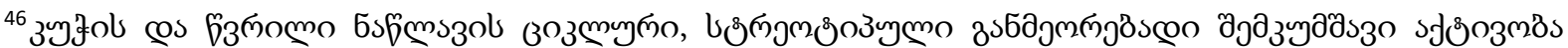

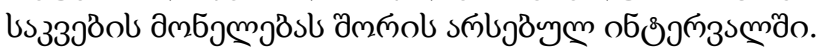




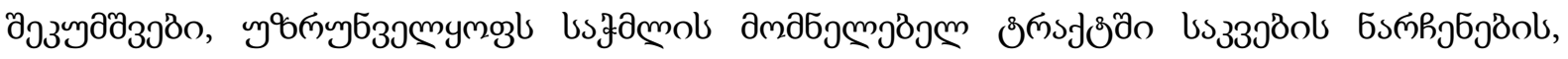

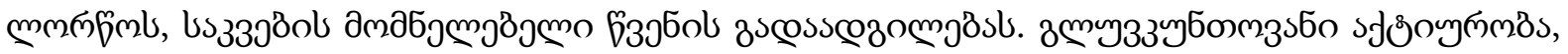

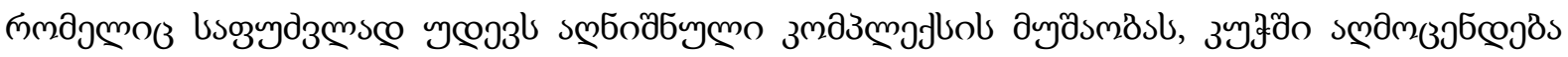

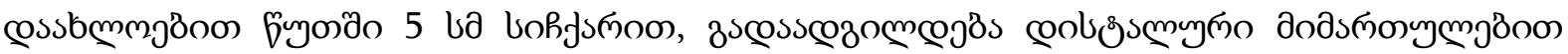

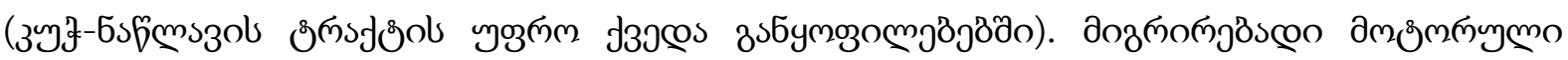
змазмлдыlol зозмоl

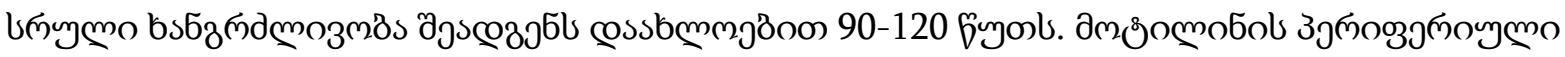

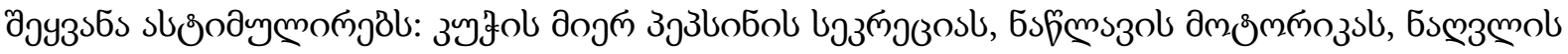

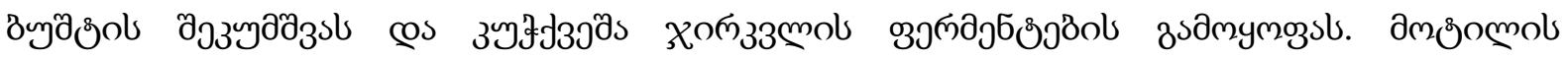

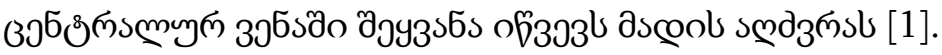

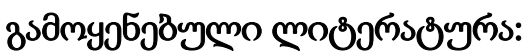

1. Chaudhri O., Small C., Bloom S. Gastrointestinal hormones regulatingappetite. Philos. Trans. R. Soc. Lond. B. Biol. Sci. 2006; 361(1471):1187-1209.

\subsection{6. oblymobo}

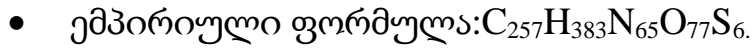

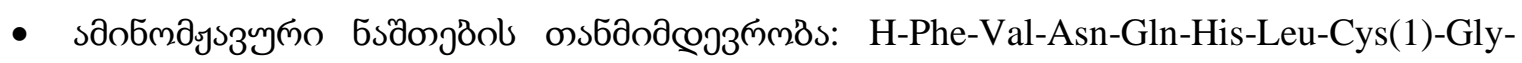
Ser-His-Leu-Val-Glu-Ala-Leu-Tyr-Leu-Val-Cys(2)-Gly-Glu-Arg-Gly-Phe-Phe-Tyr-Thr-ProLys-Thr-OH.H-Gly-Ile-Val-Glu-Gln-Cys(3)-Cys(1)-Thr-Ser-Ile-Cys(3)-Ser-Leu-Tyr-GlnLeu-Glu-Asn-Tyr-Cys(2)-Asn-OH

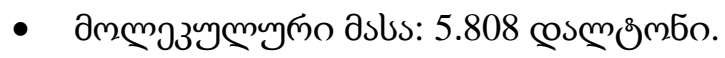

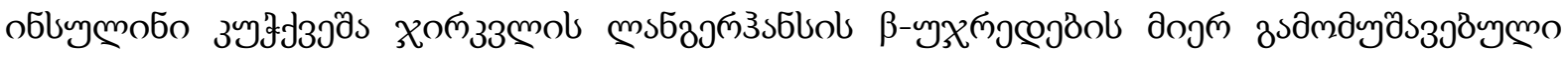

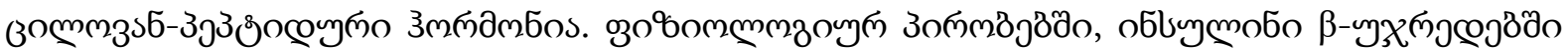

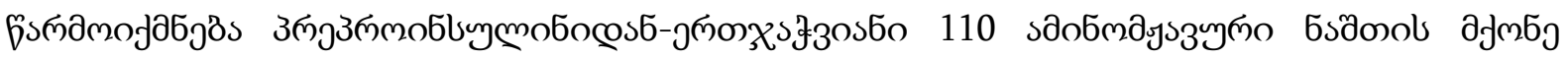

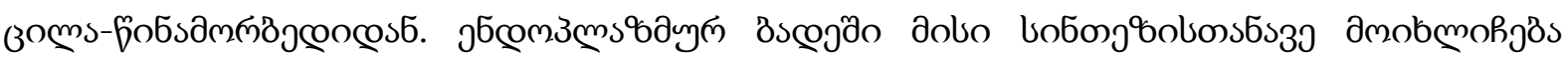

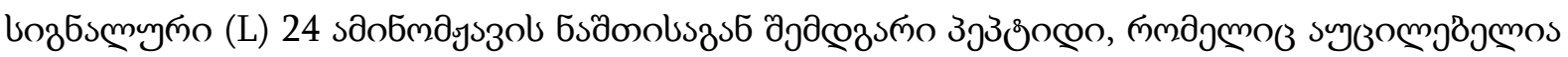

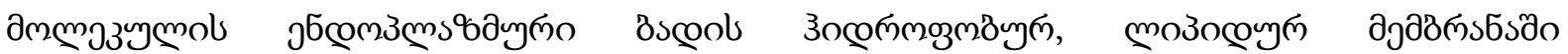

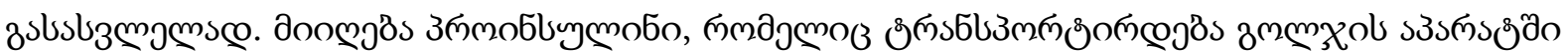

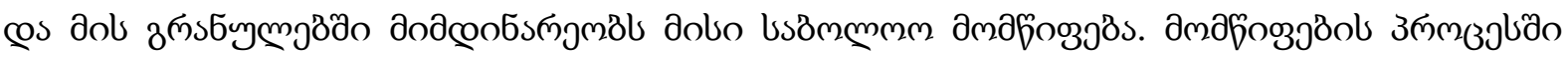

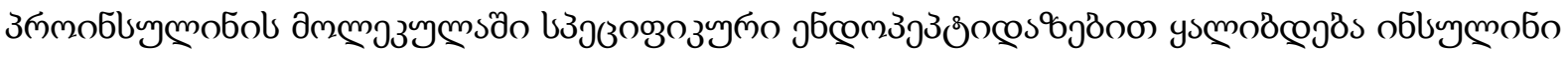

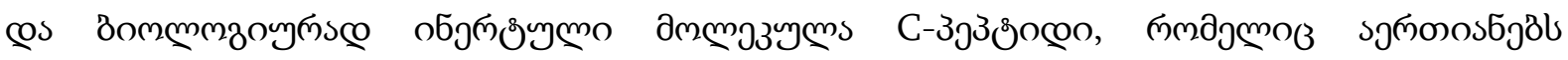

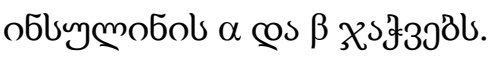

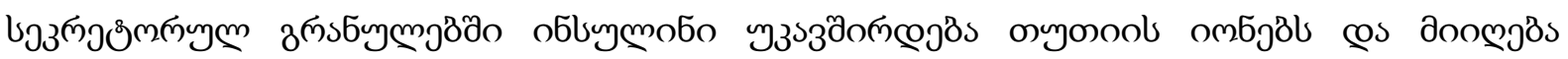

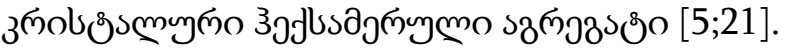

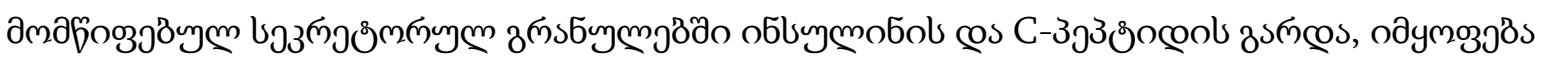

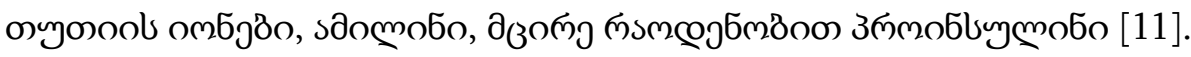




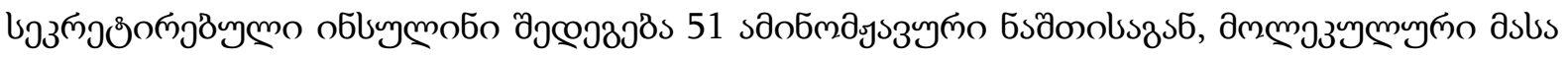

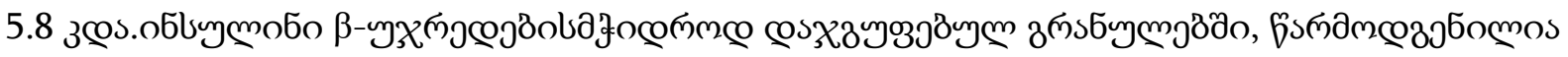

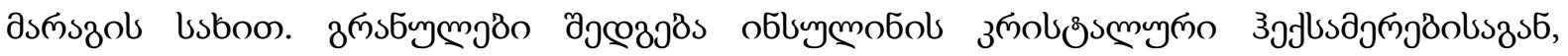

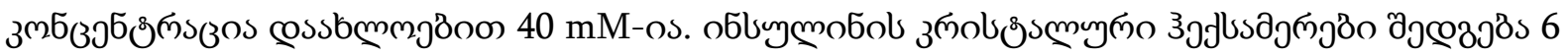

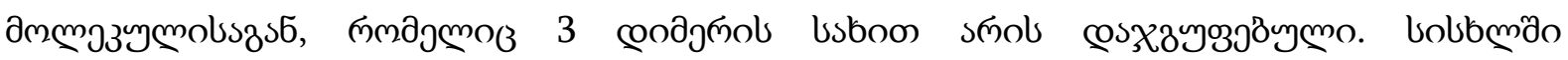

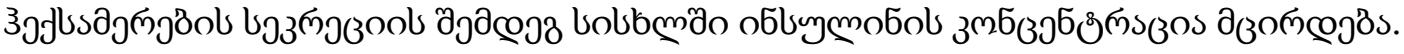

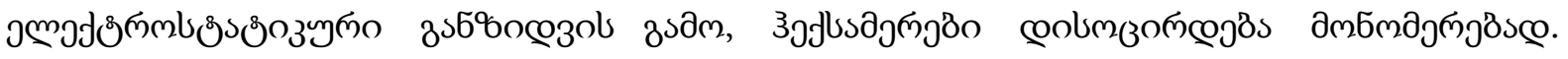

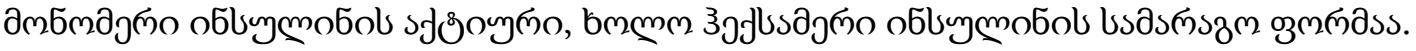

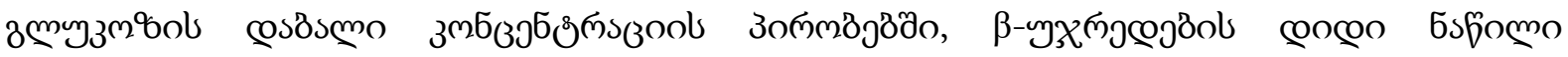

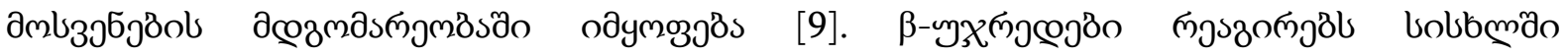

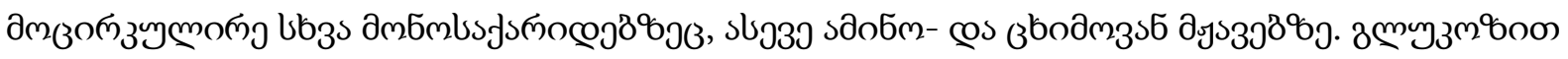

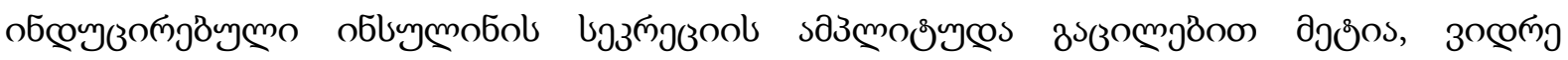

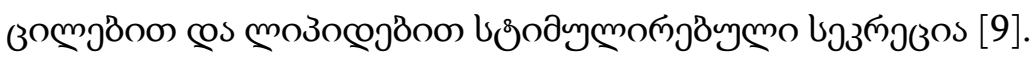

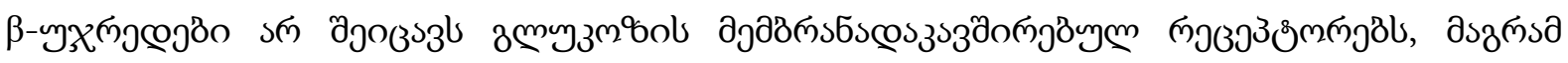

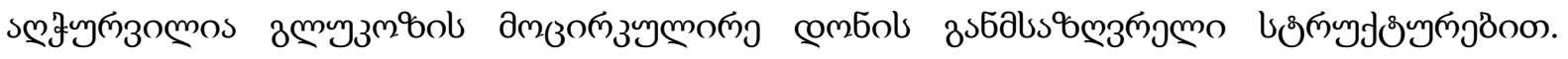

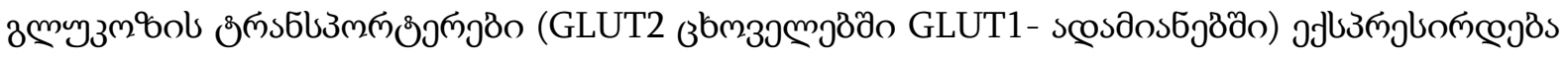

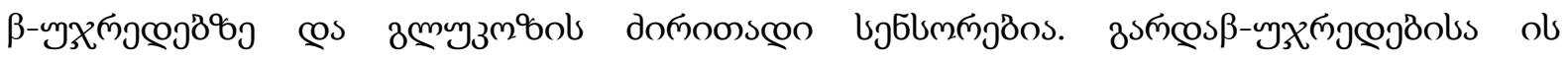

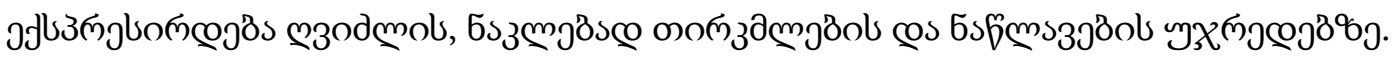

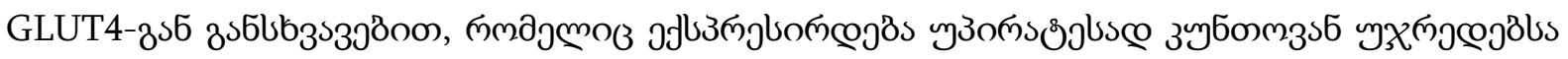

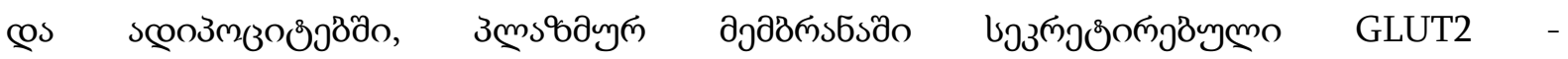

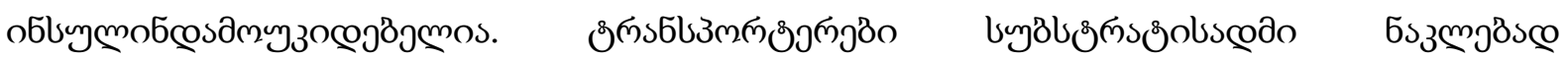

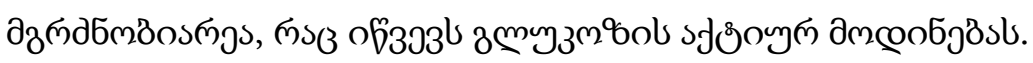

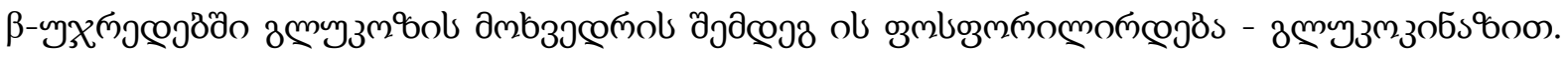

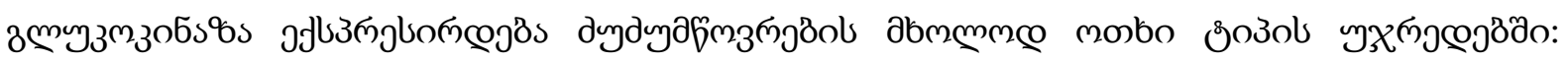

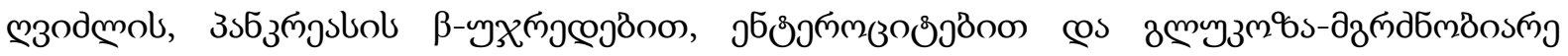

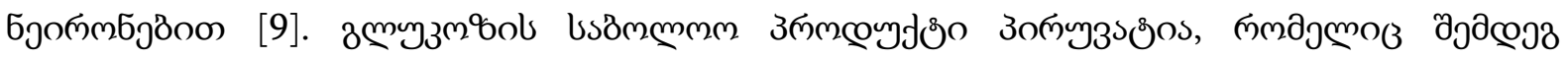

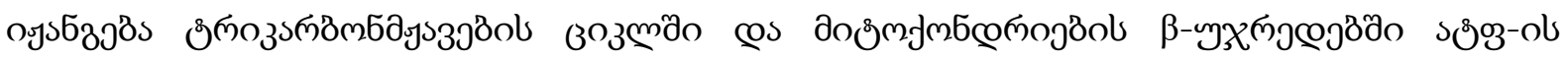

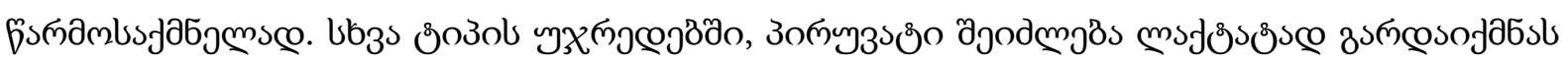

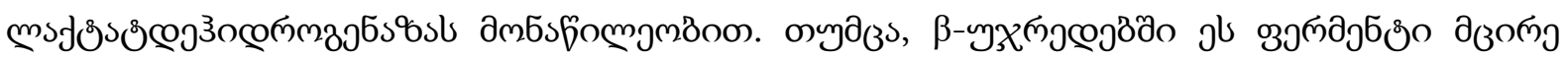

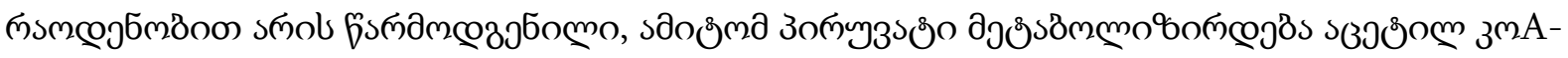

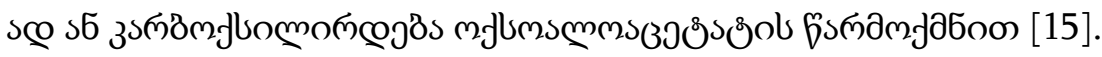

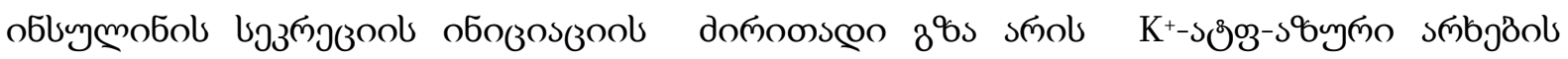

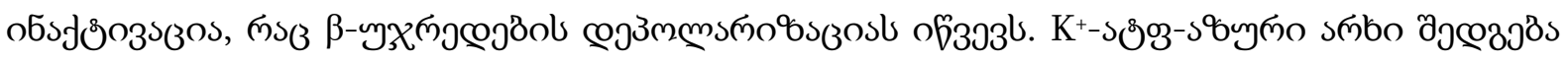

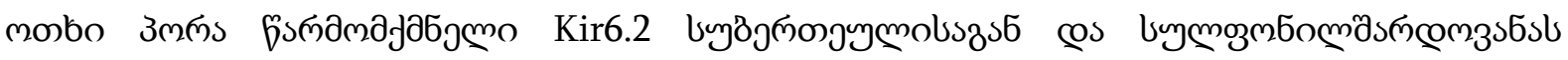

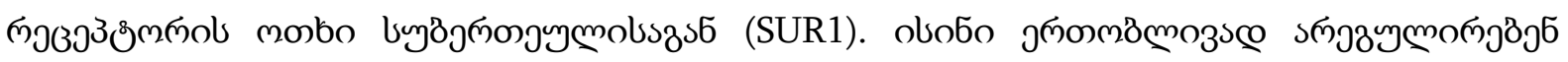

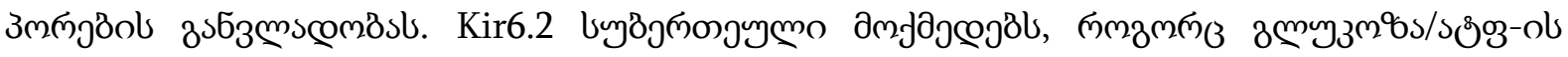

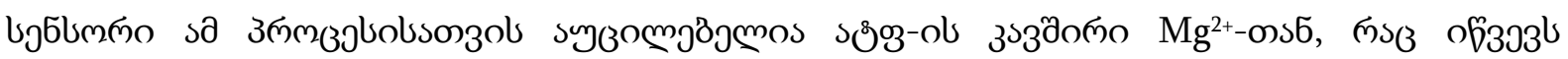

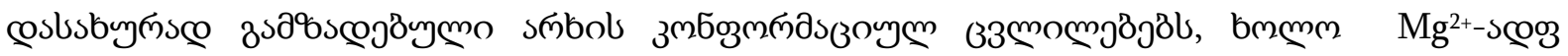

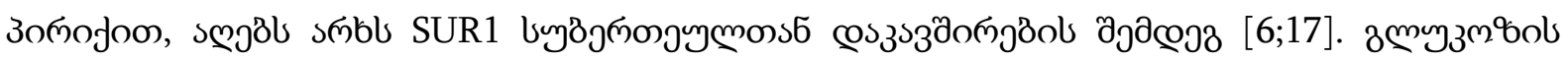

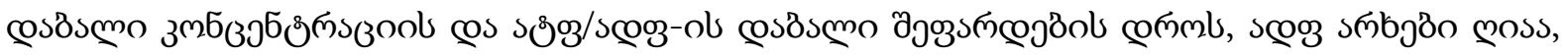

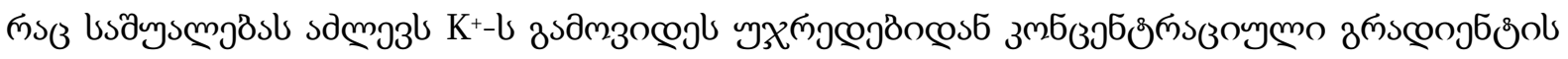

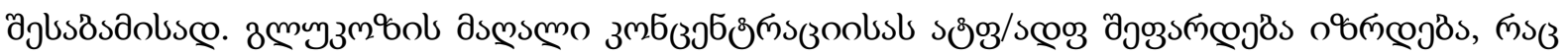




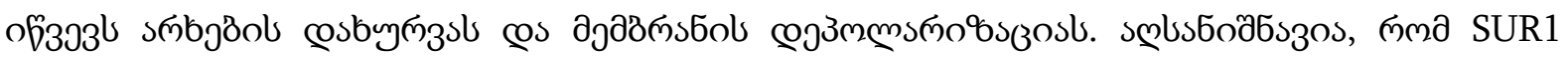

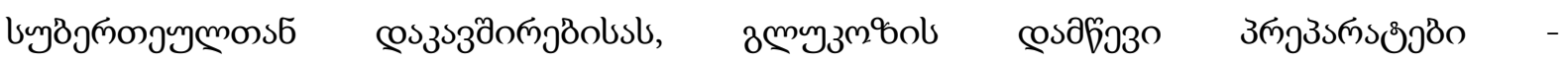

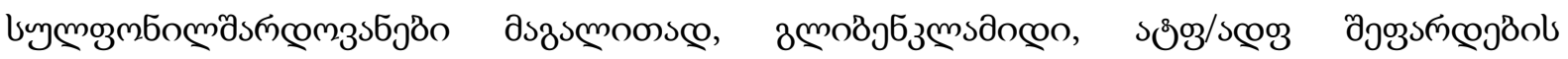

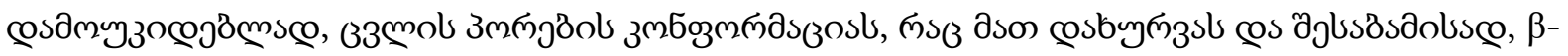

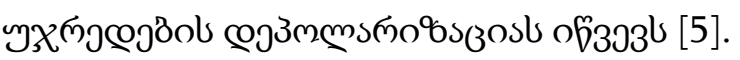

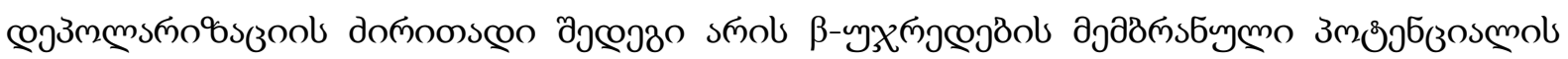

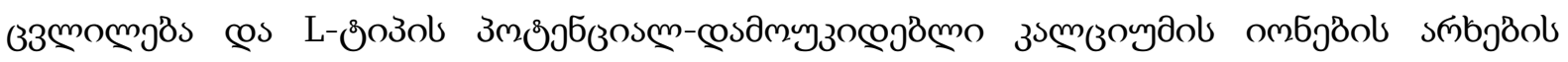

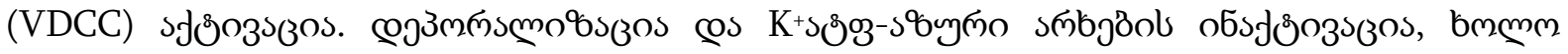

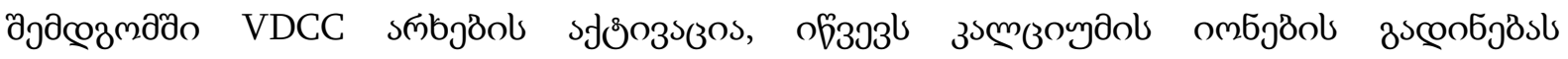

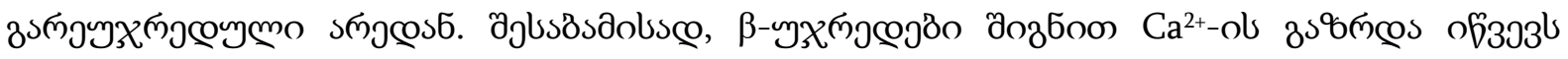

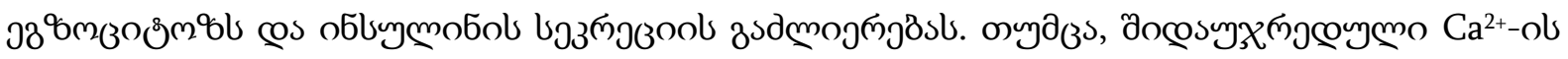

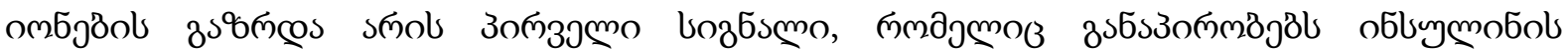

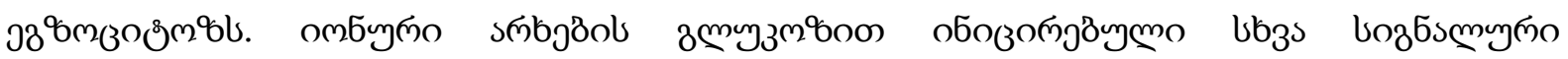

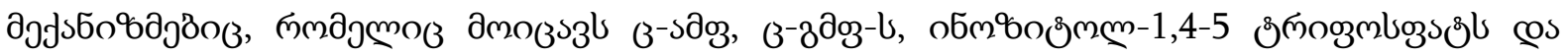

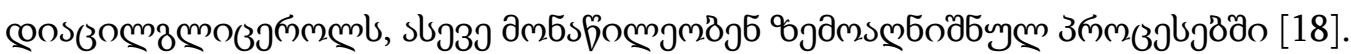

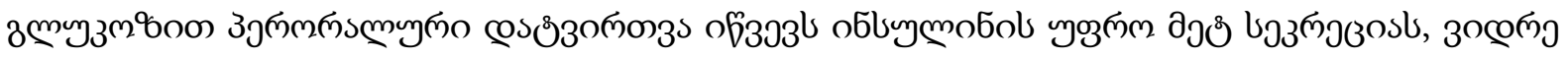

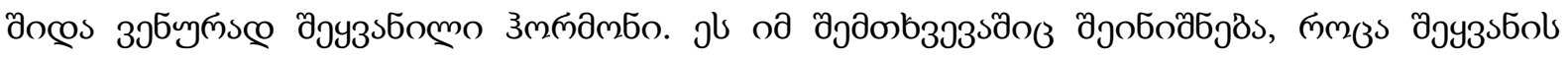

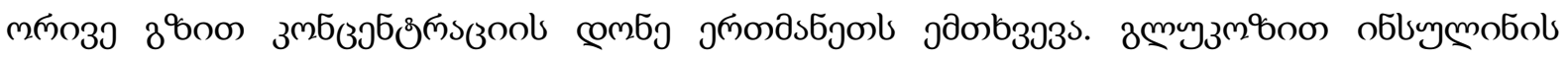

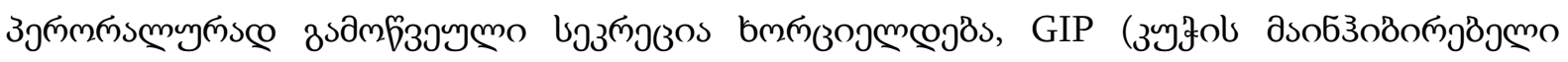

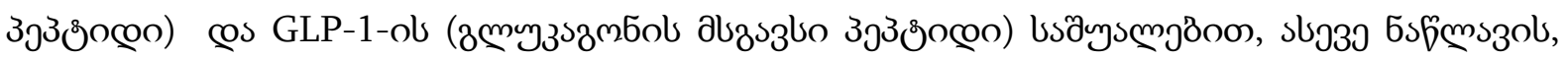

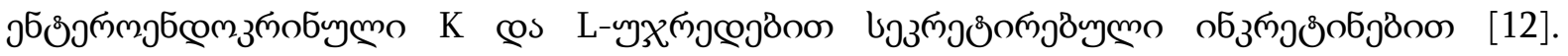

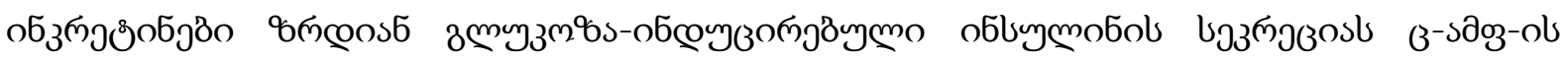

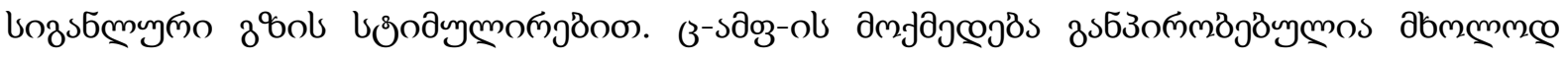

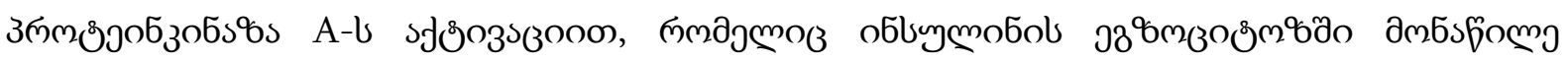

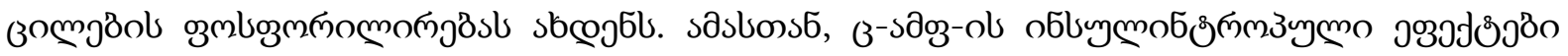

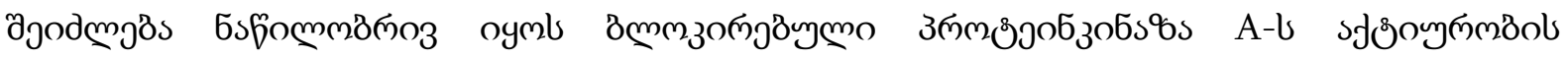

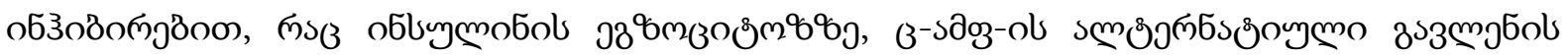

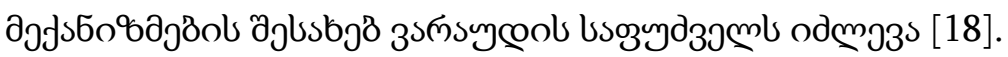

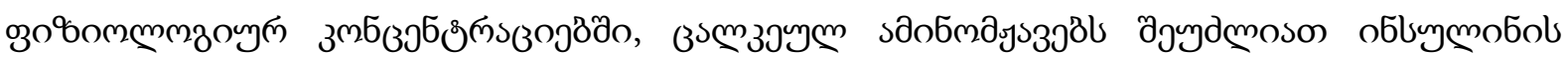

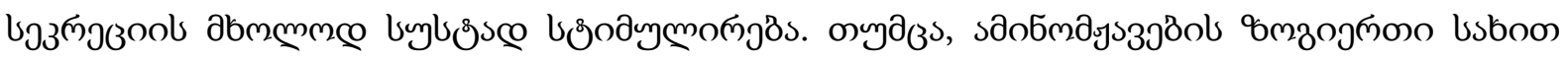

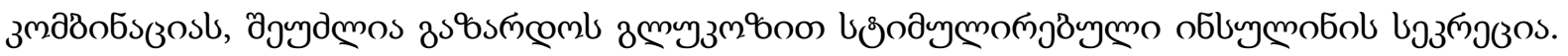

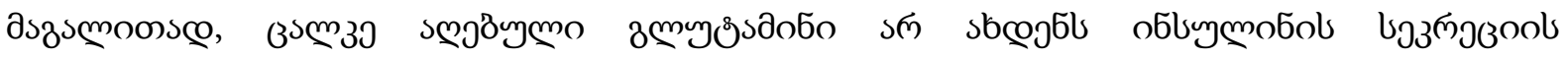

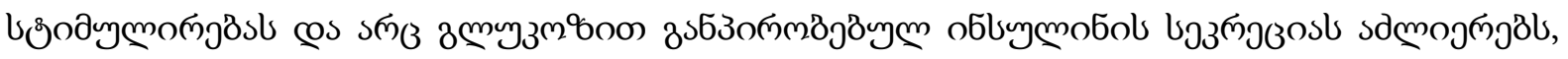

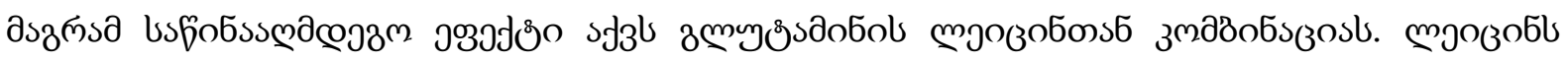

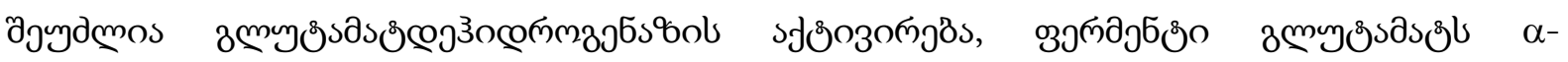

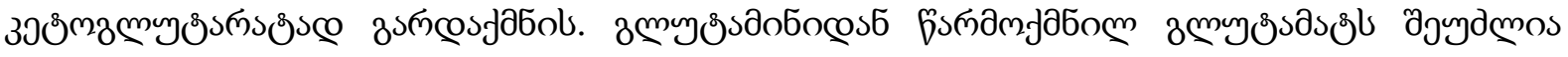

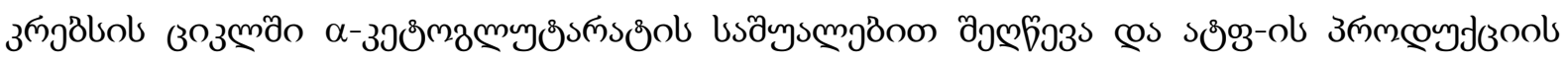

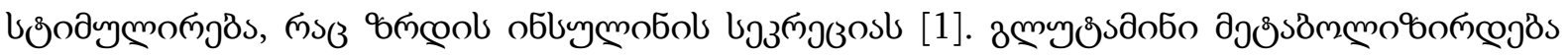

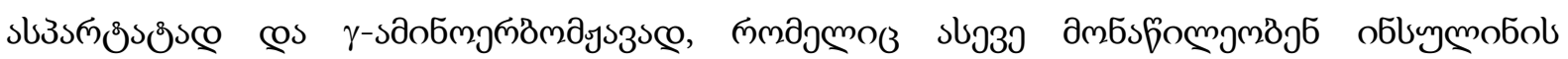

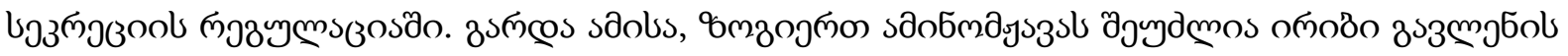

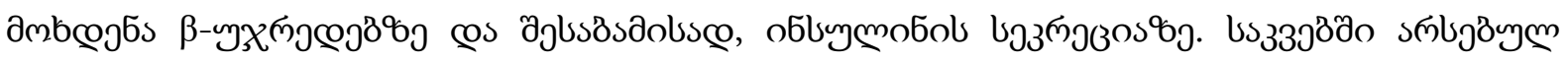

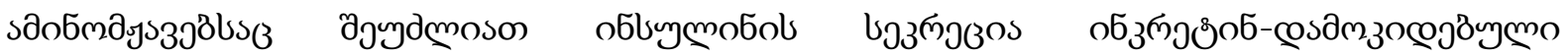




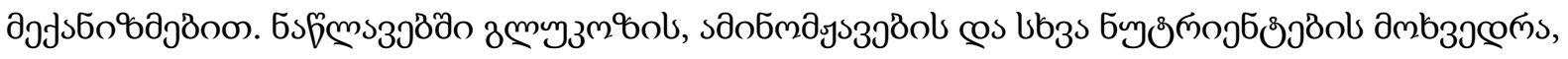

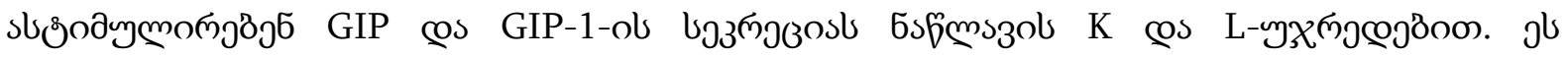

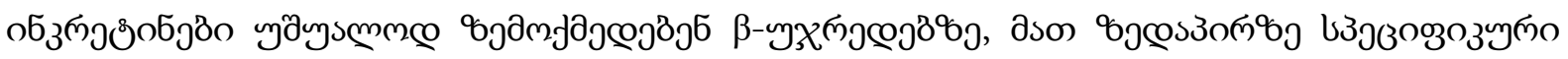

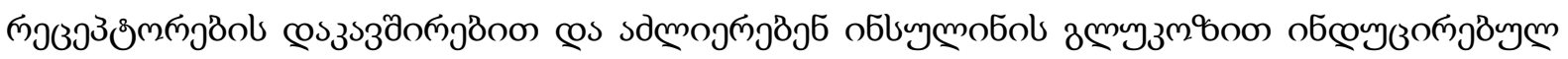

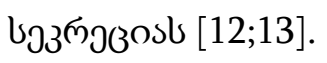

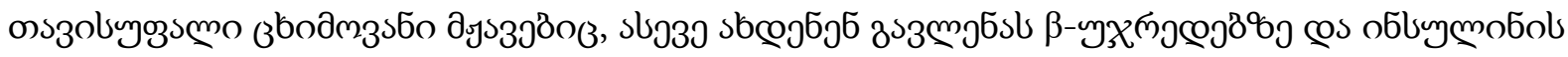

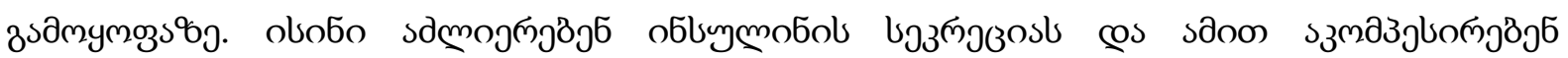

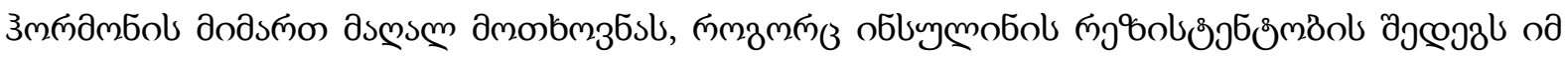

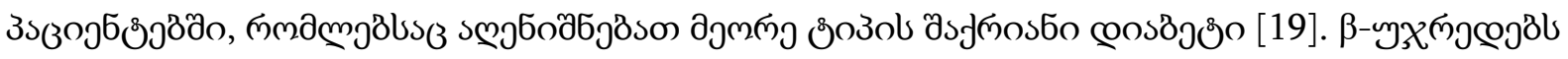

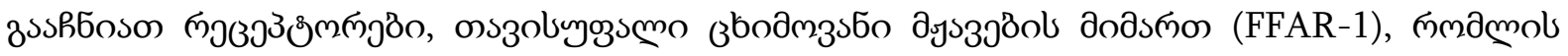

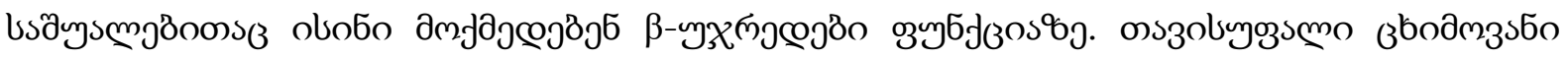

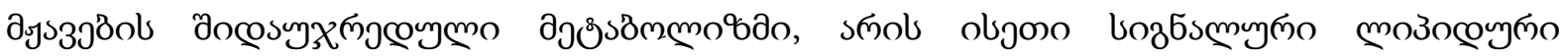

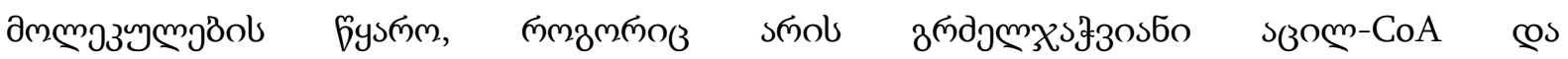

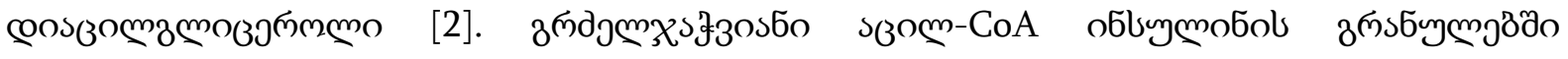

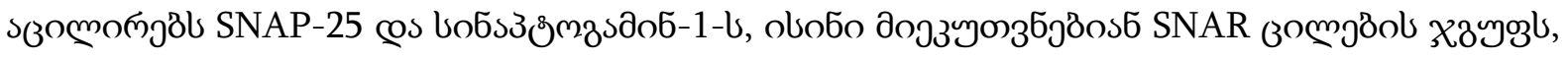

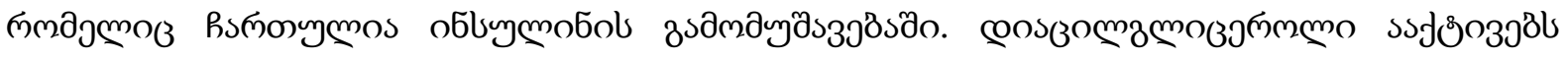

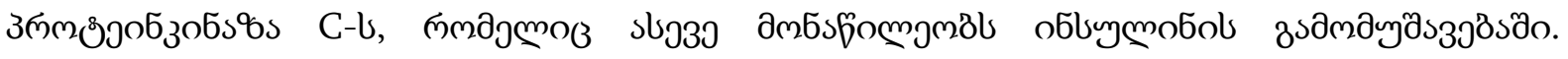

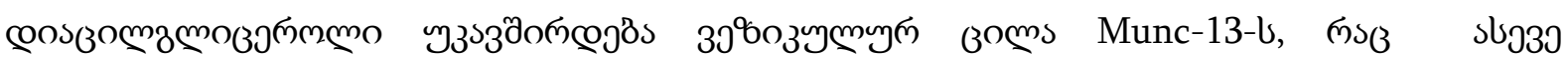

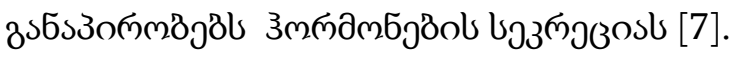

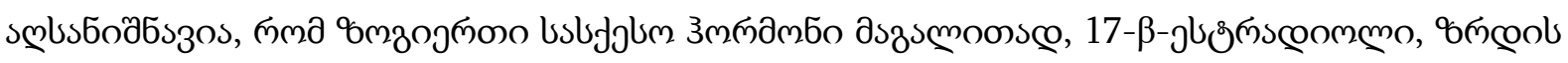

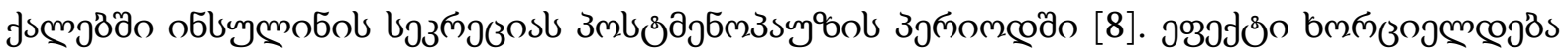

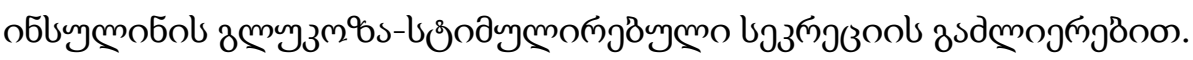

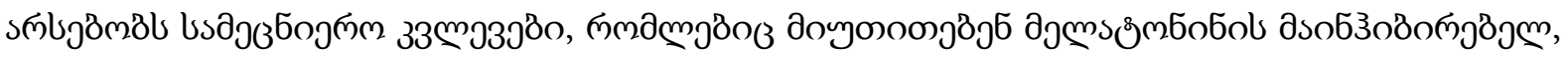

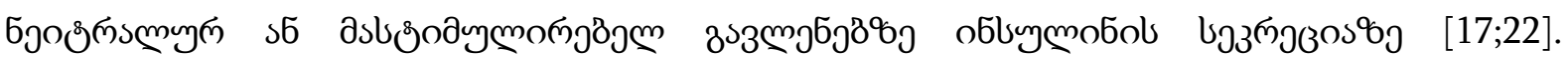

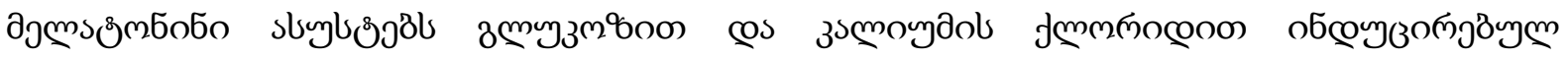

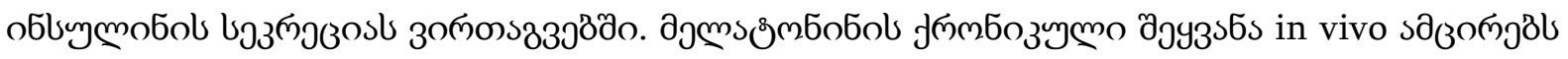

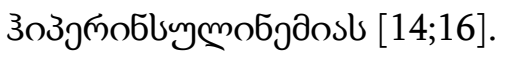

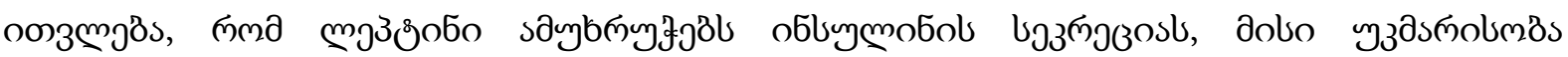

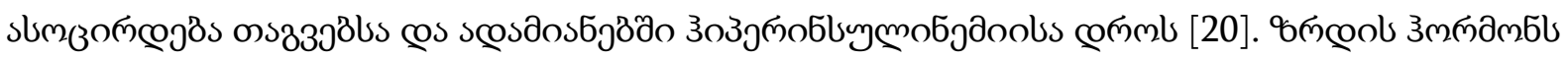

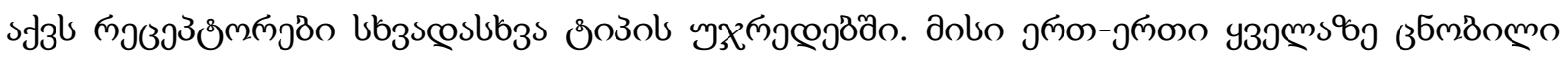

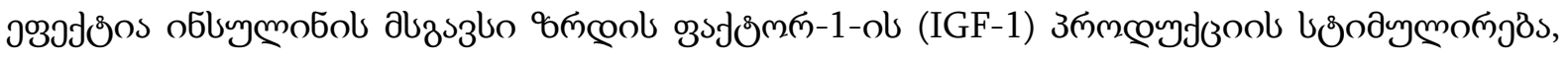

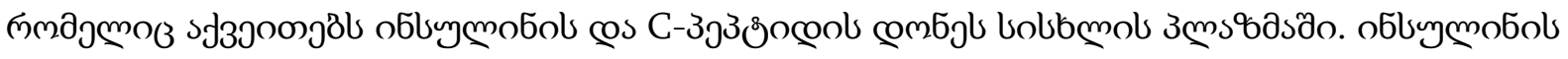

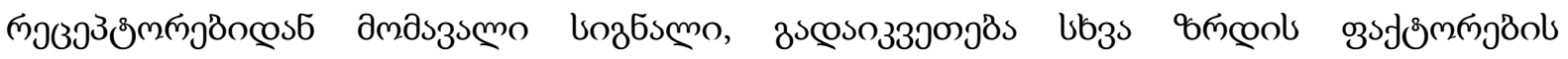

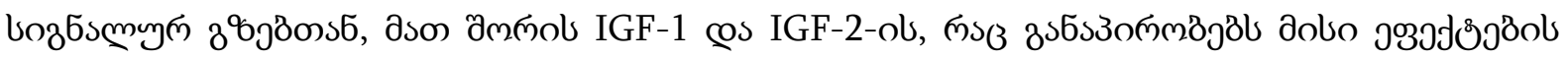

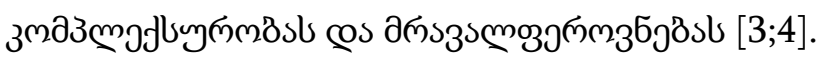

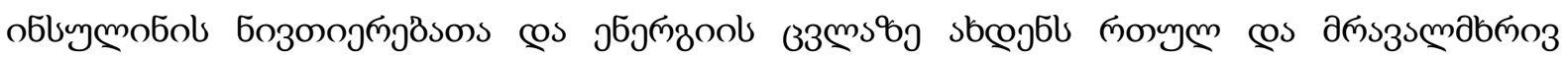

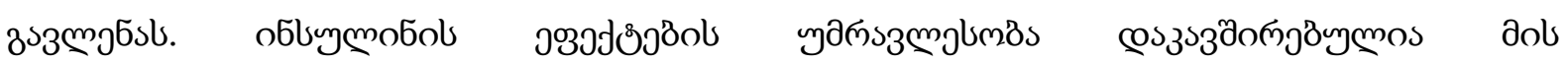

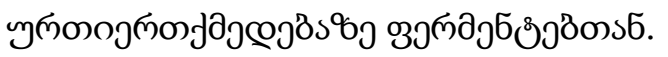

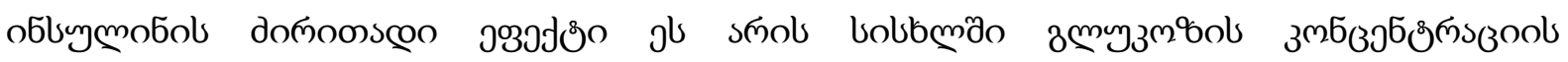

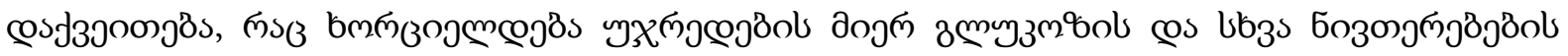

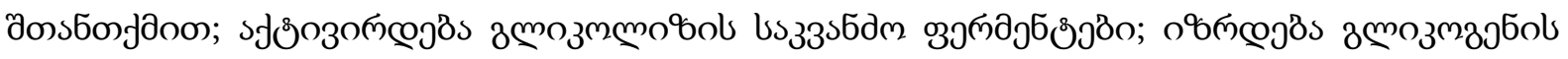

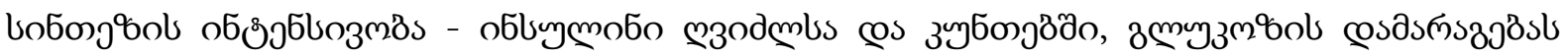




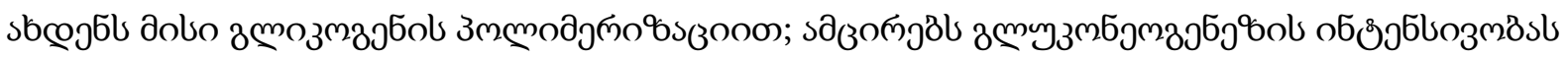

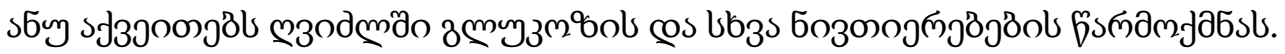

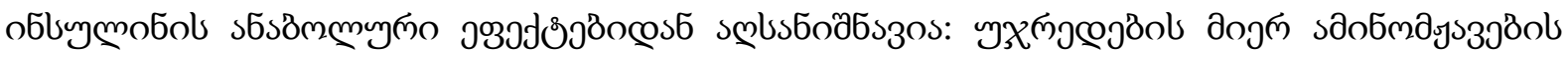

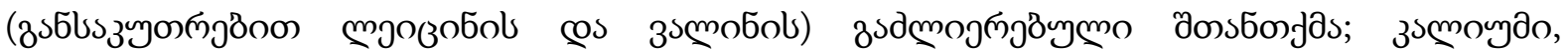

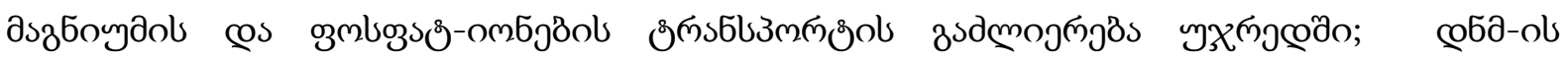

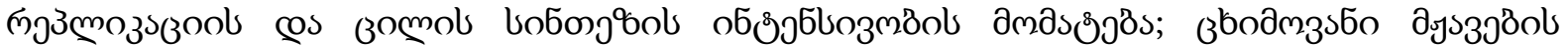

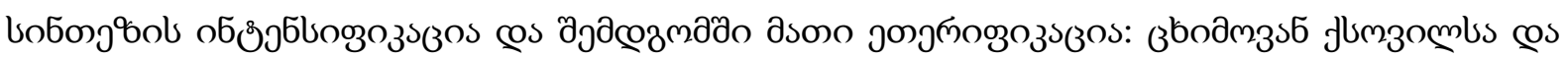

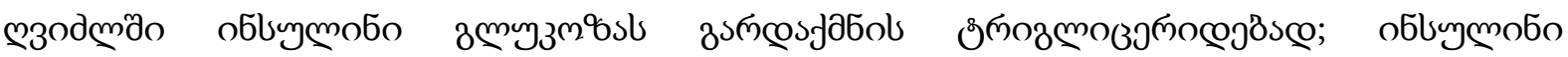

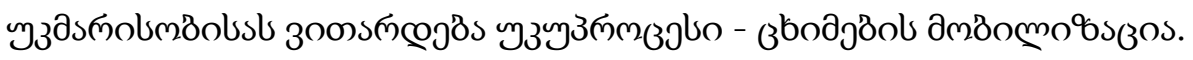

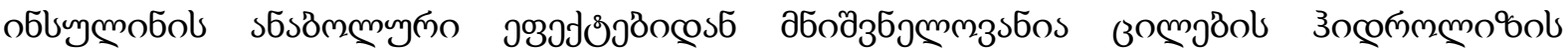

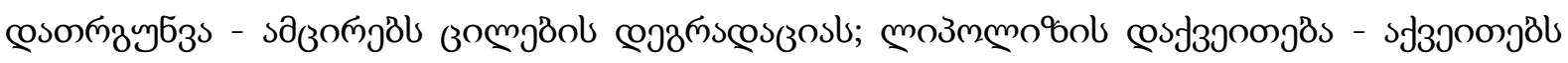

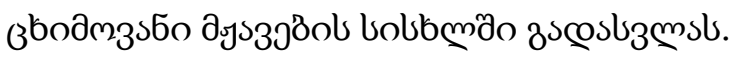

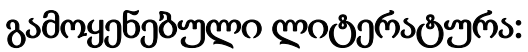

1. Amino acid metabolism, insulin secretion and diabetes / P.Newsholme [et al.] // Biochem. Soc. Trans. - 2007. - Vol. 35, №5. - P. 1180-1186.

2. A role for the malonyl-CoA/long-chain acyl-CoA pathwayof lipid signaling in the regulation of insulin secretion in responseto both fuel and nonfuel stimuli / R. Roduit [et al.] // Diabetes. -2004. - Vol. 53, № 4. - P. 1007-1019.

3. Braun, M. The somatostatin receptor in human pancreatic $\beta$-cells / M. Braun // Vitam. Horm. - 2014. - Vol. 95. - P. 165-193.

4. Combined treatment of somatostatin analogues withpegvisomant in acromegaly / S. E. Franck [et al.] // Endocrine. -2016. - Vol. 52, № 2. - P. 206-213.

5. De Meyts, P. Insulin and its receptor: structure, function and evolution / P. De Meyts // Bioessays. - 2004. - Vol. 26, № 12. - 1351-1362.

6. Doyle, M. E. Mechanisms of action of glucagon-likepeptide 1 in the pancreas / M. E. Doyle, J. M. Egan // Pharmacol.Ther. - 2007. - Vol. 113, № 3. - P. 546-593.

7. Drazin, B. Molecular mechanisms of insulin resistance /B. Drazin // Diabetes. - 2006. - Vol. 55, № 7. - P. 2392-2397.

8. Estrogen signaling prevents diet-induced hepatic insulin resistance in male mice with obesity / L. Zhu [et al.] // Am. J.Physiol. Endocrinol. Metab. - 2014. - Vol. 306, № 10. - P. 11881197.

9. $\mathrm{Fu}, \mathrm{Z}$. Regulation of Insulin Synthesis and Secretion and Pancreatic Beta - Cell Dysfunction in Diabetes / Z. Fu, E. R. Gilbert, D. Liu // Curr. Diabetes. Rev. - 2013. - Vol. 9, № 1. - P. 25-53.

10. Glucose principally regulates insulin secretion in mouse islets by controlling the numbers of granule fusion events per cell/ J. T. Low [et al.] // Diabetologia. - 2013. - Vol. 56, № 12. P.2629-2637.

11. Huang, X. F. Intracellular transport of proinsulininpancreaticbeta-cells. Structural maturation probed by disulfideaccessibility / X. F. Huang, P. Arvan // J. Biol. Chem. - 1995. -Vol. 270, № 35. - P. 20417-20423.

12. Incretins: their physiology and application in the treatmentof diabetes mellitus / H. M. Tasyurek [et al.] // Diabetes. Metab.Res. Rev. - 2014. - Vol. 30, № 5. - P. 354-371.34. 
13. In vivo and in vitro glucose-induced biphasic insulinsecretion in the mouse: pattern and role of cytoplasmic $\mathrm{Ca}^{2+}$ and amplification signals in beta-cells / J. C. Henquin [et al] //Diabetes. 2006. - Vol. 55, № 2. - P. 441-451.

14. Long-term melatonin administration reduceshyperinsulinemia and improves the altered fatty acid compositionsin type 2 diabetic rats via the restoration of delta-5 desaturaseactivity / S. Nishida [et al.] // J. Pineal. Res. - 2002. - Vol. 32, №1. - P. 26-33.

15. Maechler, P. Mitochondrial function and insulin secretion/ P. Maechler // Mol. Cell. Endocrinol. - 2013. - Vol. 379, № 1-2.- P. 12-18.28. Melatonin.

16. Melatonin inhibits insulin secretion and decreasesPKA levels without interfering with glucose metabolism in ratpancreatic islets / M. C. Picinato [et al.] // J. Pineal. Res. - 2002.- Vol. 33, № 3. - P. 156-160.

17. Peschke, E. Melatonin and pancreatic islets: interrelationships between melatonin, insulin and glucagon / E. Peschke, I. Bähr, E. Mühlbauer // Int. J. Mol. Sci. - 2013. - Vol. 14, № 4. - P. 6981-7015.

18. Ravnskjaer, K. Role of the cAMP pathway in glucose and lipid metabolism / K. Ravnskjaer, A. Madiraju, M. Montminy // Handb. Exp. Pharmacol. - 2016. - Vol. 233. - P. 29-49.

19. Sears, B. The role of fatty acids in insulin resistance/ B. Sears, M. Perry // Lipids Health Dis. - 2015. - Vol. 14. - P. 121.4.

20. The integrative role of leptin, oestrogen and the insulinfamily in obesity - associated breast cancer: potential effects ofexercise / S. Schmidt [et al.] // Obes. Rev. - 2015. - Vol. 16,№ 6. P. 473-487

21. The structure of $2 \mathrm{Zn}$ pig insulin crystals at 1.5.A resolution / E. N. Baker [et al.] // Philos. Trans. R. Soc. Lond. B.Biol. Sci. - 1988. - Vol. 319, № 1195. - P. 369-456.

22. The role of melatonin in diabetes: therapeutic implications/ S. Sharma [et al.] // Arch. Endocrinol. Metab. - 2015. - Vol. 59,№ 5. - P. 391-399.

\subsection{7. змилззамбо}

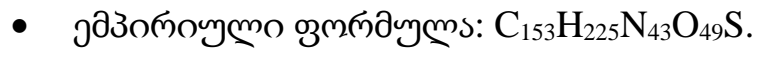

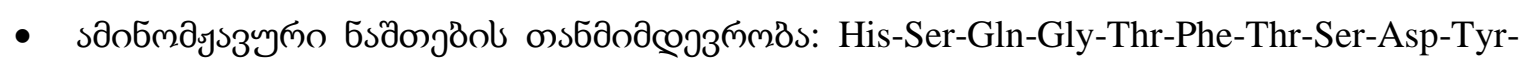
Ser-Lys-Tyr-Leu-Asp-Ser-Arg-Arg-Ala-Gln-Asp-Phe-Val-Gln-Trp-Leu-Met-Asn-Thr.

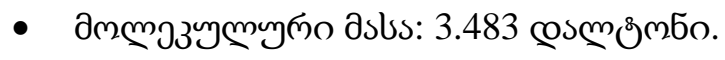

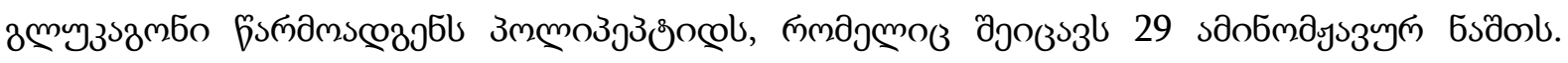

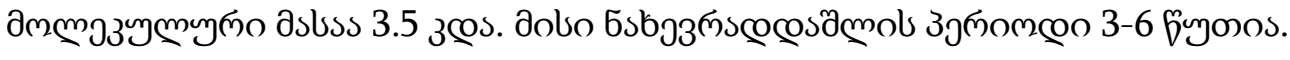

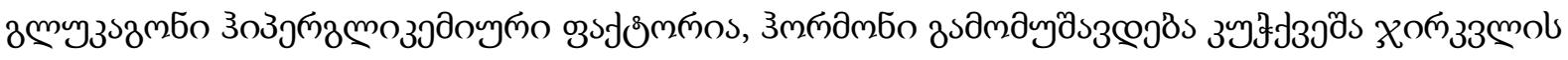

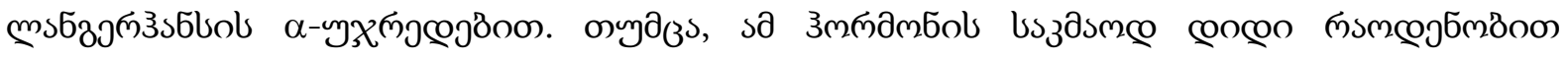

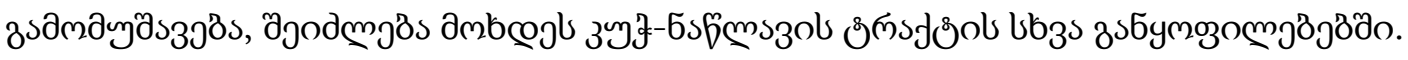

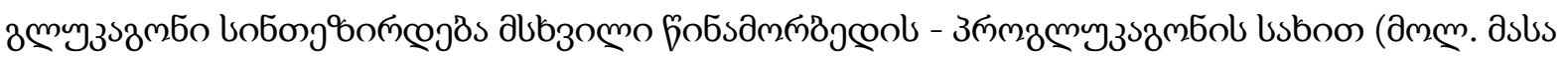

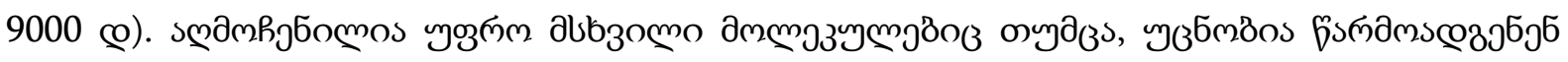

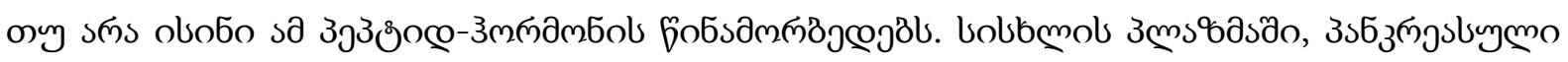

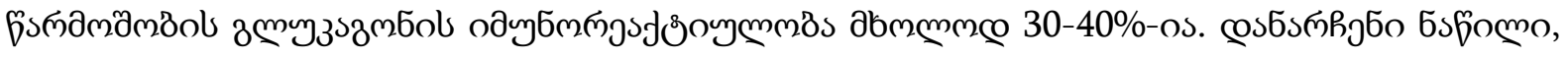

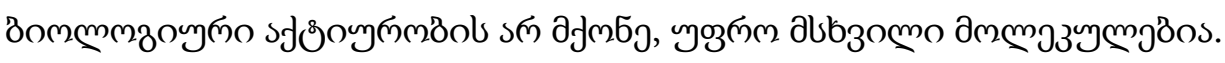




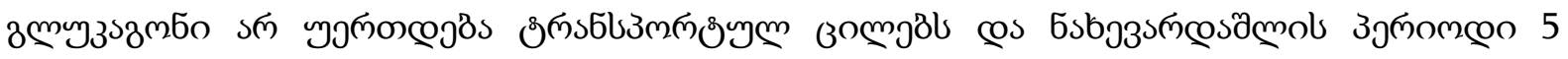

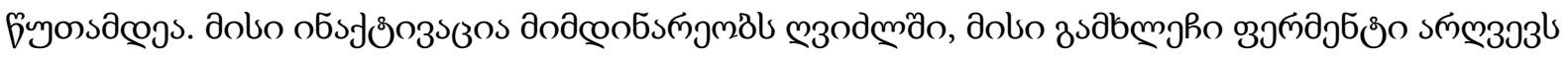

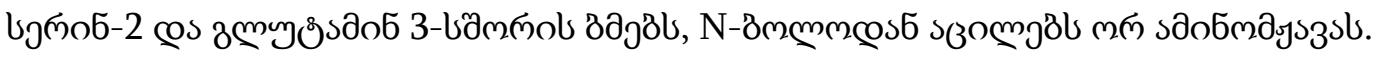

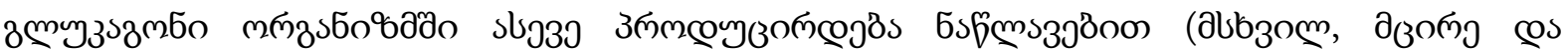

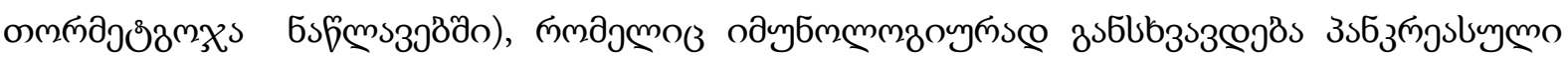

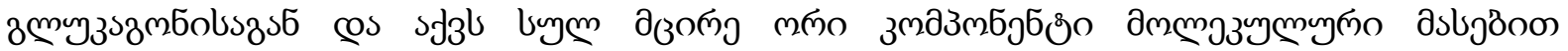

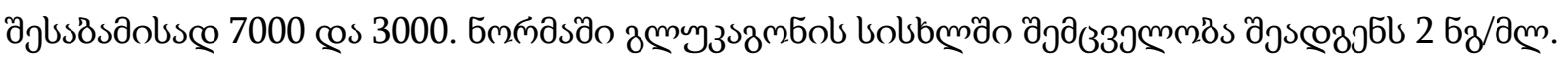

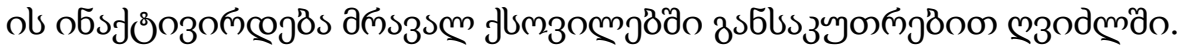

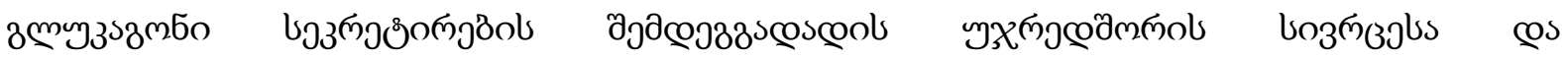

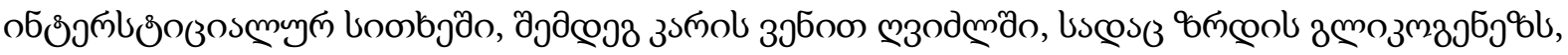

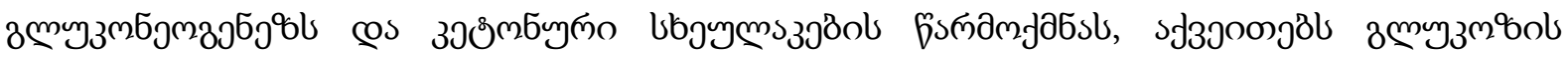

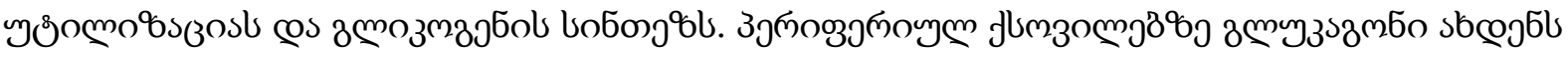

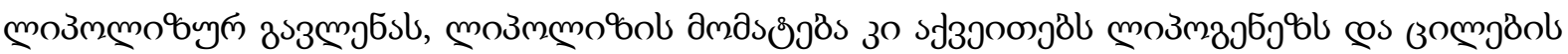

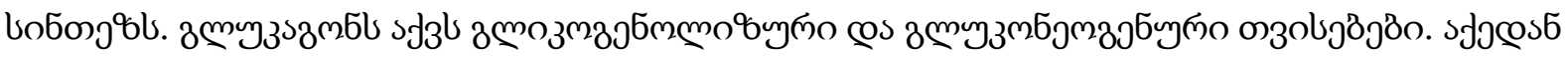

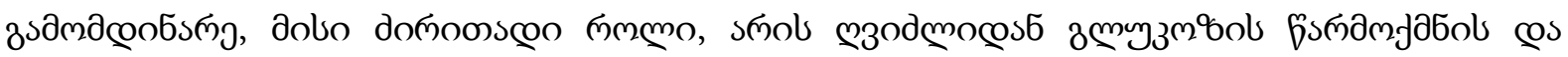

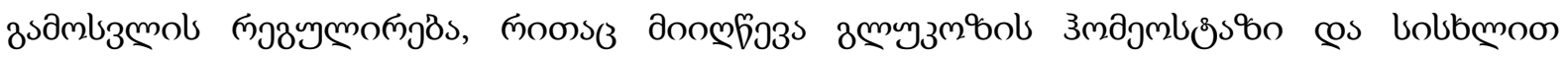

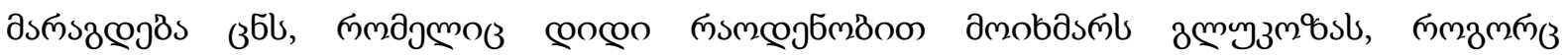

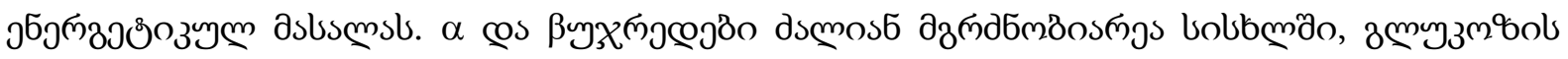

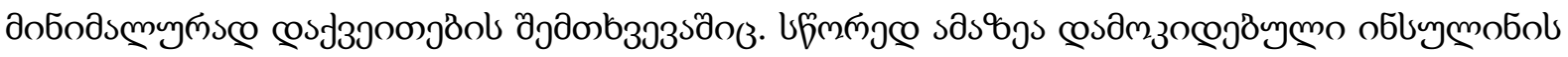

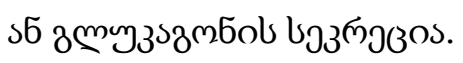

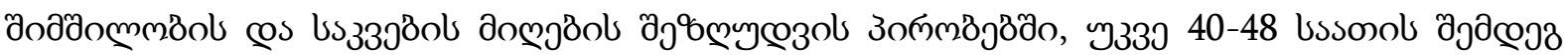

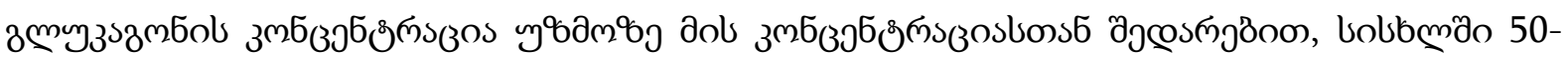

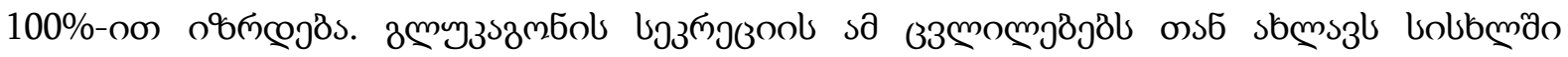

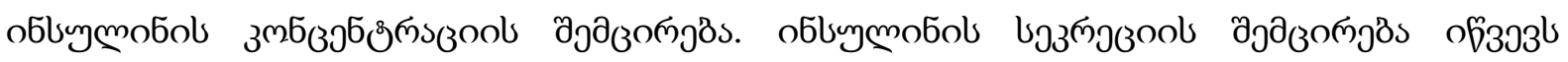

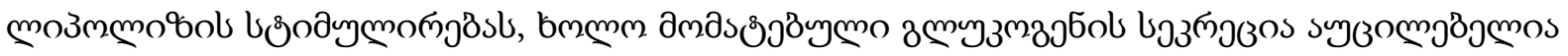

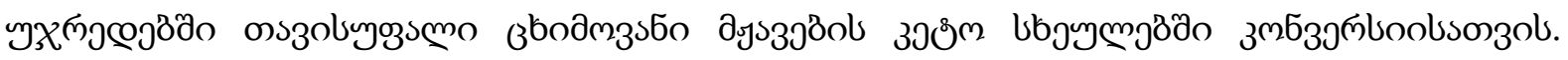

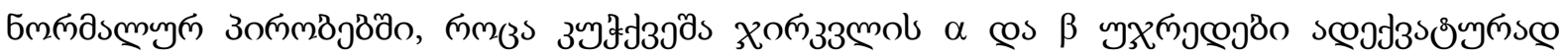

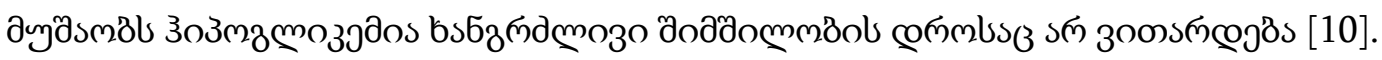

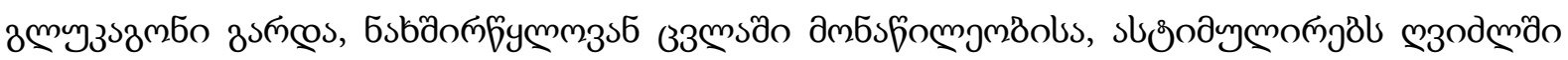

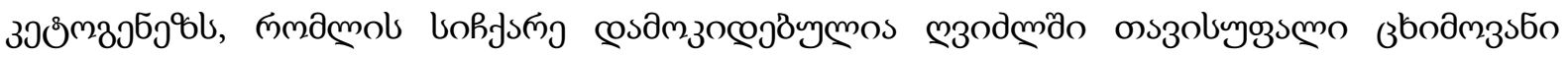

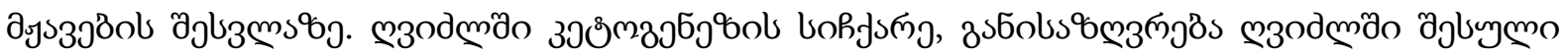

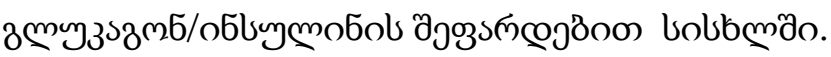

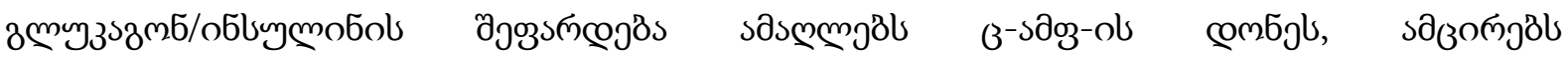

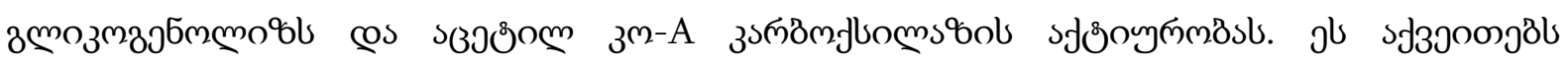

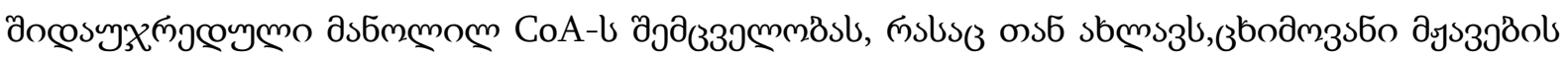

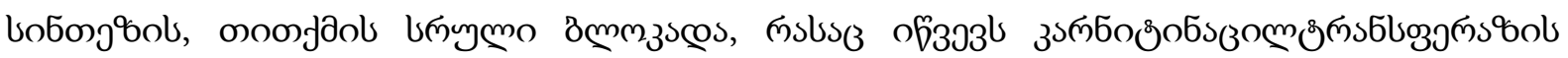

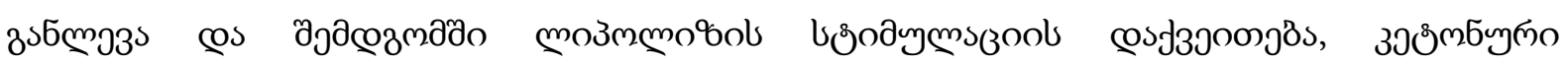

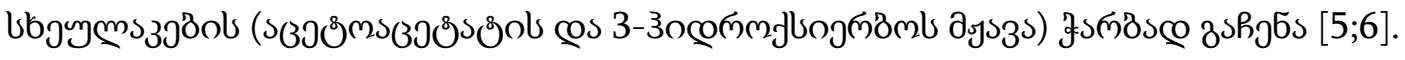

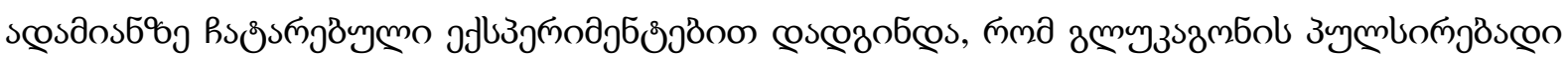

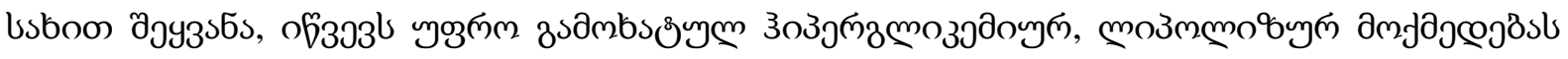

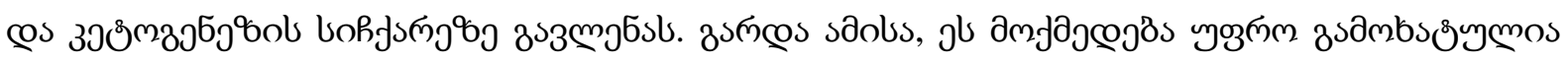

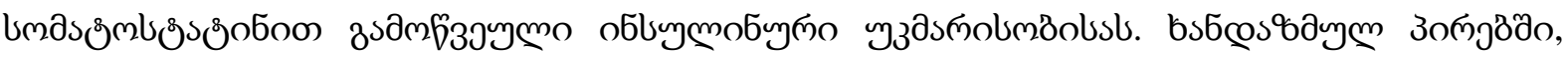




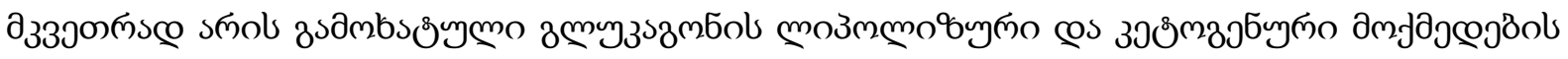

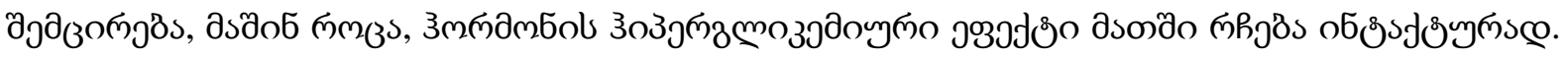

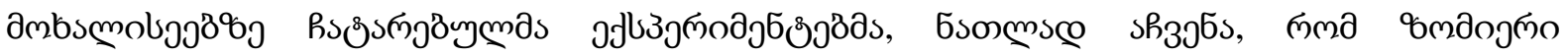

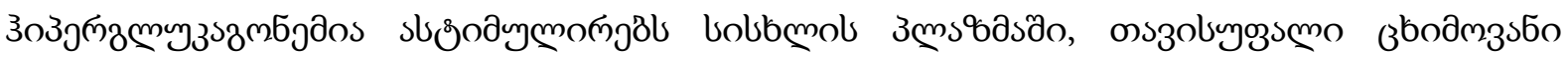

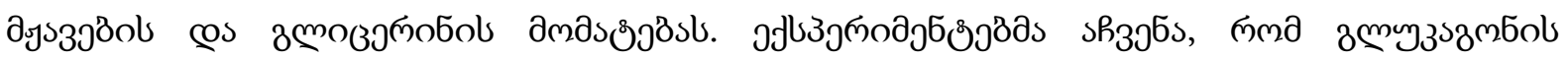

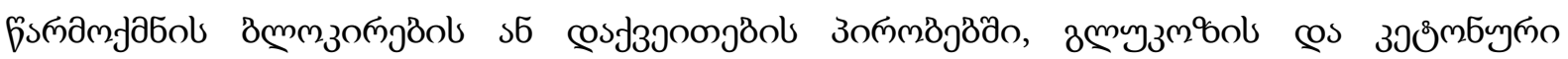

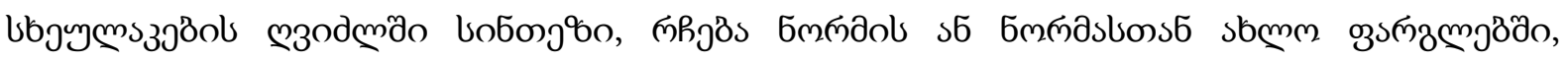

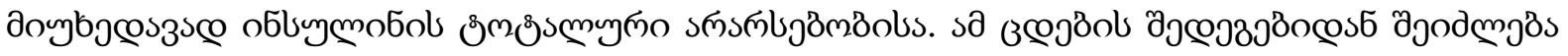

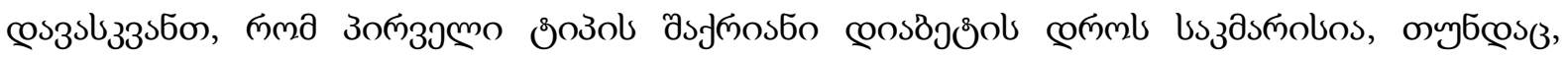

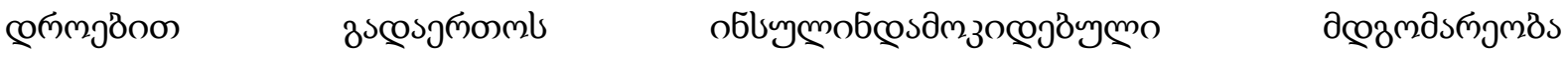

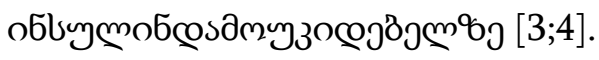

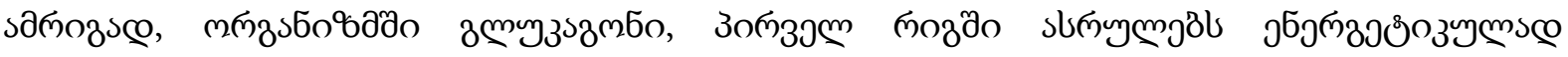

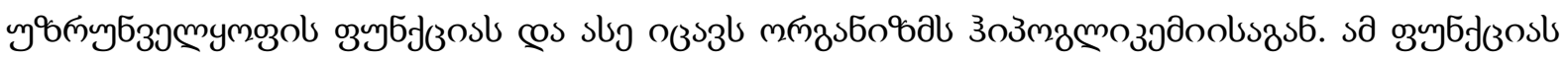

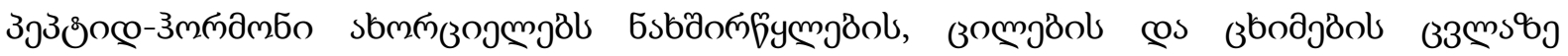

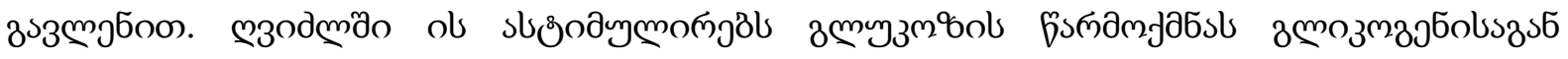

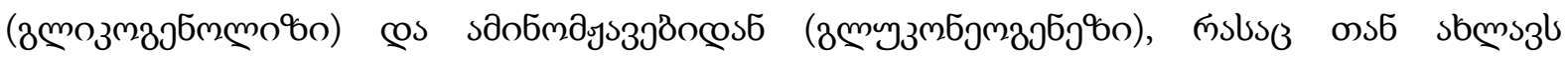

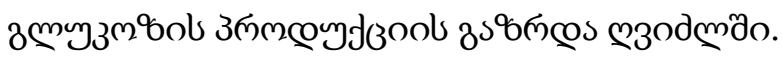

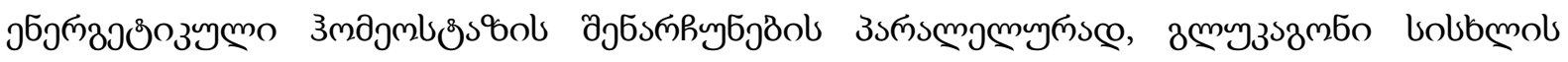

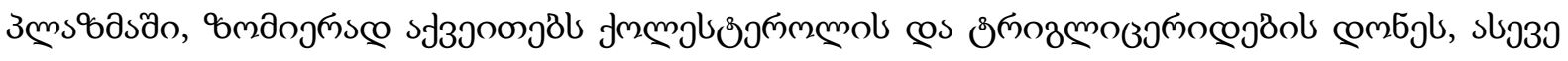

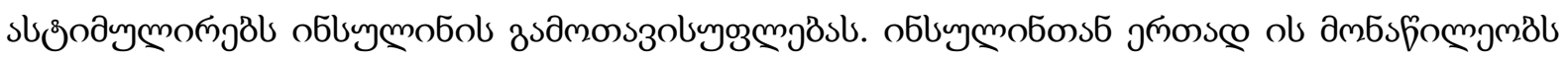

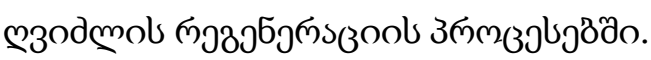

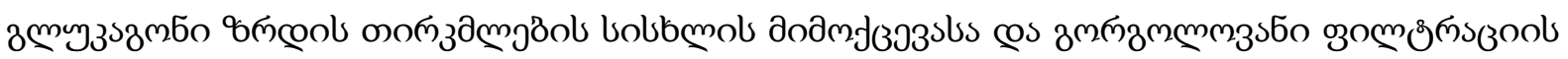

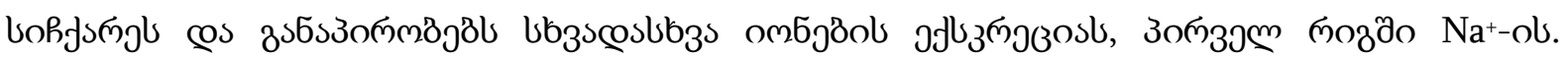

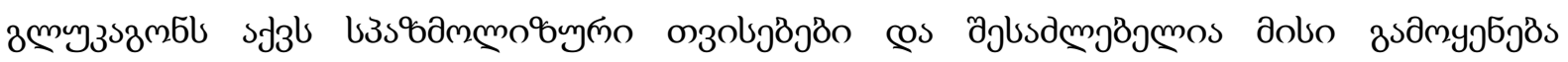

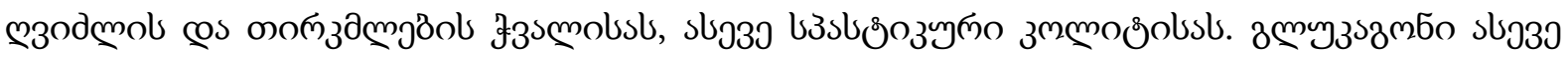

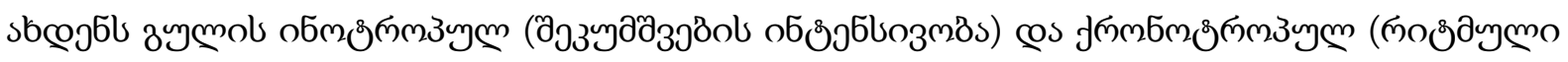

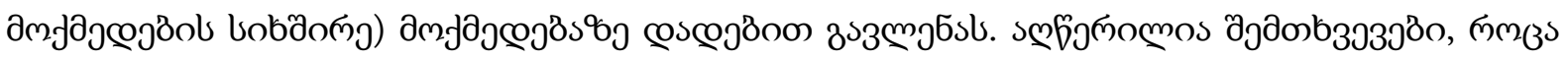

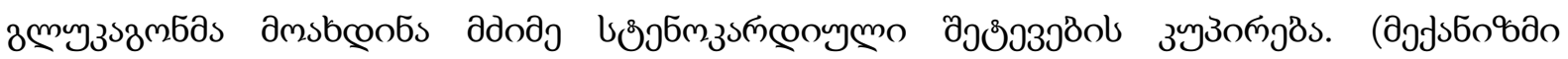

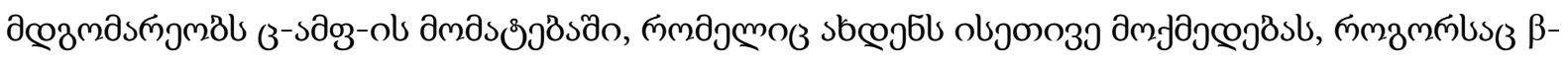

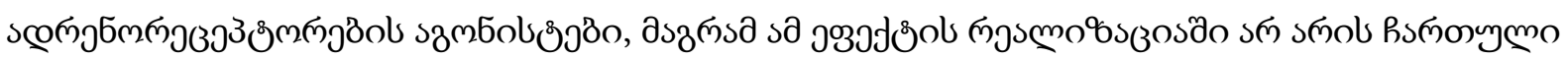

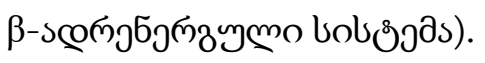

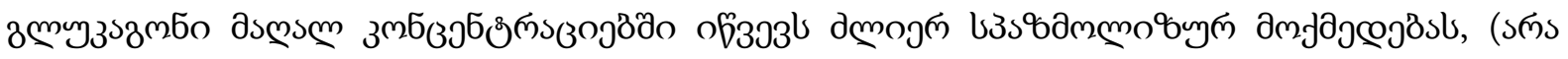

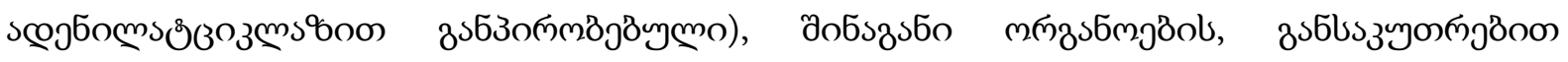

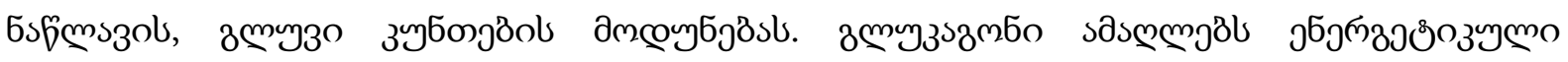

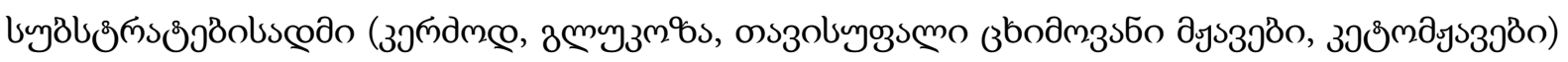

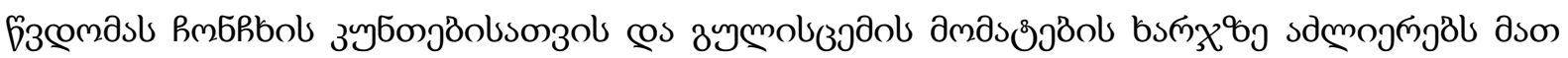

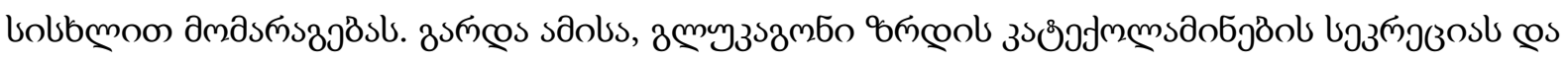

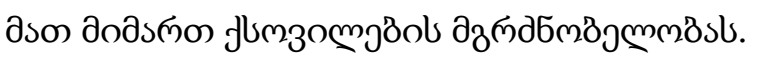

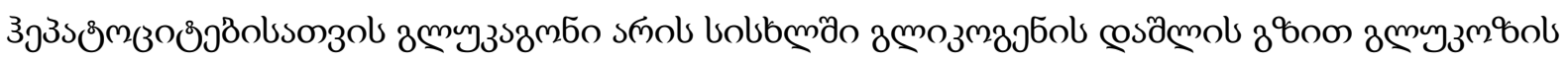

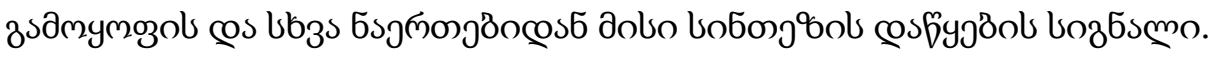

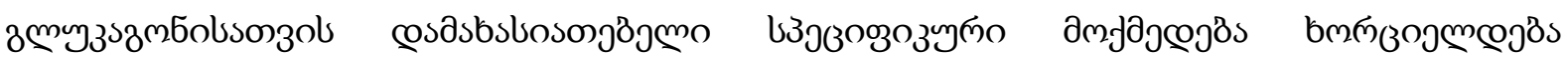

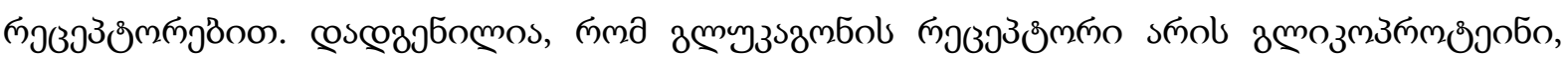




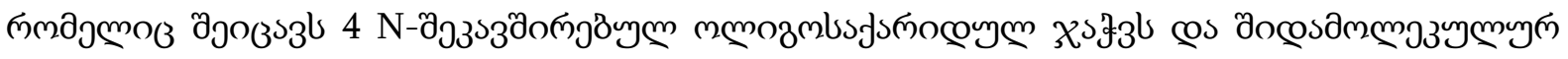

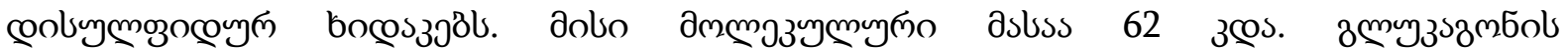

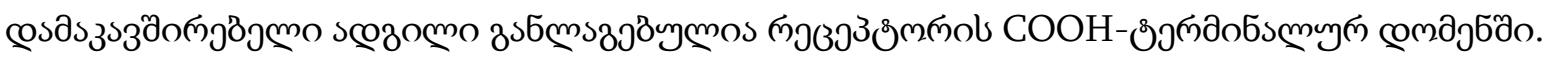

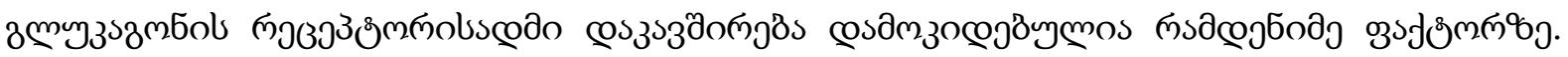

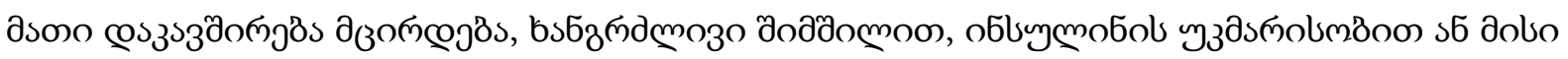

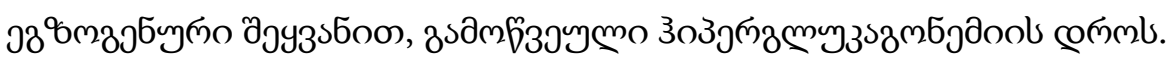

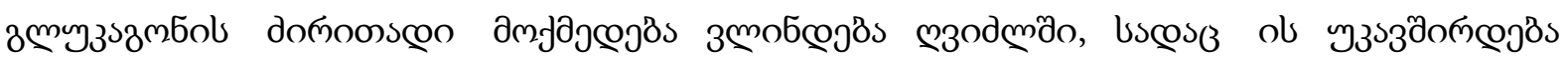

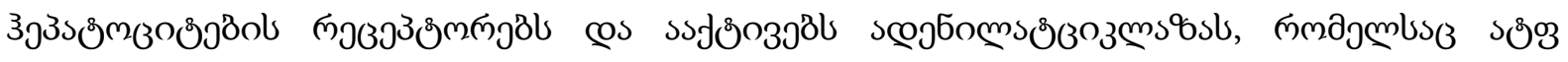

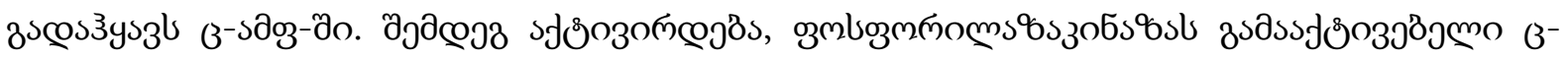

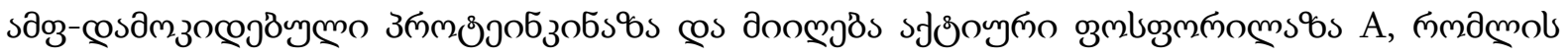

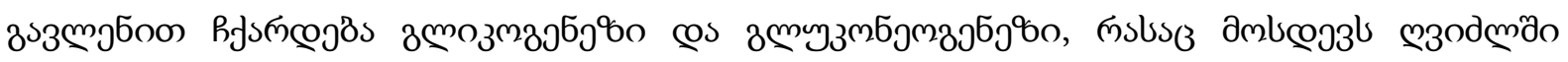

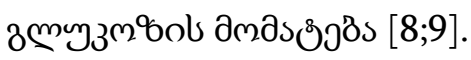

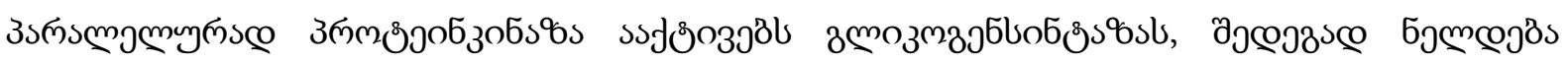

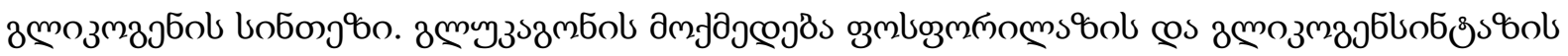

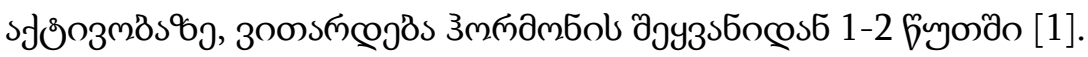

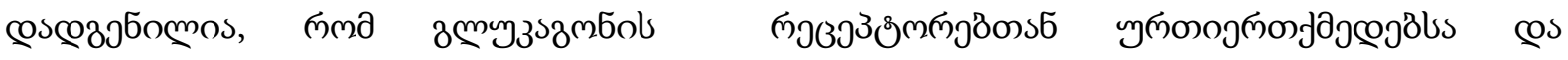

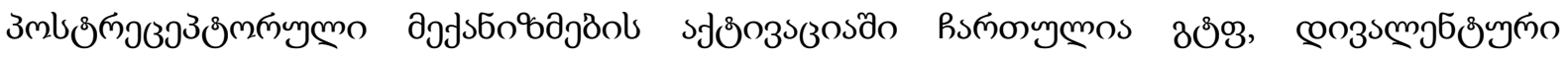

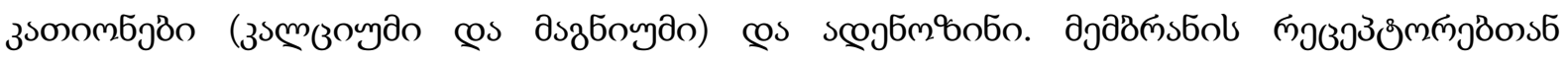

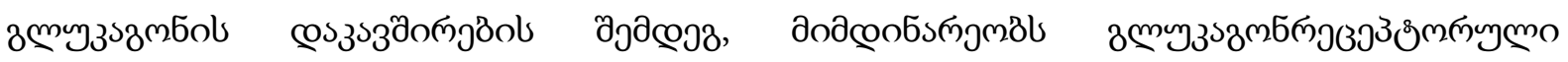

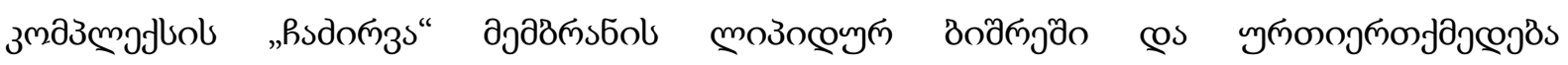

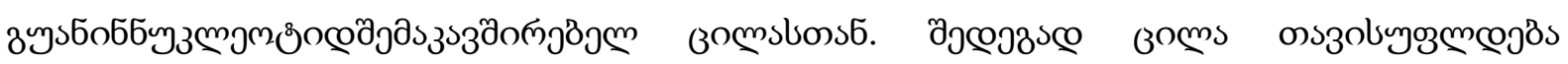

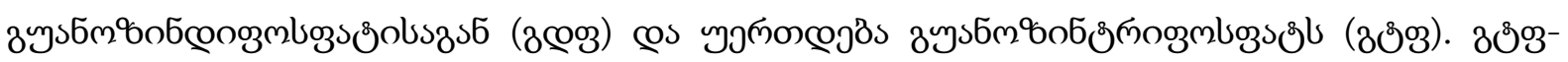

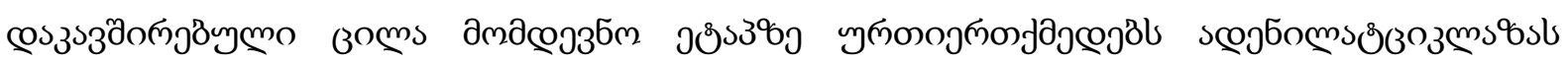

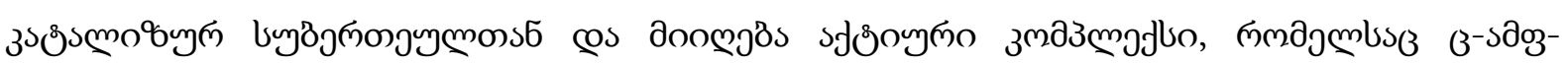

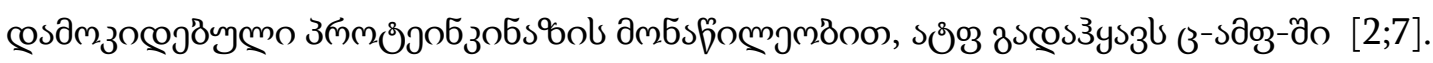

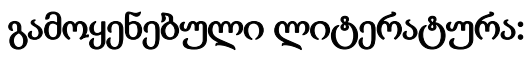

1. Ahren, B. (2015). Glucagon-early breakthroughs and recent discoveries. Peptides 67, 74-81. doi: 10.1016/j.peptides.2015.03.011

2. Aromataris, E. C., Roberts, M. L., Barritt, G. J., and Rychkov, G. Y. (2006). Glucagon activates $\mathrm{Ca}_{2} \mathrm{C}$ and $\mathrm{Cl}$ channels in rat hepatocytes. J. Physiol. 573(Pt 3), 611-625. doi: 10.1113/jphysiol.2006.109819

3. Carlson, M. G., Snead, W. L., and Campbell, P. J. (1993). Regulation of free fatty acid metabolism by glucagon. J. Clin. Endocrinol. Metab. 77, 11-15.

4. G.Paolisso; A.J. Scheen; A. Albert; P.J. Lefebvre. Effects of pulsatile delivery of insulin and

5. glucagon in humans. American Journal of Physiology-Endocrinology and Metabolism https://doi.org/10.1152/ajpendo.1989.257.5.E686

6. JD, Foster DW. Regulation of hepatic fatty acid oxidation and ketone body production.Annu Rev Biochem. 1980;49:395-420. doi: 10.1146/annurev.bi.49.070180.002143. PMID: 6157353.

7. McGarry JD, Foster DW. Regulation of hepatic fatty acid oxidation and ketone body production.Annu Rev Biochem. 1980;49:395-420. doi: 10.1146/annurev.bi. 49.070180.002143. PMID: 6157353. 
8. Peng, I. C., Chen, Z., Sun, W., Li, Y. S., Marin, T. L., Hsu, P. H., et al. (2012). Glucagon regulates ACC activity in adipocytes through the CAMKKbeta/AMPK pathway. Am. J. Physiol. Endocrinol. Metab. 302, E1560- E1568. doi: 10.1152/ajpendo.00504.2011.

9. Perry, R. J., Camporez, J. G., Kursawe, R., Titchenell, P. M., Zhang, D., Perry, C. J., et al. (2015). Hepatic acetyl CoA links adipose tissue inflammation to hepatic insulin resistance and type 2 diabetes. Cell 160, 745-758. doi: 10.1016/j.cell. 2015.01.012.

10. Li, N. X., Brown, S., Kowalski, T., Wu, M., Yang, L., Dai, G., et al. (2018). GPR119 agonism

increases glucagon secretion during insulin-induced hypoglycemia. Diabetes 67, 1401-1413. doi: $10.2337 / \mathrm{db} 18-003$.

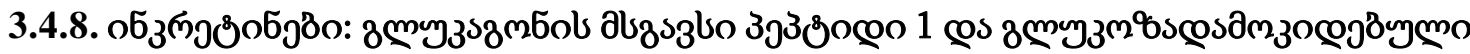

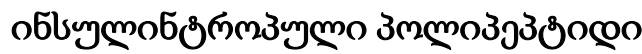

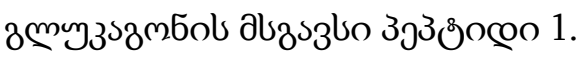

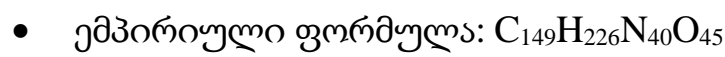

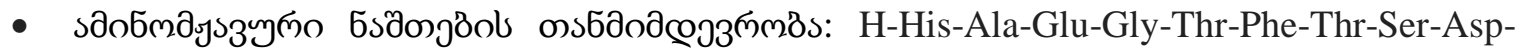
Val-Ser-Ser-Tyr-Leu-Glu-Gly-Gln-Ala-Ala-Lys-Glu-Phe-Ile-Ala-Trp-Leu-Val-Lys-Gly-Arg$\mathrm{NH}_{2}$

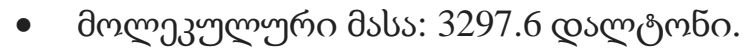

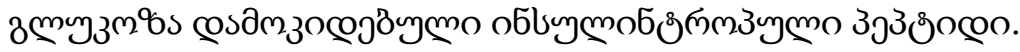

- jазополумо озмпаулмзs: $\mathrm{C}_{226} \mathrm{H}_{338} \mathrm{~N}_{60} \mathrm{O}_{66} \mathrm{~S}_{1}$

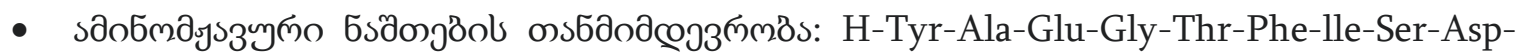
Tyr-Ser-Ile-Ala-Met-Asp-Lys-lle-His-Gln-Gln-Asp-Phe-Val-Asn-Trp-Leu-Leu-Ala-GInLys-Gly-Lys-Lys-Asn-Asp-Trp-Lys-His-Asn-lle-Thr-Gln-OH

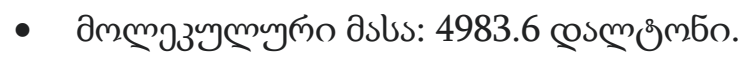

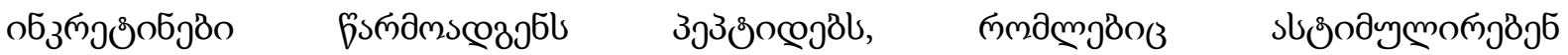

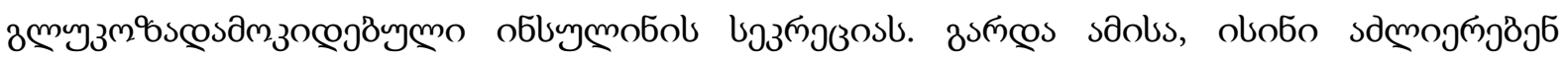

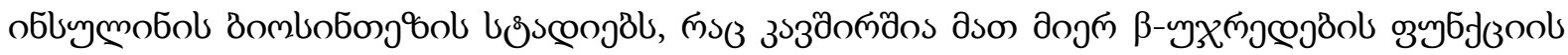

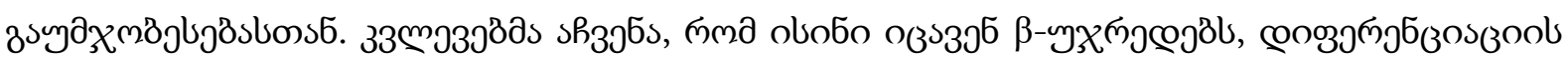

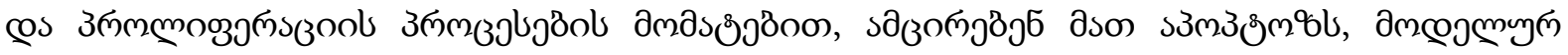

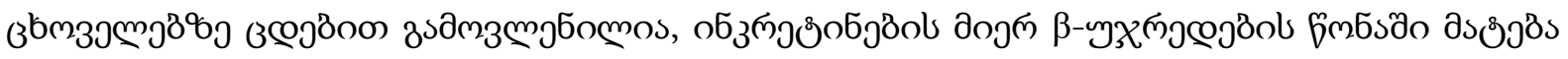
[10].

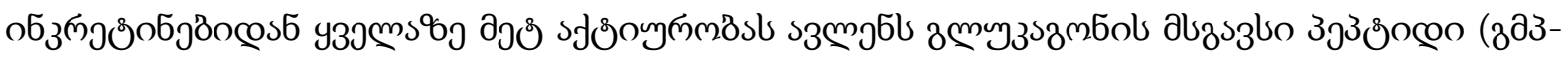

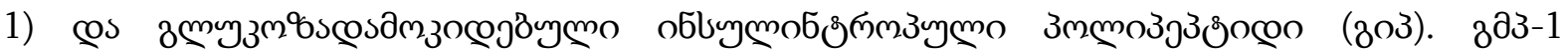

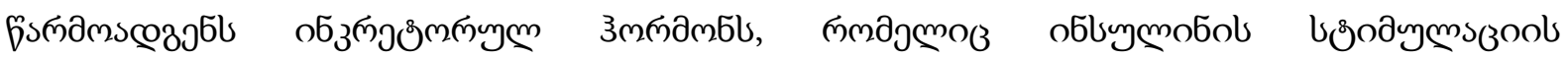

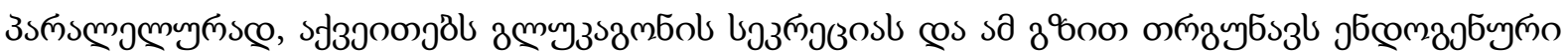

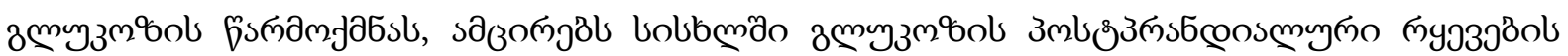

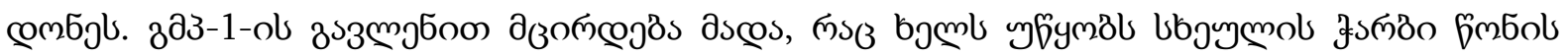

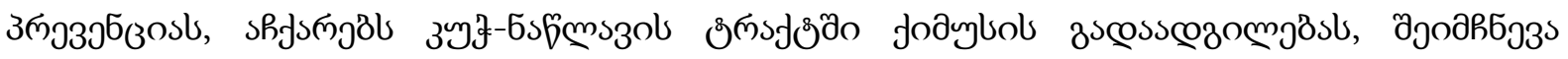




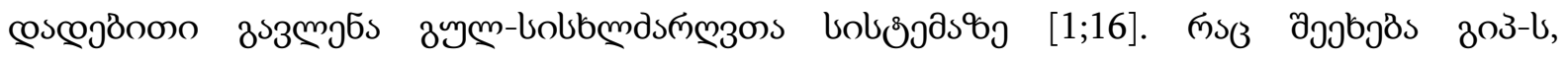

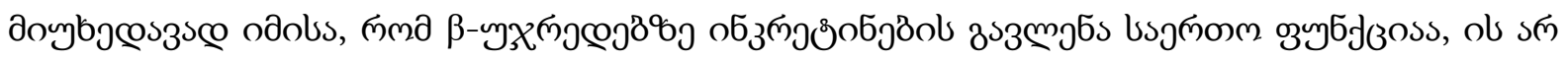

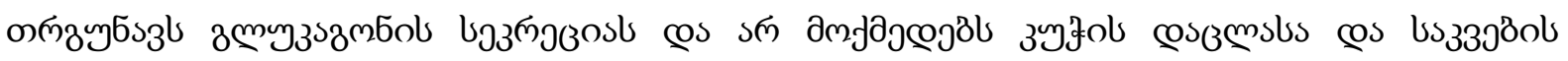

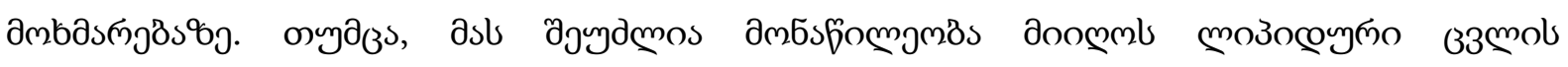

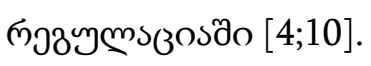

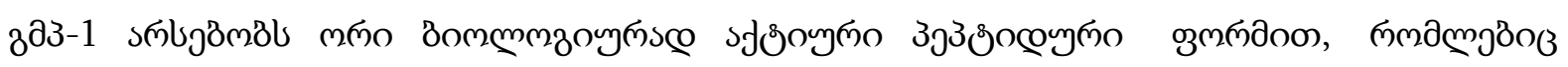

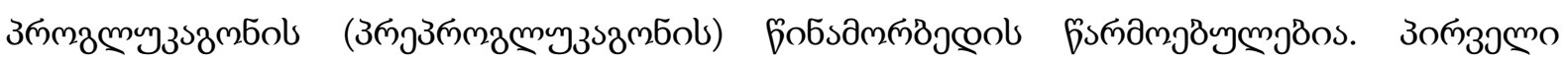

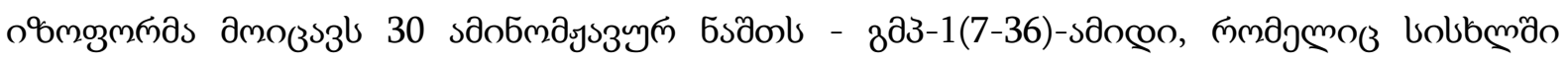

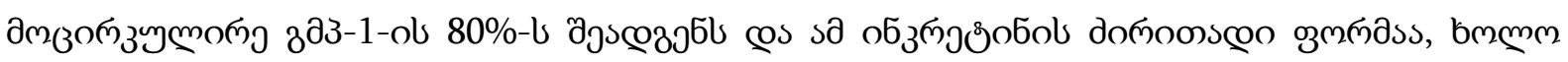

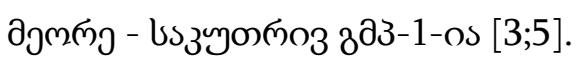

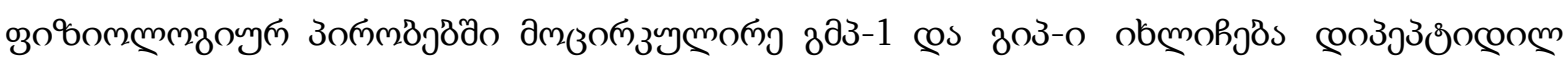

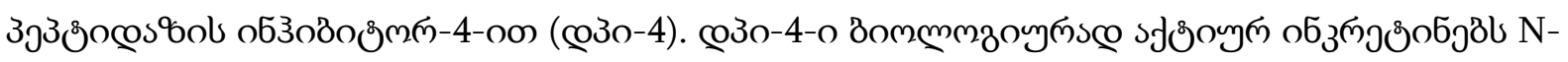

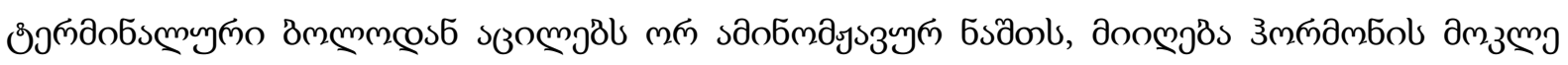

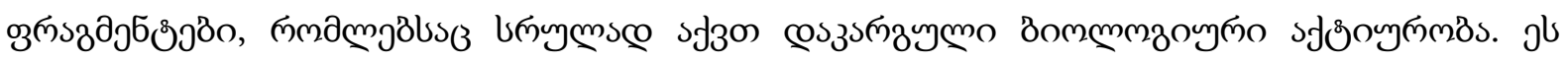

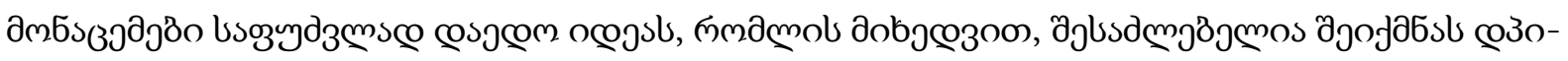

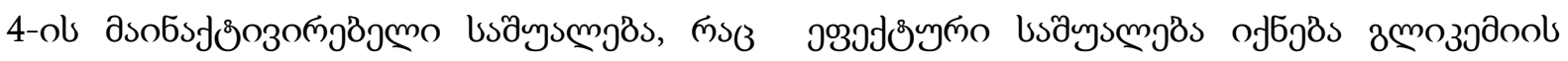

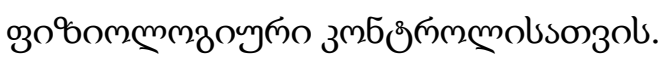

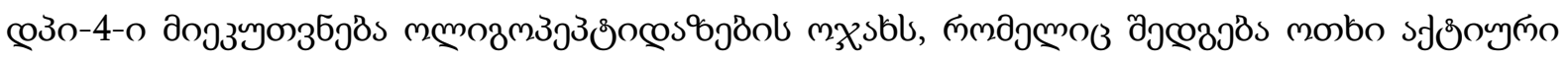

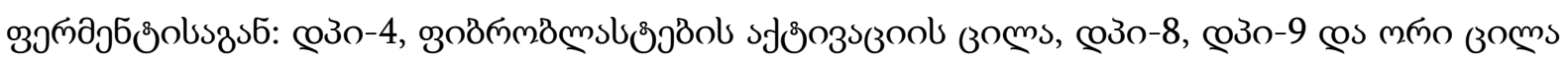

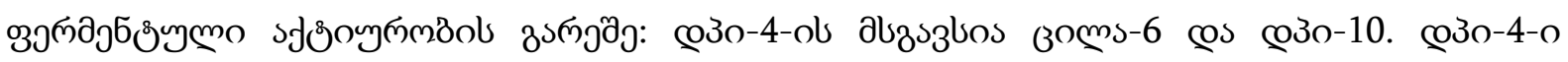

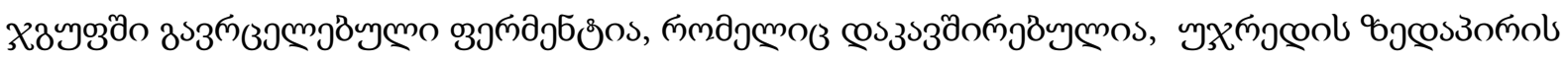

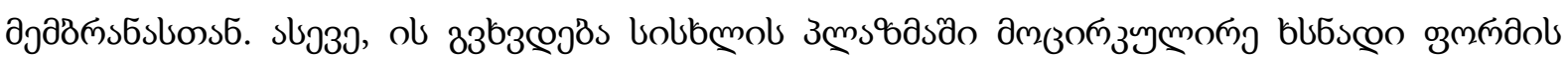

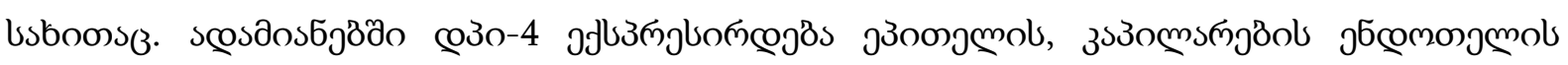

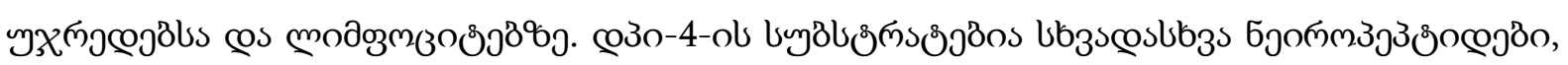

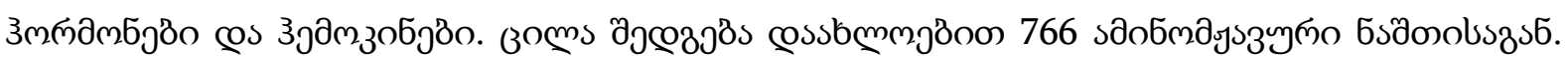

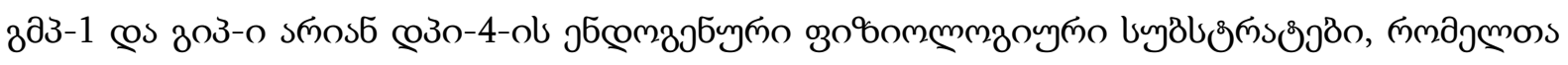

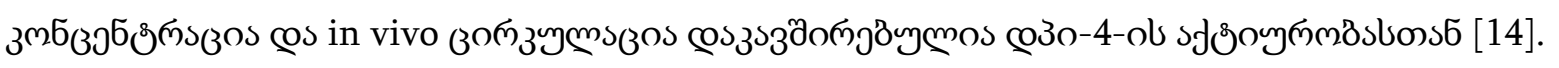

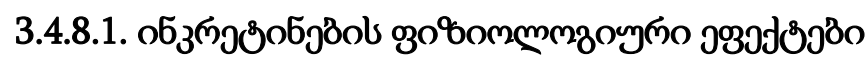

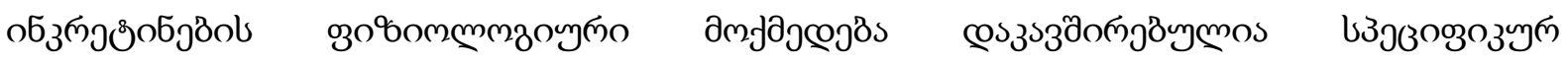

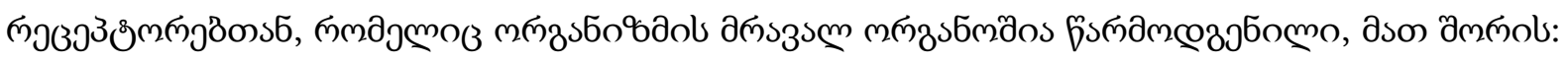

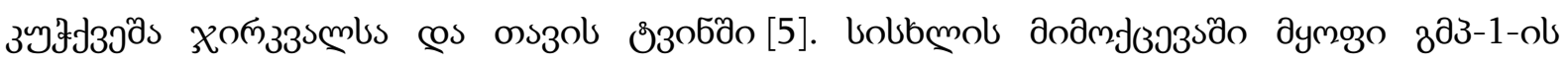

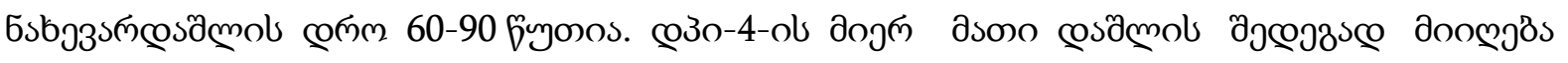

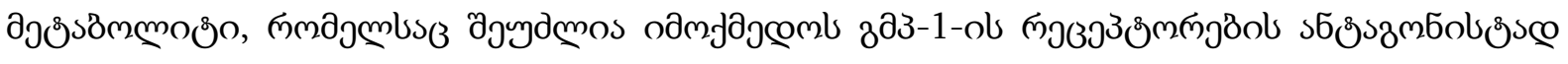
$[6 ; 15]$.

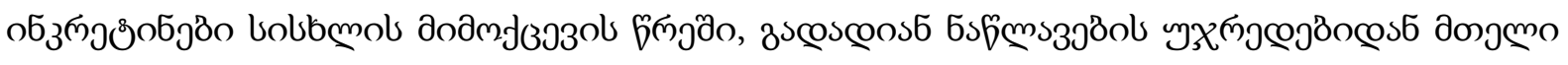

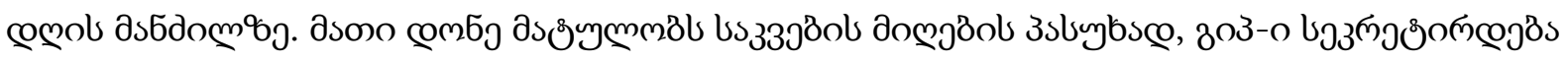




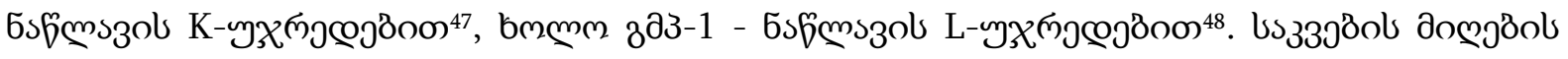

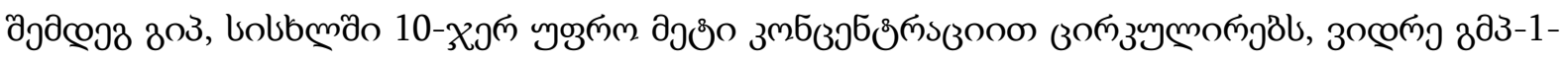

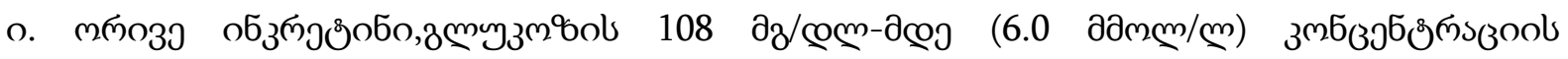

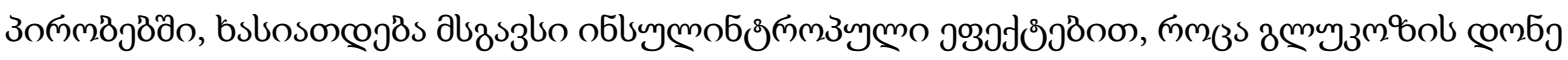

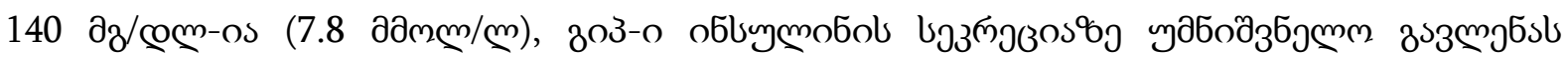

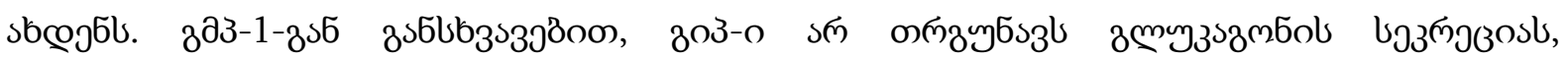

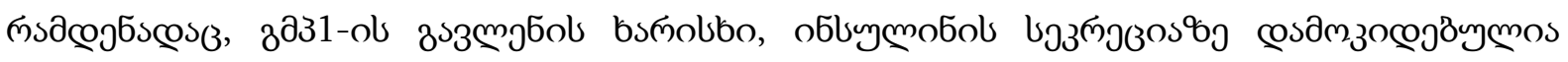

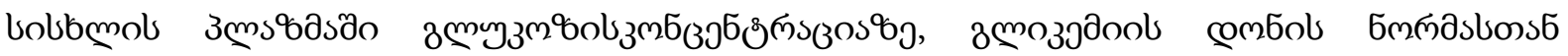

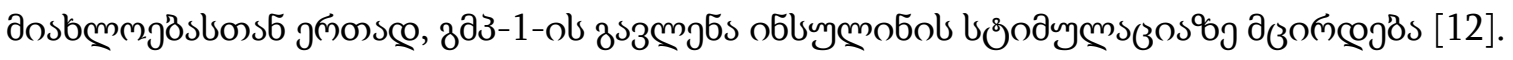

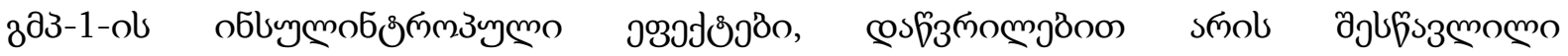

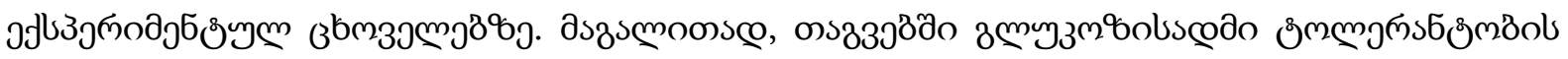

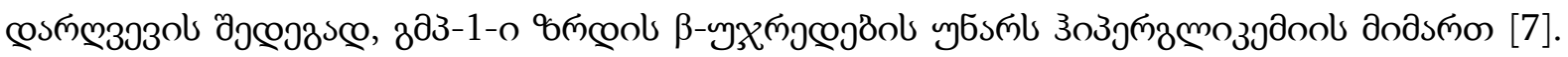

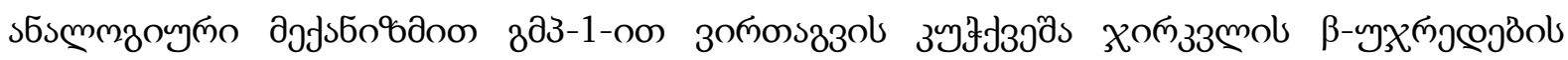

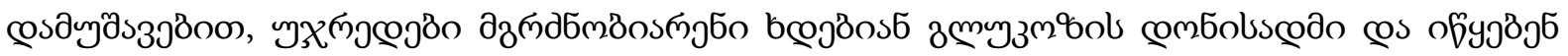

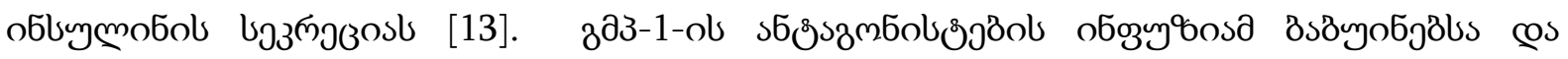

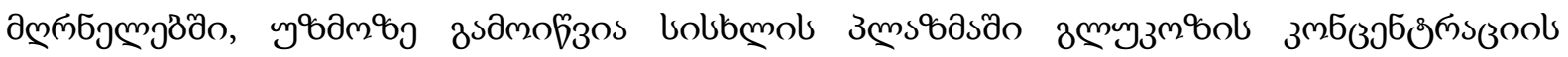

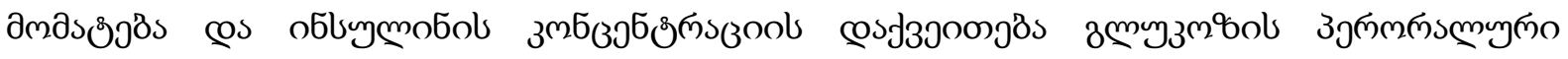

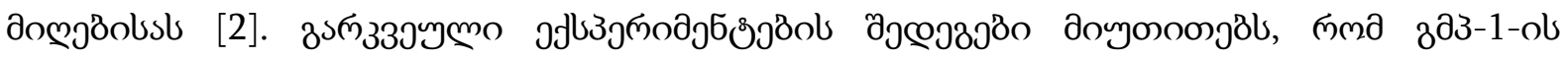

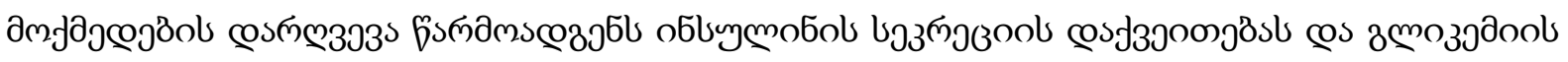

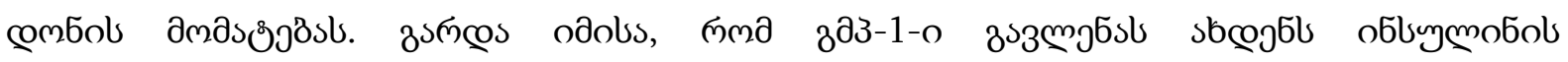

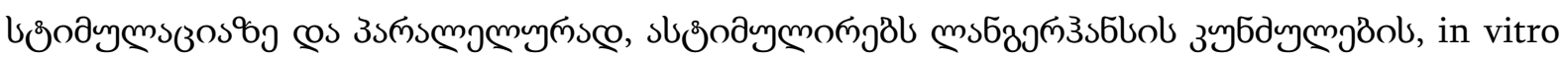

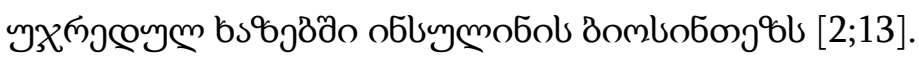

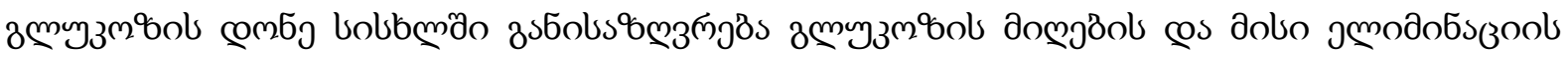

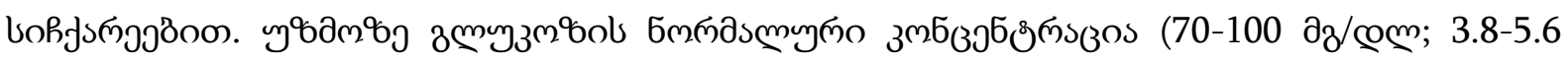

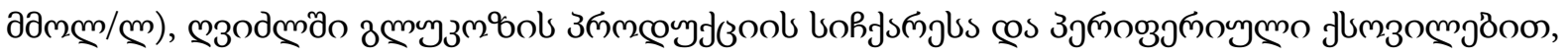

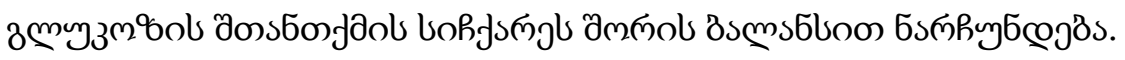

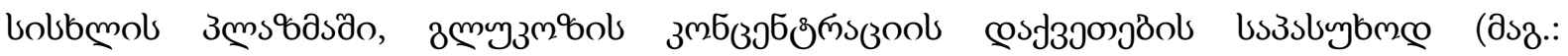

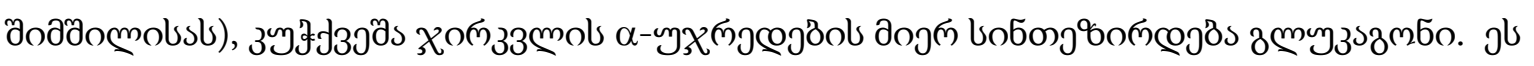

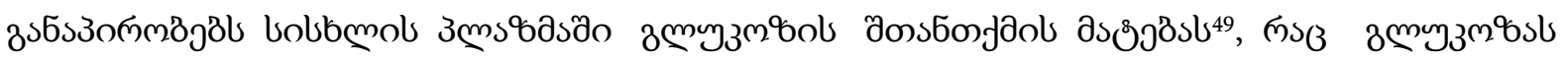

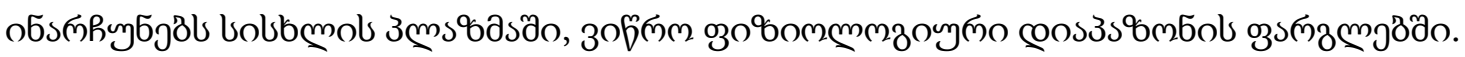

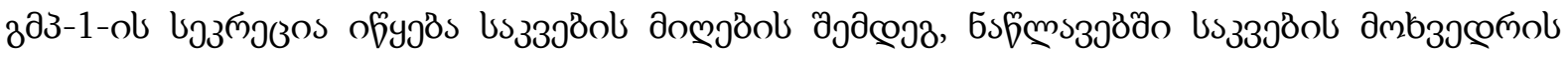

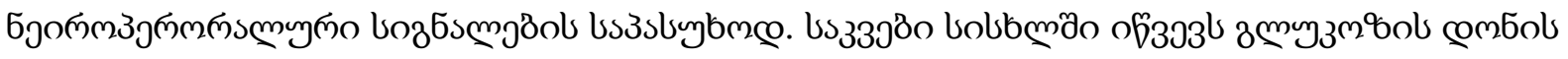

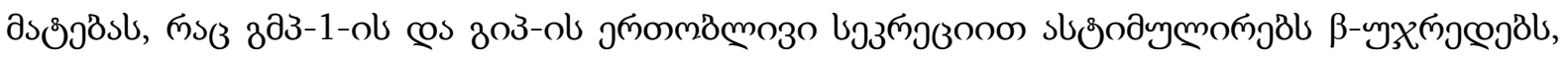

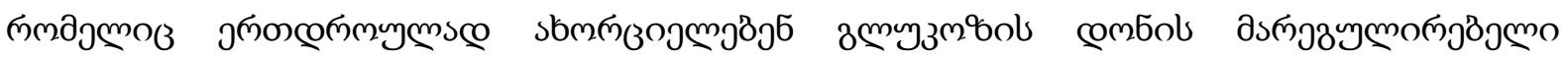

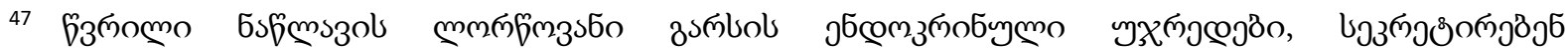

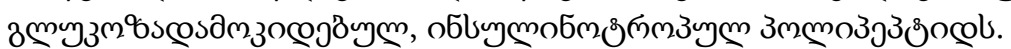

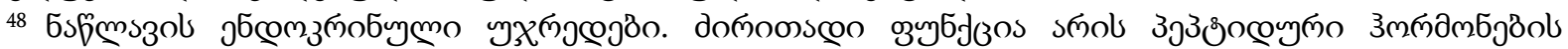

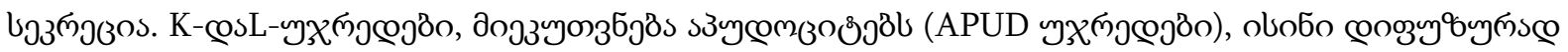

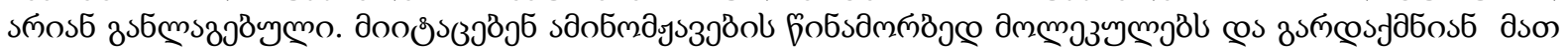

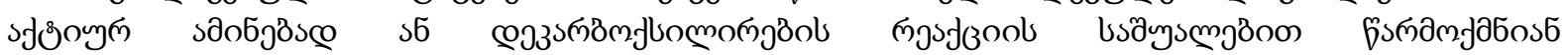

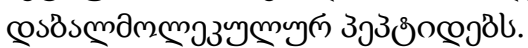

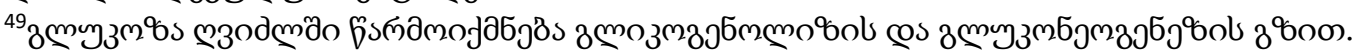




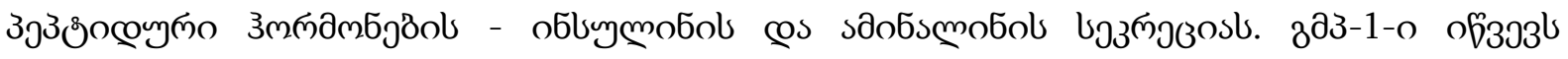

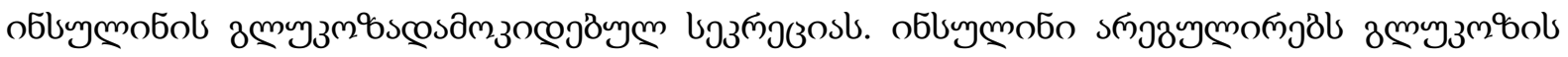

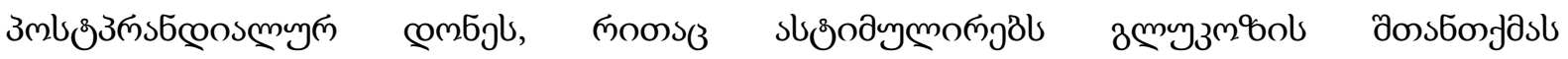

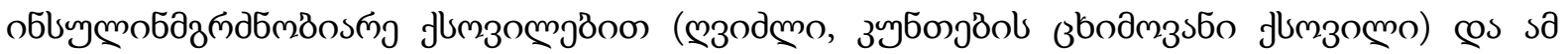

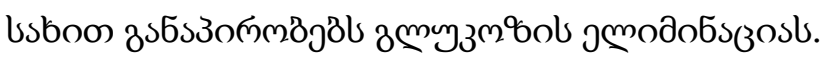

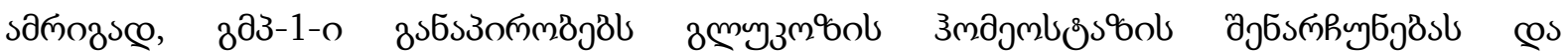

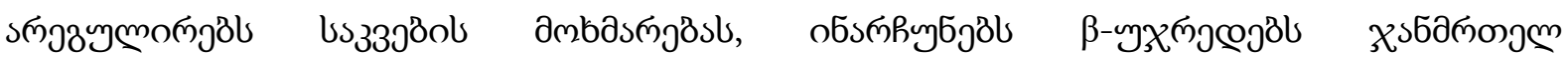

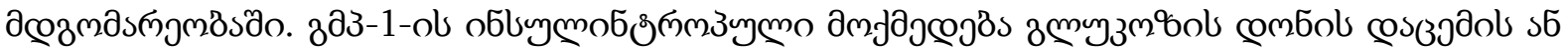

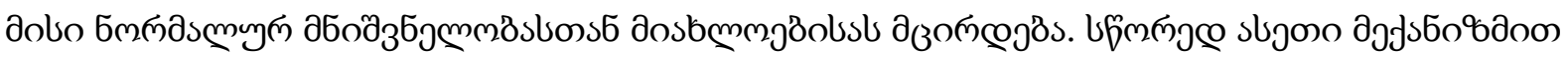

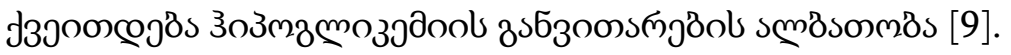

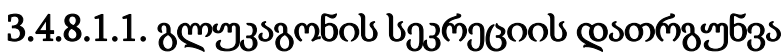

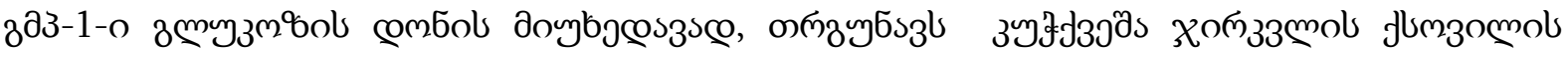

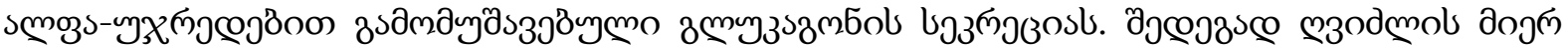

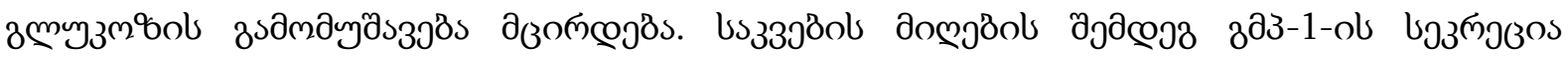

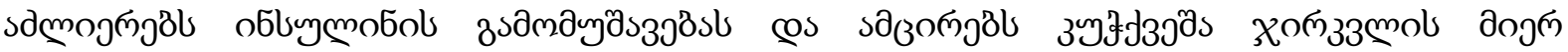

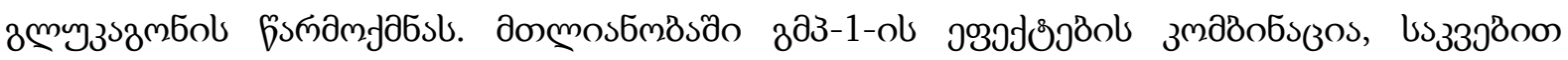

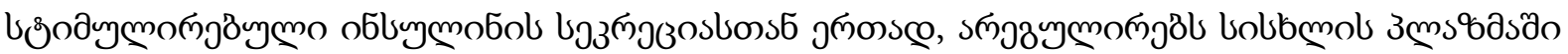

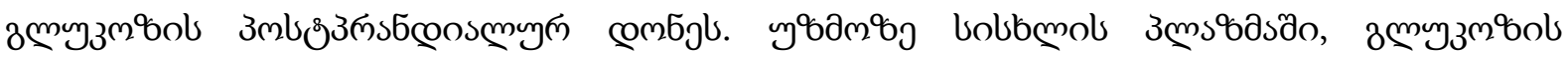

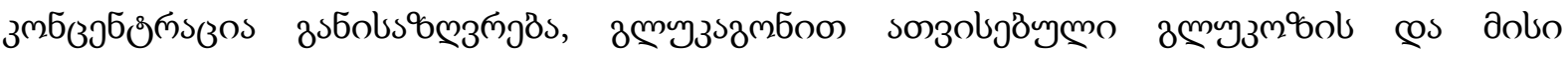

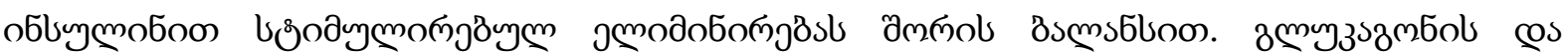

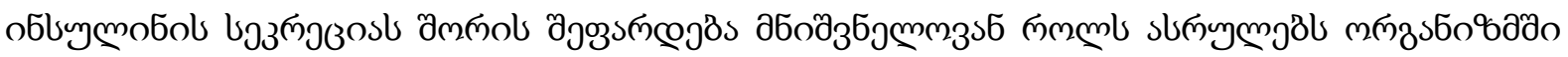
змпуз

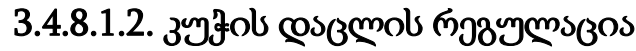

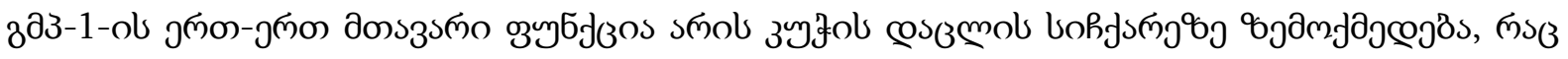

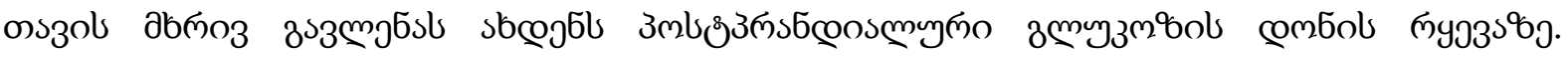

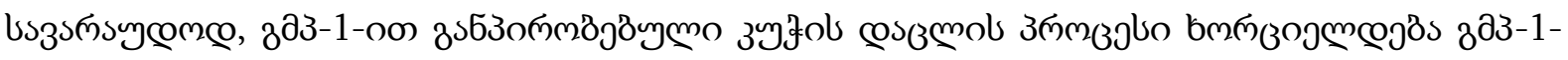

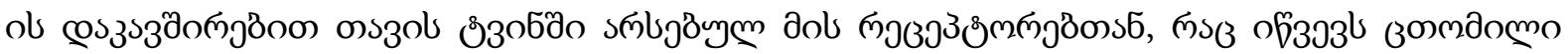

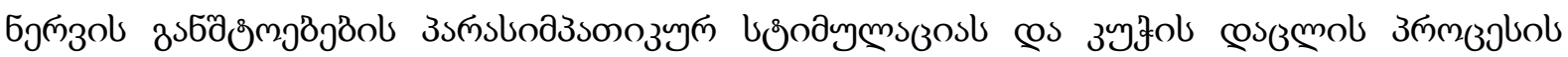

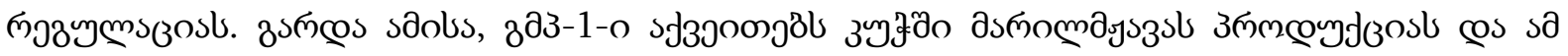

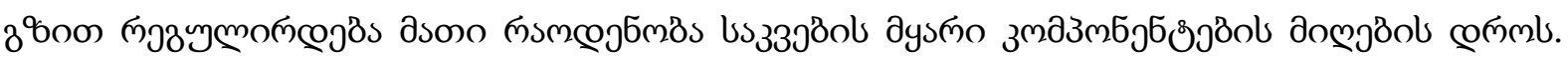

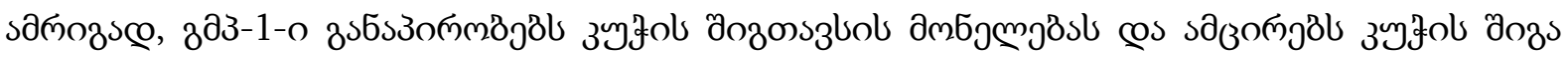

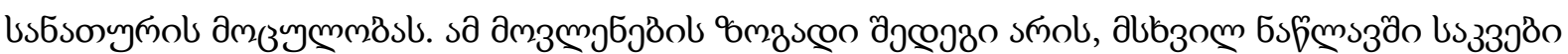

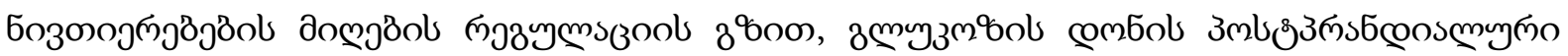

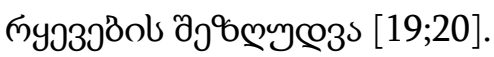




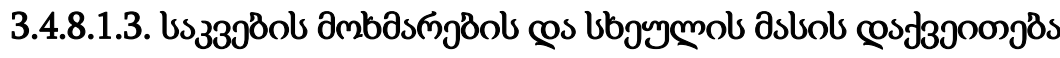

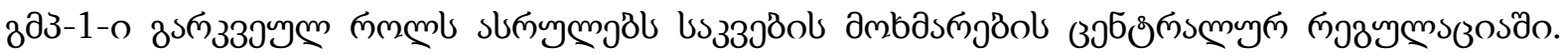

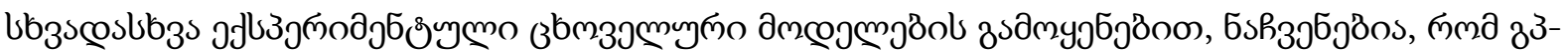

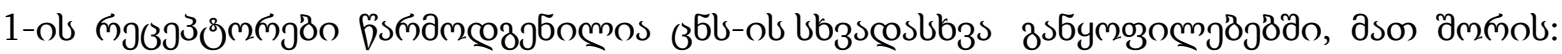

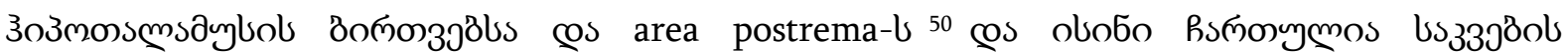

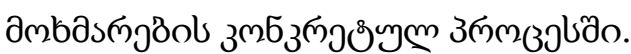

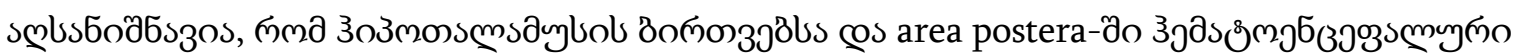

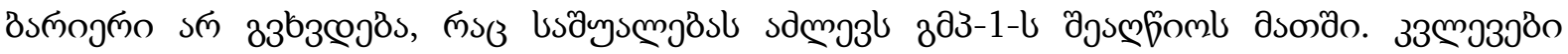

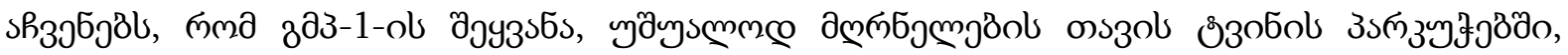

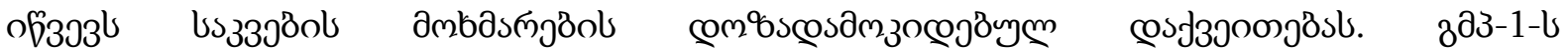

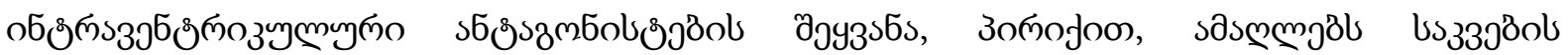

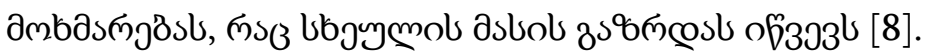

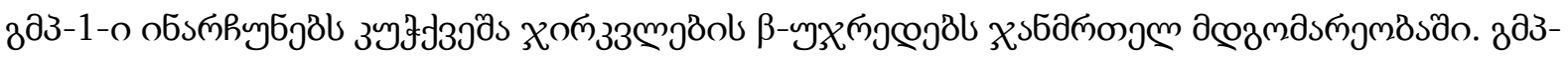

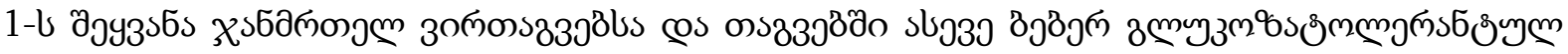

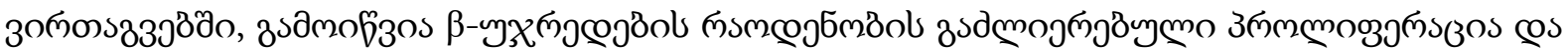

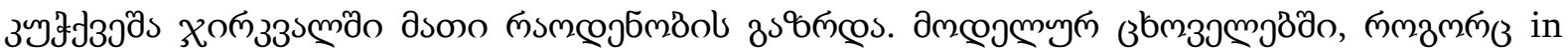

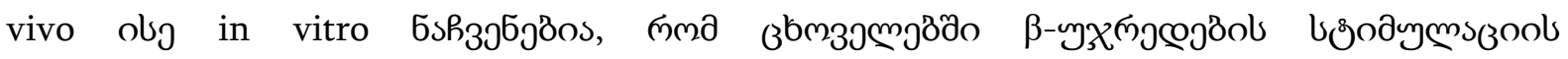

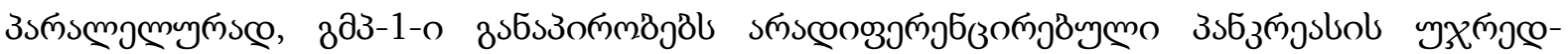

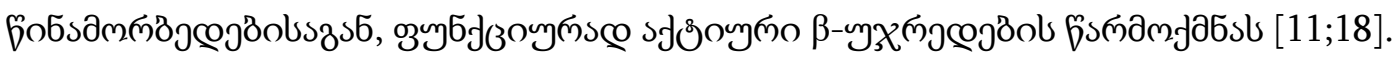

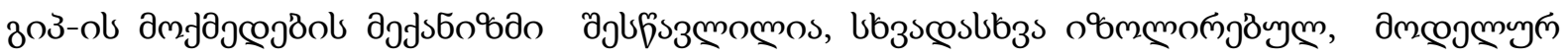

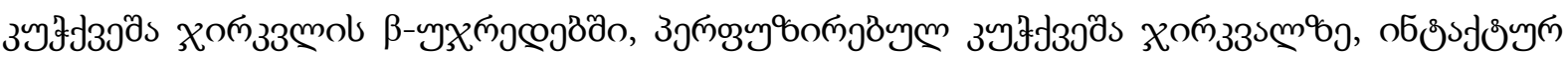

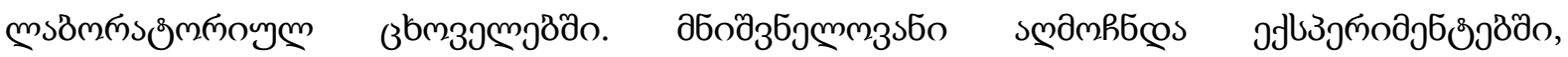

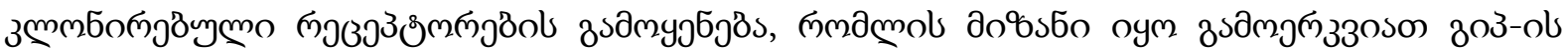

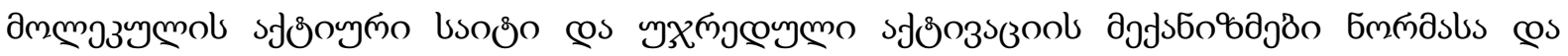

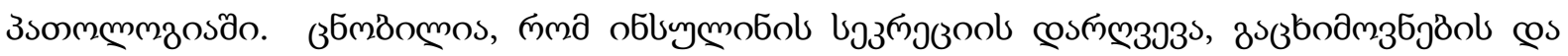

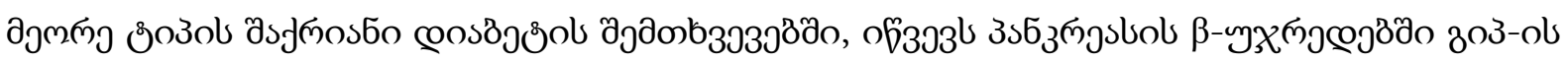

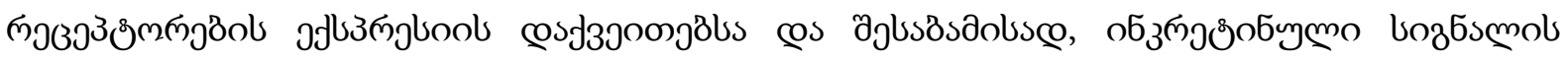

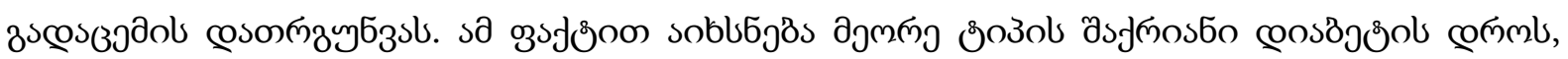

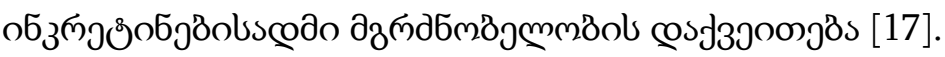

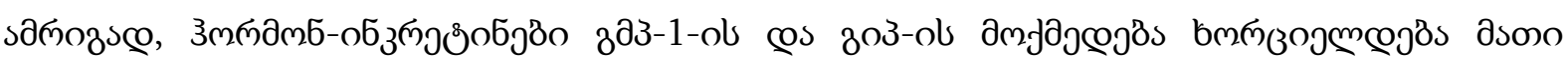

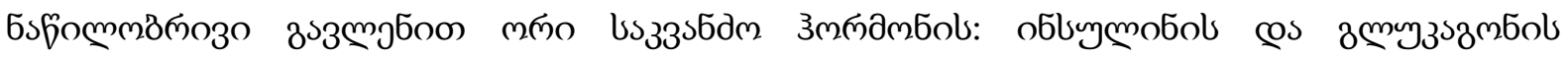

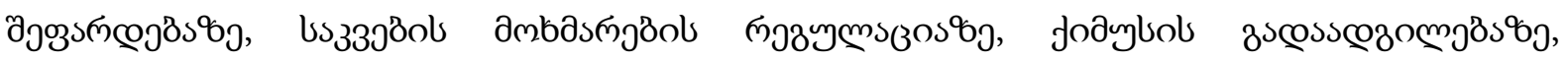

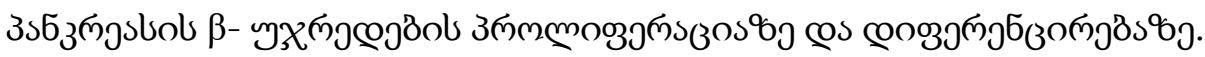

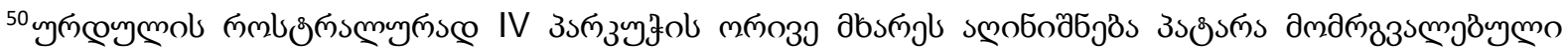

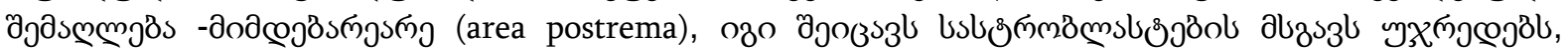

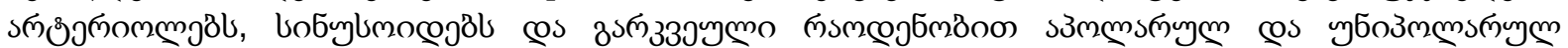

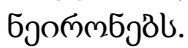




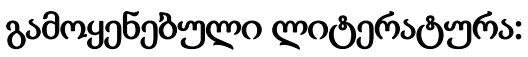

1. Ahren B. New strategy in type 2 diabetes tested in clinical trials. Glucagon-like peptide 1 (GLP-1) affects basic caused of the disease// Lakartidningen. - 2005. - 102 (8). - 545-549.

2. Baggio L., Kieffer T., Drucker D. Glucagon-like peptide-1, but not glucose-dependent insulinotropic peptide, regulates fasting glicemia and nonenteral glucose clearance in mice // Endocrinology.-2000.- 141. - 3703-3709.

3. Chang X., Keller D., Bjorn S., Led J. Structure and folding of glucagon-like peptide-1-(7-36)amide in trifluoroethanol studied by NMR // Mag. Reson. Chem. — 2001. — 39. - 477.

4. Deacon C., Holst J. Saxagliptin: a new dipeptidil peptidase-4 inhibitor for the treatment of type 2 diabetes // Adv. Ther. - 2009. - 26 (5). - 488-499.

5. Drucker D. Glucagon-like peptides: regulators of cell proliferation, differentiation, and apoptosis // Mol. Endocrinol. — 2003. - 17. - 161-171.

6. Drucker D. Minireview: The glucagon-like peptides // Endocrinology.- 2001.-142. - 521-527.

7. Flamez D., Van Breusengem A., Scrocchi L. et al. Mouse pancreatic beta-cells exhibit preserved glucose competence after disruption of the GLP-1 glucagon-like peptide-1 receptor gene // Diabetes. - 1988. - 47. - 646-652.

8. Gake B., Gallwitz B., Eriksson J., Hellqvist A., Gause-Nilsson I. Saxagliptin is non-inferior to glipizide in patients with type 2 diabetes inadequately controlled on metformin alone: a 52 week randomized controlled trial // J. Clin. Pract. — 2010. — 64 (12). - 1619-1631.

9. Goke R., Wagner B., Fehmann H., Goke B. Glucosodependency of the insulin stimulatory effect on glucagon-like peptide-1(7-36)amide on the rat pancreas // Res. Exp. Med. (Berl.).1993. - 193. - 97-103.

10. Hansen P., Corbett J. Incretin hormones and insulin sensiti-vity // Trends Endoc. Metab. 2005. - 16(4). - 135-136.

11. Henry J., Han R. Effects of exenatide (exendin-4) on glycemic control over 30 weeks in sulfonylurea-treated patients with type 2 diabetes // Diabetes Care. — 2004. — 27 (11). 2628-2635.

12. Holz G., Kuhtreiber W., Habener J. Pancreatic beta-cells are rendered glucose-competent by the insulinotropic hormone glucagon-like peptide-1 (7-37) // Nature. - 1993. - 361. - 646-652.

13. Jadinsky M., Pfutzner A., Paz-Pacheco E. Saxagliptin given in combination with metformin in patients with type 2 diabetes, compared with either monotherapy: a randomised controlled trial // Diabetes Obes. Metab. - 2009. - 10. - 110-115.

14. Kirby M., Yu D., O'Connor S., Gorrell M. Inhibitor selectivity in the clinical application of dipeptidyl peptidase-4 inhibition //Clin. Sci. - 2010. - 118. - 31-41.

15. Nauck M., Heimesaat M., Orskov C. et al. Preserved incretin activity of glucagon-like peptide-1 [7-36]amide but not not synthetic human gastric inhibitory polypeptide in patients with type 2 diabetes mellitus // J. Clin. Invest. — 1993. — 91. — 301-307.

16. Perfetti R., Zhou J., Doyle M., Egan J. Glucagon-like peptide-1 induces cell proliferation and pancreatic-duodenum homeobox-1 expression and increases endocrine cell mass in the pancreas of old, glucose-tolerant rats // Endocrinology. — 2000. - 141. - 4600-4605.

17. Perley M., Kipins D. Plasma insulin responces to oral and intravenous glucose: studies in normal and diabetic subjects // J. Clin. Invest. — 1967. — 46. — 1954-1962.

18. Poon T., Nelson P., Shen L. et al. Exenatide improves glycemic control and reduces body weight in subjects with type 2 diabetes: a dose-ranging study // Diabetes Technol. Ther. 2005. -7 (3). - $467-477$. 
19. Sheen A.J., Charpentier C.J., Ostgren A.H., Gause-NilssonI. Efficacy and safety of saxagliptin in combination with metformin compared with sitagliptin in combination with metformin in adult patients with type 2 diabetes mellitus // Diab. Metab. Res. Rev. - 2010. -26 (7). $-540-549$.

20. Zander M., Madsbad S., Madsen J., Holst J. Effect of 6-week course of glucagon-like peptide1 on glicaemic control, insulin sensitivity, and beta-cell function in type 2 diabetes: a parallelgroup study// Lancet. — 2002. — 359. - 824-830.

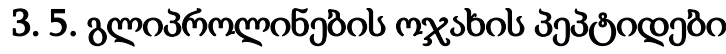

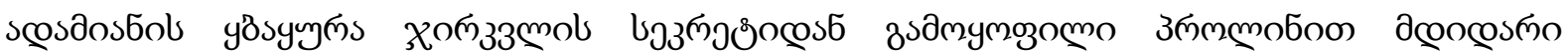

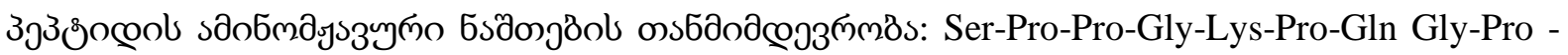
Pro-Pro-Gln-Gly-Gly-Asn-Gln-Pro-Gln-Gly-Pro-Pro-Pro-Pro-Pro-Gly-Lys-Pro-Gln-Gly-Pro-Pro-ProGln-Gly-Gly-Asn-Lys-Pro-Gln-Gly-Pro-Pro-Pro-Pro-Gly-Lys-Pro-Gln-Gly-Pro-Pro-Pro-Gln-GlyGly-Ser-Lys-Ser-Arg-Ser- Ala.

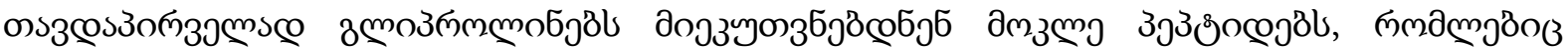

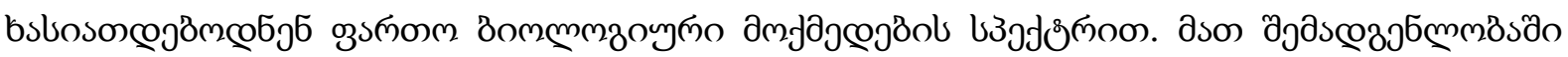

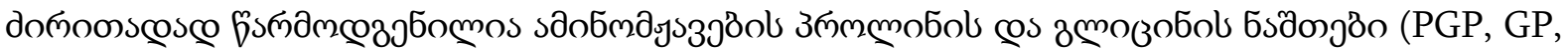

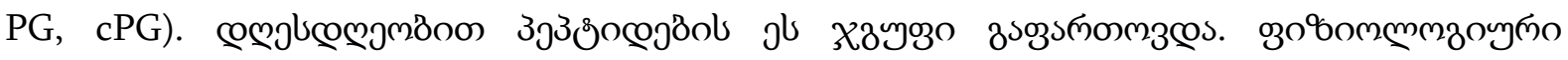

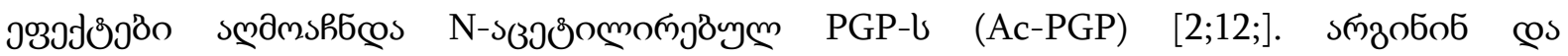

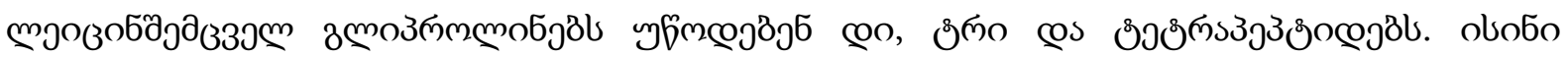

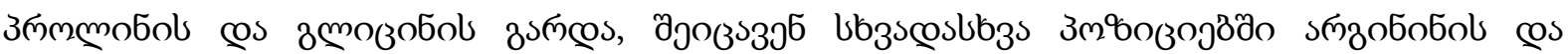

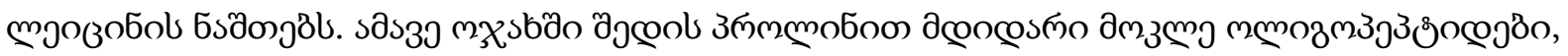

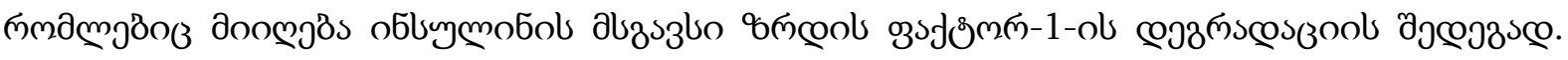

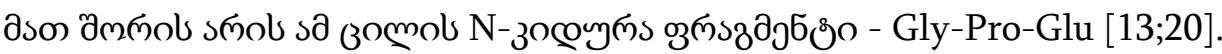

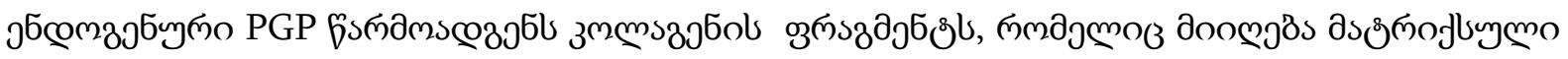

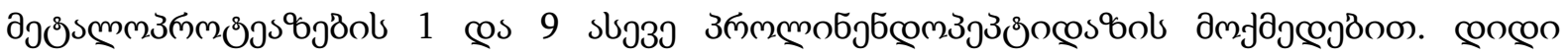

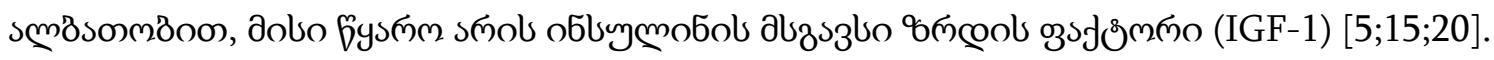

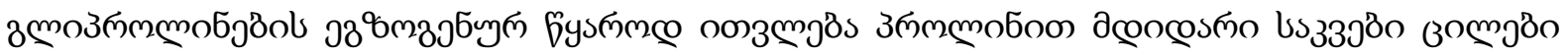

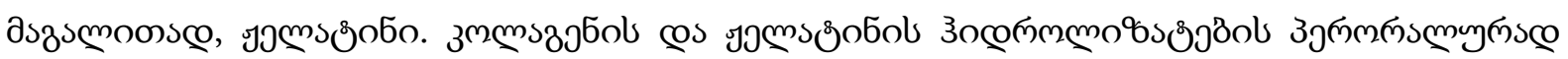

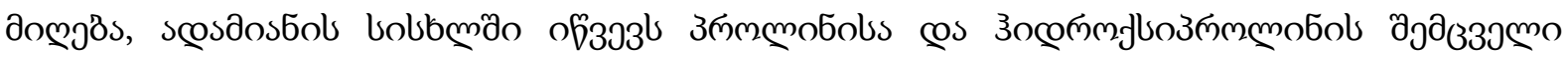

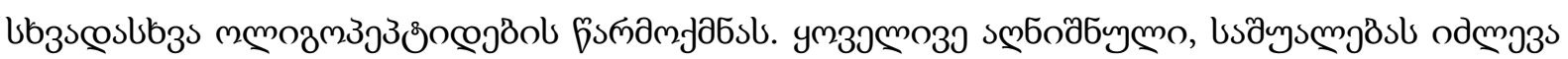

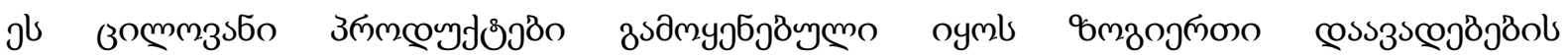

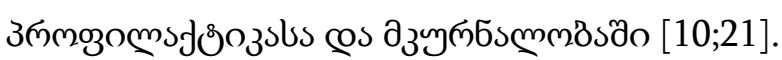

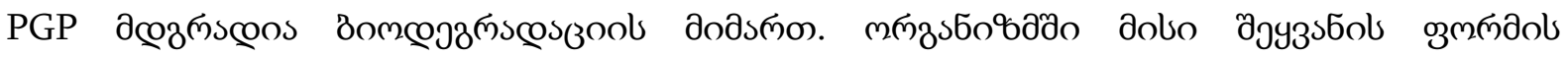

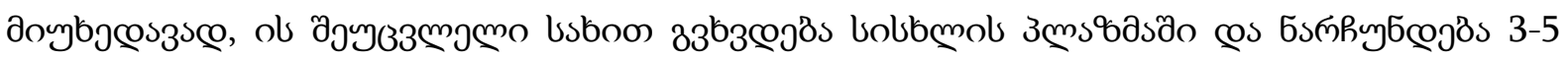
ussonol дsбдомष [24].

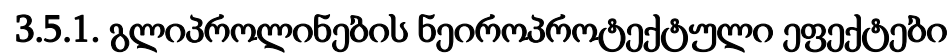

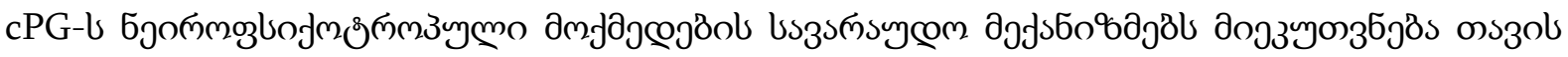

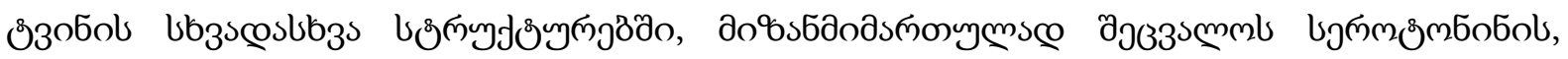




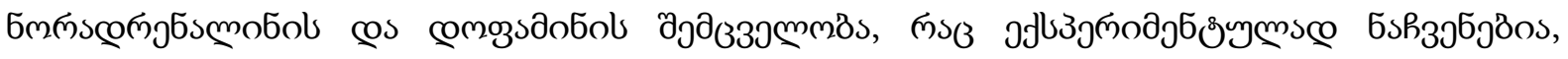

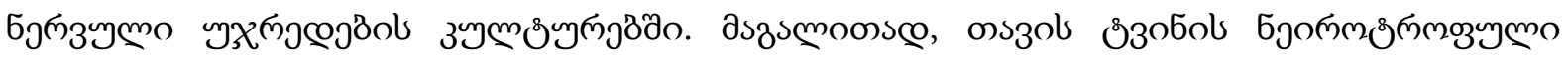

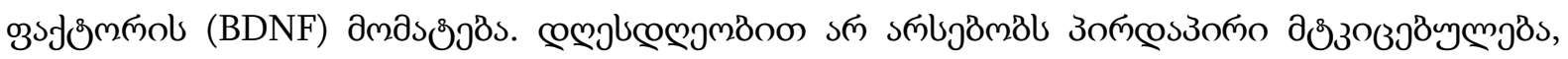

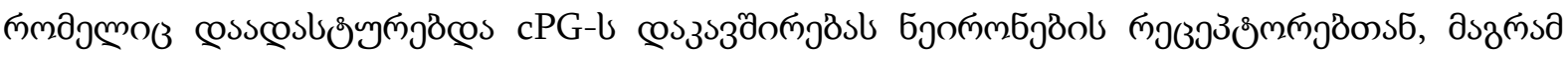

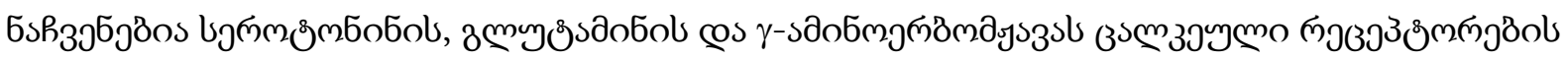

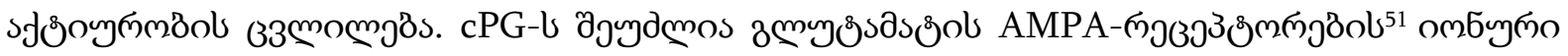

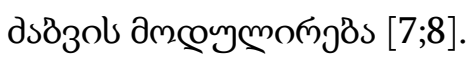

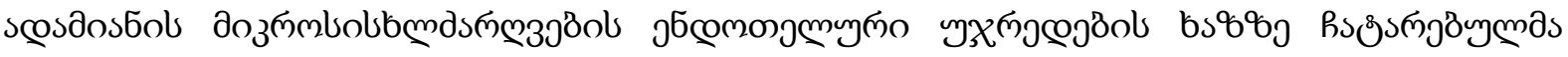

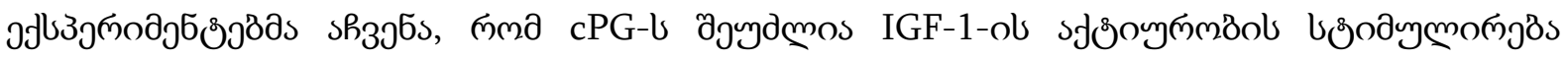

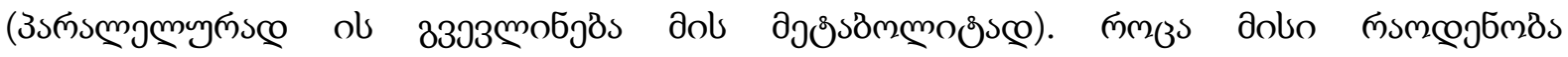

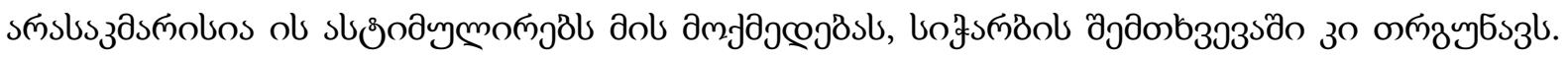

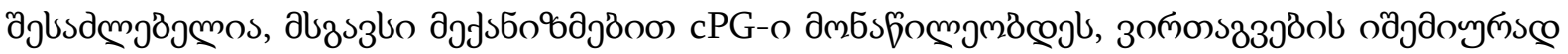

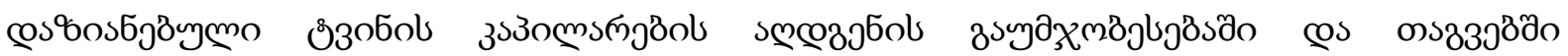

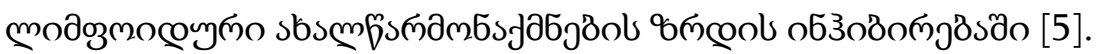

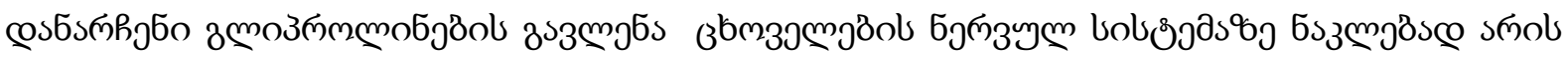

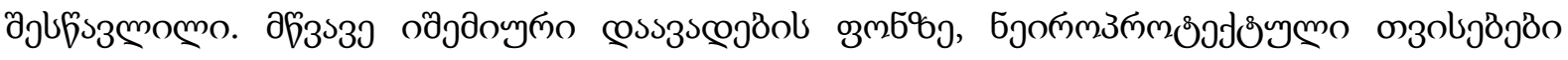

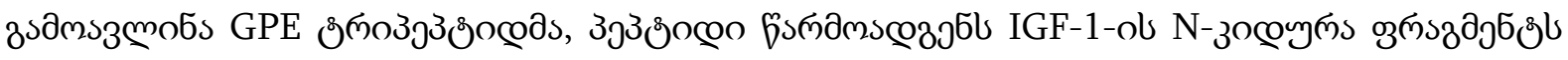

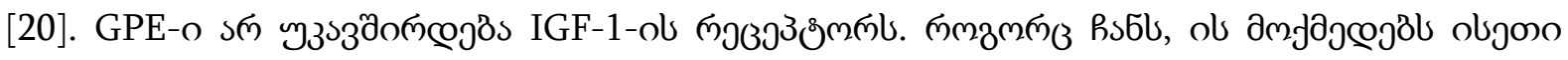

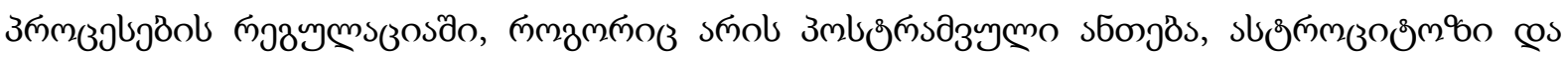

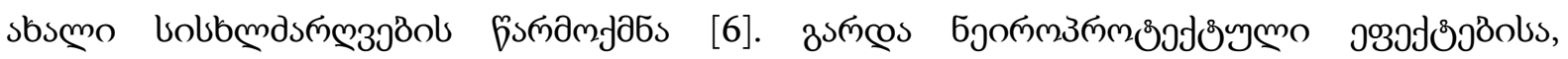

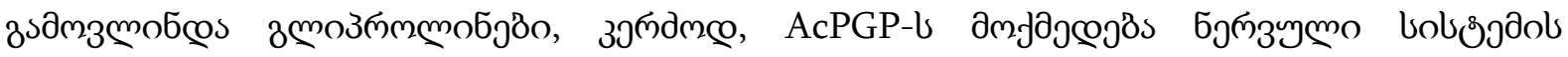

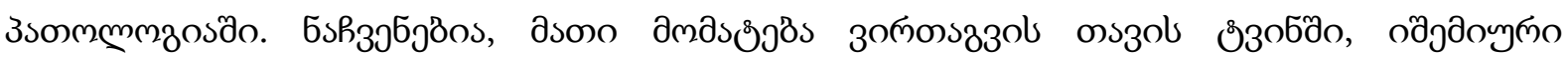

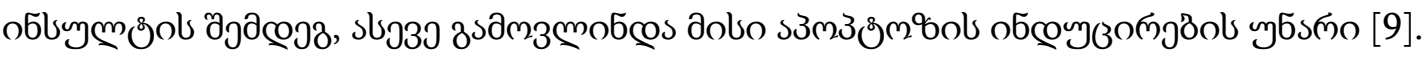

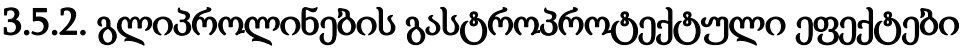

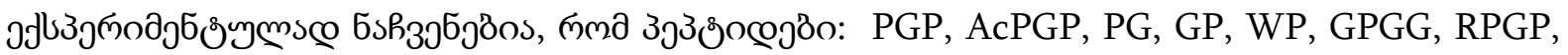

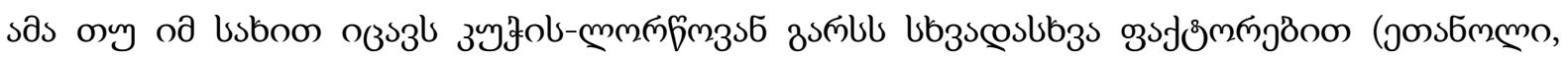

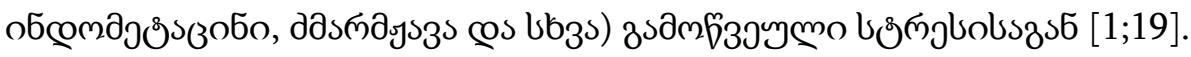

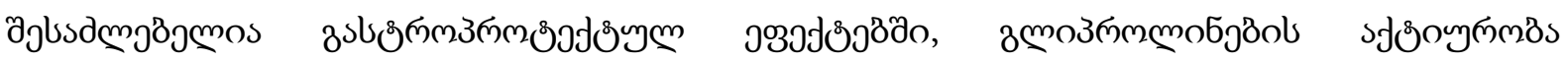

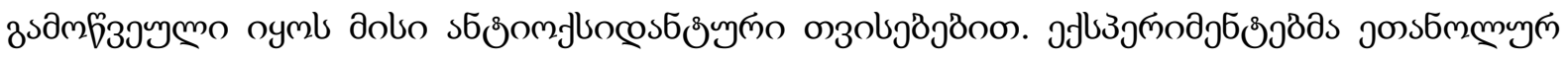

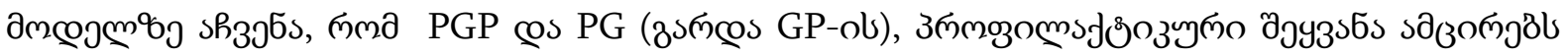

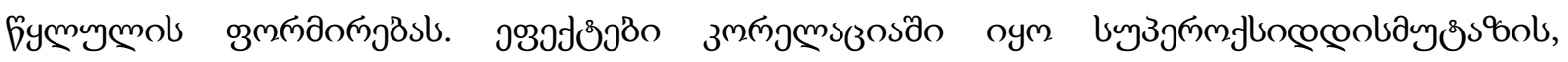

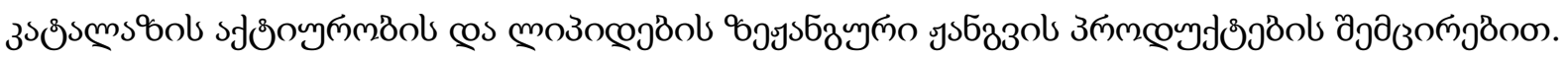

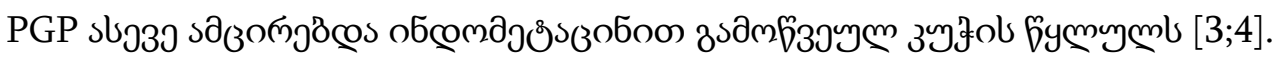

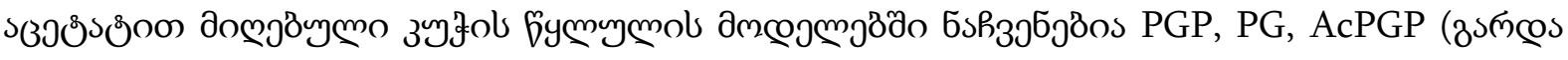

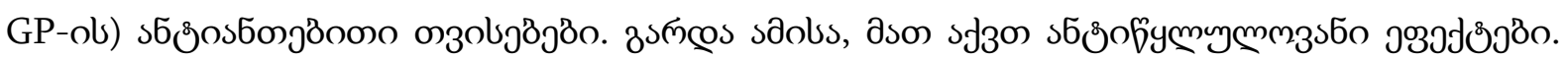

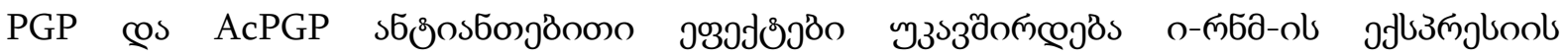

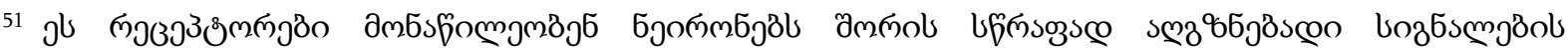
zscossgas
} 


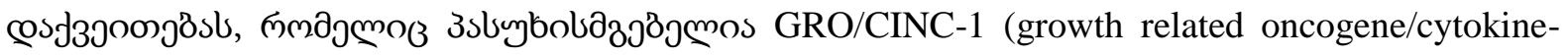

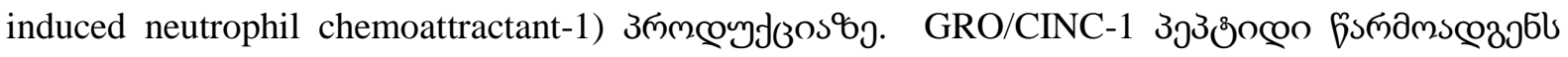

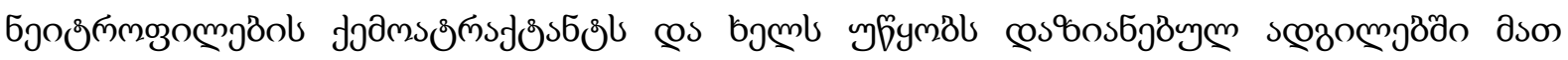
do\%oçsb[1].

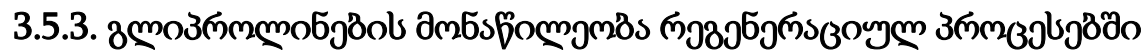

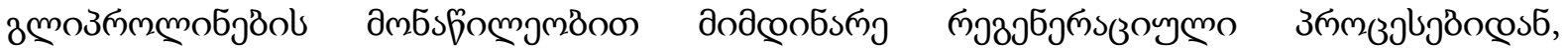

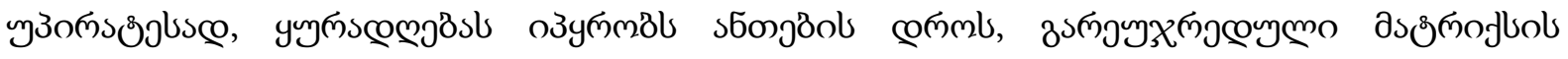

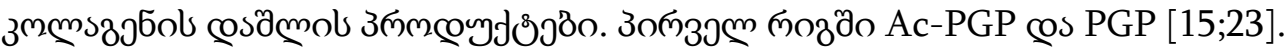

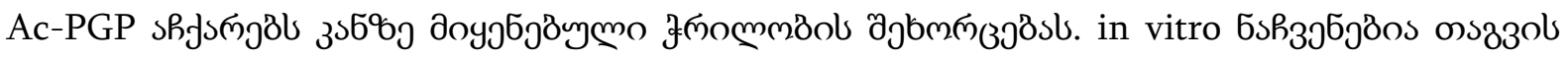

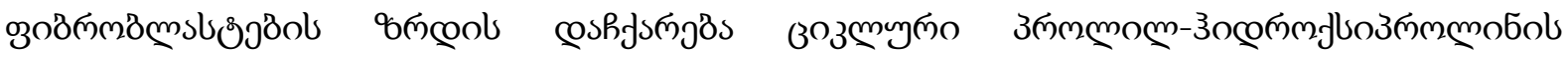
дздмyјбјठ̈оo [21].

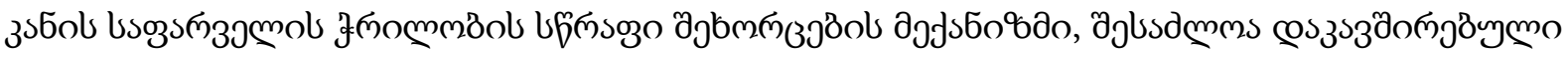

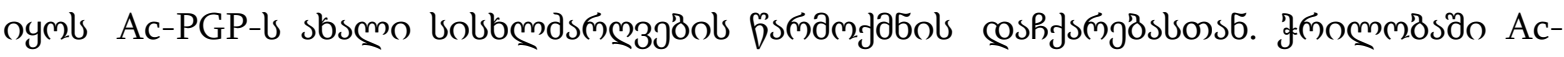

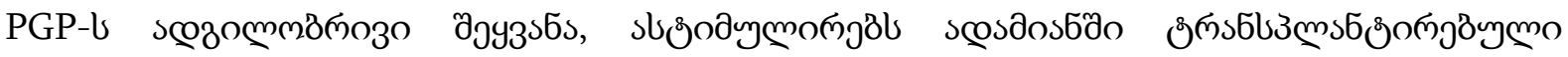

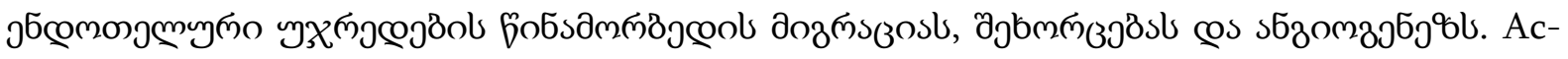

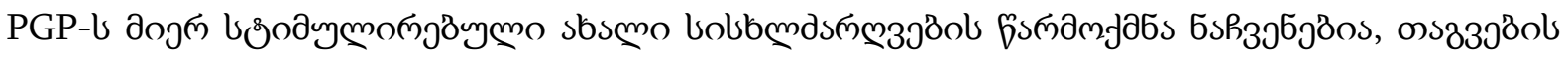

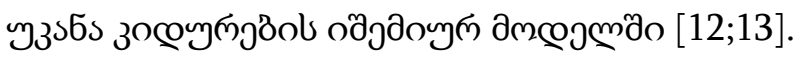

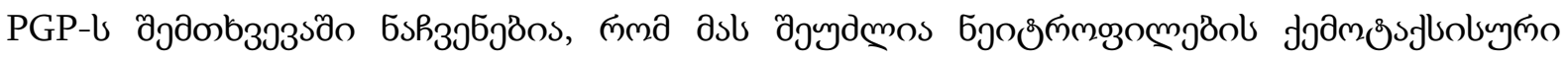

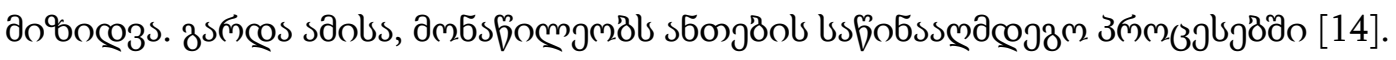

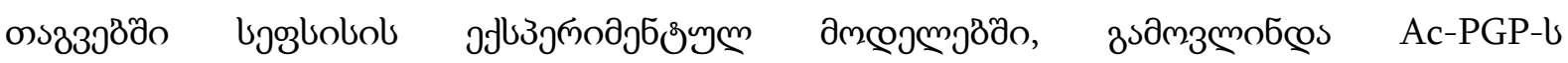

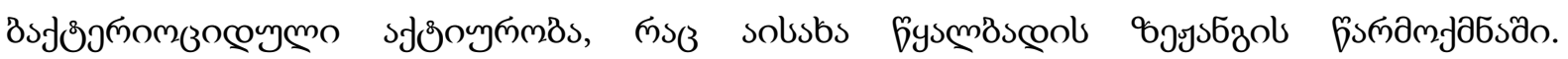

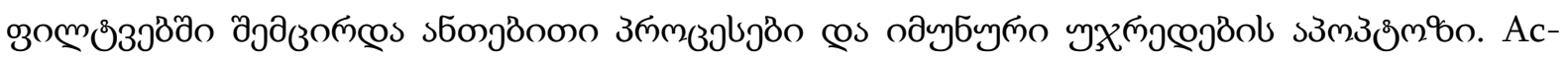

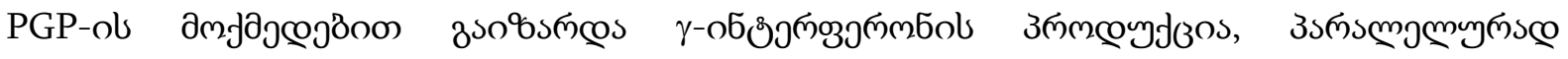

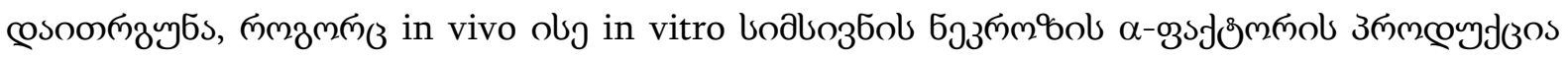
[11].

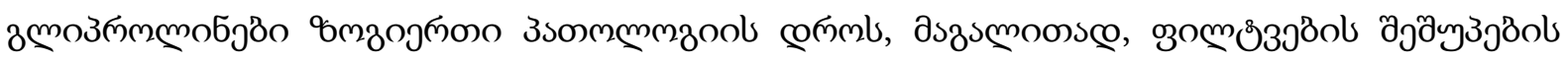

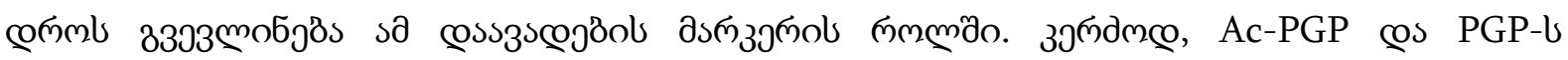

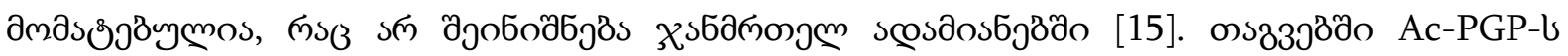

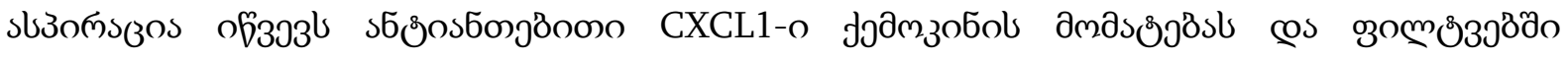

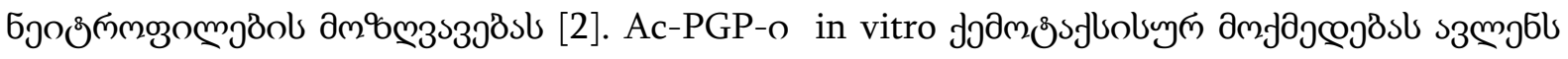

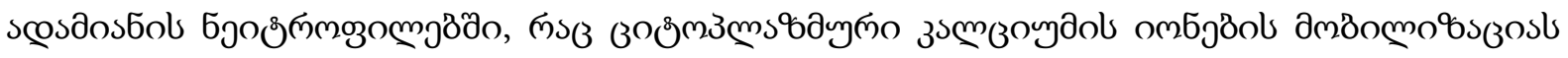

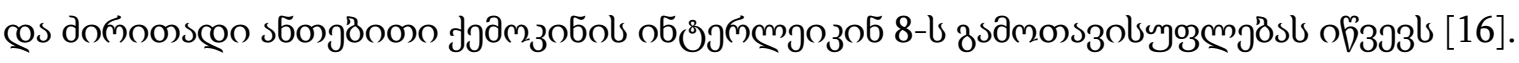

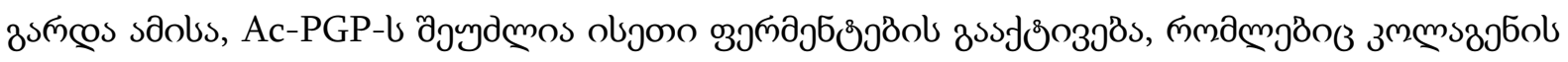

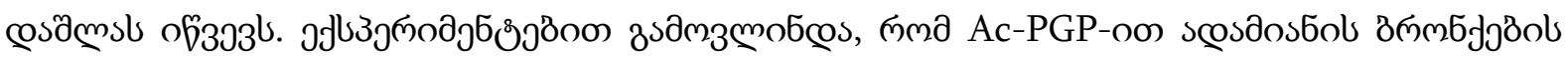

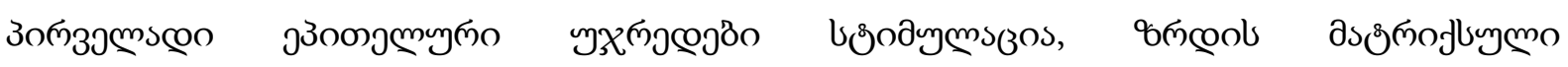

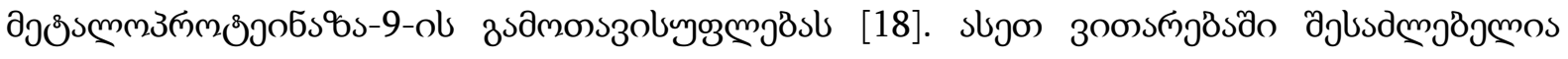

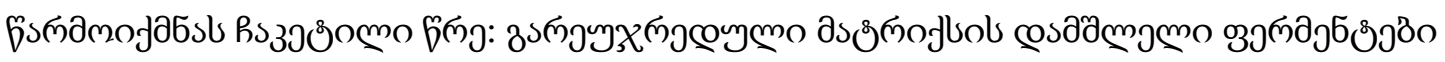

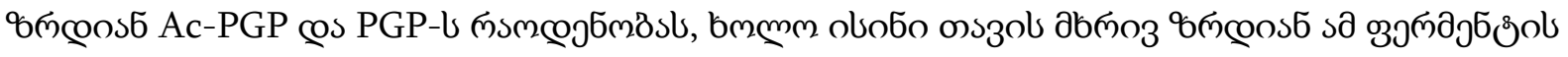

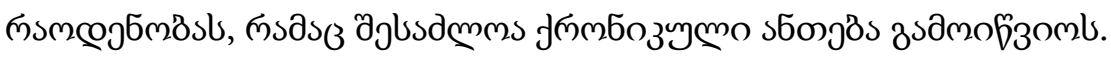




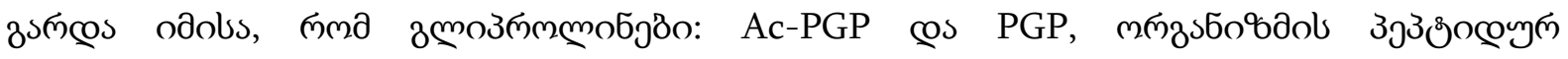

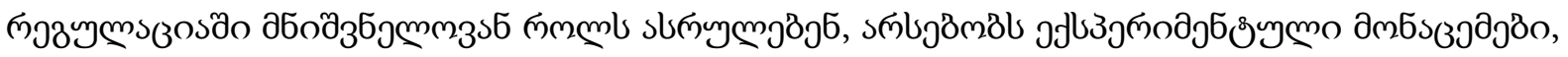

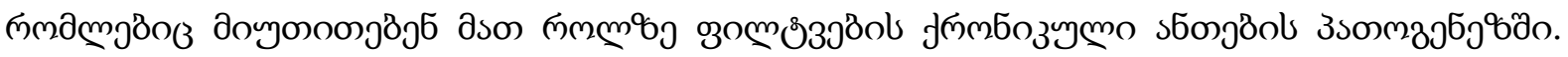

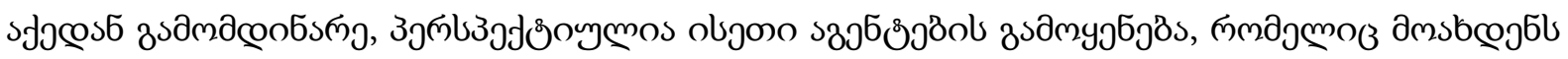

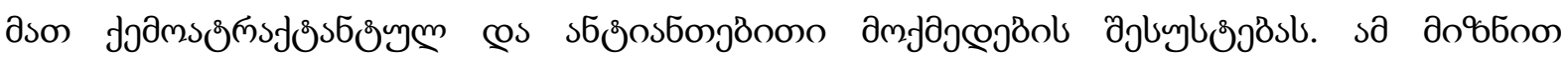

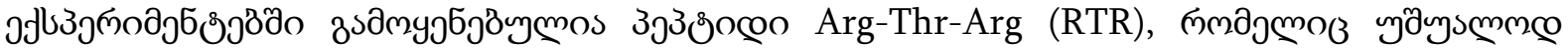

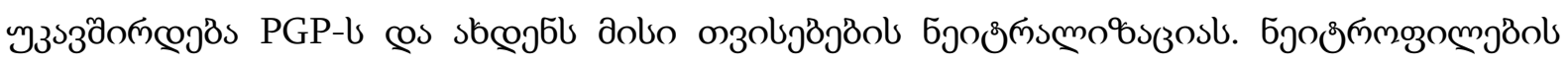

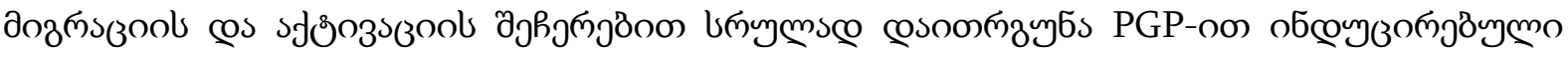

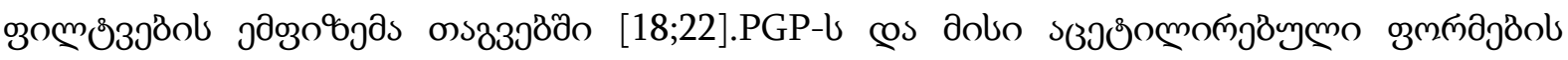

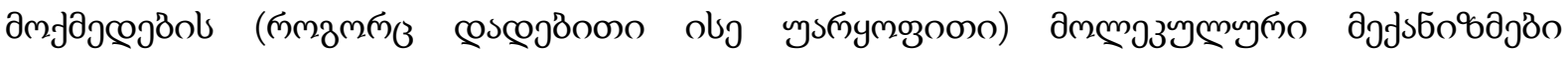

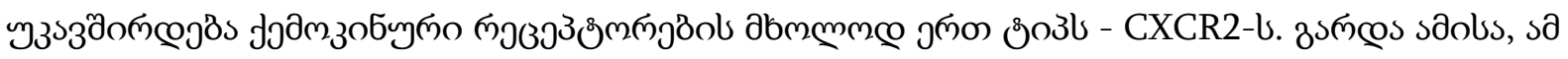

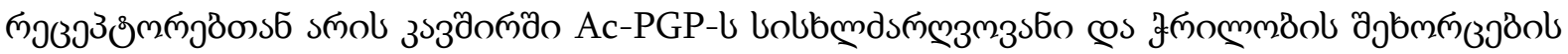

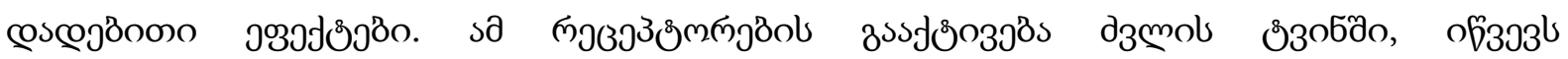

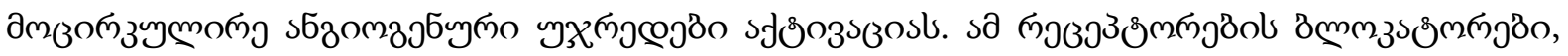

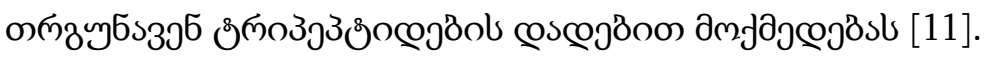

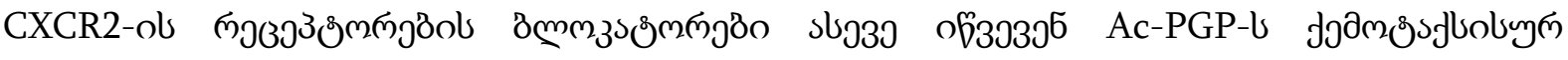

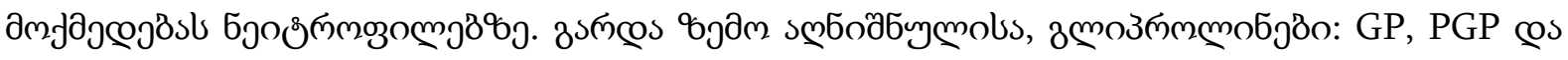

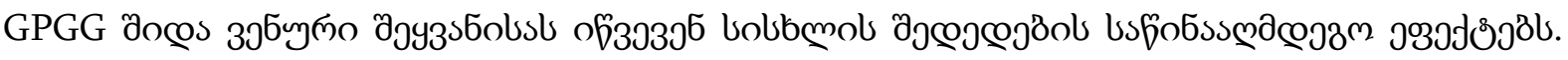

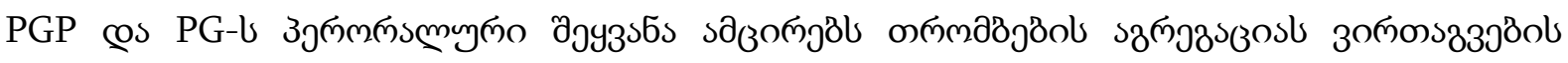

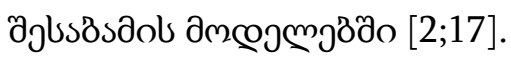

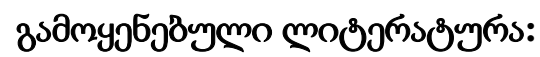

1. Bakaeva, Z. V., Sangadzhieva, A. D., Tani, S. et al. (2016) Glyprolines exert protective and repair-promoting effects in the rat stomach: Potential role of the cytokine GRO/CINC-1. Journal of Physiology and Pharmacology, vol. 67, no. 2, pp. 253-260.

2. Braber, S., Overbeek, S. A., Koelink, P. J. et al. (2011) CXCR2 antagonists block the N-AcPGP-induced neutrophil influx in the airways of mice, but not the production of the chemokine CXCL1. European Journal of Pharmacology, vol. 668, no. 3, pp. 443-449. DOI: 10.1016/j.ejphar.2011.03.025

3. Falalyeyeva, T. M., Samonina, G. E., Beregovaya, T. V. et al. (2010) Effect of glyprolines PGP, GP, and PG on homeostasis of gastric mucosa in rats with experimental ethanol-induced gastric ulcers. Bulletin of Experimental Biology and Medicine, vol. 149, no. 6, pp. 699-701. DOI: $10.1007 / \mathrm{s} 10517-010-1028-7$.

4. Fleishman, M. Yu., Tolstenok, I. V., Lebed'ko, O. A. et al. (2015) Effects of glyprolines on DNA synthesis and free radical oxidation in mouse gastric mucosa under physiological conditions and during therapy with oral non-steroid anti-inflammatory drugs. Bulletin of Experimental Biology and Medicine, vol. 159, no. 4, pp. 502-504. DOI: 10.1007/s10517-0153003-9.

5. Guan, J., Gluckman, P., Yang, P. et al. (2014) Cyclic glycine-proline regulates IGF-1 Homeostasis by altering the binding of IGFBP-3 to IGF-1. Scientific Reports, vol. 4, article 4388. DOI: $10.1038 /$ srep04388 
6. Guan, J., Mathai, S., Liang, H.-p., Gunn, A. J. (2013) Insulin-like growth factor-1 and its derivatives: Potential pharmaceutical application for treating neurological conditions. Recent Patents on CNS Drug Discovery, vol. 8, no. 2, pp. 142-160. DOI: $10.2174 / 1574889811308020004$

7. Gudasheva, T. A., Grigoriev, V. V., Koliasnikova, K. N. et al. (2016a) Neuropeptide cycloprolylglycine isanendogenous positive modulator of AMPA receptors. DokladyBiochemistry and Biophysics, vol. 471, no. 1, pp. 387-389. DOI: 10.1134/S160767291606003X

8. Gudasheva, T. A., Koliasnikova, K. N., Antipova, T. A., Seredenin, S. B. (2016b) Neuropeptide cycloprolylglycine increases the levels of brain-derived neurotrophic factor in neuronal cells.

9. Hill, J. W., Nemoto, E. M. (2015) Matrix-derived inflammatory mediator N-acetyl prolineglycine-proline is neurotoxic and upregulated in brain after ischemic stroke. Journal of Neuroinflammation, vol. 12, article 214. DOI: 10.1186/s12974-015-0428-z

10. Ichikawa, S., Morifuji, M., Ohara, H. et al. (2010) Hydroxyproline-containing dipeptides and tripeptides quantified at high concentration in human blood after oral administration of gelatin hydrolysate. International Journal of Food Sciences and Nutrition, vol. 61, no. 1, pp. 52-60. DOI: 10.3109/09637480903257711

11. Kim, S. D., Lee, H. Y., Shim, J. W. et al. (2011) Activation of CXCR2 by extracellular matrix degradation product acetylated Pro-Gly-Pro has therapeutic effects against sepsis. American Journal of Respiratory and Critical Care Medicine, vol. 184, no. 2, pp. 243-251. DOI: 10.1164/rccm.201101-0004OC

12. Kwon, Y. W., Heo, S. C., Lee, T. W. et al. (2017) N-acetylated proline-glycine-proline accelerates cutaneous wound healing and neovascularization by human endothelial progenitor cells. Scientific Reports, vol. 7, article 43057. DOI: 10.1038/srep43057

13. Kwon, Y. W., Lee, S. J., Heo, S. C. et al. (2019) Role of CXCR2 in the ac-PGP-induced mobilization of circulating angiogenic cells and its therapeutic implications. Stem Cells Translational Medicine Journal, vol. 8, no. 3, pp. 236-246. DOI: 10.1002/sctm.18-0035

14. Ma, Y., Kleinbeck, K., Kao, W. J. (2011) Extracellular matrix-derived tripeptide prolineglycine-proline inhibits keratinocyte proliferation and migration. Wound Repair and Regeneration, vol. 19, no. 6, pp. 718-726. DOI: 10.1111/j.1524-475X.2011.00734.x

15. O'Reilly, P., Jackson, P. L., Noerager, B. et al. (2009) N-alpha-PGP and PGP, potential biomarkers and therapeutic targets for COPD. Respiratory Research, vol. 10, article 38. DOI: 10.1186/1465-9921-10-38

16. Overbeek, S. A., Henricks, P. A. J., Srienc, A. I. et al. (2011) N-acetylated Proline-GlycineProline induced G-protein dependent chemotaxis of neutrophils is independent of CXCL8 release. European Journal of Pharmacology, vol. 668, no. 3, pp. 428-434. DOI: 10.1016/j.ejphar.2011.03.022

17. Pastorova, V. E., Lyapina, L. A., Ashmarin, I. P. (2003) Prevention of thrombus formation with glyprolines on various models of prethrombotic state and thrombosis in rats. Bulletin of Experimental Biology and Medicine, vol. 136, no. 4, pp. 319-322. DOI: 10.1023/b:bebm.0000010940.80757.90

18. Roda, M. A., Xu, X., Abdalla, T. H. et al. (2019) Proline-glycine-proline peptides are critical in the development of smoke-induced emphysema. American Journal of Respiratory Cell and Molecular Biology, vol. 61, no. 5, pp. 560-566. DOI: 10.1165/rcmb.2018-0216OC.

19. Samonina, G., Lyapina, L., Kopylova, G. et al. (2000) Protection of gastric mucosal integrity

20. By gelatin and simple proline-containing peptides. Pathophysiology, vol. 7, no. 1, pp. 69-73.

DOI: $10.1016 / \mathrm{s} 0928-4680(00) 00045-6$ 
21. Saura, J., Curatolo, L., Williams, C. E. et al. (1999) Neuroprotective effects of Gly-Pro-Glu, the N-terminal tripeptide of IGF-1, in the hippocampus in vitro. NeuroReport, vol. 10, no. 1, pp. 161-164. DOI: 10.1097/00001756-199901180-00031

22. Shigemura, Y., Iwasaki, Y., Tateno, M. et al. (2018) A pilot study for the detection of cyclic prolyl-hydroxyproline (Pro-Hyp) in human blood after ingestion of collagen hydrolysate. Clinical Trial Nutrients, vol. 10, no. 10, article 1356. DOI: 10.3390/nu10101356

23. van Houwelingen, A. H., Weathington, N. M., Verweij, V. et al. (2008) Induction of lung emphysema is prevented by L-arginine-threonine-arginine. The FASEB Journal, vol. 22, no. 9, pp. 3403-3408. DOI: 10.1096/fj.07-096230

24. Wells, J. M., Gaggar, A., Blalock, J. E. (2015) MMP generated matrikines. Matrix Biology, vol. 44-46, pp. 122-129. DOI: 10.1016/j.matbio.2015.01.016

25. Zolotarev, Yu. A., Zhuikova, S. E., Ashmarin, I. P. et al. (2003) Metabolism of PGP peptide after administration via different routes. Bulletin of Experimental Biology and Medicine, vol. 135, no. 4, pp. 361-364. DOI: 10.1023/a:1024612831380

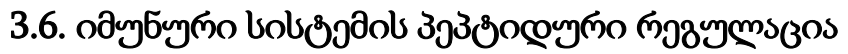

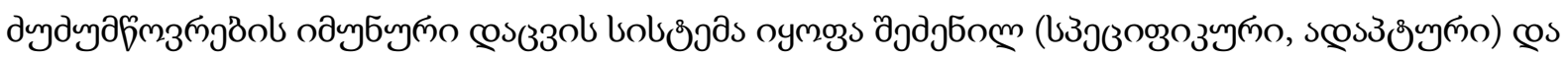

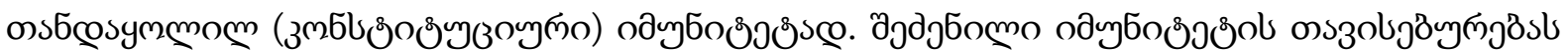

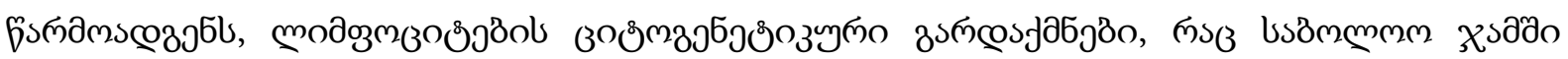

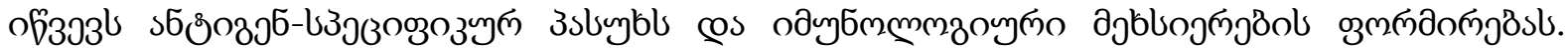

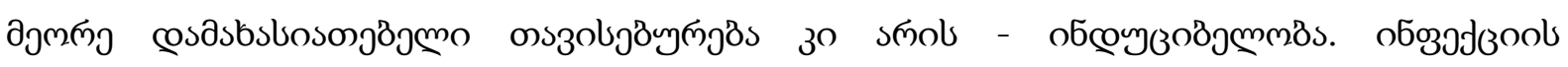

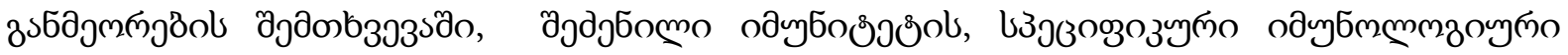

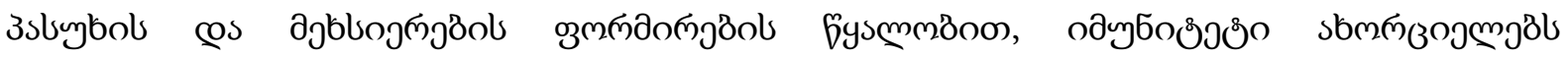

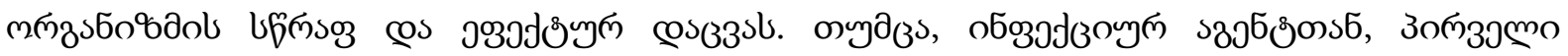

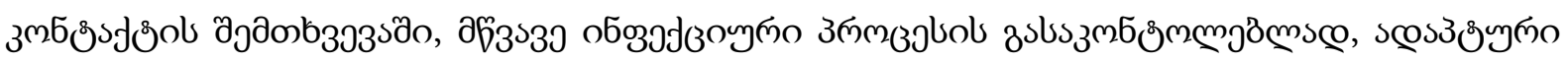

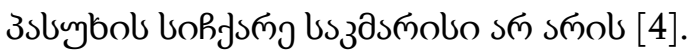

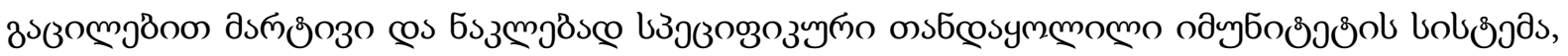

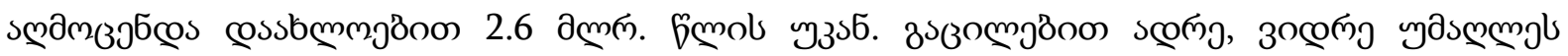

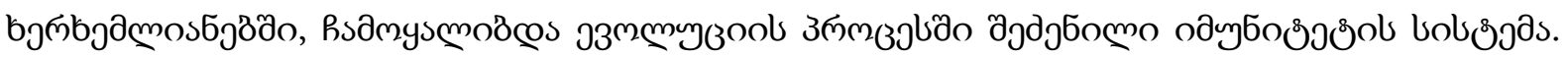

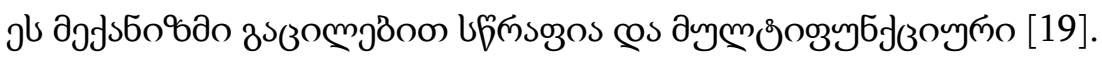

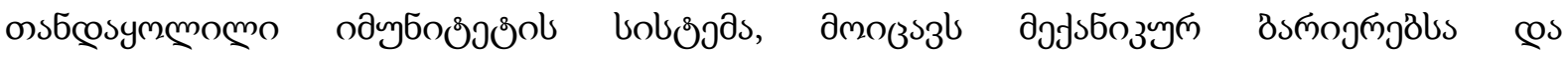

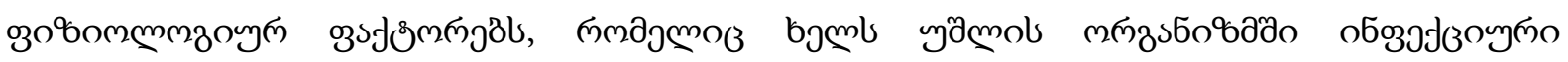

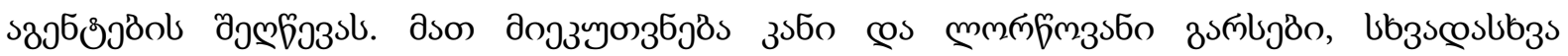

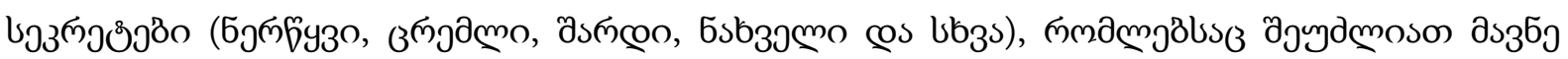

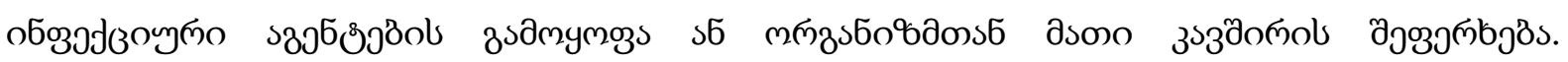

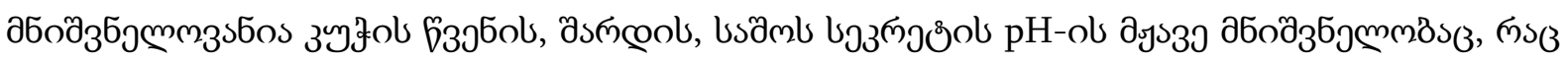

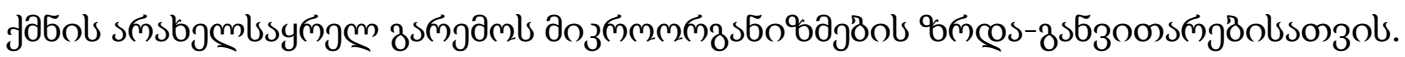

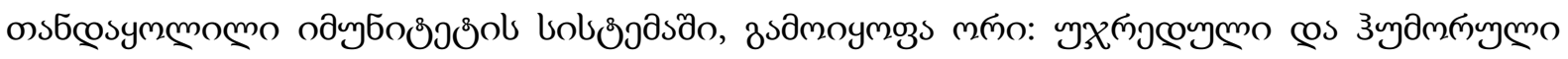

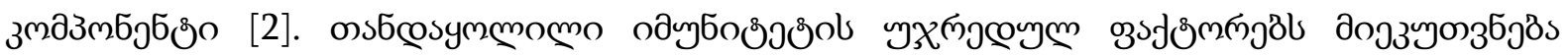

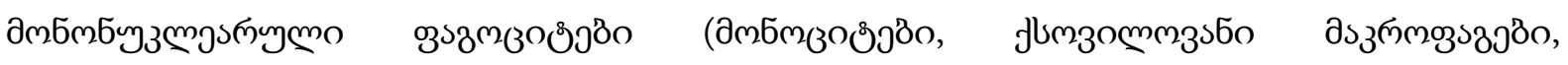




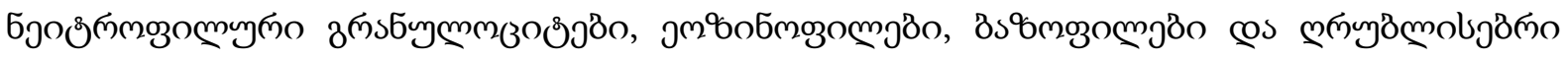

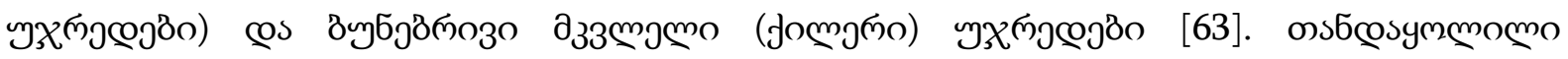

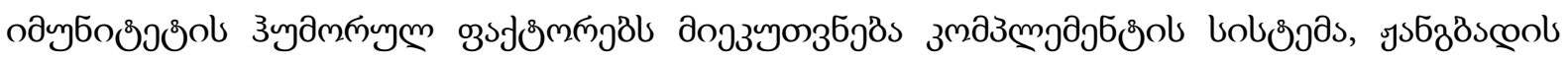

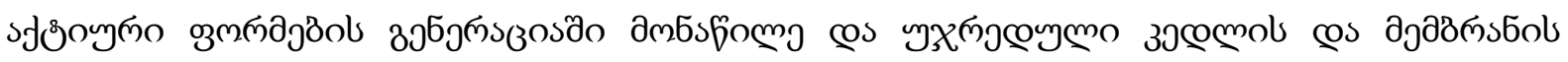

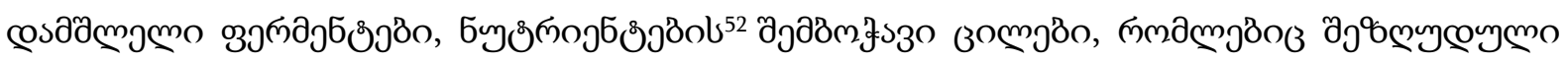

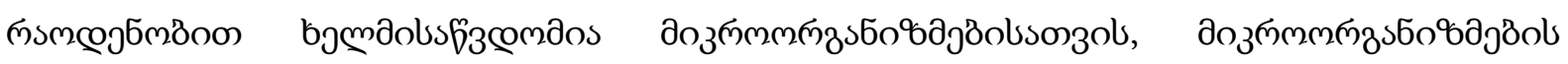

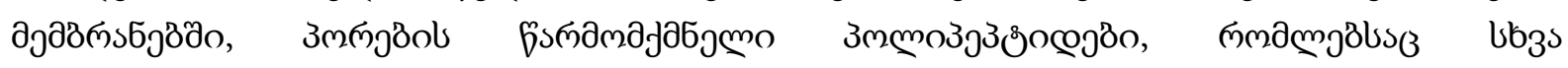

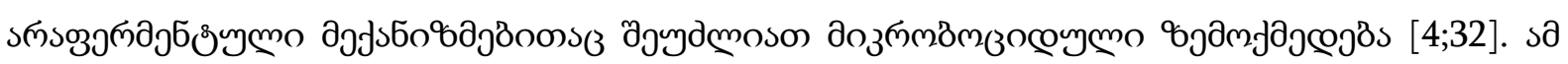

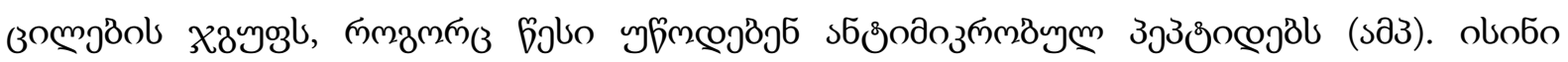

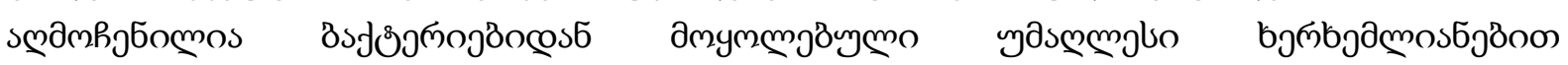

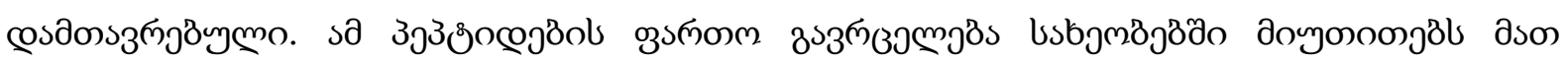

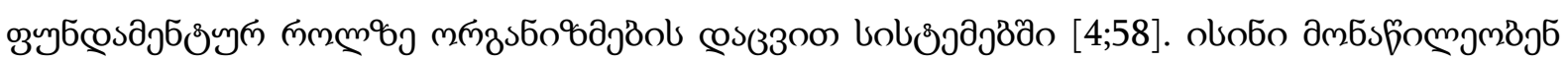

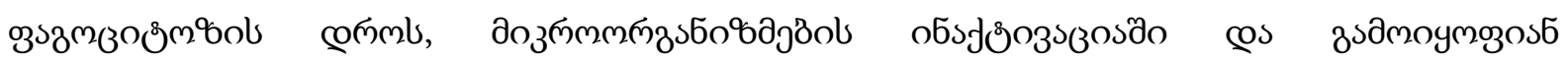

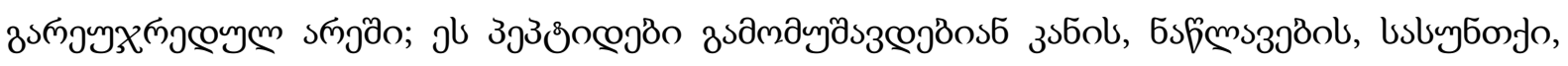

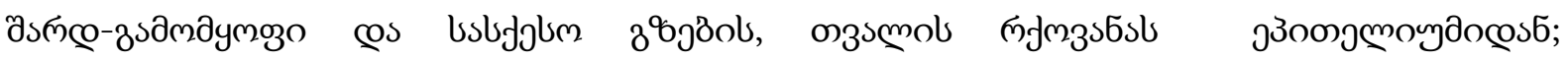

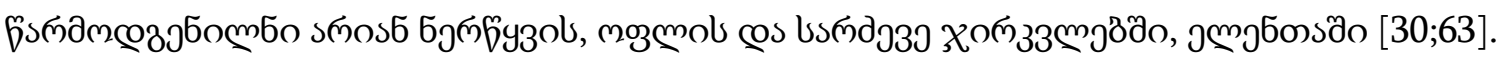

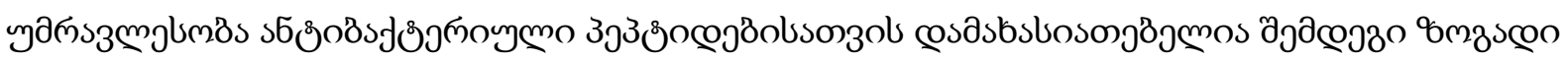

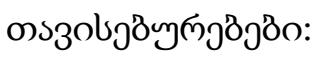

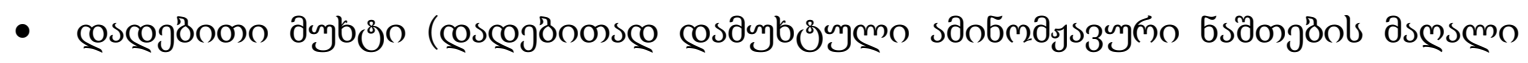

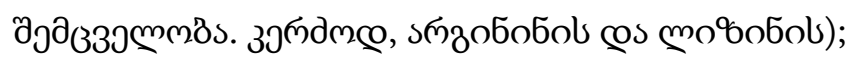

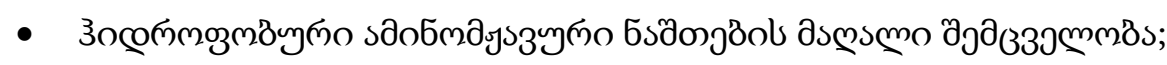

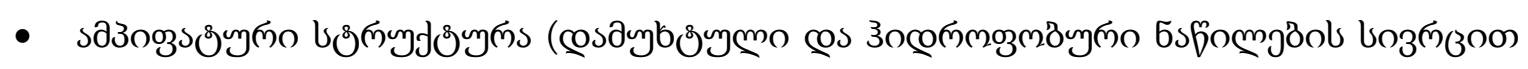

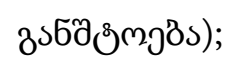

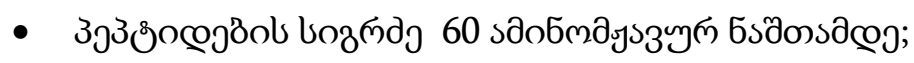

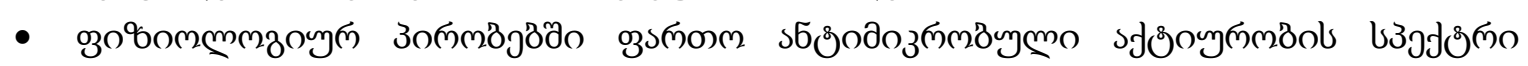
$[12 ; 48]$.

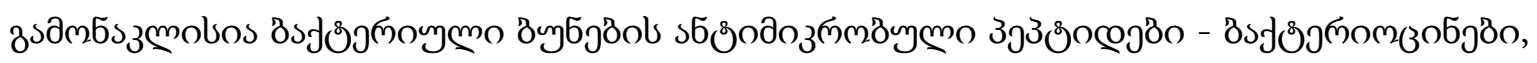

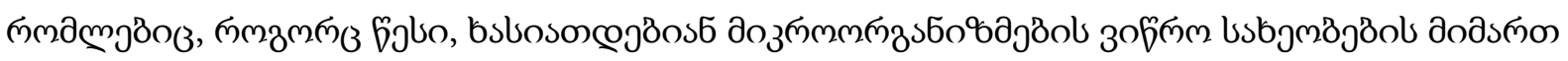

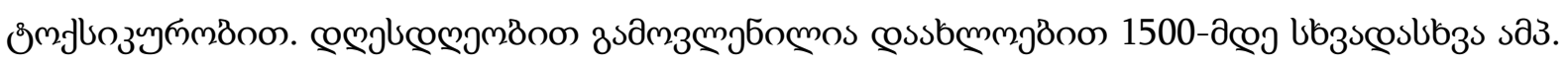

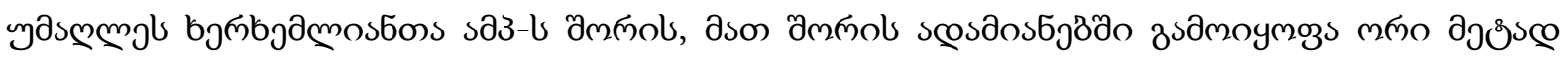

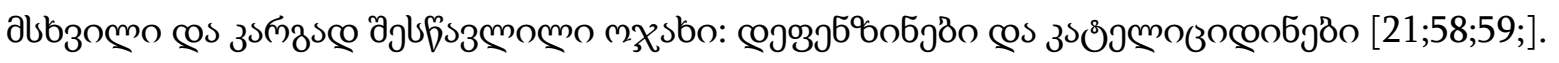

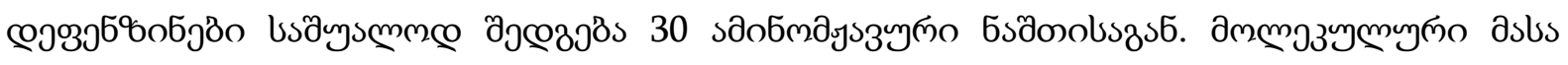

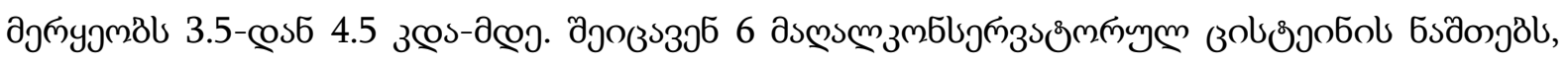

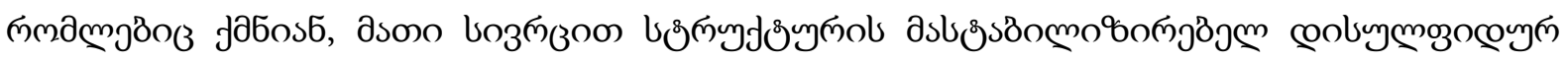

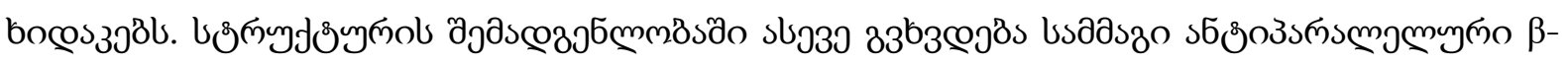

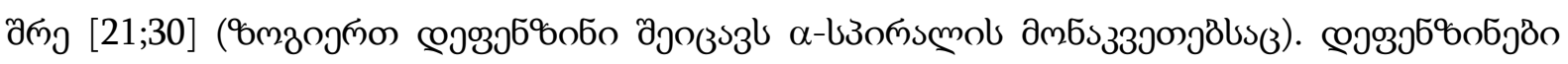

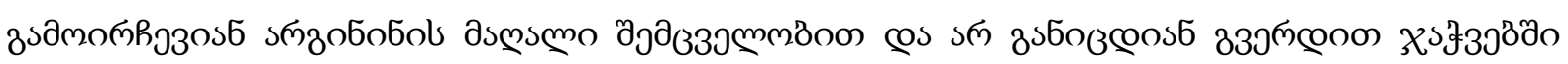

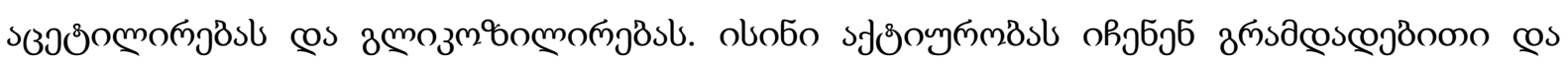

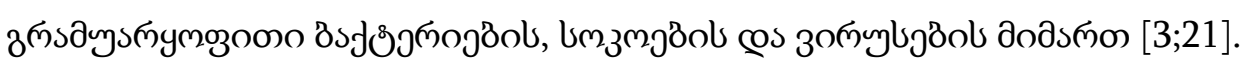

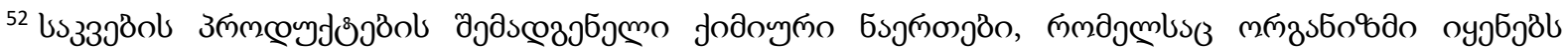

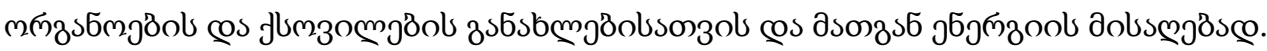




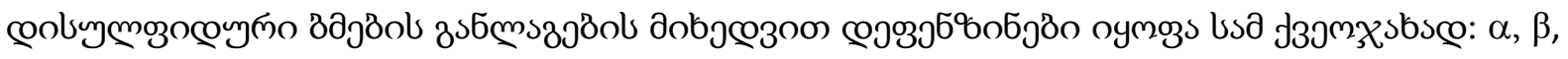

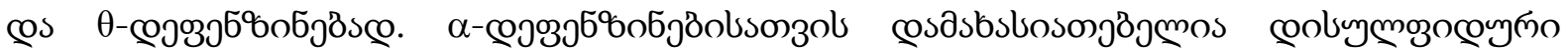

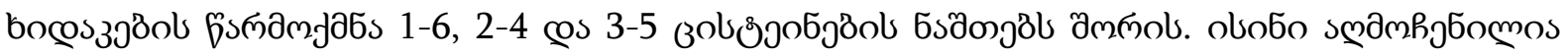

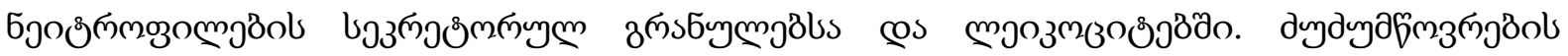

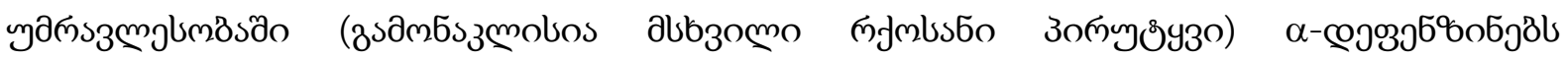

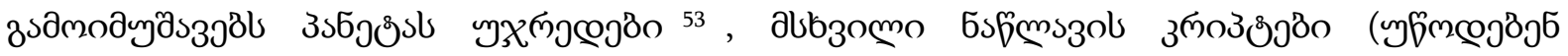

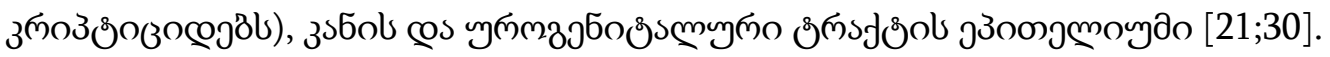

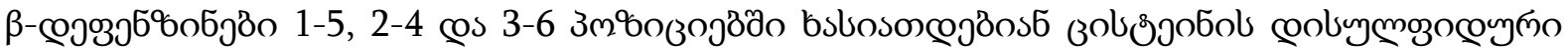

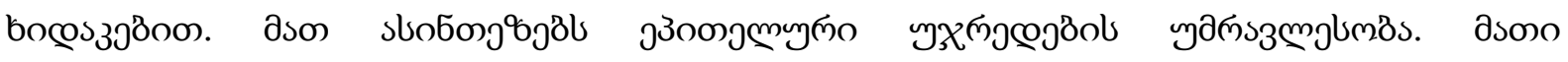

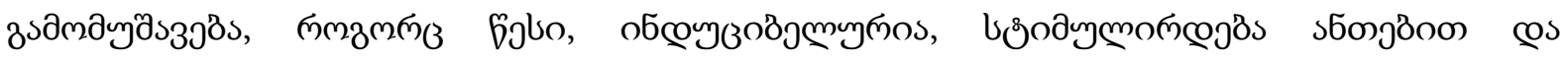

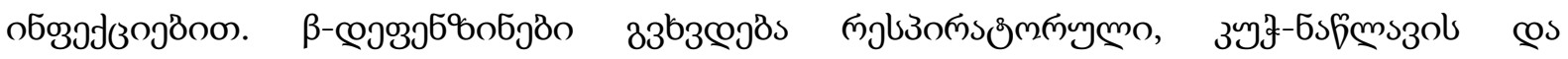

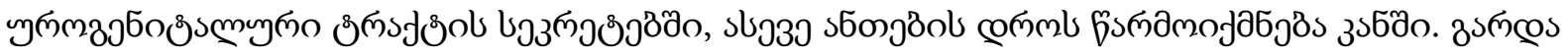

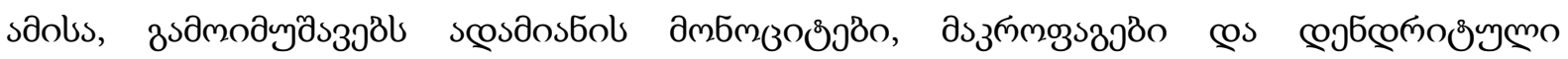

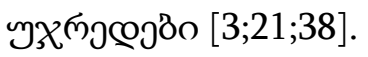

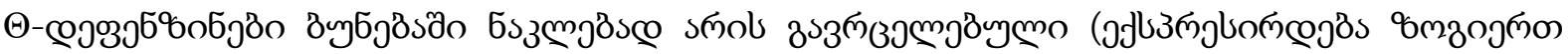

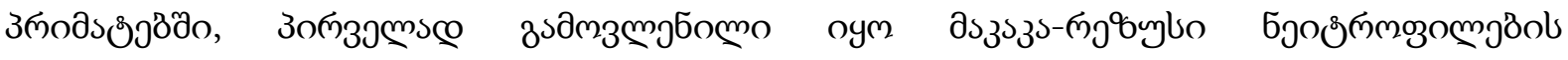

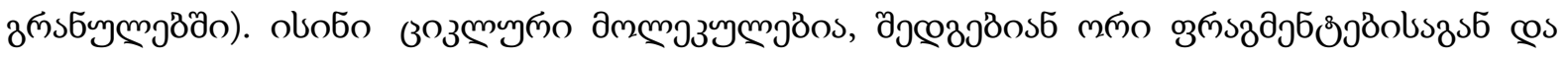

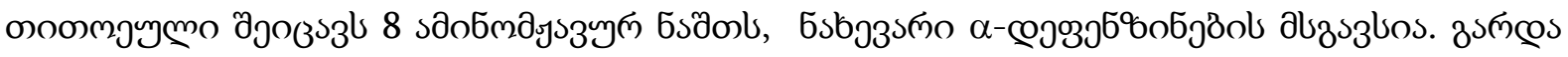

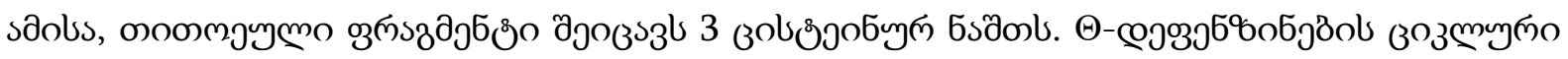

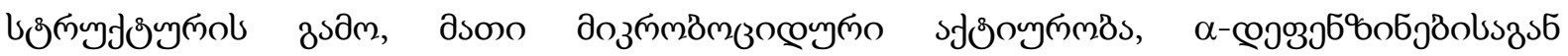

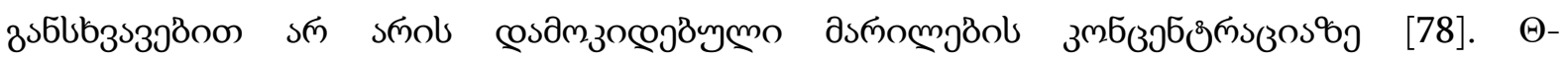

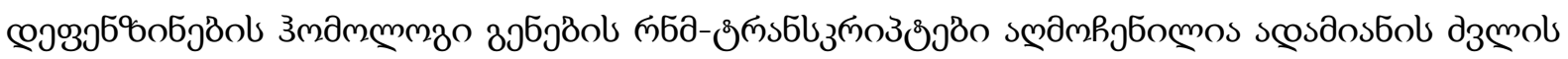

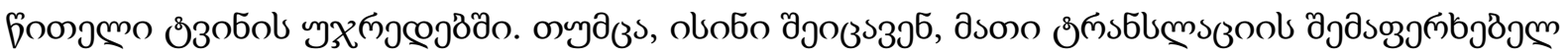

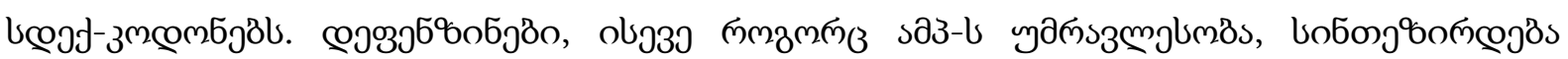

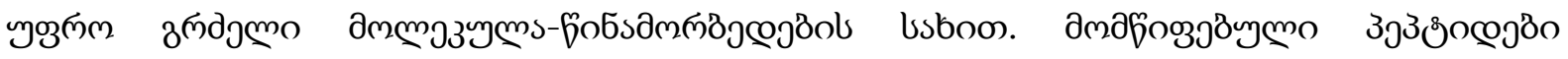

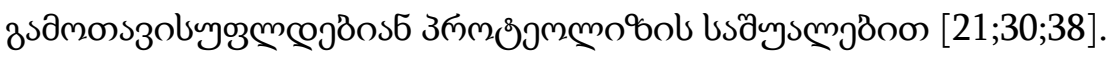

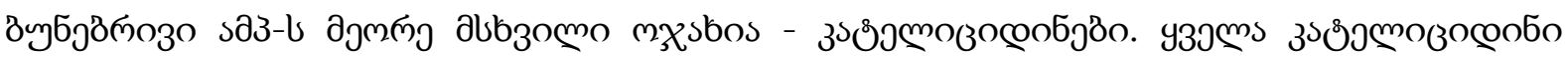

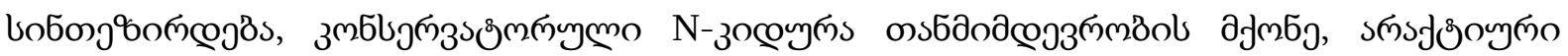

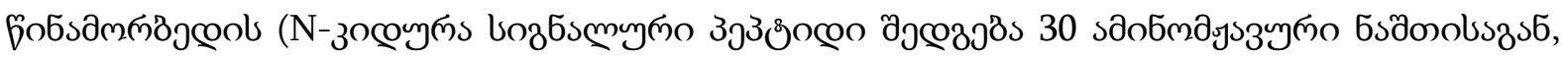

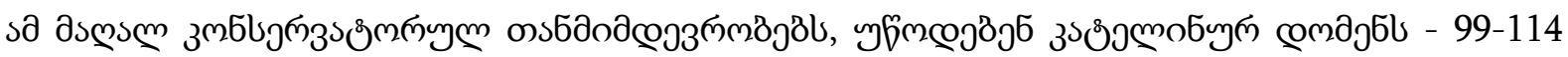

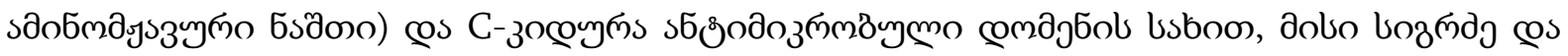

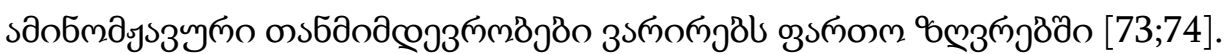

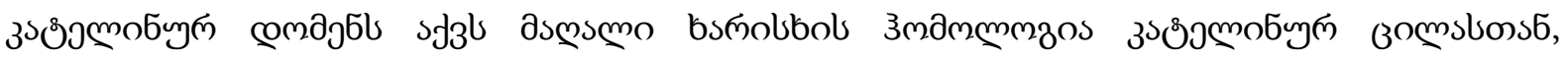

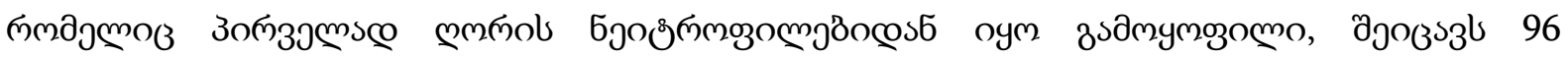

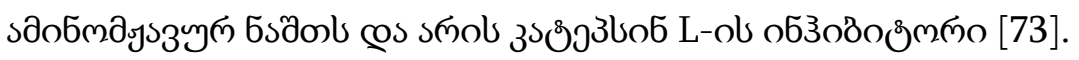

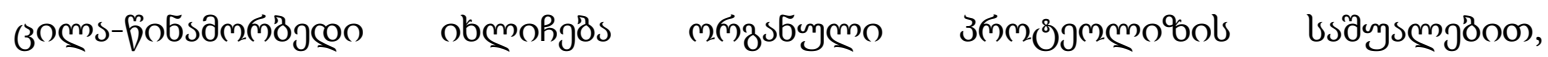

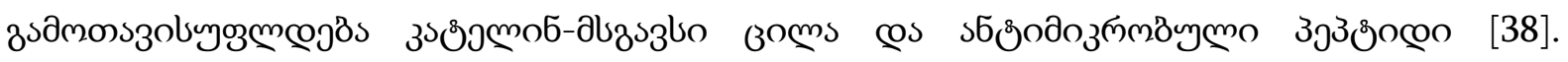

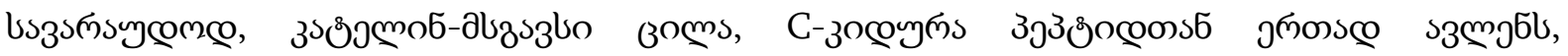

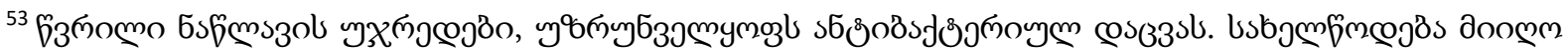

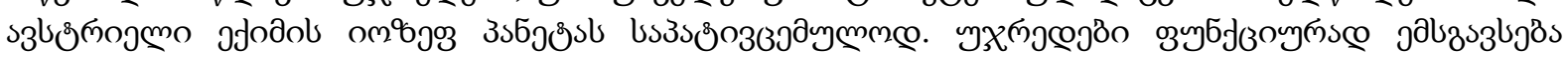

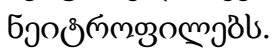




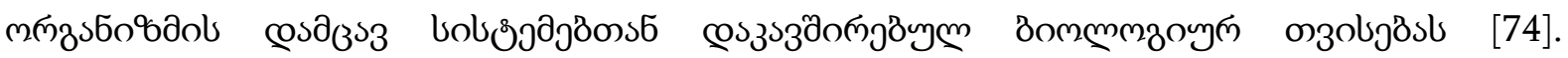

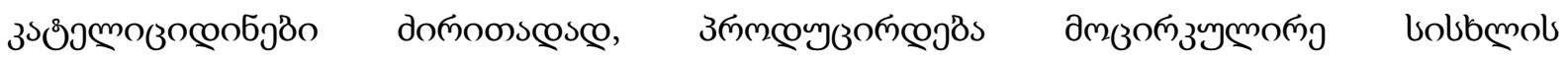

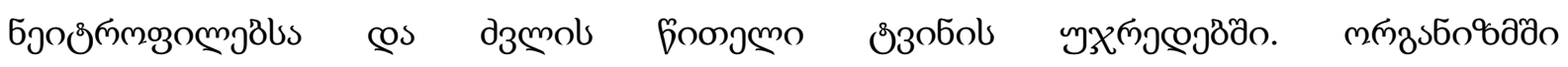

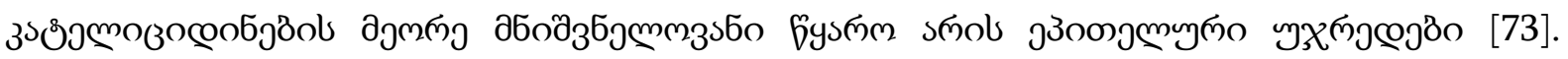

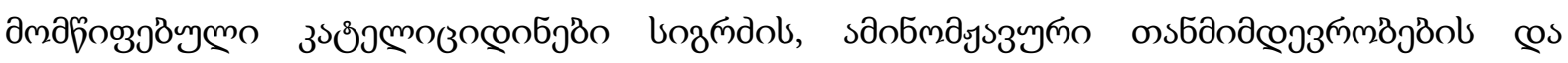

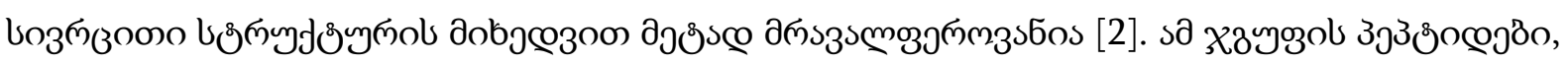

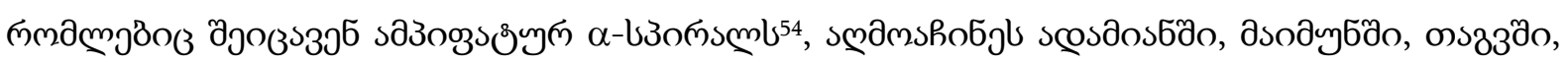

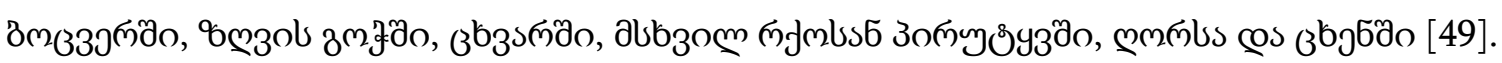

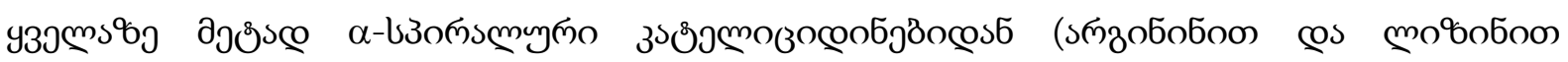

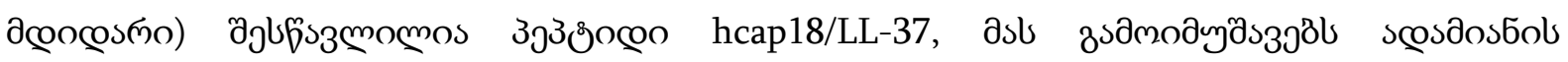

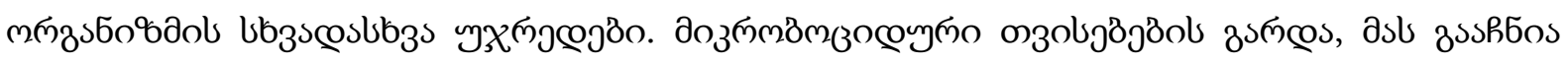

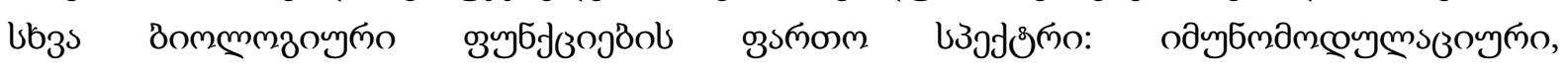

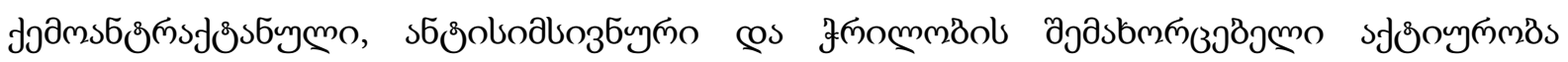
[3;30;53].

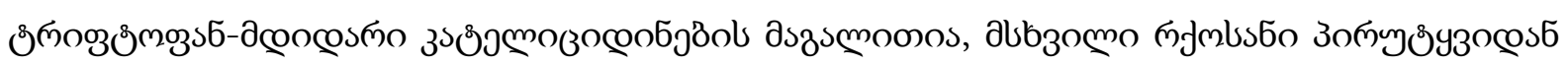

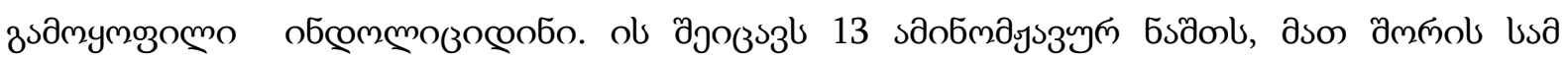

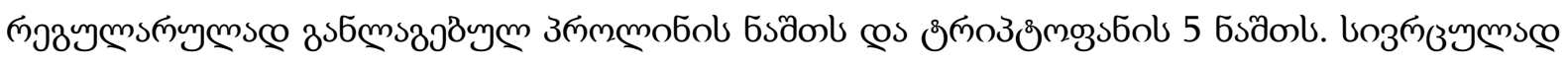

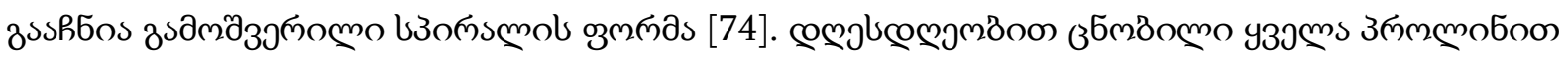

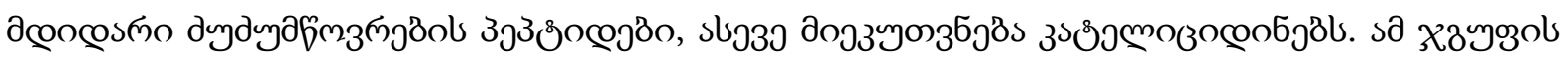

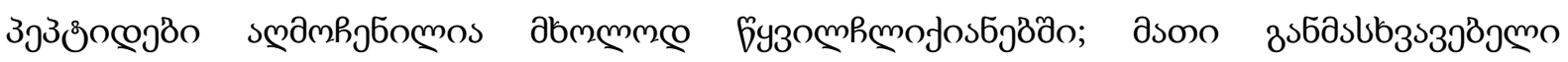

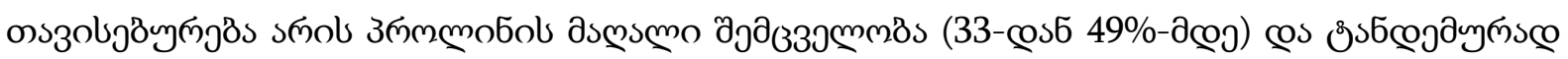

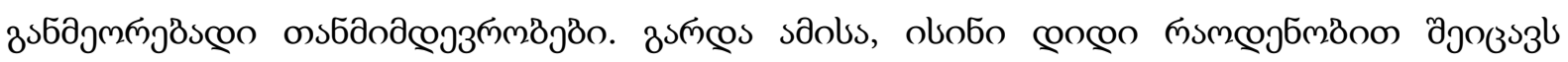

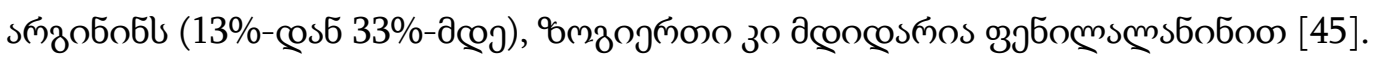

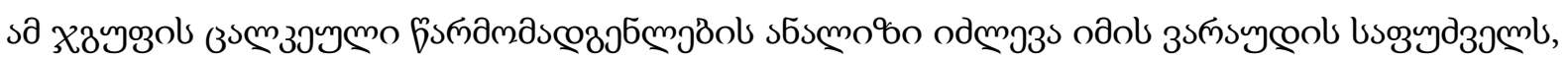

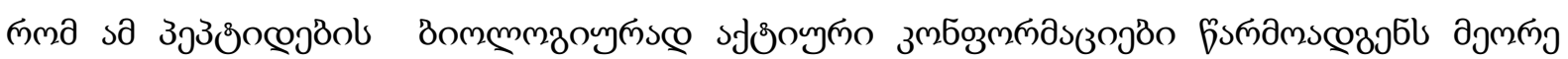

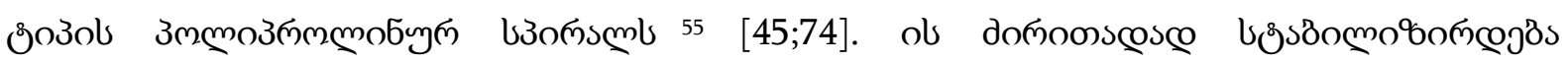

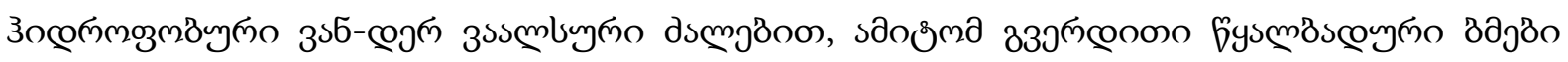

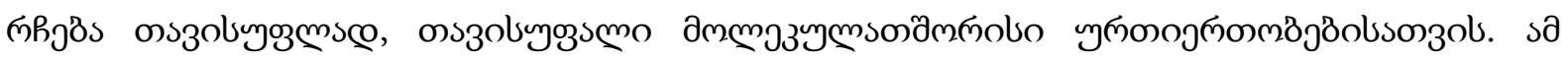

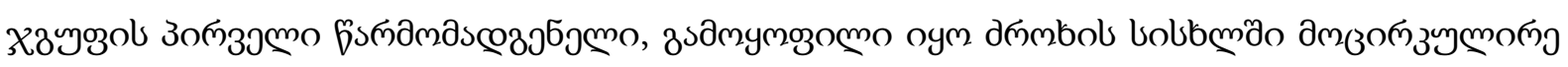

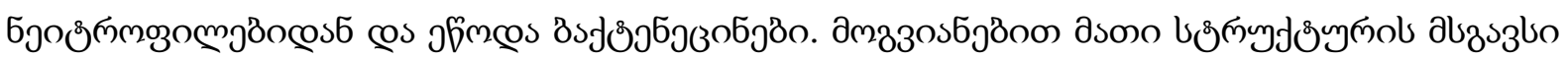

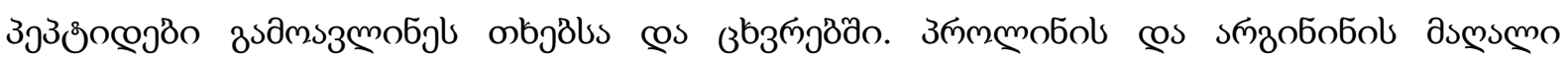

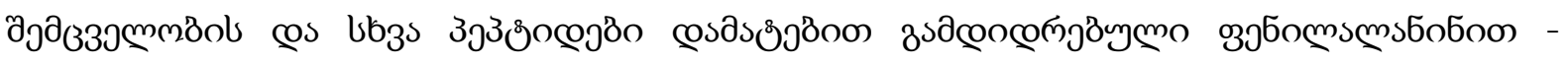

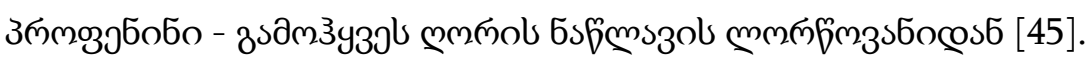

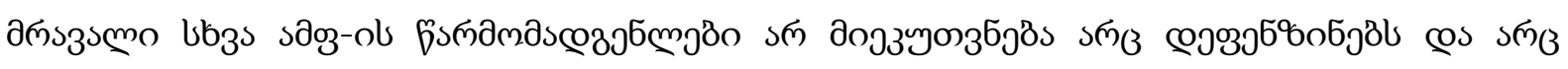

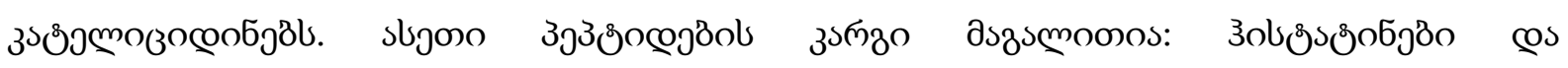

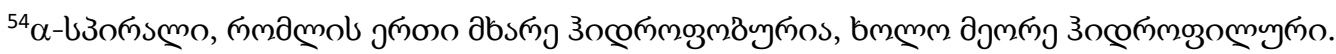

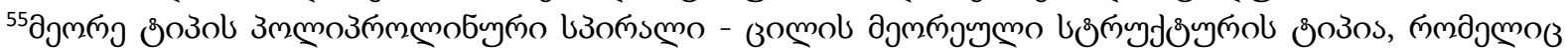

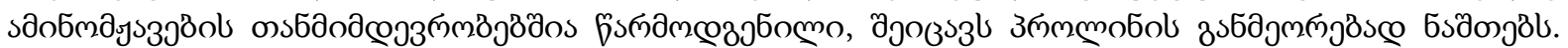

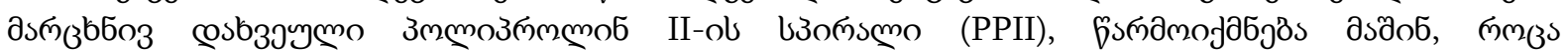

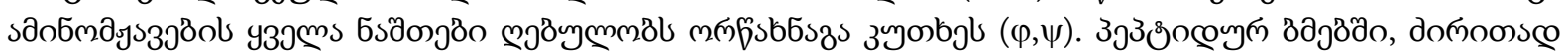

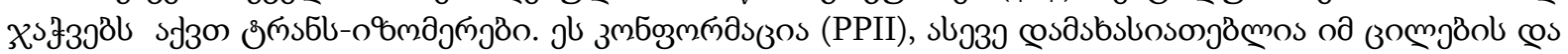

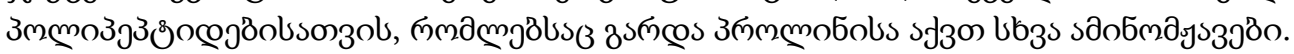




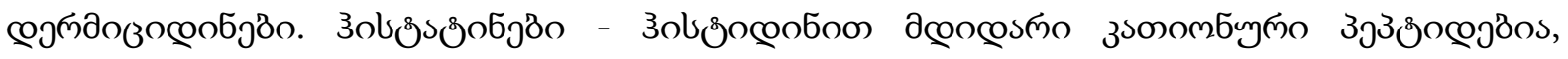

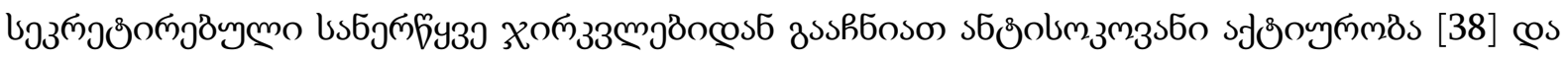

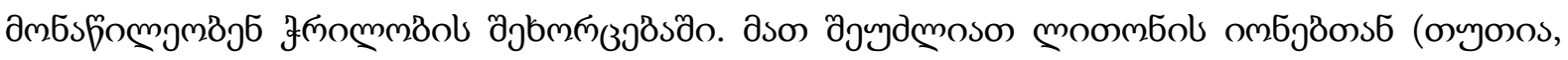

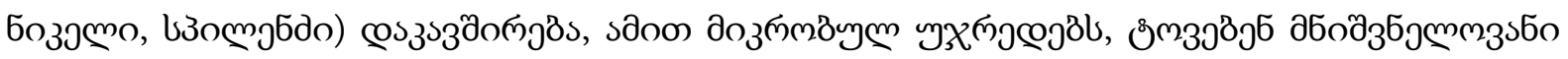

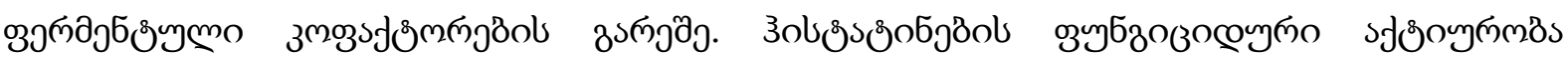

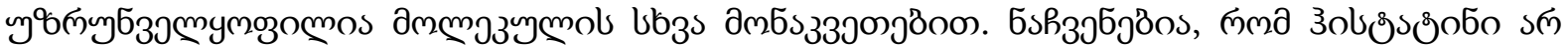

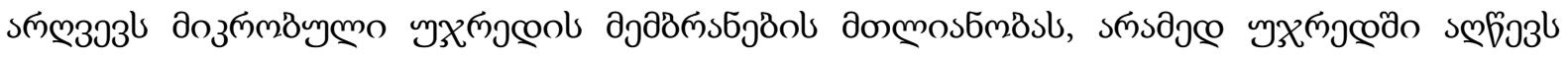

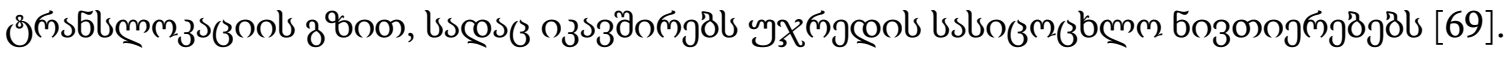

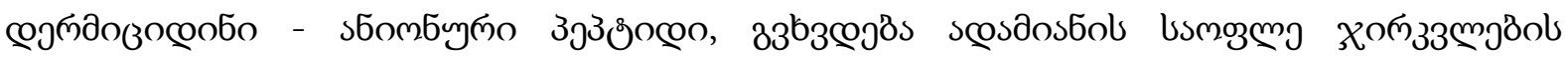

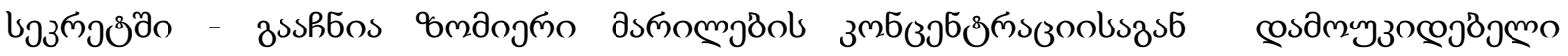

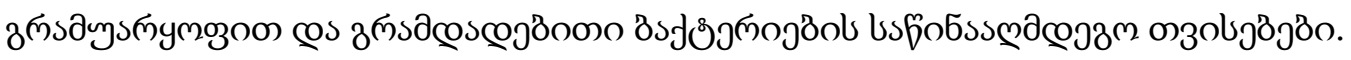

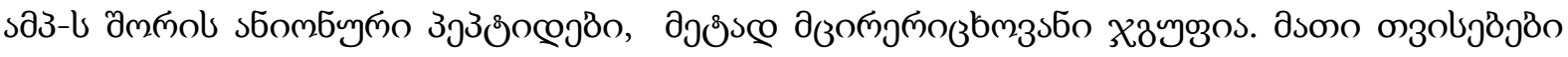

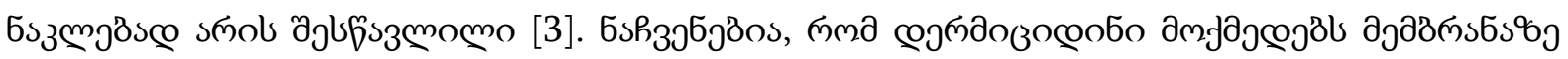

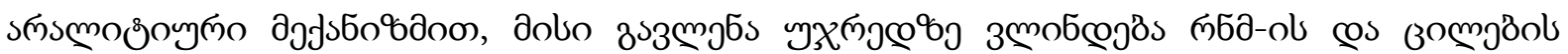

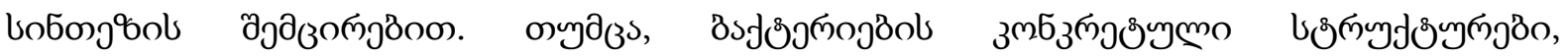

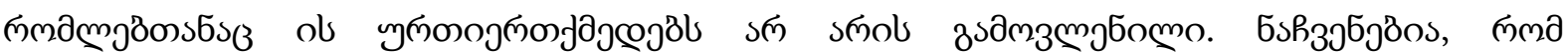

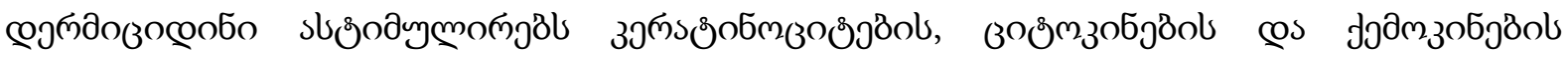

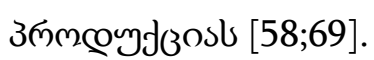

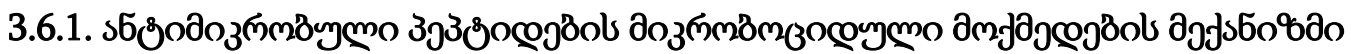

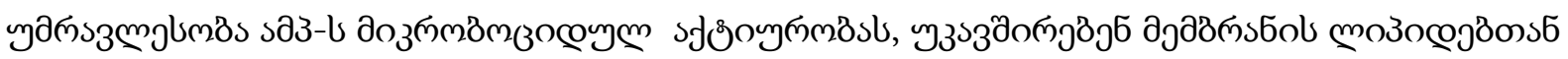

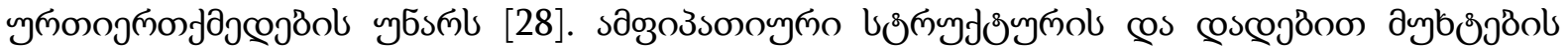

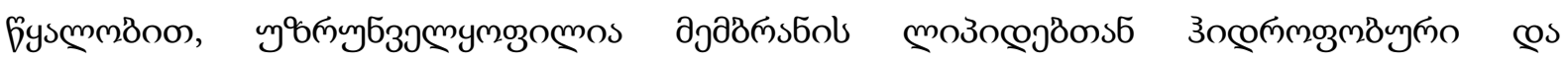
э

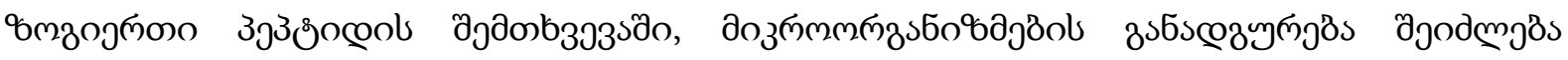

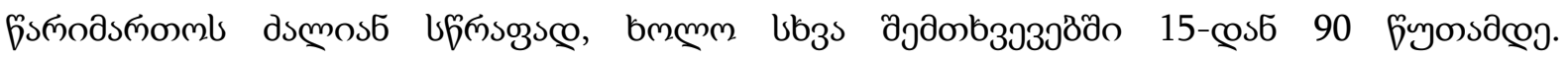

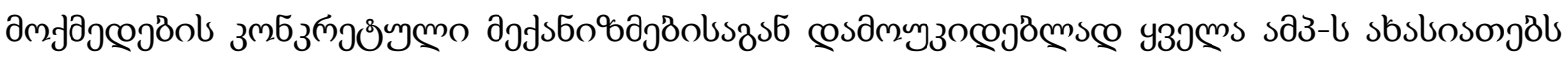

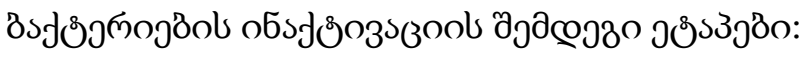

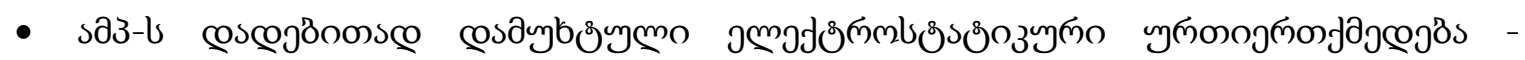

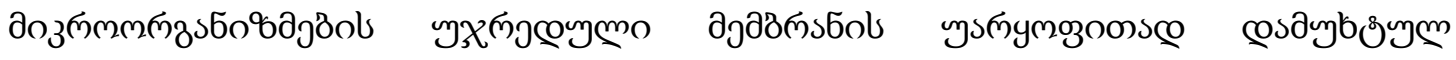

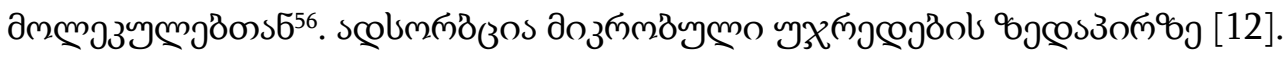

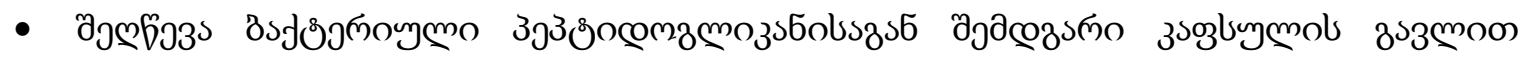

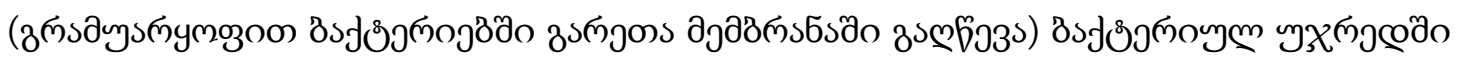

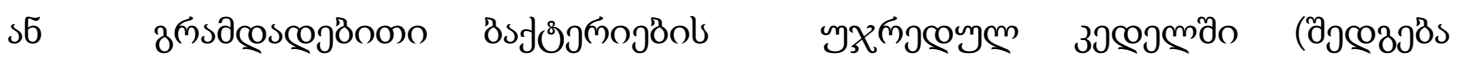

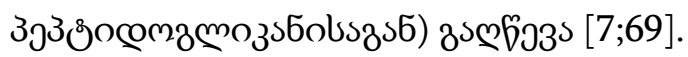

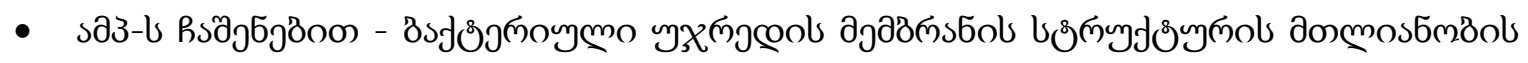

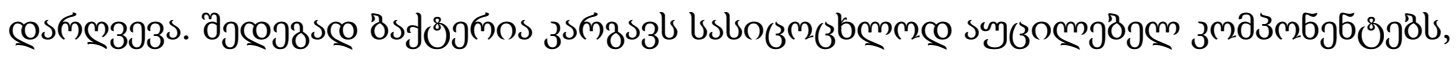

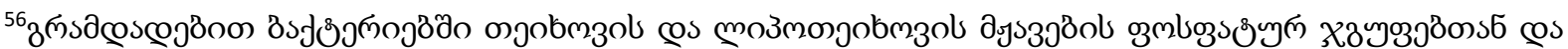

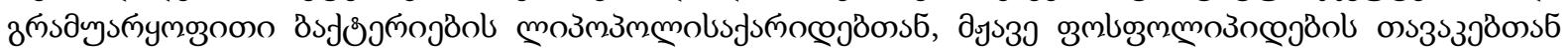
cos bb3s.
} 


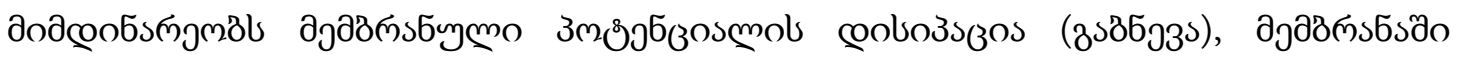

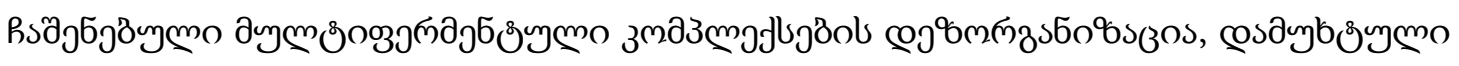

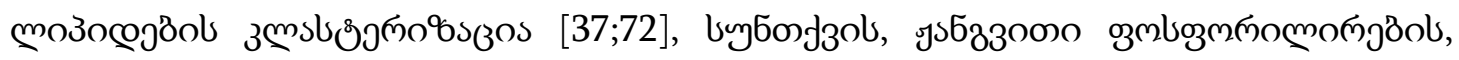

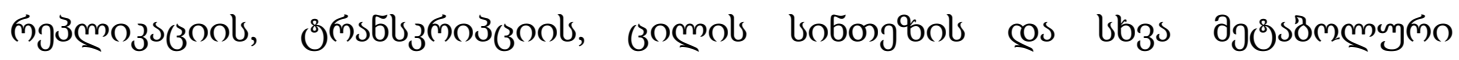

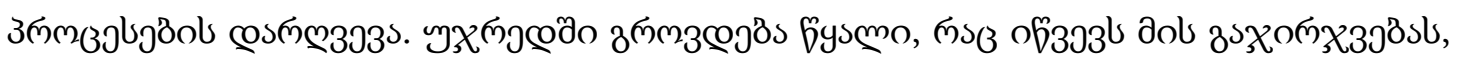

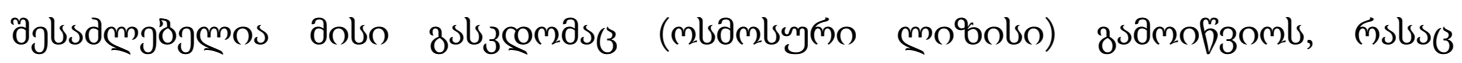

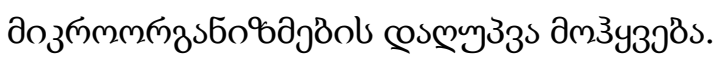

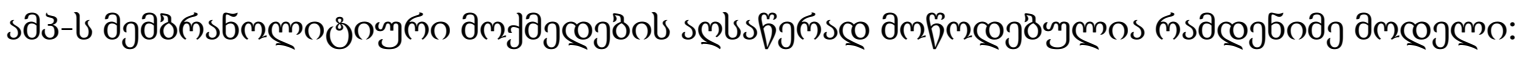

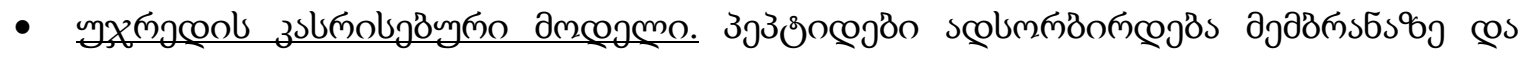

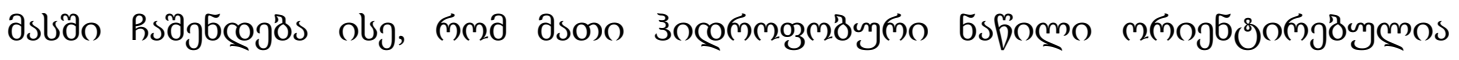

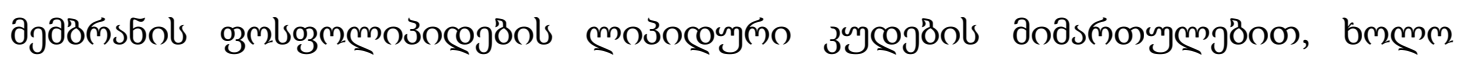

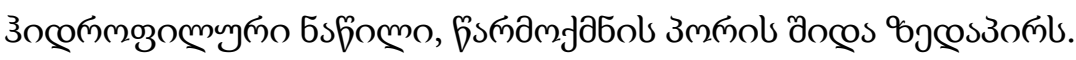

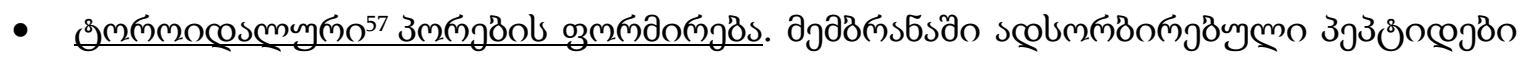

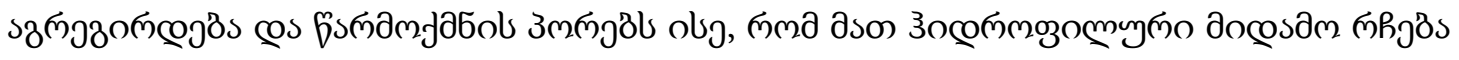

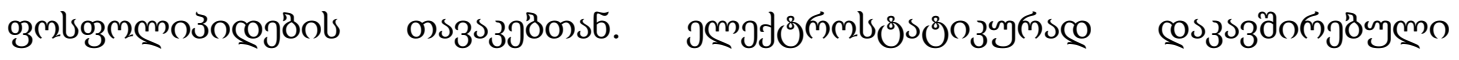

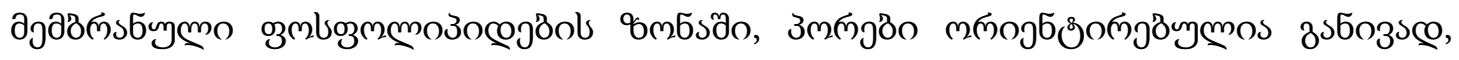

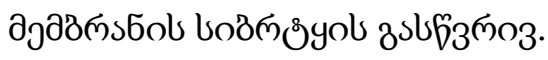

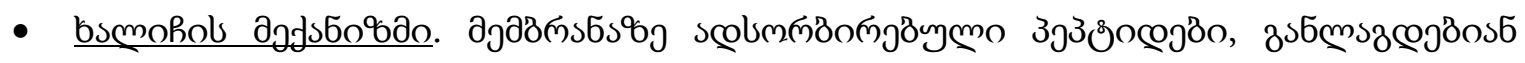

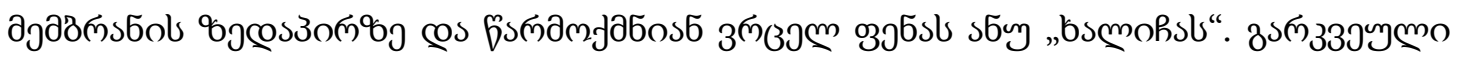

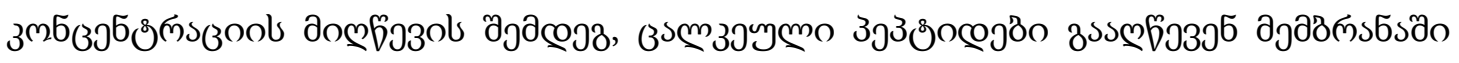

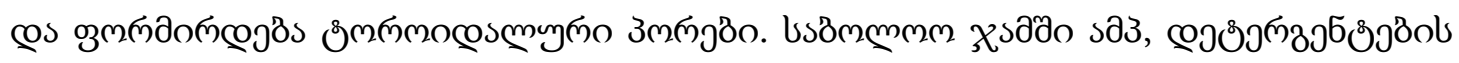

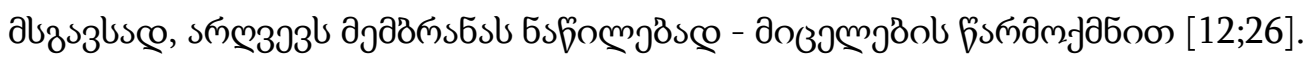

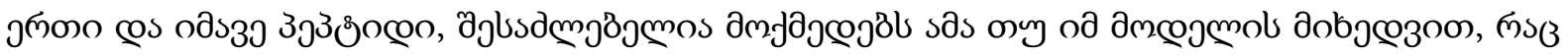

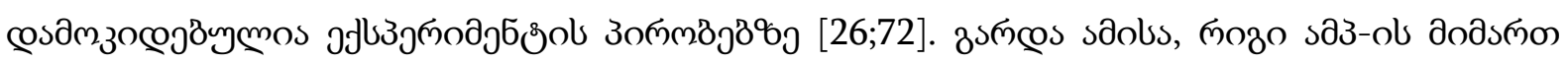

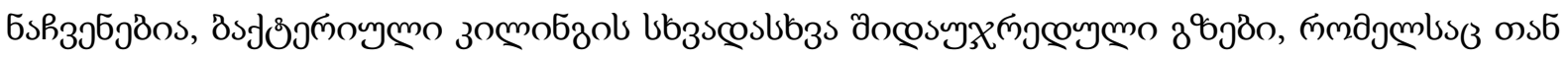

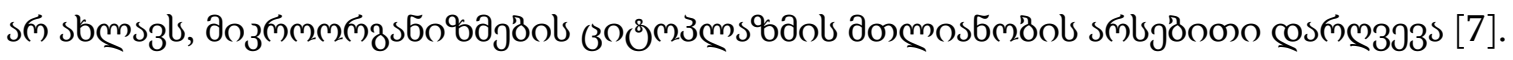

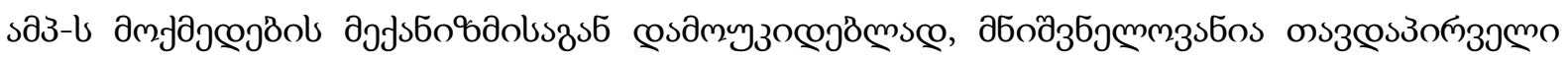

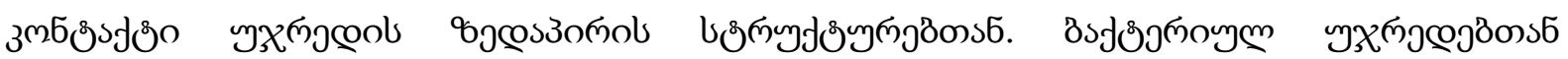

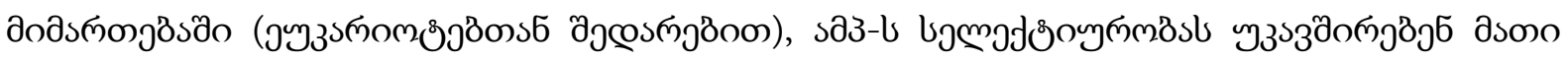

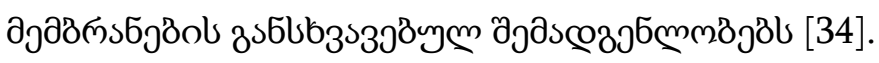

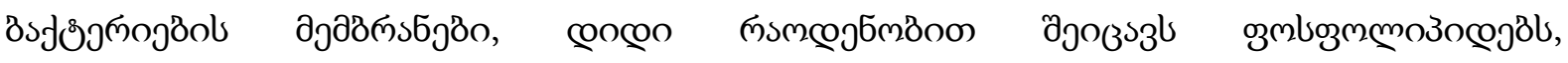

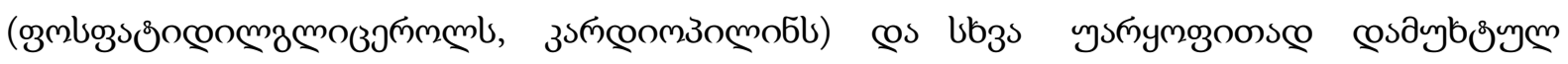

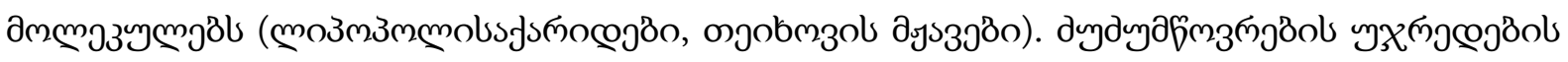

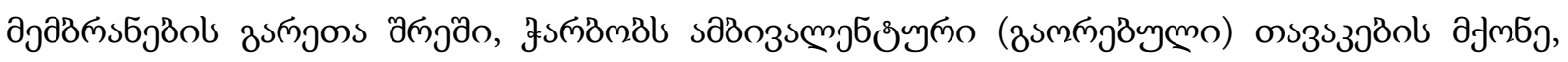

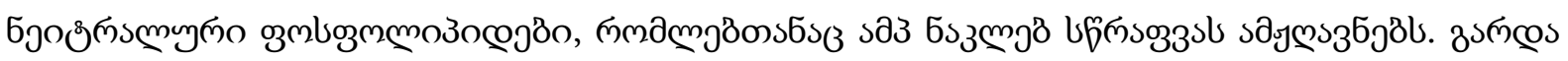

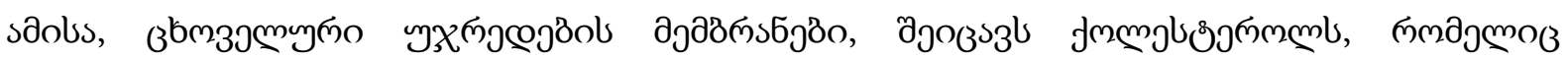

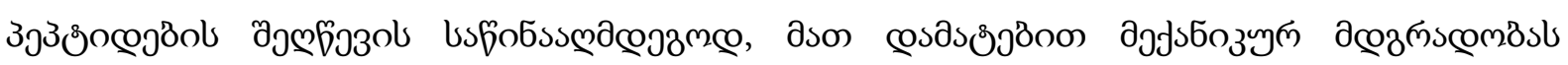

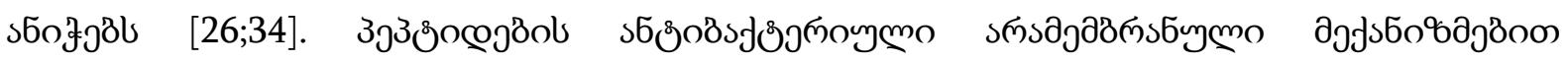

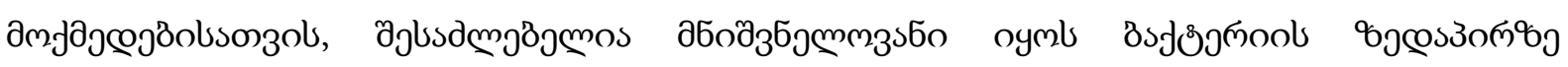

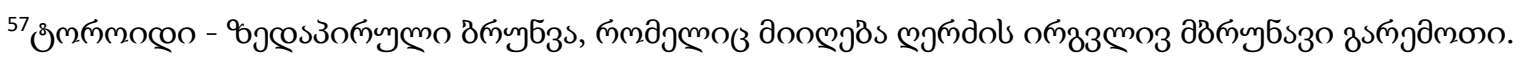




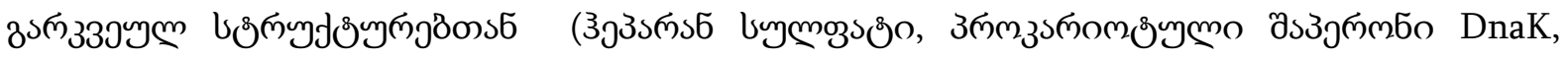

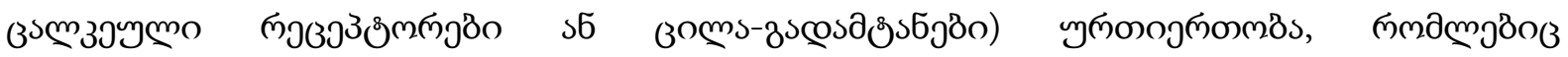

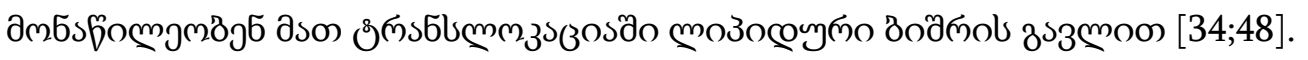

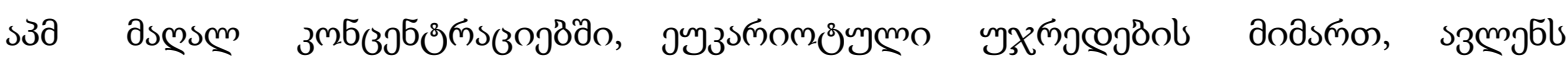

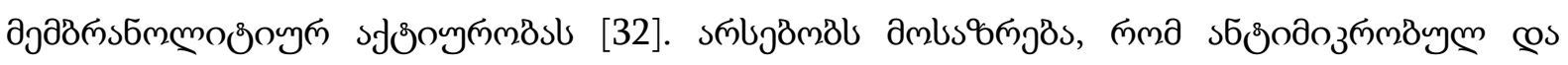

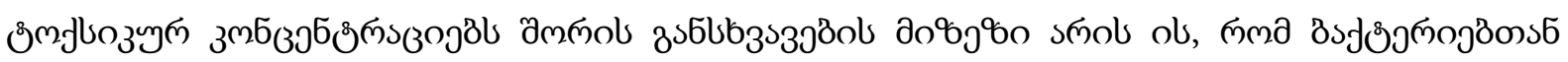

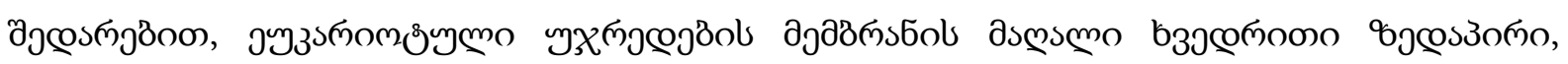

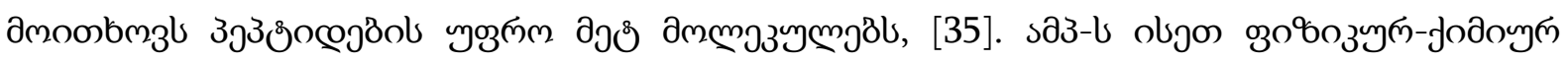

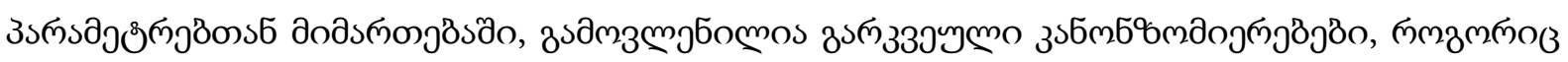

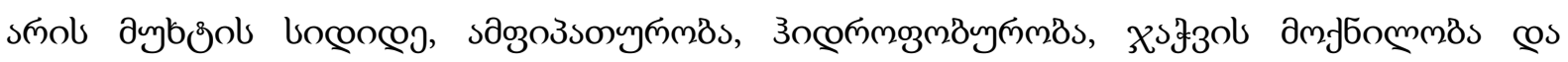

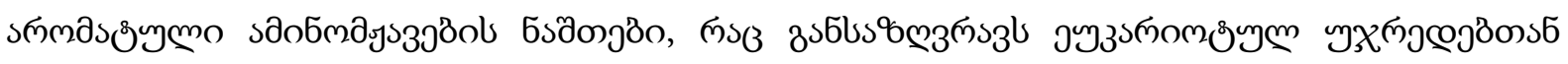

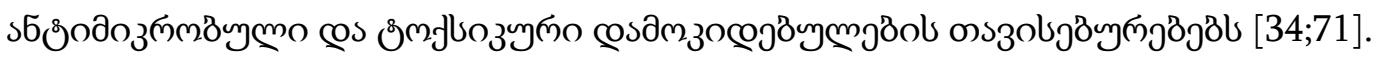

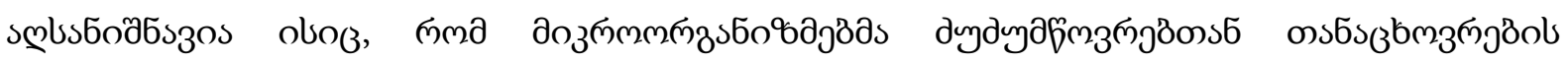

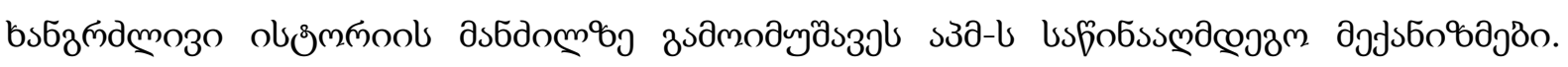

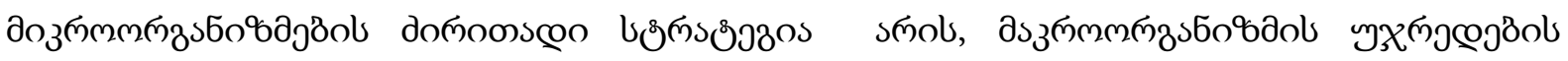

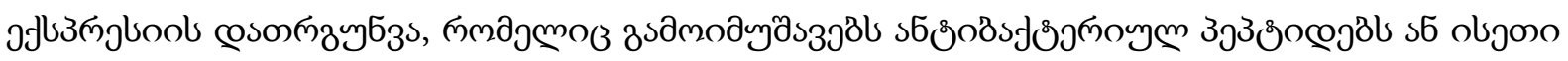
зммণீ

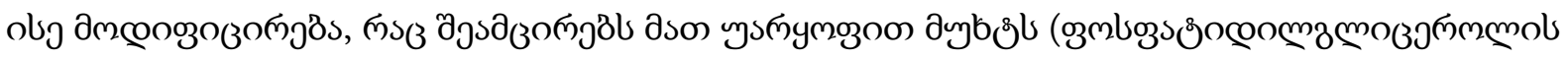

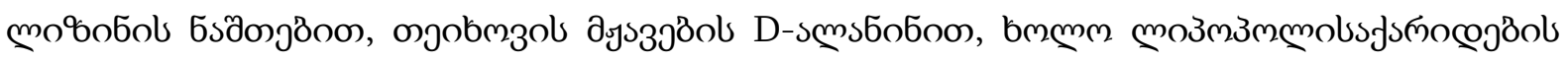

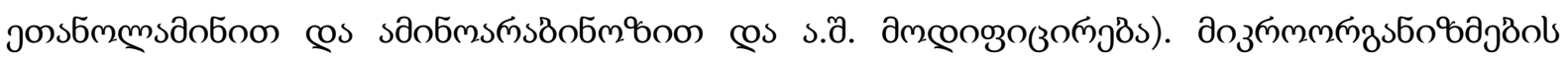

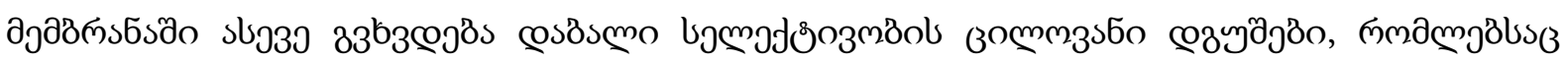

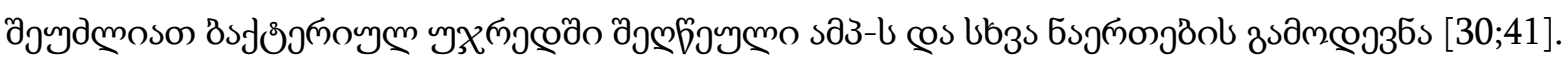

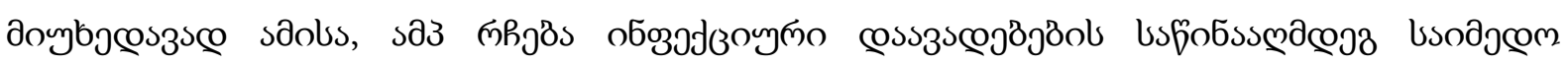

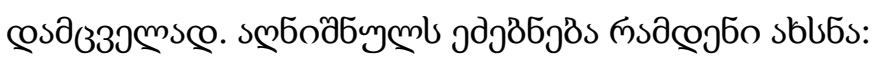

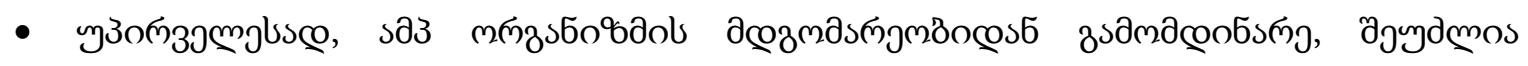

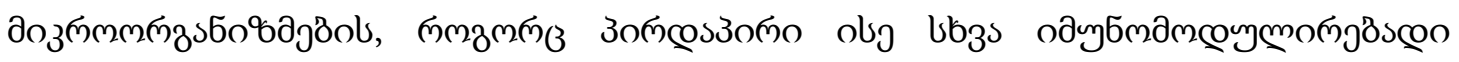

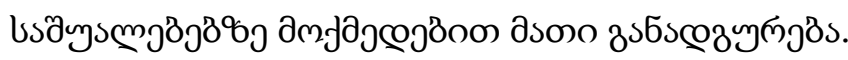

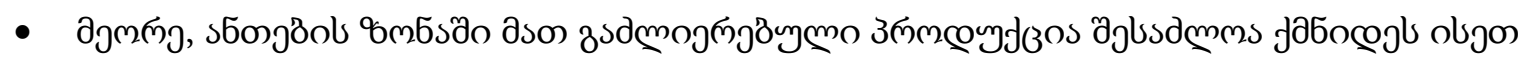
дsмsмm мпззммип змб

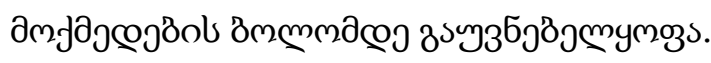

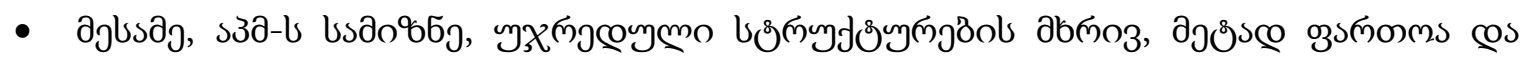

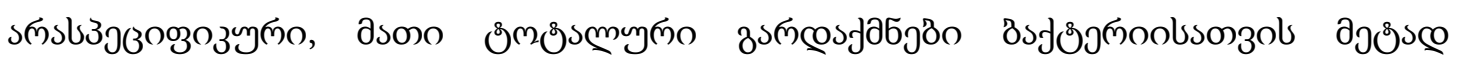

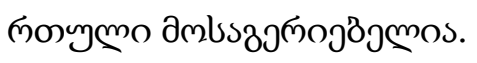

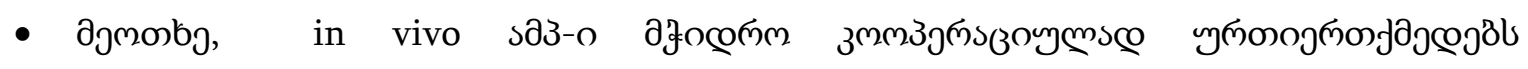

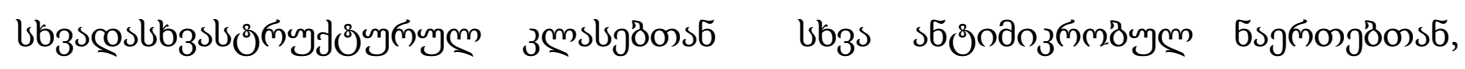

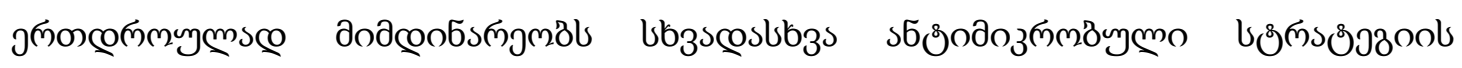

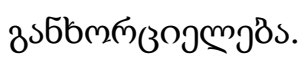

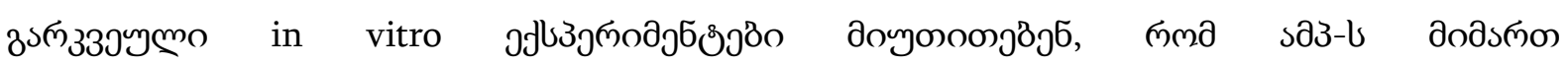

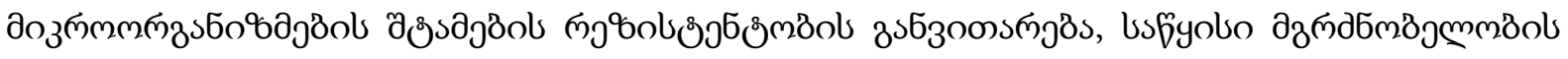

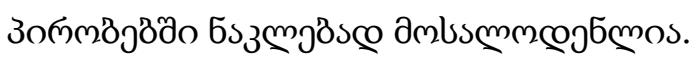

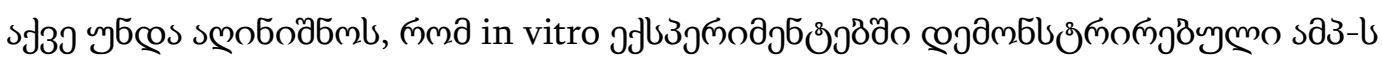




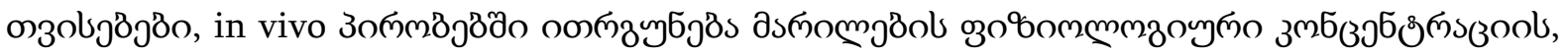

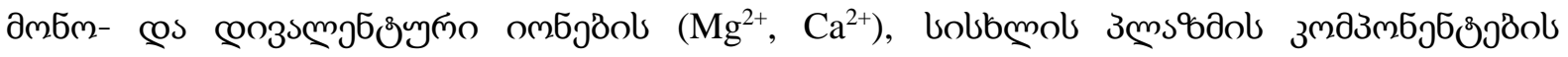
зо пмдјвдо [30;51].

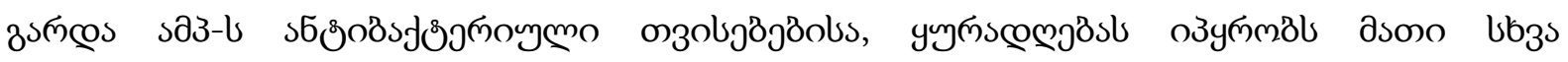

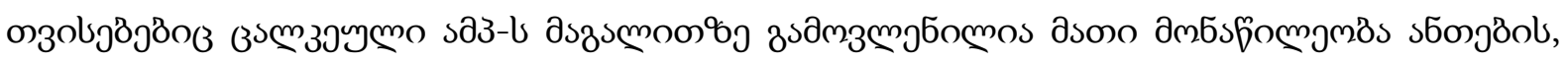

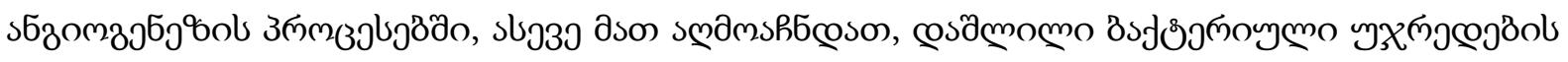

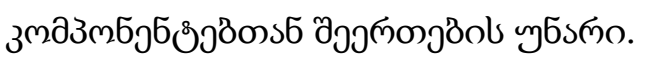

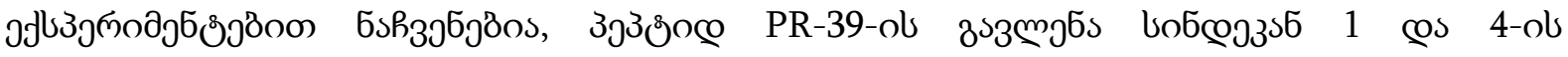

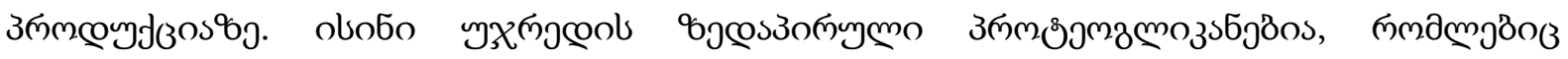

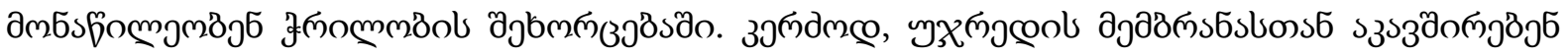

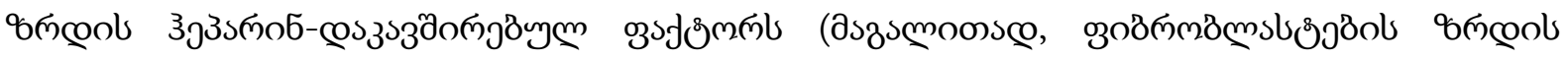

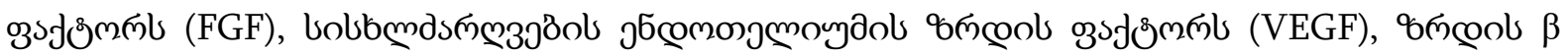

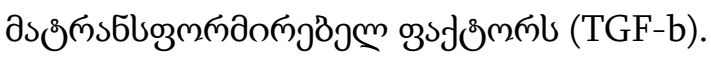

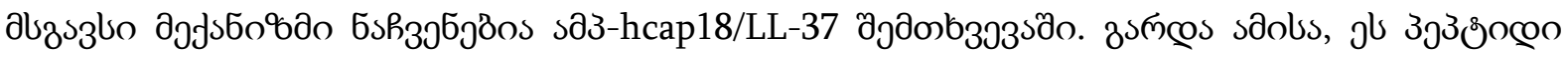

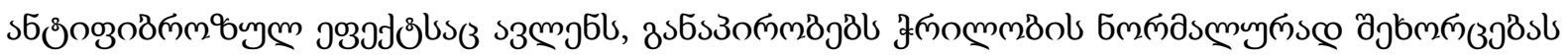
[12].

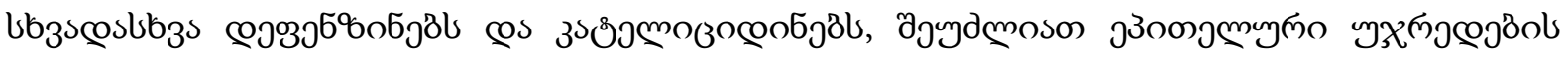

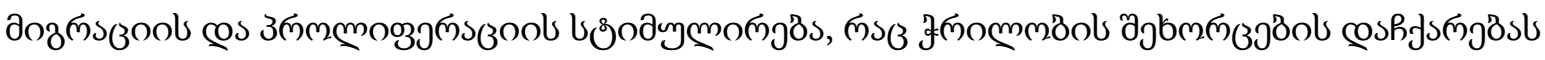
bjmb эfymols [30;26].

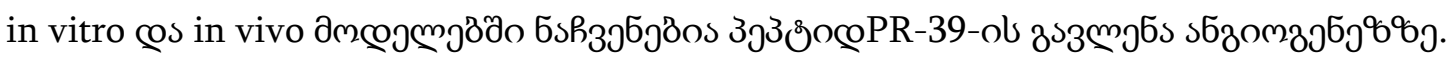

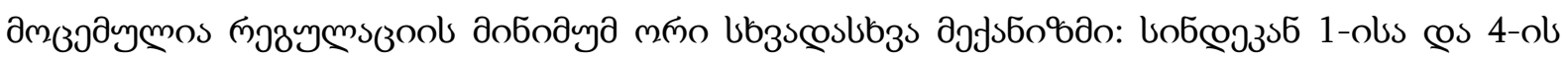

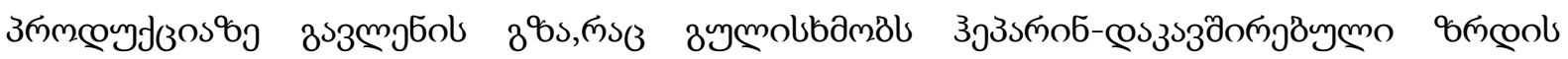

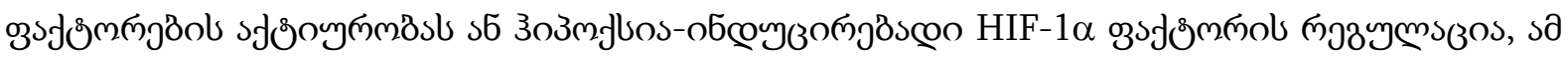

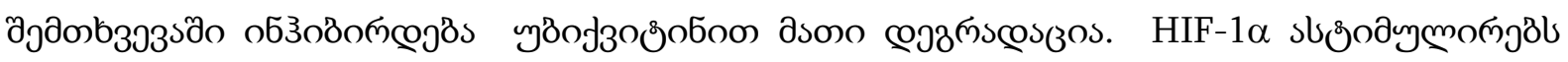

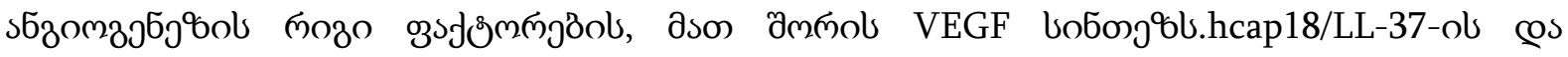
scosдos6ol œэว

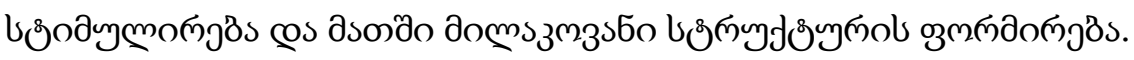

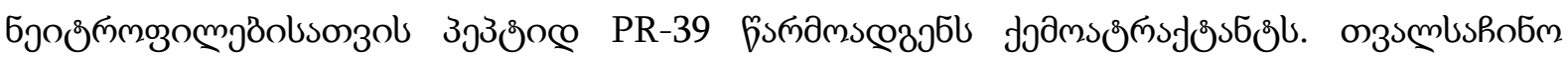

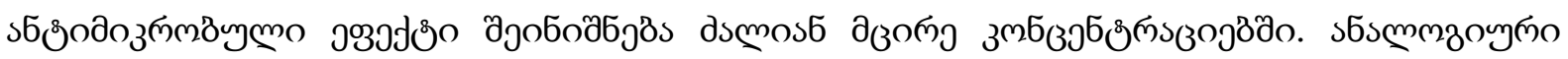

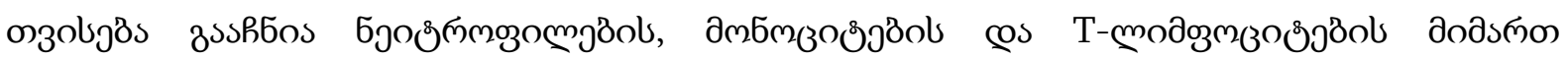

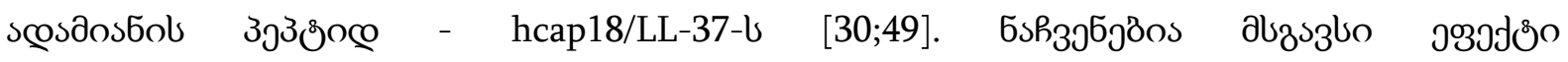
œэ

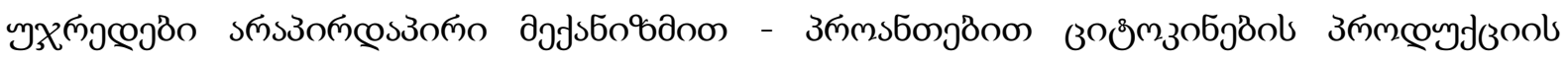

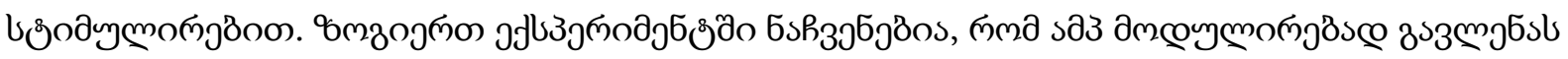

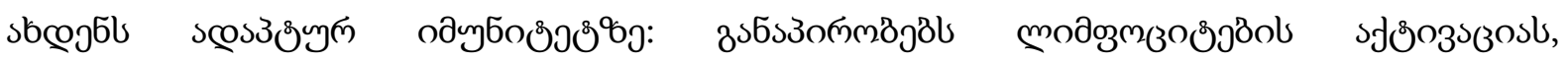

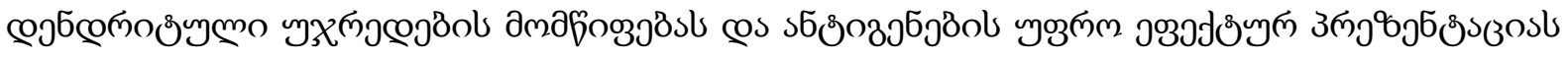

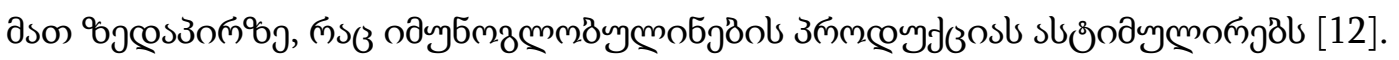

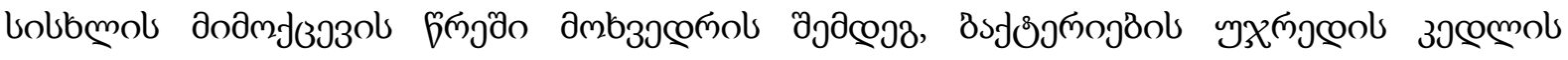

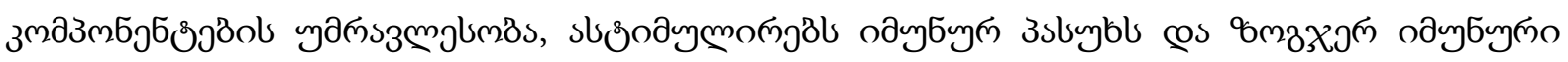

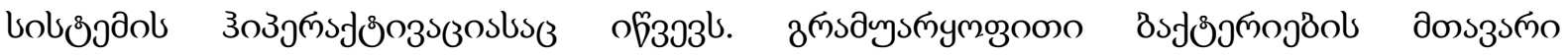

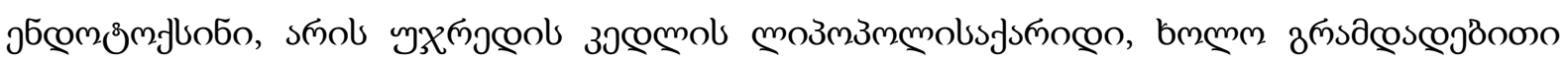

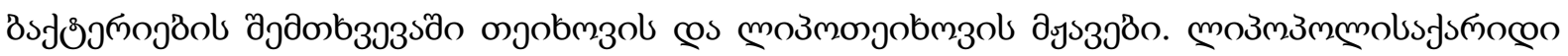




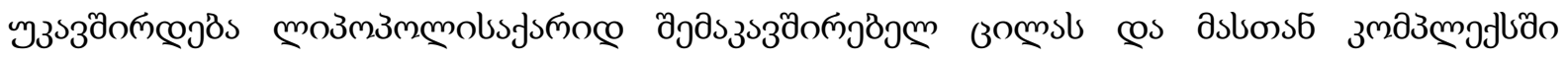
уполэполалє

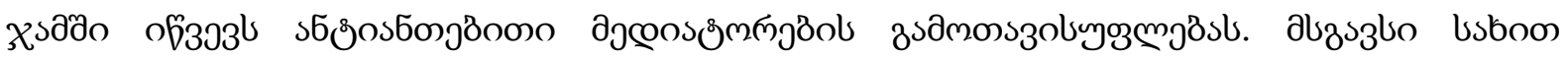

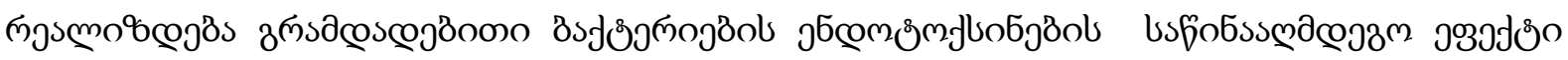
[51].

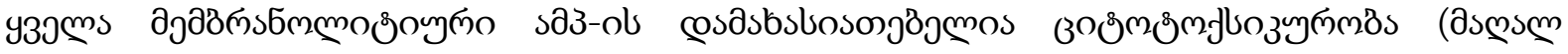

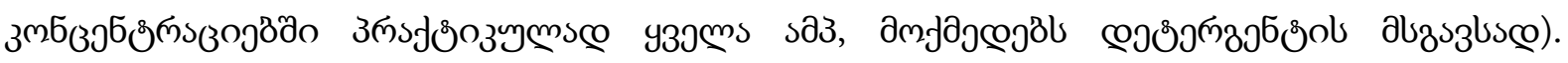

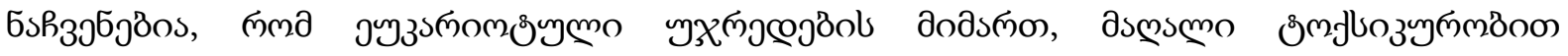

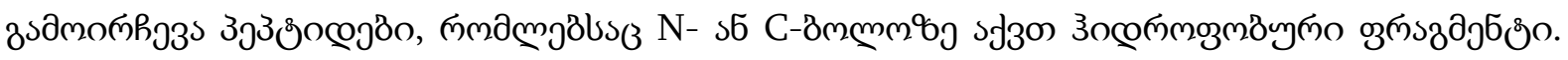

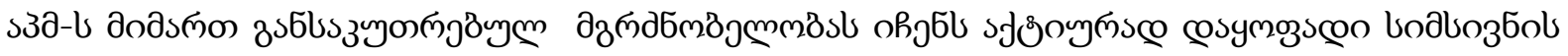

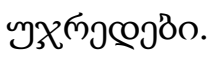

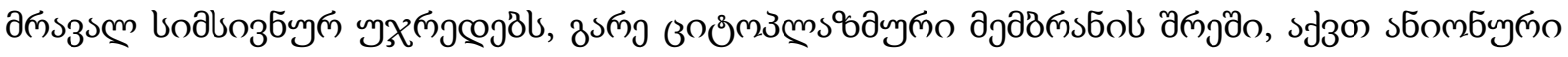

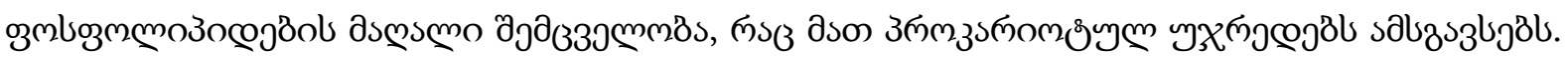

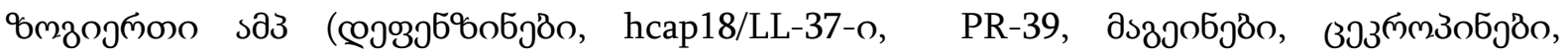

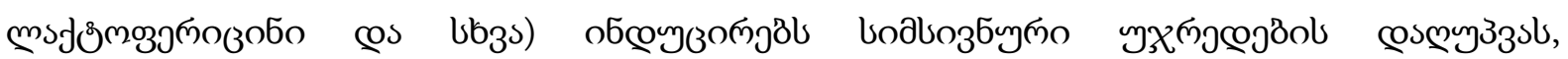

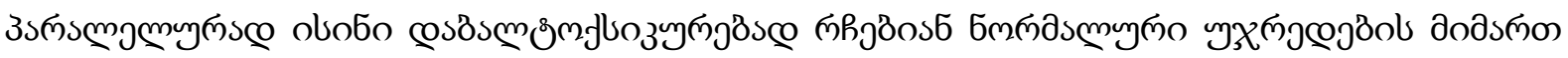

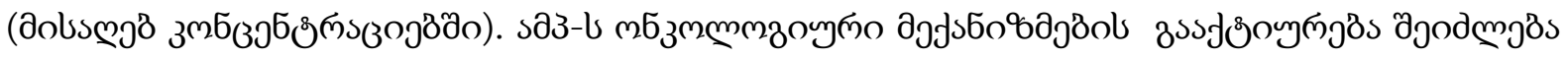

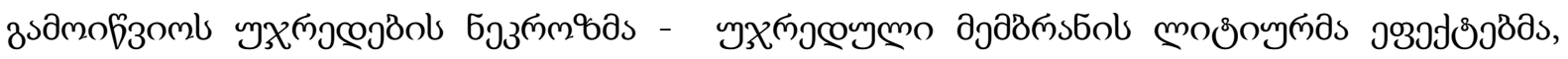

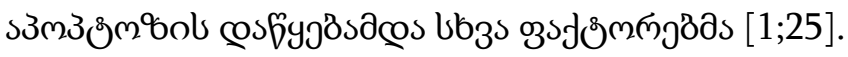

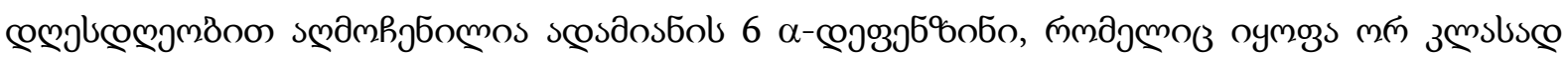

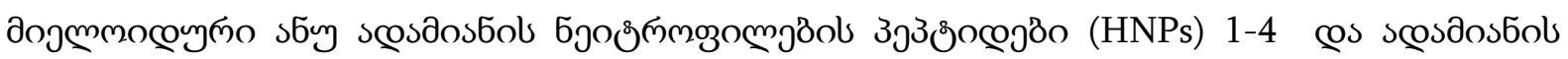

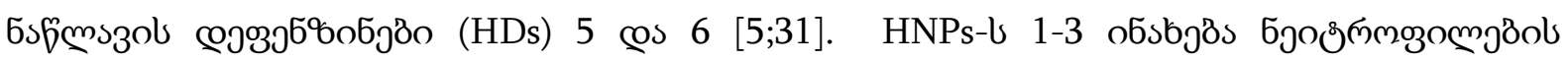

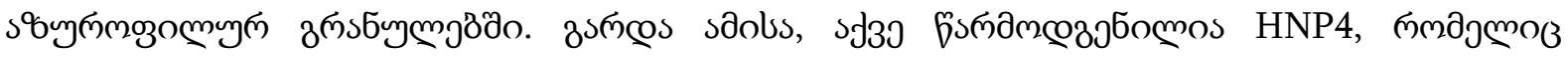

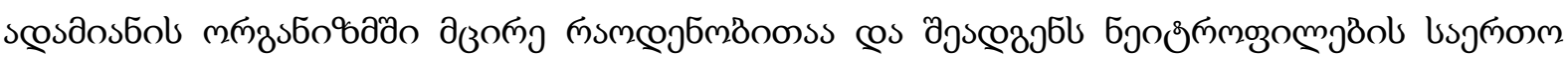

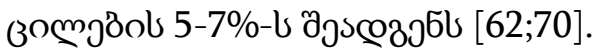

\section{HNP-1}

- jазополумо озмпаулмз: $\mathrm{C}_{150} \mathrm{H}_{222} \mathrm{~N}_{44} \mathrm{O}_{38} \mathrm{~S}_{6}$.

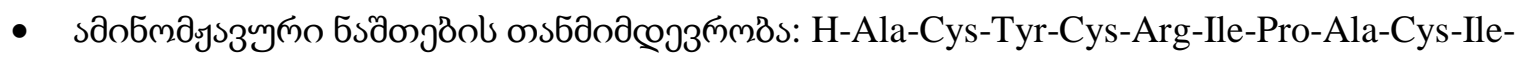
Ala-Gly-Glu-Arg-Arg-Tyr-Gly-Thr-Cys-Ile-Tyr-Gln-Gly-Arg-Leu-Trp-Ala-Phe-Cys-Cys-OH

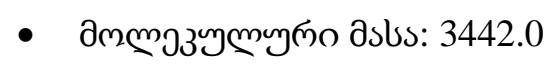

\section{HNP-2}

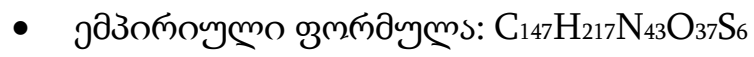

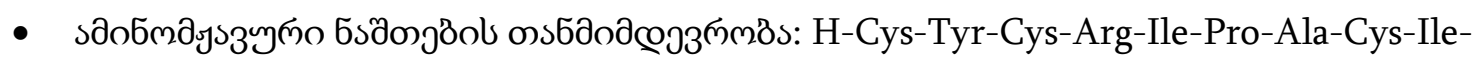
Ala-Gly-Glu-Arg-Arg-Tyr-Gly-Thr-Cys-Ile-Tyr-Gln-Gly-Arg-Leu-Trp-Ala-Phe-Cys-Cys$\mathrm{OH}$

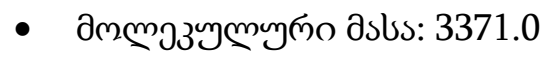

HNP-3

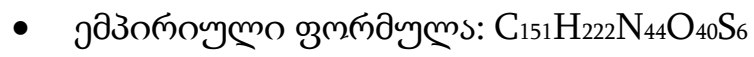




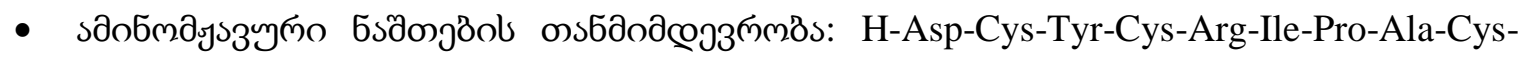
Ile-Ala-Gly-Glu-Arg-Arg-Tyr-Gly-Thr-Cys-Ile-Tyr-Gln-Gly-Arg-Leu-Trp-Ala-Phe-Cys-Cys$\mathrm{OH}$

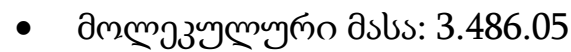

HNP-4

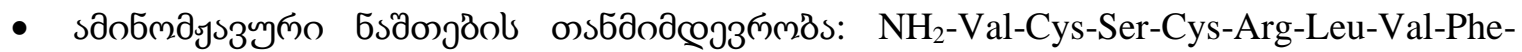
Cys-Arg-Arg-Thr-Glu-Leu-Arg-Val-Gly-Asn-Cys-Leu-Ile-Gly-Gly-Val-Ser-Phe-Thr-TyrCys-Cys-Thr- Arg-Val - COOH.

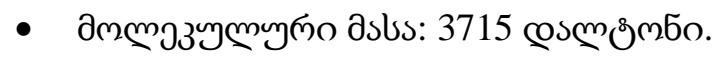

HBD1

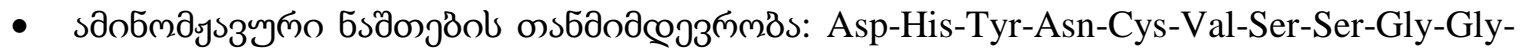
Gln-Cys-Leu-Tyr-Ser-Ala-Cys-Pro-Ile-Phe-Thr-Lys-Ile-Gln-Gly-Thr-Cys-Tyr-Arg-Gly-LysArg-Lys-Cys-Cys-Lys.

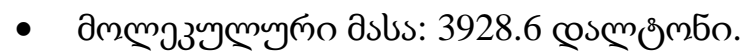

HBD2

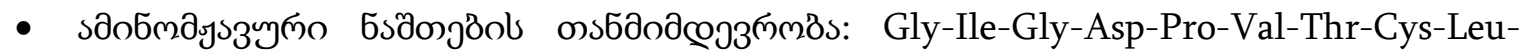
Lys-Ser-Gly-Ala-Ile-Cys-His-Pro-Val-Phe-Cys-Pro-Arg-Arg-Tyr-Lys-Gln-Ile-Gly-ThrCys-Gly-Leu-Pro-Gly-Thr-Lys-Cys-Cys-Lys-Lys-pro

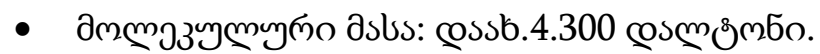

HBD3

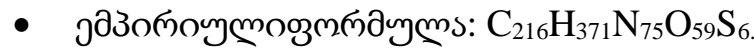

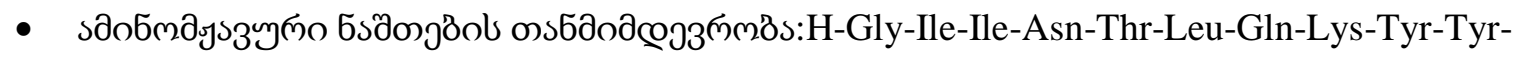
Cys-Arg-Val-Arg-Gly-Gly-Arg-Cys-Ala-Val-Leu-Ser-Cys-Leu-Pro-Lys-Glu-Glu-Gln-Ile-

Gly-Lys-Cys-Ser-Thr-Arg-Gly-Arg-Lys-Cys-Cys-Arg-Arg-Lys-Lys-OH (coobymozocoyño вةjठ̊: 11-40, 18-33, 23-41)

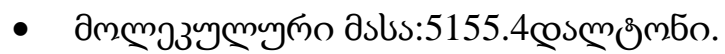

HBD4

- jазополумо озмпдулмs: $\mathrm{C}_{108} \mathrm{H}_{295} \mathrm{~N}_{63} \mathrm{O}_{52} \mathrm{~S}_{6}$

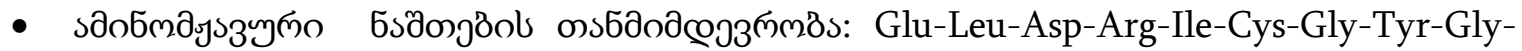
Thr-Ala-Arg-Cys-Arg-Lys-Lys-Cys-Arg-Ser-Gln-Glu-Tyr-Arg-Ile-Gly-Arg-Cys-Pro-AsnThr-Tyr-Ala-Cys-Cys-Leu-Arg-Lys

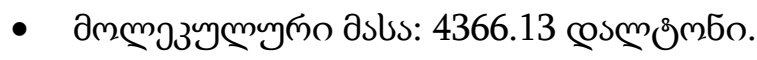

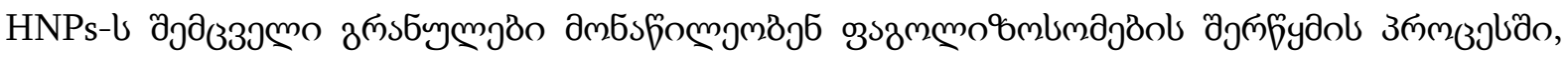

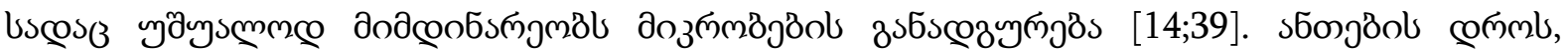

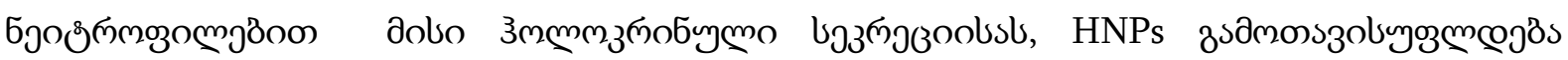

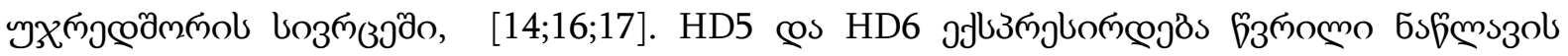

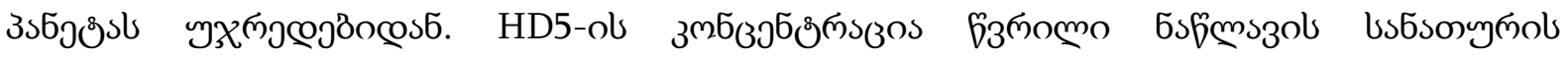




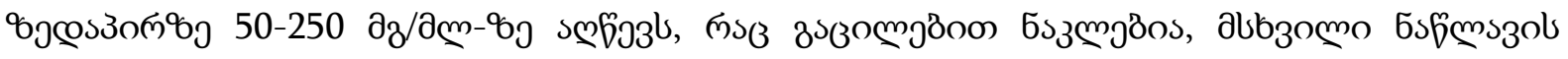

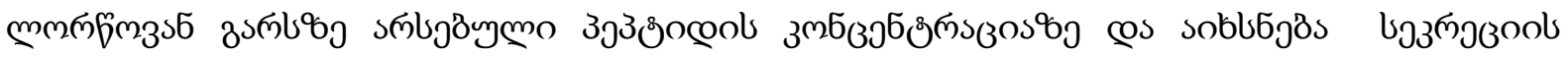

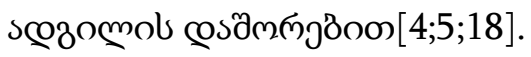

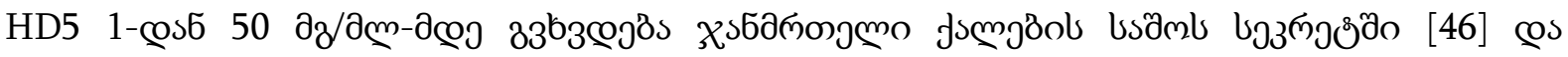

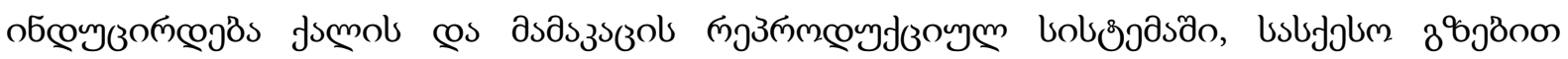

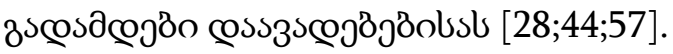

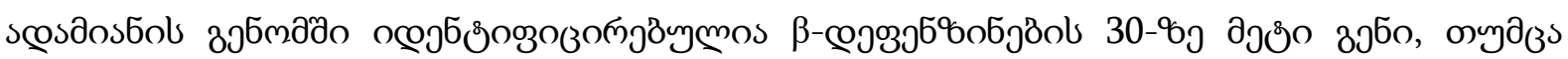

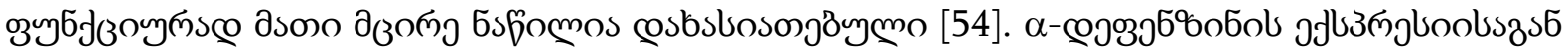

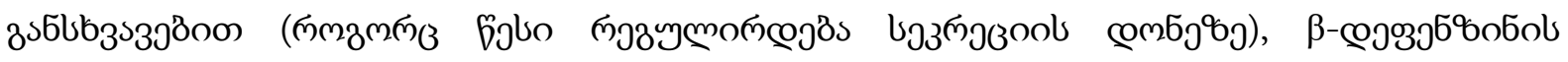

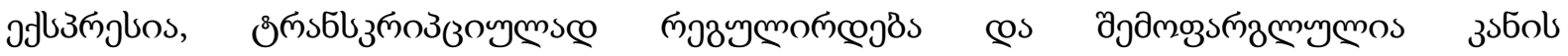

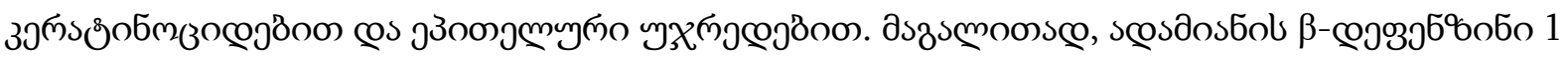

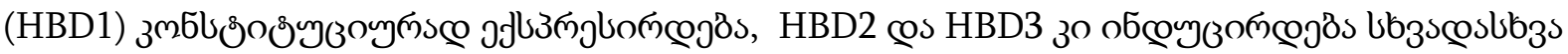

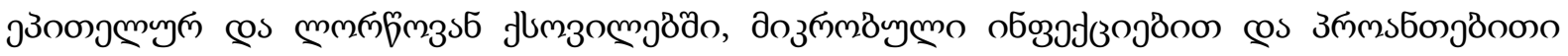

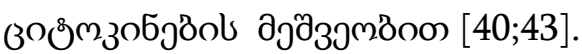

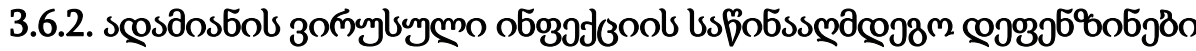

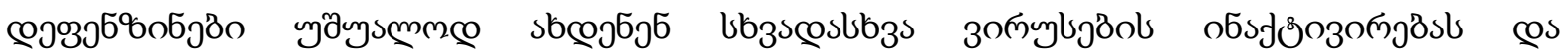

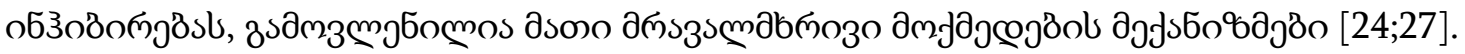

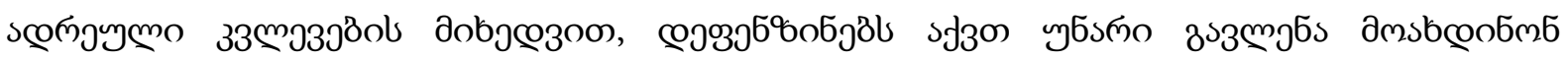

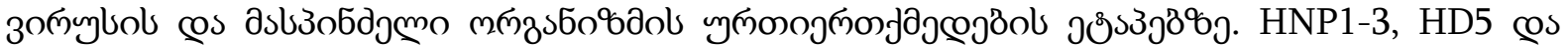

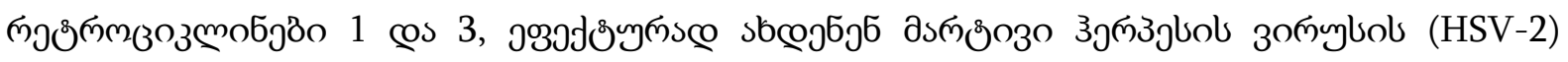

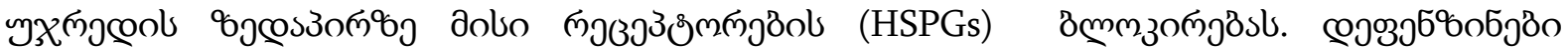

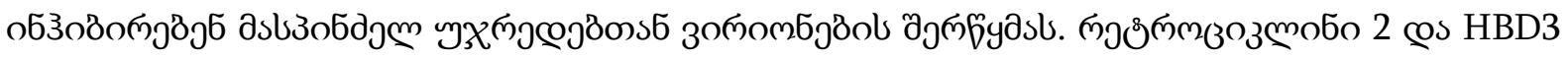

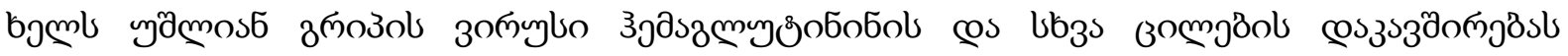

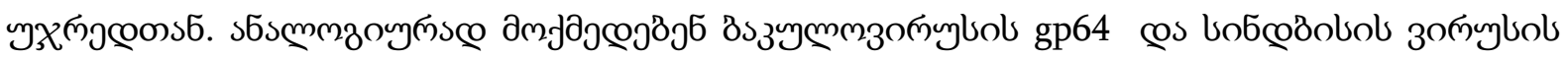
Е1 зомэ8\% [23;66;78].

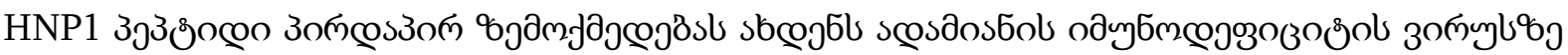

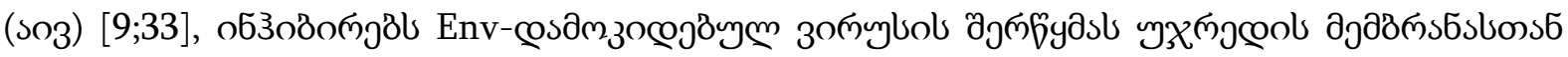

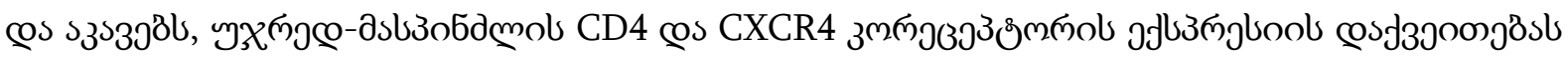

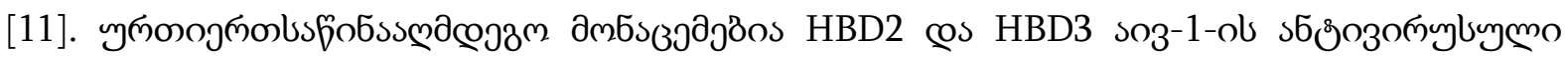
дృ

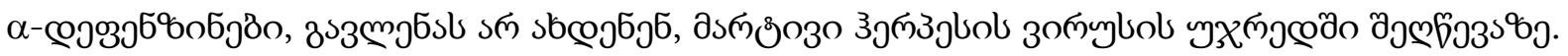

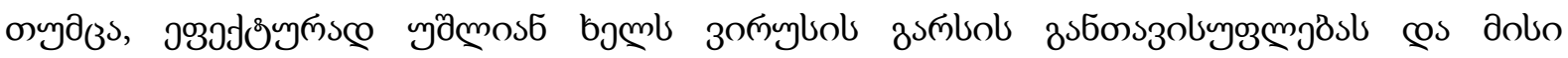

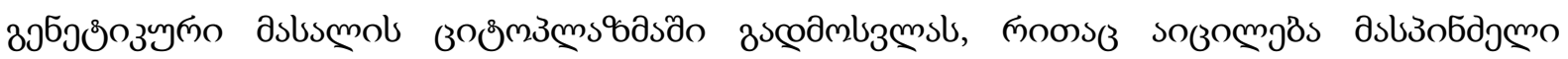

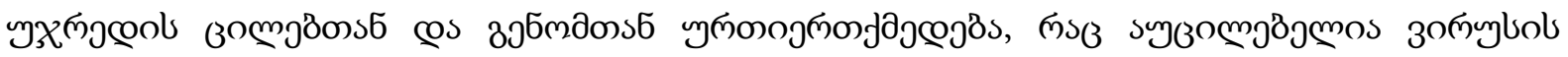

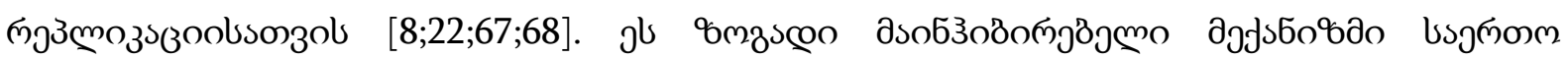

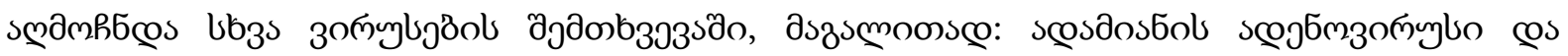

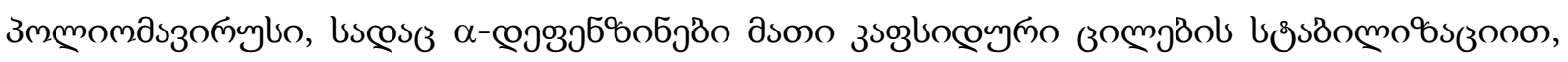

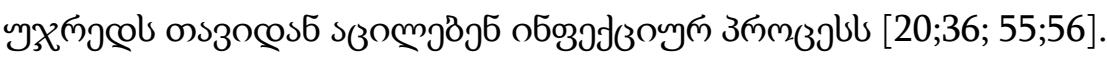




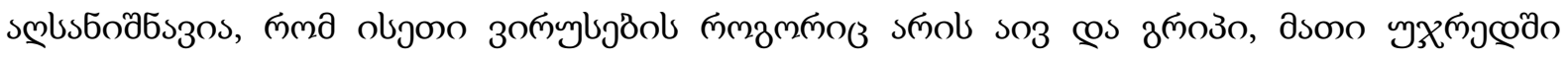

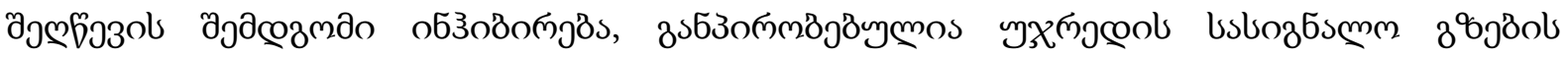

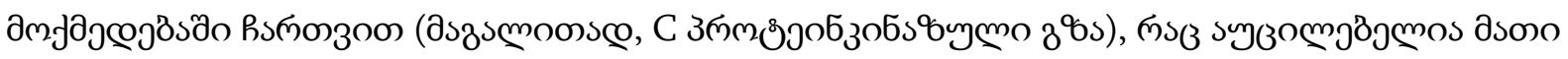

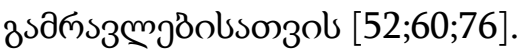

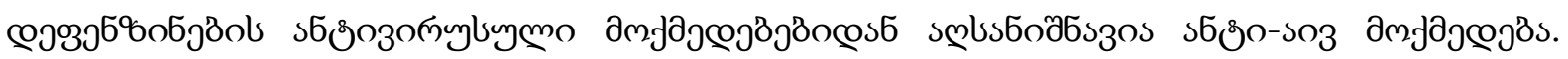

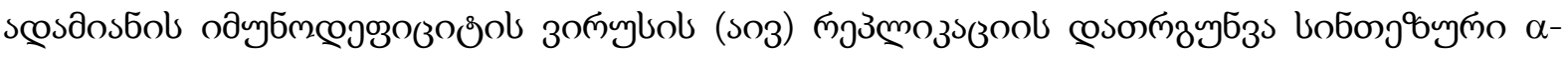

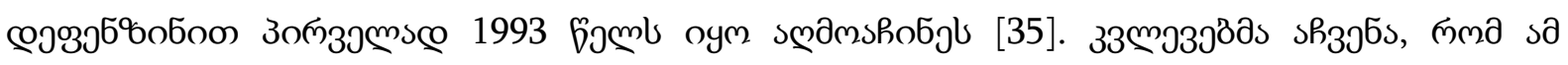

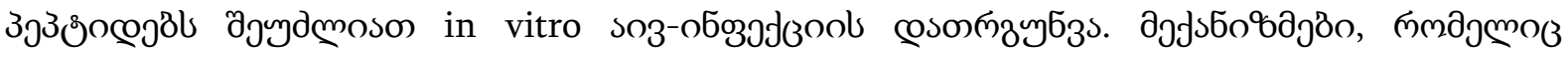

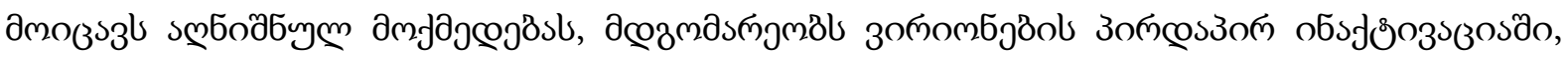

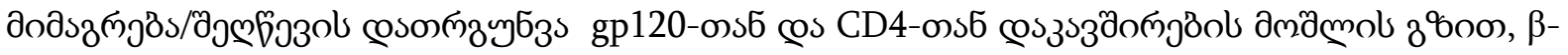

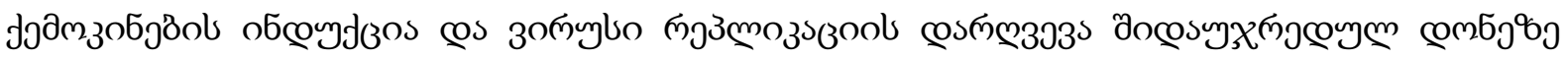

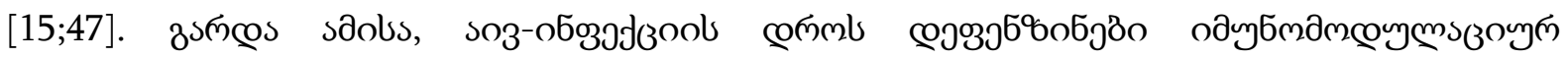

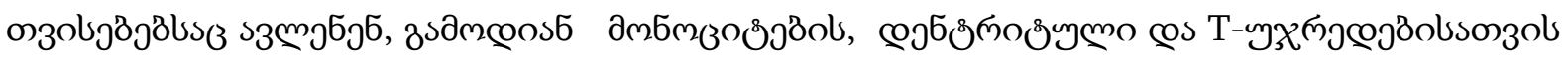

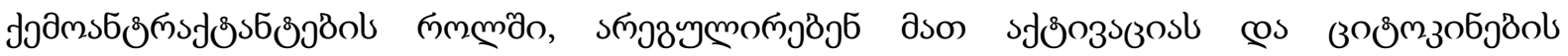
зимемлызоsl [61;77].

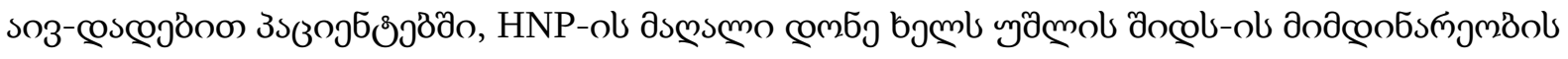

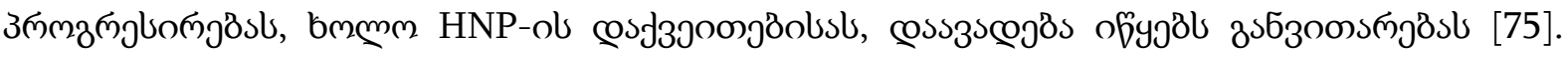

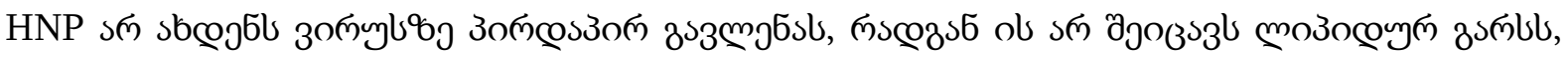

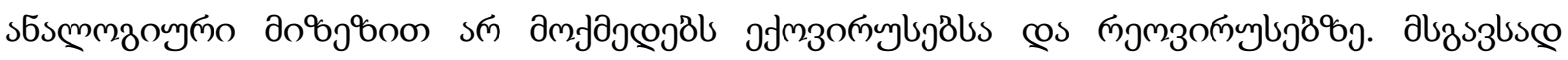

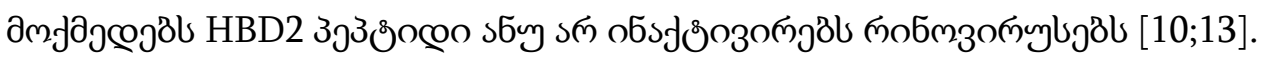

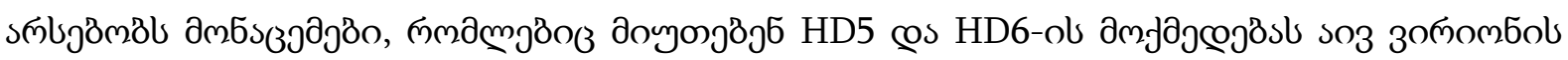

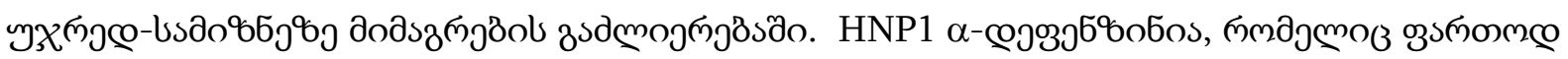

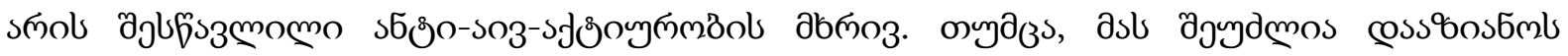

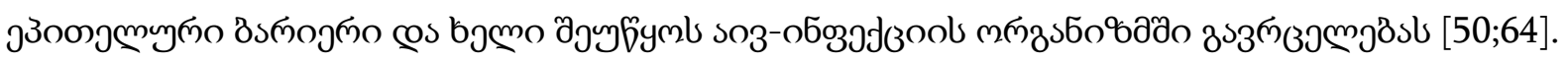

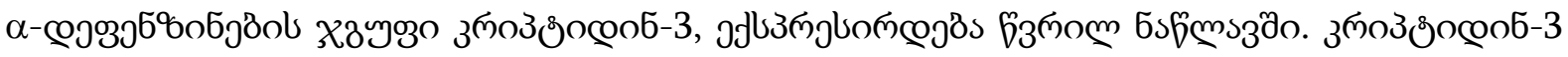

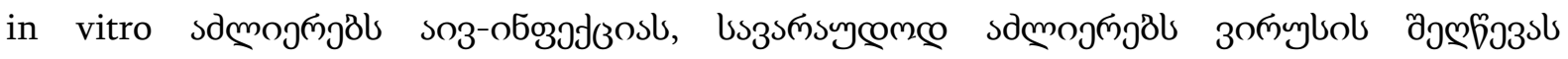

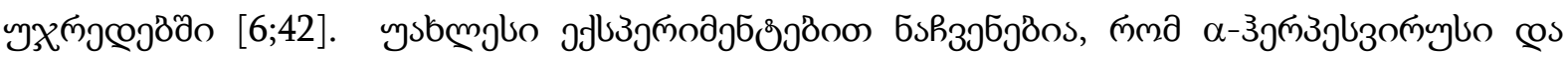

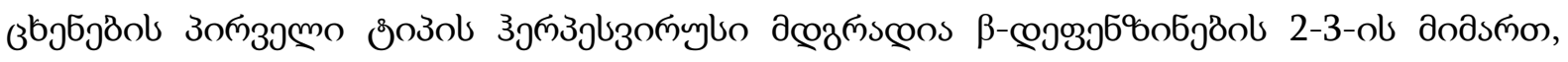

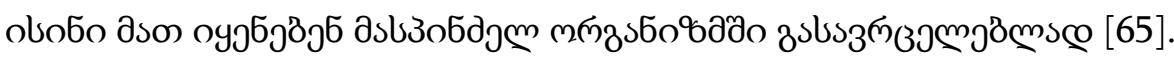

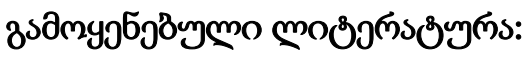

1. Al-Benna S., Shai Y., Jacobsen F., Steinstraesser L. Oncolytic activities of host defense peptides // Int. J.Mol. Sci. 2011. Vol. 12, iss. 11. P. 8027-8051.

2. Antimicrobial peptides: discovery, design, and novel therapeutic strategies / ed. by G. Wang // Advancesin molecular and cellular microbiology, 18. CAB International, 2010. $230 \mathrm{p}$.

3. Bernard J. J., Gallo R. L. Protecting the boundary: the sentinel role of host defense peptides in the skin // Cell Mol. Life Sci. 2011. Vol. 68, iss. 13. P. 2189-2199.

4. Bevins C. L. Antimicrobial peptides as eff ector molecules of mammalian host defense // Contrib. Microbiol. 2003. Vol. 10. P. 106-148.

5. Bevins CL, Martin-Porter E, Ganz T. Defensins and innate host defence ofthe gastrointestinal tract. Gut. (1999) 45:911-5. 
6. Bevins CL, Salzman NH. Paneth cells, antimicrobial peptides andmaintenance of intestinal homeostasis. Nat Rev Microbiol. (2011) 9:356-68.

7. Brogden K. A. Antimicrobial peptides: pore formers or metabolic inhibitors in bacteria? // Nat. Rev.Microbiol. 2005. Vol. 3, N 3. P. 238-250.

8. Buck CB, Day PM, Thompson CD, Lubkowski J, Lu W, Lowy DR, et al. Human a-defensins block papillomavirus infection. Proc Natl Acad Sci USA.(2006) 103:1516.

9. Chang TL, Vargas J Jr., DelPortillo A, Klotman ME. Dual role of alphadefensin-1 in antiHIV-1 innate immunity. J Clin Invest. (2005) 115:765-73.

10. Daher K.A., Selsted M.E. \& Lehrer R.I. Direct inactivationof viruses by human granulocyte defensins // J. Virol. 60, 1068-1074 (1986).

11. Demirkhanyan LH, Marin M, Padilla-Parra S, Zhan C, Miyauchi K, Jean-Baptiste M, et al. Multifaceted mechanisms of HIV-1 entry inhibition byhuman alpha-defensin. J Biol Chem. (2012) 287:28821-38.

12. Diamond G., Beckloff N., Weinberg A., Kisich K. O. Th e roles of antimicrobial peptides in innate host Defense // Curr. Pharm. Des. 2009. Vol. 15, iss. 21. P. 2377-2392.

13. Duits L.A. et al. Rhinovirus increases human $\beta$-defensin-2and -3 mRNA expression in cultured bronchial epithelial cells //FEMS Immunol. Med. Microbiol. 38, 59-64 (2003).

14. Faurschou M, Sorensen OE, Johnsen AH, Askaa J, Borregaard N. Defensinrichgranules of human neutrophils: characterization of secretory properties.Biochim Biophys Acta. (2002) 1591:29-35.

15. Furci L., Sironi F., Tolazzi M., Vassena L., Lusso P. Alpha-defensins block the early steps of HIV-1 infection: interferencewith the binding of gp120 to CD4 // Blood., 109: 29282935(2007).

16. Gabay JE, Scott RW, Campanelli D, Griffith J, Wilde C, Marra MN, et al.Antibiotic proteins of human polymorphonuclear leukocytes. Proc Natl AcadSci USA. (1989) 86:5610-4.

17. Ganz T. Extracellular release of antimicrobial defensins by humanpolymorphonuclear leukocytes. Infect Immun. (1987) 55:568-71.

18. Ghosh D, Porter E, Shen B, Lee SK, Wilk D, Drazba J, et al. Paneth celltrypsin is the processing enzyme for human defensin-5. Nat Immunol. (2002)3:583-90.

19. Gordon Y. J., Romanowski E. G., McDermott A. M. A review of antimicrobial peptides and their therapeutic potential as anti-infective drugs//Curr. Eye Res. 2005. Vol. 30, N 7. P. 505515 .

20. Gounder AP,Wiens ME,Wilson SS, Lu W, Smith JG. Critical determinants ofhuman alphadefensin 5 activity against non-enveloped viruses. J Biol Chem.(2012) 287:24554-62.

21. Guani-Guerra E., Santos-Mendoza T., Lugo-Reyes S. O., Teran L. M. Antimicrobial peptides: generaloverview and clinical implications in human health and disease // Clin. Immunol. 2010. Vol. 135, iss. 1.P. 1-11.

22. Gulati NM, Miyagi M,Wiens ME, Smith JG, Stewart PL. Alpha-defensin HD5stabilizes human papillomavirus 16 capsid/core interactions. Pathog Immun.(2019) 4:196-234.

23. Hazrati E, Galen B, Lu W, Wang W, Ouyang Y, Keller MJ, et al. Human a- andb-defensins block multiple steps in herpes simplex virus infection. J Immunol.(2006) 177:8658.

24. Holly MK, Diaz K, Smith JG. Defensins in viral infection and pathogenesis.In: Enquist L editor. Annual Review of Virology. (Vol. 4), Washington, DC:Department of Microbiology, University of Washington (2017) p. 369-91.

25. Hoskin D. W., Ramamoorthy A. Studies on anticancer activities of antimicrobial peptides // Biochim. Biophys. Acta. 2008. Vol. 1778, iss. 2. P. 357-375.

26. Khandelia H., Ipsen J. H., Mouritsen O. G. Th e impact of peptides on lipid membranes // Biochim.Biophys. Acta. 2008. Vol. 1778, iss. 7-8. P. 1528-1536. 
27. Klotman ME, Chang TL. Defensins in innate antiviral immunity. Nat RevImmunol. (2006) 6:447-56.

28. Klotman ME, Rapista A, Teleshova N, Micsenyi A, Jarvis GA, Lu W,et al. Neisseria gonorrhoeae-induced human defensins 5 and 6 increase HIVinfectivity: role in enhanced transmission. J Immunol. (2008) 180:6176-85.

29. Lafferty MK, Sun L, DeMasi L, Lu W, Garzino-Demo A. CCR6 ligands inhibitHIV by inducing APOBEC3G. Blood. (2010) 115:1564-71.

30. Lai Y., Gallo R. L. AMPed Up immunity: how antimicrobial peptides have multiple roles in immune defense // Trends Immunol. 2009. Vol. 30, iss. 3. P. 131-141.

31. Lehrer RI, Lu W. Alpha-Defensins in human innate immunity. Immunol Rev.(2012) 245:84112.

32. Maroti G., Kereszt A., Kondorosi E., Mergaert P. Natural roles of antimicrobial peptides in microbes,plants and animals // Res. Microbiol. 2011. Vol. 162, iss. 4. P. 363-374.

33. Mackewicz CE, Yuan J, Tran P, Diaz L, Mack E, Selsted ME, et al. alpha-Defensins can have anti-HIV activity but are not CD8 cell anti-HIV factors.AIDS. (2003) 17:F23-32.

34. Matsuzaki K. Control of cell selectivity of antimicrobial peptides // Biochim. Biophys. Acta. 2009. Vol. 1788, iss. 8. P. 1687-1692.

35. Nakashima H., Yamamoto N., Masuda M. \& Fujii N.Defensins inhibit HIV replication in vitro // AIDS 7, 1129(1993).

36. Nguyen EK, Nemerow GR, Smith JG. Direct evidence from singlecellanalysis that human alpha-defensins block adenovirus uncoating toneutralize infection. J Virol. (2010) 84:4041-9.

37. Nguyen L. T., Haney E. F., Vogel H. J. Th e expanding scope of antimicrobial peptide structures and theirmodes of action // Trends Biotechnol. 2011. Vol. 29, iss. 9. P. 464-472.

38. Nijnik A., Hancock R. E. W. Host defence peptides: antimicrobial and immunomodulatory activity andpotential applications for tackling antibiotic-resistant infections // Emerging Health Th reats J. 2009. Vol. 2. e1.URL: http://www.ehtjournal.net/index.php/ehtj/article/view/7078

39. Nordenfelt P, Tapper H. Phagosome dynamics during phagocytosis by neutrophils. J Leukoc Biol. (2011) 90:271-84.

40. O'Neil DA. Regulation of expression of beta-defensins: endogenous entericpeptide antibiotics. Mol Immunol. (2003) 40:445-50.

41. Otto M. Bacterial sensing of antimicrobial peptides // Contrib. Microbiol. 2009. Vol. 16. P. 136-149.

42. Ouellette AJ. Paneth cell alpha-defensins in enteric innate immunity. Cell MolLife Sci. (2011) 68:2215-29.

43. Pazgier M, Hoover DM, Yang D, Lu W, Lubkowski J. Human beta-defensins.Cell Mol Life Sci. (2006) 63:1294-313.

44. Porter E, Yang H, Yavagal S, Preza GC, Murillo O, Lima H, et al. Distinctdefensin profiles in Neisseria gonorrhoeae and Chlamydia trachomatisurethritis reveal novel epithelial cellneutrophil interactions. Infect Immun.(2005) 73:4823-33.

45. Pro-rich antimicrobial peptides from animals: structure, biological functions and mechanism of action/ Gennaro R., Zanetti M., Benincasa M., Podda E., Miani M. // Curr. Pharm. Des. 2002. Vol. 8, iss. 9.P. 763-778.

46. Quayle AJ, Porter EM, Nussbaum AA, Wang YM, Brabec C, Yip KP, et al.Gene expression, immunolocalization, and secretion of human defensin-5 inhuman female reproductive tract. Am J Pathol. (1998) 152:1247-58.

47. Quinones-Mateu M.E., Lederman M.M., Feng Z., Chakraborty B., Weber J., Rangel H.R., Marotta M.L., Mirza M., Jiang B., Kiser P. et al. Human epithelial beta-defensins 2 and 
3inhibit HIV-1 replication // AIDS., 17: F39-48 (2003).

48. Rahnamaeian M. Antimicrobial peptides. Modes of mechanism, modulation of defense responses// Plant Signal Behav. 2011. Vol. 6, iss. 9. P. 1325-1332.

49. Ramanathan B., Davis E. G., Ross C. R., Blecha F. Cathelicidins: microbicidal activity, mechanisms ofaction, and roles in innate immunity // Microbes Infect. 2002. Vol. 4, N 3. P. 361-372.

50. Rapista A, Ding J, Benito B, Lo YT, Neiditch MB, Lu W, et al. Humandefensins 5 and 6 enhance HIV-1 infectivity through promoting HIVattachment. Retrovirology. (2011) 8:45.

51. Role of host defense peptides of the innate immune response in sepsis / Hirsch T., Metzig M., Niederbichler A., Steinau H. U., Eriksson E., Steinstraesser L. // Shock. 2008. Vol. 30, N 2. P. 117-126.

52. Salvatore M, Garcia-Sastre A, Ruchala P, Lehrer RI, Chang T, KlotmanME. alpha-Defensin inhibits influenza virus replication by cell-mediatedmechanism(s). J Infect Dis. (2007) 196:835-43.

53. Schauber J., Gallo R. L. Antimicrobial peptides and the skin immune defense system // J. Allergy Clin.Immunol. 2008. Vol. 122, N 2. P. 261-266.

54. Semple F, Dorin JR. beta-Defensins: multifunctional modulators of infection,inflammation and more? J Innate Immun. (2012) 4:337-48.

55. Smith JG, Nemerow GR. Mechanism of adenovirus neutralization by humanalpha-defensins. Cell Host Microbe. (2008) 3:11-9.

56. Smith JG, Silvestry M, Lindert S, Lu W, Nemerow GR, Stewart PL. Insightinto the mechanisms of adenovirus capsid disassembly from studies ofdefensin neutralization. PLoS Pathog. (2010) 6:e1000959.

57. Spencer JD, Hains DS, Porter E, Bevins CL, DiRosario J, Becknell B, et al.Human alpha defensin 5 expression in the human kidney and urinary tract.PLoS One. (2012) 7:e31712.

58. Steinstraesser L., Kraneburg U., Jacobsen F., Al-Benna S. Host defense peptides and their antimicrobialimmunomodulatoryduality // Immunobiology. 2011. Vol. 216, iss. 3. P. 322323.

59. Strong synergy between a eukaryotic antimicrobial peptide and bacteriocins from lactic acid bacteria/ Luders T., Birkemo G. A., Fimland G., Nissen-Meyer J., Nes I. F. // Appl. Environ. Microbiol. 2003. Vol. 69,iss. 3. P. 1797-1799.

60. Tenge VR, Gounder AP, Wiens ME, Lu W, Smith JG. Delineation ofinterfaces on human alpha-defensins critical for human adenovirus andhuman papillomavirus inhibition. PLoS Pathog. (2014) 10:e1004360.

61. Territo M.C., Ganz T., Selsted M.E. \& Lehrer R. Monocyte-chemotactic activity of defensins from human neutrophils // J.Clin. Invest. 84, 2017-2020 (1989).

62. Tongaonkar P, Golji AE, Tran P, Ouellette AJ, Selsted ME. High fidelityprocessing and activation of the human alpha-defensin HNP1 precursor byneutrophil elastase and proteinase 3. PLoS One. (2012) 7:e32469.

63. Tosi M. F. Innate immune responses to infection//J. Allergy. Clin. Immunol. 2005. Vol. 116, N 2.P. 241-249.

64. Valere K, Rapista A, Eugenin E, Lu W, Chang TL. Human alpha-defensinHNP1 increases HIV traversal of the epithelial barrier: a potential role inSTI-mediated enhancement of HIV transmission. Viral Immunol. (2015)28:609-15.

65. Van Cleemput J, Poelaert KCK, Laval K, Vanderheijden N, Dhaenens M,Daled S, et al. An alphaherpesvirus exploits antimicrobial beta-defensins toinitiate respiratory tract infection. $\mathrm{J}$ Virol. (2020) 94:e1676-1619.

66. Wang A, Chen F, Wang Y, Shen M, Xu Y, Hu J, et al. Enhancement of antiviralactivity of 
human alpha-defensin 5 against herpes simplex virus 2 by argininemutagenesis at adaptive evolution sites. J Virol. (2013) 87:2835-45.

67. Wiens ME, Smith JG. Alpha-Defensin HD5 inhibits furin cleavage of humanpapillomavirus 16 L2 to block infection. J Virol. (2015) 89:2866-74.

68. Wiens ME, Smith JG. Alpha-Defensin HD5 inhibits human papillomavirus16 infection via capsid stabilization and redirection to the lysosome. mBio.(2017) 8:e2304-16.

69. Wiesner J., Vilcinskas A. Antimicrobial peptides: the ancient arm of the human immune system //Virulence. 2010. Vol. 1, iss. 5. P. 440-464.

70. Wilde CG, Griffith JE, Marra MN, Snable JL, Scott RW. Purification andcharacterization of human neutrophil peptide 4, a novel member of thedefensin family. J Biol Chem. (1989) 264:11200-3.

71. Wimley W. C. Describing the mechanism of antimicrobial peptide action with the interfacial activitymodel//ACS Chem. Biol. 2010. Vol. 5, N 10. P. 905-917.

72. Wimley W. C., Hristova K. Antimicrobial peptides: successes, challenges and unanswered questions//J. Membr. Biol. 2011. Vol. 239, iss. 1-2. P. 27-34.

73. Zaiou M., Gallo R. L. Cathelicidins, essential gene-encoded mammalian antibiotics // J. Mol. Med.2002. Vol. 80, N 9. P. 549-561.

74. Zanetti M. Th e role of cathelicidins in the innate host defenses of mammals // Curr. Issues Mol. Biol.2005. Vol. 7. P. 179-196.

75. Zhang L., Yu W., He T. et al. Contribution of human $\square$-defensin 1, 2, and 3 to the anti-HIV-1 activity of CD8 antiviralfactor // Science, 298: 995-1000 (2002).

76. Zins SR, Nelson CDS, Maginnis MS, Banerjee R, O'Hara BA, Atwood WJ.The human alpha defensin HD5 neutralizes JC polyomavirus infection byreducing endoplasmic reticulum traffic and stabilizing the viral capsid. J Virol.(2014) 88:948-60.

77. Yang D., Chen Q., Chertov O. \& Oppenheim J.J. Humanneutrophil defensins selectively chemoattract naive $\mathrm{T}$ and immaturedendritic cells//J. Leukoc. Biol. 68, 9-14 (2000).

78. Yasin B, Wang W, Pang M, Cheshenko N, Hong T, Waring AJ, et al. Thetadefensins protect cells from infection by herpes simplex virus by inhibitingviral adhesion and entry. J Virol. (2004) 78:5147-56.

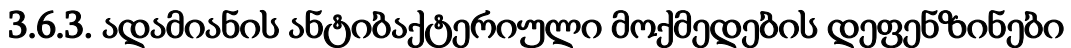

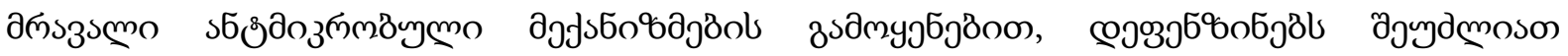

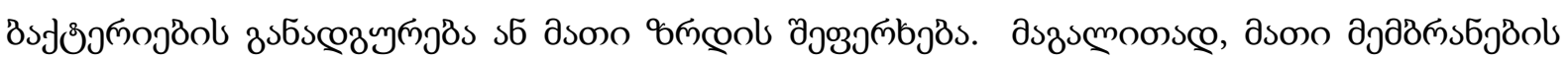

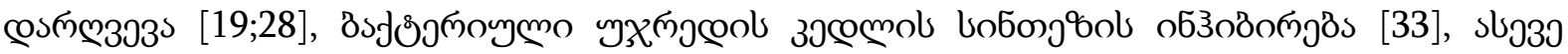

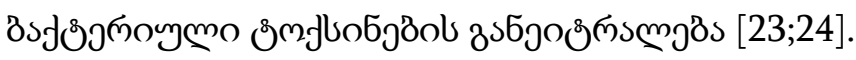

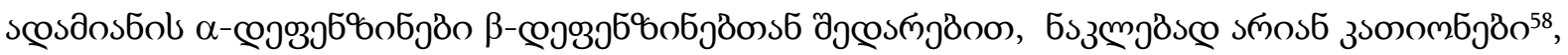

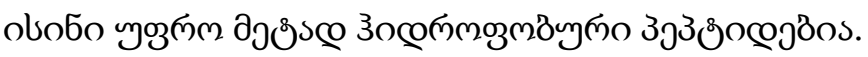

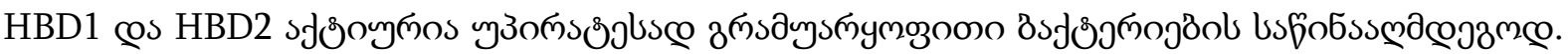

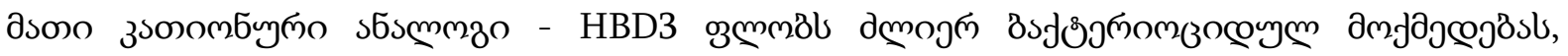

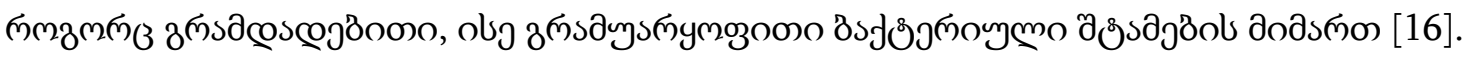

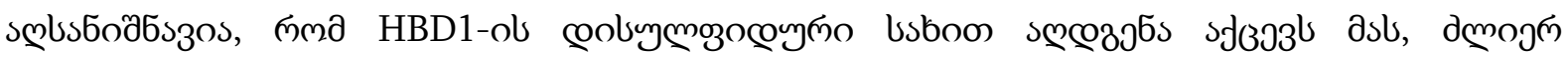

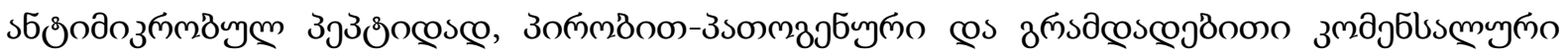

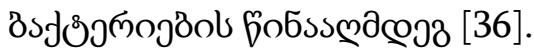

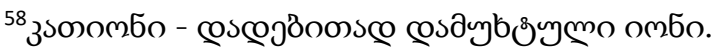




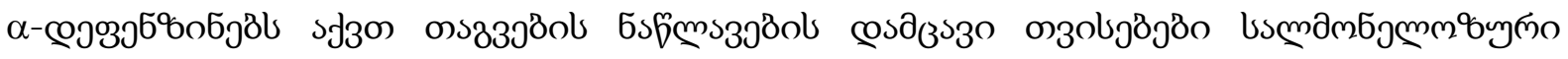

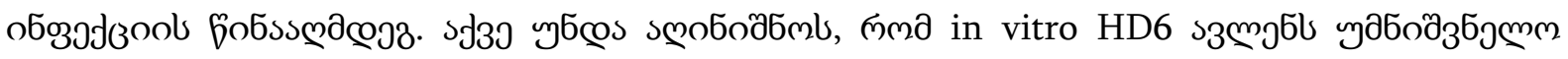

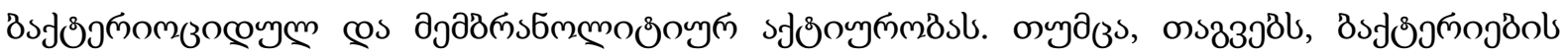

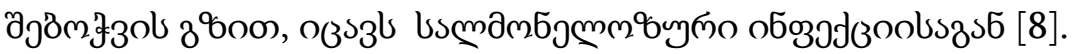

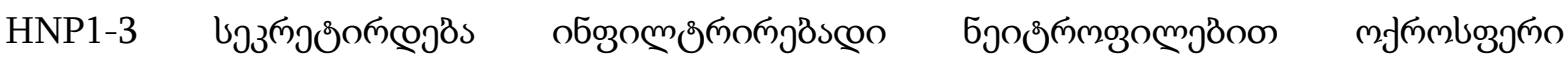

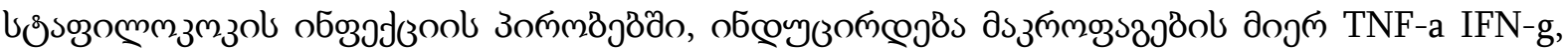

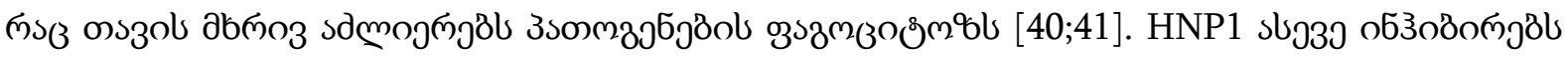

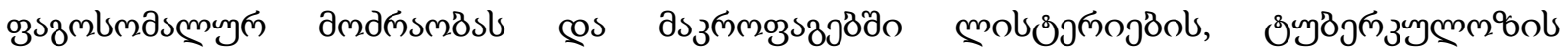

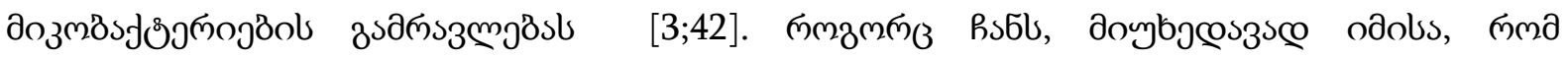

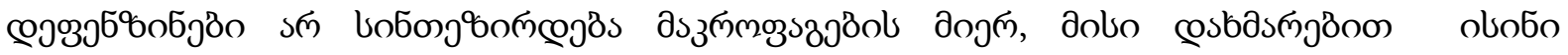

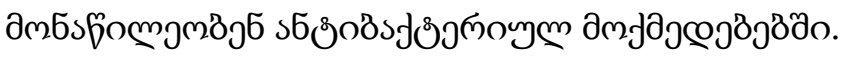

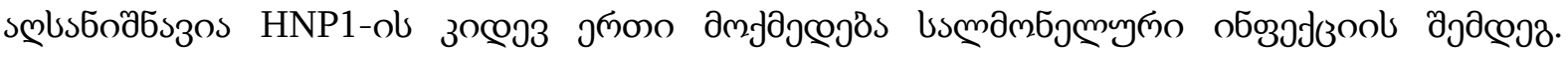

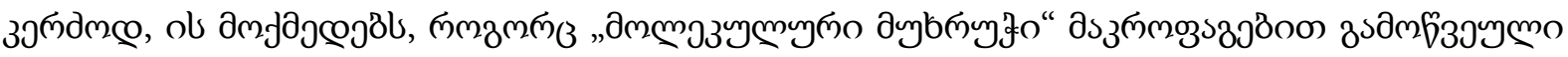

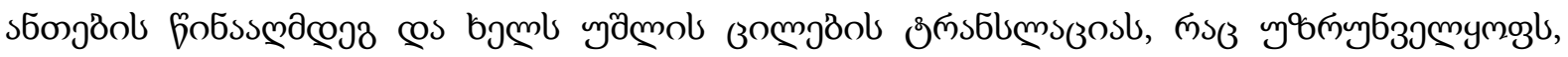

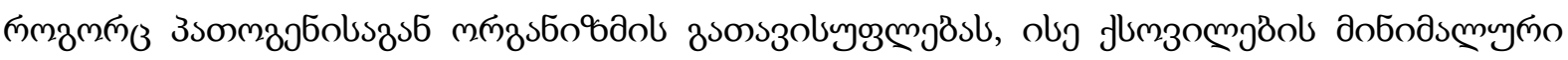

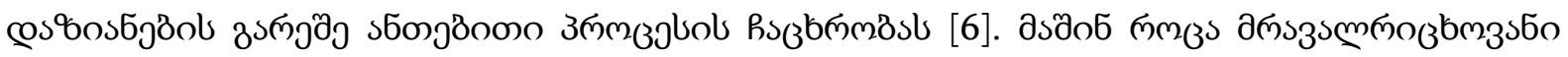

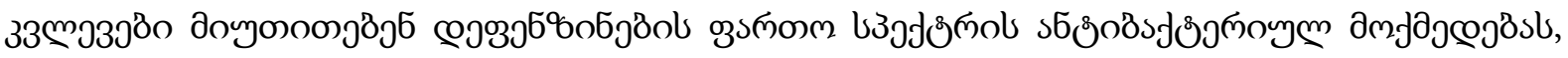

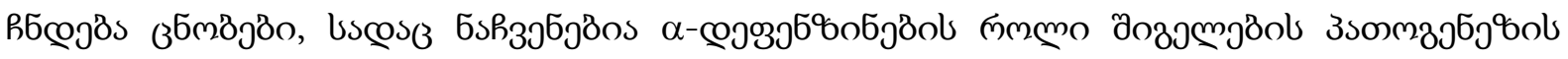

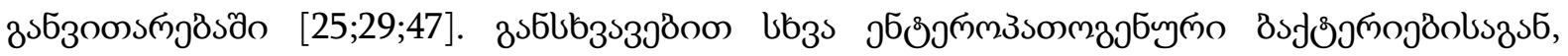

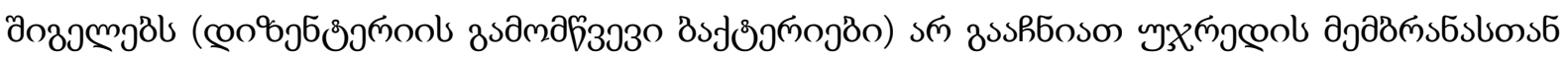

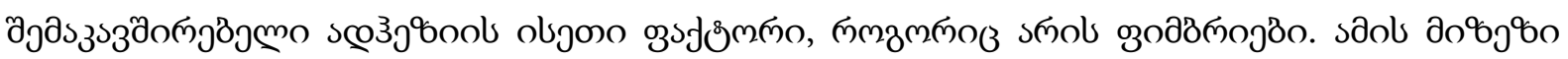

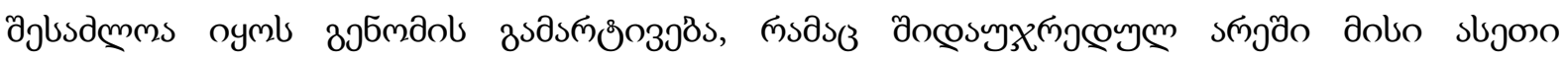

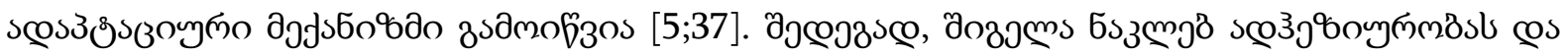

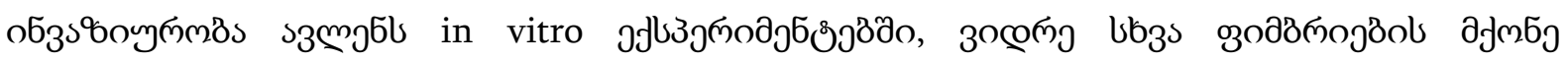

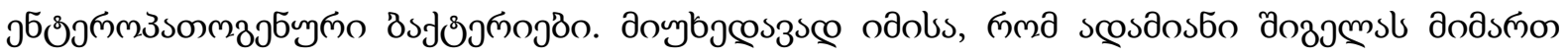

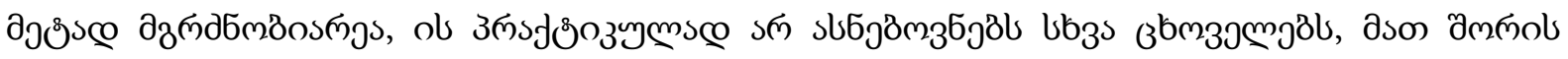

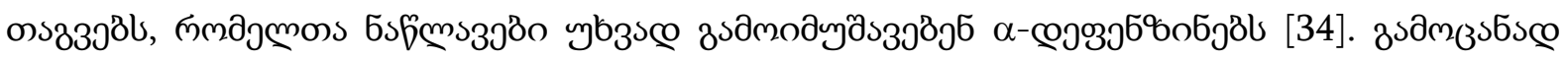

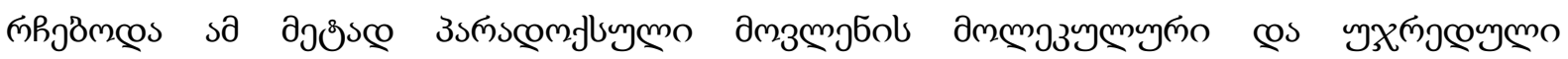

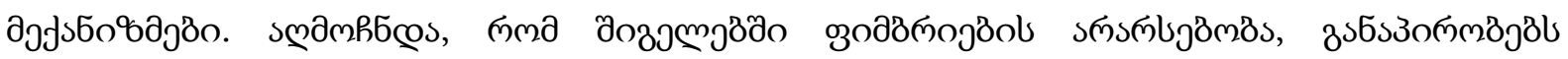

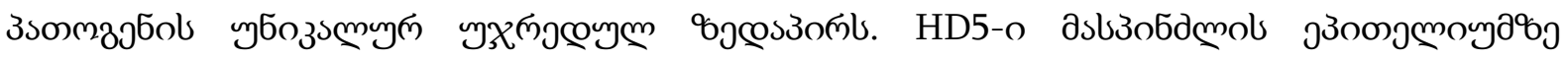

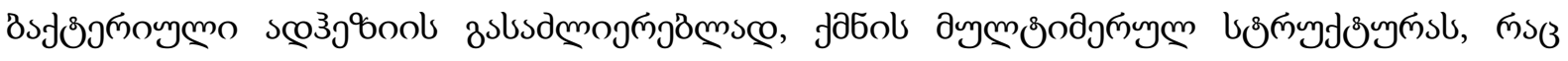

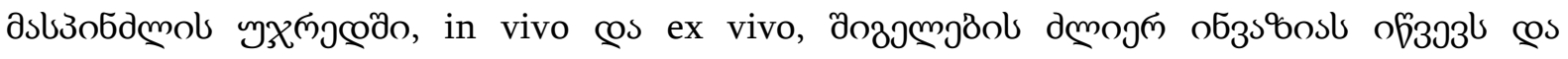

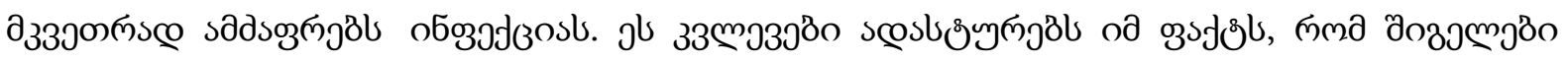

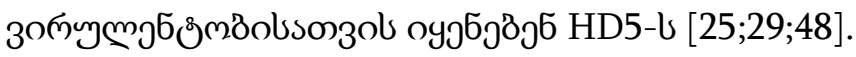

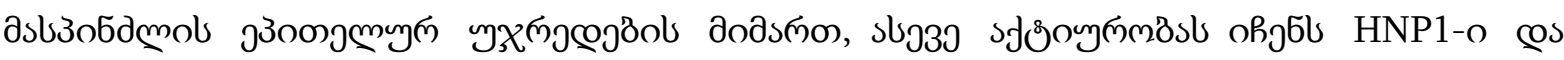

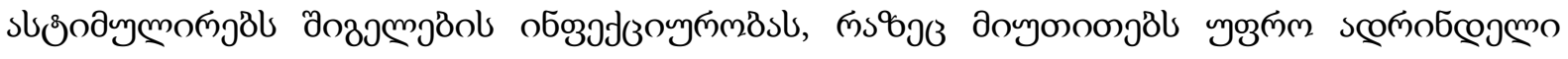

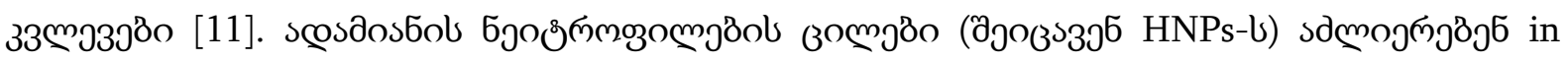

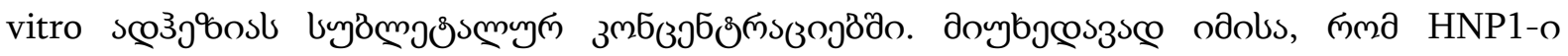

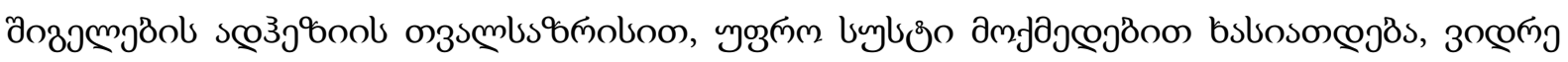

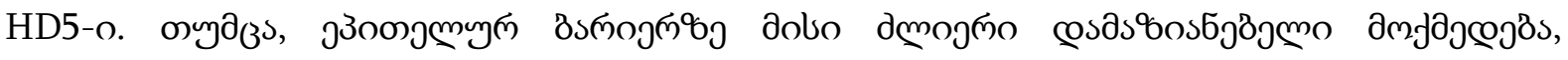

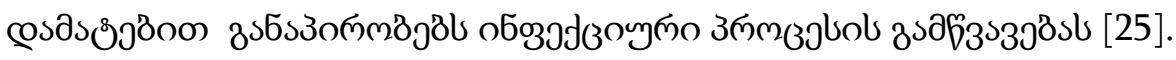




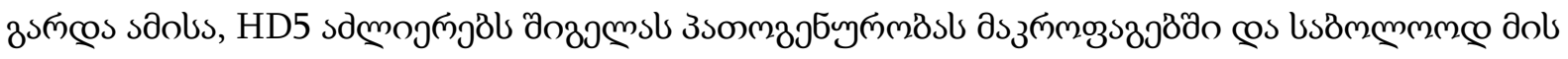

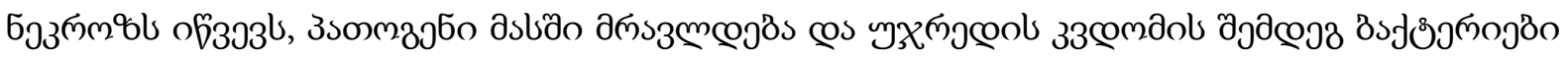

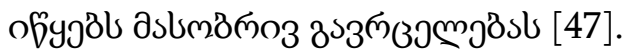

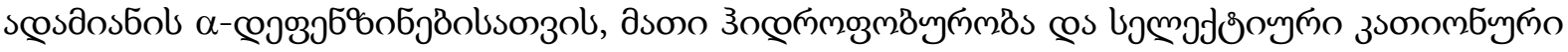

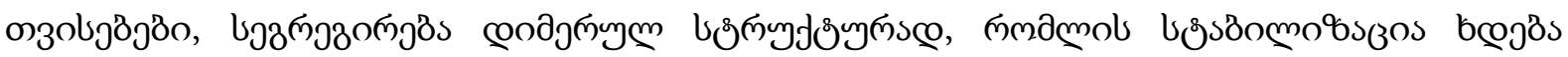

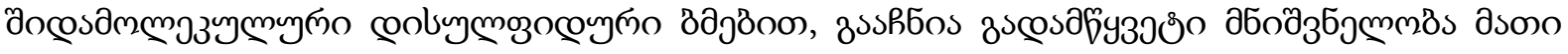

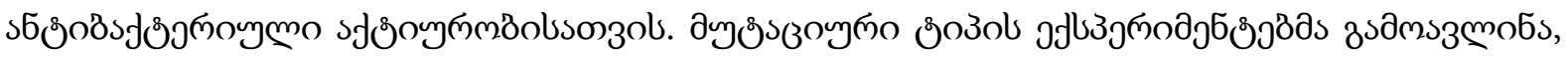

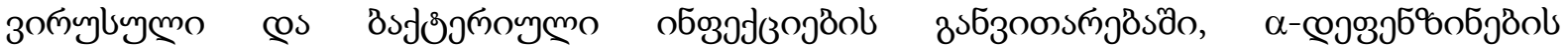

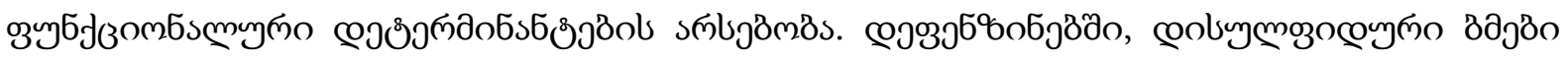

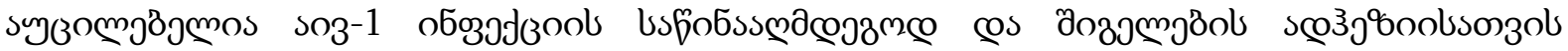

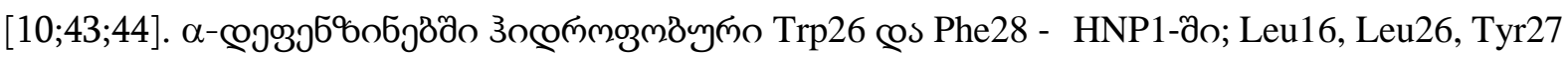

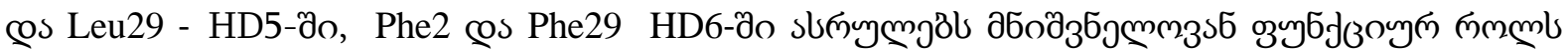
$[5 ; 47 ; 48]$.

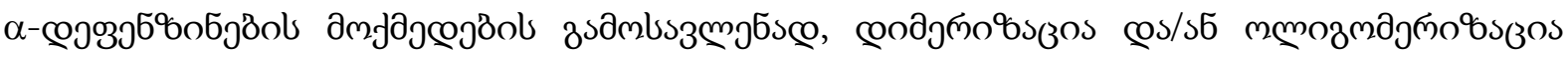

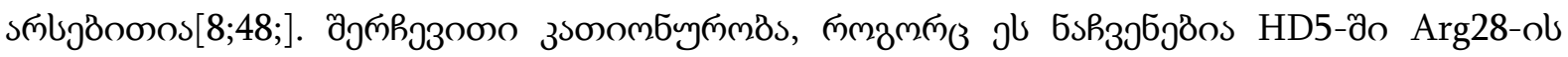

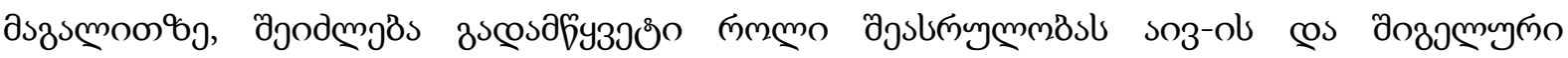

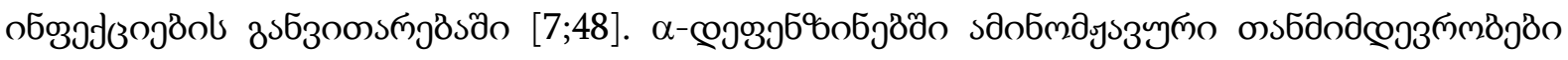

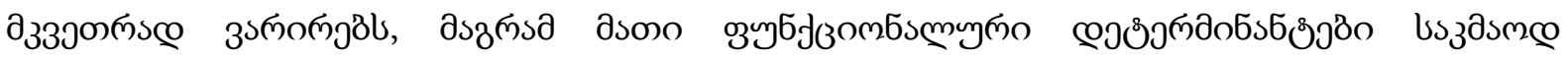

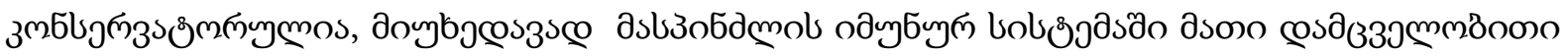
пmmols.

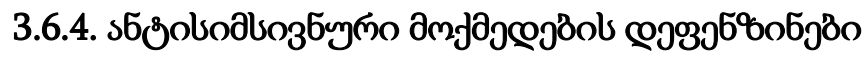

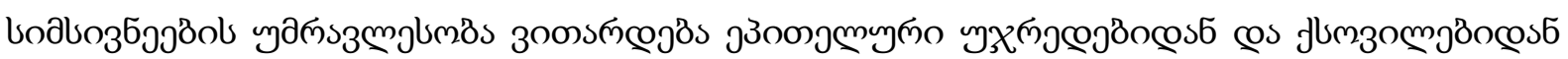

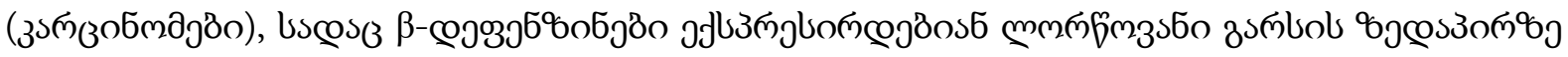

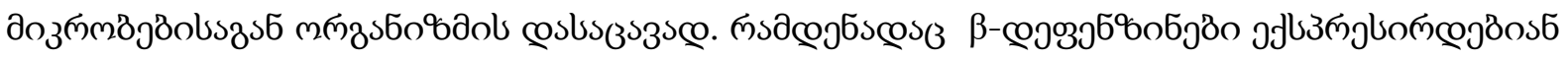

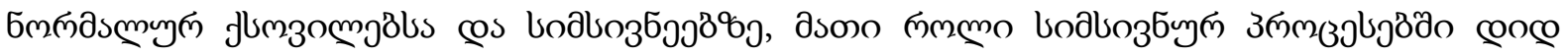

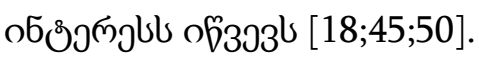

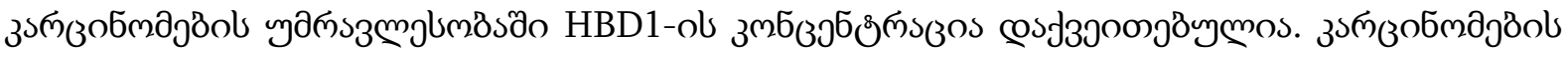

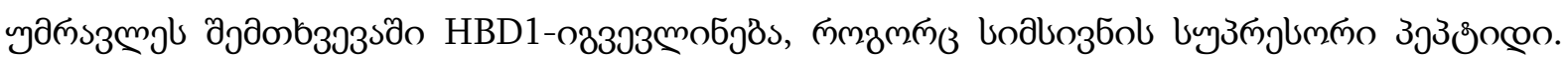

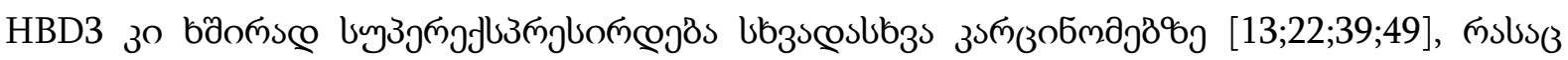

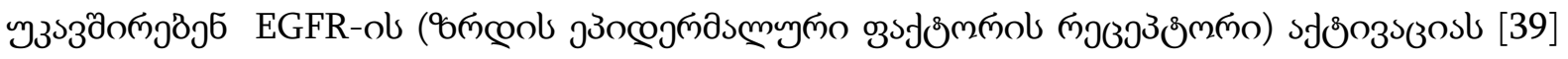

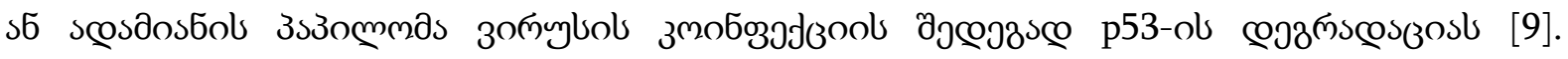

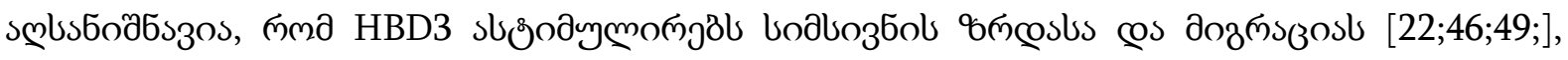

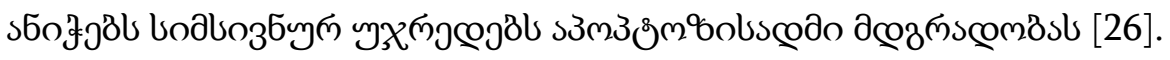

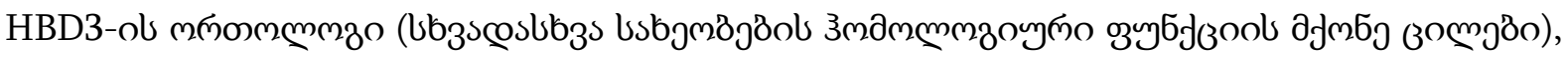

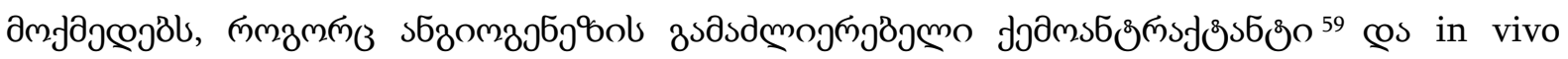

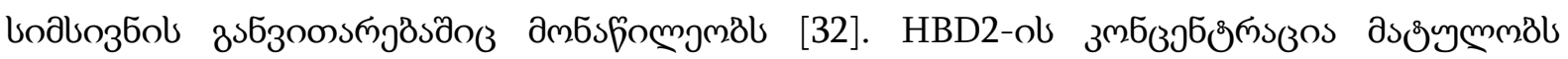

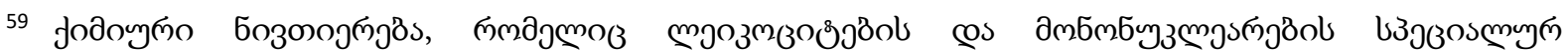

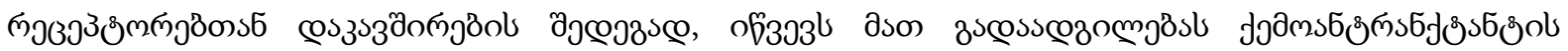

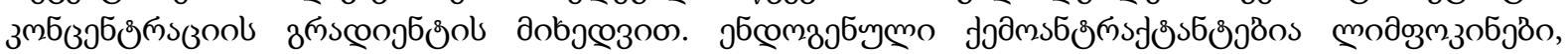

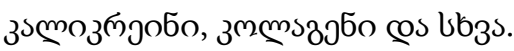




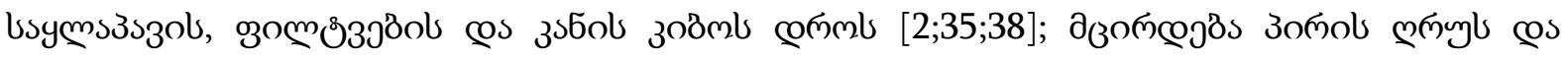

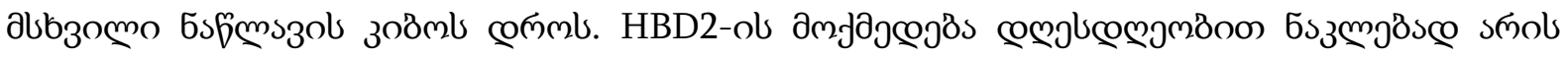

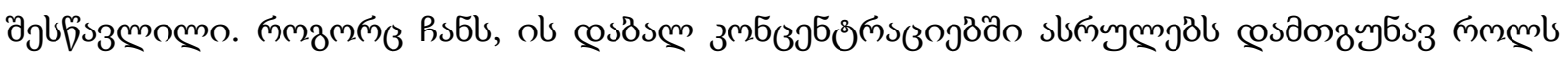

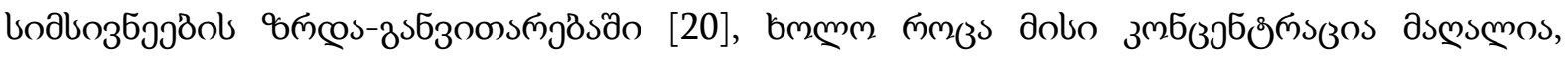

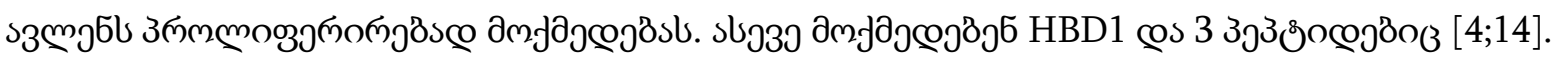

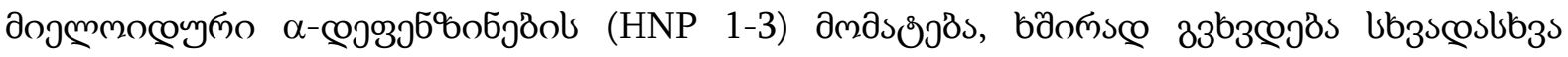

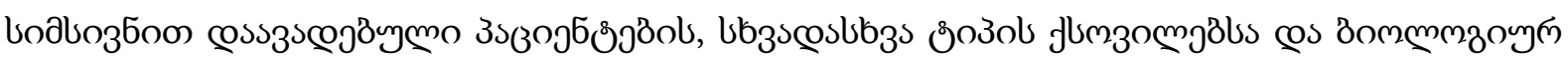

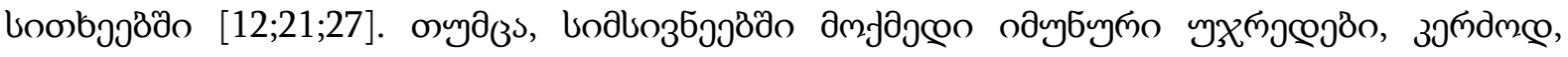

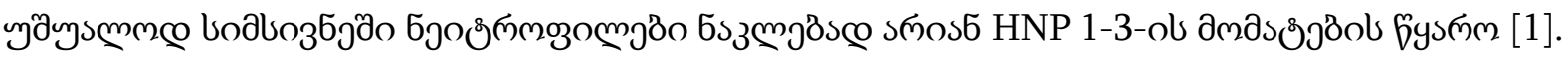

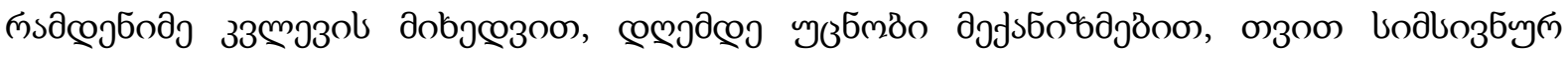

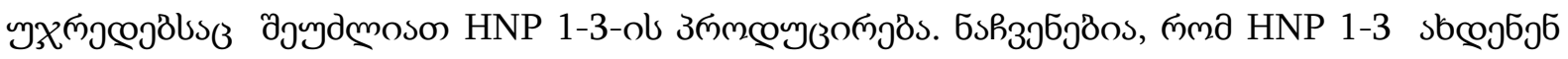

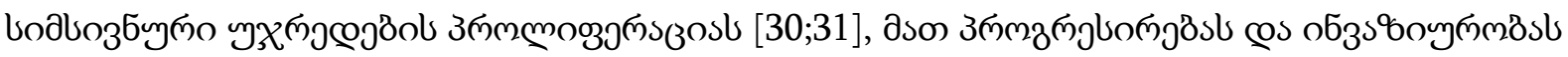
$[15 ; 17]$.

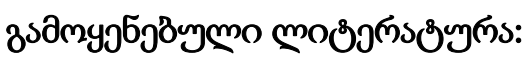

1. Albrethsen J, Bøgebo R, Gammeltoft S, Olsen J, Winther B, Raskov H. Upregulated expression of human neutrophil peptides 1, 2 and 3 (HNP 1-3) in colon cancer serum and tumours: a biomarker study. BMC Cancer. (2005)5:8. doi: 10.1186/1471-2407-5-8

2. Arinura Y, Ashitani J, Yanagi S, Tokojima M, Abe K, Mukae H, et al. Elevatedserum bdefensins concentrations in patients with lung cancer. AnticancerRes. (2004) 24:4051-8.

3. Arnett E, Lehrer RI, Pratikhya P, Lu W, Seveau S. Defensins enablemacrophages to inhibit the intracellular proliferation of Listeriamonocytogenes. Cell Microbiol. (2011) 13:635-51.

4. Baroni A, Donnarumma G, Paoletti I, Longanesi-Cattani I, Bifulco K, TufanoMA, et al. Antimicrobial human beta-defensin-2 stimulates migration,proliferation and tube formation of human umbilical vein endothelial cells.Peptides. (2009) 30:267-72.

5. Bravo V, Puhar A, Sansonetti P, Parsot C, Toro CS. Distinct mutations led toinactivation of Type 1 fimbriae expression in Shigella spp. PLoS One. (2015)10:e0121785.

6. Brook M, Tomlinson GH, Miles K, Smith RWP, Rossi AG, Hiemstra PS, et al. Neutrophilderived alpha defensins control inflammation by inhibitingmacrophage mRNA translation. Proc Natl Acad Sci USA. (2016) 113:4350.

7. Chairatana P, Nolan EM. Molecular basis for self-assembly of a human hostdefensepeptide that entraps bacterial pathogens. J Am Chem Soc. (2014)136:13267-76.

8. Chu H, Pazgier M, Jung G, Nuccio S-P, Castillo PA, de Jong MF, et al. Humanalpha-defensin 6 promotes mucosal innate immunity through self-assembledpeptide nanonets. Science. (2012) 337:477-81.

9. DasGupta T, Nweze EI, Yue H, Wang L, Jin J, Ghosh SK, et al. Humanpapillomavirus oncogenic E6 protein regulates human b-defensin 3 (hBD3)expression via the tumor suppressor protein p53. Oncotarget. (2016) 7:27430-44.

10. Ding J, Rapista A, Teleshova N, Lu W, Klotman ME, Chang TL. Mucosalhuman defensins 5 and 6 antagonize the anti-HIV activity of candidatepolyanion microbicides. J Innate Immun. (2011) 3:208-12.

11. Eilers B, Mayer-Scholl A, Walker T, Tang C, Weinrauch Y, Zychlinsky A.Neutrophil antimicrobial proteins enhance Shigella flexneri adhesion andinvasion. Cell Microbiol. (2010) 12:1134-43. 
12. Escher N, Spies-Weißhart B, Kaatz M, Melle C, Bleul A, Driesch D, et al.Identification of HNP3 as a tumour marker in CD4+ and CD4- lymphocytesof patients with cutaneous T-cell lymphoma. Eur J Cancer. (2006) 42:249-55.

13. Fathy H, Amin MM, El-Gilany A-H. Upregulation of human b-defensin-3and cathelicidin LL-37 in Kaposi's sarcoma. F1000Res. (2012) 1:38.

14. Gao C, Yue W, Tian H, Li L, Li S, Si L. Human beta-defensin 2 promotes theproliferation of lung cancer cells through ATP-binding cassette transporterG2. Int J Clin Exp Pathol. (2016) 9:5944-9.140.

15. Gunes M, Gecit I, Pirincci N, Kemik AS, Purisa S, Ceylan K, et al. Plasmahuman neutrophil proteins-1, -2, and -3 levels in patients with bladdercancer. J Cancer Res Clin Oncol. (2013) 139:195-9.

16. Harder J, Bartels J, Christophers E, Schroder JM. Isolation andcharacterization of human beta -defensin-3, a novel human induciblepeptide antibiotic. J Biol Chem. (2001) 276:5707-13.

17. Holterman DA, Diaz JI, Blackmore PF, Davis JW, Schellhammer PF, CoricaA, et al. Overexpression of a-defensin is associated with bladder cancerinvasiveness. Urol Oncol Sem Orig Investigat. (2006) 24:97-108.

18. Jin G, Weinberg A. Human antimicrobial peptides and cancer. Semin CellDev Biol. (2019) 88:156-62.

19. Kagan BL, Selsted ME, Ganz T, Lehrer RI. Antimicrobial defensinpeptides form voltagedependent ion-permeable channels inplanar lipid bilayer membranes. Proc Natl Acad Sci USA. (1990)87:210-4.

20. Kamino Y, Kurashige Y, Uehara O, Sato J, Nishimura M, Yoshida K, et al.HBD-2 is downregulated in oral carcinoma cells by DNA hypermethylation, and increased expression of hBD-2 by DNA demethylation and genetransfection inhibits cell proliferation and invasion. Oncol Rep. (2014)32:462-8.

21. Kemik O, Kemik AS, Sumer A, Begenik H, Purisa S, Tuzun S. Humanneutrophil peptides 1, 2 and 3 (HNP 1-3): elevated serum levels in colorectalcancer and novel marker of lymphatic and hepatic metastasis. Hum ExpToxicol. (2011) 32:167-71.

22. Kesting MR, Loeffelbein DJ, Hasler RJ, Wolff K-D, Rittig A, Schulte M, et al.Expression profile of human beta-defensin 3 in oral squamous cell carcinoma.Cancer Investigat. (2009) 27:575-81.

23. Kim C, Gajendran N, Mittrücker H-W, Weiwad M, Song Y-H, Hurwitz R,et al. Human alphadefensins neutralize anthrax lethal toxin and protectagainst its fatal consequences. Proc Natl Acad Sci USA. (2005) 102:4830-5.

24. Lehrer RI, Jung G, Ruchala P, Wang W, Micewicz, Waring AJ, et al. Humanalpha-defensins inhibit hemolysis mediated by cholesterol-dependentcytolysins. Infect Immun. (2009) 77:4028-40.

25. Liao C, Fang K, Xiao J, Zhang W, Zhang B, Yuan W, et al. Criticaldeterminants of human neutrophil peptide 1 for enhancing host epithelialadhesion of Shigella flexneri. Cell Microbiol. (2019) 21:e13069.

26. Mburu YK, Abe K, Ferris LK, Sarkar SN, Ferris RL. Human b-defensin3 promotes NF-kBmediated CCR7 expression and anti-apoptotic signalsin squamous cell carcinoma of the head and neck. Carcinogenesis. (2011)32:168-74.

27. Mothes H, Melle C, Ernst G, Kaufmann R, von Eggeling F, Settmacher U.Human Neutrophil Peptides 1-3-early markers in development of colorectaladenomas and carcinomas. Dis Markers. (2008) 25:123-9 
28. Munch D, Sahl HG. Structural variations of the cell wall precursor lipid Ilin Gram-positive bacteria - Impact on binding and efficacy of antimicrobialpeptides. Biochim Biophys Acta. (2015) 1848(11 Pt B):3062-71.

29. Murphy AG,Maloy KJ. Defens-IN! human a-defensin 5 Acts as an unwittingdouble agent to promote Shigella infection. Immunity. (2018) 48:1070-2.

30. Nishimura M, Abiko Y, Kurashige Y, Takeshima M, Yamazaki M, Kusano K, et al. Effect of defensin peptides on eukaryotic cells: primary epithelial cells,fibroblasts and squamous cell carcinoma cell lines. J Dermatol Sci. (2004)36:87-95.

31. Roesch-Ely M, Nees M, Karsai S, Ruess A, Bogumil R, Warnken U, et al.Proteomic analysis reveals successive aberrations in protein expression fromhealthy mucosa to invasive head and neck cancer. Oncogene. (2007) 26:54-64.

32. Rohrl J, Huber B, Koehl GE, Geissler EK, Hehlgans T. Mouse b-Defensin 14 Defb14 promotes tumor growth by inducing angiogenesis in a CCR6-dependent manner. J Immunol. (2012) 188:4931.

33. Schneider T, Kruse T,Wimmer R,Wiedemann I, Sass V, PagU, et al. Plectasin,a fungal defensin, targets the bacterial cell wall precursor lipid II. Science.(2010) 328:1168.mediated by cholesterol-dependentcytolysins. Infect Immun. (2009) 77:4028-40.

34. Schnupf P, Sansonetti PJ. Shigella pathogenesis: new insights throughadvanced methodologies. Microbiol Spect. (2019) 7:BAI-0023-2019.

35. Scola N, Gambichler T, Saklaoui H, Bechara FG, Georgas D, Stücker M,et al. The expression of antimicrobial peptides is significantly altered incutaneous squamous cell carcinoma and precursor lesions. Br J Dermatol.(2012) 167:591-7.

36. Schroeder BO, Wu Z, Nuding S, Groscurth S, Marcinowski M, Beisner J,et al. Reduction of disulphide bonds unmasks potent antimicrobial activityof human beta-defensin 1. Nature. (2011) 469:419-23.

37. Schroeder GN, Hilbi H. Molecular pathogenesis of Shigella spp.: controllinghost cell signaling. Invasion, and death by type III secretion. Clin MicrobiolRev. (2008) 21:134-56.

38. Shi N, Jin F, Zhang X, Clinton SK, Pan Z, Chen T. Overexpression ofhuman b-defensin 2 promotes growth and invasion during esophagealcarcinogenesis. Oncotarget. (2014) 5:1133344.

39. Shuyi Y, Feng W, Jing T, Hongzhang H, Haiyan W, Pingping M, et al. Humanbeta-defensin3 (hBD-3) upregulated by LPS via epidermal growth factorreceptor (EGFR) signaling pathways to enhance lymphatic invasion of oralsquamous cell carcinoma. Oral Surgery Oral Med Oral Pathol Oral RadiolEndodontol. (2011) 112:616-25.

40. Soehnlein O, Kai-Larsen Y, Frithiof R, Sorensen OE, Kenne E, Scharffetter-Kochanek K, et al. Neutrophil primary granule proteins HBP and HNP1-3boost bacterial phagocytosis by human and murine macrophages. J ClinInvest. (2008) 118:3491-502.

41. Soehnlein O, Kenne E, Rotzius P, Eriksson EE, Lindbom L. Neutrophilsecretion products regulate anti-bacterial activity in monocytes andmacrophages. Clin Exp Immunol. (2008) 151:139-45.

42. Tan BH, Meinken C, Bastian M, Bruns H, Legaspi A, Ochoa MT, et al.Macrophages acquire neutrophil granules for antimicrobial activity againstintracellular pathogens. J Immunol. (2006) 177:1864.

43. Valere K, Lu W, Chang TL. Key determinants of human alpha-defensin 5 and6 for enhancement of HIV infectivity. Viruses. (2017) 9:244.

44. Valere K, Rapista A, Eugenin E, Lu W, Chang TL. Human alpha-defensinHNP1 increases HIV traversal of the epithelial barrier: a potential role inSTI-mediated enhancement of HIV transmission. Viral Immunol. (2015)28:609-15. 
45. Weinberg A, Jin G, Sieg S,McCormick TS. The yin and yang of human Beta-defensinsin health and disease. Front Immunol. (2012) 3:294. doi: 10.3389/fimmu.2012.00294

46. Winter J, Pantelis A, Reich R, Martini M, Kraus D, Jepsen S, et al.Human beta-defensin-1, -2, and -3 exhibit opposite effects on oralsquamous cell carcinoma cell proliferation. Cancer Investigat. (2011)29:196-201.

47. Xu D, Liao C, Xiao J, Fang K, Zhang W, Yuan W, et al. Human entericdefensin 5 promotes Shigella infection of macrophages. Infect Immun. (2019)88:e769-719.

48. Xu D, Liao C, Zhang B, Tolbert WD, He W, Dai Z, et al. Human Entericalpha-defensin 5 Promotes Shigella infection by enhancing bacterial adhesionand invasion. Immunity. (2018) 48:1233-44e6.

49. Xu D, Zhang B, Liao C, Zhang W, Wang W, Chang Y, et al. Human betadefensin3 contributes to the carcinogenesis of cervical cancer via activationof NF-kB signaling. Oncotarget. (2016) 7:75902-13.

50. Yang D,Han Z, Oppenheim JJ. Alarmins and immunity. Immunol Rev. (2017)280:41-56.

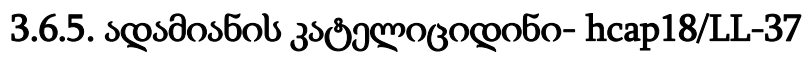

- азопочумо озмпдулмз: $\mathrm{C}_{205} \mathrm{H}_{341} \mathrm{~N}_{61} \mathrm{O}_{52}$.

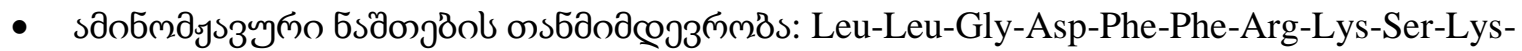
Glu-Lys-Ile-Gly-Lys-Glu-Phe-Lys-Arg-Ile-Val-Gln-Arg-Ile-Lys-Asp-Phe-Leu-Arg-Asn-LeuVal-Pro-Arg-Thr-Glu-Ser-NH

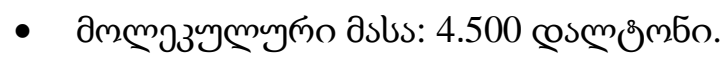

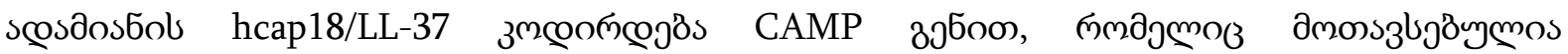

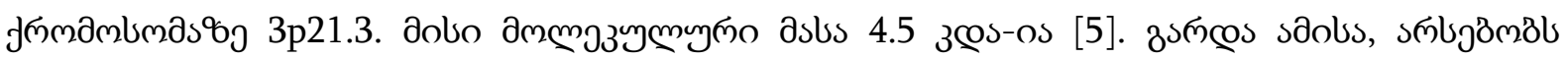

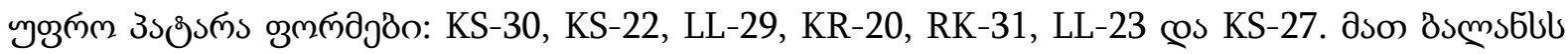

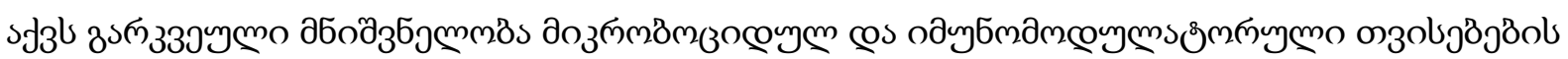

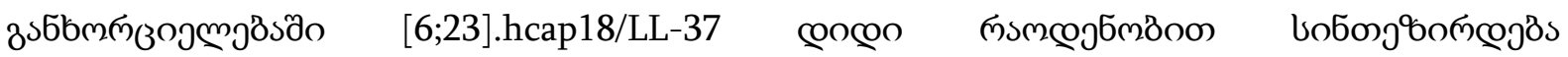

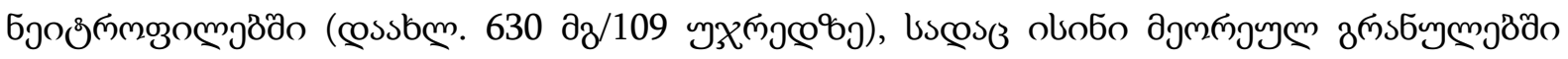

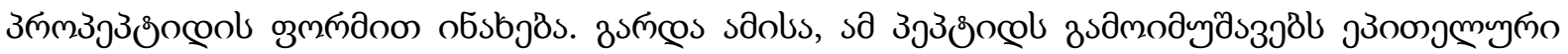

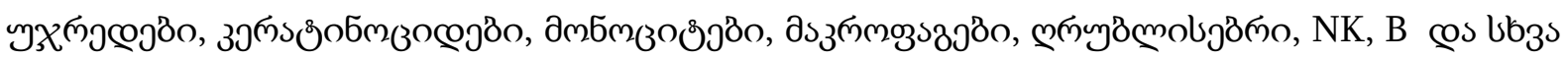

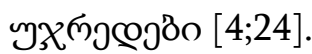

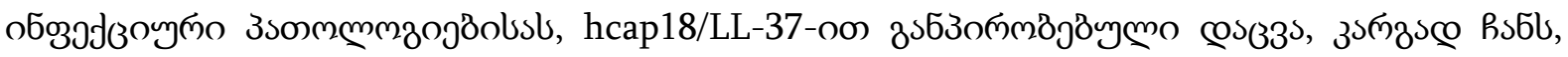

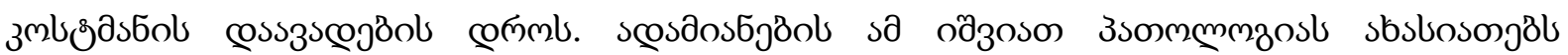

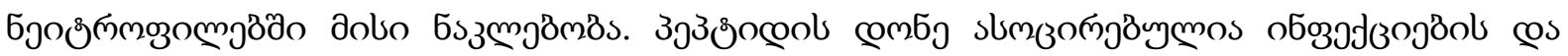

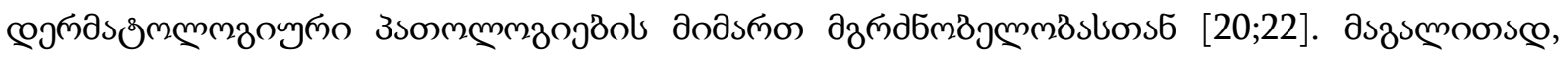

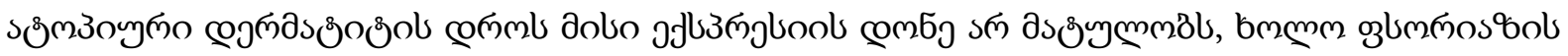

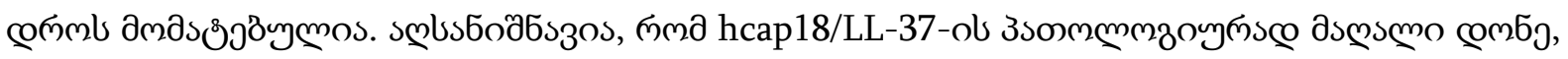

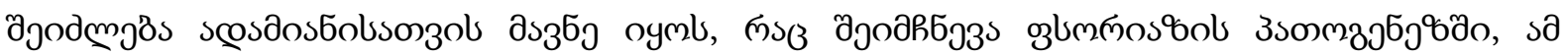

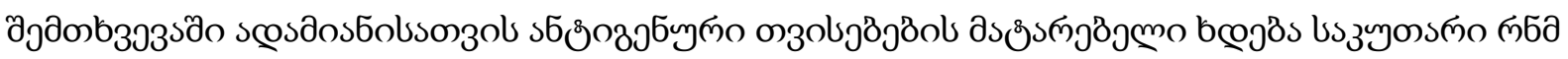

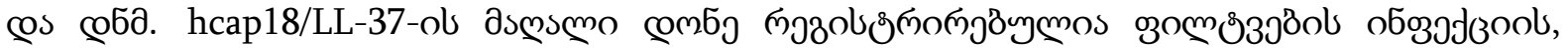

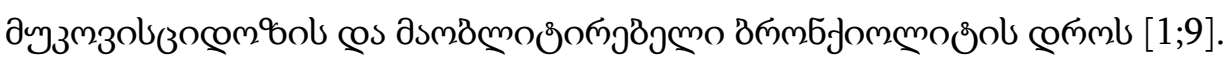




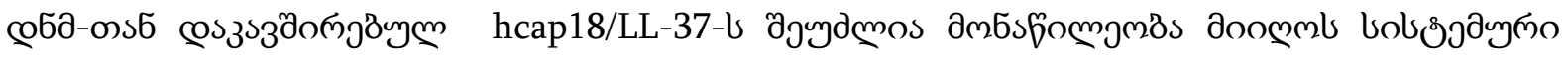

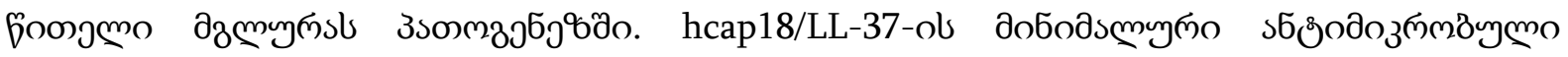

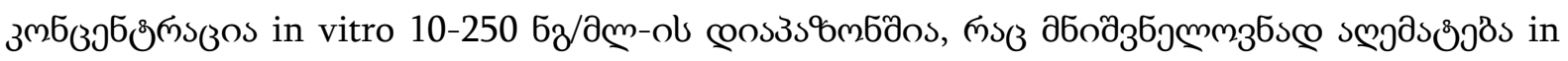

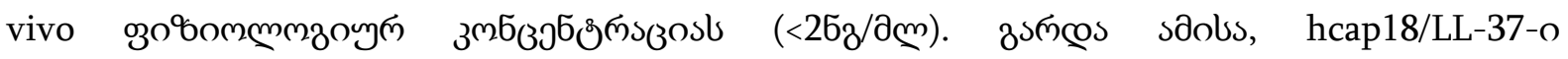

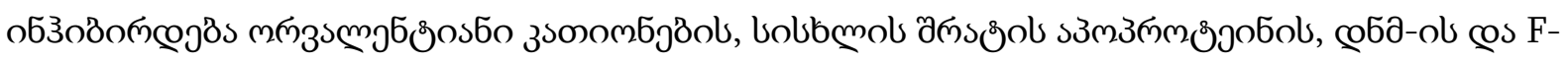

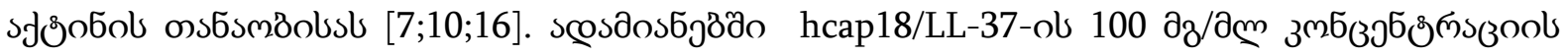

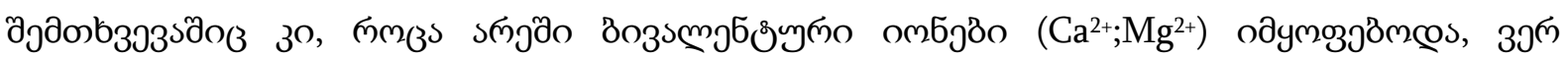

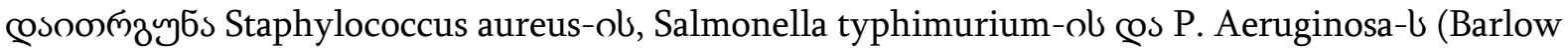

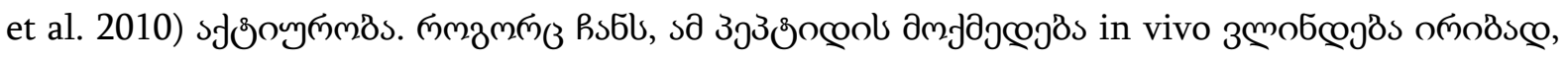

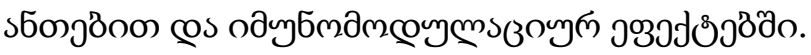

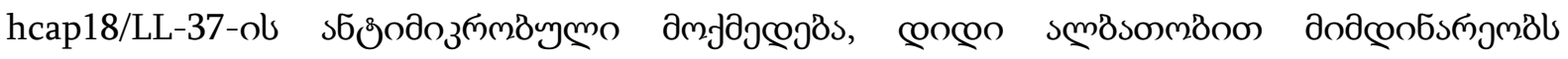

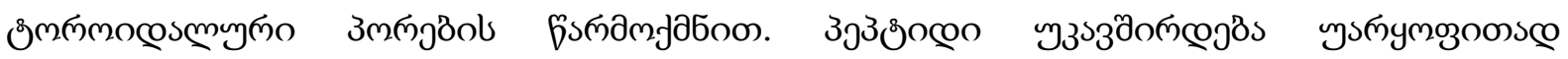

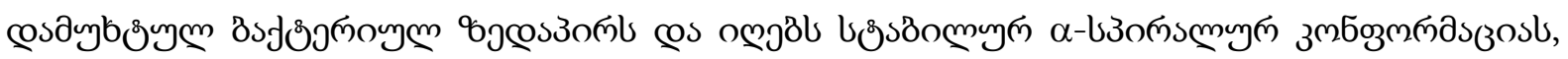

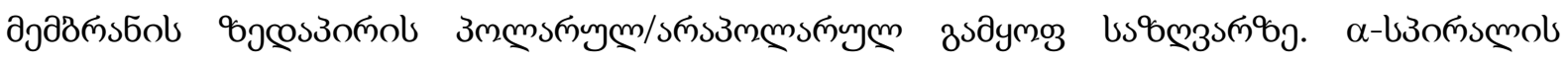

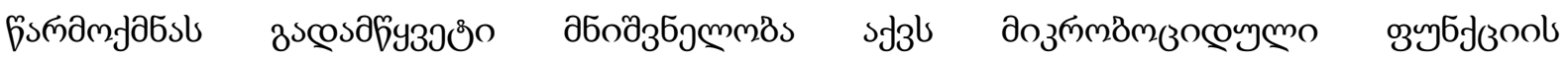

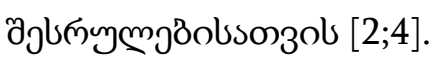

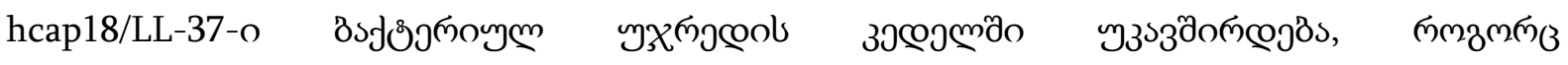

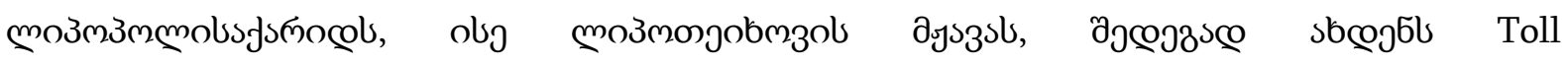

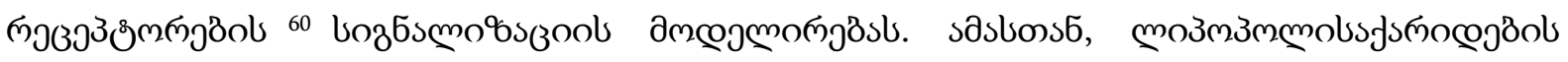

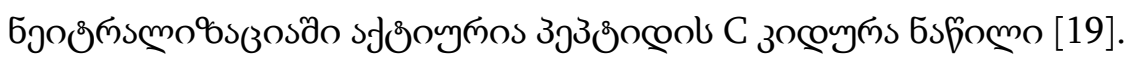

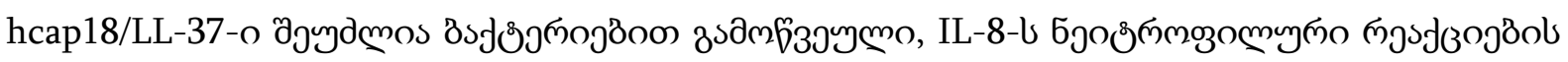

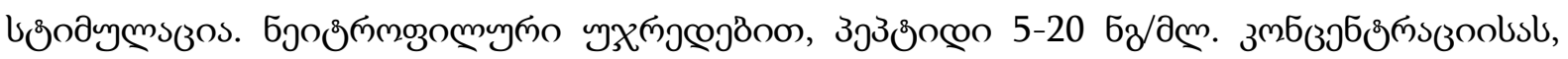

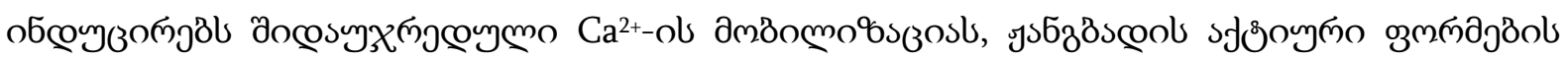

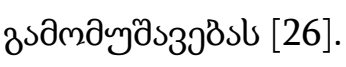

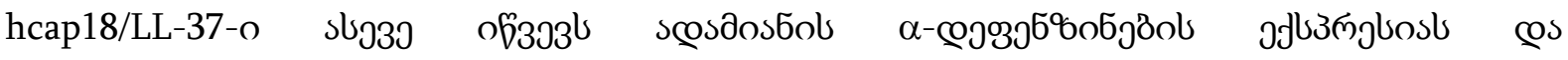

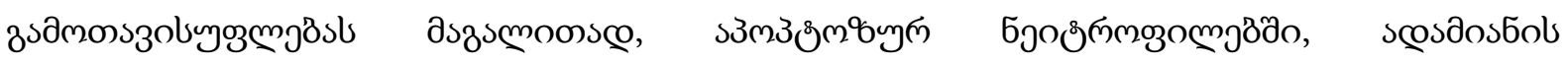

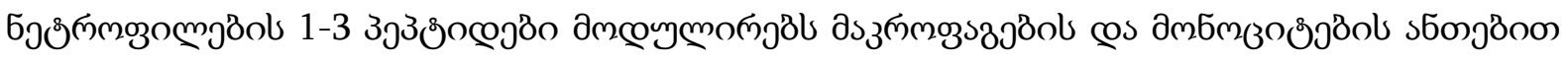

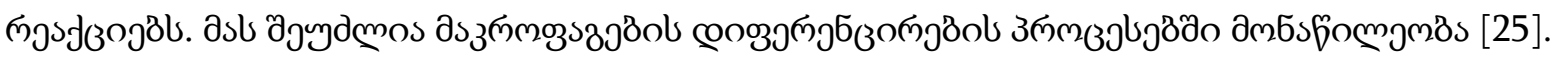

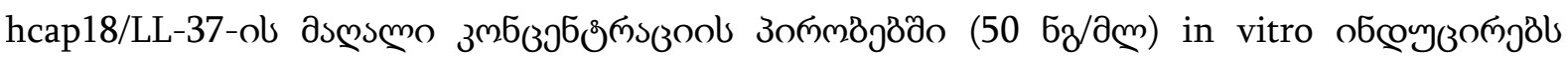

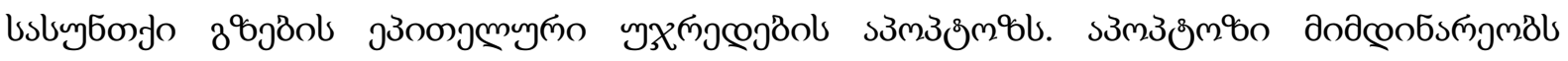

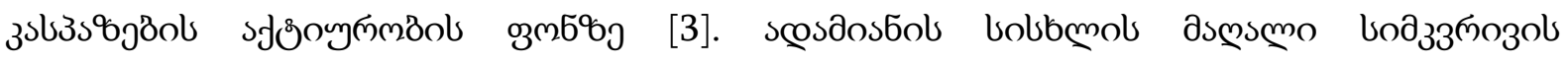

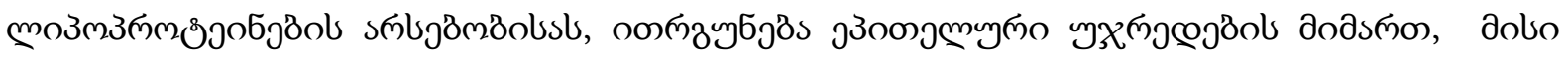

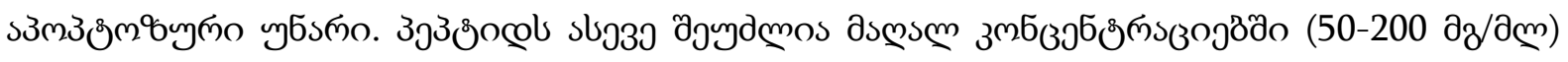

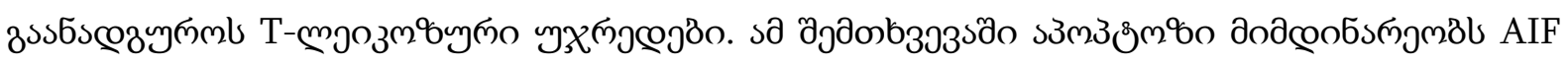

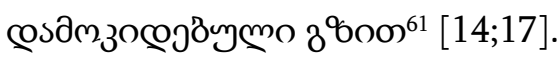

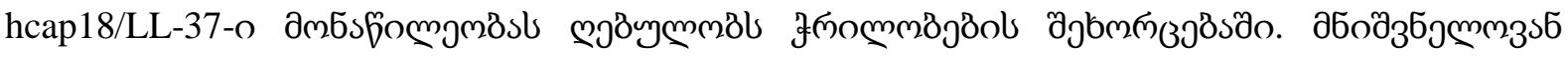

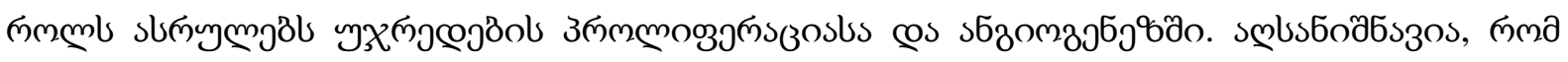

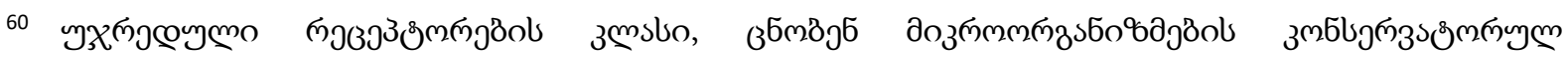

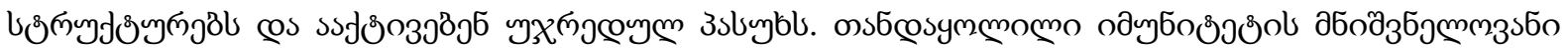

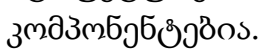

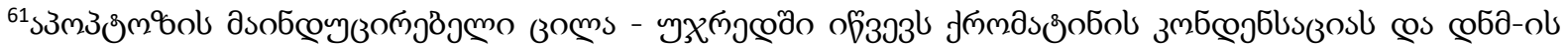

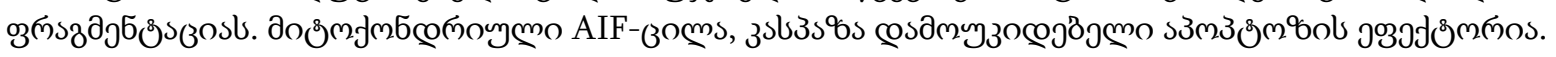




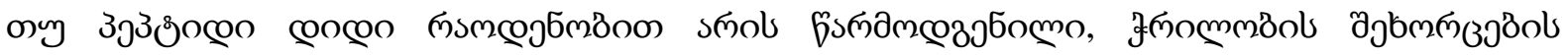

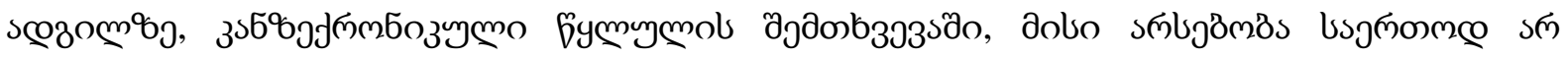

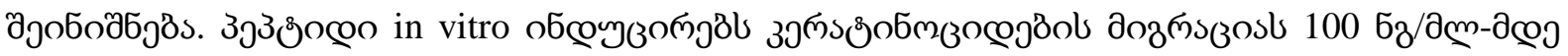

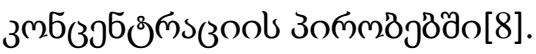

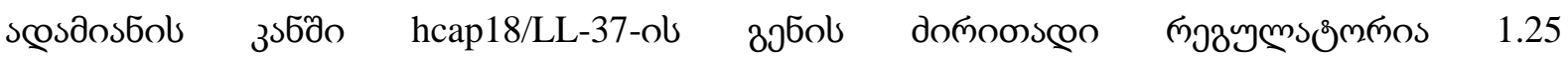

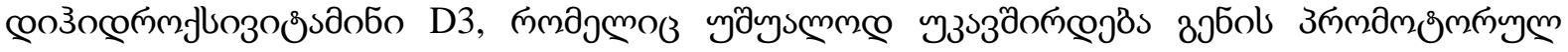

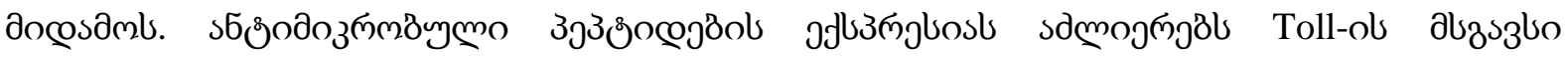

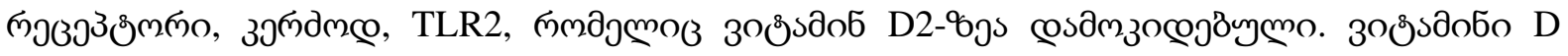

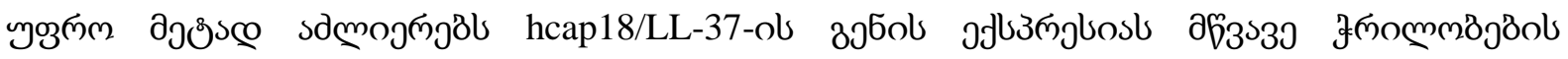

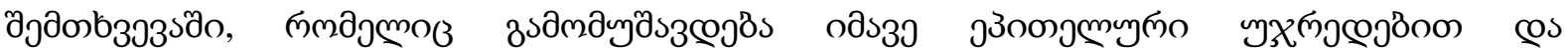

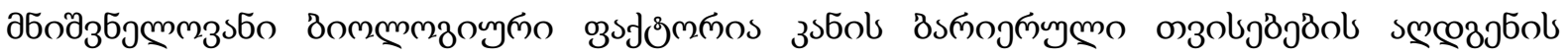
उммзј зйо [12;21].

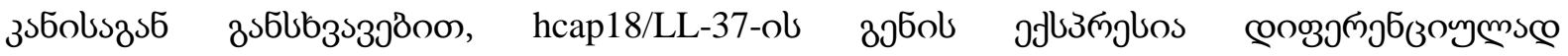

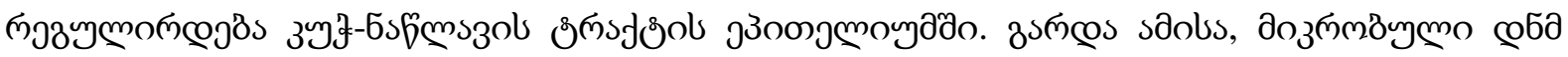

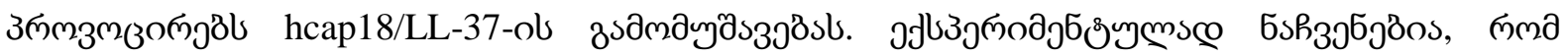

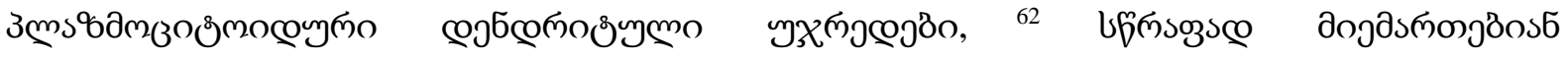

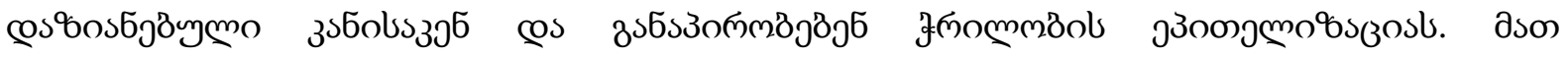

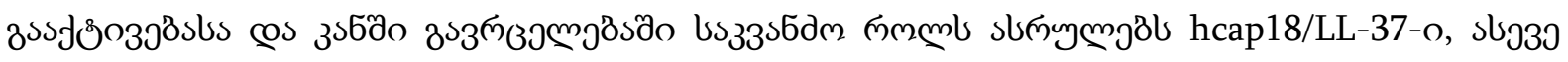

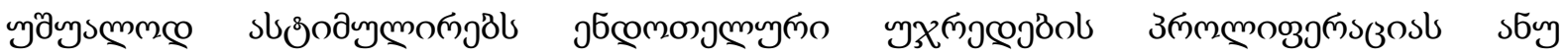

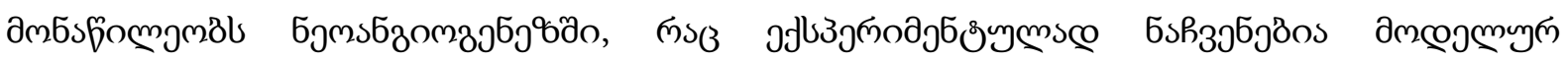

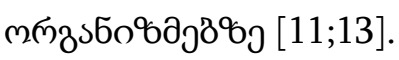

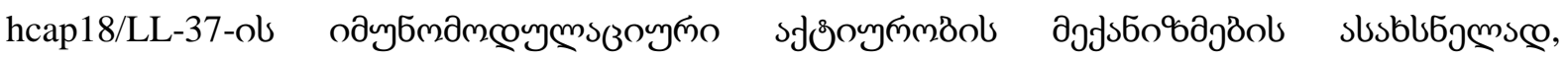

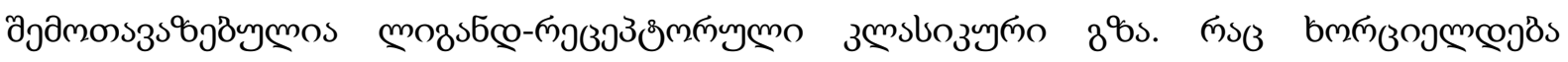

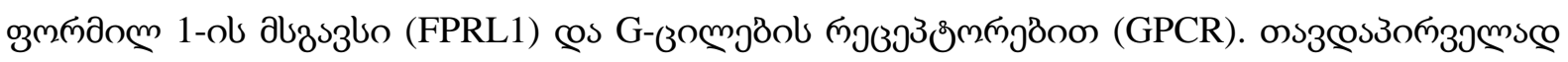

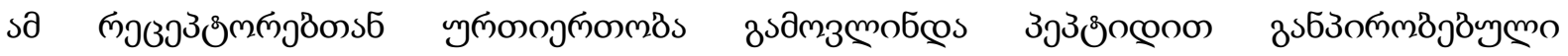

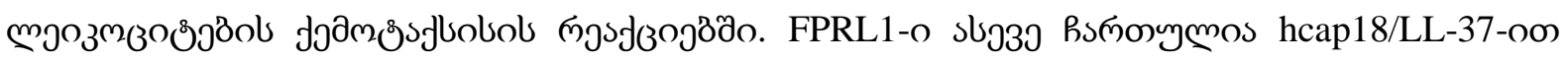

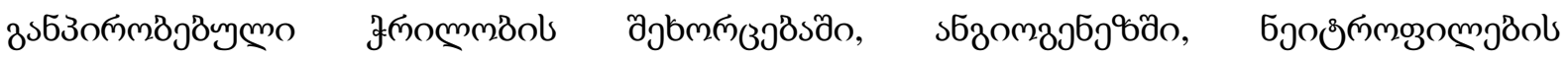

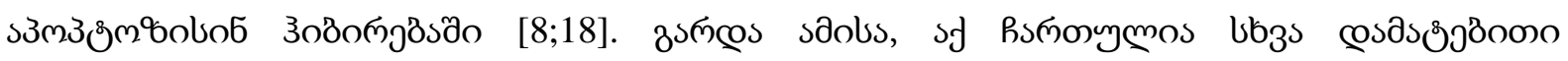

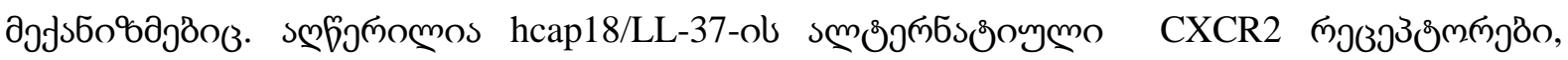

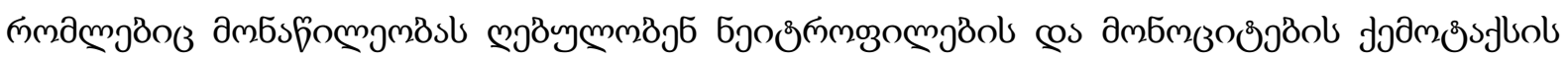

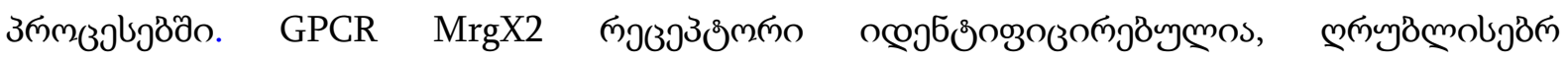

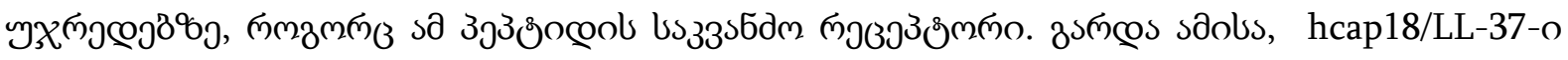

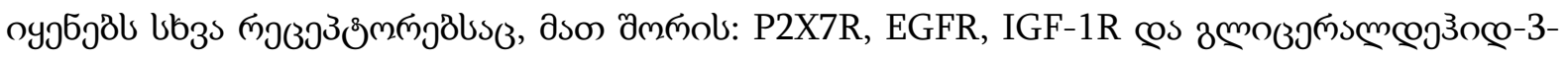

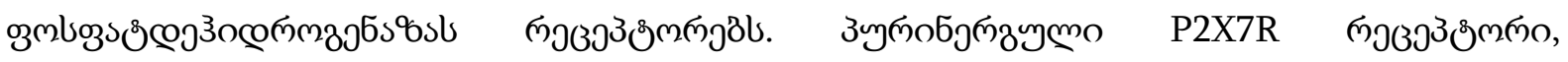

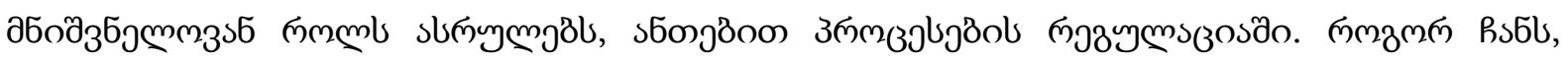

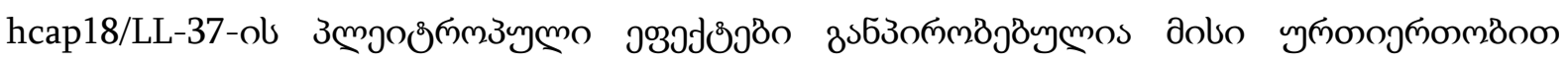

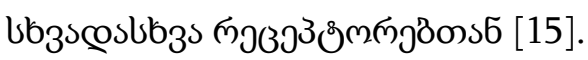

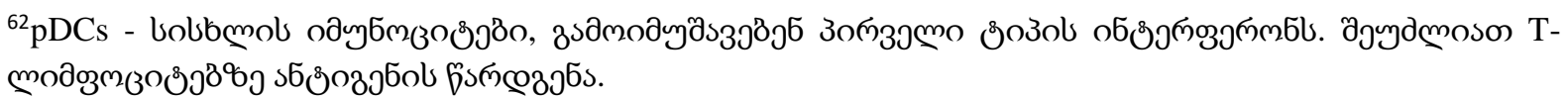




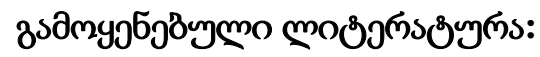

1. 1.Anderson RL, Hiemstra PS, Ward C, Forrest IA, Murphy D, Proud D, Lordan J, Corris PA, FisherAJ (2008) Antimicrobial peptides in lung transplant recipients with bronchiolitis obliteranssyndrome. Eur Respir J 32:670-677.

2. Barlow PG, Beaumont PE, Cosseau C, Mackellar A, Wilkinson TS, Hancock RE, Haslett C, Govan JRW, Simpson AJ, Davidson DJ (2010) The human cathelicidin LL-37 preferentially promotes apoptosis of infected airway epithelium. Am J Respir Cell Mol Biol 43:692-702

3. Barlow PG, Li Y, Wilkinson TS, Bowdish DM, Lau YE, Cosseau C, Haslett C, Simpson AJ,Hancock RE, Davidson DJ (2006) The human cationic host defense peptide LL-37 mediatescontrasting effects on apoptotic pathways in different primary cells of the innate immunesystem. J Leukoc Biol 80:509-520

4. Bowdish DME, Davidson DJ, Hancock REW (2005a) A re-evaluation of the role of host defence peptides in mammalian immunity. Curr Protein Pept Sci 6:35-51

5. Bowdish DME, Davidson DJ, Lau YE, Lee K, Scott MG, Hancock REW (2005b) Impact of LL-37on anti-infective immunity. J Leukoc Biol 77:451-459

6. Braff MH, Hawkins MA, Nardo AD, Lopez-Garcia B, Howell MD, Wong C, Lin K, Streib JE,Dorschner R, Leung DY, Gallo RL (2005) Structure-function relationships among humancathelicidin peptides: dissociation of antimicrobial properties from host immunostimulatoryactivities. J Immunol 174:4271-4278

7. Bucki R, Byfield FJ, Janmey PA (2007) Release of the antimicrobial LL37 peptide from DNA/F-actin bundles in CF sputum. Eur Respir J 29:624-632

8. Carretero M, Escamez MJ, Garcia M, Duarte B, Holguin A, Retamosa L, Jorcano JL, Rio MD,Larcher F (2008) In vitro and in vivo wound healing-promoting activities of human cathelicidin LL-37. J Invest Dermatol 128:223-236

9. Ganguly D, Chamilos G, Lande R, Gregorio J, Meller S, Facchinetti V, Homey B, Barrat FJ, Zal T,Gilliet M (2009) Self-RNA-antimicrobial peptide complexes activate human dendritic cells through TLR7 and TLR8. J Exp Med 206:1983-1994.

10. Garcia-Romo GS, Caielli S, Vega B, Connolly J, Allantaz F, Xu Z, Punaro M, Baisch J, GuiducciC, Coffman RL, Barrat FJ, Banchereau J, Pascual V (2011) Netting neutrophils are majorinducers of type I IFN production in pediatric systemic lupus erythematosus. Sci Transl Med3:73ra20.

11. Gregorio J, Meller S, Conrad C, di Nardo A, Homey B, Laverma A, Arai N, Gallo RL, DiGiovanniA, Gilliet M (2010) Plasmacytoid dendritic cells sense skin injury and promote wound healingthrough type I interferons. J Exp Med 207(13):2921-30. doi:10.1084/jem20101102.

12. Heilborn JD, Weber G, Gronberg A, Dieterich C, Stahle M (2010) Topical treatment with thevitamin $\mathrm{D}$ analogue calcipotriol enhances the upregulation of the antimicrobial proteinhCAP18/LL-37 during wounding in human skin in vivo. Exp Dermatol 19(4):332-338

13. Koczulla R, von Degenfeld G, Kupatt C, Krotz F, Zahler S, Gloe T, Issbrucker K, Unterberger P,Zaiou M, Lebhertz C, Karl A, Raake P, Pfosser A, Boekstegers P, Welsch U, Hiemstra PS,Vogelmeier C, Gallo RL, Clauss M, Bals R (2003) An angiogenic role for the human peptideantibiotic LL-37/hCAP18. J Clin Invest 111:1665-1672.

14. Lau YE, Bowdish DME, Cosseau CC, Hancock REW, Davidson DJ (2006) Apoptosis of airway pithelial cells: human serum sensitive induction by the cathelicidin LL-37. Am J Respir CellMol Biol 34:399-409.

15. Lister MF, Sharkey J, Sawatzky DA, Hodgkiss JP, Davidson DJ, Rossi AG, Finlayson K 
(2007) The role of the purinergic P2X7 receptor in inflammation. J Inflamm (Lond) 4:5

16. Li X, Li Y, Han H, Miller DW, Wang G (2006) Solution structures of human LL-37 fragments andNMR-based identification of a minimal membrane-targeting antimicrobial and anticancer region. J Am Chem Soc 128:5776-5785.

17. Mader JS, Mookherjee N, Hancock RE, Bleackley RC (2009) The human host defense peptideLL-37 induces apoptosis in a calpain- and apoptosis-inducing factor-dependent mannerinvolving Bax activity. Mol Cancer Res 7:689-702.

18. Nagaoka I, Tamura H, Hirata M (2006) An antimicrobial cathelicidin peptide, human CAP18/LL-37, suppresses neutrophil apoptosis via the activation of formyl-peptide receptorlike 1 andP2X7. J Immunol 176:3044-3052.

19. Nell MJ, Tjabringa GS, Wafelman AR, Verrijk R, Hiemstra PS, Drijfhout JW, Grote JJ (2006)Development of novel LL-37 derived antimicrobial peptides with LPS and LTA neutralizingand antimicrobial activities for therapeutic application. Peptides 27:649-660

20. Putsep K, Carlsson G, Boman HG, Andersson M (2002) Deficiency of antibacterial peptides in patients with morbus Kostmann: an observation study. Lancet 360:1144-1149.

21. Schauber $\mathbf{J}$ et al (2007) Injury enhances TLR2 function and antimicrobial peptide expression through a vitamin D-dependent mechanism. J Clin Invest 117(3):803-811.

22. Schauber J, Gallo RL (2008) Antimicrobial peptides and the skin immune defense system.J Allergy Clin Immunol 122:261-266.

23. Sorensen OE, Arnljots K, Cowland JB, Bainton DF, Borregaard N (1997a) The human antibacterial cathelicidin, hCAP-18, is synthesized in myelocytes and metamyelocytes and localized to specific granules in neutrophils. Blood 90:2796-2803.

24. Sorensen OE, Follin P, Johnsen AH, Calafat J, Tjabringa GS, Hiemstra PS, Borregaard N (2001) Human cathelicidin, hCAP-18, is processed to the antimicrobial peptide LL-37 by extracellular cleavage with proteinase 3. Blood 97:3951-3959.

25. van der Does AM, Beekhuizen H, Ravensbergen B, Vos T, Ottenhoff TH, van Dissel JT, Drijfhout JW, Hiemstra PS, Nibbering PH (2010) LL-37 directs macrophage differentiation toward macrophages with a proinflammatory signature. J Immunol 185:1442-1449.

26. Zhang Z, Cherryholmes G, Chang F, Rose DM, Schraufstatter I, Shively JE (2009) Evidence that cathelicidin peptide LL-37 may act as a functional ligand for CXCR2 on human neutrophils.Eur J Immunol 39:3181-3194.

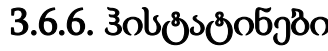

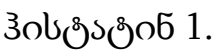

- jазополумо озмпаулмзs: $\mathrm{C}_{217} \mathrm{H}_{298} \mathrm{~N}_{69} \mathrm{O}_{64} \mathrm{P}$.

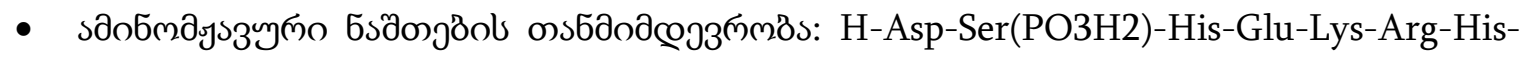
His-Gly-Tyr-Arg-Arg-Lys-Phe-His-Glu-Lys-His-His-Ser-His-Arg-Glu-Phe-Pro-Phe-TyrGly-Asp-Tyr-Gly-Ser-Asn-Tyr-Leu-Tyr-Asp-Asn-OH

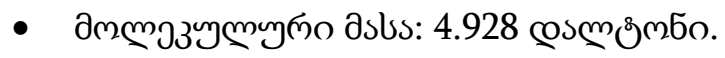

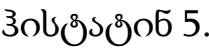

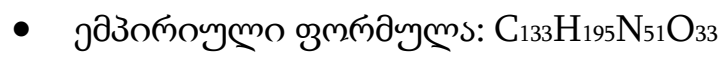

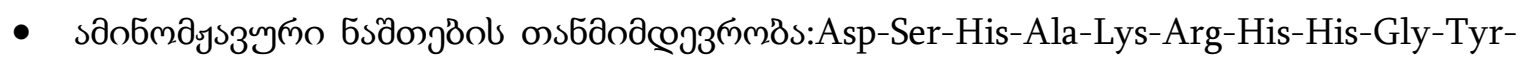
Lys-Arg-Lys-Phe-His-Glu-Lys-His-His-Ser-His-Arg-Gly-Tyr. 


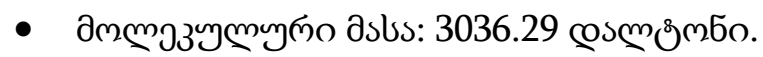

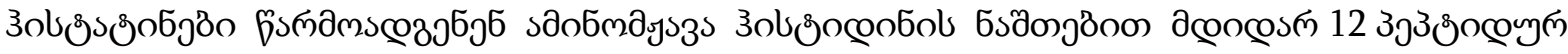

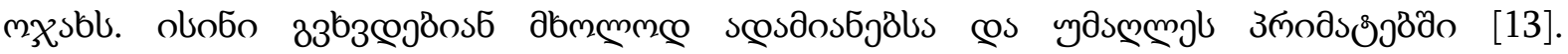

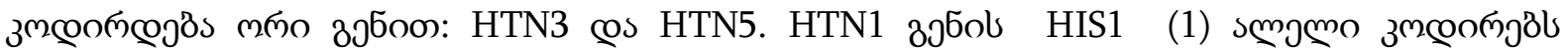

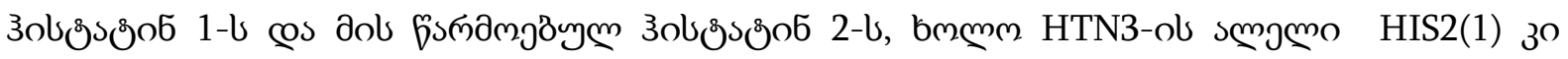

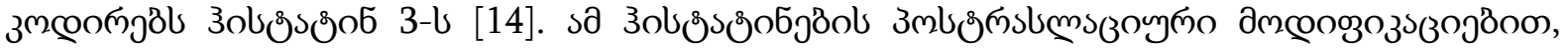

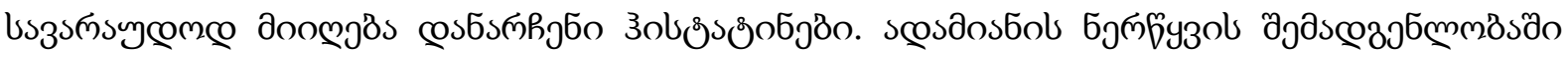

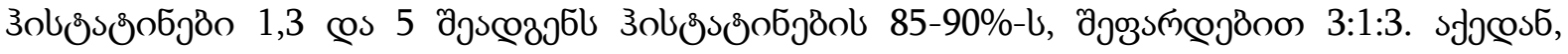

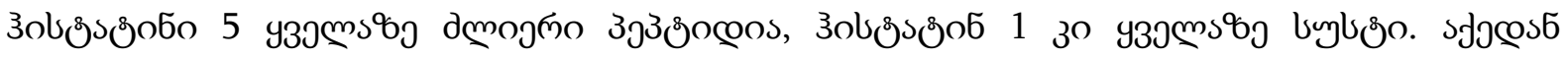

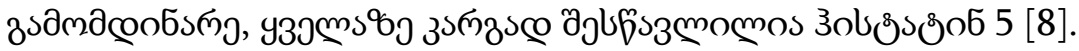

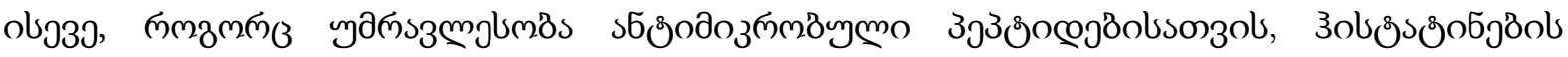

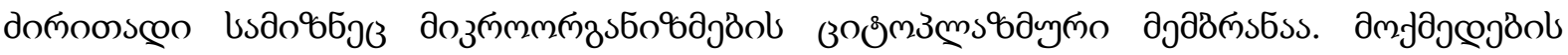

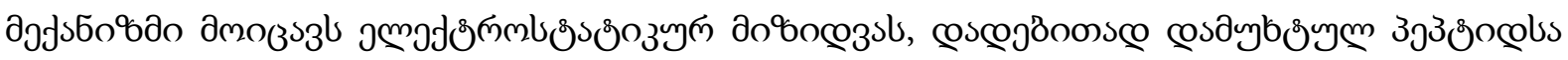

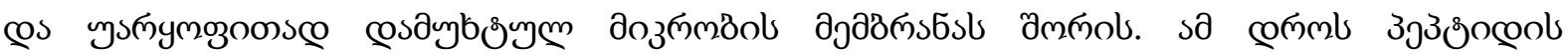

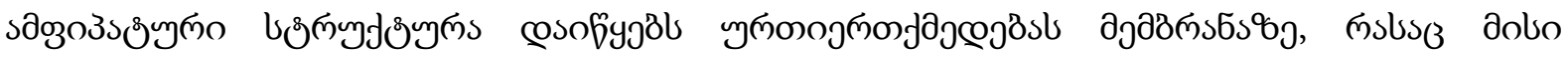

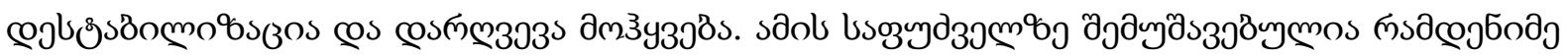

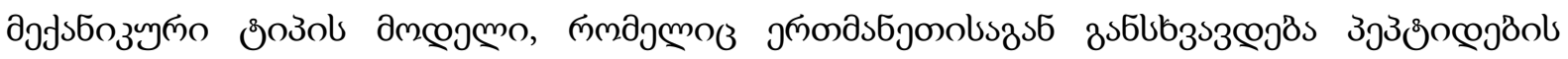

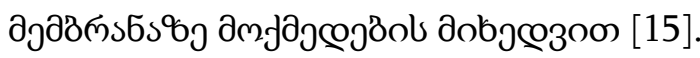

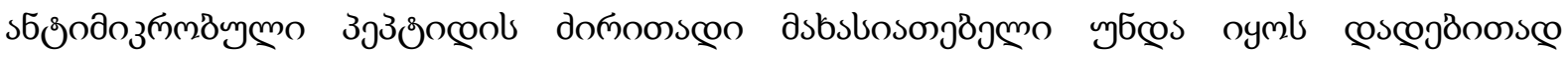

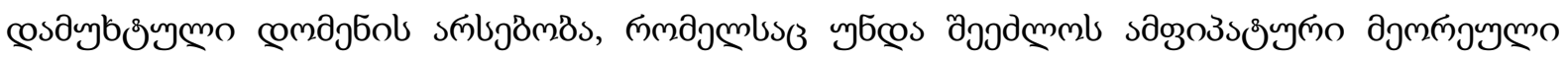

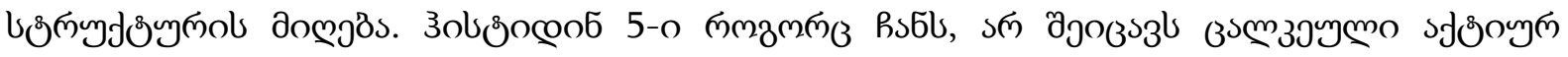

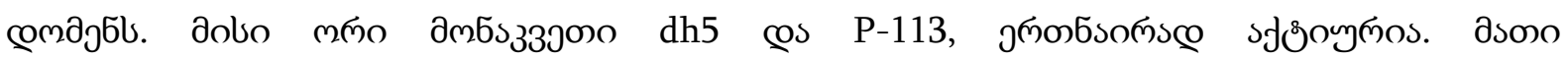

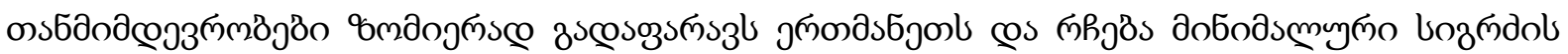

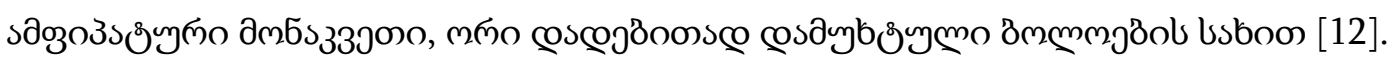

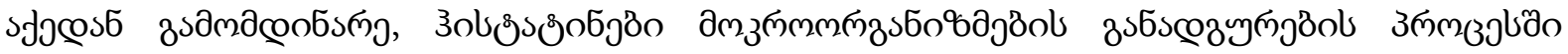

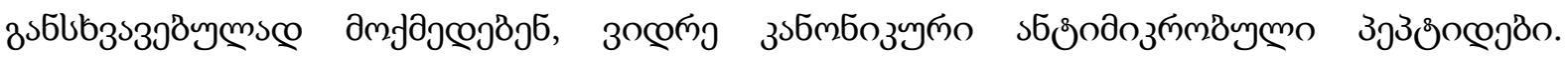

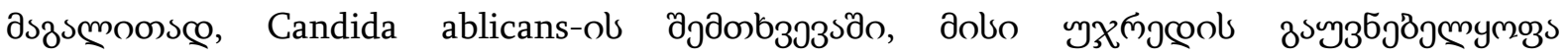

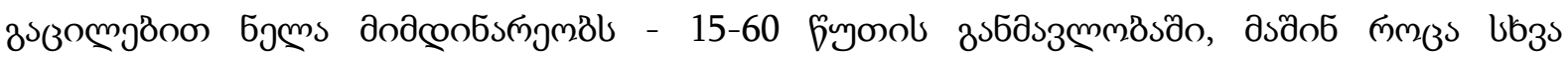

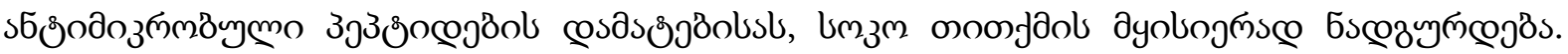

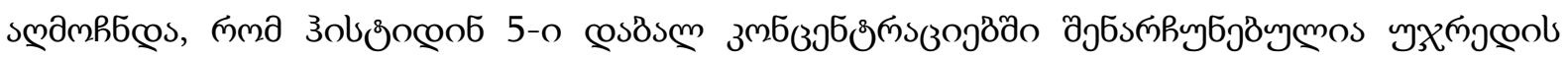

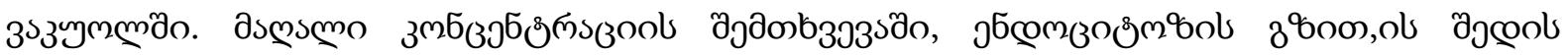

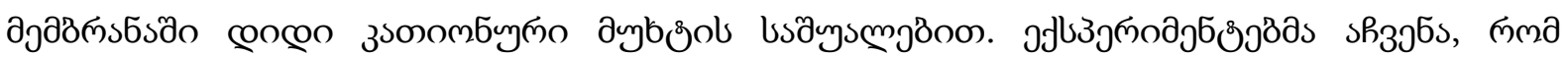

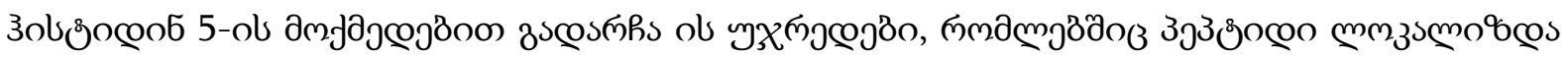

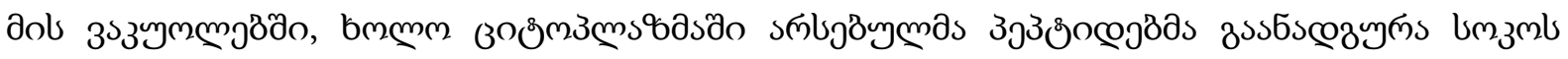

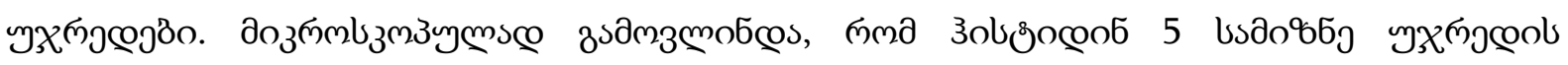

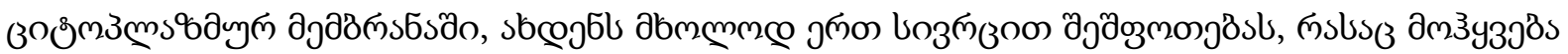

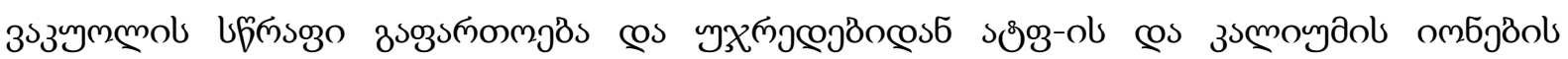

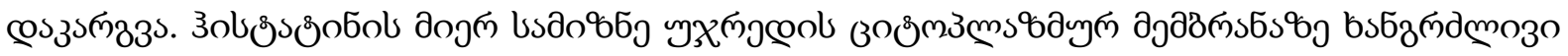

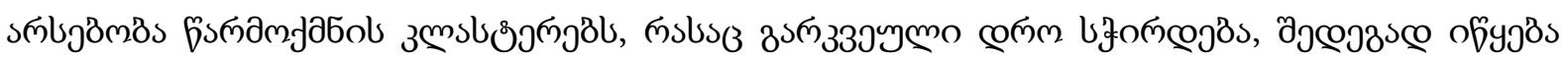

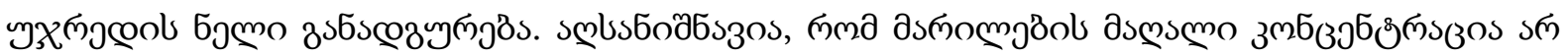

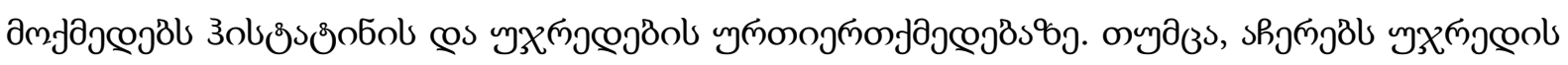




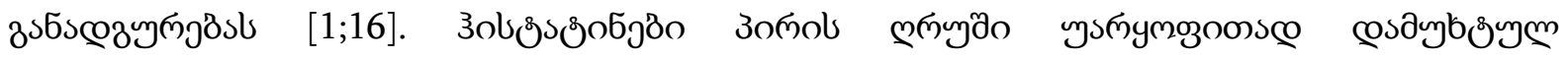

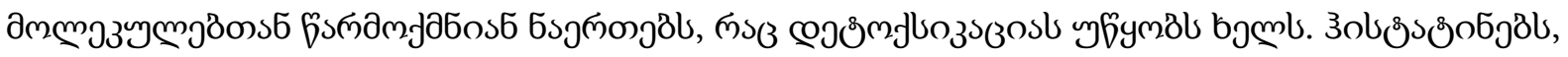

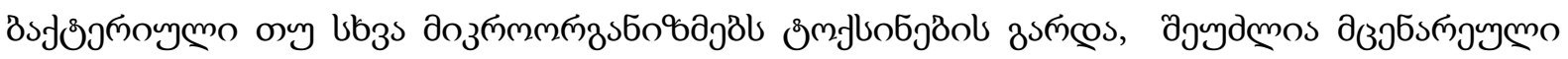

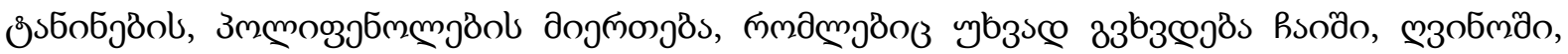

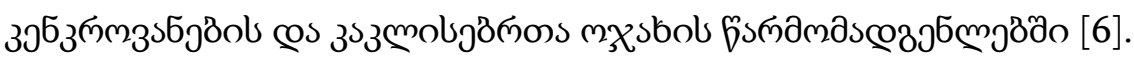

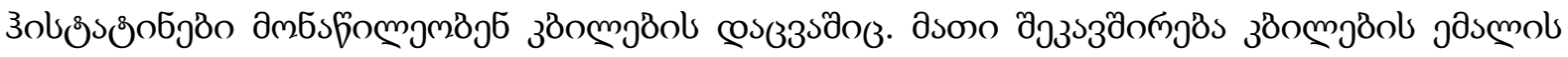

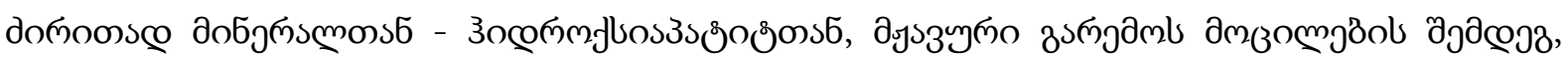

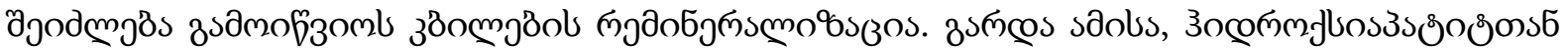

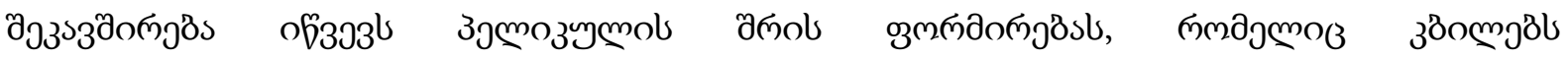

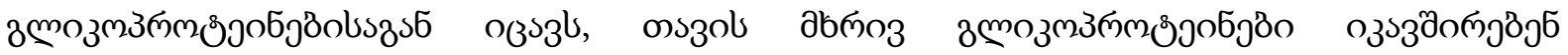

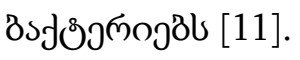

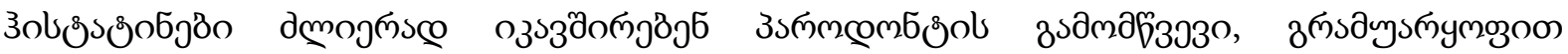

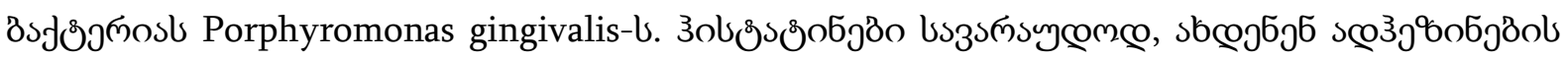

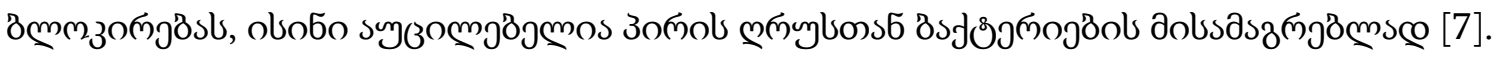

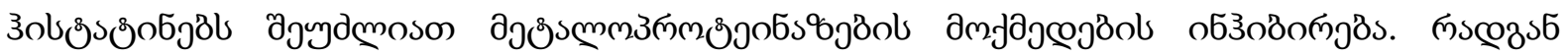

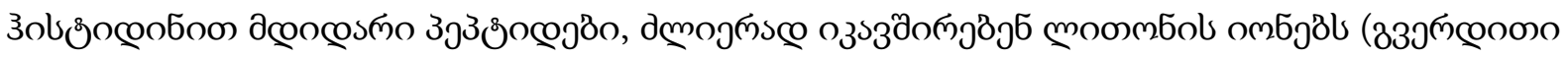

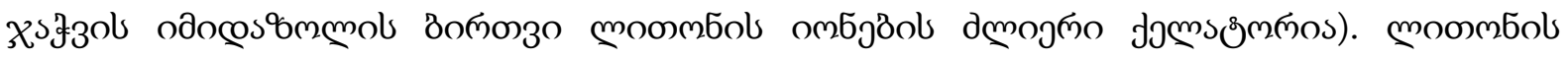

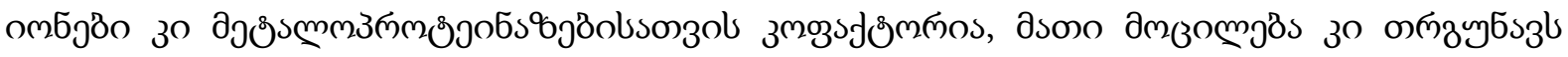

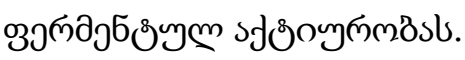

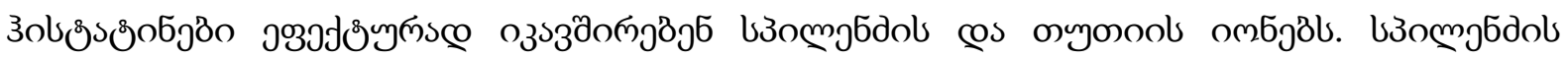

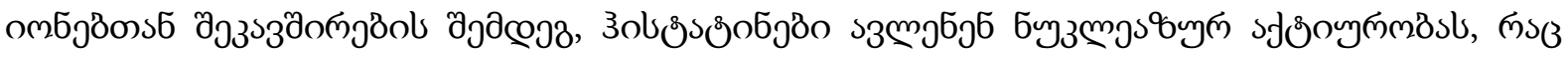

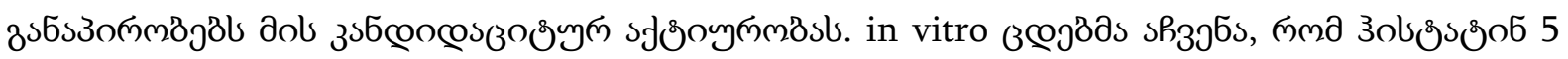

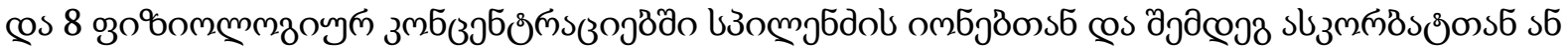

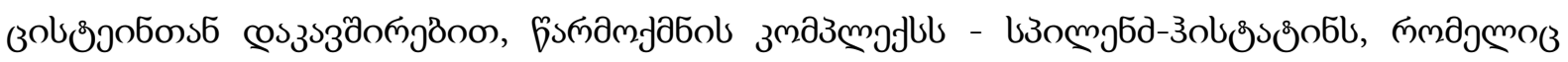

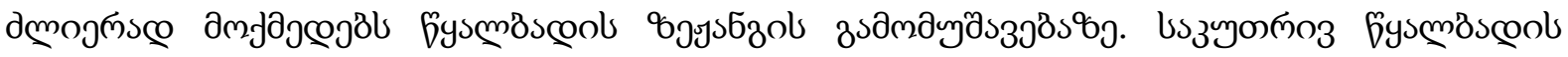

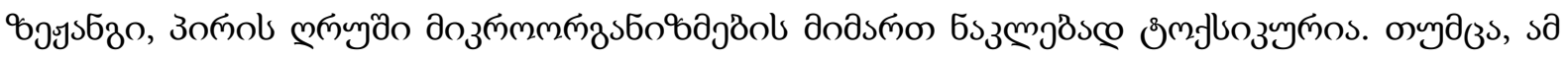

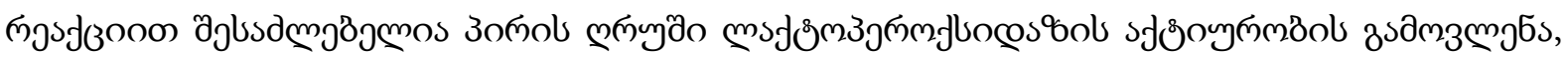

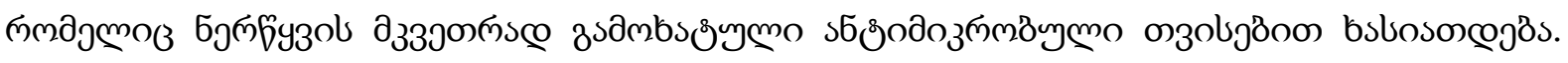

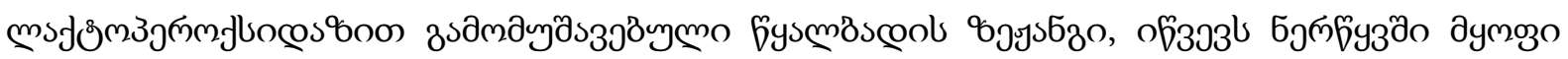

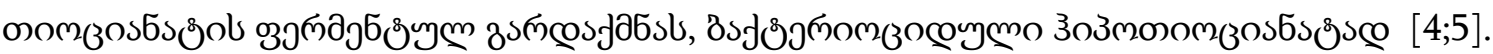

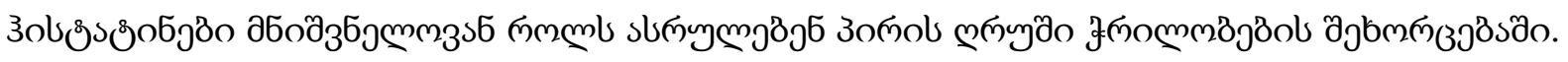

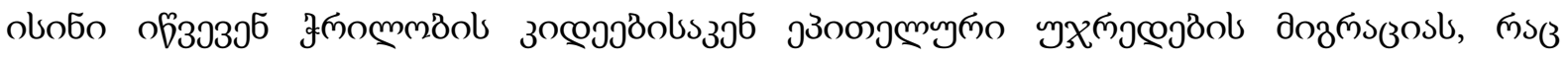

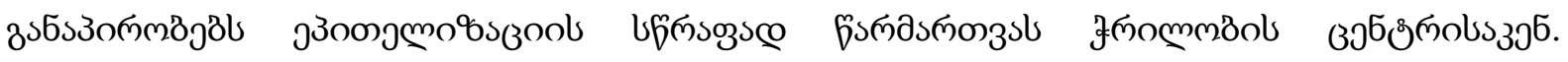

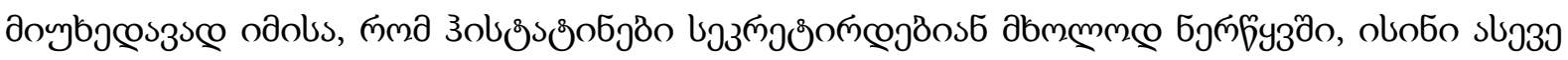

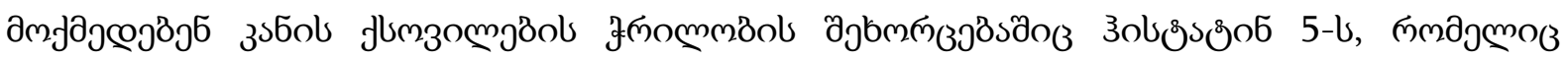

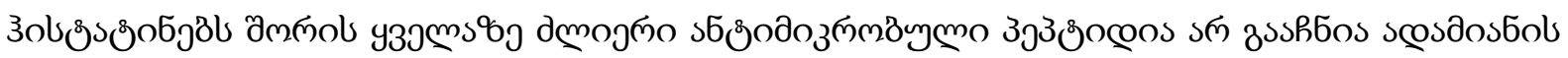

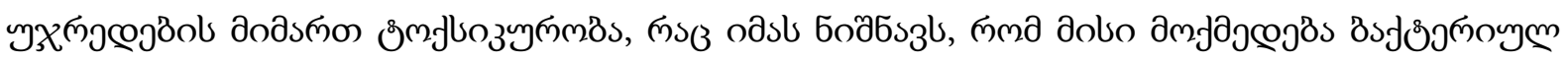

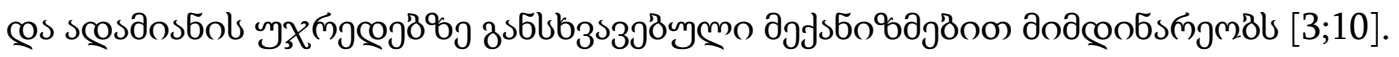

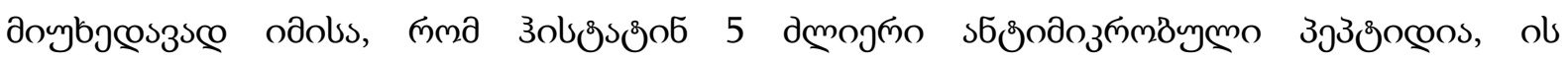

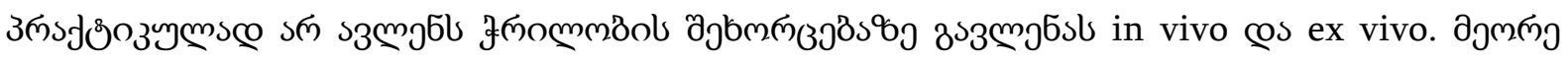

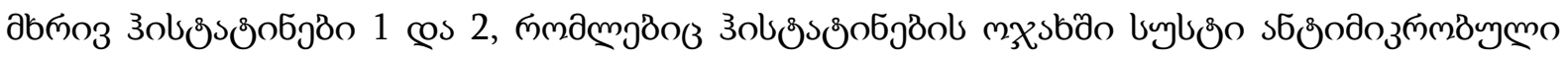

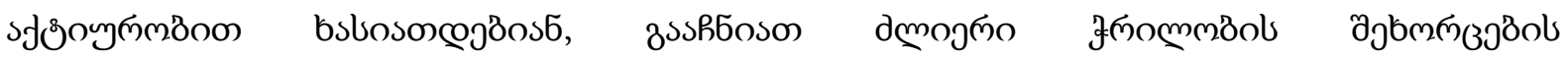




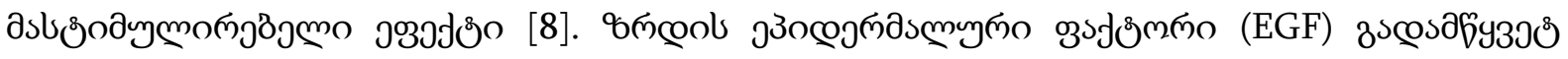

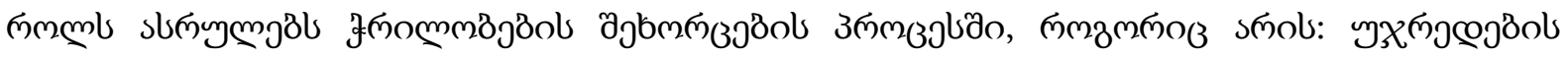

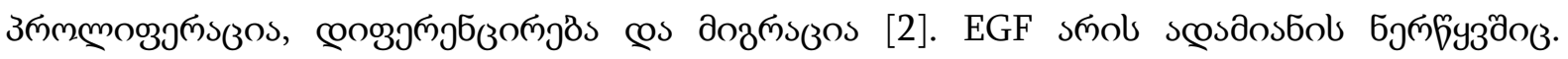

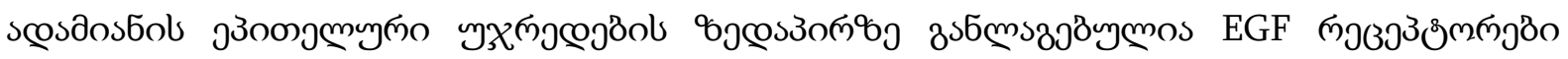
(EGFR). удаз

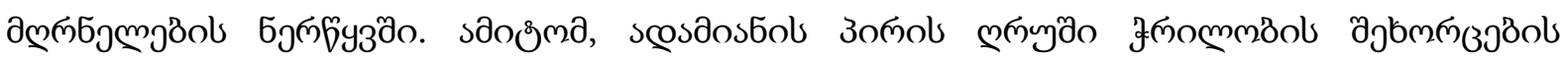

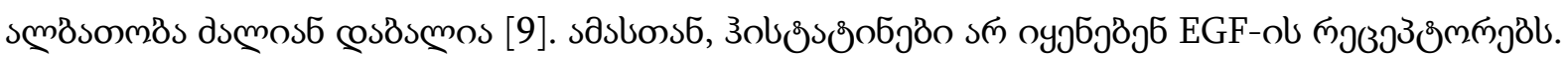

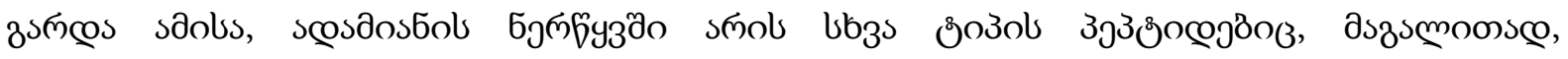

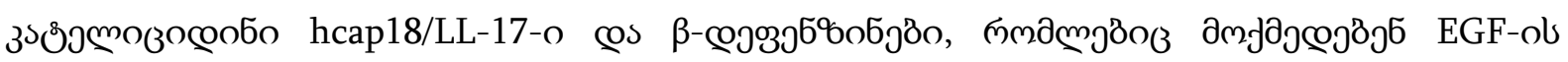

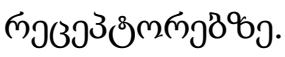

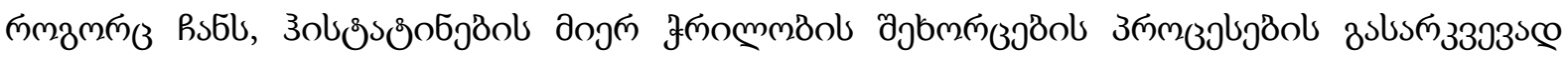

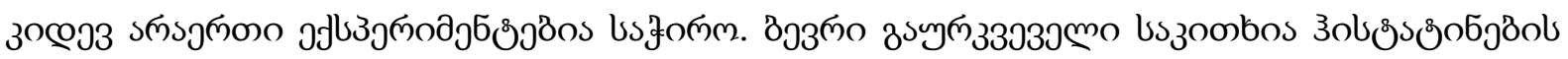

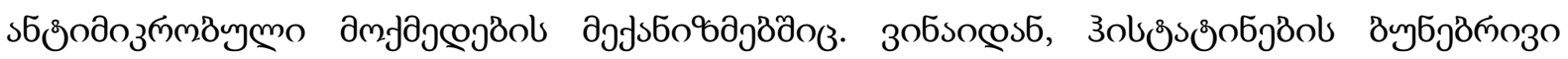

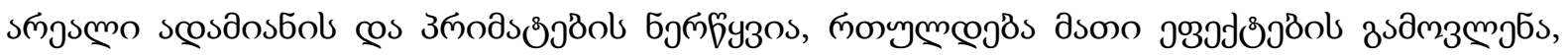

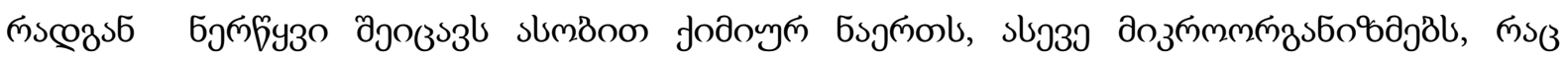

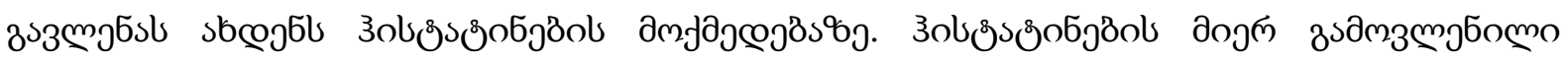

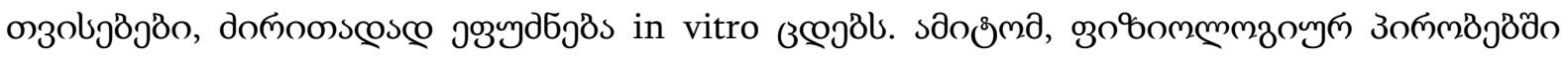

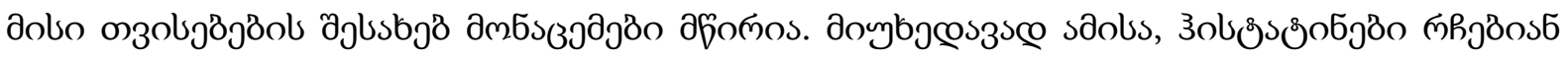

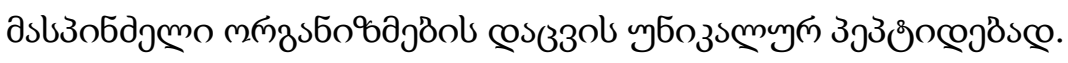

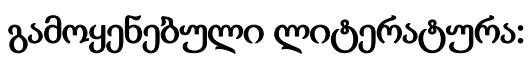

1. Bennick A (2002) Interaction of plant polyphenols with salivary proteins. Crit Rev Oral Biol Med13:184-196

2. Cohen S (2008) Origins of growth factors: NGF and EGF. J Biol Chem 283:3379333797Helmerhorst EJ, Reijnders IM, Van 't Hof W, Veerman ECI, Nieuw Amerongen AV (1999) Acritical comparison of the hemolytic and fungicidal activities of cationic antimicrobialpeptides.

FEBS Lett 449:105-110

3. Houghton EA, Nicholas KM (2009) In vitro reactive oxygen species production by histatins andcopper (I, II). J Biol Inorg Chem 14:243-251

4. Melino S, Gallo M, Trotta E, Mondello F, Paci M, Petruzzelli R (2006) Metal-binding andnuclease activity of an antimicrobial peptide analogue of the salivary histatin 5 . Biochemistry45:15373-15383

5. Mochon AB, Liu H (2008) The antimicrobial peptide histatin 5 causes a spatially restricted

6. disruption on the Candida albicans surface, allowing rapid entry of the peptide into thecytoplasm. PLOS Pathog 4(10):e1000190. doi:101371/journalppat1000190

7. Murakami Y, Tamagawa H, Shizukuishi S, Tsunemitsu A, Aimoto S (1992) Biological role of anarginine residue present in a histidine-rich peptide which inhibits hemagglutination ofPorphyromonas gingivalis. FEMS Microbiol Lett 98:201-204

8. Oppenheim FG, Yang Y-C, Diamond RD, Hyslop D, Offner GD, Troxler RF (1986) The primarystructure and functional characterization of the neutral histidine-rich polypeptide from humanparotid secretion. J Biol Chem 261:1177-1182. 
9. Oudhoff MJ, Bolscher JGM, Nazmi K, Kalay H, Van 't Hof W, Nieuw Amerongen AV, VeermanECI (2008) Histatins are the major wound-closure stimulating factors in human saliva asidentified in a cell culture assay. FASEB J 22:3805-3812

10. Oudhoff MJ, Kroeze K, Nazmi K, Van den Keijbus P, Van 't Hof W, Fernandez-Borja M, HordijkPL, Gibbs S, Bolscher JGM, Veerman ECI (2009) Structure-activity analysis of histatin, a potent wound healing peptide from human saliva: cyclization of histatin potentiates molaractivity 1,000-fold. FASEB J 23:3928-3935

11. Richardson CF, Johnsson M, Raj PA, Levine MJ, Nancollas GH (1993) The influence of histatin 5 fragments on the mineralization of hydroxyapatite. Arch Oral Biol 38:997-1002

12. Ruissen ALA, Groenink J, Krijtenberg P, Walgreen-Weterings E, Van 't Hof W, Veerman ECI,Nieuw Amerongen AV (2003) Internalisation and degradation of histatin 5 by Candidaalbicans. Biol Chem 384:183-190

13. Sabatini LM, Azen EA (1989) Histatins, a family of salivary histidine-rich proteins, are encodedby at least two loci HIS1 and HIS2. Biochem Biophys Res Commun 160:495-502

14. Sabatini LM, Warner TF, Saitoh E, Azen EA (1989) Tissue distribution of RNAs for cystatins,histatins, statherin and proline-rich salivary proteins in humans and macaques. $\mathrm{J}$ Dent Res68:1138-1145

15. Van 't Hof W, Veerman ECI, Helmerhorst EJ, Nieuw Amerongen AV (2001) Antimicrobialpeptides, properties and applicability. Biol Chem 382:597-619

16. Xu Y, Ambudkar I, Yamagishi H, Swaim W, Walsh TJ, O’Connell BC (1999) Histatin 3mediatedkilling of Candida albicans: effect of extracellular salt concentration on binding and internalization. Antimicrob Agents Chemother 43:2256-2262

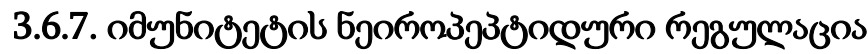

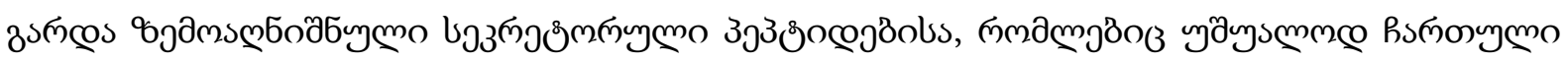

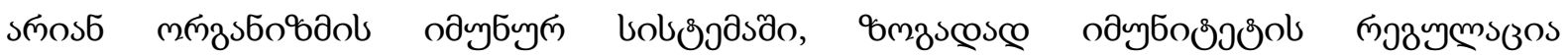

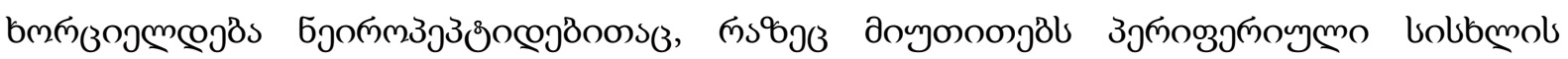

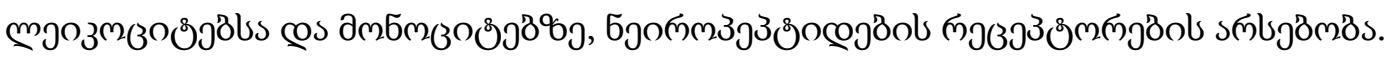

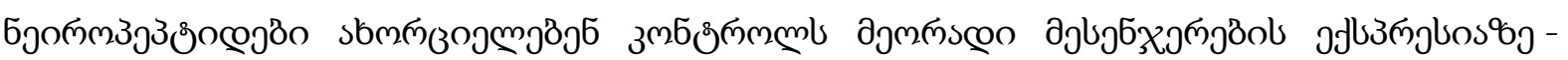

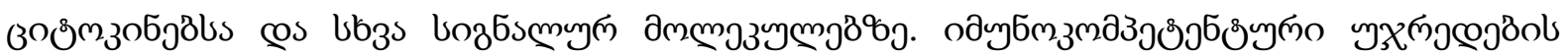

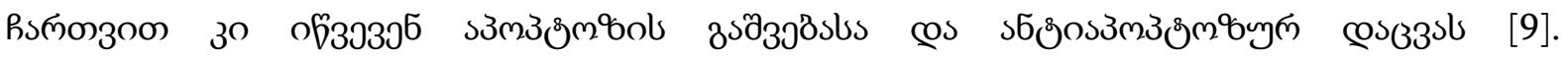

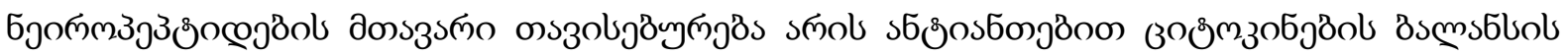

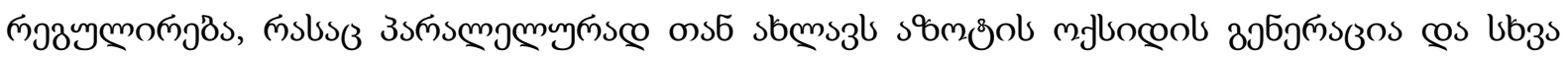

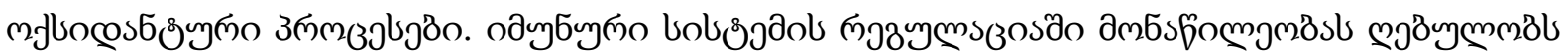

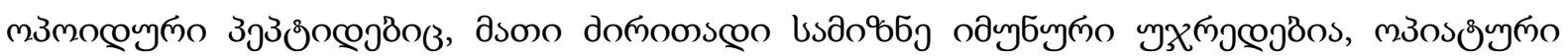

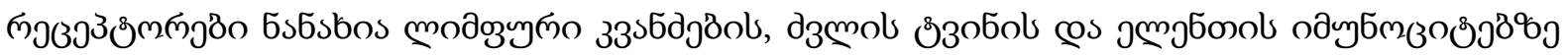
[19].

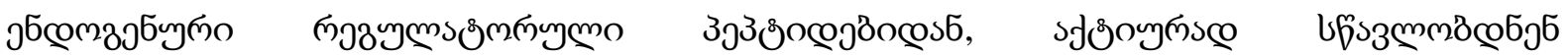

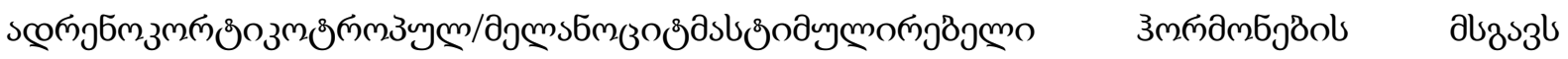

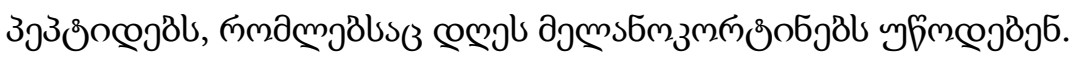

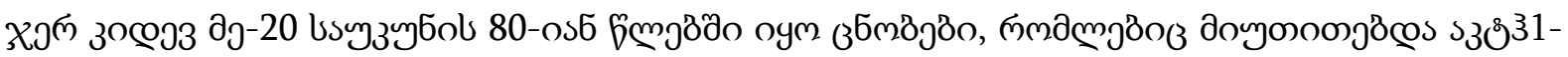

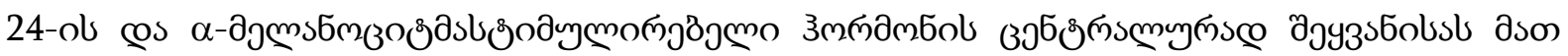




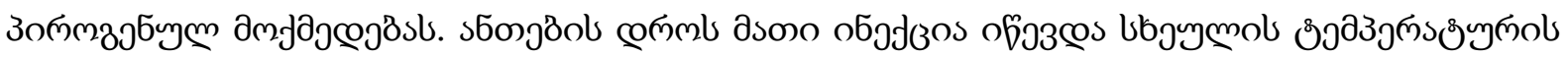

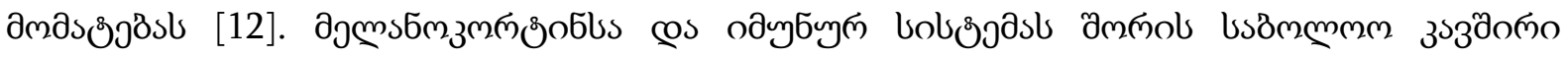

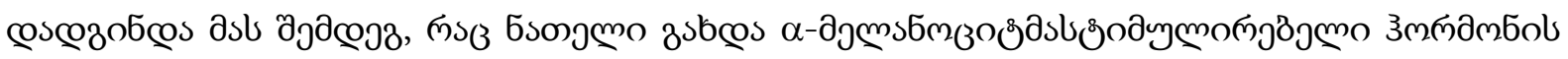

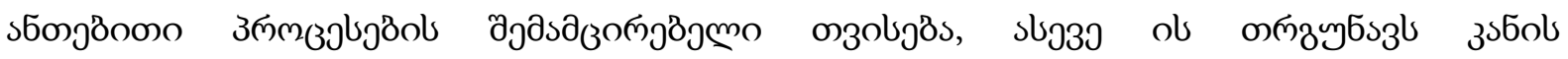

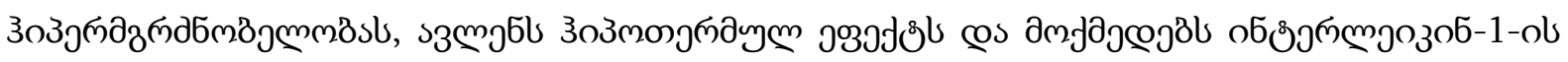

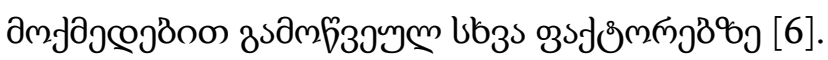

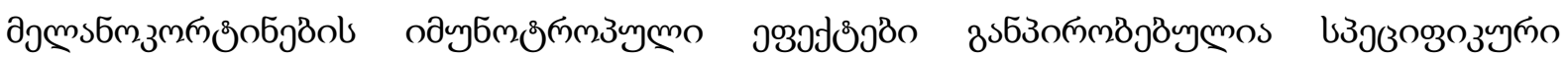

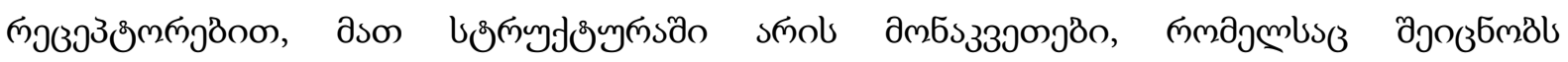

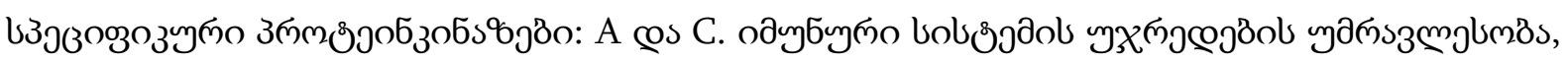

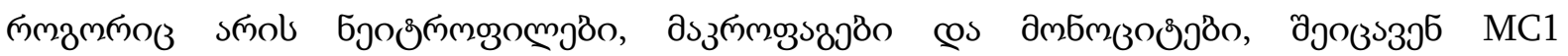

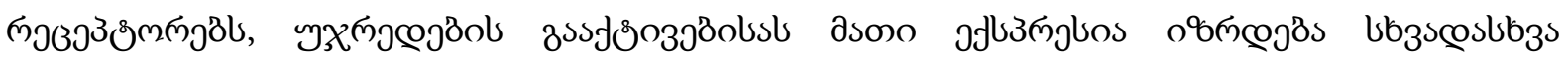

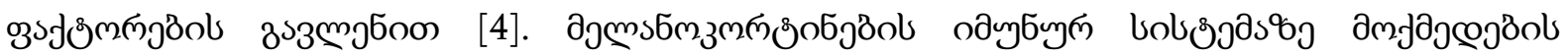

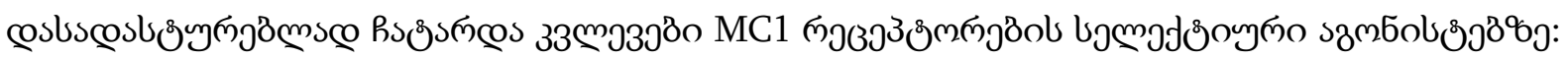

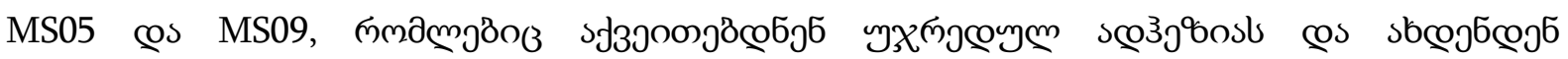

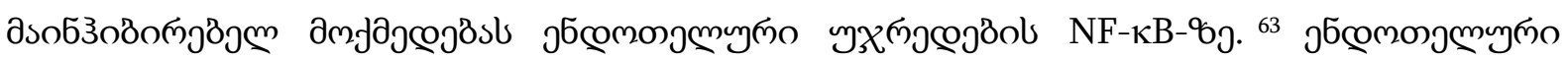

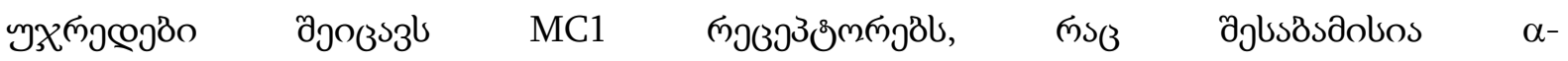

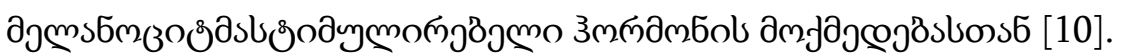

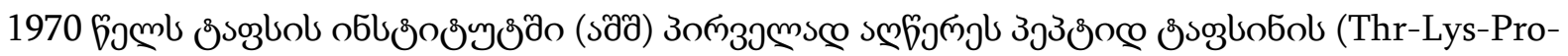

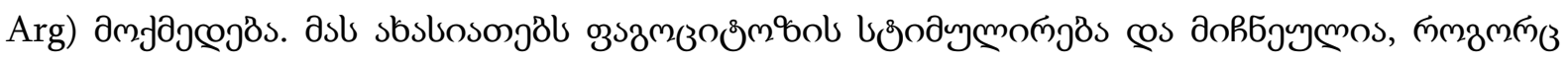

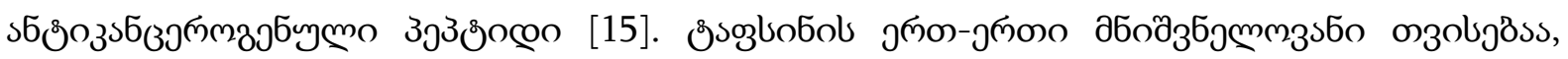

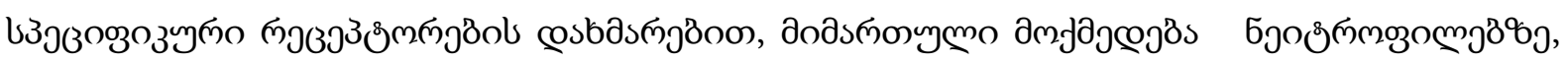

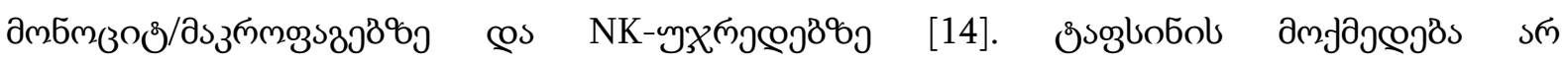

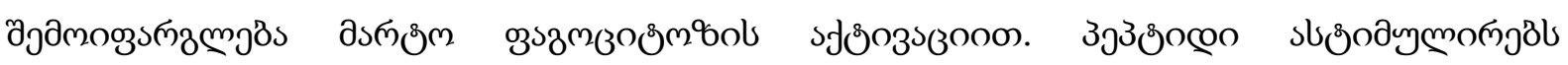

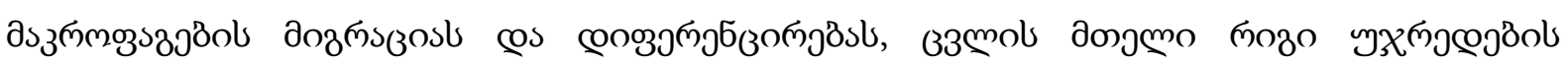

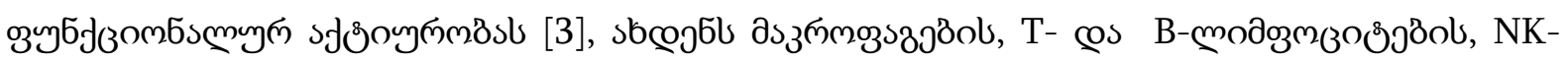

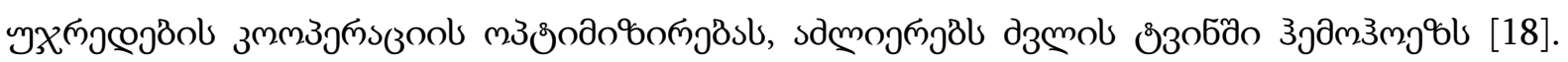

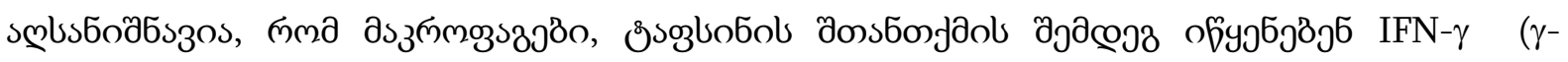

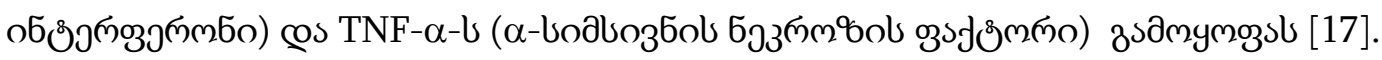

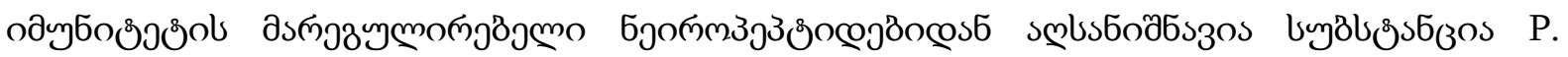

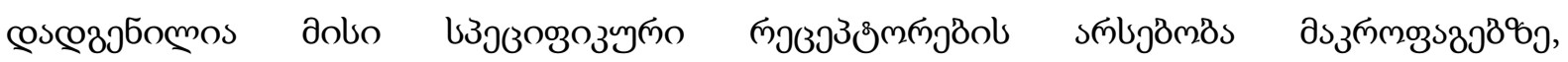

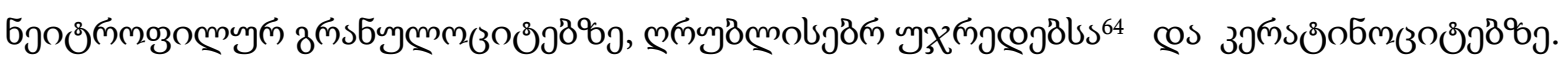

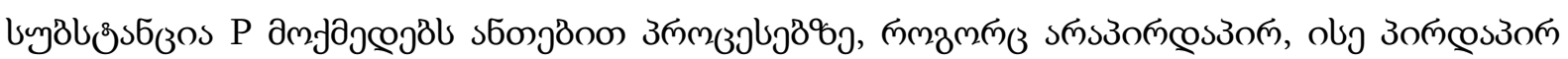

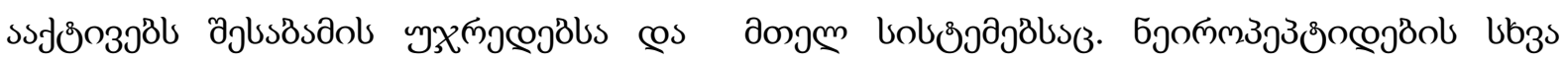

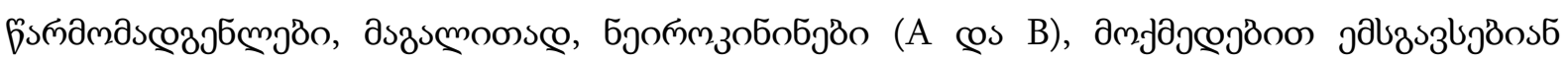

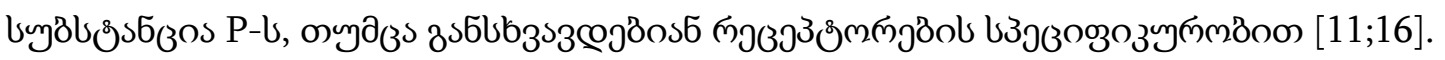

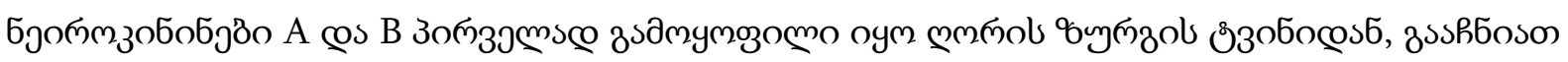

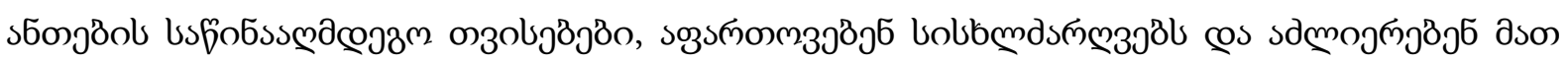

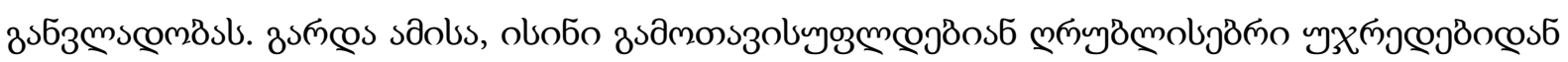

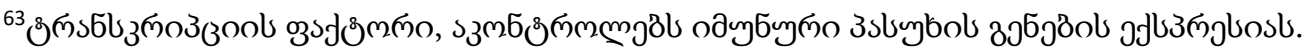

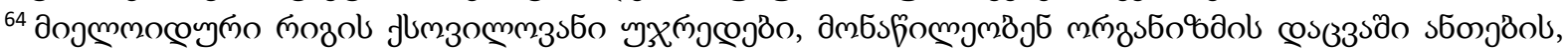

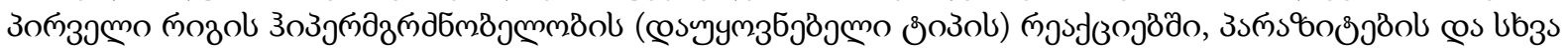

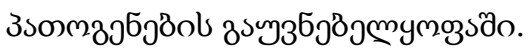




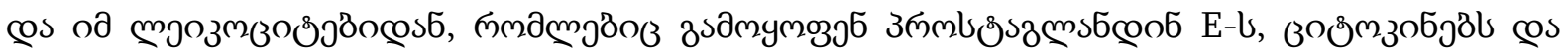

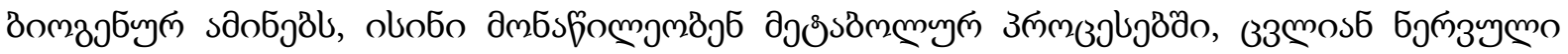

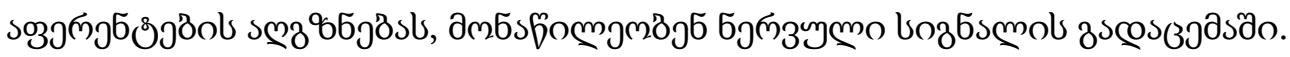

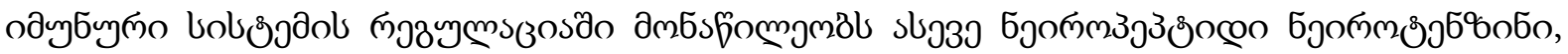

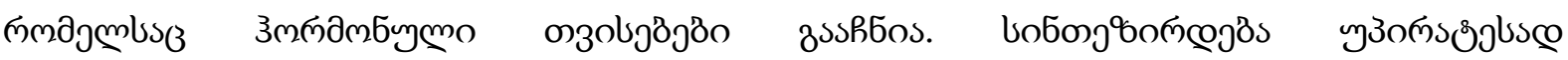

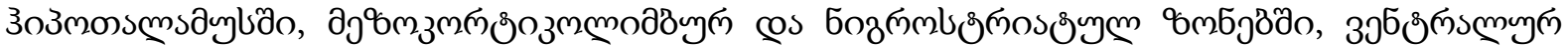

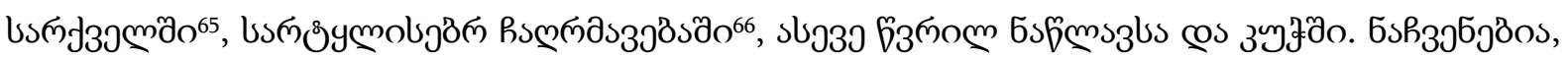

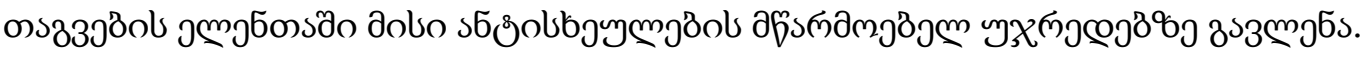

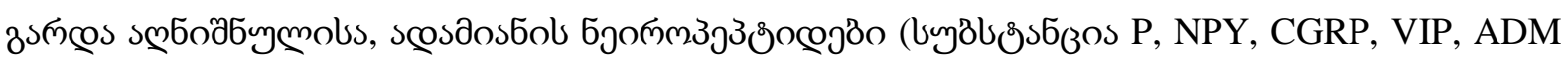

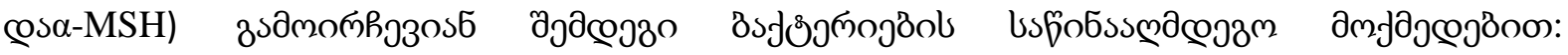
Staphylococcus aureus, Enterococcus faecalis, Streptococcus mutans, Nocardia brasiliensis), umzmgöob: Candida albicans, Candida tropicalis, Candida krusei, Candidia utilis, Cryptococcus

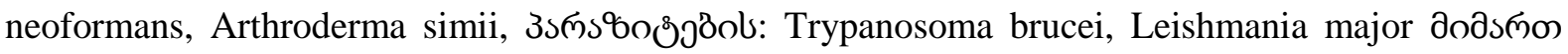
$[2 ; 7 ; 9]$.

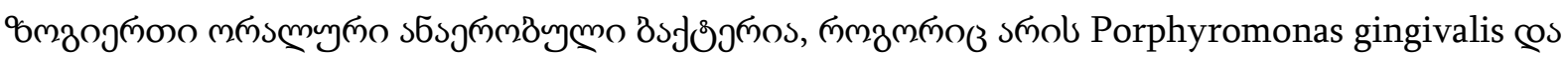

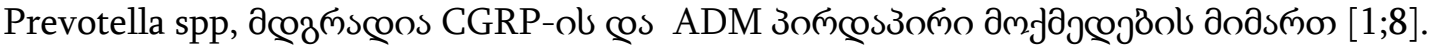

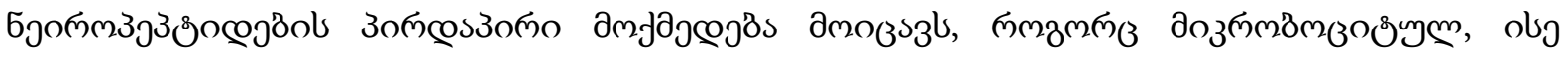

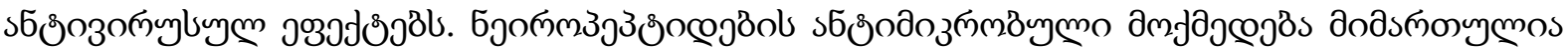

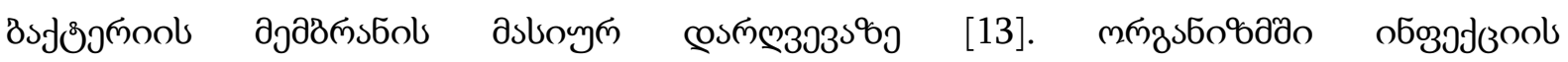

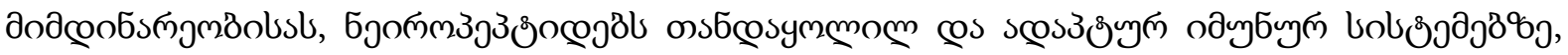

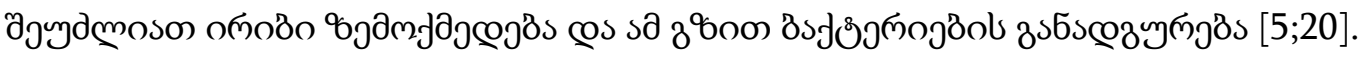

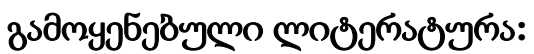

1. Allaker, R.P.; Sheehan, B.E.; McAnerney, D.C.; McKay, I.J. Interaction of adrenomedullin and calcitonin gene-related peptide with the periodontal pathogen Porphyromonas gingivalis. FEMS Immunol. Med. Microbiol. 2007, 49, 91-97.

2. Augustyniak, D.; Nowak, J.; Lundy, F.T. Direct and Indirect Antimicrobial Activities of Neuropeptides and their TherapeuticPotential. Curr. Protein Pept. Sci. 2012, 13, 723-738. [CrossRef]

3. Babcock G.F., Amoscato A.A., Nishioka K. Effect of tuftsin on the migration, chemotaxis and differentiation of macrophages and granulocytes. Ann. N. Y. Acad. Sci. 1983; 419: 6474.

4. Bhardwaj R., Becher E., Mahnke K., Hartmeyer M., Schwarz T., Scholzen T., Luger T.A. Evidence for the differential expression of the functional a-melanocyte-stimulating hormon receptor MC-1 on human monocytes. J. Immunol. 1997; 158(7); 3378-84.

5. Brogden, K.A.; Guthmiller, J.M.; Salzet, M.; Zasloff, M.; Fauq, A.H.; Osborne, B.A.; Turley, D.M.; Shin, H.M.; Joshi, I.; Telfer, J.C.; et al. The nervous system and innate immunity: The neuropeptide connection. Nat. Immunol. 2005, 6, 558-564. [CrossRef][PubMed]

6. Chiao H., Foster S., Thomas R., Lipton J., Star R.A. Alfa-melanocyte stimulating hormone reduces endotoxin-induced liver inflammation. J. Clin. Invest. 1996; 97(9): 2038-44.

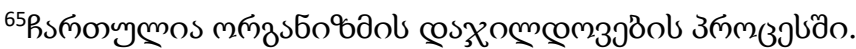

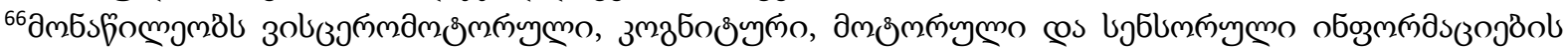

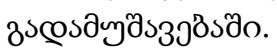


7. Cutuli, M.; Cristiani, S.; Lipton, J.M.; Catania, A. Antimicrobial effects of _-MSH peptides. J. Leukoc. Biol. 2000, 67, 233-239.[CrossRef]

8. Devine, D.A.; Marsh, P.D.; Percival, R.S.; Rangarajan, M.; Curtis, M.A. Modulation of antibacterial peptide activity by products ofPorphyromonas gingivalis and Prevotella spp. Microbiolohy 1999, 145, 965-971.

9. El Karim, I.A.; Linden, G.J.; Orr, D.F.; Lundy, F.T. Antimicrobial activity of neuropeptides against a range of micro-organismsfrom skin, oral, respiratory and gastrointestinal tract sites. J. Neuroimmunol. 2008, 200, 11-16. [CrossRef]

10. Hartmeyer M., Scholzen T., Becher E., Bhardwaj R.S., Schwarz T.,Luger T.A. Human dermal microvascular endothelial cells express the melanocortin receptor type 1 and produce increased levels of IL-8 upon stimulation with alpha-melanocyte-stimulating hormone. J. Immunol. 1997; 159(4): 1930-7.

11. Kemény L, von Restorff B, Michel G, Ruzicka T. Specific bindingand lack of growthpromoting activity of substance P in culturedhuman keratinocytes. J. Invest. Dermatol. 1994; 103(4): 605-6.

12. Lipton J.M., Glyn J.R., Zimmer J.A. ACTH and alpha-melanotropin in central temperature control. Fed Proc. 1981; 40(13): 2760-4.

13. Lundy, F.T.; Irwin, C.R.; McLean, D.F.; Linden, G.J.; El Karim, I.A. Natural Antimicrobials in the Dental Pulp. J. Endod. 2020, 46, S2-S9. [CrossRef] [PubMed]

14. Moghimi S.M., Rajabi-Siahboomi A.R. Recent advances in cellular, subcellular and molecular targeting. Adv. Drug Deliv. Rev. 2000; 41(2): 129-33.

15. Najjar V.A., Nishioka K. Tuftsin: a natural phagocytosis stimulating peptide. Nature. 1970; 228: 672-3.

16. Nsouli T.M., Nsouli S.M., Bellanti J.A. Neuroimmunoallergic inflamation:new patogenetic concepts and future perspectives of immediateand late allergic reaction. P.I. Ann. Allergy. 1988; 60(5):379-89.

17. Paulesu L., Di Stefano A., Luzzi E., Bocci V., Silvestri S., Nencioni L. Effect of tuftsin and its retro-inverso analogue on the realease of interferon (IFN-y) and tumor necrosis factor (TNF-a) by human leucocytes. Immunol. Lett. 1992; 34(1): 7-11.

18. Philips J.H., Babcock G.F, Nishioka K. Tuftsin: a natural occurring immunopotentiating factor. In vitro enhancement of murine natural cell-mediated cytotoxity. J. Immunology. 1981; 126(3): 915-21.

19. Sharp B.M. Multiple opioid receptors on immune cells modulate intracellular signaling. Brain Behav. Immun. 2006; 20: 9-14.

20. Souza-Moreira, L.; Campos-Salinas, J.; Caro, M.; Gonzalez-Rey, E. Neuropeptides as Pleiotropic Modulators of the Immune Response. Neuroendocrinology 2011, 94, 89-100. [CrossRef].

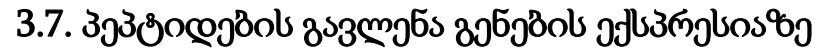

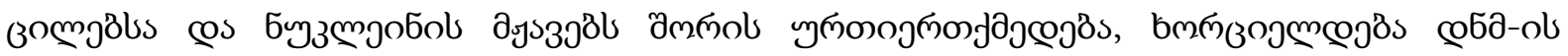

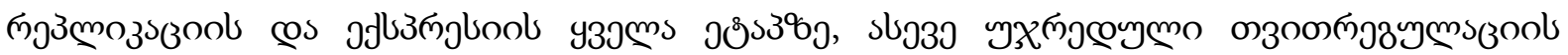

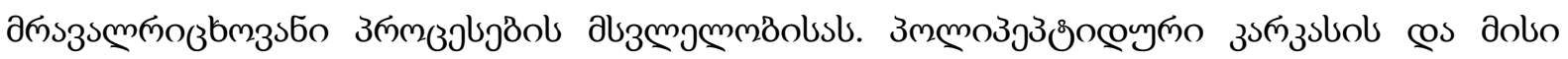

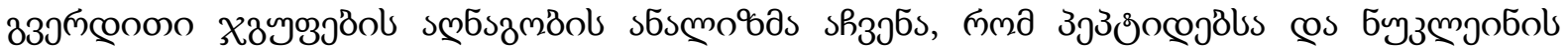

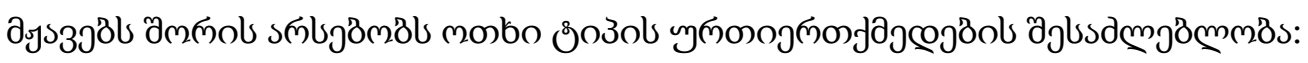




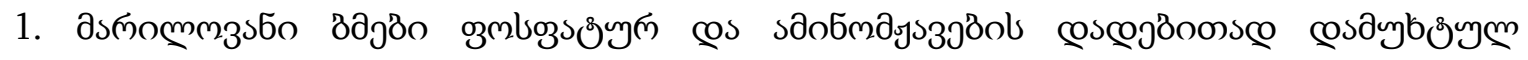

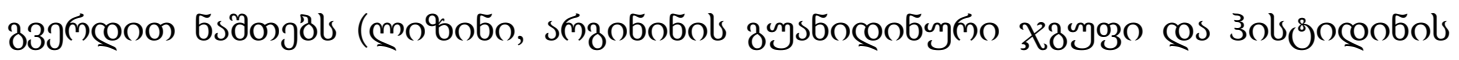

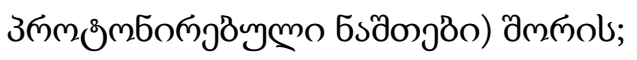

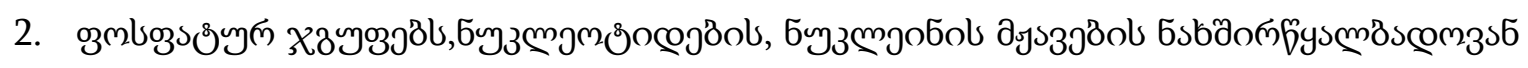

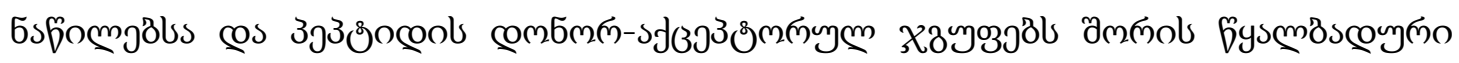
вдјठ̊०;

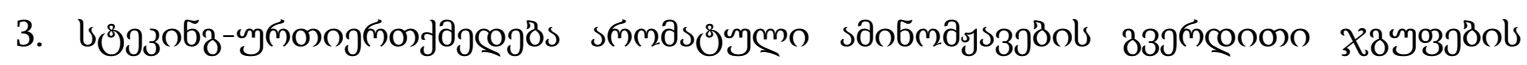

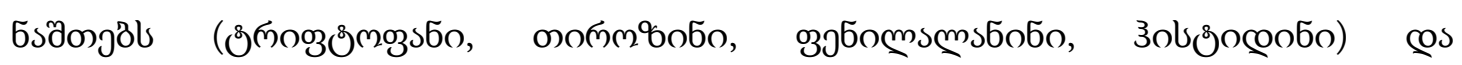

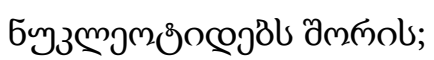

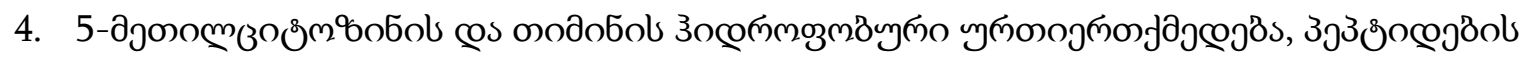

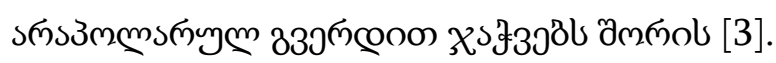

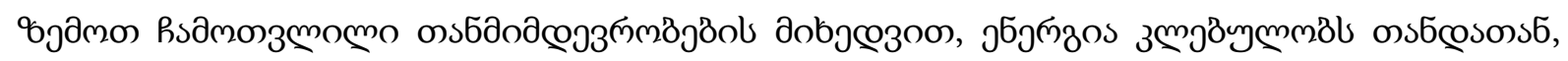

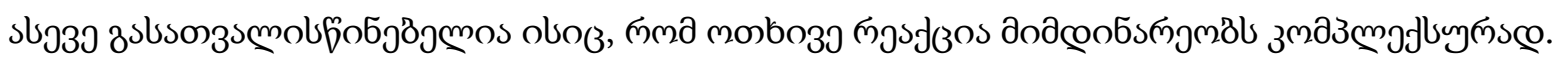

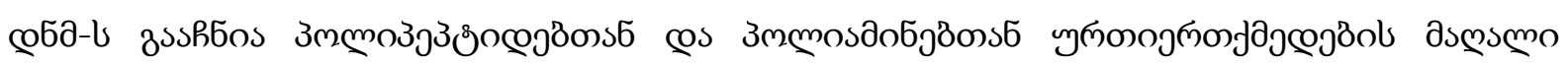

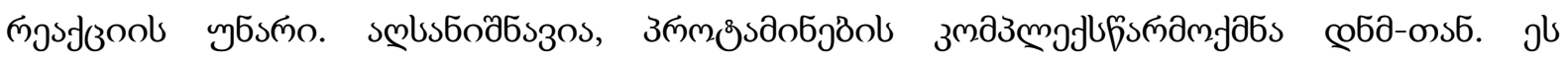

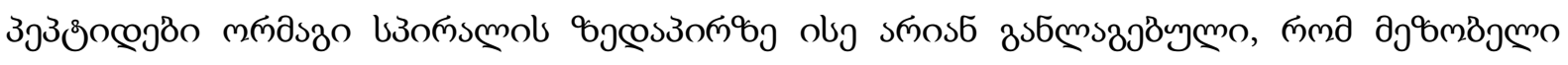

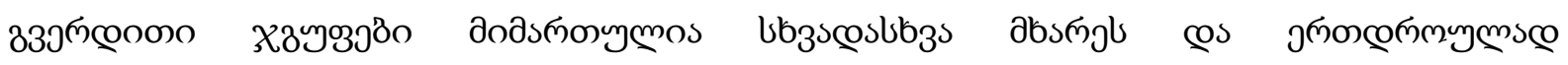

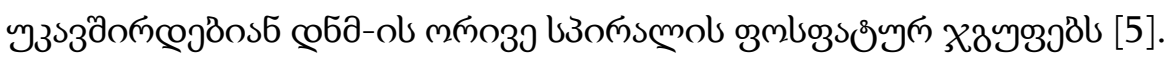

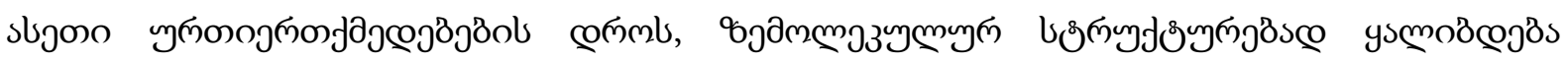

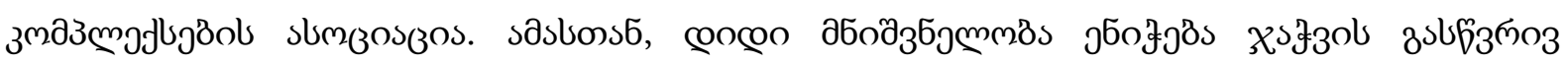

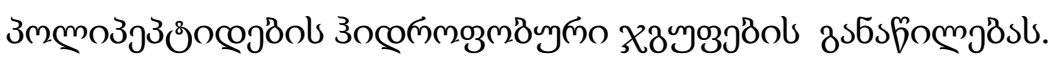

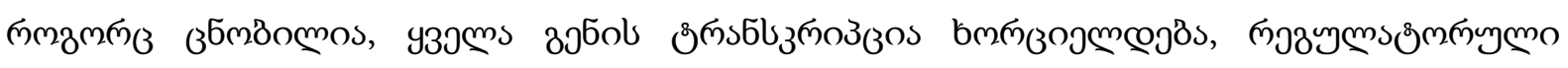

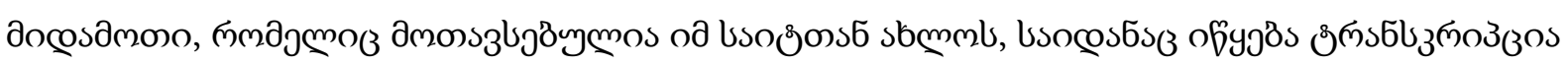

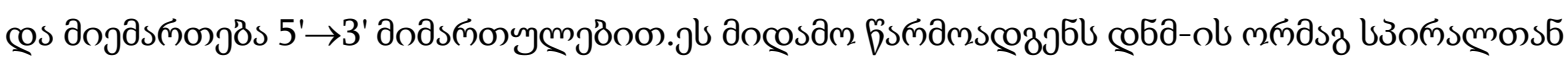

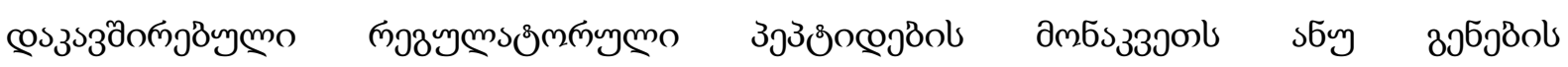

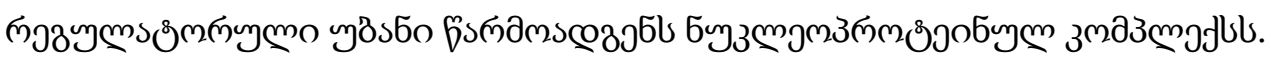

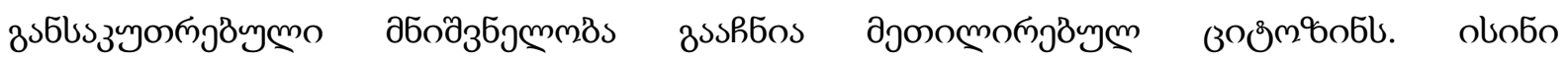

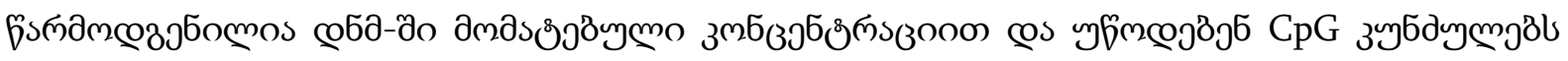

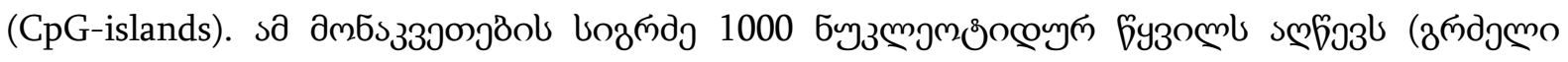

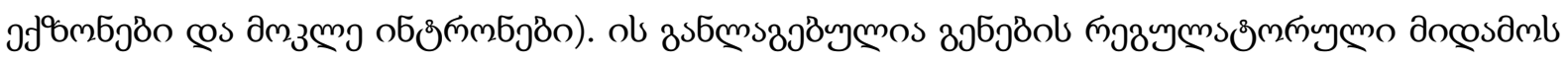

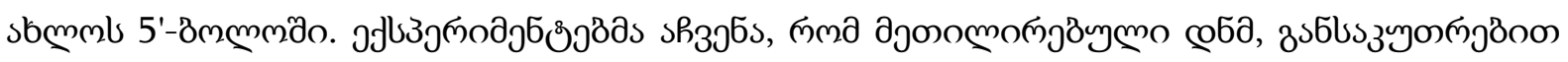

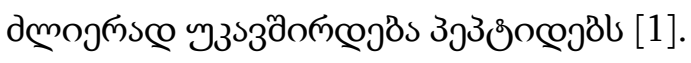

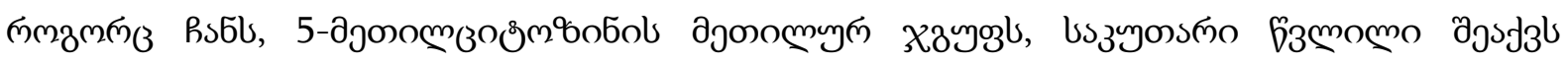

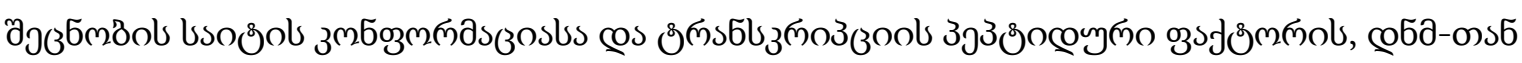

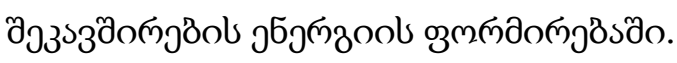

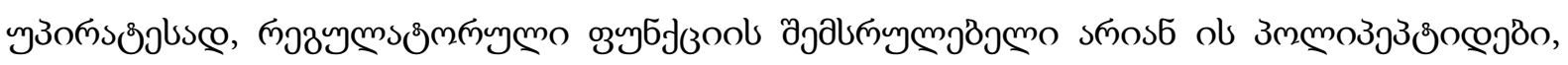

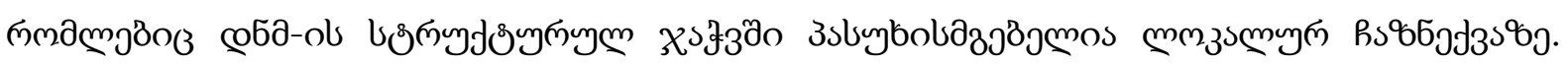

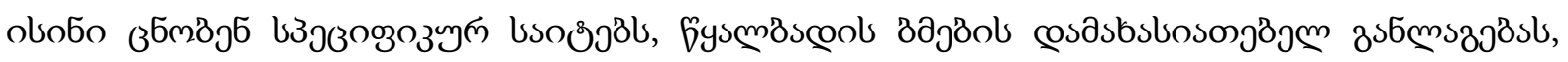

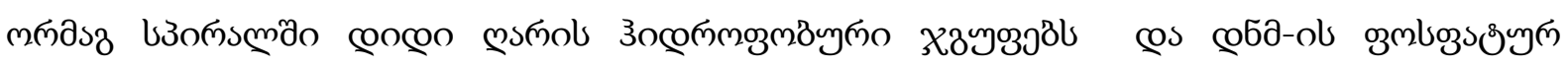

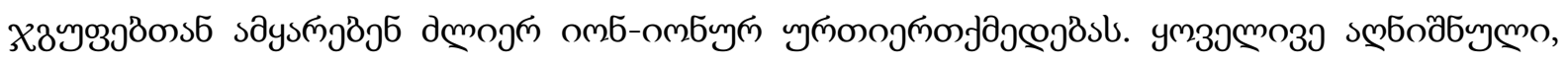

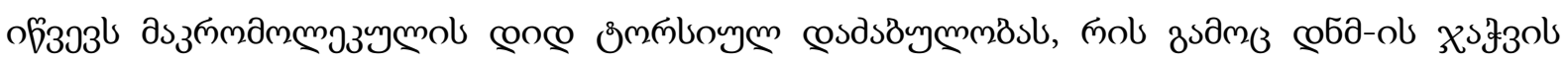




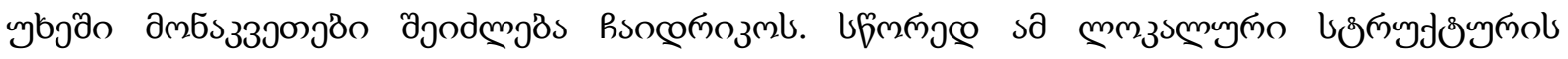

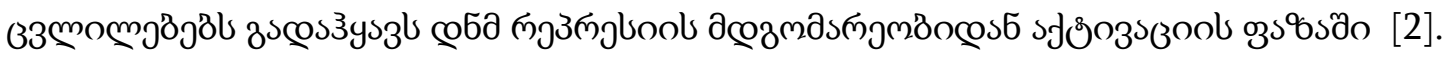

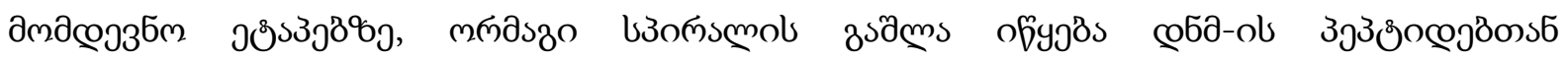

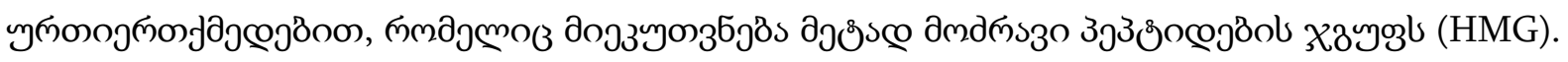

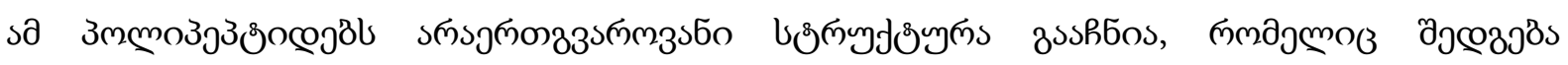

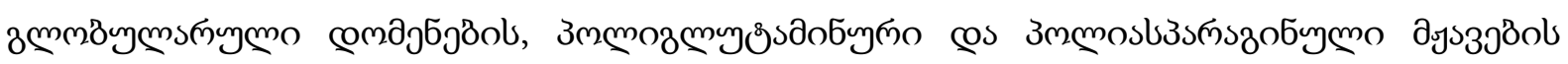

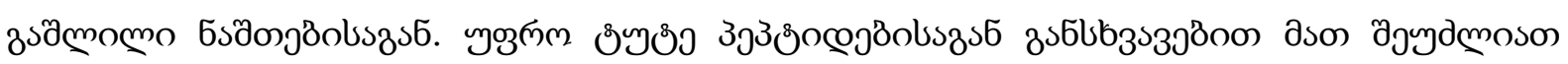

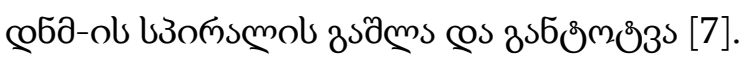

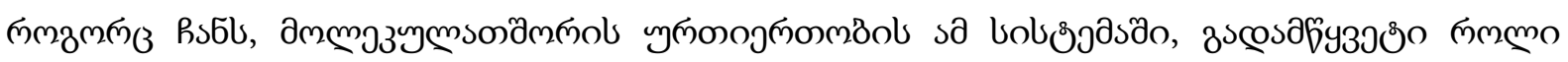

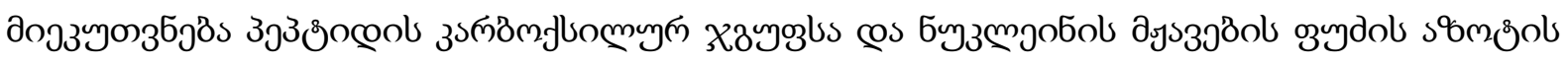

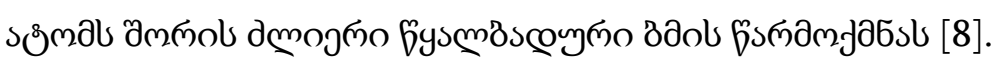

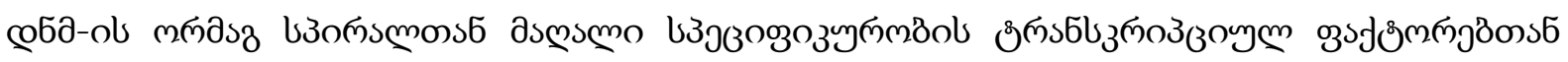

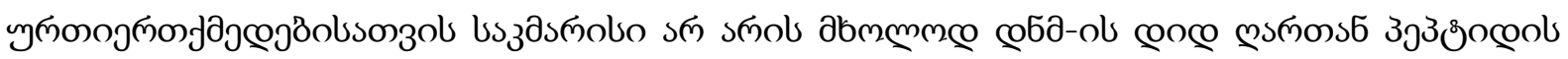

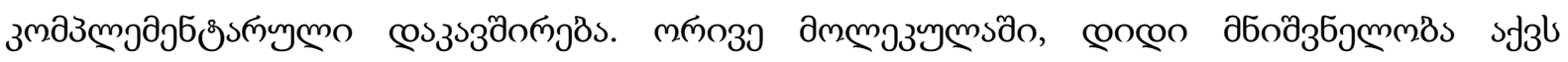

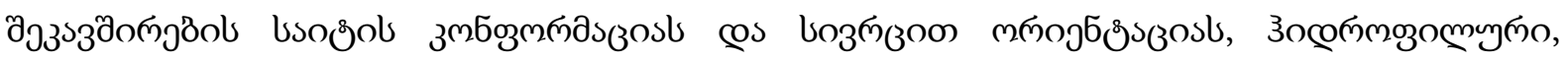

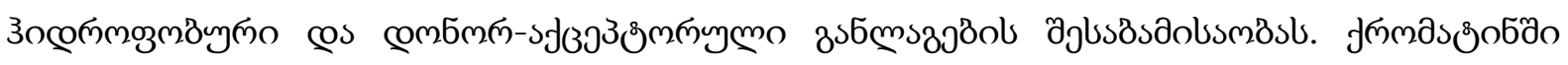

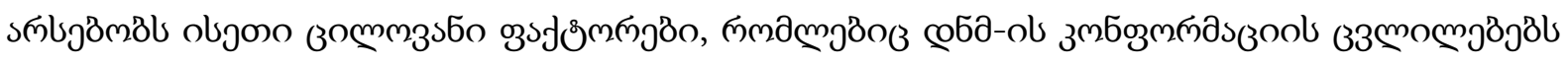

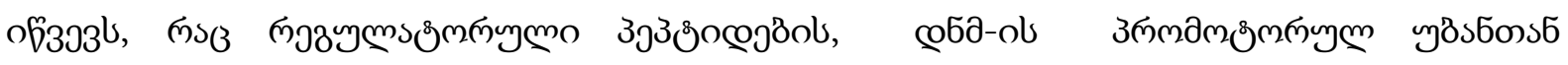

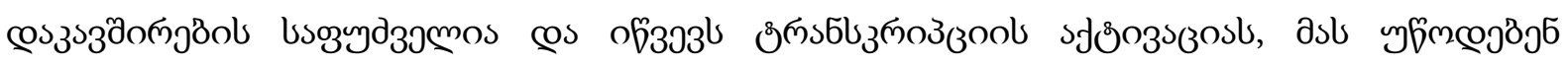

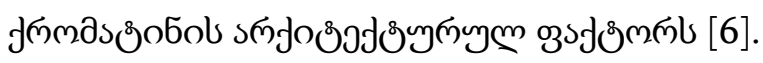

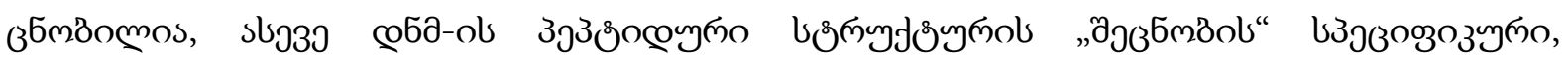

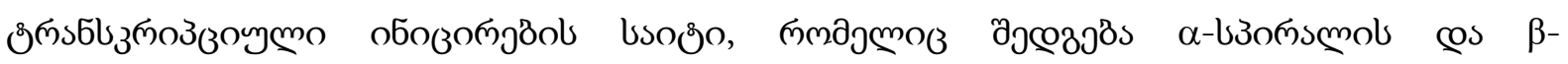

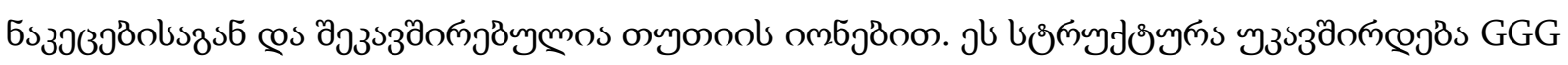

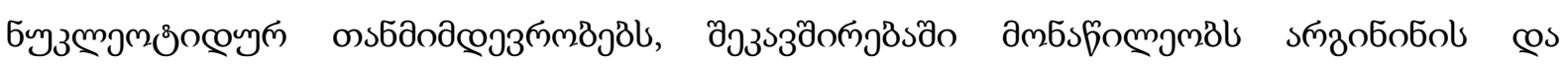

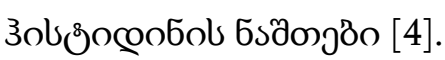

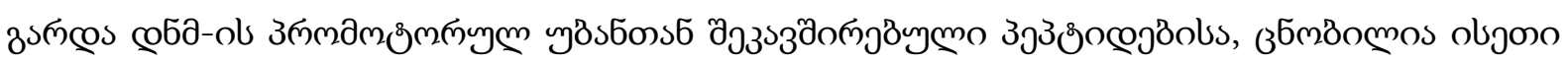

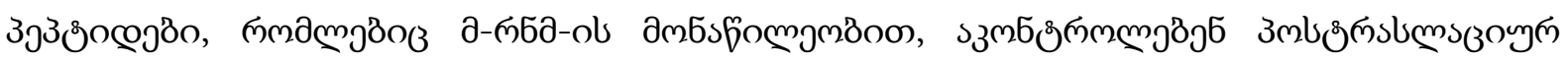

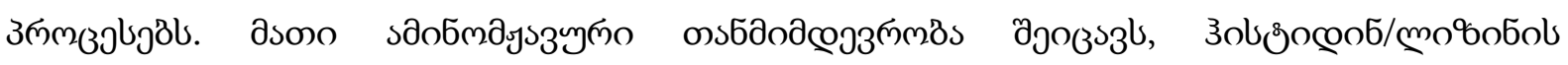

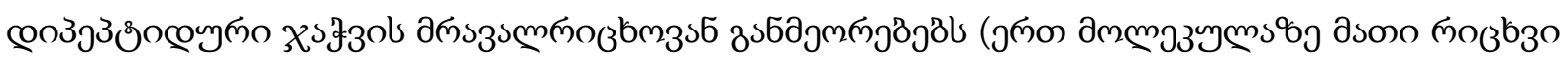

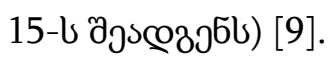

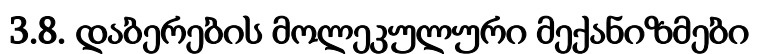

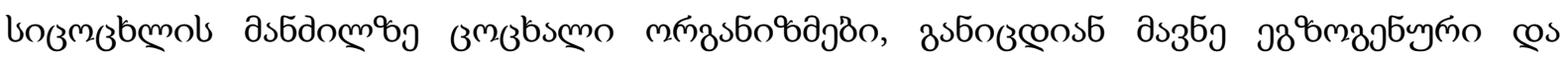

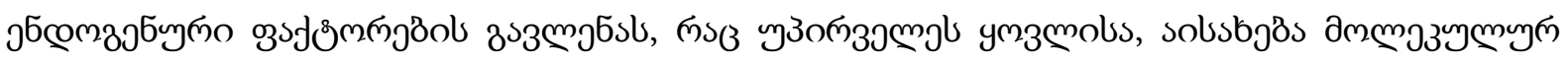

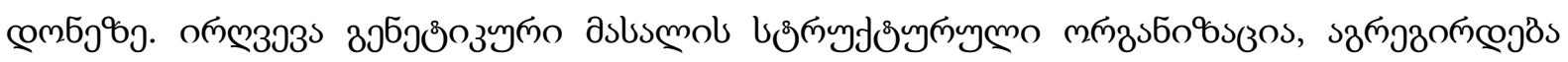

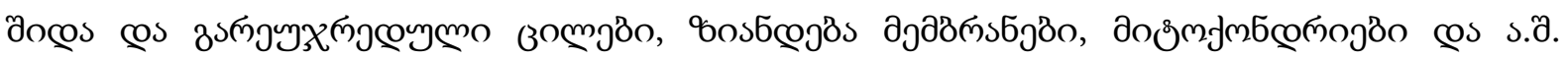

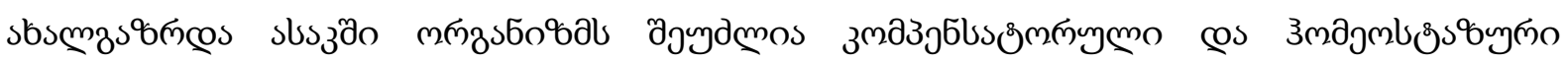

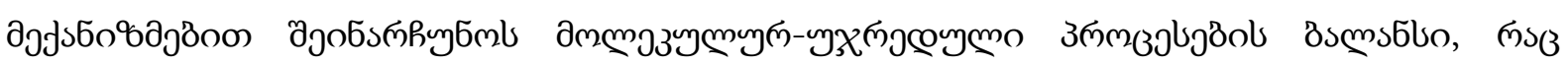

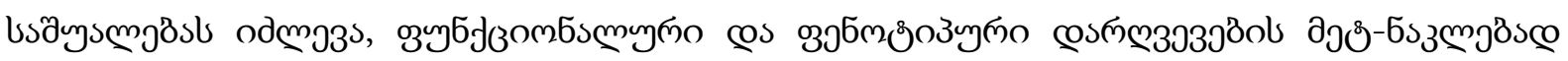

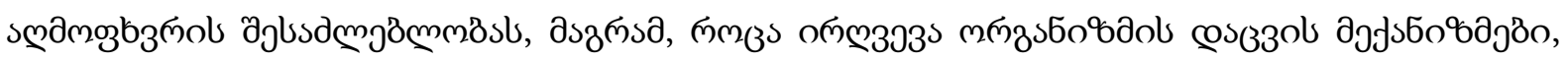

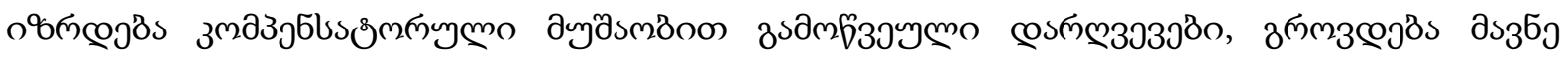




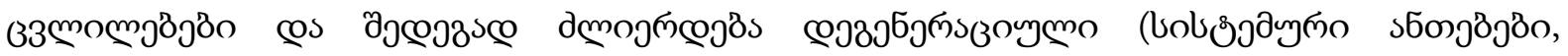

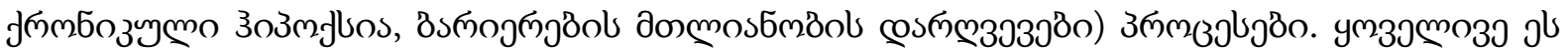

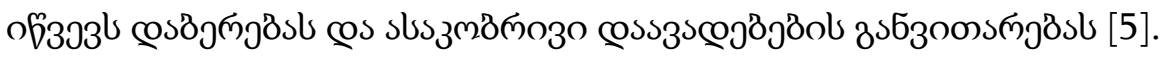

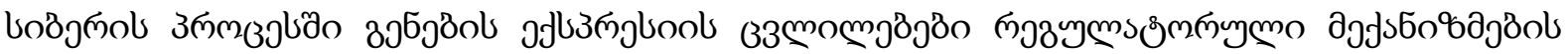

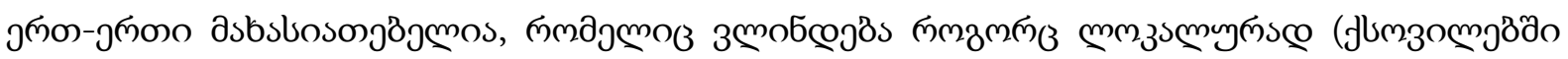

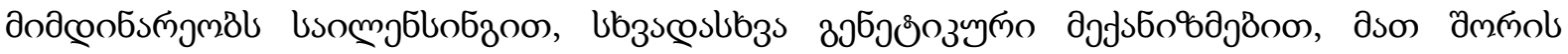
ду

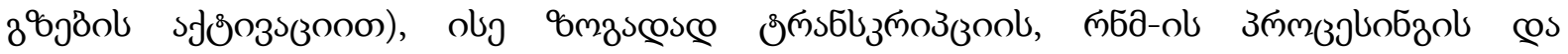

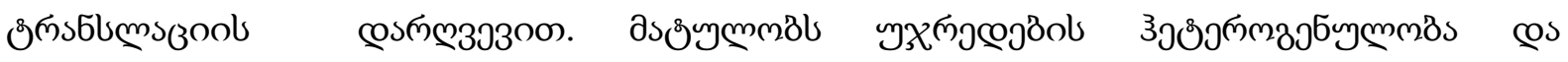

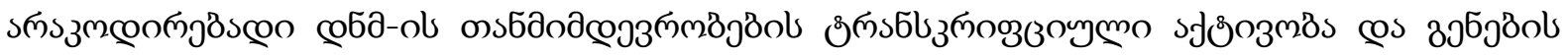

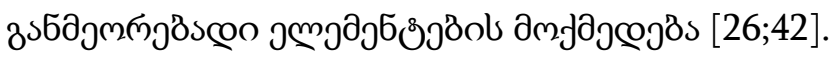

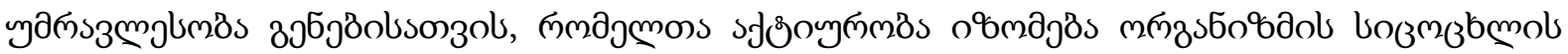

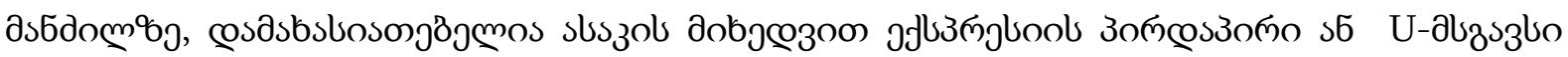

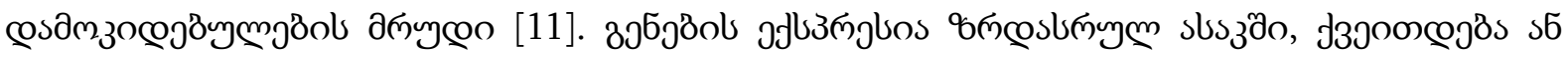

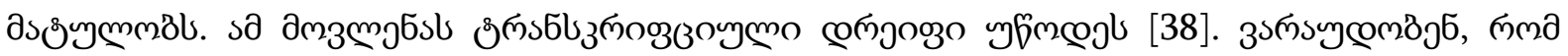

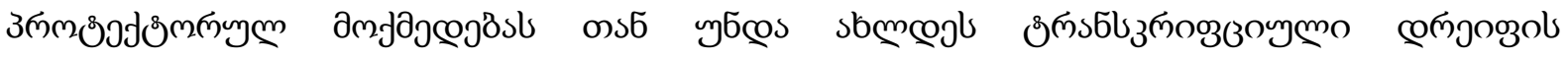

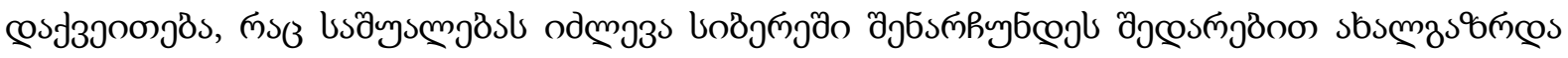

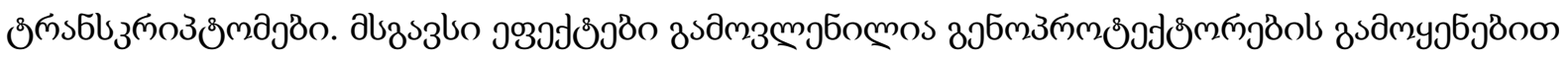

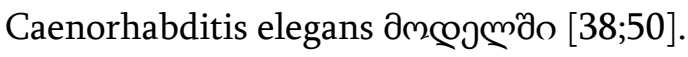

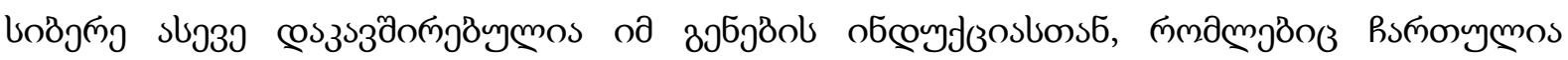

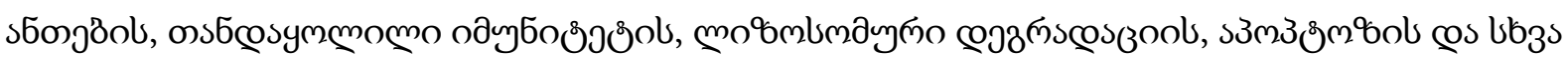

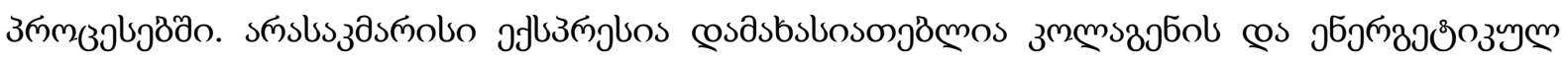

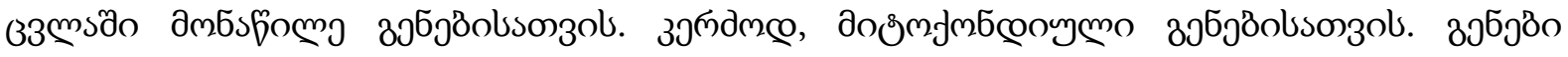

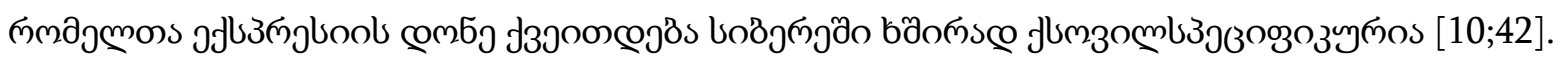

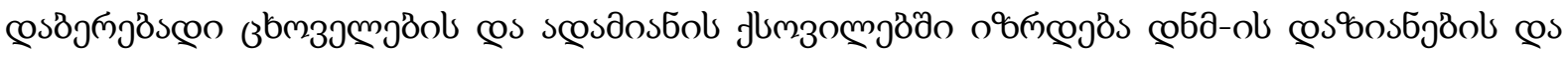

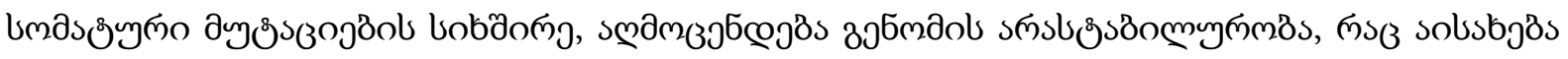

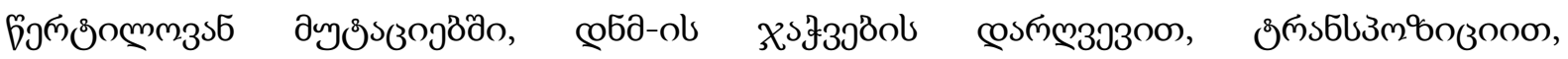

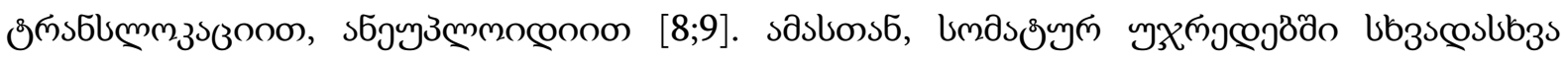

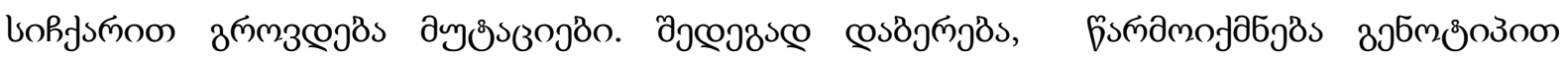

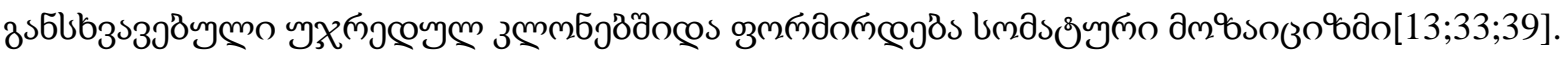

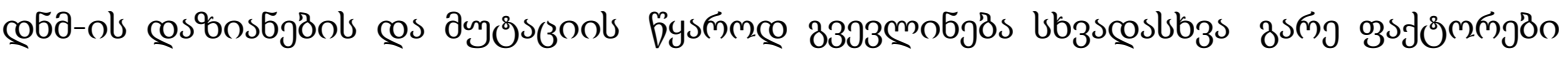

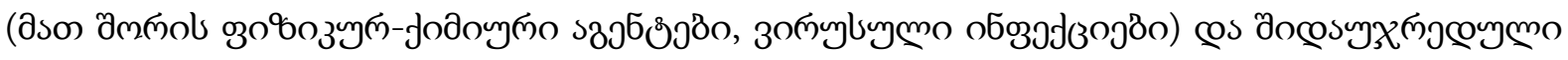

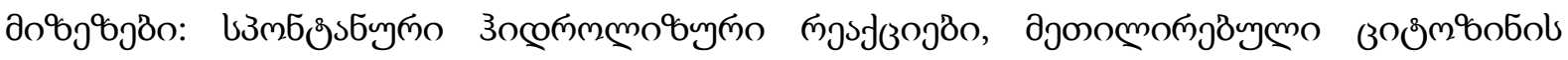

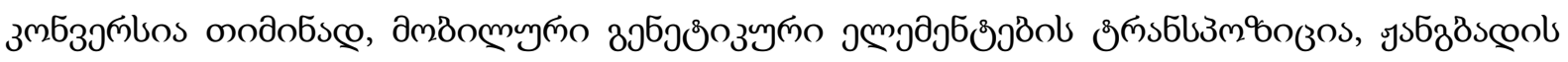

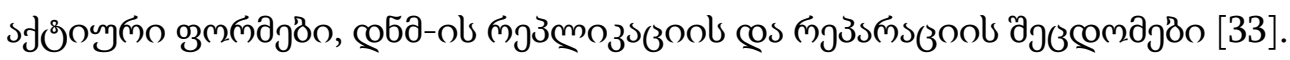

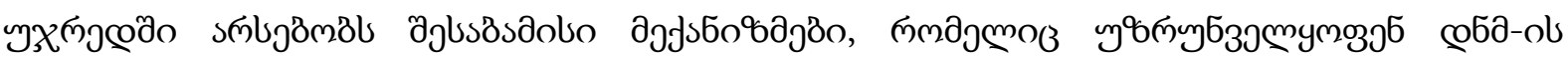

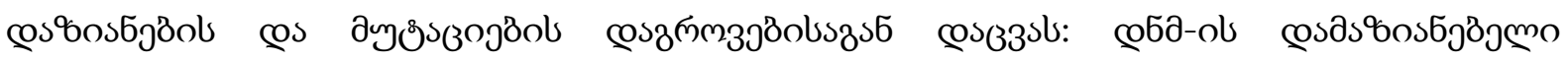

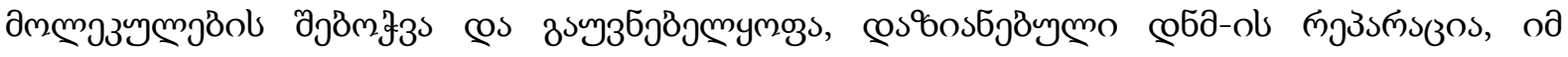

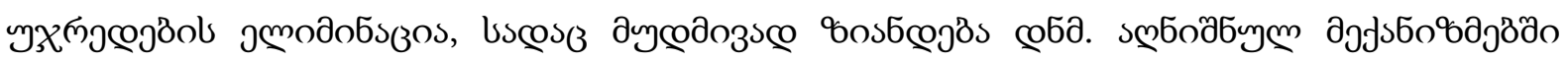

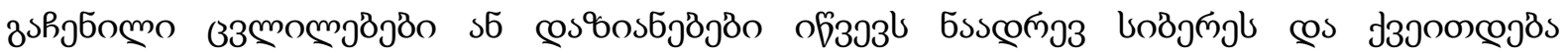

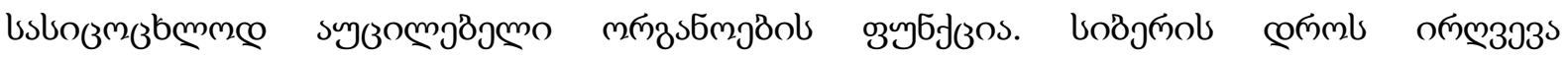

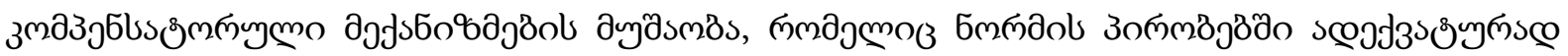




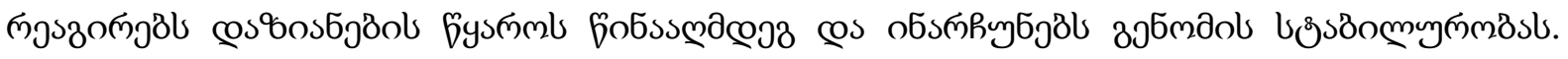

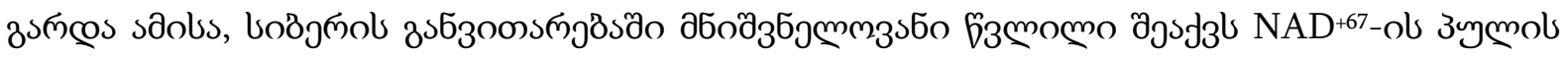

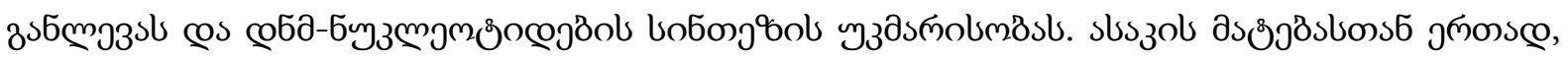

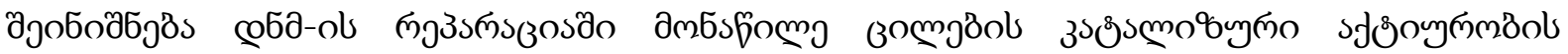

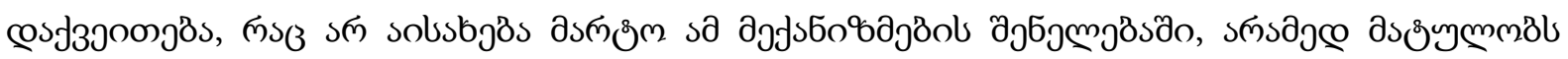

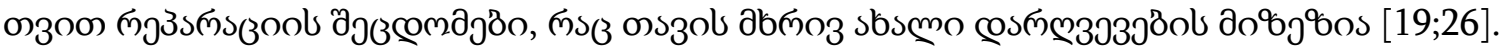

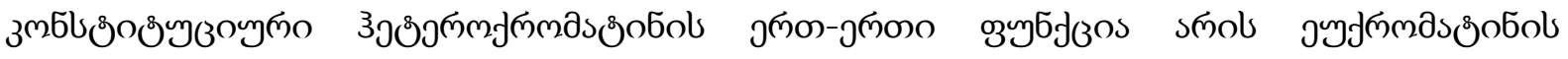

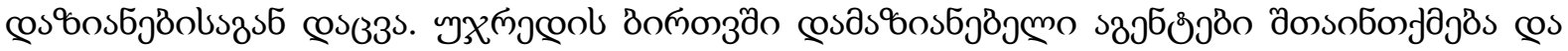

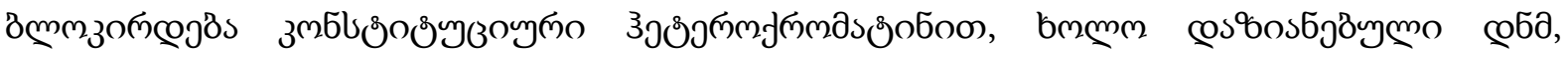

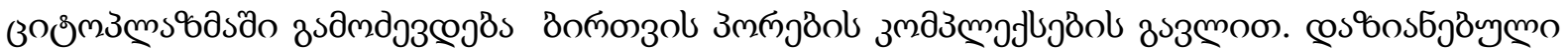

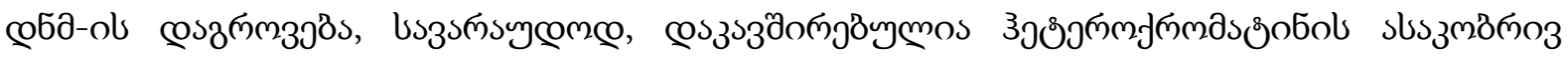

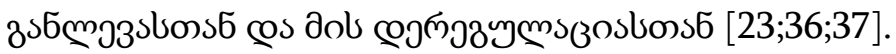

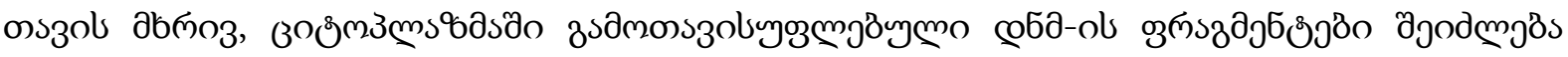

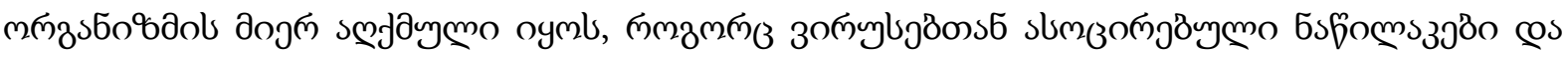

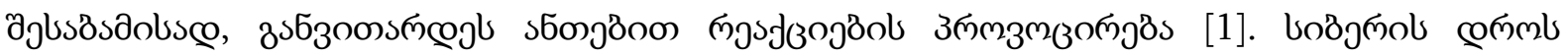

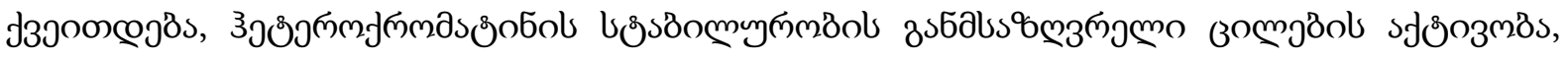

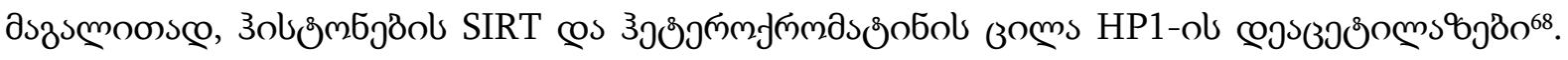

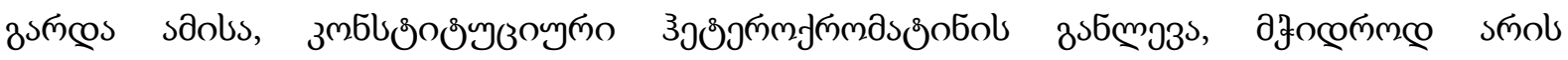

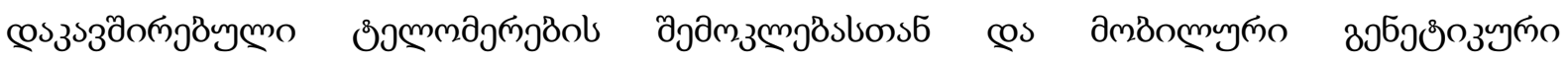

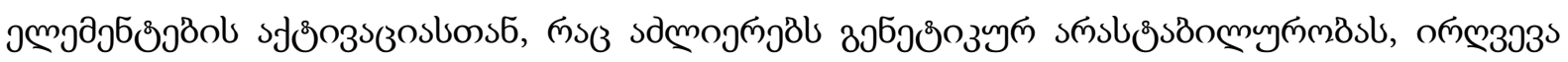

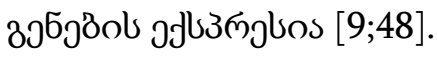

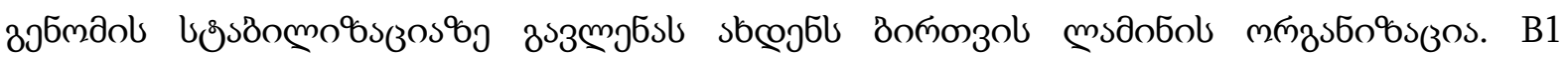

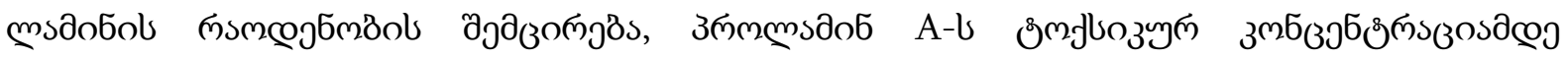

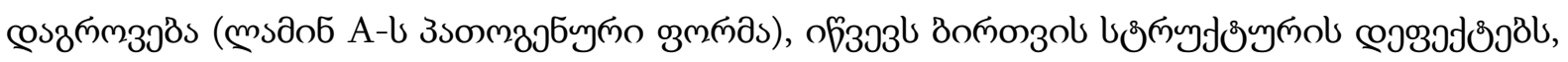

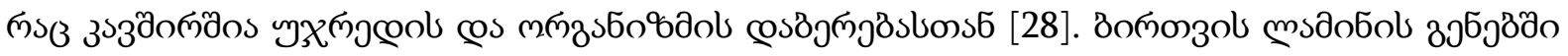

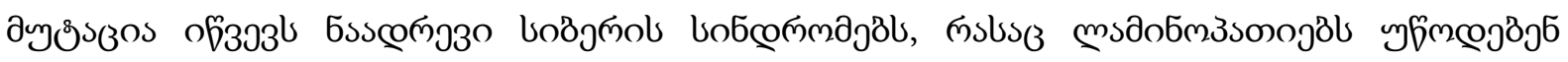

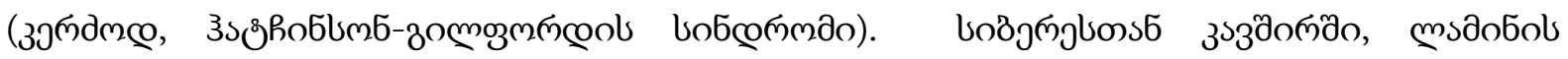

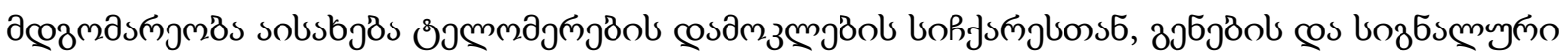

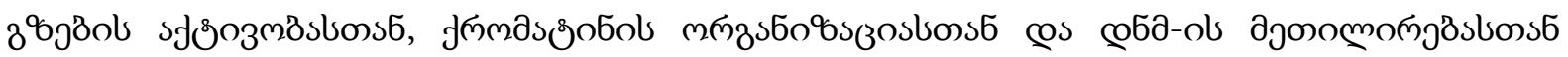
$[40 ; 49]$.

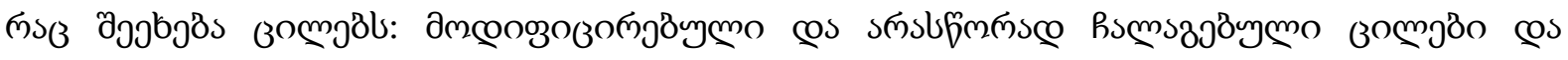

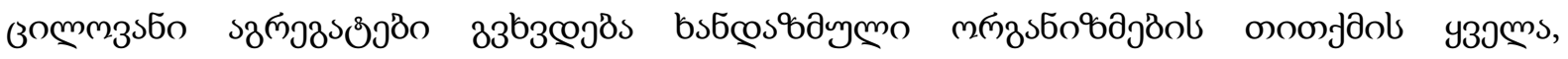

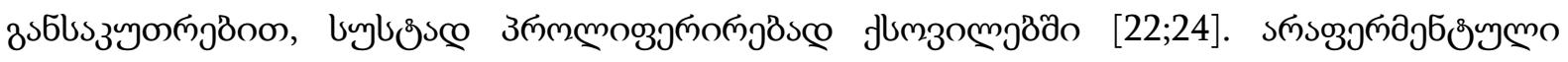

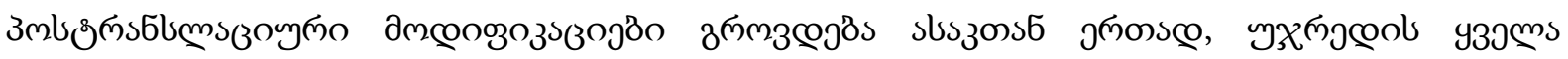

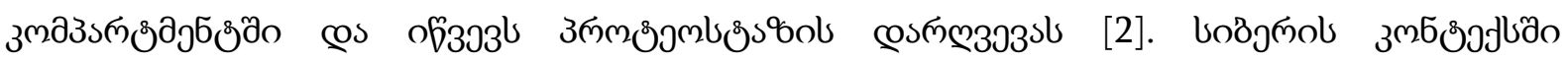

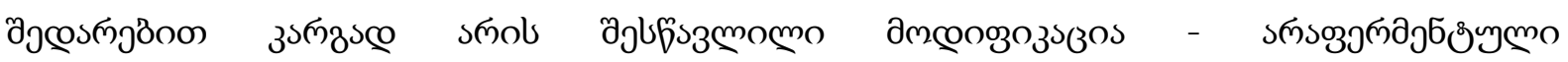

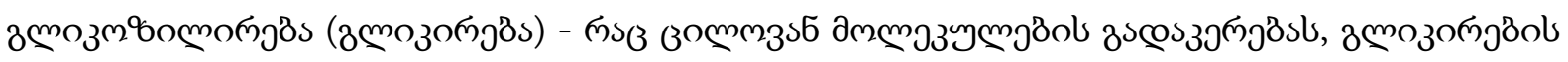

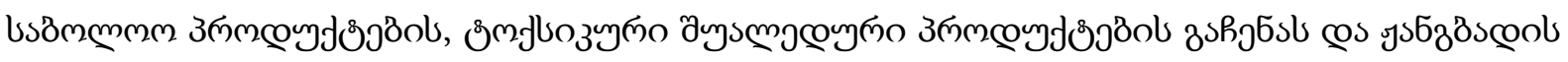

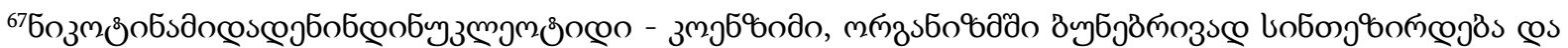

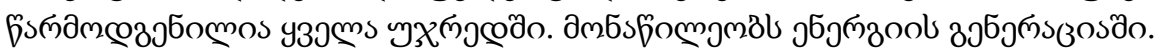

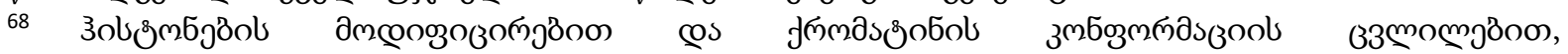

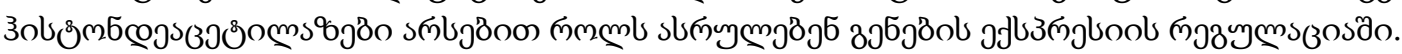




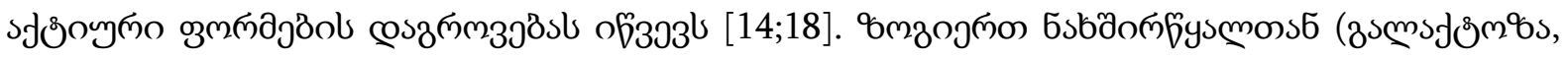

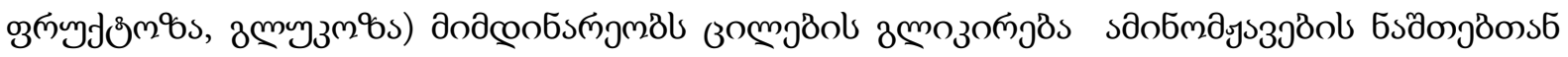

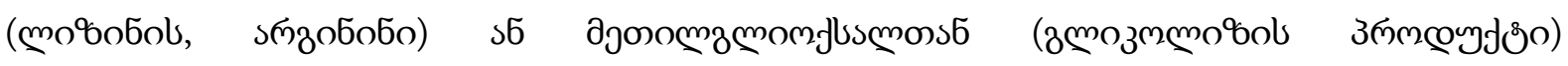

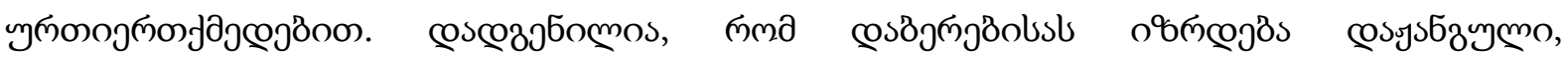

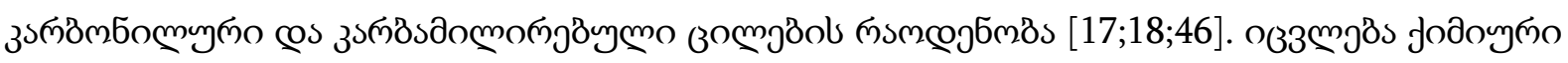

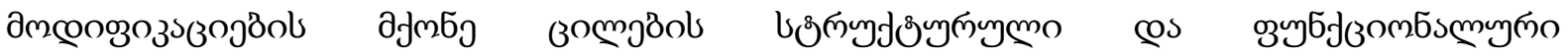

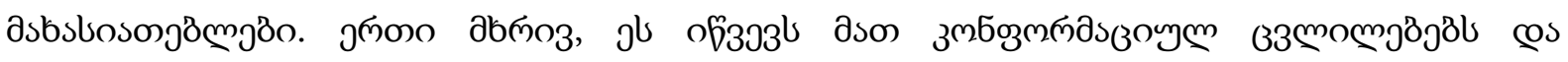

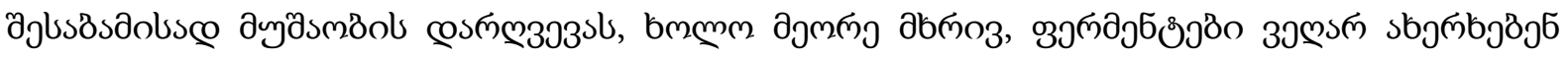

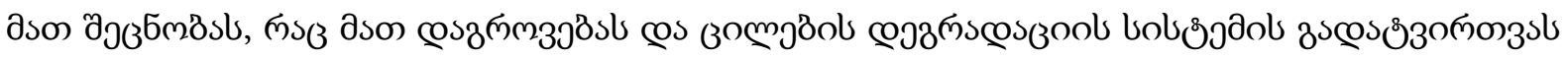

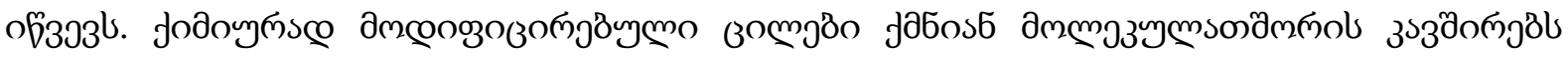

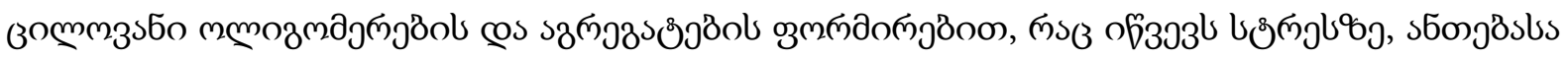

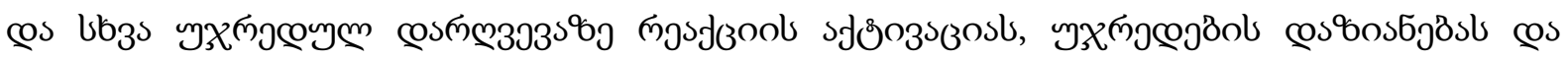

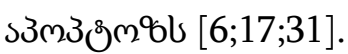

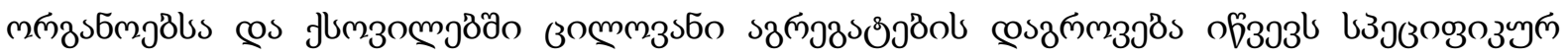

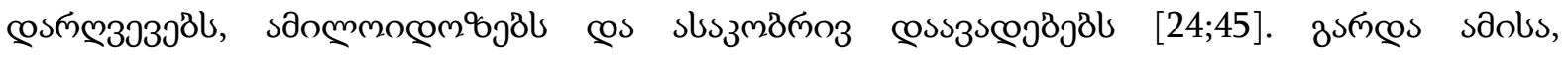

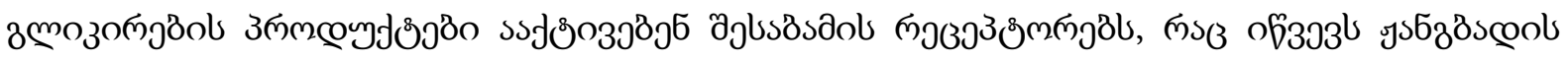

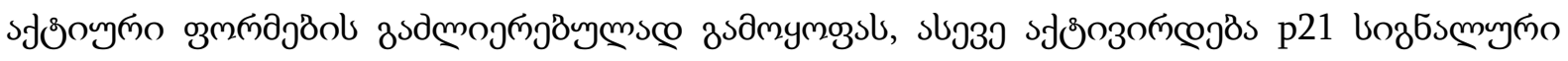

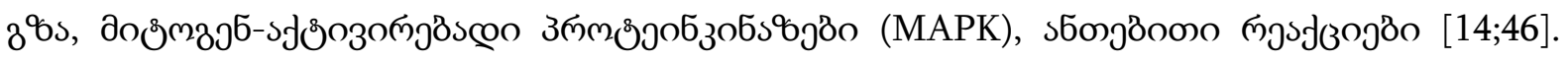

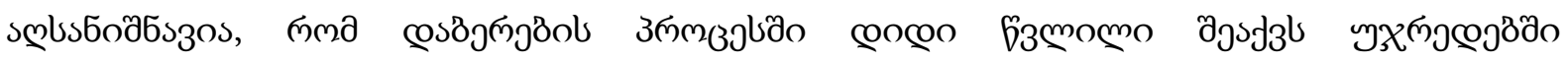

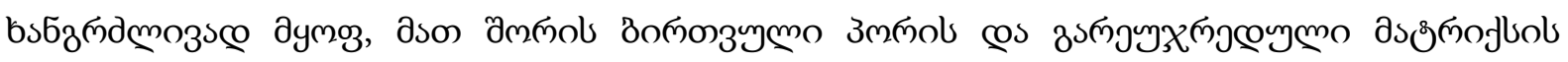

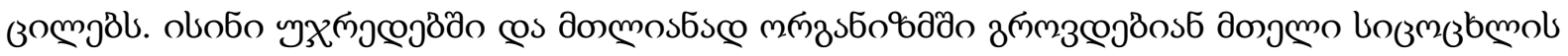

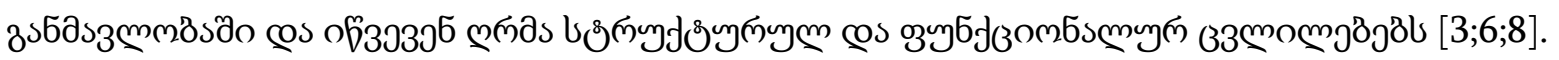

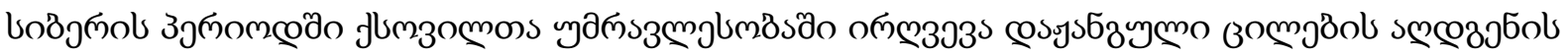

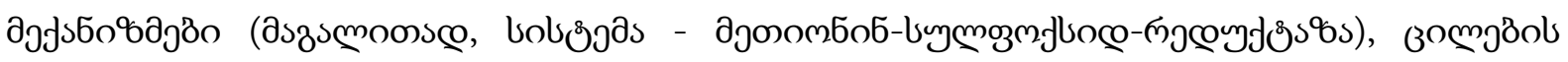

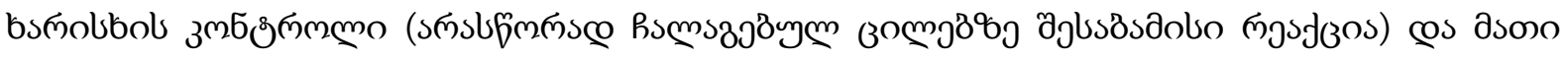

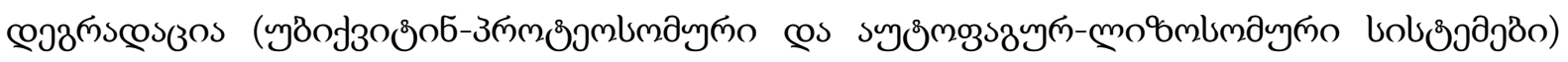

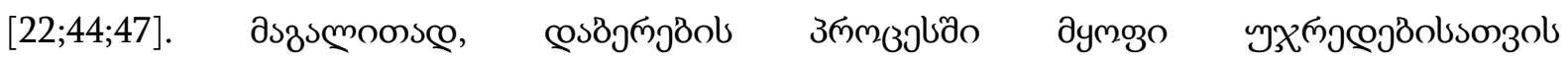

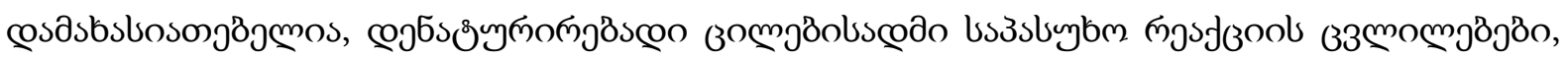

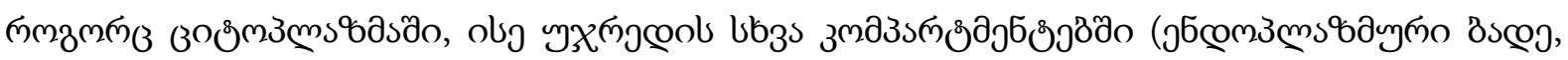

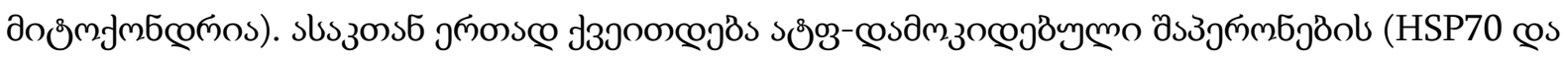

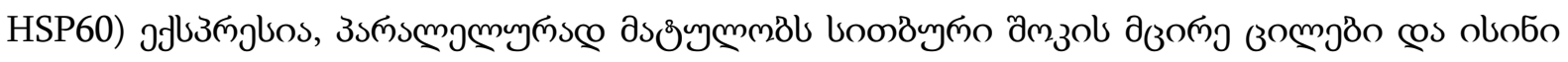

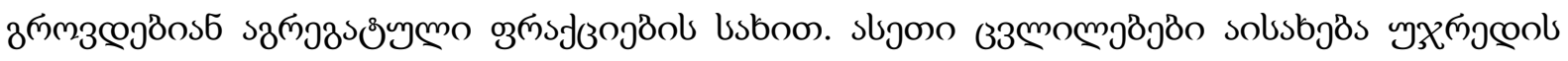

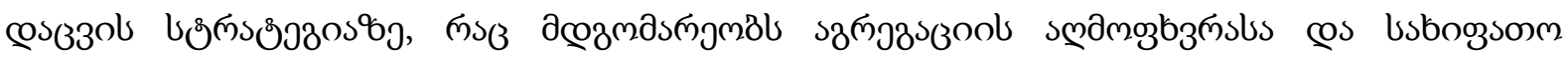

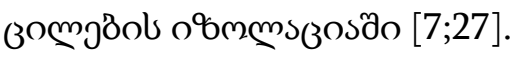

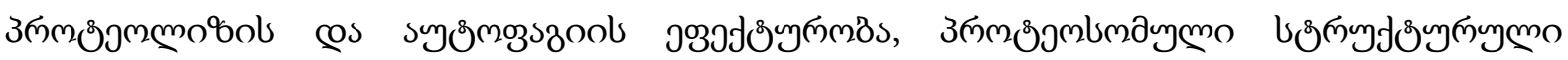

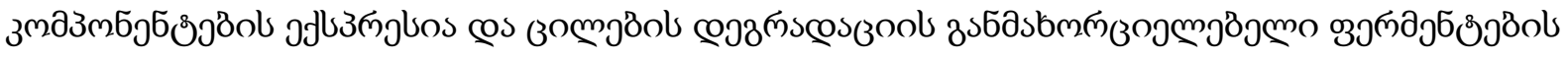

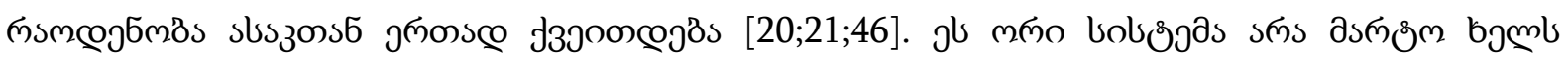

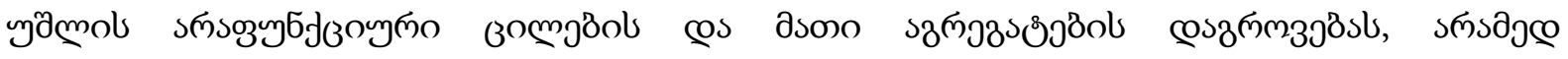

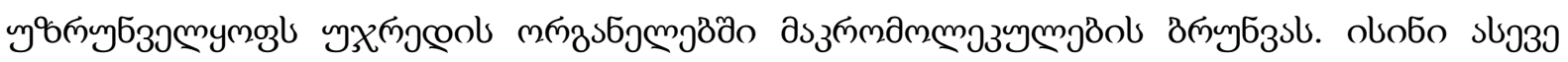

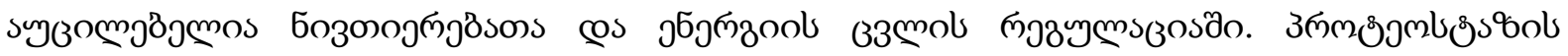

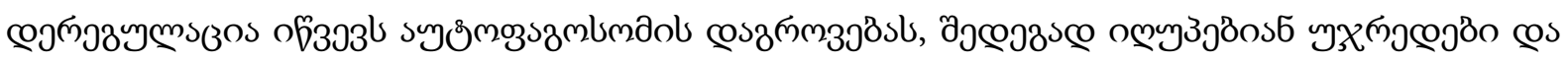




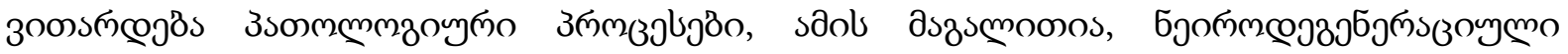

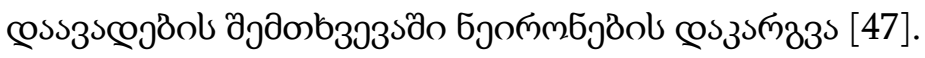

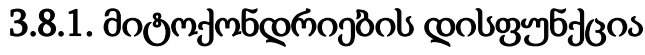

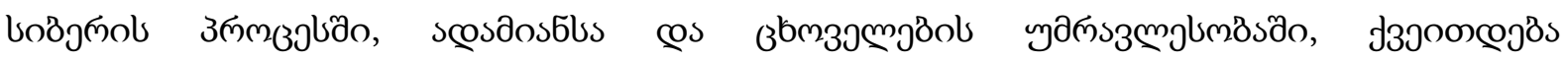

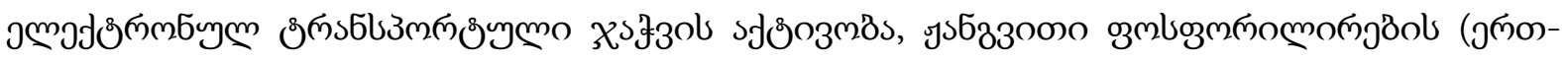

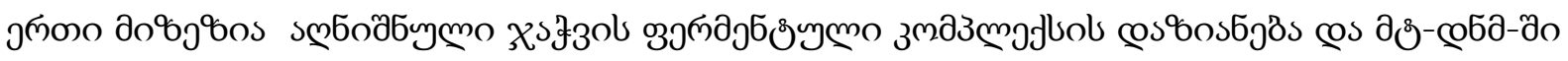

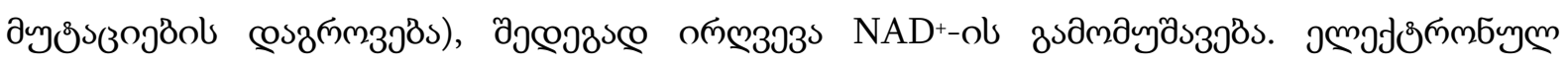

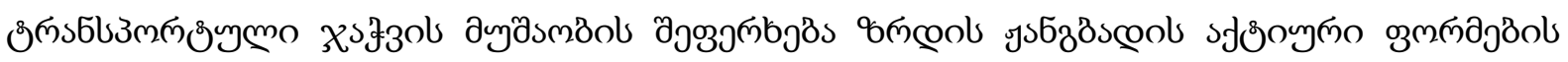

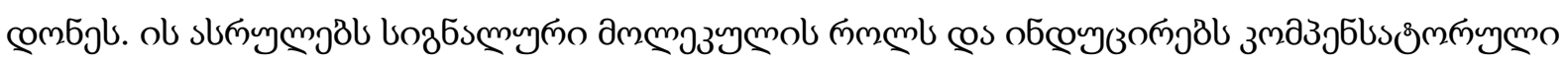

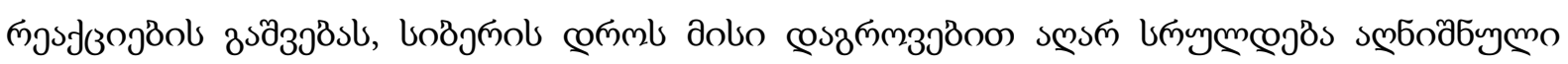

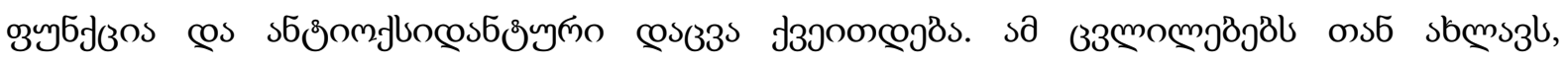

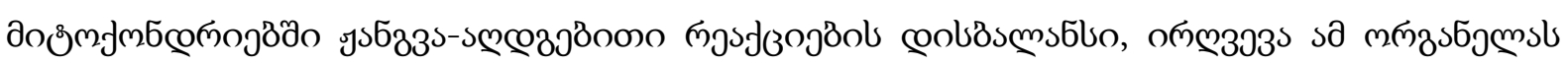

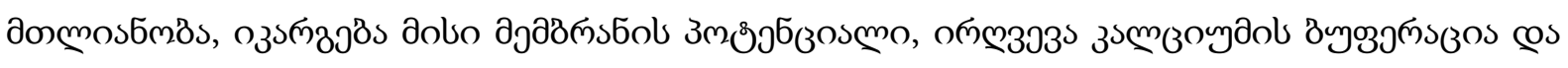

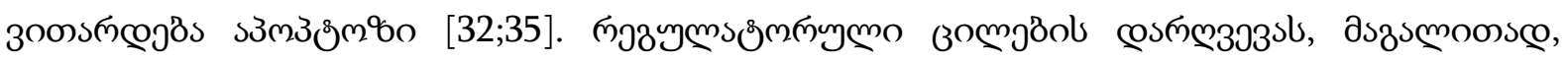

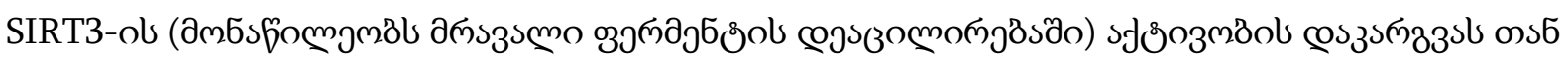

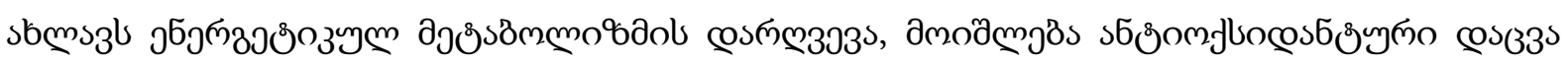

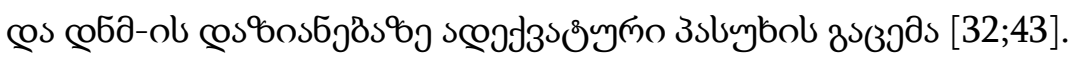

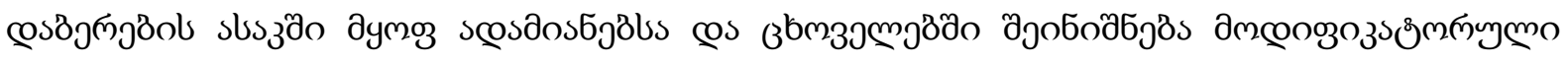

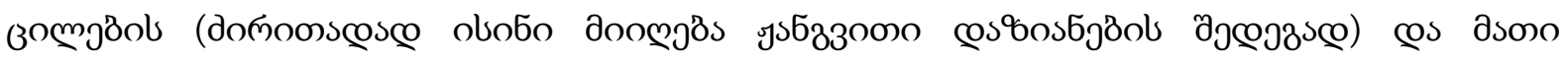

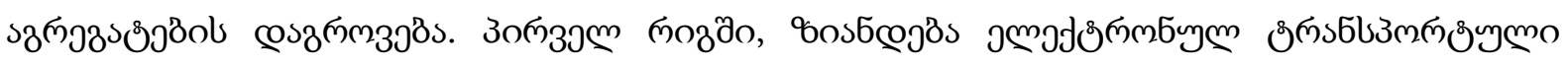

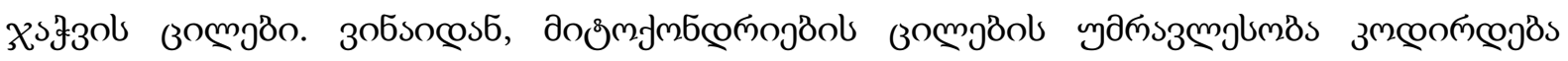

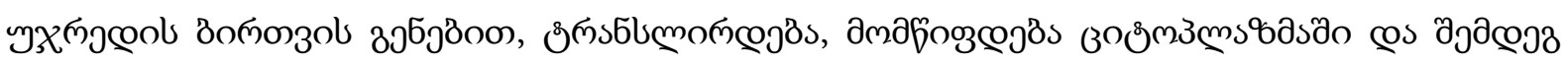

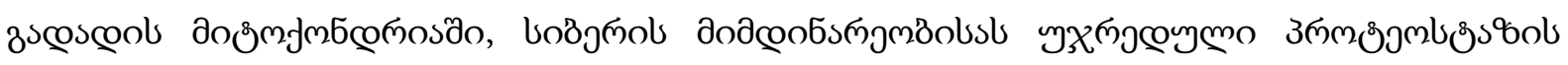

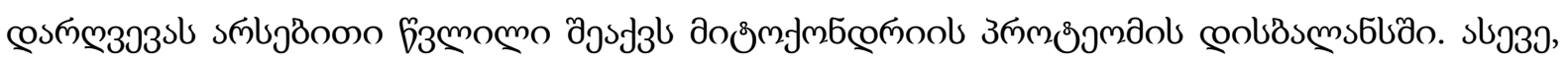

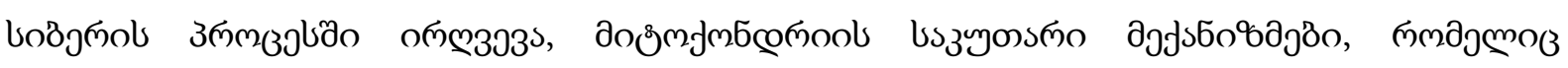

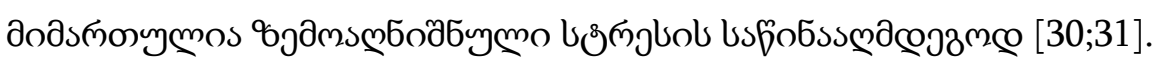

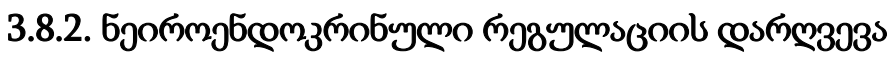

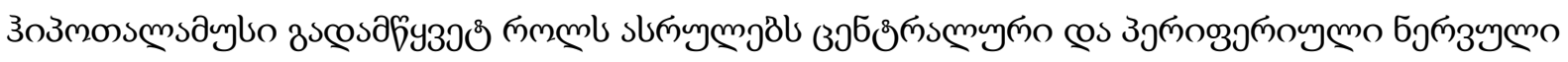

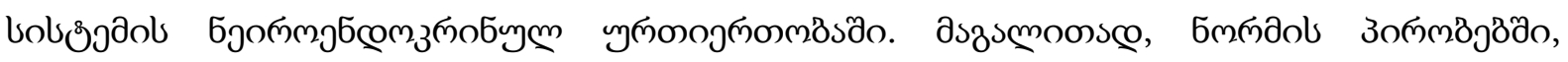

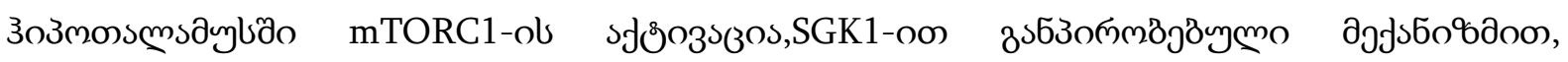

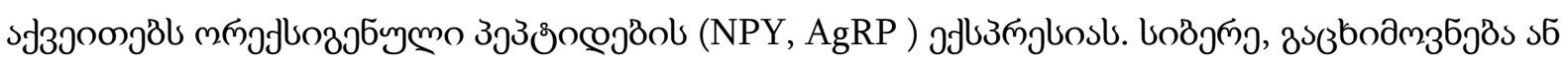

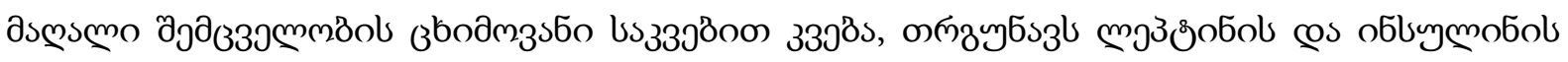

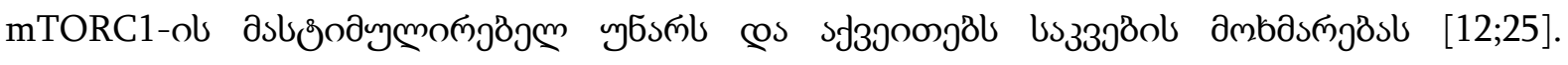

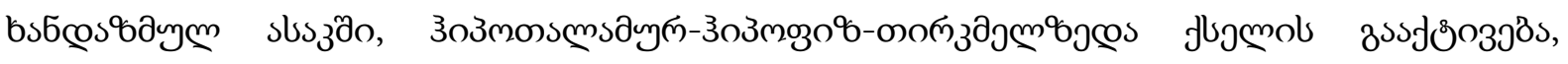

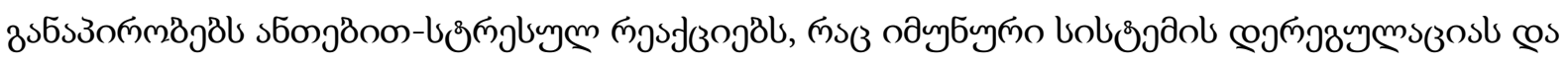

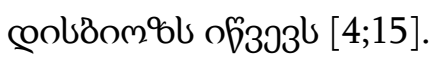




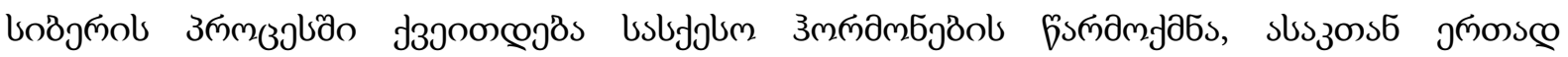

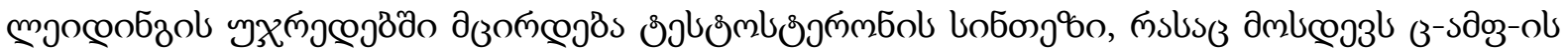

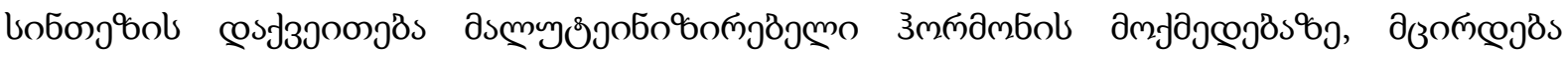

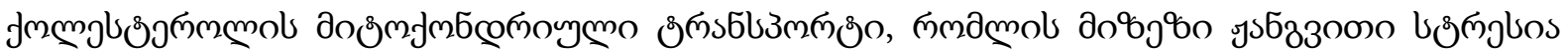
[162].

\subsection{3. одуб}

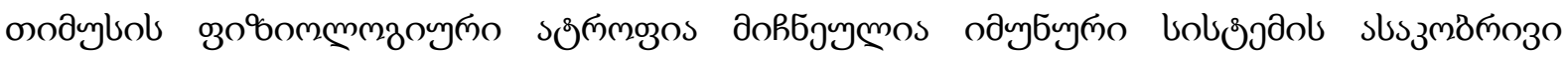

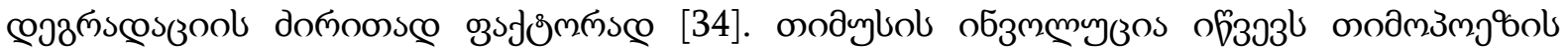

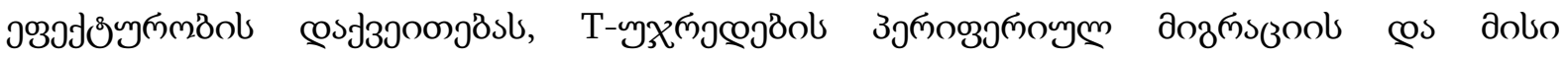

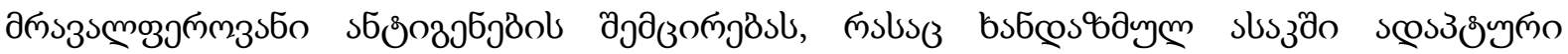

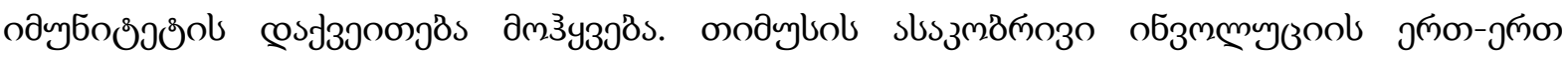

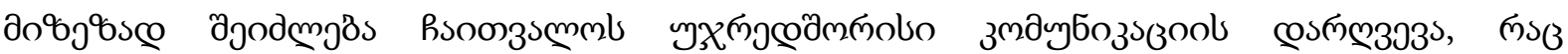

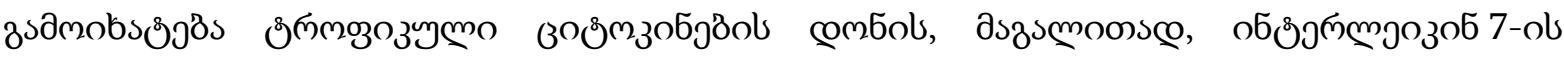

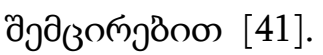

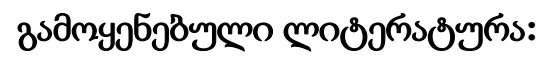

1. Akbari M., Kirkwood T.B.L., Bohr V.A. (2019) Mitochondria in the signaling pathways that control longevity and health span. Ageing Res. Rev. 54, 100940.

2. Baldensperger T., Eggen M., Kappen J., WinterhalterP.R., Pfirrmann T., Glomb M.A. (2020) Comprehensiveanalysis of posttranslational protein modificationsin aging of subcellular compartments. Sci. Rep.10, 7596.

3. Basisty N., Holtz A., Schilling B. (2020) Accumulationof "old proteins" and the critical need for MSbasedprotein turnover measurements in aging andlongevity. Proteomics. 20, e1800403.

4. Bauer M.E. (2005) Stress, glucocorticoids and ageingof the immune system. Stress. 8, 69-83.

5. Bayersdorf R., Schumacher B. (2019) Recent advances in understanding the mechanisms determining longevity. F1000Res. 8, F1000 Faculty Rev-1403.

6. Birch H.L. (2018) Extracellular matrix and ageing.Subcell. Biochem. 90, 169-190.

7. Brehme M., Voisine C., Rolland T., Wachi S.,Soper J.H., Zhu Y., Orton K., Villella A., Garza D.,Vidal M., Ge H., Morimoto R.I. (2014) A chaperomesubnetwork safeguards proteostasis in aging and neurodegenerativedisease. Cell Rept. 9, 1135-1150.

8. Cheon S.Y., Kim H., Rubinsztein D.C., Lee J.E.(2019) Autophagy, cellular aging and agerelated humandiseases. Exp. Neurobiol. 28, 643-657.

9. De Cecco M., Criscione S.W., Peckham E.J., HillenmeyerS., Hamm E.A., Manivannan J., Peterson A.L.,Kreiling J.A., Neretti N., Sedivy J.M. (2013) Genomesof replicatively senescent cells undergo global epigeneticchanges leading to gene silencing and activation oftransposable elements. Aging Cell. 12, 247-256.

10. De Magalhaes J.P., Curado J., Church G.M. (2009)Meta-analysis of age-related gene expression profilesidentifies common signatures of aging. Bioinformatics.25, 875-881.

11. Donertas H.M., İzgi H., Kamacıoğlu A., He Z., Khaitovich P., Somel M. (2017) Gene expression reversal toward pre-adult levels in the aging human brain and age-related loss of cellular identity. Sci. Rep. 7, 5894-5894.

12. Filippi B.M., Lam T.K. (2014) Leptin and aging. Aging(Albany NY). 6, 82-83. 
13. Forsberg L.A., Gisselsson D., Dumanski J.P. (2017)Mosaicism in health and disease - clones picking upspeed. Nat. Rev. Genet. 18, 128-142.

14. Fournet M., Bonte F., Desmouliere A. (2018) Glycationdamage: a possible hub for major pathophysiologicaldisorders and aging. Aging Dis. 9, 880-900

15. Galley J.D., Bailey M.T. (2014) Impact of stressor exposureon the interplay between commensal microbiotaand host inflammation. Gut Microbes. 5, 390-39.

16. Gomes P., Viana S.D., Nunes S., Rolo A.P., PalmeiraC.M., Reis F. (2020) The yin and yang faces of themitochondrial deacetylase sirtuin 3 in age-related disorders.Ageing Res. Rev. 57, 100983.

17. Gorisse L., Pietrement C., Vuiblet V., Schmelzer C.E.,Kohler M., Duca L., Debelle L., Fornes P., Jaisson S.,Gillery P. (2016) Protein carbamylation is a hallmarkof aging. Proc. Natl. Acad. Sci. USA. 113, 1191-1196.

18. Grune T. (2020) Oxidized protein aggregates: formationand biological effects. Free Radic. Biol. Med. 150,120-124.

19. Hamalainen R.H., Landoni J.C., Ahlqvist K.J., GoffartS., Ryytty S., Rahman M.O., Brilhante V., Icay K.,Hautaniemi S., Wang L., Laiho M., Suomalainen A.(2019) Defects in mtDNA replication challenge nucleargenome stability through nucleotide depletion andprovide a unifying mechanism for mouse progerias. Nat. Metab. 1, 958-965.

20. Hansen M., Rubinsztein D.C., Walker D.W. (2018)Autophagy as a promoter of longevity: insights frommodel organisms. Nat. Rev. Mol. Cell Biol. 19, 579-593.

21. Hegde A.N., Smith S.G.,Duke L.M.,Pourquoi A.,Vaz S.(2019) Perturbations of ubiquitin-proteasomemediatedproteolysis in aging and Alzheimer's disease.Front. Aging Neurosci. 11,324

22. Hipp M.S., Kasturi P., Hartl F.U. (2019) The proteostasisnetwork and its decline in ageing. Nat. Rev. Mol.Cell Biol. 20, 421-435.

23. Janssen A., Colmenares S.U., Karpen G.H. (2018) Heterochromatin: guardian of the genome. Annu. Rev.Cell. Dev. Biol. 34, 265-288.

24. Koga H., Kaushik S., Cuervo A.M. (2011) Protein homeostasisand aging: the importance of exquisite qualitycontrol. Ageing Res. Rev. 10, 205-215.

25. Laplante M., Sabatini D.M. (2012) mTOR signaling in growth control and disease. Cell. 149, 274-293.

26. Maniyadath B., Shukla N., Kolthur-Seetharam U. (2018) Gene expression, epigenetics and ageing. Subcell.Biochem. 90, 471-504.

27. Martinez G., Duran-Aniotz C., Cabral-Miranda F.,Vivar J.P., Hetz C. (2017) Endoplasmic reticulum proteostasisimpairment in aging. Aging Cell. 16, 615-623.

28. Mattioli E., Andrenacci D., Garofalo C., Prencipe S.,Scotlandi K., Remondini D., Gentilini D., Di BlasioA.M., Valente S., Scarano E., Cicchilitti L., PiaggioG., Mai A., Lattanzi G. (2018) Altered modulationof lamin A/C-HDAC2 interaction and p21 expressionduring oxidative stress response in HGPS. Aging Cell.17, e12824.

29. Mendelsohn A.R., Larrick J.W. (2017) The NAD+/PARP1/SIRT1 axis in aging. RejuvenationRes. 20, 244-247.

30. Moehle E.A., Shen K., Dillin A. (2019) Mitochondrialproteostasis in the context of cellular and organismalhealth and aging. J. Biol. Chem. 294, 5396-5407.

31. Moldogazieva N.T., Mokhosoev I.M., Mel'nikova T.I., Porozov Y.B., Terentiev A.A. (2019) Oxidative stressand advanced lipoxidation and glycation end products(ALEs and AGEs) in aging and age-related diseases.Oxid. Med. Cell Longev. 2019, 3085756.

32. Moro L. (2019) Mitochondrial dysfunction in agingand cancer. J. Clin. Med. 8, 1983.112. Hekimi S., Lapointe J., Wen Y. (2011) Taking a"good" look at free radicals in the aging process.Trends Cell Biol. 21, 569-576. 
33. Moskalev A.A., Shaposhnikov M.V., Plyusnina E.N.,Zhavoronkov A., Budovsky A., Yanai H., Fraifeld V.E.(2013) The role of DNA damage and repair in agingthrough the prism of Koch-like criteria. Ageing Res.Rev. 12, 661-684.

34. Muller L., Di Benedetto S., Pawelec G. (2019) The immune system and its dysregulation with aging. In:Biochem. Cell Biol. Ageing: Part II Clin. Sci. Eds HarrisJ.R., Korolchuk V.I. Singapore: Springer Singapore,pp. 21-43.

35. Nilsson M.I., Tarnopolsky M.A. (2019) Mitochondria and aging-the role of exercise as a countermeasure. Biology (Basel). 8, 40.

36. Qiu G.H., Huang C., Zheng X., Yang X. (2018) Theprotective function of noncoding DNA in genome defenseof eukaryotic male germ cells. Epigenomics. 10,499-517.

37. Qiu G.H., Zheng X., Fu M., Huang C., Yang X.(2019) The protective function of non-coding DNA inDNA damage accumulation with age and its roles inage-related diseases. Biogerontology. 20, 741-761.

38. Rangaraju S., Solis G.M., Thompson R.C., Gomez-Amaro R.L., Kurian L., Encalada S.E., Niculescu A.B.,3rd, Salomon D.R., Petrascheck M. (2015) Suppressionof transcriptional drift extends C. elegans lifespanby postponing the onset of mortality. eLife. 4,e08833-e08833.

39. Risques R.A., Kennedy S.R. (2018) Aging and the riseof somatic cancer-associated mutations in normal tissues.PLoS Genet. 14, e1007108.

40. Romero-Bueno R., de la Cruz Ruiz P., Artal-Sanz M.,Askjaer P., Dobrzynska A. (2019) Nuclear organizationin stress and aging. Cells. 8, 664.

41. Sempowski G.D., Hale L.P., Sundy J.S., Massey J.M.,Koup R.A., Douek D.C., Patel D.D., Haynes B.F.(2000) Leukemia inhibitory factor, oncostatin M, IL-6, and stem cell factor mRNA expression in human thymusincreases with age and is associated with thymicatrophy. J. Immunol. 164, 2180-2187.

42. Stegeman R., Weake V.M. (2017) Transcriptional signaturesof aging. J. Mol. Biol. 429, 4272437

43. Tao R., Coleman M.C., Pennington J.D., Ozden O.,Park S.H., Jiang H., Kim H.S., Flynn C.R., Hill S.,Hayes McDonald W., Olivier A.K., Spitz D.R., GiusD. (2010) Sirt3-mediated deacetylation of evolutionarilyconserved lysine 122 regulates MnSOD activityin response to stress. Mol. Cell. 40, 893-904.

44. Taylor R.C. (2016) Aging and the UPR(ER). BrainRes. 1648, 588-593.

45. Trigo D., Nadais A., da Cruz E.S.O.A.B. (2019) Unravellingprotein aggregation as an ageing related processor a neuropathological response. Ageing Res. Rev.51, 67-77.

46. Vanhooren V., Navarrete Santos A., Voutetakis K.,Petropoulos I., Libert C., Simm A., Gonos E.S.,Friguet B. (2015) Protein modification and maintenancesystems as biomarkers of ageing. Mech. AgeingDev. 151, 71-84.

47. Wong S.Q., Kumar A.V., Mills J., Lapierre L.R. (2020) Autophagy in aging and longevity. Hum. Genet. 139, 277-290.

48. Wood J.G., Helfand S.L. (2013) Chromatin structureand transposable elements in organismal aging. Front.Genet. 4, 274.

49. Worman H.J. (2012) Nuclear lamins and laminopathies.J. Pathol. 226, 316-325.

50. Zhavoronkov A., Buzdin A.A., Garazha A.V., BorisovN.M., Moskalev A.A. (2014) Signaling pathwaycloud regulation for in silico screening and ranking ofthe potential geroprotective drugs. Front. Genet. 5, 49. 


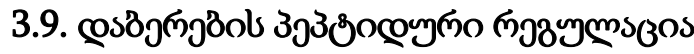

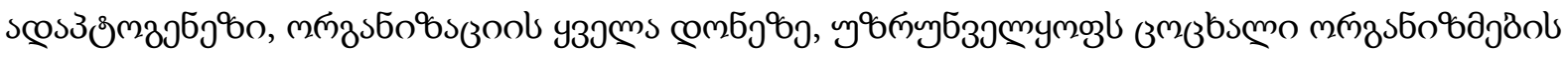

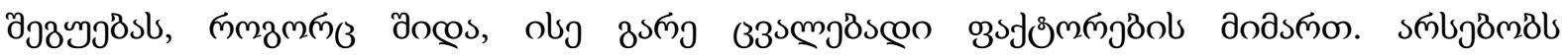

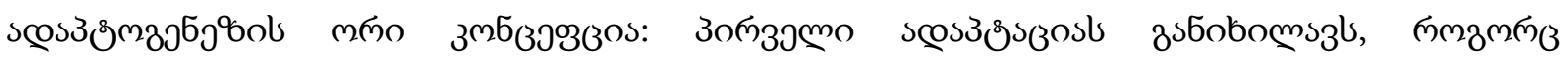

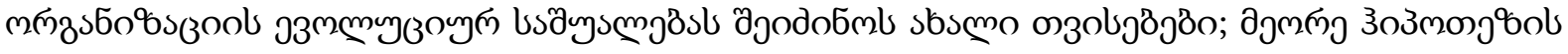

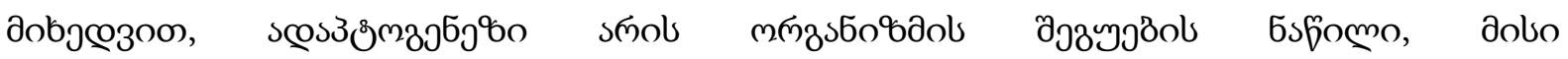

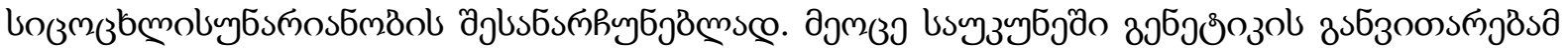

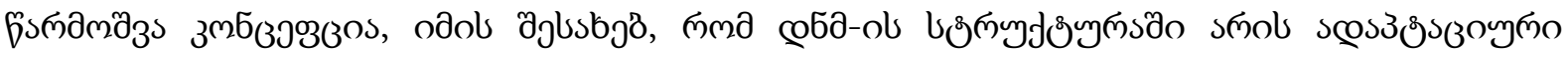

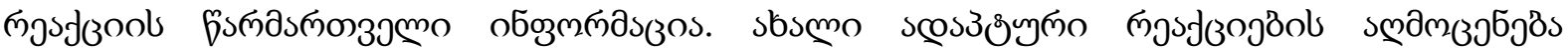

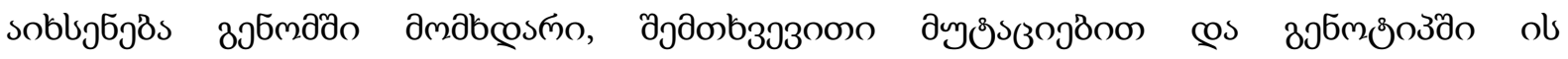

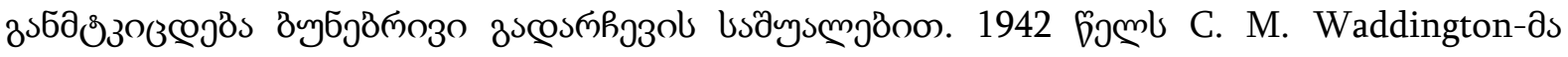

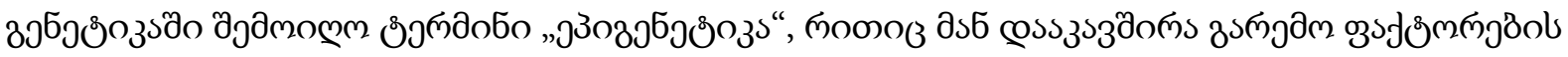

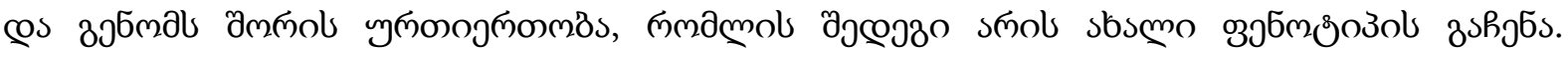

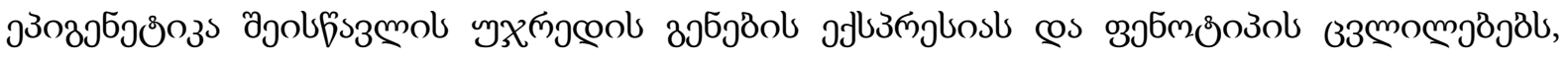

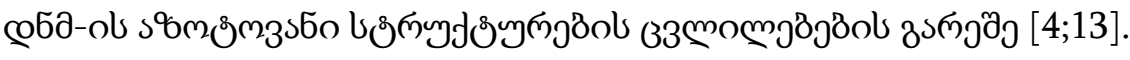

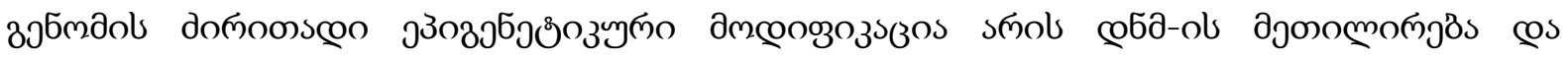

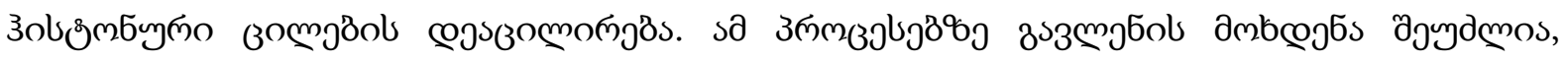

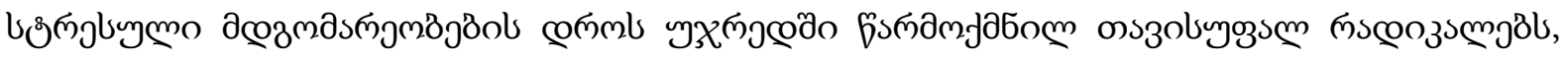

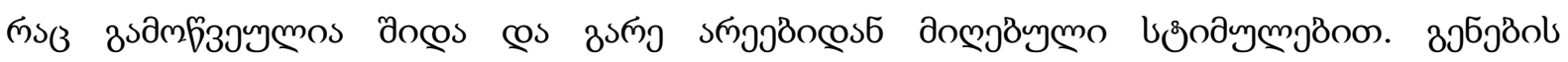

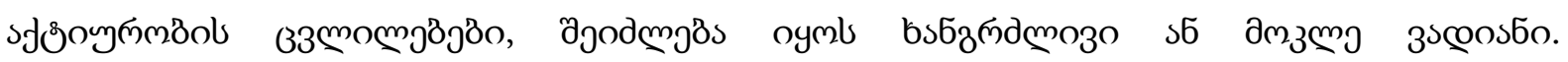

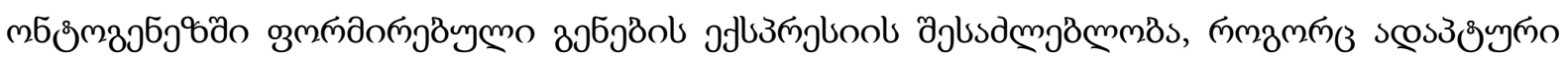

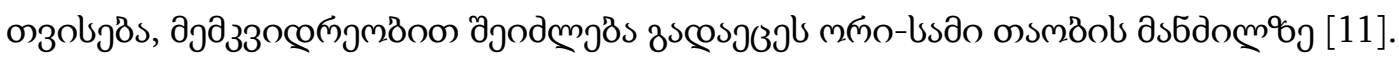

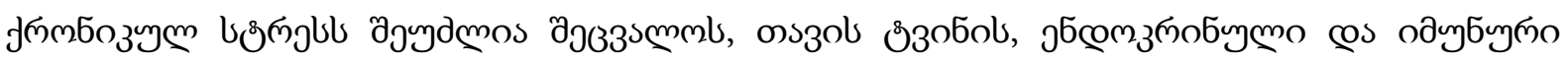

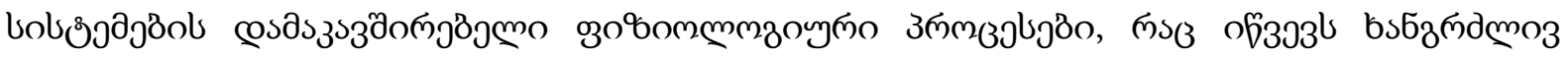

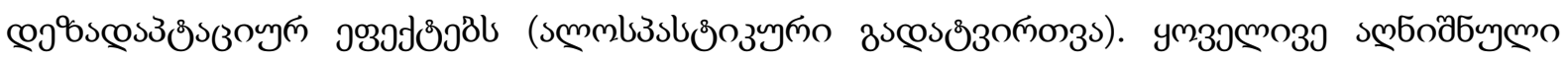

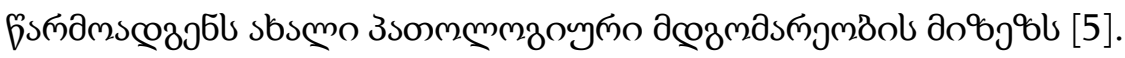

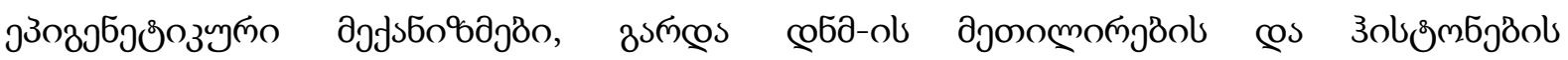

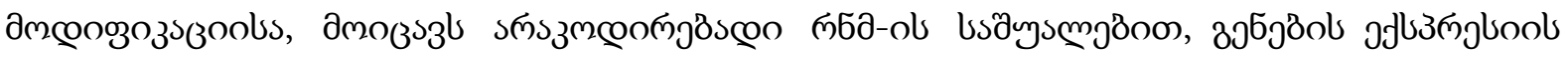

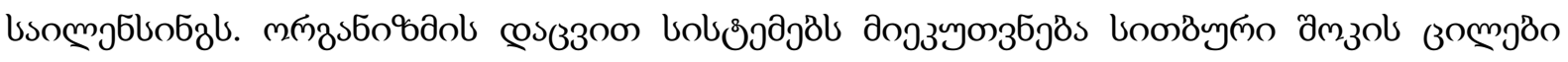

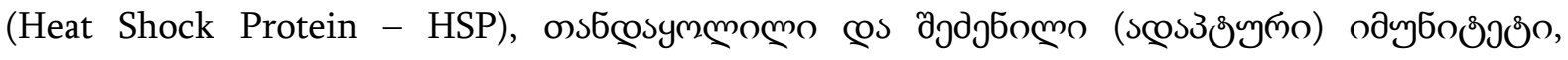

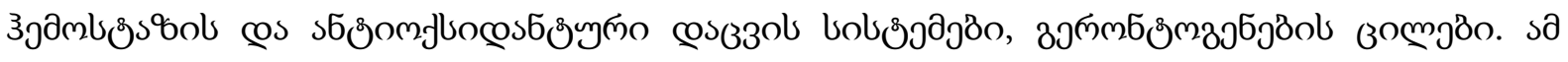

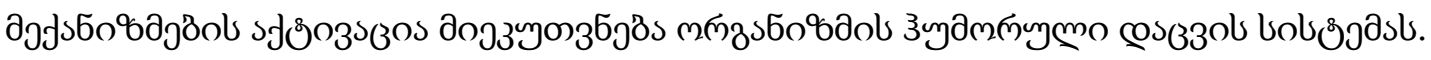

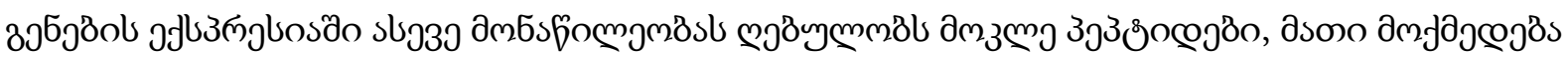

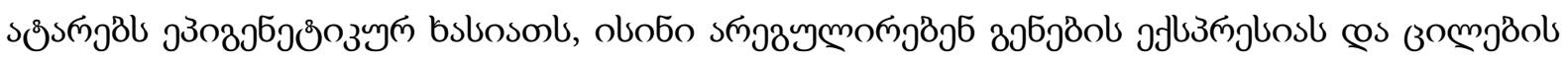

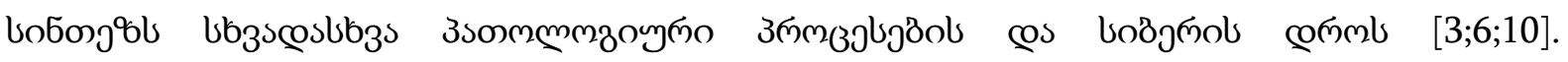

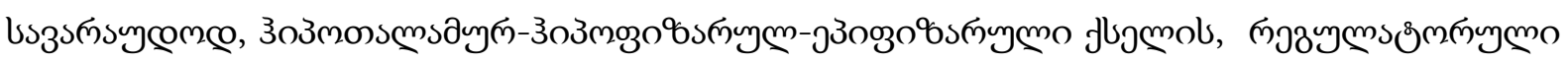

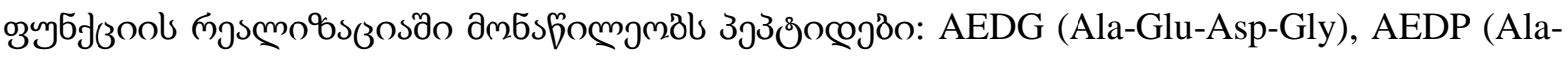

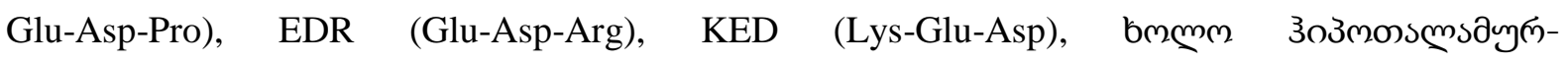

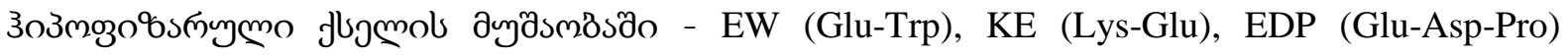

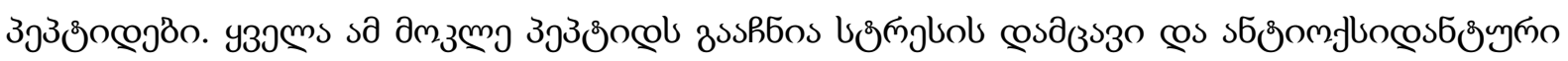

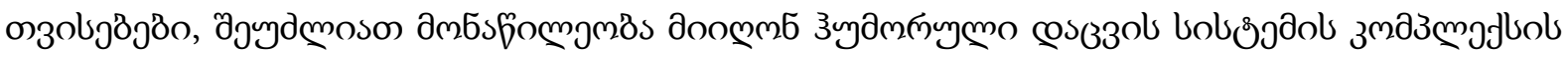




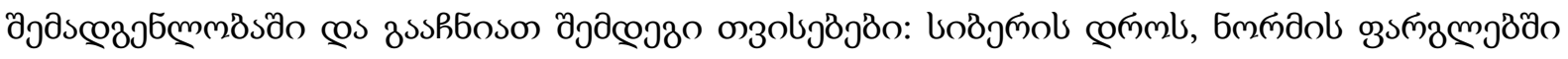

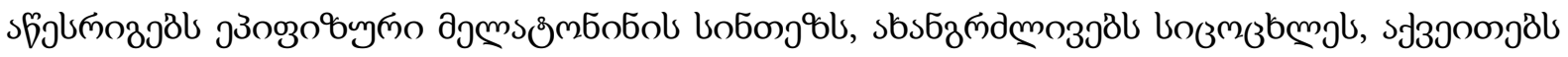

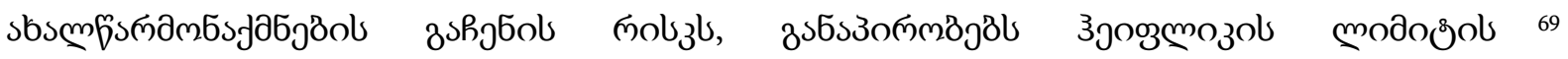

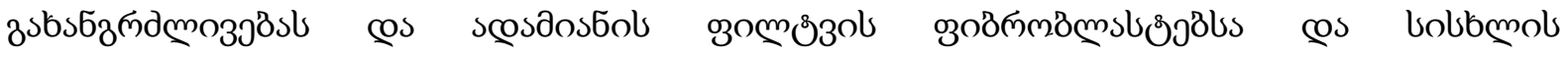

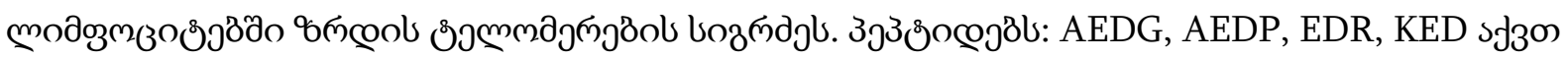

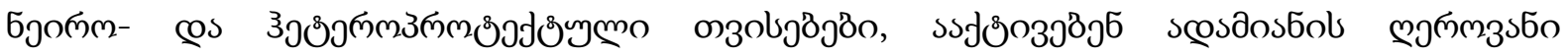

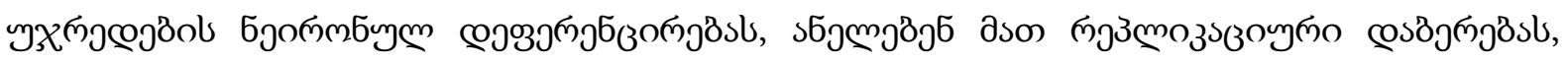

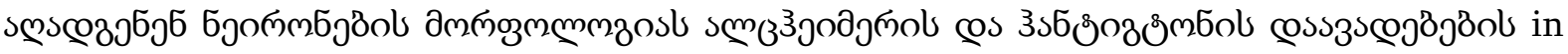

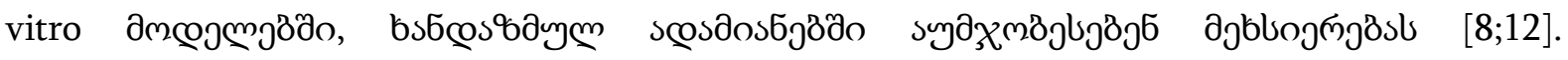

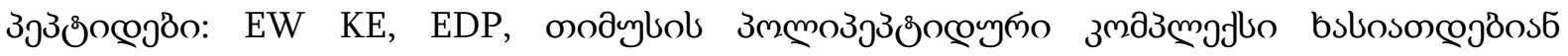

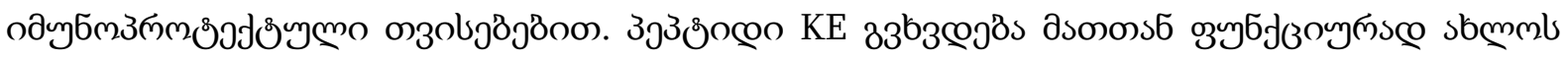

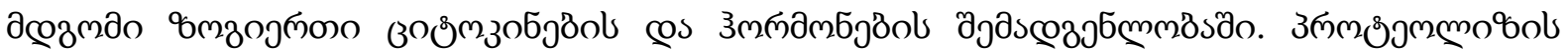

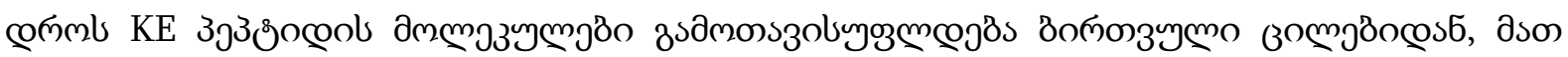

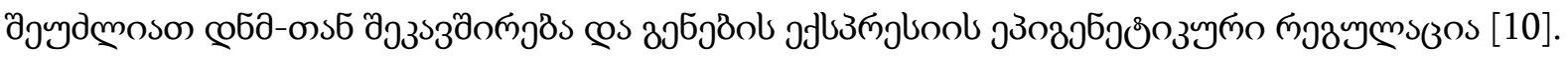

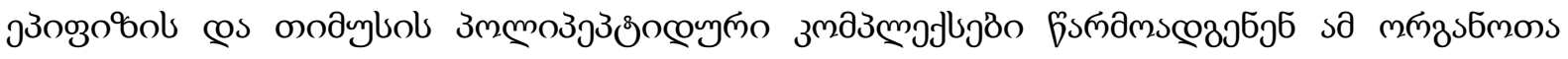

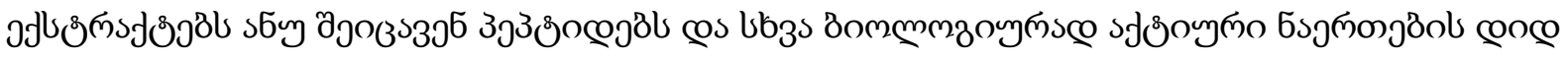

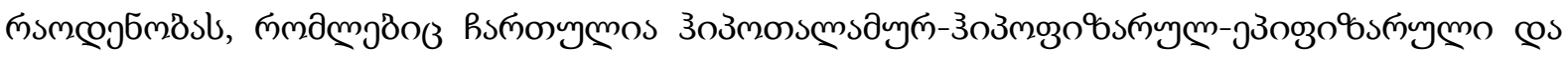

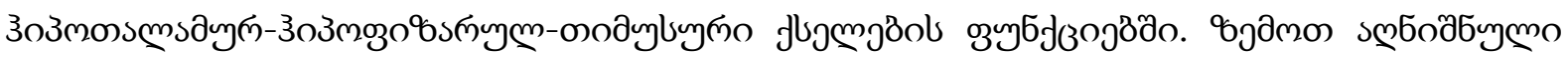

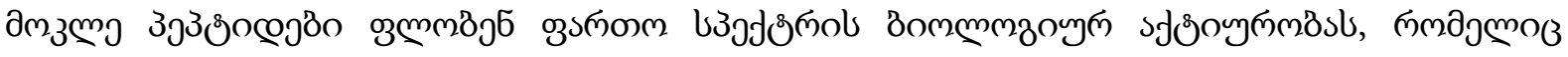

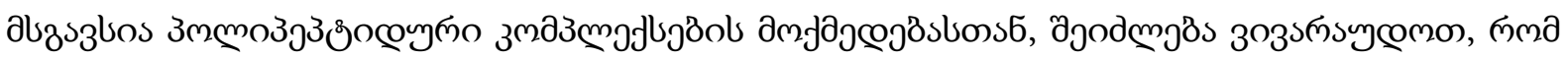

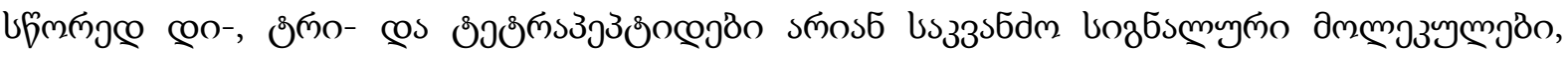

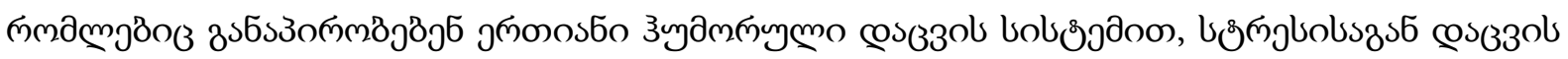

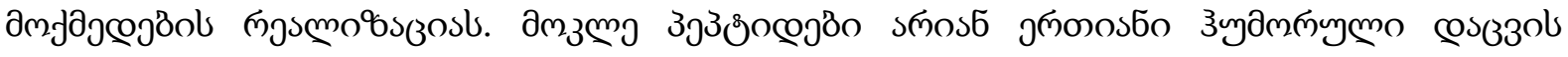

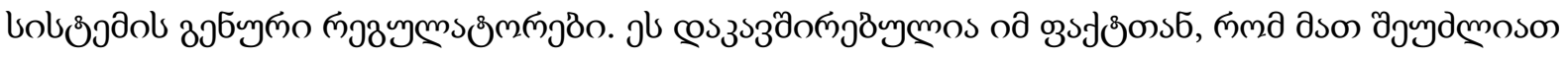

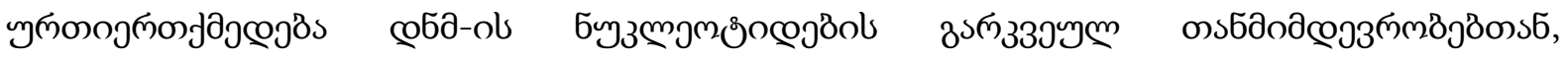

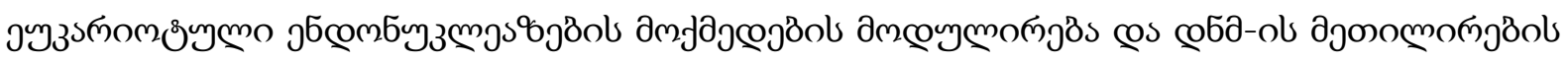

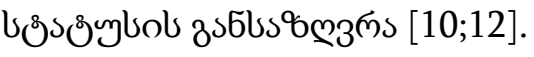

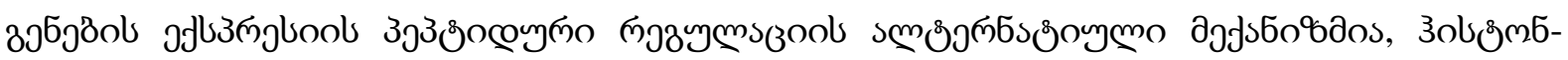

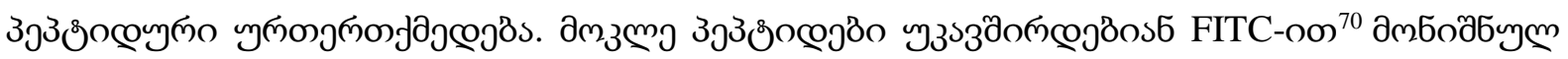

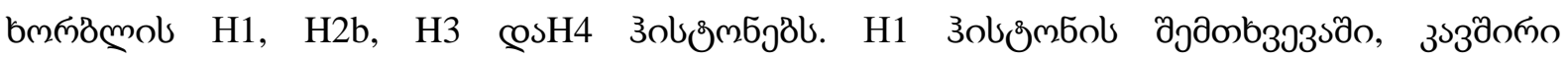

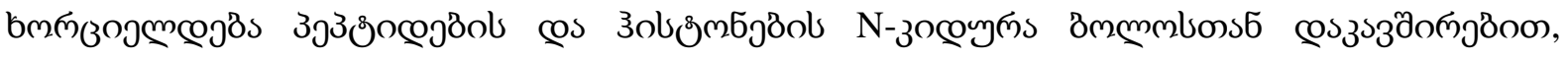

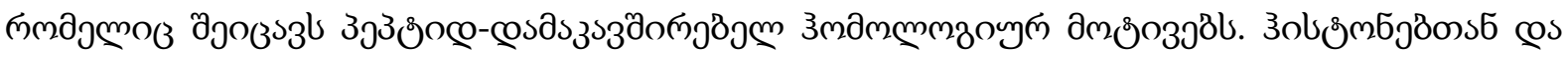

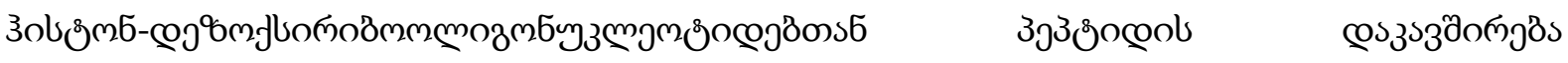

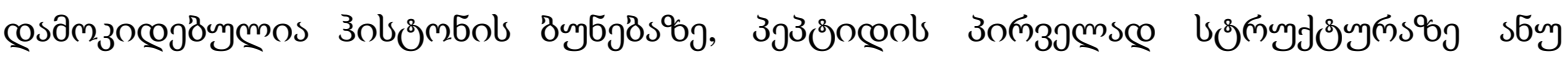

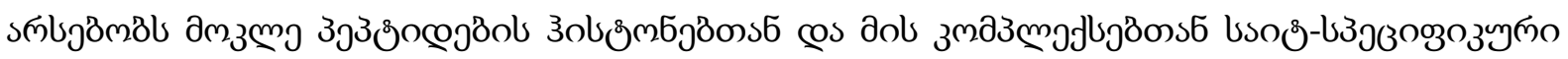

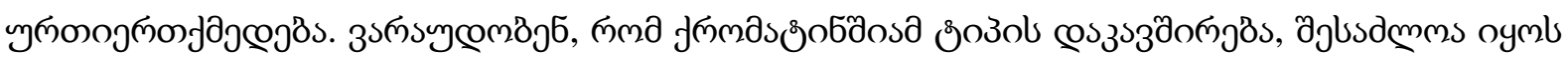

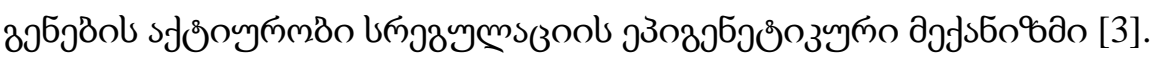

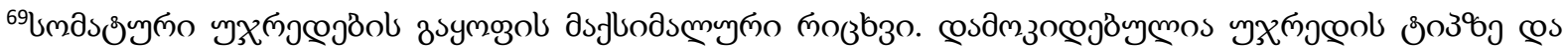

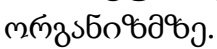

70 Fluorescein isothiocyanate - вмпумп дm6oð36olsonzol.
} 


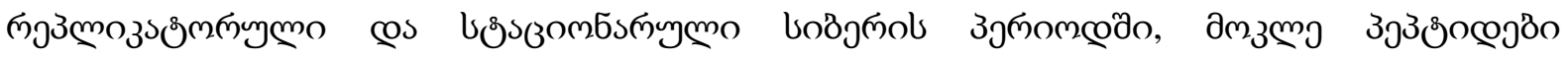

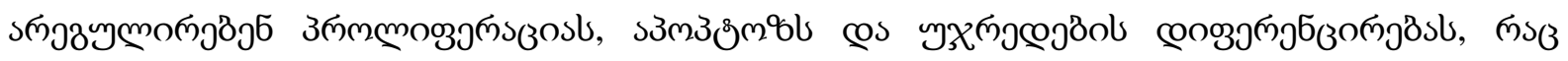

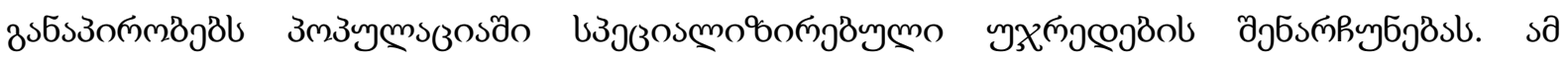

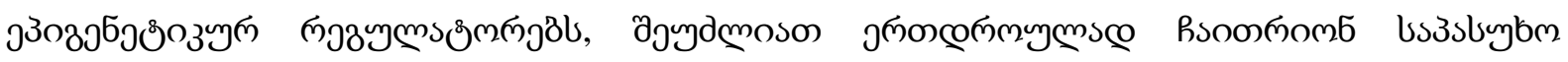

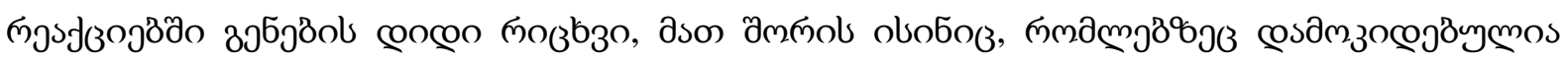

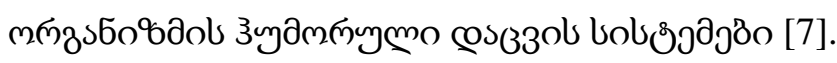

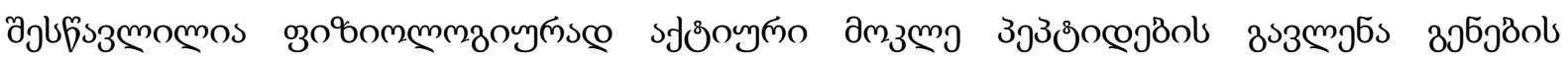

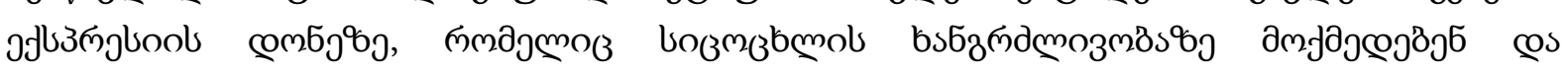

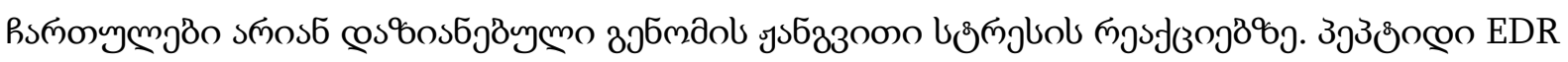

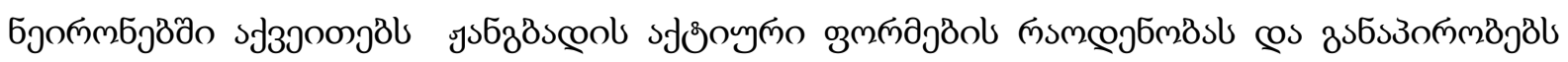

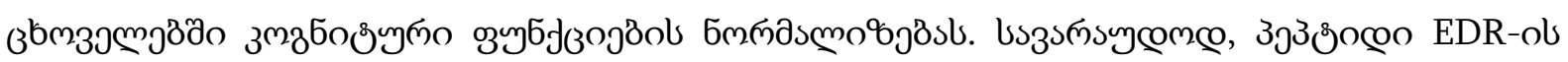

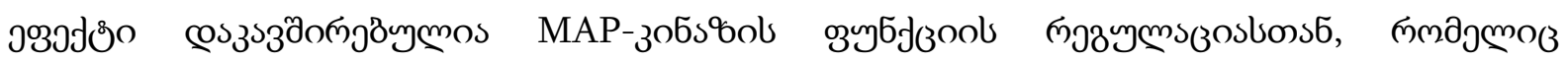

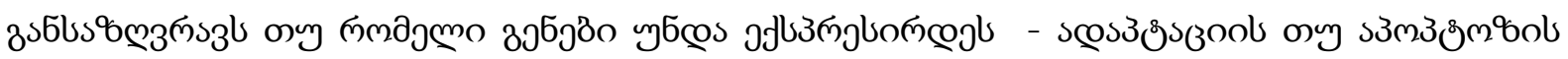

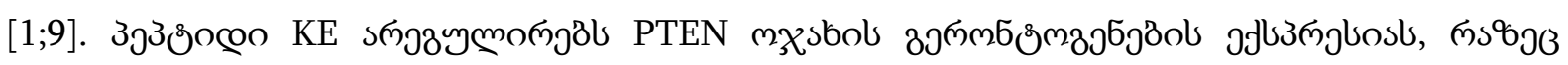

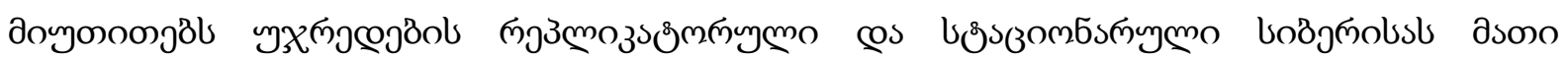

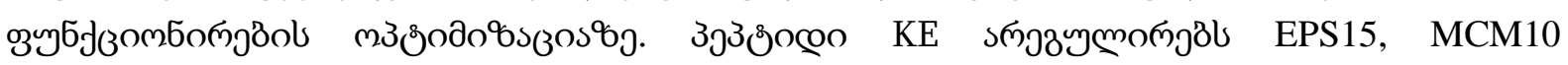
homologue, Culline 5, APG5L, FUSED, ZNF01, FLJ12848fis, ITPK1, SLC7A6, FLJ22439 fis, KIAA0029,FLJ13697 fis, KIAA0699, FLJ10914, Gdap1,MSTP028, MLLT3, PEPP2 3j5ృðol

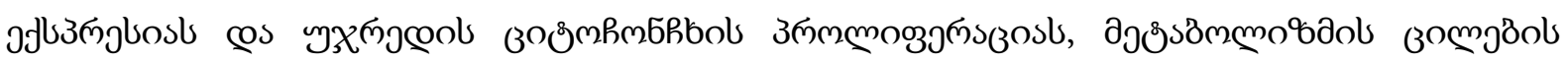
uobogobl [7].

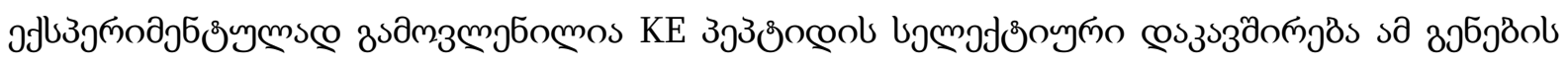

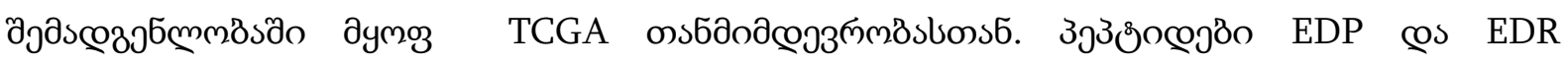

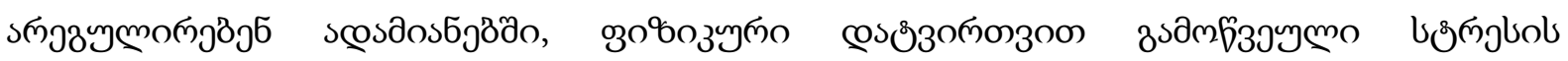

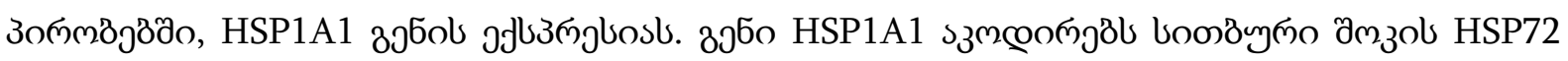

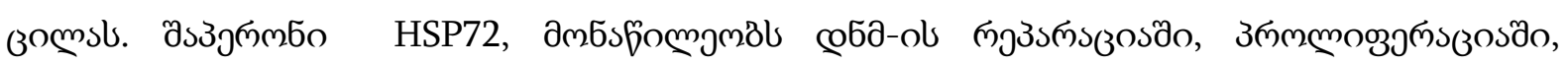

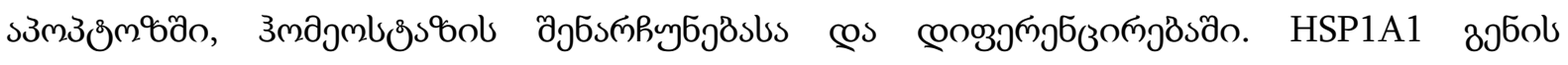

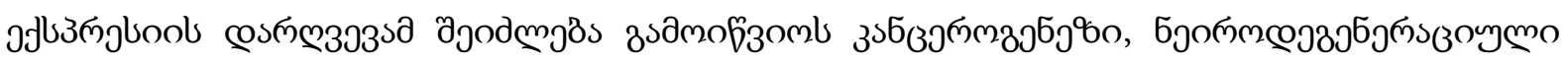

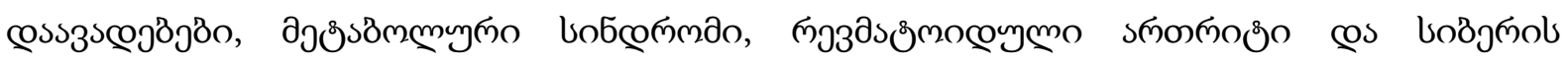
coshjs的政 [2].

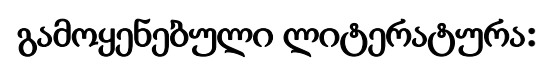

1. Arutjunyan A., Kozina L., Stvolinskiy S. et al. Pinealon prorects the rat offspring from prenatal hyperhomocysteinemia //Int. J. clin. exp. Med. 2012. Vol. 5. № 2. P. 179-185.

2. Asea A. Mechanisms of HSP72 release//J. Biosci. 2007.Vol. 32. № 3. P. 579-584.

3. Ashapkin V., Khavinson V., Shilovsky G. et al. Gene expressionin human mesenchymal stem cell aging cultures: modulationby short peptides//Molec. Biol. Rep. 2020. Vol. 47. P. 43234329.

4. Bartlett A. A., Singh R., Hunter R. G. Anxiety andEpigenetics//Adv. Exp. Med. Biol. 2017. Vol. 978. P. 145-166.

5. Bottaccioli A. G., Bottaccioli F., Minelli A. Stress and the psyche-brain-immune network in psychiatric diseases based on psychoneuroendocrineimmunology: a concise review//Ann.N. Y. Acad. Sci. 2019. Vol. 1437. № 1. P. 31-42. 
6. Khavinson V., Diomede F., Mironova E. et al. AEDGpeptide (epitalon) stimulates gene expression and protein synthesisduring neurogenesis: possible epigenetic mechanism//Molecules. 2020. Vol. 25. № 609. P. 1-17.

7. Khavinson V. Kh., Malinin V. V. Gerontological aspectsof genome peptide regulation. Basel (Switzerland): Karger AG,2005.

8. Khavinson V., Linkova N., Kukanova E. et al. Neuro -protective Effect of EDR Peptide in Mouse Model of Huntington'sDisease // J. Neurol. Neurosci. 2017. Vol. 8. № 1. P. 1-11.

9. Khavinson V., Ribakova Y., Kulebiakin K. et al. Pinealonincreases Cell Viability by Supression of Free Radical Levels andactivating Proliferative Processes//Rejuvenat. Res. 2011. Vol. 14.№ 5. P. 535-541.

10. Kolchina N., Khavinson V., Linkova N. et al. Systematicsearch for structural motifs of peptide binding to double-strandedDNA // Nucleic. Acids Res. 2019. Vol. 47. № 20. P. 10553-10563.

11. Labonte B., Turecky G. Epigenetics: a link between environmentand genome//Sante mentale au Quebec. 2012. Vol. 37.№ 2. P. 31-44.

12. Sinjari B., Diomede F., Khavinson V. et al. Short peptidesprotect oral stem cells from ageing // Stem. Cell. Rev. Rep. 2020.Vol. 16. P. 159-166.

13. Waddington C. H. Canalization of development and inheritanceof acquired characters// Nature. 1942. Vol. 150. № 3811.P. 563-565. 


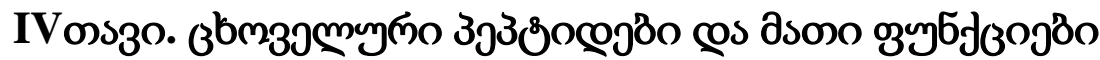

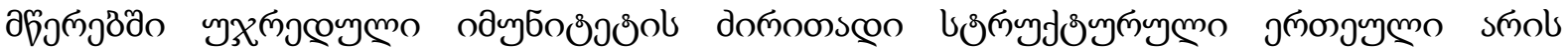

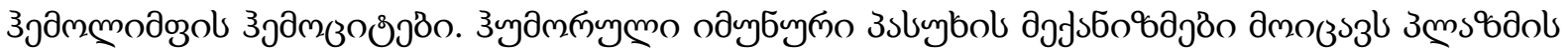

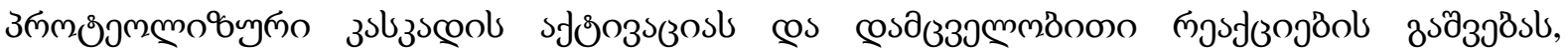

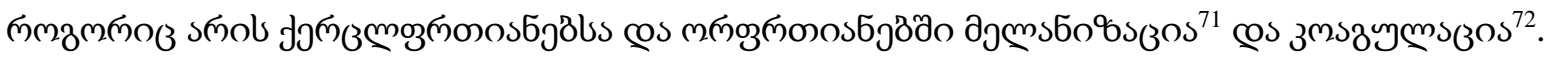

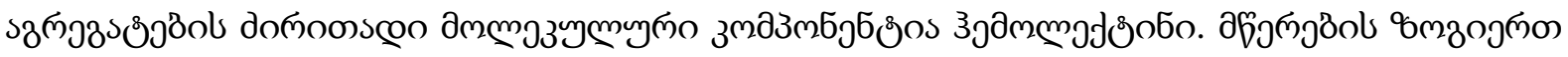

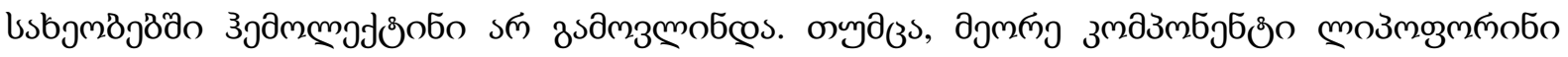

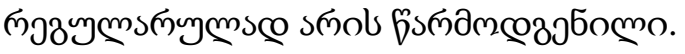

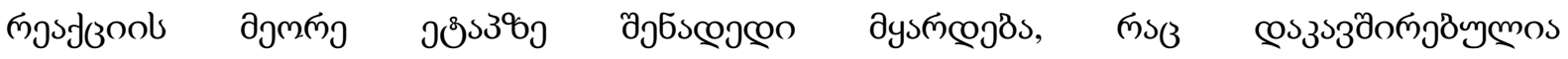

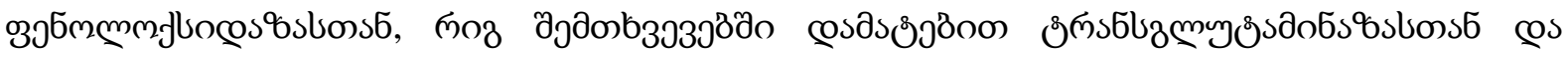

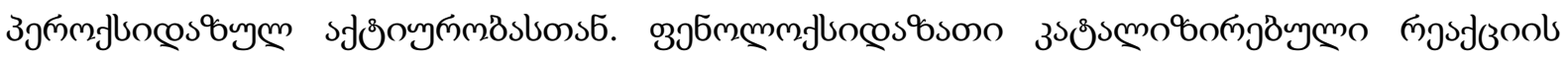

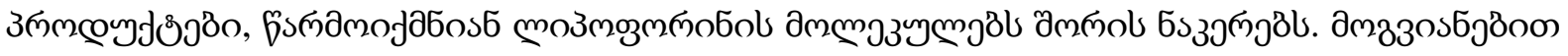

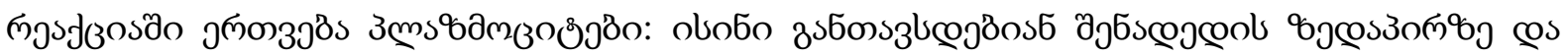

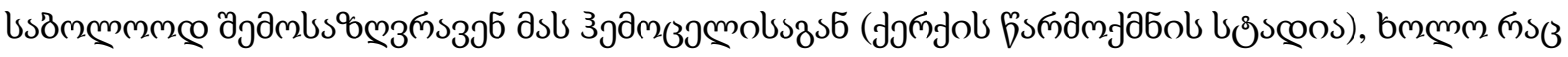

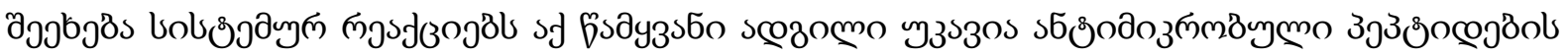

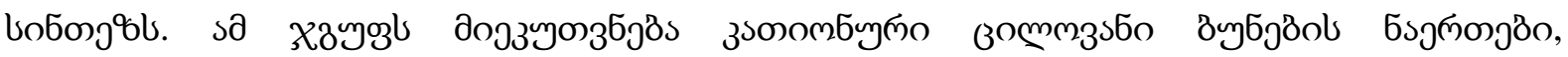

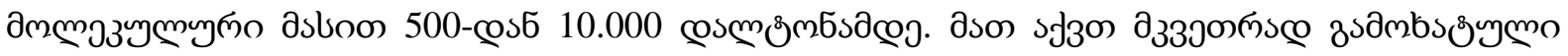

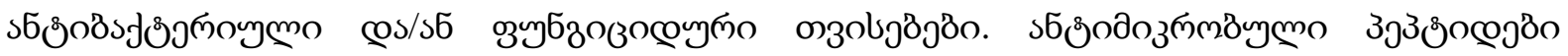

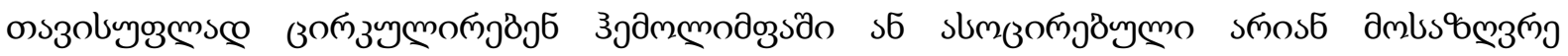

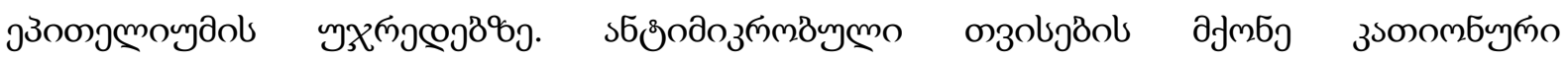

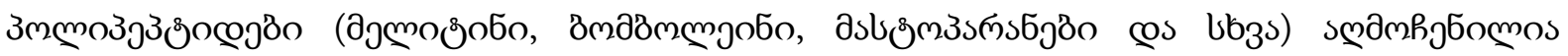

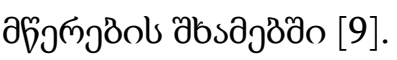

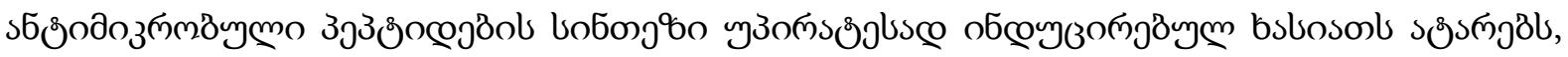

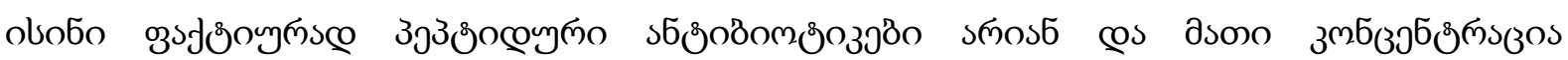

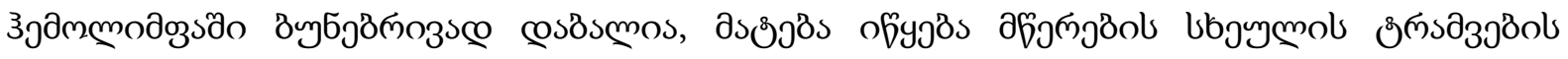

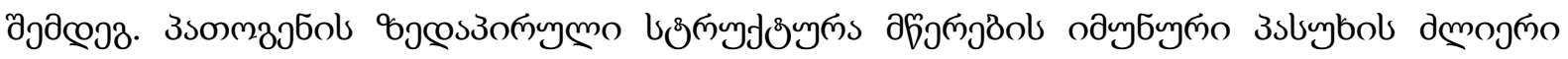

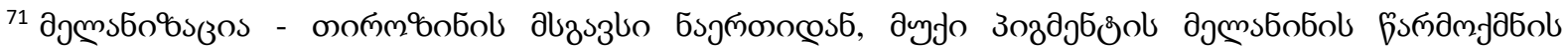

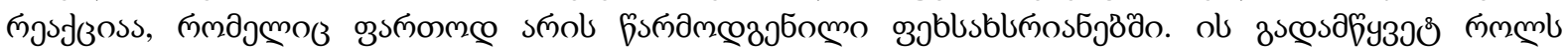

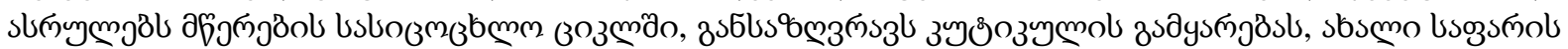

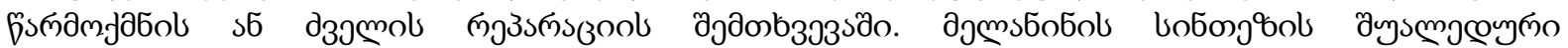

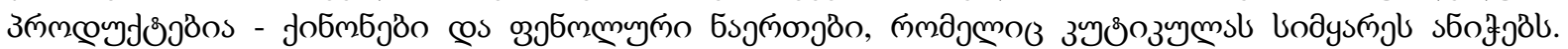

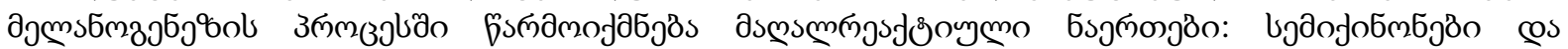

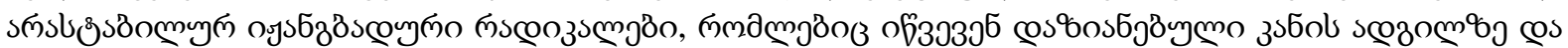

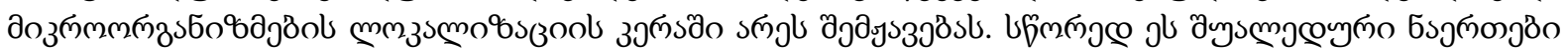

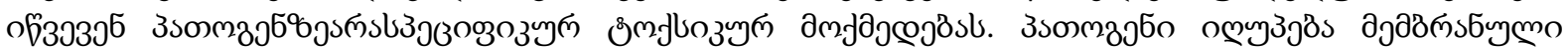

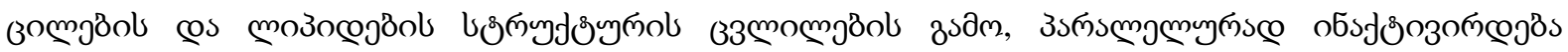

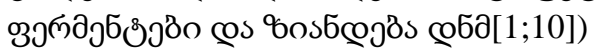

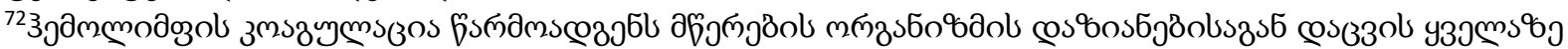

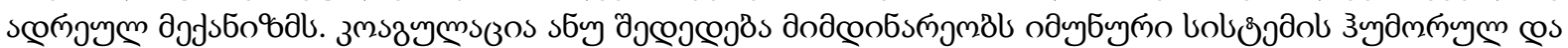

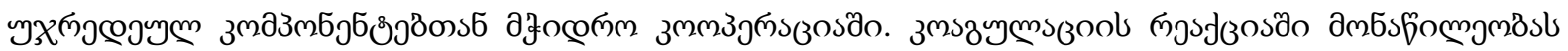

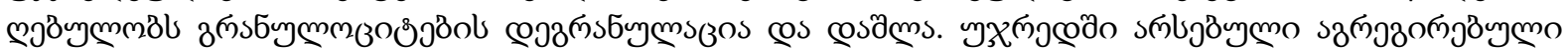

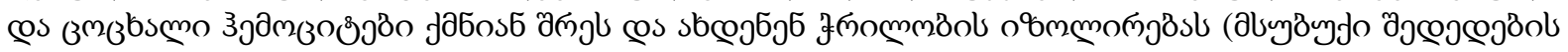
boscoos).
} 


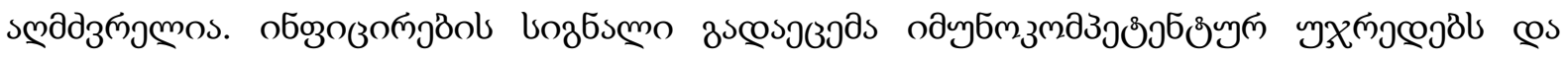

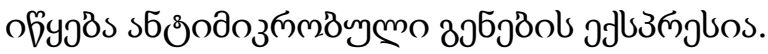

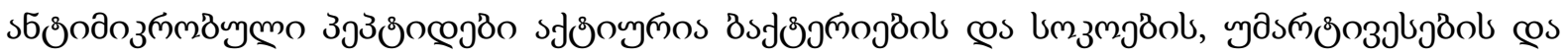

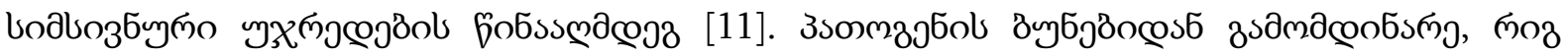

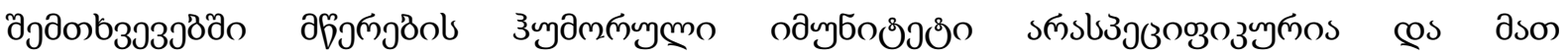

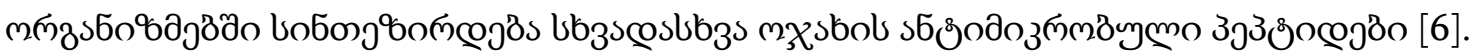

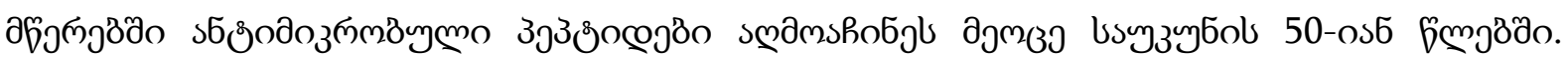

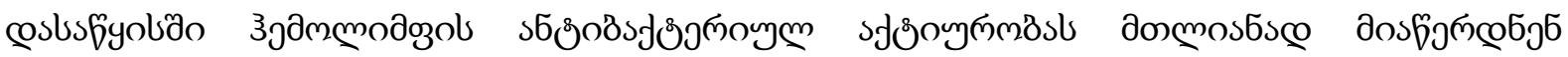

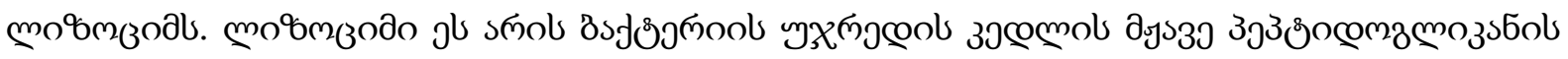

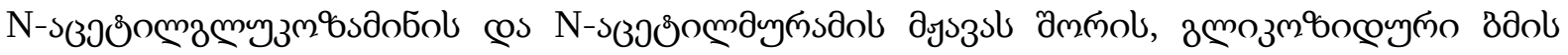

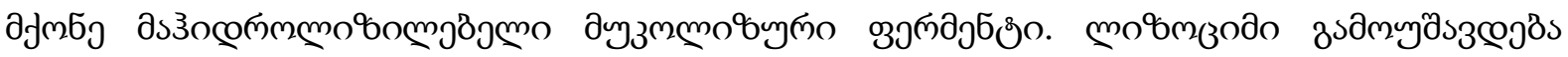

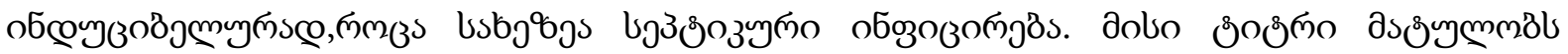

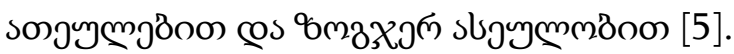

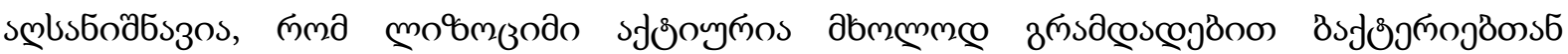

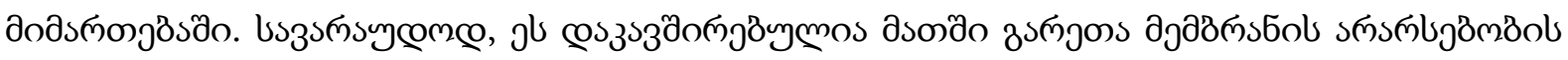

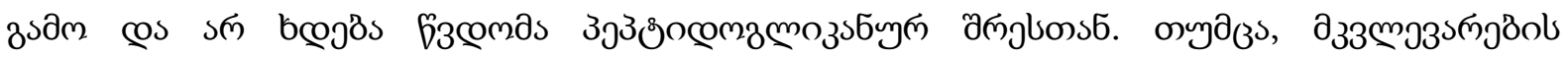

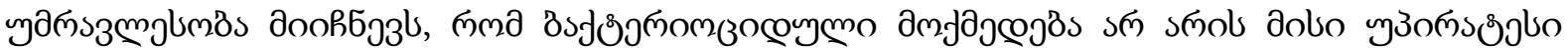
озобjठs.

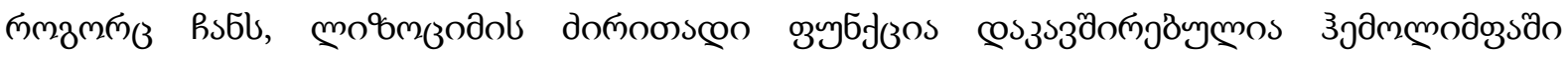

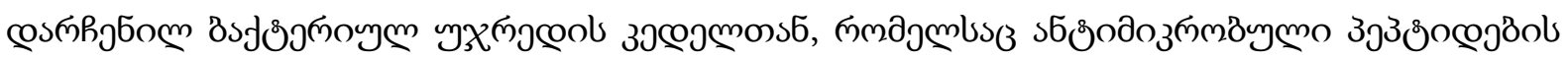

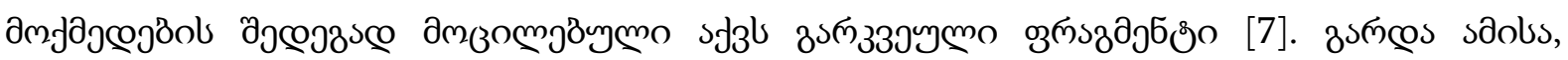

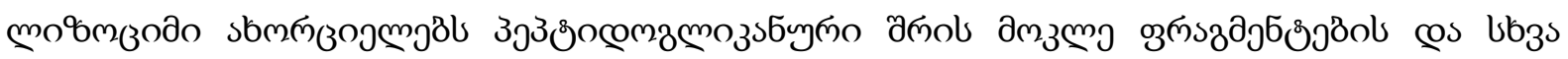

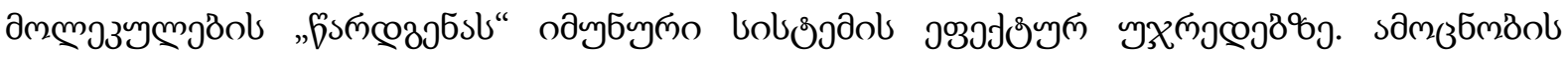

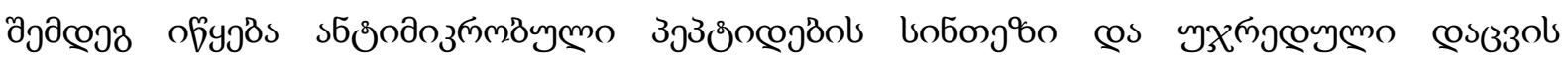

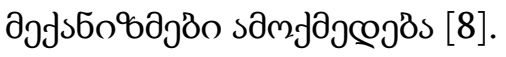

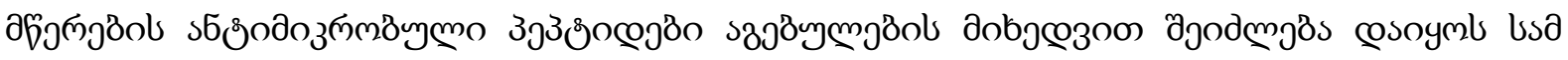

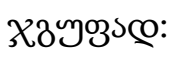

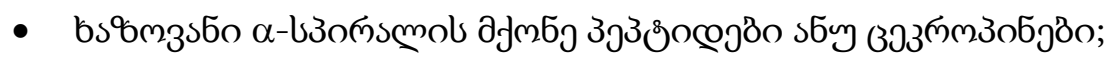

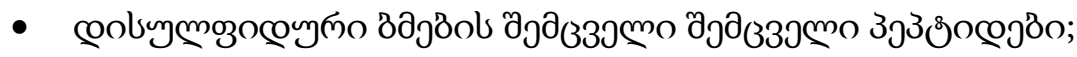

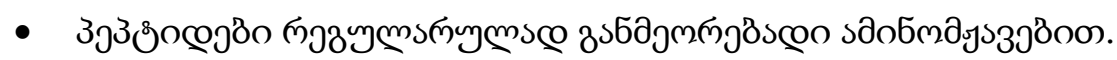

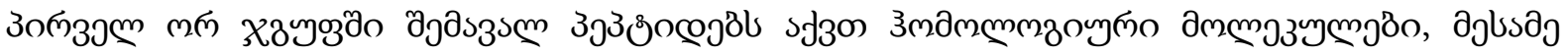

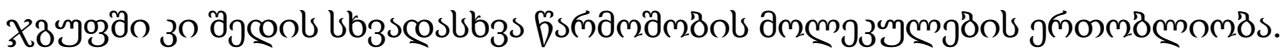

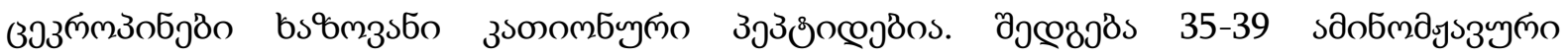

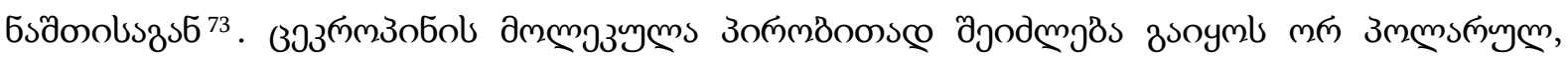

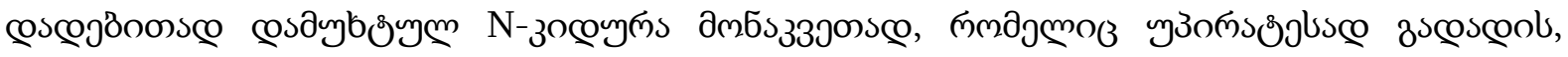

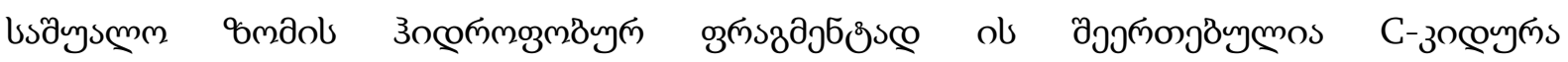

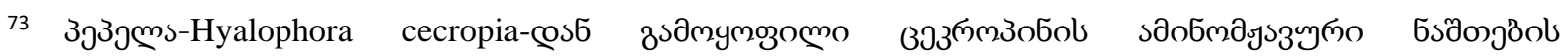
юsбДодеэзґмдిs: Lys-Trp-Lys-Leu-Phe-Lys-Lys-Ile-Glu-Lys-Val-Gly-Gln-Asn-Ile-Arg-Asp-Gly-Ile-Ile-LysAla-Gly-Pro-Ala-Val-Ala-Val-Val-Gly-Gln-Ala-Thr-Gln-Ile-Ala-Lys. 


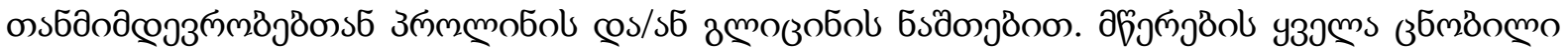

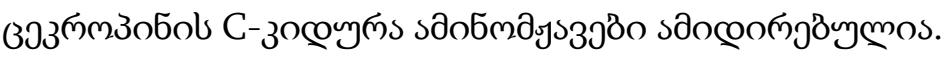

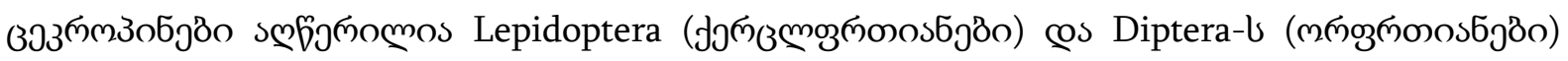

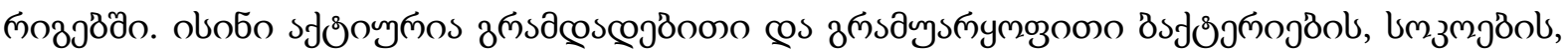

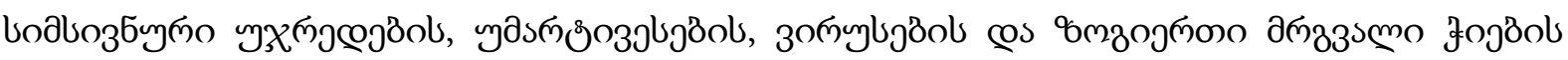

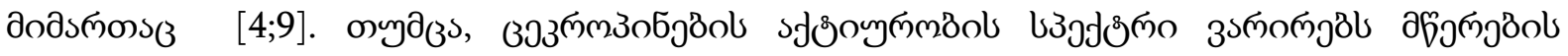

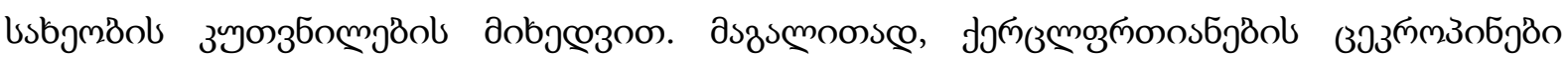

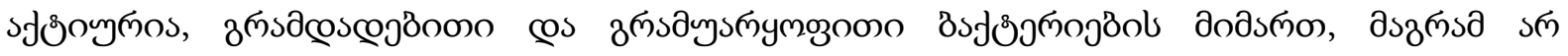

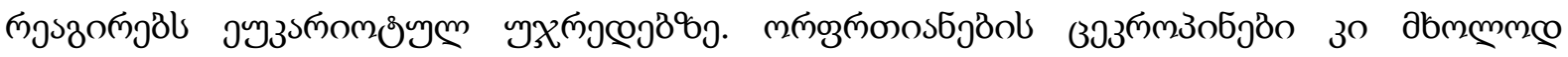

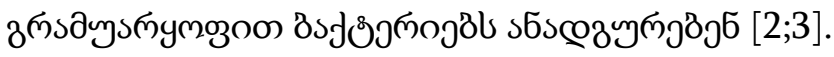

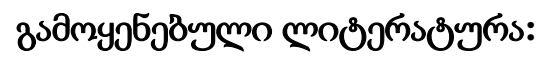

1. Ashida M., Brey P. T. Recent advances in research on the insect prophenoloxidase cascade //Molecular mechanisms of immune responses in insects (eds.: Brey P. T., Hultmark D.). London: Chapman and Hall, 1997. - P. 135-172.

2. Boman H. G. Cell-free immunity in Cecropia. A model system for antibacterial proteins // J.Biochem. — 1991. — Vol. 201. - P. 23-31.

3. Chernysh S. I., Gordja N. A., Simonenko N. P. Diapause and immune response: induction ofantimicrobial peptides synthesis in the blowfly, Calliphora vicina R.-D. (Diptera,Calliphoridae) //Entomol. Science. - 2000. - Vol. 3. - P. 139-144.

4. Cociancich S., Bulet P., Hetry C. et al. The inducible antibacterial peptides of insects//J.Parasitology Today. — 1994b. — Vol.10, No. 4. - P. 132-139.

5. Dunn P. E. Biochemical aspects of insect immunology//J. An. Rev. Entomology. - 1986. Vol. 31. - P. 321-339.

6. Hancock R. E. W., Chapple D. S. Peptide antibiotics//Antimicrob. Agents Chemother. 1999.- Vol. 43. - P. 1317-1323.

7. Kanost M. R., Dai W., Dunn P. E. Peptidoglycan fragments elicit antibacterial protein synthesisin larvae of Manduca sexta//Arch. Insect Biochem. Physiol. — 1988. - Vol. 8. P.147-164.

8. Morishima I., Yamada K., Ueno T. Bacterial peptidoglycan as elicitor of antibacterial proteinsynthesis in larvae of the silkworm, Bombyx mori//Ins. Biochem. Mol. Biol. — 1992. —Vol. 22, No. 4. - P. 363-367.

9. Ratcliffe N. A., Mello C. B., Garcia E. S. et al. Insect natural products and processes: Newtreatments for human disease//Ins. Bioch. and Mol. Biol. — 2011. — Vol. 41. — P. 747769.

10. Soderhall, K., Cerenius, L. Role of the prophenoloxidase-activating system in invertebrateimmunity//Curr. Opin. Immunol. — 1998. - Vol. 10. P. 23-28.

11. Slocinska M., Marciniak P., Rosinski G. Insects antiviral and anticancer peptides: new leads for the future?// Protein Pept. Lett. — 2008. - Vol. 15, No. 6. - P. 578-585. 


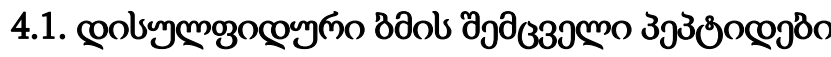

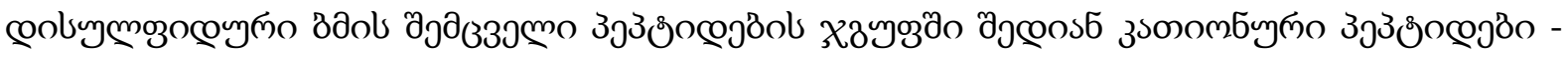

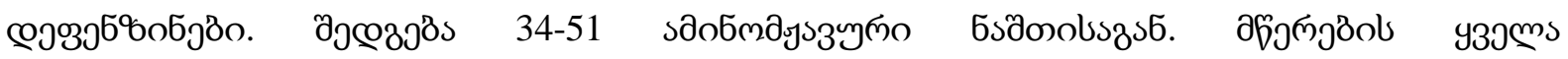

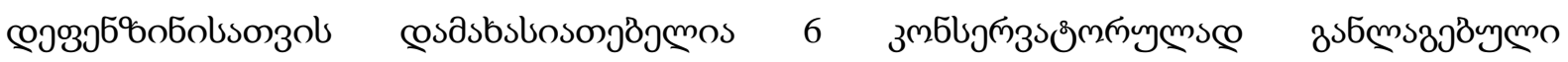

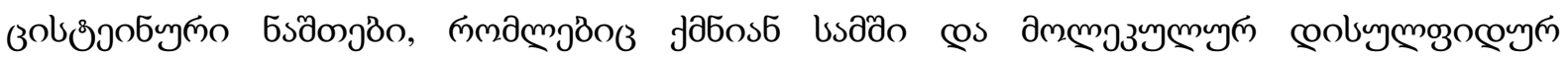

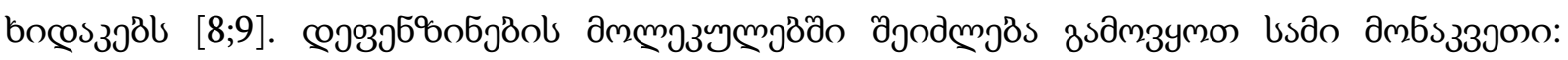

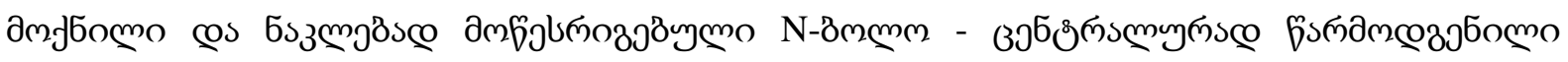

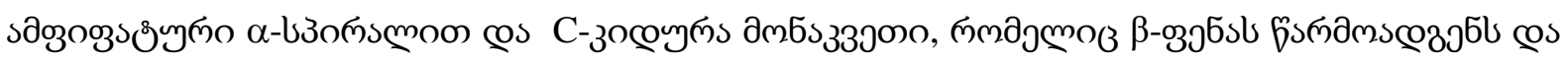

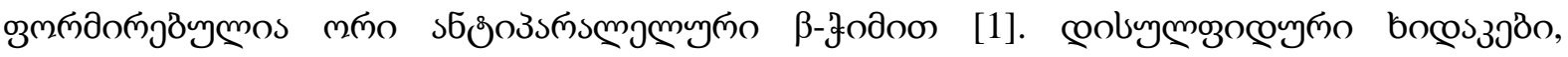

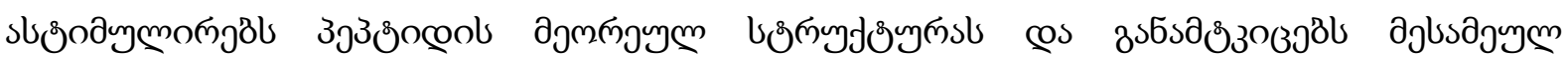

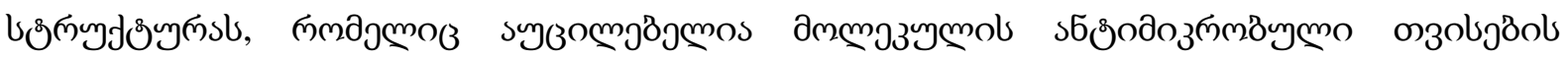

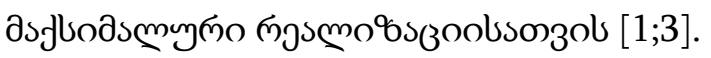

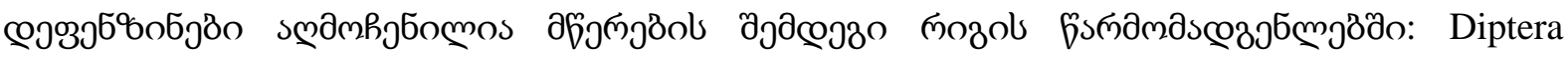

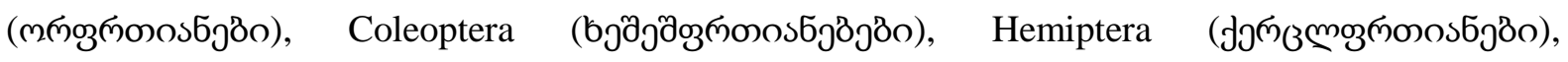

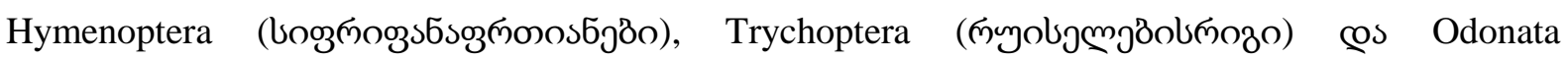

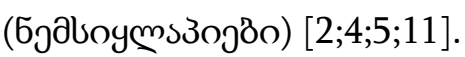

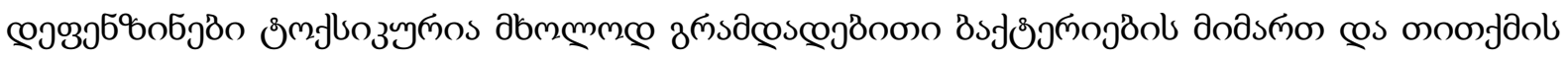

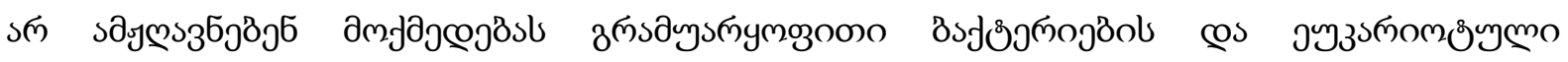

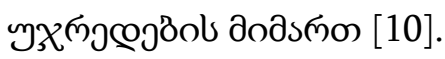

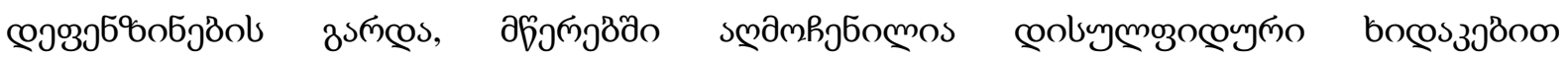

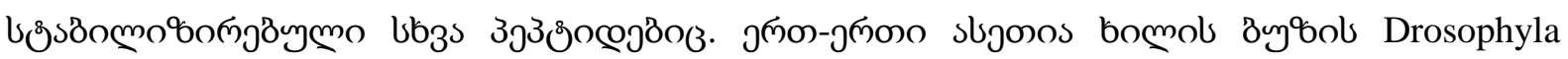

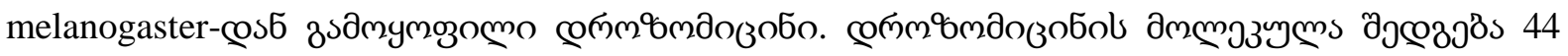

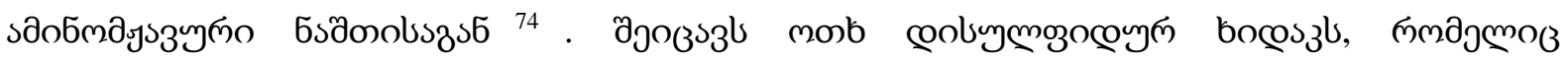

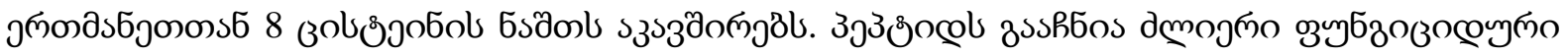

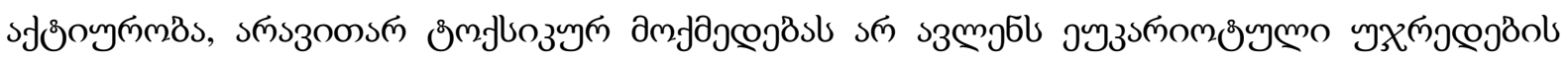

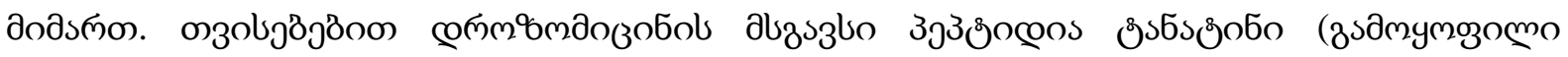

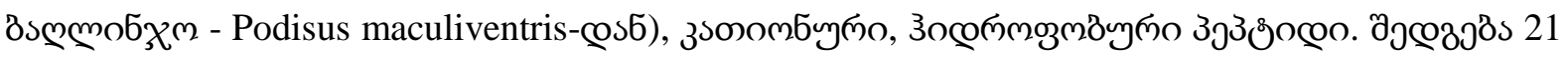

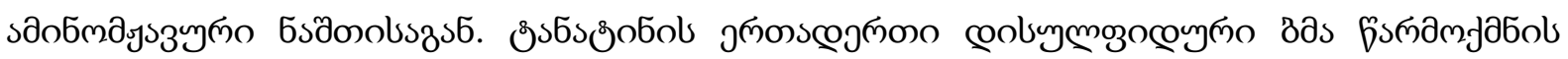

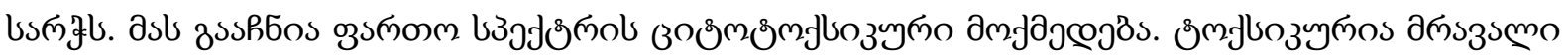

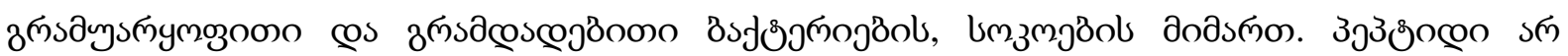

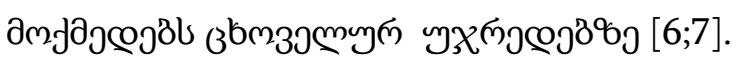

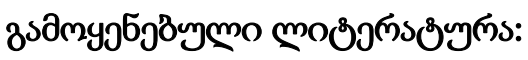

1. Bonnat J. L., Gallet X. et al. Two-dimensional H-NMR study of recombinantinsect defensin A in water. Resonance assignments, secondary structure and global folding// J. Biomolec. NMR. - 1992. - Vol. 2. - P. 235-256.

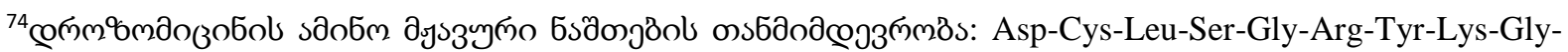
Pro-Cys-Ala-Val-Trp-Asp-Asn-Glu-Thr-Cys-Arg-Arg-Val-Cys-Lys-Glu-Glu-Gly-Arg-Ser-Ser-Gly-His-CysSer-Pro-Ser-Leu-Lys-Cys-Trp-Cys-Glu-Gly-Cys.
} 
2. Bulet P., Cociancich S., Reuland M. et al. A novel insect defensin mediates the inducibleantibacterial activity in larvae of the dragon fly Aeshna cyanea (Paleortera, Odonata) //Eur. J. Biochem. — 1992. - Vol. 209. — P. 977-984.

3. Bulet P., Stocklin R. Insect antimicrobial peptides: Structures, properties and gene regulation //Protein Pept. Lett. — 2005. - Vol. 1. - P. 3-11.

4. Cociancich S., Dupont A., Hegy G. Novel inducible antibacterial peptides from a hemipteraninsect, the sap-sucking bug Pyrrhocoris apterus // J.Biochem. - 1994a. - Vol. 300. - P.567-575.

5. Crossley A. C. AnChernysh S. I. Antimicrobial substances from insects // Proceedings of the first Korea/Russiajoint symposium on Bioresources and Biotechnology. — 1996. - P. 281296.

6. Fehlbaum P., Bulet P., Chernysh S. et al. Structure-activity analysis of thanatin, a novel 21residue inducible insect defense peptide with sequence homology to frog skin antimicrobialpeptides // Proc.Natl. Acad.Sci.USA. — 1996. - P. 1221-1225.

7. Fehlbaum P., Bulet P., Michaut L. et al. Insect immunity. Septic injury of Drosophila induces thesynthesis of a potent antifungal peptide with sequence homology to plant antifungalpeptides // J. Biol. Chem. - 1994. — No. 269. - P. 31159-31163.

8. Hoffmann J. A., Hetru C. Insect defensins: inducible antibacterial peptides // J. Immunol.today.- 1992. - Vol.13. - P. 411-415.Hoffmann J. A., Hetru C., Reichhart J.M.Bonmatin J.-M.

9. Hoffmann J. A., Hetru C., Reichhart J.-M.Bonmatin J.-M., Bonnat J. L., Gallet X. et al. Twodimensional H-NMR study of recombinantinsect defensin $\mathrm{A}$ in water. Resonance assignments, secondary structure and global folding// J. Biomolec

10. Lehrer R. I., Lichtenstein A. K., Ganz T. Defensins: antimicrobial and cytotoxic peptides of mammalian cells // J.Ann.Rev.Immunol. — 1993. — Vol. 11. — P.105-128.

11. Rees J. A., Moniatte M., Bulet P. Novel antibacterial peptides isolated from a Europeanbumblebee, Bombus pascuorum (Hymenoptera, Apoidea) // Insect Biochem. Molec. Biol.- 1997. - Vol. 27, No. 5. - P. 413-422.

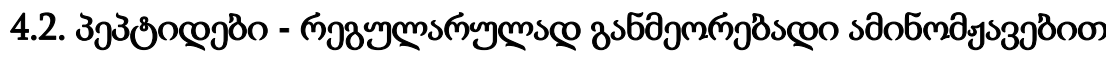

sзосезого

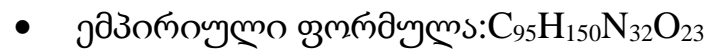

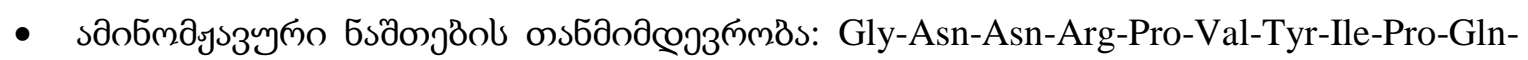
Pro-Arg-Pro-Pro-His-Pro-Arg-Leu

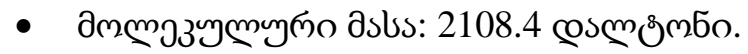

кпмовщзобо

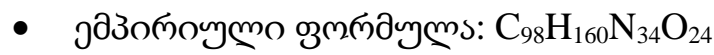

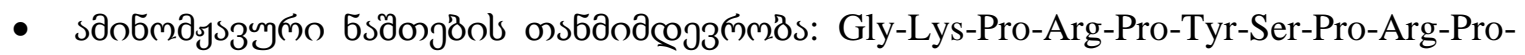
Thr-Ser-His-Pro-Arg-Pro-Ile-Arg-Val

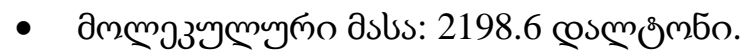

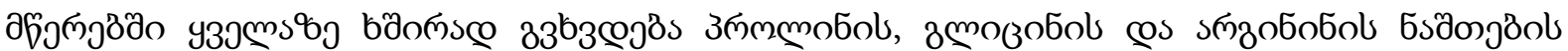

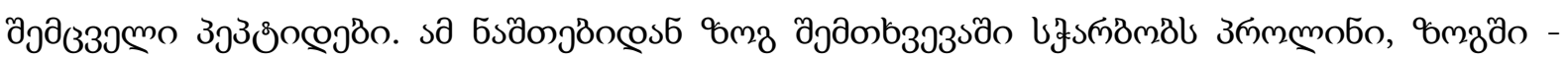




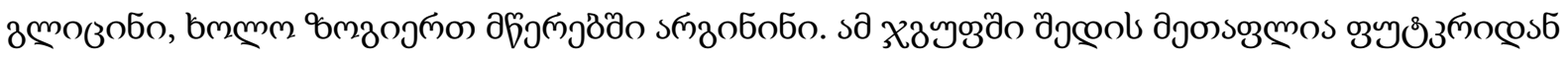

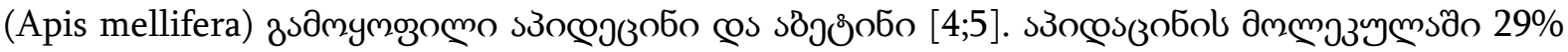

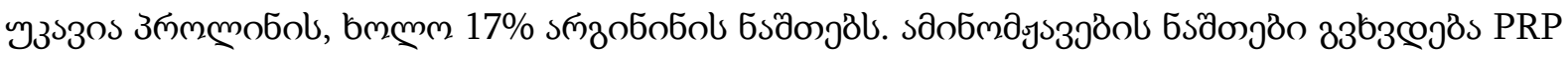

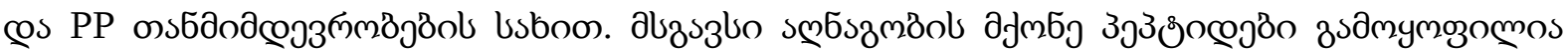

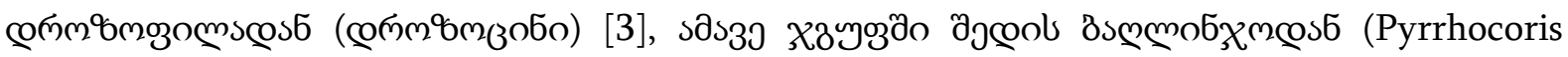

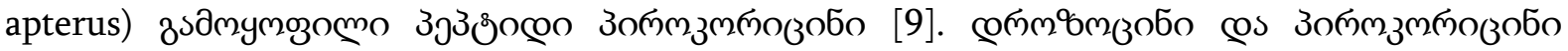

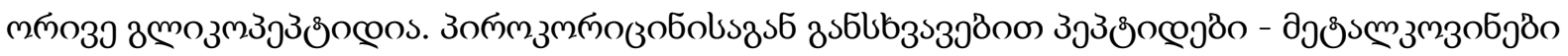

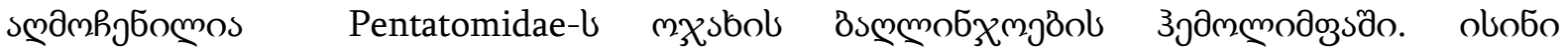

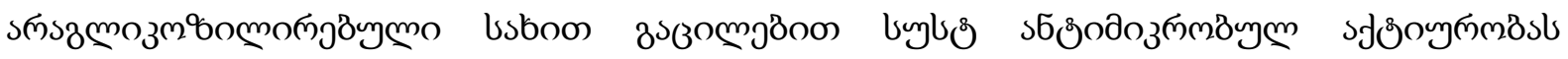

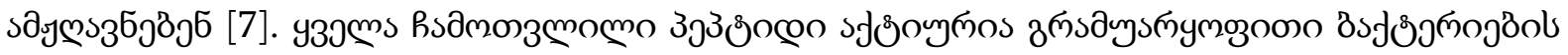

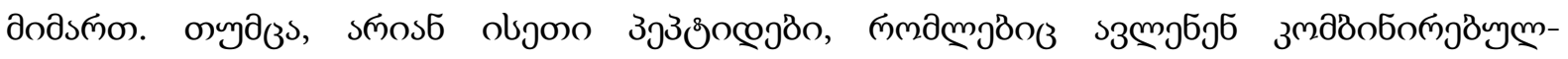

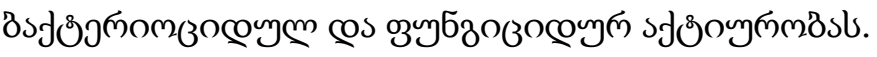

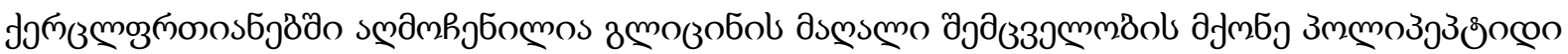

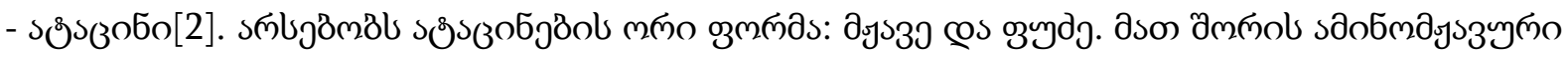

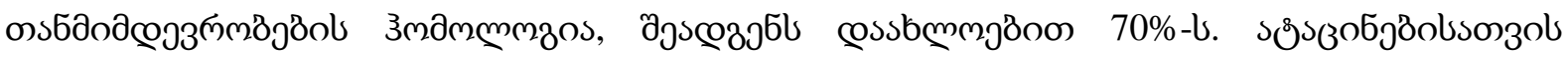

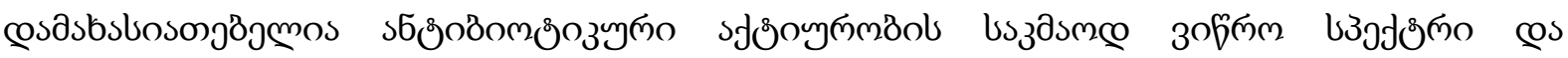

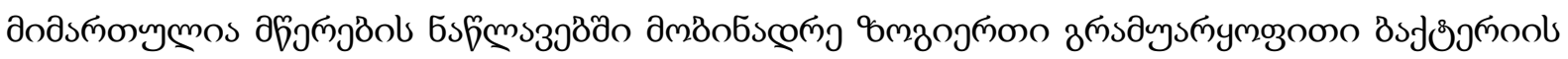

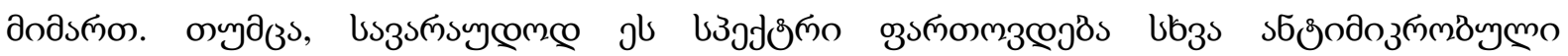

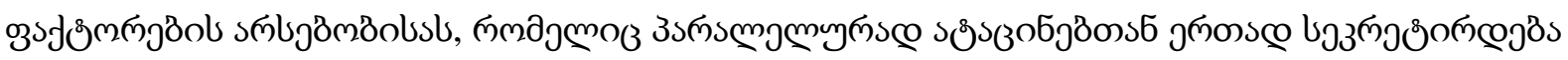

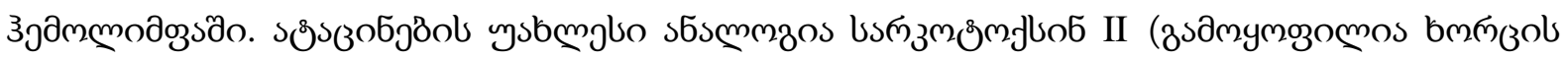

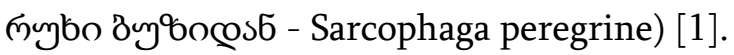

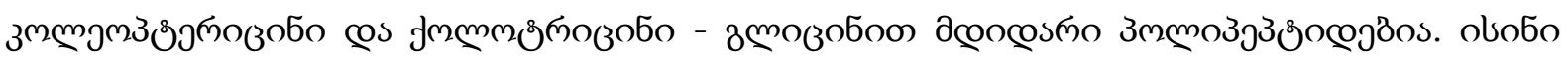

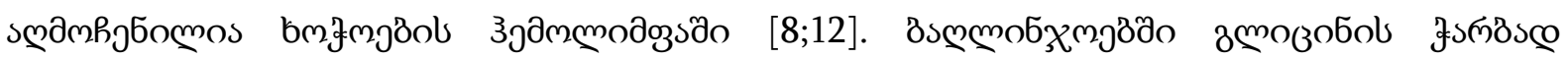

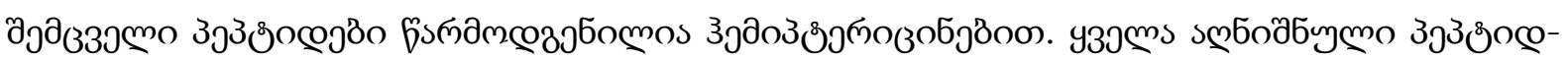

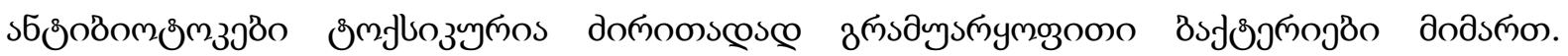

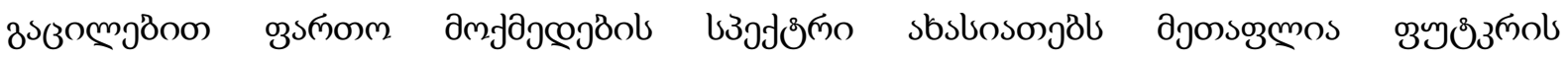

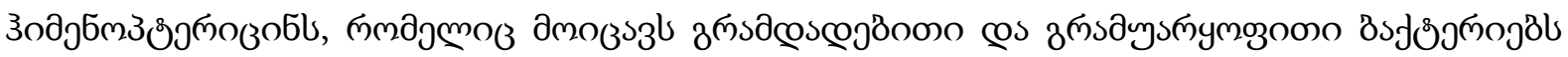

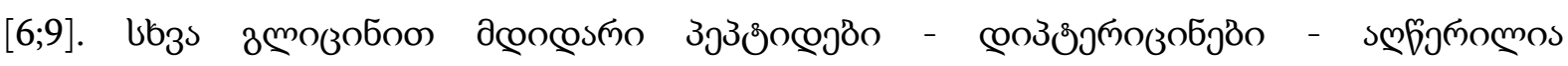

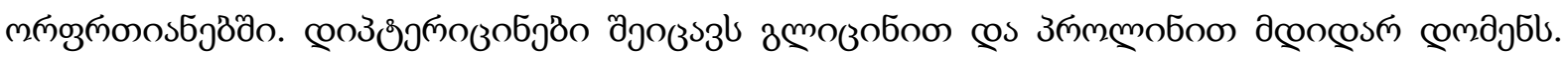

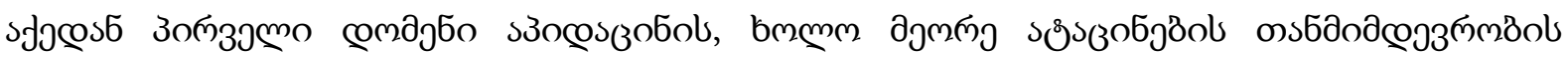

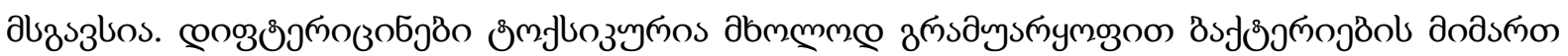
$[7 ; 8 ; 10 ; 11]$.

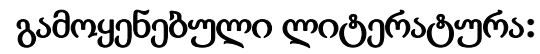

1. Ando K., Natori S. Molecular cloning, sequencing and characterisation of cDNA for sarcotoxin II, an inducible antibacterial protein of Sarcophaga peregrina // J. Biochem. 1988. - Vol. 27. - P. 1715-1721.

2. Boman H. G. Cell-free immunity in Cecropia. A model system for antibacterial proteins // J.Biochem. - 1991. - Vol. 201. - P. 23-31.

3. Bulet F., Hetru S. A novel inducible antibacterial peptide of Drosophila carries an O- 
glycosilatedsubstitution. // J. Biol. Chem. — 1993. — Vol. 268. — P. 14893-14897.

4. Casteels P., Ampe C. Isolation and characterisation of abaecin, a major antibacterial responsepeptide in the honeybee // J. Biochem. — 1990. — Vol. 187. — P.381-386.

5. Casteels P., Ampe C., Jacobs F. et al. Apidaecins: antibacterial peptides from honey bees //EMBO J. - 1989. - No. 8. - P. 2387-2391.

6. Casteels P., Ampe C., Jacobs F. et al. Functional and chemical characterisation ofhymenoptaecin, an antimicrobial polypeptide that is infection-inducible in the honeybee //J. Biol. chem. - 1993. - Vol.268. - P. 7044-7054.

7. Chernysh S. I., Cociancich S., Briand J.-P. et al. The inducible antibacterial peptides of thehemipteran insect Palomena prasina: identification of a novel family of proline-rich peptidesand of a novel insect defensin // J. Insect Physiol. — 1996. - Vol. 42, No. 1. P.81-89.

8. Cociancich S., Bulet P., Hetry C. et al. The inducible antibacterial peptides of insects // J.Parasitology Today. — 1994b. — Vol.10, No. 4. — P. 132-139.

9. Cociancich S., Dupont A., Hegy G. Novel inducible antibacterial peptides from a hemipteraninsect, the sap-sucking bug Pyrrhocoris apterus // J.Biochem. —1994a. - Vol. 300. - P.567-575.

10. Dimarcq J. L., Keppi E., Dunbar B. et al. Purification and characterization of a family of novelinducible antibacterial proteins from immunized larvae of the dipteran Phormia terranovaeand complete amino-acid sequence of the predominant member, diptericin A // Eur. J.Biochem. - 1988. - Vol. 171. - P. 17-22.

11. Ishikawa M., Kubo T., Natori S. Purification and characterization of a diptericin homologuefrom Sarcopaga peregrina (flesh fly) // Biochem. J. — 1992. — No. 287, — P. 573-578.

12. Lee S. Y., Moon H. J., Kurata S. et al. Purification and molecular cloning of cDNA for aninducible antibacterial protein of larvae of a colepteran insect, Holotrichia diomphalia //J.Biochem. - 1994. - Vol. 115. - P.82-86.

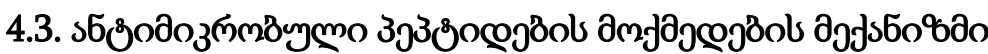

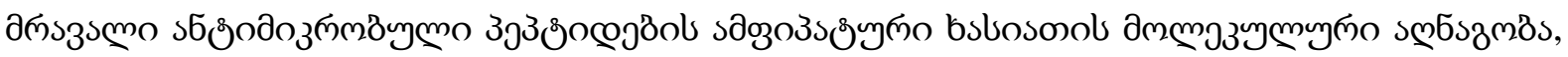

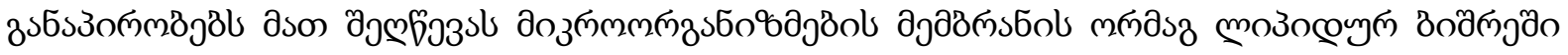

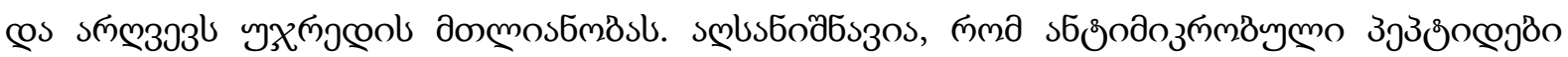

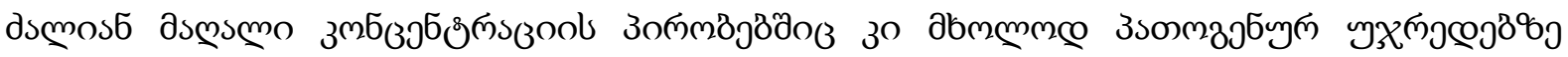

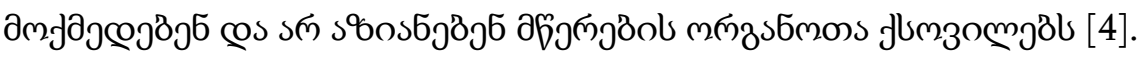

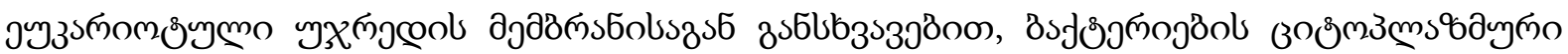

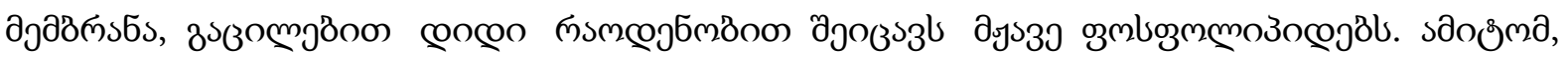

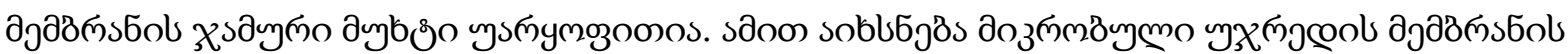

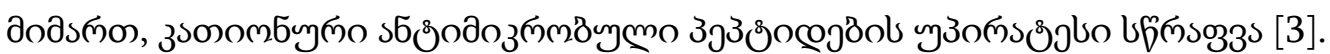

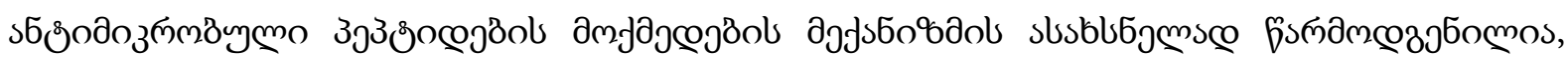

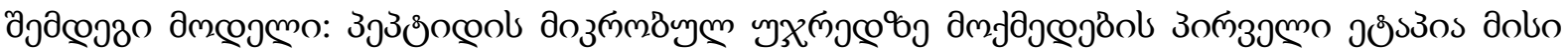

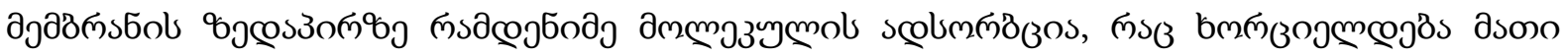

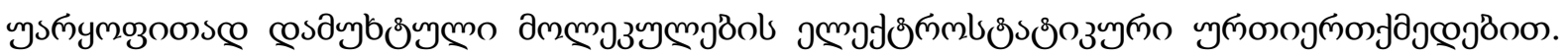




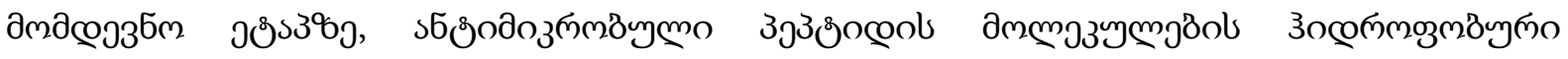

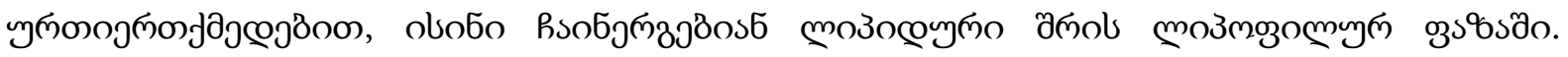

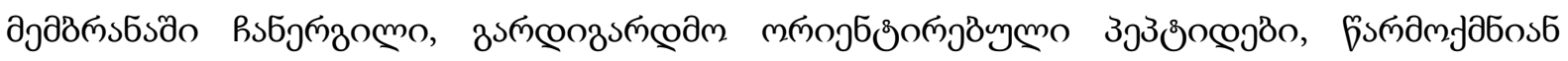

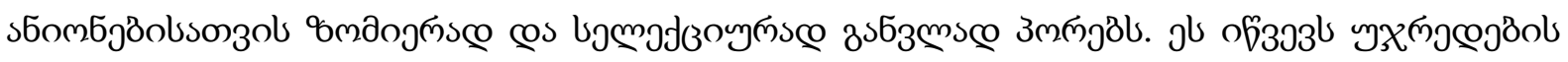

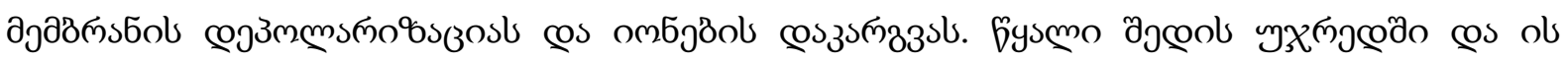
одмल

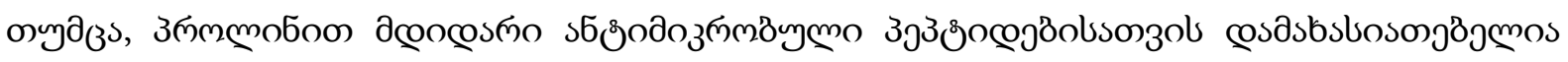

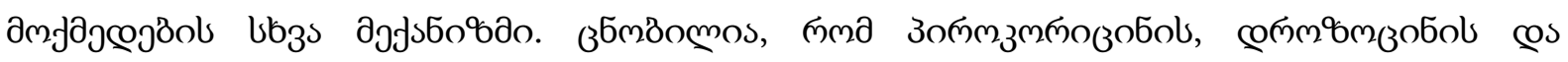

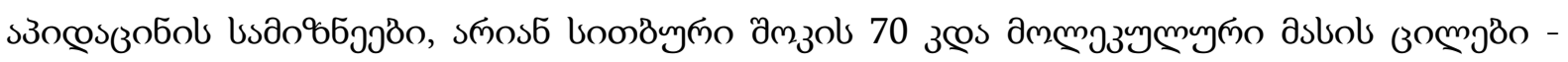

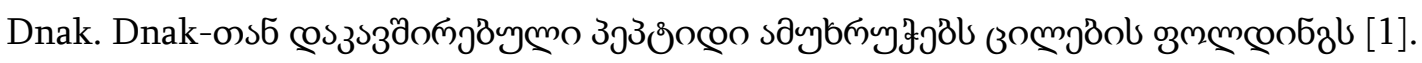

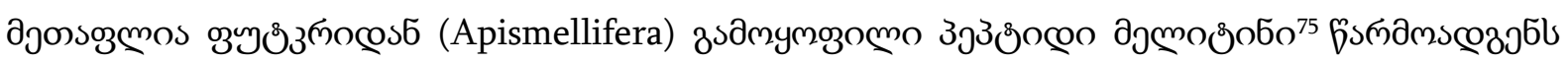

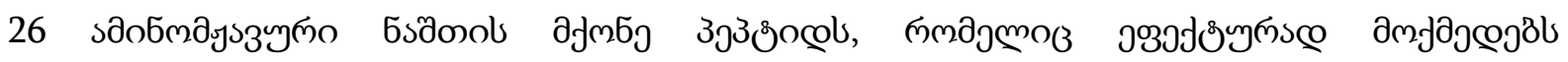

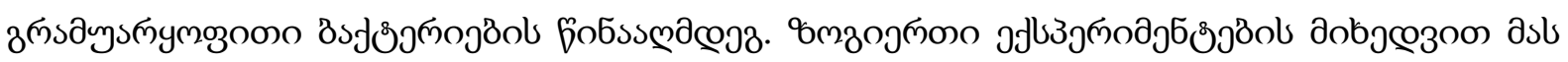

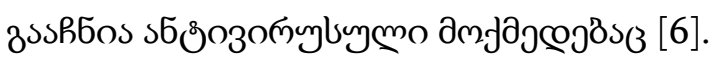

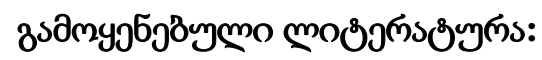

1. Cudic M., Condie B. A., Weiner D. J. et al. Development of novel antibacterial peptides that killresistant clinical isolates // Peptides. - 2002. - Vol. 23. - P. 271-283.

2. Merrifield R. B. et al. Channel-forming properties of cecropins andrelated model compounds incorporated into planar lipid membranes // Proc. Nat. Acad. Sci.USA. — 1988. — Vol. 85. - P. 5072-5076.

3. Oren Z., Shai Y. Mode of action of linear amphipatic $\alpha$ helical antimicrobial peptides //Biopolymers. - 1998. - Vol. 47. - P. 451-463.

4. Ratcliffe N. A., Mello C. B., Garcia E. S. et al. Insect natural products and processes: Newtreatments for human disease // Ins. Bioch. and Mol. Biol. — 2011. — Vol. 41. — P. 747-769.

5. Reddy K. V. R., Yedery R. D., Aranha C. Antimicrobial peptides: premises and promises //Internal. J. Antimicr. Agents. — 2004. — Vol. 24. — P. 536-547.

6. Fennell, J.F. Antibacterial action of melittin, a polypeptide from bee venom / J.F. Fennell, W.H. Shipman, L.J. Cole // Exp. Biol. Med. - 1968. - Vol. 127. - P. 707-710.

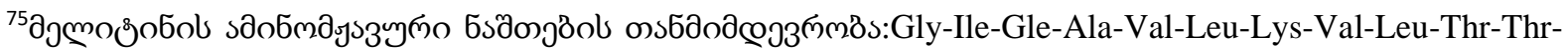
Gly-Leu-Pro-Ala-Leu-Ile-Ser-Trp-Ile-Lys-Arg-Lys-Arg-Gln-Gln.
} 


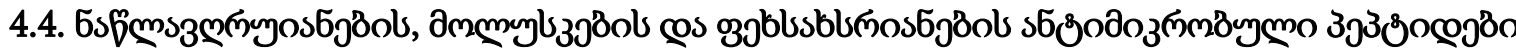

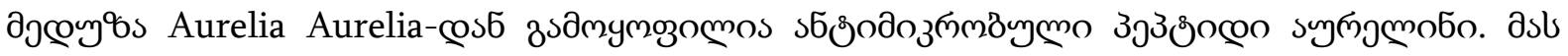

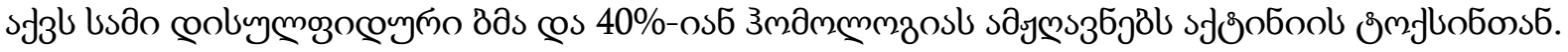

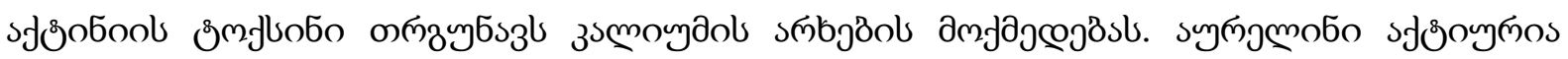

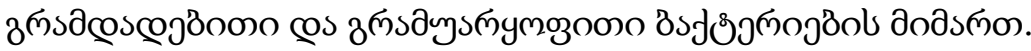

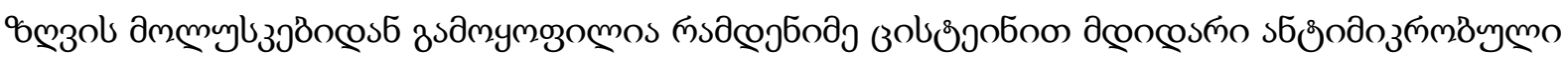

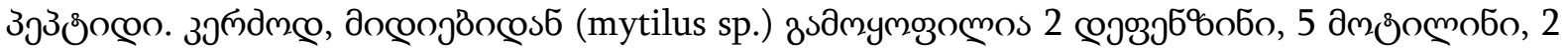

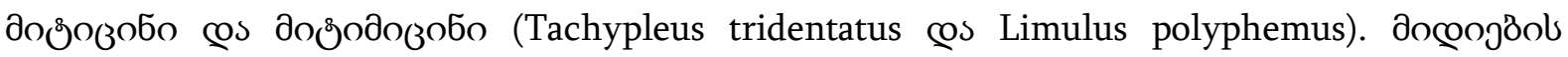

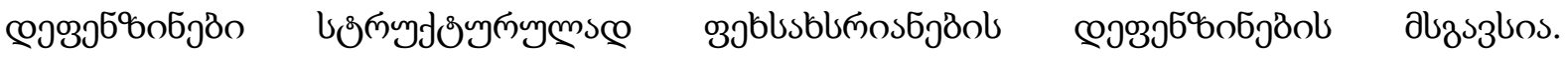

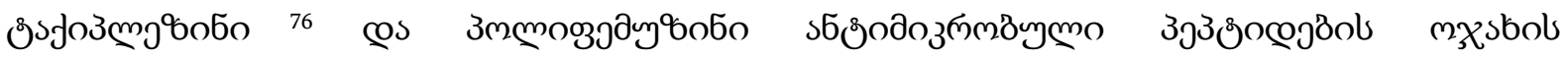

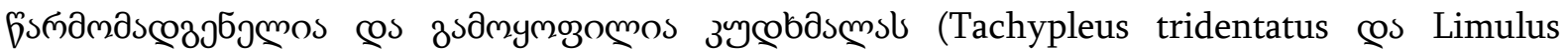

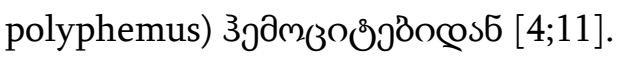

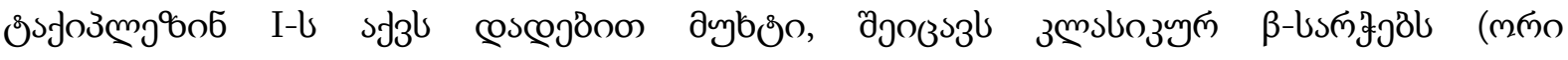

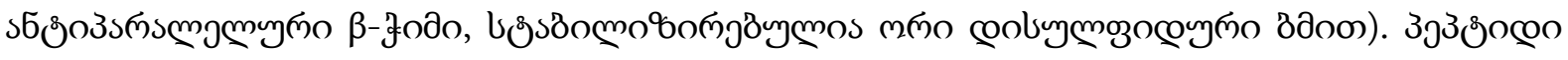

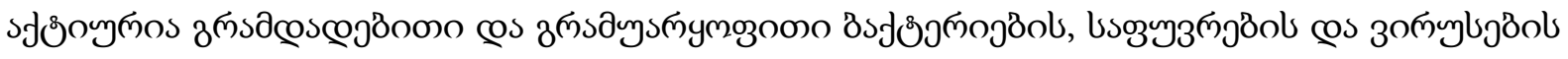

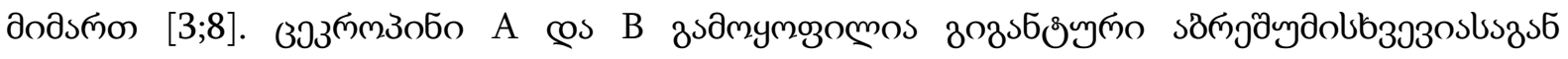

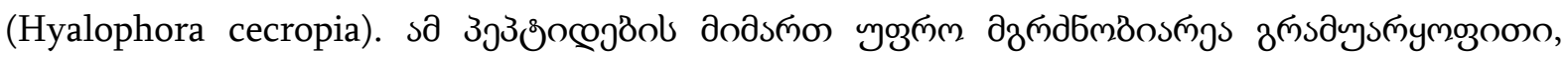

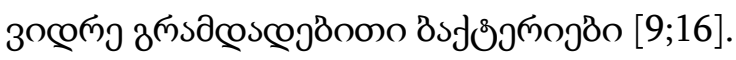

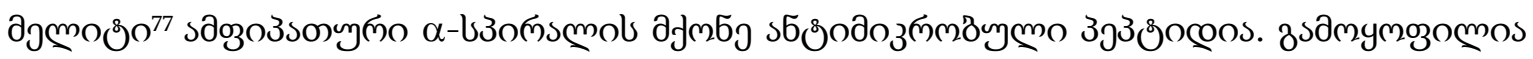

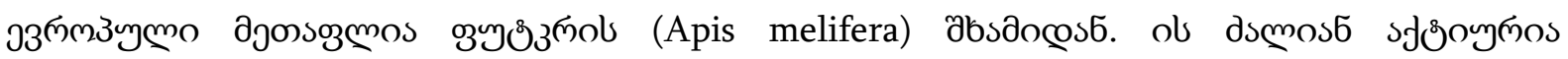

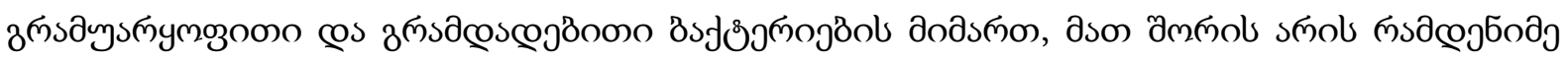

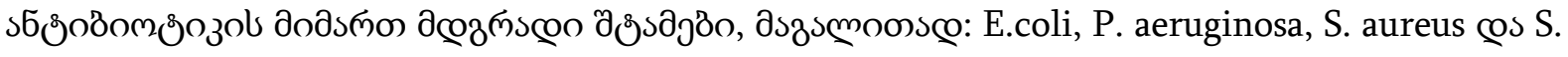

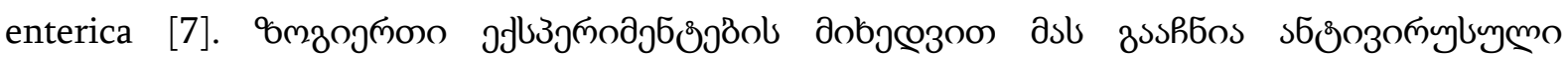

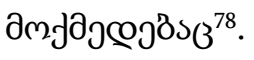

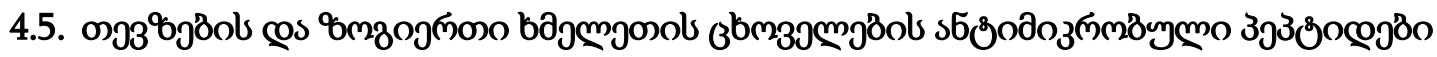

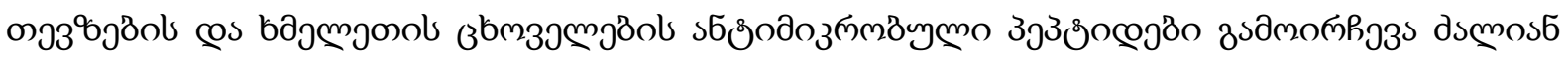

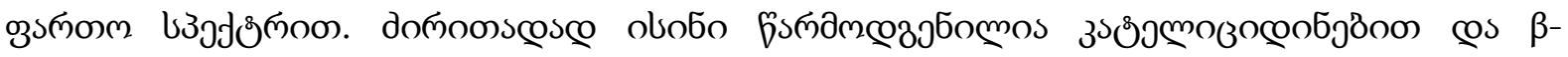

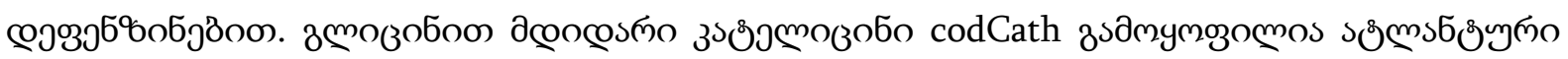

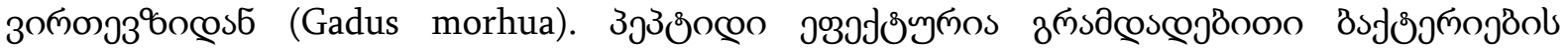

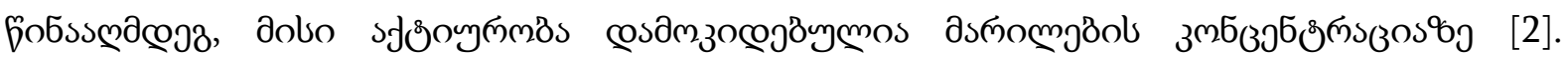

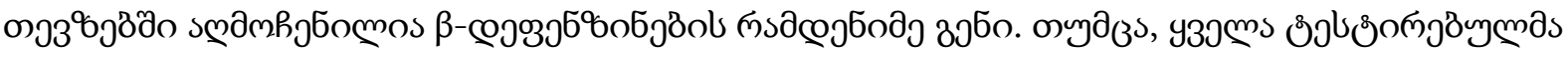

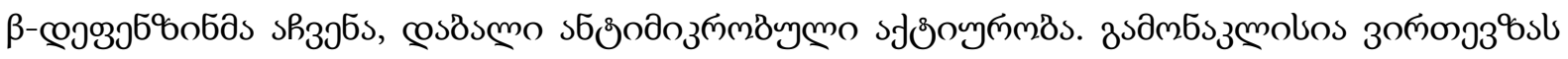

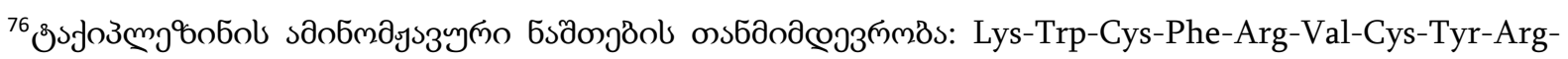
Glu-Ile-Cys-Tyr-Arg-Arg-Cys-Arg-Gly-Lys.

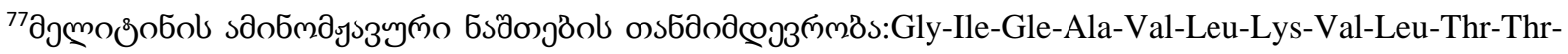
Gly-Leu-Pro-Ala-Leu-Ile-Ser-Trp-Ile-Lys-Arg-Lys-Arg-Gln-Gln.

${ }^{78}$ Wade D., Andreu, D., Mitchell, S.A., Silveira, A.M.V, Boman, A., Boman, H.G. and Merrifield, R.B. (1992) Inter. J. Pept. Prot. Res., 40, 429-436.
} 


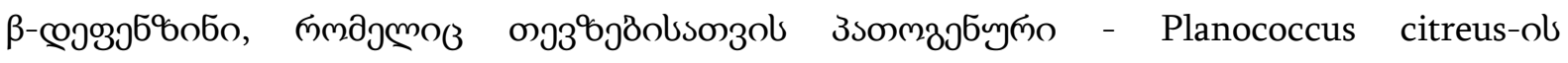

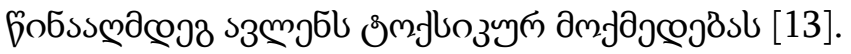

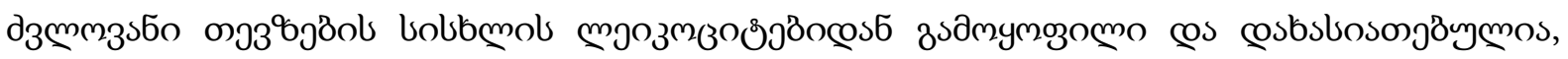

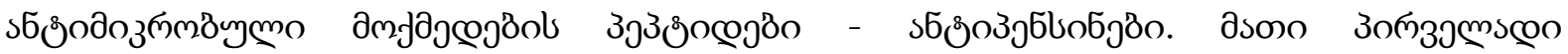

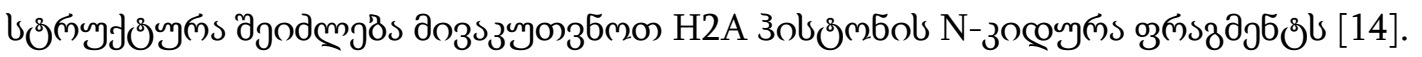

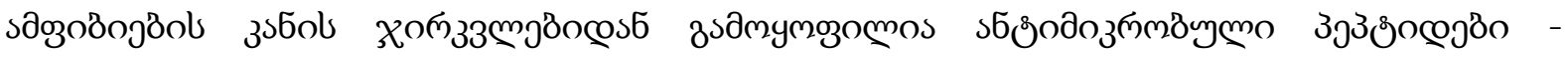

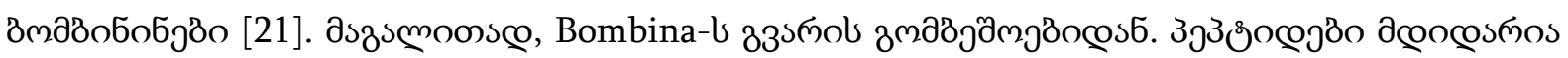

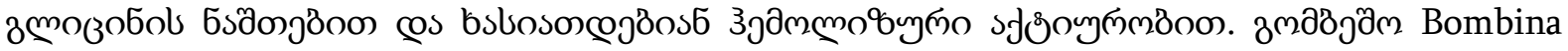

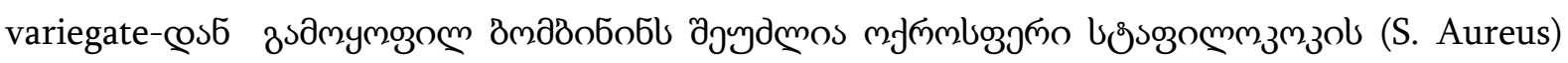

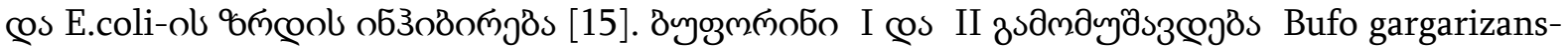

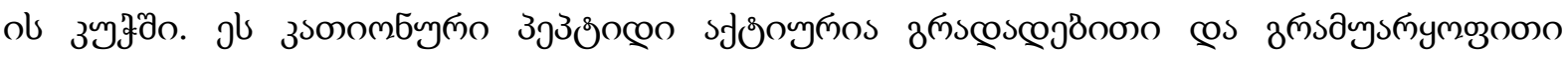

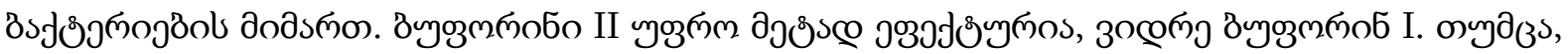

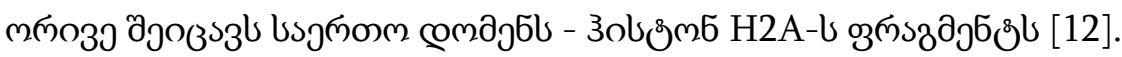

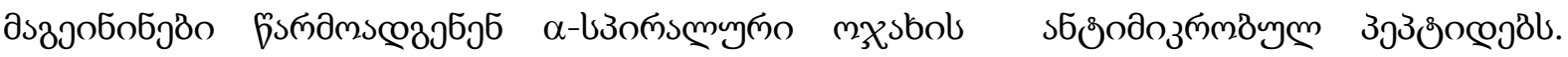

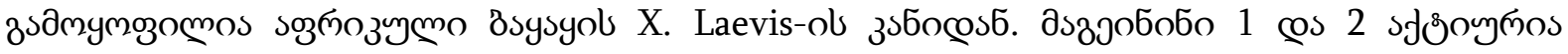

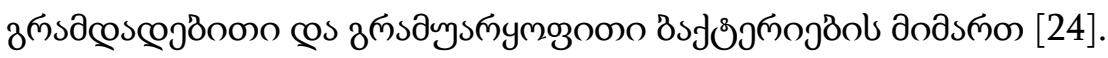

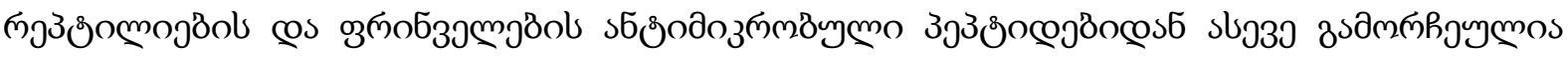

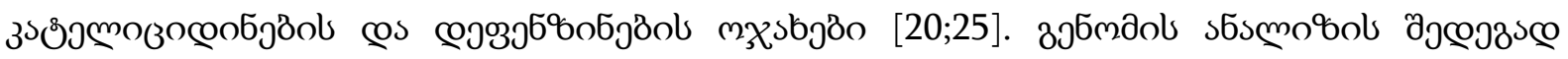

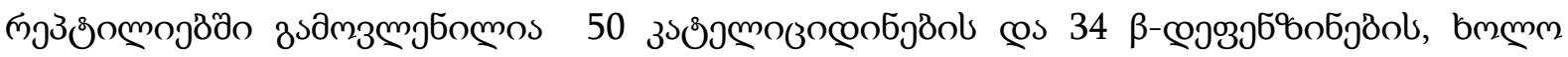

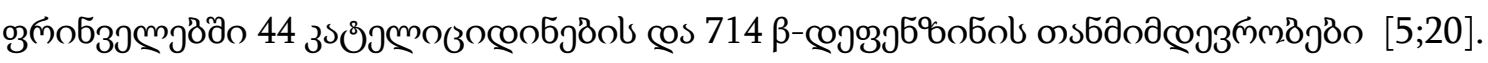

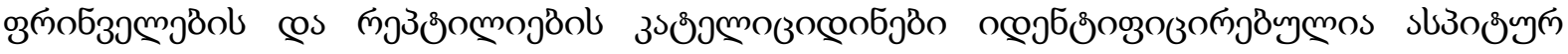

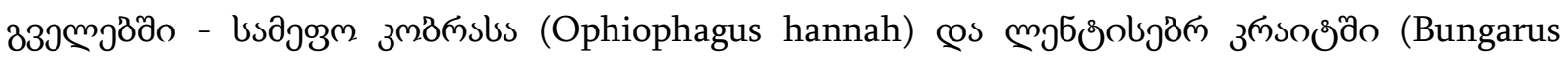

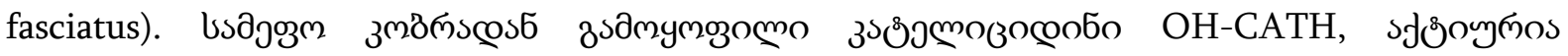

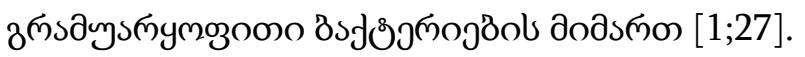

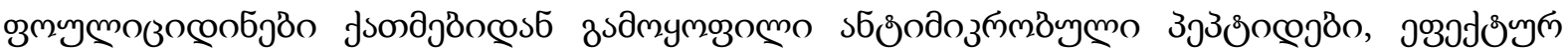

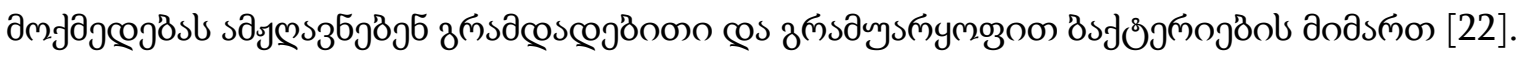

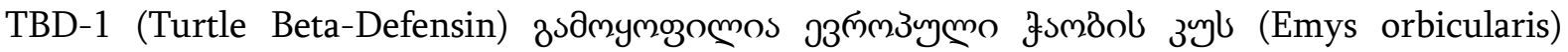

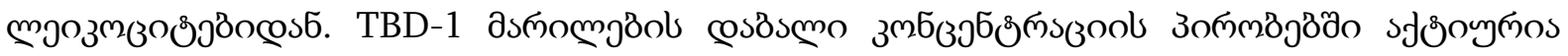
E.coli œs L. monocytogenes-ob dodsณno.

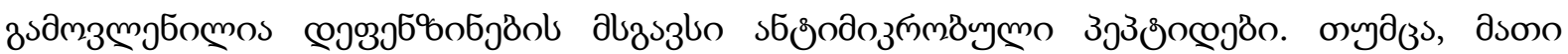

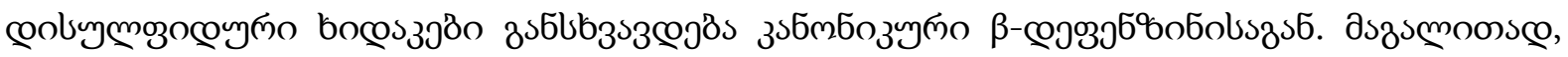

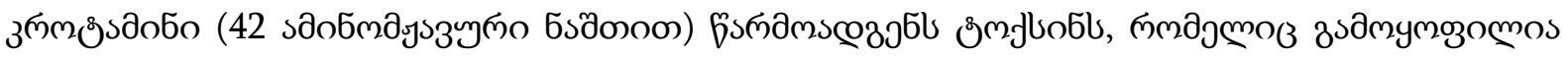

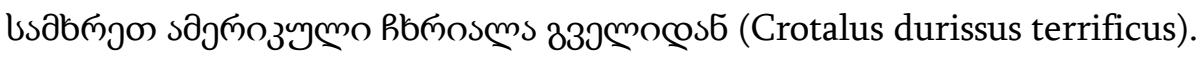

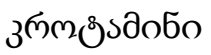

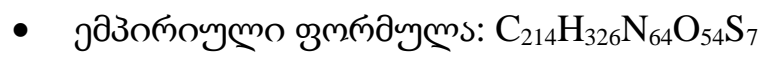

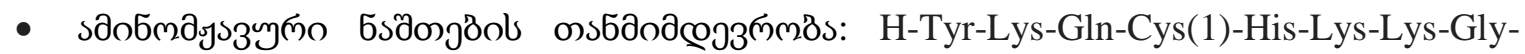
Gly-His-Cys(2)-Phe-Pro-Lys-Glu-Lys-Ile-Cys(3)-Leu-Pro-Pro-Ser-Ser-Asp-Phe-Gly-LysMet-Asp-Cys(2)-Arg-Trp-Arg-Trp-Lys-Cys(1)-Cys(3)-Lys-Lys-Gly-Ser-Gly-OH

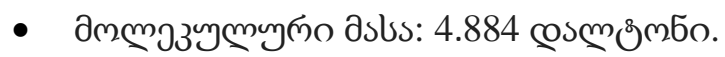

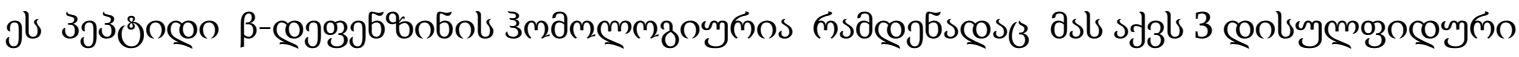




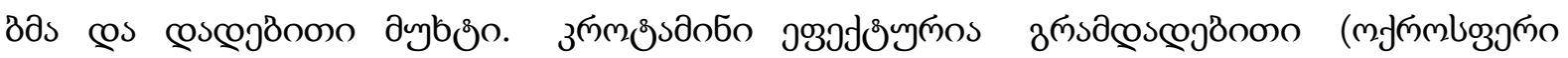

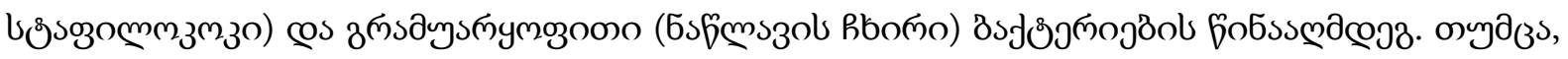

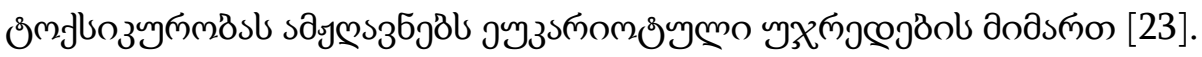

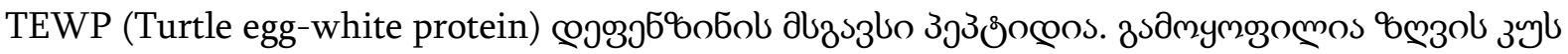

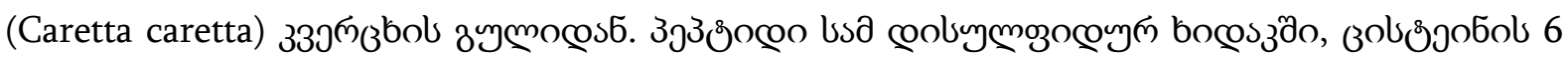

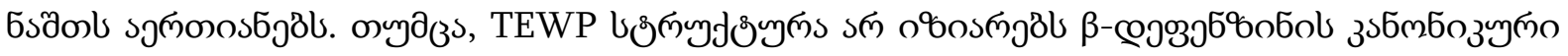

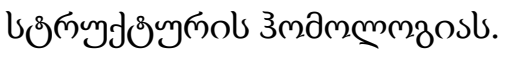

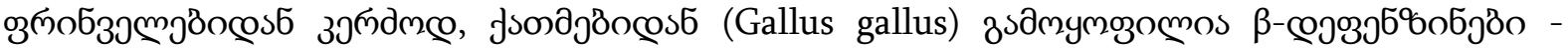

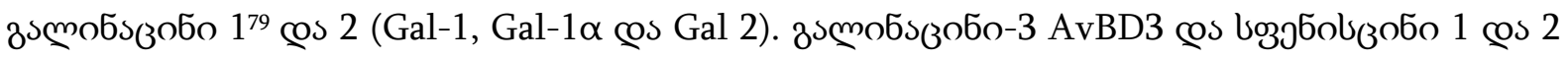
[Sphe-1 (AvBD103a) Sphe-2 (AvBD103b)], змдмЯјбомоо иsдјозм зобззобдо (Aptenodytes

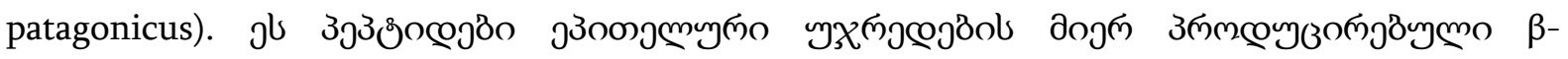

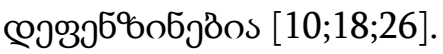

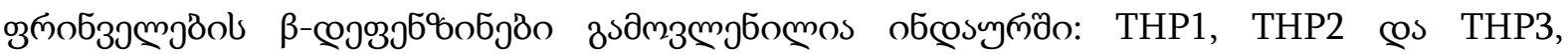

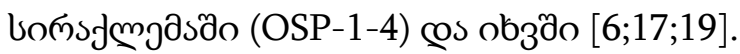

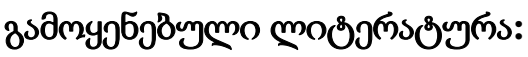

1. Antimicrobial peptides in reptiles / M.L. van Hoek // Pharmaceuticals. - 2014. - Vol. 7. - P. 723-753.

2. Broekman, D.C. Functional characterization of codCath, the mature cathelicidin antimicrobial peptide from Atlantic cod (Gadus morhua) / D.C. Broekman, A. Zenz, B.K. Gudmundsdottir, [et al.] // Peptides. - 2011a. - Vol. 32. - P. 2044-2051.

3. Bulet, P. Antimicrobial peptides: from invertebrates to vertebrates / P. Bulet, R. Stöcklin, L. Menin // Immunol. Rev. - 2004. - Vol. 198. - P. 169-184.

4. Charlet, M. Innate Immunity. Isolation of several Cysteine-rich antimicrobial peptides from the blood of a mollusc, Mytilus edulis / M. Charlet, S. Chernysh, H. Philippe, [et al.]// J. Biol. Chem. - 1996. - Vol. 271. - P. 21808-21813.

5. Cheng, Y. Evolution of the avian $\beta$-defensin and cathelicidin genes / Y. Cheng, M.D. Prickett, W. Gutowska, [et al.]// BMC Evol. Biol. - 2015. - Vol. 15. - P. 188. doi: 10.1186/s12862015-0465-3

6. Evans, E.W. Isolation of antimicrobial peptides from avian heterophils / E.W. Evans, G.G. Beach, J. Wunderlich, B.G. Harmon // J. Leukoc. Biol. - 1994. - Vol. 56. - P. 661-665.

7. Fennell, J.F. Antibacterial action of melittin, a polypeptide from bee venom / J.F. Fennell, W.H. Shipman, L.J. Cole // Exp. Biol. Med. - 1968. - Vol. 127. - P. 707-710.

8. Jain, A. Marine antimicrobial peptide tachyplesin as an efficient nanocarrier for macromolecule delivery in plant and mammalian cells / A. Jain, B.K. Yadav, A. Chugh // FEBS J. - 2014. - Vol. 282. - P. 732-745.

9. Hancock, R.E.W. Cationic peptides: effectors in innate immunity and novel antimicrobials /

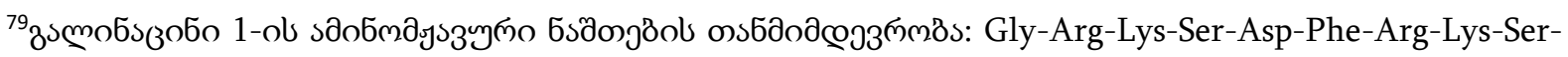
Gly-Phe-Cys-Ala-Phe-Leu-Lys-Lys-Pro-Ser-Leu-Thr-Leu-Ile-Ser-Gly-Lys-Cys-Ser-Arg-Phe-Tyr-Leu-CysLys-Arg.
} 
R.E.W. Hancock // Lancet Infect Dis. - 2001. - Vol. 1(3). - P. 156-164.

10. Harwig, S.S.L. Gallinacins: Cystein - rich antimicrobial, peptides of chicken leukocytes / S.S.L. Harwig, K.M. Swiderek, V.N. Kokryakov, [et al.] // FEBS Lett. - 1994. - Vol. 342. P. 281-285.

11. Ovchinnikova, T.V. T.V. Ovchinnikova, S.V. Balandin, G.M. Aleshina, [et al.] //Aurelin, a novel antimicrobial peptide from jellyfish Aurelia aurita with structural features of defensins and channel-blocking toxins // Biochem Biophys Res Commun. - 2006. - Vol. 348, No. 2. P. 514-523.

12. Park, C.B. A novel antimicrobial peptide from Bufo bufo gargarizans / C.B. Park, M.S. Kim, S.C. Kim // Biochem. Biophys. Res. Commun. - 1996. - Vol. 218(1). - P. 408-413.

13. Ruangsri, J. A novel beta-defensin antimicrobial peptide in atlantic cod with stimulatory effect on phagocytic activity / J. Ruangsri, Y. Kitani, V. Kiron, [et al.] // PLoS One. - 2013. Vol. 8(4). - P. e62302. doi: 10.1371/journal.pone.0062302

14. Shamova, O.V. Acipensins - novel antimicrobial peptides from leukocytes of the russian sturgeon Acipenser gueldenstaedtii. / O.V. Shamova, D.S. Orlov, S.V. Balandin, [et al.]// Acta Naturae. - 2014. - Vol. 6(4). - P. 99-109.

15. Simmaco, M. Barra, Bombinins, antimicrobial peptides from Bombina species / M. Simmaco, G. Kreil, D. Barra // Biochim. Biophys. Acta - Biomembr. - 2009. - Vol. 1788. - P. 15511555.

16. Steiner, H. Sequence and specificity of two antibacterial proteins involved in insect immunity / H. Steiner, D. Hultmark, A. Engstrom, [et al.] // Nature. - 1981.- Vol. 292. - P. 246-248.

17. Sugiarto, H. Identification of three novel ostricacins: An update on the phylogenetic perspective of $\beta$-defensins / H. Sugiarto, P.L. Yu // Int. J. Antimicrob. Agents. - 2006. - Vol. 27. - P. 229-235.

18. Thouzeau C., Y. Le Maho, G. Froget, [et al.] Spheniscins, avian $\beta$-defensins in preserved stomach contents of the king penguin, Aptenodytes patagonicus / C. Thouzeau, Y. Le Maho, G. Froget, [et al.] // J. Biol. Chem. - 2003. - Vol. 278. - P. 51053-51058.

19. Van Dijk, A. Avian defensins / A. van Dijk, E.J.A. Veldhuizen, H.P. Haagsman // Vet. Immunol. Immunopathol. - 2008. - Vol. 124. - P. 1-18.

20. Van Hoek, M.L. Antimicrobial peptides in reptiles / M.L. van Hoek // Pharmaceuticals. 2014. - Vol. 7. - P. 723-753.

21. Xiao, Y. Antimicrobial peptides from amphibians / Y. Xiao, C. Liu, R. Lai // Biomol. Concepts. -2011. - Vol. 2. - P. 27-38.

22. Xiao, Y. Identification and functional characterization of three chicken cathelicidins with potent antimicrobial activity / Y. Xiao, Y. Cai, Y.R. Bommineni, [et al.] // J. Biol. Chem. 2006. - Vol. 281. - P. 2858-2867.

23. Yount, N.Y. Selective reciprocity in antimicrobial activity versus cytotoxicity of hBD-2 and crotamine / N.Y. Yount, D. Kupferwasser, A. Spisni, [et al.] // Proc. Natl. Acad. Sci. U. S. A. - 2009. - Vol. 106. - P. 14972-14977.

24. Zasloff, M. Antimicrobial peptides of multicellular organisms / M. Zasloff // Nature. - 2002. - Vol. 415, № 6870. - P. 389-395.

25. Zhang, G. Avian antimicrobial host defense peptides: From biology to therapeutic applications / G. Zhang, L.T. Sunkara // Pharmaceuticals. - 2014. - Vol. 7. - P. 220-247.

26. Zhao, C. Gallinacin-3, an inducible epithelial $\beta$-defensin in the chicken / C. Zhao, T. Nguyen, L. Liu, [et al.] // Infect. Immun. - 2001. - Vol. 69. - P. 2684-2691.

27. Zhao, H. Identification and characterization of novel reptile cathelicidins from elapid snakes / H. Zhao, T.X. Gan, X.D. Liu, [et al.] // Peptides. - 2008. - Vol. 29. - P. 1685-1691. 


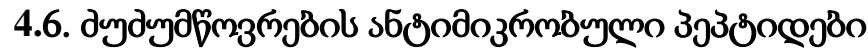

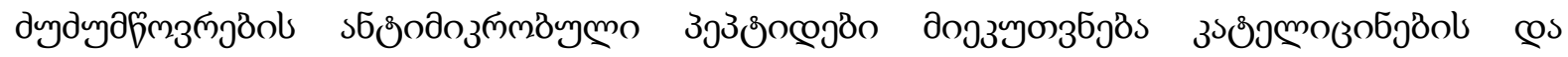

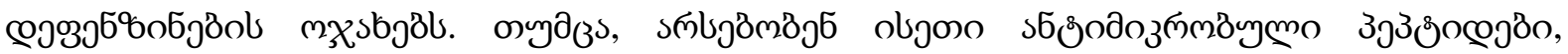

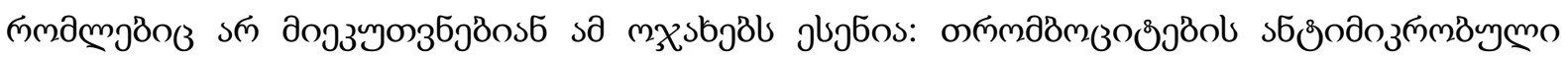

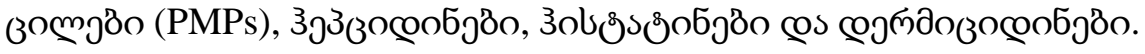

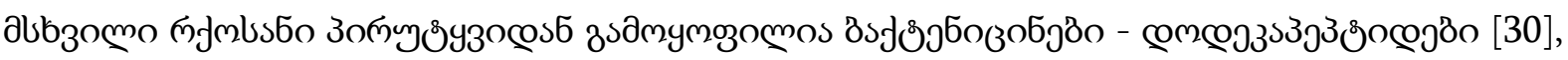

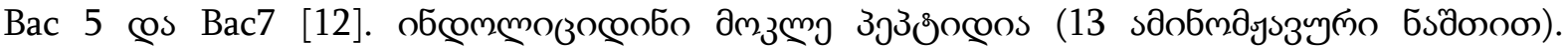

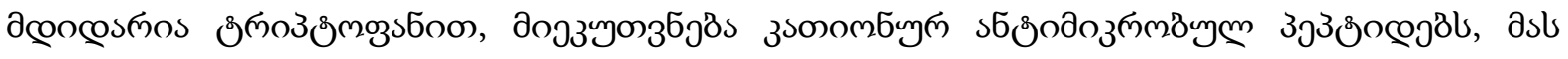

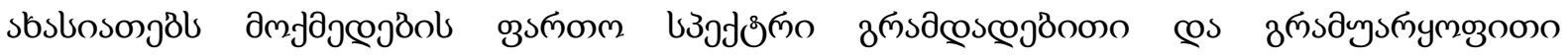

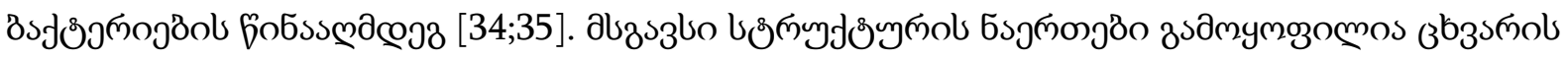

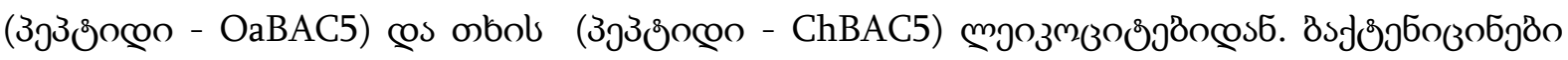

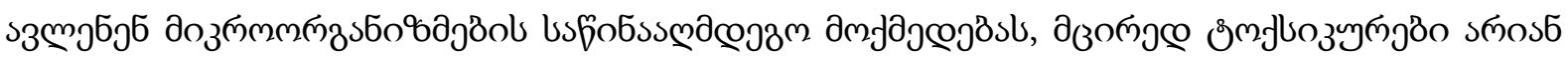

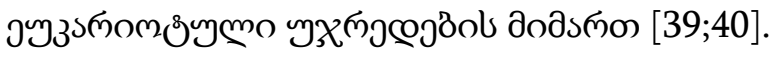

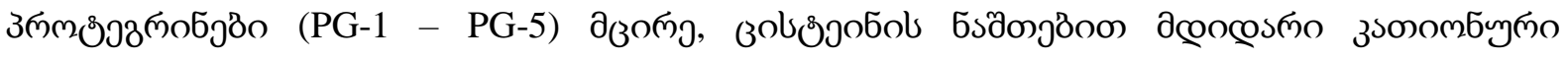

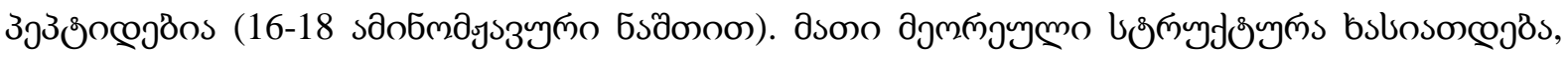

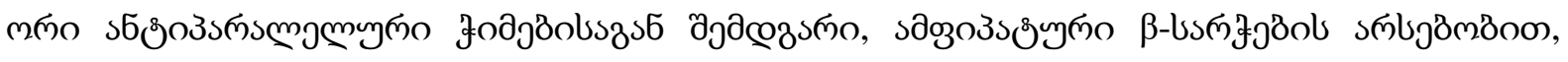

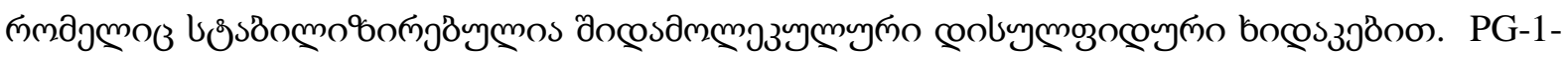

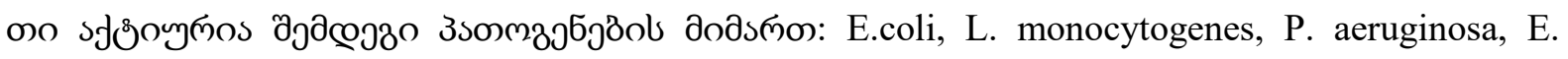

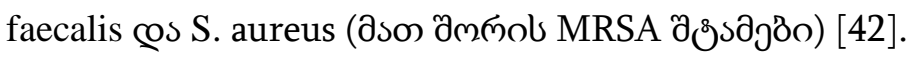

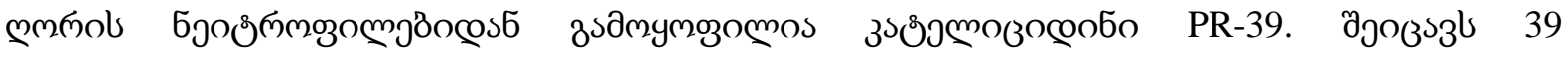

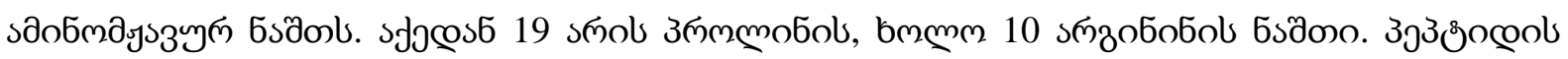

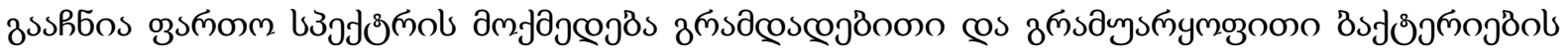

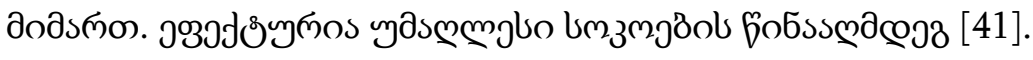

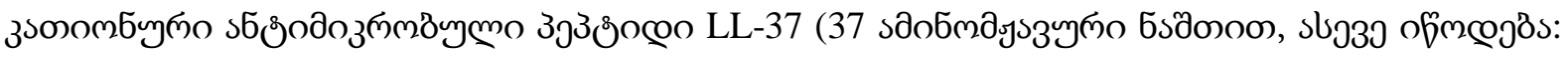

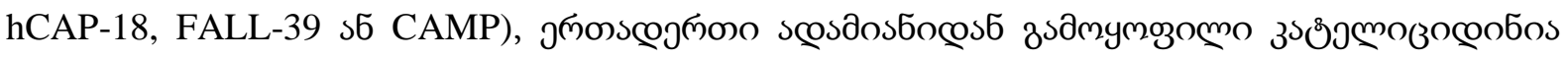

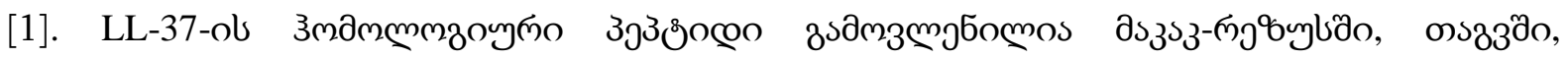

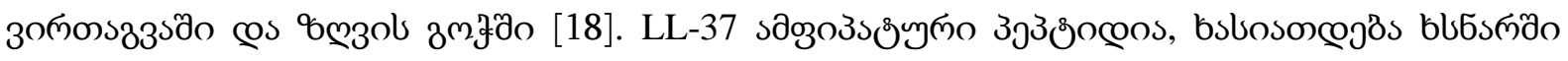

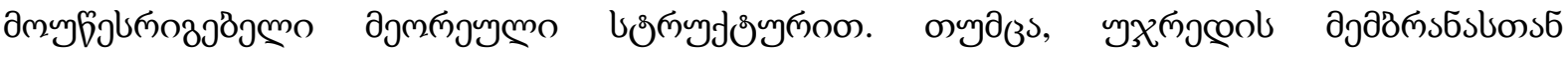

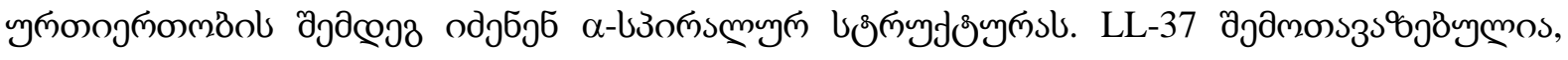

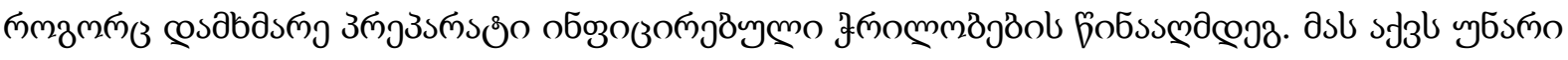

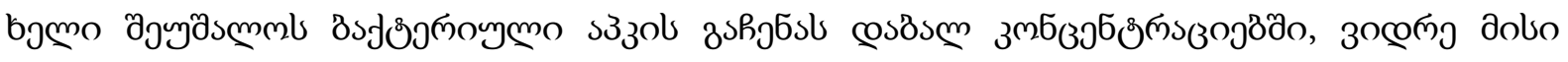

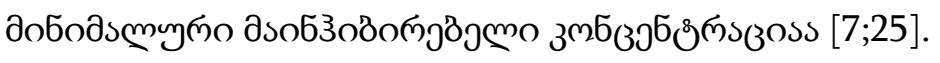

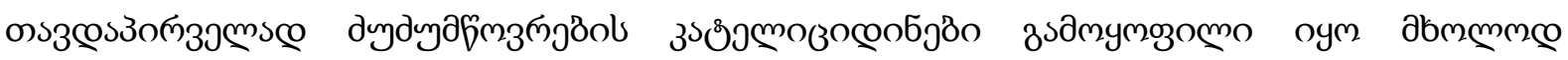

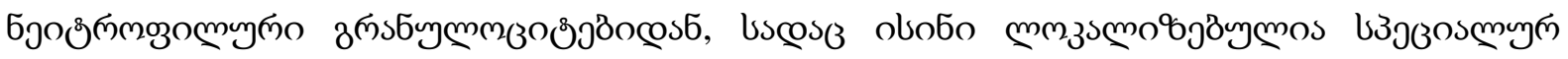

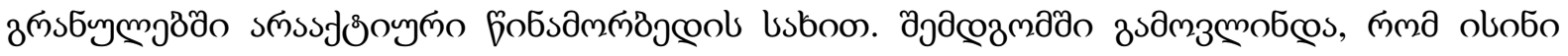

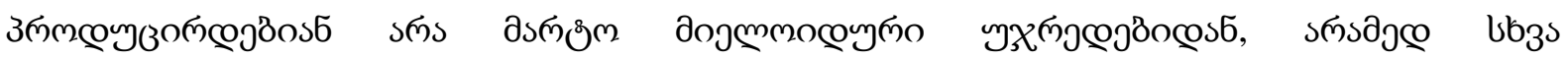

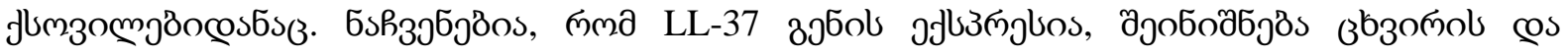

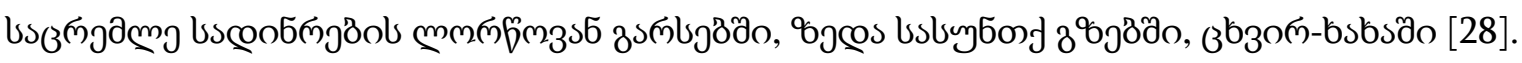




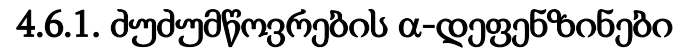

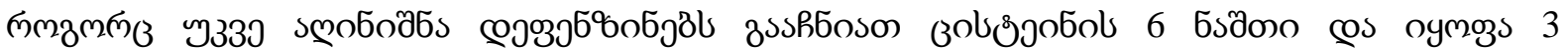

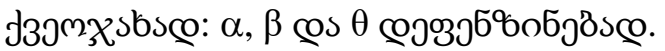

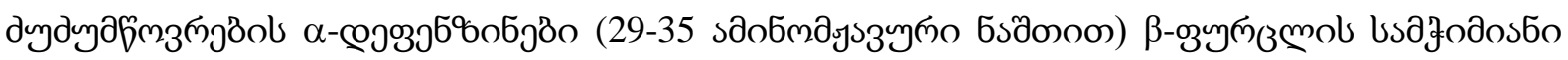

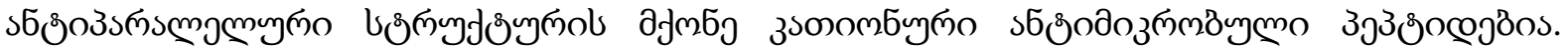

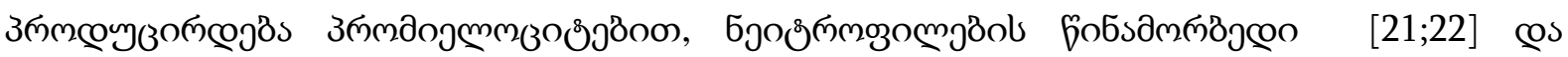

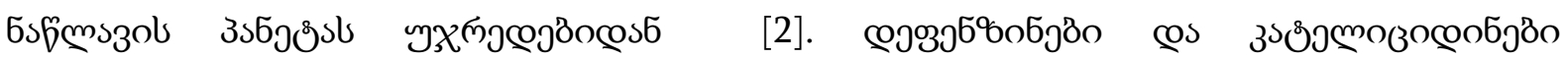

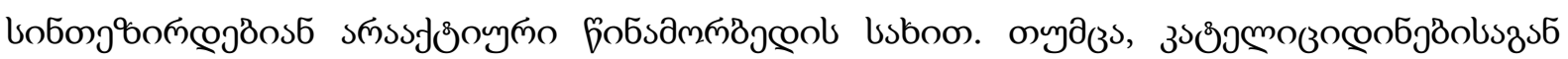

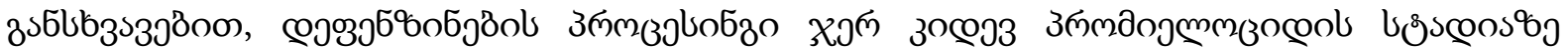

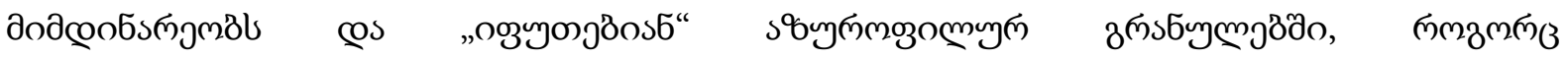

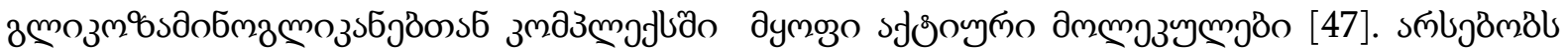

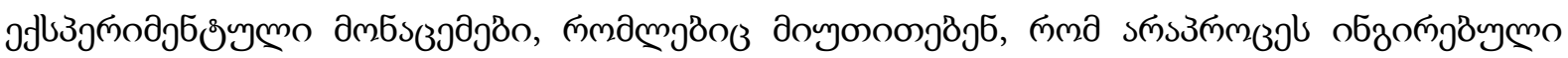

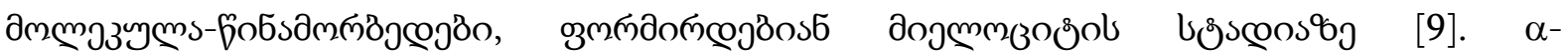

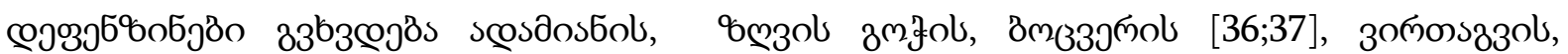

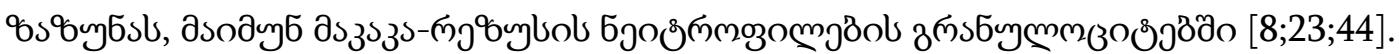

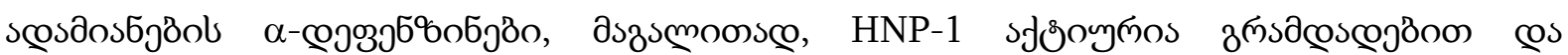

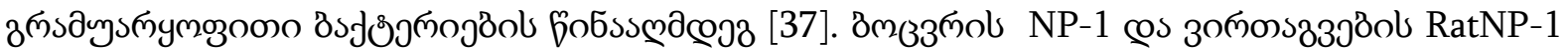

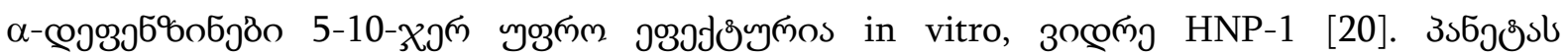

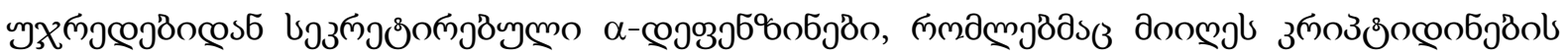

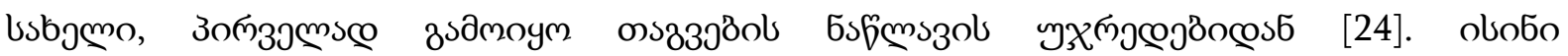

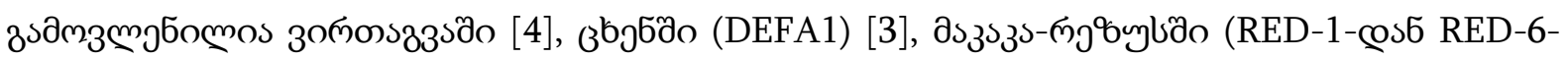
дœ)), [43] cos scosaos6ð̃o (HD-5 cos HD-6) [33].

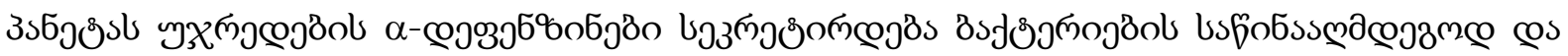

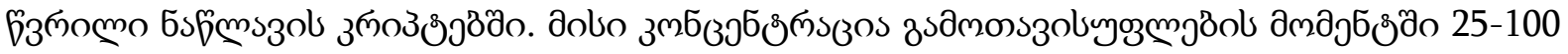

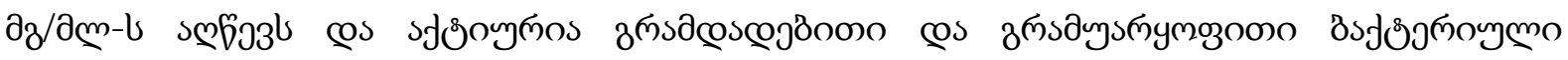
озммпо foбssмдасов [2].

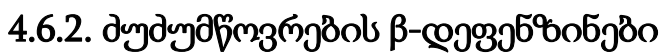

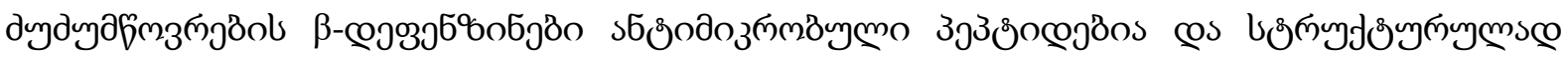

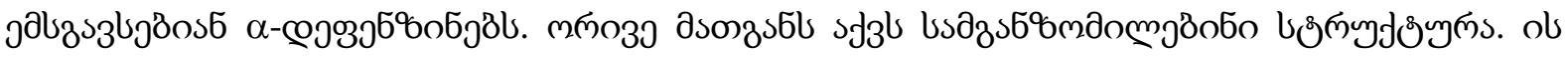

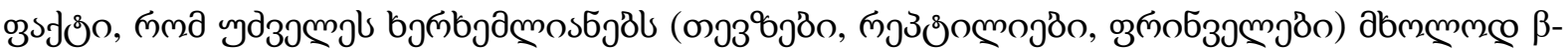

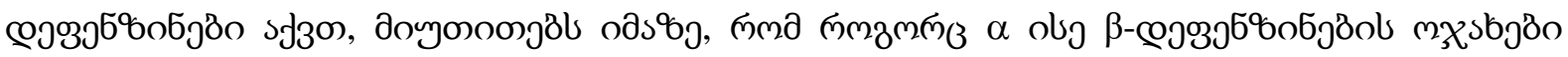

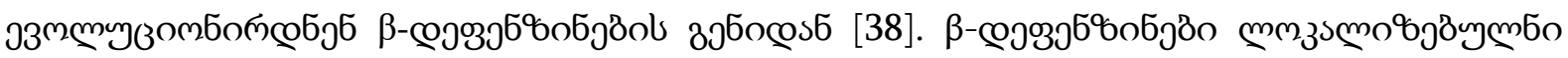

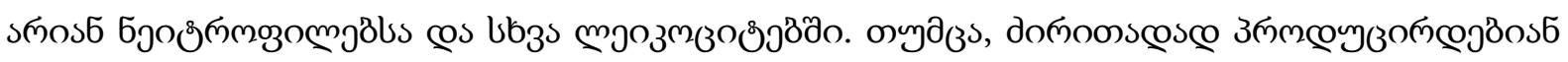

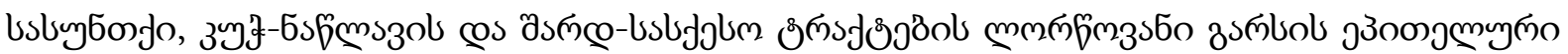

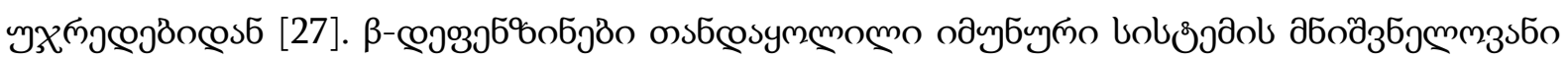

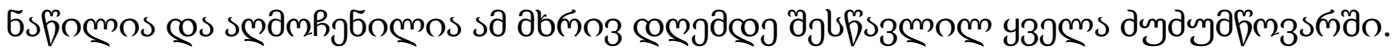

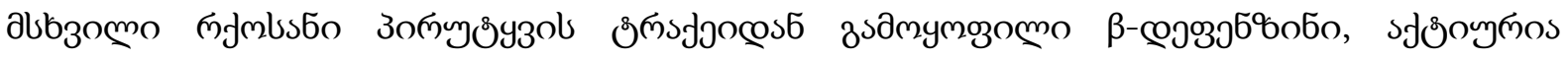

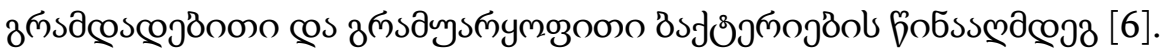

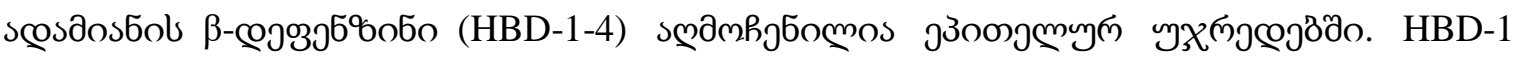




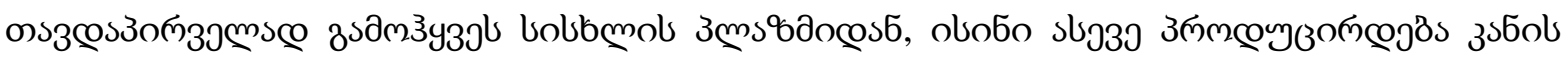

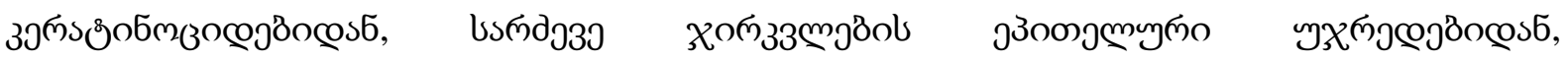

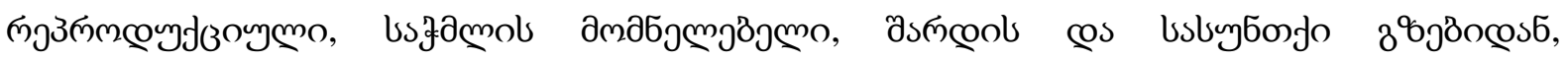

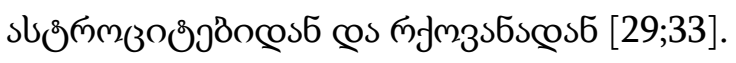

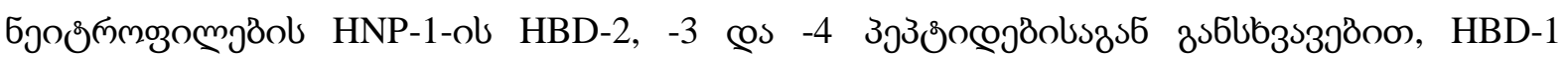

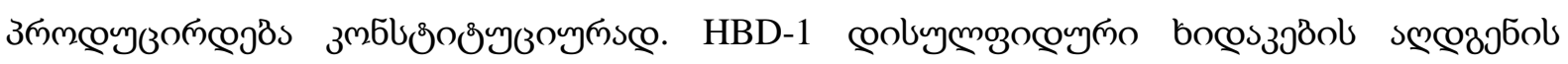

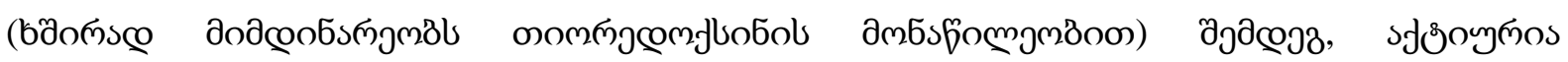

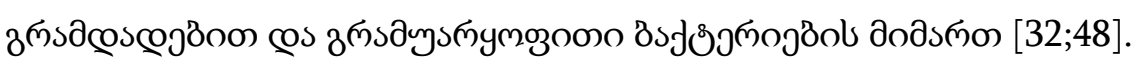

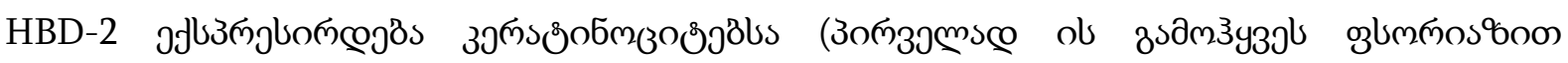

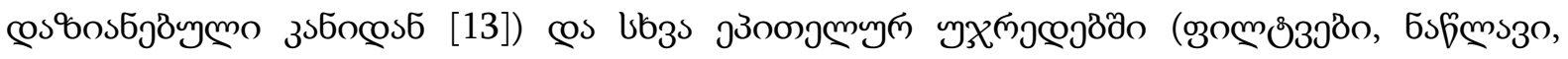

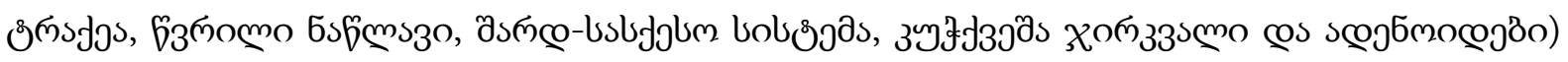

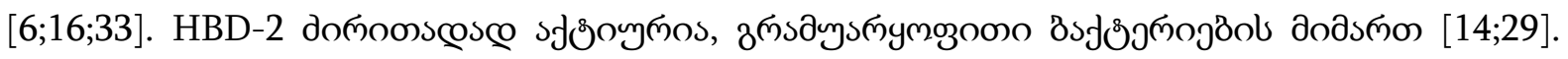

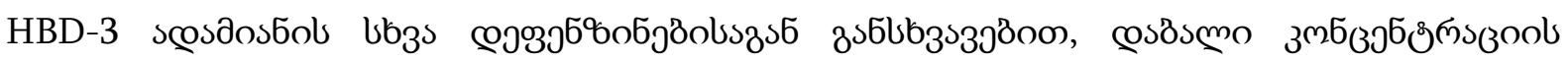

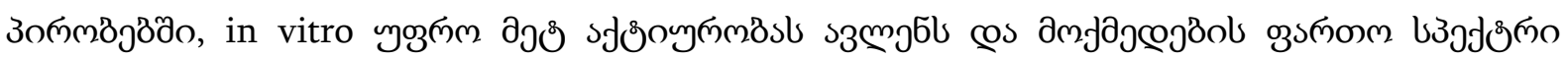

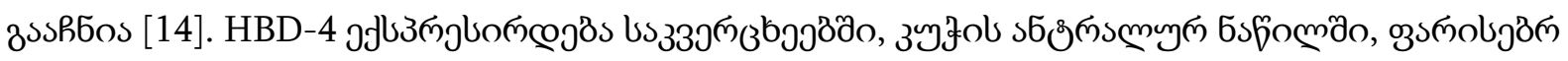

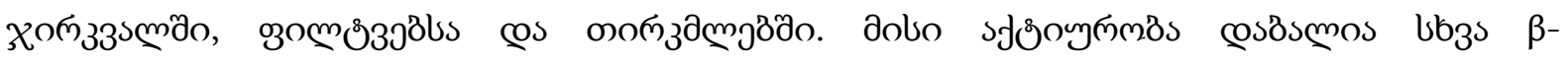

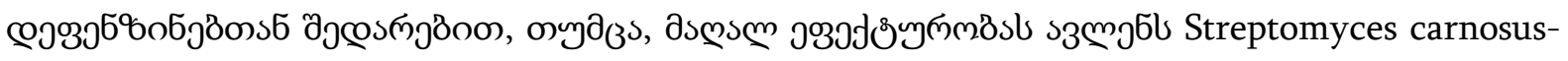
ol cos P. Aeruginosa-l aodsॅno [11].

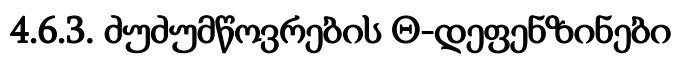

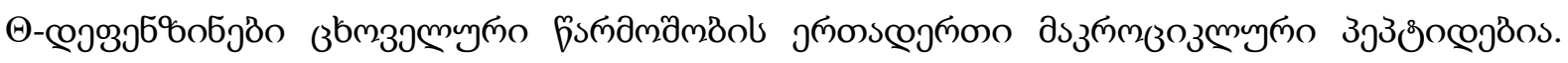

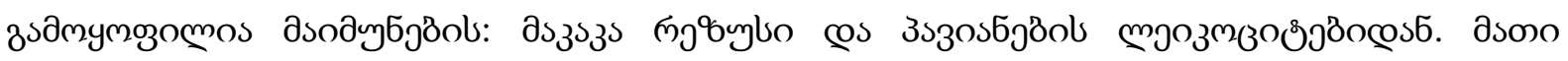

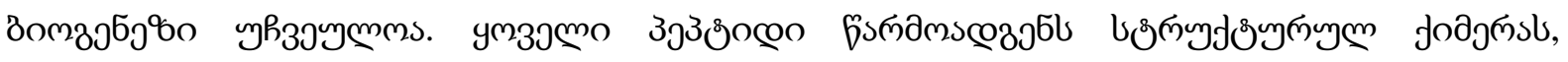

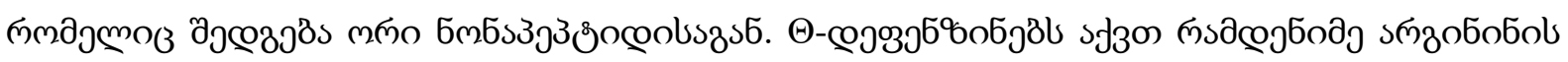

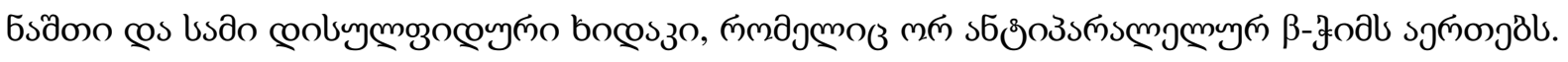

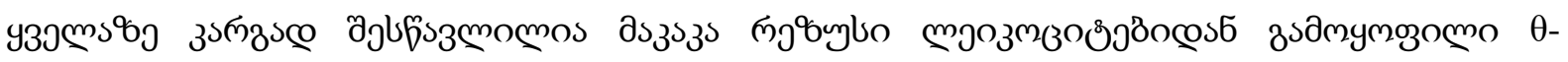

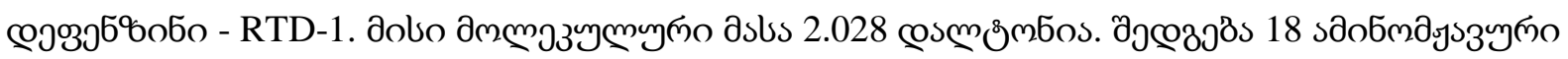

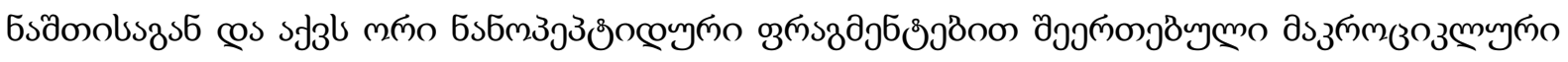

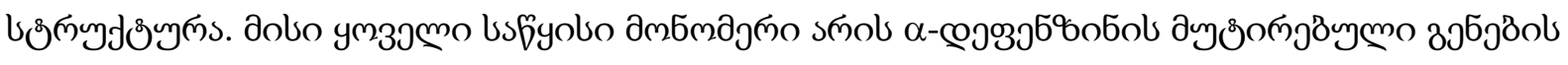

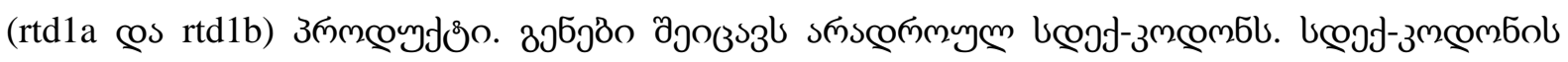

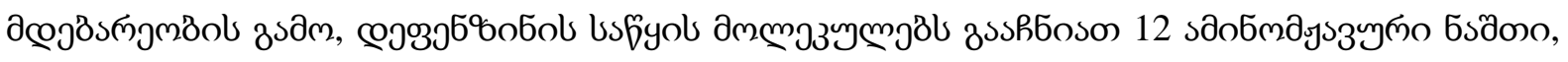

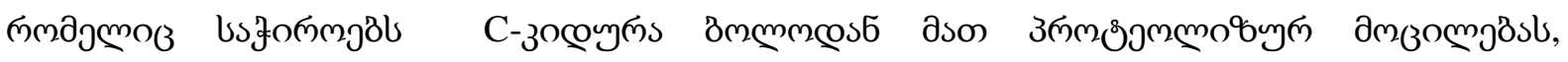

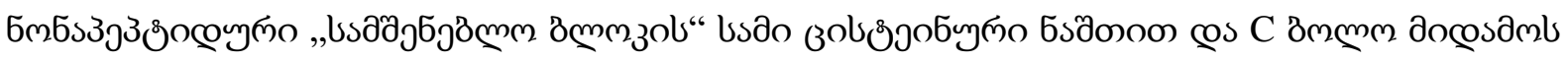

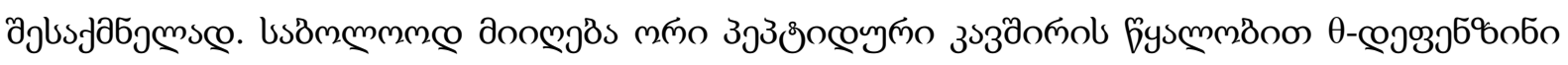
[22].

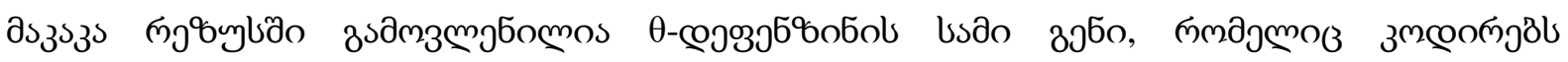

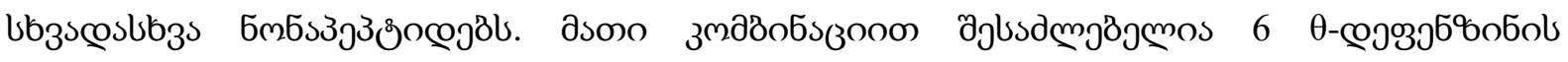

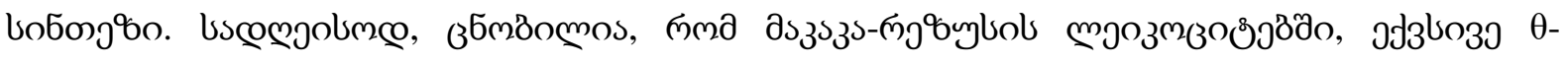

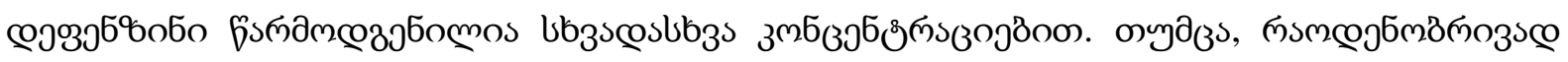

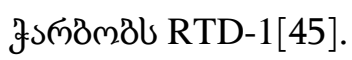




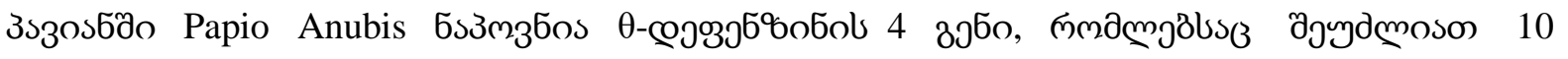

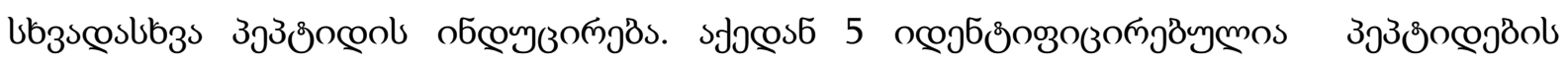

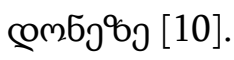

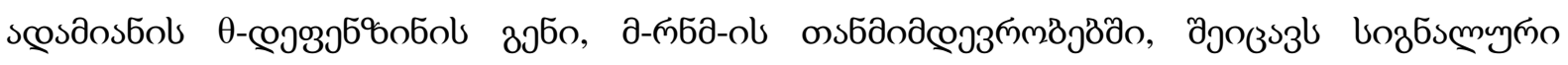

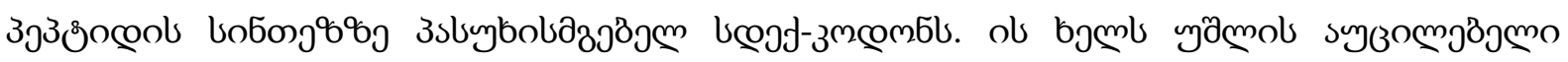

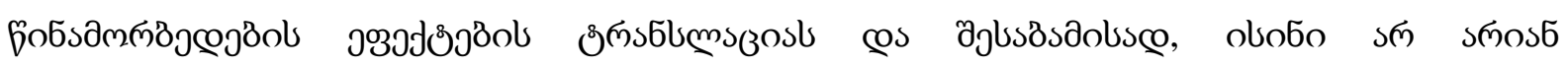

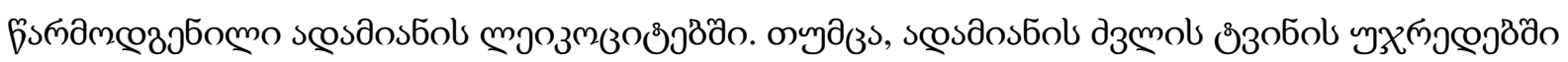

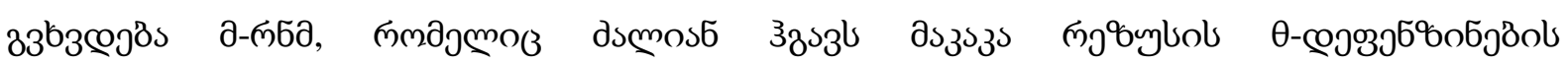

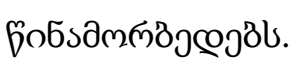

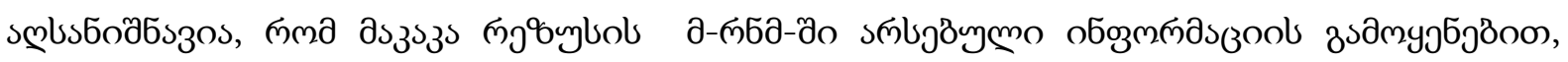

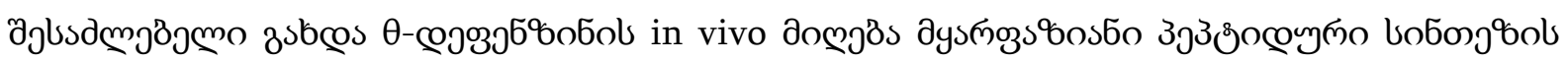

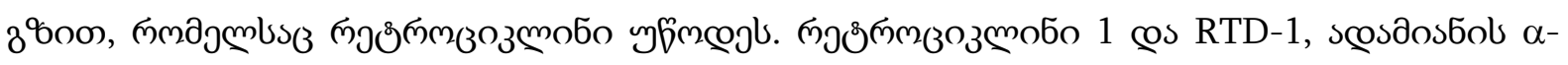

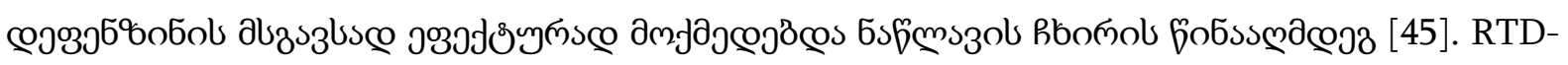

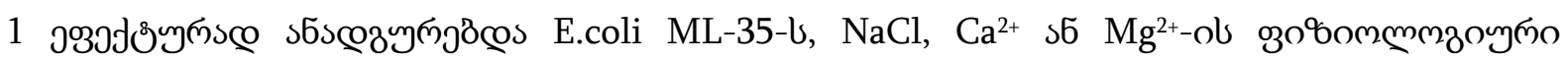

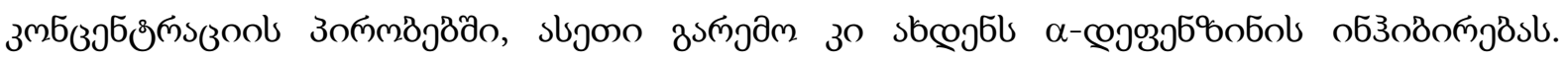

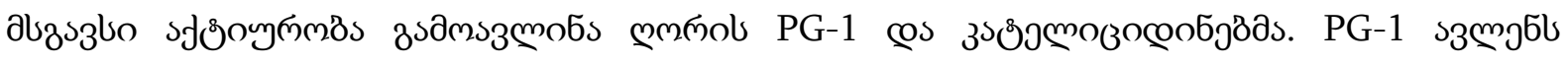

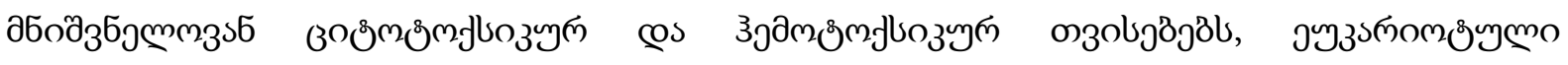

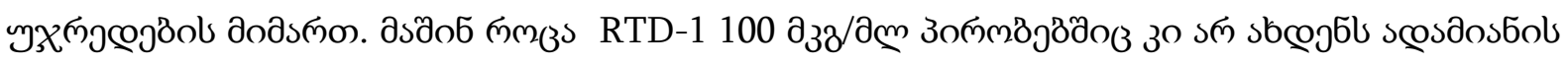

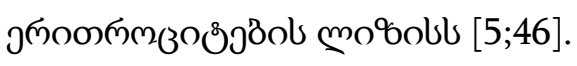

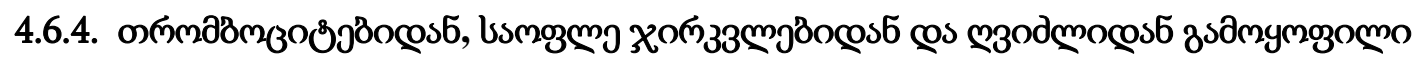

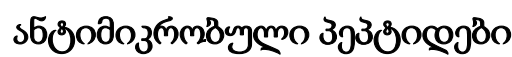

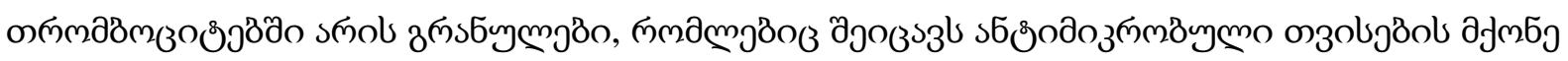

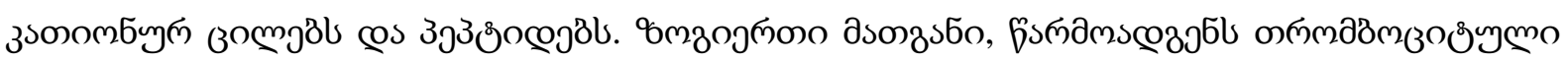

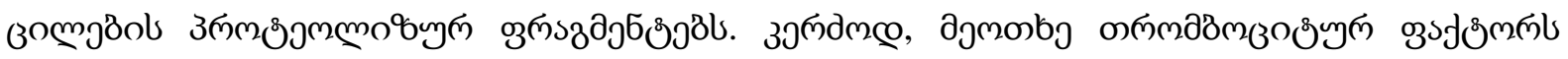
$[49 ; 50]$.

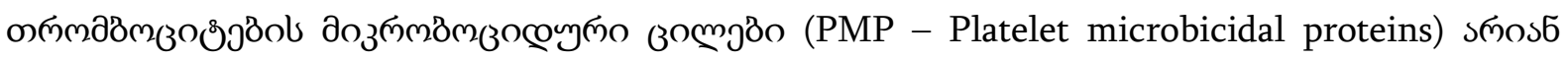

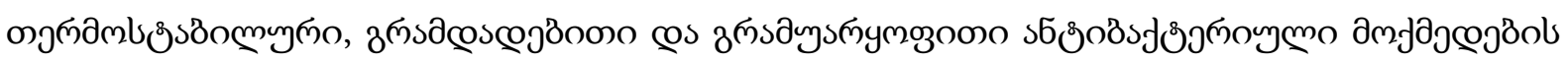

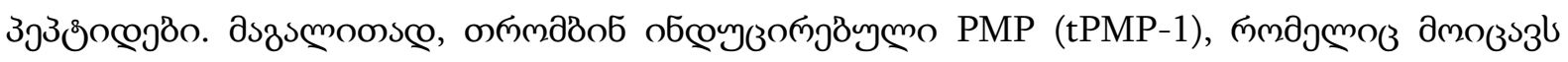

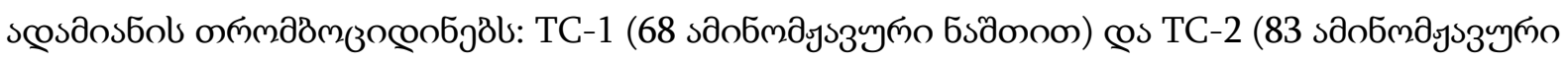

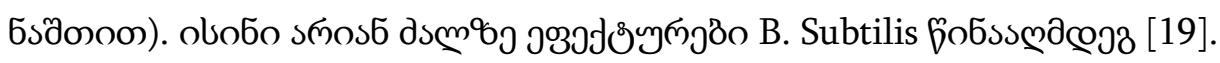

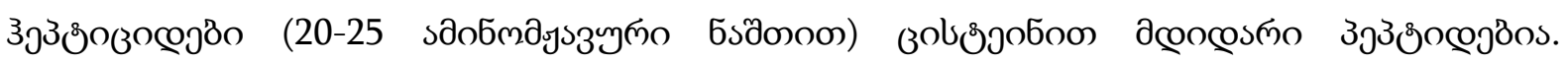

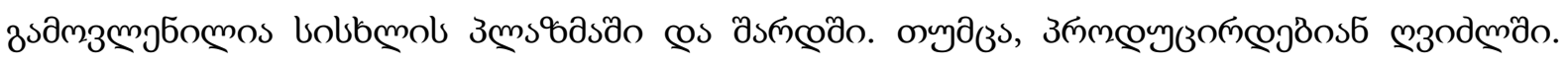

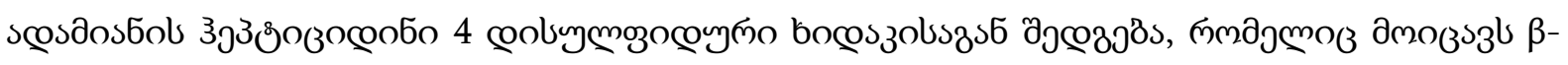

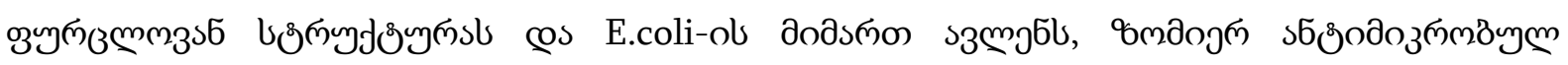

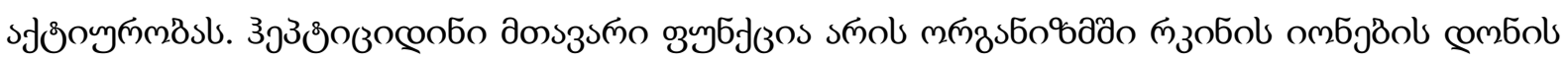

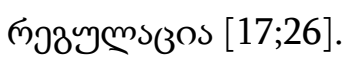

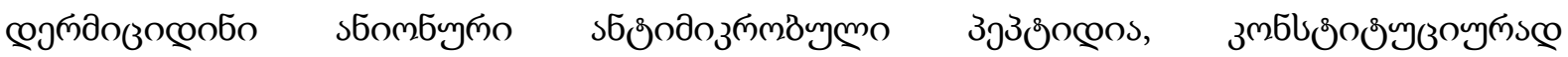

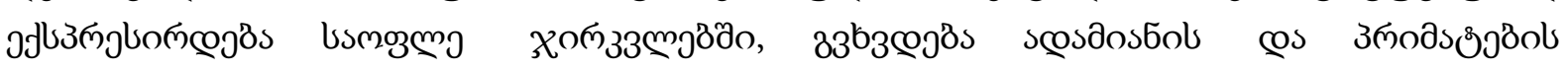

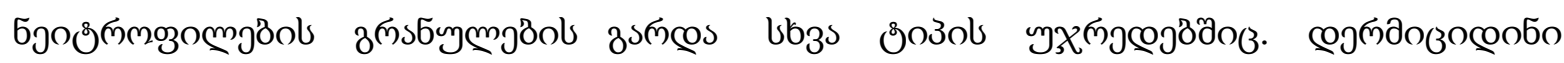




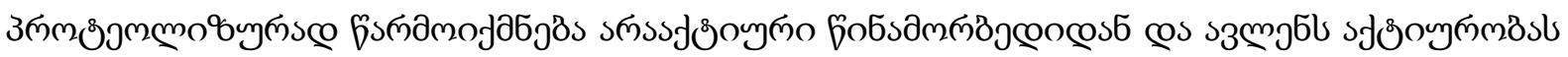

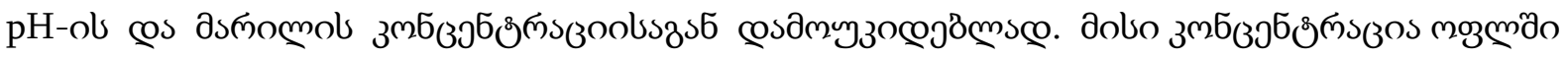

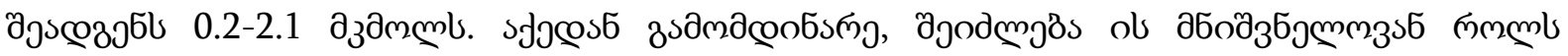

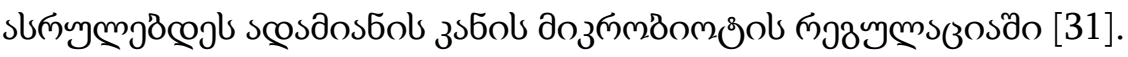

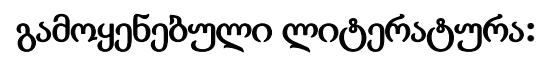

1. Agerberth, B. FALL-39, a putative human peptide antibiotic, is cysteine-free and expressed in bone marrow and testis / B. Agerberth, H. Gunne, J. Odeberg, [et al.] // Proc. Natl. Acad. Sci. U.S.A. - 1995. - Vol. 92. - P. 195-199.

2. Ayabe, T. Secretion of microbicidal alpha-defensins by intestinal Paneth cells in response to bacteria / T. Ayabe, D.P. Satchell, C.L. Wilson, [et al.] // Nat. Immunol. -2000. - Vol. 1. - P. 113-118.

3. Bruhn, O. Antimicrobial properties of the equine alpha-defensin DEFA1 against bacterial horse pathogens / O. Bruhn, J. Cauchard, M. Schlusselhuber, [et al.] // Vet. Immunol. Immunopathol. - 2009. - Vol. 130. - P. 102-106.

4. Condon, M.R. Induction of a rat enteric defensin gene by hemorrhagic shock / M.R. Condon, A. Viera, M. D’Alessio, G. Diamond // Infect. Immun. - 1999. - Vol. 67. - P. 4787-4793.

5. Cole, A.M. Retrocyclins: using past as prologue / A.M. Cole, W. Wang, A.J. Waring, R.I. Lehrer // Curr Protein Pept Sci. - 2004. - Vol. 5(5). - P. 373-381.

6. Diamond, G. Tracheal antimicrobial peptide, a cysteine-rich peptide from mammalian tracheal mucosa: peptide isolation and cloning of a cDNA / G. Diamond, M. Zasloff, H. Eck, [et al.] // Proc. Natl. Acad. Sci. U. S. A. - 1991. - Vol. 88. - P. 3952-3956.

7. Duplantier, A.J. The human cathelicidin antimicrobial peptide LL-37 as a potential treatment for polymicrobial infected wounds / A.J. Duplantier, M.L. van Hoek // Front. Immunol. 2013. - Vol. 4. - P. 1-14.

8. Eisenhauer, P.B. Purification and antimicrobial properties of three defensins from rat neutrophils / P.B. Eisenhauer, S.S. Harwig, D. Szklarek, [et al.] // Infect Immun. - 1989. Vol. 57(7). - P. 2021-2027.

9. Faurschou, M. Prodefensins are matrix proteins of specific granules in human neutrophils / M. Faurschou, S. Kamp, J.B. Cowland, [et al.] // J Leukoc Biol. - 2005. - Vol. 78(3). - P. 785-793.

10. Garcia, A.E. Isolation, synthesis, and antimicrobial activities of naturally occurring thetadefensin isoforms from baboon leukocytes. / A.E. Garcia, G. Osapay, P.A. Tran, [et al.] // Infect Immun. - 2008. - Vol. 76(12). - P. 5883-5891.

11. García, J.R. Human beta-defensin 4: a novel inducible peptide with a specific salt-sensitive spectrum of antimicrobial activity / J.R. García, A. Krause, S. Schulz, [et al.] // FASEB J. 2001. - Vol. 15. - P. 1819-1821.

12. Gennaro, R. Purification, composition, and activity of two bactenecins, antibacterial peptides of bovine neutrophils / R. Gennaro, B. Skerlavaj, D. Romeo // Infect. Immun. - 1989. Vol.57, N 10. - P.3142-3146.

13. Harder, J. A peptide antibiotic from human skin / J. Harder, J. Bartels, E. Christophers, J.-M. Schröder // Nature. - 1997. - Vol. 387. - P. 861-861.

14. Harder, J. Isolation and characterization of human $\beta$-defensin-3, a novel human inducible peptide antibiotic / J. Harder, J. Bartels, E. Christophers, J.M. Schröder // J. Biol. Chem. 2001. -Vol. 276. - P. 5707-5713. 
15. Joly, S. Human $\beta$-defensins 2 and 3 demonstrate strain-selective activity against oral microorganisms / S. Joly, C. Maze, P.B. McCray, J.M. Guthmiller // J. Clin. Microbiol. 2004. - Vol. 42. - P. 1024-1029.

16. Agerberth, B. FALL-39, a putative human peptide antibiotic, is cysteine-free and expressed in bone marrow and testis / B. Agerberth, H. Gunne, J. Odeberg, [et al.] // Proc. Natl. Acad. Sci. U.S.A. - 1995. - Vol. 92. - P. 195-199.

17. Ayabe, T. Secretion of microbicidal alpha-defensins by intestinal Paneth cells in response to bacteria / T. Ayabe, D.P. Satchell, C.L. Wilson, [et al.] // Nat. Immunol. - 2000. - Vol. 1. - P. 113-118.

18. Bruhn, O. Antimicrobial properties of the equine alpha-defensin DEFA1 against bacterial horse pathogens / O. Bruhn, J. Cauchard, M. Schlusselhuber, [et al.] // Vet. Immunol. Immunopathol. - 2009. - Vol. 130. - P. 102-106.

19. Condon, M.R. Induction of a rat enteric defensin gene by hemorrhagic shock / M.R. Condon, A. Viera, M. D’Alessio, G. Diamond // Infect. Immun. - 1999. - Vol. 67. - P. 4787-4793.

20. Cole, A.M. Retrocyclins: using past as prologue / A.M. Cole, W. Wang, A.J. Waring, R.I. Lehrer // Curr Protein Pept Sci. - 2004. - Vol. 5(5). - P. 373-381.

21. Diamond, G. Tracheal antimicrobial peptide, a cysteine-rich peptide from mammalian tracheal mucosa: peptide isolation and cloning of a cDNA / G. Diamond, M. Zasloff, H. Eck, [et al.] // Proc. Natl. Acad. Sci. U. S. A. - 1991. - Vol. 88. - P. 3952-3956.

22. Duplantier, A.J. The human cathelicidin antimicrobial peptide LL-37 as a potential treatment for polymicrobial infected wounds / A.J. Duplantier, M.L. van Hoek // Front. Immunol. 2013. - Vol. 4. - P. 1-14.

23. Eisenhauer, P.B. Purification and antimicrobial properties of three defensins from rat neutrophils / P.B. Eisenhauer, S.S. Harwig, D. Szklarek, [et al.] // Infect Immun. - 1989. Vol. 57(7). - P. 2021-2027.

24. Faurschou, M. Prodefensins are matrix proteins of specific granules in human neutrophils / M. Faurschou, S. Kamp, J.B. Cowland, [et al.] // J Leukoc Biol. - 2005. - Vol. 78(3). - P. 785-793.

25. Garcia, A.E. Isolation, synthesis, and antimicrobial activities of naturally occurring thetadefensin isoforms from baboon leukocytes. / A.E. Garcia, G. Osapay, P.A. Tran, [et al.] // Infect Immun. - 2008. - Vol. 76(12). - P. 5883-5891.

26. García, J.R. Human beta-defensin 4: a novel inducible peptide with a specific salt-sensitive spectrum of antimicrobial activity / J.R. García, A. Krause, S. Schulz, [et al.] // FASEB J. 2001. - Vol. 15. - P. 1819-1821.

27. Gennaro, R. Purification, composition, and activity of two bactenecins, antibacterial peptides of bovine neutrophils / R. Gennaro, B. Skerlavaj, D. Romeo // Infect. Immun. - 1989. Vol.57, N 10. - P.3142-3146.

28. Harder, J. A peptide antibiotic from human skin / J. Harder, J. Bartels, E. Christophers, J.-M. Schröder // Nature. - 1997. - Vol. 387. - P. 861-861.

29. Harder, J. Isolation and characterization of human $\beta$-defensin-3, a novel human inducible peptide antibiotic / J. Harder, J. Bartels, E. Christophers, J.M. Schröder // J. Biol. Chem. 2001. -Vol. 276. - P. 5707-5713.

30. Joly, S. Human $\beta$-defensins 2 and 3demonstrate strain-selectiveactivity against oral microorganisms / S. Joly, C. Maze, P.B. McCray, J.M. Guthmiller // J. Clin. Microbiol. 2004. - Vol. 42. - P. 1024-1029.

31. Kaiser, V. Expression of mammalian defensin genes / V. Kaiser, G. Diamond // J. Leukoc. Biol. - 2000. - Vol. 68. - P. 779-784. 
32. Knutson, M.D. Iron release from macrophages after erythrophagocytosis is up-regulated by ferroportin 1 overexpression and down-regulated by hepcidin / M.D. Knutson, M. Oukka, L.M. Koss, [et al.]// Proc. Natl. Acad. Sci. U. S. A. - 2005. - Vol. 102. - P. 1324-1328.

33. Kosciuczuk, E.M. Cathelicidins: family of antimicrobial peptides. A review, / E.M. Kosciuczuk, P. Lisowski, J. Jarczak, N. [et al.] // Mol. Biol. Rep. - 2012. - Vol. 39(12). - P. 10957-10970.

34. Krijgsveld, J. Thrombocidins, microbicidal proteins from human blood platelets, are Cterminal deletion products of CXC chemokines / J. Krijgsveld, S.A Zaat, J. Meeldijk, [et al.] // J. Biol. Chem. - 2000. - Vol. 275. - P. 20374-20381.

35. Lehrer, R.I. Defensins: antimicrobial and cytotoxic peptides of mammalian cells / R.I. Lehrer, A.K. Lichtenstein, T. Ganz // Annu. Rev. Immunol. - 1993. - Vol. 11. - P. 105-128.

36. Lehrer, R.I. $\alpha$-Defensins in human innate immunity / R.I. Lehrer, W. Lu // Immunol. Rev. 2012. - Vol. 245. - P. 84-112.

37. Lehrer, R.I. $\theta$-Defensins: cyclic peptides with endless potential. / R.I. Lehrer, A.M. Cole, M.E. Selsted // J Biol Chem. - 2012b. - Vol. 287(32). - P. 27014-27019

38. Mak, P. Isolation, antimicrobial activities, and primary structures of hamster neutrophil defensins / P. Mak, K. Wójcik, I.B. Thogersen, A. Dubin // Infect. Immun. - 1996. - Vol. 64. - P. 4444-4449.

39. Ouellette, A.J. Mouse Paneth cell defensins: Primary structures and antibacterial activities of numerous cryptdin isoforms / A.J. Ouellette, M.M. Hsieh, M.T. Nosek, [et al.] // Infect. Immun. - 1994. - Vol. 62. P. - 5040-5047.

40. Overhage, J. Human host defense peptide LL-37 prevents bacterial biofilm formation / J. Overhage, A. Campisano, M. Bains, [et al.] // Infect. Immun. - 2008. - Vol. 76. - P. 41764182.

41. Park, S. Structural study of novel antimicrobial peptides, nigrocins, isolated from Rana nigromaculata / S. Park, S.H. Park, H.C. Ahn, [et al.] // FEBS Lett. - 2001. - Vol. 507. - P. 95-100.

42. Patil, A.A. Cross-species analysis of the mammalian beta-defensin gene family: presence of syntenic gene clusters and preferential expression in the male reproductive tract / A.A Patil, Y. Cai, Y. Sang, [et al.]// Physiol. Genomics. - 2005. - Vol. 23. - P. 5-17.

43. Paulsen, F.P. Detection of natural peptide antibiotics in human nasolacrimal ducts / F.P. Paulsen, T. Pufe, U. Schaudig, [et al.] // Invest Ophthalmol Vis Sci. - 2001. - Vol. 42(10). P. 2157-2163.

44. Pazgier, M. Human $\beta$-defensins / M. Pazgier, D.M. Hoover, D. Yang, [et al.]// Cell. Mol. Life Sci. - 2006. - Vol. 63. - P. 1294-1313.

45. Romeo, D. Structure and bactericidal activity of an antibiotic dodecapeptide purified from bovine neutrophils / D. Romeo, B. Skerlavaj, M. Bolognesi, R. Gennaro // J. Biol. Chem. 1988. - Vol. 263. - P. 9573-9575.

46. Schittek, B. The multiple facets of dermcidin in cell survival and host defense / B. Schittek // J. Innate Immun. -2012. - Vol. 4. - P. 349-360.

47. Schroder, B.O. Reduction of disulphide bonds unmasks potent antimicrobial activity of human $\beta$-defensin 1 / B.O. Schröder, Z. Wu, S. Nuding, [et al.] // Nature. - 2011. - Vol. 469. - P. 419-423.

48. Schneider, J.J. Human defensins / J.J. Schneider, A. Unholzer, M. Schaller, [et al.] // J. Mol. Med. - 2005. - Vol. 83. - P. 587-595.

49. Selsted, M.E. Indolicidin, / M.E. Selsted, M.J. Novotny, W.L. Morris, [et al.] // a novel bactericidal tridecapeptide amide from neutrophils. J. Biol. Chem. - 1992. - Vol. 267. - P. 4292-4295. 
50. Selsted, M.E. Primary structures of six antimicrobial peptides of rabbit peritoneal neutrophils / M.E. Selsted, D.M. Brown, R.J. De Lange [et al.] // J. Biol. Chem. - 1985. - Vol.260. P.4579-4584.

51. Selsted, M.E. Purification, primary structure and antimicrobial activities of a guinea pig neutrophil defensin / M.E. Selsted, S.S. Harwig // Infect. Immun. - 1987. - Vol.55, N 9. - P. 2281-2286.

52. Selsted, M.E. Primary structures of three human neutrophil defensins / M.E. Selsted, S.S. Harwig, T. Ganz [et al.] // J. Clin. Invest. - 1985a. - Vol.76. - P.1436-1439.

53. Semple, C.A. Duplication and selection in the evolution of primate beta-defensin genes / C.A. Semple, M. Rolfe, J.R. Dorin // Genome Biol. - 2003. - Vol. 4. - R31. doi:10.1186/gb-20034-5- r31.

54. Shamova, O.V. Minibactenecins ChBac7.N $\alpha$ and ChBac7. N $\beta$ - antimicrobial peptides from leukocytes of the goat Capra hircus / O.V. Shamova, D.S. Orlov, M.S. Zharkova, [et al.] // Acta Naturae. - 2016. - Vol. 8(3). - P. 136-146.

55. Shamova, O.V. Purification and properties of proline-rich antimicrobial peptides from sheep and goat leukocytes / O.V. Shamova, K.A. Brogden, C. Zhao [et al.] // Infection and Immunity. - 1999. - Vol. 67, № 8. - P. 4106-4111.

56. Shi, J. Identification of a proline-arginine-rich antibacterial peptide from neutrophils that is analogous to PR-39, an antibacterial peptide from the small intestine / J. Shi, C.R. Ross, M.M. Chengappa, F. Blecha // J. Leukoc. Biol. - 1994. - Vol. 56(6). - P. 807-811.

57. Steinberg, D.A. Protegrin-1: A broad-spectrum, rapidly microbicidal peptide with in vivo activity / D.A. Steinberg, M.A. Hurst, C.A. Fujii, [et al.] // Antimicrob. Agents Chemother. 1997. - Vol. 41. - P. 1738-1742.

58. Tanabe, H. Paneth cell alpha-defensins from rhesus macaque small intestine / H. Tanabe, J. Yuan, M.M. Zaragoza, [et al.] // Infect. Immun. - 2004. - Vol. 72. - P. 1470-1478.

59. Tang, Y.-Q. Isolation, characterization, cDNA cloning, and antimicrobial properties of two distinct subfamilies of $\alpha$-defensins from rhesus macaque leukocytes / Y.-Q. Tang, J. Yuan, C.J. Miller, M.E. Selsted // Infect. Immun. - 1999a. - Vol. 67. - P. 6139-6144.

60. Tongaonkar, P. Rhesus macaque $\theta$-defensin isoforms: expression, antimicrobial activities, and demonstration of a prominent role in neutrophil granule microbicidal activities. / P. Tongaonkar, P. Tran, K. Roberts, [et al.] // J Leukoc Biol. - 2011. - Vol. 89(2). - P. 283-290.

61. Tran, D. Microbicidal properties and cytocidal selectivity of rhesus macaque theta defensins. / D. Tran, P. Tran, K. Roberts, [et al.] // Antimicrob Agents Chemother. - 2008. - Vol. 52(3). P. 944-953.

62. Valore, E.V. Posttranslational processing of defensins in immature human myeloid cells / E.V. Valore, T. Ganz //Blood. - 1992. - Vol. 79. P. 1538-1544.

63. Zhao, C. Widespread expression of beta-defensin hBD-1 in human secretory glands and epithelial cells //C. Zhao, I. Wang, R.I. Lehrer // FEBS Lett. - 1996. - Vol. 396. - P. 319-322.

64. Yeaman, M.R. Platelets in defense against bacterial pathogens / Michael R. Yeaman // Cell. Mol. Life Sci. - 2010. - Vol. 67. - P. 525-544.

65. Yeaman, M.R. Purification and in vitro activities of rabbit platelet microbicidal proteins / M.R. Yeaman, Y.I.Q. Tang, A.J. Shen [et al.] //Infect. Immun.- 1997.-Vol.65.-P.10231031. 


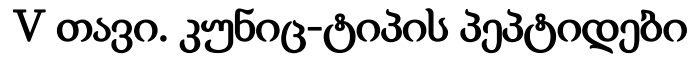

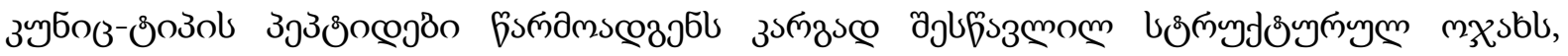

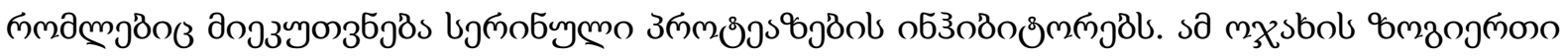

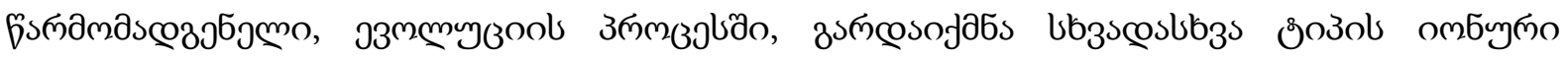

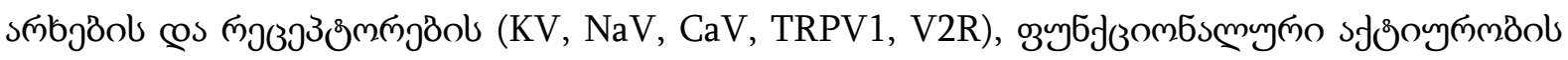

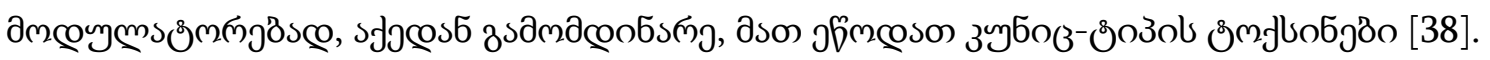

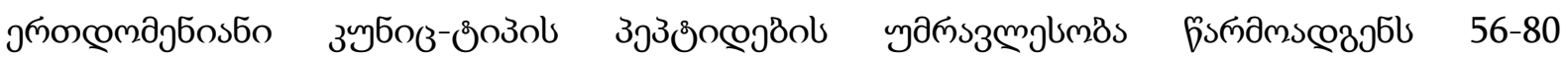

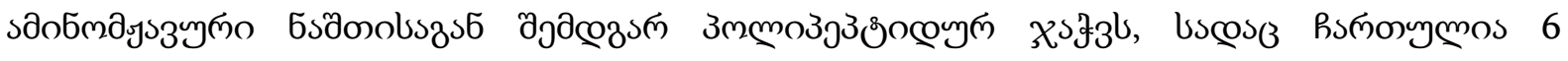

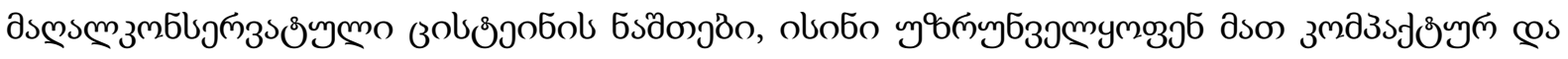

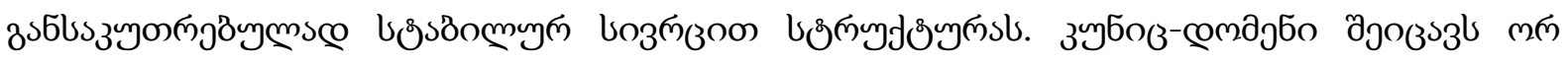

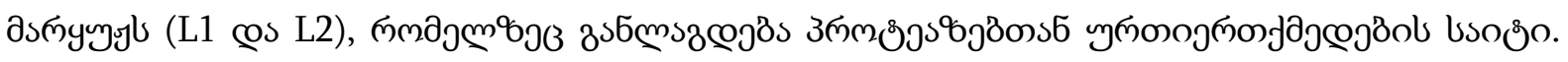

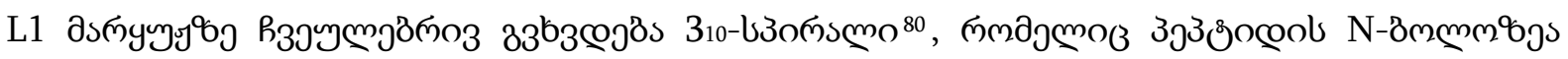

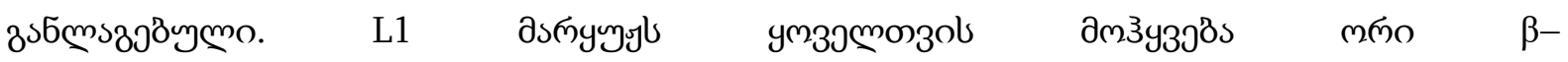

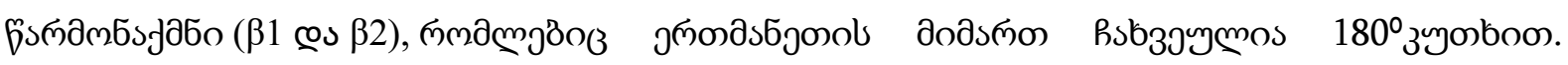

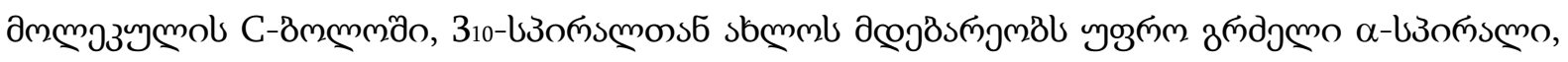

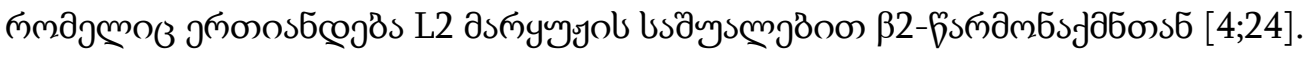

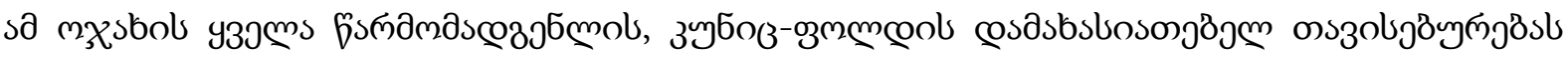

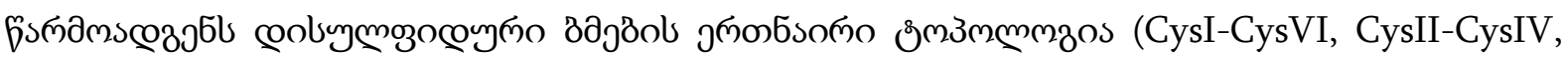

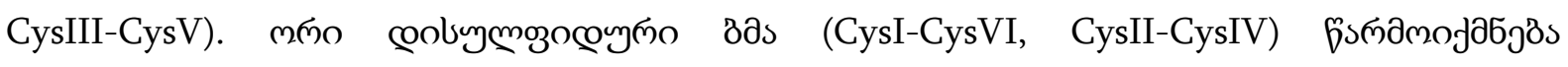

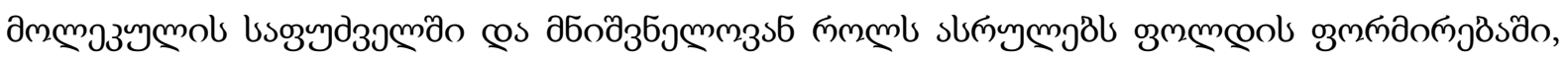

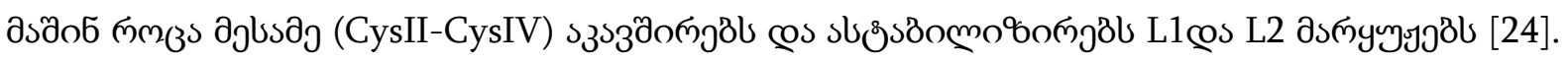

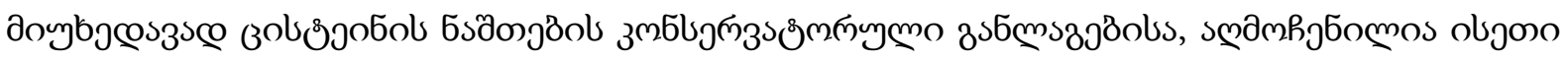

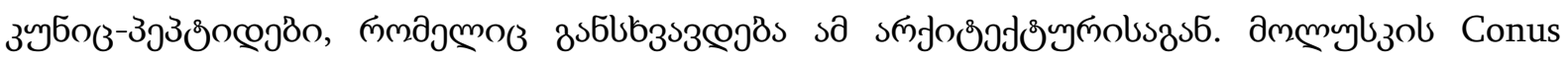

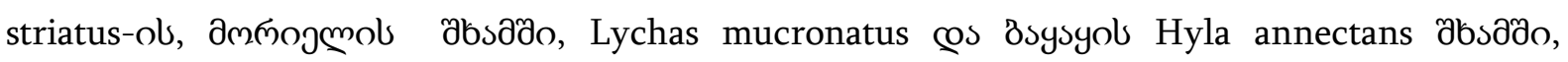

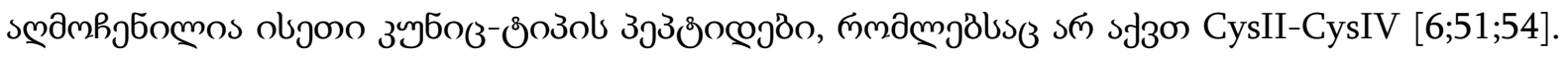

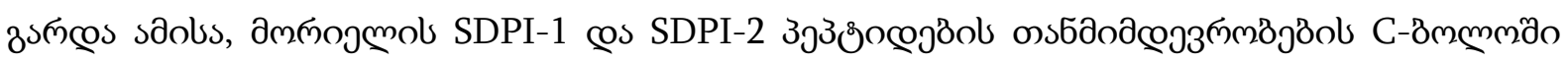

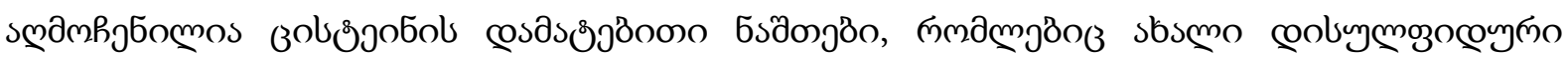

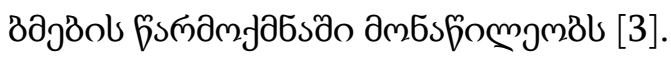

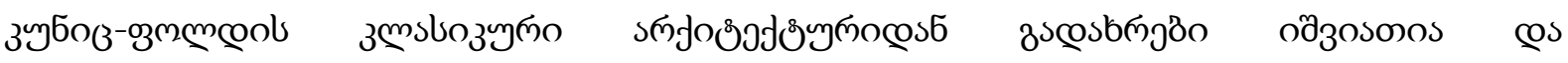

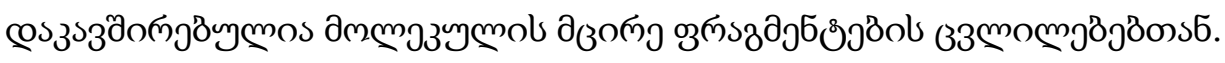

๓ృб

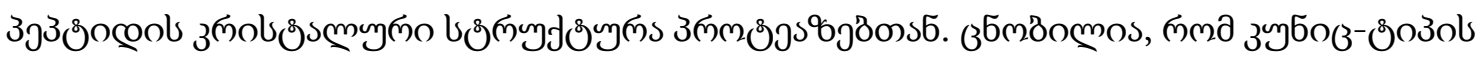

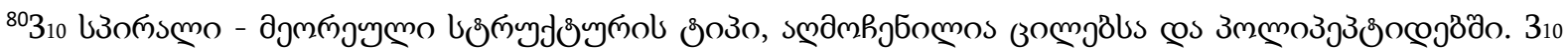

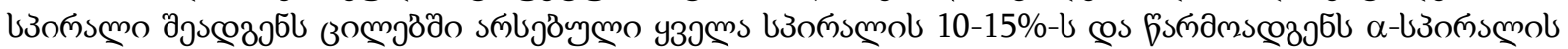

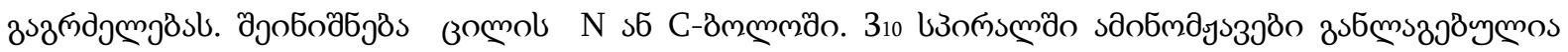

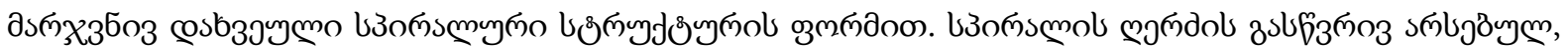

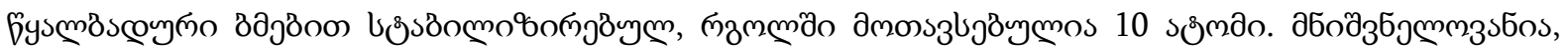

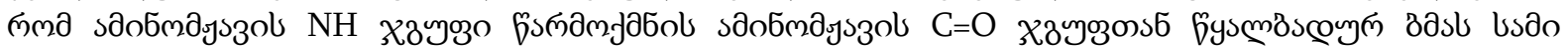
5sð̄onom sẹmg.
} 


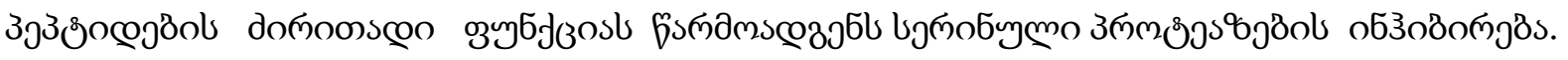

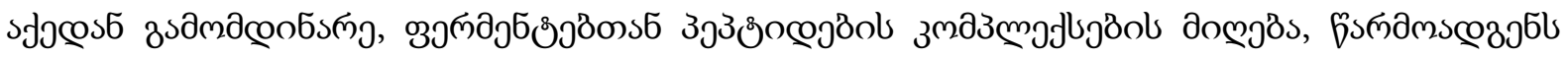

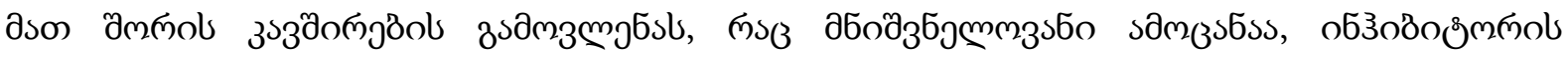

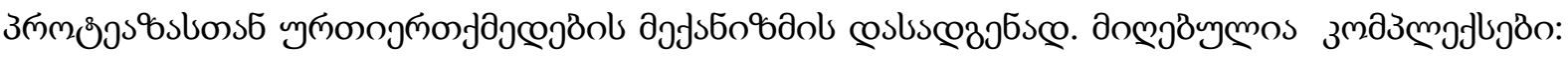

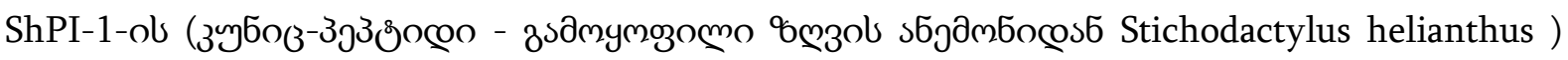

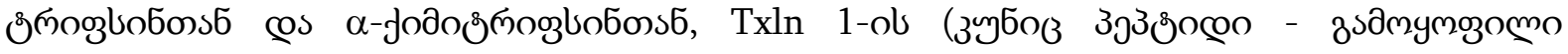

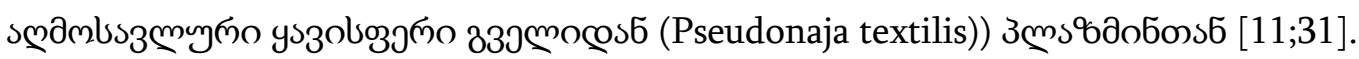

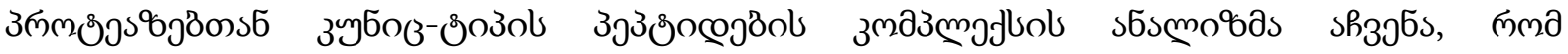

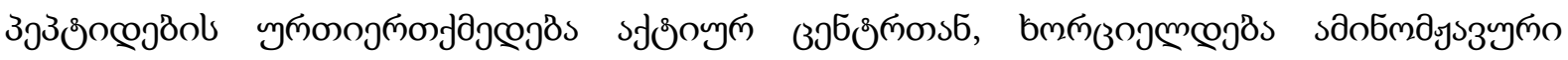

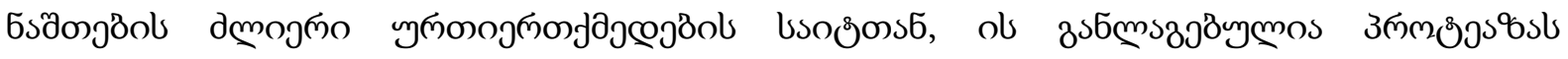

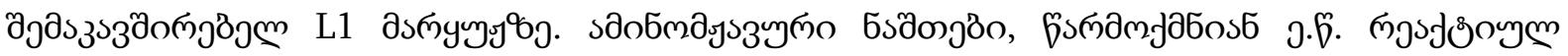

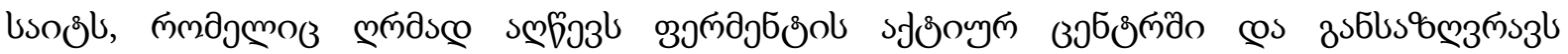

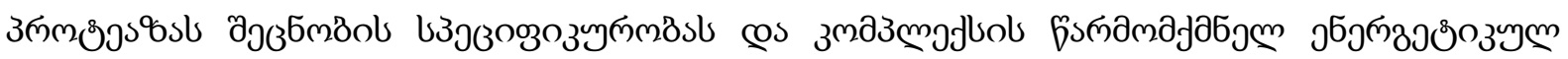

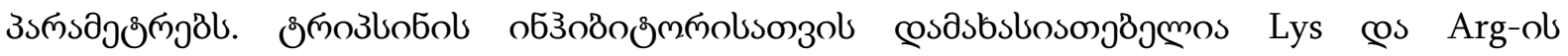

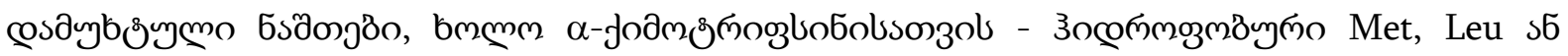

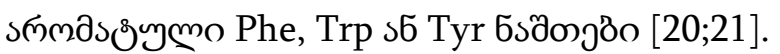

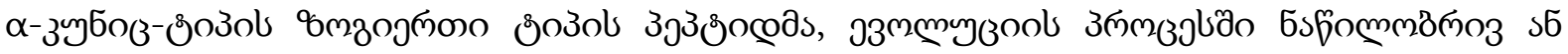

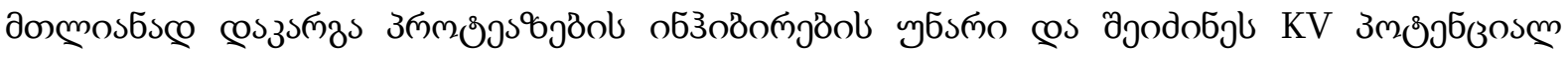

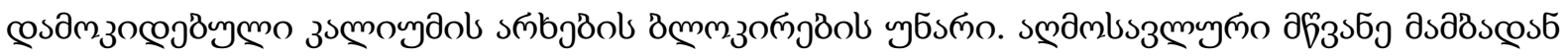

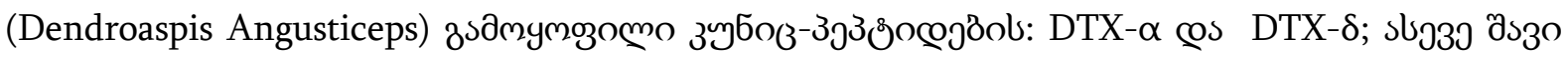

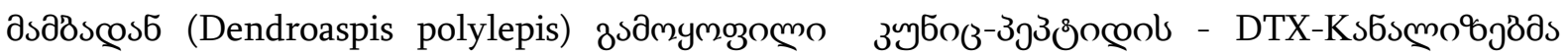

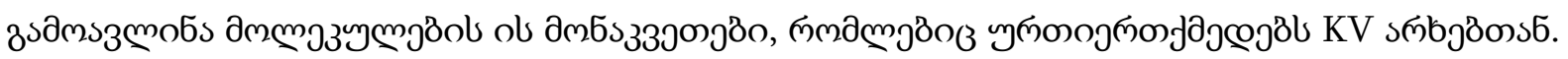

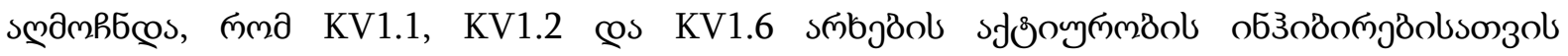

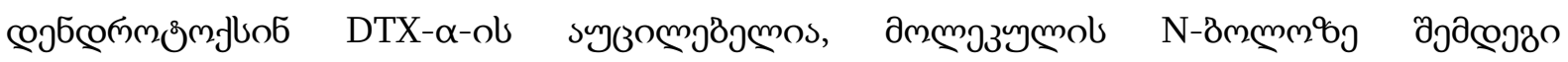

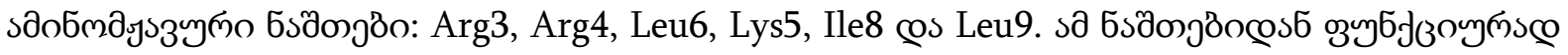

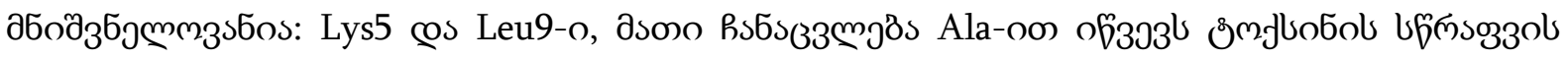

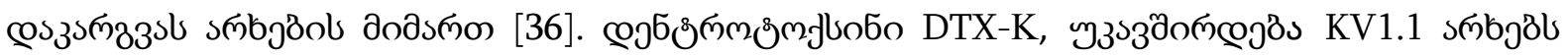

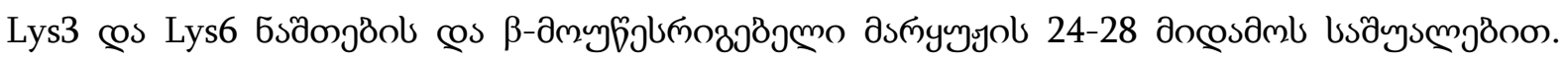

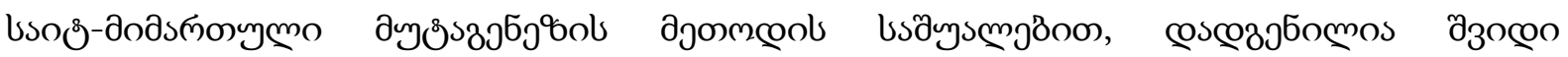

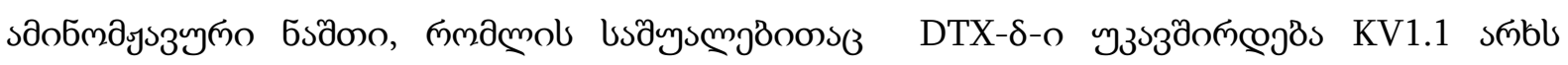
$[17 ; 42 ; 47]$.

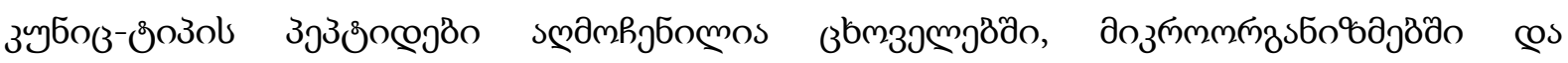

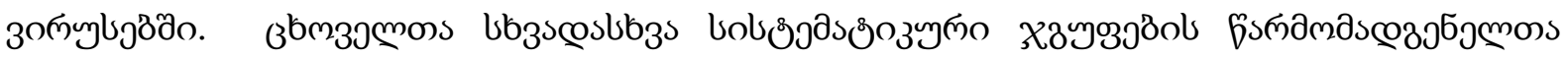

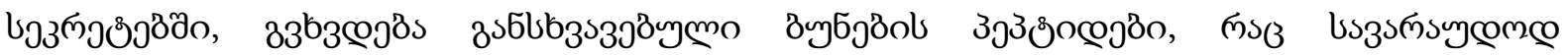

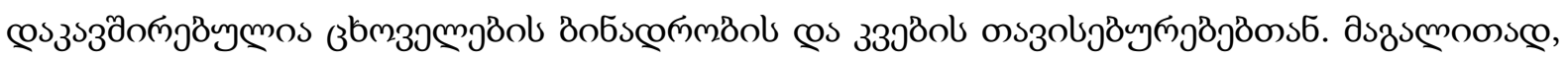

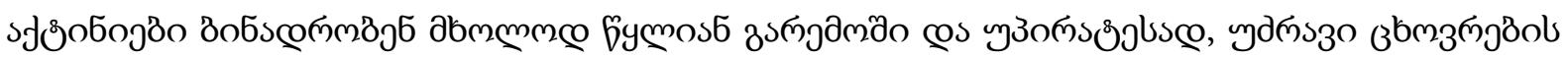

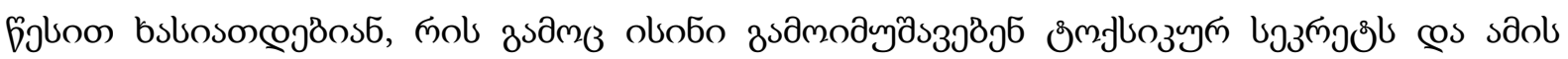

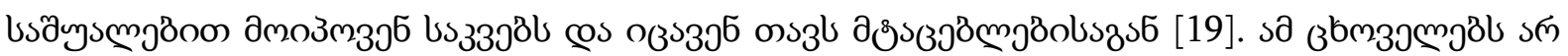

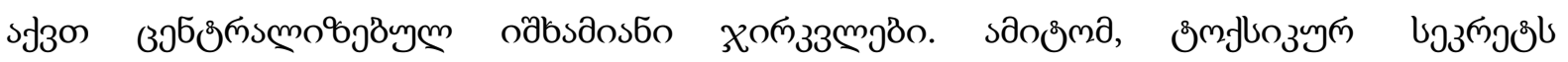




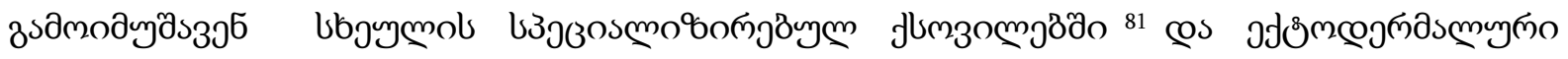

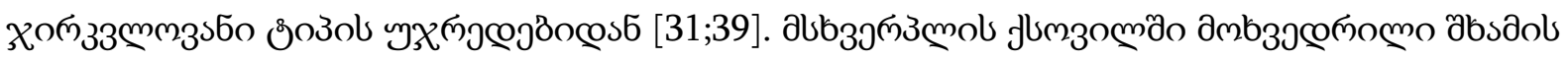

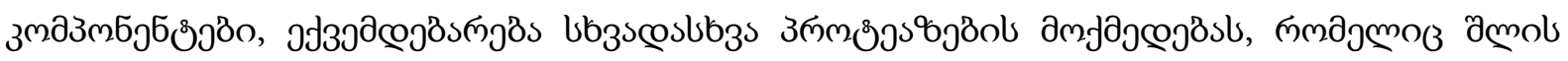

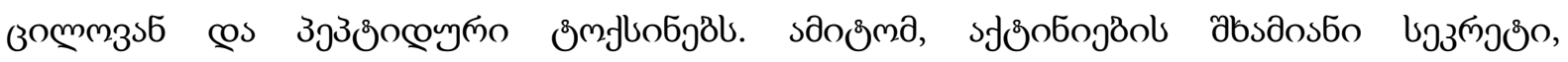

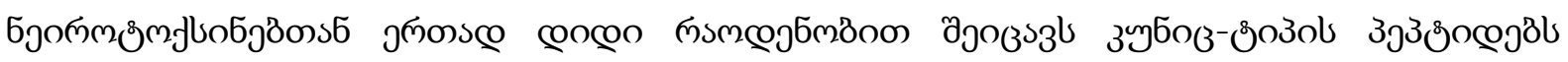
$[5 ; 16 ; 18 ; 28]$.

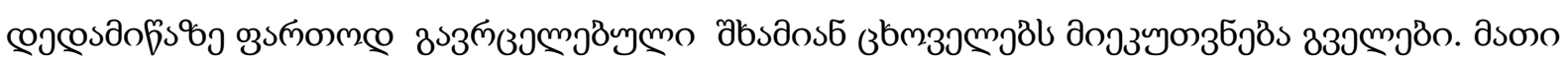

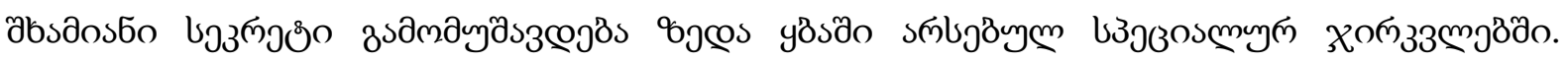

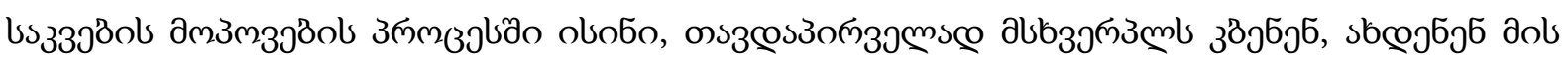

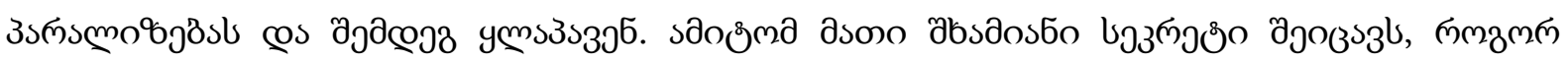

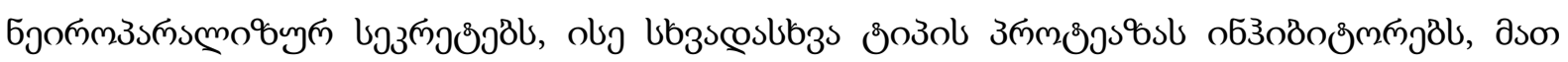

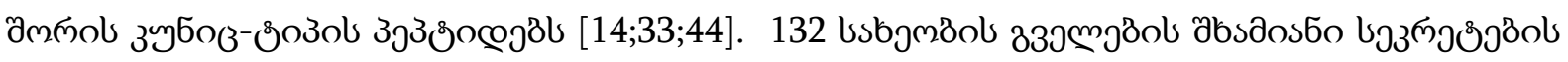

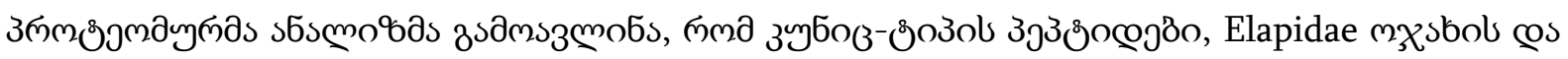

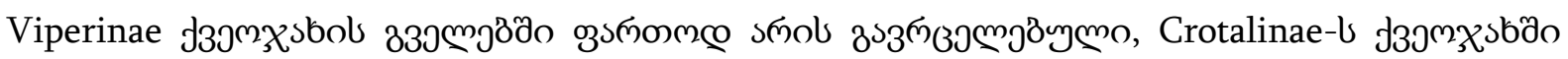

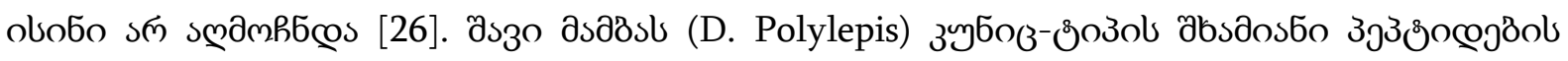

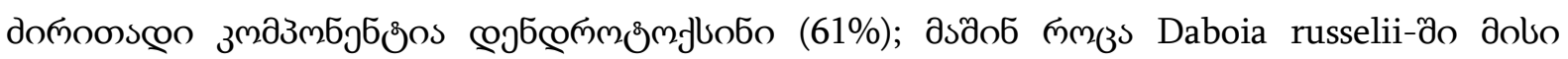
бృ

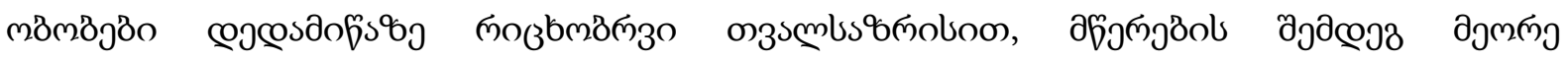

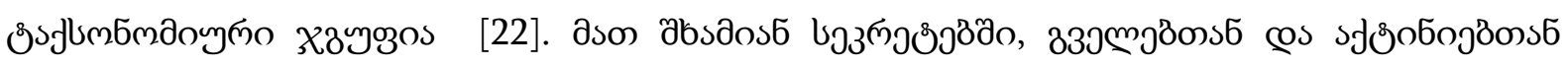

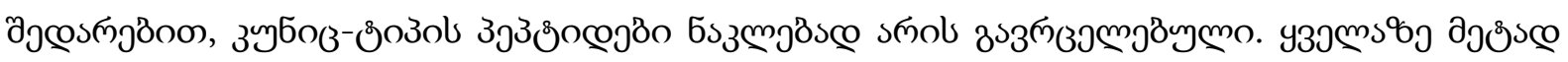

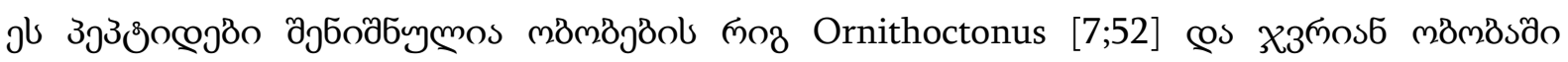

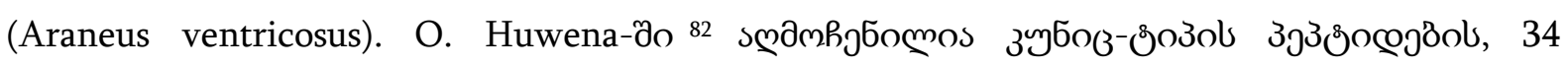

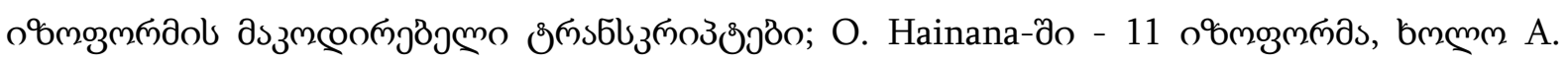

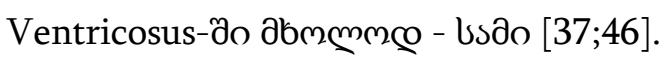

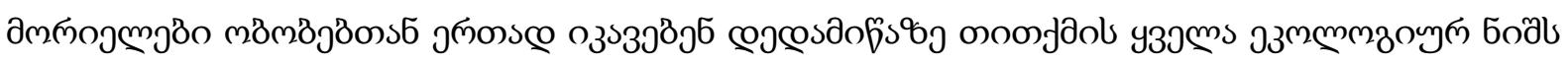

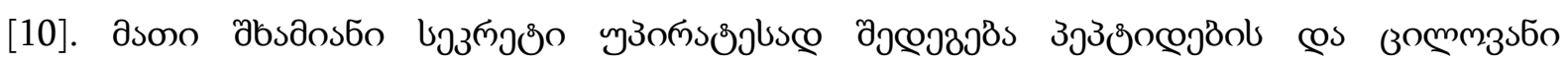

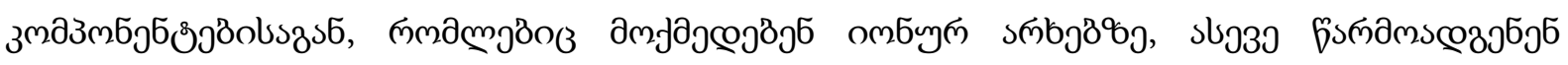

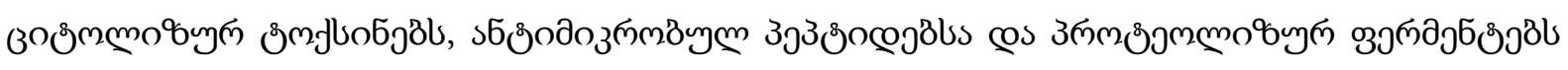

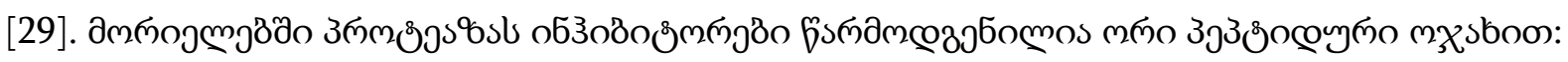

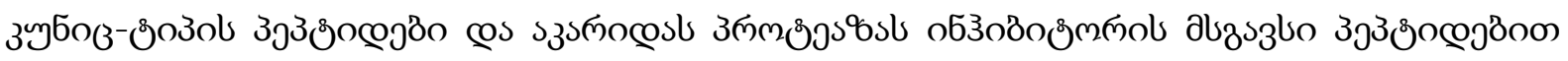

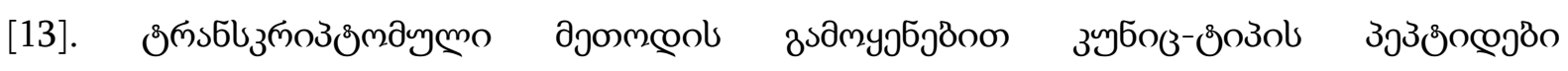

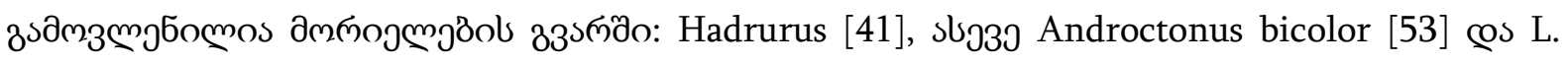
Mucronatus-ðొo [40].

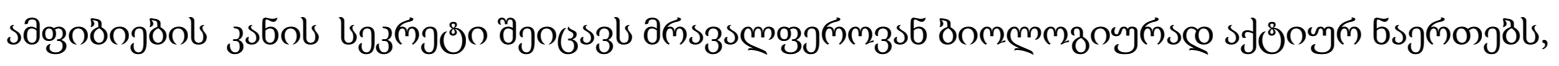

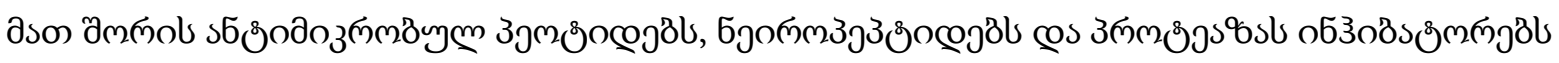

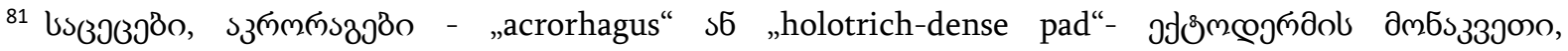

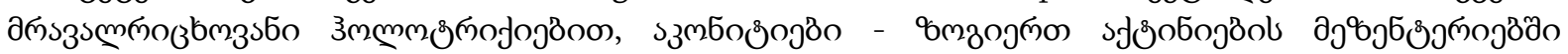

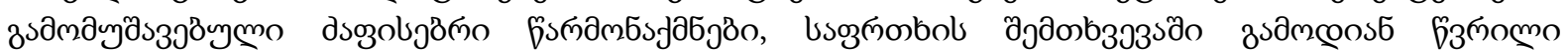

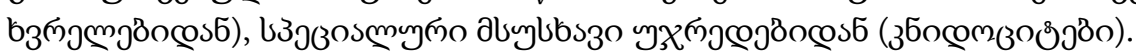

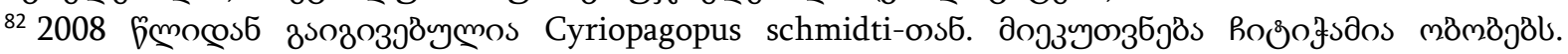

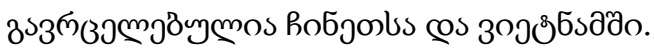




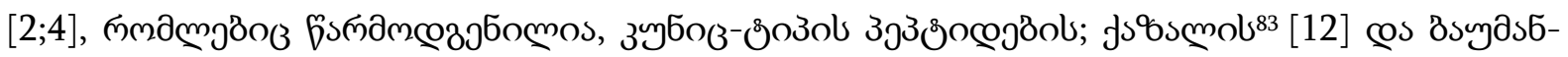

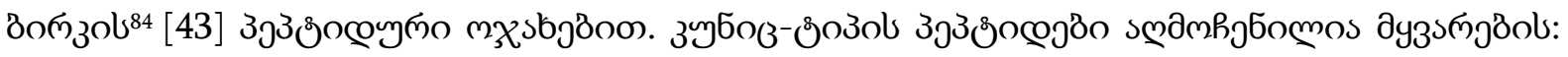
Dyscophus guineti; Hyla annectans (s6sఠిmfluo6o, AnnTx) [51], Hyla simplex (AnnTx-S2-AnnTxS6) [49], Kassina senegalensis (KSCI) [48] œs Dryophytes arenicolor (১๓ুб6o6o, ArTx) зsбob

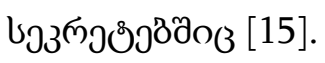

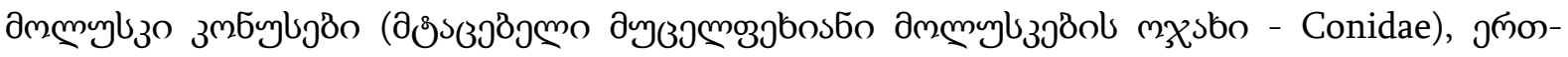

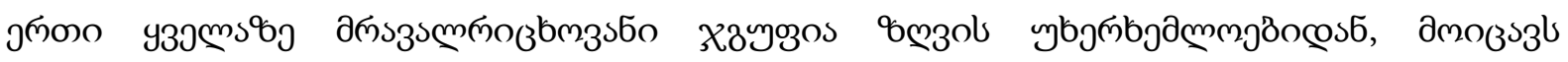

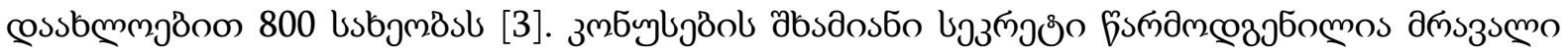

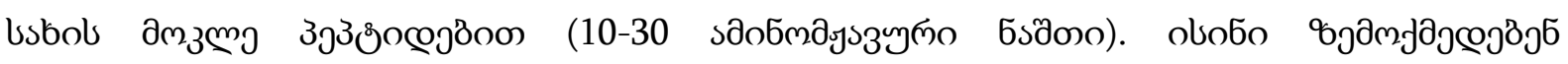

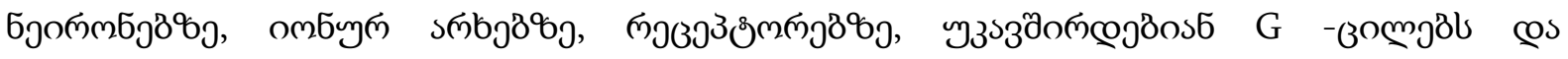

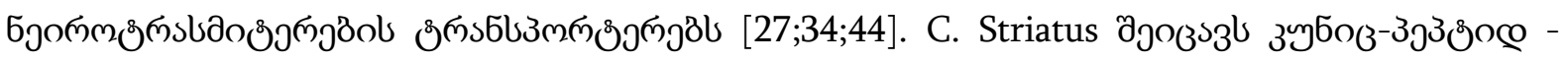

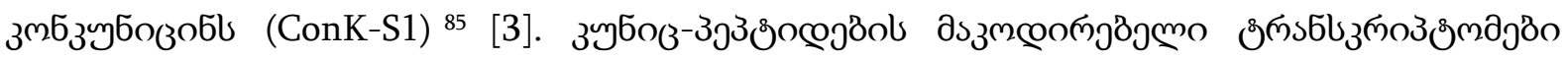

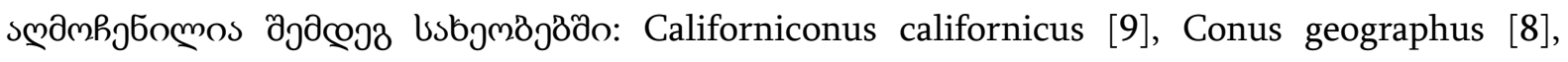
Conus bullatus [23], Conus betulinus [36], Conus ermineus [1] @s Conus magus [35].

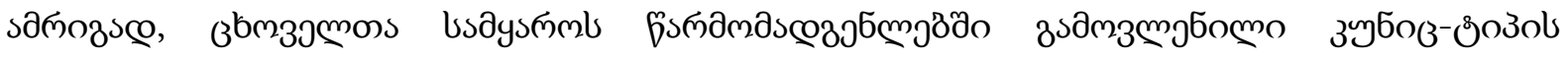

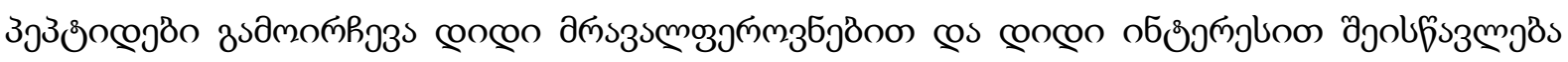

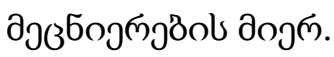

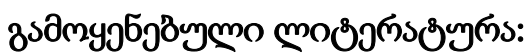

1. Abalde S. et al. Conotoxin diversity in Chelyconus ermineus (Born, 1778) and the convergent origin of piscivory in the atlantic and indo-pacific cones // Genome Biol. Evol. 2018. V. 10, No 10. P. 2643-2662.

2. Ali M.F. et al. Antimicrobial peptides and protease inhibitors in the skin secretions of the crawfish frog, Rana areolata // Biochim. Biophys. Acta. 2002. V. 1601. P. 55-63.

3. Bayrhuber M. et al. Conkunitzin-S1 is the first member of a new Kunitz-type neurotoxin family: Structural and functional characterization // J. Biol. Chem. 2005. V. 280, No 25. P. 23766-23770.

4. Bevins C.L., Zasloff M. Peptides from frog skin // Annu. Rev. Biochem. 1990. V. 59, No 1. P. 395-414.

5. Cassoli J.S. et al. The proteomic profile of Stichodactyla duerdeni secretion reveals the presence of a novel O-linked glycopeptide // J. Proteomics. 2013. V. 87. P. 89-102.

6. Chen Z. et al. Genomic and structural characterization of Kunitz-type peptide LmKTT-1a highlights diversity and evolution of scorpion potassium channel toxins // PLoS One. 2013. V. 8, No 4. P. e60201.

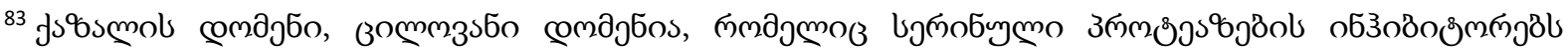

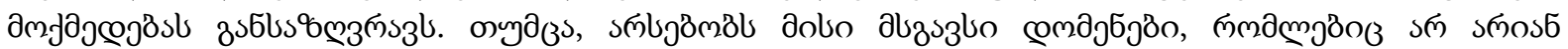

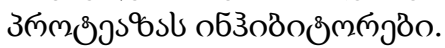

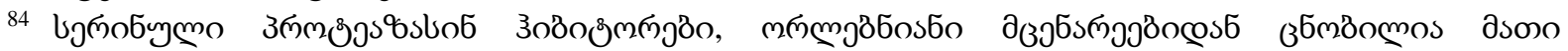

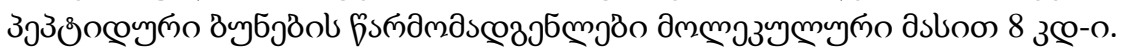

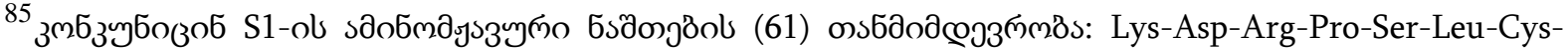
Asp-Ile-Leu-Pro-Arg-Asp-Ser-Gly-Ser-Gly-Thr-Lys-Ala-Glu-Lys-Arg-Ile-Tyr-Tyr-Asn-Ser-Ala-Arg-LysGln-Cys-Leu-Arg-Phe-Asp-Tyr-Thr-Gly-Gln-Gly-Gly-Asn-Glu-Asn-Asn-Phe-Arg-Arg-Thr-Tyr-Asp-CysGln-Arg-Thr-Cys-Leu-Tyr-Thr.
} 
7. Cheng T.C. et al. Identification and characterization of toxins in the venom gland of the Chinese bird spider, Haplopelma hainanum, by transcriptomic analysis // Insect Sci. 2016. V. 23, No 3. P. 487-499.

8. Dutertre S. et al. Evolution of separate predation-and defence-evoked venoms in carnivorous cone snails // Nat. Commun. 2014. V. 5. P. 3521.

9. Elliger C.A. et al. Diversity of conotoxin types from Conus californicus reflects a diversity of prey types and a novel evolutionary history // Toxicon. 2011. V. 57, No 2. P. 311-322.

10. Fet V. et al. Catalog of the scorpions of the world ( 1758-1998). The New York Entomological Society, 2000. 690 p.

11. Garcia-Fernandez R. et al. Structural insights into serine protease inhibition by a marine invertebrate BPTI Kunitz-type inhibitor // J. Struct. Biol. 2012. V. 180, No 2. P. 271-279.

12. Gebhard L.G. et al. A Kazal prolyl endopeptidase inhibitor isolated from the skin of Phyllomedusa sauvagii // Eur. J. Biochem. 2004. V. 271, No 11. P. 2117-2126.

13. Hakim M.A., Yang S. Discoveries of serine protease inhibitors from scorpions // J. Proteomics Bioinform. 2016. V. 9, No 4. P. 101-106.

14. Harvey A.L. Twenty years of dendrotoxins // Toxicon. 2001. V. 39, No 1. P. 15-26.

15. Hernández-Pérez J. et al. Identification of arenin, a novel kunitz-like polypeptide from the skin secretions of Dryophytes arenicolor // Int. J. Mol. Sci. 2018. V. 19, No 11. P. 3644.

16. Honma T. et al. Novel peptide toxins from the sea anemone Stichodactyla haddoni // Peptides. 2008. V. 29, No 4. P. 536-544.

17. Imredy J.P., MacKinnon R. Energetic and structural interactions between $\delta$-dendrotoxin and a voltage-gated potassium channel // J. Mol. Biol. 2000. V. 296, No 5. P. 1283-1294.

18. Isaeva M.P. et al. A new multigene superfamily of Kunitz-type protease inhibitors from sea anemone Heteractis crispa // Peptides. 2012. V. 34. P. 88-97.

19. Jouiaei M. et al. Ancient venom systems: A review on cnidaria toxins // Toxins (Basel). 2015. V. 7, No 6. P. 2251-2271.

20. Krowarsch D. et al. Canonical protein inhibitors of serine proteases // Cell. Mol. Life Sci. 2003. V. 60, No 11. P. 2427-2444.

21. Krowarsch D. et al. Structure-function relationships in serine protease - bovine pancreatic trypsin inhibitor interaction // Protein Pept. Lett. 2005. V. 12, No 5. P. 403-407.

22. Kuhn-Nentwig L., Stocklin R., Nentwig W. Venom composition and strategies in spiders. is everything possible? // Advances in Insect Physiology. 2011. V. 40. 1-86 p.

23. Kumar P.S., Kumar D.S., Umamaheswari S. A perspective on toxicology of Conus venom peptides // Asian Pac. J. Trop. Med. 2015. V. 8, No 5. P. 337-351.

24. Laskowski M. Protein Inhibitors // Nature. 1969. V. 223. P. 426-426.

25. Lauridsen L.P. et al. Toxicovenomics and antivenom profiling of the Eastern green mamba snake (Dendroaspis angusticeps) // J. Proteomics. 2016. V. 136. P. 248-261.

26. Laustsen A.H. et al. Unveiling the nature of black mamba (Dendroaspis polylepis) venom through venomics and antivenom immunoprofiling: Identification of key toxin targets for antivenom development // J. Proteomics. 2015. V. 119. P. 126-142.

27. Lewis R.J. et al. Conus venom peptide pharmacology//Pharmacol. Rev. 2012. V. 64, No 2. P. 259-298.

28. Madio B., King G.F., Undheim E.A.B. Sea anemone toxins: A structural overview // Mar. Drugs. 2019. V. 17, No 6. P. 325.

29. Ma Y. et al. Extreme diversity of scorpion venom peptides and proteins revealed by transcriptomic analysis: Implication for proteome evolution of scorpion venom arsenal // J. Proteomics. 2012. V. 75, No 5. P. 1563-1576. 
30. Millers E.K.I. et al. The structure of human microplasmin in complex with textilinin-1, an aprotinin-like inhibitor from the Australian brown snake//PLoS One. 2013. V. 8, No 1. P. e54104.

31. Moran Y. et al. Neurotoxin localization to ectodermal gland cells uncovers an alternative mechanism of venom delivery in sea anemones // Proc. R. Soc. B. 2012. V. 279, No 1732. P. 1351-1358.

32. Mukherjee A.K., Kalita B., Mackessy S.P. A proteomic analysis of Pakistan Daboia russelii russelii venom and assessment of potency of Indian polyvalent and monovalent antivenom // J. Proteomics. 2016. V. 144. P. 73-86.

33. Mukherjee A.K., Mackessy S.P., Dutta S. Characterization of a Kunitz-type protease inhibitor peptide (Rusvikunin) purified from Daboia russelii russelii venom // Int. J. Biol. Macromol. 2014. V. 67. P. 154-162.

34. Norton R.S., Olivera B.M. Conotoxins down under//Toxicon. 2006. V. 48, No 7. P. 780-798.

35. Pardos-Blas J.R. et al. Conotoxin diversity in the venom gland transcriptome of the magician's cone, Pionoconus magus // Mar. Drugs. 2019. V. 17, No 10. P. 553.

36. Peng C. et al. High-throughput identification of novel conotoxins from the Chinese tubular cone snail (Conus betulinus) by multi-transcriptome sequencing//Giga Sci. 2016. V. 5, No 1. P. 1-14.

37. Pineda S.S. et al. ArachnoServer 3.0: An online resource for automated discovery, analysis and annotation of spider toxins // Bioinformatics. 2018. V. 34, No 6. P. 1074-1076.

38. Ranasinghe S., McManus D.P. Structure and function of invertebrate Kunitz serine protease inhibitors // Dev. Comp. Immunol. 2013. V. 39, No 3. P. 219-227.

39. Reft A.J., Daly M. Morphology, distribution, and evolution of apical structure of nematocysts in hexacorallia // J. Morphol. 2012. V. 273, No 2. P. 121-136.

40. Ruiming Z. et al. Comparative venom gland transcriptome analysis of the scorpion Lychas mucronatus reveals intraspecific toxic gene diversity and new venomous components // BMC Genomics. 2010. V. 11, No 1. P. 452.

41. Schwartz E.F. et al. Transcriptome analysis of the venom gland of the Mexican scorpion Hadrurus gertschi (Arachnida: Scorpiones) // BMC Genomics. 2007. V. 8. P. 119.

42. Smith L.A. et al. Site-directed mutagenesis of dendrotoxin K reveals amino acids critical for its interaction with neuronal K+ channels // Biochemistry. 1997. V. 36, No 25. P. 7690-7696.

43. Song G. et al. HV-BBI-A novel amphibian skin Bowman-Birk-like trypsin inhibitor // Biochem. Biophys. Res. Commun. 2008. V. 372, No 1. P. 191-196.

44. Tasoulis T., Isbister G.K. A review and database of snake venom proteomes // Toxins (Basel). 2017. V. 9. P. 290.

45. Terlau H., Olivera B.M. Conus venoms: A rich source of novel ion channel-targeted peptides // Physiol. Rev. 2004. V. 84, No 1. P. 41-68.

46. Wan $\mathrm{H}$. et al. A spider-derived Kunitz-type serine protease inhibitor that acts as a plasmin inhibitor and an elastase inhibitor // PLoS One. 2013. V. 8, No 1. P. 1-8.

47. Wang F.C. et al. Identification of residues in dendrotoxin $\mathrm{K}$ responsible for its discrimination between neuronal K+ channels containing KV1.1 and $1.2 \alpha$ subunits // Eur. J. Biochem. 1999. V. 263, No 1. P. 222-229.

48. Wang H. et al. Functional peptidomics of amphibian skin secretion: A novel Kunitz-type chymotrypsin inhibitor from the African hyperoliid frog, Kassina senegalensis // Biochimie. 2012. V. 94, No 3. P. 891-899.

49. Wu J. et al. Proteomic analysis of skin defensive factors of tree frog Hyla simplex // J. Proteome Res. 2011. V. 10, No 9. P. 4230-4240. 
50. Yamaguchi Y. et al. Screening and cDNA cloning of KV1 potassium channel toxins in sea anemones // Mar. Drugs. 2010. V. 8, No 12. P. 2893-2905.

51. You D. et al. The first gene-encoded amphibian neurotoxin // J. Biol. Chem. 2009. V. 284, No 33. P. 22079-22086.

52. Yuan C.H. et al. Discovery of a distinct superfamily of Kunitz-type toxin (KTT) from tarantulas // PLoS One. 2008. V. 3, No 10. P. e3414.

53. Zhang L. et al. Unique diversity of the venom peptides from the scorpion Androctonus bicolor revealed by transcriptomic and proteomic analysis // J. Proteomics. 2015. V. 128. P. 231-250.

54. Zhao R. et al. SdPI, the first functionally characterized Kunitz-type trypsin inhibitor from scorpion venom // PLoS One. 2011. V. 6, No 11. P. e27548. 


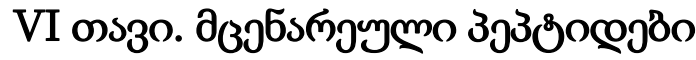

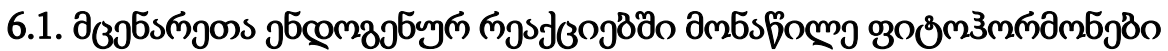

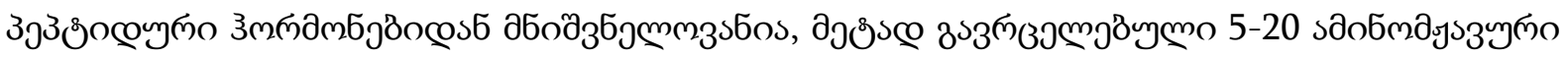

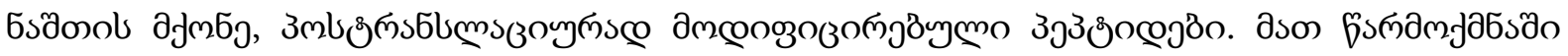

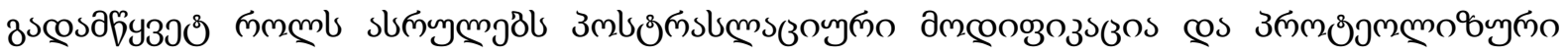

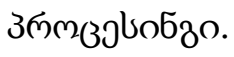

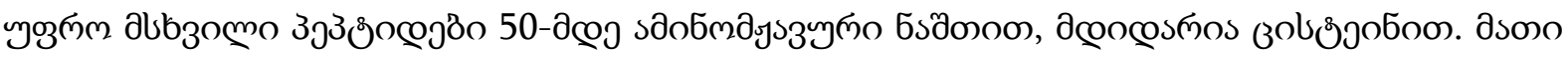

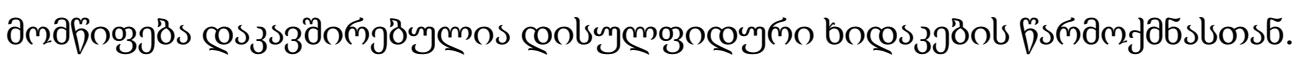

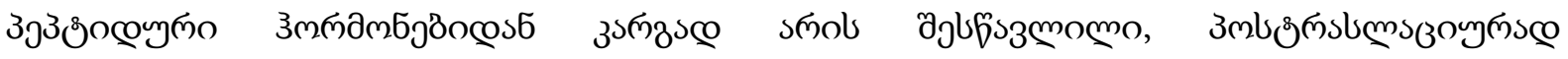

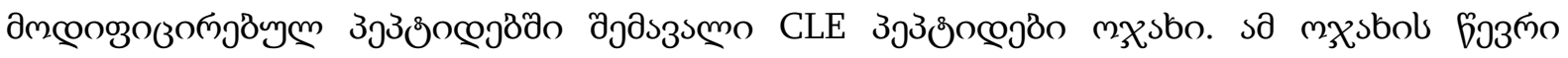

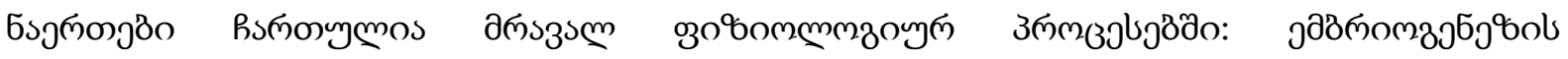

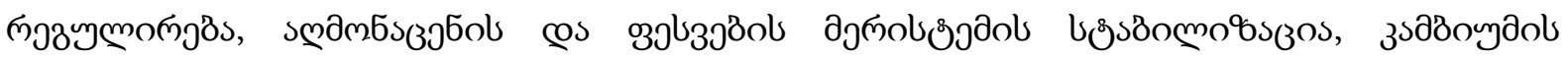

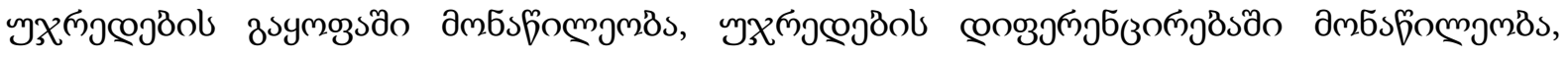

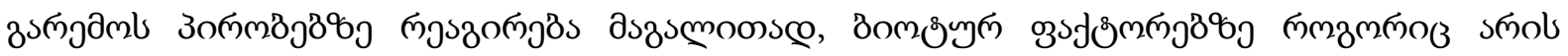

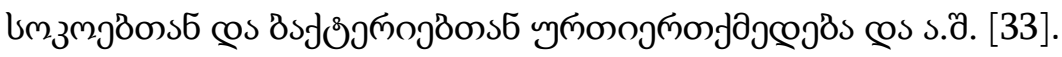

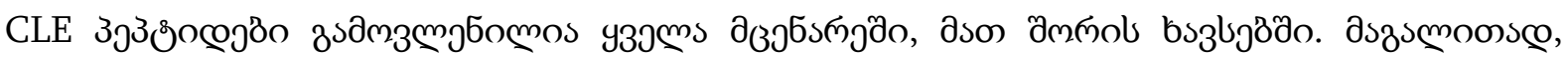

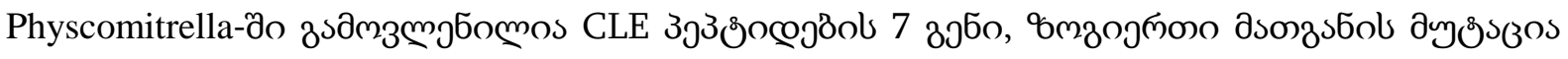

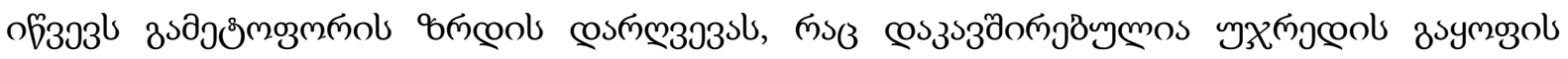

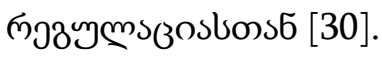

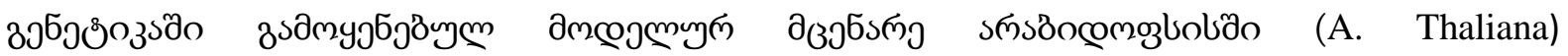

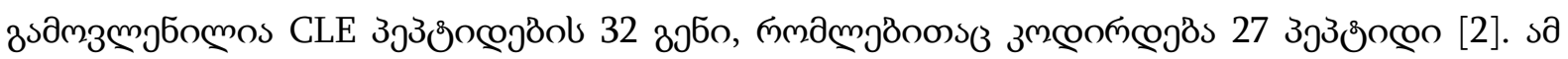

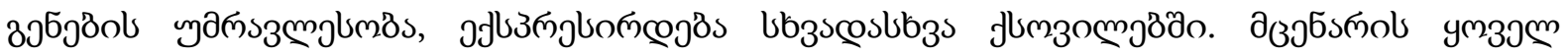

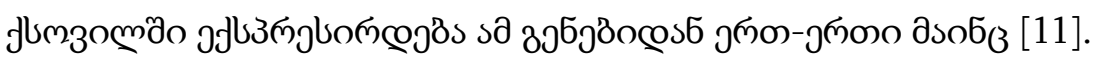

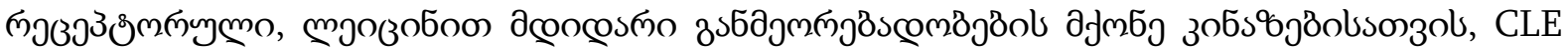

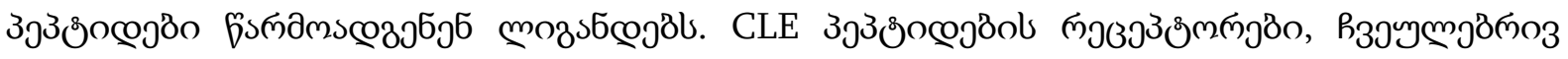

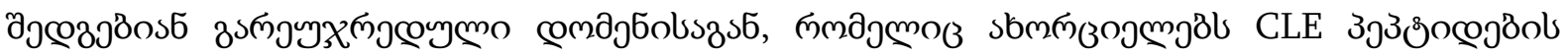

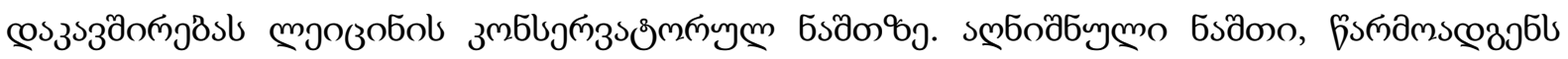

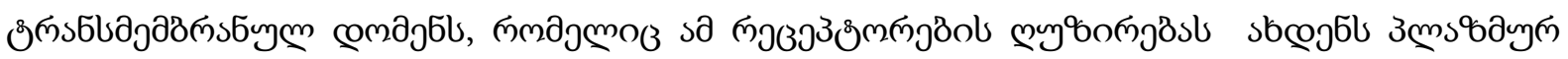

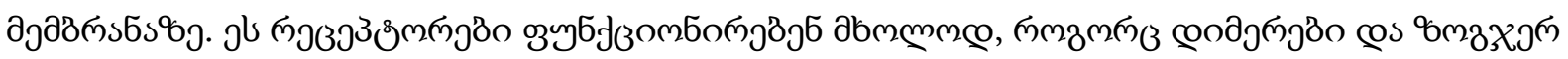

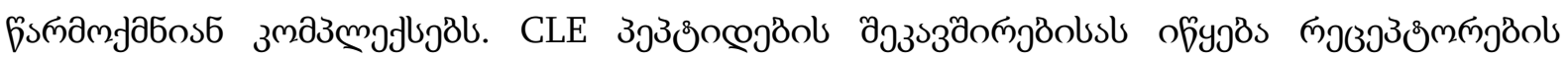

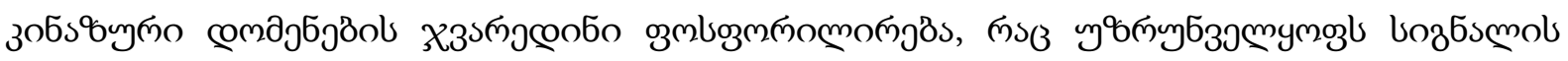

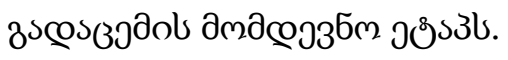

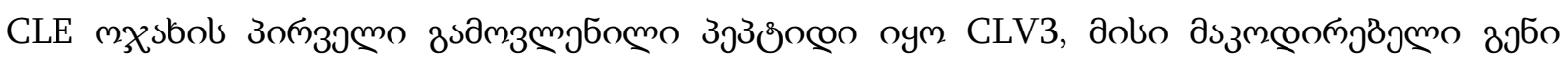

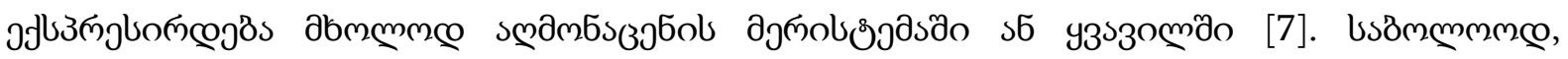

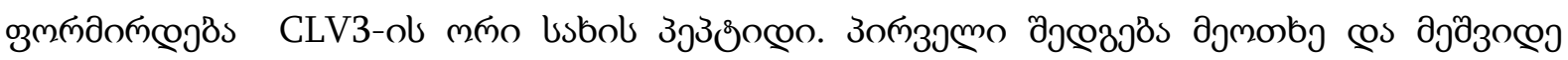

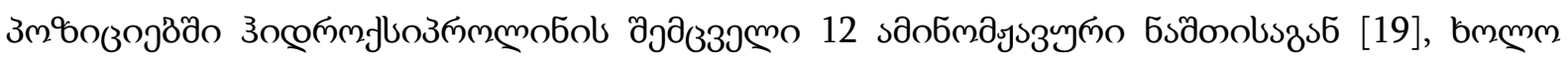

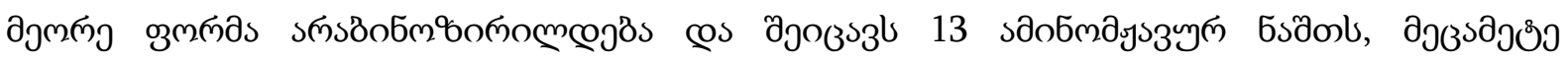

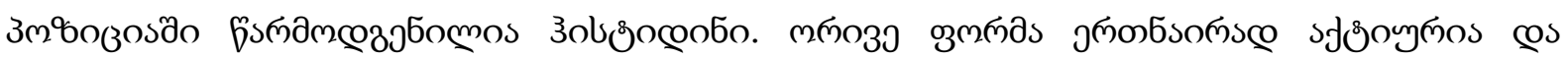

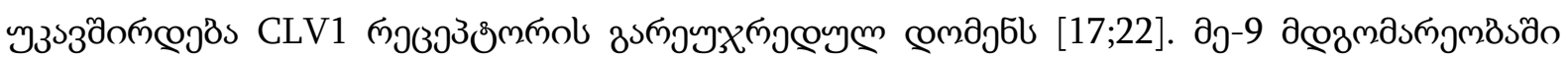

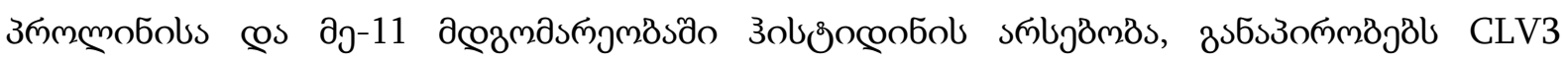




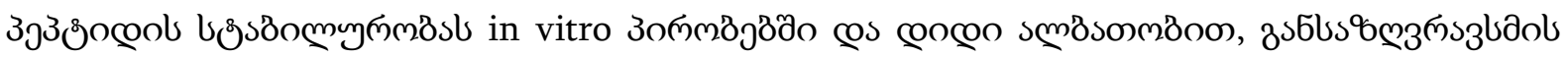

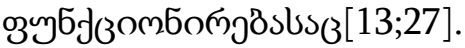

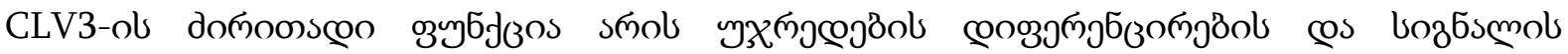

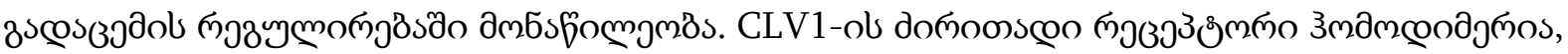

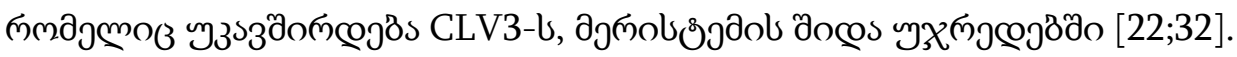

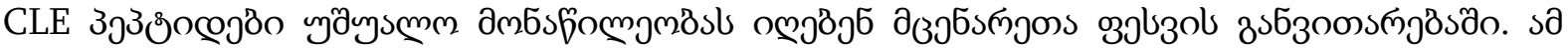

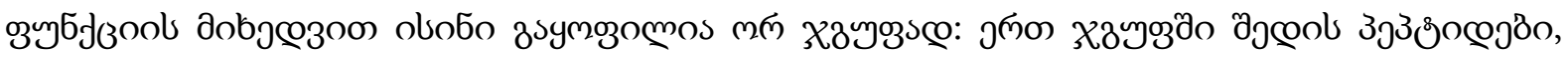

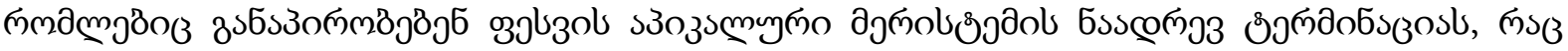

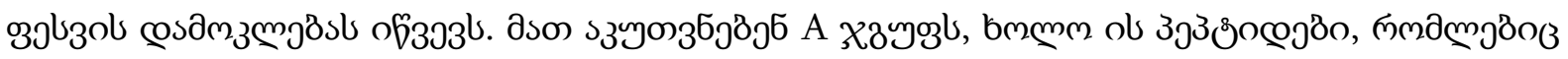

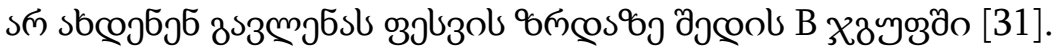

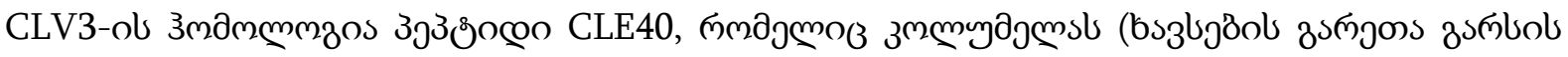

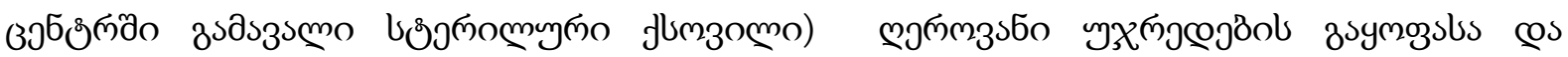

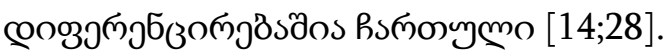

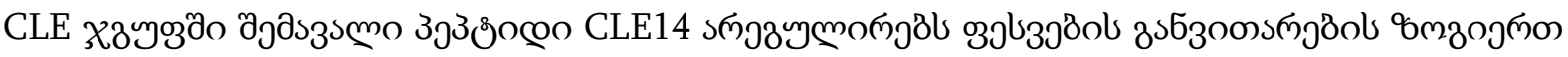

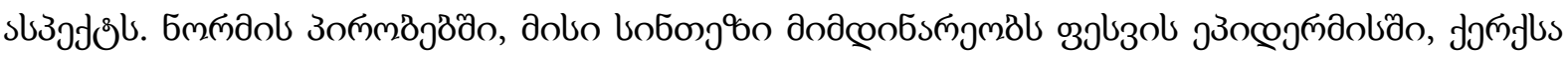

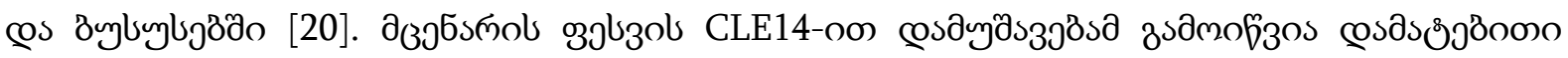

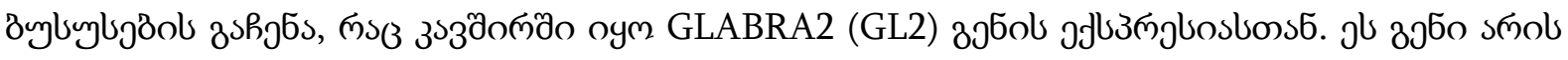

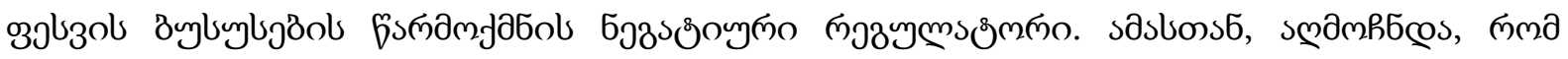

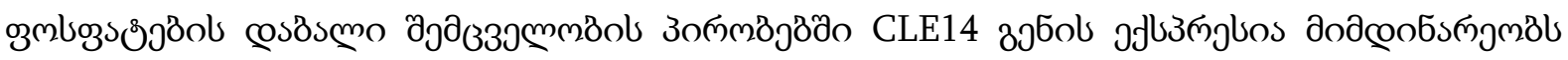

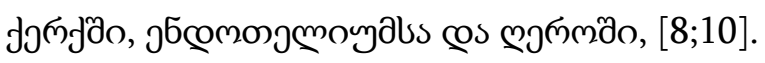

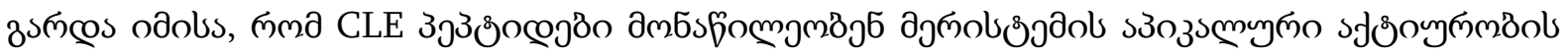

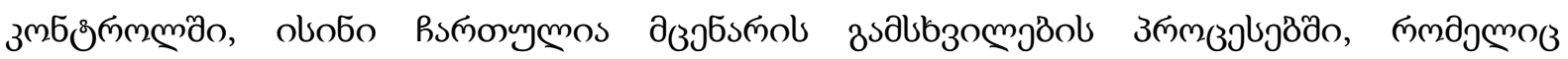

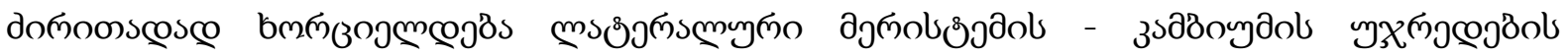

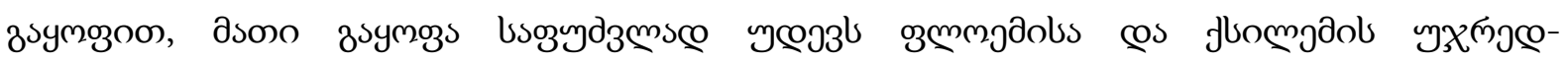

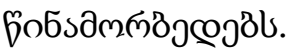

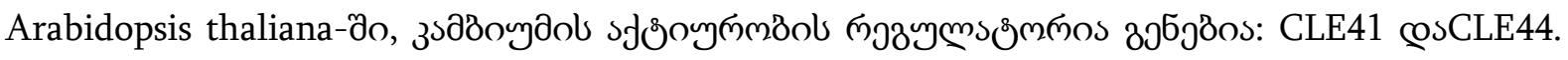

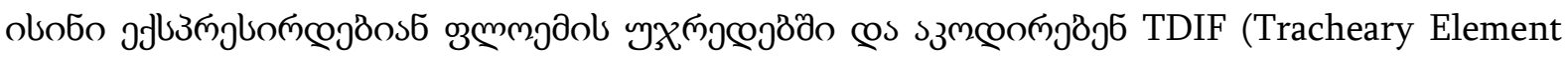

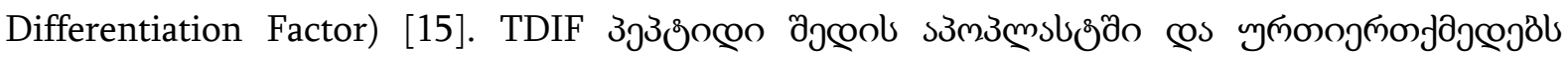

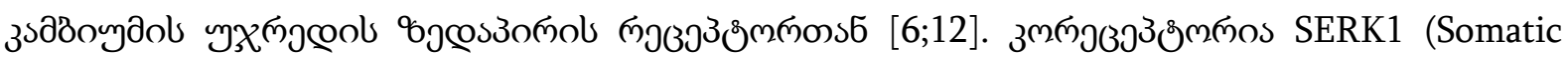
Embryogenesis Receptor Kinase 1) [34].

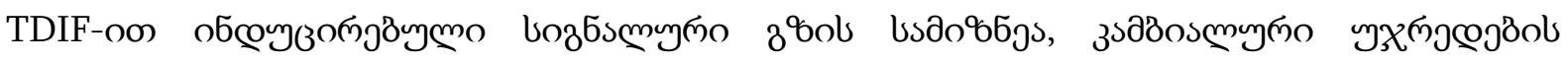

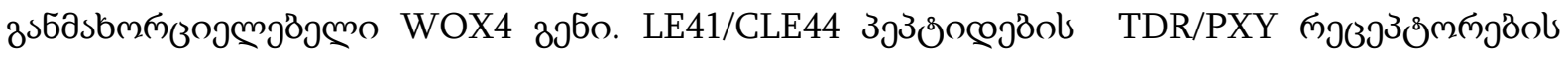

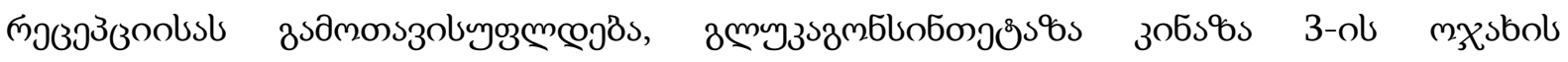

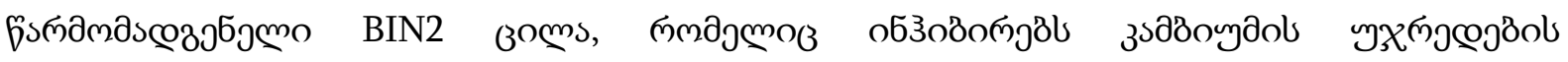

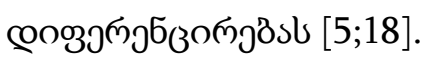

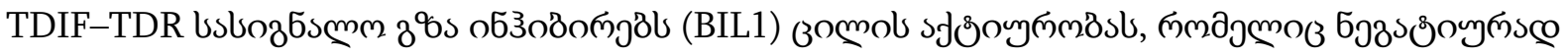

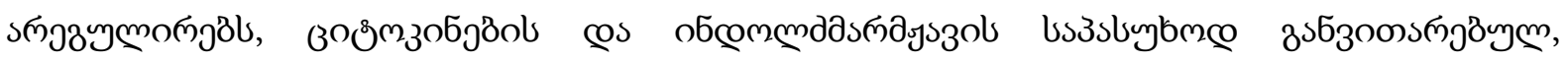

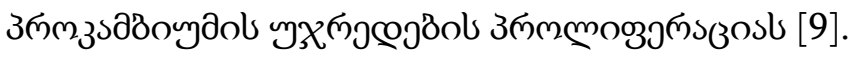

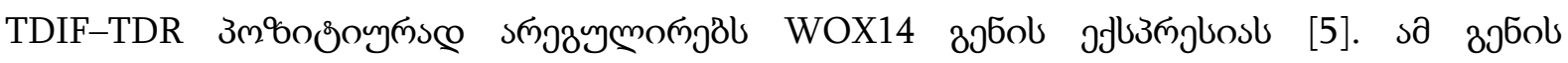

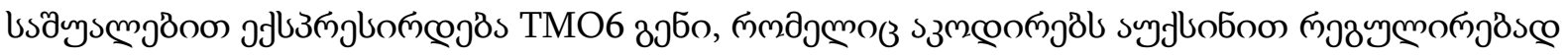

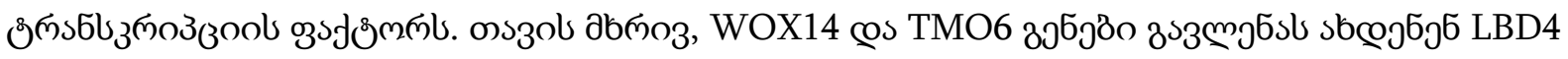




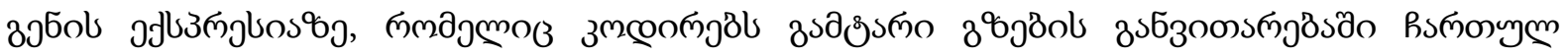

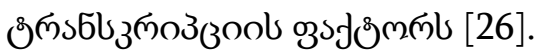

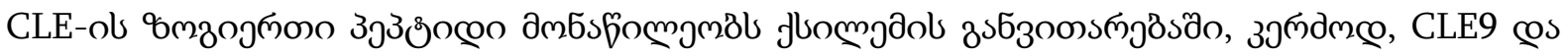

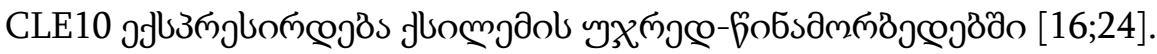

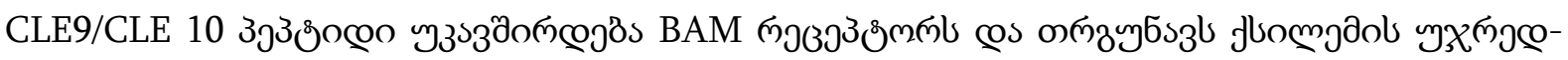

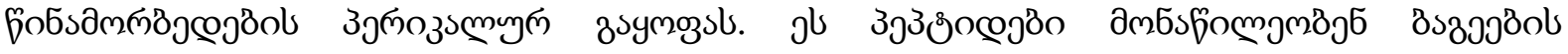

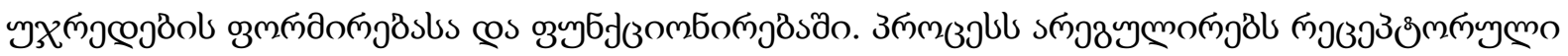

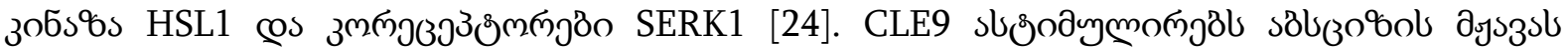

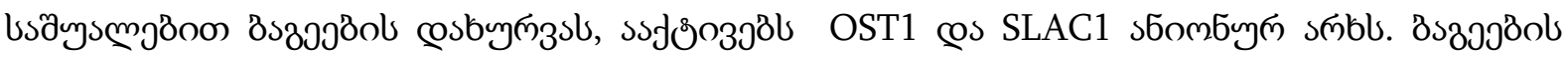

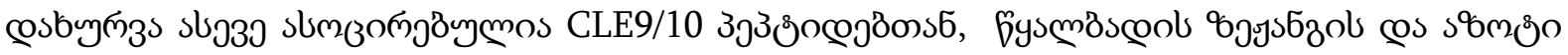

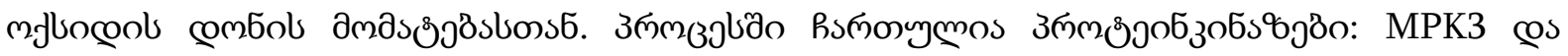

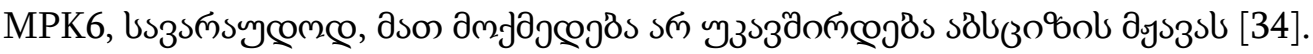

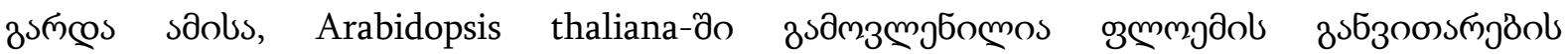

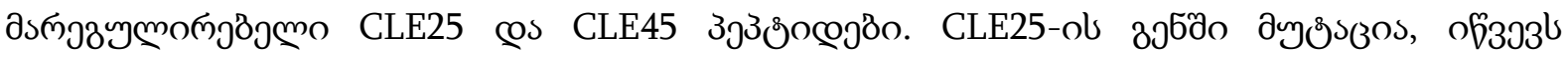

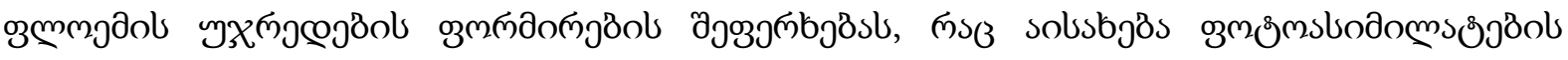

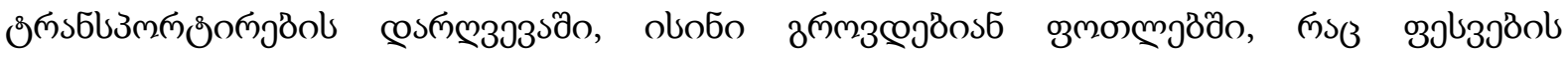

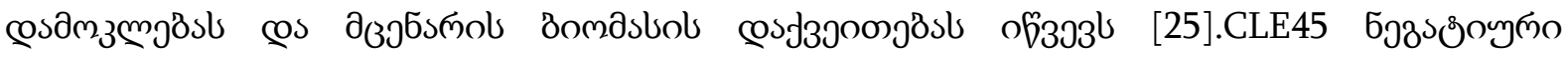

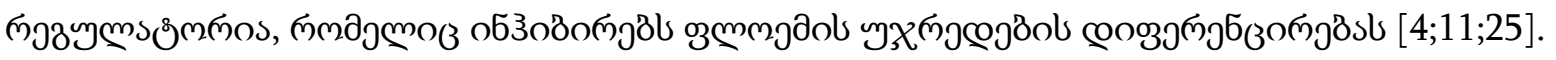

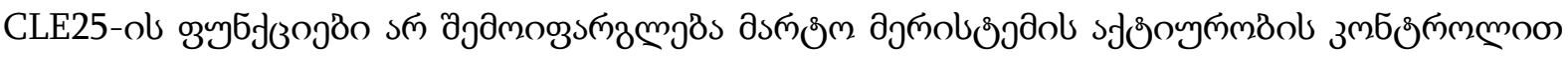

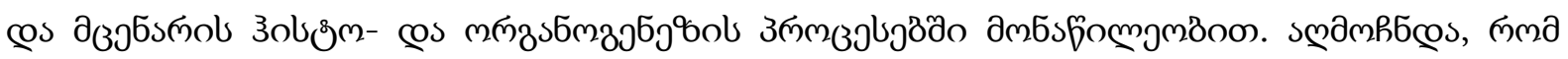

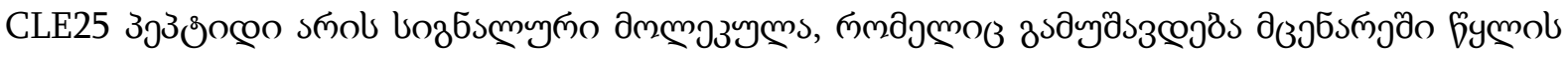

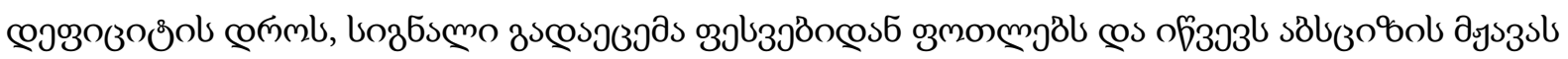

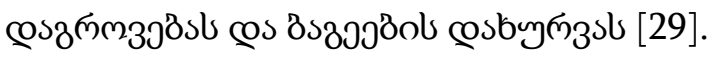

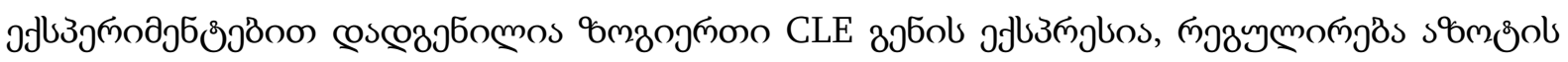

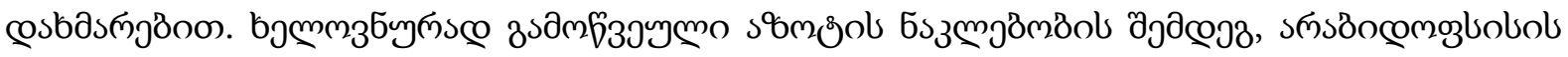

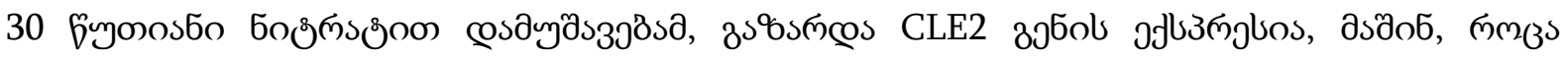

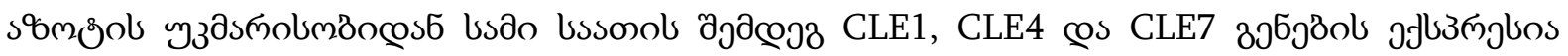

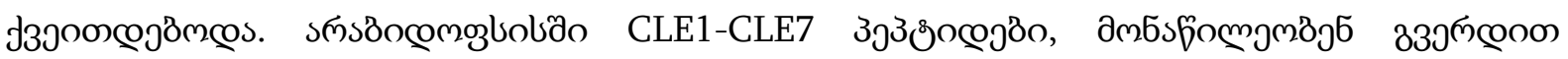

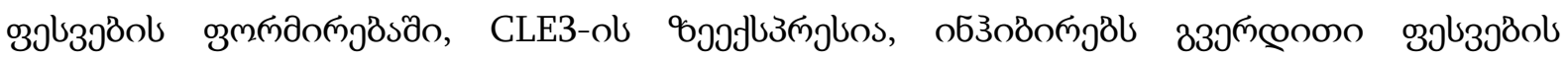

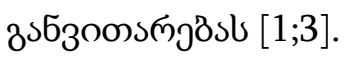

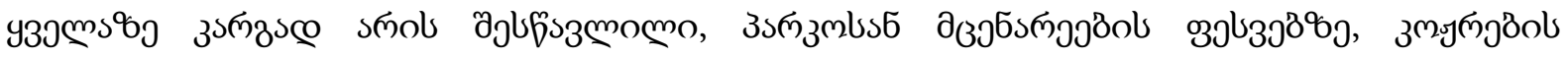

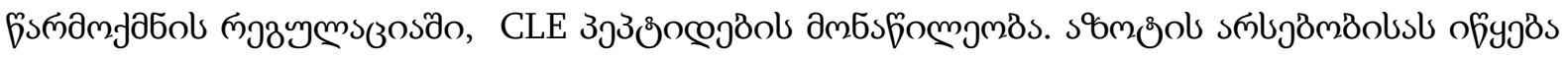

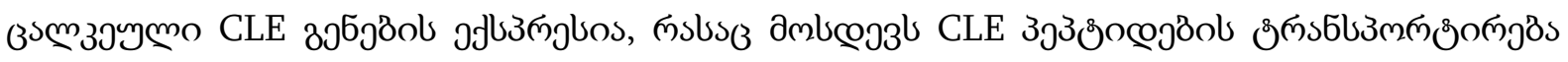

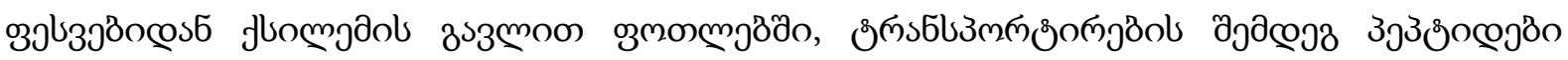

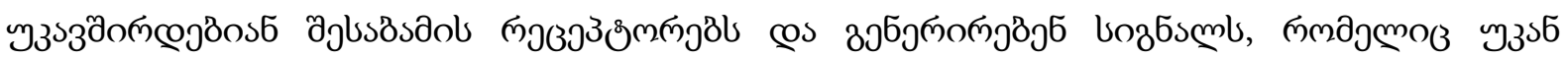

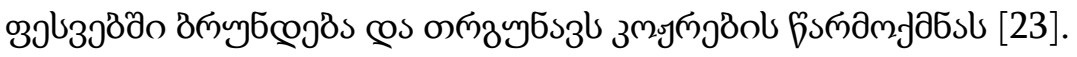

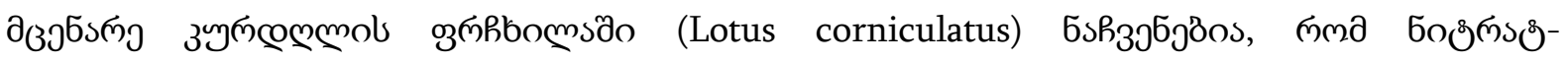

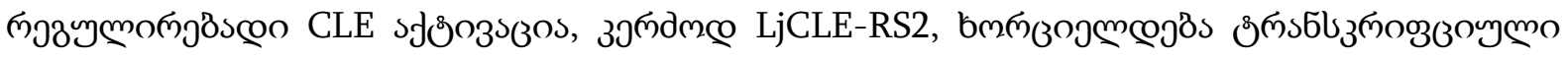

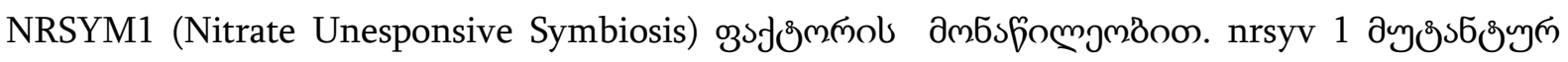

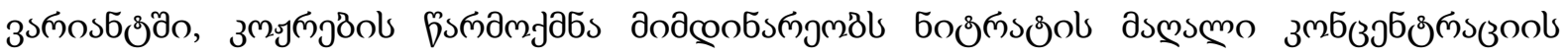

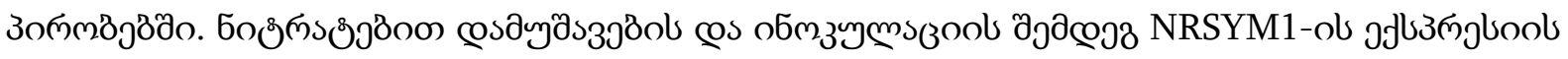




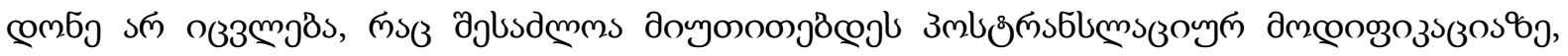

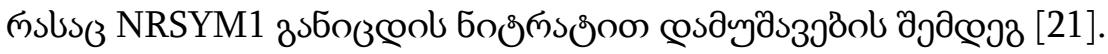

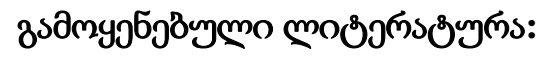

1. Araya $\mathrm{T}$, Miyamoto $\mathrm{M}$, Wibowo J, et al. CLE-CLAVATA1 peptide-receptor signaling module regulates the expansion of plant root systems in a nitrogen-dependent manner. Proc Natl Acad Sci U S A. 2014;111(5):2029-2034. doi:10.1073/pnas.1319953111

2. Cock JM, McCormick S. A large family of genes that share homology with CLAVATA3. Plant Physiol. 2001;126(3):939-942. doi:10.1104/pp.126.3.939

3. De Bang TC, Lay KS, Scheible WR, Takahashi H. Small peptide signaling pathways modulating macronutrient utilization in plants. Curr Opin Plant Biol. 2017;39:31-39. doi:10.1016/j.pbi.2017.05.005

4. Depuydt S, Rodriguez-Villalon A, Santuari L, Wyser-Rmili C, Ragni L, Hardtke CS. Suppression of Arabidopsis protophloem differentiation and root meristem growth by CLE45 requires the receptor-like kinase BAM3. Proc Natl Acad Sci U S A. 2013;110(17):7074-7079. doi:10.1073/pnas.1222314110

5. Etchells JP, Provost CM, Mishra L, Turner SR. WOX4 and WOX14 act downstream of the PXY receptor kinase to regulate plant vascular proliferation independently of any role in vascular organisation. Development. 2013;140(10):2224-2234. doi:10.1242/dev.091314

6. Etchells JP, Turner SR. The PXY-CLE41 receptor ligand pair defines a multifunctional pathway that controls the rate and orientation of vascular cell division. Development. 2010;137(5):767-774. doi:10.1242/dev.044941

7. Fletcher JC, Brand U, Running MP, Simon R, Meyerowitz EM. Signaling of cell fate decisions by CLAVATA3 in Arabidopsis shoot meristems. Science. 1999;283(5409):19111914. doi:10.1126/science.283.5409.1911

8. Gutiérrez-Alanís D, Yong-Villalobos L, Jiménez-Sandoval P, et al. Phosphate StarvationDependent Iron Mobilization Induces CLE14 Expression to Trigger Root Meristem Differentiation through CLV2/PEPR2 Signaling. Dev Cell. 2017;41(5):555-570.e3. doi:10.1016/j.devcel.2017.05.009

9. Han H, Liu X, Zhou Y. Transcriptional circuits in control of shoot stem cell homeostasis. Curr Opin Plant Biol. 2020;53:50-56. doi:10.1016/j.pbi.2019.10.004

10. Hayashi N, Tetsumura T, Sawa S, Wada T, Tominaga-Wada R. CLE14 peptide signaling in Arabidopsis root hair cell fate determination. Plant Biotechnol (Tokyo). 2018;35(1):17-22. doi:10.5511/plantbiotechnology.18.0122a

11. Hazak O, Brandt B, Cattaneo P, et al. Perception of root-active CLE peptides requires CORYNE function in the phloem vasculature. EMBO Rep. 2017;18(8):1367-1381. doi:10.15252/embr.201643535

12. Hirakawa Y, Shinohara H, Kondo Y, et al. Non-cell-autonomous control of vascular stem cell fate by a CLE peptide/receptor system. Proc Natl Acad Sci U S A. 2008;105(39):1520815213. doi:10.1073/pnas.0808444105

13. Hirakawa Y, Torii KU, Uchida N. Mechanisms and Strategies Shaping Plant Peptide Hormones. Plant Cell Physiol. 2017;58(8):1313-1318. doi:10.1093/pcp/pcx069

14. Hobe M, Müller R, Grünewald M, Brand U, Simon R. Loss of CLE40, a protein functionally equivalent to the stem cell restricting signal CLV3, enhances root waving in Arabidopsis. Dev Genes Evol. 2003;213(8):371-381. doi:10.1007/s00427-003-0329-5 
15. Ito Y, Nakanomyo I, Motose H, et al. Dodeca-CLE peptides as suppressors of plant stem cell differentiation. Science. 2006;313(5788):842-845. doi:10.1126/science.1128436.

16. Jun J, Fiume E, Roeder AH, et al. Comprehensive analysis of CLE polypeptide signaling gene expression and overexpression activity in Arabidopsis. Plant Physiol. 2010;154(4):1721-1736. doi:10.1104/pp.110.163683

17. Kim HJ, Wu CY, Yu HM, Sheen J, Lee H. Dual ClAVATA3 Peptides in Arabidopsis Shoot Stem Cell Signaling. J Plant Biol. 2017;60(5):506-512. doi:10.1007/s12374-017-0083-2

18. Kondo Y, Fukuda H. The TDIF signaling network. Curr Opin Plant Biol. 2015;28:106-110. doi:10.1016/j.pbi.2015.10.002

19. Kondo T, Sawa S, Kinoshita A, et al. A plant peptide encoded by CLV3 identified by in situ MALDI-TOF MS analysis. Science. 2006;313(5788):845-848. doi:10.1126/science.1128439

20. Meng L, Feldman LJ. CLE14/CLE20 peptides may interact with CLAVATA2/CORYNE receptor-like kinases to irreversibly inhibit cell division in the root meristem of Arabidopsis. Planta. 2010;232(5):1061-1074. doi:10.1007/s00425-010-1236-4

21. Nishida H, Tanaka S, Handa Y, et al. A NIN-LIKE PROTEIN mediates nitrate-induced control of root nodule symbiosis in Lotus japonicus. Nat Commun. 2018;9(1):499. Published 2018 Feb 5. doi:10.1038/s41467-018-02831-x

22. Ogawa M, Shinohara H, Sakagami Y, Matsubayashi Y. Arabidopsis CLV3 peptide directly binds CLV1 ectodomain. Science. 2008;319(5861):294. doi:10.1126/science.1150083

23. Okamoto S, Tabata R, Matsubayashi Y. Long-distance peptide signaling essential for nutrient homeostasis in plants. Curr Opin Plant Biol. 2016;34:35-40. doi:10.1016/j.pbi.2016.07.009

24. Qian P, Song W, Yokoo T, et al. Author Correction: The CLE9/10 secretory peptide regulates stomatal and vascular development through distinct receptors. Nat Plants. 2019;5(2):238. doi:10.1038/s41477-018-0347-y

25. Ren SC, Song XF, Chen WQ, Lu R, Lucas WJ, Liu CM. CLE25 peptide regulates phloem initiation in Arabidopsis through a CLERK-CLV2 receptor complex. J Integr Plant Biol. 2019;61(10):1043-1061. doi:10.1111/jipb.12846

26. Smit ME, McGregor SR, Sun H, et al. A PXY-Mediated Transcriptional Network Integrates Signaling Mechanisms to Control Vascular Development in Arabidopsis. Plant Cell. 2020;32(2):319-335. doi:10.1105/tpc.19.00562

27. Song XF, Guo P, Ren SC, Xu TT, Liu CM. Antagonistic peptide technology for functional dissection of CLV3/ESR genes in Arabidopsis. Plant Physiol. 2013;161(3):1076-1085. doi:10.1104/pp.112.211029

28. Stahl Y, Simon R. Is the Arabidopsis root niche protected by sequestration of the CLE40 signal by its putative receptor ACR4?. Plant Signal Behav. 2009;4(7):634-635. doi:10.4161/psb.4.7.8970

29. Takahashi F, Suzuki T, Osakabe Y, et al. A small peptide modulates stomatal control via abscisic acid in long-distance signalling. Nature. 2018;556(7700):235-238. doi:10.1038/s41586-018-0009-2

30. Whitewoods CD, Cammarata J, Nemec Venza Z, et al. CLAVATA Was a Genetic Novelty for the Morphological Innovation of 3D Growth in Land Plants [published correction appears in Curr Biol. 2020 Jul 6;30(13):2645-2648]. Curr Biol. 2018;28(15):2365-2376.e5. doi:10.1016/j.cub.2018.05.068

31. Whitford R, Fernandez A, De Groodt R, Ortega E, Hilson P. Plant CLE peptides from two distinct functional classes synergistically induce division of vascular cells. Proc Natl Acad Sci U S A. 2008;105(47):18625-18630. doi:10.1073/pnas.0809395105 
32. Yadav RK, Perales $M$, Gruel $J$, et al. Plant stem cell maintenance involves directtranscriptional repression of differentiation program. Mol Syst Biol. 2013;9:654. doi:10.1038/msb.2013.8

33. Yamaguchi YL, Ishida T, Sawa S. CLE peptides and their signaling pathways in plant development. J Exp Bot. 2016;67(16):4813-4826. doi:10.1093/jxb/erw208.

34. Zhang L, Shi X, Zhang Y, et al. CLE9 peptide-induced stomatal closure is mediated by abscisic acid, hydrogen peroxide, and nitric oxide in Arabidopsis thaliana. Plant Cell Environ. 2019;42(3):1033-1044. doi:10.1111/pce.13475

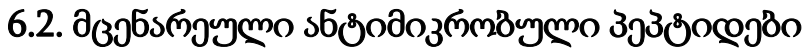

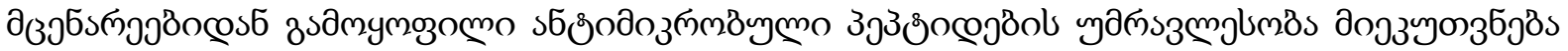

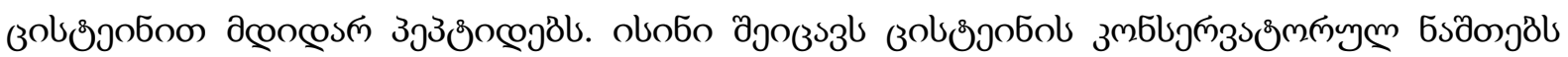

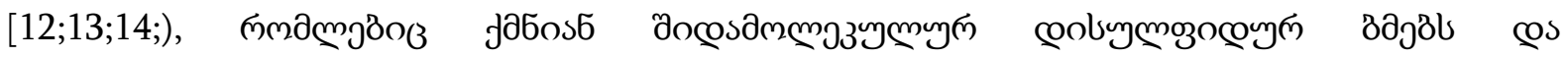

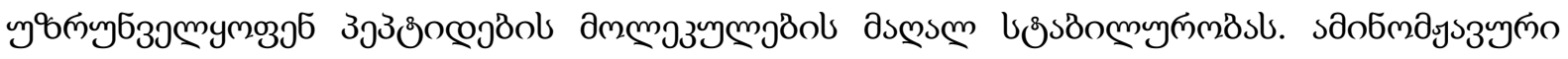

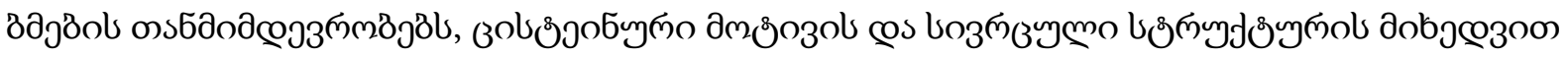

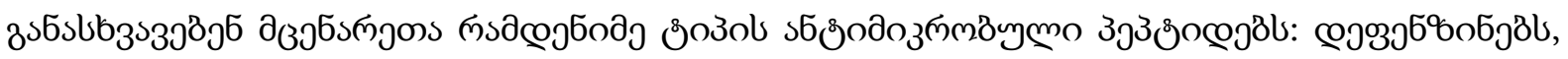

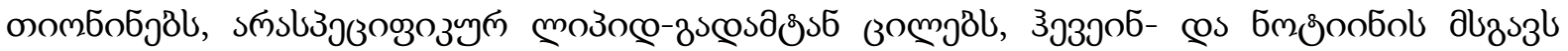

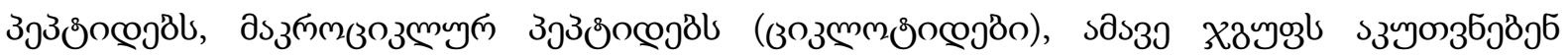

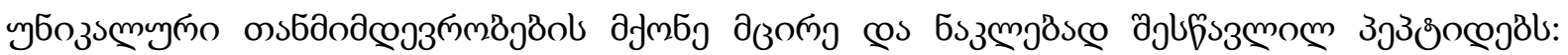

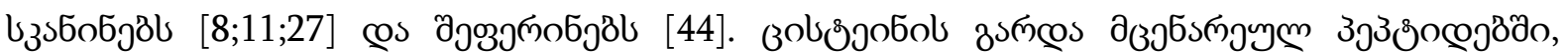

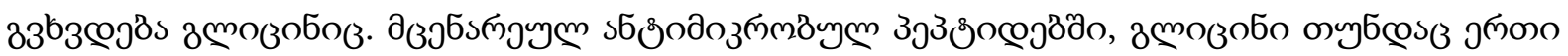

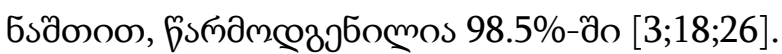

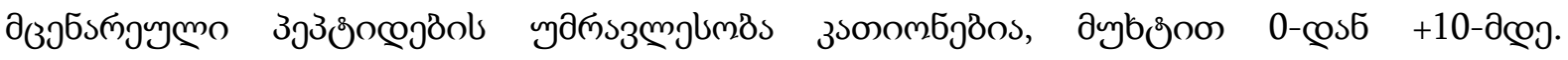

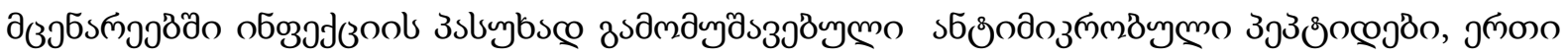

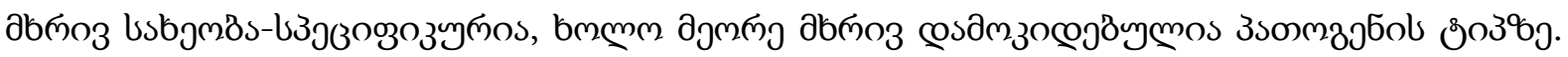

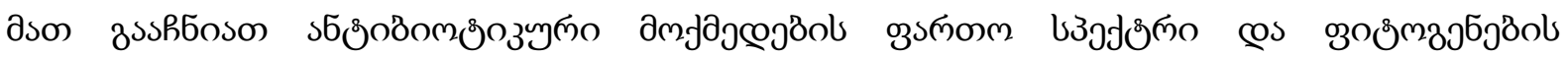

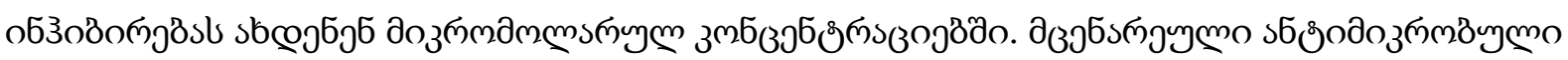

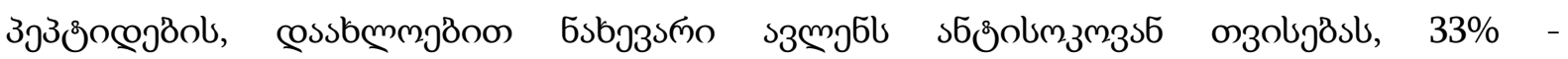

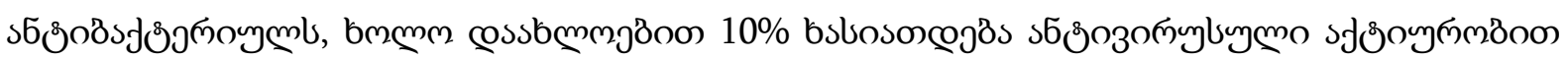
$[5 ; 24]$.

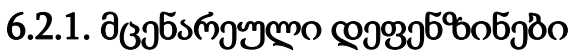

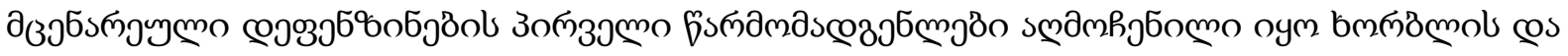

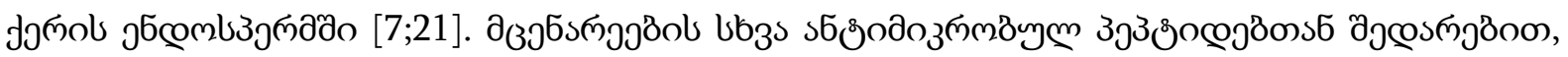

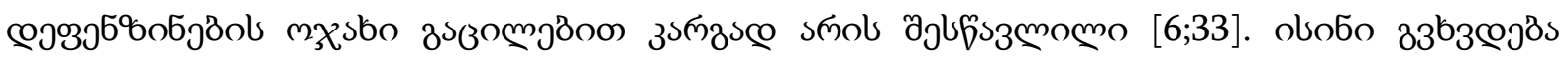

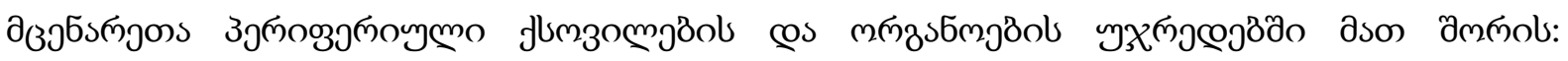

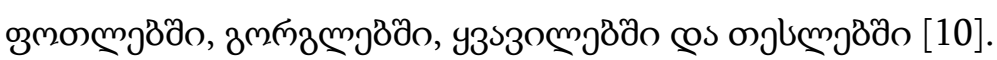

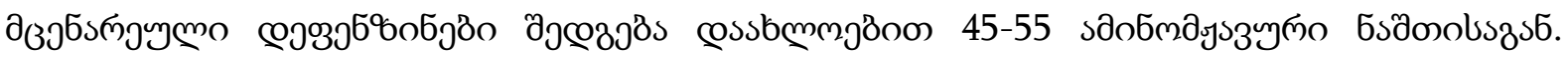

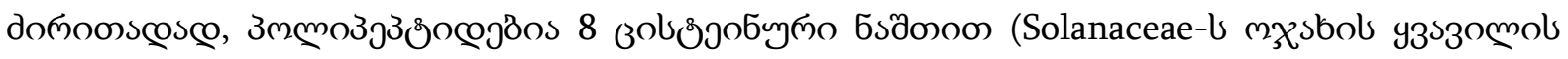

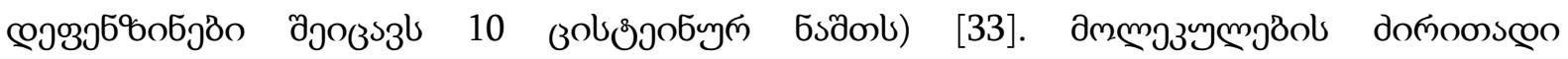




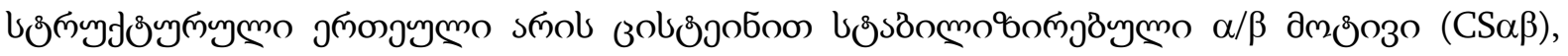

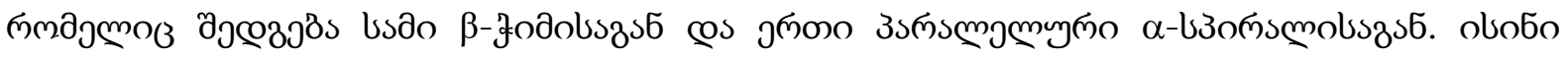

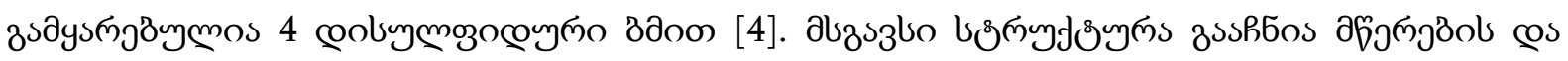

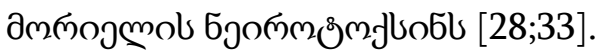

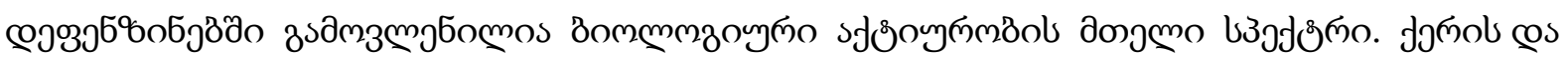

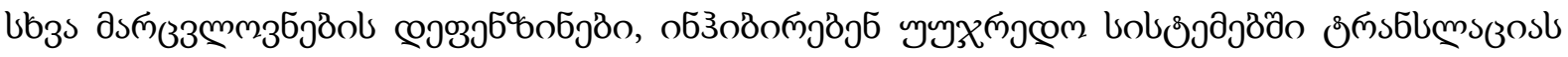

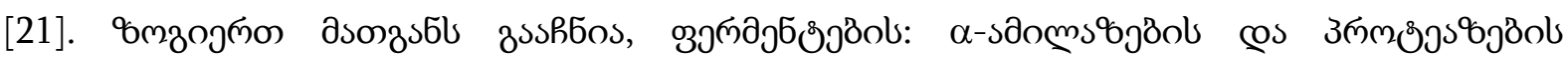

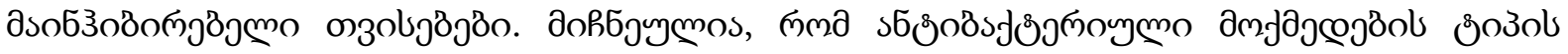

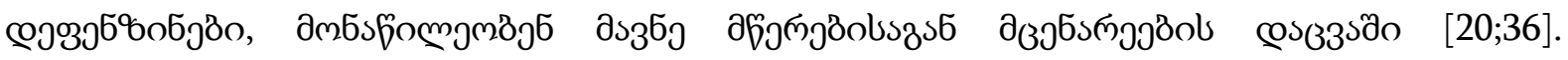

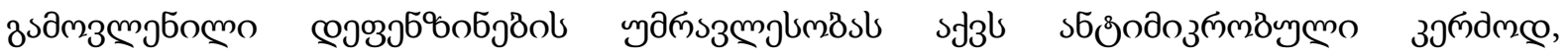

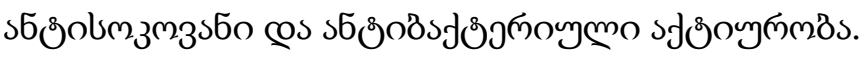

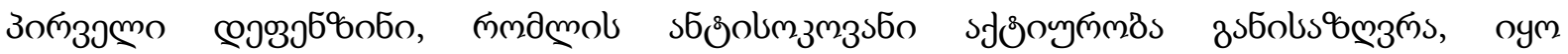

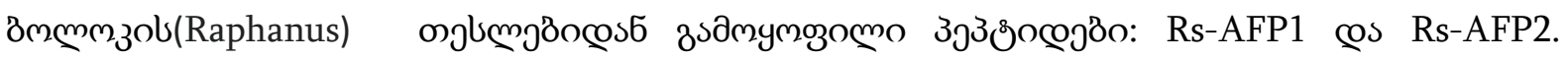

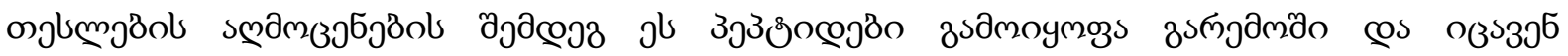

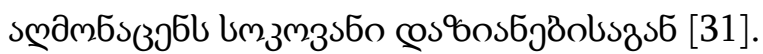

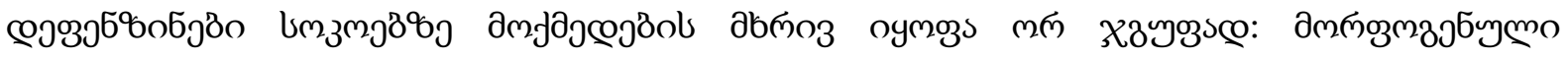

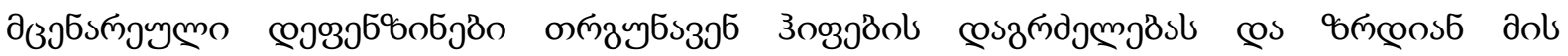

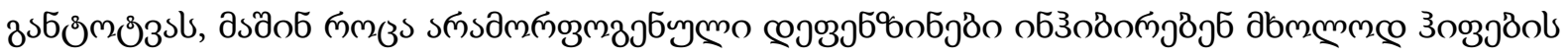

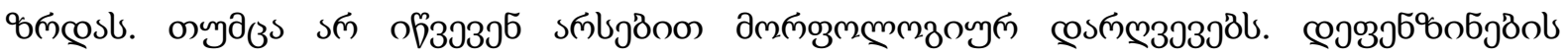

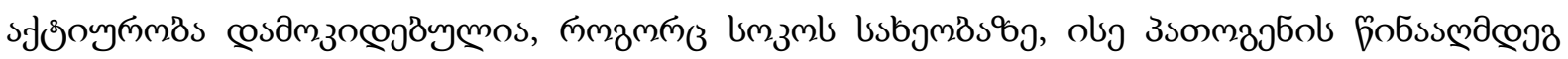

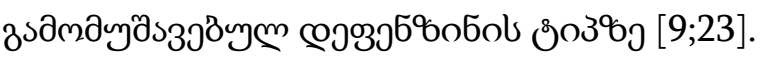

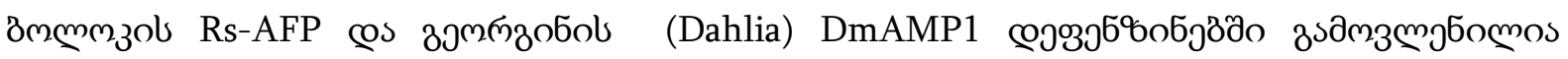

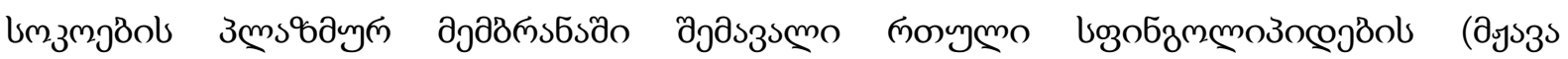

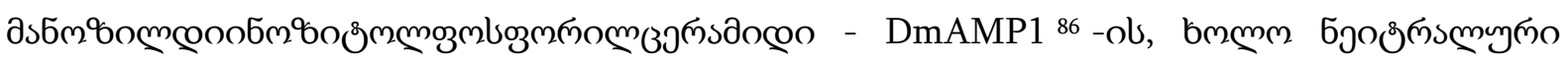

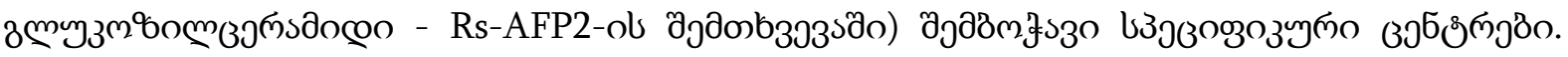

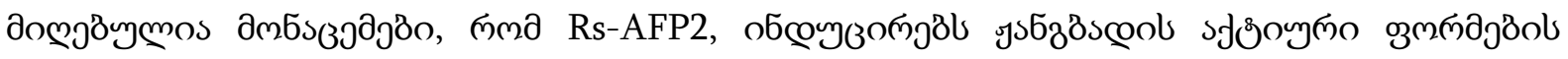

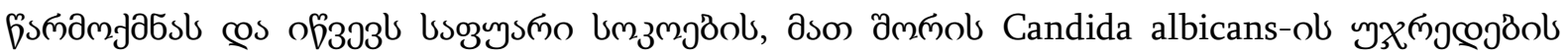

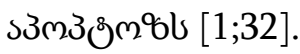

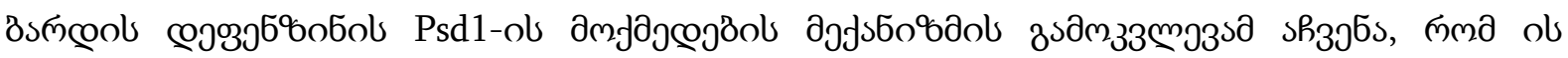

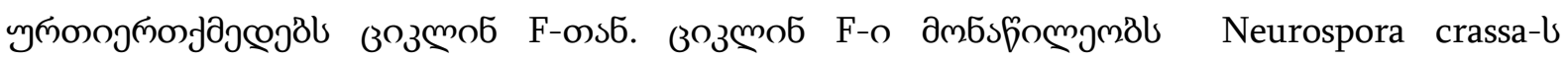

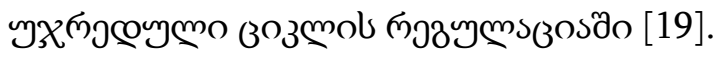

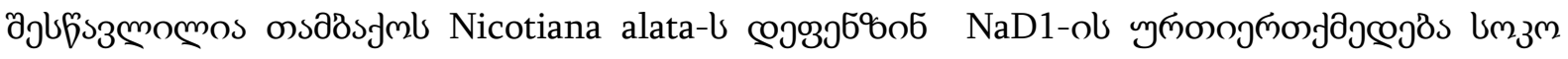

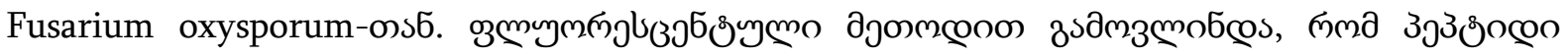

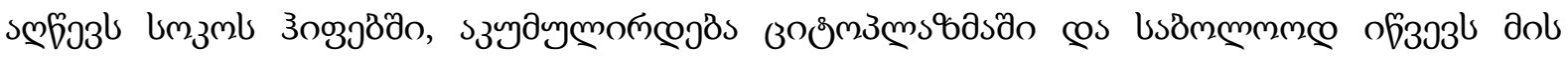

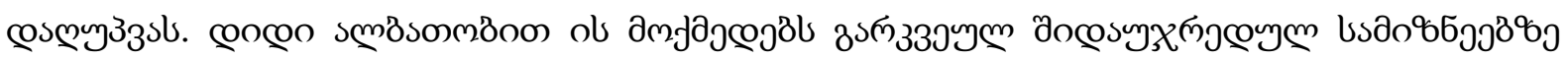
[35].

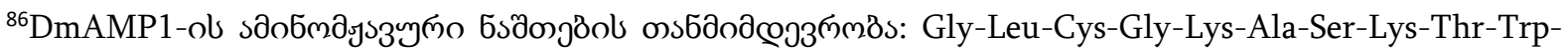
Ser-Gly-Asn-Cys-Gly-Asn-Thr-Gly-His-Cys-Asp-Asn-Gln-Cys-Lys-Ser-Trp-Glu-Gly-Ala-Ala-His-Gly-AlaCys-His-Val-Arg-Asn-Gly-Lys-His-Met-Cys-Phe-Cys-Tyr-Phe-Asn-Cys.
} 


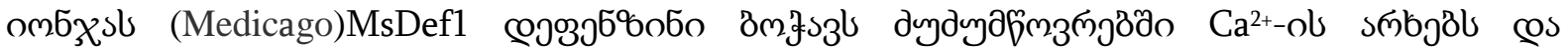

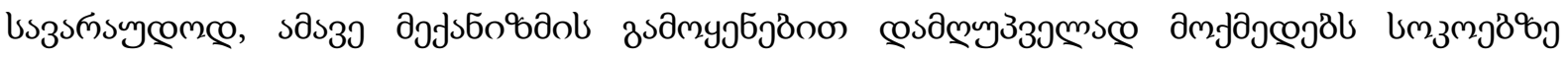

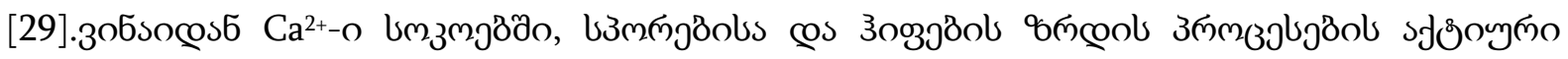

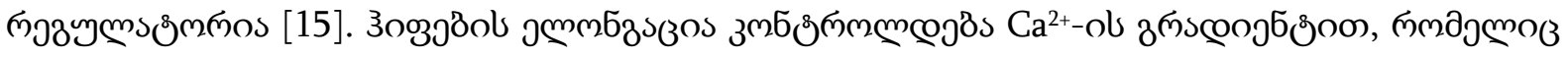

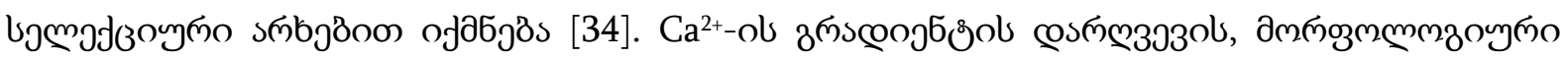

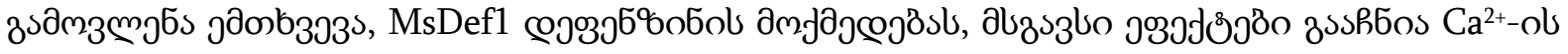

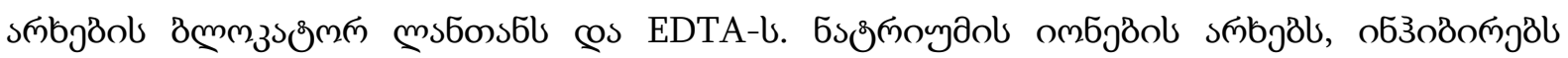

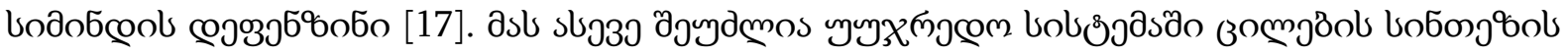
cosom

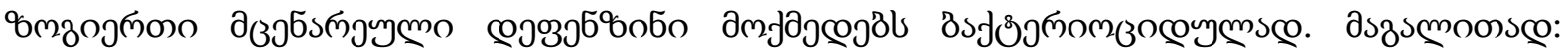

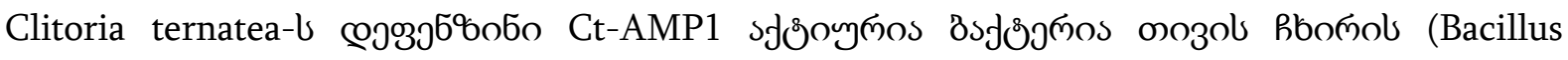

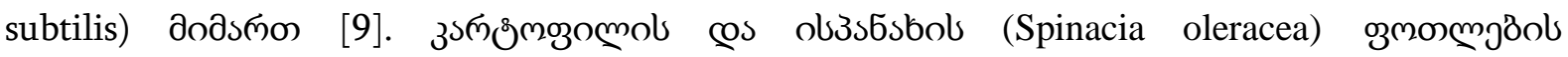

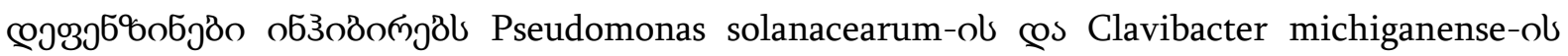

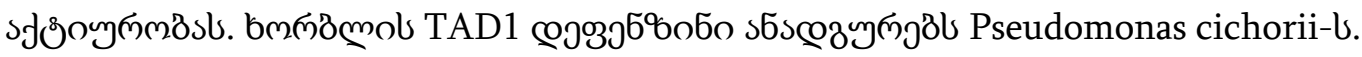

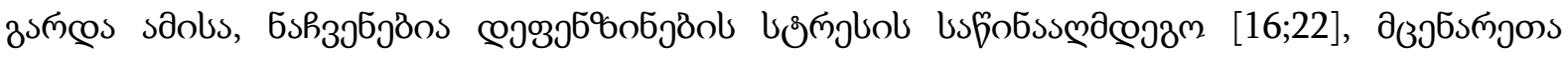

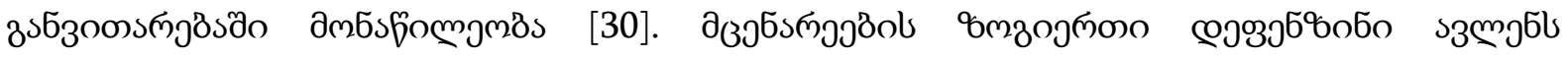

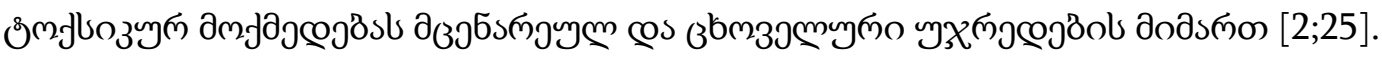

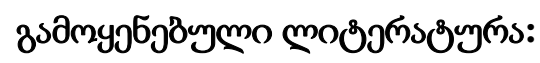

1. Aerts, A. M., Francois, I. E. J. A., Meert, E. M. K., Li, Q. T., Cammue, B. P. A., and Thevissen, K. (2007) The antifungal activity of RsAFP2, a plant defensin from Raphanus sativus, involves the induction of reactive oxygen species in Candida albicans. J. Mol. Microbiol. Biotechnol. 13, 243-247.

2. Anaya-Lopez, J. L., Lopez-Meza, J. E., Baizabal-Aguirre, V. M., Cano-Camacho, H., and

3. Ochoa-Zarzosa, A. (2006) Fungicidal and cytotoxic activity of a Capsicum chinense defensinexpressed by endothelial cells. Biotechnol. Lett. 28, 1101-1108.

4. Boller, T., and Felix, G. (2009) A renaissance of elicitors: perception of microbeassociatedmolecular patterns and danger signals by pattern-recognition receptors. Annu. Rev. Plant Biol. 60,379-406.

5. Bruix, M., Jiménez, M. A., Santoro, J., González, C., Colilla, F. J., Méndez, E., and Rico, M.(1993) Solution structure of gamma 1-H and gamma 1-P thionins from barley and wheat endospermdetermined by 1H-NMR: a structural motif common to toxic arthropod proteins. Biochemistry 32,715-24.

6. Cai, G., Wang, G., Wang, L., Pan, J., Liu, Y., and Li, D. (2014) ZmMKK1, a novel group Amitogen-activated protein kinase kinase gene in maize, conferred chilling stress tolerance and wasinvolved in pathogen defense in transgenic tobacco. Plant Sci. 214, 57-73.

7. Carvalho, A. de O., and Gomes, V. M. (2009) Plant defensins--prospects for the biologicalfunctions and biotechnological properties. Peptides 30, 1007-20.

8. Colilla, F. J., Rocher, A., and Mendez, E. (1990) gamma-Purothionins: amino acid sequence of two polypeptides of a new family of thionins from wheat endosperm. FEBS Lett. 270, $191-4$. 
9. Daneshmand, F., Zare-Zardini, H., and Ebrahimi, L. (2013) Investigation of the antimicrobialactivities of Snakin-Z, a new cationic peptide derived from Zizyphus jujuba fruits. Nat. Prod. Res.27, 2292-6.

10. De Bolle, M. F., Eggermont, K., Duncan, R. E., Osborn, R. W., Terras, F. R., and Broekaert,W. F. (1995) Cloning and characterization of two cDNA clones encoding seedspecificantimicrobial peptides from Mirabilis jalapa L. Plant Mol Biol 28, 713-721.

11. Farrokhi, N., Whitelegge, J. P., and Brusslan, J. A. (2008) Plant peptides and peptidomics.Plant Biotechnol J 6, 105-134.

12. Fritz-Laylin, L. K., Krishnamurthy, N., Tör, M., Sjölander, K. V, and Jones, J. D. G. (2005) Phylogenomic analysis of the receptor-like proteins of rice and Arabidopsis. Plant Physiol. $138,611-23$.

13. Felix, G., and Boller, T. (2003) Molecular sensing of bacteria in plants. The highly conservedRNA-binding motif RNP-1 of bacterial cold shock proteins is recognized as an elicitor signal intobacco. J. Biol. Chem. 278, 6201-8.

14. Gómez-Gómez, L., and Boller, T. (2002) Flagellin perception: a paradigm for innate immunity.Trends Plant Sci. 7, 251-6.

15. Hayafune, M., Berisio, R., Marchetti, R., Silipo, A., Kayama, M., Desaki, Y., Arima, S., Squeglia, F., Ruggiero, A., Tokuyasu, K., Molinaro, A., Kaku, H., and Shibuya, N. (2014)Chitininduced activation of immune signaling by the rice receptor CEBiP relies on a unique sandwich-type dimerization. Proc. Natl. Acad. Sci. U. S. A. 111, E404-13.

16. Jackson, S. L., and Heath, I. B. (1993) Roles of calcium ions in hyphal tip growth. MicrobiolRev 57, 367-382.

17. Koike, M., Okamoto, T., Tsuda, S., and Imai, R. (2002) A novel plant defensin-like gene ofwinter wheat is specifically induced during cold acclimation. Biochem. Biophys. Res. Commun. 298,46-53.

18. Kushmerick, C., Castro, M. D., Cruz, J. S., Bloch, C., and Beirao, P. S. L. (1998) Functionaland structural features of gamma-zeathionins, a new class of sodium channel blockers. Febs Lett.440, 302-306.

19. Liu, T., Liu, Z., Song, C., Hu, Y., Han, Z., She, J., Fan, F., Wang, J., Jin, C., Chang, J., Zou, J.-M., and Chai, J. (2012) Chitin-induced dimerization activates a plant immune receptor. Science 336,1160-4.

20. Lobo, D. S., Pereira, I. B., Fragel-Madeira, L., Medeiros, L. N., Cabral, L. M., Faria, J., Bellio,M., Campos, R. C., Linden, R., and Kurtenbach, E. (2007) Antifungal Pisum sativum defensin linteracts with Neurospora crassa cyclin F related to the cell cycle. Biochemistry 46, 987-996

21. Melo, F. R., Rigden, D. J., Franco, O. L., Mello, L. V, Ary, M. B., de Sa, M. F. G., and Bloch,C. (2002) Inhibition of trypsin by cowpea thionin: Characterization, molecular modeling, anddocking. Proteins-Structure Funct. Genet. 48, 311-319.

22. Mendez, E., Moreno, A., Colilla, F., Pelaez, F., Limas, G. G., Mendez, R., Soriano, F., Salinas,M., and de Haro, C. (1990) Primary structure and inhibition of protein synthesis in eukaryotic cellfree system of a novel thionin, gamma-hordothionin, from barley endosperm. Eur. J. Biochem. 194, 533-9.

23. Mirouze, M., Sels, J., Richard, O., Czernic, P., Loubet, S., Jacquier, A., Francois, I. E. J. A.,Cammue, B. P. A., Lebrun, M., Berthomieu, P., and Marques, L. (2006) A putative novel role forplant defensins: a defensin from the zinc hyper-accumulating plant, Arabidopsis halleri, confers zinctolerance. Plant J. 47, 329-342.

24. Osborn, R. W., De Samblanx, G. W., Thevissen, K., Goderis, I., Torrekens, S., Van Leuven, F.,Attenborough, S., Rees, S. B., and Broekaert, W. F. (1995) Isolation and characterisation of 
plantdefensins from seeds of Asteraceae, Fabaceae, Hippocastanaceae and Saxifragaceae. FEBS Lett.368, 257-62.

25. Park, C. J., Park, C. B., Hong, S. S., Lee, H. S., Lee, S. Y., and Kim, S. C. (2000)Characterization and cDNA cloning of two glycine- and histidine-rich antimicrobial peptides fromthe roots of shepherd's purse, Capsella bursa-pastoris. Plant Mol. Biol. 44, 18797.

26. Pitta, M. G. D., and Galdino, S. L. (2010) Development of Novel Therapeutic Drugs in Humansfrom Plant Antimicrobial Peptides. Curr. Protein Pept. Sci. 11, 236-247.

27. Sheikh, A. H., Raghuram, B., Jalmi, S. K., Wankhede, D. P., Singh, P., and Sinha, A. K.

28. (2013)Interaction between two rice mitogen activated protein kinases BMC Plant Biol. $13,121$.

29. Shiu, S. H., and Bleecker, A. B. (2001) Plant receptor-like kinase gene family: diversity,function, and signaling. Sci. STKE 2001, re22.

30. Song, J., Gilquin, B., Jamin, N., Drakopoulou, E., Guenneugues, M., Dauplais, M., Vita, C., and Menez, A. (1997) NMR solution structure of a two-disulfide derivative of charybdotoxin:structural evidence for conservation of scorpion toxin alpha/beta motif and its hydrophobic sidechain packing. Biochemistry 36, 3760-3766.

31. Spelbrink, R. G., Dilmac, N., Allen, A., Smith, T. J., Shah, D. M., and Hockerman, G. H.(2004) Differential antifungal and calcium channel-blocking activity among structurally relatedplant defensins. Plant Physiol. 135, 2055-2067.

32. Stotz, H. U., Thomson, J. G., and Wang, Y. (2009) Plant defensins: defense, development and application. Plant Signal Behav 4, 1010-1012.

33. Terras, F. R., Eggermont, K., Kovaleva, V., Raikhel, N. V, Osborn, R. W., Kester, A., Rees, S.B., Torrekens, S., Van Leuven, F., and Vanderleyden, J. (1995) Small cysteine-rich antifungal proteins from radish: their role in host defense. Plant Cell 7, 573-88.

34. Thevissen, K., Warnecke, D. C., Francois, E. J. A., Leipelt, M., Heinz, E., Ott, C., Zahringer,U., Thomma, B. P. H. J., Ferkel, K. K. A., and Cammue, B. P. A. (2004) Defensins from insects andplants interact with fungal glucosylceramides. J. Biol. Chem. 279, 39003905 .

35. Thomma, B. P., Cammue, B. P., and Thevissen, K. (2002) Plant defensins. Planta 216, 193202.Tsien, R. W., and Tsien, R. Y. (1990) Calcium channels, stores, and oscillations. Annu Rev CellBiol 6, 715-760.

36. Van der Weerden, N. L., Hancock, R. E. W., and Anderson, M. A. (2010) Permeabilization of Fungal Hyphae by the Plant Defensin NaD1 Occurs through a Cell Wall-dependent Process. J. Biol.Chem. 285, 37513-37520.

37. Wijaya, R., Neumann, G. M., Condron, R., Hughes, A. B., and Polya, G. M. (2000) Defenseproteins from seed of Cassia fistula include a lipid transfer protein homologue and a proteaseinhibitory plant defensin. Plant Sci. 159, 243-255.

\subsection{2. ом606j8ం}

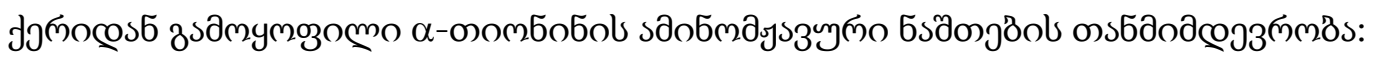
Lys-Ser-Cys-Cys-Arg-Ser-Thr-Leu-Gly-Arg-Asn-Cys-Tyr-Asn-Leu-Cys-Arg-Val-Arg-Gly-Ala-GlnLys-Leu-Cys-Ala-Gly-Val-Cys-Arg-Cys-Lys-Leu-Thr-Ser-Ser-Gly-Lys-Cys-Pro-Thr-Gly-Pro-Pro-Lys.

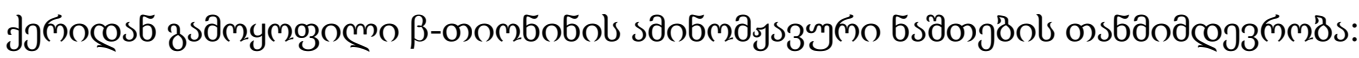


Lys-Ser-Cys-Cys-Arg-Ser-Thr-Leu-Gly-Arg-Asn-Cys-Tyr-Asn-Leu-Cys-Arg-Val-Arg-Gly-Ala-GlnLys-Ile-Cys-Ala-His-Ala-Cys-Arg-Cys-Lys-Leu-Thr-Ser-Gly-Leu-Ser-Cys-Pro-Lys-Gly-Pro-Pro-Lys.

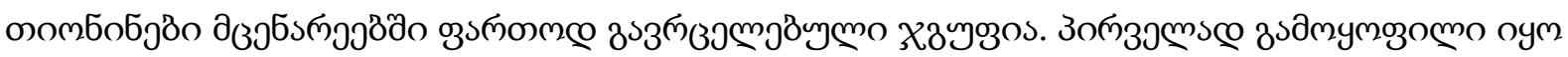

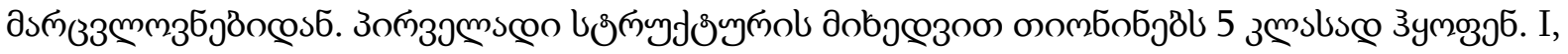

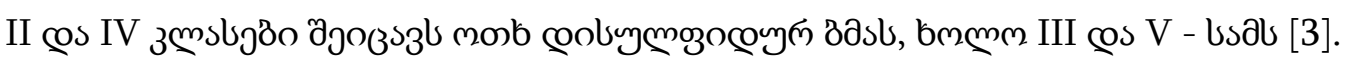

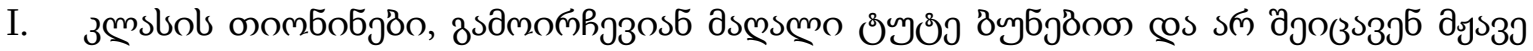

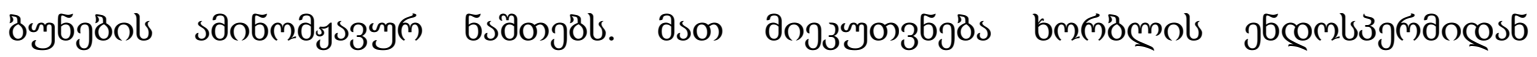
зsдмумозомп зйпмоомбобо.

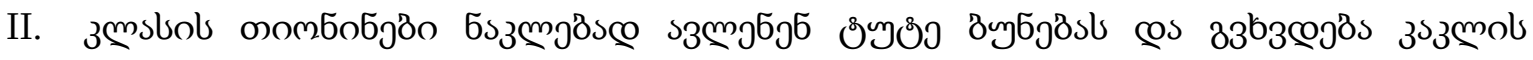

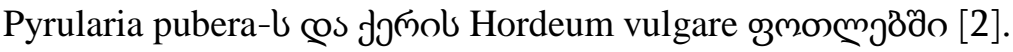

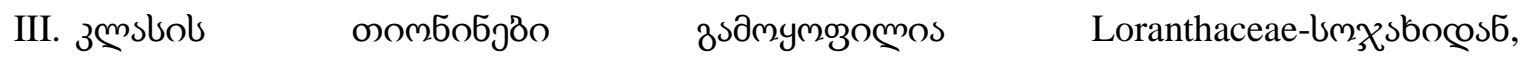

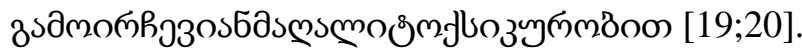

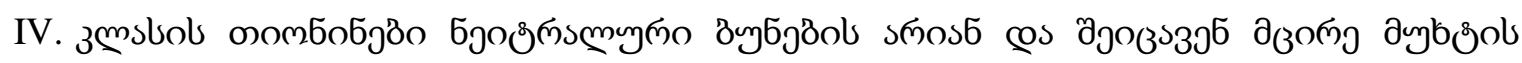

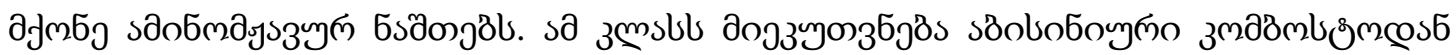
(Crambe hispanica) zsamymozomo зйsавобо [17;18].

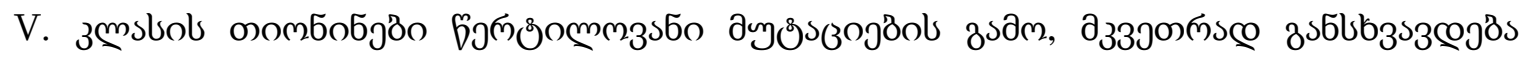

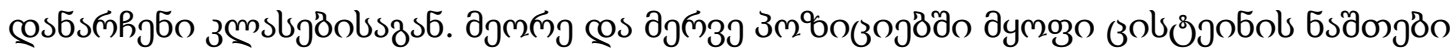

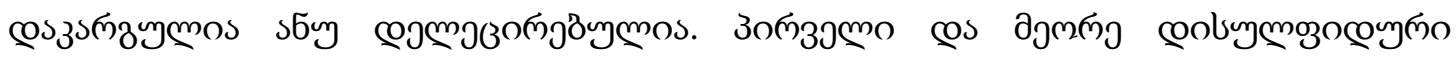

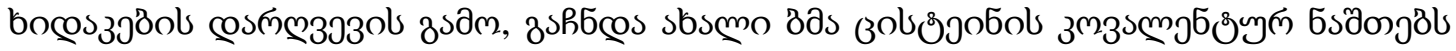

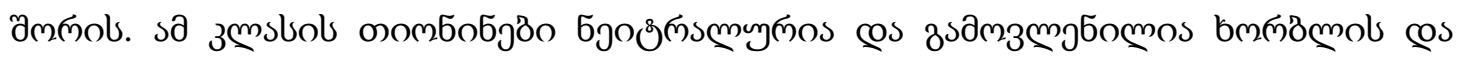

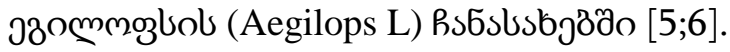

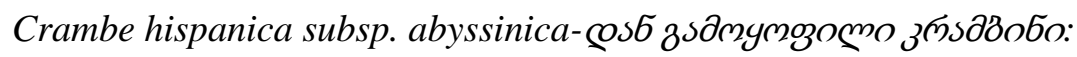

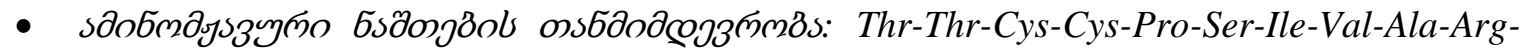
Ser-Asn-Phe-Asn-Val-Cys-Arg-Leu-Pro-Gly-Thr-Pro-Glu-Ala-Ile-Cys-Ala-Thr-Tyr-Gly-CysIle-Ile-Ile-Ile-Pro-Gly-Ala-Thr-Cys-Pro-Gly-Asp-Tyr-Ala-Asn

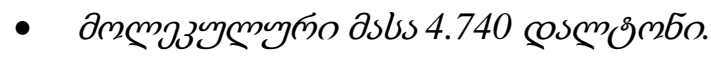

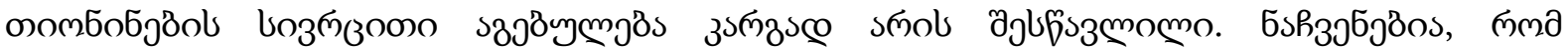

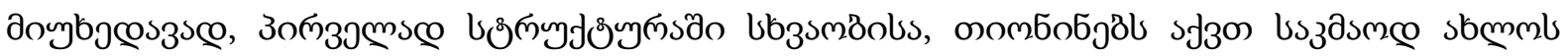

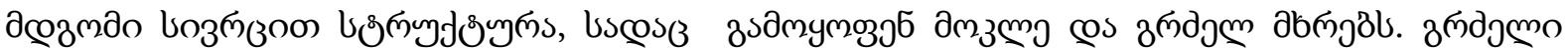

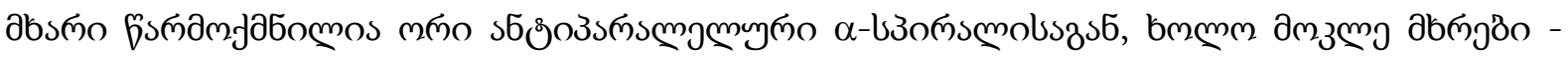

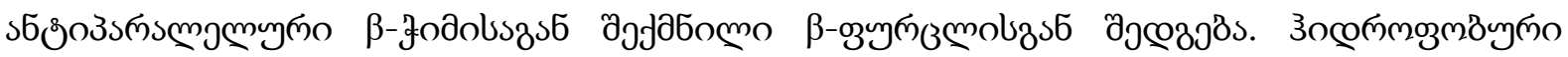

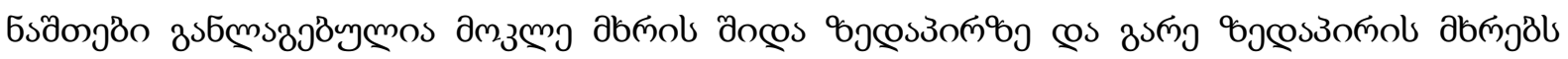

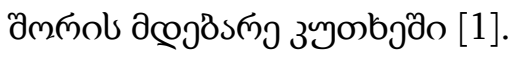

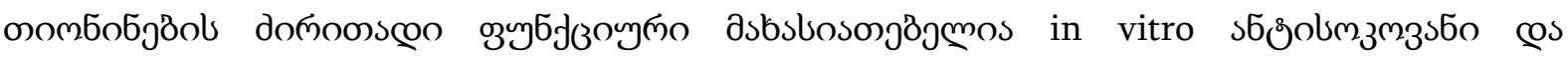

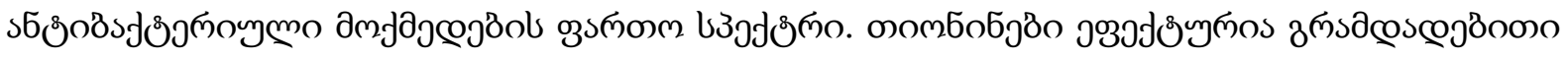

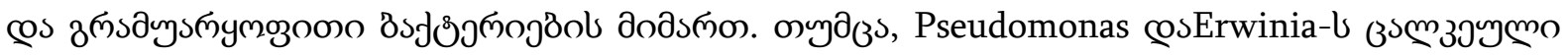

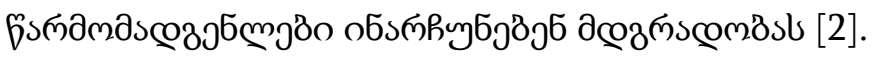

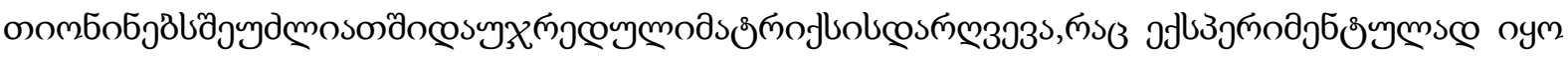

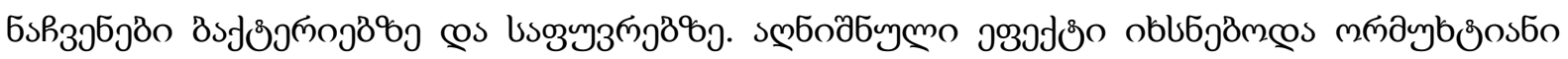

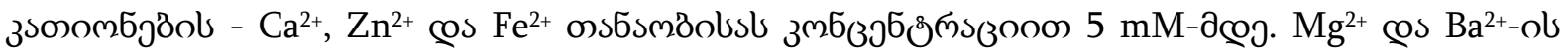




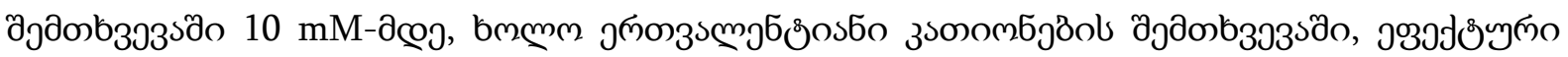

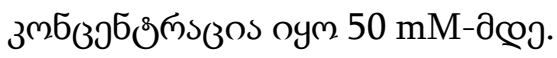

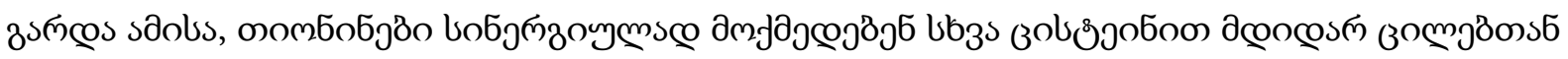

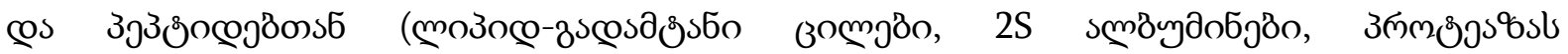

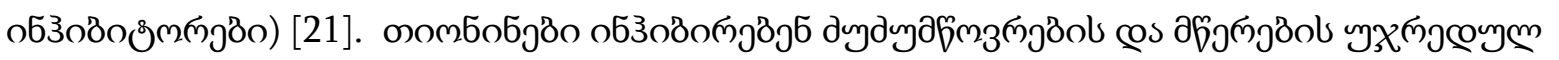
cos ప абрб

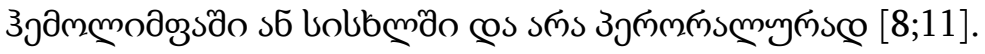

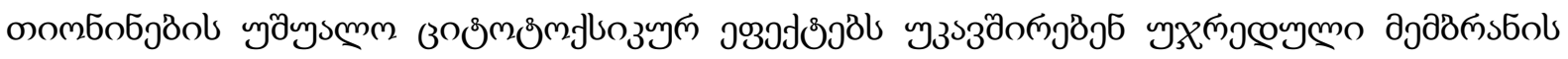

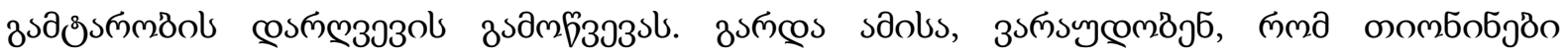

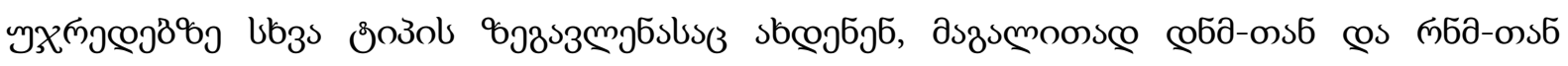

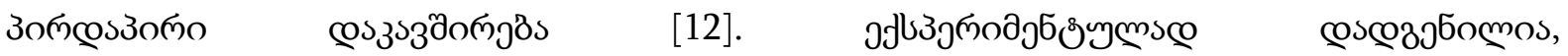

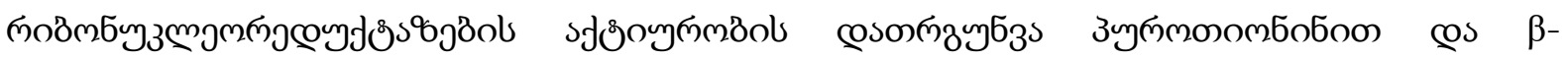

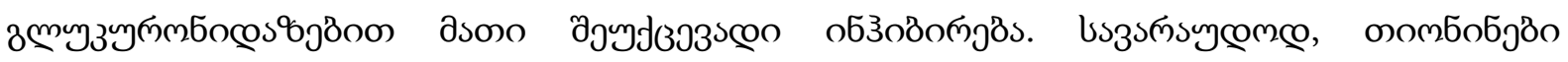

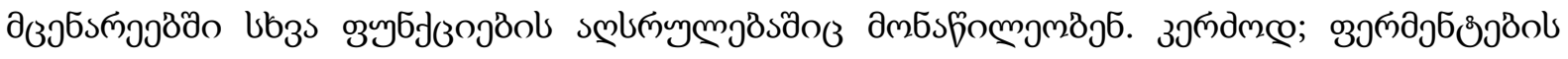

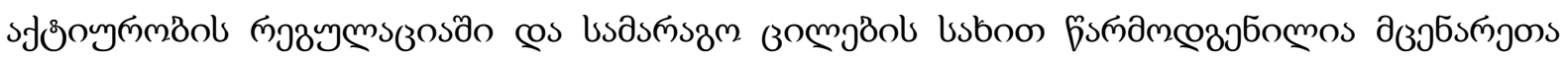
ojlemgzðo [7].

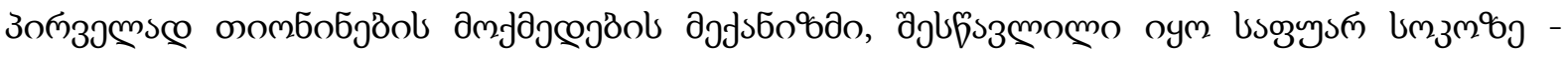

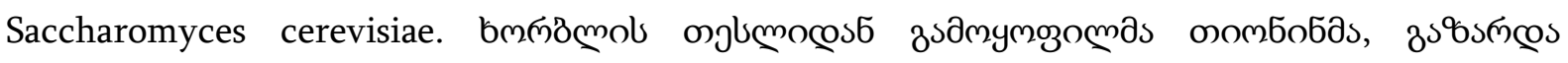

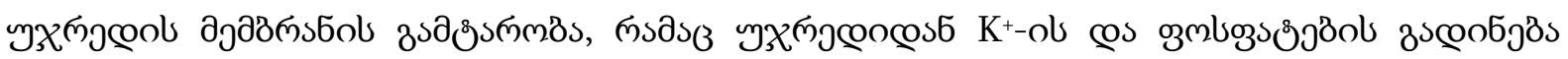

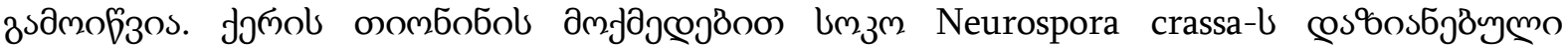

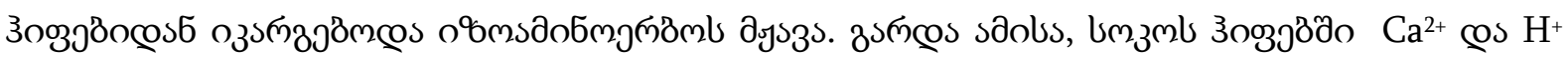

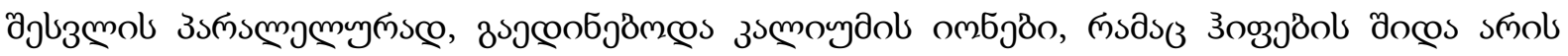

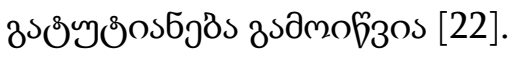

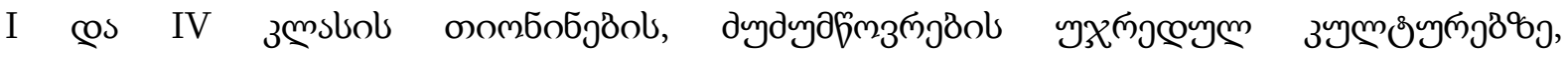

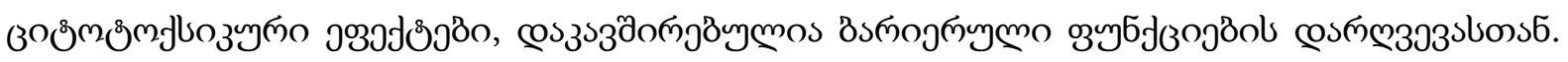

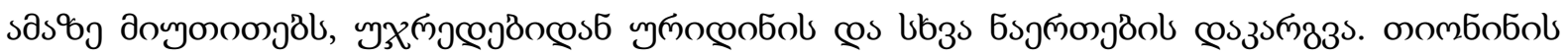

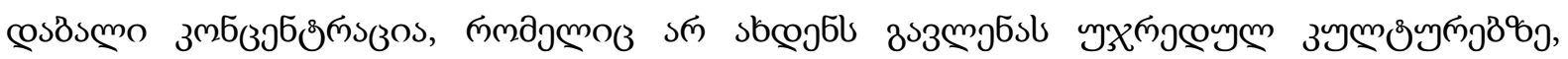

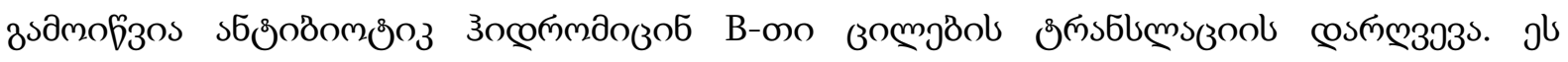

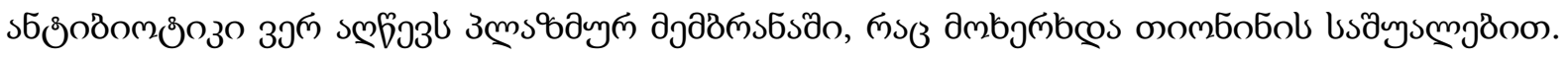

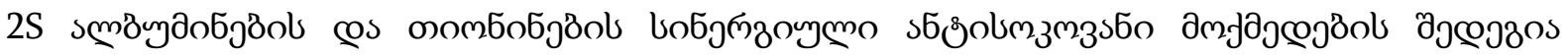

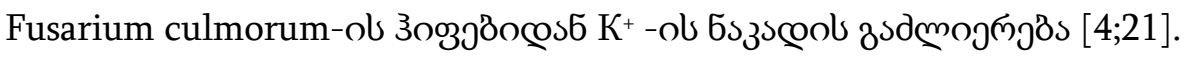

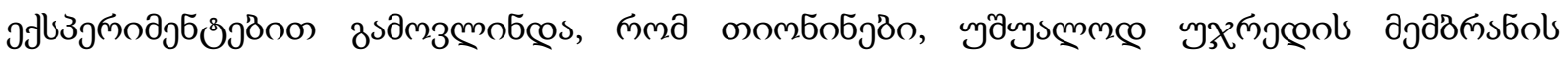

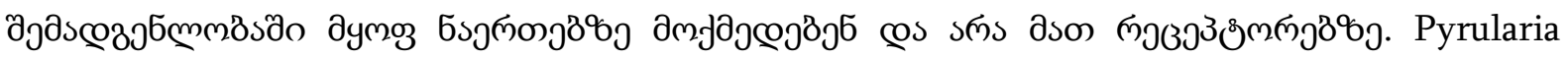

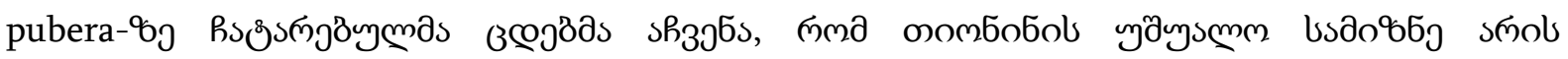

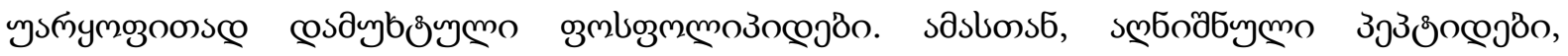

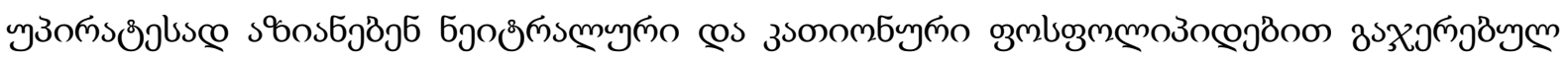

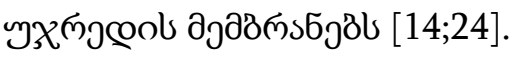

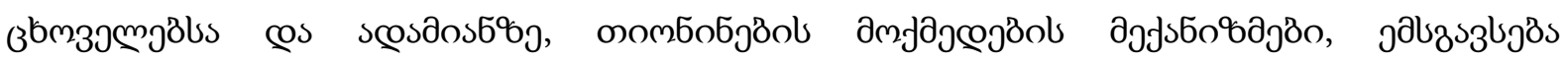

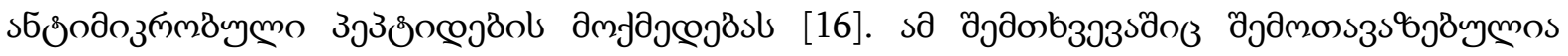

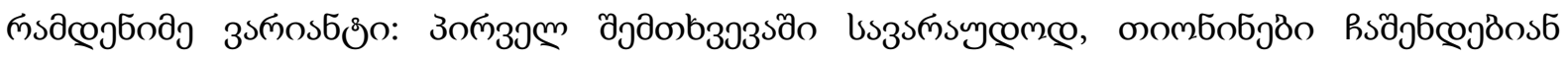

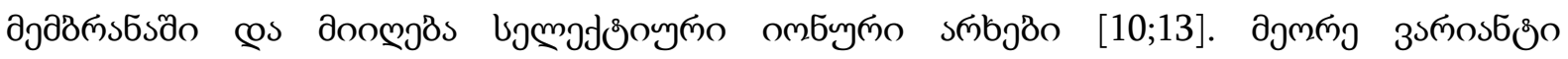




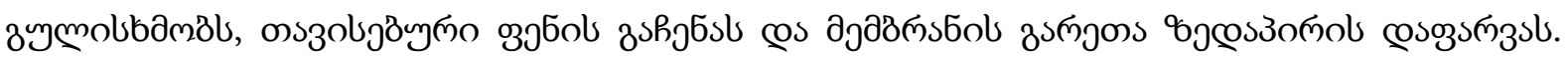

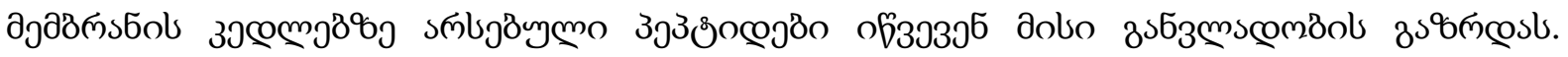

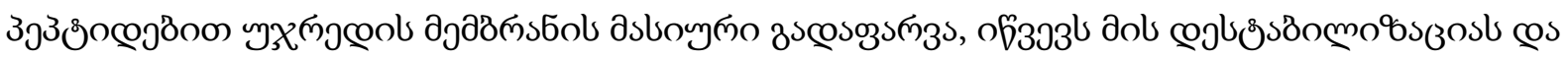

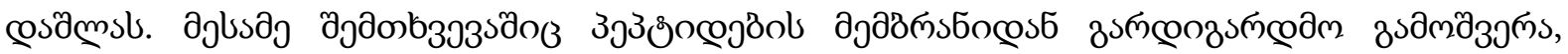

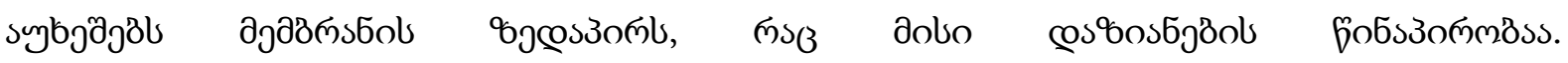

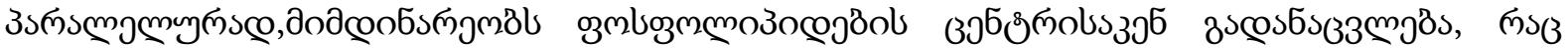

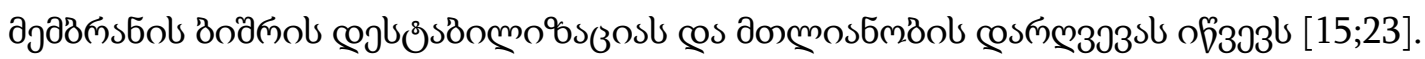

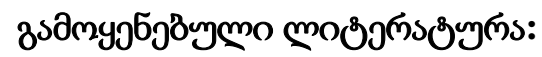

1. Bohlmann, H., and Apel, K. (1987) Isolation and Characterization of Cdnas Coding for LeafSpecific Thionins Closely Related to the Endosperm-Specific Hordothionin of Barley (Hordeum-Vulgare-L). Mol. Gen. Genet. 207, 446-454.

2. Bohlmann, H., Clausen, S., Behnke, S., Giese, H., Hiller, C., Reimann-Philipp, U., Schrader,G., Barkholt, V., and Apel, K. (1988) Leaf-specific thionins of barley-a novel class of cell wallproteins toxic to plant-pathogenic fungi and possibly involved in the defence mechanism of plants.Embo J 7, 1559-1565.

3. Broekaert, W. F., Cammue, B. P. A., De Bolle, M. F. C., Thevissen, K., De Samblanx, G. W., and Osborn, R.W. (1997) Antimicrobial peptides from plants. Crit. Rev. Plant Sci.16, $297-$ 323.

4. Broekaert, W. F. (1993) Synergistic Enhancement of the Antifungal Activity of Wheat and BarleyThionins by Radish and Oilseed Rape 2S Albumins and by Barley Trypsin Inhibitors. Plant Physiol103, 1311-1319.

5. Castagnaro, A., Marana, C., Carbonero, P., and Garciaolmedo, F. (1992) Extreme Divergenceof a Novel Wheat Thionin Generated by a Mutational Burst Specifically Affecting the MatureProtein Domain of the Precursor. J. Mol. Biol. 224, 1003-1009.

6. Castagnaro, A., Segura, A., and Garciaolmedo, F. (1995) High Conservation among SequencesEncoding Type-V Thionins in Wheat and Aegilops. Plant Physiol. 107, 1475-1476.

7. Castro, M. S., and Fontes, W. (2005) Plant defense and antimicrobial peptides. Protein PeptLett 12, 13-18.

8. Evett, G. E., Donaldson, D. M., and Vernon, L. P. (1986) Biological properties of Pyrularia thionin prepared from nuts of Pyrularia pubera. Toxicon 24, 622-625.

9. Florack, D. E., and Stiekema, W. J. (1994) Thionins: properties, possible biological roles andmechanisms of action. Plant Mol Biol 26, 25-37.

10. Hughes, P., Dennis, E., Whitecross, M., Llewellyn, D., and Gage, P. (2000) The cytotoxic plant protein, beta-purothionin, forms ion channels in lipid membranes. J Biol Chem 275, 823-827.

11. Kramer, K. J., Klassen, L. W., Jones, B. L., Speirs, R. D., and Kammer, A. E. (1979) Toxicityof purothionin and its homologues to the tobacco hornworm, Manduca sexta (L.) (Lepidoptera:Sphingidae). Toxicol Appl Pharmacol 48, 179-183.

12. Li, S. S., Gullbo, J., Lindholm, P., Larsson, R., Thunberg, E., Samuelsson, G., Bohlin, L., andClaeson, P. (2002) Ligatoxin B, a new cytotoxic protein with a novel helix-turn-helix DNA-bindingdomain from the mistletoe Phoradendron liga. Biochem. J. 366, 405-413.

13. Llanos, P., Henriquez, M., Minic, J., Elmorjani, K., Marion, D., Riquelme, G., Molgo, J., and Benoit, E. (2004) Neuronal and muscular alterations caused by two wheat endosperm 
proteins, puroindoline-a and alpha1-purothionin, are due to ion pore formation. Eur Biophys $\mathbf{J}$ 33, 283-284.

14. Richard, J. A., Kelly, I., Marion, D., Auger, M., and Pezolet, M. (2005) Structure of betapurothionin in membranes: a two-dimensional infrared correlation spectroscopy study. Biochemistry 44, 52-61.

15. Richard, J. A., Kelly, I., Marion, D., Pezolet, M., and Auger, M. (2002) Interaction between beta-Purothionin and dimyristoylphosphatidylglycerol: a (31)P-NMR and infrared spectroscopic study. Biophys J 83, 2074-2083.

16. Sauviat, M. P. (1990) Effect of Phoratoxin-B, a Toxin Isolated from Mistletoe, on FrogSkeletal-Muscle Fibers. Toxicon 28, 83-89.

17. Schmidt, A., Teeter, M., Weckert, E., and Lamzin, V. S. (2011) Crystal structure of small protein crambin at $0.48 \AA$ resolution. Acta Crystallogr. Sect. F. Struct. Biol. Cryst. Commun. 67,424-8.

18. Schraderfischer, G., and Apel, K. (1994) Organ-Specific Expression of Highly Divergent Thionin Variants That Are Distinct from the Seed-Specific Crambin in the Crucifer CrambeAbyssinica. Mol. Gen. Genet. 245, 380-389.

19. Stein, G. M., Bussing, A., Schaller, G., Pfuller, U., and Schietzel, M. (1998) Thionins frommistletoe: Viscotoxin-associated effects on human granulocytes. Ann. Oncol. 9, 87.

20. Stein, G. M., Pfuller, U., and Schietzel, M. (1999) Viscotoxin-free aqueous extracts from European mistletoe (Viscum album L.) stimulate activity of human granulocytes. Anticancer Res.19, 2925-2928.

21. Terras, F., Schoofs, H., Thevissen, K., Osborn, R. W., Vanderleyden, J., Cammue, B., andBroekaert, W. F. (1993) Synergistic Enhancement of the Antifungal Activity of Wheat and Barley Thionins by Radish and Oilseed Rape $2 \mathrm{~S}$ Albumins and by Barley Trypsin Inhibitors. Plant Physiol 103, 1311-1319.

22. Thevissen, K., Ghazi, A., De Samblanx, G. W., Brownlee, C., Osborn, R. W., and Broekaert, W. F. (1996) Fungal membrane responses induced by plant defensins and thionins. J. Biol. Chem. 271, 15018-25.

23. Thevissen, K., Terras, F. R., and Broekaert, W. F. (1999) Permeabilization of fungal membranes by plant defensins inhibits fungal growth. Appl Env. Microbiol 65, 5451-5458.

24. Wang, F., Naisbitt, G. H., Vernon, L. P., and Glaser, M. (1993) Pyrularia thionin binding to and the role of tryptophan- 8 in the enhancement of phosphatidylserine domains in erythrocytemembranes. Biochemistry 32, 12283-12289.

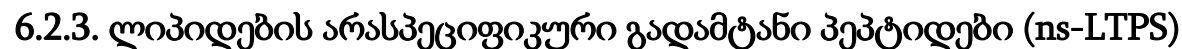

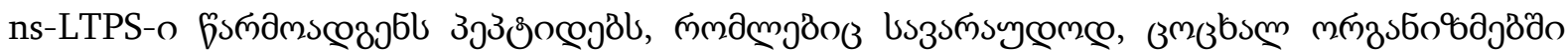

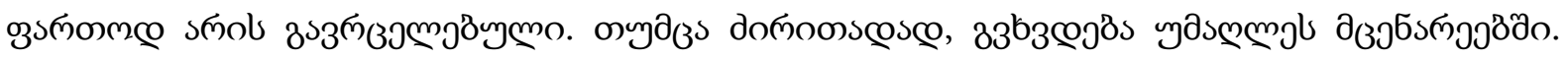

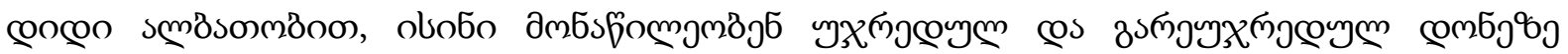

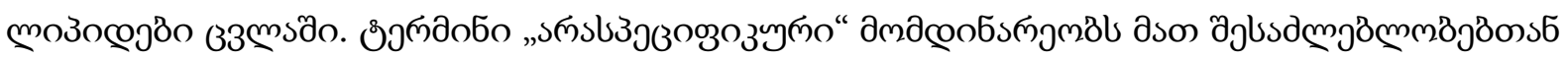

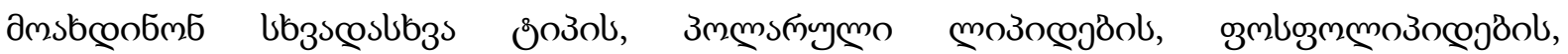

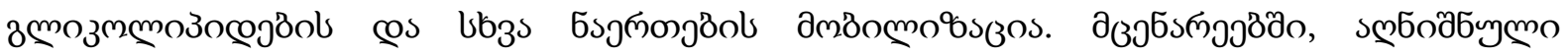

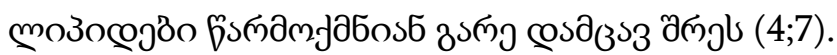

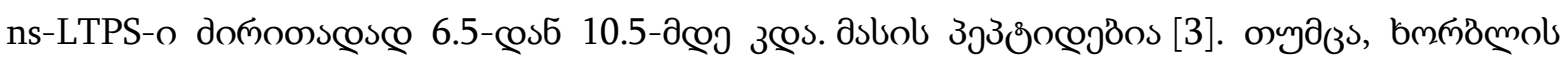




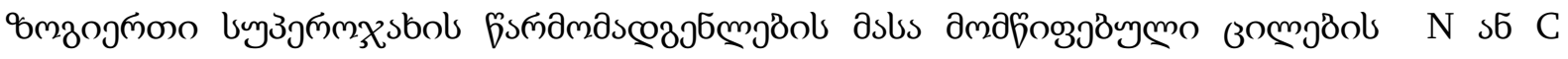

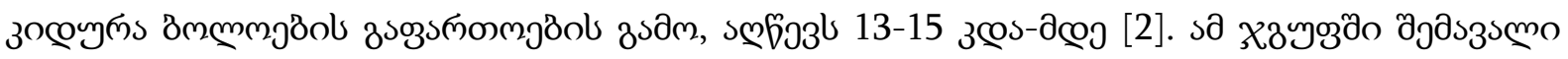

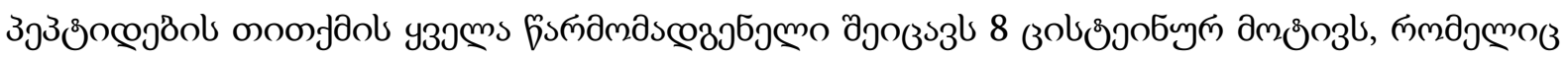

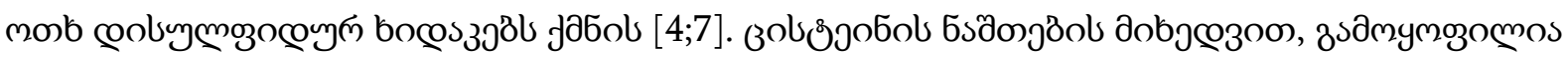

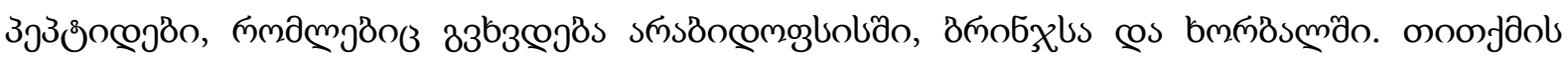

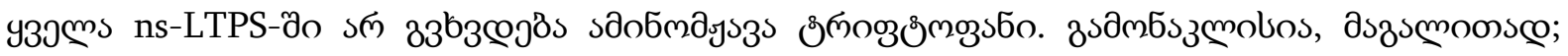

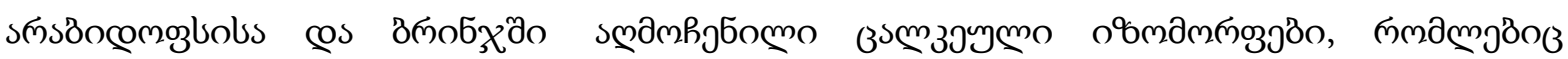

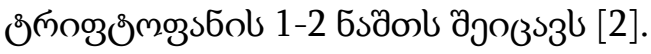

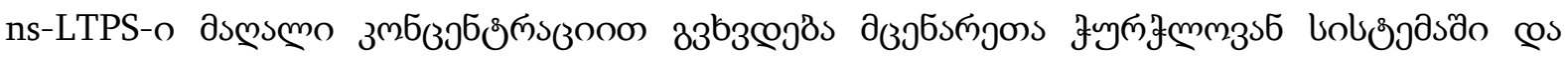

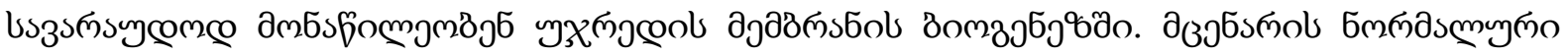

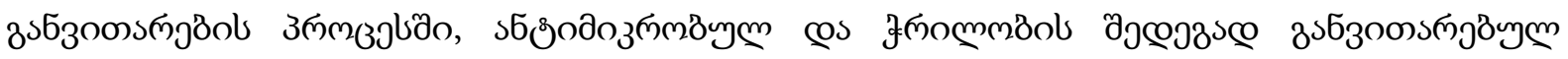

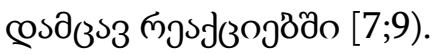

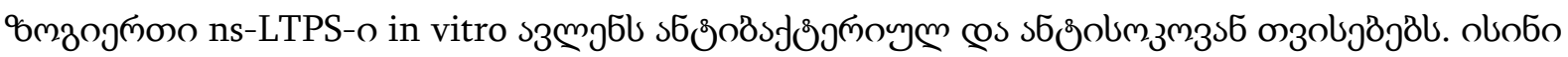

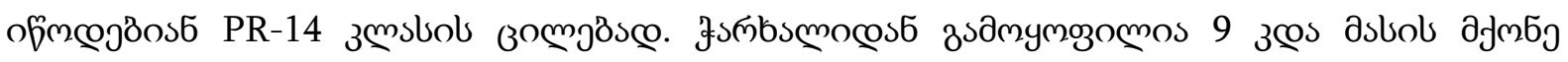

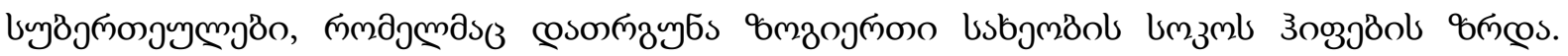

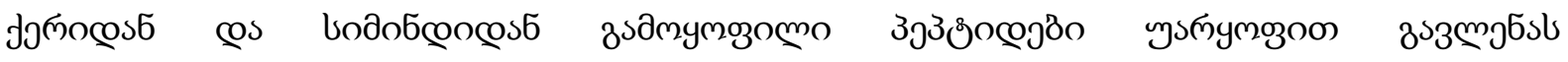

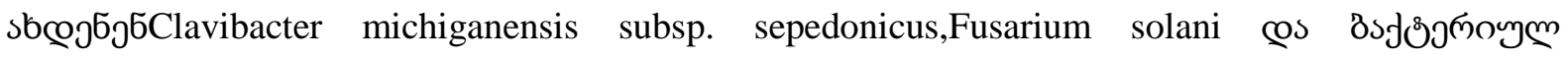
3sоm 39 6\% Pseudomonas solanacearum [12;15;16].

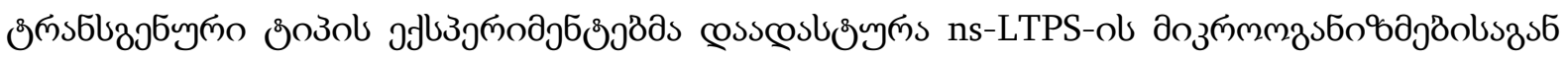

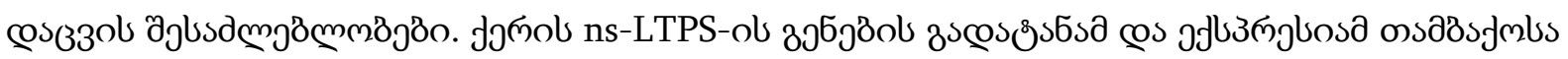

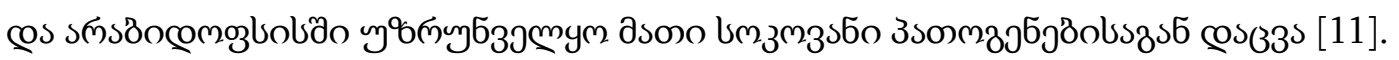

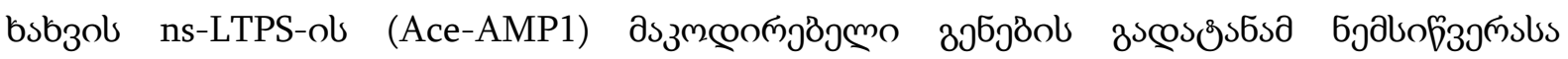

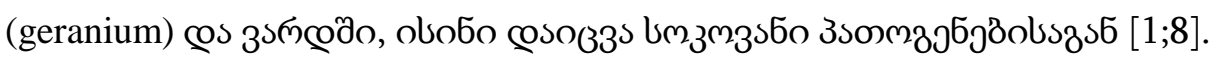

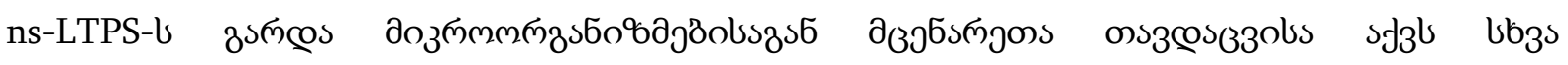

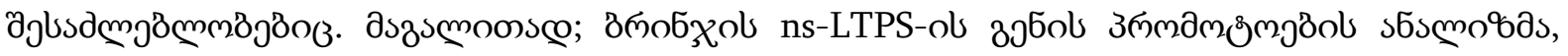

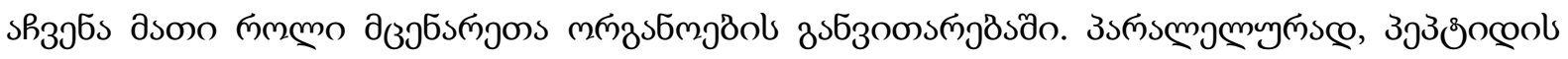

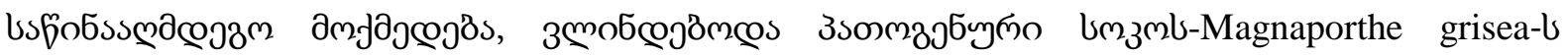
дodsmon [5].

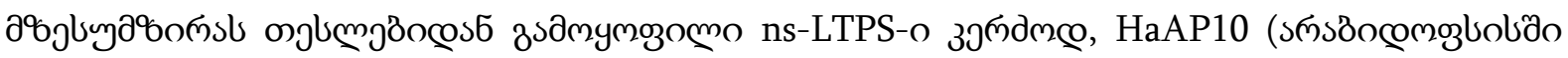

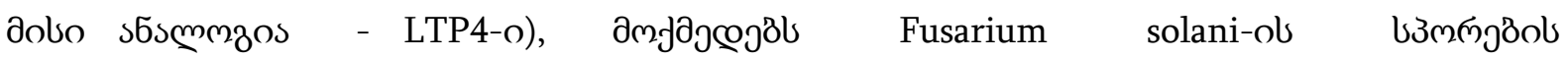

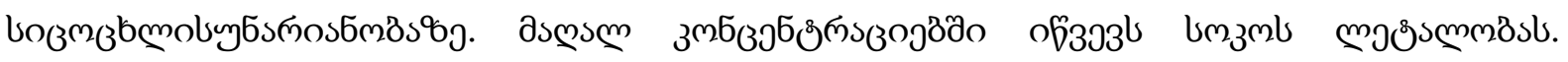

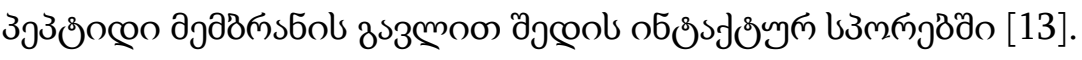

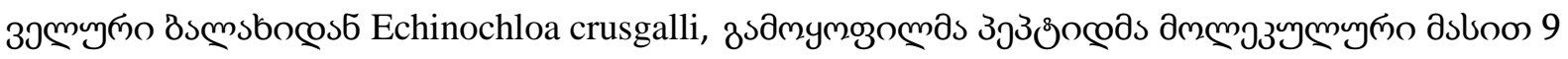

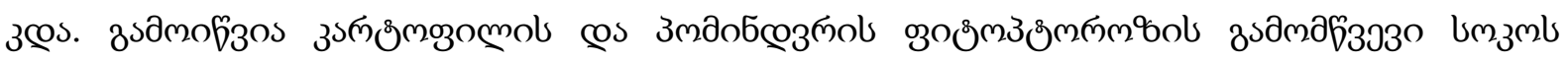

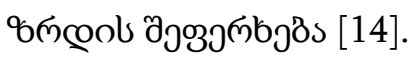

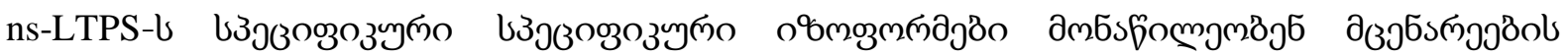

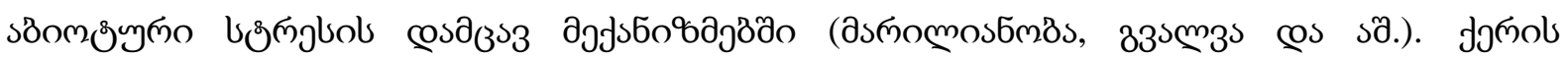

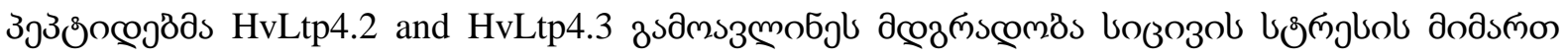
[4;10].

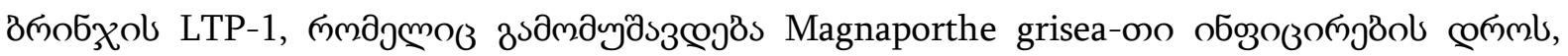

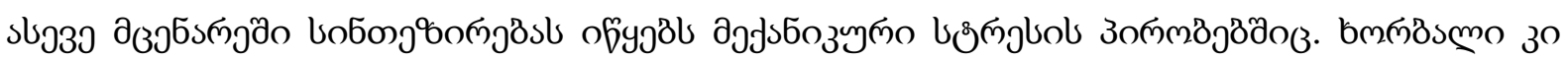

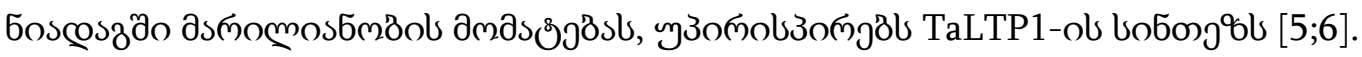




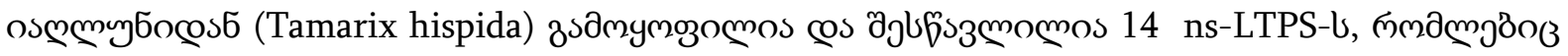

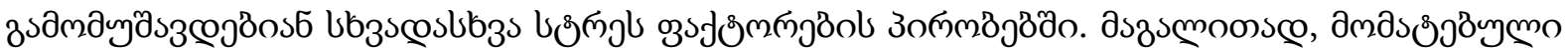

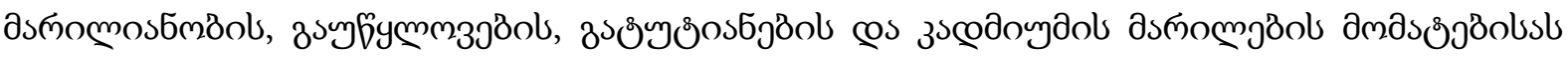
[17].

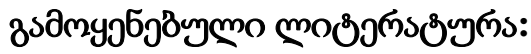

1. Bi Y-M, Cammue BPA, Goodwin PH, Krishna Raj S, Saxena PK (1999) Resistance to Botrytis cinerea in scented geraniumtransformed with a gene encoding the antimicrobial protein Ace-AMP1. Plant Cell Rep (1999) 18: 835-840.

2. Boutrot F, Chantret N, Gautier MF (2008) Genome-wide analysis of the rice and Arabidopsis non-specific lipid transferprotein (nsLtp) gene families and identification of wheat nsLtp genes by EST data mining. BMC Genomics 9: 86.

3. Douliez JP, Michon T, Elmorajani K, Marion D (2000) Structure, biological and technological functions of lipid transfer proteins and indolines, the major lipid binding proteins from cereal kernels. J Cereal Sci 32: 1-20.

4. Garcia-Olmedo F, Molina A, Alamillo J, Rodriguez-Palenzuela P (1998) Plant defence peptides. Biopolymers 47: 479-491.

5. Guiderdoni E, Cordero MJ, Vignols F, Garcia-Garrido JM, Lescot M, Tharreau D, Meynard D, Ferriere N, Notteghem JL, Delseny M (2002) Inducibility by pathogen attack and developmental regulation of the rice Ltp1 gene. Plant Mol Biol 49: 683-699.

6. Jang CS, Lee HI, Chang SI, Seo YW (2004) Expression and promoter analysis of the TaLTP1 gene induced by drought and salt stress in wheat(Triticum aestivum L).Plant Sci 2004: 9951001.

7. Kader JC (1996) Lipid-transfer proteins in plants. Annu Rev Plant Physiol Plant Mol Biol 47: 627-654.

8. Li X, Gasic K, Cammue B, Broekaert W, Korban SS (2003) Transgenic rose lines harboring an antimicrobial protein gene, Ace-AMP1, demonstrate enhanced resistance to powdery mildew (Sphaerotheca pannosa) Planta 218: 226-232.

9. Marion D, Bakan B, Elmorjani K (2007) Plant lipid binding proteins: properties and applications. Biotech Adv 25: 195-197.

10. Molina A, Diaz I, Vasil I, Carbonero P, Garcia-Oimedo F (1996) Two cold-inducible genes encoding lipid transfer protein LTP4 from barley show differential responses to bacterial pathogens. Mol Gen Genet 252: 162-168.

11. Molina A, Garcia-Olmedo F (1997) Enhanced tolerance to bacterial pathogens caused by the transgenic expression of barley lipid transfer protein LTP2. Plant J 12: 669-675.

12. Molina A, Segura A, García-Olmedo F (1993) Lipid transfer proteins (nsLTPs) from barley and maize leaves are potent inhibitors of bacterial and fungal plant pathogens. FEBS Lett 316: 119-122.

13. Regente MC, Giudici AM, Villalain JL, de la Canal L (2005) The cytotoxic properties of a plant lipid transfer protein involve membrane permeabilization of target cells. Lett Applied Microbiol 40: 183-189.

14. Rogozhin EA, Odintsova TI, Musolyamov, A, Smirnov AN, Babakov AV, Egorov TA, Grishin EV (2009) Purification and characterization of a novel lipid transfer protein from caryopsis of barnyard Grass (Echinochloa crusgalli). Appl Biochem Microbiol 45: 363-368. 
15. Terras FRG, Goderis IJ, Van Leuven F, Vanderleyden J, Cammue BPA, Broekaert WF (1992) In vitro antifungal activity of a radish (Raphanus sativus L.) seed protein homologous to nonspecific lipid transfer proteins. Plant Physiol 100: 1055-1058.

16. Velazhahan R, Radhajayalakshmi R, Thangavelu R, Muthukrishnan S (2001) An antifungal protein purified from pearl millet seeds shows sequence homology to lipid transfer proteins Physiol Plant 4: 417-421.

17. Wang C, Yang C, Gao C, Wang Y (2009) Cloning and expression analysis of 14 lipid transfer protein genes from Tamarix hispida responding to different abiotic stresses. Tree Physiol 29: $1607-1619$.

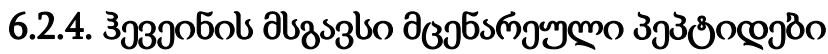

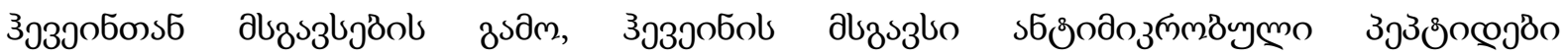

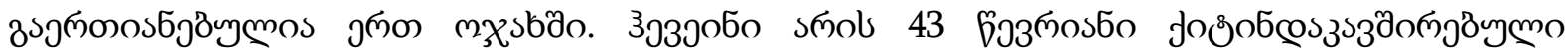

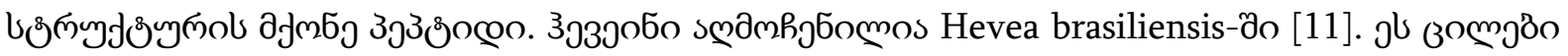

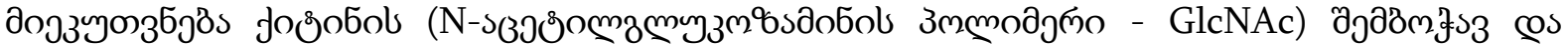

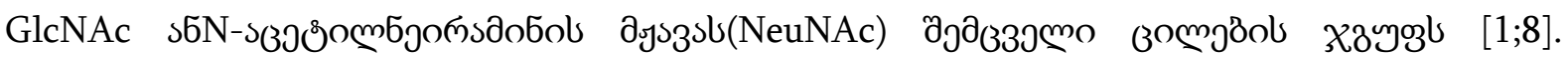

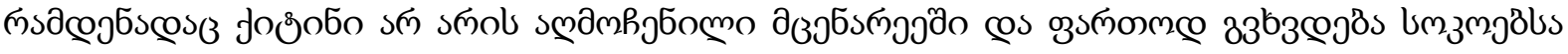

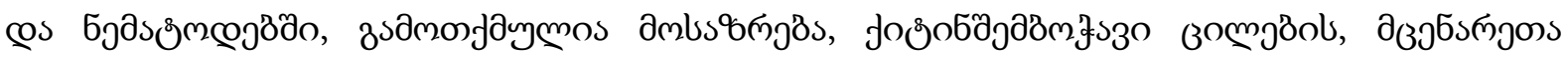

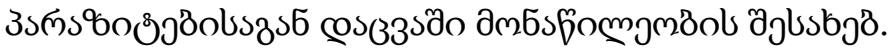

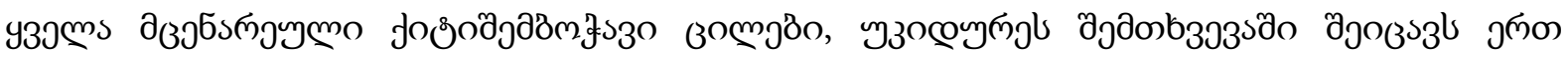

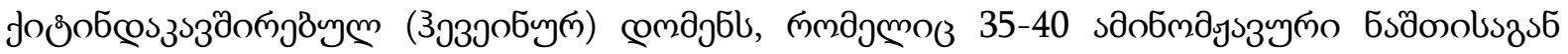

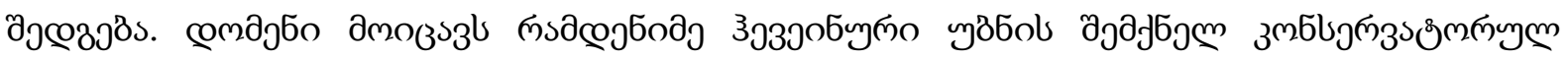

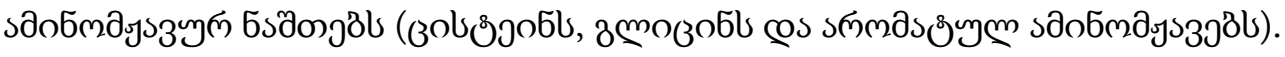

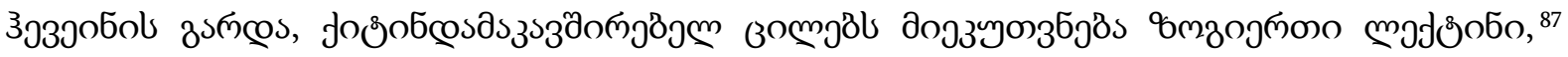

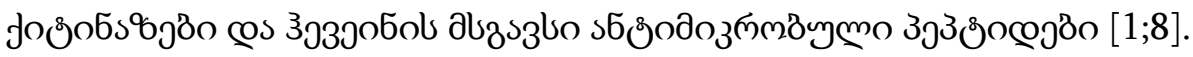

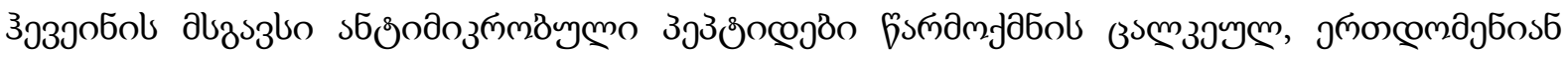

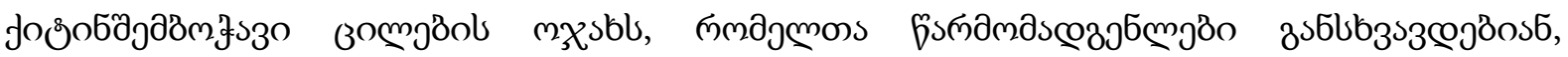

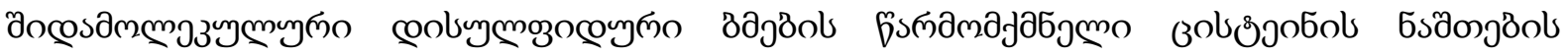

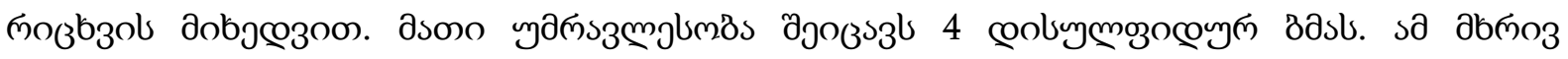

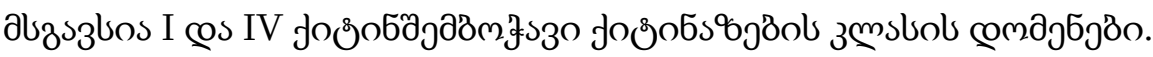

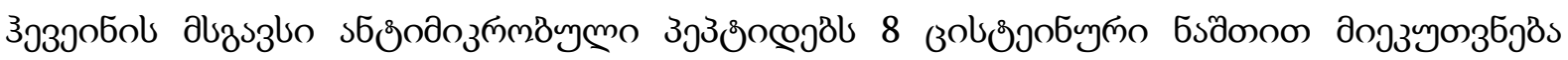

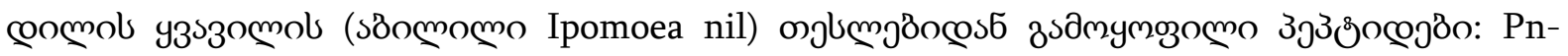

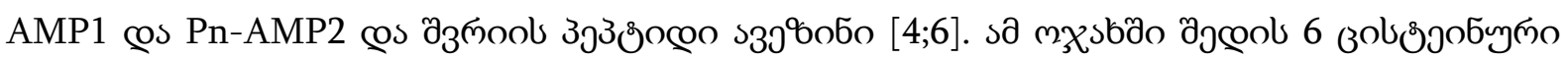

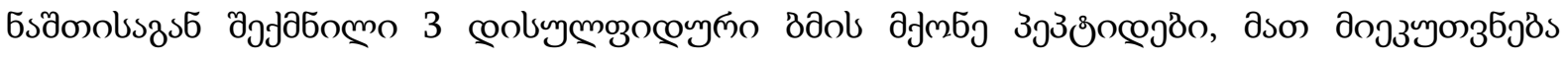

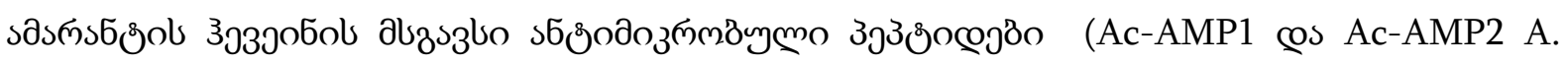
Caudatus-ol oglumgßoọs6 [2]; Ay-AMP -A. Hypochondriacus-@os6 [9] @s Ar-AMP - A.

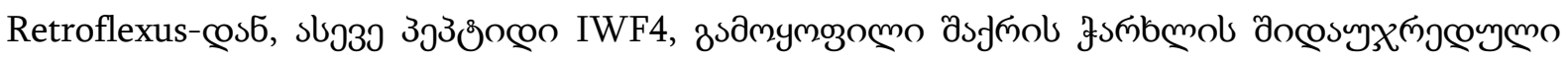

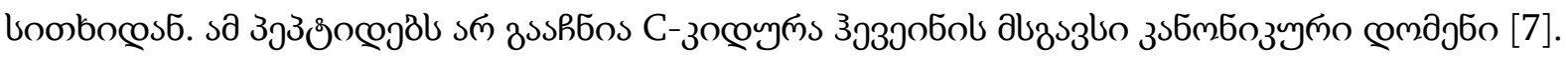

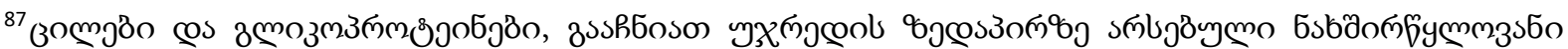

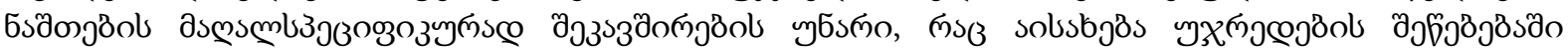

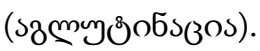




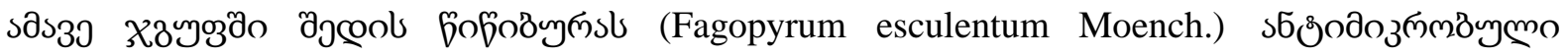

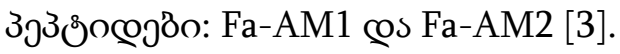

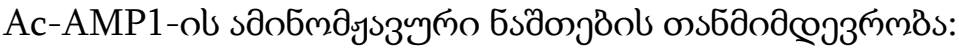

- Val-Gly-Glu-Cys-Val-Arg-Gly-Arg-Cys-Pro-Ser-Gly-Met-Cys-Cys-Ser-Gln-Phe-GlyTyr-Cys-Gly-Lis-Gly-Phe-Lys-Tyr-Cys-Gly

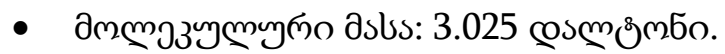

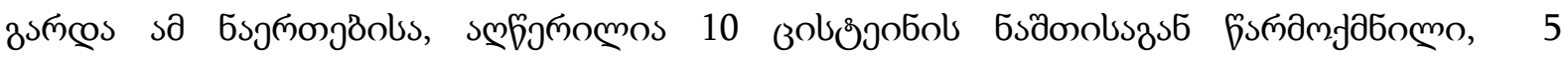

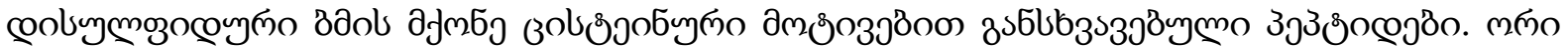
asongsбo zsдmymozomos bja

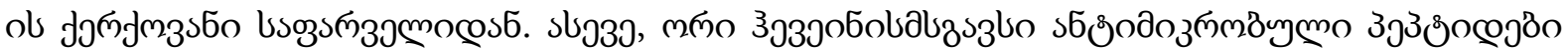

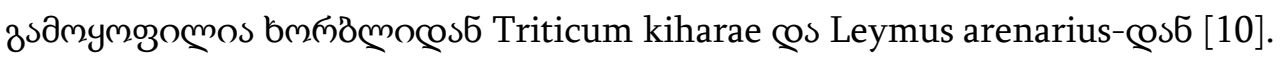

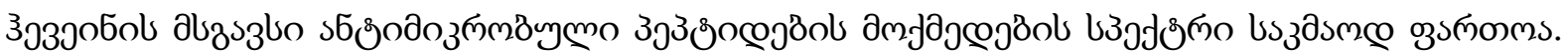

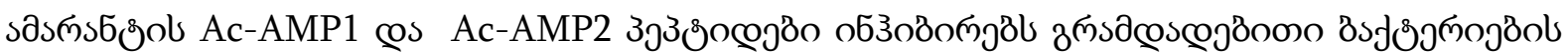

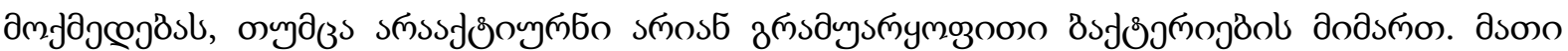

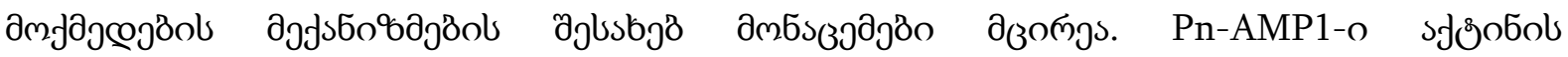

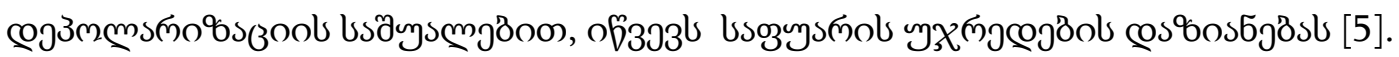

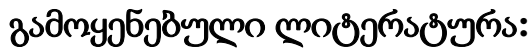

1. Beintema, J. J. (1994) Structural Features of Plant Chitinases and Chitin-Binding Proteins.Febs Lett. 350, 159-163.

2. Broekaert, W. F., Marien, W., Terras, F. R. G., Debolle, M. F. C., Proost, P., Vandamme, J.,Dillen, L., Claeys, M., Rees, S. B., Vanderleyden, J., and Cammue, B. P. A. (1992) Antimicrobial Peptides from Amaranthus-Caudatus Seeds with Sequence Homology to the Cysteine Glycine-Rich Domain of Chitin-Binding Proteins. Biochemistry 31, 4308-4314.

3. Fujimura, M., Minami, Y., Watanabe, K., and Tadera, K. (2003) Purification, characterization, and sequencing of a novel type of antimicrobial peptides, Fa-AMP1 and FaAMP2, from seeds of buckwheat (Fagopyrum esculentum Moench.), Biosci. Biotechnol. Biochem., 67, 1636-1642.

4. Koo, J. C., Lee, S. Y., Chun, H. J., Cheong, Y. H., Choi, J. S., Kawabata, S., Miyagi, M.,Tsunasawa, S., Ha, K. S., Bae, D. W., Han, C. D., Lee, B. L., and Cho, M. J. (1998) Two heveinhomologs isolated from the seed of Pharbitis nil L. exhibit potent antifungal activity. BiochimBiophys. Acta-Protein Struct. Mol. Enzymol. 1382, 80-90.

5. Koo, J. C., Lee, B., Young, M. E., Koo, S. C., Cooper, J. A., Baek, D., Lim, C. O., Lee, S. Y., Yun, D. J., and Cho, M. J. (2004) Pn-AMP1, a plant defense protein, induces actin depolarization in yeasts. Plant Cell Physiol. 45, 1669-1680.

6. Li, S. S., and Claeson, P. (2003) Cys/Gly-rich proteins with a putative single chitinbindingdomain from oat (Avena sativa) seeds. Phytochemistry 63, 249-255.

7. Nielsen, K. K., Nielsen, J. E., Madrid, S. M., and Mikkelsen, J. D. (1997) Characterization of a new antifungal chitin-binding peptide from sugar beet leaves. Plant Physiol. 113, 83-91.

8. Raikhel, N. V, Lee, H. I., and Broekaert, W. F. (1993) Structure and Function of ChitinBinding Proteins. Annu. Rev. Plant Physiol. Plant Mol. Biol. 44, 591-615. 
9. Rivillas-Acevedo, L. A., and Soriano-Garcia, M. (2007) Isolation and biochemical characterization of an antifungal peptide from Amaranthus hypochondriacus seeds. J. Agric. Food Chem. 55, 10156-10161.

10. Van den Bergh, K. P. B., Proost, P., Van Damme, J., Coosemans, J., Van Damme, E. J. M.,and Peumans, W. J. (2002) Five disulfide bridges stabilize a hevein-type antimicrobial peptide from the bark of spindle tree (Euonymus europaeus L.). Febs Lett. 530, 181-185.

11. Vanparijs, J., Broekaert, W. F., Goldstein, I. J., and Peumans, W. J. (1991) Hevein - an Antifungal Protein from Rubber-Tree (Hevea-Brasiliensis) Latex. Planta 183, 258-264.

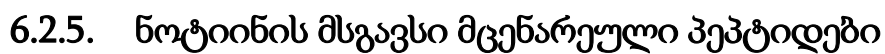

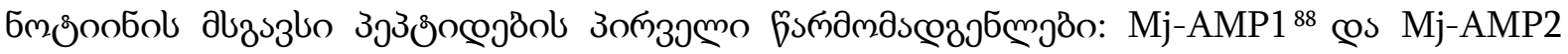

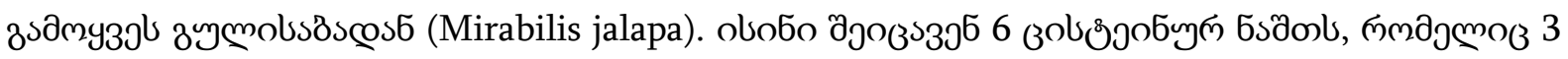

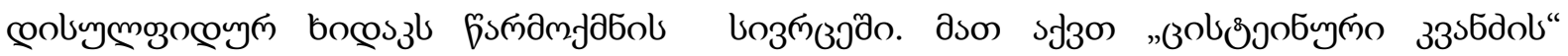

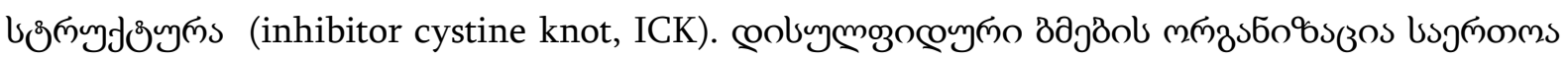
y39ms дm млзйmolsonzob: C1-C4, C2-C5, C3-C6 [2].

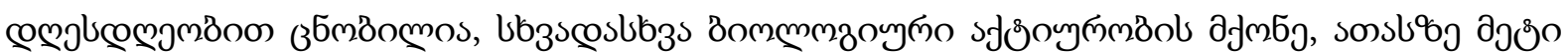

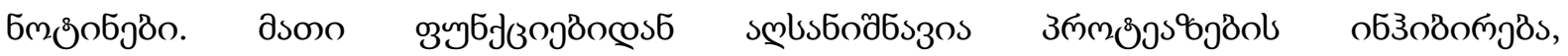

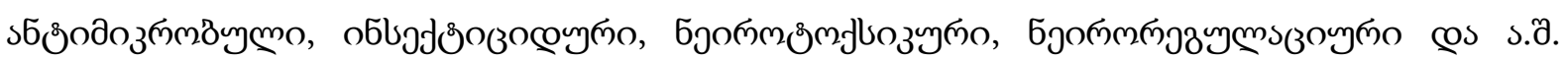

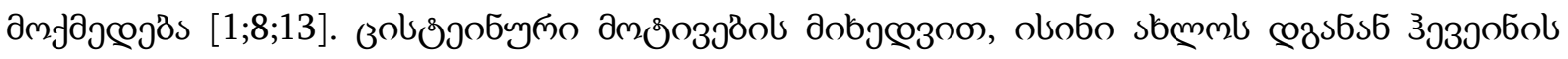

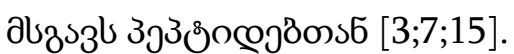

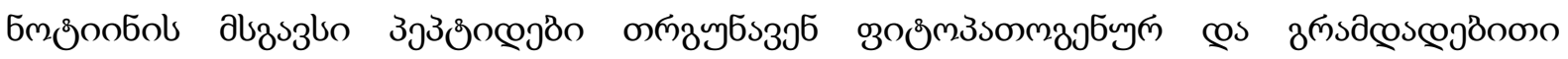

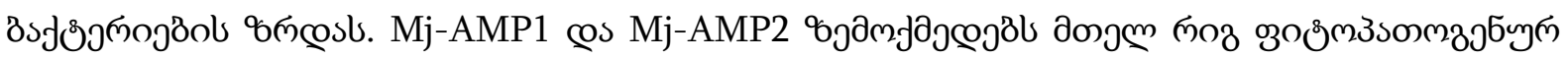

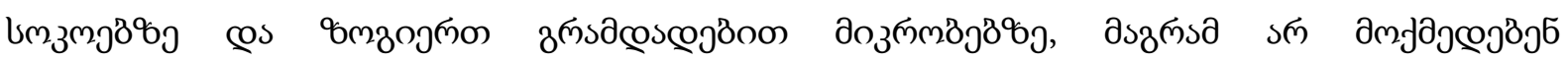

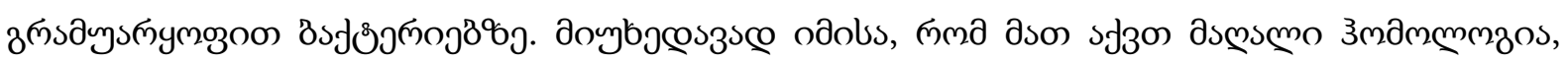

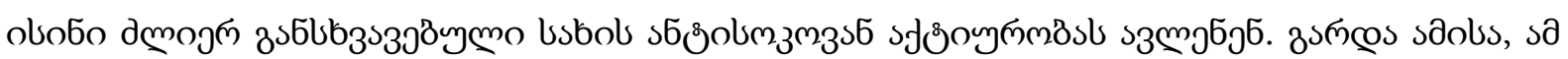

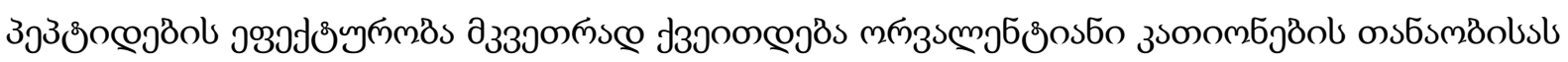
[2].

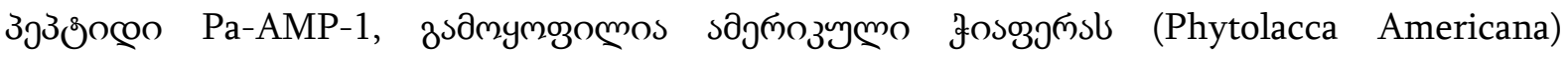

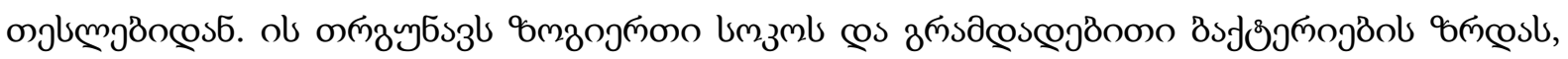

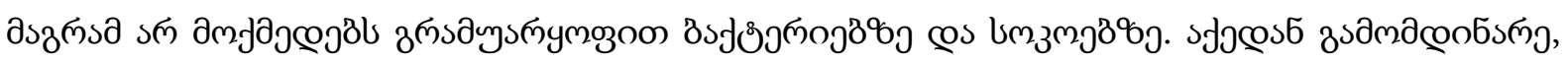

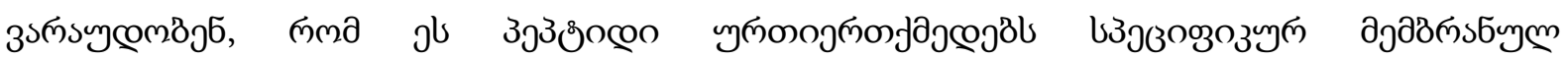

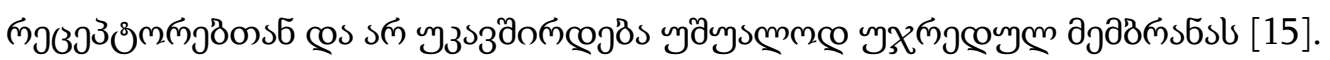

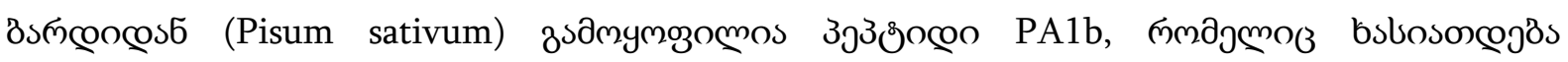

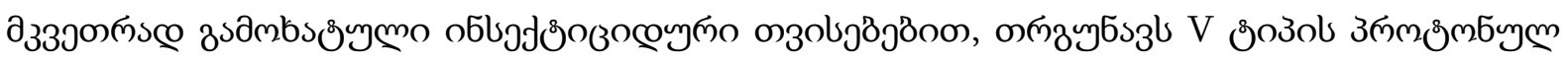
১৪ิ\%-s

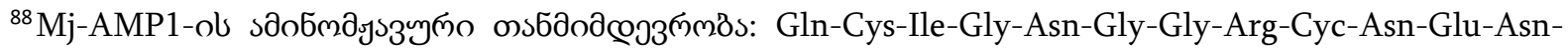
Val-Gly-Pro-Pro-Tyr-Cys-Cys-Ser-Gly-Phe-Cys-Leu-Arg-Gln-Pro-Gly-Gln-Gly-Tyr-Gly-Tyr-Cys-LysAsn-Arg.

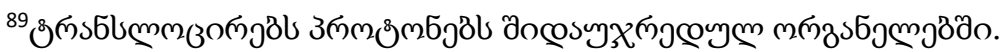




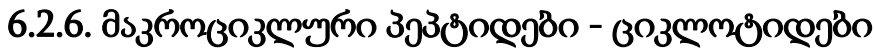

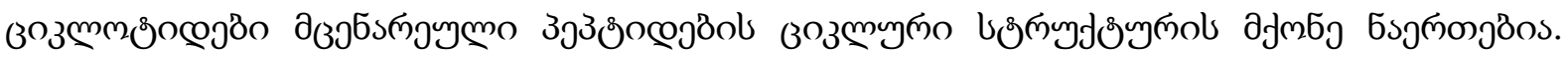

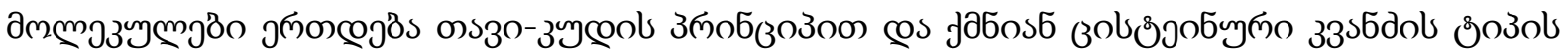

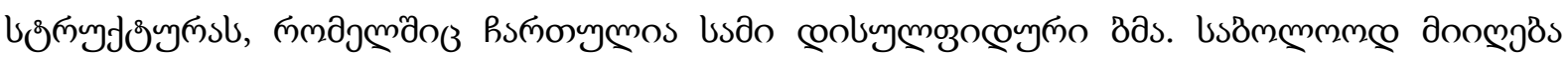

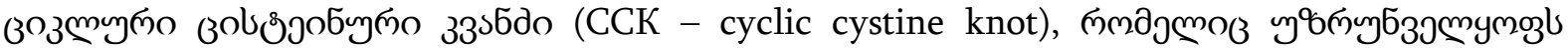

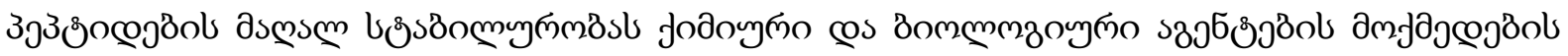
бобзsмдасов [6].

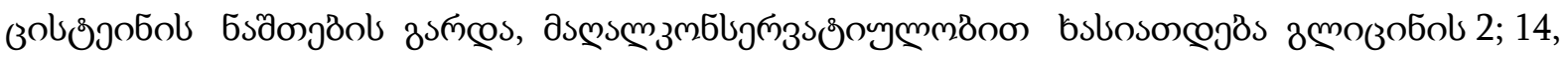

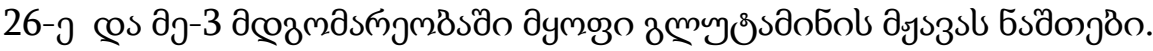

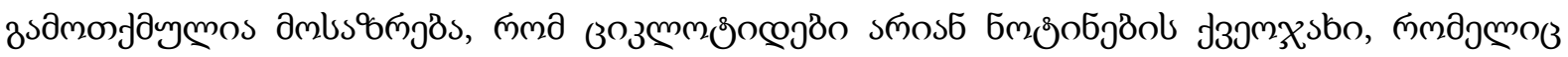

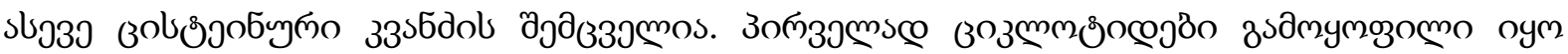

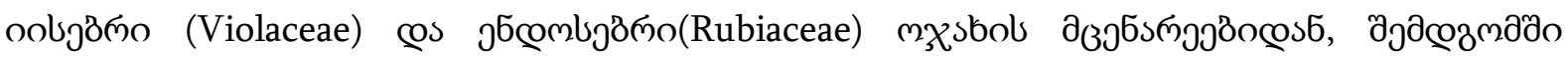

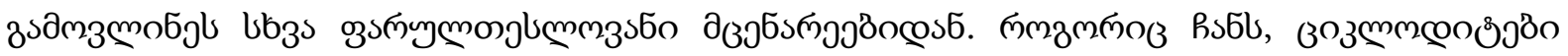

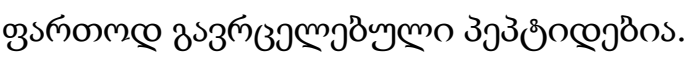

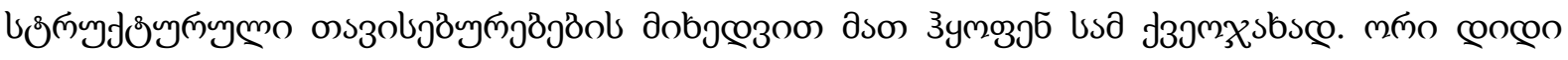

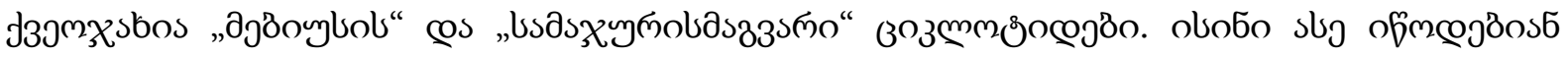

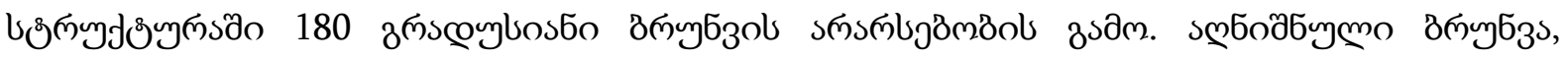

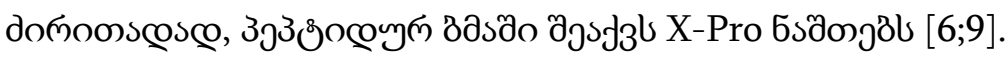

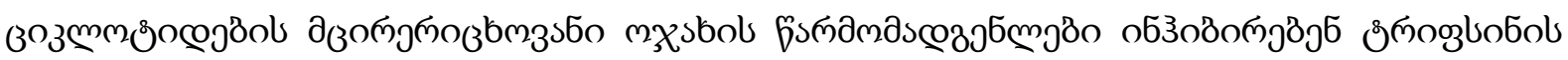

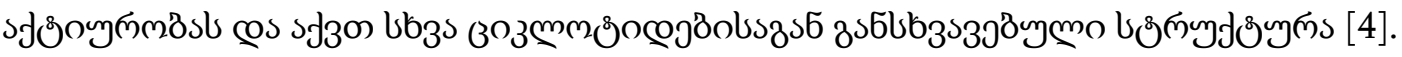

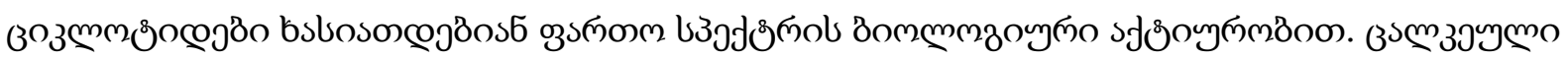

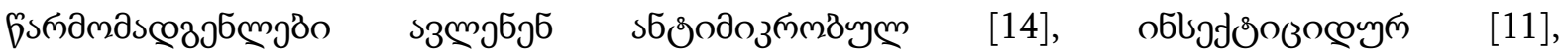

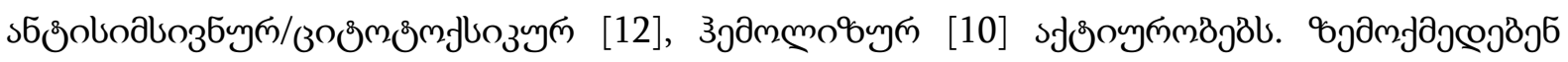

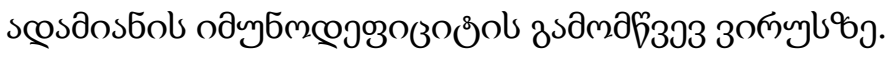

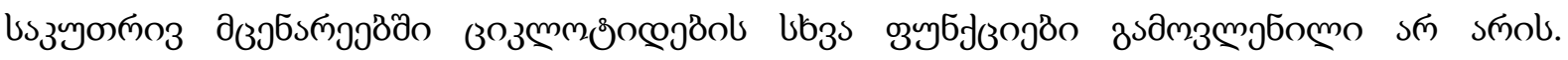

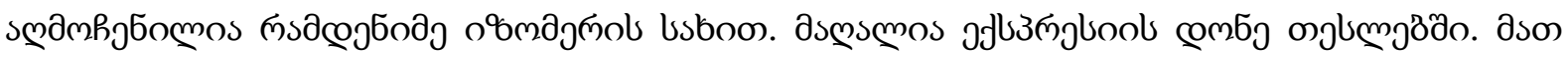

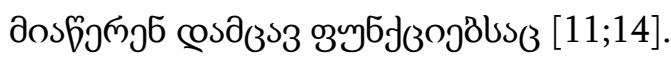

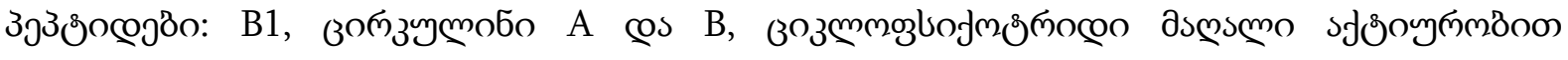

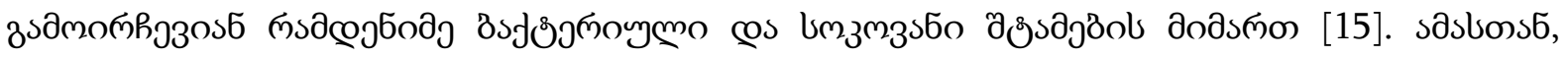

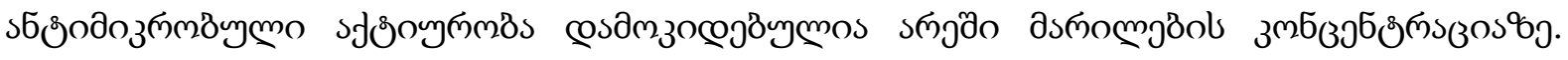

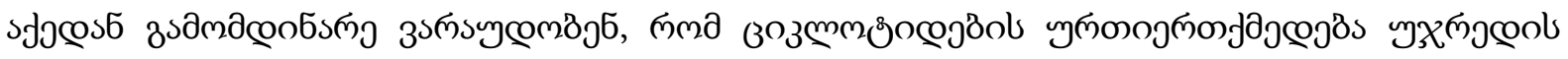

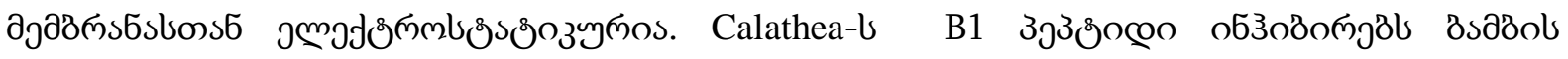

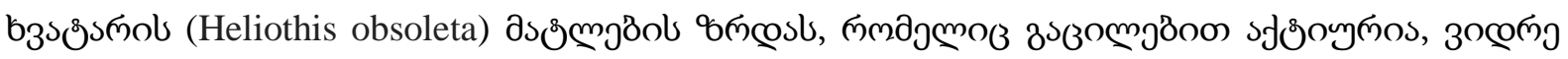

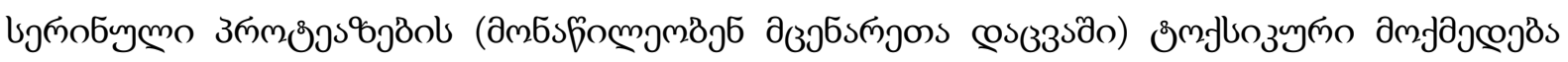
$[11 ; 14]$.

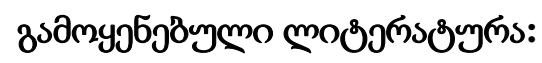

1. Bulet, P., and Stocklin, R. (2005) Insect antimicrobial peptides: structures, properties and gene regulation. Protein Pept Lett 12, 3-11.

2. Cammue, B.P., De Bolle, M. F., Terras, F. R., Proost, P., Van Damme, J., Rees, S. 
B.,Vanderleyden, J., and Broekaert, W. F. (1992) Isolation and characterization of a novel class ofplant antimicrobial peptides form Mirabilis jalapa L. seeds. J Biol Chem 267, 2228 2233.

3. Chagolla-Lopez, A., Blanco-Labra, A., Patthy, A., Sanchez, R., and Pongor, S. (1994) A novelalpha-amylase inhibitor from amaranth (Amaranthus hypocondriacus) seeds. J Biol Chem 269,23675-23680.

4. Chiche, L., Heitz, A., Gelly, J. C., Gracy, J., Chau, P. T., Ha, P. T., Hernandez, J. F., and LeNguyen, D. (2004) Squash inhibitors: from structural motifs to macrocyclic knottins. Curr ProteinPept Sci 5, 341-349.

5. Chouabe, C., Eyraud, V., Da Silva, P., Rahioui, I., Royer, C., Soulage, C., Bonvallet, R.,

6. Huss,M., and Gressent, F. (2011) New mode of action for a knottin protein bioinsecticide: pea albumin 1subunit b (PA1b) is the first peptidic inhibitor of V-ATPase. J Biol Chem 286, 36291-36296.

7. Craik, D. J., Daly, N. L., Bond, T., and Waine, C. (1999) Plant cyclotides: A unique family ofcyclic and knotted proteins that defines the cyclic cystine knot structural motif. J. Mol. Biol. 294,1327-1336.

8. Craik, D. J., Daly, N. L., and Waine, C. (2001) The cystine knot motif in toxins andimplications for drug design. Toxicon 39, 43-60.

9. Gracy, J., Le-Nguyen, D., Gelly, J. C., Kaas, Q., Heitz, A., and Chiche, L. (2008) KNOTTIN:the knottin or inhibitor cystine knot scaffold in 2007. Nucleic Acids Res. 36, D314-9.

10. Gruber, C. W., Elliott, A. G., Ireland, D. C., Delprete, P. G., Dessein, S., Goransson, U.,Trabi, M., Wang, C. K., Kinghorn, A. B., Robbrecht, E., and Craik, D. J. (2008) Distribution andEvolution of Circular Miniproteins in Flowering Plants. Plant Cell 20, 2471-2483.

11. Henriques, S. T., Huang, Y. H., Rosengren, K. J., Franquelim, H. G., Carvalho, F. A.,Johnson, A., Sonza, S., Tachedjian, G., Castanho, M. A., Daly, N. L., and Craik, D. J. (2011)Decoding the membrane activity of the cyclotide kalata B1: the importance ofphosphatidylethanolamine phospholipids and lipid organization on hemolytic and antiHIVactivities. J Biol Chem 286, 24231-24241.

12. Jennings, C., West, J., Waine, C., Craik, D., and Anderson, M. (2001) Biosynthesis andinsecticidal properties of plant cyclotides: the cyclic knotted proteins from Oldenlandia affinis. ProcNatl Acad Sci U S A 98, 10614-10619.

13. Lindholm, P., Goransson, U., Johansson, S., Claeson, P., Gullbo, J., Larsson, R., Bohlin, L., and Backlund, A. (2002) Cyclotides: a novel type of cytotoxic agents. Mol Cancer Ther 1, 365-369.

14. Norton, R. S., and Pallaghy, P. K. (1998) The cystine knot structure of ion channel toxins andrelated polypeptides. Toxicon 36, 1573-1583.

15. 14.Tam, J. P., Lu, Y. A., Yang, J. L., and Chiu, K. W. (1999) An unusual structural motif ofantimicrobial peptides containing end-to-end macrocycle and cystine-knot disulfides. Proc NatlAcad Sci U S A 96, 8913-8918.

16. Thevissen, K., Osborn, R. W., Acland, D. P., and Broekaert, W. F. (1997) Specific, highaffinity binding sites for an antifungal plant defensin on Neurospora crassa hyphae and microsomalmembranes. J Biol Chem 272, 32176-32181. 


\subsection{7. $\alpha$-sâoms}

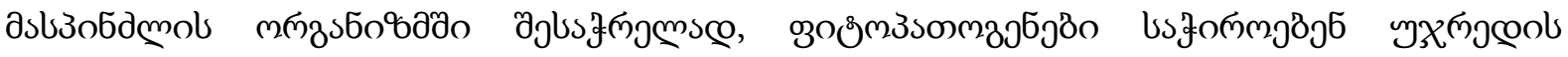

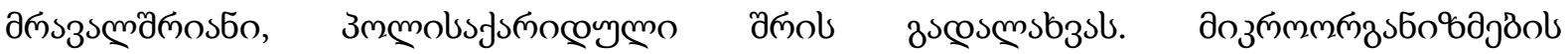

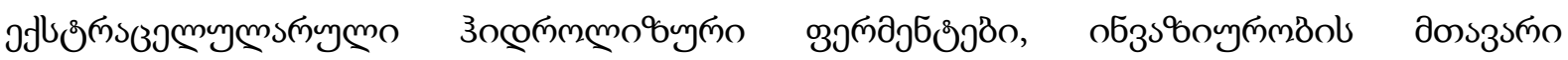

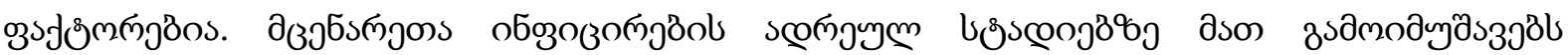

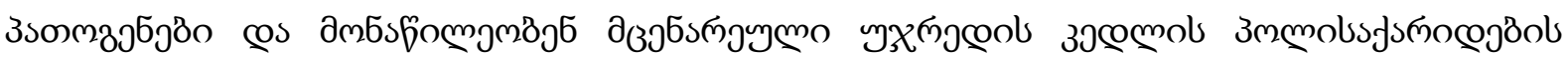

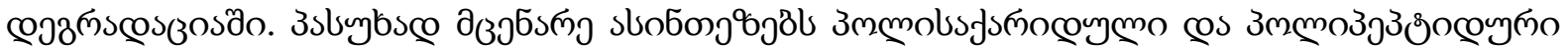

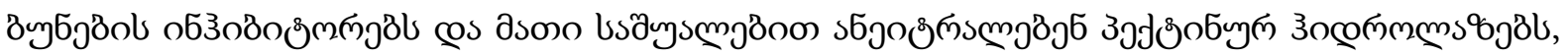

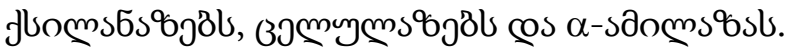

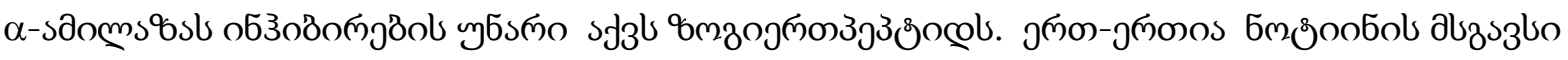

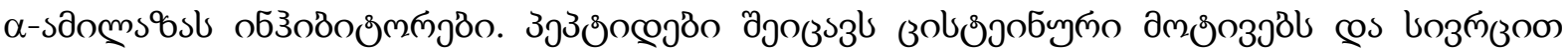

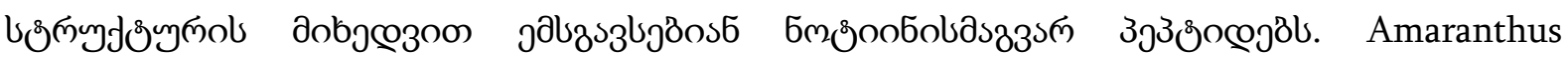

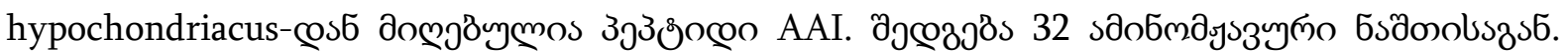

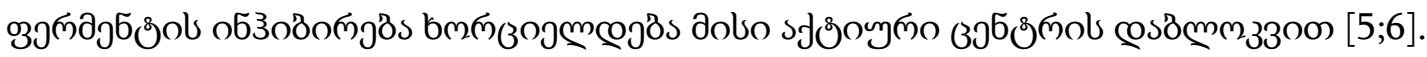

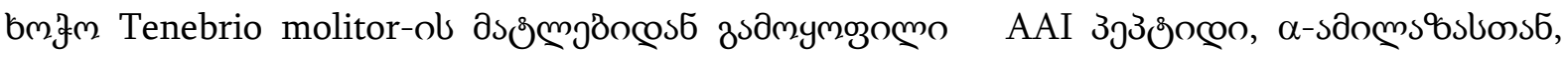

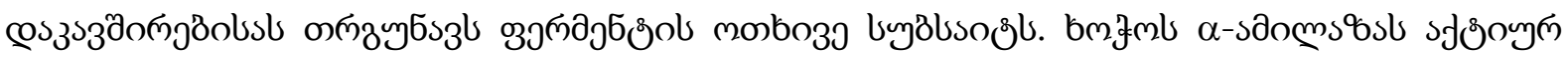

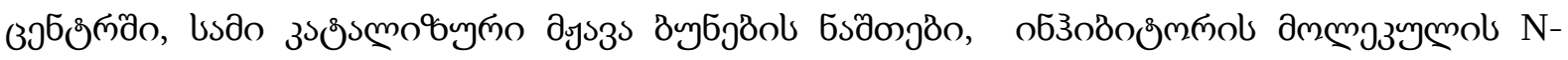

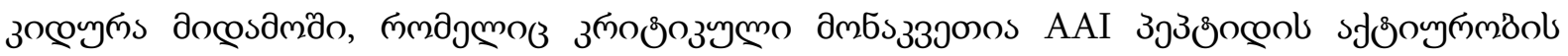

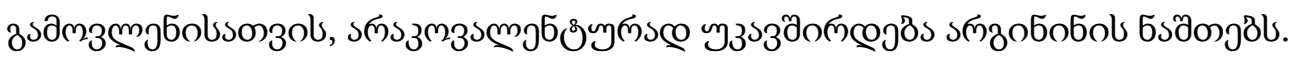

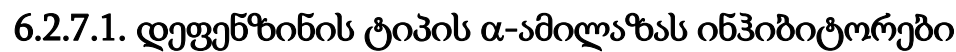

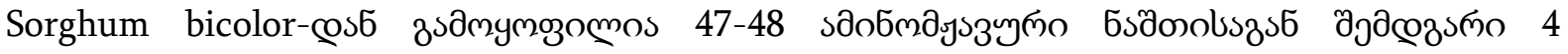

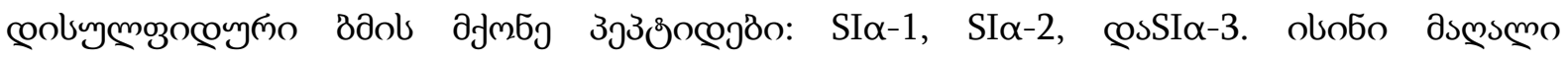

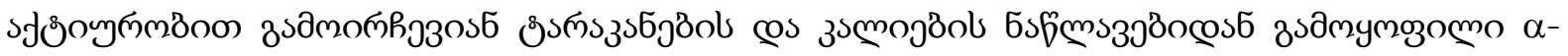

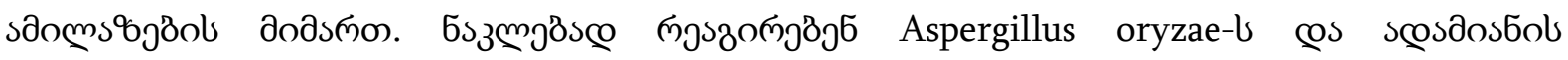

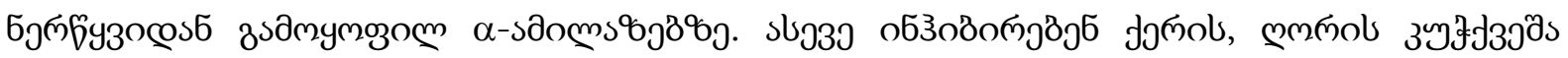

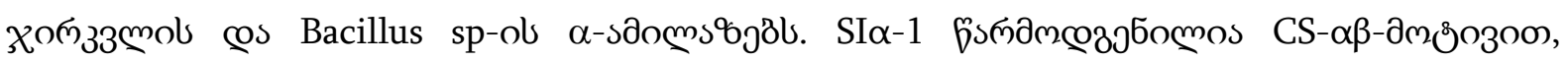

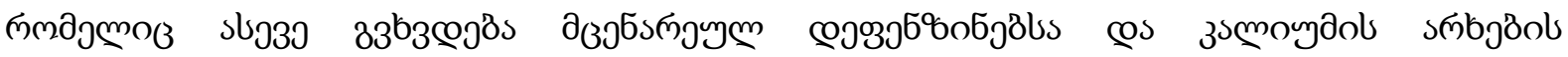

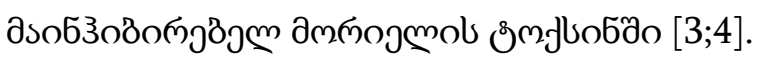

\subsection{8. Зங்mతి}

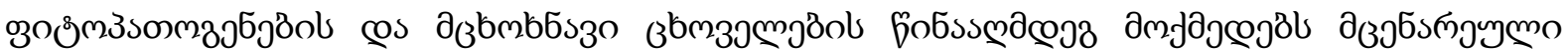

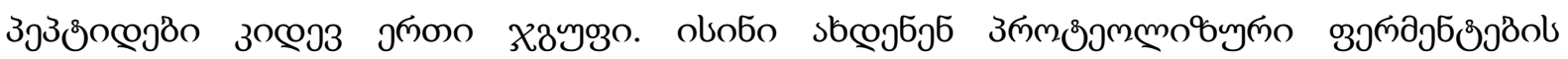

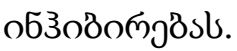

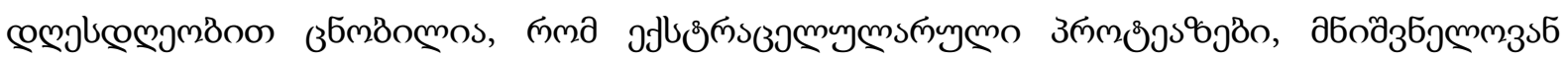

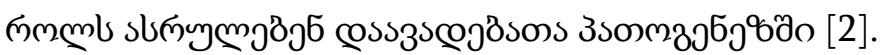

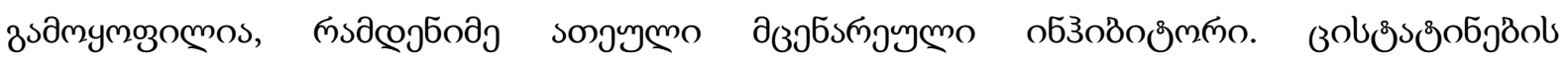

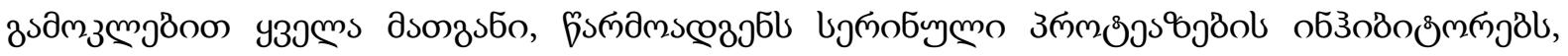

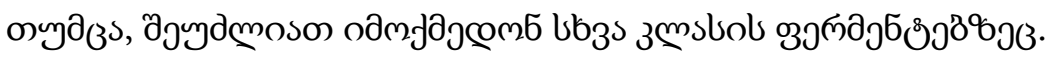




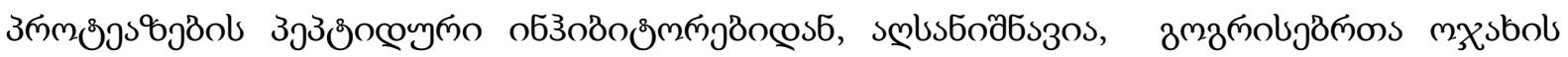

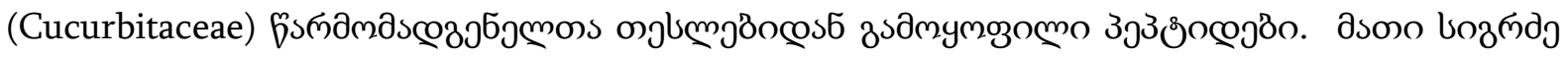

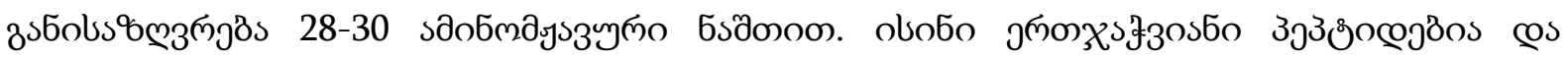

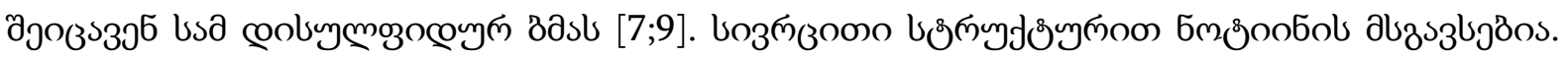

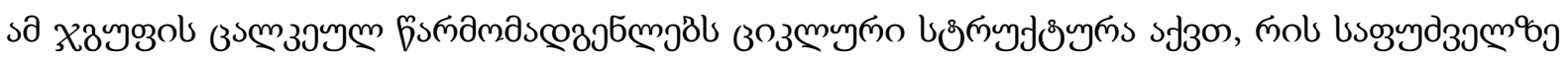

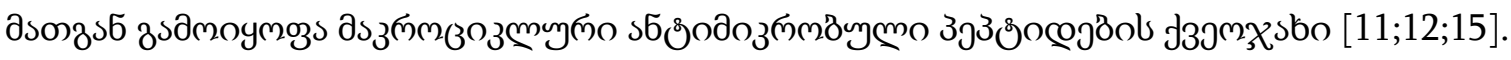

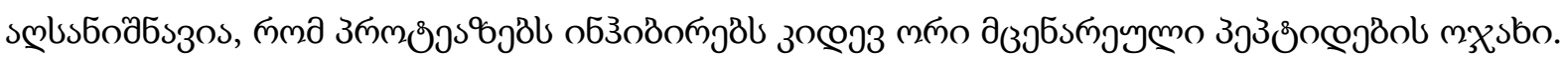

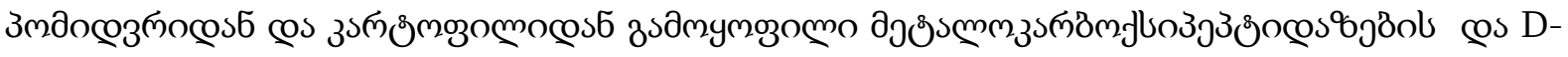

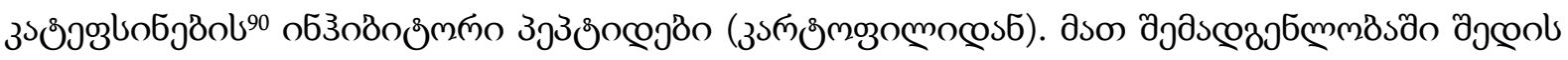

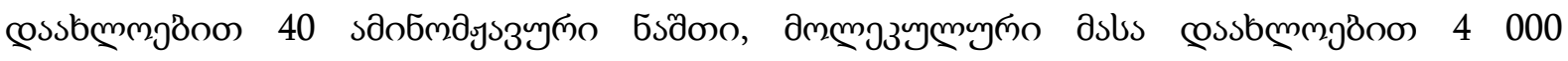

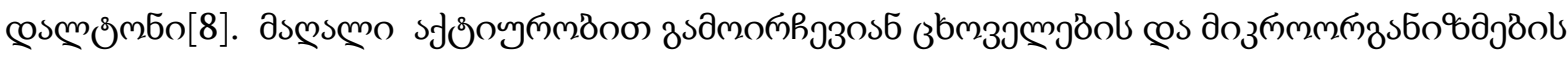

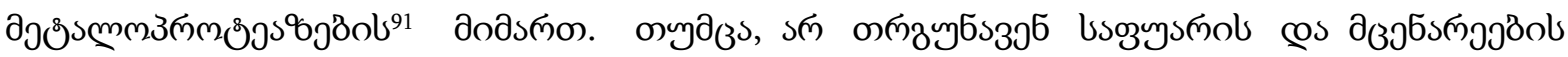

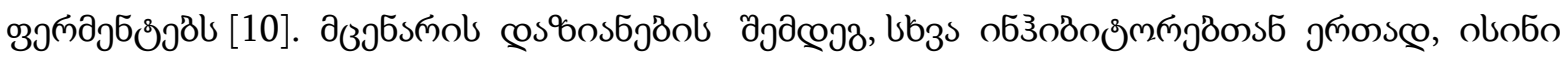

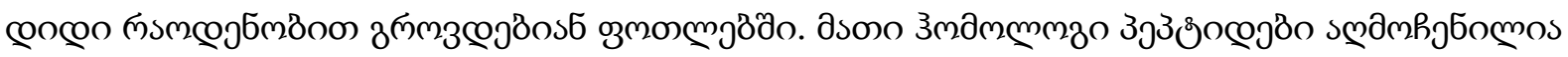

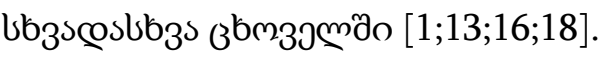

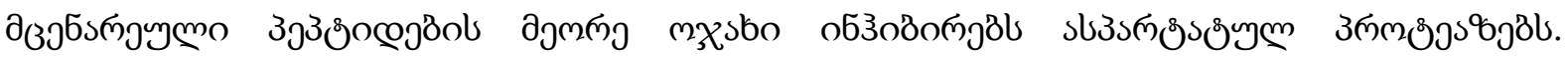

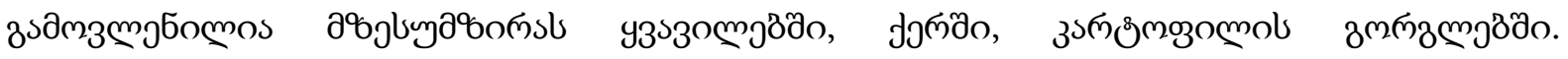

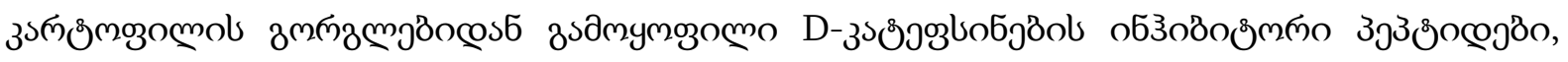

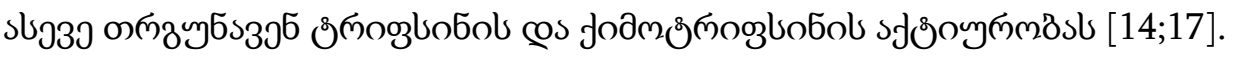

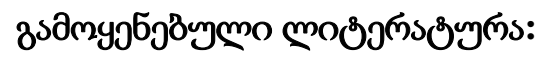

1. Arolas, J. L., Lorenzo, J., Rovira, A., Castellà, J., Aviles, F. X., and Sommerhoff, C. P. (2005) A carboxypeptidase inhibitor from the tick Rhipicephalus bursa: isolation, cDNA cloning, recombinant expression, and characterization. J. Biol. Chem. 280, 3441-8.

2. Ball, A. S. (1991) Degradation by Streptomyces viridosporus T7A of plant material grown under elevated CO2 conditions. FEMS Microbiol Lett 68, 139-142.

3. Bloch Jr., C., and Richardson, M. (1991) A new family of small (5 kDa) protein inhibitors of insect alpha-amylases from seeds or sorghum (Sorghum bicolar (L) Moench) have sequencehomologies with wheat gamma-purothionins. FEBS Lett 279, 101-104.

4. Bloch Jr., C., Patel, S. U., Baud, F., Zvelebil, M. J., Carr, M. D., Sadler, P. J., and Thornton,J. M. (1998) 1H NMR structure of an antifungal gamma-thionin protein SIalpha1: similarity toscorpion toxins. Proteins-Structure Funct. Genet. 32, 334-349.

5. Carugo, O., Lu, S., Luo, J., Gu, X., Liang, S., Strobl, S., and Pongor, S. (2001) Structural analysis of free and enzyme-bound amaranth alpha-amylase inhibitor: classification within the knottin fold superfamily and analysis of its functional flexibility. Protein Eng. 14, 639-46.

6. Chagolla-Lopez, A., Blanco-Labra, A., Patthy, A., Sanchez, R., and Pongor, S. (1994) A novelalpha-amylase inhibitor from amaranth (Amaranthus hypocondriacus) seeds. J Biol Chem 269,23675-23680.

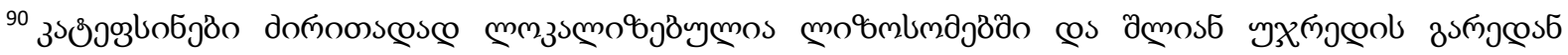

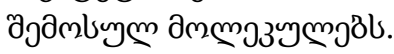

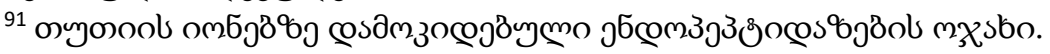


7. Felizmenio-Quimio, M. E., Daly, N. L., and Craik, D. J. (2001) Circular proteins in plants: solution structure of a novel macrocyclic trypsin inhibitor from Momordica cochinchinensis. J. Biol.Chem. 276, 22875-82.

8. Hass, G. M., and Hermodson, M. A. (1981) Amino acid sequence of a carboxypeptidase inhibitor from tomato fruit. Biochemistry 20, 2256-60.

9. Hara, S., Makino, J., and Ikenaka, T. (1989) Amino acid sequences and disulfide bridges of serine proteinase inhibitors from bitter gourd (Momordica charantia LINN.) seeds. J. Biochem. 105,88-91.

10. Haukioja, E., and Neuvonen, S. (1985) Induced Long-Term Resistance of Birch Foliage against Defoliators: Defensive or Incidental? Ecology 66, 1303.

11. Heitz, A., Hernandez, J. F., Gagnon, J., Hong, T. T., Pham, T. T., Nguyen, T. M., LeNguyen,D., and Chiche, L. (2001) Solution structure of the squash trypsin inhibitor MCoTIII. A new familyfor cyclic knottins. Biochemistry 40, 7973-83.

12. Le Nguyen, D., Heitz, A., Chiche, L., Castro, B., Boigegrain, R. A., Favel, A., and ColettiPreviero, M. A. Molecular recognition between serine proteases and new bioactive microproteins with a knotted structure. Biochimie 72, 431-5.

13. Liu, Q., Yu, L., Gao, J., Fu, Q., Zhang, J., Zhang, P., Chen, J., and Zhao, S. (2000) Cloning,tissue expression pattern and genomic organization of latexin, a human homologue of ratcarboxypeptidase A inhibitor. Mol. Biol. Rep. 27, 241-6.

14. Mares, M., Meloun, B., Pavlik, M., Kostka, V., and Baudys, M. (1989) Primary structure of athepsin D inhibitor from potatoes and its structure relationship to soybean trypsin inhibitor family.FEBS Lett. 251, 94-8.

15. Nilges, M., Habazettl, J., Brünger, A. T., and Holak, T. A. (1991) Relaxation matrixrefinement of the solution structure of squash trypsin inhibitor. J. Mol. Biol. 219, 499510 .

16. Normant, E., Martres, M. P., Schwartz, J. C., and Gros, C. (1995) Purification, cDNA cloning, functional expression, and characterization of a $26-\mathrm{kDa}$ endogenous mammalian carboxypeptidaseinhibitor. Proc. Natl. Acad. Sci. U. S. A. 92, 12225-9.

17. Petek, M., Turnšek, N., Gašparič, M. B., Novak, M. P., Gruden, K., Slapar, N., Popovič, T.,Strukelj, B., and Jongsma, M. A. (2012) A complex of genes involved in adaptation of Leptinotarsadecemlineata larvae to induced potato defense. Arch. Insect Biochem. Physiol. 79, 153-81.

18. Ryan, C. A. (1990) Protease Inhibitors in Plants: Genes for Improving Defenses Against Insects and Pathogens. Annu. Rev. Phytopathol. 28, 425-449. 


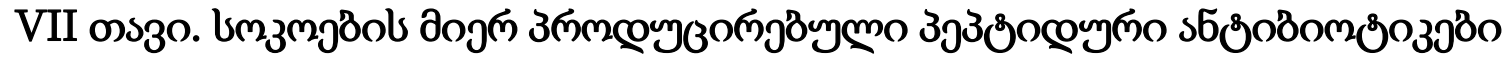

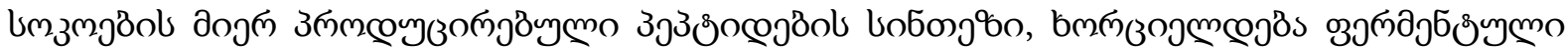

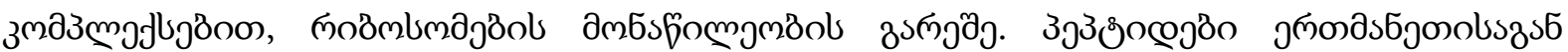

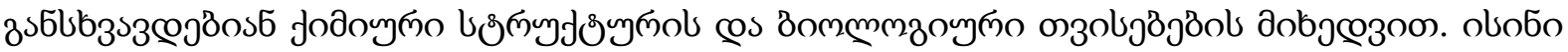

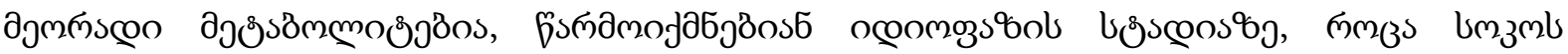

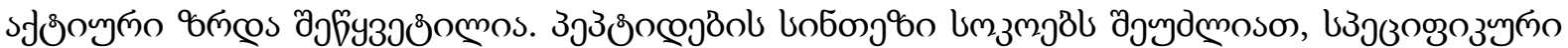

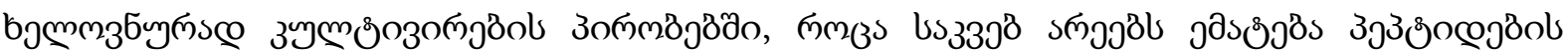

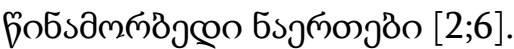

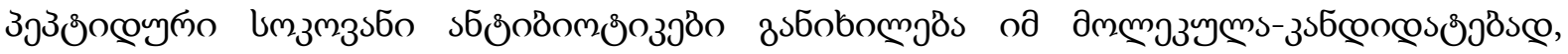

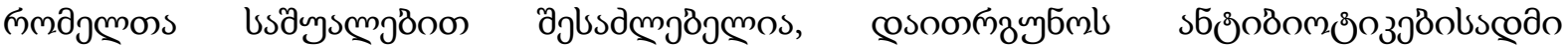

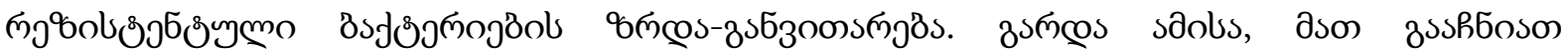

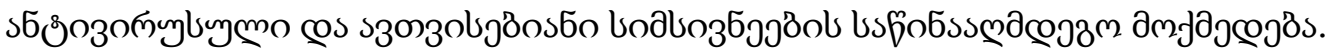

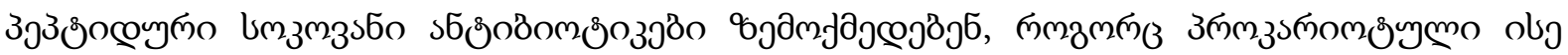

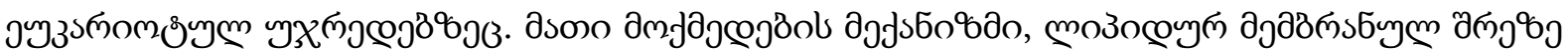

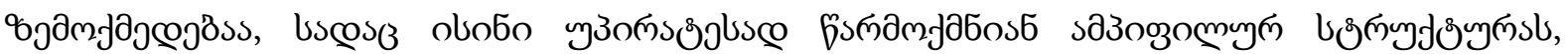

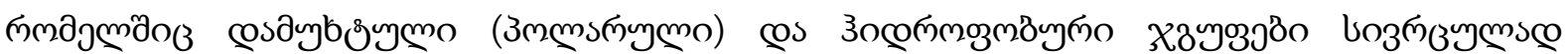

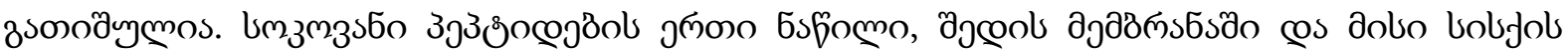

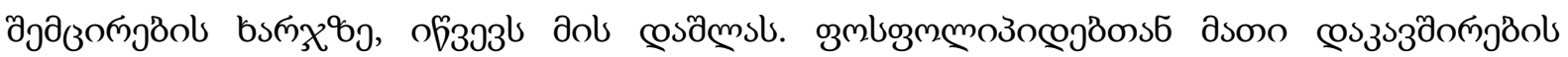

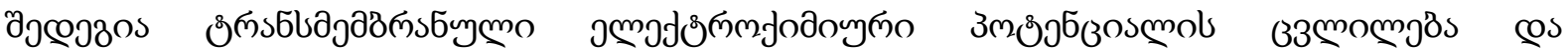

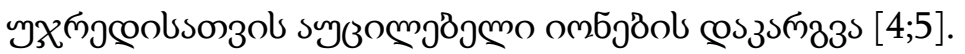

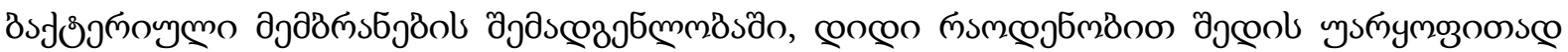

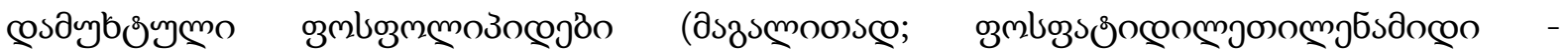

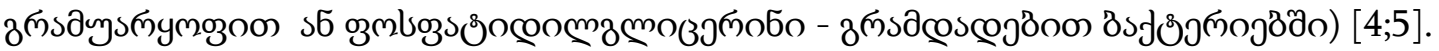

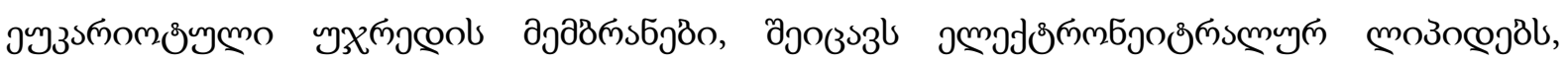

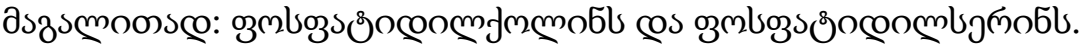

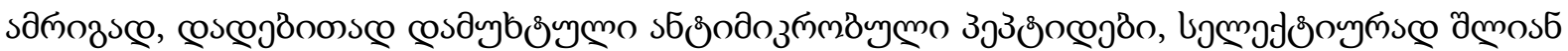

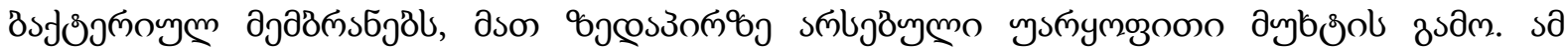

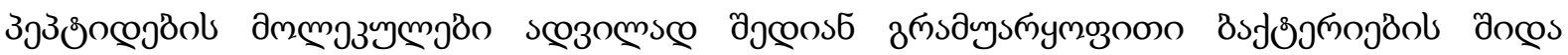

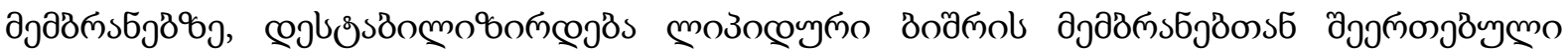

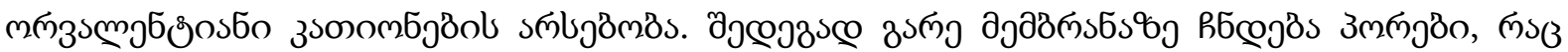

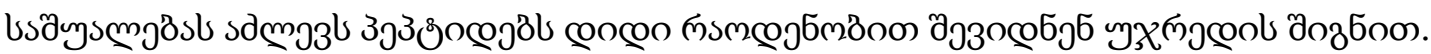

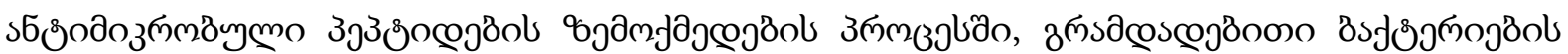

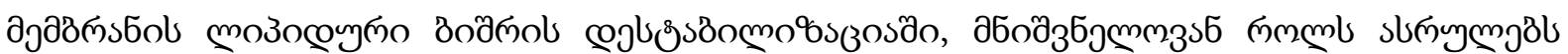

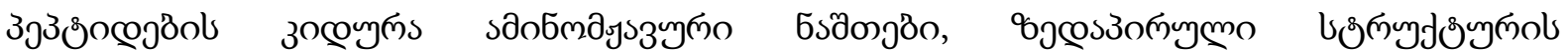

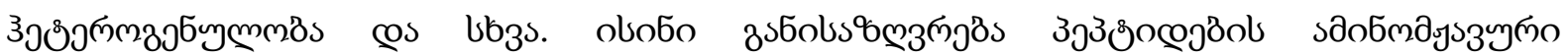

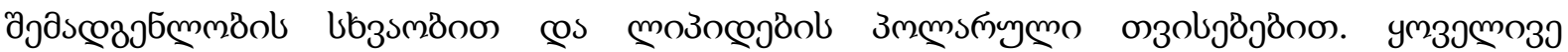

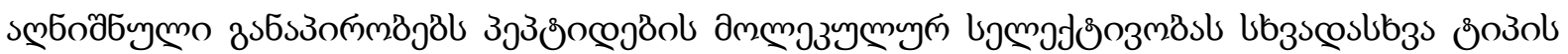

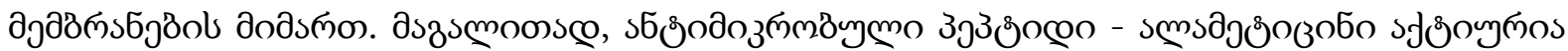

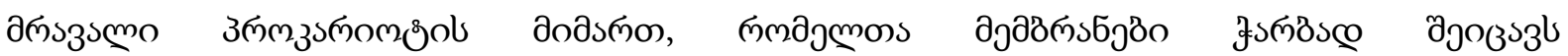

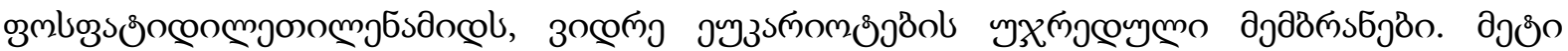

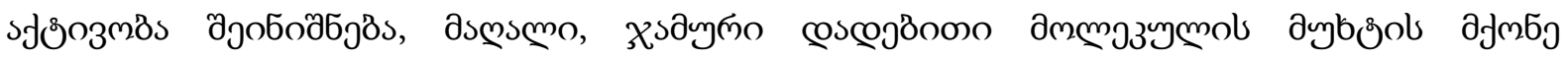




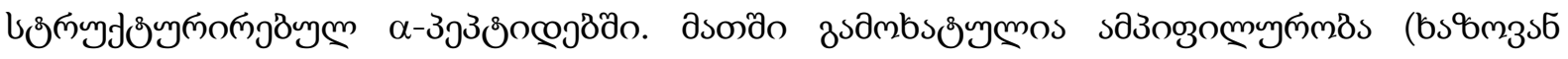

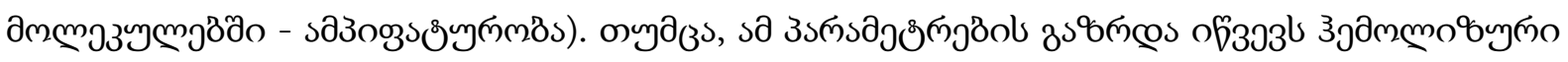

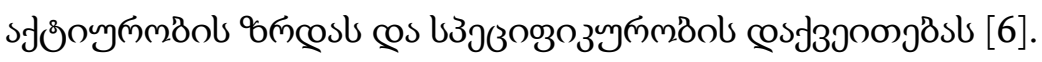

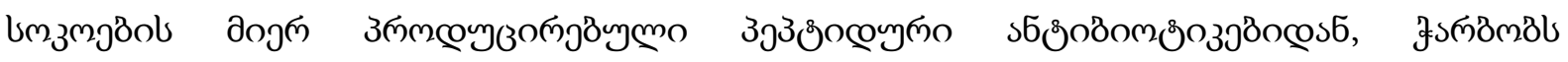

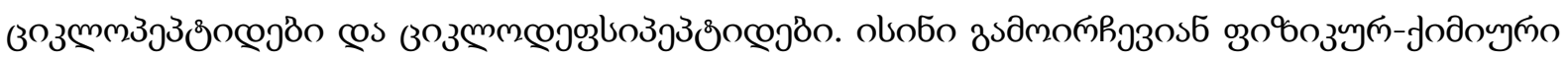

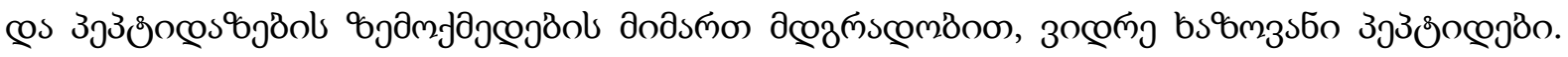

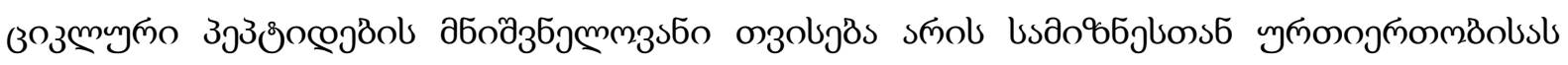

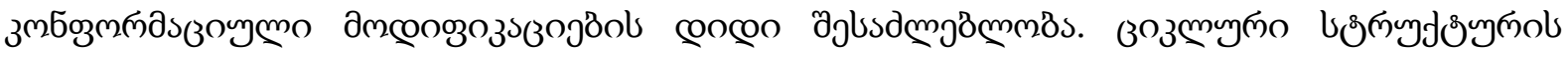

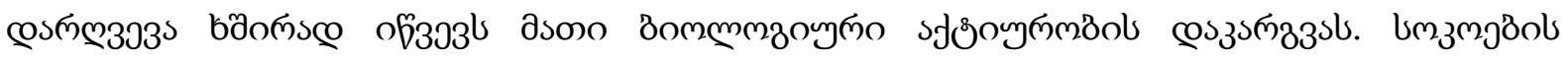

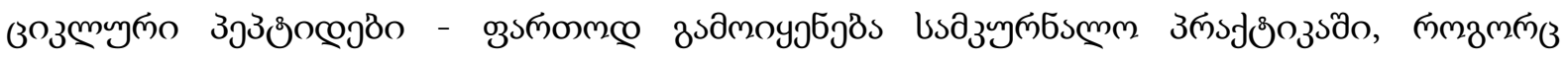

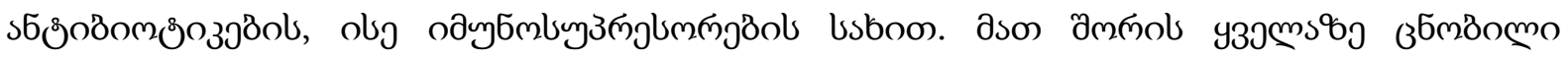

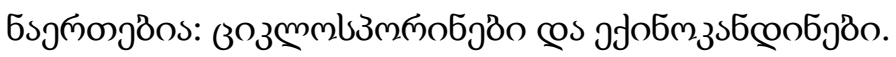

зозмпмизмпобо.

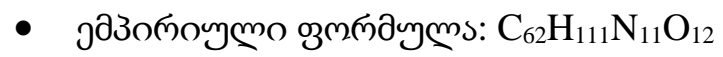

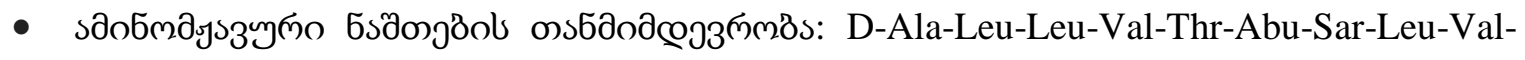
Leu-Ala

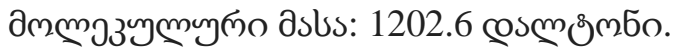

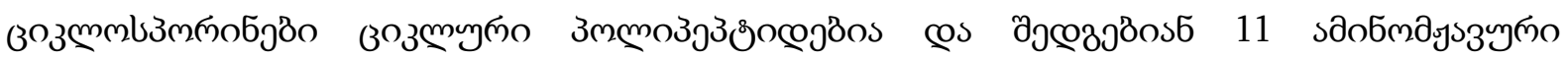

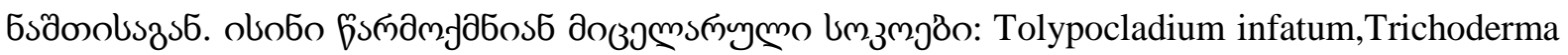

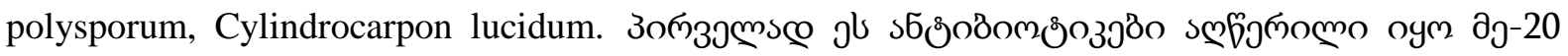

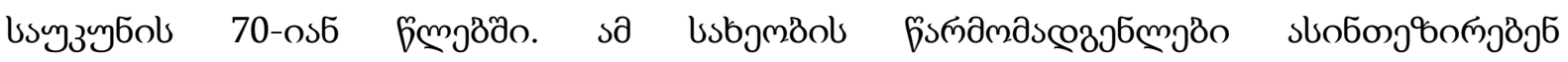

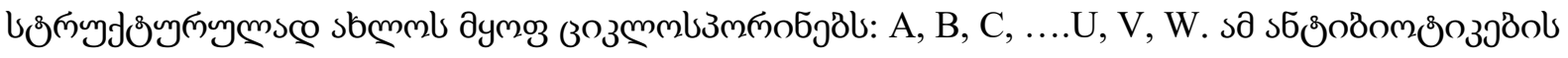

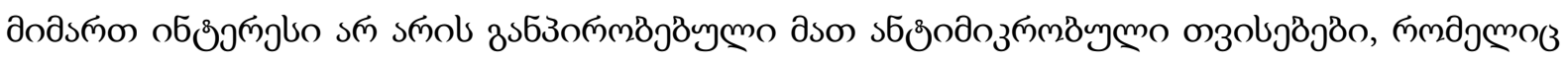

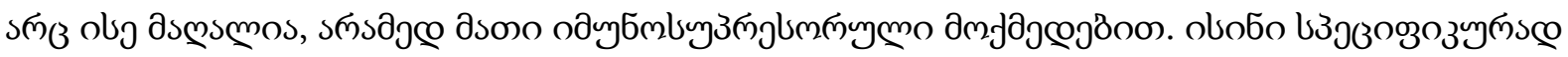

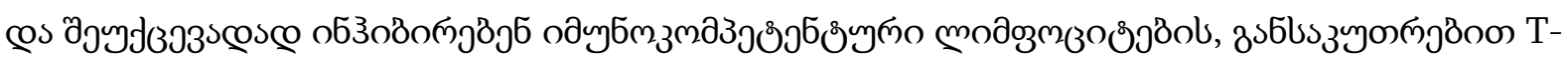

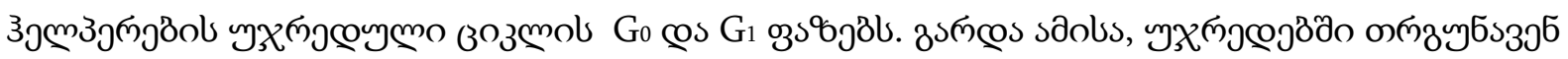

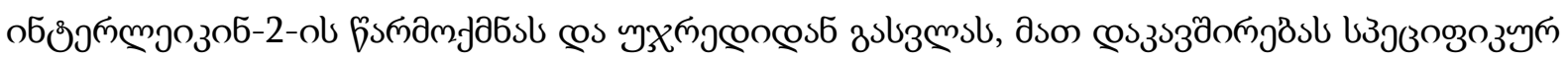

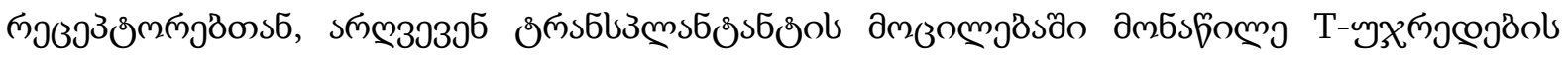

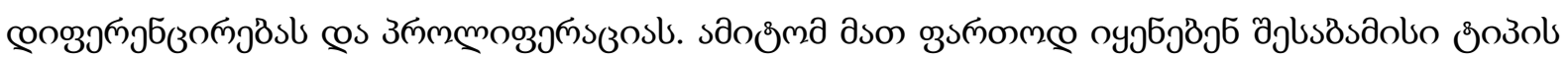

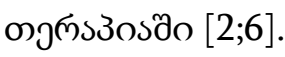

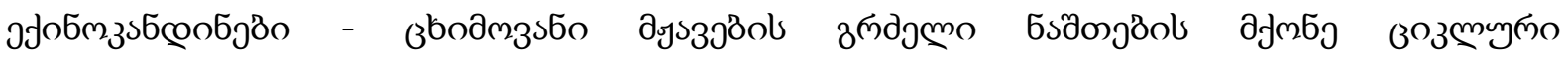

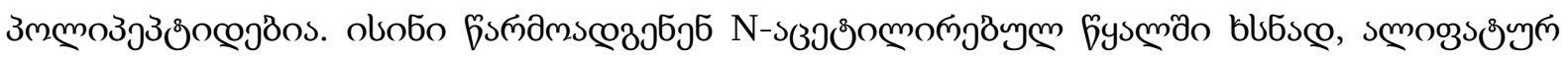

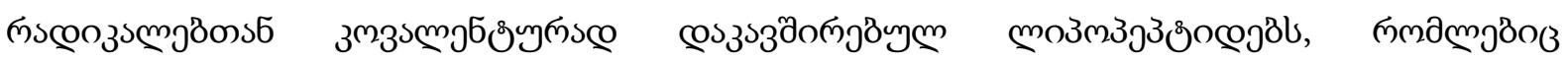

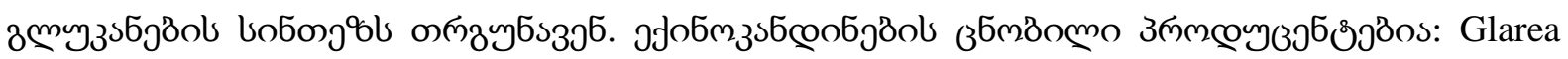

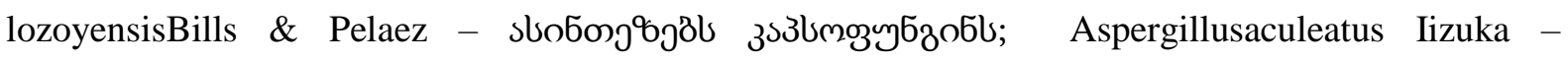

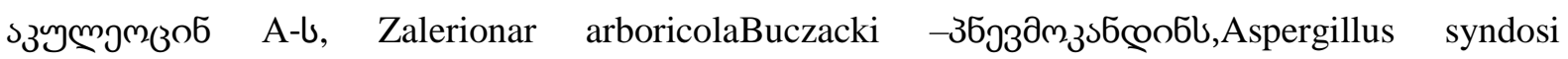

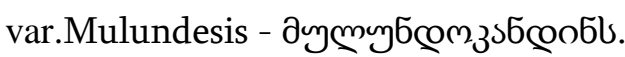

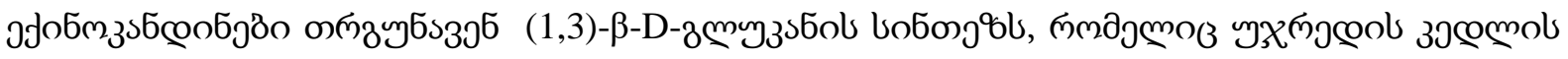

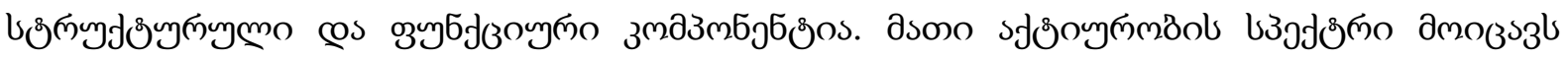

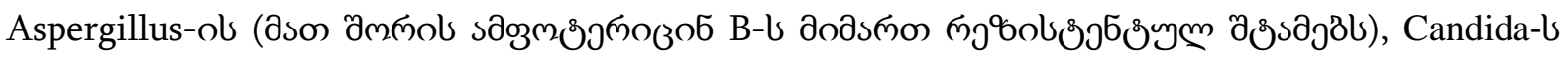




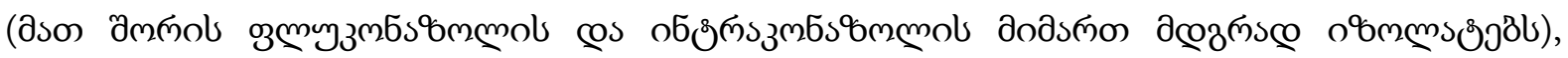
Pneumocystis jiroveci-ol zзsmol bmzmgibl.

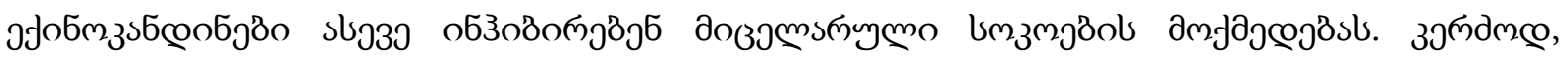

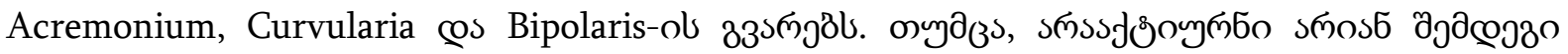

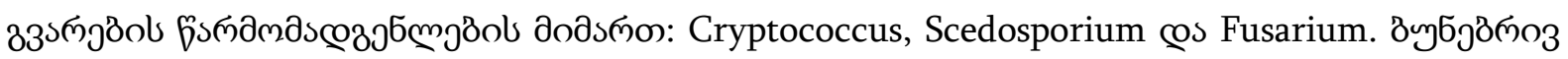

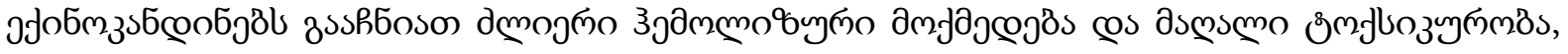

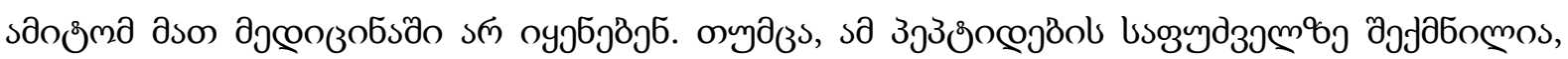

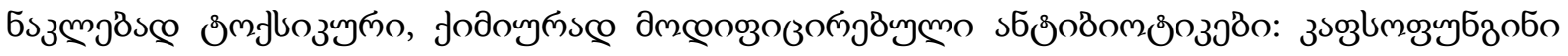
cos zommöз5бобо.

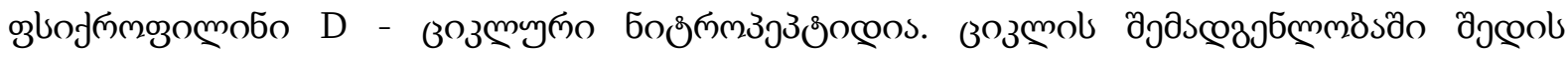

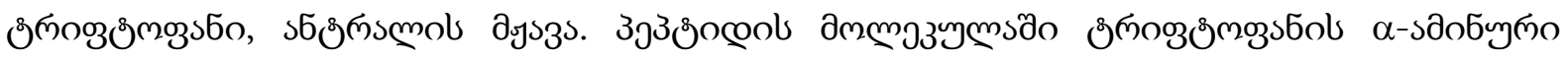

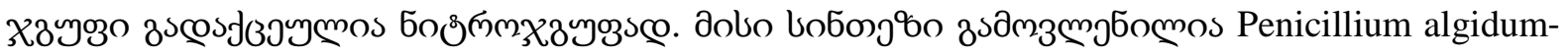

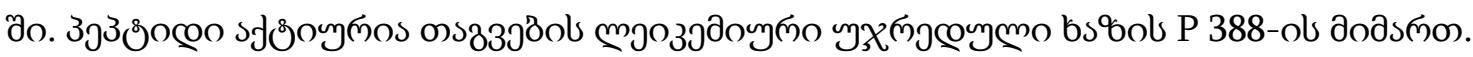

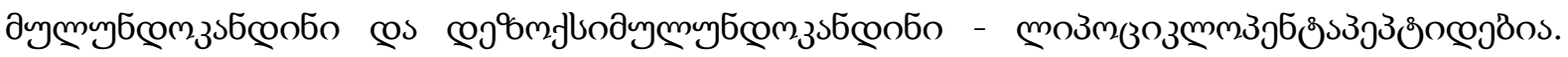

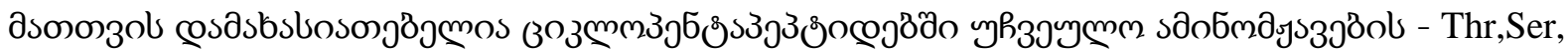

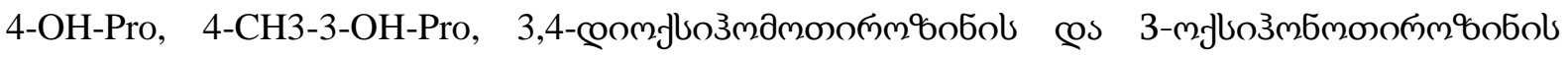

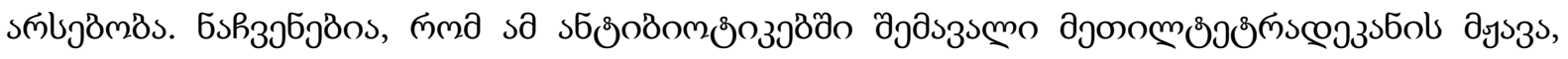

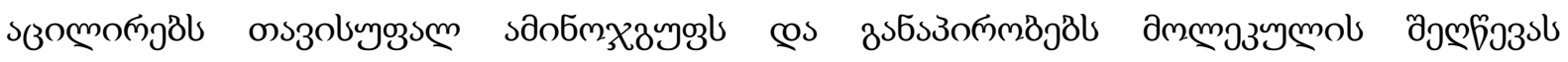

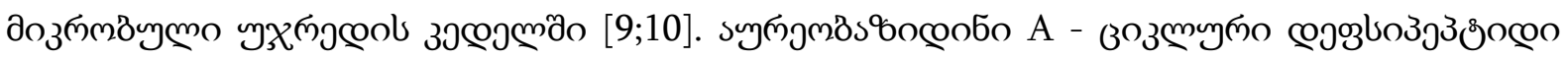

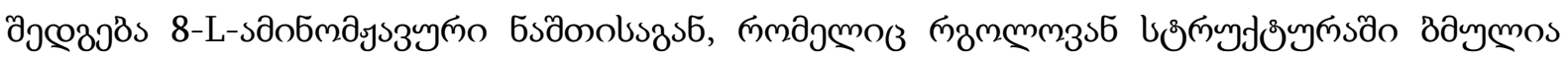

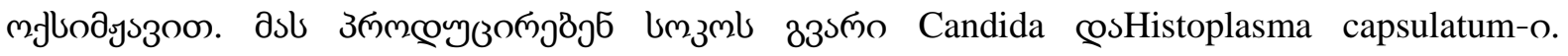

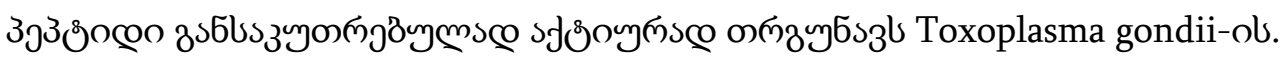

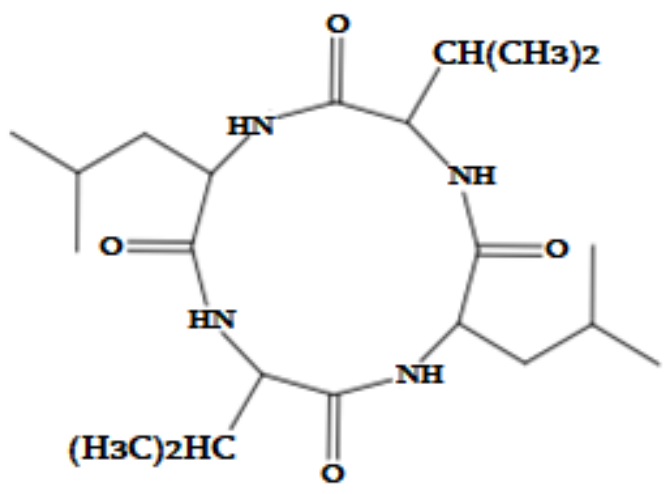

Cyclo-(L-Val-L-Leu-L-Val-L-Leu)

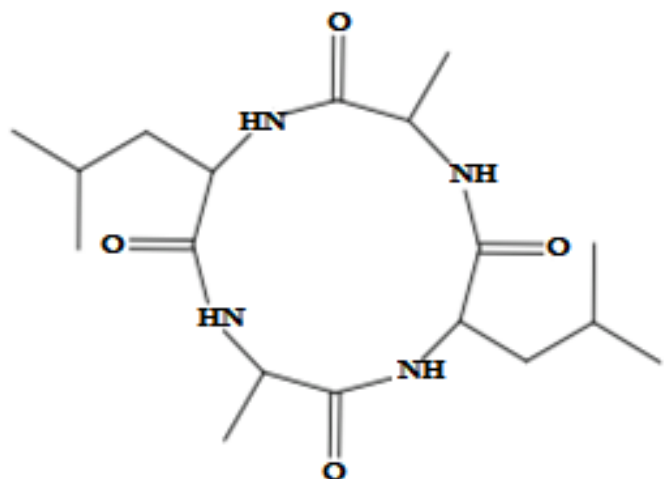

Cyclo-(L-Leu-L-Ala-L-Leu-L-Ala)

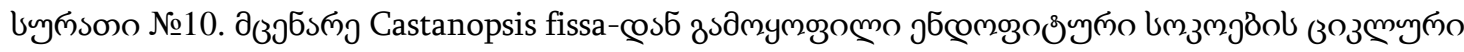

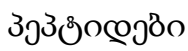




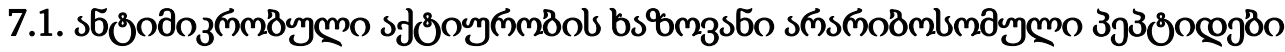

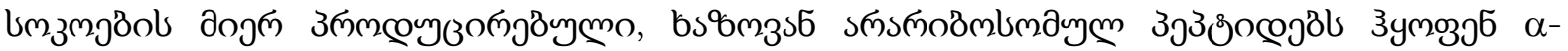

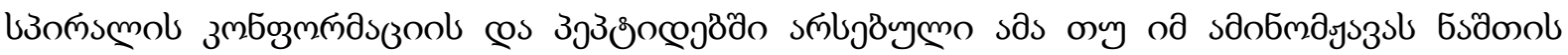

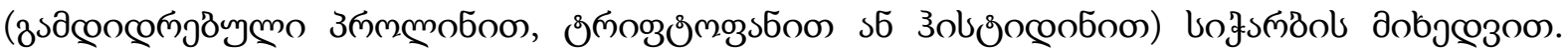

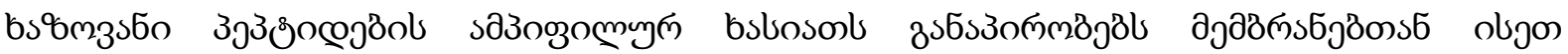

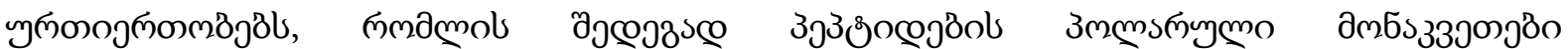

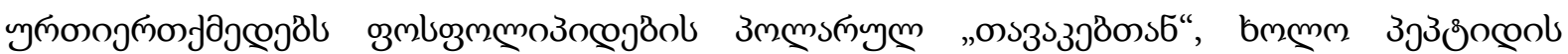

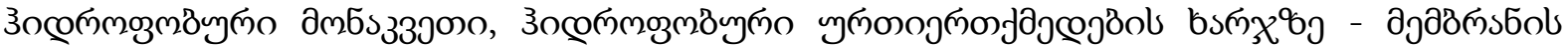

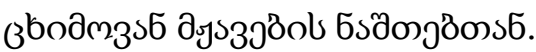

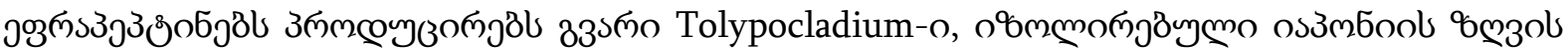

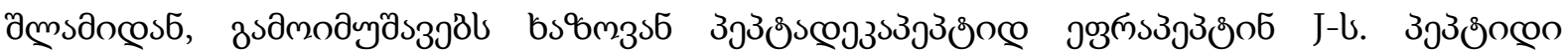

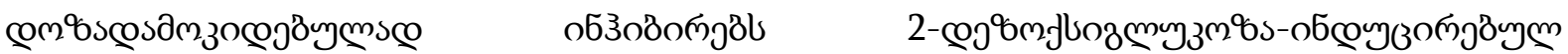

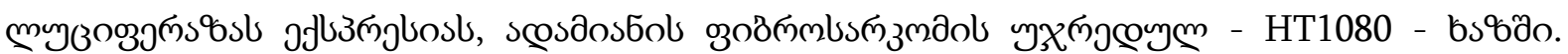

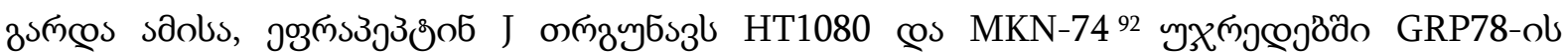

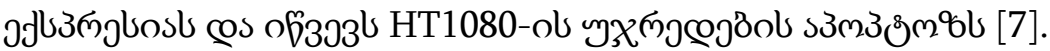

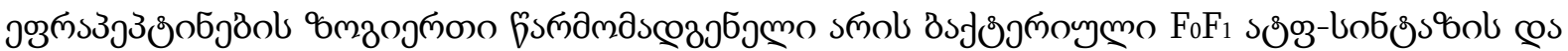

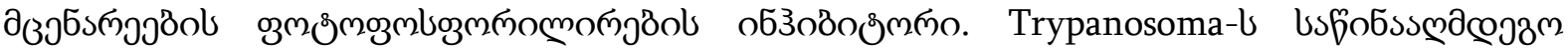

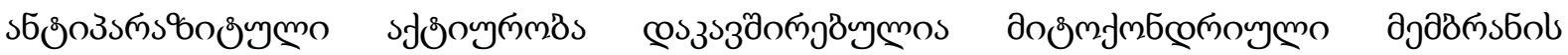

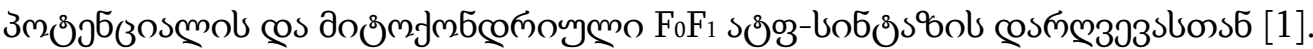

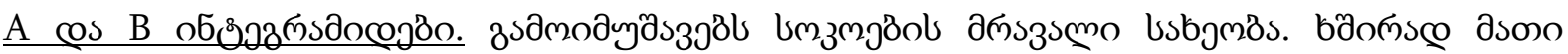

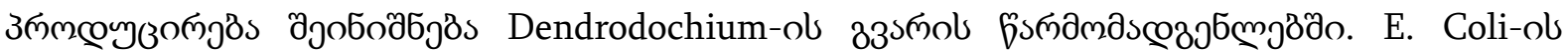

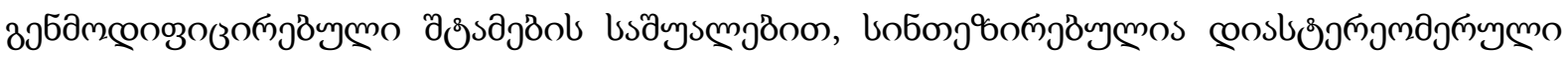

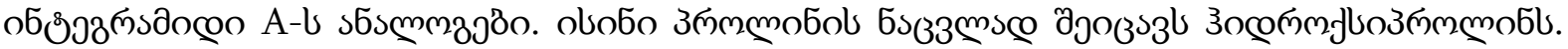

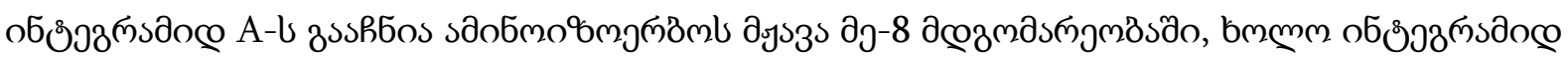

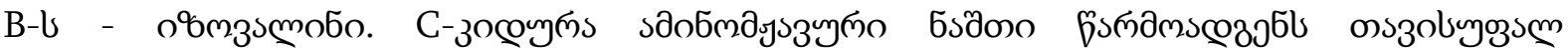

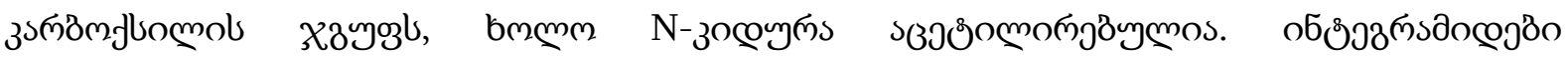

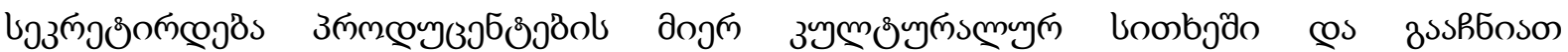

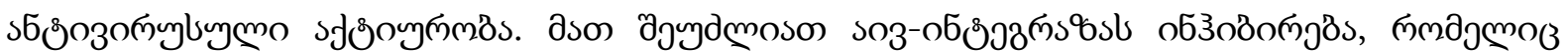

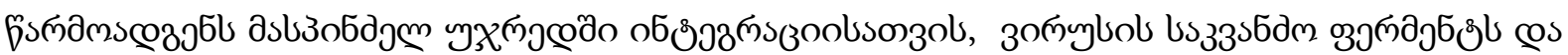

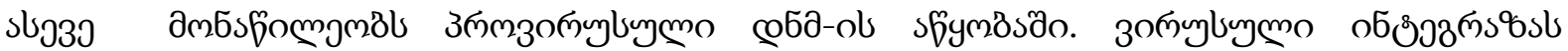

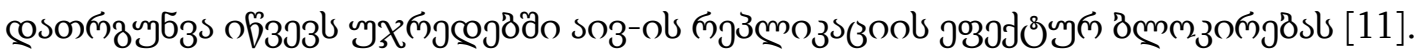

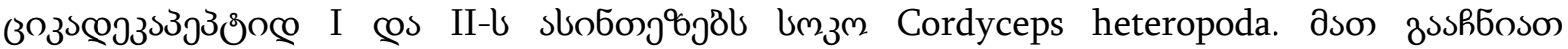

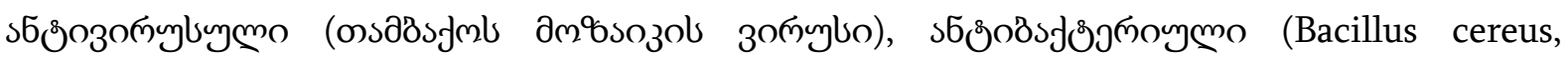

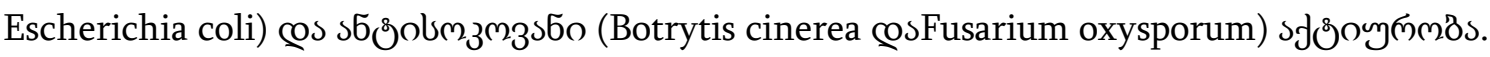

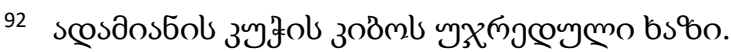




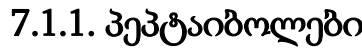

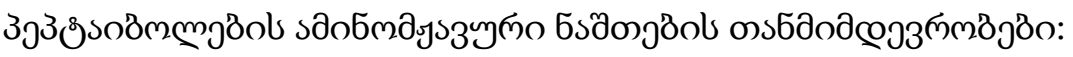

Ac-Ala-Pro-Aib-Ala-Aib-Ala-Gln-Aib-Val-Aib-Gly-Leu-Aib-Pro-Val-Aib-Aib-Gln-Gln-Pheol sช்๓озопоособо D 2

Ac-Aib-Pro-Aib-Ala-Aib-Ser-Gln-Aib-Val-Aib-Gly-Leu-Aib-Pro-Val-Aib-Aib-Gln-Gln-Pheol

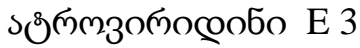

Ac-Aib-Pro-Aib-Ala-Aib-Ser-Gln-Aib-Vxx-Aib-Gly-Leu-Aib-Pro-Vxx-Aib-Vxx-Gln-Gln-Pheol

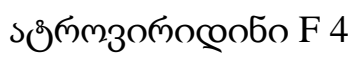

Ac-Aib-Pro-Aib-Ala-Aib-Gly-Gln-Aib-Val-Aib-Gly-Leu-Aib-Pro-Val-Aib-Aib-Gln-Gln-

Pheolsøঞmзоп̆особо G 5

Ac-Aib-Pro-Aib-Ser-Aib-Ala-Gln-Aib-Val-Aib-Gly-Leu-Aib-Pro-Val-Aib-Aib-Gln-Gln-Pheol

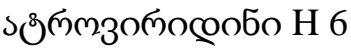

Ac-Aib-Pro-Aib-Ala-Aib-Ala-Gln-Aib-Val-Aib-Gly-Val-Aib-Pro-Val-Aib-Aib-Gln-Gln-Pheol

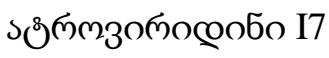

Ac-Aib-Ser-Val-Ile-Aib-Pro-Leu-Leu-Aib-Pro-Valol

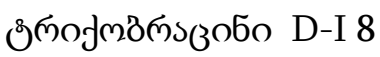

Ac-Aib-Pro-Aib-Ala-Aib-Ala-Gln-Aib-Val-Aib-Gly-Leu-Aib-Pro-Val-Aib-Aib-Gln-Gln-Pheol

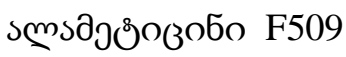

Ac-Aib-Pro-Aib-Ala-Aib-Ala-Gln-Aib-Val-Aib-Gly-Leu-Aib-Pro-Val-Aib-Iva-Gln-Gln-Pheol

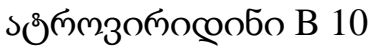

Ac-Aib-Pro-Aib-Ala-Aib-Aib-Gln-Aib-Val-Aib-Gly-Leu-Aib-Pro-Val-Aib-Aib-Gln-Gln-Pheol зммповзмпобо В 11

Ac-Aib-Pro-Aib-Ala-Aib-Aib-Gln-Aib-Val-Aib-Gly-Leu-Aib-Pro-Val-Aib-Aib-Glu-Gln-Pheol

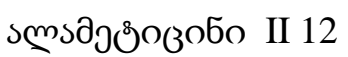

Ac-Aib-Pro-Aib-Ala-Aib-Aib-Gln-Aib-Val-Aib-Gly-Leu-Aib-Pro-Val-Aib-Iva-Glu-Gln-Pheol

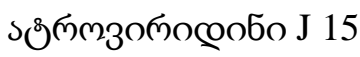

Ac-Aib-Ala-Aib-Ala-Aib-Ala-Gln-Aib-Val-Aib-Gly-Leu-Aib-Pro-Val-Aib-Aib-Gln-Gln-Pheol

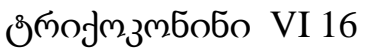

Ac-Aib-Ala-Aib-Ala-Aib-Ala-Gln-Aib-Val-Aib-Gly-Leu-Aib-Pro-Val-Aib-Iva-Gln-Gln-Pheol

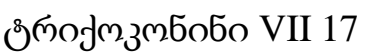

Ac-Aib-Ala-Aib-Ala-Aib-Ala-Gln-Aib-Val-Aib-Gly-Leu-Aib-Pro-Val-Aib-Iva-Glu-Gln-Pheol ммбзовпьзобо BIII ${ }^{93}$

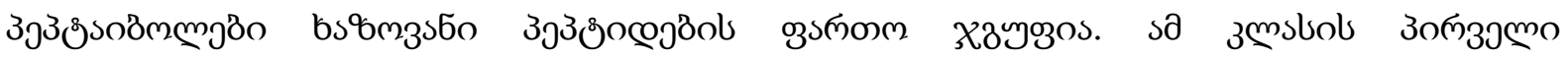

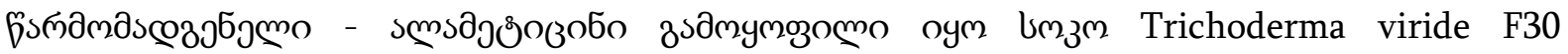

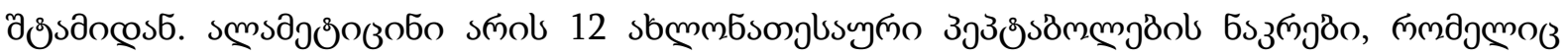

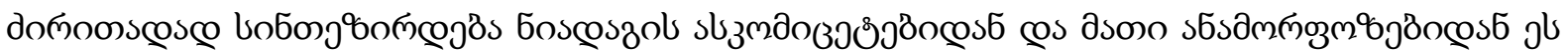

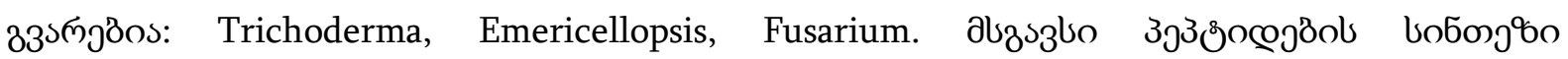

\footnotetext{
${ }^{93}$ Sloan Ayers,a Brandie M. Ehrmann,a Audrey F. Adcock,b and et al. Peptaibols from two unidentified fungi of the order Hypocreales with cytotoxic, antibiotic, and anthelmintic activities. Journal of Peptide Science. DOI $10.1002 /$ psc. 2425
} 


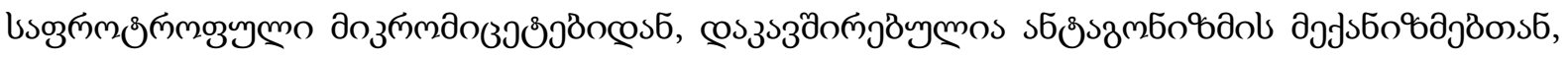

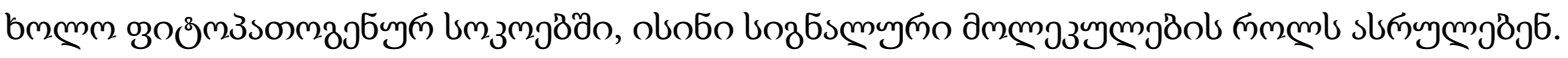

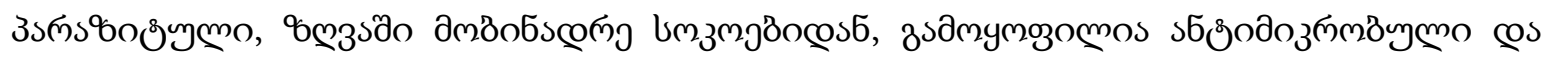

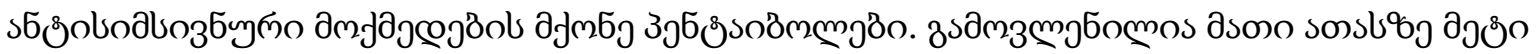

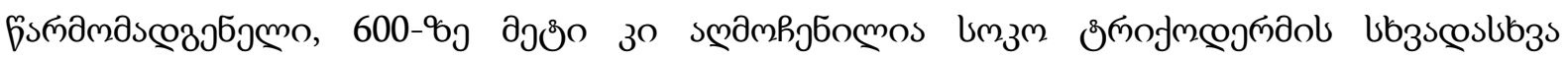
usbjmд̈j8ðo [12].

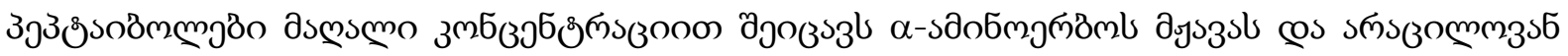

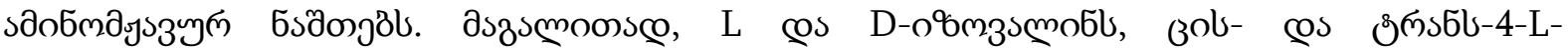

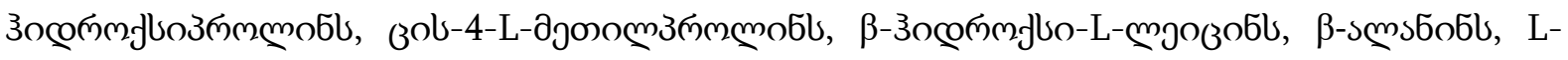

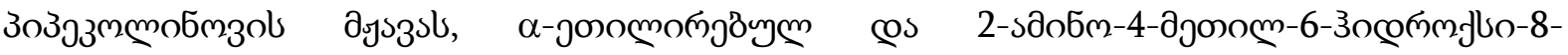

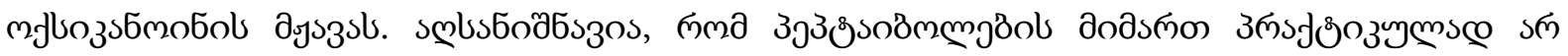

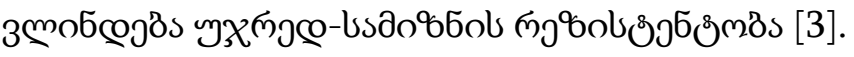

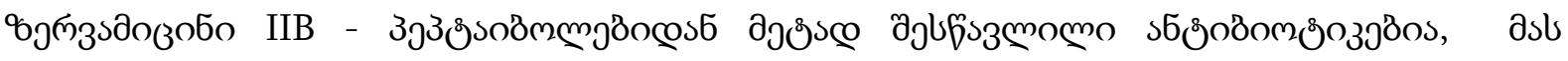

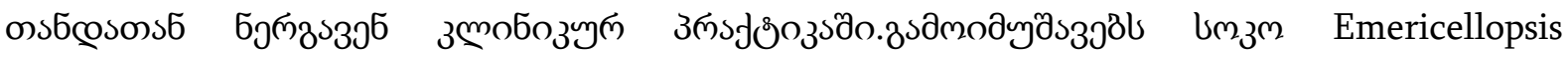

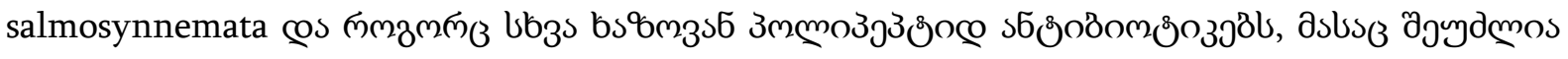

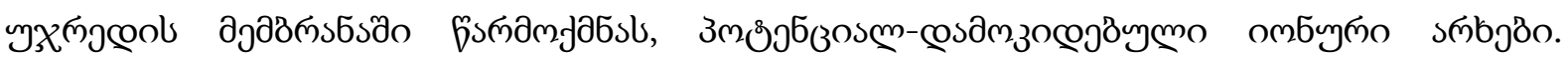

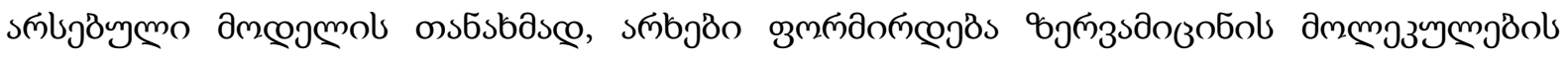

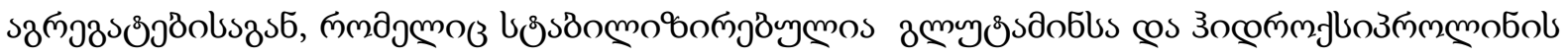

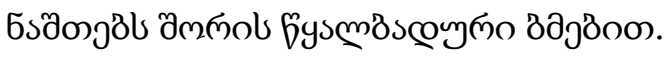

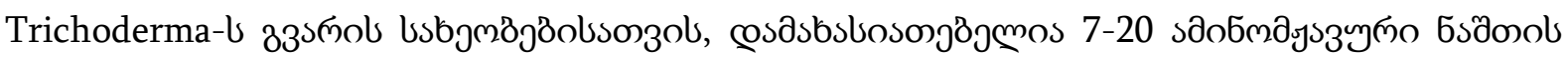

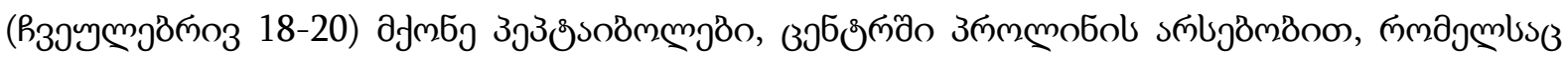

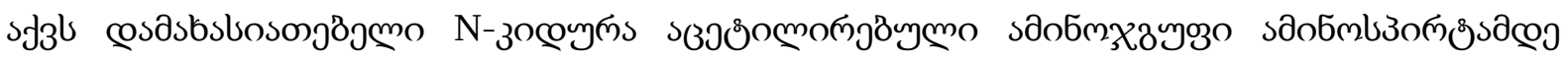

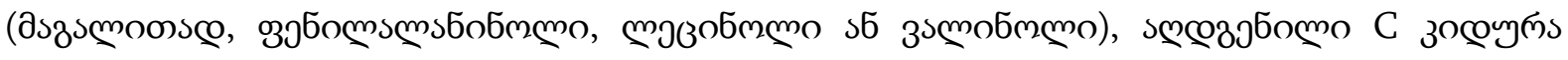

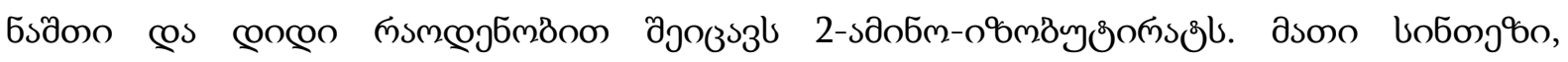

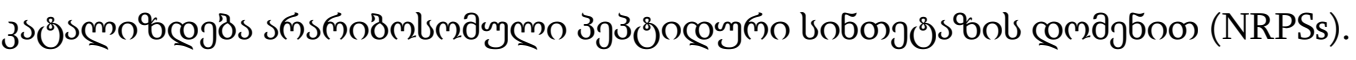

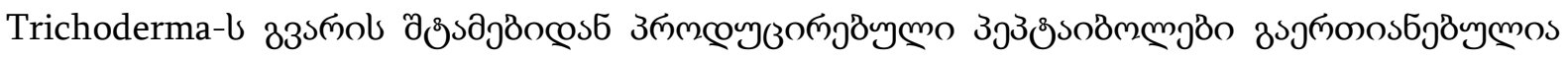

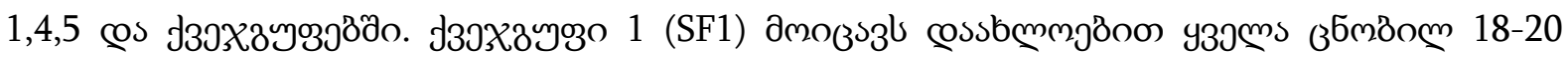

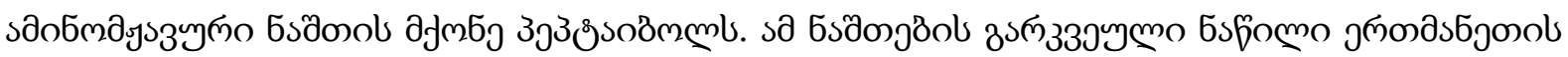
alszşus.

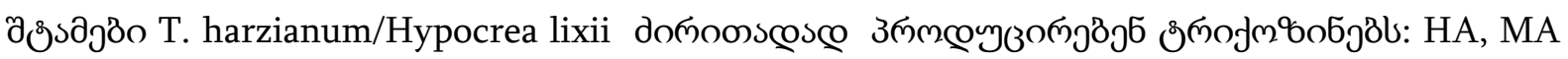

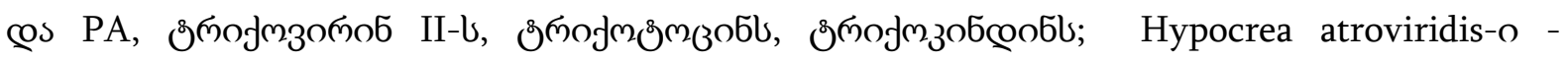

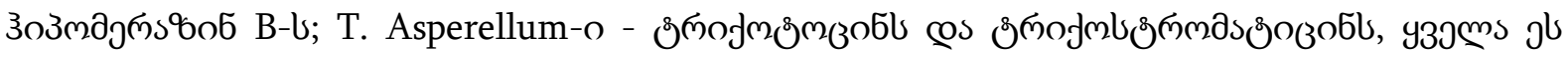

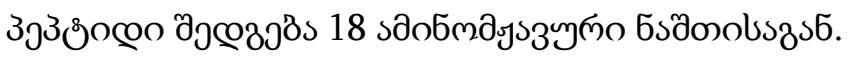

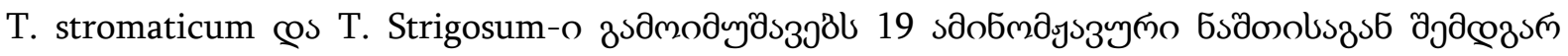

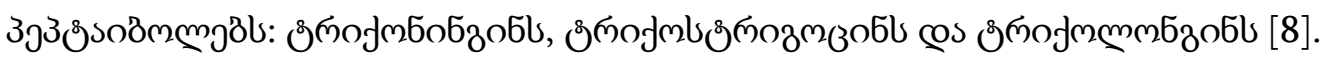

T. reesei /Hypocrea jecorina, T. longibrachiatum, T. citrinoviride, T. pubescens @s T. Strictipile-

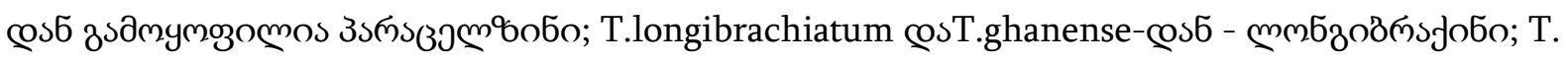

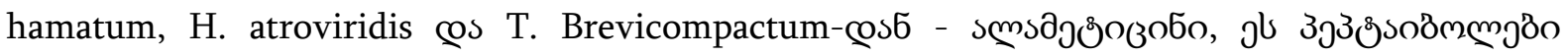

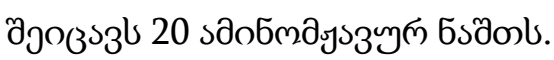

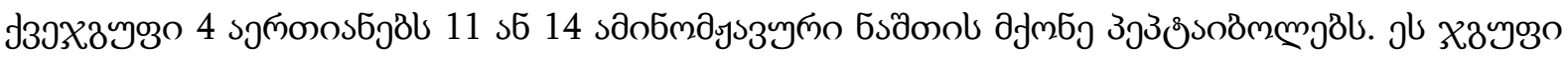
эзопьљ̊

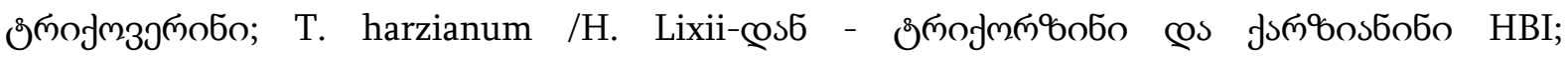


T.Pseudokoningii-@

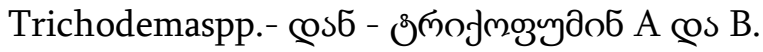

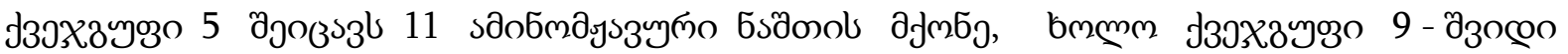

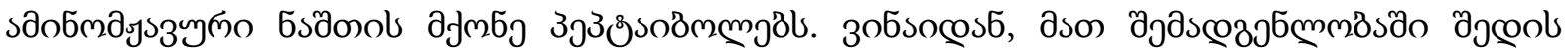

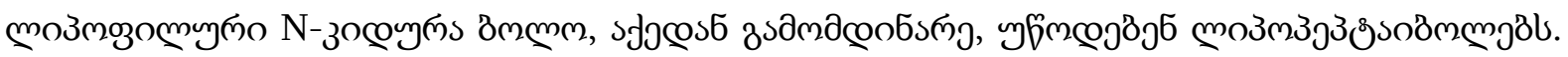

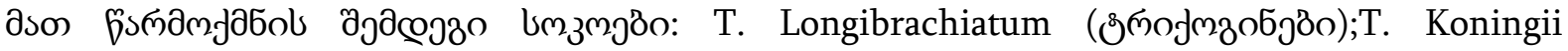

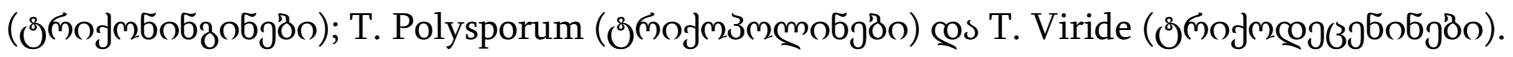

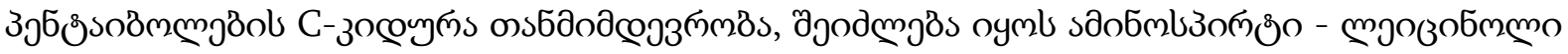

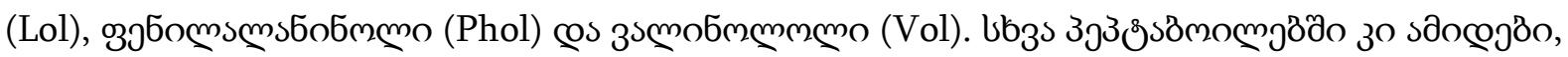

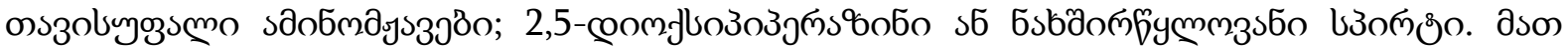

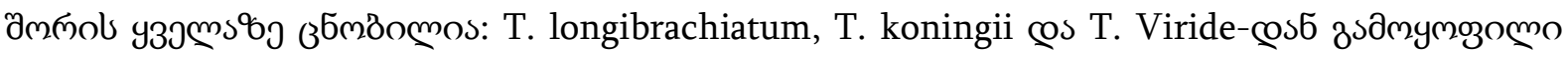

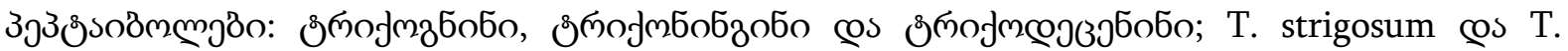

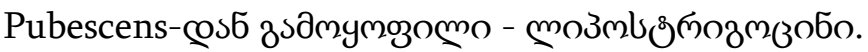

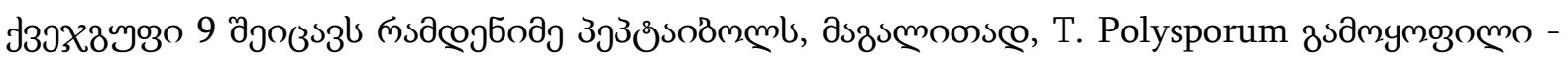

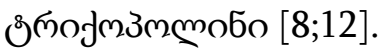

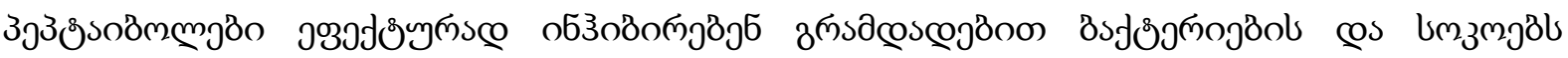

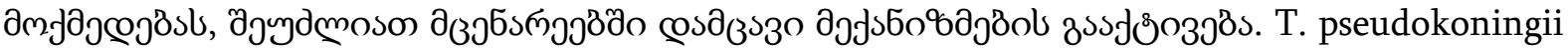

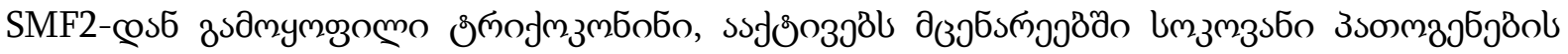

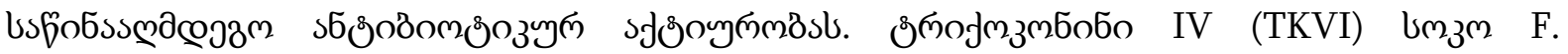

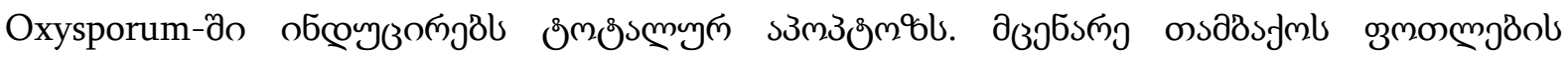

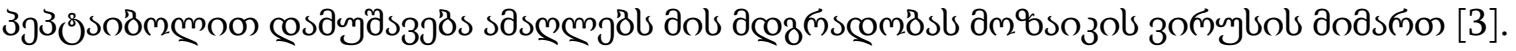

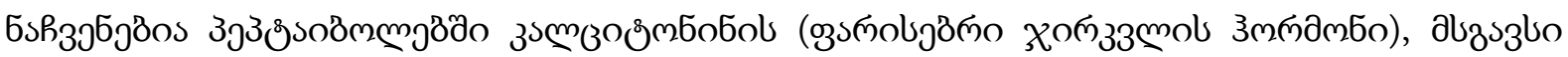

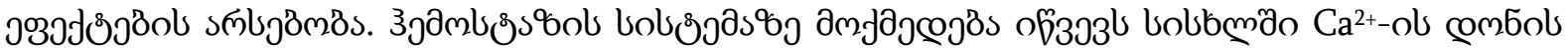

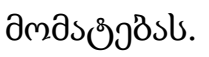

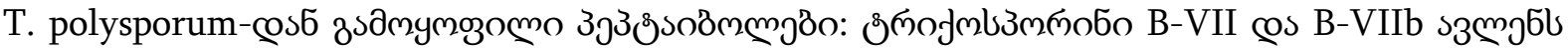

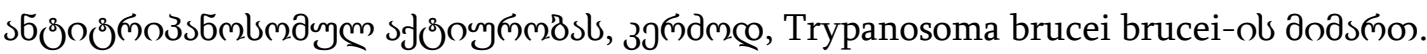

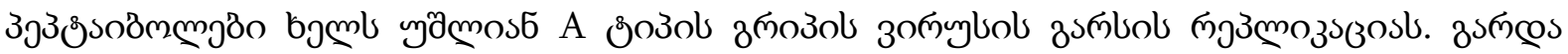

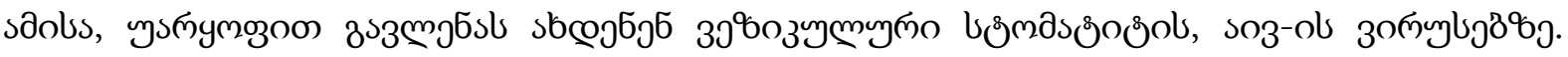

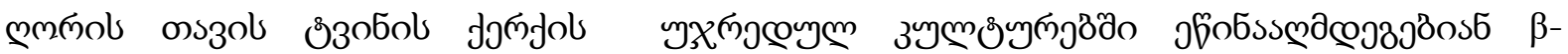

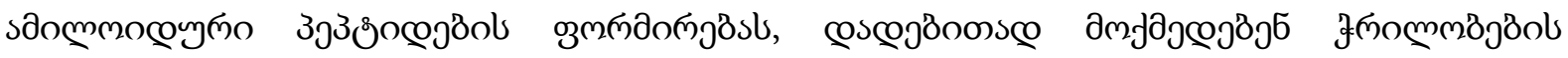

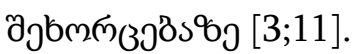

\footnotetext{
${ }_{94}^{94}$ дృ Leu-Aib-Pro-Leuol.
} 


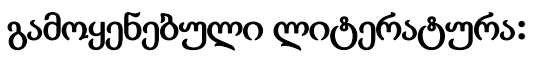

1. Abdalla M., Matasyoh C. Endophytes as producers of peptides: An overview about the recently discovered peptides fromendophytic microbes //Nat. Prod. Bioprospect. - 2014. Vol. 4. - P. 257-270.

2. Abid A., Bacha N., Ahmad B., et al. Fungi as chemical industries and genetic engineering for the production of biologically activesecondary metabolites //Asian Pac. J. Trop. Biomed. 2014. - Vol. 4, №11. - P. 859-870

3. Atanasova L., Druzhinina I.S., Jaklitsch W.M. Two hundred Trichoderma species recognized based on molecular phylogeny/ In:Trichoderma: Biology and Applications. (Eds.) - UK: CABI of Nosworthy Way. Wallingford, Oxon. -2013.

4. Bocchinfuso G., Palleschi A., Orioni B., et al. Different mechanisms of action of antimicrobial peptides: insights from fluorescencespectroscopy experiments and molecular dynamics simulations // J. Pept. Sci. - 2009. - Vol. 15. - P. 550-558.

5. Brakhage A. Regulation of fungal secondary metabolism //Nature Rev. Microbiology. -2012. - P. 1-12

6. Holt A., Killian J.A. Orientation and dynamics of transmembrane peptides: the power of simple models// Eur. Biophys. J. - 2010.- Vol. 39. - P. 609-621.

7. McDonagh A., et al. Sub-telomere directed gene expression during initiation of invasive aspergillosis // PLoS Pathog. - 2008. -Vol. 4. - e1000154.

8. Neuhof T., Dieckmann R., Druzhinina I., et al. Intact-cell MALDI-TOF mass spectrometry analysis of peptaibol formation by thegenus Trichoderma. Hypocrea: can molecular phylogeny of species predict peptaibol structures? // Microbiology. - 2007. -Vol.153. - P. 3417-3437.

9. Qinggui W. and Xu L. Beauvericin, a bioactive compound produced by fungi: a short review // Molecules. - 2012. - Vol. 17. - P.2367-2377.

10. Ribet D. \& Cossart P. Pathogen-mediated posttranslational modifications: a re-emerging field // Cell. - 2010. - Vol. 143. - P.694-702.

11. Sheo B Singh ${ }^{1}$, Kithsiri Herath, Ziqiang Guan, Deborah L Zink, Anne W Dombrowski, Jon D Polishook, Keith C Silverman, Russell B Lingham, Peter J Felock, Daria J HazudaIntegramides $\mathrm{A}$ and $\mathrm{B}$, two novel non-ribosomal linear peptides containing nine C(alpha)-methyl amino acids produced by fungal fermentations that are inhibitors of HIV-1 integrase 2002 May 2;4(9):1431-4. doi: 10.1021/ol025540a.

12. Stoppacher N., Neumann N.K.N., Burgstaller L., et al. The comprehensive peptaibiotics database // Chem. Biodiv. - 2013. - Vol.10, №5. - P. 734-743. 


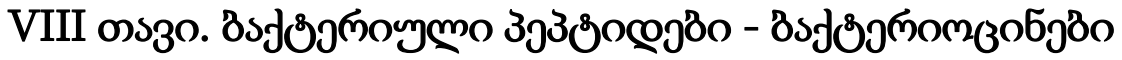

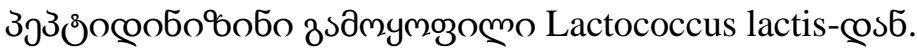

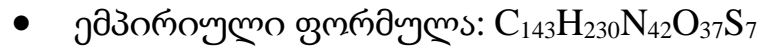

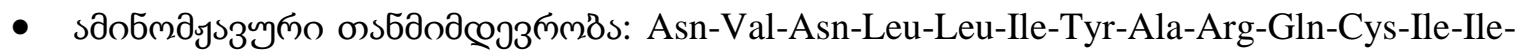
Leu-Ala-Ile-His-Glu-Glu-Gly-Ser-Ala-Asn.

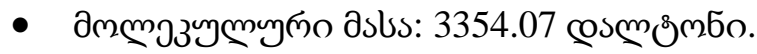

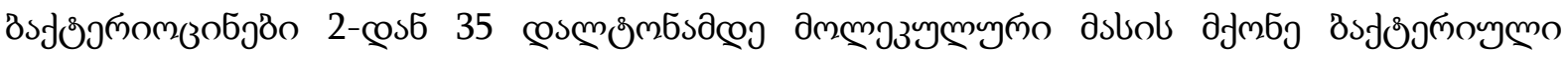

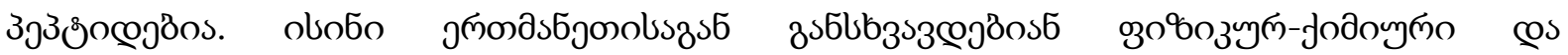

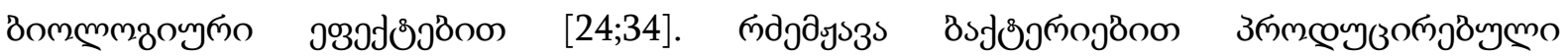

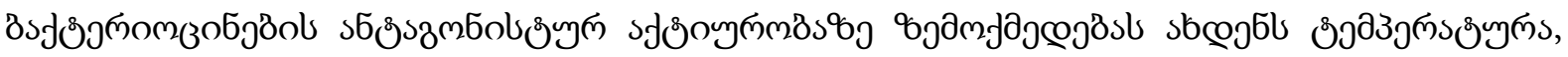

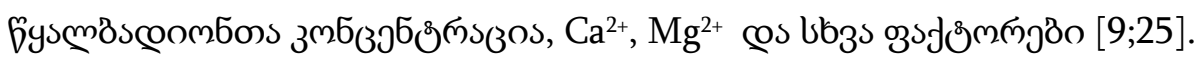

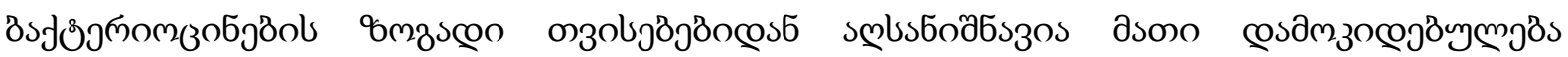

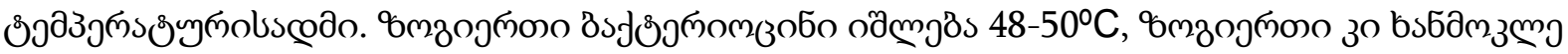

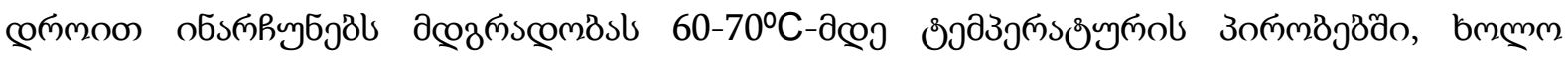

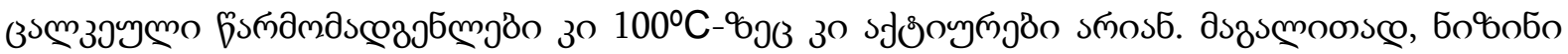

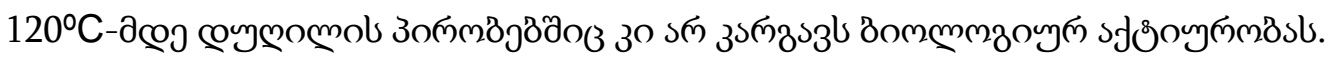

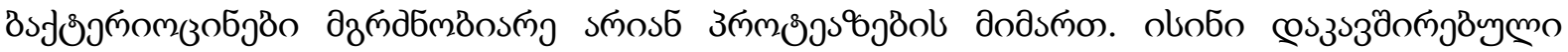

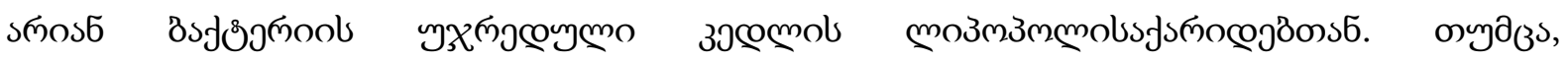

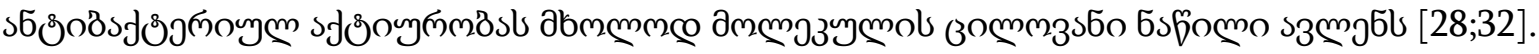

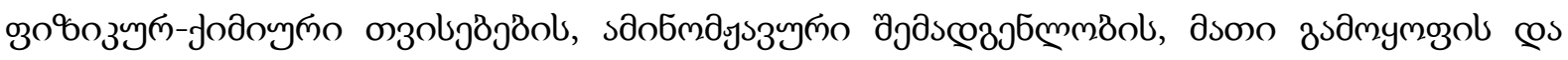

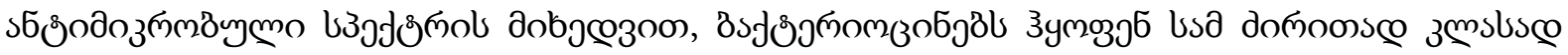
$[3 ; 12 ; 25]$.

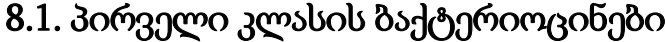

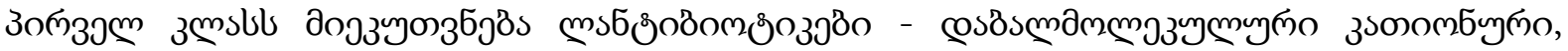

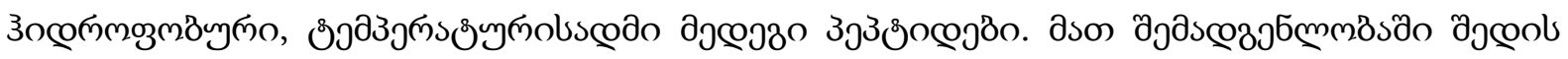

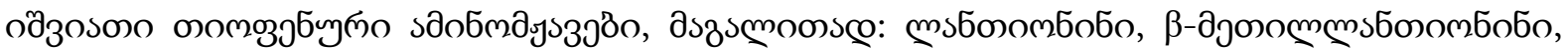

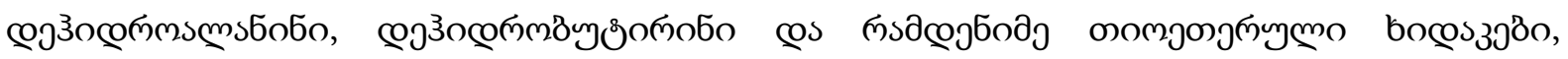

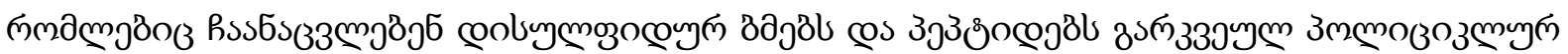

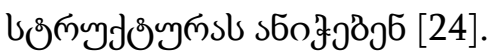

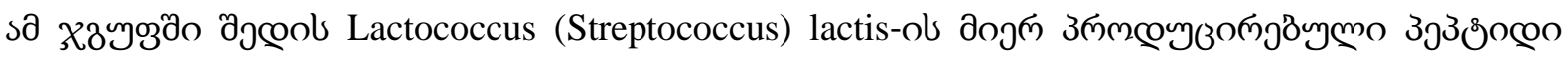

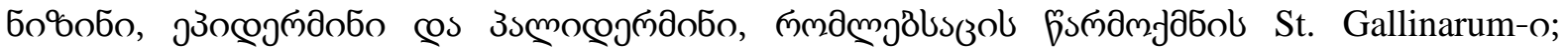

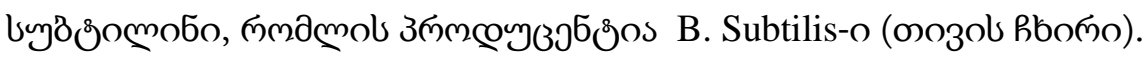

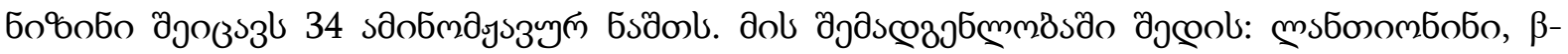

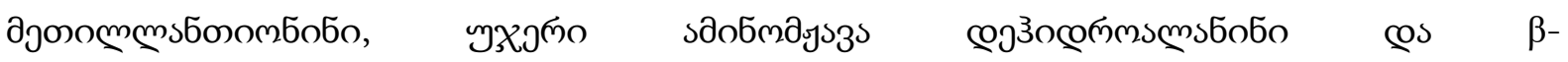

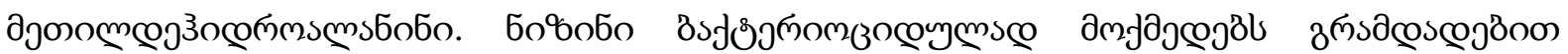

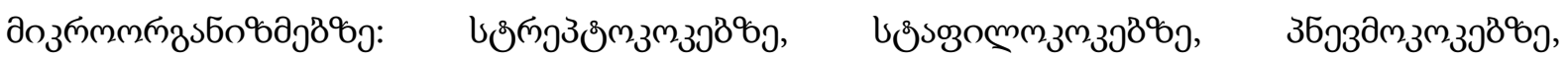

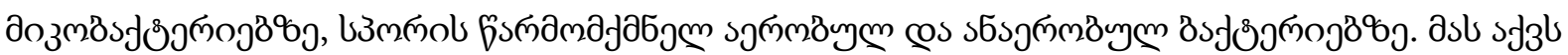




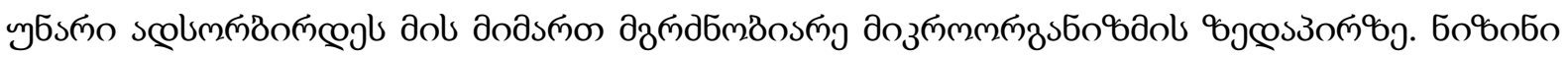

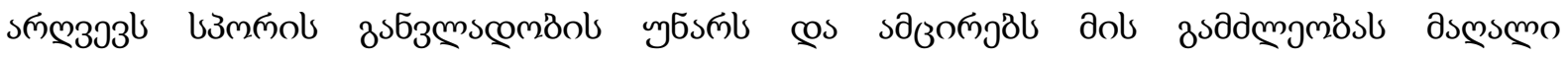

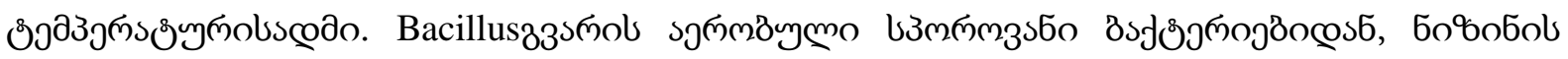

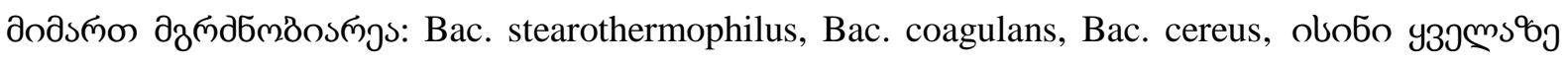

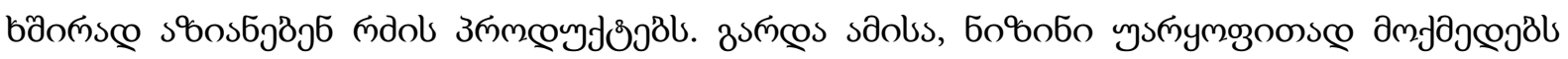

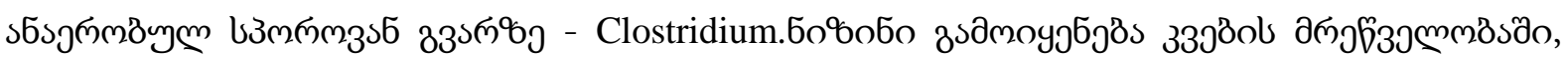

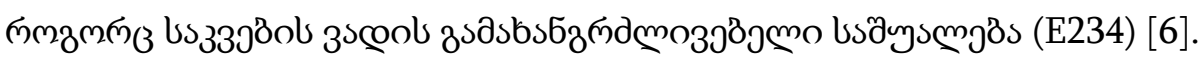

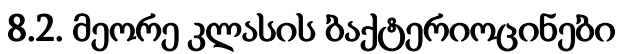

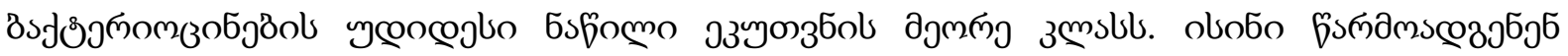

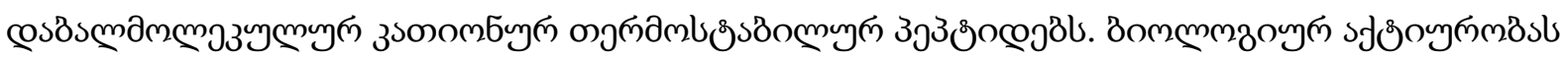

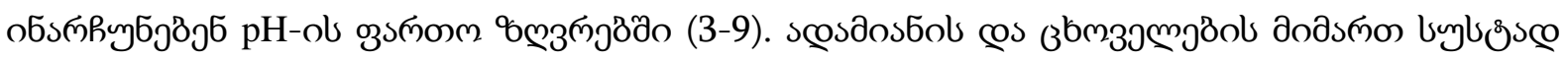

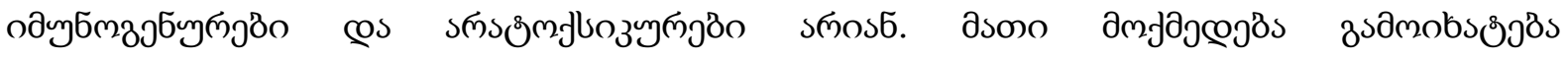

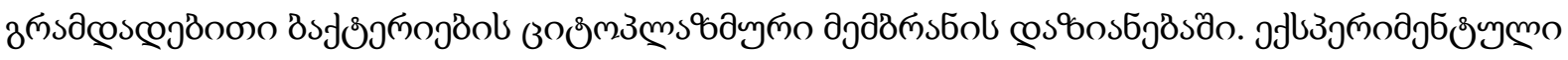

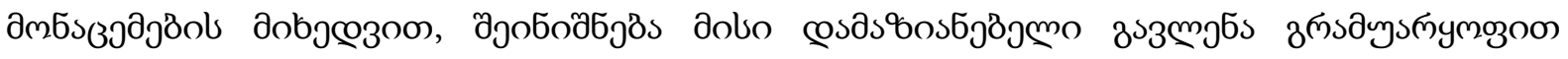

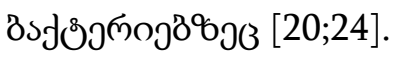

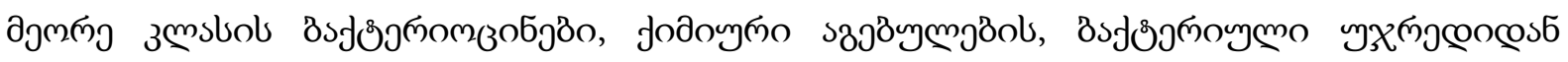

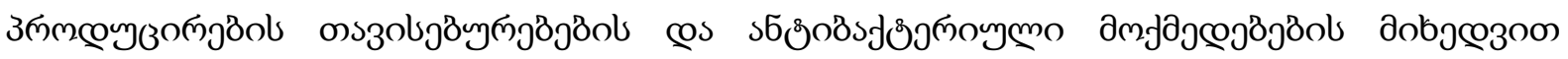

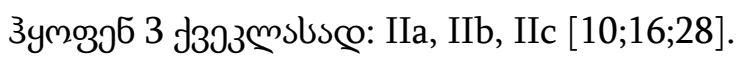

\section{J333ల̊sbo IIa}

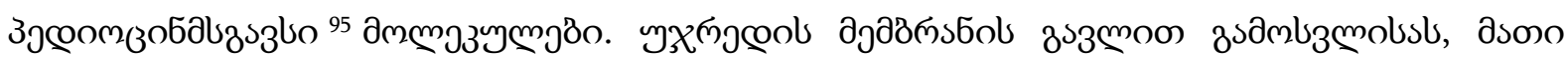

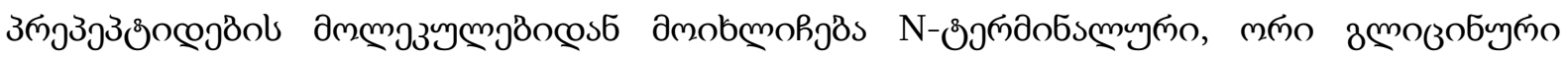

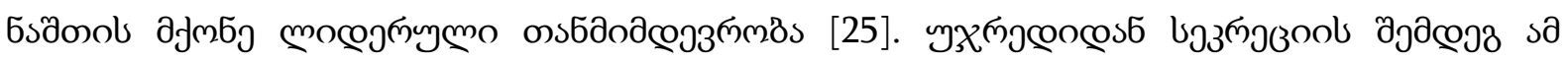

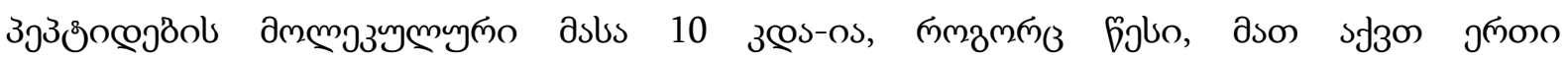

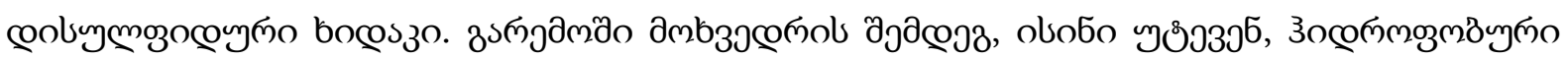

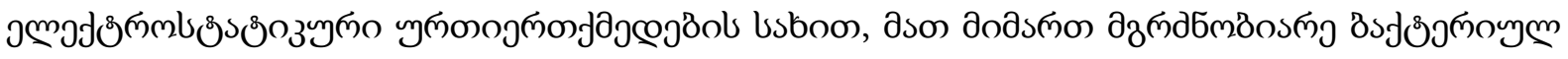

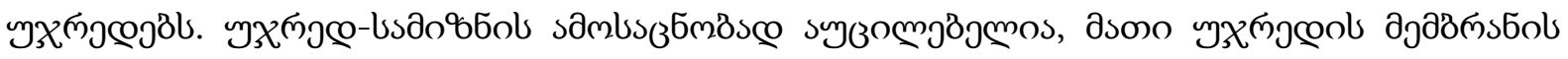

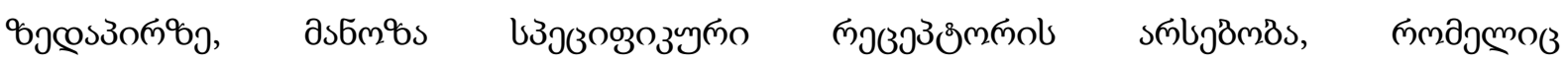

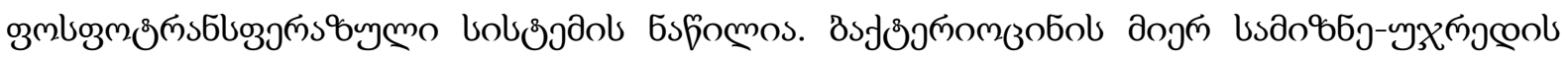

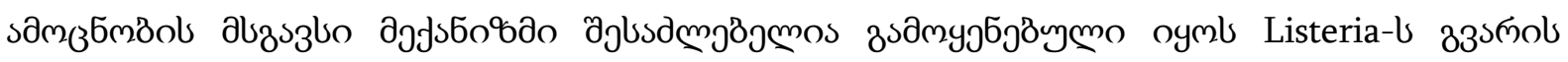

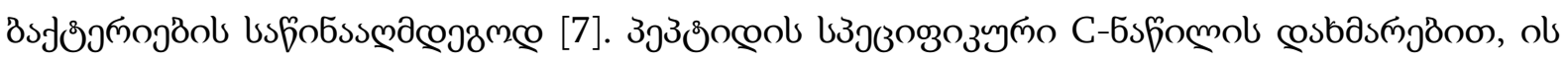

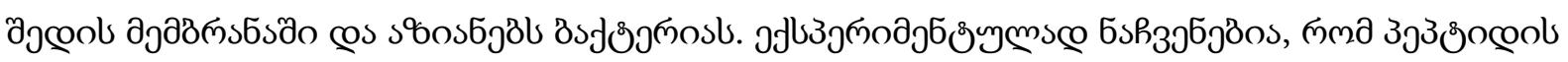

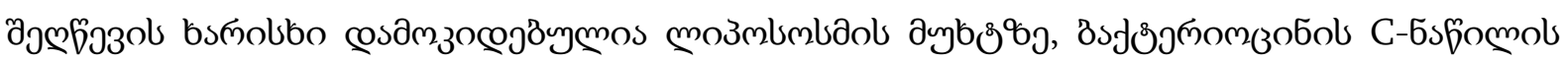

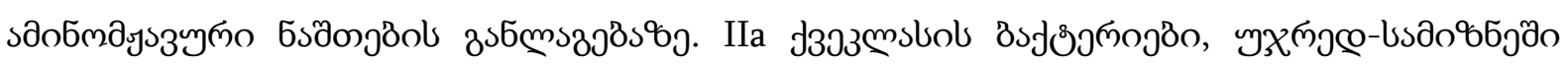

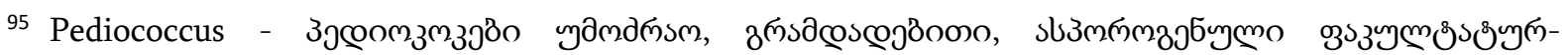

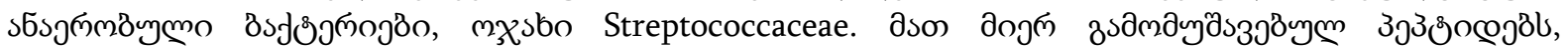

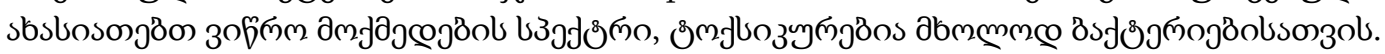




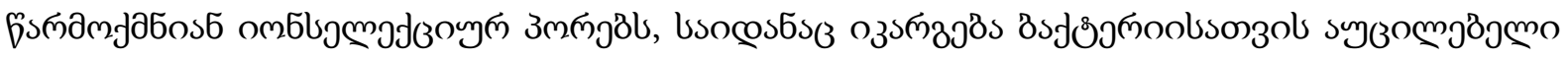

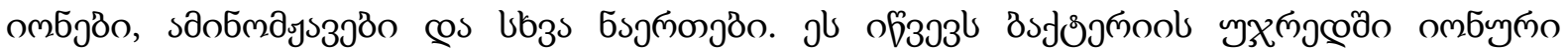

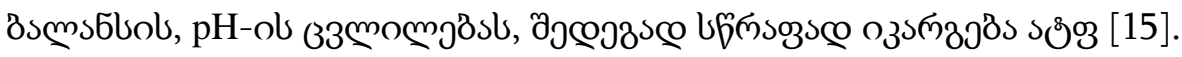

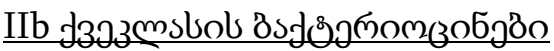

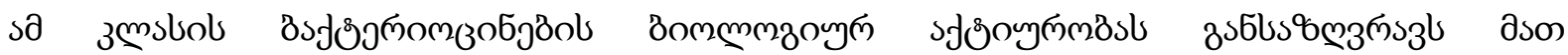

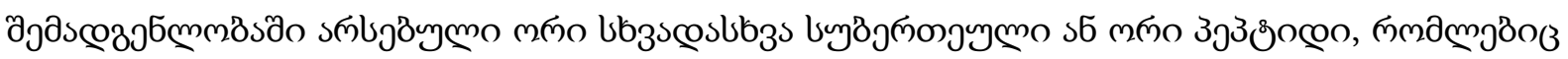

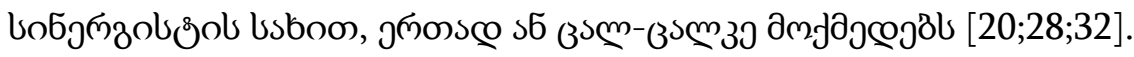

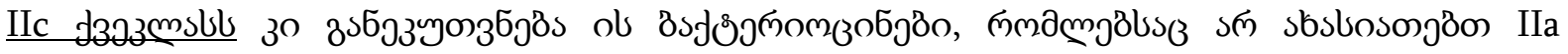

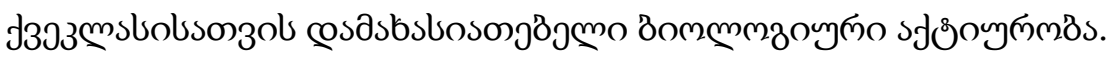

IId d3azmsluol os dogonomzo6jöo

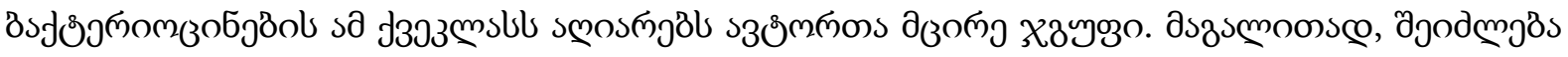

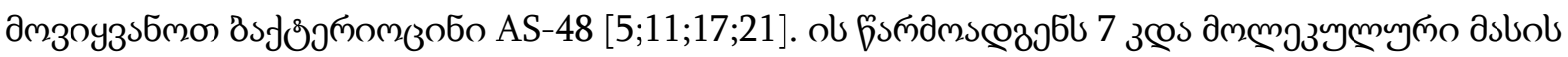

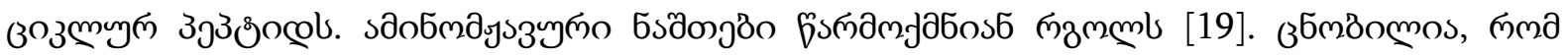

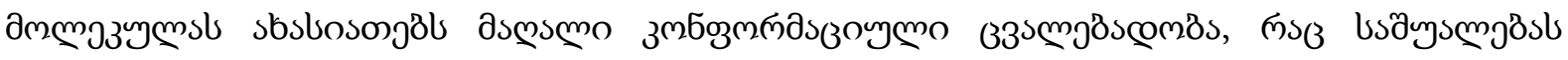

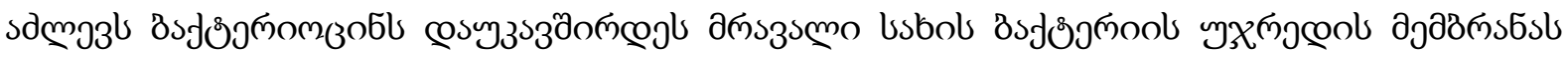
$[4 ; 7 ; 24 ;$.

\section{3. ajbsaj зmslob}

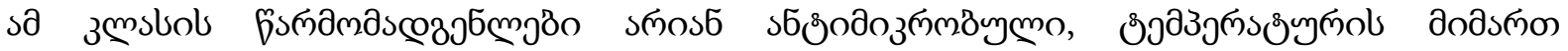

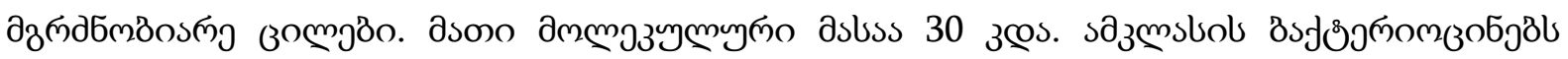

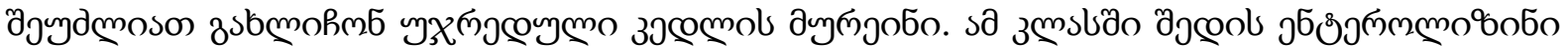
A.

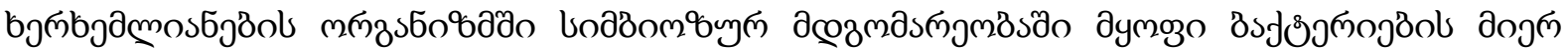

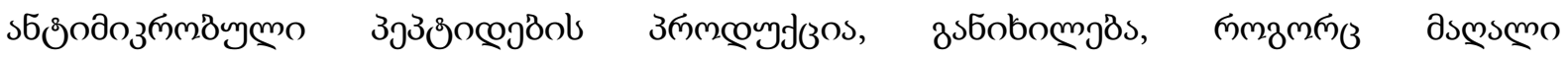

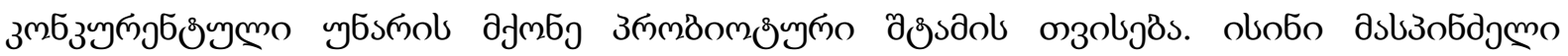

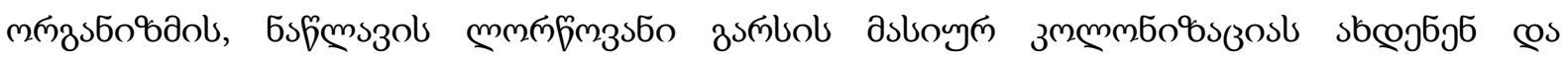

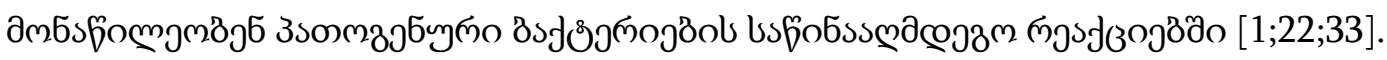

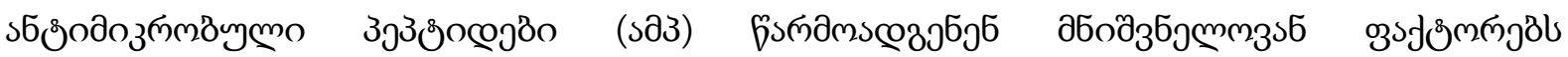

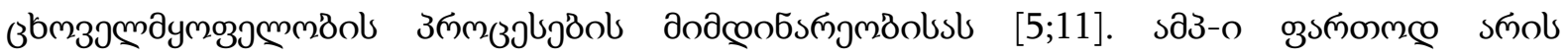

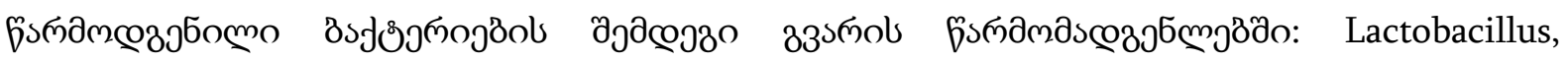
Streptococcus, Lactococcus, Pediococcus, Enterococcus @os bb3s [14;35]. Lactobacillus reuteri-@os6

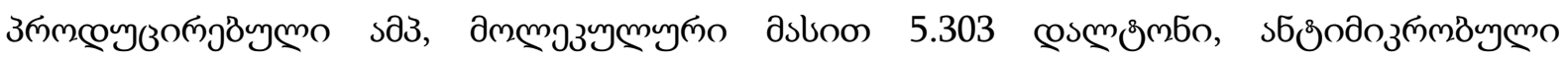

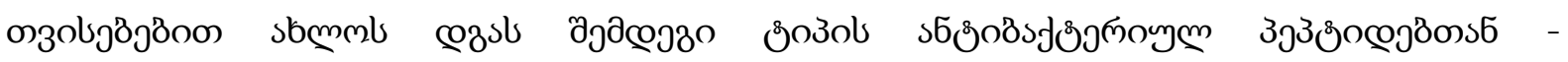

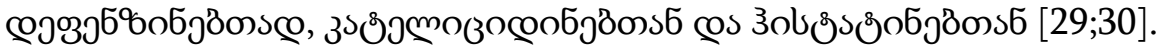

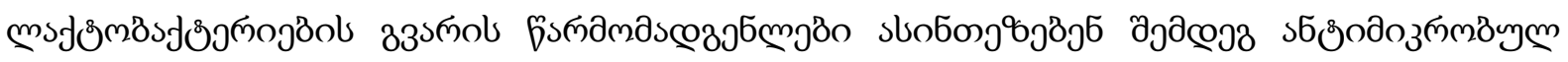

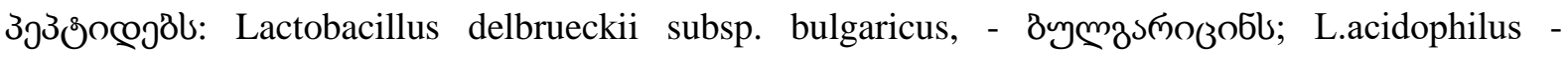

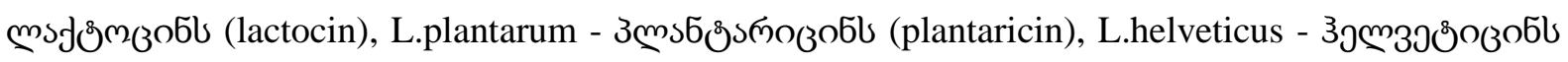
(helveticin), L.casei - зs\% (sakacin) [19;28].

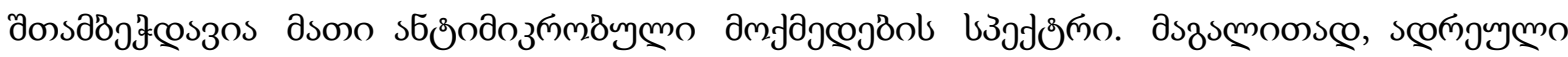




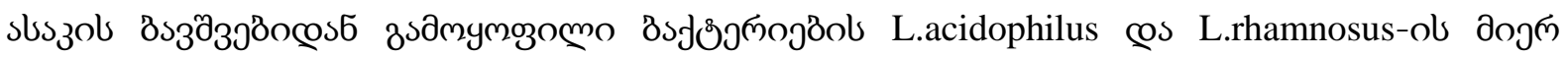

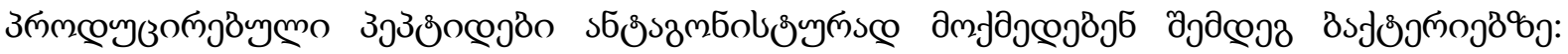
E.coli, Klebsiella pneumoniae,Staphylococcus aureus, Enterococcus faecalis @os Clostridium

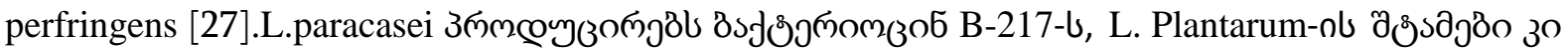

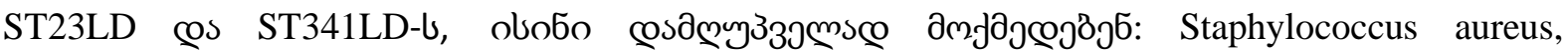
Streptococcus pneumoniae ,Enterococcus faecalis, Escherichia coli, Bacillus cereus, Salmonella spp.,

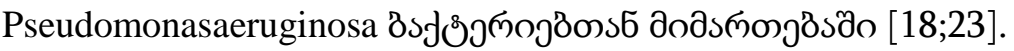

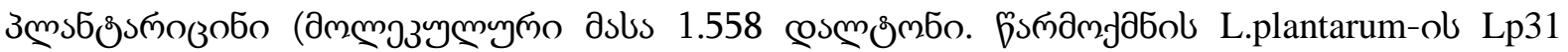

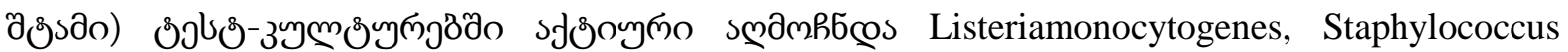

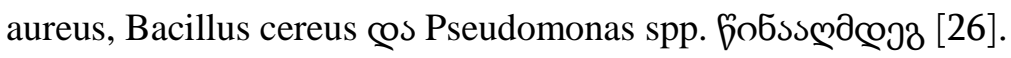

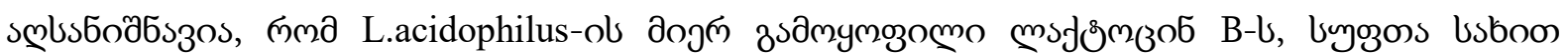

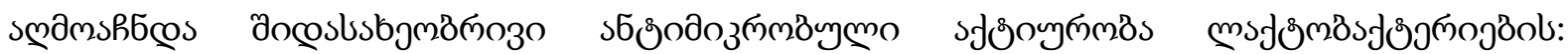
L.leichmanii, L.helviticus, L.lactis @os L.delbrueckii-ob dods๙non [2].

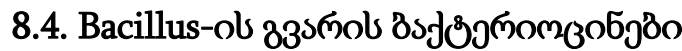

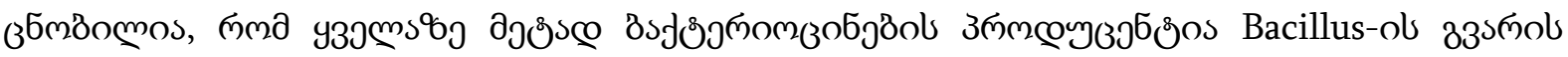

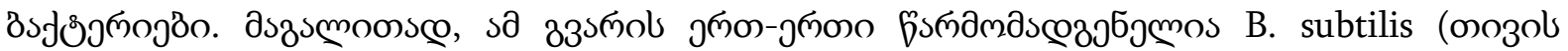

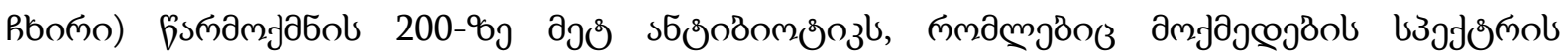

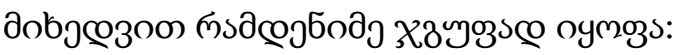

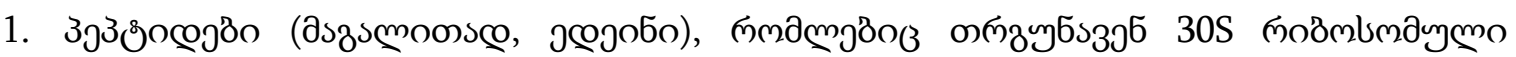

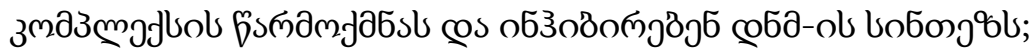

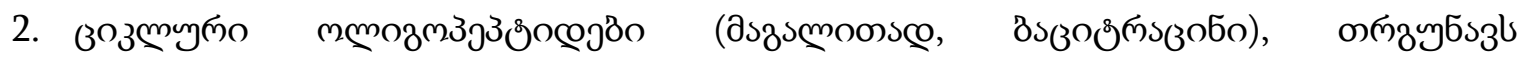

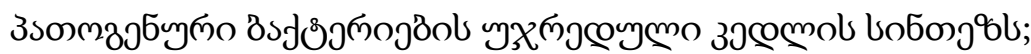

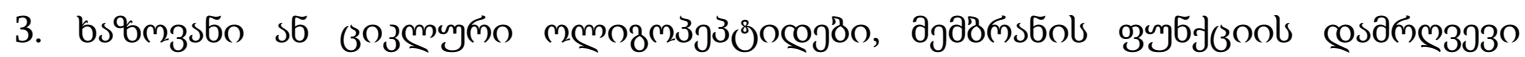

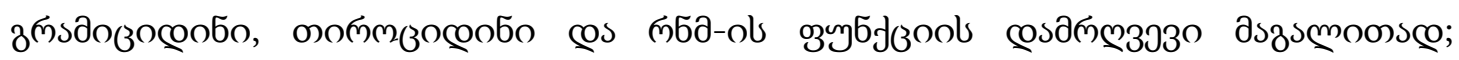

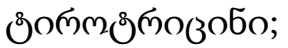

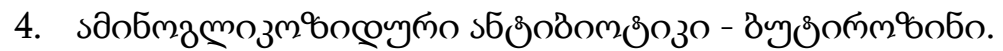

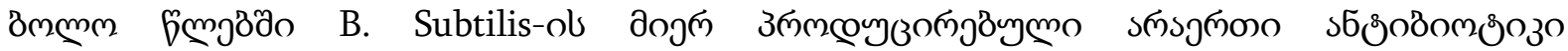

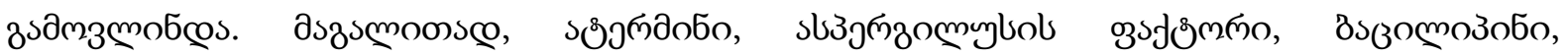

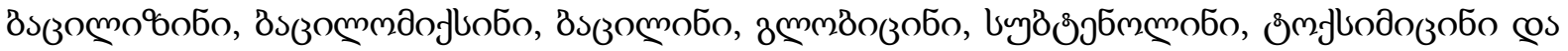

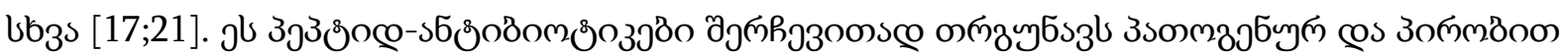

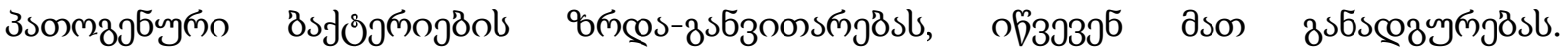

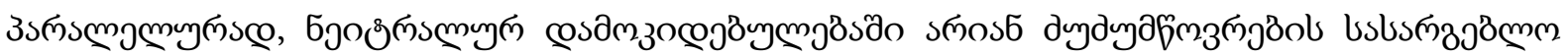

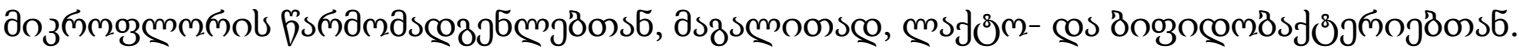

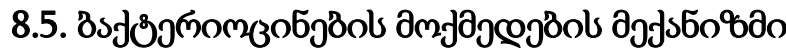

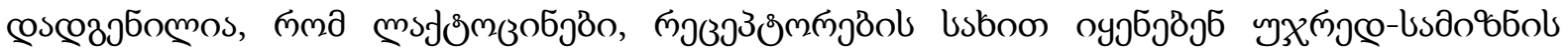

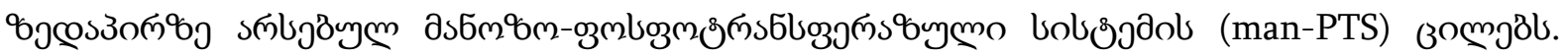

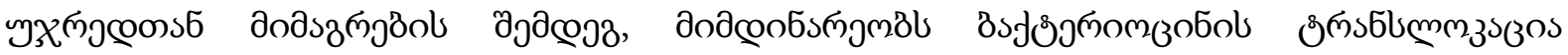

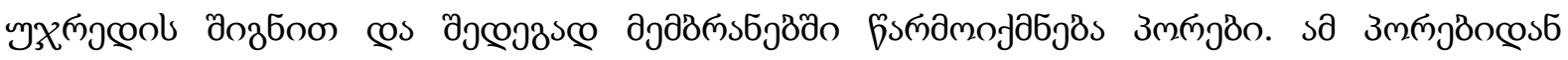




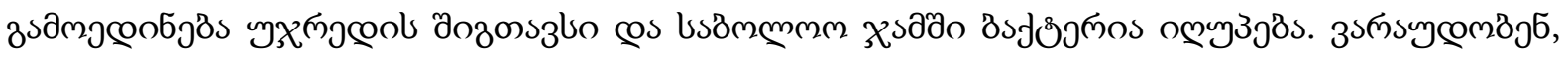

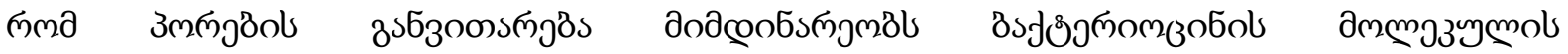

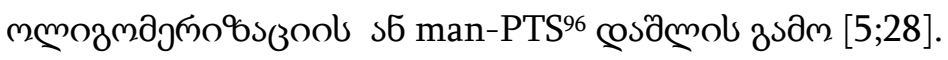

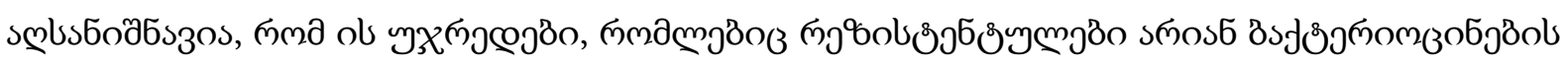

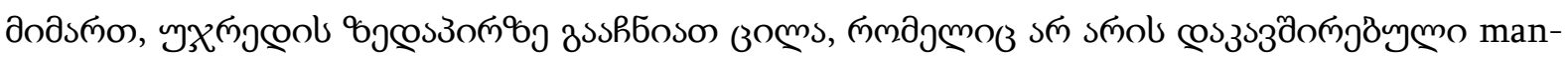

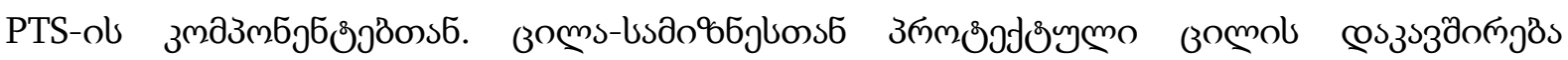

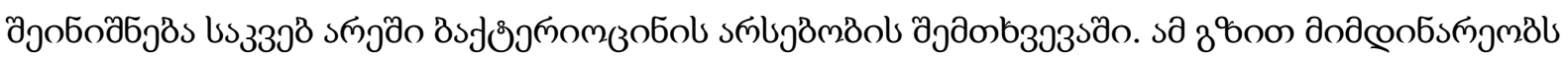

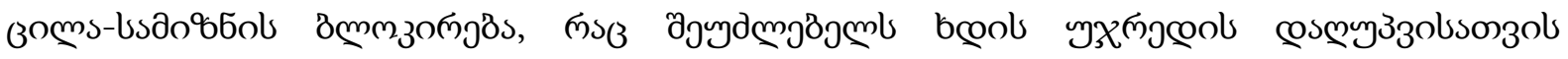

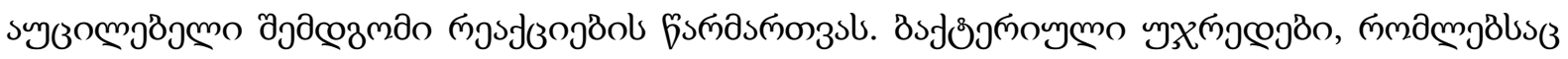

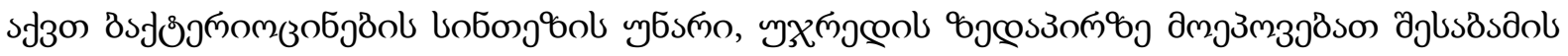

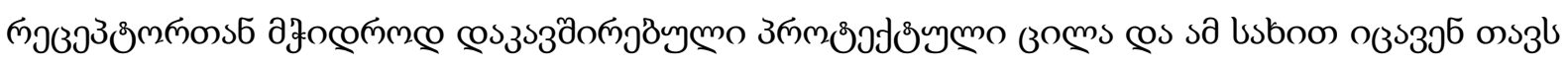

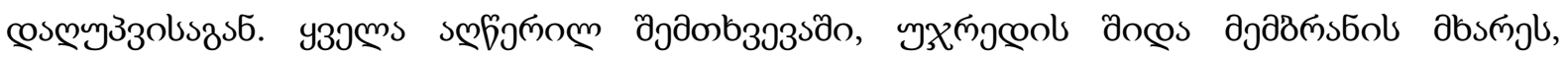

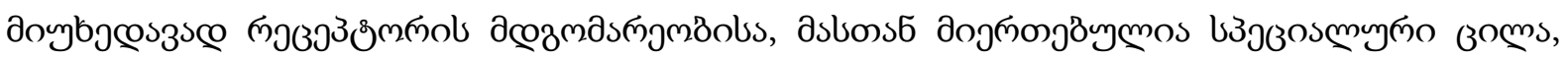

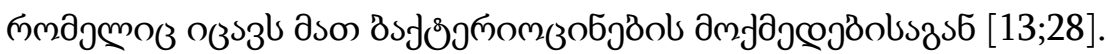

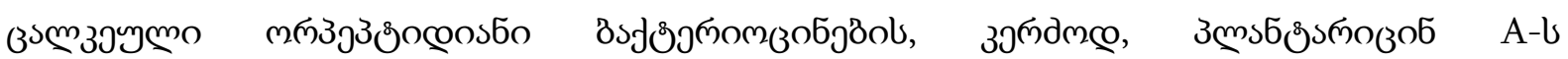

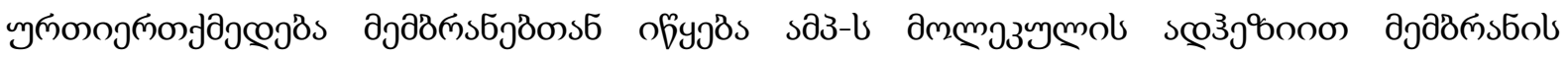

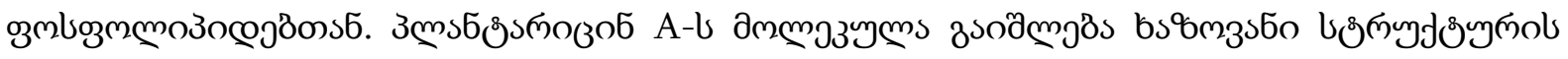

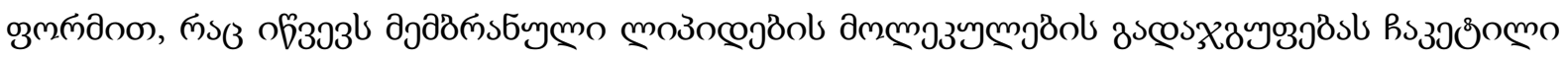

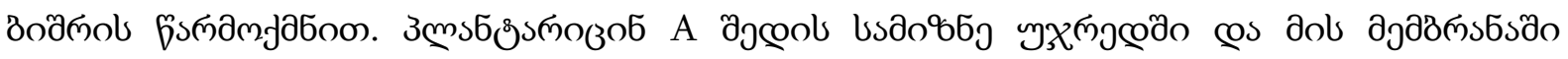

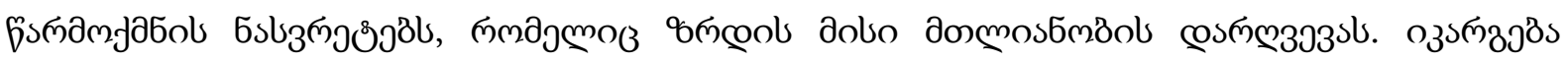

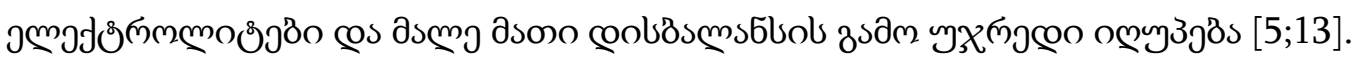

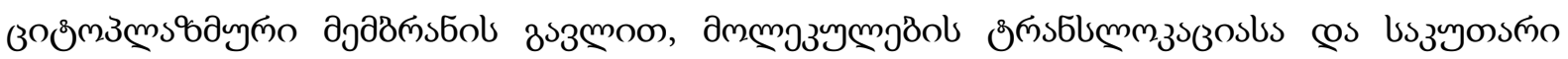

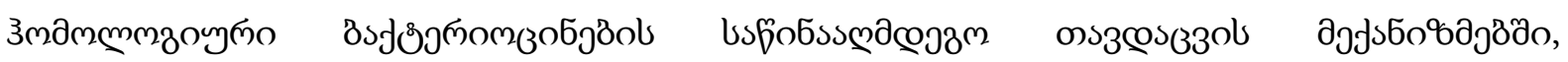

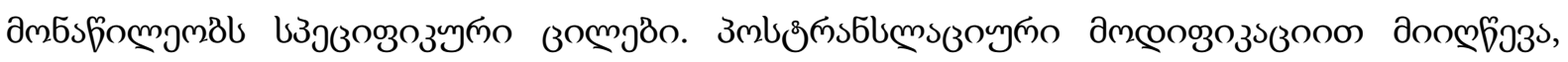

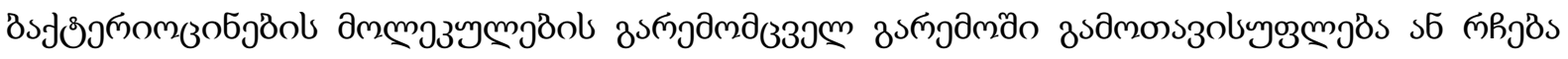

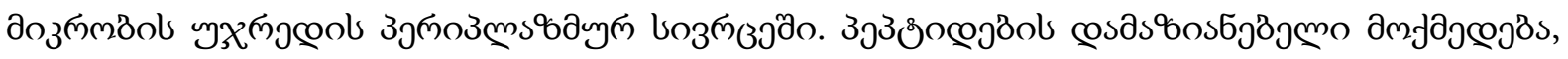

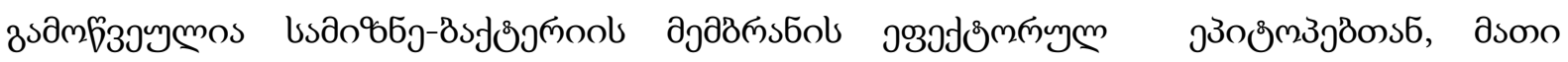

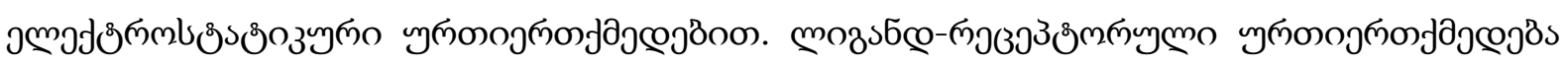

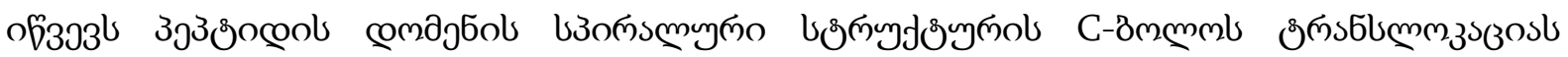

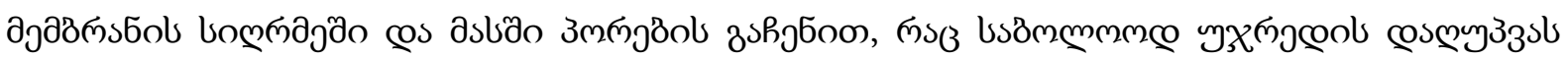

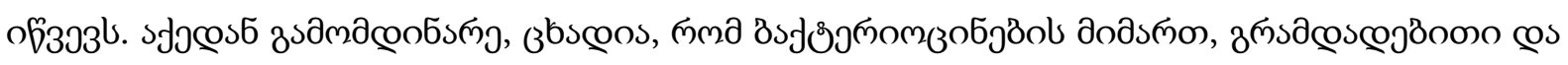

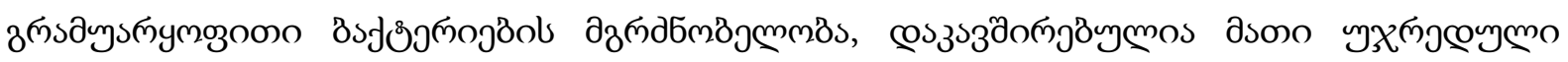

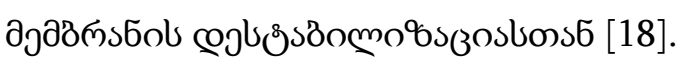

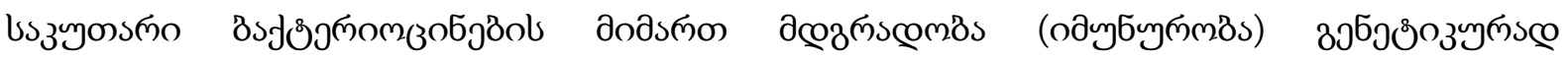

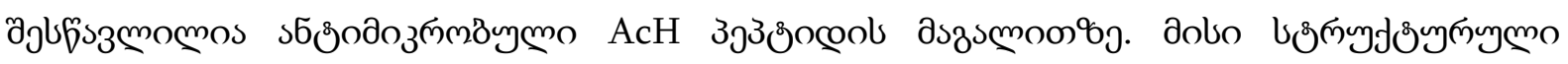

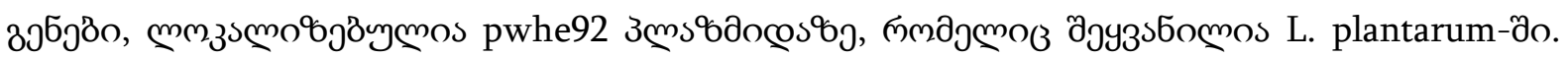

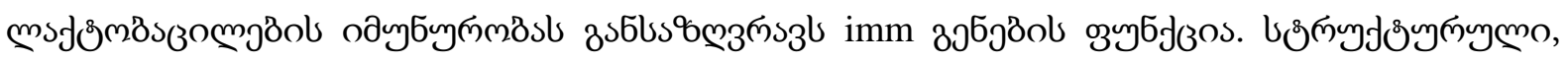

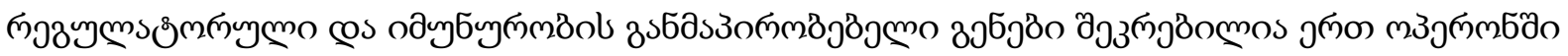
$[8 ; 31]$.

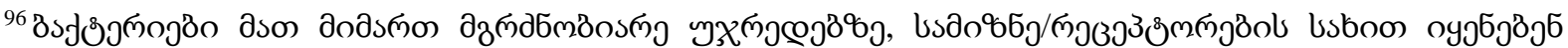

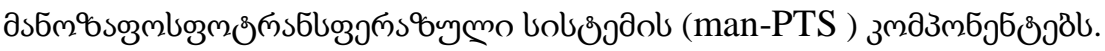




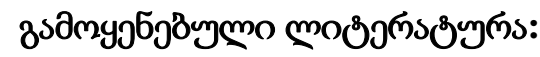

1. Alander M., Korpela R., Salexin M. et al. Recovery of Lactobacillus rhamnosus GG from human colonic biopsies. Lett.Appl.Microbiol.1997, 24 (5): 361-364.

2. Barefoot S.F., Chen Y.R., Hughes T.A. et al. Identification and purification of a protein thatinduces production of the Lactobacillus acidophilus bacteriocin lactocin B. Appl. Environ.Microbiol. 1994. 60: 3522-3528.

3. Bittencourt E., Suzart S. Occurrence of virulence-associated genes in clinical Enterococcus faecalis strains isolated in Londrina, Brazil // J. Med. Microbiol. -2004. -Vol. 53. -P. 10691073 .

4. Brasseui R. Bennik M. H. J., Berlinda V. A novel bacteriocin from vegetable associated Enterococcus mundtii: full characterization and interaction with target organisms // Biochim. Biophys. Acta: Biomembr. -2008. -Vol. 1679, Is. 1. -P. 47-58.

5. Breukink E. A lession in efficient killing from two-component lantibiotics. Mol. microbiol.2006, 61 (2): 271-273.

6. Budde, B. B., and Rasch, M. (2001). A comparative study on the use of flow cytometry and colony forming units for assessment of the antibacterial effect of bacteriocins. Int. J. Food Microbiol. 63, 65-72. doi: 10.1016/S0168-1605(00) 00399-8

7. Criado R., Dzung B., Diep A. et al. Complete Sequence of the Enterocin Q-Encoding Plasmid pCIZ2 from the Multiple Bacteriocin Producer Enterococcus faecium L50 and Genetic Characterization of Enterocin Q Production and Immunity // Ibid. -2006. -Vol. 72, N 10. -P. 6653-6666.

8. De Vries M.C. Analyzing global gene expression of Lactobacillus plantarum in the human gastrointestinal tract. Netherlands, Wageningen, 2006.

9. De Vuyst L., Leroy F. Bacteriocins from Lactic Acid Bacteria: Production, Purification, and Food Applications // Mol. Microbiol. Biotechnol. -2007.-Vol. 13. - P. 194-199.

10. Dicks L. M. T., Balla E., Toit M. Characterization and Cloning of the Genes Encoding Enterocin 1071A and Enterocin 1071B, Two Antimicrobial Peptides Produced by Enterococcus faecalis BFE 1071 // Appl. Environ. Microbiol. -2013. -Vol. 93, N 4. -P. 12981304.

11. Diep D.B., Nes I.F. Ribosomally synthesized antibacterial peptides in grampositive bacteria.Curr. Drug Targets. 2002, 3: 107-122.

12. Drider D., Fimland G., Héchard Y. The Continuing Story of Class IIa Bacteriocins // Microbiol. Mol. Biol. Rev. -2006. -Vol. 70, N 2. -P. 564-582.

13. Dzung B.,Diep D.B., Skaugen M. et al. Common mechanisms of target cell recognition and immunity for class II bacteriocins. Proc. Natl. Acad. Sci. USA. 2007, 104 (7): 2384-2389.

14. Eijsink V.G., Axelsson L., Diep D.B. et al. Production of class II bacteriocins by lactic acidbacteria; an example of biological warfare and communication. Antonie van Leeuwenhoek. 2002, 81: 639-654.

15. Ennahar S., Descamps N. Anti-Listerial effect of enterocin A, produced by cheese-isolated Enterococcus faecium EFMO1, relative to other bacteriocins from lactic acid bacteria // J. Appl. Microbiol. -2010. -Vol. 76, Is. 3. -P. 449-457.

16. Farias R. N., Farias M. E., Holgado R. Letters in Purification and N-terminal acid sequence of enterocin CRL35, a pediocin-like bacteriocin produced by Enterococcus faecium CRL35 // Appl. Microbiol. -2005. -Vol. 56. -P. 417-419.

17. Hassan M., Kjos M., Nes I., Diep D.B,Lotfipour F. // J Appl Microbiol. 2012. V. 113 (4), pp.723-736. 
18. Hechard Y., Sahl H. G. Mode of action of modified and unmodified bacteriocins from grampositivebacteria. Biochimie. 2002, 84: 545-557.

19. Jack R.W., Tagg J.R., Ray B. Bacteriocins of gram-positive bacteria. Microbiol. Rev. 1995, 59(2): 171-200.

20. Kraus A., Peschel D. Molecular Mechanisms of Bacterial Resistance to Antimicrobial Peptides. -Berlin; Heidelberg, 2006. -P. 231-250.

21. Kumariya R., Kumari G. A., Rajput Y., Sood .S.K. // Microb. 2019. V. 128, pp. 171-177.

22. Lebeer S., Vanderleydes G., De Keersmaecker S.C. Genes and molecules of lactobacillus supporting probiotic action. Microbiol. Mol. Biol. Rev. 2008, 72: 728-764.

23. Lozo J., Vukasinovic M., Strahinic I. et al. Characterization and antimicrobial activity ofbacteriocin 217 produced by natural isolate Lactobacillus paracasei BGBUK2-16. J. Food Prot. 2004, 67 (12): 2727-2734.

24. Minah C.J., Morero R.D. Inhibition of enterocin CRL35 antibiotic activity by mono- and divalent ions // Lett. Appl. Microbiol. -2003. -Vol. 37, N 5. -P. 374-379.

25. Moreno M. R. F., Sarantinopoulos P., Tsakalidou, De Vuyst L. The role of appplication of enterococci in food and health // Int. J. Food Microbiol. - 2006. - Vol. 106.- P. 1-24.

26. Muller D.M., Carrasco M.S., Tonarelli G.G. et al. Characterization and purification of a newbacteriocin with a broad inhibitory spectrum produced by Lactobacillus plantarum lp31 strainisolated from dry-fermented sausage. J.Appl.Microbiol.2009, 106 (6): 2031-2040.

27. Ocana V.S, Nader-Macías E.M. Production of antimicrobial substances by lactic acid bacteriaII: screening bacteriocin-producing strains with probiotic purposes andcharacterization ofa Lactobacillus bacteriocin. Methods Mol. Biol. 2004, 268: 347-353.

28. Oscariz J.C., Pissaboro A.G. Classification and mode of action of membrane-active bacteriocinsproduced by grampositive bacteria. Int.Microbiol. 2001, 4: 13-19.

29. Papagianni M. Ribosomally synthesis peptides with antimicrobial properties: biosynthesis, structure, function and application. Biotechnol. Adv. 2003, 21 (6): 465-499.

30. Rivas-Santiago B., Serrano C.J., Enrico-Moreno J.A. Susceptibility to infectious diseases based on antimicrobial peptide production. Infect.Immun. 2009, 77 (11): 4690-4695.

31. Sablon E., Contreras B., Vandamme E. Antimicrobial peptides of lactic acid bacteria: mode of action, genetics and biosynthesis. Adv.Biochem. Engineering Biotechnol. 2000, 68: 21-60.

32. Segarra R.A., Gilmore M. S., Booth M C. Genetic structure of the Enterococcus faecalis plasmid pAD1-encoded cytolytic toxin system and its relationship to lantibiotic determinants // J. Bacteriol. -2004. -Vol. 176. -P. 734-735.

33. Troost F.J., van Baarlen P., Lindsey P. et al. Identification of the transcriptional response of human intestinal mucosa to Lactobacillus plantarum WCFS-1 in vivo. BMC Genomics. 2008, 9: 374 .

34. Van den Berghe E., de Winter T., de Vuyst L. Enterocin A production by Enterococcus faecium FAIR-E 406 is characterised by a temperature and $\mathrm{pH}$-dependent switch-off mechanism when growth is limited due to nutrient depletion // Int. J. Food Microbiol. -2006. Vol. 107, Is. 2.- P. 159-165.

35. Willey J.M., van der Donk W.A. Lantibiotics: peptides of diverse structure and function. Ann.Rev.Microbiol. 2007, 61: 477-501. 


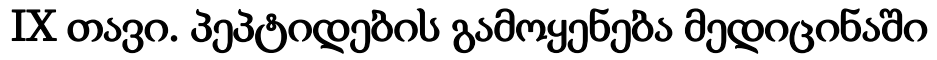

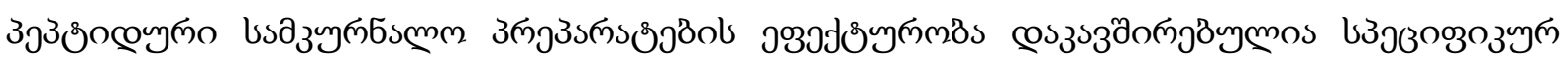

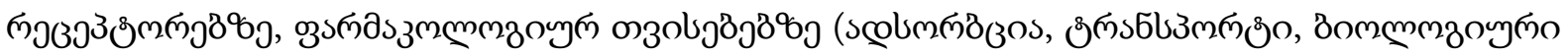

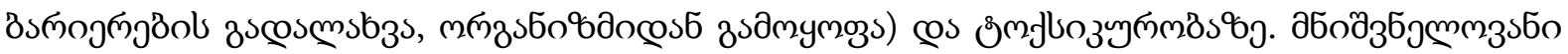

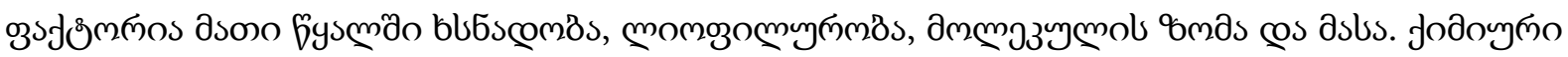

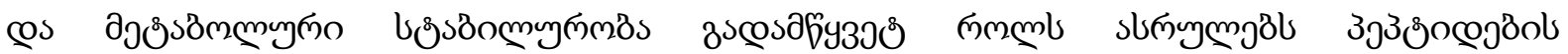

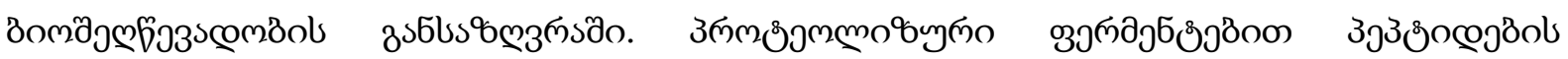

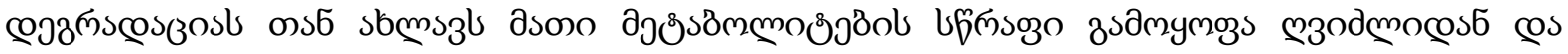

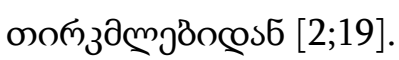

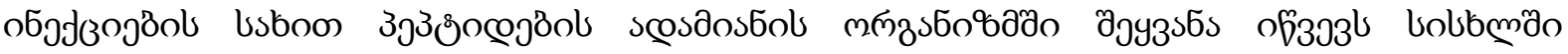

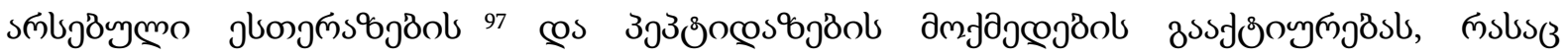

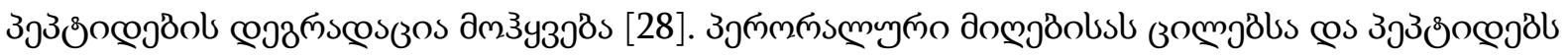

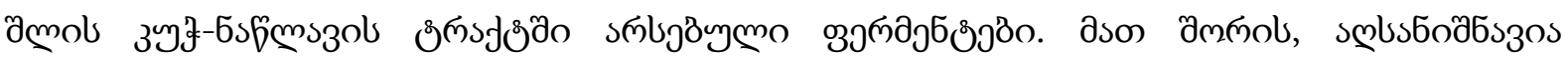

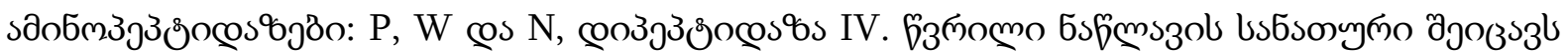

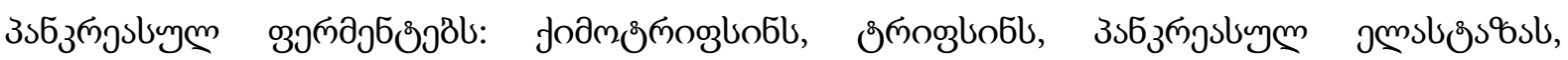

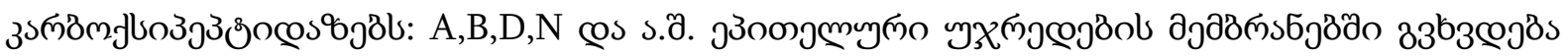

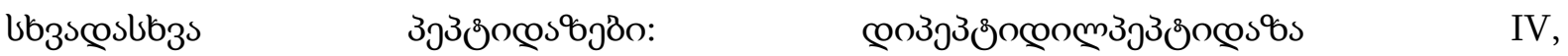

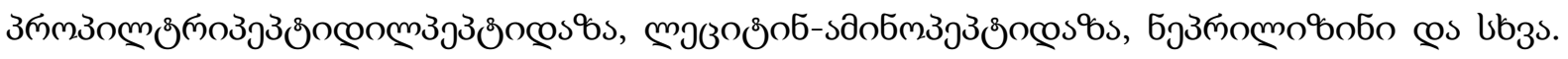

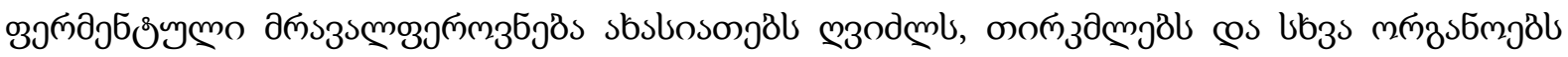

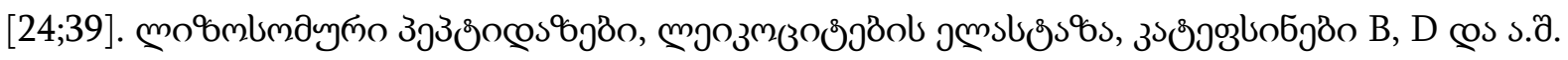

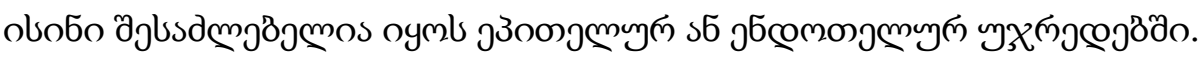

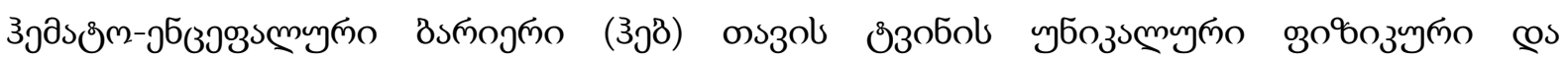

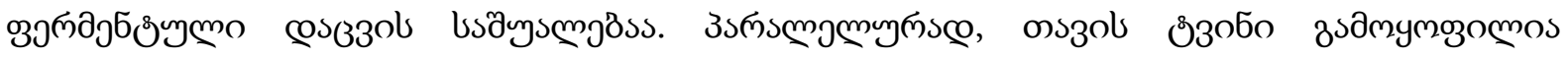

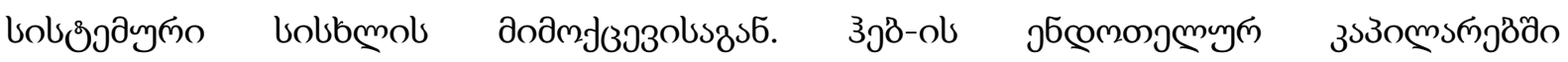

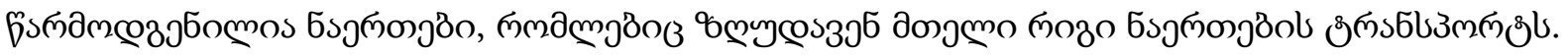

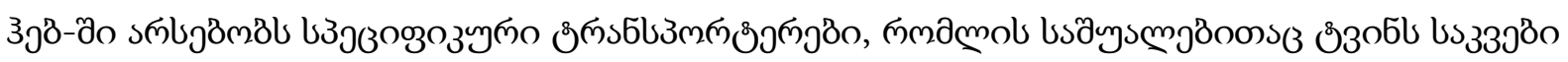

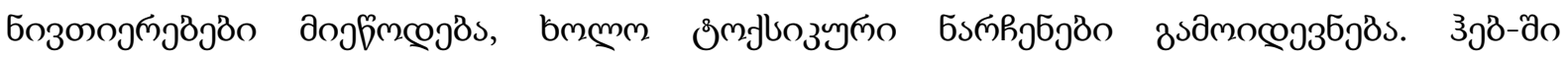

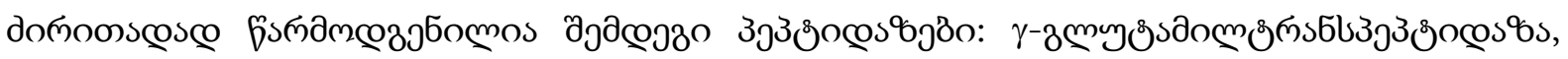

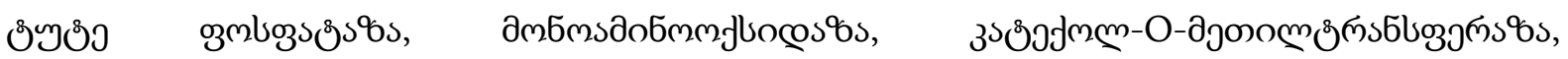

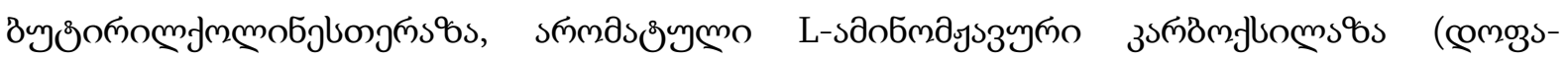

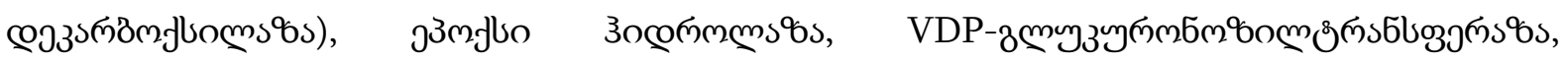

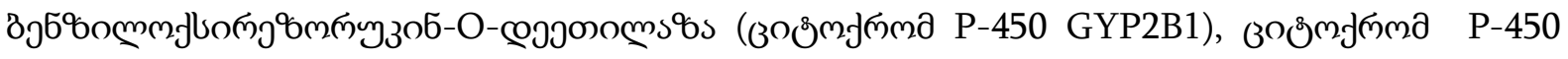
NADPH-ஈ

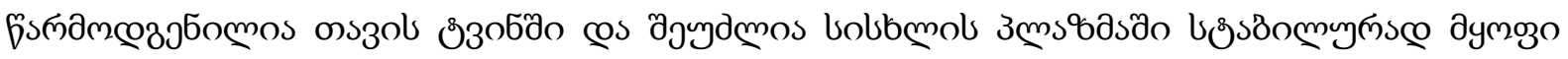

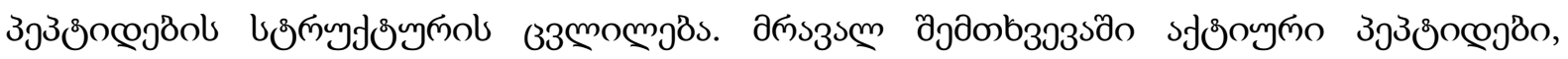

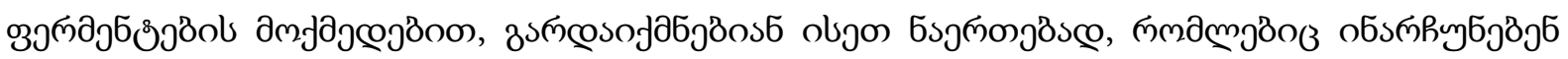

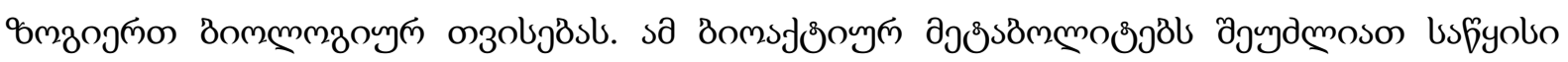

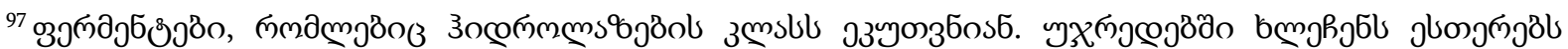

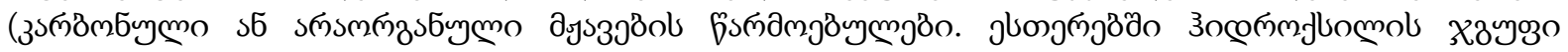

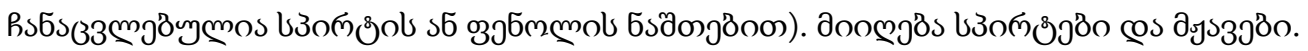




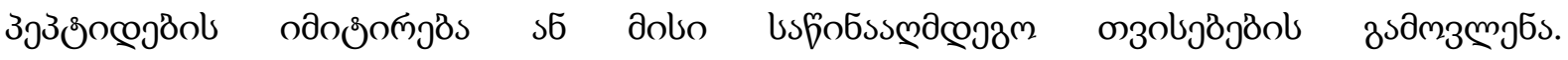

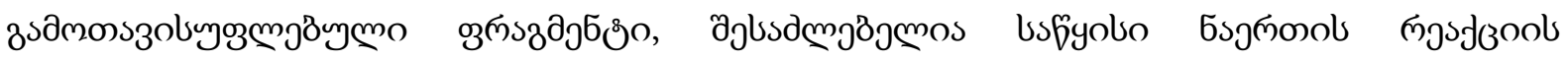

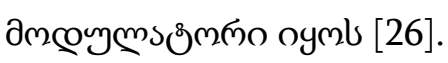

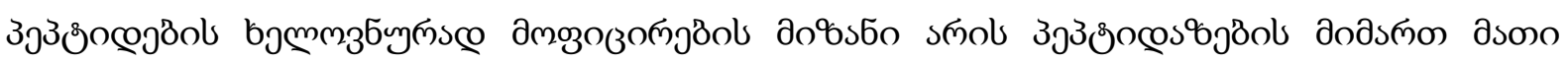

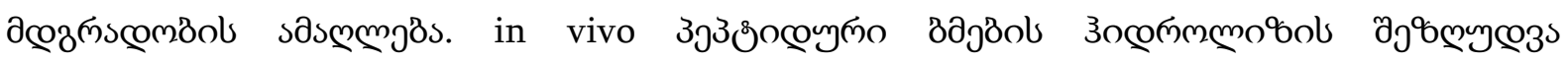

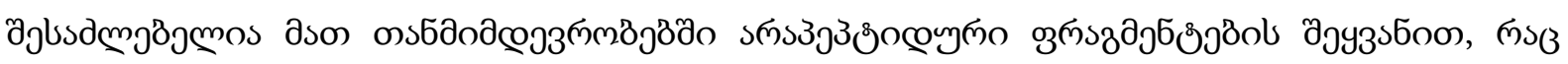

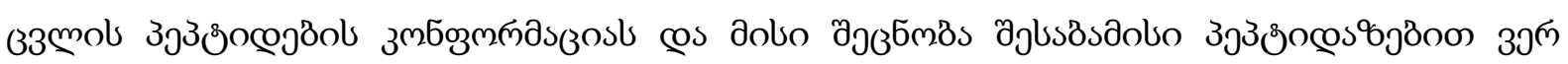

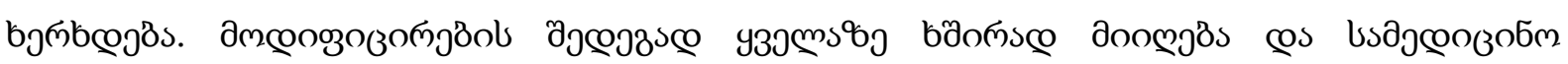

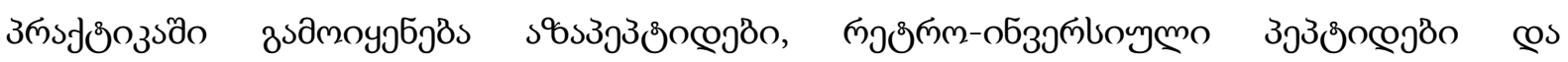

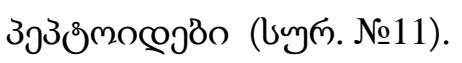

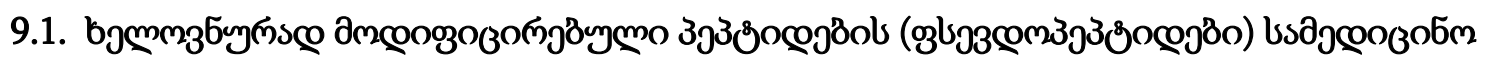

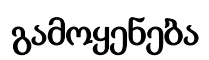

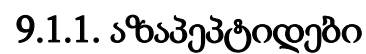

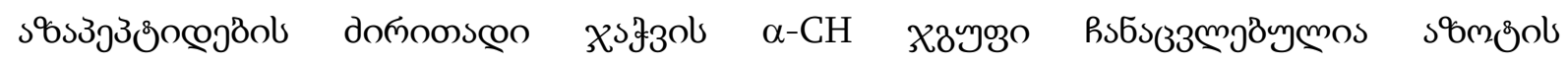

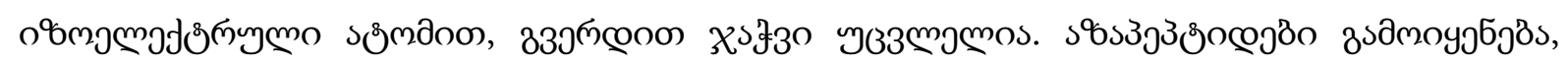

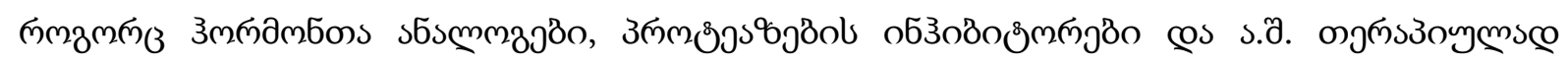

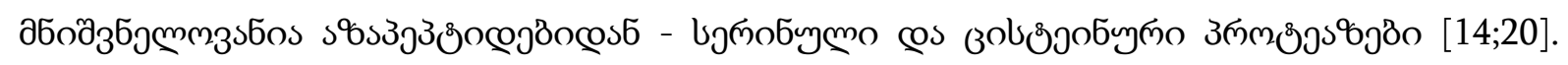

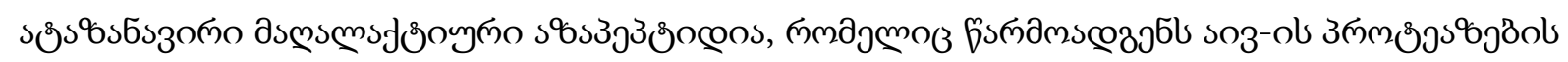

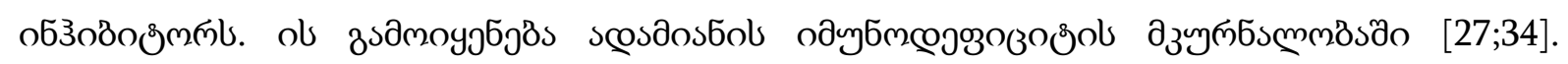

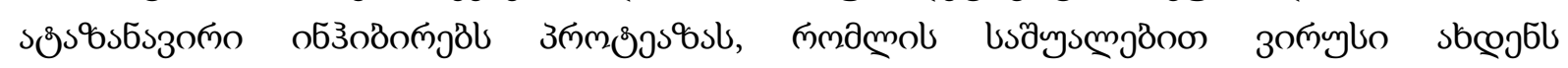

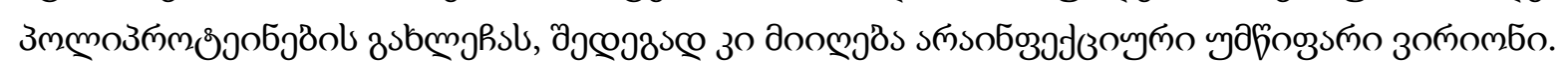

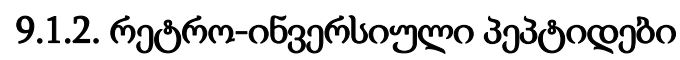

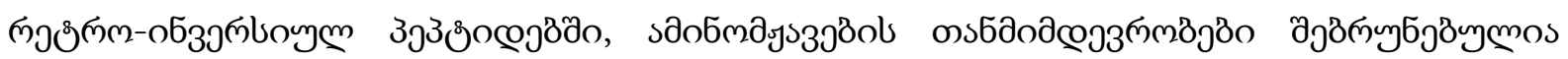

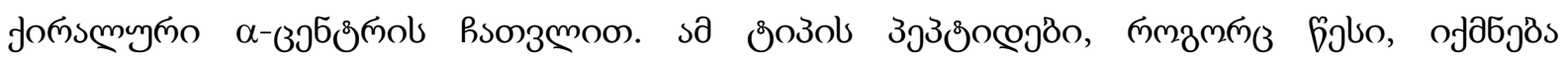

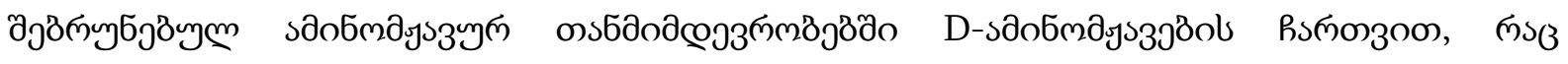

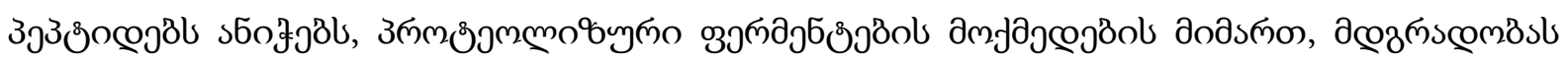

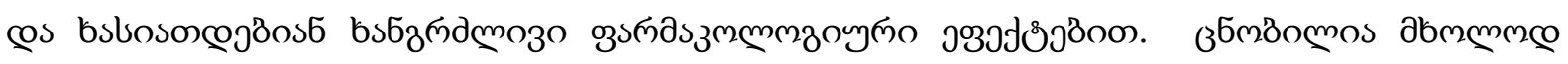

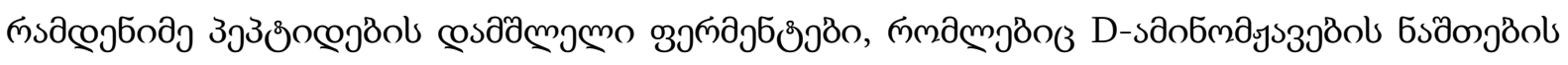

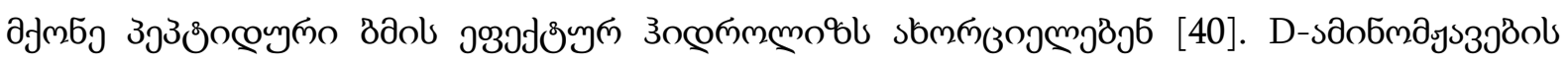

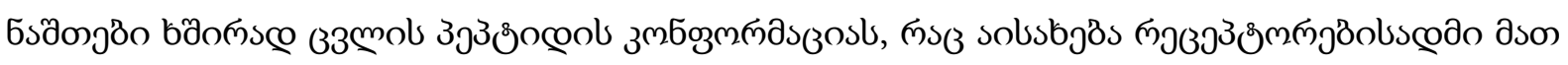

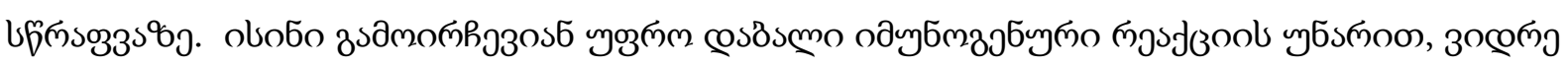

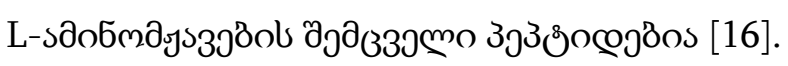

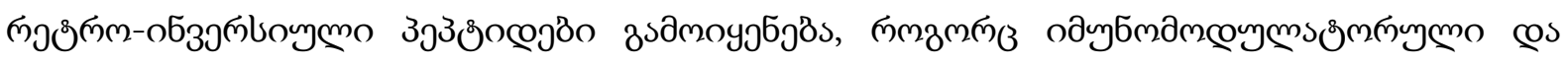
одэб

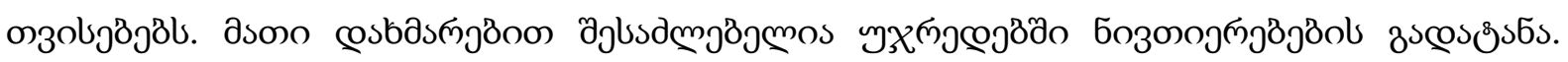




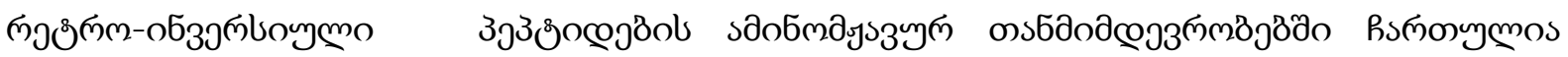

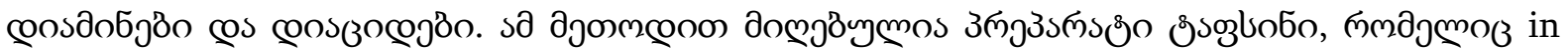

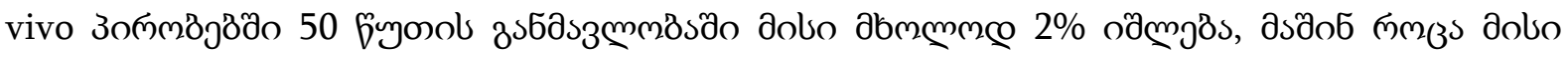

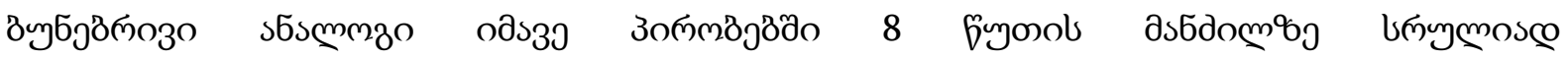

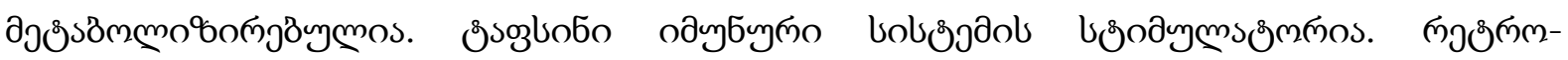

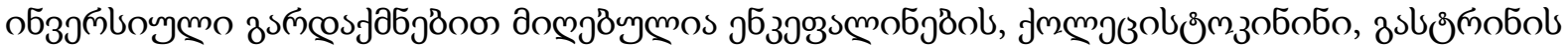

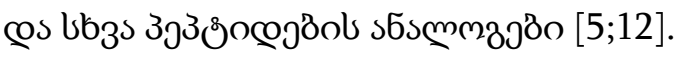

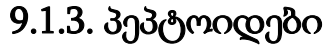

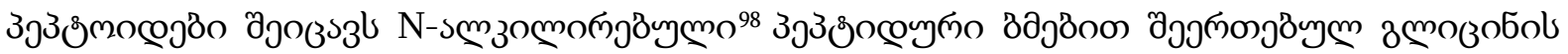

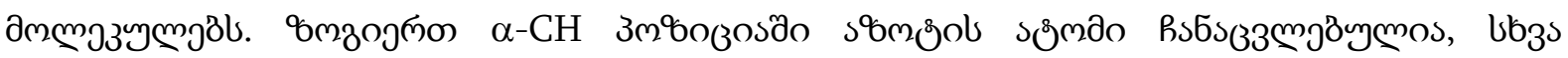

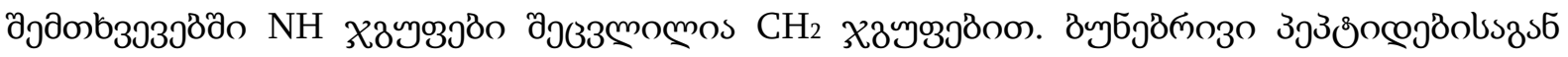

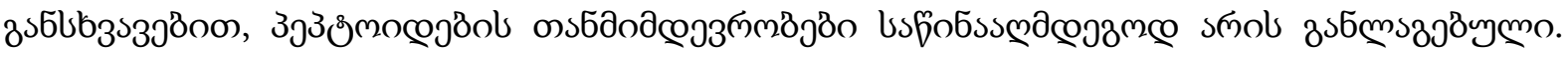

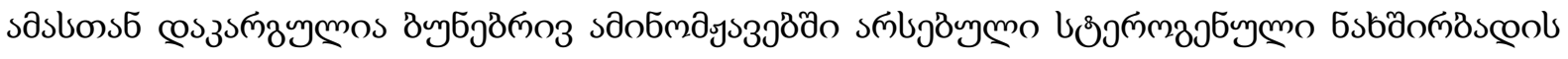

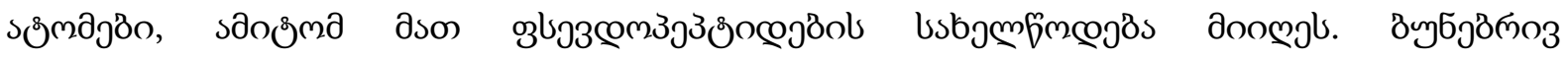

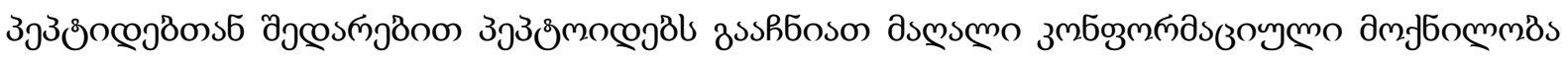

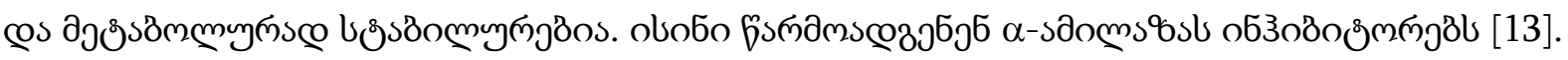

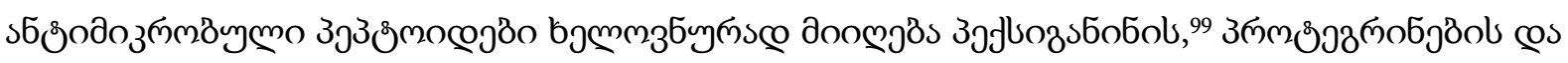

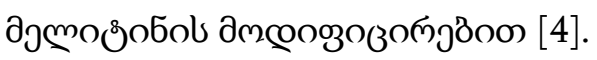<smiles>[R]C(NC)C(=O)NN([R])C(C)=O</smiles>

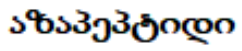<smiles>[R]C(NC)C(=O)CN([R])C(C)=O</smiles>

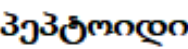<smiles>[R]C(NC(=O)C([R])NC)C(C)=O</smiles>

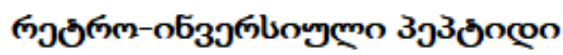

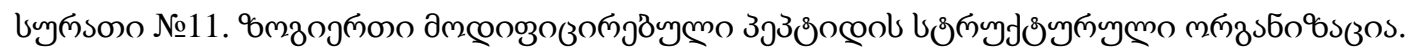

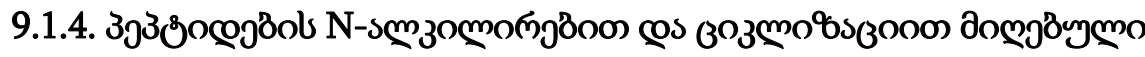

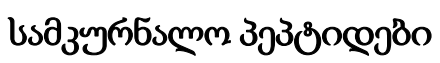

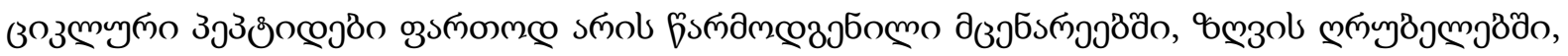

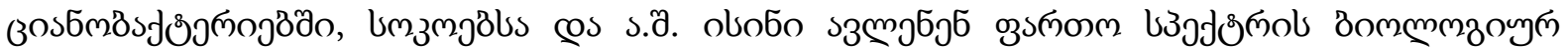

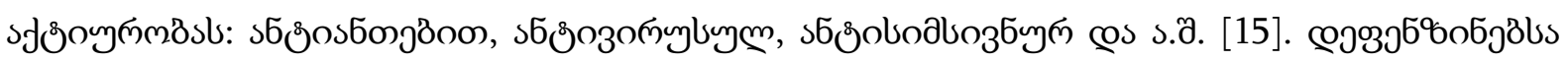

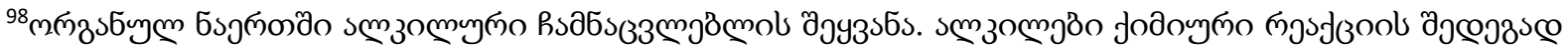

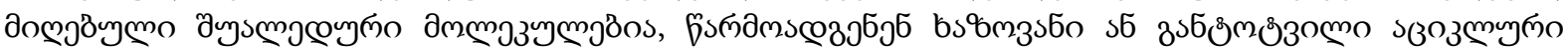

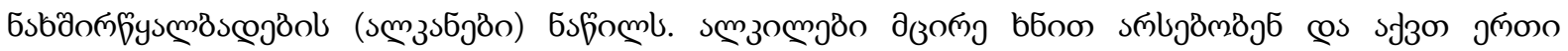

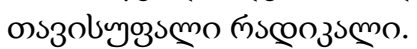

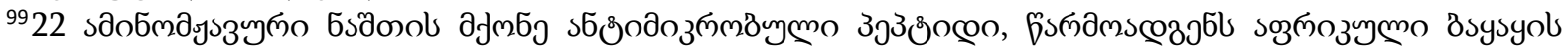

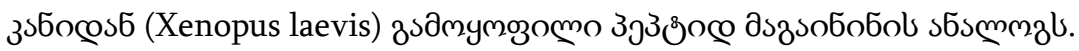




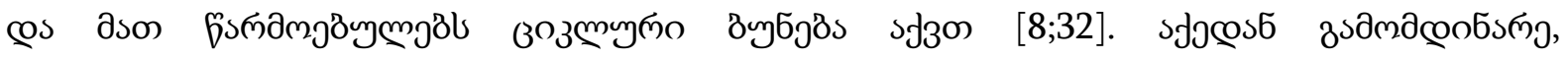

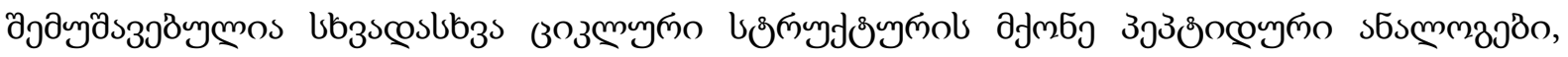

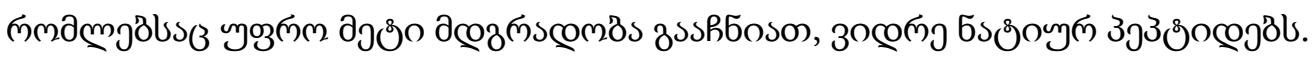

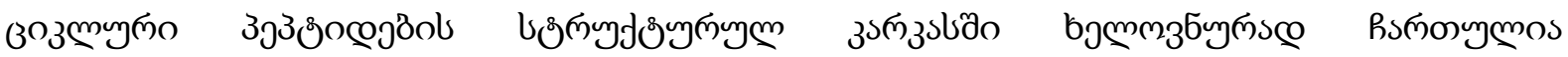

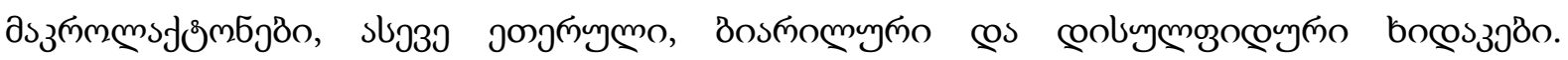

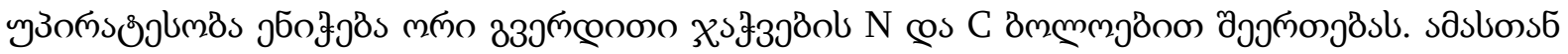

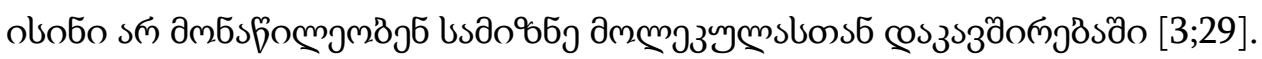

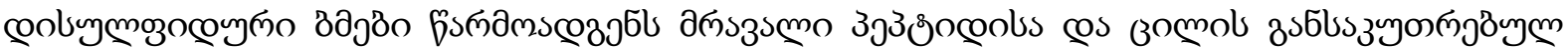

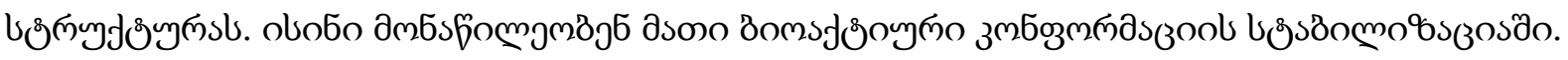

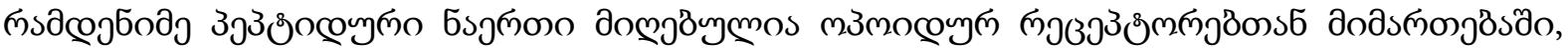

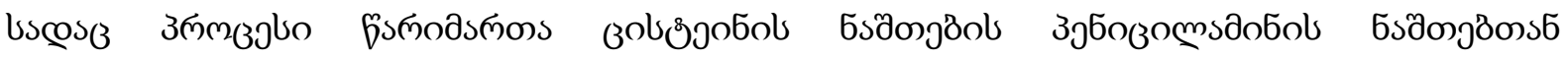

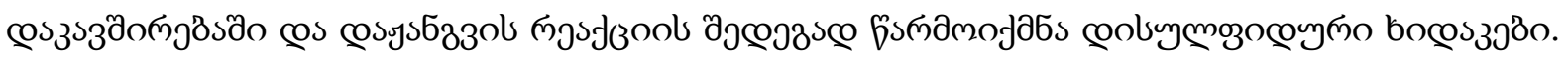

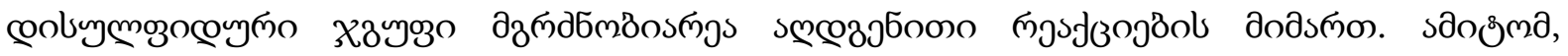

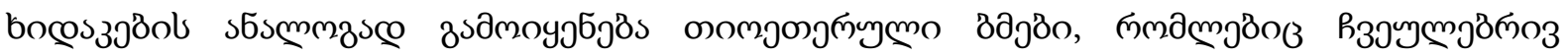

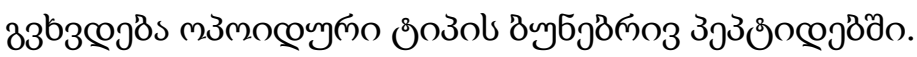

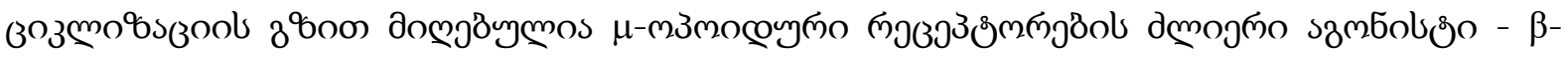

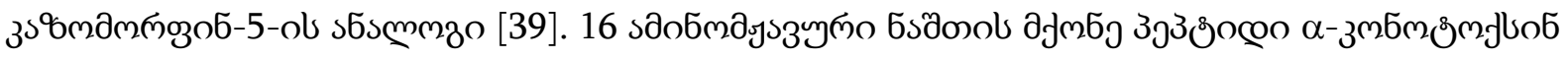

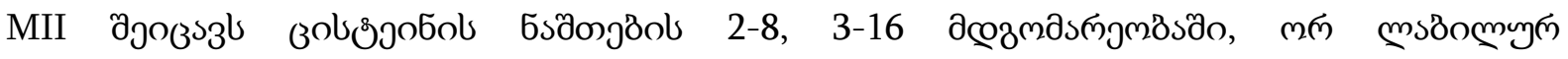

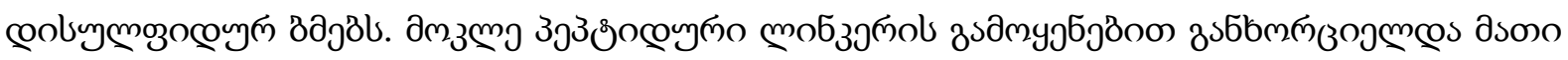

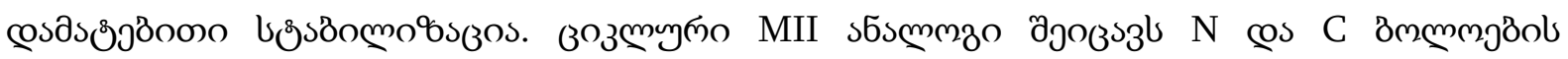

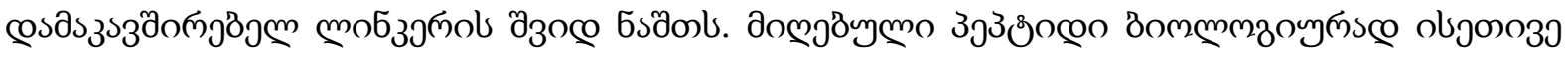

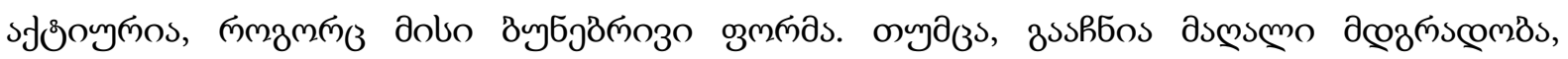

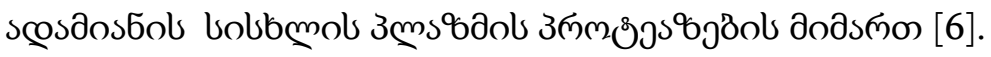

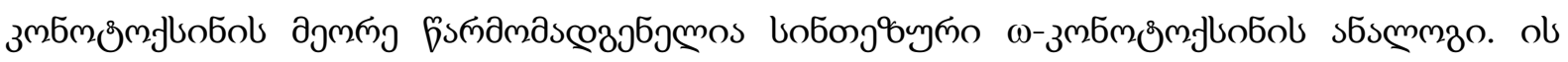

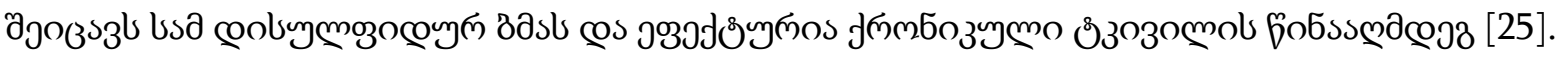

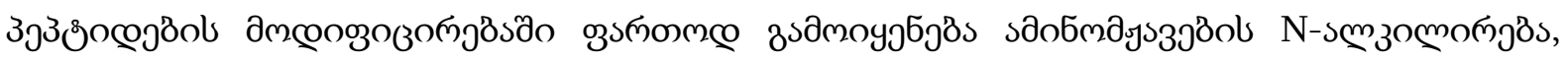

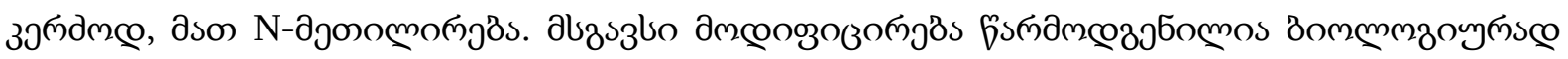

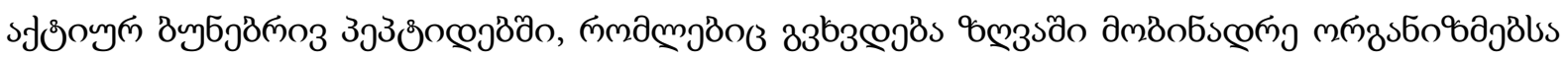

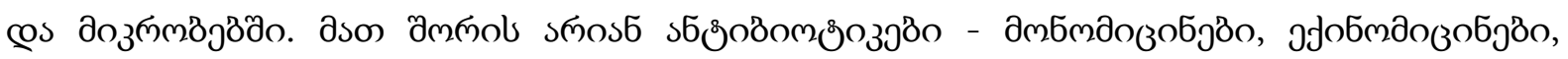

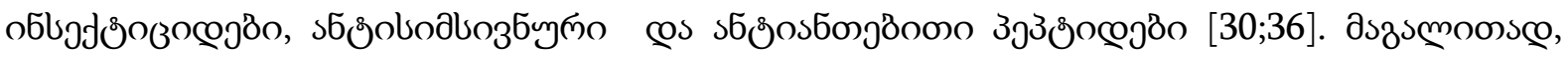

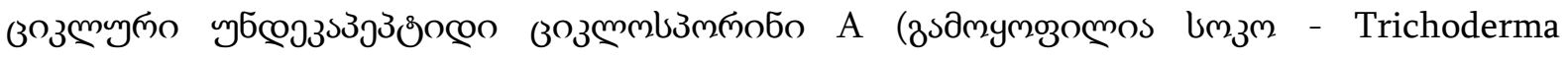

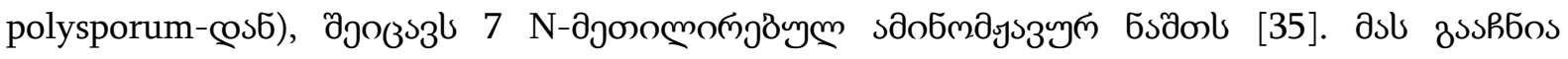

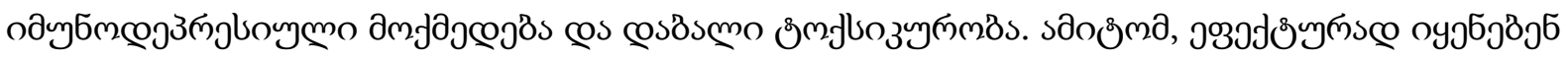

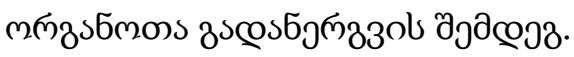

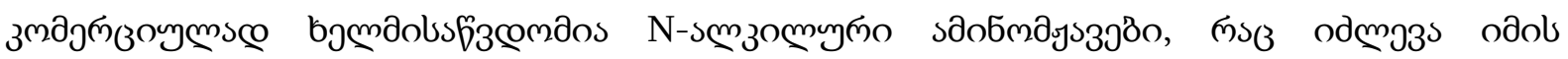

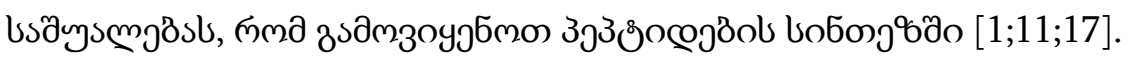

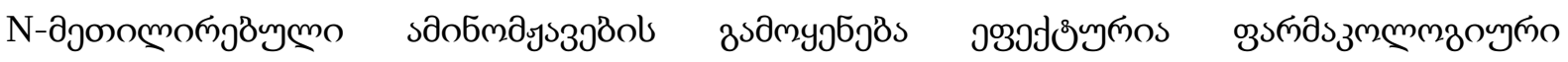

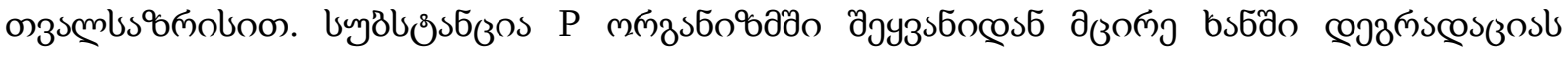

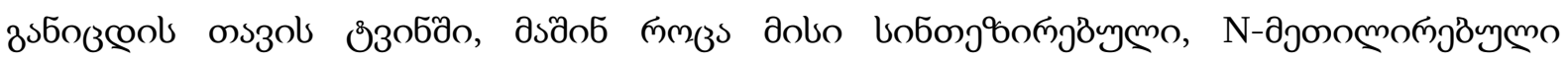

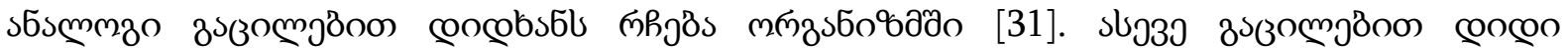

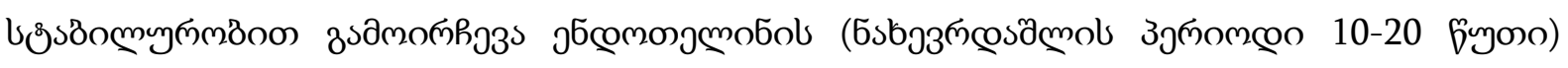




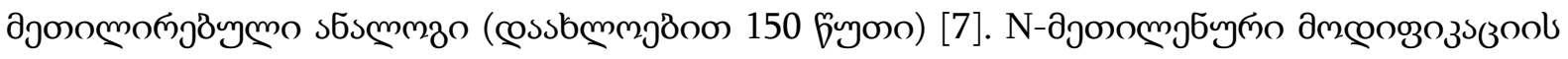

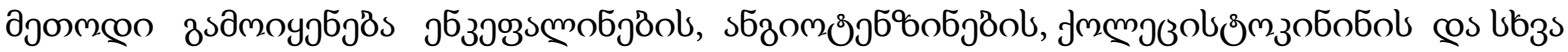

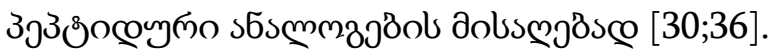

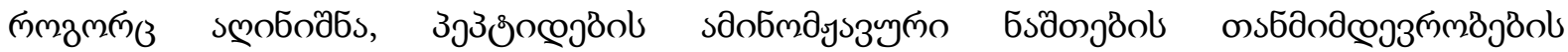

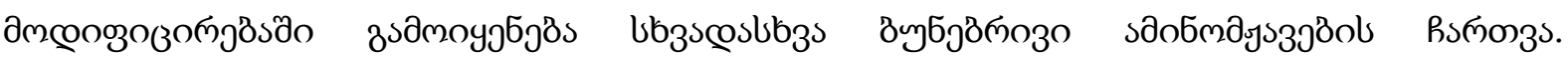

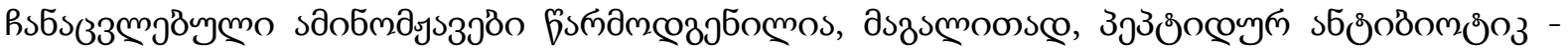

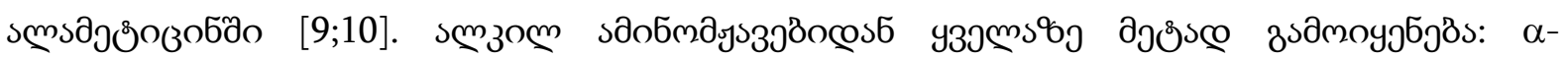

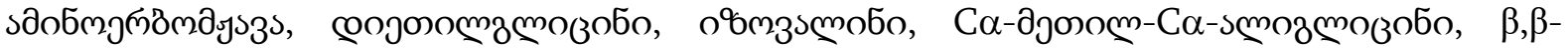

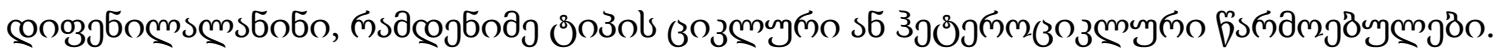

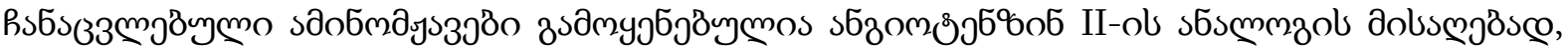

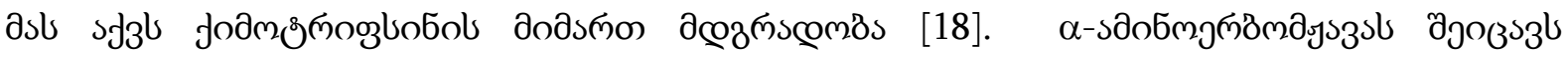

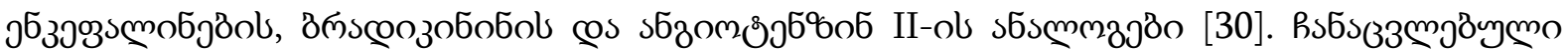

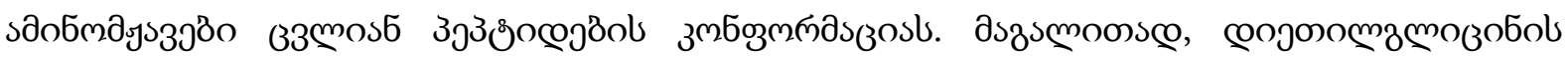

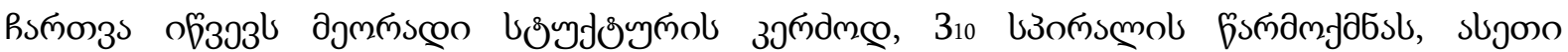

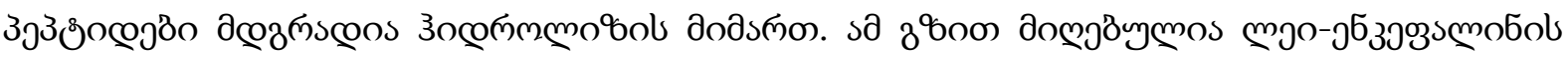
sбзммзо [21;22;30].

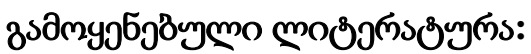

1. Aurelio L, Brownlee RTC, Hughes AB. Synthetic preparation ofN- methyl- $\square$-amino acids. Chem Rev 2004; 104: 5823-46.

2. Bocci V. Catabolism of therapeutic proteins and peptides with implicationsfor drug delivery. Adv Drug Deliv Rev 1990; 4: 149-69.

3. Cardillo G, Gentilucci L, Tolomelli A, et al. Synthesis and evaluationof the affinity toward mu-opioid receptors of atypical, lipophilicligands based on the sequence c[-Tyr-Pro-Trp-PheGly-]. J.Med Chem 2004; 47: 5198-203.

4. Chongsiriwatana NP, Patch JA, Czyzewski AM, et al. Peptoids thatmimic the structure, function, and mechanism of helicalantimicrobial peptides. Proc Natl Acad Sci USA 2008; 105: 2794-9.

5. Chorev M. The partial retro-inverso modification: a road traveledtogether. Biopolymers 2005; 80: 67-84.

6. Clark RJ, Fischer H, Dempster L, et al. Engineering stable peptidetoxins by means of backbone cyclization: Stabilization of the alfa -conotoxin MII. Proc Natl Acad Sci 2005; 102: 13767-72.

7. Cody WL, He JX, Reily MD, et al. Design of a potent combinedpseudopeptide endothelinA/endothelin-B receptor antagonist, AcdBhg16-Leu-Asp-Ile-[NMe]Ile-Trp21 (PD 156252):examinationof its pharmacokinetic and spectral properties. J Med Chem 1997;40: 2228-40.

8. Cole AM, Hong T, Boo LM, et al. Retrocyclin: A primate peptidethat protects cells from infection by T- and M-tropic strains ofHIV-1. PNAS 2002; 99: 1813-8.

9. Degenkolb T, Brückner H. Peptaibiomics: Towards a myriad ofbioactive peptides containing C-alpha-dialkylaimino acids. Chem. Biodivers 2008; 5: 1817-43.

10. Duclohier H. Peptaibiotics and peptaibols. An alternative to classicalantibiotics. Chem Biodivers 2007; 4: 1023-6. 
11. Fairlie DP, Abbenante G, March DR. Macrocyclic peptidomimetics- forcing peptides into bioactive conformations. Curr Med Chem1995; 2: 654-86.

12. Fletcher MD, Campbell MM. Partially modified retro-inverso peptides:development, synthesis and conformational behavior. ChemRev 1998; 98: 763-96.

13. Gante J. Peptidomimetics-tailored enzyme inhibitors. Angew ChemInt Ed 1994; 33: 1699720.

14. Gante J, Krug M, Lauterbach G, Weitzel R, Hiller W. Synthesisand properties of the first allaza analogue of a biologically activepeptide. J Pept Sci 1995; 1: 201-6.

15. Gentilucci L, Tolomelli A, Squassabia F. Peptides and peptidomimetics in medicine, surgery and biotechnology. Curr Med Chem 2006; 13: 2449-66.

16. Gentilucci L, Cardillo G, Spampinato S, et al. Antiangiogenic effectof dual/selective $\alpha 5 \beta 1 / \alpha v \beta 3$ integrin antagonists designed onpartially modified retro-inverso cyclotetrapeptide mimetics. J MedChem 2010; 53: 106-18.

17. Gilon C, Dechantsreiter MA, Burkhart F, Friedler A, Kessler H.Synthesis of N-Alkylated Peptides. In: Goodman M, Eds, Methodsof organic chemistry: synthesis of peptides and peptidomimetics.New York: Georg Thieme Verlag Stuttgart 2003; vol. 22: pp. 215-71.

18. Khosla MC, Stachowiak K, Smeby RR, et al. Synthesis of [ $\alpha$-methyltyrosine-4]angiotensin II: Studies of its conformation, pressoractivity, and mode of enzymatic degradation. Proc Natl AcadSci USA 1981; 78: 757-60.

19. Lee VHL, Yamamoto A. Penetration and enzymatic barriers topeptide and protein absorption. Adv Drug Deliv Rev 1990; 4: 171-207.

20. Magrath J, Abeles RH. Cysteine protease inhibition by azapeptideesters. J Med Chem 1992; 35: 4279-83.

21. Maity P, Konig B. Enantio- and diastereoselective syntheses ofcyclic C $\alpha$-tetrasubstituted $\beta$ amino acids and their use to inducestable conformations in short peptides. Biopolymers 2008; 90: 8-27.

22. Maity P, Zabel M, König B. Tetrahydrofuran C $\alpha$-tetrasubstitutedamino acids: two consecutive $\alpha$-turns in a crystalline linear tripeptide. J Org Chem 2007; 72: 8046-53.

23. Marks DL, Gores GJ, La Russo NF. Hepatic processing of peptides.In Taylor MD, Amidon GL, Eds. Peptide-based drug design:controlling transport and metabolism. Washington, DC: AmericanChemical Society 1995; pp. 221-48.

24. Meisel H. Biochemical properties of regulatory peptides derivedfrom milk proteins. Biopolymers 1997; 43: 119-28.

25. Miljanich GP. Ziconotide: neuronal calcium channel blocker fortreating severe chronic pain. Curr Med Chem 2004; 11: 3029-40.

26. Nyberg F, Hallberg M. Peptide conversion - a potential pathwaymodulating G-protein signalling. Curr Drug Targets 2007; 8: 147-54.

27. Orrick JJ, Steinhart CR. Atazanavir. The Annals of pharmacotherapy.Ann Pharmacother 2004; 38: 1664-74.

28. Powell MF. Peptide stability in drug development: in vitro peptidedegradation in plasma and serum. In: Bristol JA, Ed. Annual Reports in Medicinal Chemistry. London: Academic Press Ltd. 1993;28: pp. 285-94.

29. Reichelt A, Martin SF. Synthesis and properties of cyclopropanederivedpeptidomimetics. Acc Chem Res 2006; 39: 433-42.

30. Sagan S, Karoyan P, Lequin O, Chassaing G, Lavielle S. N- andC $\alpha$-methylation in biologically active peptides: synthesis, structuraland functional aspects. Curr Med Chem 2004; 11: 2799-822. 
31. Sandberg BE, Lee CM, Hanley MR, Iversen LL. Synthesis andbiological properties of enzyme-resistant analogues of substance P.Eur J Biochem 1981; 114: 329-37.

32. Tang YQ, Yuan J, Ösapay G, et al. A cyclic antimicrobial peptideproduced in primate leukocytes by the ligation of two truncatedalfa-defensins. Science 1999; 286: 498-502.

33. Teschemacher H, Koch G, Brantl V. Milk protein-derived opioidreceptor ligands. Biopolymers 1997; 43: 99-117.

34. Von Hentig N, Johann W. Atazanavir/ritonavir: a review of its usein HIV therapy. Drugs Today 2008; 44: 103-32.

35. Wenger RM. Synthesis of cyclosporine. Total syntheses of "cyclosporinA“ and "cyclosporin $\mathrm{H}^{\prime \prime}$, two fungal metabolites isolatedfrom the species Tolypocladium inflatum GAMS. Helv Chim Acta1984; 67: 502-25.

36. Wipf P. Synthetic studies of biologically active marine cyclopeptides.Chem Rev 1995; 95: 2115-34.

37. Witt KA, Davis TP. CNS drug delivery: opioid peptides and the bloodbrain barrier. AAPS J 2008; 8: E76-E88.

38. Witt KA, Gillespie TJ, Huber JD, Egleton RD, Davis TP. Peptidedrug modifications to enhance bioavailability and bloodbrain barrierpermeability. Peptides 2001; 22: 2329-43.

39. Woodley JF. Enzymatic barriers for GI peptide and protein delivery.Crit Rev Ther Drug Carr Syst 1994; 11: 61-95.

40. Yamada R, Kera Y. D-amino acid hydrolyzing enzymes. (D-AminoAcids in Sequences of Secreted Peptides of Multicellular Organisms),EXS 1998; 85: 143-55.

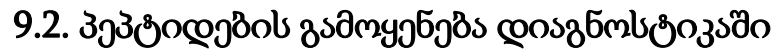

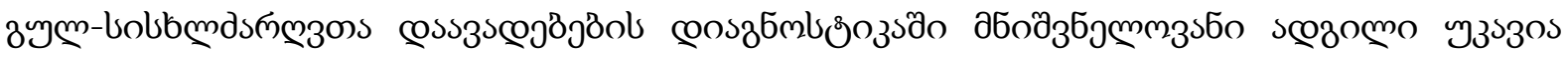

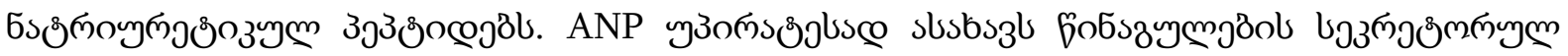

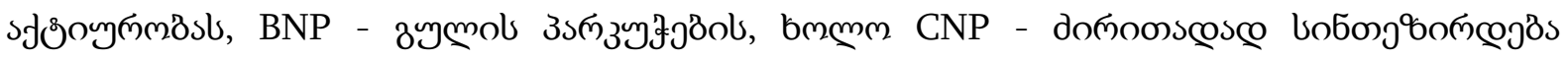

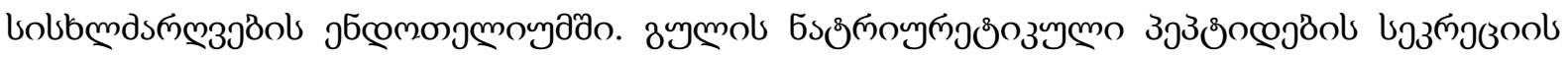

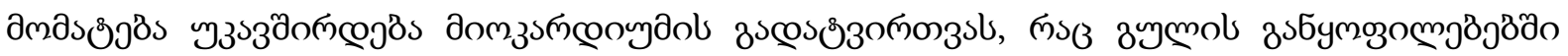

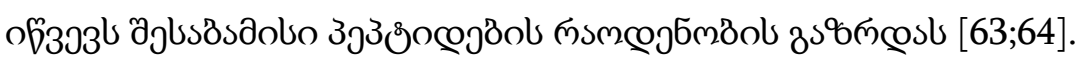

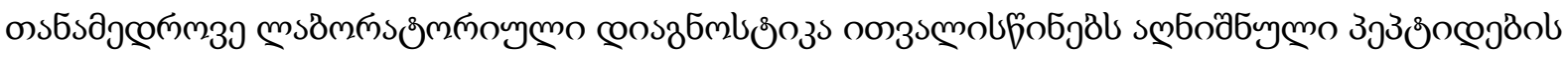

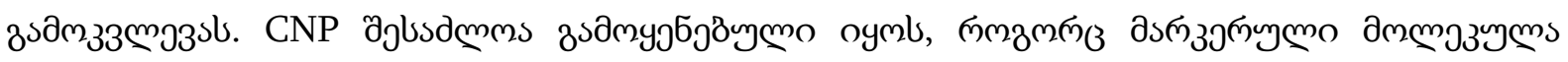

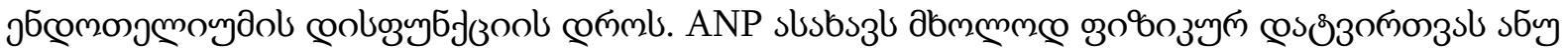

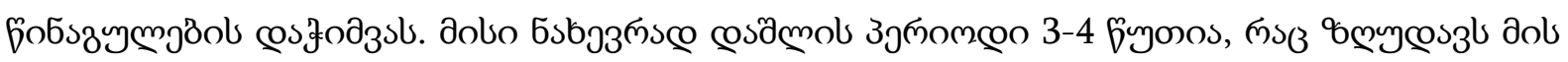

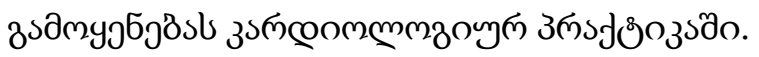

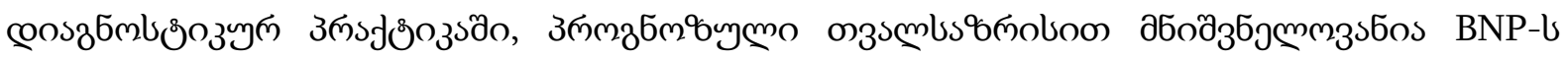

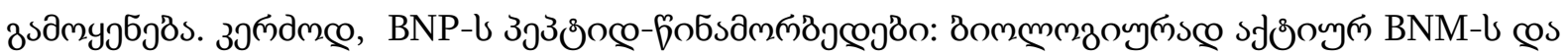

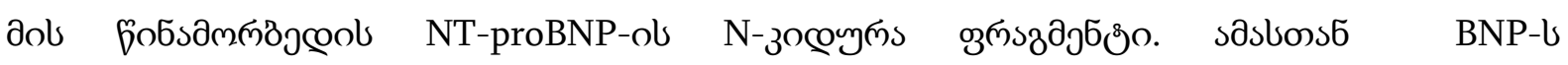

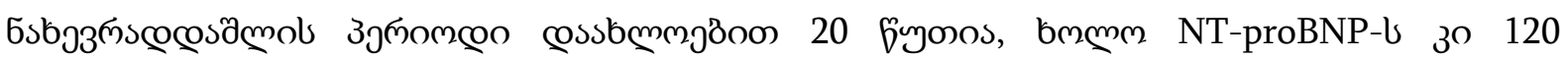

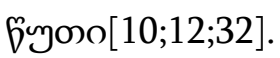

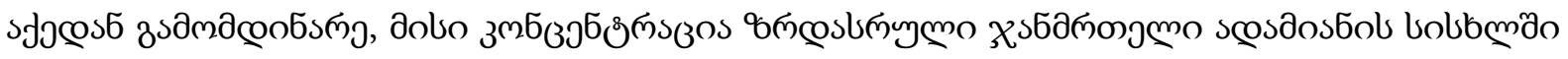

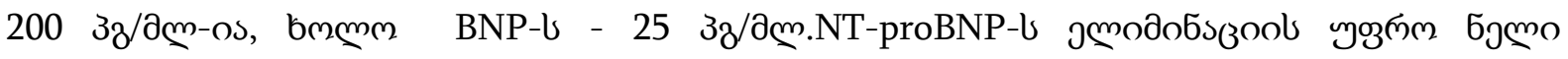

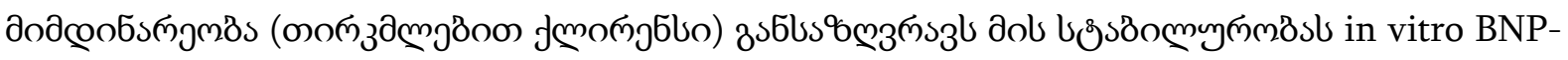

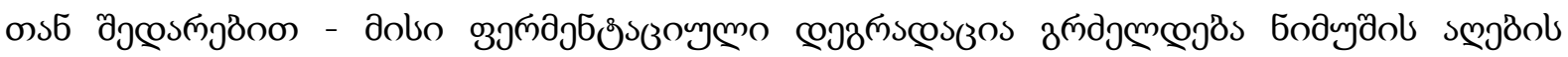




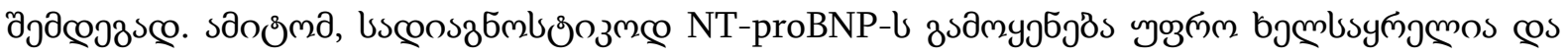

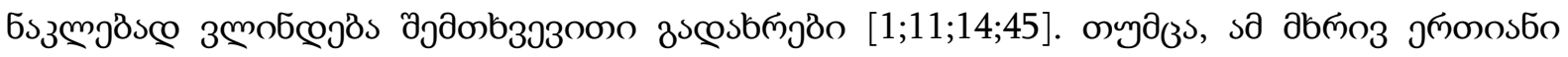

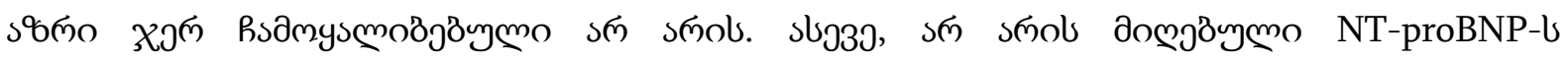

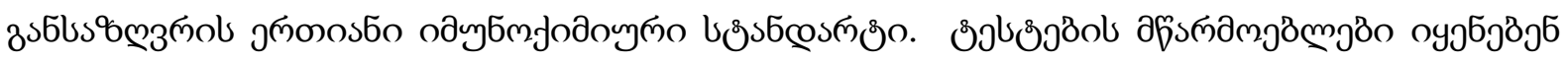

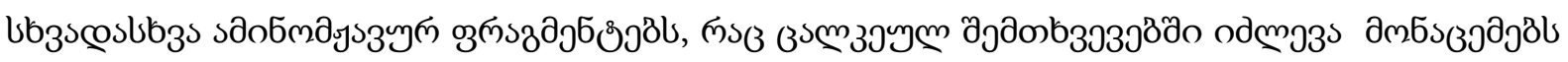

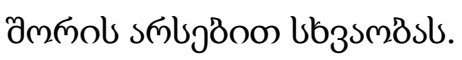

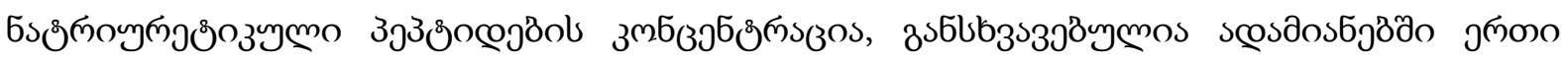

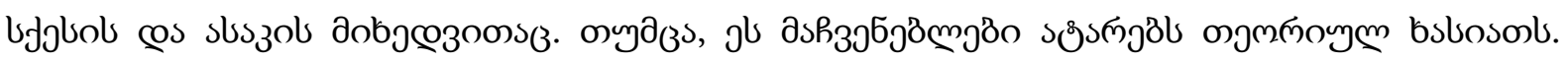

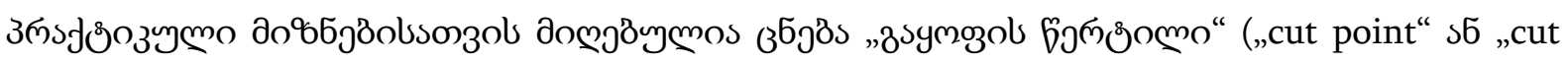

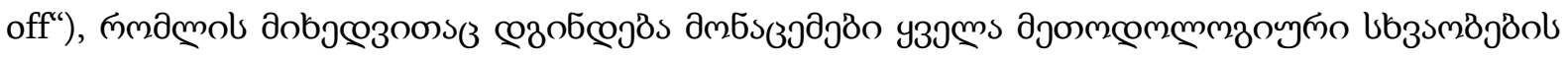

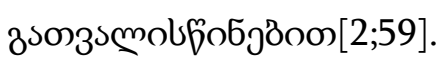

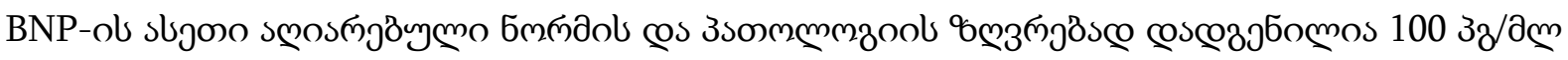

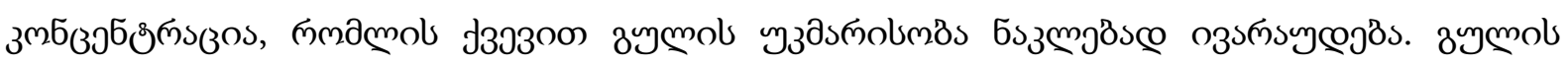

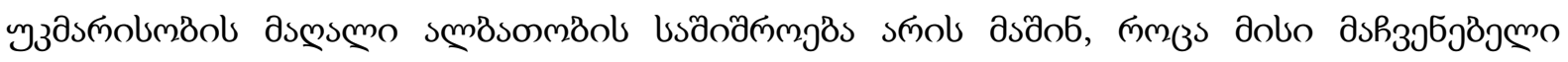
słs

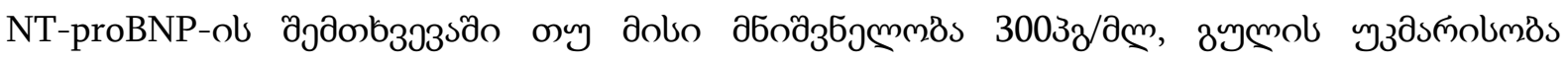

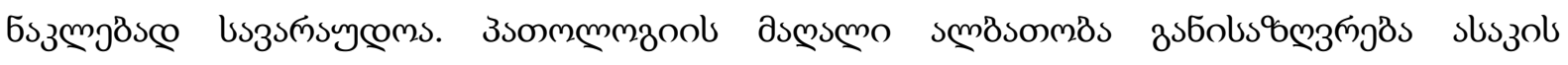

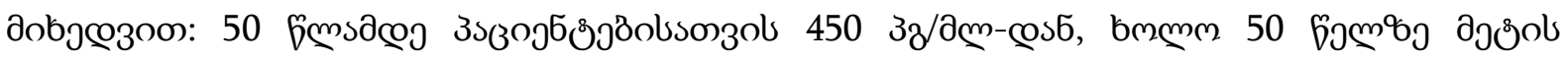

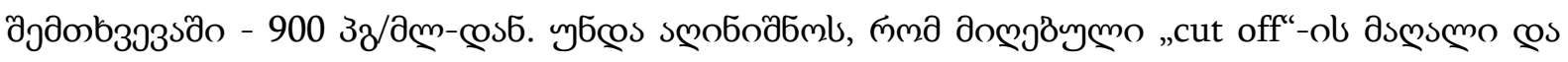

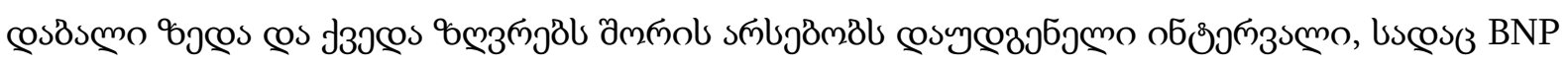

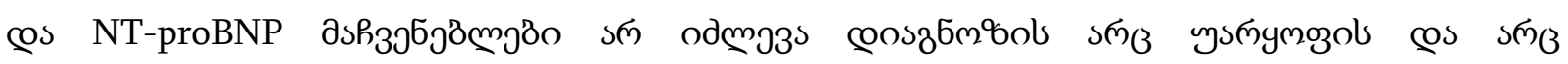

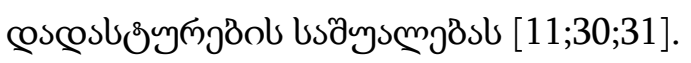

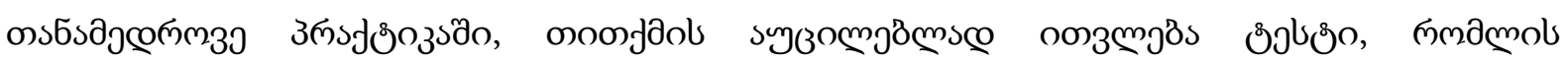

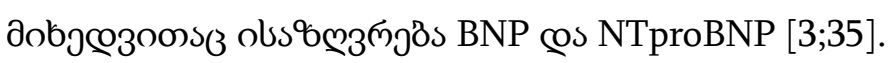

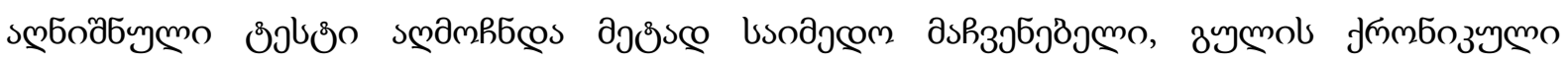

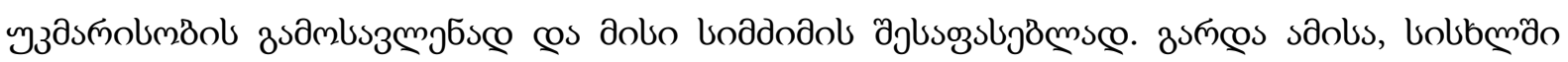

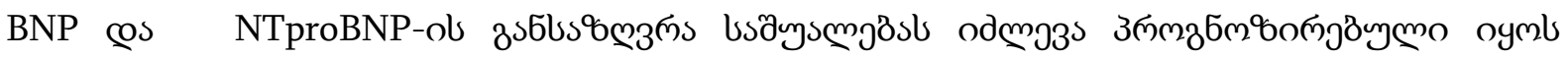

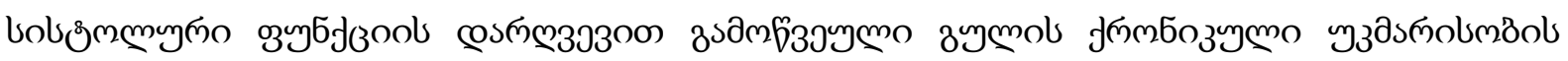

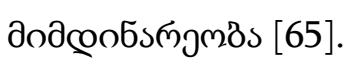

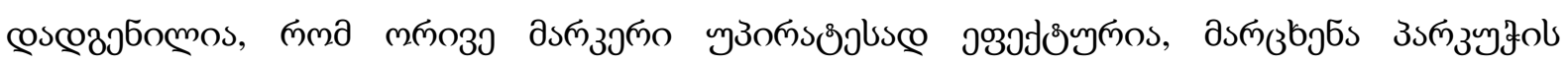

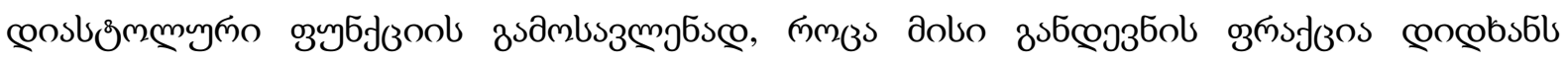

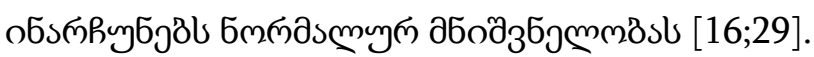

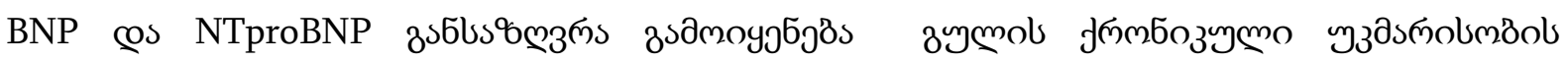

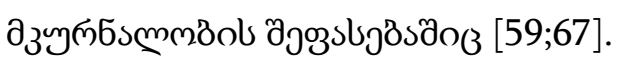

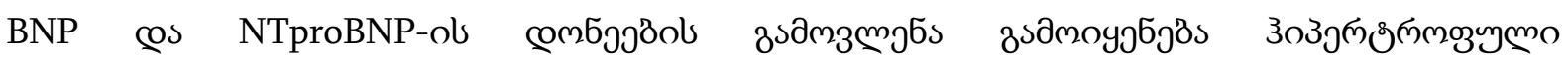

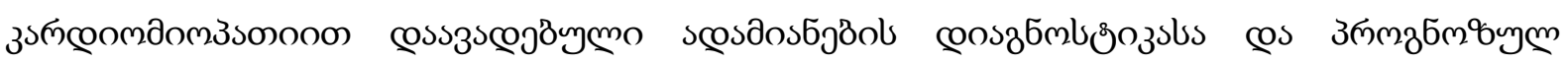

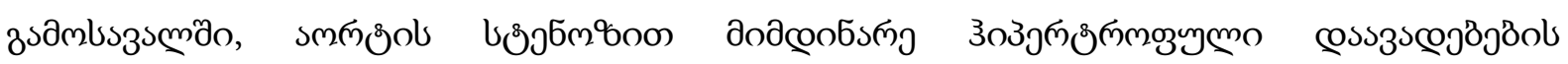

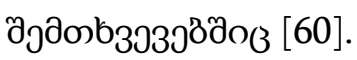

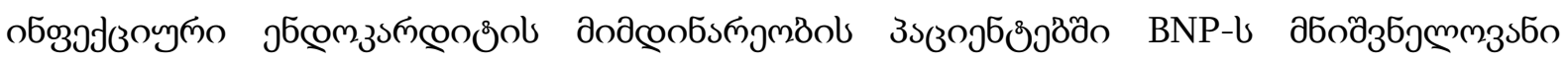

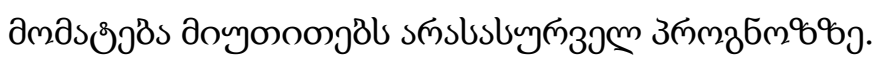

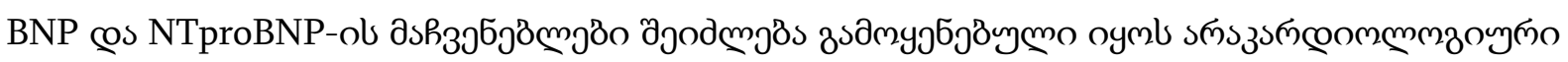

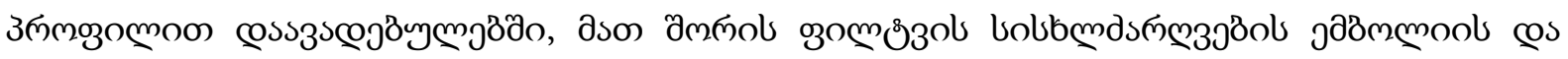




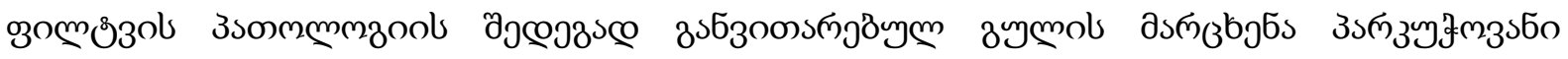

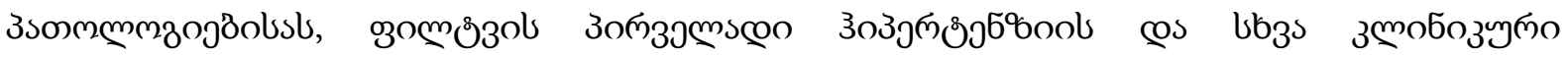

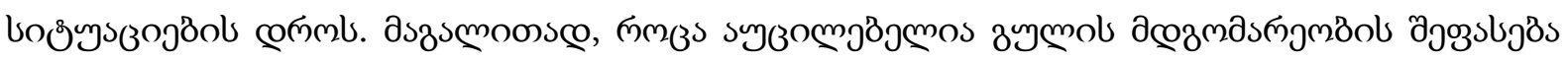

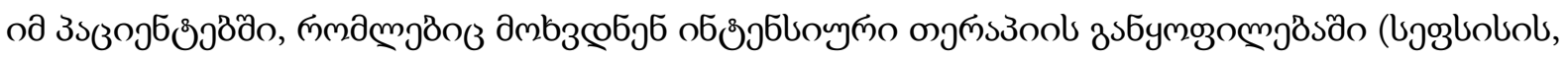
ఠ̊msazs cos bb3s)[50;57].

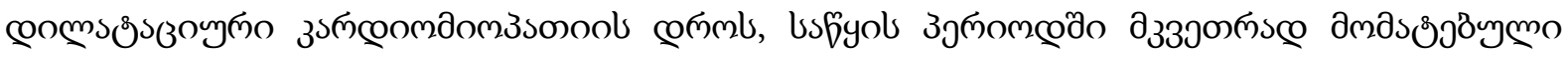

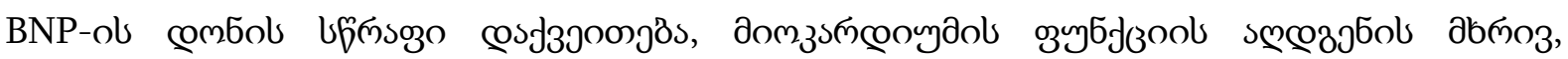

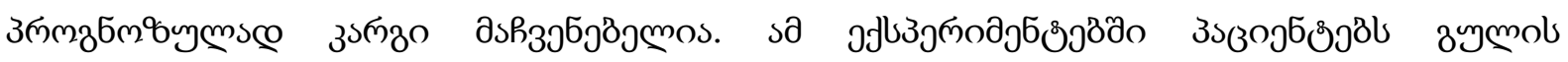

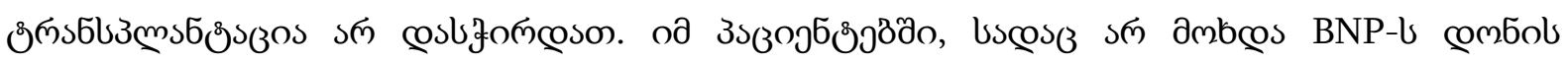

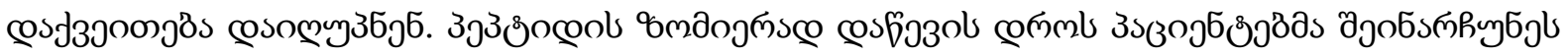

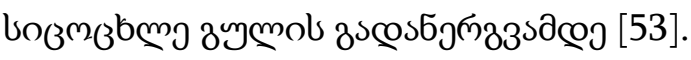

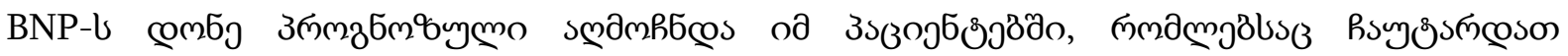

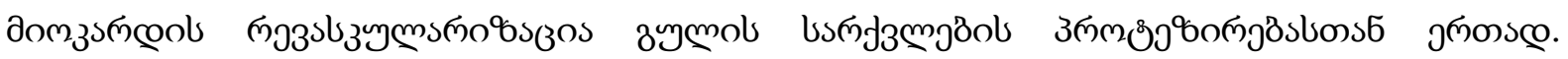

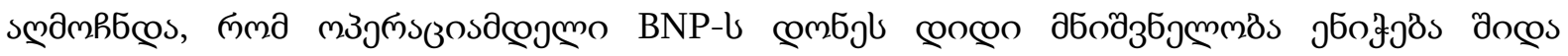

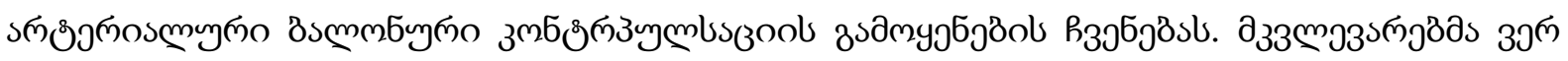

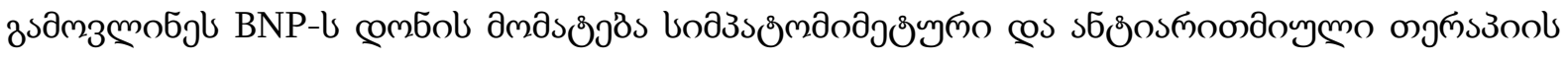

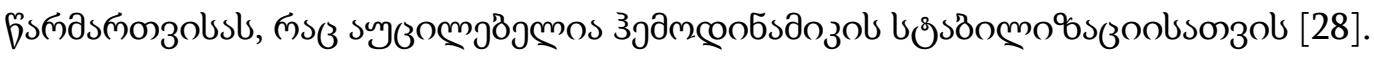

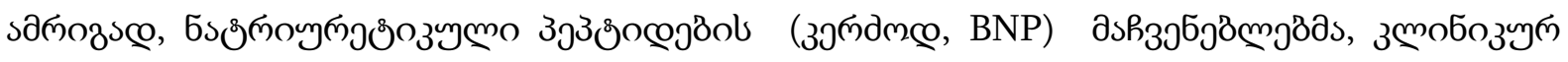

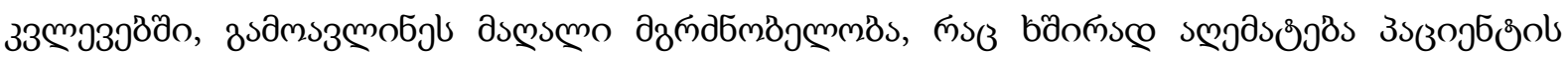

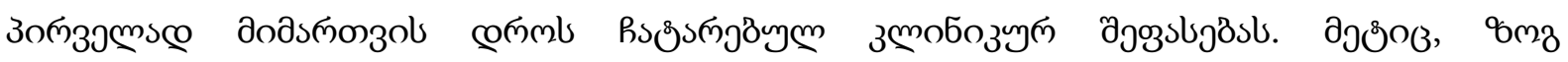

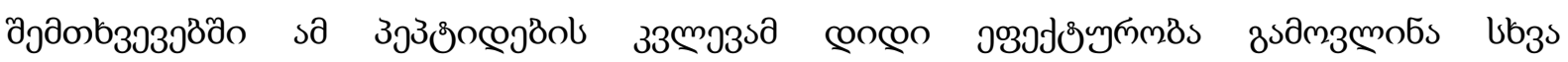

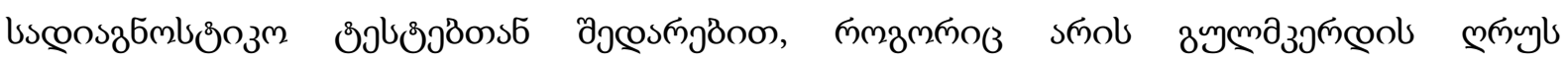

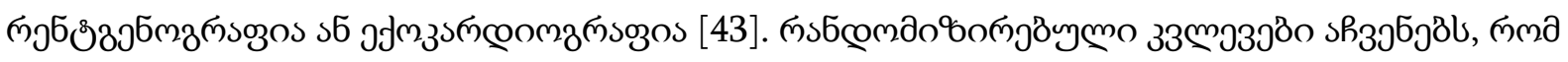

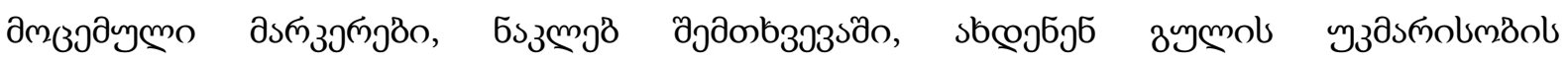

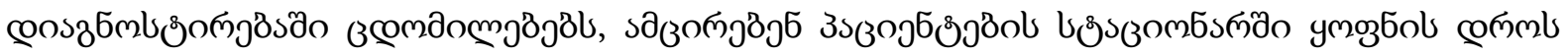

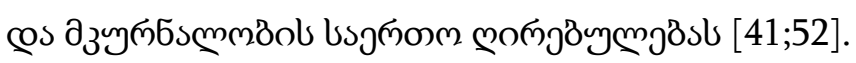

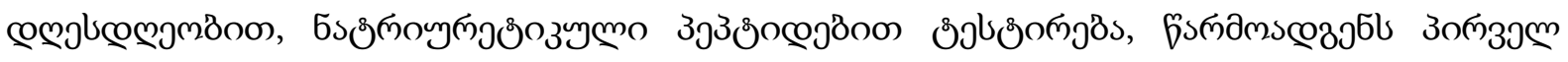

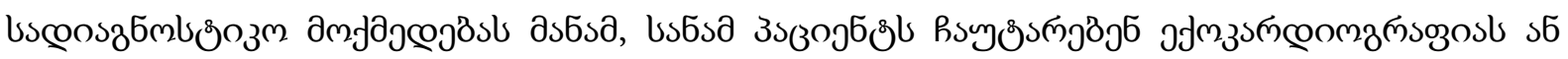

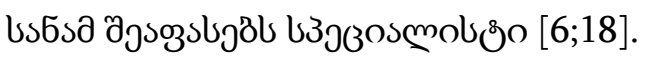

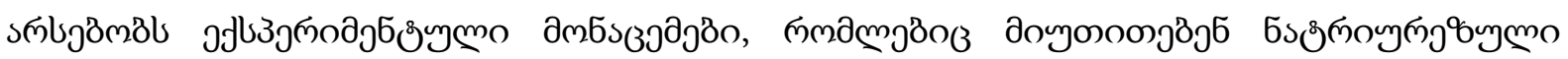

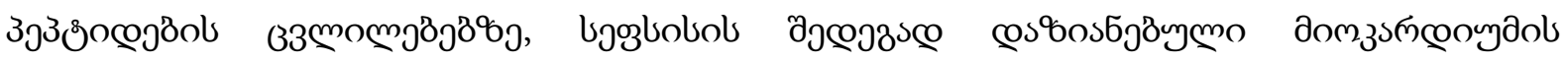

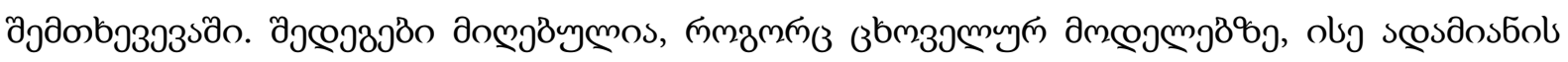

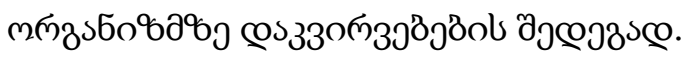

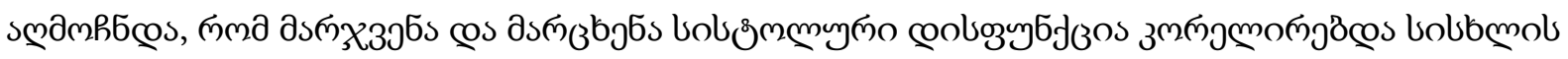

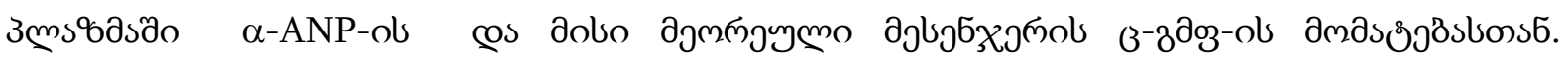

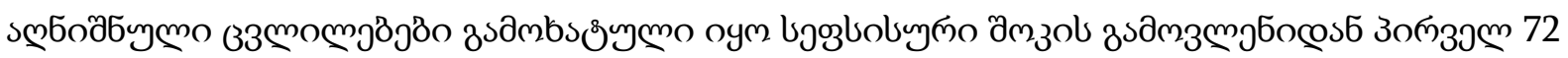
ussoño.

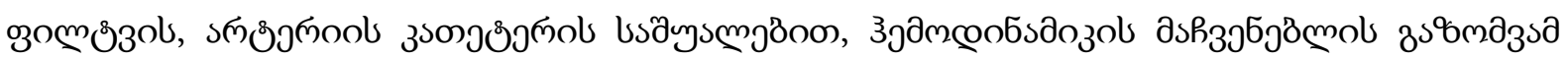

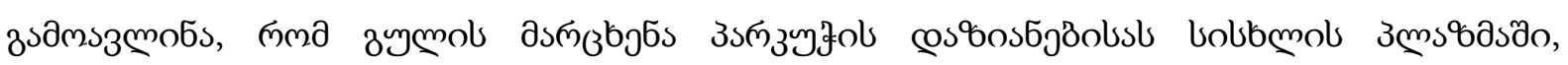

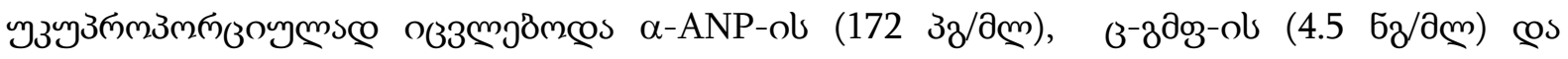

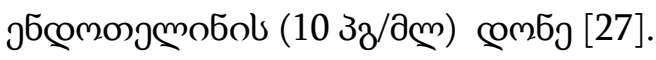

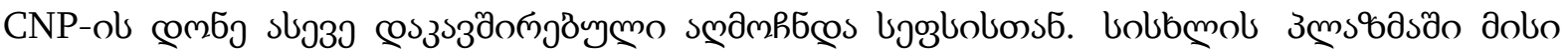




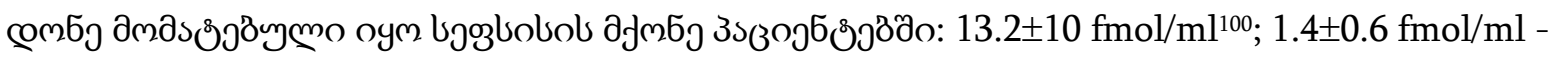

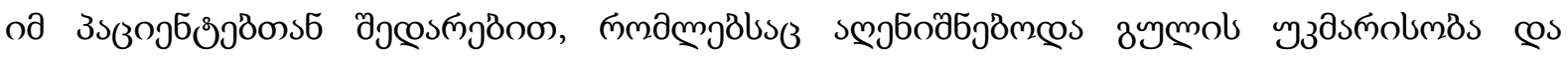

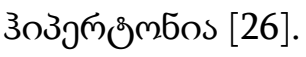

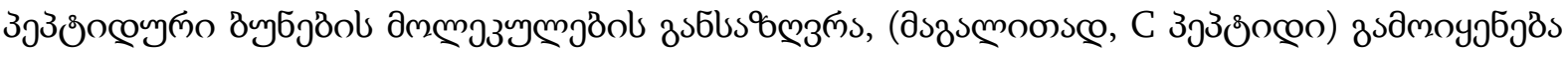

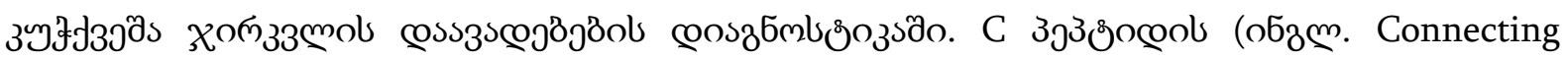

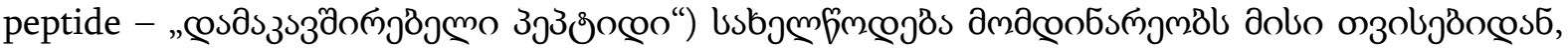

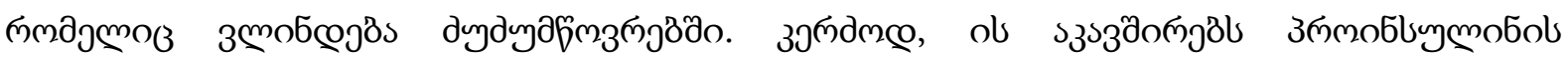

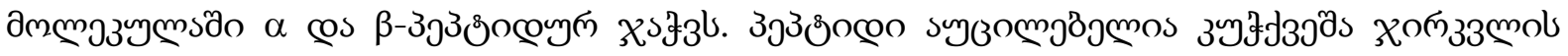

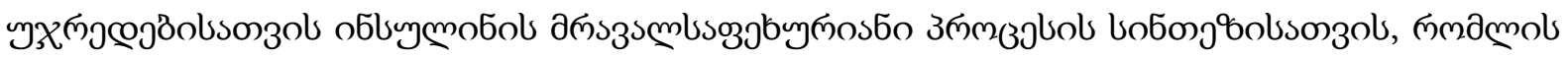

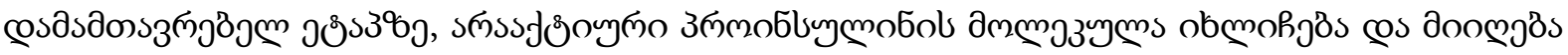

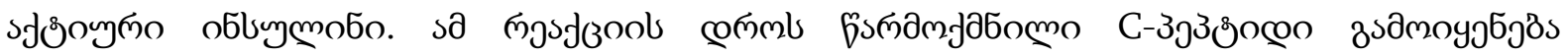

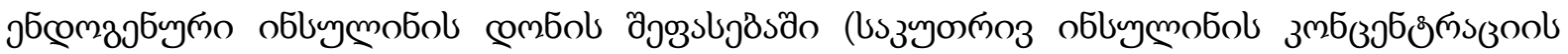

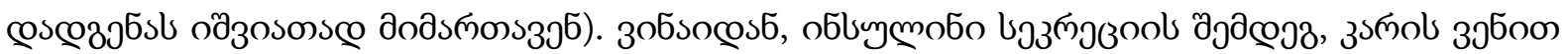

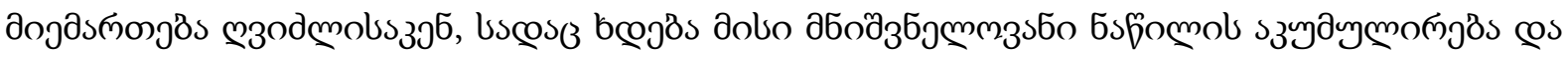

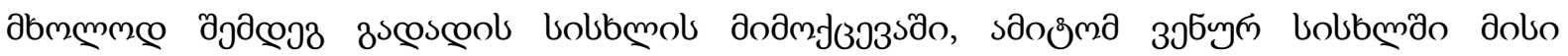

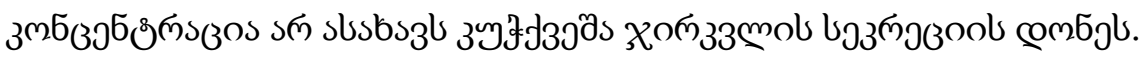

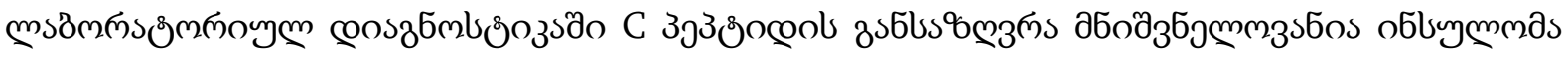

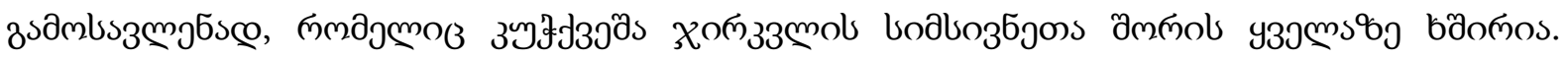

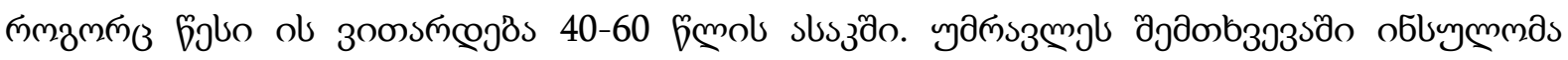

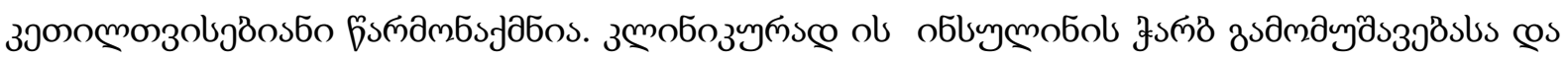

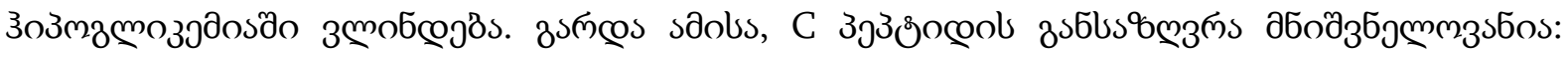

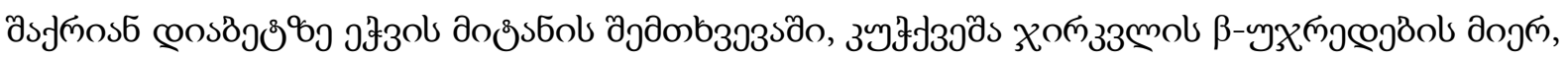

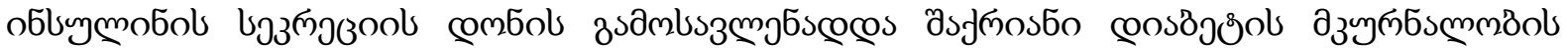

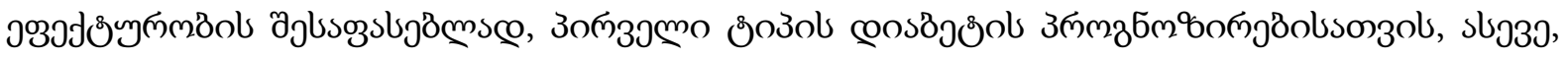

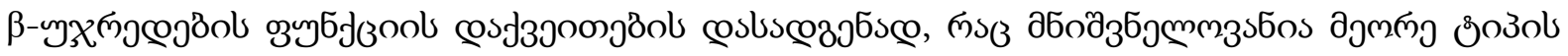

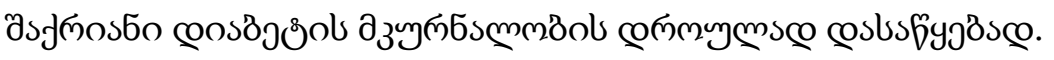

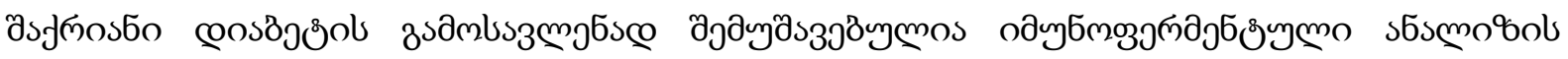

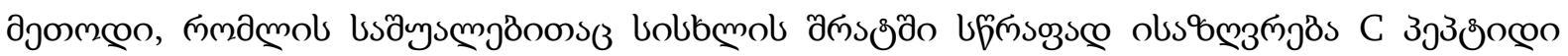
[40].

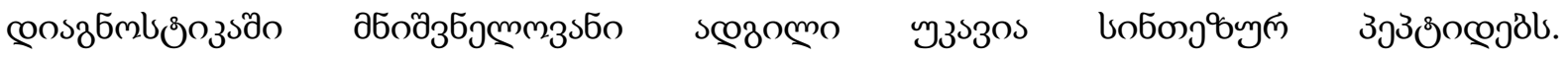

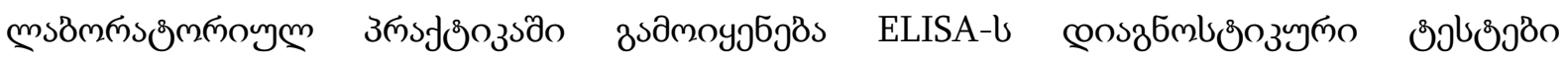

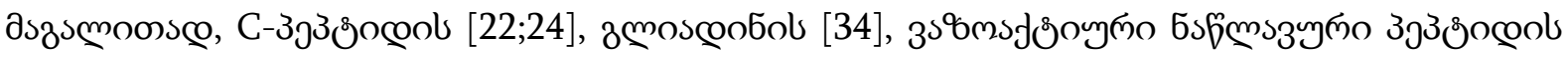
[38], coojój

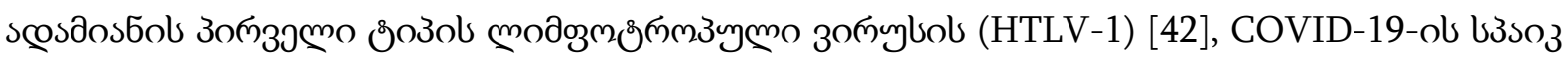

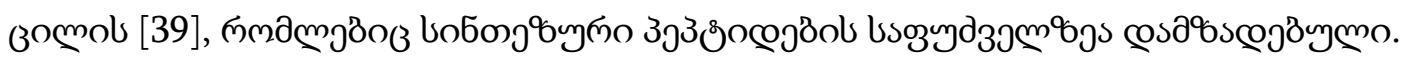

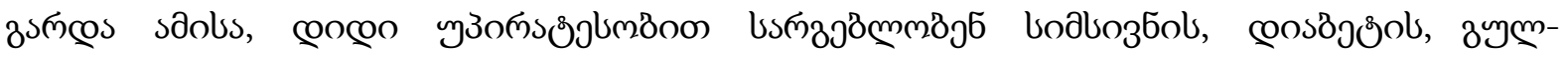

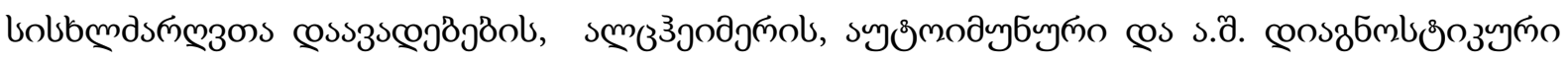

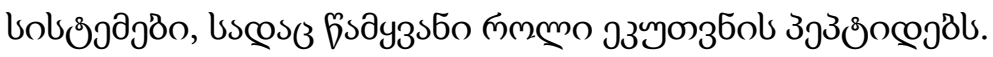

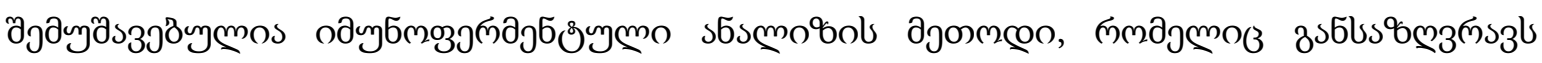

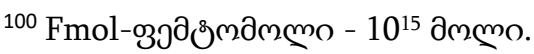




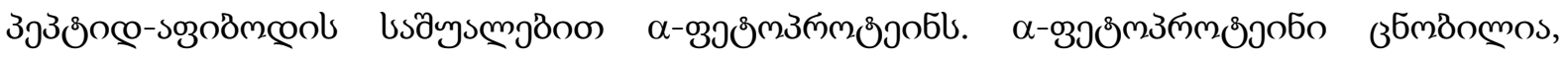

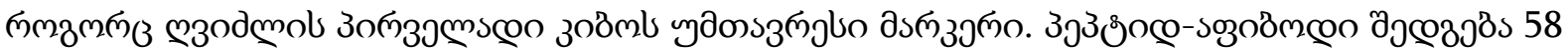

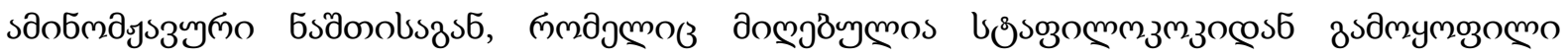

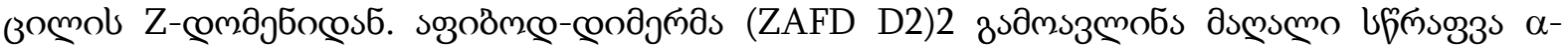

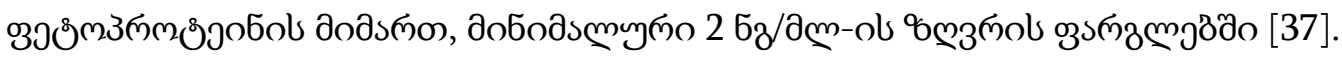

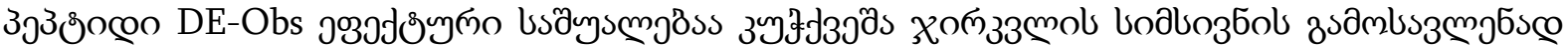

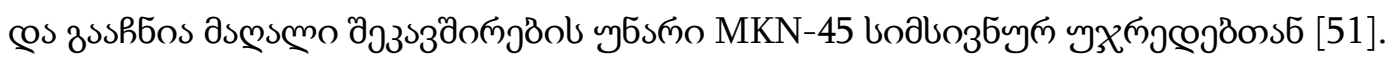

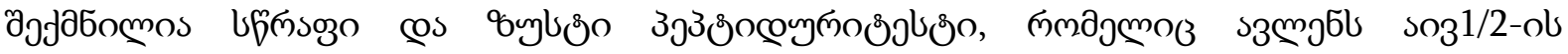

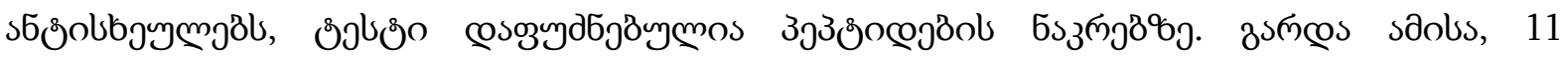

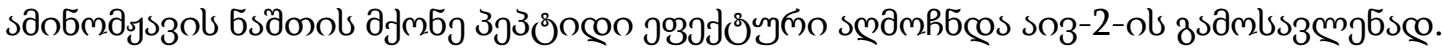

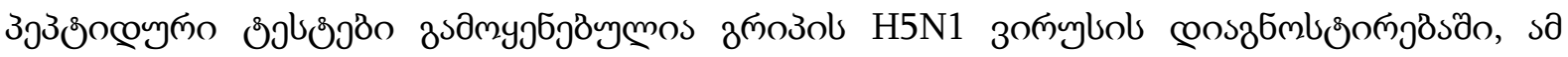

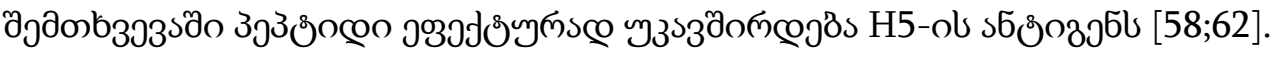

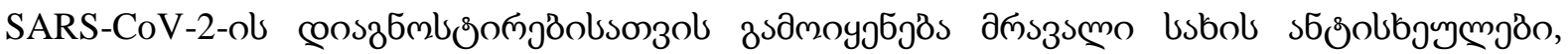

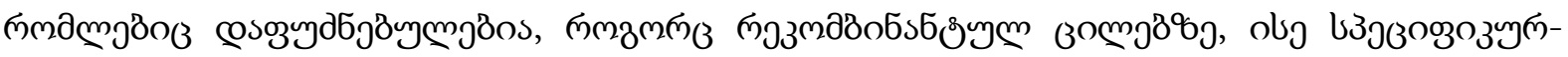

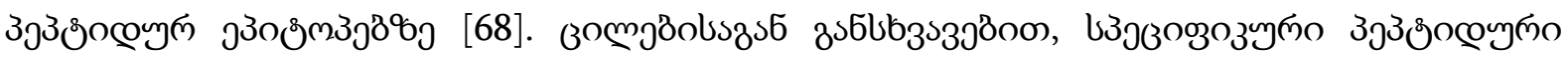

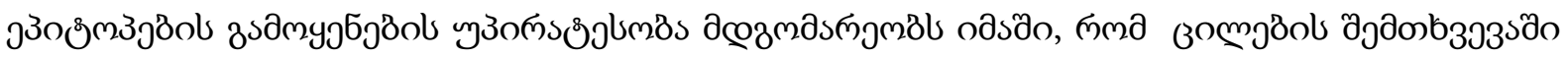

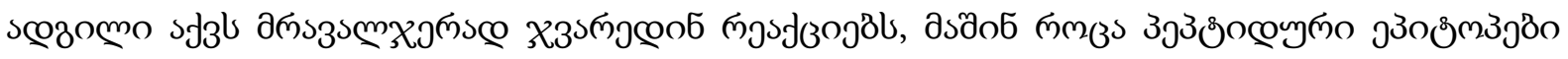

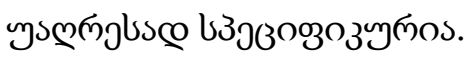

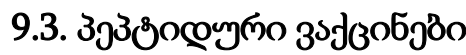

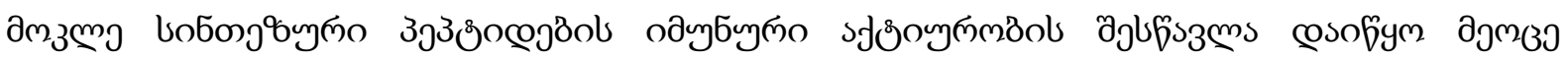

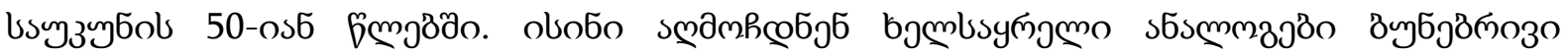

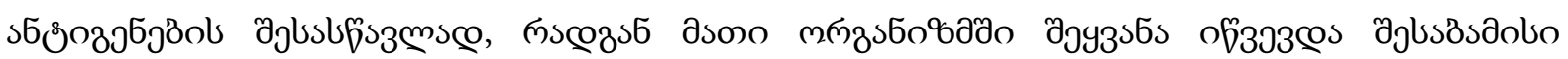

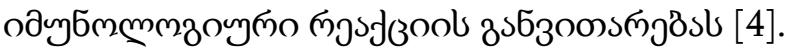

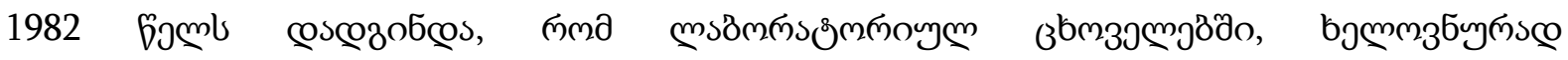

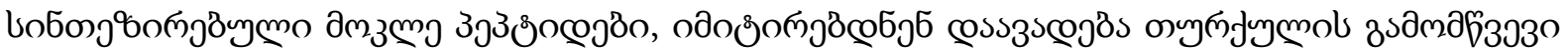

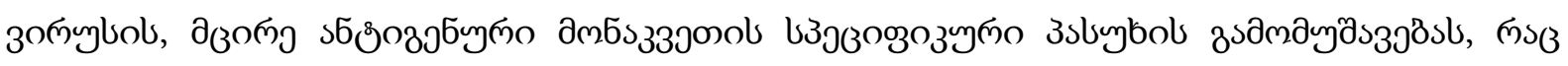

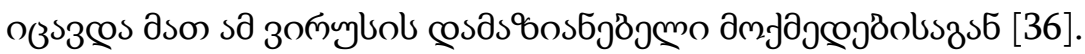

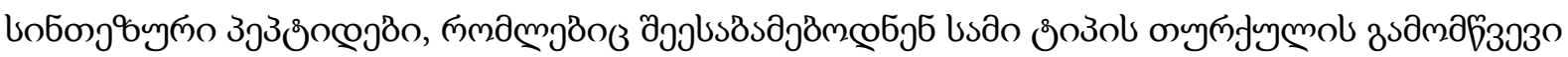

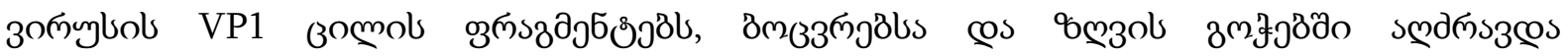

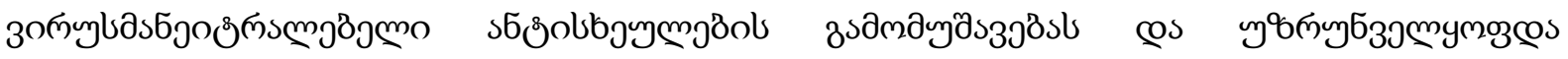

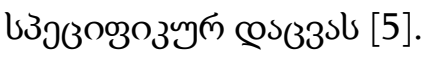

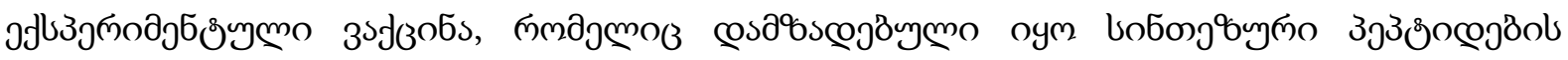

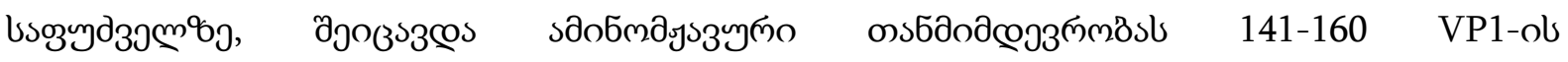

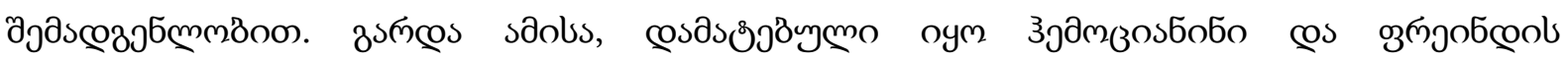

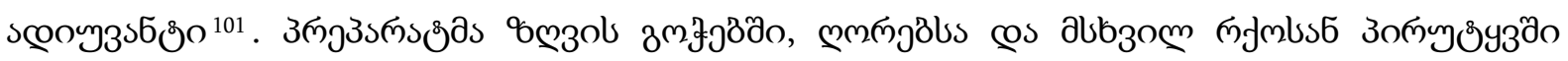

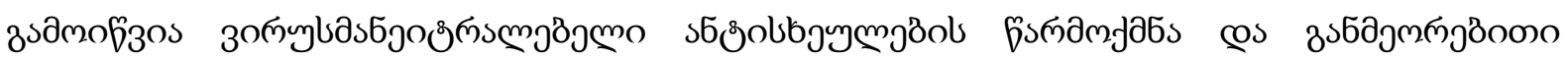

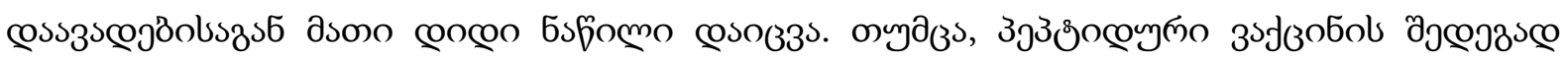

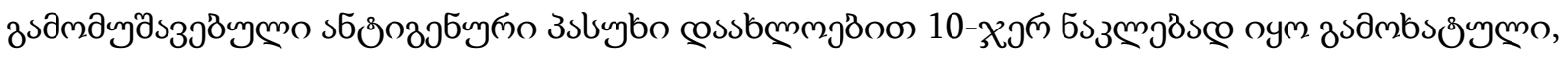

\footnotetext{
${ }^{101}$ жुп

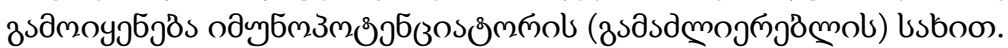




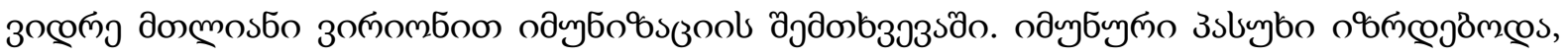

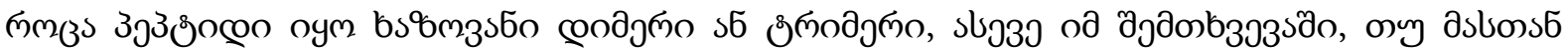

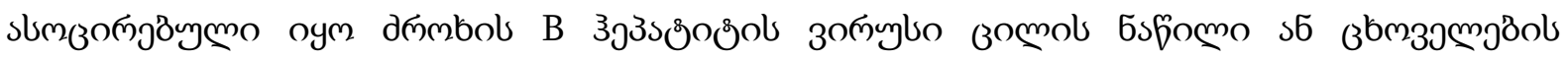

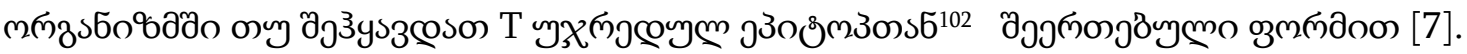

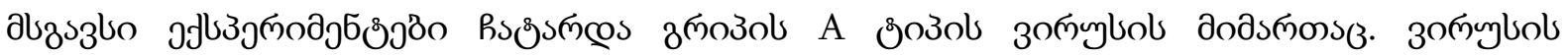

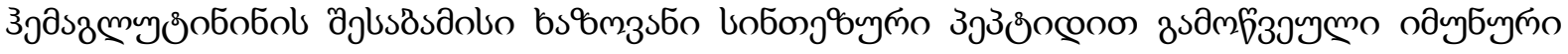

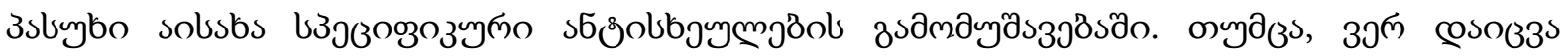

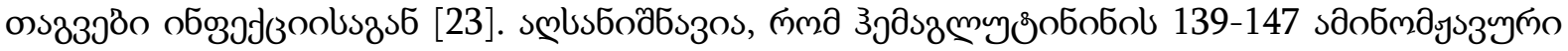

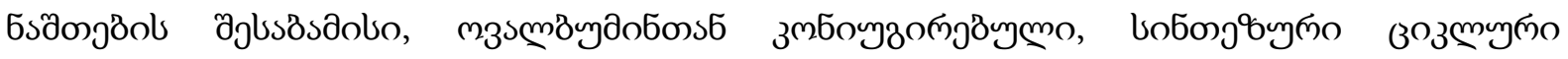

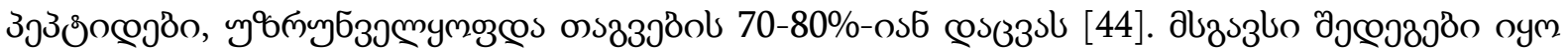

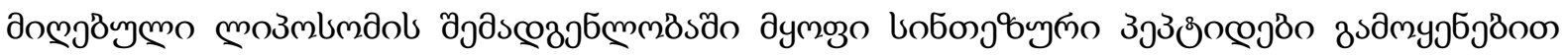
[17].

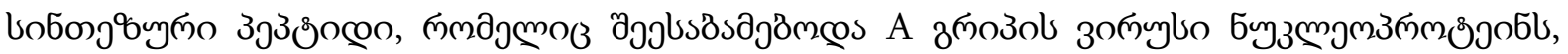

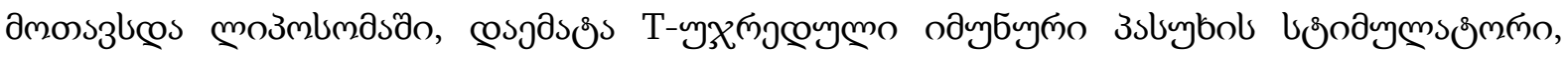

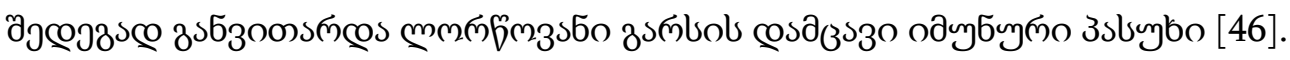

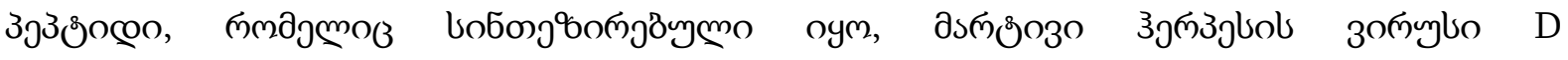

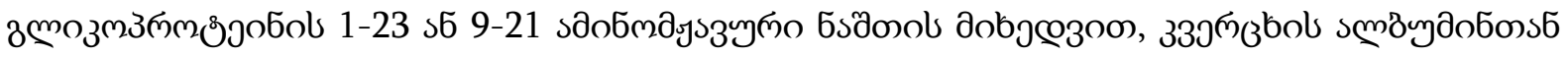

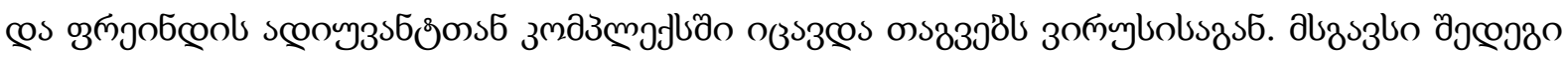

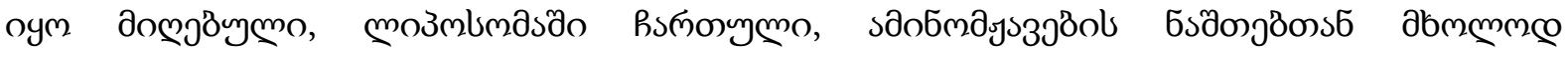

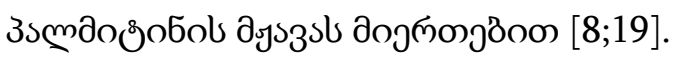

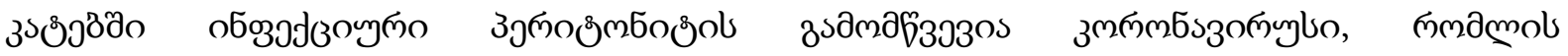

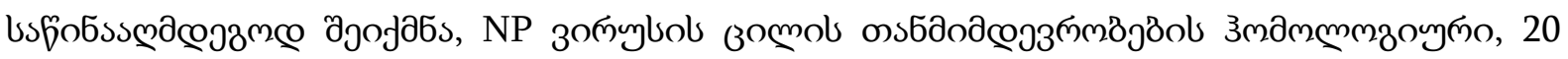

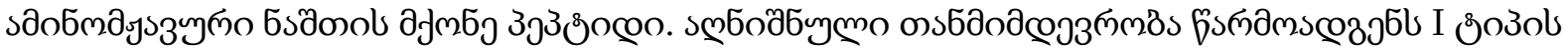

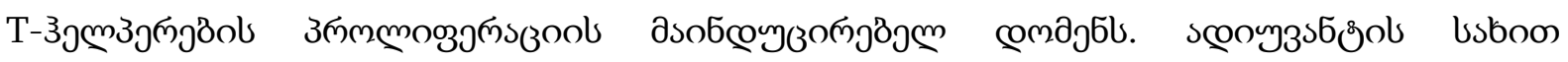

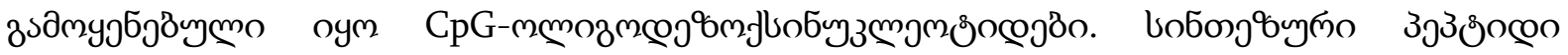

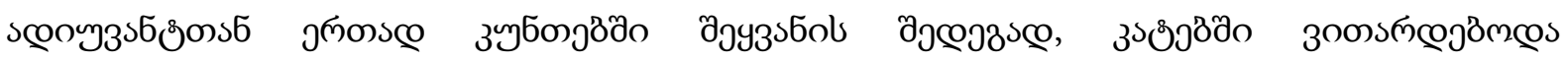

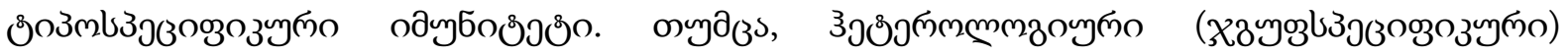

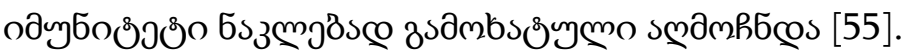

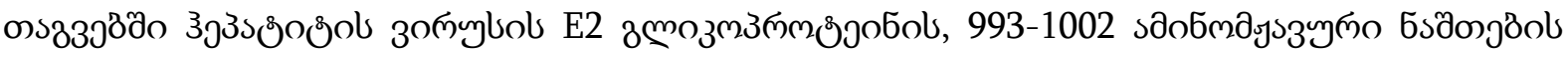

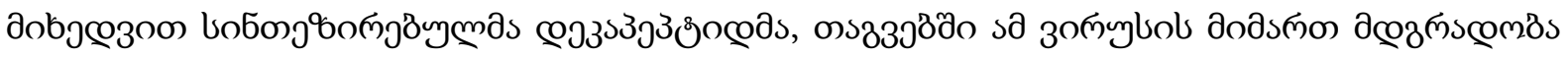

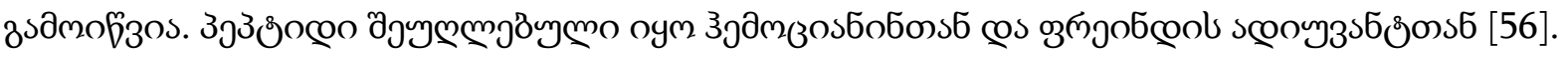

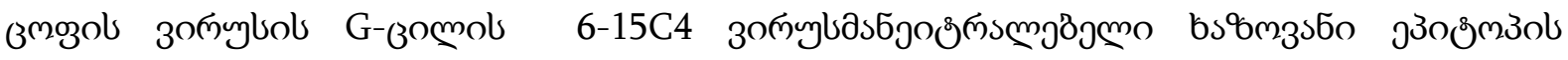

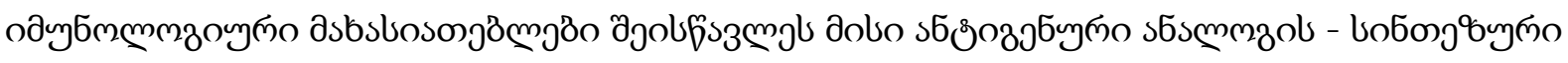

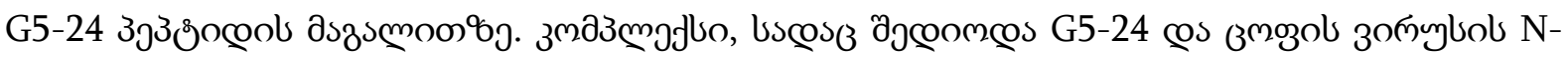

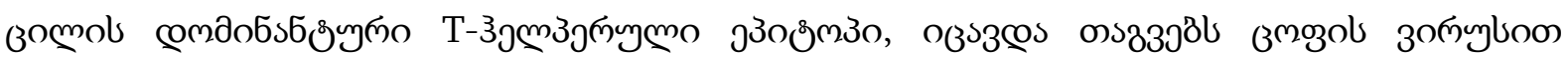

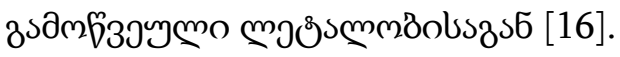

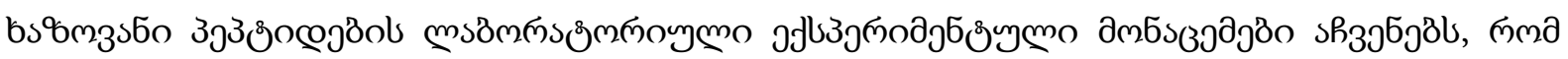

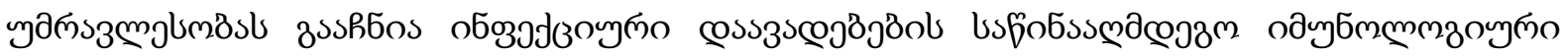

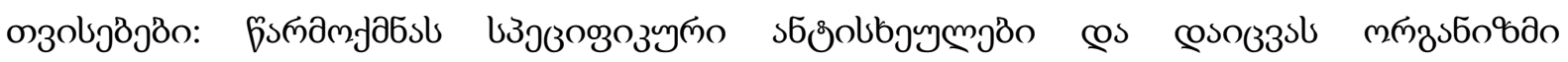

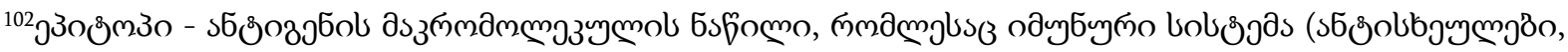

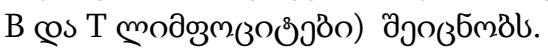




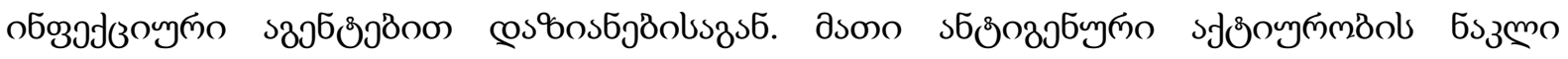

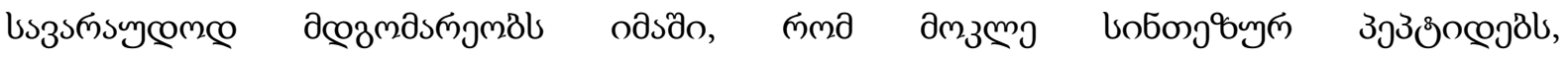

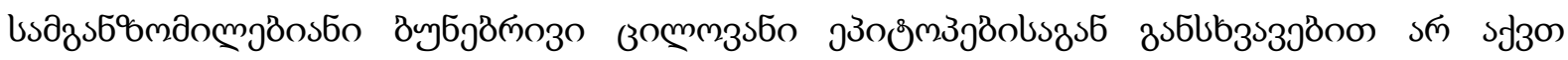

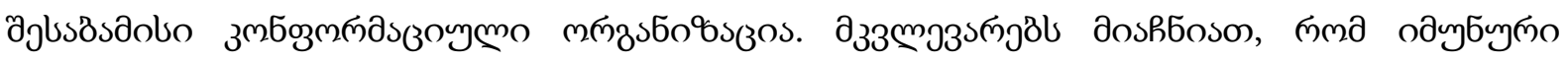

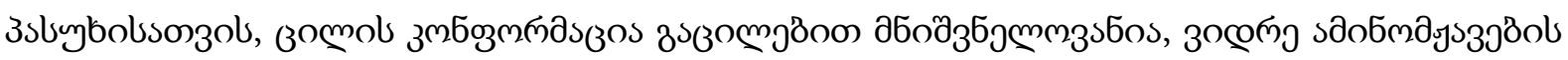

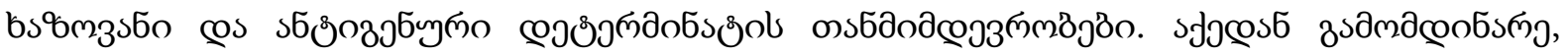

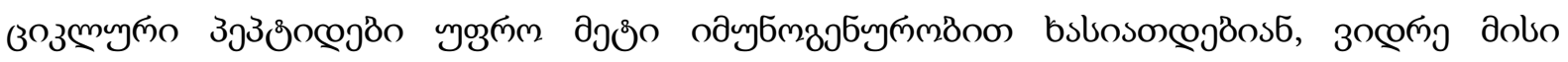

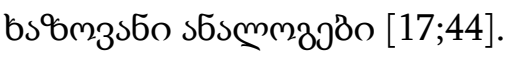

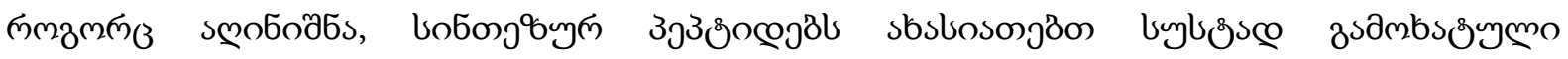

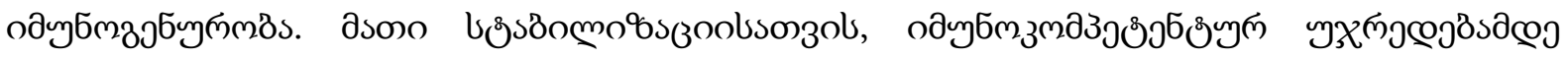

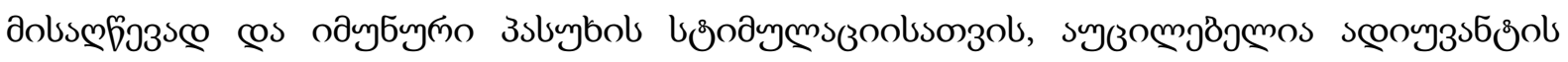

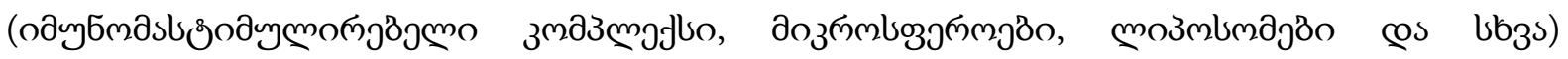

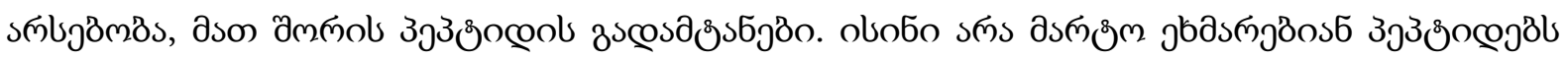

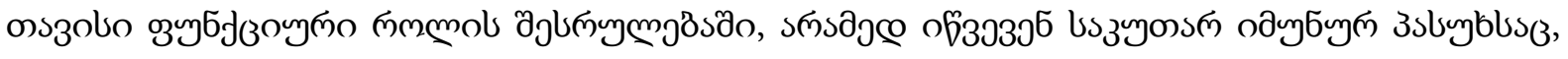

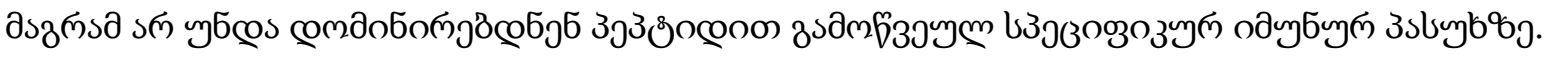

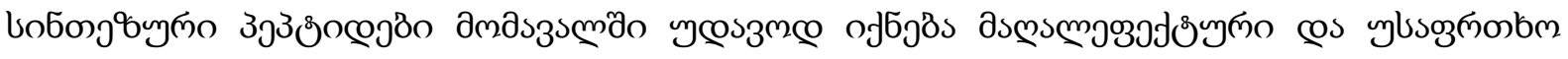

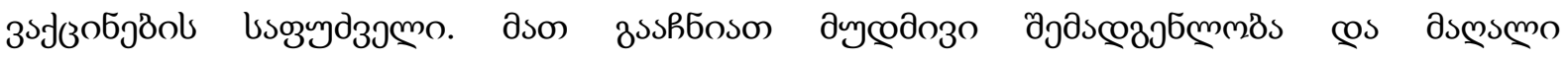

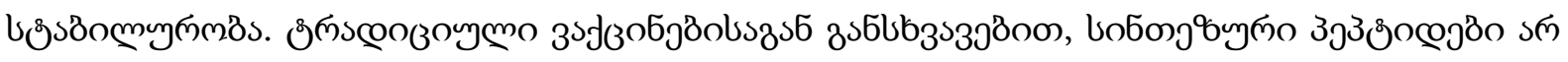

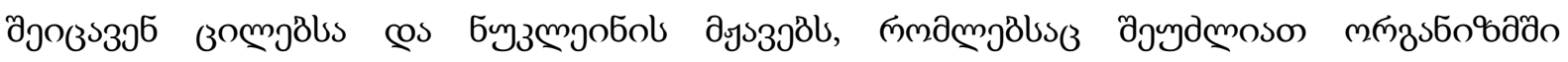

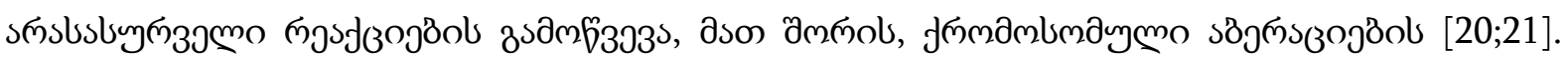

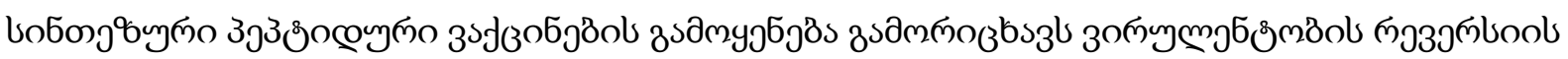

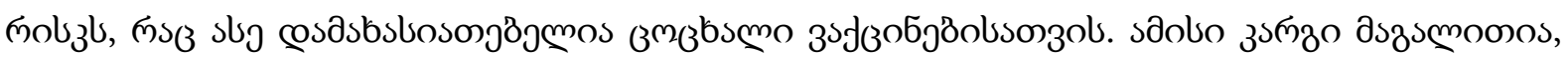

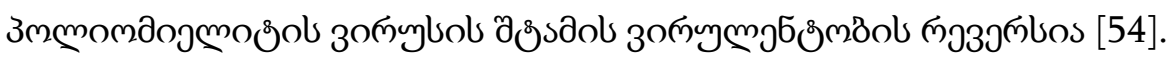

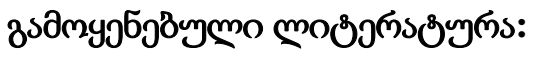

1. Adams K. F., Mathur V. S., Gheorghiade M. et al. B-type natriuretic peptide from bench to bedside //Amer. Heart J. - 2003. - Vol. 145. - P. 34-46.

2. Ala-Kopsala M., Magga J., Peuhkurinen K. et al. Molecular heterogeneity has a major impact on the measurement of circulating N-terminal fragments of A- and B-type natriuretic peptides // Clin. Chem. - 2004. - Vol. 50. - P. 1576-1588.

3. Alibay Y., Beauchet A., El Mahmoud R. et al. Plasma N"terminal probrain natriuretic peptide and brain natriuretic peptide in assessment ofacute dyspnea. Biomed. Pharmacother. 2005; 59 $(1-2): 20-24$.

4. Arnon R., Sela M. Antibodies to a unique region in lysozyme provokedby a synthetic antigen conjugate. Proc. Natl. Acad. Sci. USA.1969; 62(1): 163-71.

5. Bittle J. L., Houghten R. A., Alexander H., Shinnick T. M., SutcliffeJ.G., Lerner R. A. et al. Protection against foot-and-mouth diseaseimmunization with a chemically synthesized peptide predicted fromthe viral nucleotide sequence. Nature. 1982; 298(5869): 30-3.

6. Brady AJ, Poole-Wilson PA. ESC-CHF guidelines for the aspirational and the practical. Heart 2006; 92:437-440.

7. Brown F. Use of peptides for immunization against foot-and-mouthdisease. Vaccine. 1988; 6: $180-2$. 
8. Brynestad K., Babbit B., Huang L., Rouse B.T. Influence of peptideacylation, liposome incorporation, and synthetic immunomodulatorson the immunogenicity of a 1-23 peptide of glycoprotein Dof herpes simplex virus: implications for subunit vaccines. J. Virol.1990; 64(2): 680-5.

9. Cardarelli R., Lumicao T. G. B-type natriuretic peptide:a review of its diagnostic, prognostic, and therapeuticmonitoring value in heart failure for primarycare physicians // J. Amer. Board FamilyPractice. - 2003. - Vol. 16. - P. 327-333.

10. Clerico A., Emdin M. Diagnostic accuracy and prognosticrelevance of the measurement of cardiacnatriuretic peptides: a review // Clin. Chem. -2004. - Vol. 50. - P. 33-50.

11. Collins S. P. Use of Nt-proBNP in the emergencydepartment evaluation of shortness of breath:implications for clinical practice // Emerg. Med.Card. Research Educat. Group. - 2005. - Vol. 6. -P. 11-22.

12. Cowie M. R., Struthers A. D., Wood D. A. et al. Valueof natriuretic peptides in assessment of patientswith possible new heart failure in primary care //Lancet. - 1997. - Vol. 350. - P. 1349-1353.

13. 13.Dahlstrom U. Can natriuretic peptides be used for the diagnosis of diastolic heart failure? Eur. J. Heart Failure 2004; 6 (3): 281-287.

14. De Lemos J., McGuire D. K., Drazner M. H. et al.B-type natriuretic peptide in cardiovascular disease //Lancet. - 2003. - Vol. 362. - P. 316-322

15. De-Simone, S.G.; Gomes, L.R.; Napoleão-Pêgo, P.; Lechuga, G.C.; de Pina, J.S.; Epitope, F.R.D. Mapping of the Diphtheria Toxinand Development of an ELISA-Specific Diagnostic Assay. Vaccines 2021, 9, 313. [CrossRef] [PubMed]

16. Dietzschold B., Gore M., Marchadier D., Niu H.S., Bunschoten H.M.,Otvos L.Jr. et al. Structural and immunological characterization oflinear virus-neutralizing epitope of the rabies virus glycoprotein andits possible use in a synthetic vaccine. J. Virol. 1990; 64(8): 3804-9.

17. Friede M., Muller S., Briand J.P., Plaué S., Fernandes I., Frisch B. etal. Selective induction of protection against influenza virus infectionin mice by a lipid-peptide conjugate delivered in liposomes. Vaccine.1994; 12(9): 791-7.

18. 18.Fuat A, Murphy JJ, Hungin AP et al. The diagnostic accuracy and utility of a B-type natriuretic peptide test in a community population of patients with suspected heart failure. $\mathrm{Br} /$ Gen Pract 2006; 56: 327-333.

19. Geerligs H.J., Weijer W.J., Welling G.W., Welling-Wester S. Theinfluence of different adjuvants on the immune response to a syntheticpeptide comprising amino acid residues 9-12 of herpes simplex virustype 1 glycoprotein D. J. Immunol. Methods. 1989; 124(1): 95-102.

20. Genghini R., Tiranti I., Bressan E., Zamorano-Ponce E., FernándezJ., Dulout F. Determination of genotoxicity of classical swine fevervaccine in vitro by ytogenetic and comet tests. Mutagenesis. 2006;21(3): 213-7.

21. Genghini R., Tiranti I., Segade G., Amado J., Wittouck P., Mian L.In vivo effect on pig 9 chromosomes of high dosage vaccine againstclassic swine fever. Mutat.Res. 1998; 422(2): 357-65.

22. Graham, M.L.; Gresch, S.C.; Hardy, S.K.; Mutch, L.A.; Janecek, J.L.; Hegstad-Davies, R.L. Evaluation of commercial ELISA andRIA for measuring porcine C-peptide: Implications for research. Xenotransplantation 2015, 22, 62-69. [CrossRef]

23. Green N., Alexander H., Olson A., Alexander S., Shinnick T.M., Sutcliffe J.G. et al. Immunogenic structure of the influenzahaemagglutinin. Cell. 1982; 28(3): 477-87.

24. Gresch, S.C.; Mutch, L.A.; Janecek, J.L.; Hegstad-Davies, R.L.; Graham, M.L. Crossvalidation of commercial enzyme-linked immunosorbent assay and radioimmunoassay for

25. porcine C-peptide concentration measurements in non-human primate serum. 
Xenotransplantation 2017, 24, e12320. [CrossRef]

26. Gupta, K.; Brown, L.; Bakshi, R.K.; Press, C.G.; Chi, X.; Gorwitz, R.J.; Papp, J.R.; Geisler, W.M. Performance of Chlamydiatrachomatis OmcB Enzyme-Linked Immunosorbent Assay in Serodiagnosis of Chlamydia trachomatis Infection inWomen. J.Clin. Microbiol. 2018, 56, e00275-18. [CrossRef] [PubMed]

27. Hama N, Itoh H, Shirakami G, Suga S, Komatsu Y, Yoshimasa T et al. Detection of C-type natriuretic peptide in humancirculation and marked increase of plasma CNP level in septicshock patients. Biochem Biophys Res Commun 1994;198:1177—82

28. 27.Hartemink KJ, Groeneveld J, de Groot MC, Strack van Schijndel RJ, van Kamp G. Thijs LG. a-Atrial natriuretic peptide,cyclic guanosine monophosphate, and endothelin in plasmaas markers of myocardial depression in human septic shock. Crit Care Med 2001;29:80 - 7.

29. Hutfless R., Kazanegra R., Madani M. et al. Utility of B"type natriuret"ic peptide in predicting postoperative complications and outcomes inpatients undergoing heart surgery. J. Am. Coll. Cardiol. 2004; 43 (10):1873-1879.

30. Iwanaga Y., Nishi I., Furuichi S. et al. B"type natriuretic peptide strongly reflects diastolic wall stress in patients with chronic heart failure:comparison between systolic and diastolic heart failure. J. Am. Coll.Cardiol. 2006; 47 (4): 742-748.

31. Januzzi J. L., Camargo C. A., Anwaruddins et al. TheN-Terminal Pro-BNP Investigation of Dyspnea inthe Emergency Department (PRIDE) Study //Amer. J. Card. - 2005. - Vol. 95. P. 948-954.

32. Januzzi J. L. Natriuretic peptide testing: A windowinto the diagnosis and prognosis of heart failure// Cleveland Clin. J. Med. - 2006. - Vol. 73. -P. 149-157.

33. Juffe A. S., Babuin L., Apple F. S. Biomarkers inacute cardiac disease // J. Amer. Coll. Cardiol. -2006. - Vol. 48. - P. 1-11.

34. Langbeheim H., Arnon R., Sela M. Antiviral effect on MS-2 coliphageobtained with a synthetic antigen. Proc. Natl. Acad. Sci. USA. 1976;73: 4636-40.

35. Lau, M.S.; Mooney, P.D.; White, W.L.; Rees, M.A.; Wong, S.H.; Hadjivassiliou, M.; Green, P.H.R.; Lebwohl, B.; Sanders, D.S.Office-Based Point of Care Testing (IgA/IgG-Deamidated Gliadin Peptide) for Celiac Disease. Am. J. Gastroenterol. 2018, 113,1238-1246. [CrossRef] [PubMed]

36. Le Jemtel T. H., Padeletti M., Jelic S. Diagnostic and therapeutic challenges in patients with coexistent chronic obstructive pulmonary diseaseand chronic heart failure. J. Am. Coll. Cardiol. 2007; 49 (2): 171-180.

37. Lerner R.A. Tapping the immunological repertoire to produceantibodies of predetermined specificity. Nature. 1982; 299: 593-6.

38. Liu, J.; Cui, D.; Jiang, Y.; Li, Y.; Liu, Z.; Tao, L.; Zhao, Q.; Diao, A. Selection and characterization of a novel affibody peptide and its application in a two-site ELISA for the detection of cancer biomarker alpha-fetoprotein. Int. J. Biol. Macromol. 2021, 166, 884892.[CrossRef]

39. Liu, M.; Zhao, G.; Wei, B.F. Attenuated serum vasoactive intestinal peptide concentrations are correlated with disease severity ofnon-traumatic osteonecrosis of femoral head. J. Orthop. Surg. Res. 2021, 16, 325. [CrossRef].

40. Li, Y.; Lai, D.Y.; Lei, Q.; Xu, Z.W.; Wang, F.; Hou, H.; Chen, L.; Wu, J.; Ren, Y.; Ma, M.L.; et al. Systematic evaluation of IgGresponses to SARS-CoV-2 spike protein-derived peptides for monitoring COVID-19 patients. Cell Mol. Immunol. 2021, 18, 621-631.[CrossRef] [PubMed]. 41

41. Lv, R.; Chen, Y.; Xia, N.; Liang, Y.; He, Q.; Li, M.; Qi, Z.; Lu, Y.; Zhao, S. Development of a double-antibody andwich ELISA for rapid detection to C-peptide in human urine. J. Pharm. 
Biomed. Anal. 2019, 162, 179-184. [CrossRef].

42. 41.Maisel A. Algorithms for using B-type natriuretic peptide levels in the diagnosis and management of congestive heart failure. Git Path Cardiol 2002; 1: 67-73.

43. Mosadeghi, P.; Heydari-Zarnagh, H. Development and Evaluation of a Novel ELISA for Detection of Antibodies against HTLV-IUsing Chimeric Peptides. Iran. J. Allergy Asthma Immunol. 2018, 17, 144-150.

44. Mueller C, Laule-Kilian K, Schindlcr C et al. Cost-effectiveness of B-type natriuretic peptide testing in patients with acute dyspnea. Arch Intern Med 2006; 166: 1081-1087.

45. Mueller S., Plaue S., Samama J.P., Valette M., Briand J.P., VanRegenmortel M.H. Antigenic property and protective capacity ofa cyclic peptide corresponding to site A of influenza vimshaemagglutinin. Vaccine. 1990; 8(4): 308-14.

46. Mueller T., Gegenhuber A., Poelz W., Haltmeyer M.Head-to-head comparison of the diagnostic utilityof BNP and proBNP in symptomatic and asymptomaticstructural heart disease // Clin. Chim.Acta. - 2004. - Vol. 341. - P. 41-48.

47. Ninomiya A., Ogasawara K., Kajino K., Takada A., Kida H.Intranasal administration of a synthetic peptide vaccine encapsulatedin liposome together with an anti-CD40 antibody induces protectiveimmunity against influenza A virus in mice. Vaccine. 2002; 20(25-26): 3123-9.

48. Rahman, K.S.; Darville, T.; Russell, A.N.; O'Connell, C.M.; Wiesenfeld, H.C.; Hillier, S.L.; Chowdhury, E.U.; Juan, Y.C.;Kaltenboeck, B. Discovery of Human-Specific Immunodominant Chlamydia trachomatis B Cell Epitopes. Msphere 2018,3, e00246-18. [CrossRef]

49. Rahman, K.S.; Darville, T.; Russell, A.N.; O'Connell, C.M.; Wiesenfeld, H.C.; Hillier, S.L.; Lee, D.E.; Kaltenboeck, B. ComprehensiveMolecular Serology of Human Chlamydia trachomatis Infections by Peptide Enzyme-Linked Immunosorbent Assays.Msphere 2018, 3, e00253-18. [CrossRef] [PubMed]

50. Rahman, K.S.; Darville, T.; Wiesenfeld, H.C.; Hillier, S.L.; Kaltenboeck, B. Mixed Chlamydia trachomatis Peptide AntigensProvide a Specific and Sensitive Single-Well Colorimetric Enzyme-Linked Immunosorbent Assay for Detection of Human AntiC.trachomatis Antibodies. Msphere 2018, 3, e00484-18. [CrossRef] [PubMed]

51. Reesink H. J., Tulevski I. I., Marcus J. T. et al. Brain natriuretic peptide asnoninvasive marker of the severity of right ventricular dysfunction inchronic thromboembolic pulmonary hypertension. Ann. Thorac. Surg.2007; 84 (2): 537—543.

52. Sahin, D.; Taflan, S.O.; Yartas, G.; Ashktorab, H.; Smoot, D.T. Screening and Identification of Peptides Specifically Targeted to Gastric Cancer Cells from a Phage Display Peptide Library. Asian Pac. J. Cancer Prev. 2018, 19, 927-932.

53. Siebert U, Januzzi JL Jr, Beinfeld MT et al. Cos:-effectiveness of using N-terminal pro-brain natriuretic peptide to guide the diagnostic assessment and management of dyspneic patients in the emergency department. Am I Cardiol 2006; 98: 800-805.

54. Sodian R., Loebe M., Schmitt C. et al. Decreased plasma concentration ofbrain natriuretic peptide as a potential indicator of cardiac recovery inpatients supported by mechanicalcirculatory assist systems. J. Am.Coll. Cardiol. 2001; 38 (7): 1942-1949.

55. Sutter R. W. Poliomyelitis vaccines. In: Plotkin S., Orenstein W., Offit P., eds. Vaccines. 5th ed. Saunders Elsevier; 2008: 62-101.

56. Takano T., Tomizawa K., Morioka H., Doki T., Hohdatsu T.Evaluation of protective efficacy of the synthetic peptide vaccinecontaining the T-helper 1 epitope with $\mathrm{CpG}$ oligodeoxynucleotideagainst feline infectious peritonitis virus infection in cats. Antivir.Ther. 2014; 19(7): 645-50. 
57. TalbotP.J., Dionne J., Lacroix M. Vaccinationagainst lethalcoronavirus-induced encephalitis with a synthetic decapeptidehomologous to a domain in the predicted peplomer stalk. J. Virol.1988; 62: 3032-6.

58. Teodorovich N., Krakover R., Vered Z. B"Type natriuretic peptide: a universal cardiac biomarker? Isr. Med. Assoc. J. 2008; 10 (2): 152-153.

59. Tiwari, R.P.; Jain, A.; Khan, Z.; Kumar, P.; Bhrigu, V.; Bisen, P.S. Designing of novel antigenic peptide cocktail for the detection of antibodies to HIV-1/2 by ELISA. J. Immunol. Methods 2013, 387, 157-166. [CrossRef] [PubMed]

60. Troughton R. W., Frampton C. M., Yandle T. G.et al. Treatment of heart failure guided by plasmaaminoterminal brain natriuretic peptide(N-BNP) concentrations // Lancet. - 2000. Vol. 355. - P. 1126-1130.

61. Vanderheyden M., Bartunek J., Goethals M. Brain and other natriuretic peptides: molecular aspects. Eur. J. Heart Failure 2004; 6 (3): 261-268.

62. Van Kruiningen, H.J.; Helal, Z.; Leroyer, A.; Garmendia, A.; Gower-Rousseau, C. ELISA Serology for Antibodies AgainstChlamydia trachomatis in Crohn's Disease. Gastroenterol. Res. 2017, 10, 334-338. [CrossRef]

63. Velumani, S.; Ho, H.T.; He, F.; Musthaq, S.; Prabakaran, M.; Kwang, J. A novel peptide ELISA for universal detection of antibodies to human H5N1 influenza viruses. PLoS ONE 2011, 6, e20737. [CrossRef] [PubMed]

64. Weber M., Hamm C. Role of B-type natriuretic peptide (BNP) and Nt-proBNP in clinical routine //Heart. - 2006. - Vol. 92. - P. 843-849.

65. Weber M., Hausen M., Arnold R. et al. Prognosticvalue of N-terminal pro-B-type natriuretic peptidefor conservatively and surgically treated patientswith aortic valve stenosis // Ibid. 2006. - Vol. 92.- P. 1639-1644.

66. Wieczorek S. J., Wu A. H., Christenson R. et al. A rapid B"type natriuretic peptide assay accurately diagnoses left ventricular dysfunction andheart failure: a multicenter evaluation. Am. Heart J. 2002; 144 (5):834-839.

67. Wu A. H., Packer M., Smith A. et al. Analyticaland clinical evaluation of the Bayer ADVIACentaur automated B-type natriuretic peptideassay in patients with heart failure: a multisitestudy // Clin. Chem. - 2004. - Vol. 50. -P. 867-873.

68. Wu A. H. Serial testing of B"type natriuretic peptide and NT"proBNPfor monitoring therapy of heart failure: the role of biologic variation inthe interpretation of results. Am. Heart J. 2006; 152 (5): $828-834$.

69. Zhang, Y.; Yang, Z.; Tian, S.; Li, B.; Feng, T.; He, J.; Jiang, M.; Tang, X.; Mei, S.; Li, H.; et al. A newly identified linear epitope onnon-RBD region of SARS-CoV-2 spike protein improves the serological detection rate of COVID-19 patients. BMC Microbiol. 2021,21, 194. [CrossRef].

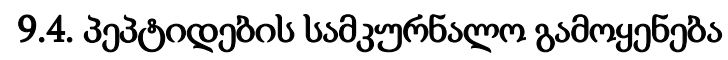

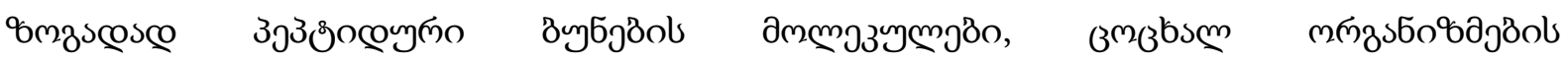

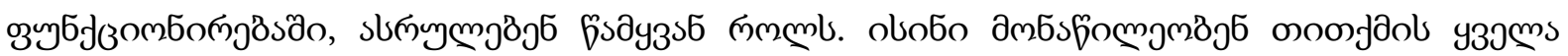

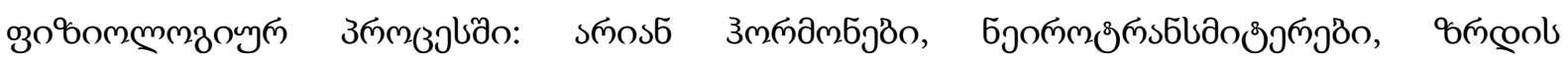

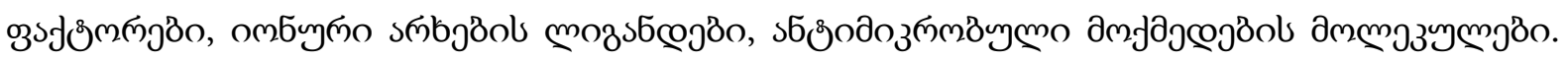

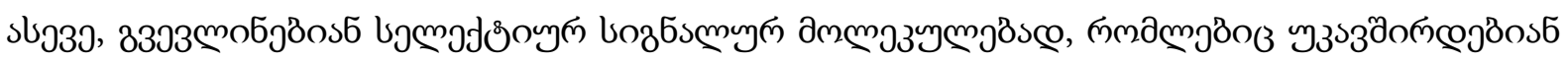

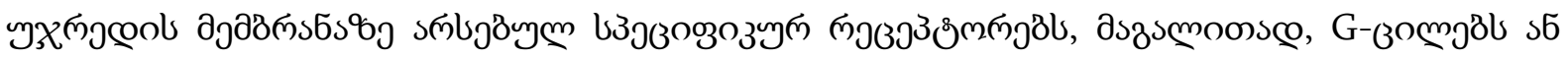

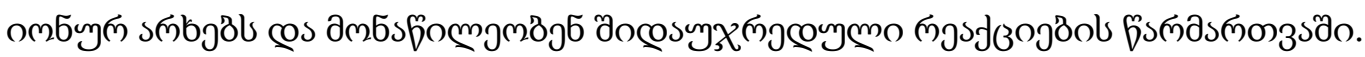




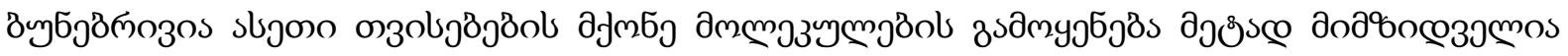

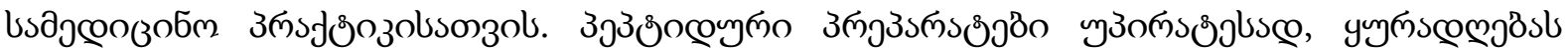

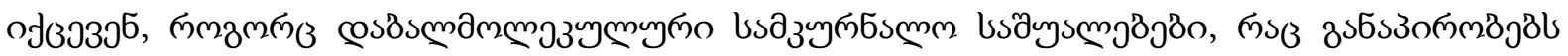

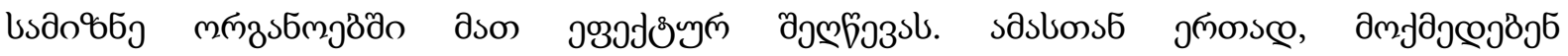

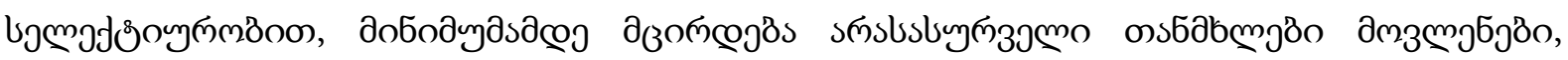

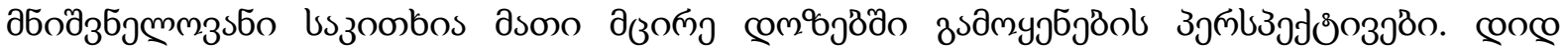

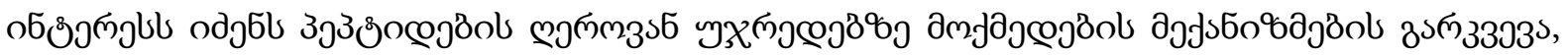

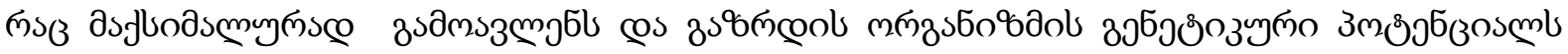
$[13 ; 14 ; 58]$.

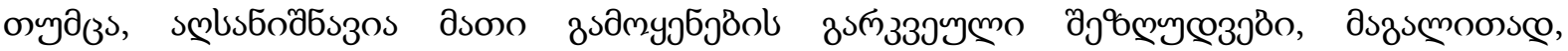

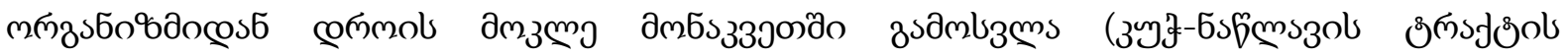

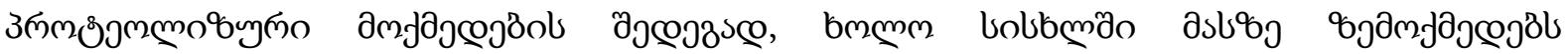

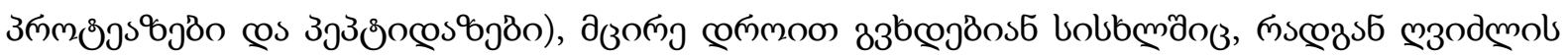

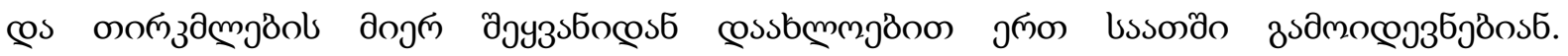

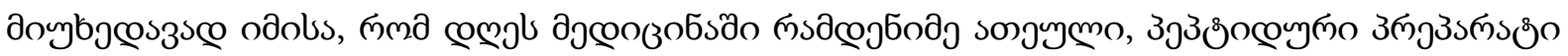

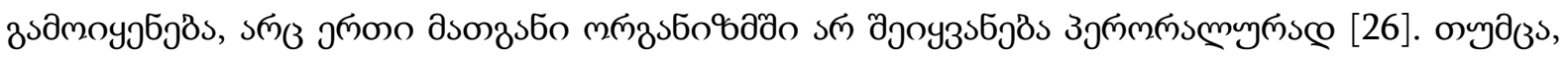

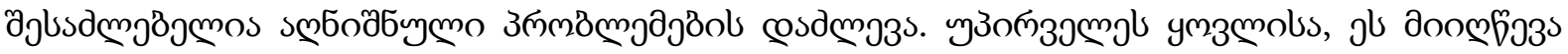

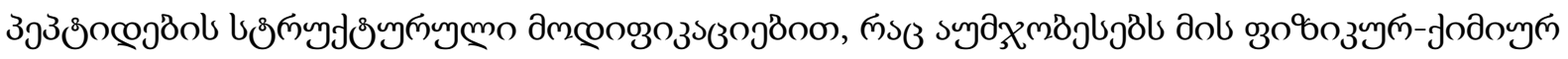

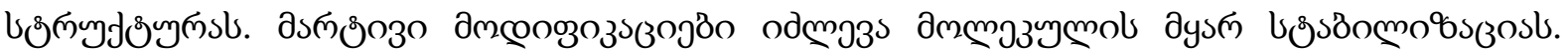

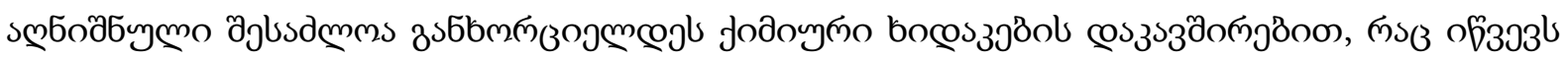

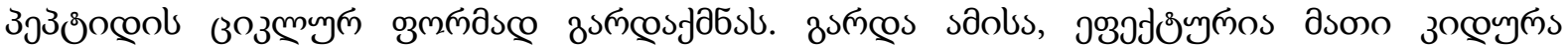

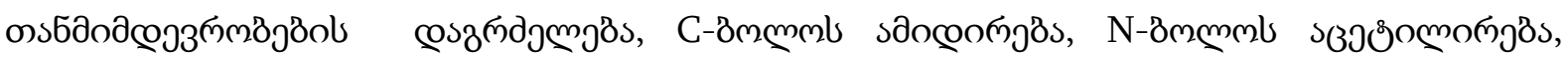

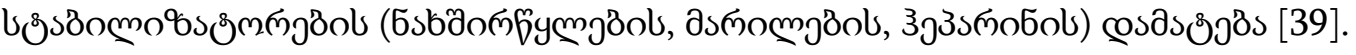

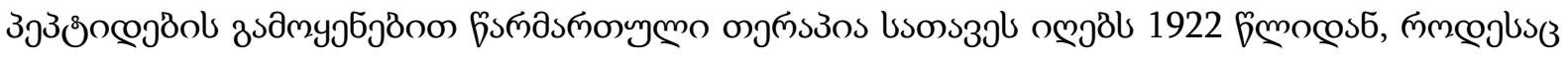

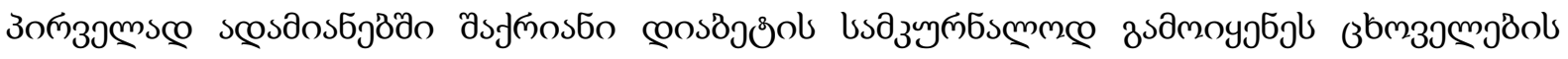

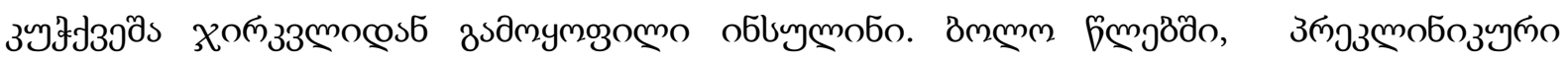

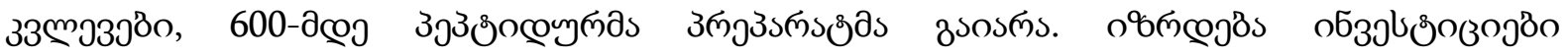

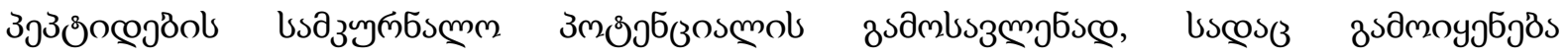

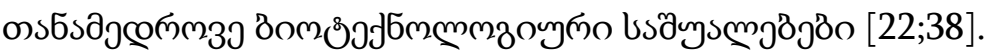

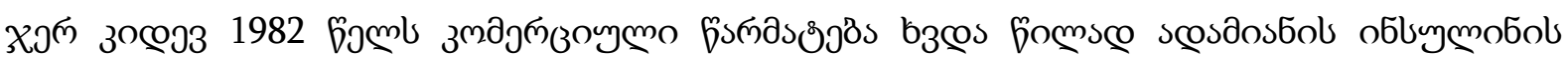

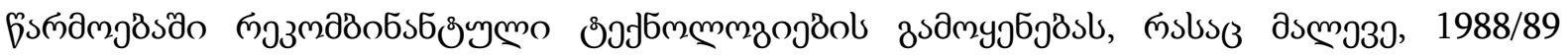

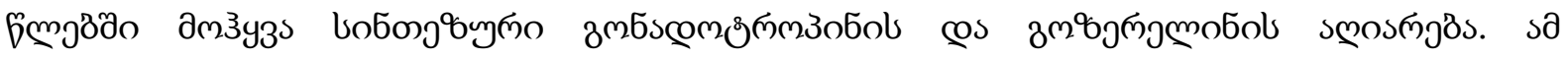

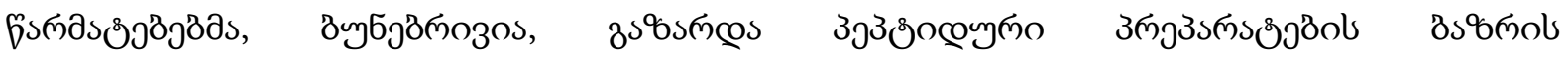

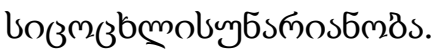

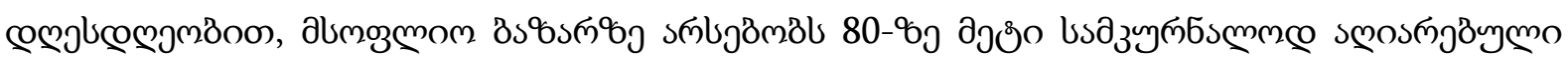

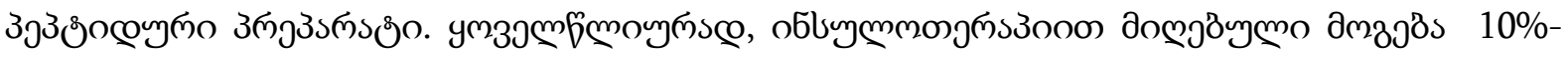

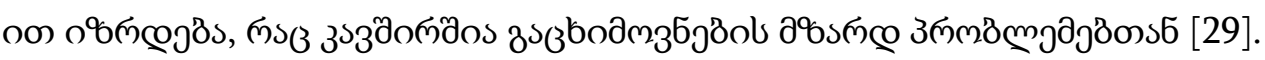

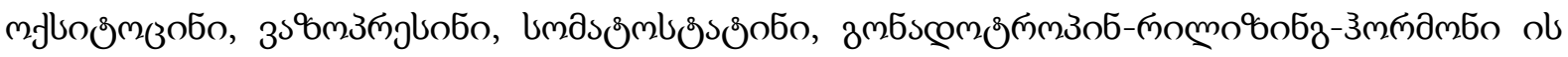

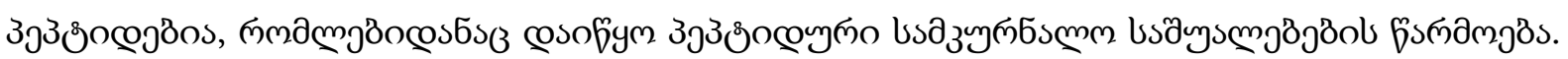

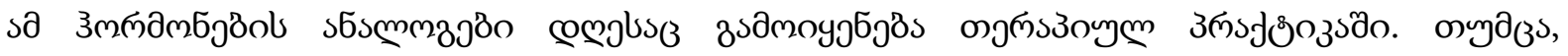

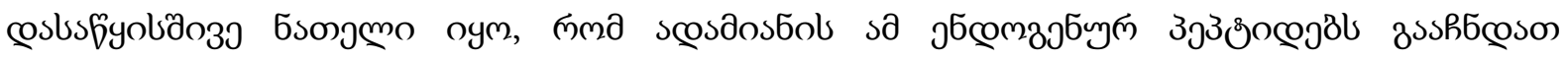

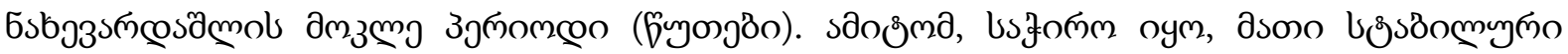




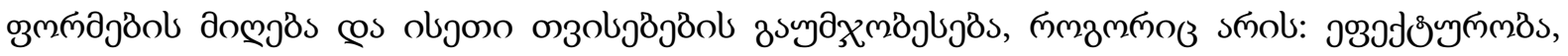

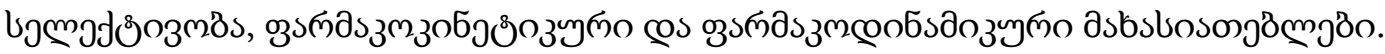

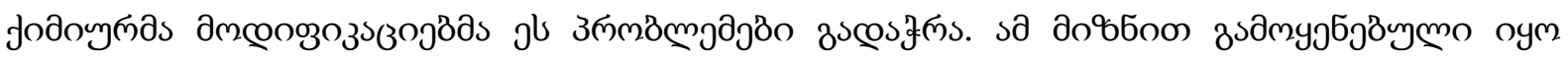

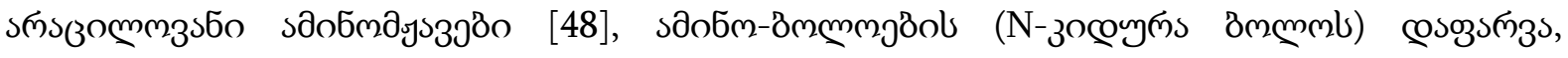

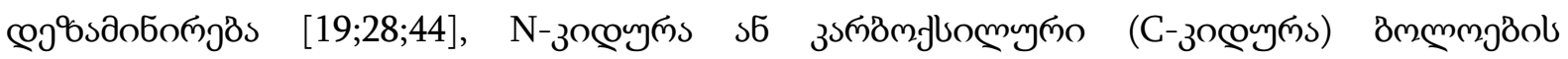

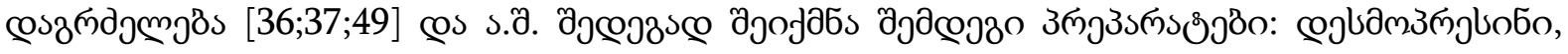

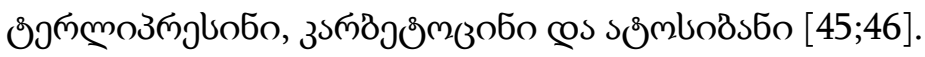

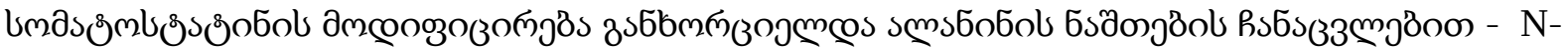

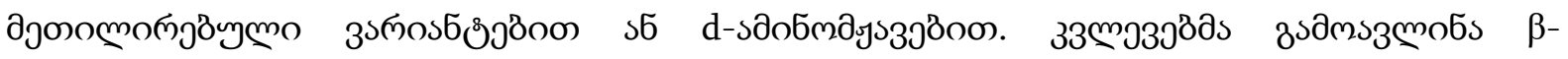

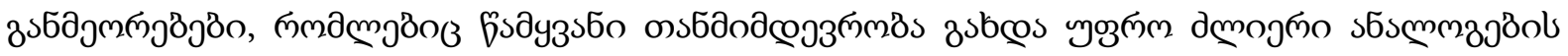

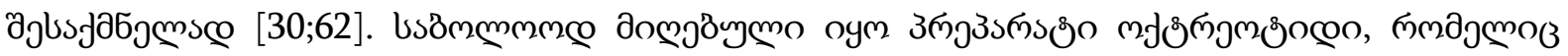

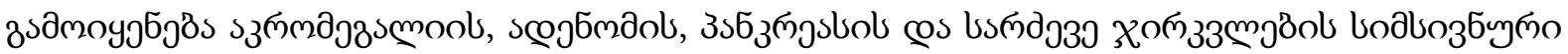

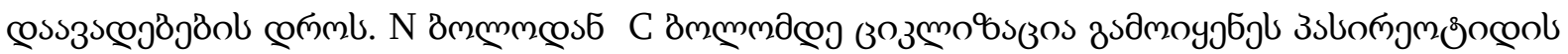

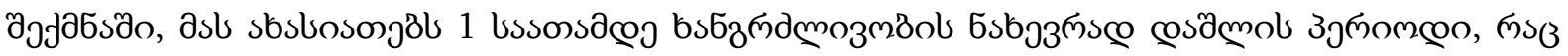

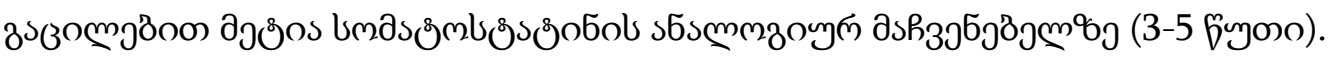

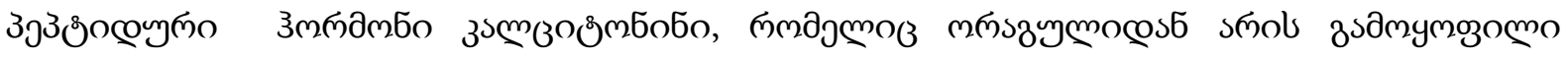

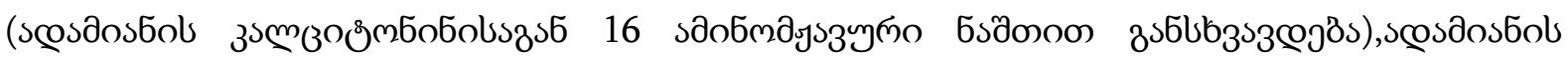

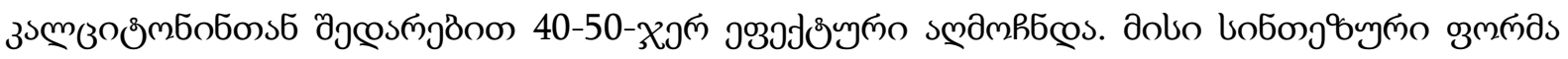

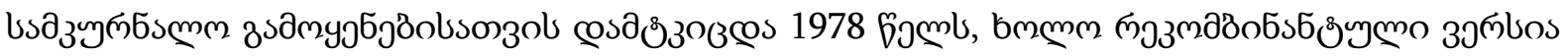

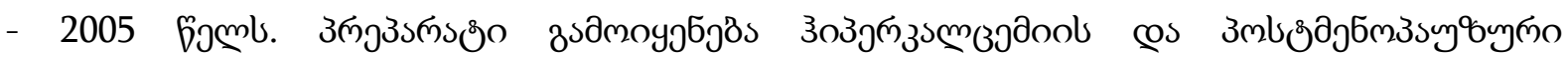

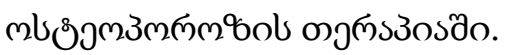

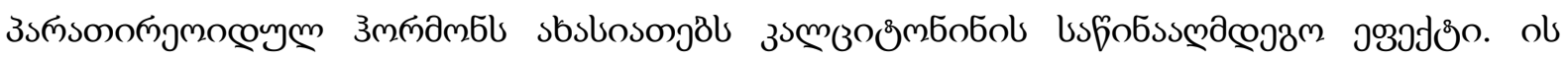

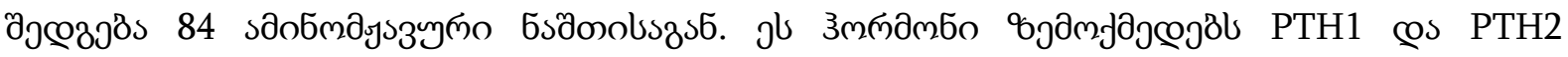

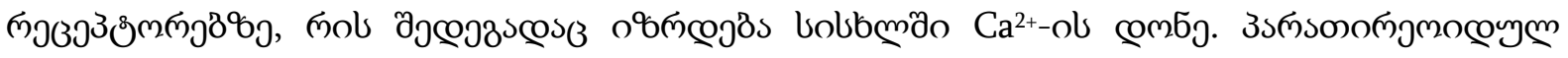

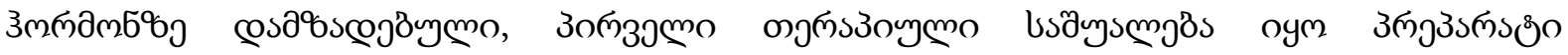

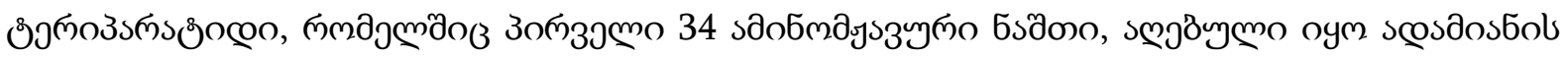

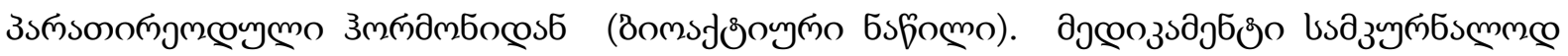

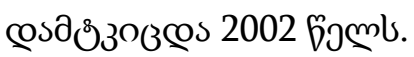

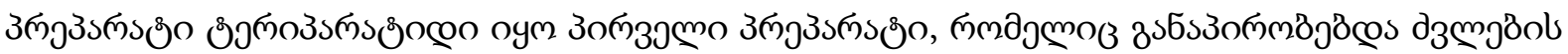

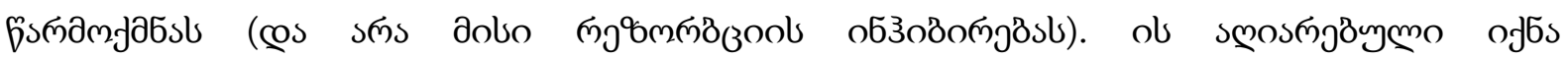

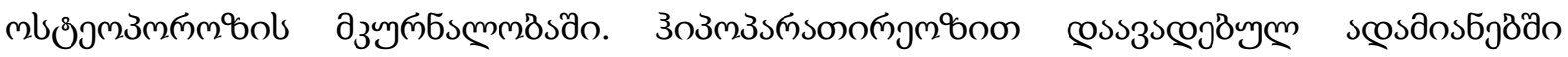

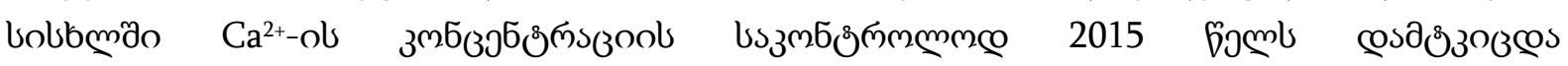

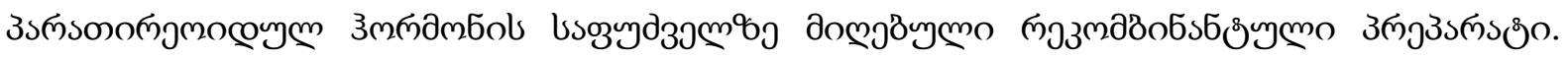

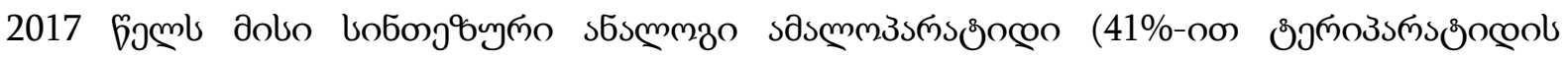

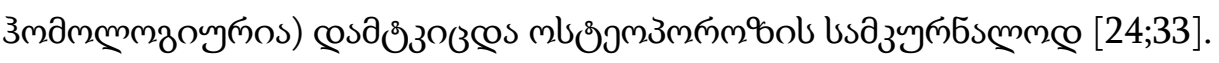

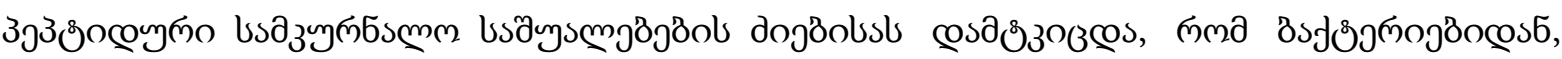

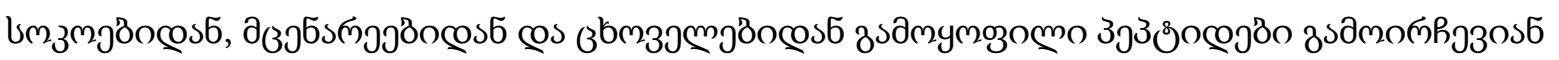

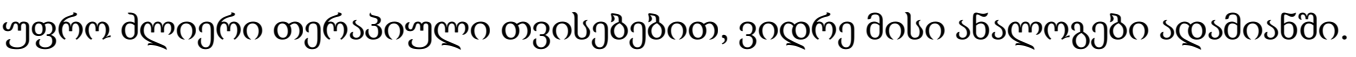

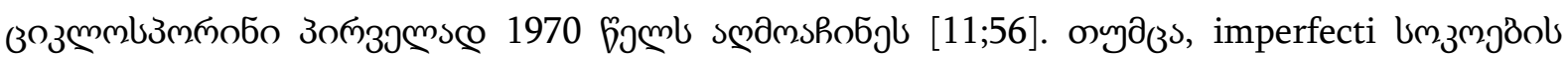

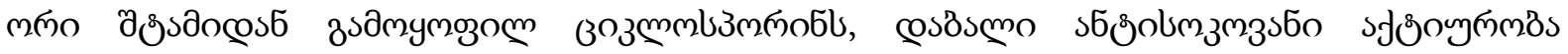

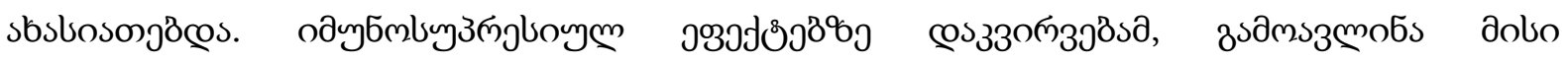

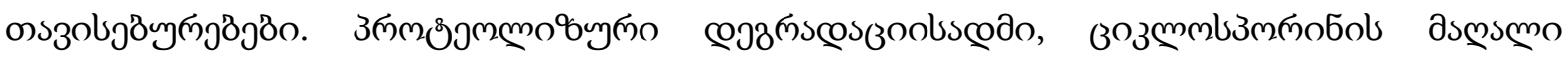




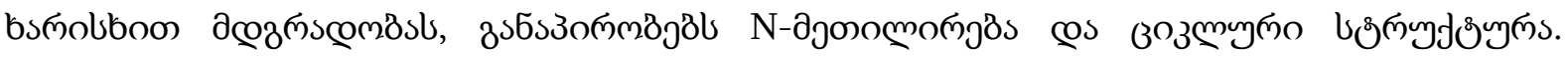

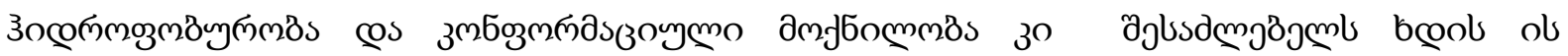

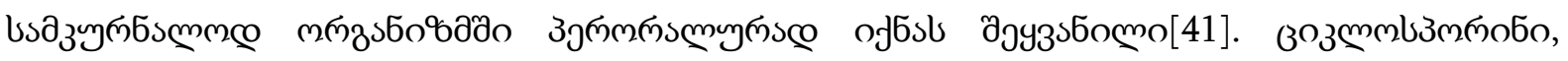

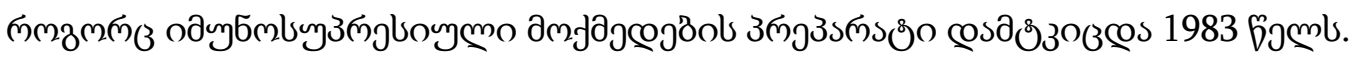

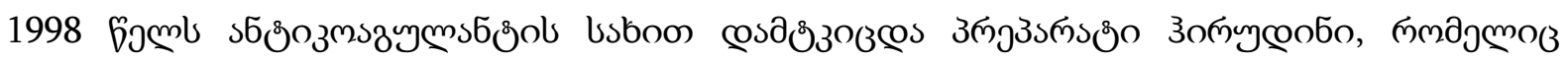

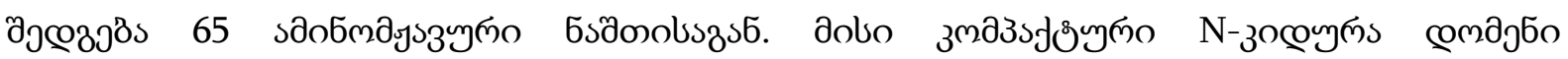

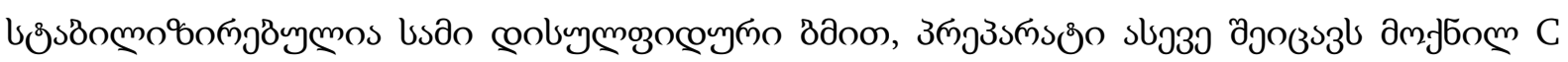

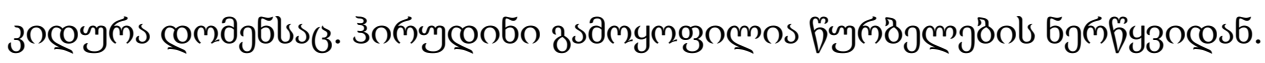

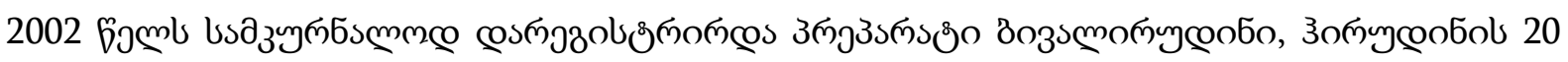

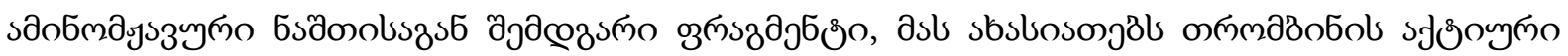
usoðீol o63ం8ిonூன் [65].

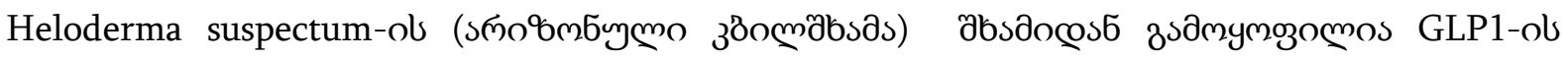

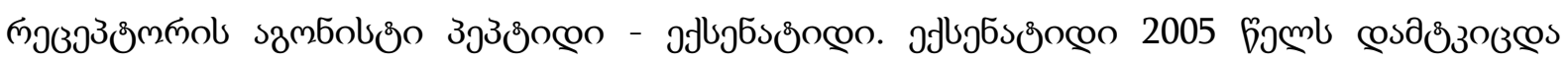

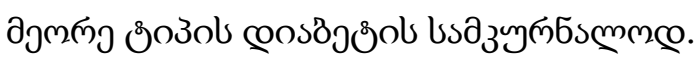

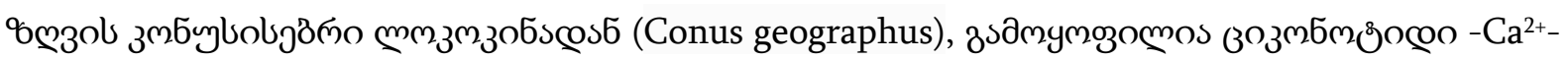

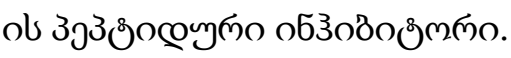

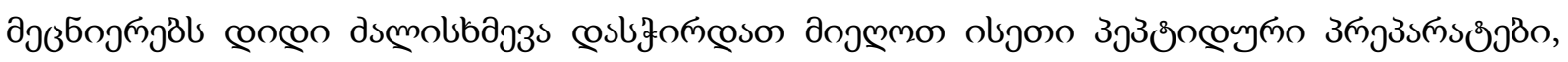

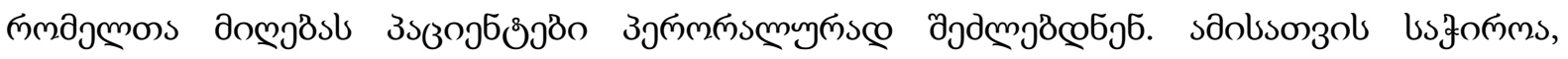

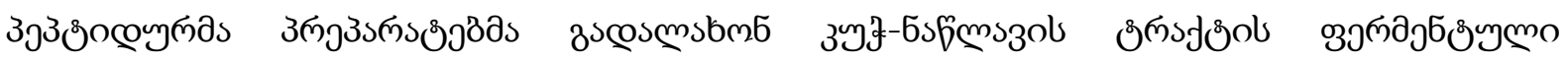

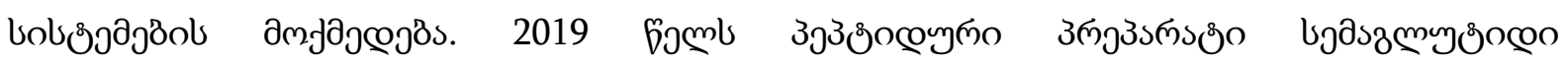

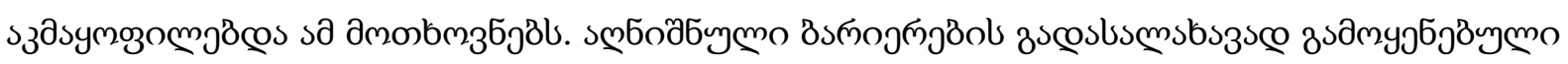

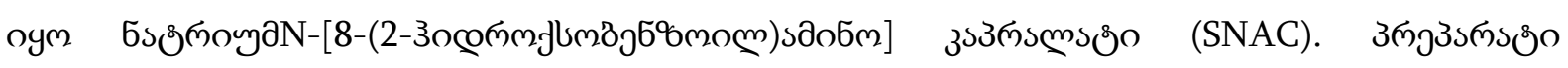

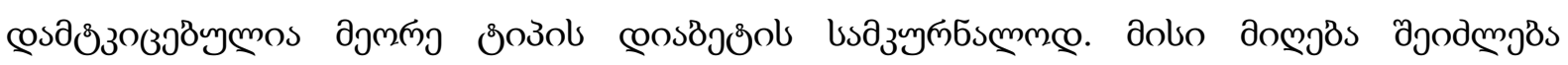

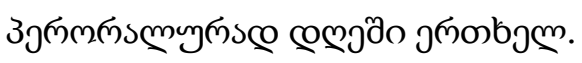

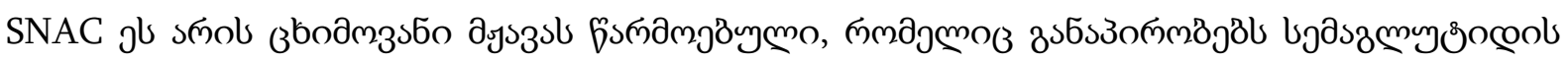

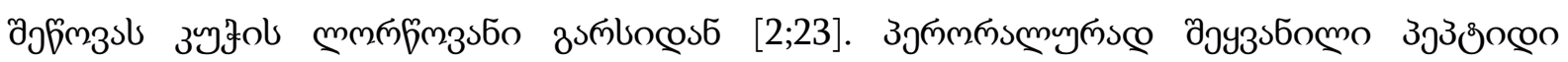

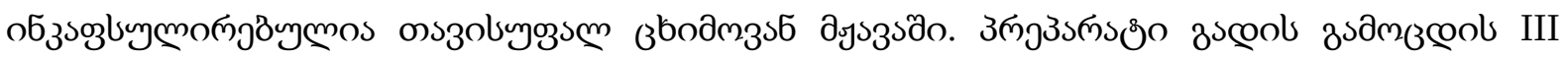

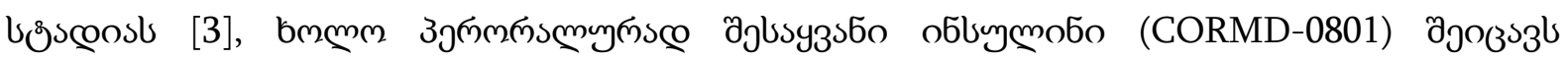

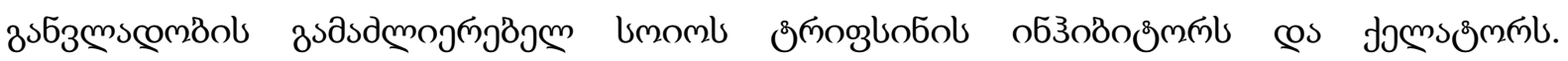

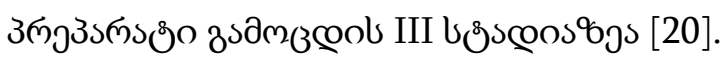

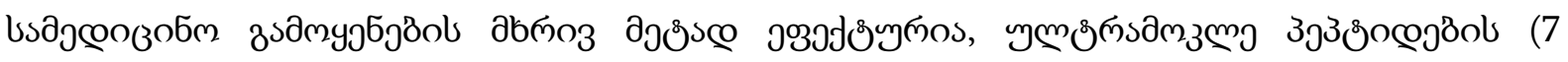

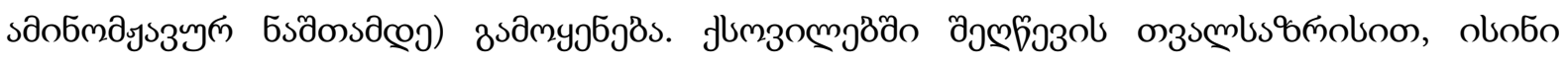

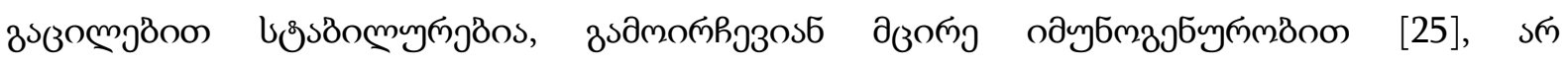

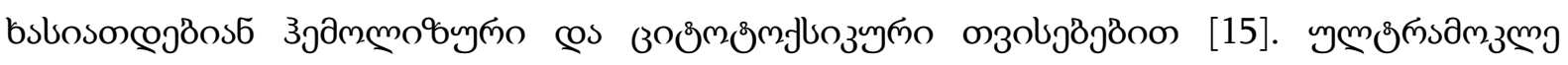

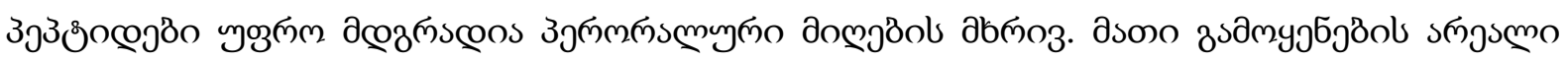

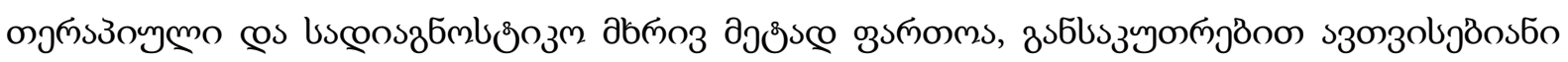

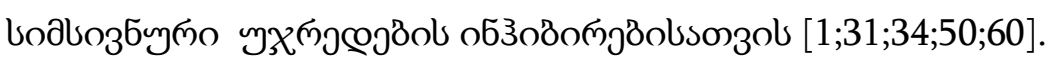

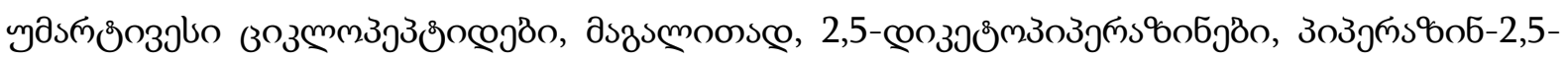

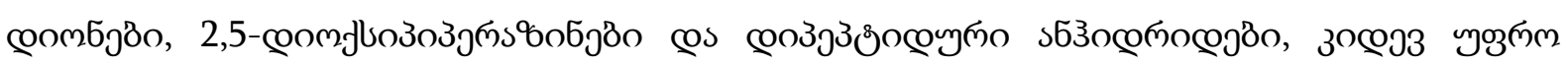

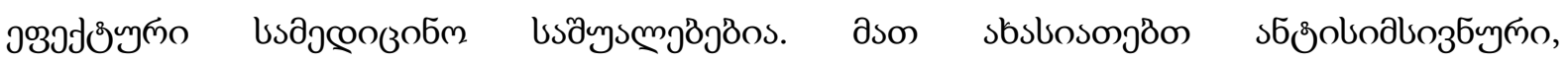

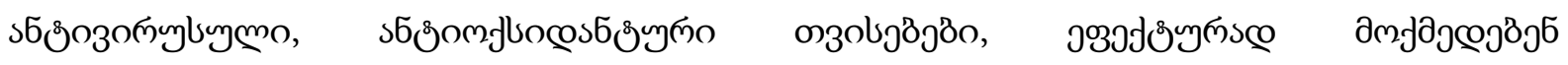

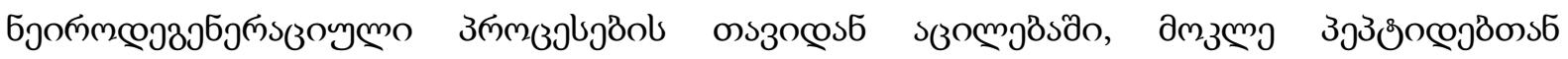




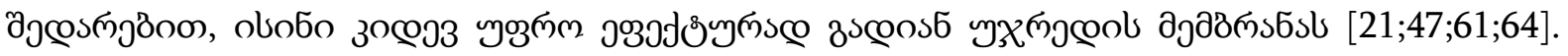

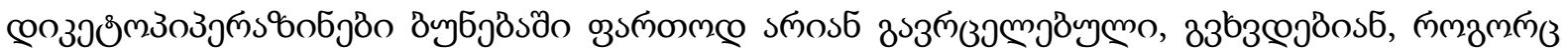

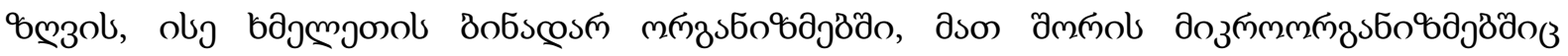
$[5 ; 6 ; 7 ; 8 ; 9 ; 10 ; 51 ; 52 ; 53 ; 54]$.

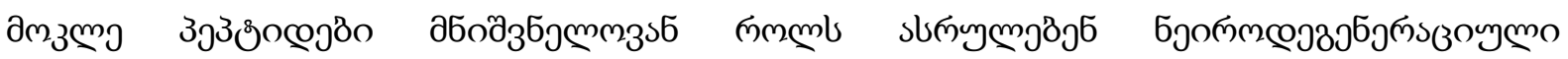

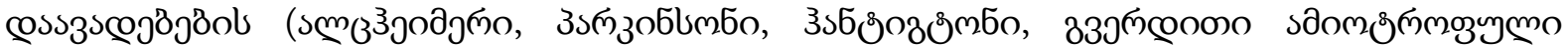

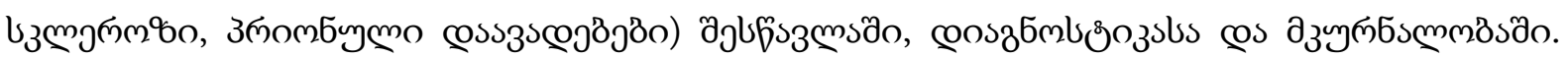

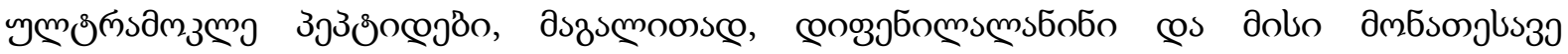

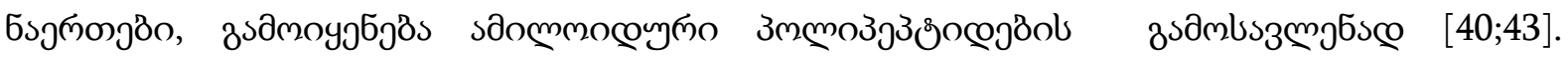

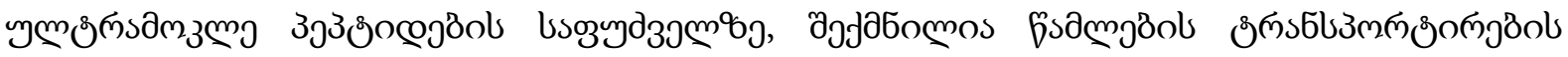

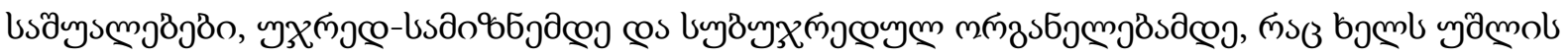

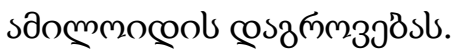

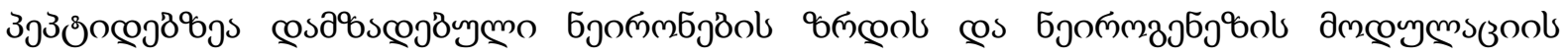

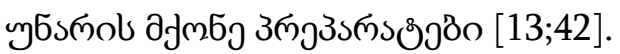

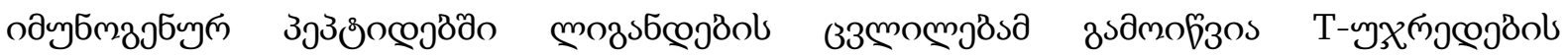

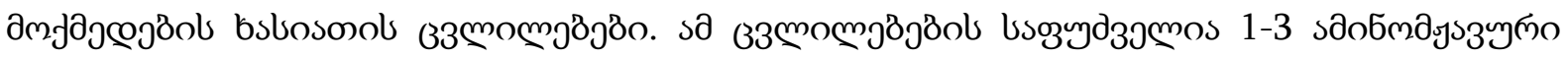

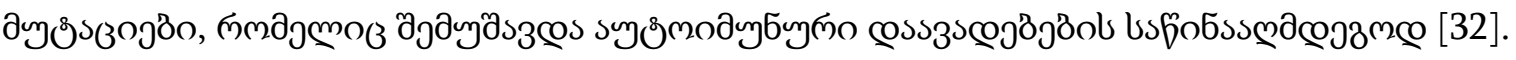

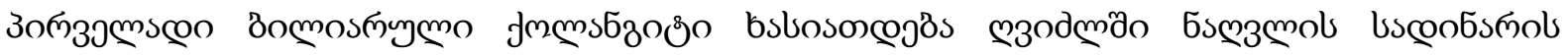

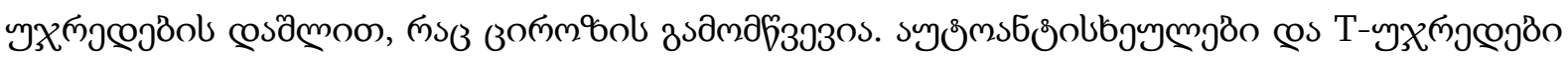

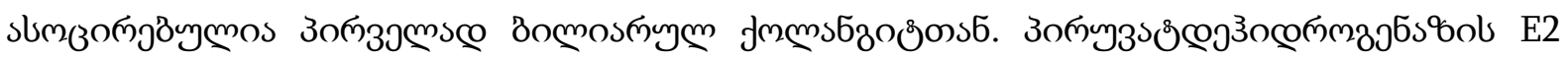

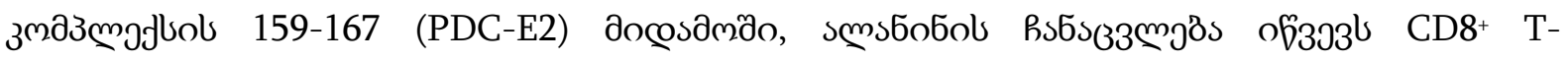

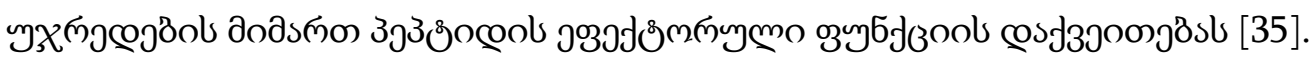

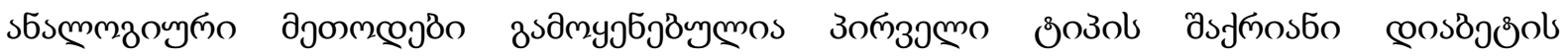

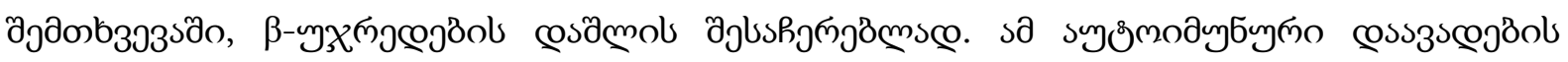

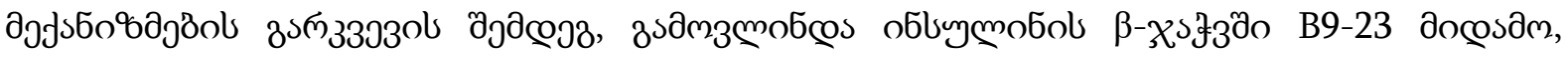

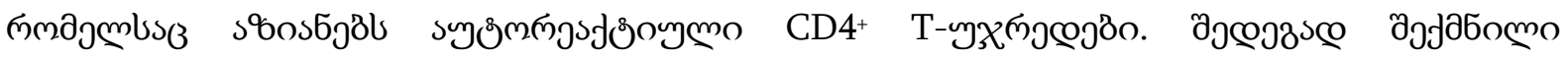

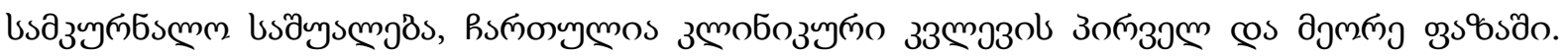
ю⿻а

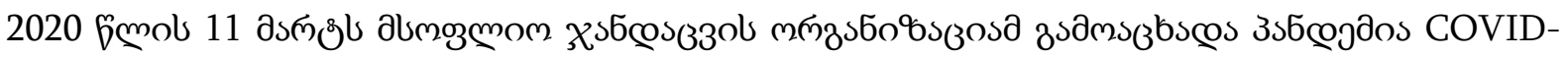

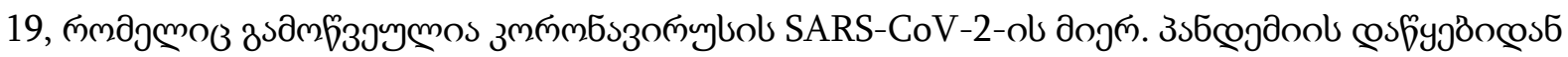

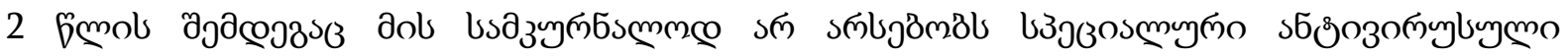

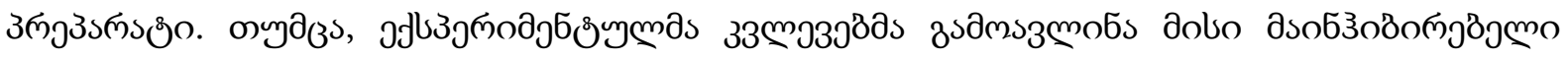

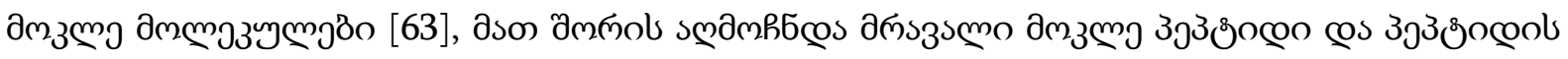

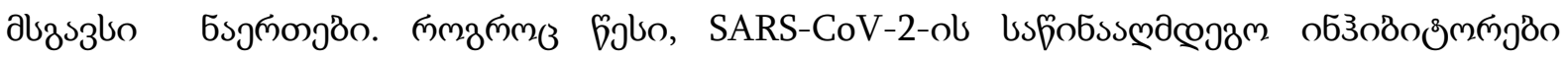

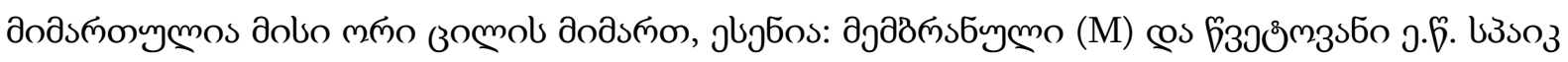

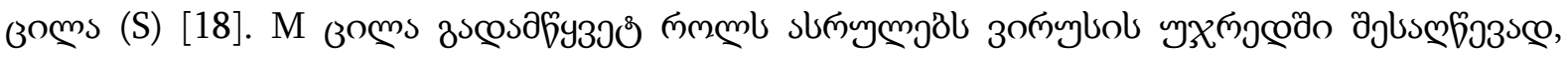

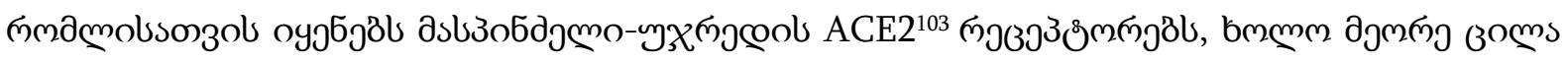

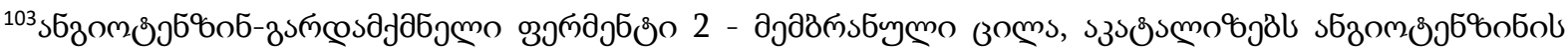

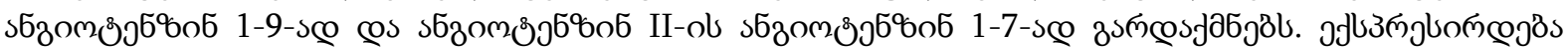

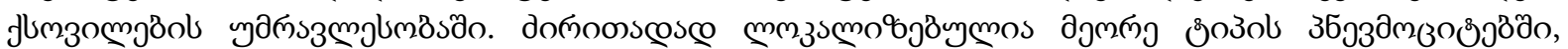

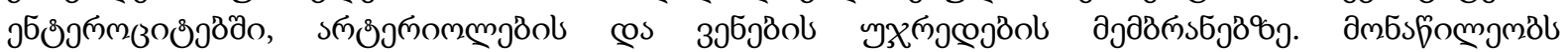

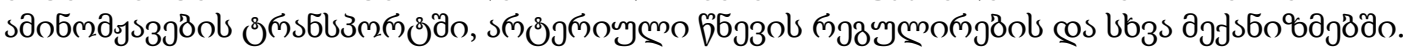




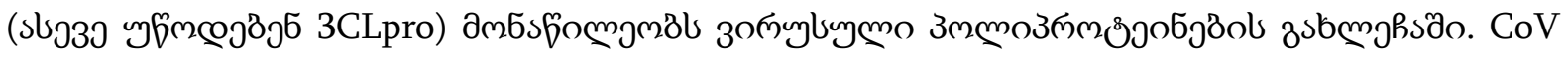

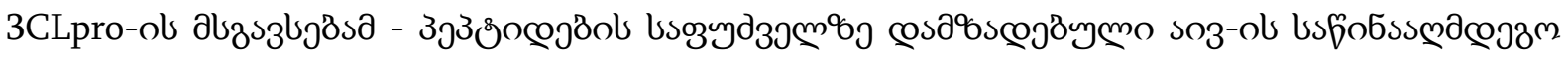

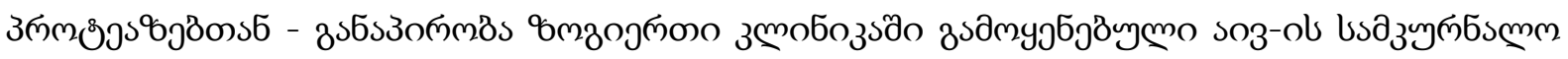

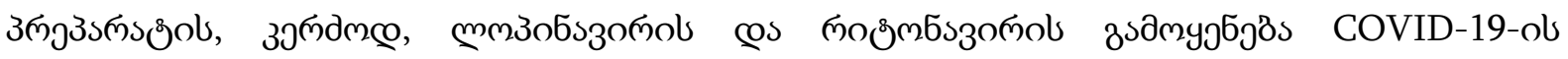

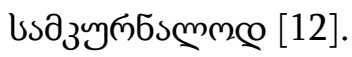

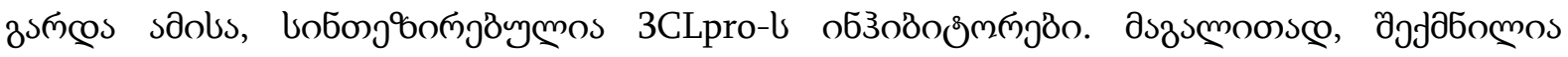

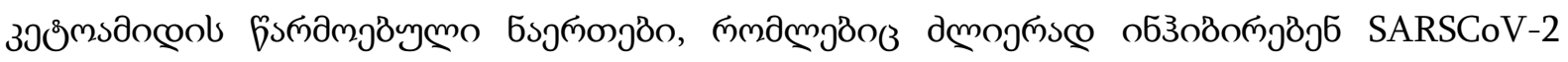
3CLpro-l [68].

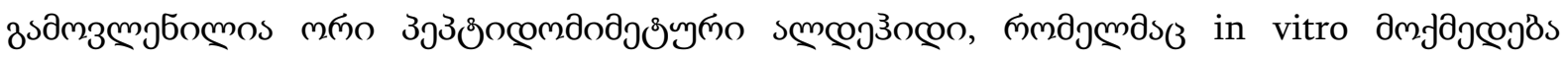
з дамззмобs SARS-CoV-2 3Clpro-৬ додзпо [17].

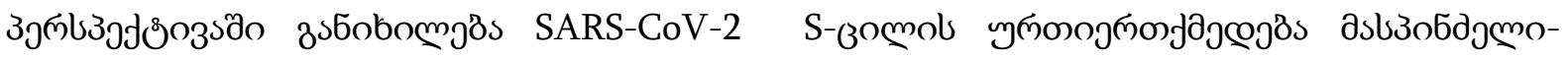

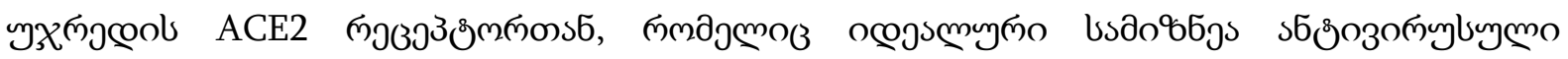

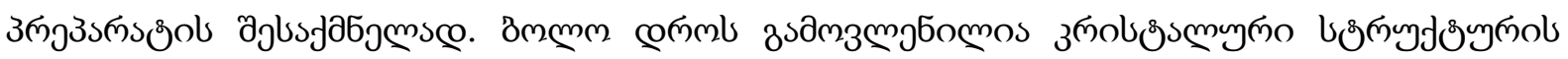

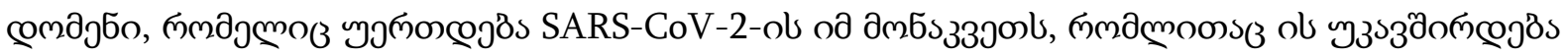

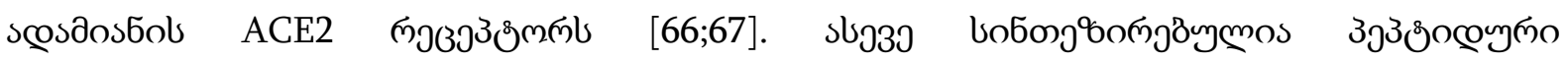

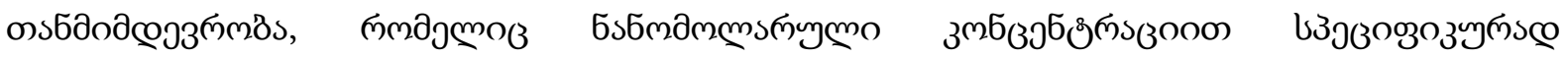

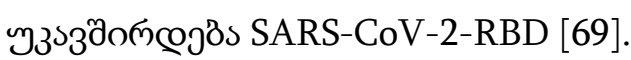

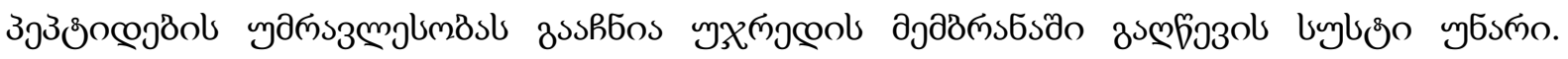

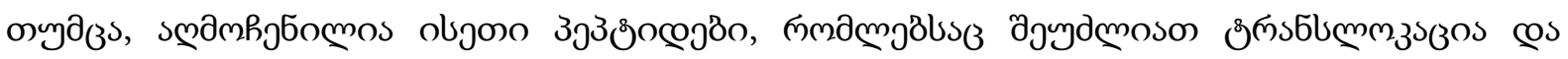

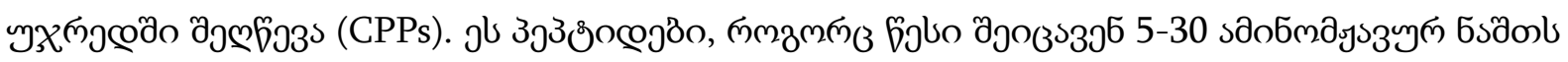

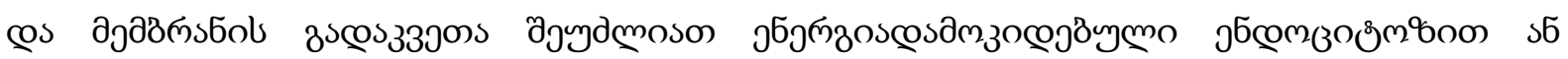

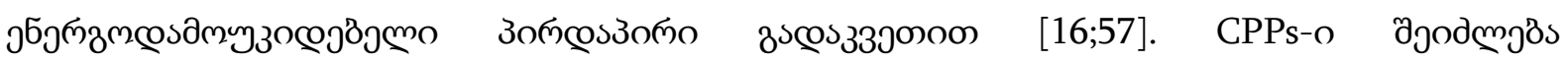

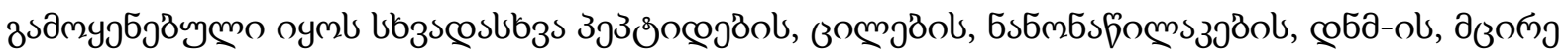

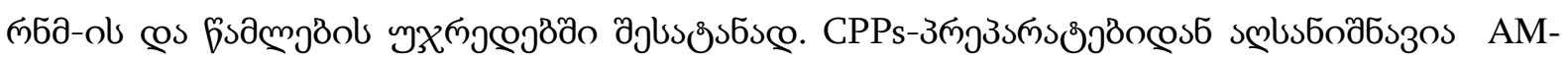

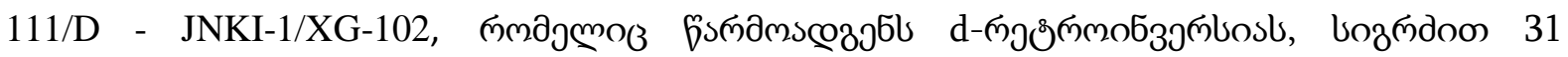

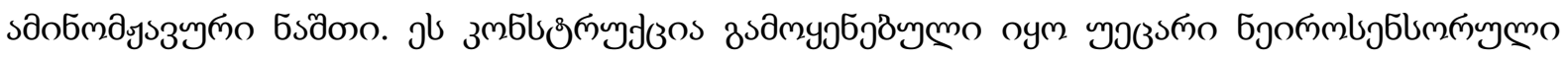

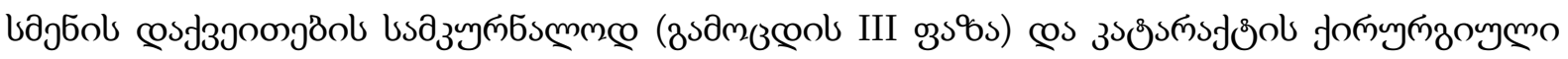

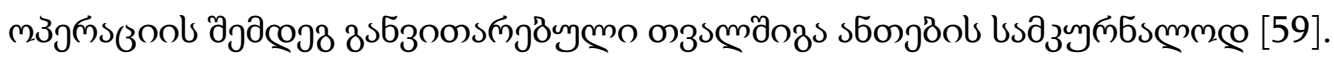

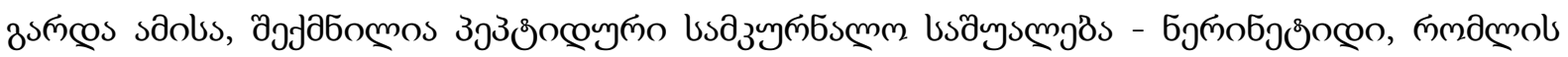

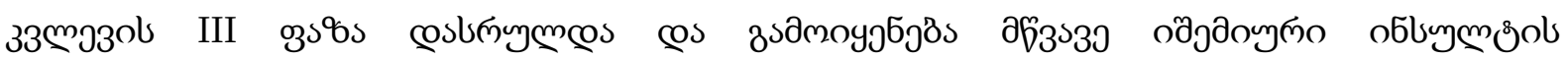

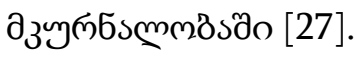

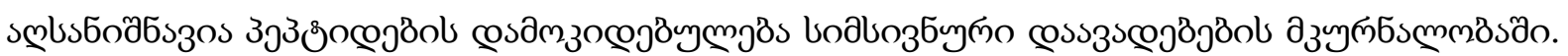

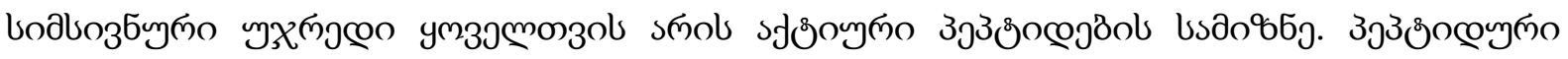

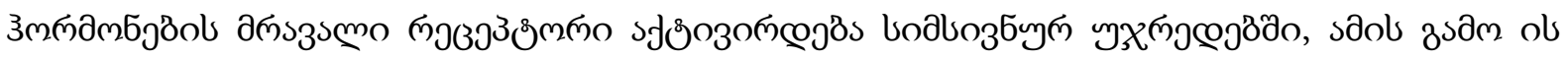

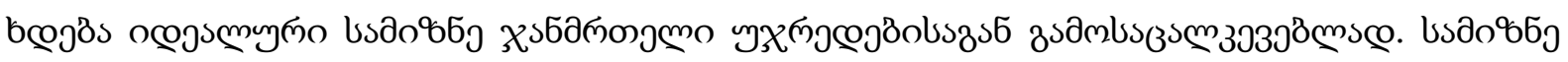

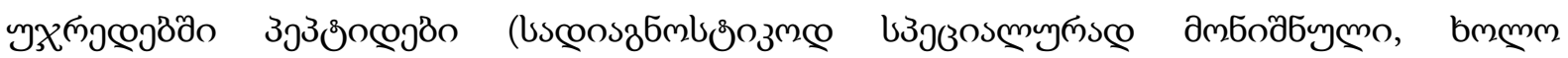

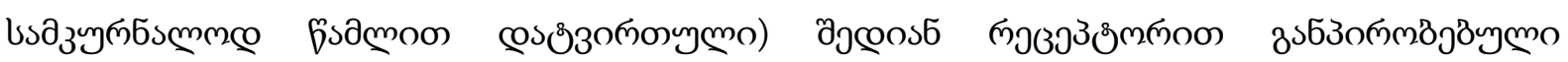

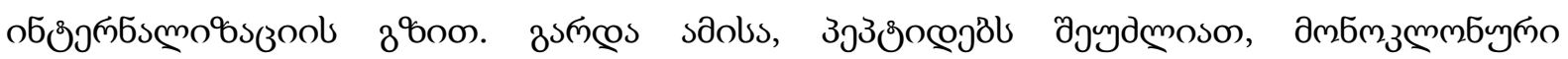

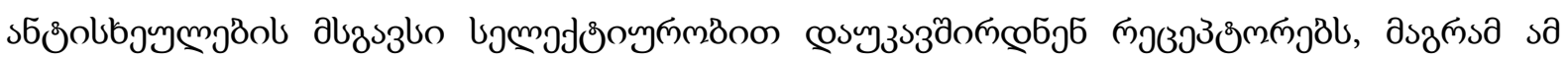

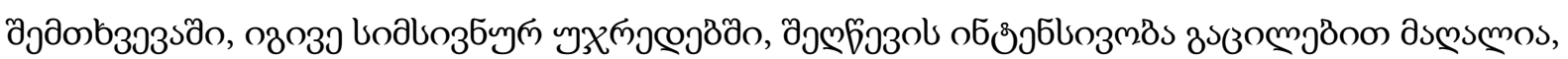

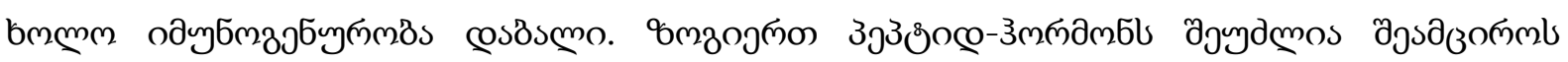

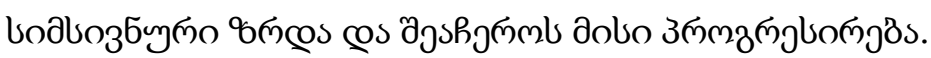




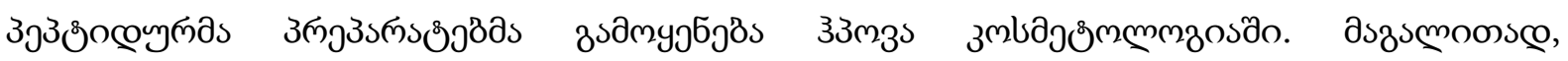

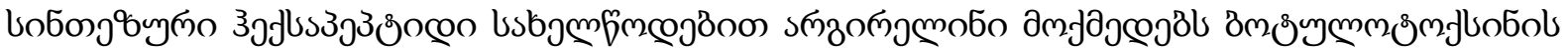

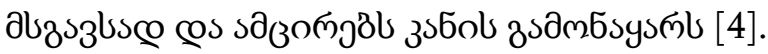

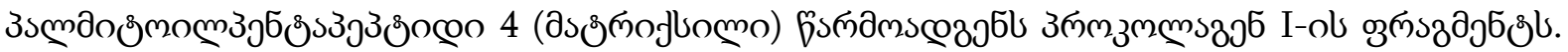

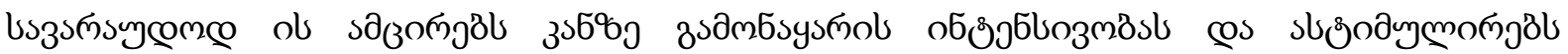

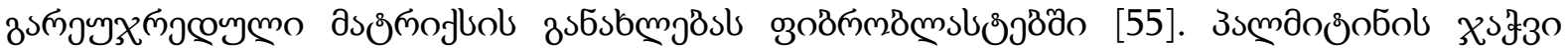

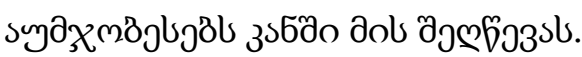

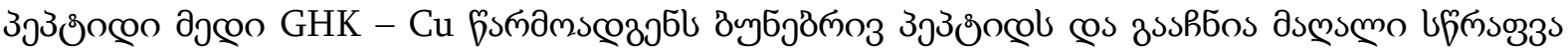

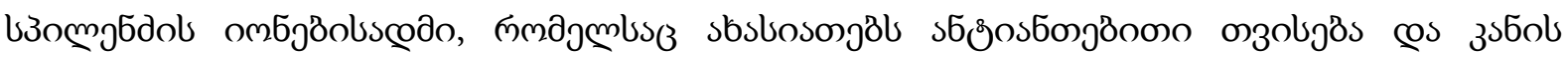

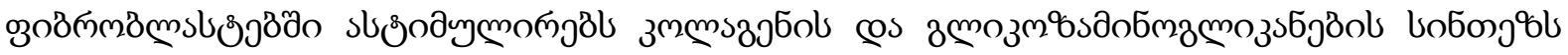
[51].

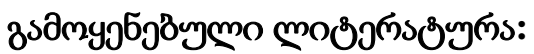

1. Agarwal, G.; Gabrani, R. Antiviral peptides: Identification and validation. Int. J. Pept. Res. Ther. 2020, 18, 1-20. [CrossRef][PubMed]

2. Ahnfelt- Roenne, J. et al. Transcellular stomachabsorption of a derivatized glucagon- like peptide-1receptor agonist. Sci. Transl. Med. 10, eaar7047(2018).

3. Biermasz, N. R. New medical therapies on the horizon:oral octreotide. Pituitary 20, 149-153 (2017).

4. Blanes- Mira, C. et al. A synthetic hexapeptide(Argireline) with antiwrinkle activity. Int. J. Cosmet. Sci.24, 303-310 (2002).

5. Bojarska, J.; Maniukiewicz,W.; Sieron, L.; Fruzinski, A.; Kopczacki, P.;Walczynski, K.; Remko, M. Novel pseudopolymorph of theactive metabolite of perindopril. Acta Cryst. C 2012, 68, o341-o343. [CrossRef]

6. Bojarska, J.; Maniukiewicz,W.; Sieron, L.; Kopczacki, P.;Walczynski, K.; Remko, M. Perindoprilat monohydrate. Acta Cryst. C2012, 68, o443-o446. [CrossRef]

7. Bojarska, J.; Maniukiewicz,W.; Fruzi'nski, L.; Sieron, L.; Remko, M. Captopril and its dimer captopril disulfide: Comparative structuraland conformational studies. Acta Cryst. C 2015, 71, 199-203.CrossRef]

8. Bojarska, J.; Maniukiewicz, W.; Główka, M.L.; Siero'n, L.; Remko, M. Crystal structure of perindopril cyclization product. J. Chil.Chem. Soc. 2013, 58, 1530-1532. [CrossRef]

9. Bojarska, J.; Maniukiewicz, W.; Sieron, L.; Remko, M. An orthorhombic polymorph of a cyclization product of perindopril.Acta Cryst. C 2013, 69, 630-633. [CrossRef] [PubMed]

10. Bojarska, J.; Remko, M.; Wojciechowski, J.; Madura, I.; Kaczmarek, K.; Zabrocki, J.; Zimecki, M.; Wolf, W. M. Cyclic tetrapeptidesas promising scaffold for innovative therapeutic agents: Synthesis, crystallographic, biological and in silico studies. Zeitschrift furKristallographie. 2020, 40.

11. Borel, J. F., Feurer, C., Gubler, H. U. \& Staehelin, H. Biological effects of cyclosporin A: a newantilymphocytic agent. Agents Actions 6, 468-475(1976).

12. Cao, B.;Wang, Y.;Wen, D.; Liu,W.;Wang, J.; Fan, G.; Ruan, L.; Song, B.; Cai, Y.;Wei, M.; et al. A trial of lopinavir-ritonavir in adults hospitalized with severe Covid-19. N. Engl. J. Med. 2020, 382, 1787-1799. [CrossRef].

13. Caputi S., Trubiani O., Sinjari B., Trofimova S., Diomede F., Linkova N., Diatlova A., Khavinson V. Eff ect of short peptides on neuronal diff erentiation of stem cells. Int. J. Immunopathol.Pharmacol. 2019;33:1-12. 
14. Ceafalan L.C., Enciuab A.-M., Fertig T.E., Popescu B.O., GherghiceanuM., Hinescu M.E., et al. Heterocellular molecular contacts inthe mammalian stem cell niche. Eur. J. Cell Biol. 2018;97(6):442-461.

15. Chan, K.H.; Xue, B.; Robinson, R.C.; Hauser, C.A.E. Systematic moiety variations of ultrashort peptides produce profound effectson self-assembly, nanostructure formation, hydrogelation, and phase transition. Sci. Rep. 2017, 7, 12897-12908. [CrossRef]

16. Copolovici, D. M., Langel, K., Eriste, E. \& Langel, U.Cell- penetrating peptides: design, synthesis, and applications. ACS Nano 8, 1972-1994 (2014).

17. Dai,W.H.; Zhang, B.; Jiang, X.M.; Su, X.H.; Li, L.; Zhao, Y.; Xie, X.; Jin, Z.M.; Peng, J.J.; Liu, F.J.; et al. tructure-based design of antiviral drug candidates targeting the SARS-CoV-2 main protease. Science 2020, 368, 1331-1335. [CrossRef]

18. Domling, A.; Gao, L. Chemistry and Biology of SARS-CoV-2. Chem 2020, 6, 1283-1295. [CrossRef] [PubMed]

19. Du Vigneaud, V., Winestock, G., Murti, V. V.,Hope, D. B. \& Kimbrough, R. D. Jr. Synthesis of 1-beta- mercantopropionic acid oxytocin (desaminooxytocin), a highly potent analogue of oxytocin. J. Biol.Chem. 235, PC64-PC66 (1960).

20. Eldor, R., Arbit, E., Corcos, A. \& Kidron, M. Glucosereducingeffect of the ORMD-0801 oral insulinpreparation in patients with uncontrolled type 1diabetes: a pilot study. PLoS ONE 8, e59524 (2013).

21. Feni, L.; Jutten, L.; Parente, S.; Piarulli, U.; Neundorf, I.; Dia, D. Cell-penetrating peptides containing 2,5-DKP scaffolds as shuttlesfor anti-cancer drugs: Conformational studies and biological activities. Chem. Commun. 2020, 56, 5685-5688. [CrossRef]

22. Fosgerau, K. \& Hoffmann, T. Peptide therapeutics: current status and future directions. Drug Discov.Today 20, 122-128 (2014).

23. Granhall, C., Soendergaard, F. L., Thomsen, M. \& Anderson, T. W. Pharmacokinetics, safety and tolerability of oral semaglutide in subjects with renal impairment. Clin. harmacokinet. 57, 1571-1580(2018).

24. Haas, A. V. \& LeBoff, M. S. Osteoanabolic agents forosteoporosis. J. Endocr. Soc. 2, $922-$ $932(2018)$.

25. Haggag, Y.A.; Donia, A.A.; Osman, M.A.; El-Gizawy, S.A. Peptides as drug candidates: Limitations and recent development perspectives. Biomed. J. Sci. Tech. Res. 2018, 8, 66596663. [CrossRef]

26. Henninot, A.; Collins, J.C.; Nuss, J.M. The current state of peptide drug discovey: Back to the future? J. Med. Chem. 2018,61, 1382-1414. [CrossRef]

27. Hill, M. D. et al. Efficacy and safety of nerinetide forthe treatment of acute ischaemic stroke (ESCAPE- NA1):a multicentre, double- blind, randomised controlledtrial. Lancet 395, 878887 (2020).

28. Hope, D. B., Murti, V. V. S. \& du Vigneaud, V. A highlypotent analog of oxytocin, deaminooxytocin. J. Biol.Chem. 237, 1563-1566 (1962).

29. Infoholic Research LLP. Global Human Insulin Market2018-2024. Research and Markets, ID: 4470733(2018).

30. Janecka, A., Zubrzycka, M. \& Janecki, T. Somatostatinanalogs. J. Pept. Res. 58, 91-107 (2001)

31. Ji, W.; Zhang, C.; Ji, H. Purification, identification and molecular mechanism of two dipeptidyl peptidase IV (DPP-IV) inhibitorypeptides from Antarctic krill (Euphausia superba) protein hydrolysate. J. Chromatogr. B Anal. Technol. Biomed. Life Sci. 2017,1064, 56-61. [CrossRef].

32. Katsara, M.; Minigo, G.; Plebanski, M.; Apostolopoulos, V. The good, the bad and the ugly: 
How altered peptide ligands modulate immunity. Expert Opin. Biol. Ther. 2008, 8, $1873-$ 1884. [CrossRef]

33. Kim, E. S. \& Keating, G. M. Recombinant human parathyroid hormone (1-84): a review in hypoparathyroidism. Drugs 75, 1293-1303 2015).

34. Kim, H.J.; Antel, J.P.; Duquette, P.; Alleva, D.G.; Conlon, P.J.; Bar-Or, A. Persistence of immune responses to altered and nativemyelin antigens in patients with multiple sclerosis treated with altered peptide ligand. Clin. Immunol. 2002, 104, 105-114.[CrossRef]

35. Kita, H.; Matsumura, S.; He, X.S.; Ansari, A.A.; Lian, Z.X.; Van de Water, J.; Coppel, R.L.; Kaplan, M.M.; Gershwin, M.E. Analysis of TCR antagonism and molecular mimicry of an HLA-A0201-restricted CTL epitope in primary biliary cirrhosis.Hepatology 2002, 36, 918926. [CrossRef] [PubMed]

36. Kruszynski, M. et al. [1-( $\beta$ - mercapto- $\beta, \beta$-cyclopentamethylenepropionic acid),2-(Omethyl)tyrosine $]$ arginine-vasopressin and $[1-(\beta$-mercapto- $\beta, \beta$-cyclopentamethylenepropionic acid)] argininevasopressin,two highly potent antagonists of thevasopressor response to arginine- vasopressin. J. Med.Chem. 23, 364-368 (1980).

37. Kyncl, J. \& Rudinger, J. Excretion of antidiuretic activityin the urine of cats and rats after administration of thesynthetic hormonogen, Na-glycyl-glycyl- glycyl-[8-lysine]-vasopressin (triglycylvasopressin). J. Endocrinol. 48,157-165 (1970).

38. Lau, J. L. \& Dunn, M. K. Therapeutic peptides:historical perspectives, current development trends, and future directions. Bioorg. Med. Chem. 26,2700-2707 (2018).

39. Lee, A.C.; Harris, J.L.; Khanna, K.K.; Hong, J.H. A Comprehensive Review on Current Advances in Peptide Drug Development and Design. Int. J. Mol. Sci. 2019, 20, 2383-2404. [CrossRef]

40. Levin, A.; Hakala, T.; Schnaider, L.; Lopes Bernardes, G.; Gazit, E.; Knowles, T. Biomimetic peptide self-assembly for functional materials. Nat. Rev. Chem. 2020, 4, 615-634. [CrossRef]

41. Lipinski, C. A., Lombardo, F., Dominy, B. W. \&Feeney, P. J. Experimental and computationalapproaches to estimate solubility and permeability indrug discovery and development settings. Adv. DrugDeliv. Rev. 46, 3-26 (2001).

42. Magzoub, M. Combating proteins with proteins: Engineering cell-penetrating peptide antagonists of amyloid-beta aggtregation and associated neurotoxicity. DNA Cell Biol. 2020, 39, 920-925. [CrossRef]

43. Makam, P.; Gazit, E. Minimalistic peptide supramolecular co-assembly: Expanding the conformational space for nanotechnology. Chem. Soc. Rev. 2018, 47, 3406-3420. [CrossRef]

44. Manning, M., Balaspiri, L., Acosta, M. \& Sawyer, W. H.Solid phase synthesis of [1deamino,4-valine]-8-D- arginine-vasopressin (DVDAVP), a highly potentand specific antidiuretic agent possessing protractedeffects. J. Med. Chem. 16, 975-978 (1973).

45. Manning, M. et al. Oxytocin and vasopressin agonistsand antagonists as research tools and potentialtherapeutics. J. Neuroendocrinol. 24, 609-628(2012).

46. Manning, M. et al. Peptide and non- peptide agonistsand antagonists for the vasopressin and oxytocin V1a,V1b, V2 and OT receptors: research tools andpotential therapeutic agents. Prog. Brain Res. 170,473-512 (2008).

47. Martins, M.B.; Carvalho, I. Diketopiperazines: Biological activity and synthesis. Tetrahedron 2007, 63, 9923-9932. [CrossRef]

48. Melin, P., Trojnar, J., Johansson, B., Vilhardt, H. \&Aakerlund, M. Synthetic antagonists of the myometrialresponse to vasopressin and oxytocin. J. Endocrinol.111, 125-131 (1986).

49. Meraldi, J. P., Hruby, V. J. \& Brewster, A. I. R.Relative conformational rigidity in oxytocin and[1-penicillamine]oxytocin: a proposal for the relationof conformational flexibility to peptide hormoneagonism and antagonism. Proc. Natl Acad. Sci. USA74, 1373-1377 (1977). 
50. Nygren, P.A. Alternative binding proteins: Affibody binding proteins developed from a small three-helix bundle scaffold. FEBS J.2008, 275, 2668-2676. [CrossRef]

51. Pickart, L. The human tri- peptide glycine- histidine-lysineand tissue remodeling. J. Biomater. Sci. Polym. Ed. 19,969-988 (2008).

52. Remko, M.; Bojarska, J.; Jezko, J.; Sieron, L.; Olczak, A.; Maniukiewicz, W. Crystal and molecular structure of perindoprilerbumine salt. J. Mol. Struct. 2011, 997, 103-109. [CrossRef]

53. Remko, M.; Bojarska, J.; Jezko, L.; Olczak, A.; Maniukiewicz, W. Molecular structure of antihypertensive drug perindopril,its active metabolite perindoprilat and impurity F. J. Mol. Struct. 2013, 1036, 292-297. [CrossRef]

54. Remko, M.; Bojarska, J.; Remkova, A.; Maniukiewicz, W. Molecular structure and acidity of captopril, zofenopril and theirmetabolites captopril disulfide and zofenoprilat. Comput. Theor. Chem. 2015, 1062, 50-55. [CrossRef]

55. Robinson, L. R. et al. Topical palmitoyl pentapeptideprovides improvement in photoaged human facial skin.Int. J. Cosmet. Sci. 27, 155-160 (2005).

56. Saehelin, H. F. The history of cyclosporin A(Sandimmune) revisited: another point of view.Experientia 52, 5-13 (1996).

57. Shi, N.-Q., Qi, X.-R., Xiang, B. \& Zhang, Y. A surveyon “Trojan Horse” peptides: opportunities, issues andcontrolled entry to "Troy". J. Control. Rel. 194, 53-70(2014).

58. Sinjari B., Diomede F., Khavinson V., Mironova E., Linkova N.,Trofi mova S., Trubiani O., Caputi S. Short peptides protect oral stemcells from ageing. Stem. Cell. Rev. Reports. 2019;1-8. doi: 10.1007/s12015-019-09921-3

59. Staecker, H. et al. Efficacy and safety of AM-111 in thetreatment of acute unilateral sudden deafness - adouble- blind, randomized, placebo- controlled phase 3study. Otol. Neurotol. 40, 584-594 (2019).

60. Subbarao, N.K.; Parente, R.A.; Szoka, F.C.; Nadasdi, L.; Pongracz, K. The pH-dependent bilayer destabilization by an amphipathicpeptide. Biochemistry 1987, 26, 2964-2972. [CrossRef] [PubMed]

61. Sun, S.J.; Liu, Y.C.; Weng, C.H.; Sun, S.W.; Li, F.; Li, H.; Zhu, H. Cyclic dipeptides mediating quorum sensing and their biologicaleffects in Hypsizygus Marmoreus. Biomolecules 2020, 10, 298-311. [CrossRef]

62. Vale, W., Brown, M., Rivier, C., Perrin, M. \& Rivier, J.Development and applications of analogs of LRF andsomatostatin. in Brain Peptides: A New Endocrinology,71-88 (Elsevier/North- Holland Biomedical Press,1979).

63. Walter, M.; Philotheou, A.; Bonnici, F.; Ziegler, A.G.; Jimenez, R.; Group, N.B.I.S. No effect of the altered peptide ligand NBI-6024 on beta-cell residual function and insulin needs in new-onset type 1 diabetes. Diabetes Care 2009, 32, 2036-2040. [CrossRef]

64. Wang, Y.; Wang, P.; Ma, H.; Zhu, W. Developments around the bioactive diketopiperazines: A patent review. Expert Opin.Ther. Patents. 2013, 32, 1415-1433. [CrossRef]

65. Warkentin, T. E. \& Koster, A. Bivalirudin: a review. Expert Opin. Pharmacother. 6, 13491371 (2005).

66. Wrapp, D.;Wang, N.; Corbett, K.S.; Goldsmith, J.A.; Hsieh, C.L.; Abiona, O.; Graham, B.S.; McLellan, J.S. Cryo-EM structure of the 2019-nCoV spike in the prefusion conformation. Science 2020, 367, 1260-1263. [CrossRef]

67. Yan, R.; Zhang, Y.; Li, Y.; Xia, L.; Guo, Y.; Zhou, Q. Structural basis for the recognition of the SARS-CoV-2 by full-length human ACE2. Science 2020, 367, 1444-1448. [CrossRef] [PubMed].

68. Zhang, L.; Lin, D.; Sun, X.; Curth, U.; Drosten, C.; Sauerhering, L.; Becker, S.; Rox, K.; 
Hilgenfeld, R. Crystal structure of SARS-CoV-2 main protease provides a basis for design of improved alpha-ketoamide inhibitors. Science 2020, 368, 409-412. [CrossRef]

69. Zhang, G.; Pomplun, S.; Loftis1, A.R.; Loas, A.; Pentelute, B.L. The first-in-class peptide binder to the SARS-CoV-2 spike protein. bioRxiv 2020. [CrossRef]

70. Zhao, K.; Xing, R.; Yan, X. Cyclic dipeptides: Biological activities and self-assembled materials. Pept. Sci. 2020, e24202. [CrossRef].

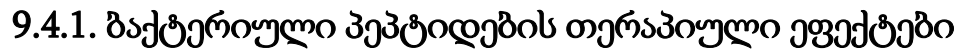

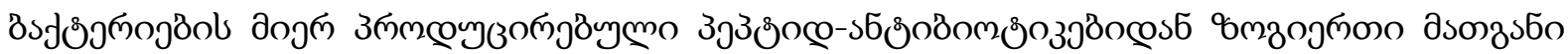

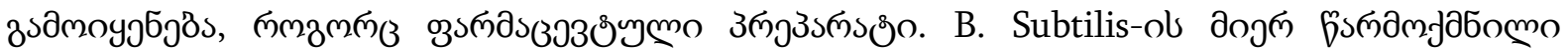

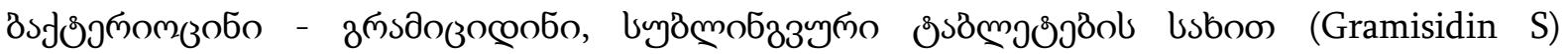

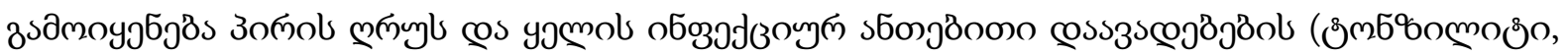

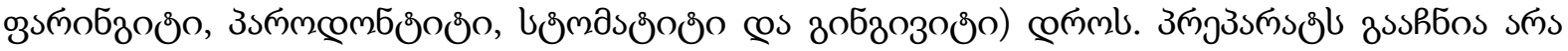

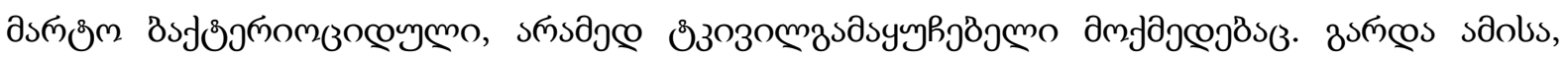

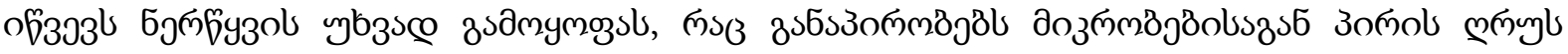

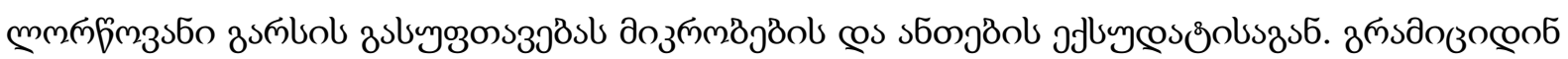

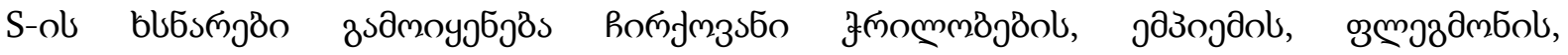

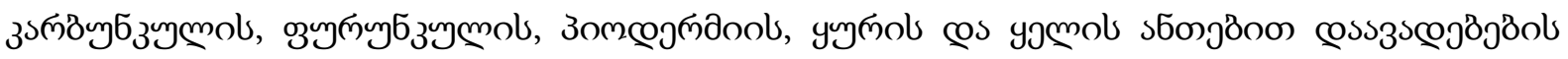

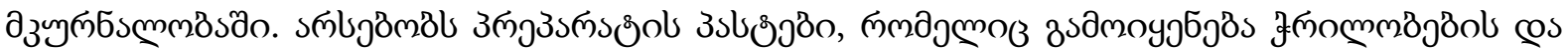

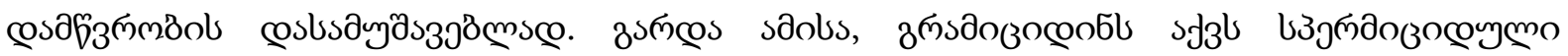

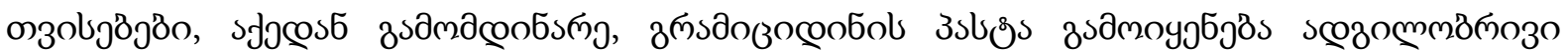

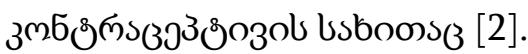

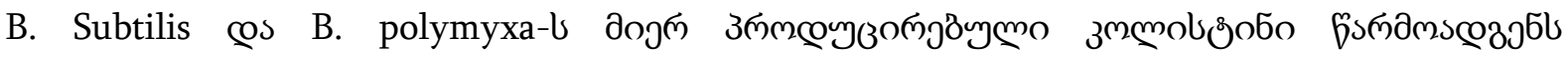

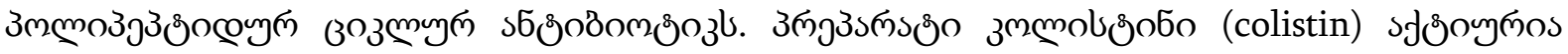
Pseudomonasaeruginosa, Haemophilus influenzae, Acinetobacterspp., Citrobacter spp., Enterobacter

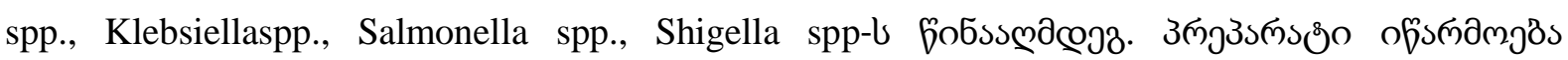

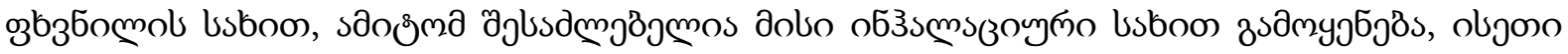

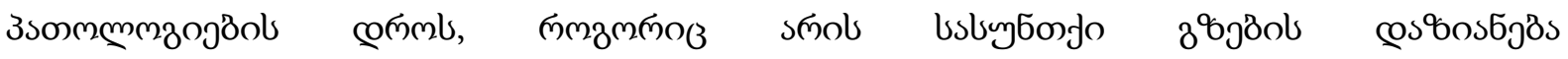

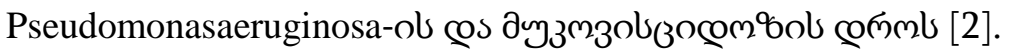

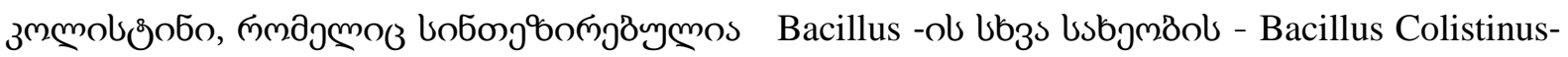

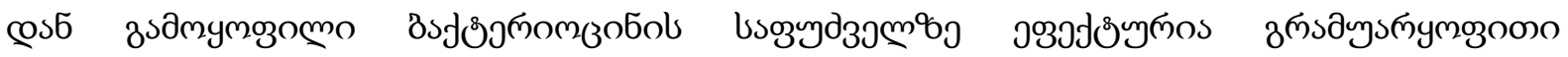

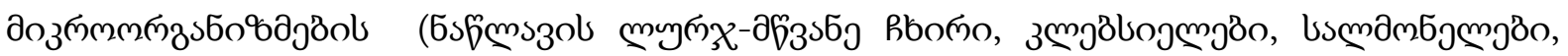

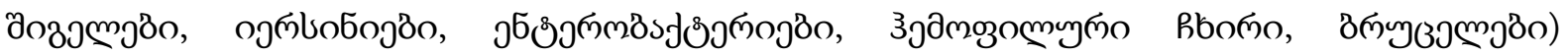

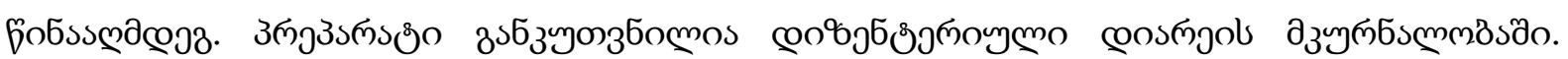

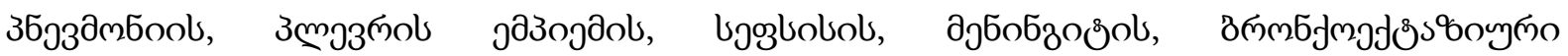

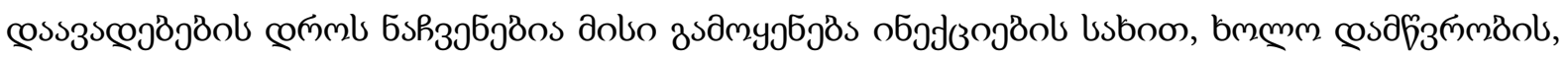

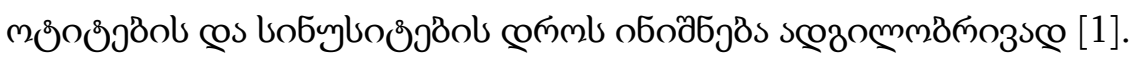

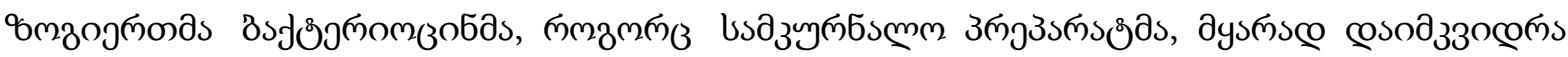

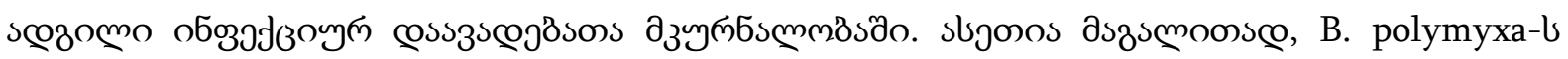

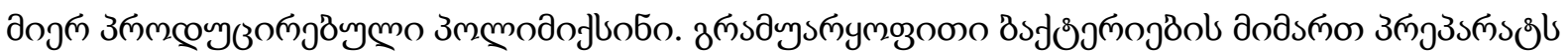

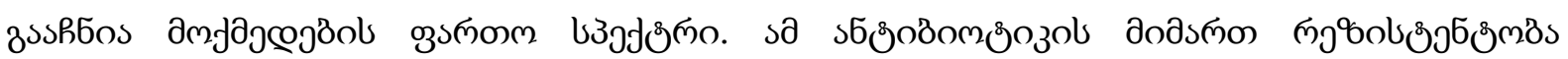




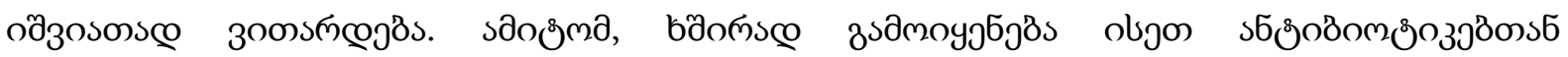

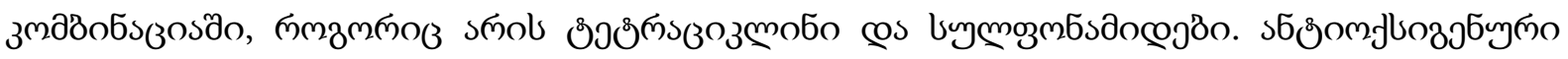

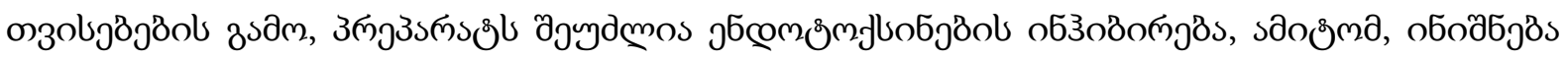

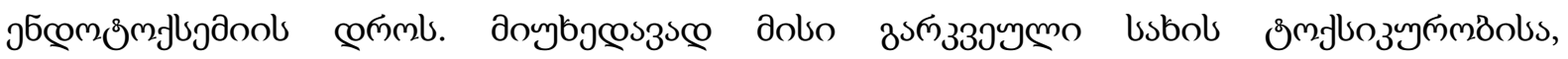

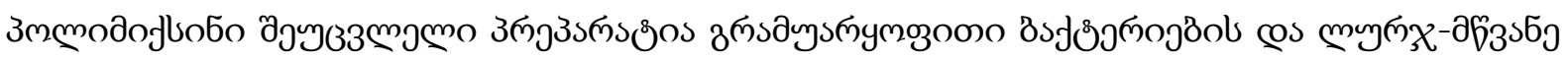

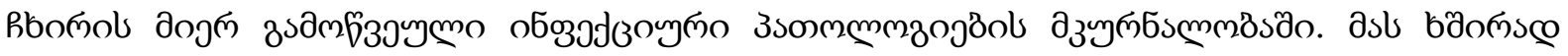

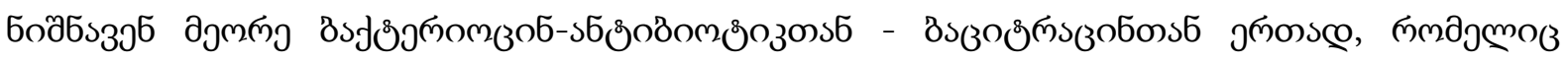

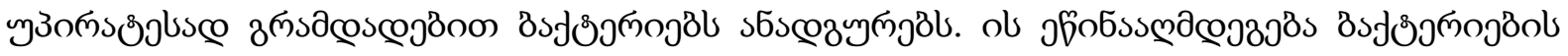

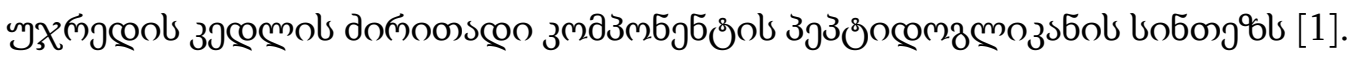

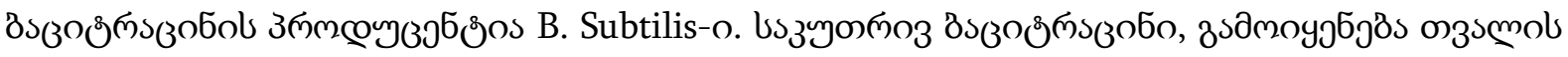

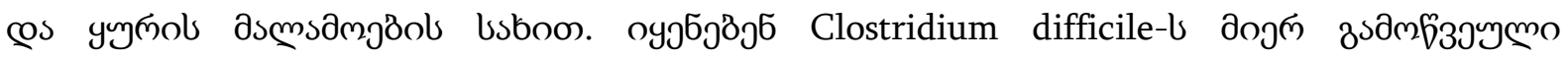

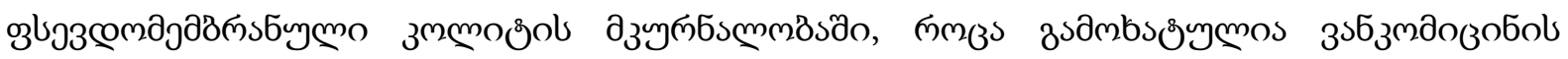

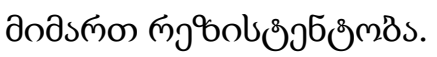

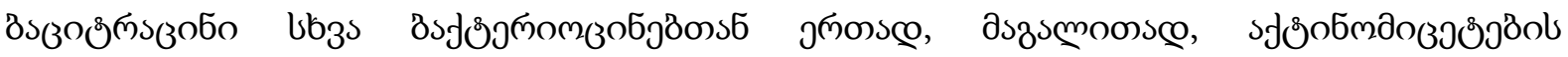

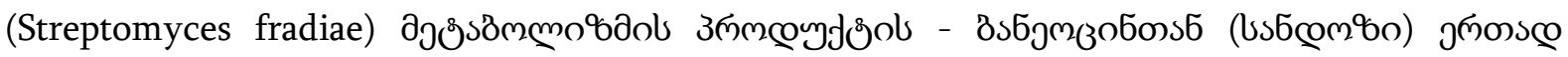

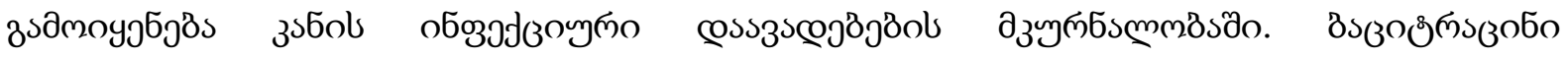

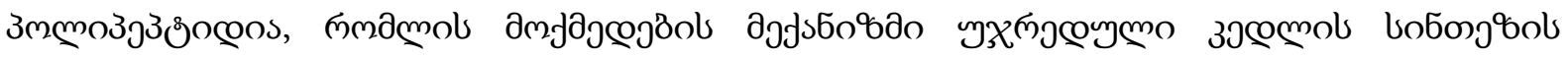

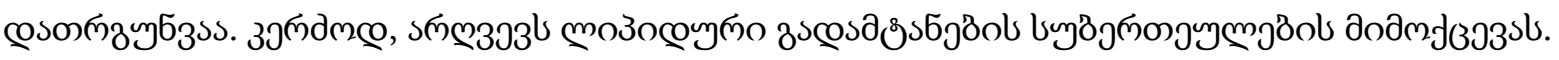

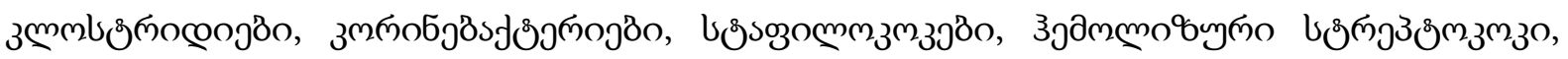

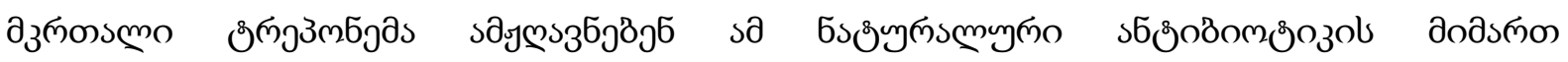

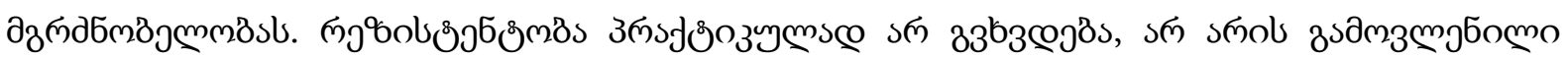

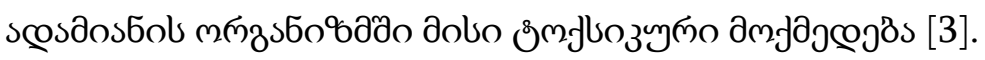

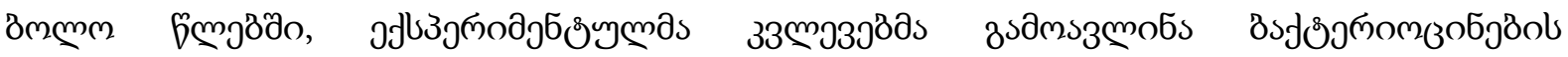

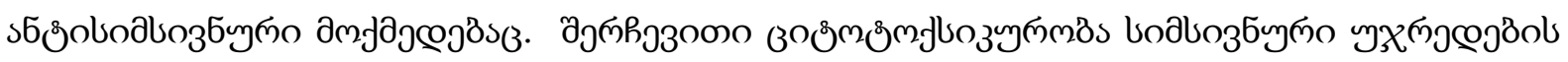

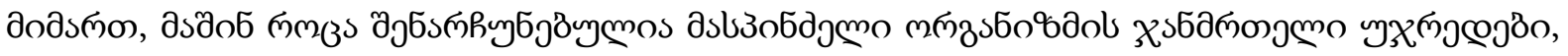

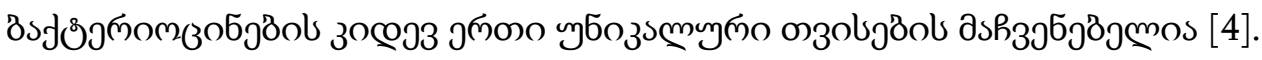

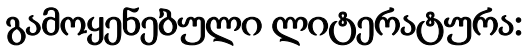

1. Marrec C., Hyronimus B., Bressollier P.,Verneuil B., Urdaci M.C., Appl Environ Microbiol.,2000, V. 66(12), pp. 5213-5220. doi: 10.1128/aem.66.12.5213-5220.2000. Available at: https://pubmed.ncbi.nlm.nih.gov/11097892/(Accessed:22.06.2020)

2. Robert L. Dorit, Sandra M., Royand M.A.The Bacteriocins: Current Knowledge and FutureProspects. Caister Academic Press. USA, 2016, p. 168.

3. Shih-Chun Yang, Chih-Hung Lin, Calvin T.Sung, Front Microbiol., V. 2014, V. 5, P. 241. Availableat: https://www.frontiersin.org/articles/10.3389/fmicb.2014.00241/full( Accessed: 20 June2020).

4. Vaindara P., Korpole S., Grover V., Appl Microbiol Biotechnol., 2018, V. 102(24), pp.10393 -10408 Available at: https://link.springer.com/article/10.1007/s00253-018-9420-8 (Accessed:15 May 2020). 


\section{вмmmonfas}

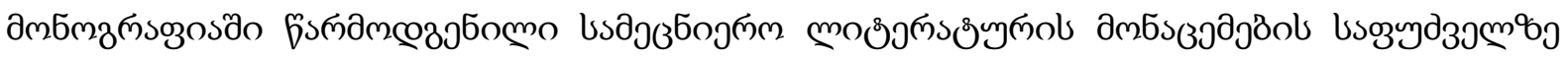

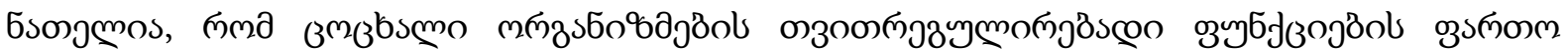

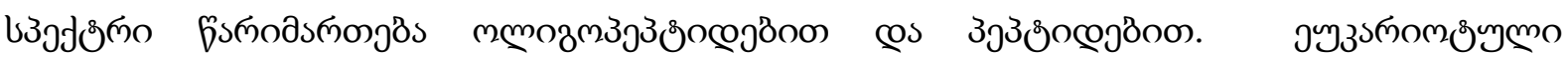

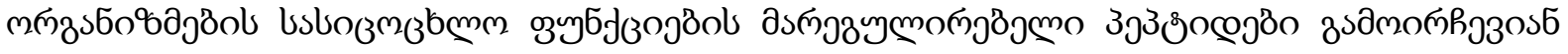

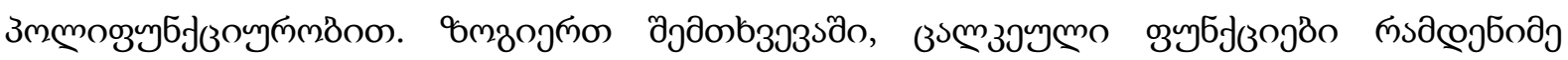

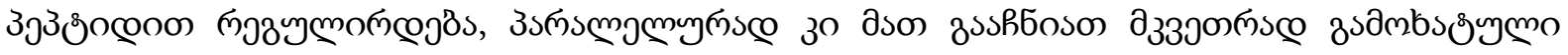

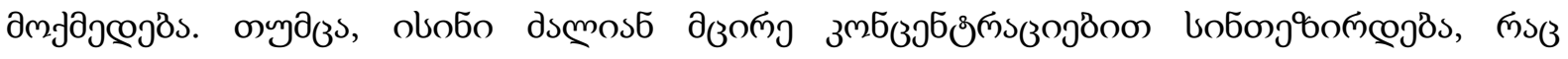

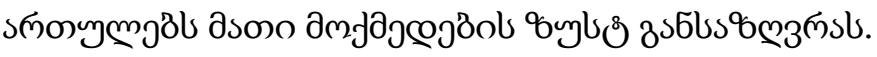

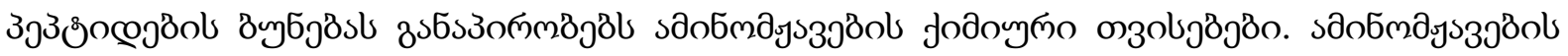

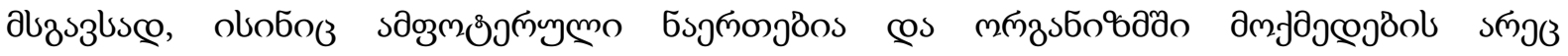

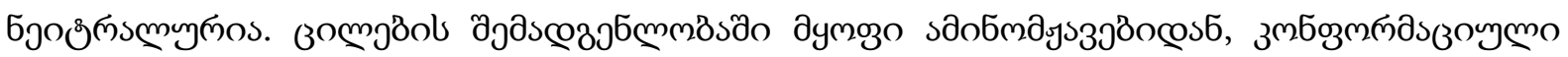

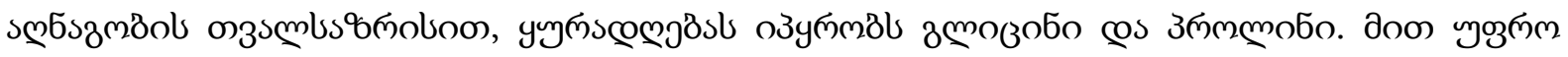

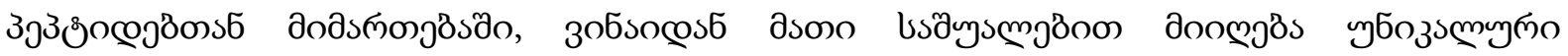

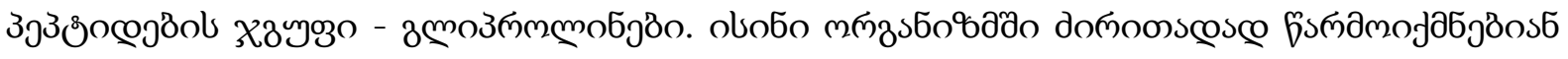

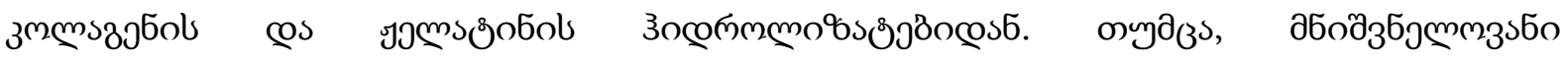

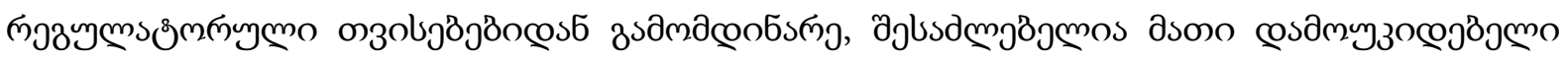

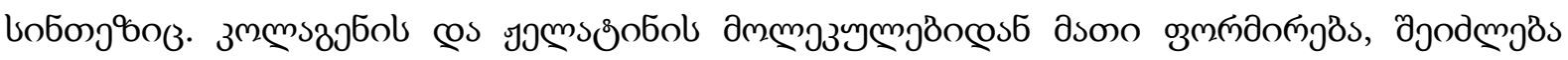

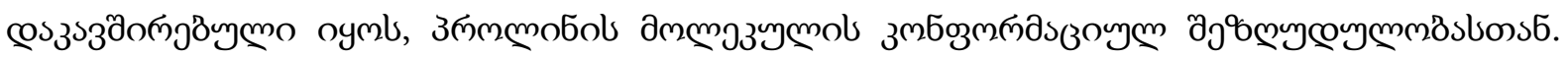

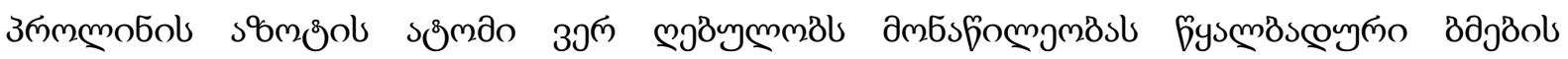

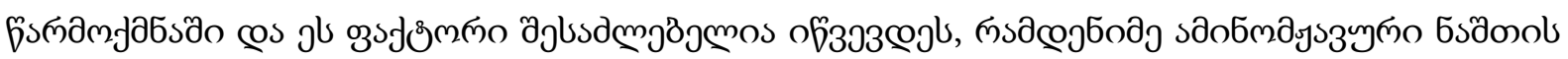

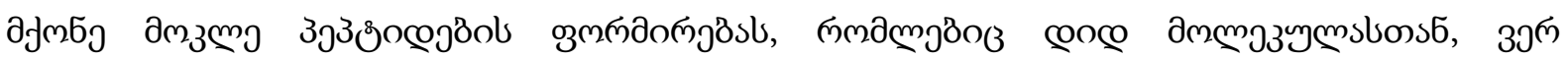

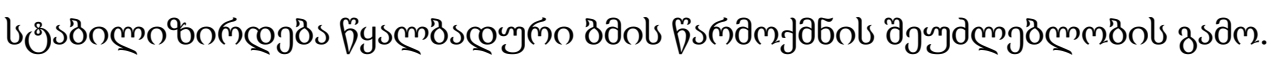

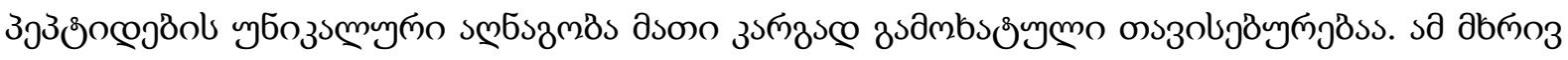

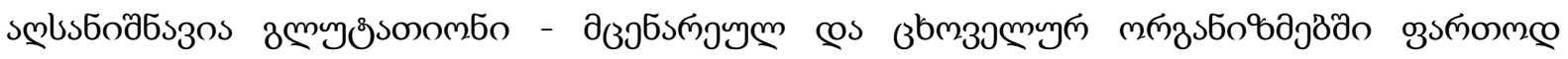

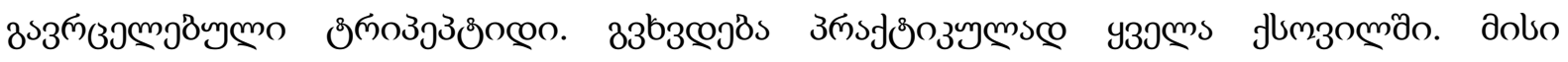

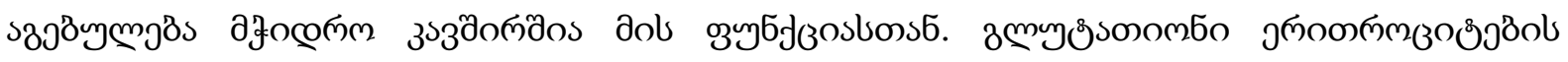

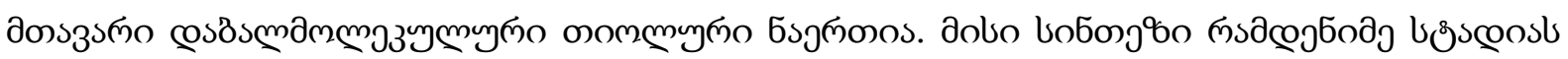

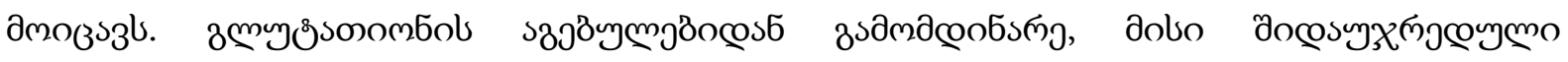

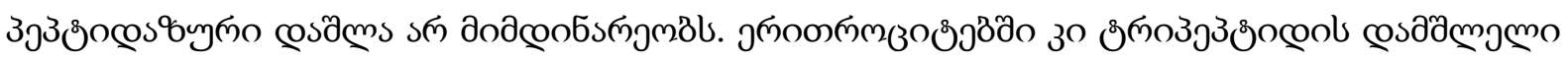

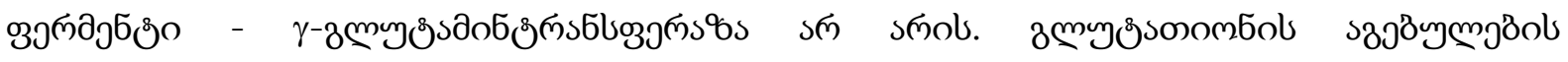

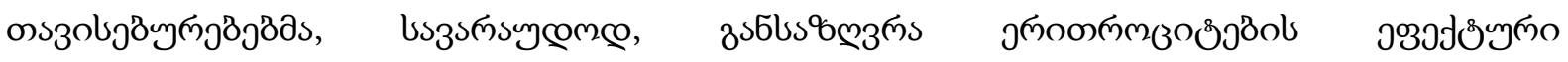

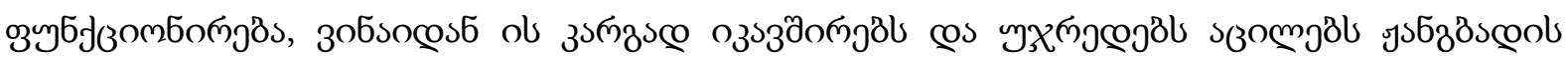

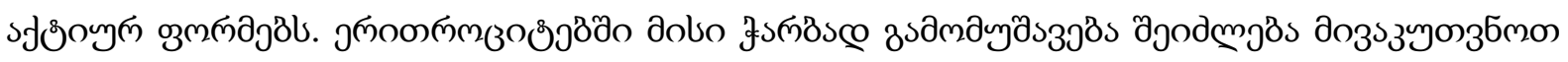

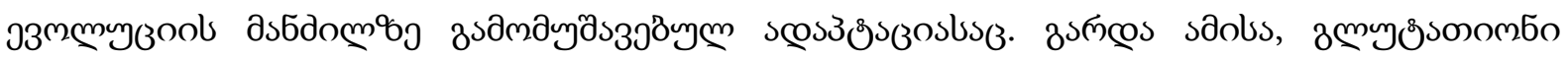

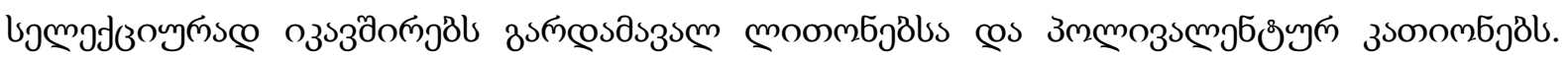

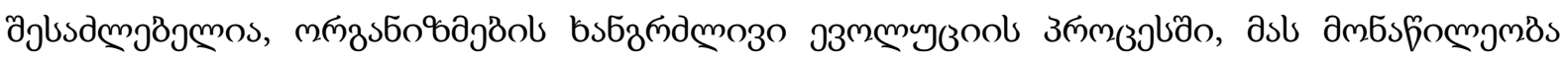

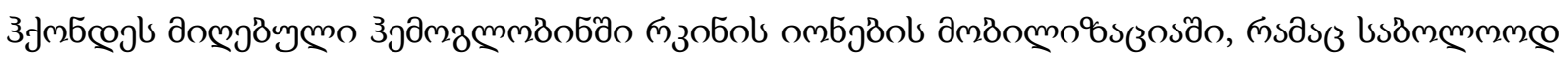

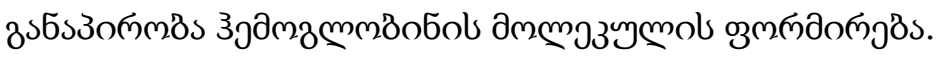




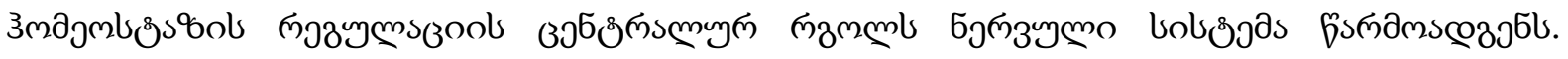

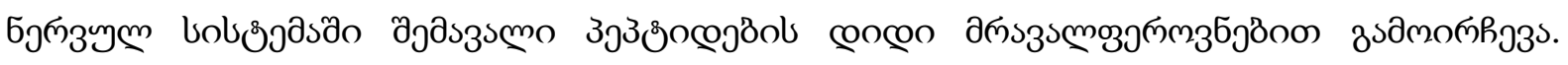

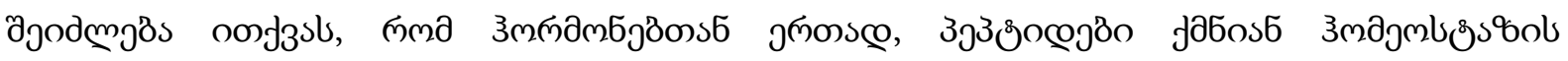

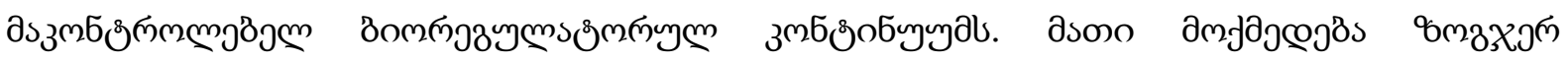

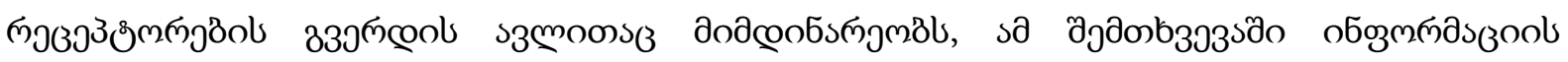

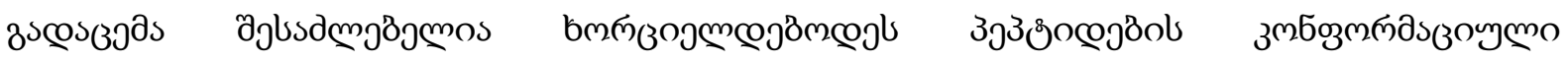

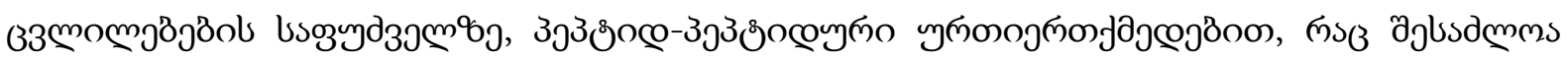

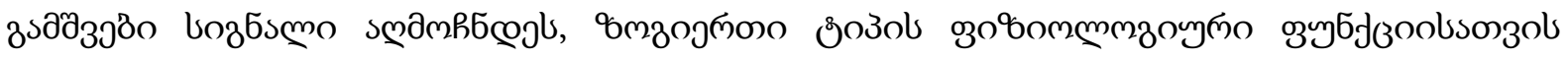

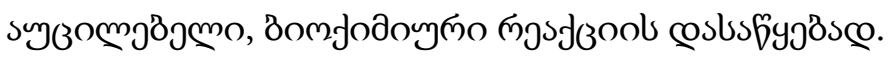

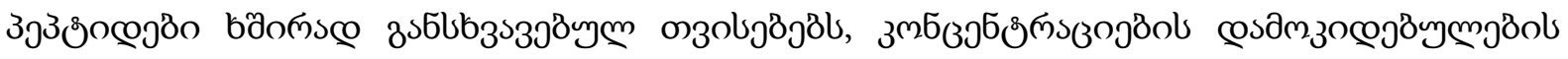

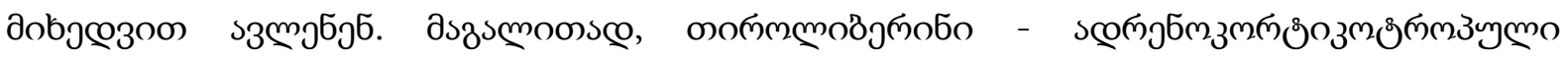

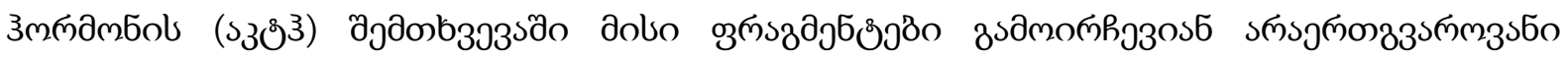

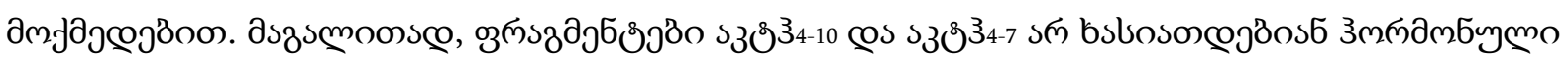

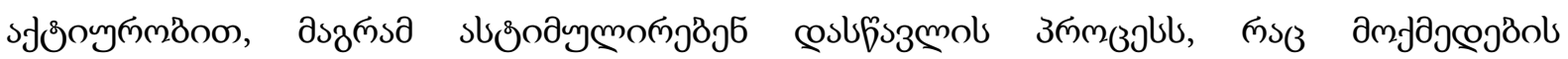

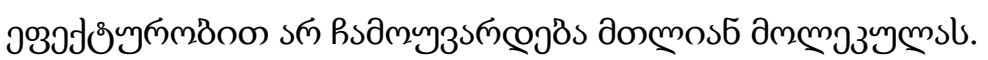

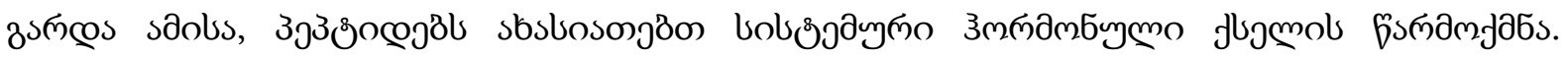

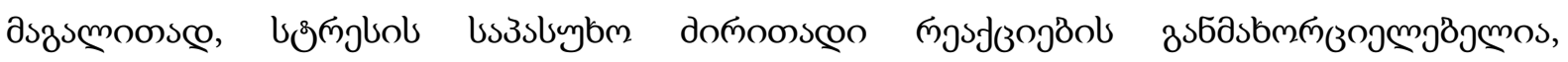

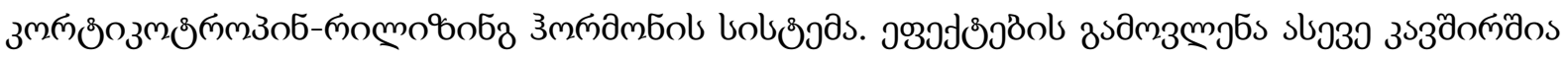

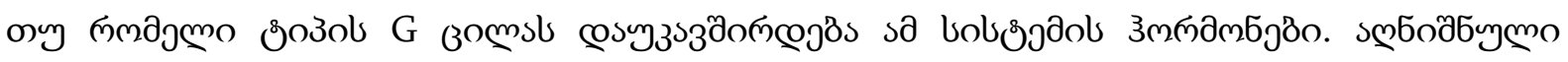

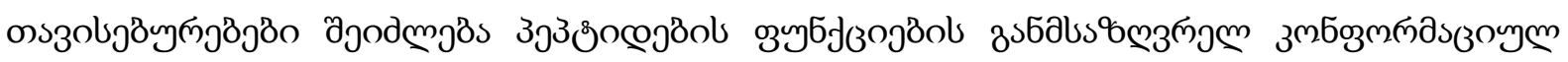

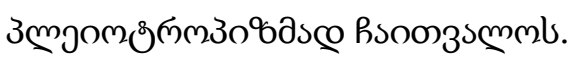

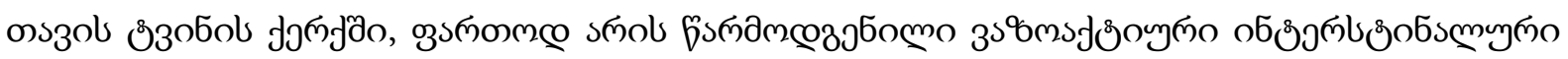

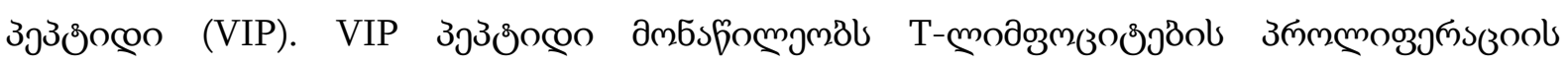

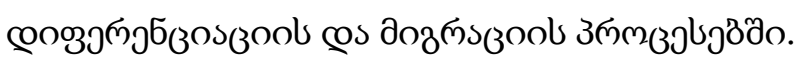

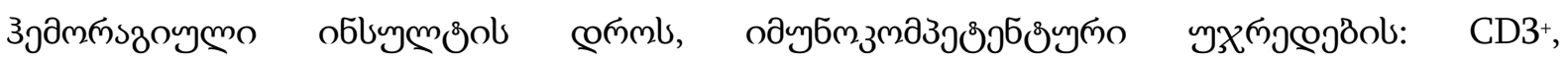
$\mathrm{CD}^{+}, \mathrm{CD}{ }^{+}, \mathrm{CD} 16+$

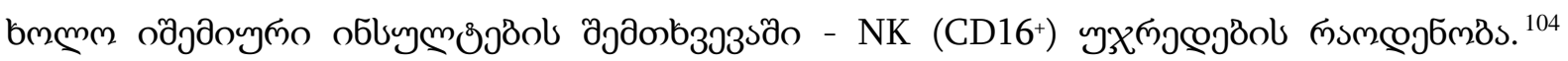

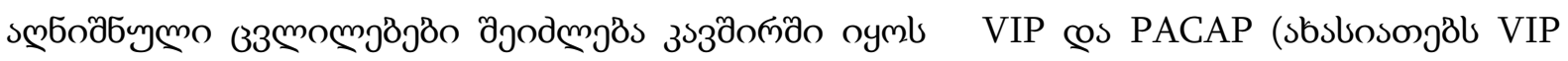

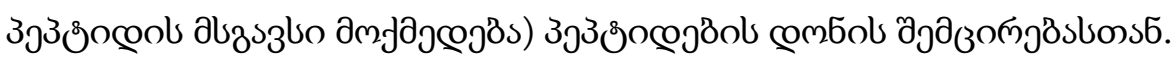

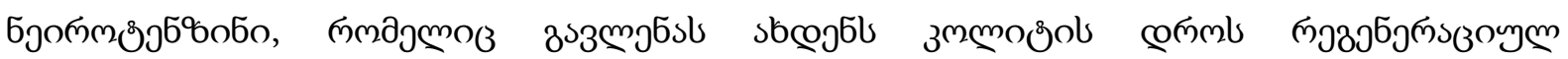

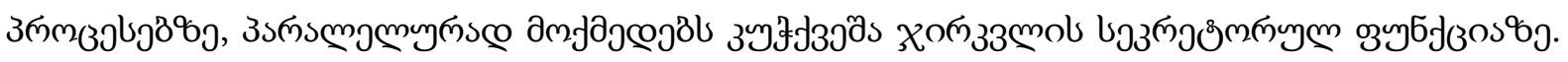

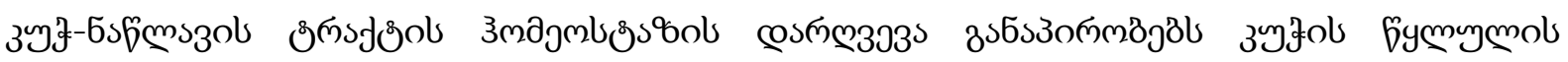

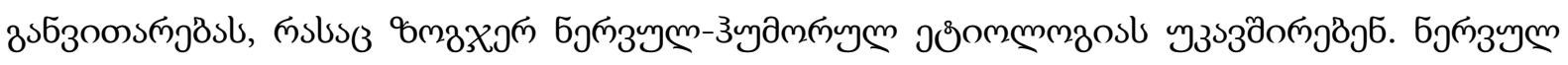

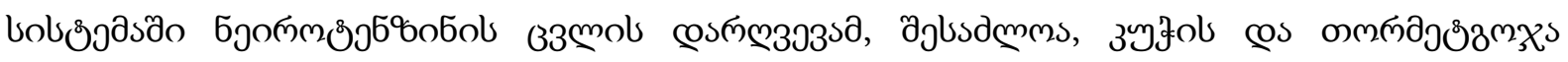

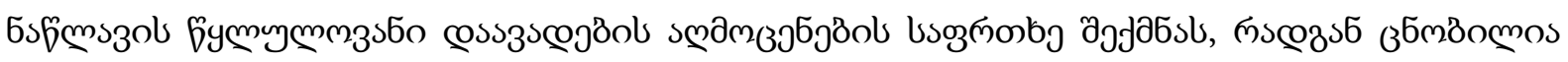

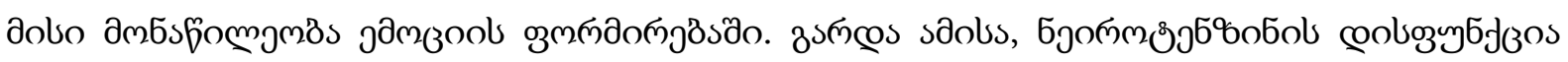

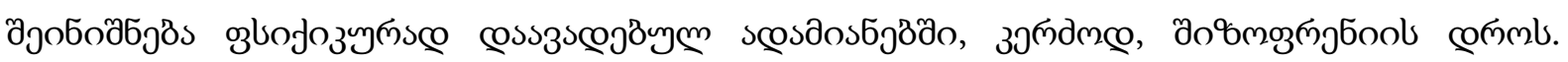

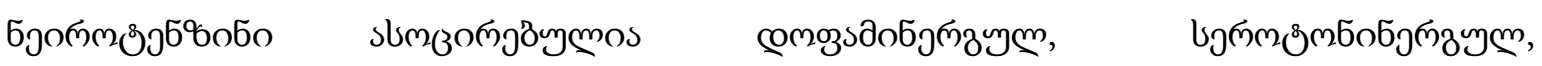

\footnotetext{
${ }^{104}$ Brea D., Sobrino T., Ramos-Cabrer P. et. al. Inflammatory and Neuroimmunomodulatory Changes in Acute Cerebral Ischemia // Cerebrovasc Dis. — 2009. — Vol. 27. — Suppl. 1. — P. 48-64.
} 


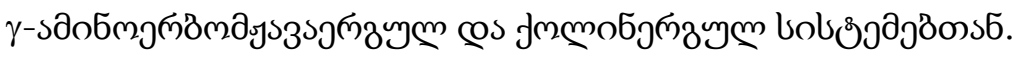

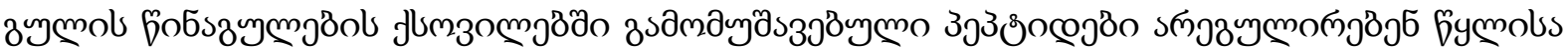

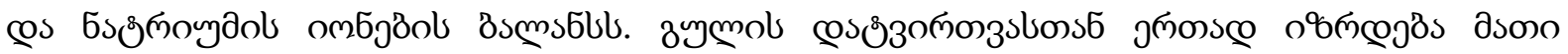
uoboggon.

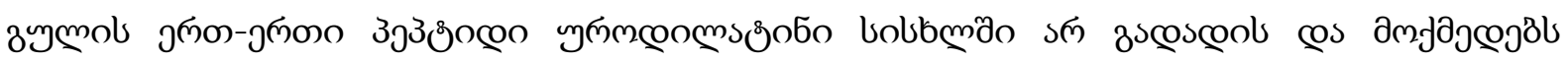

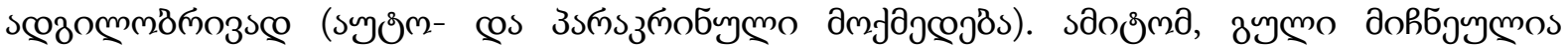

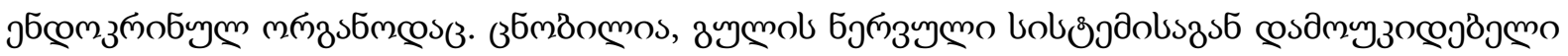

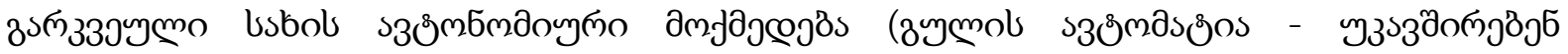

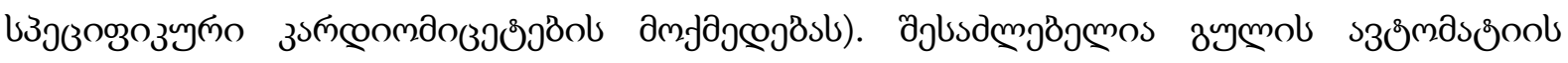

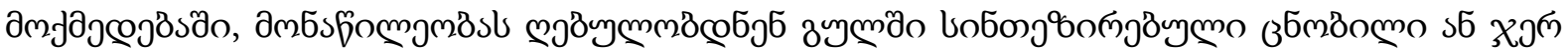

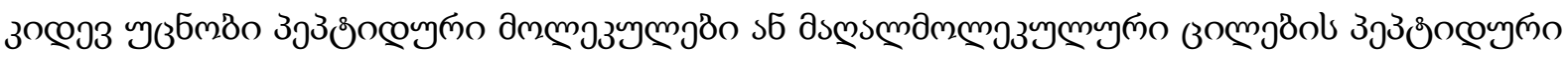

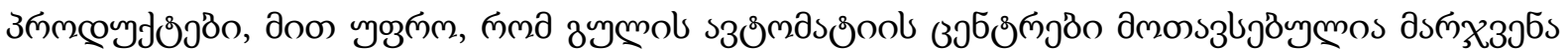
бобьзутудо.

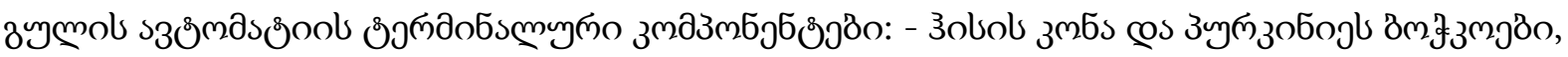

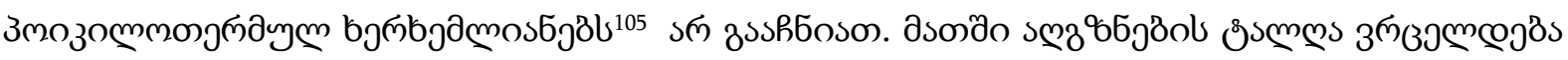

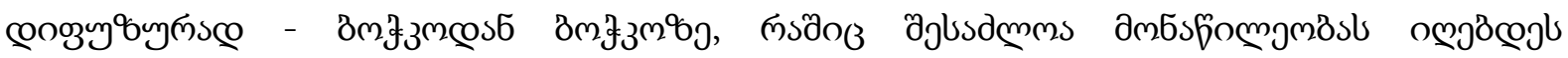

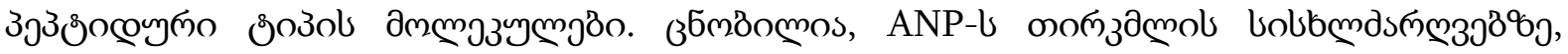

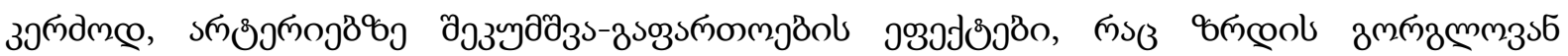
gominşzosl.

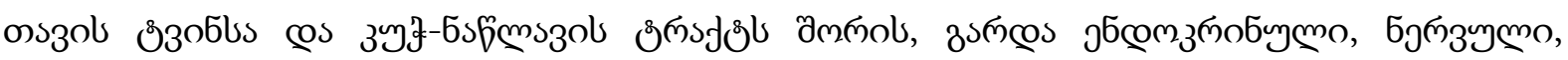

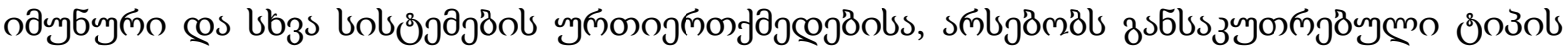

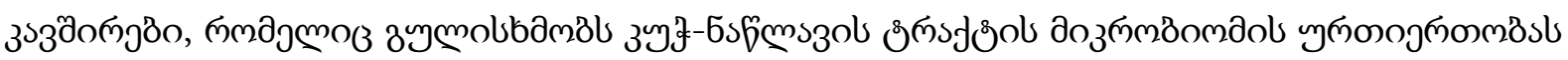

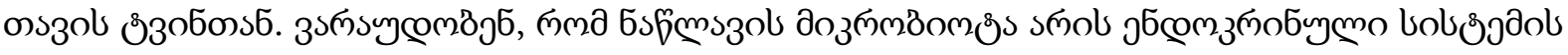

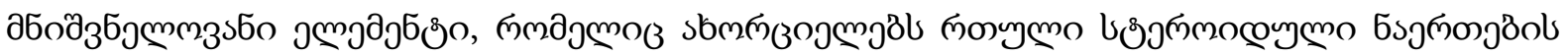

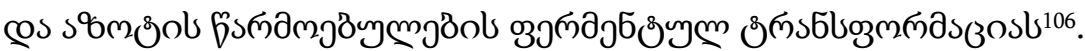

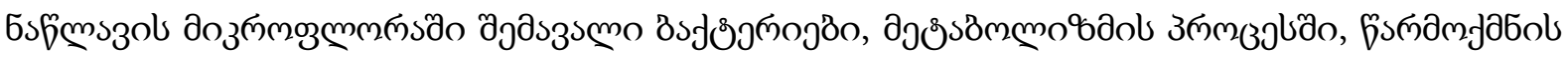

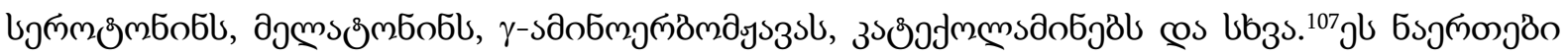

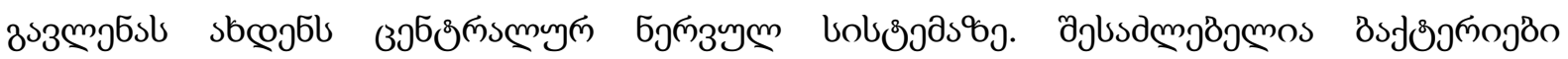

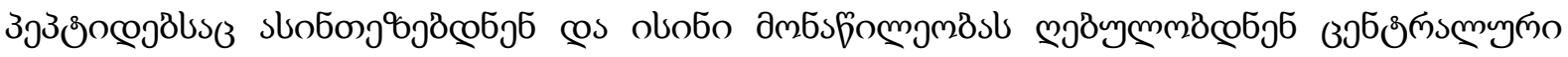

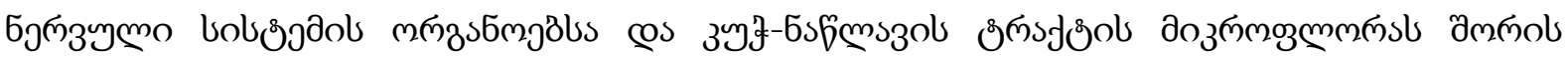

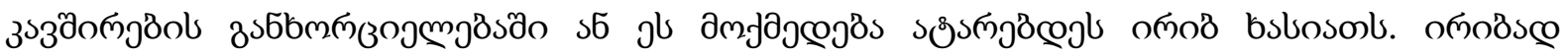

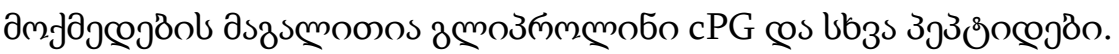

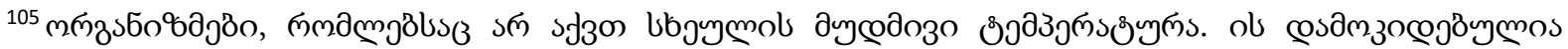

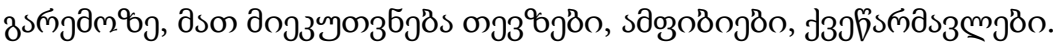

${ }^{106}$ Bienenstock J., Collins S. 99th Dahlem conference on infection, inflammation and chronicinflammatory disorders: psycho-neuroimmunology and the intestinal microbiota: clinicalobservations and basic mechanisms. Clin.Exp.Immunol. 2010, 160 (1): 85-91.

Savidge T.C., Sofroniew M.V. Starring roles for astroglia in barrier pathologies of gut and brain.Labor. Investig. 2007, 87: 731-736

${ }^{107}$ O'Hara A.M., Shanahan F. The gut flora as a forgotten organ. EMBO. 2006, 7 (7): 688-693.
} 


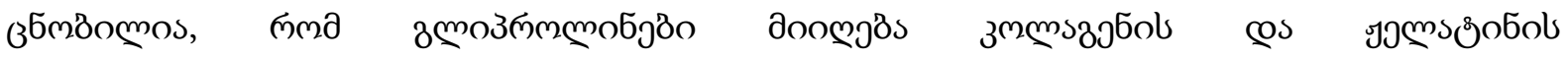

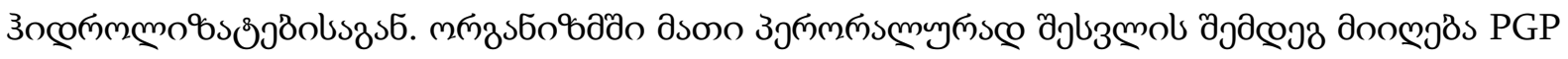

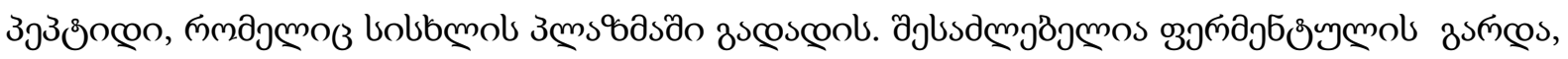

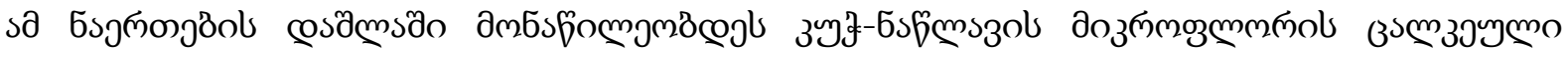

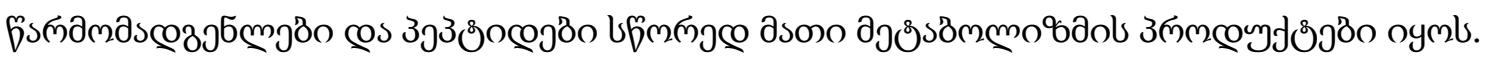

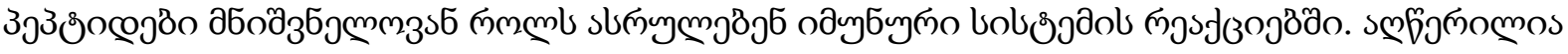

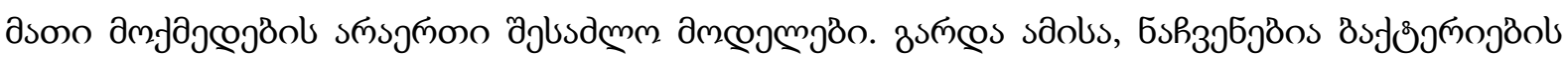

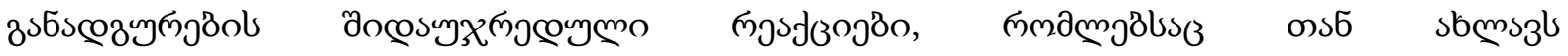

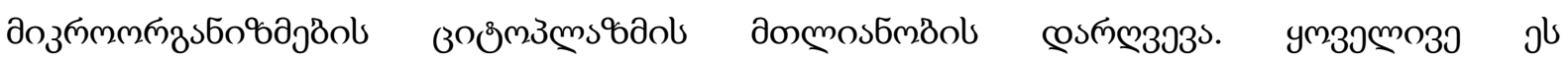

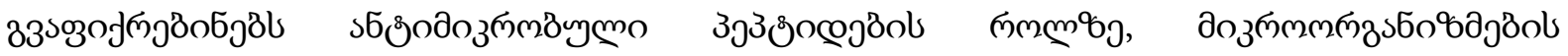

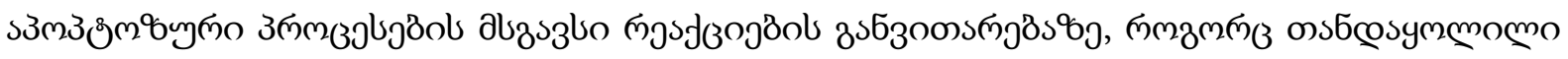

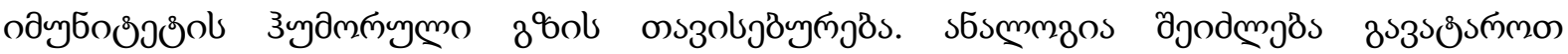

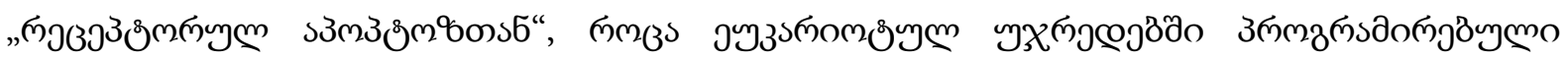

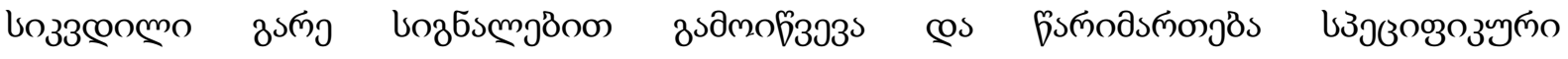

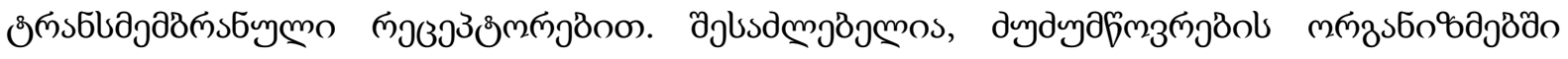

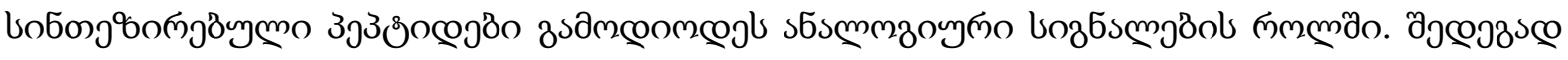

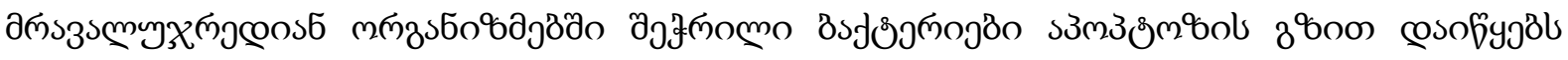

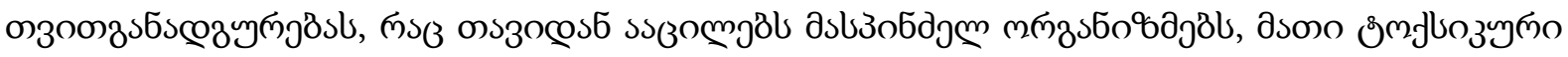

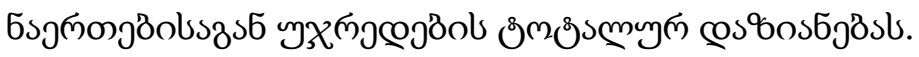

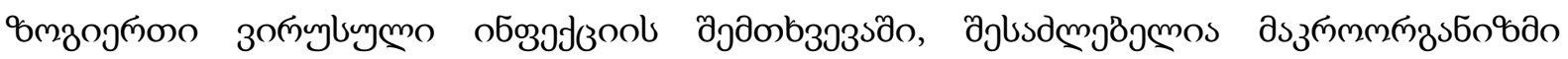

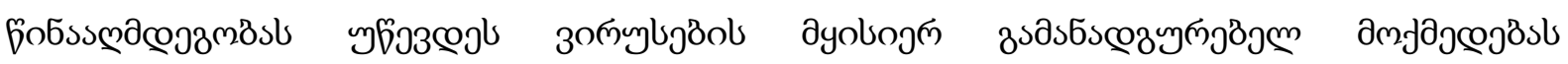

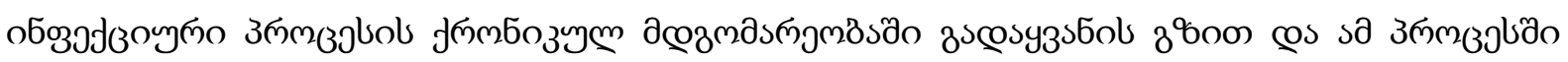

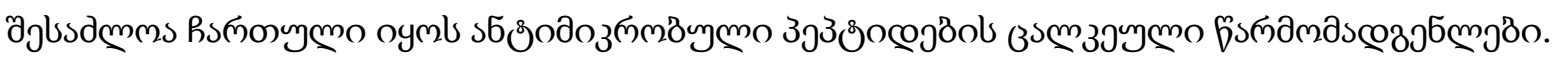

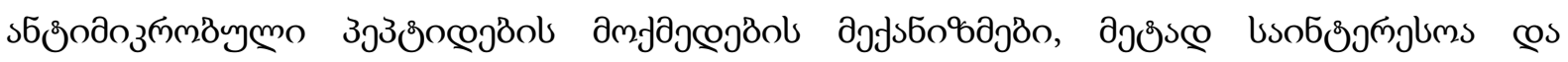

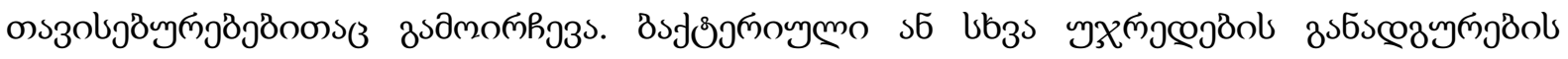

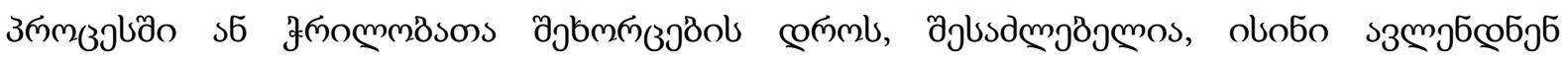

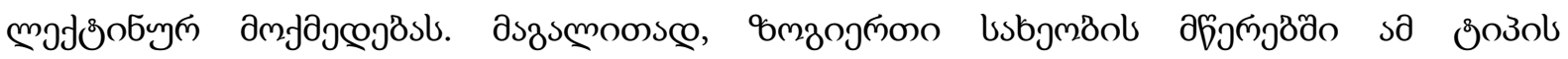

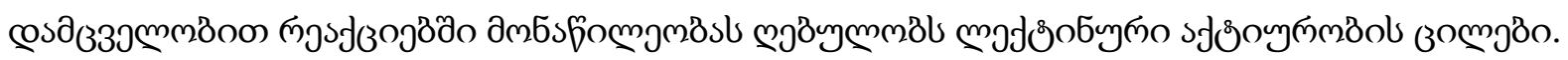

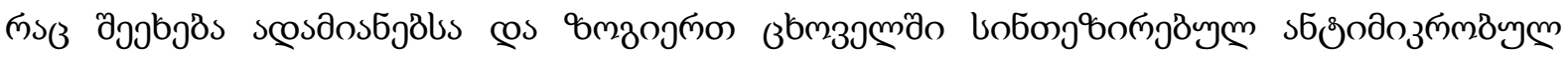

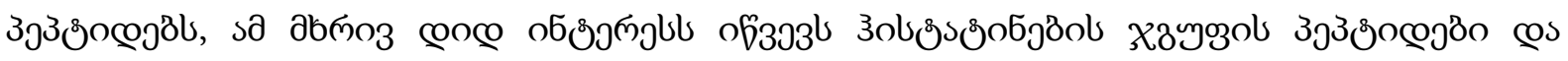

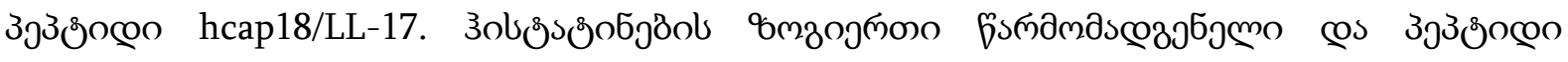

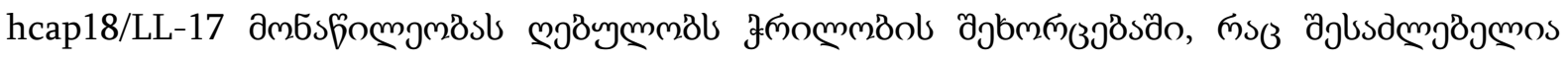

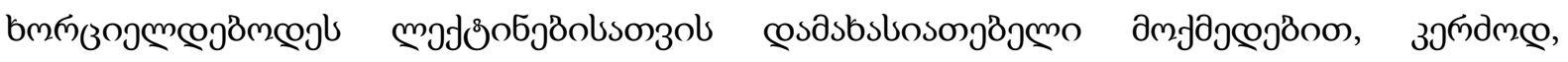

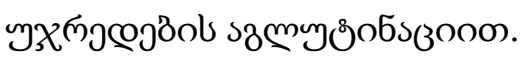

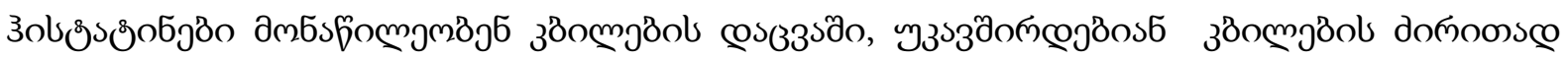

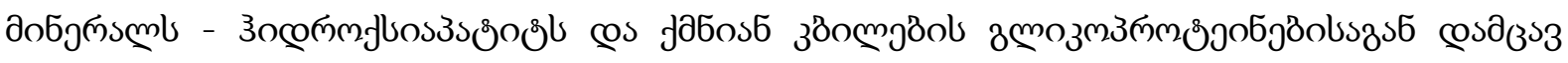

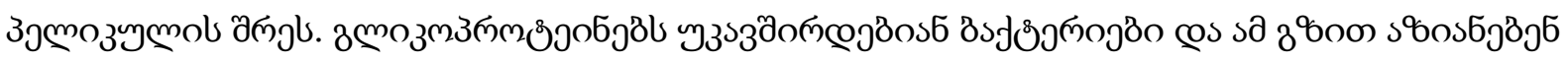

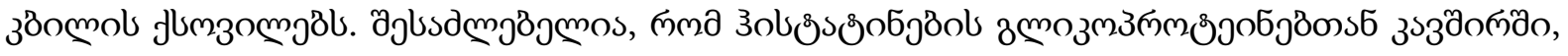

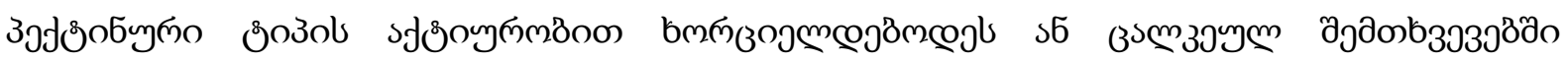

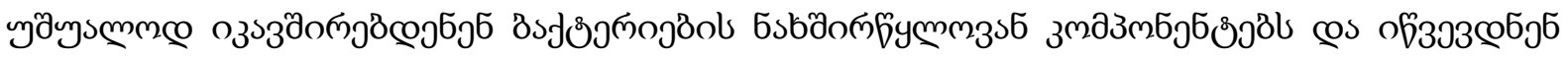

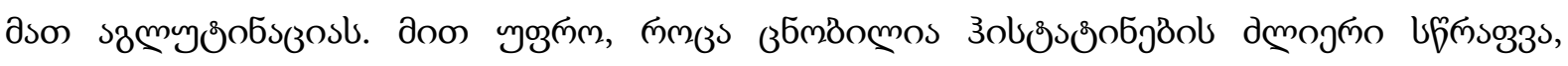

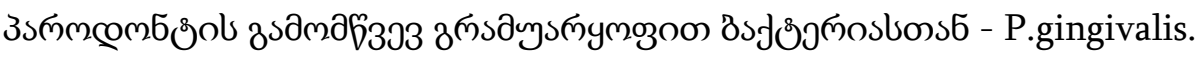




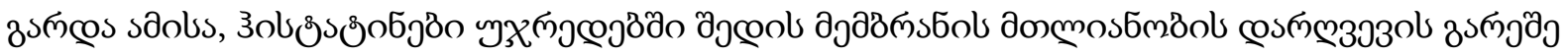

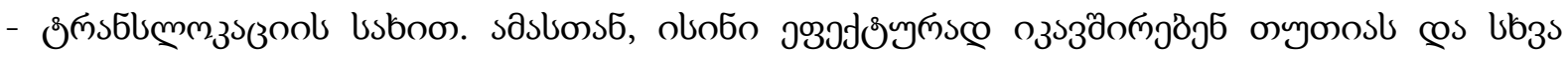

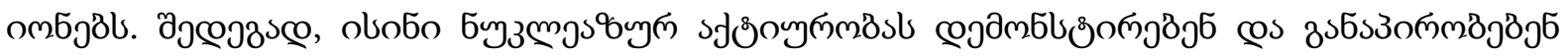

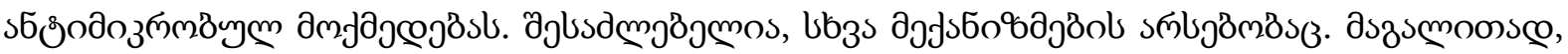

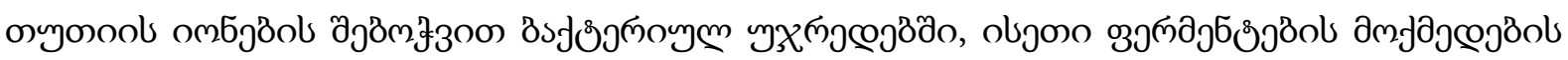

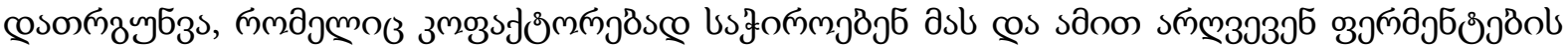

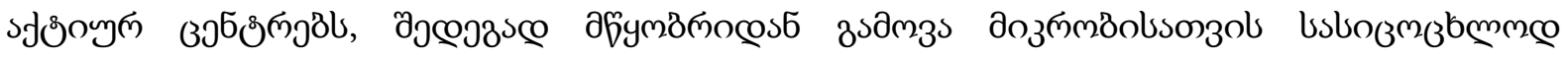

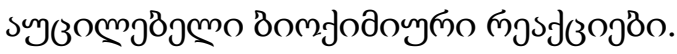

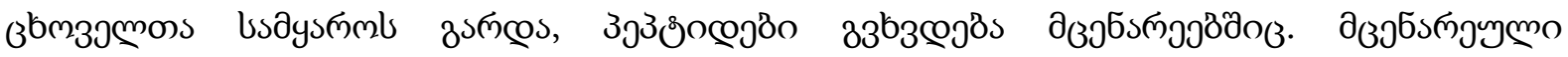

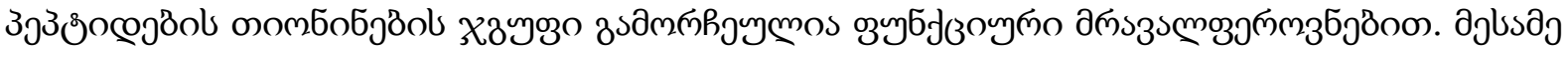

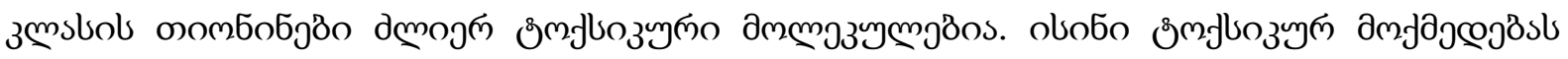

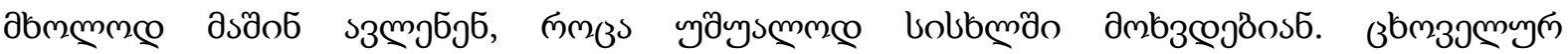

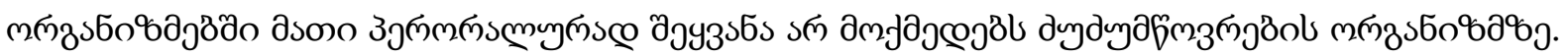

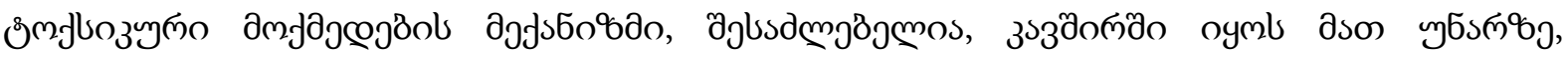

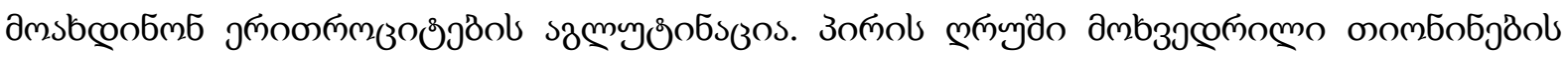

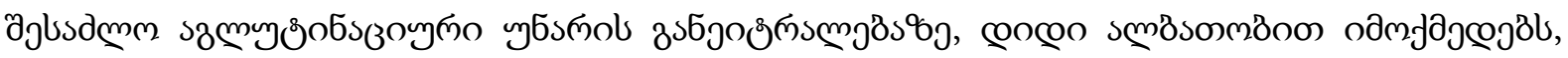

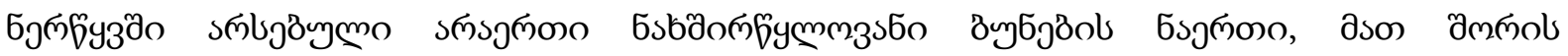

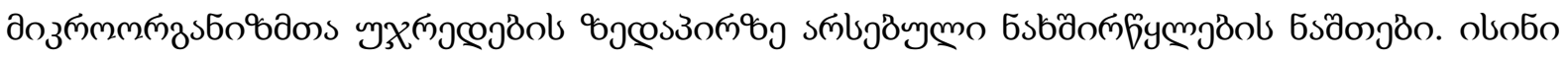

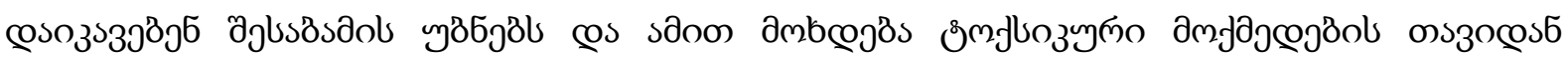

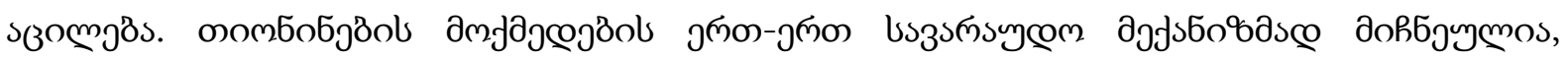

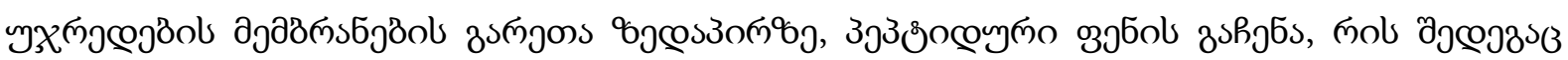

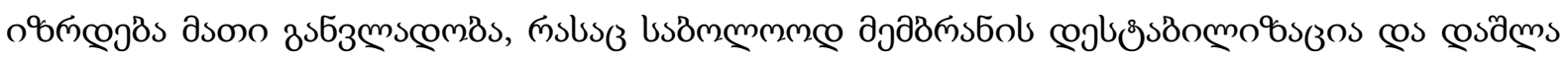

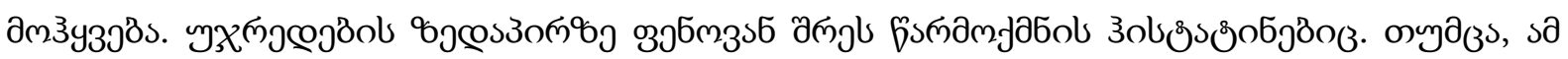

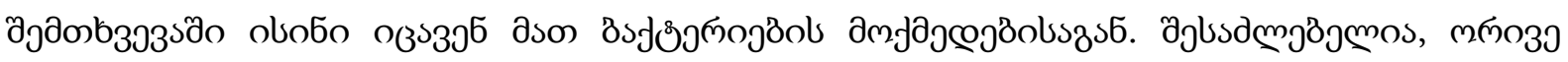

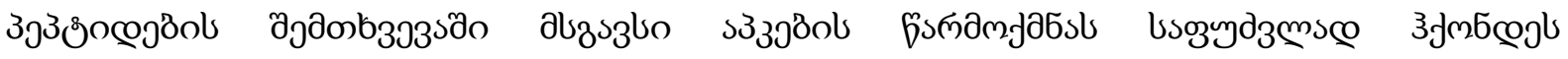

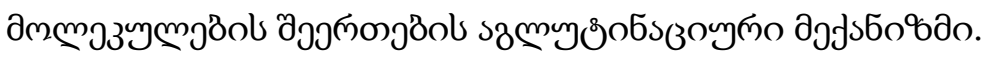

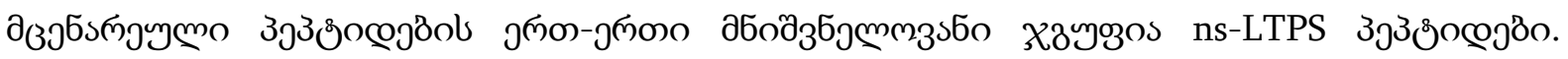

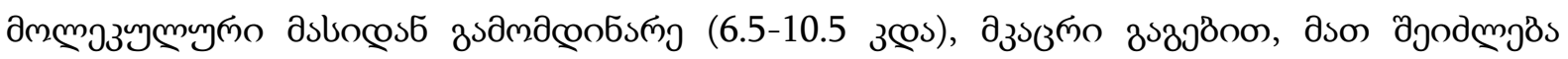

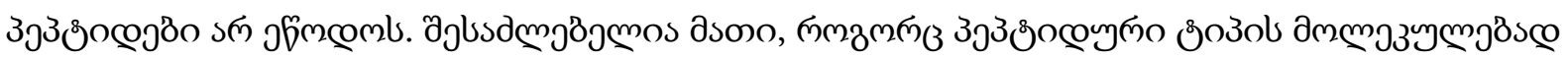

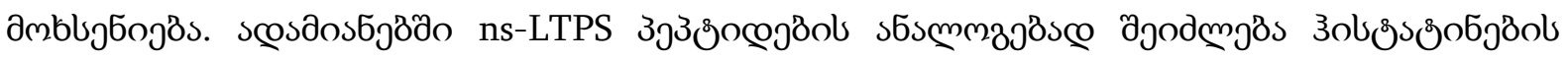
доһб

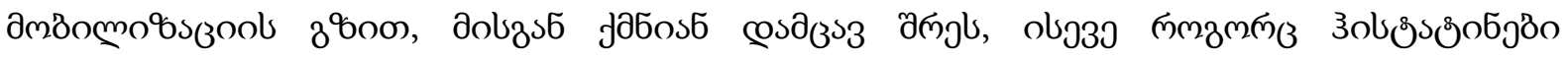

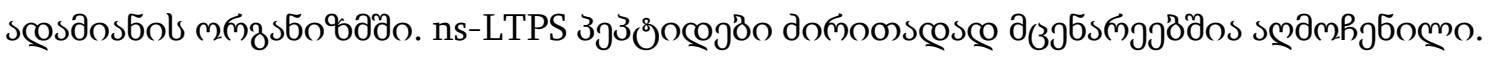

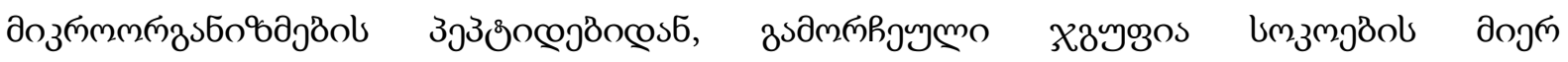

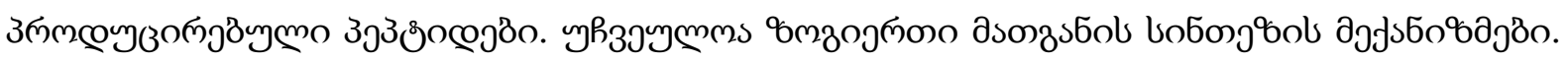

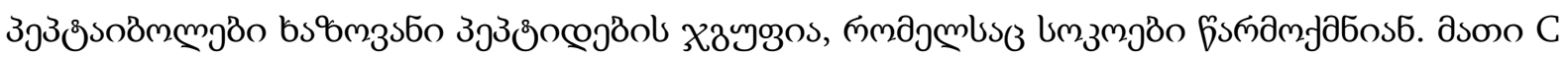

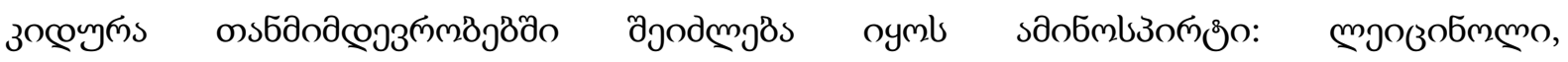

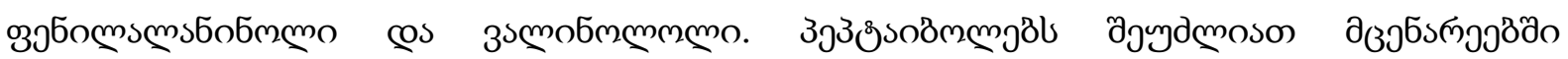

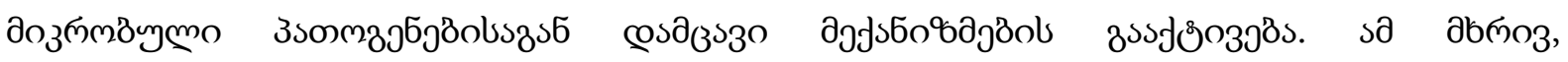

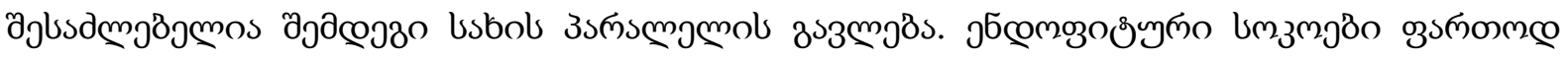

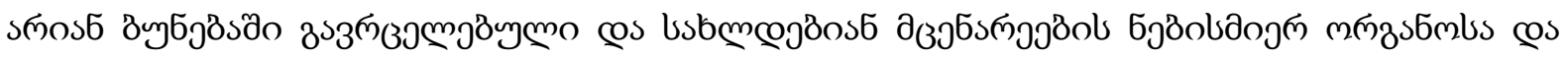

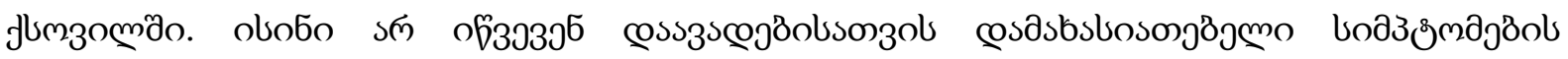




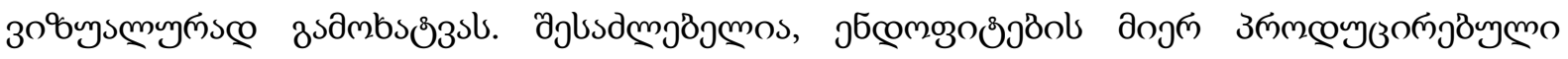

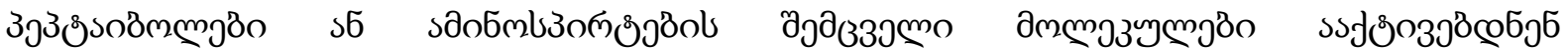

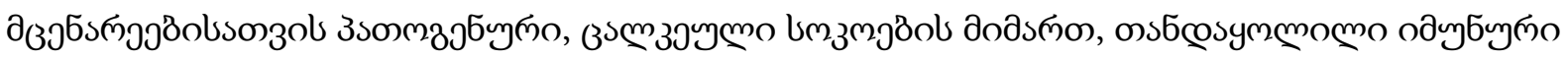

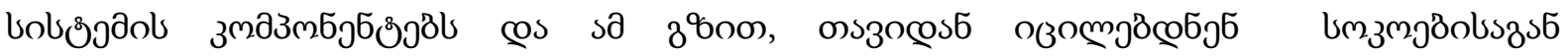

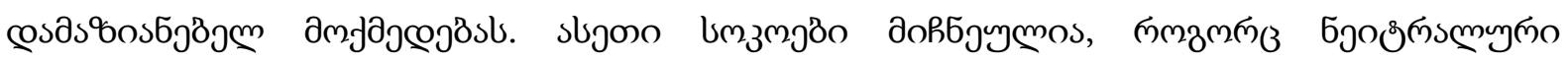

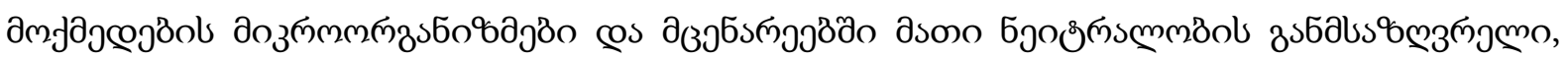

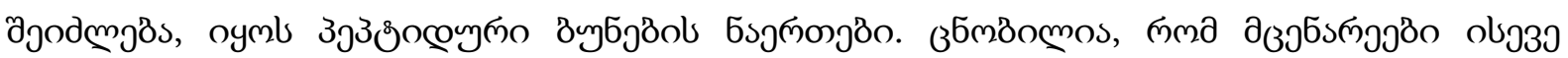

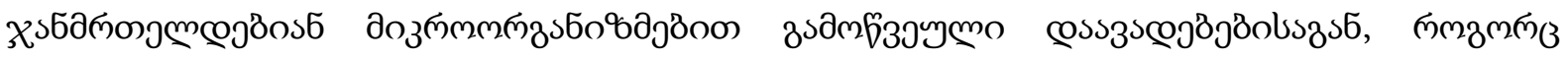

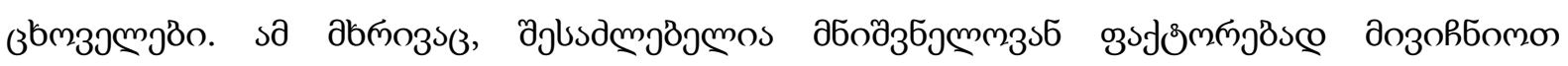

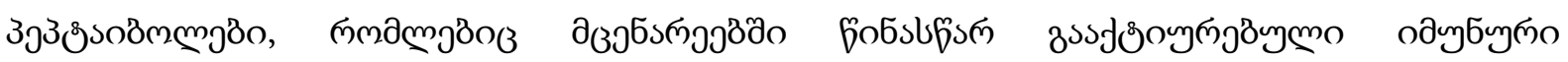
змдзмбјбఠ์

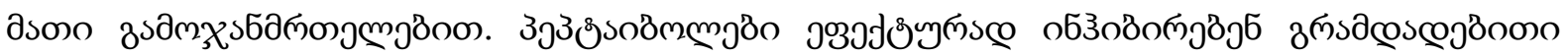

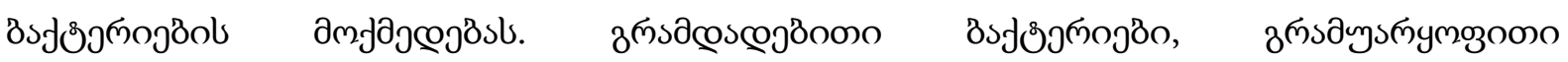

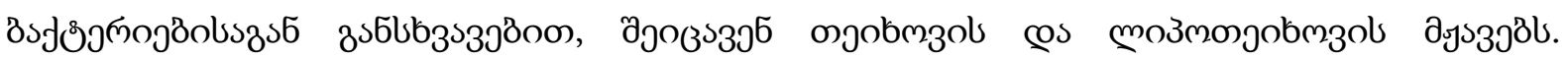

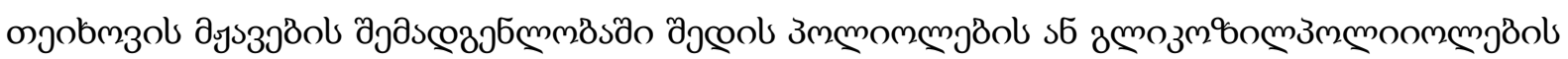

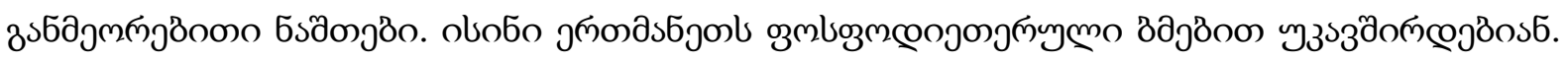

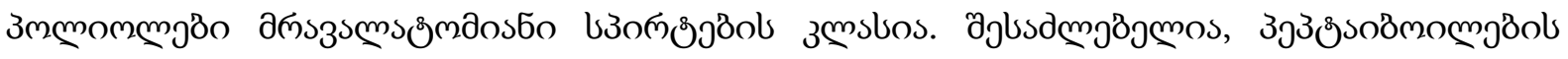

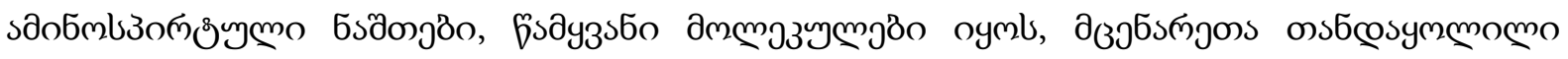

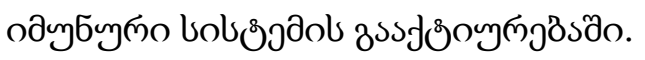

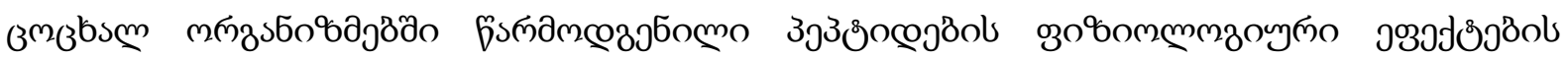

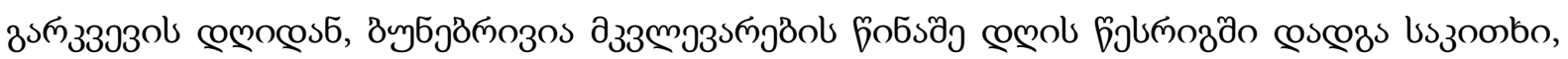

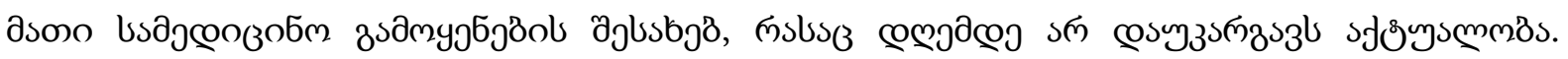

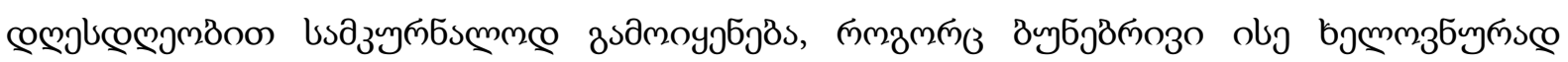

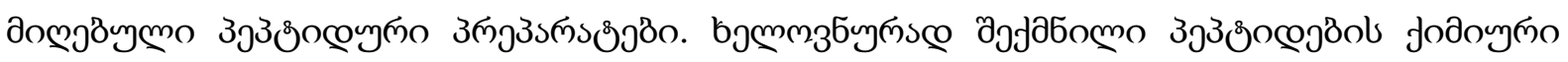

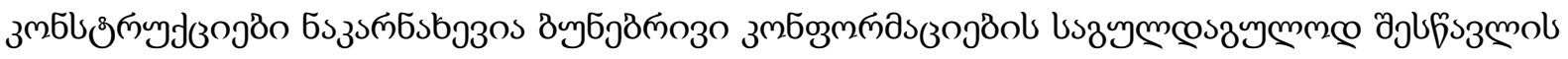

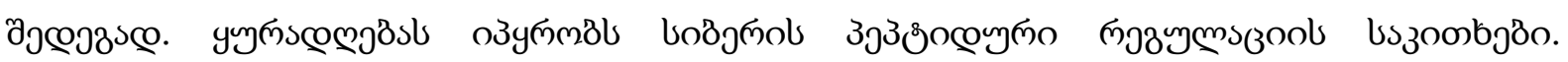

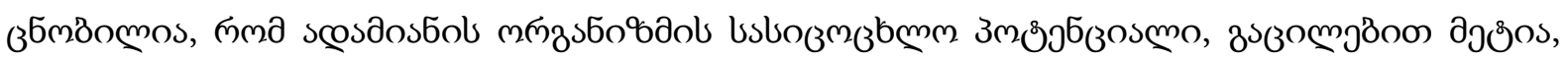

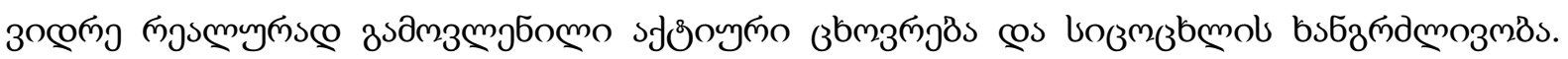

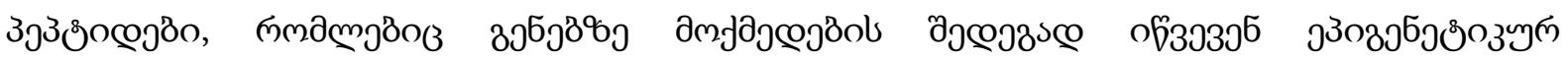

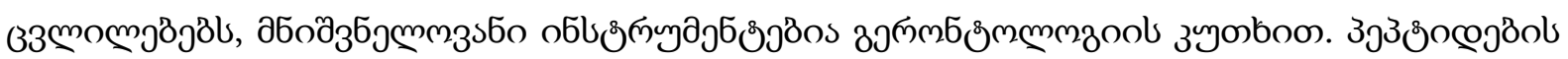

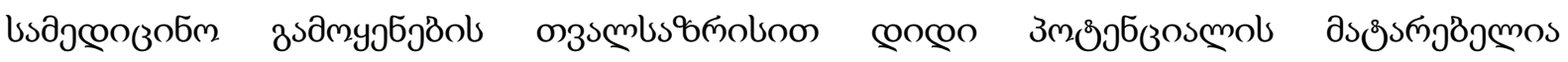

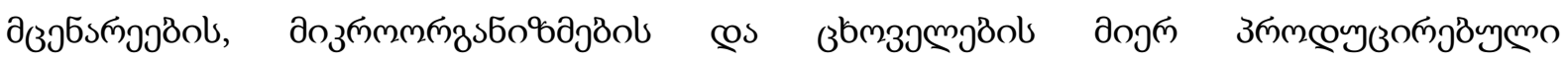

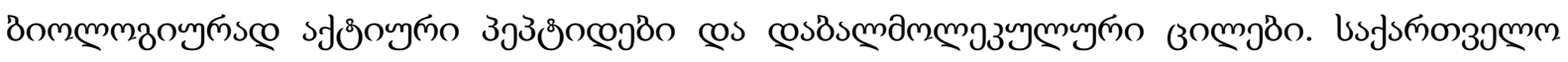

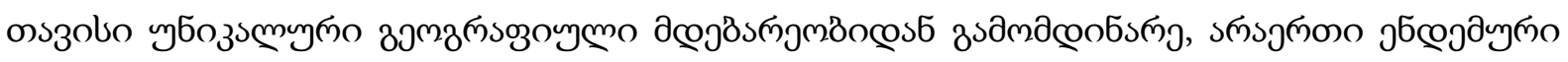

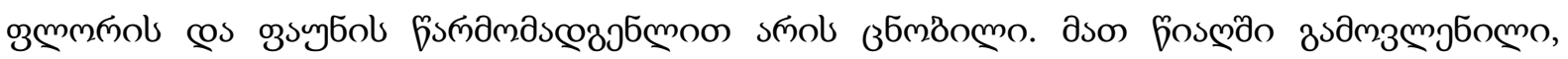

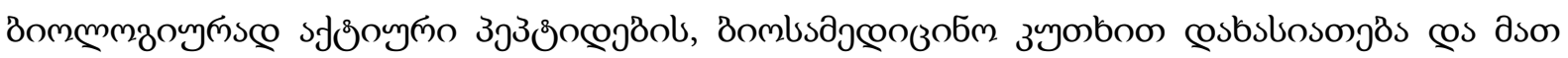

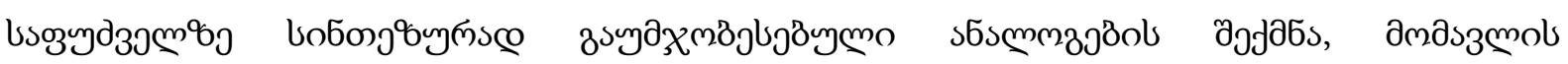

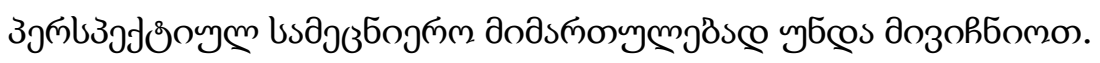

